\title{
Evaluation of Gas Reburning and Low Nox Burners on a Wall Fired Boiler \\ Performance and Economics Report Gas Reburning-Low NOx Burner System Cherokee Station Unit 3 Public Service Company of Colorado
}

\author{
Final Report \\ July 1998
}

Work Performed Under Contract No.: DE-FC22-91PC90547

\author{
$\checkmark$ For \\ U.S. Department of Energy \\ Office of Fossil Energy \\ Federal Energy Technology Center \\ P.O. Box 880 \\ Morgantown, West Virginia 26507-0880
}

By

Energy \& Environmental Research Corporation

18 Mason

Irvine, California 92718 


\section{Disclaimer}

This report was prepared as an account of work sponsored by an agency of the United States Government. Neither the United States Government nor any agency thereof, nor any of their employees, makes any warranty, express or implied, or assumes any legal liability or responsibility for the accuracy, completeness, or usefulness of any information, apparatus, product, or process disclosed, or represents that its use would not infringe privately owed rights. Reference herein to any specific commercial product, process, or service by trade name, trademark, manufacturer, or otherwise does not necessarily constitute or imply its endorsement, recommendation, or favoring by the United States Government or any agency thereof. The views and opinions of authors expressed herein do not necessarily state or reflect those of the United States Government or any agency thereof. 


\section{DISCLAIMER}

Portions of this document may be illegible in electronic image products. Images are produced from the best available original document. 


\section{ABSTRACT}

Under the U.S. Department of Energy's Clean Coal Technology Program (Round 3), a project was completed to demonstrate control of boiler $\mathrm{NO}_{x}$ emissions and to a lesser degree, due to coal replacement, $\mathrm{SO}_{2}$ emissions. The project involved combining Gas Reburning with Low $\mathrm{NO}_{x}$ Burners (GR-LNB) on a coal-fired electric utility boiler to determine if high levels of $\mathrm{NO}_{x}$ reduction $(70 \%)$ could be achieved. Sponsors of the project included the U.S. Department of Energy, the Gas Research Institute, Public Service Company of Colorado, Colorado Interstate Gas, Electric Power Research Institute, and the Energy and Environmental Research Corporation. The GR-LNB demonstration was performed on Public Service Company of Colorado's (PSCo) Cherokee Unit \#3, located in Denver, Colorado. This unit is a $172 \mathrm{MW}_{\mathrm{e}}$ wall-fired boiler that uses Colorado Bituminous, low-sulfur coal. It had a baseline $\mathrm{NO}_{x}$ emission level of $0.73 \mathrm{lb} / 10^{6} \mathrm{Btu}$ using conventional burners.

Low $\mathrm{NO}_{x}$ burners are designed to yield lower $\mathrm{NO}_{x}$ emissions than conventional burners. However, the $\mathrm{NO}_{x}$ control achieved with this technique is limited to $30-50 \%$. Also, with LNBs, CO emissions can increase to above acceptable standards. Gas Reburning (GR) is designed to reduce $\mathrm{NO}_{x}$ in the flue gas by staged fuel combustion. This technology involves the introduction of natural gas into the hot furnace flue gas stream. When combined, $\mathrm{GR}$ and $\mathrm{LNBs}$ minimize $\mathrm{NO}_{\mathrm{x}}$ emissions and maintain acceptable levels of $\mathrm{CO}$ emissions. A comprehensive test program was completed, operating over a wide range of boiler conditions. Over 4,000 hours of operation were achieved, providing substantial data. Measurements were taken to quantify reductions in $\mathrm{NO}_{\mathrm{x}}$ emissions, the impact on boiler equipment and operability and factors influencing costs. The GR-LNB technology achieved good $\mathrm{NO}_{\mathrm{x}}$ emission reductions and the goals of the project were achieved. Although the performance of the low $\mathrm{NO}_{\mathrm{x}}$ burners (supplied by others) was less than expected, a NO $\mathrm{NO}_{x}$ reduction of $65 \%$ was achieved at an average gas heat input of $18 \%$. The performance goal of $70 \%$ reduction was met on many test runs, but at a higher reburn gas heat input. $\mathrm{SO}_{2}$ emissions, based on coal replacement, were reduced by $18 \%$. 
Toward the end of the program, a Second Generation gas injection system was installed. Higher injector gas pressures were used that eliminated the need for flue gas recirculation as used in the first generation design. The Second Generation GR resulted in similar $\mathrm{NO}_{\mathrm{x}}$ reduction performance as that for the First Generation. With an improvement in the LNB performance in combination with the new gas injection system, the reburn gas could be reduced to $12.5 \%$ of the total boiler heat input to achieve al $64 \%$ reduction in $\mathrm{NO}_{\mathrm{x}}$ emissions. In addition, the OFA injectors were modified to provide for better mixing to lower $\mathrm{CO}$ emissions.

A key issue affecting the implementation of technology is economics. The application of GR-LNB requires modifications to existing power plant equipment. Capital and operating costs depend largely on the following site-specific factors; natural gas availability at the site, the coal-gas price differential, sulfur dioxide reduction requirements and the value of $\mathrm{SO}_{2}$ allowances. Operating costs are almost entirely related to the differential cost of the gas over the coal as reduced by the value of $\mathrm{SO}_{2}$ emissions reduction (due to the zero sulfur content of natural gas). Other operating cost factors are related to reductions in ash, mill power and maintenance, and a minor reduction in boiler efficiency, typically 0.0 to $1.0 \%$. Based on the test results, EER expects that GR-LNB installations will achieve at least $60 \% \mathrm{NO}_{x}$ control over the uncontrolled level when firing $10-15 \%$ gas.

Title IV, Phase 2 of the Clean Air Act Amendments (CAAA) of 1990 specify a NO emissions limit of $0.46 \mathrm{lb} / 10^{6} \mathrm{Btu}$ for wall-fired boilers. It is expected that this limit will be lowered in the future. The test results show that burners alone will yield a $\mathrm{NO}_{x}$ emission level of $0.46 \mathrm{lb} / 10^{6} \mathrm{Btu}$. Although sufficient to meet the CAAA limit, $C O$ control may not be satisfactory with certain LNBs unless low levels of GR are utilized. Also, any future more stringent limits will not be met with burners alone. For the Cherokee unit, it was demonstrated that GR could be an economic technology due to its low capital and operating cost (low levels of natural gas consumption). Based on the success of the project, the host utility has elected to purchase the GR-LNB equipment for future use. 


\section{ACKNOWLEDGMENTS}

The Energy and Environmental Research Corporation wishes to express its appreciation to the project sponsors and their project managers for the fine assistance and support provided to the GR-LNB demonstration:

U. S. Department of Energy - Mr. Harry Ritz

Gas Research Institute - Mr. Paul Bautista

Electric Power Research Institute - Mr. George Offen

Colorado Interstate Gas Company - Mr. John Grossman

Public Service Company of Colorado - Mr. Charles Bomberger

The assistance and cooperation of the operations and maintenance personnel of Public Service Company of Colorado's Cherokee Station is also greatly appreciated. 


\title{
POINTS OF CONTACT
}

For more information regarding Gas Reburning or Gas Reburning integrated with Low $\mathrm{NO}_{\mathrm{x}}$ Burners, please contact:

Dr. Blair A. Folsom, Senior Vice President

Energy and Environmental Research Corporation

18 Mason

Irvine, California 92718

Phone (949) 859-8851

FAX (949) 859-3194

or

Mr. Todd M. Sommer, Vice President

Energy and Environmental Research Corporation

1345 N. Main St.

Orrville, Ohio 44667

Phone (330) 682-4007

FAX (330) 684-2110

\section{AUTHORS}

The following EER personnel contributed in the preparation of this report:

\author{
Robert Ashworth \\ Rafik Beshai \\ Donald Engelhardt \\ Blair Folsom \\ David Moyeda \\ Roy Payne \\ Todd Sommer
}


Section

Page

EXECUTIVE SUMMARY

1.0 INTRODUCTION ............................... 1-1

1.1 Purpose of the Project Performance and Economics Report ...... 1-1

1.2 Overview of the Project ......................

1.2.1 Background and History of Project ............. 1-2

1.2.2 Project Organization .................. 1-2

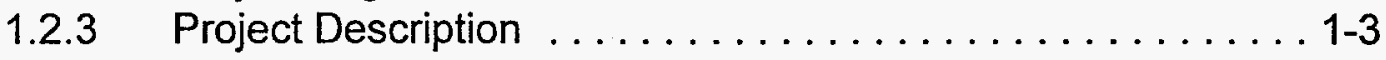

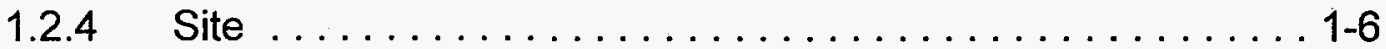

1.2.5 Project Schedule . . . . . . . . . . . . . . . . 1-6

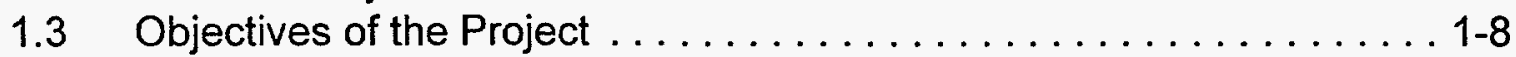

1.4 Significance of the Project . . . . . . . . . . . . . . .

1.5 DOE's Role in the Project $\ldots \ldots \ldots \ldots \ldots \ldots \ldots \ldots \ldots \ldots \ldots \ldots$

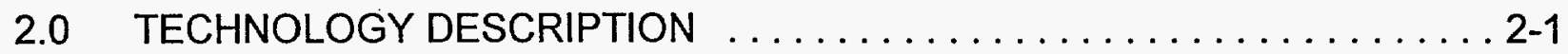

2.1 Description of the Demonstrated Technology .............. 2-1

2.1.1 Overview of GR-LNB Technology . . . . . . . . . 2-1

2.1.2 Process Design Tools . . . . . . . . . . . . . . . 2-6

2.2 Description of the Demonstration Facilities . . . . . . . . . . 2-9

2.2.1 Detailed Site Description ................... 2-9

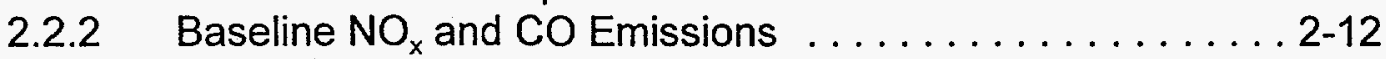

2.3 Retrofit Description ....................... 2-14

2.3.1 GR-LNB Design Criteria .................. 2-14

2.3.2 Low $\mathrm{NO}_{\mathrm{x}}$ Burners $\ldots \ldots \ldots \ldots \ldots \ldots \ldots \ldots \ldots \ldots .2 .20$

2.3.3 Gas Reburning System . . . . . . . . . . . . . 2-20

2.3.4 Control System . . . . . . . . . . . . . . . . . . . . 2-23

2.4 Expected Impacts of GR-LNB . . . . . . . . . . . . . . . . 2-23

2.4.1 Thermal Impacts .................... 2-23

2.4.2 Environmental Impacts . . . . . . . . . . . . . 2-25

2.5 Proprietary Information . . . . . . . . . . . . . . . . . . 2-29

2.6 Simplified Process Flow Diagram . . . . . . . . . . . . . . 2-30

2.7 Stream Data .......................... 2-30

2.8 Process and Instrumentation Diagrams $\ldots \ldots \ldots \ldots \ldots \ldots \ldots 2-33$

3.0 UPDATE OF THE PUBLIC DESIGN REPORT $\ldots \ldots \ldots \ldots \ldots \ldots \ldots . \ldots \ldots$

3.1 Design and Equipment Changes . . . . . . . . . . . . . . . 3-1

3.1.1 Disposition of Flue Gas Recirculation System . . . . . . . 3-1

3.1.2 Reburning Fuel Injector Modification ............ 3-2

3.1.3 OFA System Modification .................... 3-3

3.2 Demonstration Plant Capital Cost Update . . . . . . . . . . . . 3-3

3.3 Demonstration Plant Operating Costs Update .............. . . .4 


\section{TABLE OF CONTENTS (con't)}

Section

Page

4.0 DEMONSTRATION PROGRAM $\ldots \ldots \ldots \ldots \ldots \ldots \ldots \ldots \ldots \ldots \ldots .4 .1$

4.1 Test Plans . . . . . . . . . . . . . . . . . . . . . . . . . 4

4.1.1 Parametric/Optimization Testing . . . . . . . . . . 4-4

4.1.2 Long Term Testing . . . . . . . . . . . . . . . 4-9

4.1.3 Second Generation GR System Testing ............ . 4-9

4.1.4 Gas Firing and Gas/Gas Reburning Testing . . . . . . . 4-15

4.2 Operating Procedures . . . . . . . . . . . . .

4.2.1 Instrumentation and Data Acquisition ............ 4-20

4.2.2 Test Methods ........................ . 4-25

4.2.2.1 Input Measurements . . . . . . . . . . 4-31

4.2.2.2 Boiler Performance Measurements . . . . . . . . 4-33

4.2.2.3 Emissions Measurements . . . . . . . . . 4-36

4.2.2.4 Durability and Operability ........... 4-39

4.3 Analyses of Feed Stocks, Products and Reagents . . . . . . . . . 4-42

4.4 Data Analysis Methodology . . . . . . . . . . . . . . . . 4-42

4.5 Data Summary .......................... . .45

$4.6 \quad$ Operability and Reliability $\ldots \ldots \ldots \ldots \ldots \ldots \ldots \ldots \ldots \ldots \ldots \ldots \ldots \ldots$

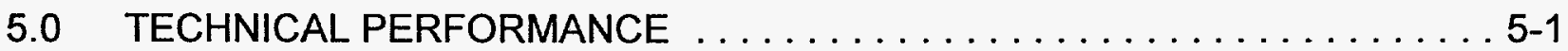

5.1 Pre-Construction Baseline Testing ............... 5-1

5.2 GR-LNB Optimization Testing (First Generation GR) . . . . . . . 5-5

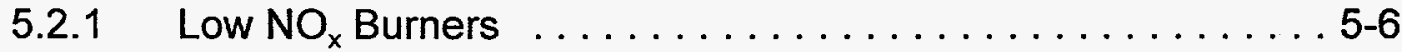

5.2.1.1 LNB Baseline ................. 5-7

5.2.1.2 Combustion Air Variation ........... 5-11

5.2.2 Gas Reburning with Low $\mathrm{NO}_{x}$ Burners $\ldots \ldots \ldots \ldots \ldots .5-11$

5.2.2.1 Gas Heat Input Variation . . . . . . . . . . . 5-14

5.2.2.2 Overfire Air Variation . . . . . . . . . . . . . 5-18

5.2.2.3 Flue Gas Recirculation Variation . . . . . . . . . 5-18

5.2 .3 Assessment of Results . . . . . . . . . . . . . 5-23

5.2.4 Reduced Load Testing . . . . . . . . . . . . . . . . 5-27

5.3 GR-LNB Optimization Testing (Second Generation GR) . . . . . . 5-29

5.3.1 Low $\mathrm{NO}_{\mathrm{x}}$ Burners .................... 5-31

5.3.2 Gas Reburning with Low $\mathrm{NO}_{x}$ Burners ........... 5-31

5.3.3 Assessment of Results . . . . . . . . . . . . . . . 5-38

5.4 Gas Gas/Reburning Testing $\ldots \ldots \ldots \ldots \ldots \ldots \ldots \ldots \ldots .41$

$5.5 \quad$ Boiler Impacts . . . . . . . . . . . . . . . . . . . . . . . . 5-45

5.5.1 Furnace Conditions . . . . . . . . . . . . . . . . . 5-45

5.5.2 Thermal Performance/Efficiency . . . . . . . . . . . . . 5-46

5.5 .3 Tubewear ......................... . 5-51

5.6 Additional Observations . . . . . . . . . . . . . . . . 5-52

5.7 Coal and Natural Gas Analysis . . . . . . . . . . . . . . . 5-53 
Section

6.0 ENVIRONMENTAL PERFORMANCE $\ldots \ldots \ldots \ldots \ldots \ldots \ldots \ldots \ldots .6 \ldots \ldots$

6.1 Impact on the Environment .....................

6.2 Waste Streams and Their Disposal . . . . . . . . . . . . . . 6-6

6.3 Potential Environmental Concerns $\ldots \ldots \ldots \ldots \ldots \ldots \ldots \ldots 6.6 \ldots$

7.0 ECONOMICS ............................

7.1 GR-LNB Economic Parameters $\ldots \ldots \ldots \ldots \ldots \ldots \ldots \ldots \ldots .1$

7.2 GR-LNB Capital Cost . . . . . . . . . . . . . . . . . . 7-2

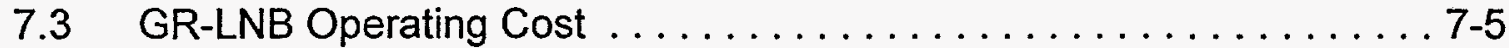

7.4 Summary of Performance and Economics ............ $\ldots .7$

7.5 Effect of Variables on Economics .................... . 7-10

8.0 COMMERCIALIZATION POTENTIAL AND PLANS $\ldots \ldots \ldots \ldots \ldots \ldots$ 8-1

8.1 Market Analysis ......................

8.1.1 Applicability of the Technology . . . . . . . . . . . . .

8.1.2 Market Size ...................... 8.4

8.1.3 Market Barriers . . . . . . . . . . . . . . . . 8

8.1.4 Economic Comparison with Competing Technologies . . . . 8 8-6

8.2 Commercialization Plans . . . . . . . . . . . . .

9.0 CONCLUSIONS AND RECOMMENDATIONS $\ldots \ldots \ldots \ldots \ldots \ldots . . .1$

BIBLIOGRAPHY

APPENDICES:

Instrument and Component List .................. Appendix A

First Generation Gas Reburning Test Data .............. Appendix B

Second Generation Gas Reburning Test Data ............. Appendix C 


\section{LIST OF TABLES}

Table

Description

Page

2-1 Boiler and baghouse specifications for Cherokee Station Unit $3 \ldots \ldots \ldots$ 2-11

2-2 Design criteria for Cherokee GR-LNB system . . . . . . . . . . . . 2-16

2-3 Coal and natural gas composition used in the design phase . . . . . . . 2-19

2-4 Projected impacts of GR-LNB on thermal performance . . . . . . . . . 2-24

2-5 Project impact of GR-LNB on gross boiler efficiency $\ldots \ldots \ldots \ldots \ldots \ldots .2-26$

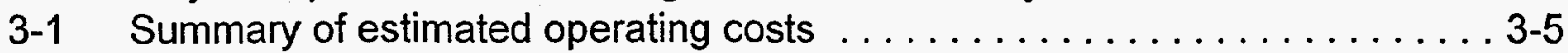

4-1 GR-LNB parametric test matrix ...................... 4 4

4-2 Second Generation GR-LNB parametric test matrix . . . . . . . . . 4-10

4-3 $\quad 100 \%$ gas firing and gas/gas reburning parametric test matrix . . . . . . 4-16

4-4 Inputs to BPMS heat transfer/combustion model . . . . . . . . . . . 4-22

4-5 Output data from BPMS heat transfer/combustion model . . . . . . . . . . 4-24

4-6 Continuous emissions monitoring system (CEMS) $\ldots \ldots \ldots \ldots \ldots \ldots 4$ 4-28

4-7 Sampling schedule . . . . . . . . . . . . . . . . . . . 4-29

4-8 Analysis of Empire Coal fired at Cherokee Unit $3 \ldots \ldots \ldots \ldots \ldots .4 .43$

4-9 Program objectives for critical measurement data . . . . . . . . . . 4-46

5-1 Thermal performance summary, full load $\left(150 \mathrm{MW}_{\mathrm{e}}\right) \ldots \ldots \ldots \ldots \ldots .548$

5-2 Thermal performance summary, mid load $\left(120 \mathrm{MW}_{\mathrm{e}}\right) \ldots \ldots \ldots \ldots \ldots .549$

5-3 Thermal performance summary, low load $\left(90 \mathrm{MW}_{\mathrm{e}}\right) \ldots \ldots \ldots \ldots \ldots \ldots .50$

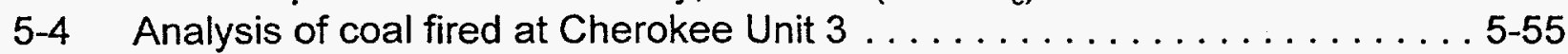

5-5 Annual average natural gas compositions .............. 5-56

6-1 Average emissions for conditions tested on Unit $3 \ldots \ldots \ldots \ldots \ldots .6 .6$

6-2 Measurement of $\mathrm{N}_{2} \mathrm{O}$ with $\mathrm{LNB}$ and GR-LNB operation ...........6.5

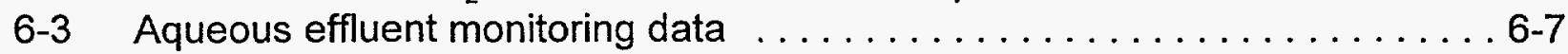

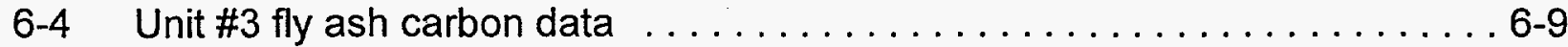

6-5 Worker area dust levels ...................... 6. $6 \ldots \ldots$

6-6 Ambient dust levels outside of plant $\ldots \ldots \ldots \ldots \ldots \ldots \ldots \ldots \ldots 6.13$

6-7 Noise levels in boiler house . . . . . . . . . . . . . . . . . . . 6 6

$7-1$ Cost factors . . . . . . . . . . . . . . . . . . . . . . .

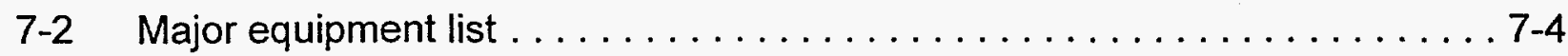

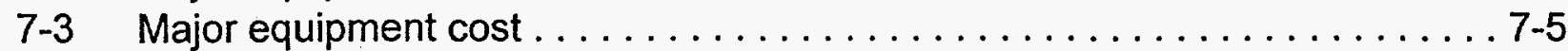

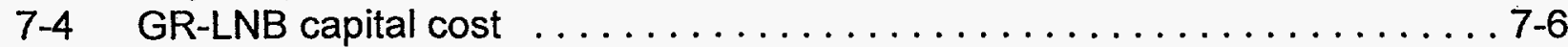

7-5 Annual incremental operating cost . . . . . . . . . . . .

7-6 GR-LNB economics and performance summary .............. 7-9

8-1 U.S. EPA proposed $\mathrm{NO}_{\mathrm{x}}$ emission regulations $\ldots \ldots \ldots \ldots \ldots \ldots \ldots . . .6 .2$

8-2 Reburning fuel comparison .......................

8-3 $400 \mathrm{MW}_{\mathrm{e}}$ Unit $\mathrm{NO}_{\mathrm{x}}$ control comparison $\ldots \ldots \ldots \ldots \ldots \ldots \ldots \ldots .6 .10$ 


\section{LIST OF FIGURES}

Figure Description

Page

1-1

1-2

2-1

2-2

2-3

2-4

2-5

2-6

2-7

2-8

2-9

2-10

2-11

2-12

2-13

2-14

2-15

4-1

4-2

4-3

4-4

4-5

4-6

4-7

4-8

5-1

$5-2$

5-3

5-4

5-5

5-6

5-7

5-8

5-9

5-10

5-11

5-12

5-13

$5-14$

$5-15$

$5-16$

Project management structure $\ldots \ldots \ldots \ldots \ldots \ldots \ldots \ldots \ldots$ 1-4

Schedule for GR-LNB demonstration $\ldots \ldots \ldots \ldots \ldots \ldots \ldots \ldots$ 1-7

Schematic of Gas Reburning system ............... 2-3

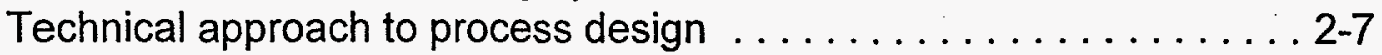

Schematic of Cherokee Station Unit $3 \ldots \ldots \ldots \ldots \ldots \ldots \ldots$ 2-10

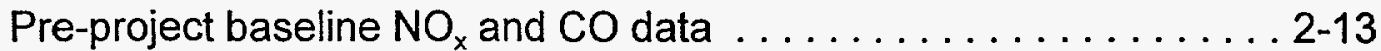

Cherokee Unit 3 GR-LNB system isometric . . . . . . . . . . 2-15

Cherokee Unit 3 gas reburning system injector specification . . . . 2-18

Predicted mean gas temperature profile for the Cherokee boiler . . . 2-27

Cherokee Unit 3 GR material balance . . . . . . . . . . . . . . 2-31

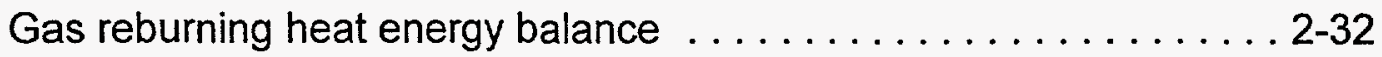

Piping and instr. diagram, First Generation gas reburning . . . . . 2-34

Piping and instr. diagram, First Generation gas reburning . . . . . 2-35

Piping and instr. diagram, First Generation gas reburning . . . . 2-36

Piping and instr. diagram, Second Generation gas reburning . . . . . 2-37

Piping and instr. diagram, Second Generation gas reburning . . . . . 2-38

Piping and instr. diagram, Second Generation gas reburning . . . . . 2 2-39

Reburn fuel injector configurations planned for evaluation . . . . . 4-14

Schematic of continuous emissions monitoring system . . . . . 4-26

Economizer exit gas sampling grid $\ldots \ldots \ldots \ldots \ldots \ldots \ldots \ldots .4-27$

EER RotoProbe ${ }^{\mathrm{TM}}$ pulverized coal sampling probe $\ldots \ldots \ldots \ldots \ldots 4-32$

Suction pyrometer tip . . . . . . . . . . . . . . . . . . . . 4-34

Economizer exit gas sampling grid $\ldots \ldots \ldots \ldots \ldots \ldots \ldots \ldots$ 4-37

Baghouse inlet duct arrangement . . . . . . . . . . . . 4-40

Baghouse sampling locations . . . . . . . . . . . . . 4-41

Pre-construction baseline $\mathrm{NO}_{x}$ vs. furnace exit flue gas $\mathrm{O}_{2} \ldots \ldots \ldots 5-2$

Pre-construction baseline fly ash carbon vs. furnace exit flue gas $\mathrm{O}_{2} \ldots$ 5-3

Pre-construction baseline $\mathrm{CO}$ vs. furnace exit flue gas $\mathrm{O}_{2} \ldots \ldots \ldots 5-4$

LNB baseline $\mathrm{NO}_{x}$ vs. furnace exit flue gas $\mathrm{O}_{2} \ldots \ldots \ldots \ldots \ldots \ldots 5-8$

LNB baseline fly ash carbon vs. furnace exit flue gas $\mathrm{O}_{2} \ldots \ldots \ldots .5-9$

LNB baseline $\mathrm{CO}$ vs. furnace exit flue gas $\mathrm{O}_{2} \ldots \ldots \ldots \ldots \ldots$ 5-10

LNB w/OFA NO ${ }_{x}$ vs. primary zone stoichiometric ratio $\ldots \ldots \ldots \ldots 5-12$

LNB w/OFA CO vs. primary zone stoichiometric ratio . . . . . 5-13

GR-LNB NO ${ }_{x}$ vs. natural gas heat input reburn fuel $\ldots \ldots \ldots \ldots \ldots$ 5-15

GR-LNB $\mathrm{SO}_{2}$ vs. natural gas heat input reburn fuel . . . . . . 5-16

GR-LNB CO vs. natural gas heat input reburn fuel . . . . . . . . 5-17

GR-LNB NO $\mathrm{O}_{x}$ vs. furnace exit flue gas $\mathrm{O}_{2} \ldots \ldots \ldots \ldots \ldots \ldots .45$

GR-LNB fly ash carbon vs. furnace exit flue gas $\mathrm{O}_{2} \ldots \ldots \ldots \ldots .5-20$

GR-LNB CO vs. furnace exit flue gas $\mathrm{O}_{2} \ldots \ldots \ldots \ldots \ldots \ldots \ldots$ 5-21

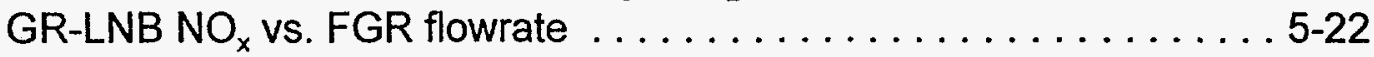

GR-LNB NOx reduction vs. time $\ldots \ldots \ldots \ldots \ldots \ldots \ldots \ldots \ldots .5-26$ 


\section{LIST OF FIGURES (con't)}

Figure

5-17

$5-18$

$5-19$

5-20

5-21

5-22

5-23

5-24

5-25

5-26

5-37

$7-1$

$7-2$

$7-3$

$7-4$

Description

$\mathrm{NO}_{x}$ vs. load

LNB-Modified baseline $\mathrm{NO}_{x}$ vs. furnace exit flue gas $\mathrm{O}_{2}$ Page

LNB-Modified baseline CO vs. furnace exit flue gas $\mathrm{O}_{2}$ 2nd Generation GR-LNB NO $x$ vs. gas heat input

$\mathrm{O}_{2}$

2nd Generation GR-LNB NO vs. furnace exit flue gas $\mathrm{O}_{2}$

2nd Generation GR-LNB fly ash carbon vs. furnace exit flue gas $\mathrm{O}_{2}$. $.5-36$ 2nd Generation GR-LNB CO vs. furnace exit flue gas $\mathrm{O}_{2} \ldots \ldots \ldots$ 5-37 2nd generation GR-LNB NO reduction vs. time GR-LNB $100 \%$ gas w/GR NO ${ }_{x}$ vs. gas heat input . . . . . . . . 5-42 GR-LNB $100 \%$ gas w/GR NO $\mathrm{N}_{x}$ vs. furnace exit flue gas $\mathrm{O}_{2} \ldots \ldots \ldots 5-43$ GR-LNB $100 \%$ gas w/GR CO vs. furnace exit flue gas $\mathrm{O}_{2} \ldots \ldots \ldots 5-44$ The effect of unit size on the cost of $\mathrm{NO}_{x}$ reduction $\ldots \ldots \ldots \ldots \ldots 7-12$ The effect of capacity factor on the cost of $\mathrm{NO}_{x}$ reduction $\ldots \ldots \ldots 7-13$ The effect of gas to coal price differential on cost of $\mathrm{NO}_{x}$ reduction . . 7-14 The effect of $\mathrm{SO}_{2}$ allowance price on cost of $\mathrm{NO}_{x}$ reduction $7-15$ 


\section{LIST OF ABBREVIATIONS}

\begin{tabular}{|c|c|}
\hline AFT & Ash Fusion Temperature \\
\hline AHT & Ash Hemispherical Temperature \\
\hline APCD & Air Pollution Control Division \\
\hline ASME & American Society of Mechanical Engineers \\
\hline AST & Ash Softening Temperature \\
\hline ASTM & American Society of Testing Materials \\
\hline B\&W & Babcock \& Wilcox \\
\hline BPMS & Boiler Performance Monitoring System \\
\hline BPR & Bypass Pressure Regulator \\
\hline CAAA & Clean Air Act Amendment \\
\hline ССТ & Clean Coal Technology \\
\hline CEMS & Continuous Emissions Monitoring System \\
\hline CIG & Colorado Interstate Gas \\
\hline CRT & Cathode Ray Tube \\
\hline CSA & Coal Stoichiometric Air \\
\hline DOE & U.S. Department of Energy \\
\hline EER & Energy and Environmental Research Corporation \\
\hline EPA & Environmental Protection Agency \\
\hline EPRI & Electric Power Research Institute \\
\hline EMP & Environmental Monitoring Plan \\
\hline ESP & Electrostatic Precipitator \\
\hline FD & Forced Draft \\
\hline FF & Fouling Factors \\
\hline FFDC & Fabric Filter Dust Collector \\
\hline FGR & Flue Gas Recirculation \\
\hline GR & Gas Reburning \\
\hline GR-LNB & Gas Reburning with Low $\mathrm{NO}_{x}$ Burners \\
\hline GRI & Gas Research Institute \\
\hline GSA & Natural Gas Stoichiometric Air \\
\hline HGI & Hardgrove Grindability Index \\
\hline HHV & Higher Heating Value \\
\hline HVT & High Velocity Temperature \\
\hline IDT & Initial Deformation Temperature \\
\hline ISO & International Standards Organization \\
\hline LHV & Lower Heating Value \\
\hline LNB & Low $\mathrm{NO}_{x}$ Burner \\
\hline NG & Natural Gas \\
\hline NPDES & National Pollution Discharge Elimination System \\
\hline NSPS & New Source Performance Standards \\
\hline OFA & Overfire Air \\
\hline OTR & Ozone Transport Region \\
\hline PC & Pulverized Coal \\
\hline PID & Proportional Integral Derivative \\
\hline
\end{tabular}

TOC - 7 
LIST OF ABBREVIATIONS (con't)

PSCo

QA

RSD

SNCR

SCR

SR

TA

TSS

U.S.

UT

WDPF

WQCD

w/o
Public Service Company of Colorado

Quality Assurance

Relative Standard Deviation

Selective Non-catalytic Reduction

Selective Catalytic Reduction

Stoichiometric Ratio

Total Combustion Air

Total Suspended Solids

United States

Ultrasonic Thickness

Westinghouse Distributed Process Family

Water Quality Control Division

Without 


\section{LIST OF UNITS}

\begin{tabular}{|c|c|}
\hline acfm & Actual Cubic Feet per Minute \\
\hline Btu & British Thermal Unit \\
\hline $\mathrm{cfm}$ & Cubic Feet per Minute \\
\hline $\mathrm{cm}$ & Centimeter \\
\hline $\mathrm{db}$ & Decibel \\
\hline dscf & Dry Standard Cubic Foot \\
\hline $\mathrm{ft}$ & Feet \\
\hline g & Gram \\
\hline gal & Gallon \\
\hline $\mathrm{gr}$ & Grain \\
\hline $\mathrm{hr}$ & Hour \\
\hline $\mathrm{J}$ & Joule \\
\hline $\mathrm{kg}$ & Kilogram \\
\hline $\mathrm{kJ}$ & Kilojoule \\
\hline klb & Thousand Pounds \\
\hline $\mathrm{kPa}$ & Kilopascal \\
\hline kscfm & 1,000 Standard Cubic Feet per Minute \\
\hline kW & Kilowatt \\
\hline 1 & Liter \\
\hline $\mathrm{Ib}$ & Pound \\
\hline $\mathrm{m}$ & Meter \\
\hline $10^{6} \mathrm{Btu}$ & Million Btu \\
\hline MJ & Million Joules \\
\hline $\mathrm{mg}$ & Milligram \\
\hline MGD & Million Gallons per Day \\
\hline $\min$ & Minute \\
\hline $\mathrm{MW}_{\mathrm{e}}$ & Megawatts Electric \\
\hline $\mathrm{Nm}$ & Normal Cubic Meter \\
\hline pH & Measure of acidity of a solution \\
\hline ppm & Parts per Million \\
\hline psi & Pounds per Square Inch \\
\hline psig & Pounds per Square Inch (Gauge) \\
\hline $\mathrm{rpm}$ & Revolutions per Minute \\
\hline sec & Second \\
\hline scfm & Standard Cubic Feet per Minute \\
\hline scf & Standard Cubic Foot \\
\hline TPY & Tons per Year \\
\hline W.C. & Water Column \\
\hline$\mu \mathrm{g}$ & Micro-gram \\
\hline${ }^{\circ} \mathrm{C}$ & Degrees Centigrade \\
\hline$\%$ & $\begin{array}{l}\text { Degrees Fahrenheit } \\
\text { Percent }\end{array}$ \\
\hline & Percent \\
\hline
\end{tabular}

TOC - 9 


\section{GLOSSARY OF TERMS}

Chemical Symbols:
$\mathrm{Al}_{2} \mathrm{O}_{3}$
$\mathrm{C}_{2} \mathrm{H}_{6}$
Aluminum Oxide (Alumina)
$\mathrm{C}_{3} \mathrm{H}_{8}$
Ethane
$\mathrm{Ca}$
Propane
$\mathrm{CaO}$
Calcium
$\mathrm{CH}$
Calcium Oxide
$\mathrm{CH}_{2}$
$\mathrm{CH}_{4}$
$\mathrm{CO}$
Hydrocarbon Radical
Hydrocarbon Radical
Methane
$\cos$
Carbon Monoxide
Carbonyl Sulfide
co.
Carbon Dioxide
$\mathrm{Fe}$
Iron
$\mathrm{FeS}$
Ferrus (II) Sulfide
$\mathrm{Fe}_{2} \mathrm{O}_{3}$
$\mathrm{HCl}$
Ferric Oxide
$\mathrm{HCN}$
Hydrogen Chloride
Hydrogen Cyanide
$\mathrm{H}_{2} \mathrm{O}$
Water
$\mathrm{H}_{2} \mathrm{~S}$
Hydrogen Sulfide
$\mathrm{K}_{2} \mathrm{O}$
Potassium Oxide
$\mathrm{Mg}$
$\mathrm{MgO}$
$\mathrm{N}_{2}$
$\mathrm{Na}_{2} \mathrm{O}$
$\mathrm{NH}_{3}$
$\mathrm{NO}_{x}$
$\mathrm{N}_{2} \mathrm{O}$
$\mathrm{NO}$
$\mathrm{NO}_{2}$
$\mathrm{O}_{2}$
$\mathrm{PM}_{10}$
$\mathrm{P}_{2} \mathrm{O}_{5}$
$\mathrm{SiO}_{2}$
$\mathrm{SO}_{2}$
$\mathrm{SO}_{3}$
$\mathrm{SR}$
Magnesium
Magnesium Oxide
Nitrogen (Diatomic)
Sodium Oxide
Ammonia
Nitrogen Oxides
Nitrous Oxide (Colorless Gas)
Nitric Oxide (Colorless Gas)
Nitrogen Dioxide (Brownish-red Gas)
Oxygen (Diatonic)
Particulate matter less than 10 microns in size
Phosphorous Pentoxide
Silicon Dioxide (Silica)
Sulfur Dioxide
Sulfur Trioxide
Stoichiometric Ratio
THC
Total Hydrocarbons
Titanium Dioxide 


\section{EXECUTIVE SUMMARY}

Under the U.S. Department of Energy's Clean Coal Technology Program (Round 3), a project was completed by the Energy and Environmental Research Corporation to demonstrate control of boiler flue gas emissions, specifically $\mathrm{NO}_{\mathrm{x}}$. The project involved Gas Reburning (GR) used in combination with low $\mathrm{NO}_{x}$ burners (LNBs) on an electric utility wall-fired coal boiler. This GR-LNB demonstration was sponsored by:

- U.S. Department of Energy (DOE)

- Gas Research Institute (GRI)

- $\quad$ Electric Power Research Institute (EPRI)

- Colorado Interstate Gas (CIG)

- Public Service Company of Colorado (PSCo)

- Energy and Environmental Research Corporation (EER)

Low $\mathrm{NO}_{x}$ burners (LNB) are designed to produce less $\mathrm{NO}_{\mathrm{x}}$ emissions than conventional burners. This is accomplished by mixing the air with the coal in such a way to yield lower flame temperatures (lower thermal $\mathrm{NO}_{\mathrm{x}}$ ) and in-flame zone combustion staging (lower fuel bound $\mathrm{NO}_{\mathrm{x}}$ ). GR is designed to reduce $\mathrm{NO}_{\mathrm{x}}$ in the flue gas by staged combustion, converting $\mathrm{NO}_{x}$ that has formed in the burner zone to diatomic nitrogen. $\mathrm{GR}$ involves the introduction of natural gas into the hot furnace flue gas stream. When combined, GR-LNB work together to minimize $\mathrm{NO}_{\mathrm{x}}$ emissions and maintain acceptable levels of $\mathrm{CO}$ emissions and carbon burnout. Several benefits are derived by adding GR to LNB's, including:

- Low capital cost

- Compatibility with high sulfur coal

- Incremental reduction in $\mathrm{SO}_{2}$ emissions

- No adverse effects on boiler thermal performance

- Minimal system operating complexity 
The objective of the project was to demonstrate the commercial readiness of the GR-LNB technology for application to pre-NSPS (New Source Performance Standards) utility boilers. These older boilers have one of several common firing configurations with the wall-fired type being the most common. The specific goal was to demonstrate that high levels of $\mathrm{NO}_{\mathrm{x}}$ reduction $(70 \%)$ could be achieved with minimal impacts to other areas of unit operation including carbon burnout, furnace slagging or corrosion, convective pass fouling, steam capacity and steam conditions, and other areas of unit performance.

\section{Site}

The site for this demonstration was PSCo's Cherokee Station, located in Denver, Colorado. The Cherokee Station is PSCo's largest electric power generating station, containing four steam generating units that generate a total of some $775 \mathrm{MW}_{\mathrm{e}}$. The GR-LNB was applied to Cherokee Unit \#3. The unit was constructed in 1962 and was not required to meet NSPS required under the Clean Air Act Amendments (applies to units constructed after 1971). Unit \#3 is a wall-fired unit with the original conventional burners being Babcock and Wilcox's flare-type pulverized coal (PC) burners. It has a nominal rating of $172 \mathrm{MW}_{\mathrm{e}}$ gross (158 $\mathrm{MW}_{\mathrm{e}}$ net). It fires Colorado Bituminous coal, with $0.40 \%$ sulfur and $10 \%$ ash. The unit has 16 burners that are located on the front wall of the furnace.

\section{Project Schedule}

The project, awarded in October, 1990 was completed in three phases:

$\begin{array}{lll}\text { - } & \text { Phase I } & \text { Design and Permitting } \\ \text { - } & \text { Phase II } & \text { Construction and Startup } \\ \text { - } & \text { Phase III } & \text { Operation, Data Collection, Reporting and Disposition }\end{array}$


Construction and startup was completed in November, 1992. Following parametric/ optimization testing, a one-year long term test program began in May, 1993. Testing was interrupted to install the Second Generation GR technology, and testing with this design was completed in January, 1995.

\section{Technology Description}

The technology is a co-application of two previously demonstrated technologies, GR and LNBs. The application of GR-LNB yields higher $\mathrm{NO}_{x}$ emission reductions than that achievable with either technology alone. LNBs reduce emissions of $\mathrm{NO}_{x}$ by staging the mixing of coal and air, resulting in a fuel-rich region within long flames and low peak flame temperatures. While LNBs reduce $\mathrm{NO}_{\mathrm{x}}$, they may result in higher levels of unburned carbon and higher emissions of $\mathrm{CO}$. Incomplete combustion can occur as a result of the burner air staging.

GR involves reducing the levels of coal and combustion air in the burner area and injecting natural gas into a reburn zone above the burners. Following this overfire air (OFA) is injected above the reburn zone. This three-zone process creates a reducing or reburn zone in the furnace wherein $\mathrm{NO}_{x}$ created in the primary zone is reduced to diatomic nitrogen. Each zone has a unique stoichiometric ratio (SR, ratio of air to that theoretically required for complete fuel combustion) as determined by the flow rates of coal, burner air, natural gas, and OFA. Flue gas recirculation (FGR) may be used to provide momentum to the injected natural gas. FGR has a low $\mathrm{O}_{2}$ content and as such has a minor impact on reburn and burnout zone SR's.

In this demonstration, FGR was used initially to provide momentum to the natural gas to achieve optimum penetration into the furnace flue gas. However, during long term testing it was determined that $\mathrm{FGR}$ had minimal effect on $\mathrm{NO}_{x}$ emissions. Cherokee Unit \#3 has 
a reburn zone residence time of 0.50 seconds which is sufficient to yield good $\mathrm{NO}_{\mathrm{x}}$ reduction without the need for FGR.

A second series of tests were added to evaluate the modified configuration and evaluate its impact. The natural gas injectors were re-designed to operate at higher pressure to increase the velocity of gas injection and the OFA ports were modified to enhance upper furnace flue gas/air mixing. This modified configuration is referred to as Second Generation Gas Reburning. FGR adds substantially to the capital cost of the GR system requires a slight increase in superheat attemperation water spray rates. Elimination of FGR is therefore a benefit to the economics of the GR technology.

\section{Demonstration Program}

The GR-LNB test program was developed to first optimize the system with short parametric tests and then operate it over a one-year demonstration period. The objective of the GRLNB parametric/optimization test program was to define the relationships that exist between the controlling parameters and the boiler outputs. These relationships were then used to approximate the boiler set points required for optimum reburning performance. Optimization testing was then completed to fine tune the system.

A one-year period of long-term GR-LNB testing was completed, with the unit operating under normal dispatch by the PSCo staff. The data from the testing were used to establish the impacts of GR-LNB on long term boiler performance and economics. These impacts included furnace conditions such as slagging and waterwall corrosion rates, bottom ash characteristics and sluicing requirements, convective pass fouling, steam generation and final steam temperatures and pressures, process auxiliary power requirements, impacts on the fabric filter dust collector, and process economics. 


\section{Technical Performance}

The new LNB's, installed by Foster Wheeler, reduced $\mathrm{NO}_{x}$ emissions from a preconstruction baseline of $0.73 \mathrm{lb} / 10^{6} \mathrm{Btu}$ to $0.46 \mathrm{lb} / 10^{6} \mathrm{Btu}$ at $3.5 \% \mathrm{O}_{2}$. This was a reduction of $37 \%$, not meeting the targeted $45 \%$ reduction. Also, the carbon-in-ash and CO could not be maintained at acceptable levels.

When GR was introduced, the $\mathrm{NO}_{\mathrm{x}}$ emissions dropped to an average of $0.25 \mathrm{lb} / 10^{6} \mathrm{Btu}$ at $3.25 \% \mathrm{O}_{2}$, yielding an overall GR-LNB reduction of $66 \%$. The gas heat input for this level of reduction was $18 \%$. Both carbon-in-ash and CO were at acceptable levels. Due to the substandard performance of the LNBs, the $70 \%$ reduction target could not be achieved without significant levels of reburn gas heat input.

Following installation of the Second Generation GR equipment and tune up of the LNBs, the system achieved similar reductions in $\mathrm{NO}_{x}$ emissions ( $64 \%$ ), but with only $12.5 \%$ reburn gas heat input. Again, both carbon-in-ash and $\mathrm{CO}$ were at acceptable levels.

The reburning zone operates under reducing or slightly fuel rich conditions. This suggests the possibility of increased tube wastage due to removal of the protective oxide layer and/or sulfide attack. Accordingly, the field evaluations included a comprehensive program of non-destructive (ultrasonic tube thickness) evaluations. The evaluations showed no evidence of increased tube wastage attributable to GR.

Although not part of the planned demonstration, the opportunity presented itself to perform testing with natural gas as the primary fuel coupled with GR. The Gas/Gas Reburning testing demonstrated a reduction in $\mathrm{NO}_{\mathrm{x}}$ emissions of $43 \%\left(0.30 \mathrm{lb} / 10^{6}\right.$ Btu reduced to 0.17 $\left.\mathrm{lb} / 10^{6} \mathrm{Btu}\right)$ when using $7 \%$ gas heat input. 


\section{Economics}

The cost and performance data from the Cherokee project were used to estimate the costs of a retrofit installation, operation and $\mathrm{NO}_{\mathrm{x}}$ reduction performance for commercial installation of a Second Generation GR-LNB on a 300 MWe power plant. The estimate is based on mature technology; i.e., a so-called "nth" plant which incorporates process improvements resulting from experience gained in earlier installations. The results of the economic analysis are as follows:

GR-LNB

Total installed cost

Capital requirement

Operation and maintenance cost

$\mathrm{NO}_{\mathrm{x}}$ removal cost - current dollars

$\mathrm{NO}_{x}$ removal cost - constant dollars
$\$ 7.48$ million

$\$ 7.80$ million

$\$ 2.14$ million

$\$ 1,027 /$ ton

$\$ 786 /$ ton

The analysis is based on a coal-to-gas differential of $\$ 1.00 / 10^{6} \mathrm{Btu}$, a $64 \% \mathrm{NO}_{x}$ removal efficiency with $12.5 \%$ gas heat input, and a $\$ 95 /$ ton $\mathrm{SO}_{2}$ allowance credit.

\section{Commercial Potential and Plans}

The market for the GR technology is difficult to assess at the present time in light of the recent Northeast State filings (states within the Northeast Ozone Transport Region) regarding $\mathrm{NO}_{x}$ emissions from other states. The Northeast States petitioned other states (AL, AR, DE, GA, IL, IN, IA, KY, LA, MA, MD, MI, MN, MS, MO, NC, NH, NY, PA, OH, RI, SC, TN, VA, WV \& WI) to reduce power plant (units $\geq 250$ million Btu/hr) $\mathrm{NO}_{x}$ emissions. The petitions vary, but most ask that the named states reduce their $\mathrm{NO}_{x}$ emissions by $85 \%$ or down to a level of $0.15 \mathrm{lb} / 10^{6} \mathrm{Btu}$, whichever is less stringent. If the targeted states implement regulations to meet these requested levels it could open a market for GR; 
however, the $\mathrm{NO}_{\mathrm{x}}$ emission level is so low that $\mathrm{GR}$ would have to be used in combination with other technologies such as selective catalytic reduction (SCR) or selective noncatalytic reduction (SNCR). It is unlikely that the combined GR-LNB technology would be used in this case for the combined technologies could not meet the requested $\mathrm{NO}_{\mathrm{x}}$ emission levels. A third technology such as SCR or SNCR would have to be added.

In addition to the state implementation plan (SIP) call, there are proposed new National Ambient Air Quality Standards (NAAQS) that would reduce ambient ozone levels by $50 \%$. If these proposed regulations become law there will be more ozone non-attainment areas in the U.S. putting added pressure on the electric utilities to reduce $\mathrm{NO}_{x}$ emissions (a precursor to ozone production).

These three $\mathrm{NO}_{x}$ reduction initiatives have created a great deal of confusion regarding the standards that electric utilities will have to meet. It has also delayed the electric utility industry from making decisions regarding $\mathrm{NO}_{x}$ emissions reductions.

\section{Conclusions}

The following results can be highlighted from the GR-LNB demonstration:

- $\quad$ GR-LNB can be installed and operated successfully on a wall-fired unit

- $70 \% \mathrm{NO}_{\mathrm{x}}$ reduction can be achieved

- The system can be operated consistently and reliably

- $\quad$ Carbon-in-ash and CO can be controlled to acceptable levels

- Boiler equipment experienced no mechanical degradation or failure 


\subsection{INTRODUCTION}




\subsection{Purpose of the Project Performance and Economics Report}

The Project Performance and Economics Report is a designated deliverable under U.S. Department of Energy Agreement No. DE-FC22-90PC90547, Attachment C (Federal Assistance Reporting Checklist). The purpose of this report is to discuss the technology performance results and to present economic analyses for evaluation of the commercial viability of the demonstrated technology, Gas Reburning with Low NO $\mathrm{N}_{x}$ Burners (GR-LNB). The report provides performance results for LNB, First Generation GR-LNB, and SecondGeneration GR-LNB in regard to their impact on $\mathrm{NO}_{x}$ control, thermal performance (i.e. steam conditions, efficiency, heat rate), and the environment (air emissions and aqueous discharges). The report also includes updated information made since the issuance of the Public Design Report.

The GR-LNB project goal at PSCo was to demonstrate that combined GR-LNB could be successfully used on wall-fired boilers to achieve significant reductions in $\mathrm{NO}_{\mathrm{x}}$ emissions. The total value of the GR-LNB project was $\$ 17.8$ million. This GR-LNB demonstration complements two other full-scale GR demonstrations completed by EER, in a CCT Round 1 program. These involved the co-application of GR with furnace Sorbent Injection (SI) at Illinois Power's Hennepin Station Unit 1 located in Hennepin, Illinois and at City Water, Light and Power's Lakeside Station Unit 7, located in Springfield, Illinois. These units have tangential and cyclone firing configurations respectively.

\subsection{Overview of the Project}

As part of the U.S. Department of Energy's Clean Coal Technology Program (Round 3), a project was completed by Energy and Environmental Research Corporation to demonstrate control of boiler emissions that comprise acid rain precursors, specifically 
$N_{x}$. The project involved combined Gas Reburning and Low NO ${ }_{x}$ Burners (GR-LNB) on a coal-fired utility boiler to determine its potential for reducing $\mathrm{NO}_{\mathrm{x}}$ emissions. Low $\mathrm{NO}_{\mathrm{x}}$ burners are designed to create less $\mathrm{NO}_{\mathrm{x}}$ than conventional burners. However, the $\mathrm{NO}_{\mathrm{x}}$ control achieved is limited to $30-50 \%$. Also, $\mathrm{CO}$ emissions tend to be at levels above acceptable standards.

Gas Reburning (GR) is designed to reduce the level of $\mathrm{NO}_{x}$ in the flue gas by staged fuel combustion. This technology involves the introduction of natural gas into the flue gas stream downstream of the primary coal burners (reburn zone) followed by the addition of overfire air to complete the combustion process. When combined, gas reburning and low $\mathrm{NO}_{x}$ burners work in harmony to both minimize $\mathrm{NO}_{x}$ emissions and maintain an acceptable level of $\mathrm{CO}$ emissions. Several additional benefits are also derived from adding GR to LNBs including:

- Low capital cost relative to more expensive scrubbers

- Compatibility with high-sulfur coal

- Incremental reduction in $\mathrm{SO}_{2}$ emissions, since natural gas contains no sulfur

- $\quad$ No adverse effects on boiler thermal performance

- Minimal system operating complexity

\subsubsection{Background and History of Project}

The development of gas reburning technology has been underway in various laboratories since the 1970's. EER, with the support of the EPA and GRI, began extensive bench and pilot-scale testing in 1981 to characterize the fundamental process variables. These tests provided valuable scale-up information needed for the development of commercial applications under industrial conditions. 


\subsubsection{Project Organization}

The GR-LNB demonstration was sponsored by:

- U.S. Department of Energy (DOE)

- $\quad$ Gas Research Institute (GRI)

- $\quad$ Electric Power Research Institute (EPRI)

- $\quad$ Colorado Interstate Gas (CIG)

- Public Service Company of Colorado (PSCo)

- Energy and Environmental Research Corporation (EER)

Figure 1-1 presents the Project Management Structure describing the contributions of the various sponsors and their relationships to each other and to DOE.

\subsubsection{Project Description}

Gas reburning involves the injection of natural gas, typically accounting for 15 to $25 \%$ of the total heat input, into the furnace region above the coal burners. In First Generation GR systems, such as the original GR system retrofitted to Unit 3, recirculated flue gas (FGR) was used as a carrier gas to add momentum to the reburning fuel to enhance mixing with the furnace flue gas.

The injected natural gas forms a slightly fuel-rich zone in which $\mathrm{NO}_{x}$ from the burner region is reduced to a series of nitrogenous intermediates such as $\mathrm{NH}_{3}$ and $\mathrm{HCN}$ and finally to diatomic nitrogen, $\mathrm{N}_{2}$. Overfire air (OFA) is added higher up in the furnace to burn out combustible matter under a normal excess air level. 


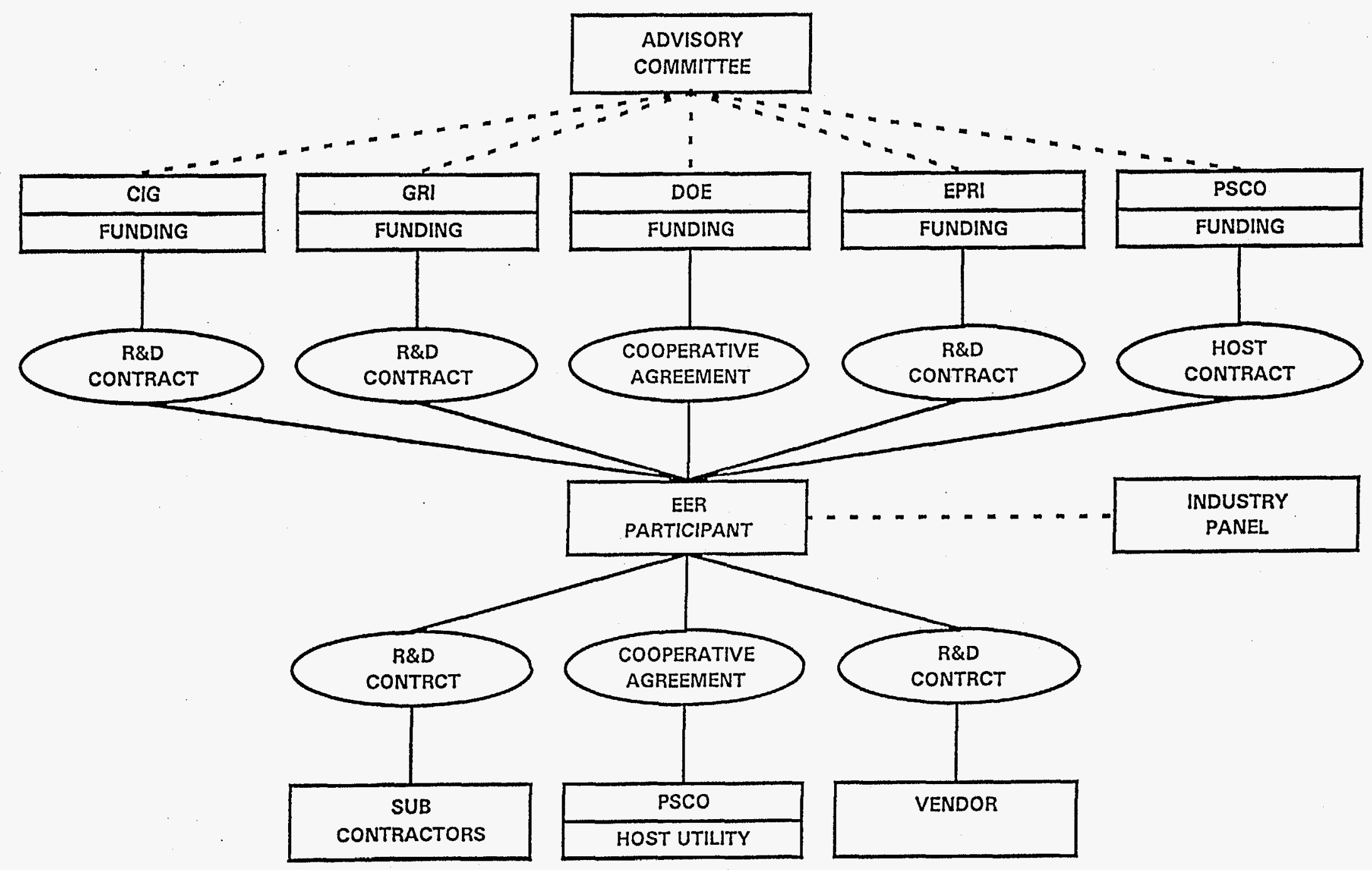

Figure 1-1. Project management structure 
Low $\mathrm{NO}_{x}$ burners operate by delaying the mixing of coal and air and hence creating a fuelrich reducing zone at their core. They typically have secondary (in some cases tertiary) air zones, with the air split impacting the final $\mathrm{NO}_{x}$ level. They also create longer flames with lower peak flame temperatures. This reduces $\mathrm{NO}_{x}$ formation from fuel bound nitrogen and from thermal fixation of $\mathrm{N}_{2}$ in the flame. Typically, $\mathrm{LNBs}$ achieve $\mathrm{NO}_{x}$ reductions in the 30 to $50 \%$ range.

The GR-LNB project was completed in three planned project phases as described below:

$\begin{array}{ll}\text { - Phase I } & \begin{array}{l}\text { Engineering Design } \\ \text { Permitting }\end{array} \\ \text { - Phase II } & \begin{array}{l}\text { Construction } \\ \text { Startup }\end{array} \\ \text { - Phase III } & \begin{array}{l}\text { Optimization Testing } \\ \text { Long Term Testing } \\ \text { Second Generation Gas Reburning Testing } \\ \text { Reporting and Disposition }\end{array}\end{array}$

Following long term testing, it was determined that the system could operate effectively without a flue gas recirculation system and the GR system was modified. The modified configuration is referred to as Second Generation Gas Reburning and was tested in conjunction with an extension to the program granted by the DOE. Specific modifications included the removal of the FGR system, installation of high velocity natural gas jets, and installation of double concentric overfire air ports for enhanced CO burnout.

\subsubsection{Site}

The demonstration was performed at PSCo's Cherokee Unit 3, located in Denver, Colorado. This unit is a $172 \mathrm{MW}_{\mathrm{e}}$ wall-fired boiler that uses Colorado Bituminous, low- 
sulfur coal. The PSCo unit is larger than the previous units that demonstrated GR and provided an excellent scale-up from laboratory testing. PSCo voluntarily agreed to reduce boiler $\mathrm{NO}_{\mathrm{x}}$ emissions as a public relations move in response to the unique political environment of the Denver area (i.e., the "brown cloud" phenomenon) and proved to be both a forward thinking utility and a very cooperative Host.

The target for the project was a reduction of 70 percent in $\mathrm{NO}_{x}$ emissions. The gas reburning system was designed by EER and the low $\mathrm{NO}_{\mathrm{x}}$ burners were provided by Foster Wheeler Energy Corporation. Based on the successful results of the program, the installed equipment was retained by PSCo.

\subsubsection{Project Schedule}

Figure 1-2 is a schedule of the GR-LNB demonstration. The key dates from the schedule were as follows:

October, 1990

November, 1992

April, 1993

January, 1994

August, 1994

January, 1995
Initiated project

Construction and startup completed

Optimization testing completed

Long term testing completed

Second generation GR testing initiated

Second generation GR testing completed

During the second generation testing, approximately two weeks of $100 \%$ gas firing was completed using Gas/Gas Reburning. The low $\mathrm{NO}_{x}$ burners were capable of firing either $100 \%$ coal or $100 \%$ natural gas up to full load. 


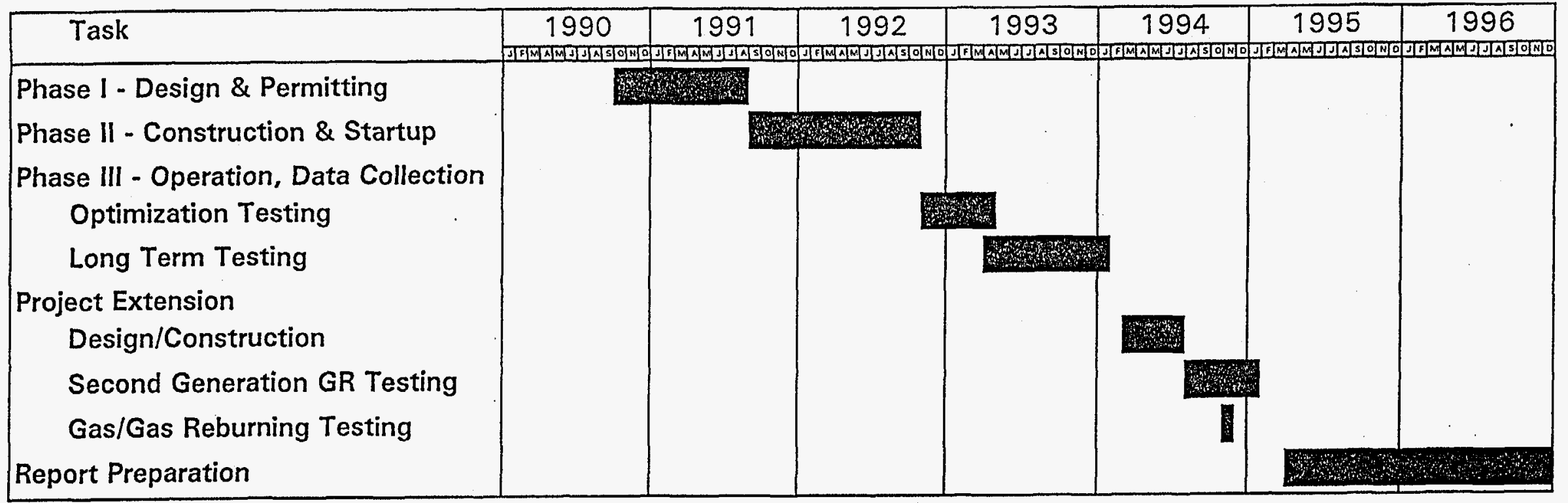

Figure 1-2. Schedule for GR-LNB demonstration 


\subsection{Objectives of the Project}

The objective of the project is to demonstrate the commercial readiness of the GR-LNB technology for application to older pre-NSPS utility boilers. These older boilers have one of several common firing configurations with the wall-fired type being the most common. The specific goal was to demonstrate that high levels of $\mathrm{NO}_{x}$ reductions could be achieved over the long term with minor impacts on other areas of unit operation including combustion completion (quantified by unburned carbon-in-ash), furnace slagging or corrosion, convective pass fouling, steam capacity and final steam conditions, and other areas of unit performance. To achieve this goal the GR-LNB system was optimized through parametric tests to evaluate each process parameter individually, then the GRLNB system was operated over an extended period with the unit under dispatch load control. During this period the boiler and GR-LNB system was operated by regular plant personnel. Ultrasonic Thickness (UT) mapping of the waterwall and convective pass tubes was conducted to determine the impact of GR-LNB on tubewall wastage rates.

\subsection{Significance of the Project}

This project demonstrated a co-application of two $\mathrm{NO}_{\mathrm{x}}$ control technologies which are at different stages of commercial readiness. Gas Reburning is a relatively new technology, which has only recently been applied at full scale in the U.S. Low $\mathrm{NO}_{x}$ Burners is a far more common $\mathrm{NO}_{\mathrm{x}}$ control technology which has been widely applied, especially in response to regulatory mandates outlined in Title IV of the Clean Air Act Amendments of 1990. The combined technologies can yield $\mathrm{NO}_{\mathrm{x}}$ control exceeding $70 \%$, which is also achieved by the far more costly technology, Selective Catalytic Reduction (SCR). Hence, the demonstration of GR-LNB aids the electric utility industry by offering an alternate cost effective $\mathrm{NO}_{x}$ control technology. 


\subsection{TECHNOLOGY DESCRIPTION}




\subsection{Description of the Demonstrated Technology}

The technology evaluated for Cherokee Station Unit \#3 is a co-application of two previously demonstrated technologies, GR and LNB. The GR system was designed and constructed by EER, which previously completed demonstrations of the technology at boilers with other firing configurations in conjunction with a DOE CCT (Round 1) program. GR has been demonstrated at the following units:

- $\quad$ Illinois Power

Hennepin Station Unit 1

$71 \mathrm{MW}_{\mathrm{e}}$ (net) tangentially-fired unit

GR reduced $\mathrm{NO}_{\mathrm{x}}$ by $67 \%$ using $18 \%$ gas heat input

- $\quad$ City Water Light and Power

Lakeside Station Unit 7

$33 \mathrm{MW}_{\mathrm{e}}$ cyclone-fired unit

GR reduced $\mathrm{NO}_{x}$ by $66 \%$ using $22 \%$ gas heat input

Following an evaluation of major burner suppliers, PSCo selected Foster Wheeler Energy Corporation's Controlled Flow/Split Flame burners for the LNBs.

\subsubsection{Overview of GR-LNB Technology}

The co-application of GR and LNB yields a higher $\mathrm{NO}_{x}$ emissions reduction than either technology can achieve alone. LNBs nominally reduce $\mathrm{NO}_{x}$ by 30 to $50 \%$, while GR nominally achieves a 50 to $60 \%$ reduction. The targeted $\mathrm{NO}_{\mathrm{x}}$ reduction for this demonstration was $70 \%$. The technology is compared on economic and performance bases to selective catalytic reduction (SCR) and selective non-catalytic reduction (SNCR). SCR is more efficient but has high capital and operating costs. SNCR is low in capital cost 
but $\mathrm{NO}_{\mathrm{x}}$ reductions are not as great and it has a potential ammonia slip problem that can result in fouling of the air heater.

In addition to $\mathrm{NO}_{x}$ reduction, the co-application of $\mathrm{GR}$ and $\mathrm{LNB}$ results in reductions in $\mathrm{SO}_{2}$ by $18 \%$ and $\mathrm{CO}_{2}$ by $8 \%$ plus some reduction in particulate emissions when the natural gas heat input is $18 \%$. The reductions in species other than $\mathrm{NO}_{\mathrm{x}}$ are due to differences between the fuels cofired. Natural gas is free of sulfur, fuel-bound nitrogen, and ash and has a higher hydrogen-to-carbon ratio than coal.

LNBs reduce emissions of $\mathrm{NO}_{x}$ by staging the mixing of coal and air resulting in a fuel-rich region for char combustion, longer flames, and lower peak flame temperatures. They generally use dual air registers in parallel to delay the mixing of air with coal injected through a coal nozzle in the center of the burner. LNB retrofits involve modification of the coal nozzle, air registers, and the burner throat. The burner throat is formed by the bending of furnace tubewalls, then addition of refractory lining. If the LNB burner throat diameter is the same as that the original burners, then minor modifications such as that associated with a change in refractory is sufficient. However, wider burner throat diameters generally favor more gradual coal/air mixing, so that new tubewall sections necessitating pressure part modifications may be required.

While $\mathrm{LNBs}$ reduce $\mathrm{NO}_{x}$, they may result in higher levels of unburned carbon and higher emissions of $\mathrm{CO}$. These are formed by incomplete combustion which may result from the staging of coal/air mixing. LNBs do not affect the emissions of other species such as $\mathrm{CO}_{2}$, $\mathrm{SO}_{2}$, and particulate matter.

GR involves reducing the levels of coal and combustion air in the burner area and injecting natural gas above the burners followed by the injection of overfire air (OFA) above the reburn zone as shown in Figure 2-1. 


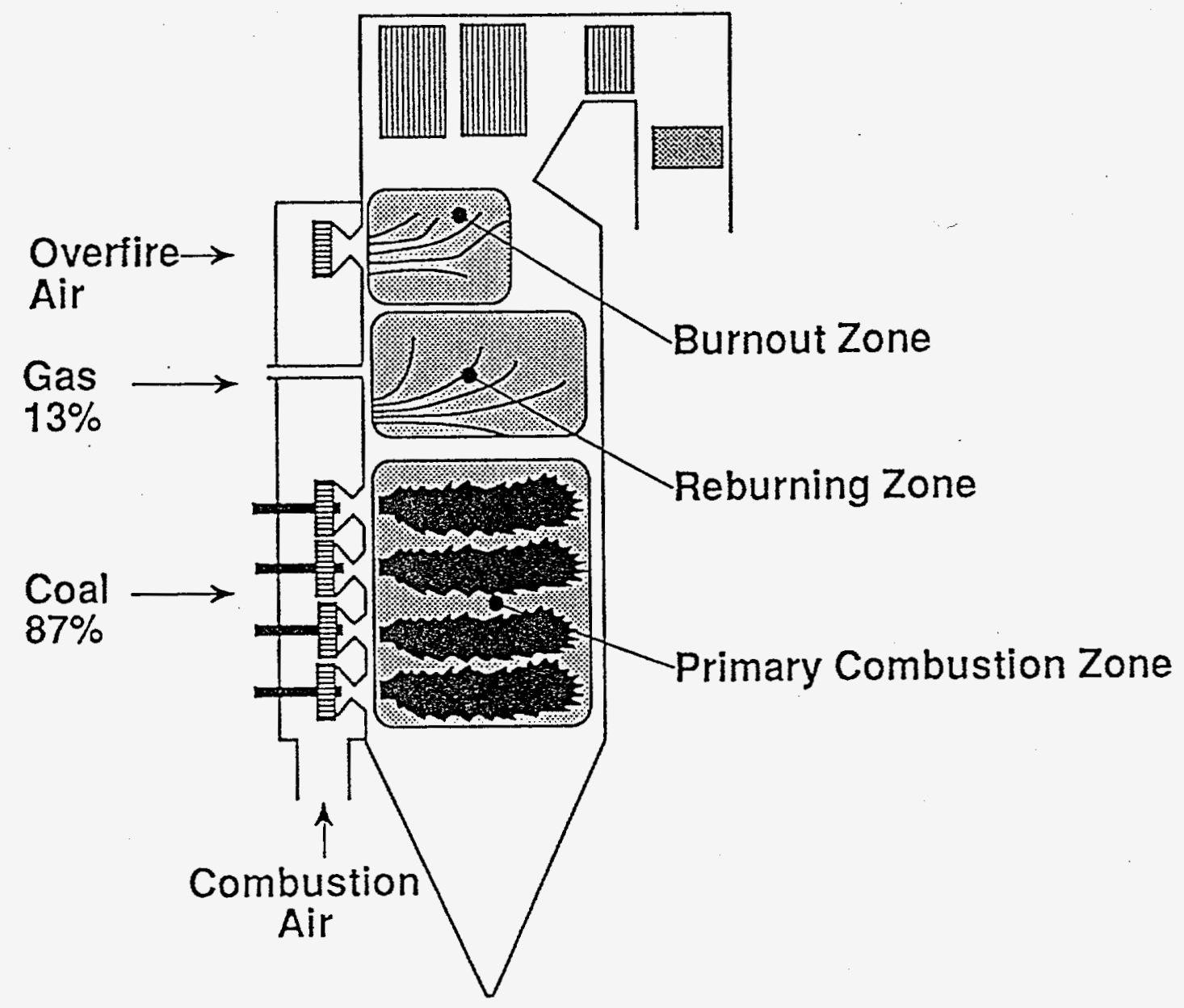

Figure 2-1. Schematic of Gas Reburning System 
This three-zone process creates a reducing area in the boiler furnace within which $\mathrm{NO}_{\mathrm{x}}$ created in the primary zone is reduced to elemental nitrogen and other less harmful nitrogen species. Each zone has a unique stoichiometric ratio (SR, ratio of air to that theoretically required for complete combustion) as determined by the flow of coal, burner air, natural gas, and OFA. Flue gas recirculation (FGR) may be used to provide momentum to the injected natural gas. FGR has a low $\mathrm{O}_{2}$ content and therefore has a minor impact on reburn and burnout zone SR's. The descriptions of the zones are as follows:

- Primary (burner) Zone: Coal is fired at a rate corresponding to 75 to 90 percent of the total heat input, under low excess air. $\mathrm{NO}_{\mathrm{x}}$ created in this zone is limited by the lower heat release and the reduced excess air level. The burner zone is nominally operated at a stoichiometric ratio $\left(\mathrm{SR}_{1}\right)$ of 1.10 (10\% excess air) forming a balance between $\mathrm{NO}_{x}$ formation and carbon conversion. The flow of combustion air to the burners is reduced to create this condition.

- Reburn Zone: Reburn fuel (natural gas in this case) injection creates a fuelrich region within which carbon monoxide and hydrogen are formed and methane breaks down to hydrocarbon fragments $\left(\mathrm{CH}_{1} \mathrm{CH}_{2}\right.$, etc.), all three of which react with $\mathrm{NO}_{x}$, reducing it to atmospheric nitrogen. The optimum reburn zone stoichiometric ratio $\left(\mathrm{SR}_{2}\right)$ is 0.90 , achieved by injecting natural gas at a rate corresponding to 10 to 25 percent of the total heat input. At this condition there exists insufficient oxygen to complete the combustion of the fuel in the zone. The injection of natural gas must be optimized with respect to rapid dispersion and mixing with the furnace flue gas since typically the residence time in the upper furnace is limited. Analyses of these conditions are used to select the number and size of injectors, their placement and the quantity of carrier gas (FGR) used. 
- Burnout (exit) Zone: OFA is injected higher up in the furnace to complete the combustion. OFA is typically 20 percent of the total air flow, maintaining a minimum excess air of 15 percent. The burner zone stoichiometric ratio $\left(\mathrm{SR}_{3}\right)$ is optimized to minimize $\mathrm{CO}$ emissions and carbon-in-fly ash.

In general, the SRs in all three zones should be at the lowest acceptable values to maintain the highest possible boiler efficiency consistent with gas reburning technology.

The GR-LNB system was controlled by a Westinghouse Distributed Process Family system (WDPF). The WDPF provides integrated modulating control, sequential control and data acquisition for a wide variety of system applications. All start/modulation/stop operations are performed in the control room using a keyboard-CRT with custom graphics. The control system was designed to accommodate operation of the boiler with or without GR.

FGR was used initially to provide momentum to the natural gas to achieve good furnace flue gas penetration and mixing. However, during the long term testing phase of the project, it was determined that the FGR had minimal effect on $\mathrm{NO}_{x}$ emissions. Therefore, a second series of tests was added to the project to evaluate a modified configuration and measure its impact. This technology is referred to as Second Generation Gas Reburning and is described as follows:

- The FGR system, originally designed to provide momentum to the natural gas, was removed. The change will result in reduced capital costs on future designs.

- Natural gas injection was optimized at about $13 \%$ gas heat input, compared to the First Generation operating value of $18 \%$. FGR elimination required incorporation of high velocity injectors, which made greater use of the 
available natural gas pressure. The change resulted in reduced operating cost due to the lower gas usage.

- The OFA ports were modified to provide higher jet momentum, especially at low total flows.

- The OFA ports were also modified to provide air swirl capability and velocity control. The modification was designed to improve lateral coverage of the furnace and turbulence in mixing with unburned fuel. This change provided $\mathrm{CO}$ control at lower gas levels, which was a concern with the First Generation design.

\subsubsection{Process Design Tools}

The design of the GR-LNB system was completed according to a standardized methodology developed by EER. It includes the use of tools such as an isothermal physical flow model, computational heat transfer model, and kinetics ( $\mathrm{NO}_{\mathrm{x}}$ reduction) model. The overall approach to the GR system design is illustrated in Figure 2-2. The process design began with site characterization of the host unit in a brief field test. The data generated in this test included emissions (normal $\mathrm{NO}_{x}$ and $\mathrm{O}_{2}$ levels), furnace gas temperatures and velocities (taken through available ports), and detailed boiler operating and steam cycle data. These were used with the extensive data base developed for the GR to devise preliminary GR process and injector specifications.

A three dimensional heat transfer code was used to evaluate the impacts of GR on the boiler gas temperature profile and heat transfer characteristics. The heat transfer code in conjunction with a boiler performance code evaluated the mean gas temperature profile, heat absorptions by the heat exchangers, temperatures of the deposit surface, steam generation rate, and final steam temperature. A reduced scale isothermal physical flow 


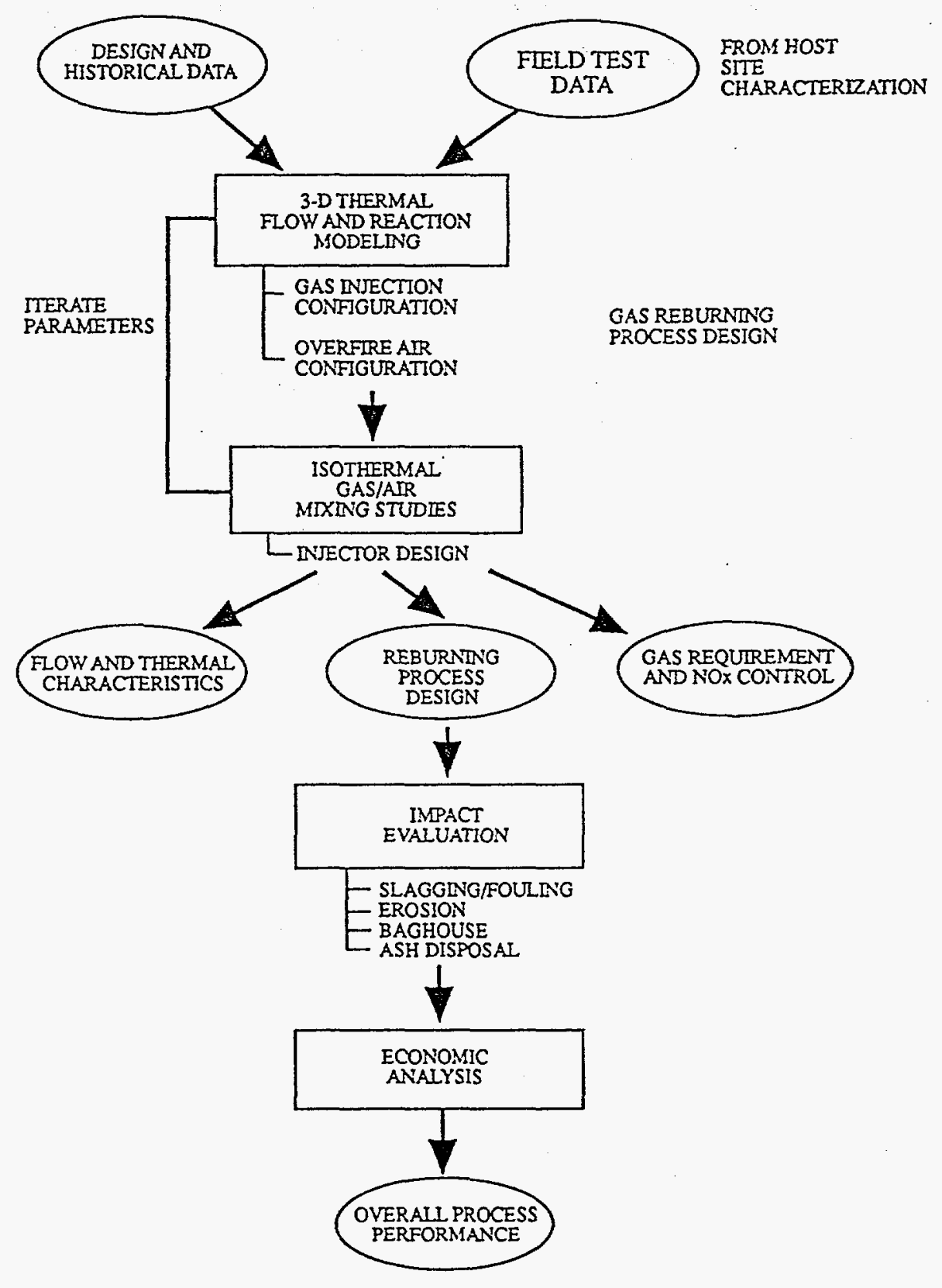

Figure 2-2. Technical approach to process design 
model was built and fitted with the preliminary $G R$ injection scheme. The natural gas/FGR and OFA injector configurations were evaluated for dispersion and mixing and optimized for these parameters through an iterative procedure. After flow rates and injection details of the reburn fuel and OFA were finalized, the kinetics code was run to predict the final $\mathrm{NO}_{x}$ level. The process design was completed by evaluating potential impacts on various areas of boiler performance such as slagging/fouling, tubewall wastage, baghouse performance, ash disposal, and overall power cost impacts.

A $1 / 15$ scale isothermal physical flow model of the Cherokee Unit \#3 boiler was constructed. This Plexiglas model was designed to match the velocity profile and pressure drop coefficient of each heat exchanger to those of the full-scale unit. The injection configurations for the reburn fuel/FGR and OFA were evaluated for dispersion and mixing using visual and tracer dispersion mapping techniques. Visual jet mixing patterns were observed using either smoke or neutrally buoyant soap bubbles. Tracer dispersion was determined through injection of a species such as methane and final tracer mapping at selected planes of interest.

A two dimensional steady state heat transfer code was used to evaluate the impacts of GR on the heat transfer characteristics. The model divided the furnace into a grid of radial/axial zones. The heart of the code was a radiation heat transfer model which used a semistochastic approach to follow the radiative beams through the processes of emission, reflection and absorption within a prescribed numerical tolerance. The model also calculated convective heat transfer in the sections of the boiler where radiation heat transfer was dominant. A boiler performance code performed a steam side energy balance, but also calculated flue gas side temperature changes in parts of the boiler where convective heat transfer dominated. The output of both codes was the mean gas temperature profile in the furnace, heat absorption by each heat exchanger, temperature of deposit surfaces, and impacts on steam flow rate and temperature. 
A NO $\mathrm{N}_{\mathrm{x}}$ control code was run using the temperature profile and mixing rate data as inputs. This code was programmed with the kinetics of reactions for hydrocarbon combustion and fixed nitrogen reactions to yield final $\mathrm{NO}_{x}$ emissions/reductions. It has representation of 200 fundamental reactions and has been extensively validated with field measurements.

\subsection{Description of the Demonstrated Facilities}

\subsubsection{Detailed Site Description}

The site for this demonstration was PSCO's Cherokee Station, located in Denver, Colorado. The Cherokee Station is PSCO's largest electric power generating station, containing four steam generating boilers, with a total capacity of $775 \mathrm{MW}_{\mathrm{e}}$. Unit \# 3 served as the host boiler for the GR-LNB demonstration. The unit was constructed in 1962 and therefore is not required to meet New Source Performance Standards (NSPS) required by the Clean Air Act Amendments (CAAA) for units constructed after 1971. The boiler is a balanced draft wall-fired unit, the original burners being Babcock and Wilcox (B\&W) flaretype PC burners. It has an electric power rating of $172 \mathrm{MW}_{\mathrm{e}}$ gross, or $158 \mathrm{MW}_{\mathrm{e}}$ net. It fires pulverized Western U.S. bituminous coal, with a sulfur content of $0.4 \%$ and an ash content of $10 \%$, through 16 burners on the front wall of the unit.

Coal is pulverized with four Riley Stoker No. 556 duplex drum pulverizers to specified fineness of $70 \%$ passing 200 mesh U.S. Standard sieve (74 micron) and $98.5 \%$ passing 50 mesh (297 micron) sieve. Pulverized coal is conveyed by $160^{\circ} \mathrm{F}\left(71^{\circ} \mathrm{C}\right)$ primary air to the burners and combusted with $600^{\circ} \mathrm{F}\left(316^{\circ} \mathrm{C}\right)$ secondary air in the $4 \times 4$ burner array. Combustion occurs in the furnace. The flue gas flows up through the furnace then through a secondary superheater, reheat superheater, primary superheater, economizer, and two rotary air preheaters. The flue gas then is ducted to a baghouse fabric filter dust collector (FFDC) for particulate collection. Figure 2-3 is a schematic of the boiler; boiler and baghouse design specifications are listed in Table $2-1$. 


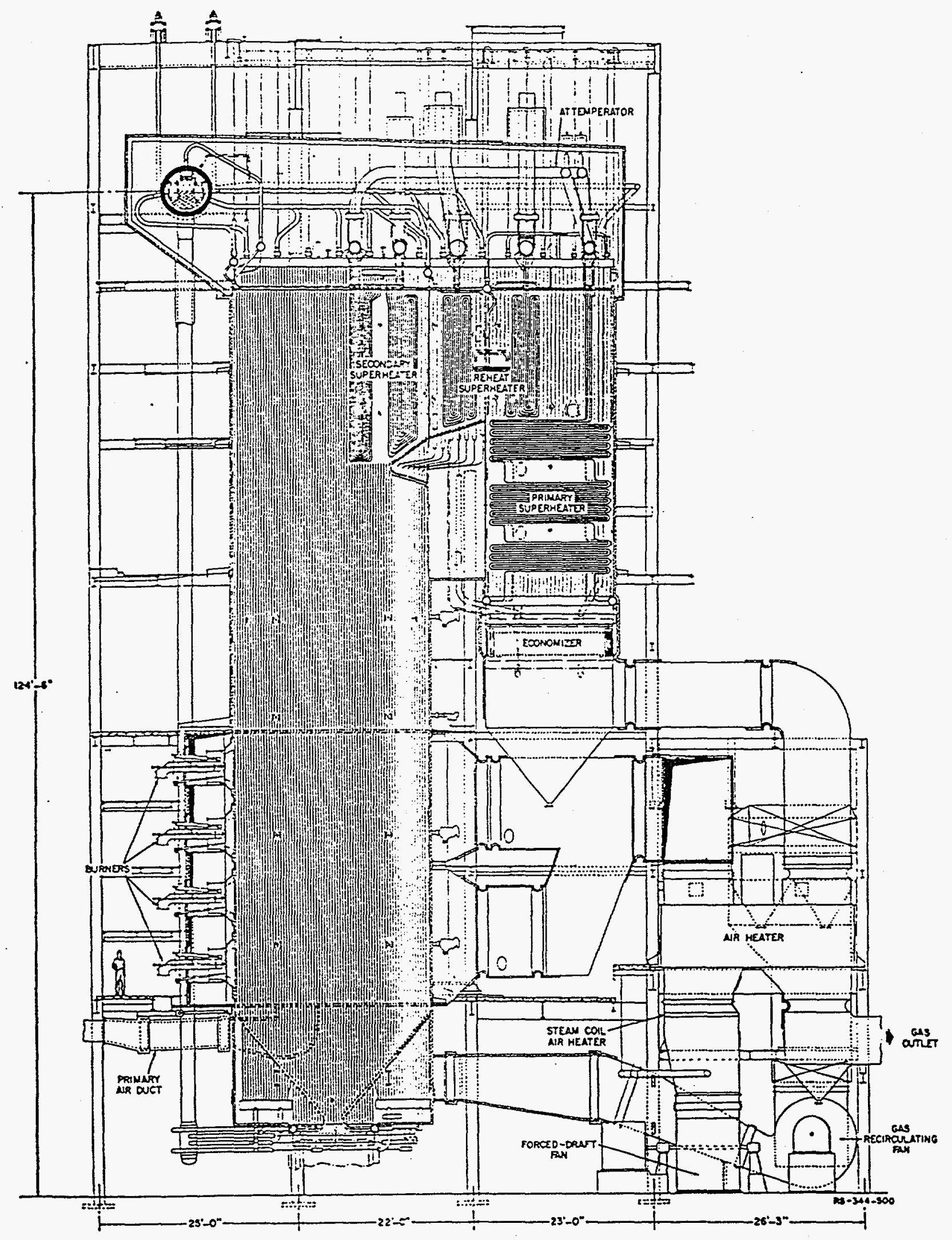

Figure 2-3. Schematic of Cherokee Station Unit 3 
TABLE 2-1. BOILER AND BAGHOUSE SPECIFICATIONS FOR CHEROKEE Unit \#3

\begin{tabular}{|c|c|}
\hline \multicolumn{2}{|l|}{ Boiler } \\
\hline Year Installed & 1962 \\
\hline Manufacturer & Babcock \& Wilcox \\
\hline Fuel Type & Pulverized Coal, Western U.S. Bituminous \\
\hline Boiler Firing Configuration & Front Wall-Fired, Balanced Draft \\
\hline Number of Pulverizers & 4, with 4 Burner Elevations \\
\hline Superheat Steam Flow & $1,140,000 \mathrm{lb} / \mathrm{hr}$ \\
\hline Steam Temperature & $1005^{\circ} \mathrm{F}$ \\
\hline Steam Pressure & 1925 psig \\
\hline Reheat Steam Flow & $932,000 \mathrm{lb} / \mathrm{hr}$ \\
\hline RH Steam Temperature & $1005^{\circ} \mathrm{F}$ \\
\hline Furnace Dimensions & 42' Width, 24' Depth, 104' Height \\
\hline Furnace Volume & $91,320 \mathrm{ft}^{3}$ \\
\hline Furnace Heat Release Rate & $1,637,000 \mathrm{Btu} / \mathrm{ft}^{2}$ \\
\hline \multicolumn{2}{|l|}{ Heat Exchanger Surface Area } \\
\hline -Furnace & $16,362 \mathrm{ft}^{2}$ \\
\hline -Primary Superheater & $62,939 \mathrm{ft}^{2}$ \\
\hline - Secondary Superheater & $11,963 \mathrm{ft}^{2}$ \\
\hline - Reheat Superheater & $23,806 \mathrm{ft}^{2}$ \\
\hline -Economizer & $14,020 \mathrm{ft}^{2}$ \\
\hline \multicolumn{2}{|l|}{ Baghouse } \\
\hline Year Installed & 1980 \\
\hline Manufacturer & Buell \\
\hline Gross Air/Cloth Ratio & 2.03 \\
\hline Design Flue Gas Flow & $825,000 \mathrm{acfm}$ \\
\hline Design Flue Gas Temperature & $290^{\circ} \mathrm{F}$ \\
\hline
\end{tabular}


At its capacity Cherokee Unit \#3 produces $1,140,000 \mathrm{lb} / \mathrm{hr}(143.7 \mathrm{~kg} / \mathrm{s})$ of main steam, at a temperature of $1005^{\circ} \mathrm{F}\left(541^{\circ} \mathrm{C}\right)$ and pressure of $1925 \mathrm{psig}(13,270 \mathrm{kPa})$. It reheats $932,000 \mathrm{lb} / \mathrm{hr}(117.5 \mathrm{~kg} / \mathrm{s})$ steam to the same design temperature. The design full load heat input is $1.65 \times 10^{9} \mathrm{Btu} / \mathrm{hr}\left(483.6 \mathrm{MW}_{\mathrm{e}}\right)$, for a net heat rate of $10,400 \mathrm{Btu} / \mathrm{kWhr}(10,970$ $\mathrm{kJ} / \mathrm{kWhr}$. Steam temperature is controlled by attemperation sprays in both the main and reheat cycles and by recirculation of flue gas over the load range. FGR is typically employed as load drops in order to improve flue gas mass velocity and thereby enhance convective heat transfer to the superheaters. The FGR system has a capacity to recycle $20 \%$ of the total boiler exit flue gas at full load.

The baghouse was erected by Buell in 1980, replacing an electrostatic precipitator (ESP) and wet scrubber system used for particulate collection. It was designed to treat 825,000 $\mathrm{cfm}\left(389 \mathrm{~m}^{3} / \mathrm{s}\right)$ of flue gas at a temperature of $290^{\circ} \mathrm{F}\left(143^{\circ} \mathrm{C}\right)$. It also has a gross cloth to air ratio of 2.03 and a design maximum pressure drop of $7.6^{\prime \prime}$ W.C (1.9 kPa). The bag house has a guarantee outlet grain loading of $0.007 \mathrm{gr} / \mathrm{dscf}\left(0.016 \mathrm{~g} / \mathrm{m}^{3}\right)$; testing has verified that the guarantee is being met.

\subsubsection{Baseline $\mathrm{NO}_{x}$ and $\mathrm{CO}$ Emissions}

Boiler emissions and combustion characteristics were evaluated through a field test performed during July, 1991. The test measured unit performance over a wide range of loads and excess air levels and included boiler emissions at the economizer outlet and measurements of furnace heat flux, furnace exit gas temperatures (with local $\mathrm{CO}$ and $\mathrm{O}_{2}$ concentrations), and unburned carbon-in-ash. The emissions of $\mathrm{NO}_{x}$ and $\mathrm{CO}$ at full load are shown as a function of boiler $\mathrm{O}_{2}$ in Figure 2-4. $\mathrm{NO}_{x}$ emissions at a medium $\mathrm{O}_{2}$ level of $3.5 \%$ were approximately $0.73 \mathrm{lb} / 10^{6} \mathrm{Btu}\left(314 \mathrm{mg} / 10^{6} \mathrm{~J}\right)$. The peak $\mathrm{NO}_{\mathrm{x}}$ emissions rate was $0.83 \mathrm{lb} / 10^{6} \mathrm{Btu}\left(357 \mathrm{mg} / 10^{6} \mathrm{~J}\right)$, measured at boiler $\mathrm{O}_{2}$ levels above $4.2 \%$. Emissions of $\mathrm{CO}$ varied significantly with $\mathrm{O}_{2}$, as typically observed in coal-fired boilers. CO emissions 


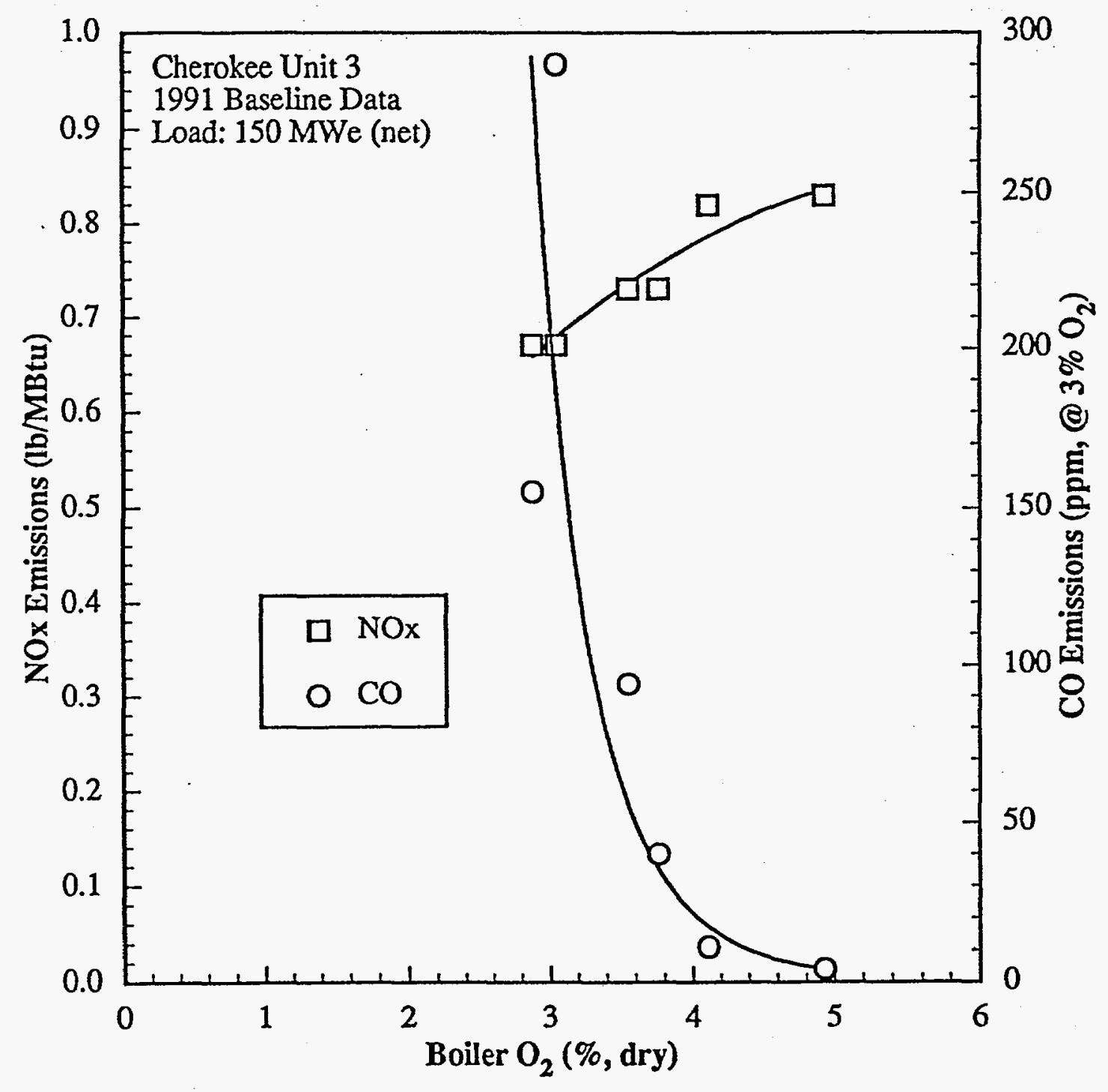

Figure 2-4. Pre-project baseline $\mathrm{NO}_{x}$ and $\mathrm{CO}$ data 
were under $200 \mathrm{ppm}$ at boiler $\mathrm{O}_{2}$ levels above $3.0 \%$ and under $50 \mathrm{ppm}$ at boiler $\mathrm{O}_{2}$ levels above $3.7 \%$.

\subsection{Retrofit Description}

Figure 2-5 is an overview of the GR system equipment. Cherokee Unit \#3 had been capable of firing natural gas up to $100 \%$ of full load prior to initiation of the project. Natural gas for the reburning system was routed through a 6-inch $(15 \mathrm{~cm})$ line from the existing natural gas header to a metering and control station. From there, natural gas piping is divided into two 8 -inch $(20 \mathrm{~cm})$ lines, through valve trains to meter and modulate the flow, then to sixteen injection nozzles, eight each on the boiler front and rear walls. Flue gas is extracted from the existing FGR header, then routed to a multiclone for particulate matter removal, a high static fan to boost the pressure to that required for injection, through two venturis for flow measurement, and then to the nozzles on the furnace walls. OFA is extracted from two secondary air ducts, routed to an OFA fan to boost the pressure to the needed level, then directed to six injection ports on the front wall of the unit.

\subsubsection{GR-LNB Design Criteria}

The process design criteria for the GR-LNB system and expected performance are discussed in this section. The primary goal of the design was to reduce emissions of $\mathrm{NO}_{\mathrm{x}}$ by $70 \%$. This was to be accomplished while minimizing potentially harmful impacts such as furnace wall corrosion and superheater tubewall erosion and maximizing beneficial impacts such as reduction in emissions of particulates, $\mathrm{SO}_{2}$ and $\mathrm{CO}_{2}$. The design conditions for GR-LNB are presented in Table 2-2.

The boiler was expected to achieve its design capacity of $158 \mathrm{MW}_{\mathrm{e}}$ (net) with a net heat rate of $10,400 \mathrm{Btu} / \mathrm{kWhr}(11,000 \mathrm{~kJ} / \mathrm{kWhr})$ and a boiler efficiency of $87 \%$, while operating GR-LNB. It was also expected that the main and reheat steam conditions could be 


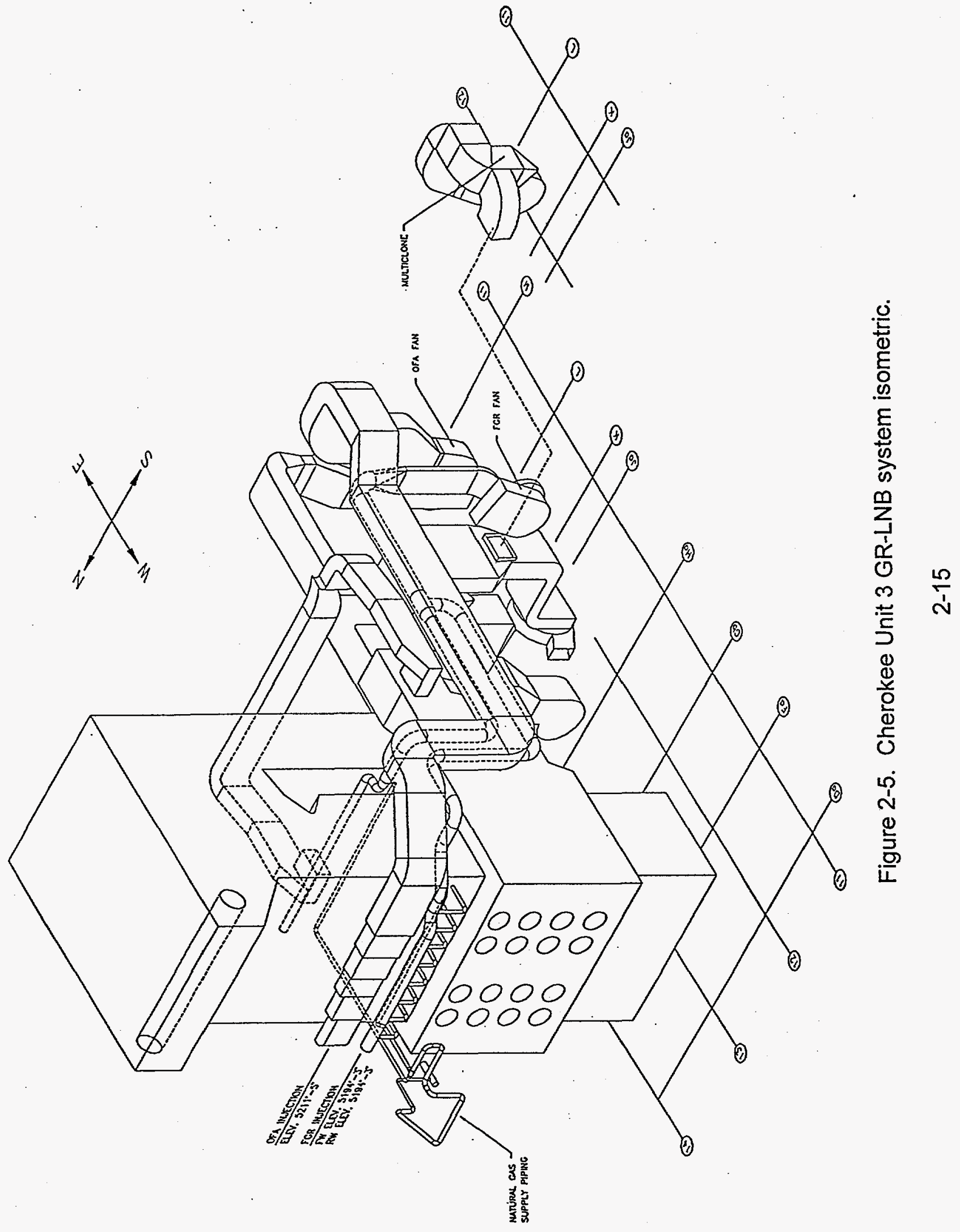




\begin{tabular}{|l|c|}
\hline Boiler Net Load & \\
Nominal Capacity (MWe) & 158 \\
Boiler Thermal Efficiency (\%) & 87 \\
Net Heat Rate (Btu/kW-hr) & 10,400 \\
Steam Conditions (Nominal Capacity) & \\
Main Steam Flow (klb/hr) & 1,140 \\
Secondary Superheater Outlet Temperature ( $\left.{ }^{\circ} \mathrm{F}\right)$ & 1,005 \\
Reheat Steam Flow (klb/hr) & 930 \\
Reheat Superheater Outlet Temperature ( $\left.{ }^{\circ} \mathrm{F}\right)$ & 1,005 \\
& \\
Gas Reburning System & \\
NOx Reduction w/LNB (\%) & 70 \\
Uncontrolled NOx Emissions At Full Load (lb/MBtu) & 0.73 \\
Natural Gas Heat Input (\% of Total) & 18 \\
Minimum Reburning Zone Residence Time (sec) & 0.50 \\
Burner Stoichiometry & 1.10 \\
Reburning Zone Stoichiometry & 0.90 \\
Burnout Zone Stoichiometry & 1.16 \\
Overfire Air (\% of Total Combustion Air) & 22 \\
Flue Gas Recirculation (\% of Total Flue) & 3.4 \\
& \\
Ash Distribution & 23 \\
Bottom Ash (\%) & 2 \\
Economizer Hopper (\%) & 75 \\
Baghouse (\%) & \\
\hline
\end{tabular}


maintained at their design level of $1,140,000 \mathrm{lb} / \mathrm{hr}(143.7 \mathrm{~kg} / \mathrm{s})$ of main steam and 930,000 $\mathrm{lb} / \mathrm{hr}(117.3 \mathrm{~kg} / \mathrm{s})$ of reheat steam at a temperature of $1005^{\circ} \mathrm{F}\left(541^{\circ} \mathrm{C}\right)$. In practice this temperature is generally not attained; the steam temperatures are maintained up to $20^{\circ} \mathrm{F}$ $\left(11^{\circ} \mathrm{C}\right)$ below this point to ensure safe metal temperatures.

The GR-LNB system was expected to achieve $70 \% \mathrm{NO}_{x}$ control from the $0.73 \mathrm{lb} / 10^{6} \mathrm{Btu}$ $\left(314 \mathrm{mg} / 10^{6} \mathrm{~J}\right)$ baseline measured at a normal boiler $\mathrm{O}_{2}$ level of $3 \%$. The system was designed to inject natural gas at a rate corresponding to $18 \%$ of the total heat input. While the burners operate nominally at $10 \%$ excess air $\left(S R_{1}=1.10\right)$, the reburn zone would be reduced to a SR of 0.90 . The placement of the reburn fuel injectors and the OFA ports allowed a reburn zone residence time of 0.50 seconds, sufficient for reactions to occur. FGR flow corresponding to $3.4 \%$ of the total boiler exit flue gas helped propel the reburn fuel into the furnace. The GR injection system is illustrated in Figure 2-6. Reburn fuel was injected through a total of sixteen injectors, eight each on the front and rear walls which are spaced equally from the side walls. OFA was injected higher up in the furnace, providing nominally $22 \%$ of the total combustion air. The $600^{\circ} \mathrm{F}\left(316^{\circ} \mathrm{C}\right)$ secondary air was diverted from the burners and injected through six ports mounted on the front wall of the boiler.

The coal supply was, by rank, a high volatile $C$ Bituminous coal. The coal composition used in the design phase of the project is shown in Table 2-3. It had a sulfur content of approximately $0.4 \%$, corresponding to a theoretical $\mathrm{SO}_{2}$ emissions rate of $0.80 \mathrm{lb} / 10^{6} \mathrm{Btu}$ $\left(344 \mathrm{mg} / 10^{6} \mathrm{~J}\right)$. It had relatively low moisture and ash content and relatively high heating value, all of which are characteristics of this rank of coal. The coal ash fusion temperatures, under oxidizing and reducing conditions, indicated a medium slagging propensity. Therefore, minimal slag buildup would be expected under normal oxidizing conditions in a relatively large furnace. The natural gas composition considered in the design phase is also shown in Table 2-3. As expected, methane and ethane constitute approximately $90 \%$ of the gas on a volume basis. The higher heating value was 966 Btu/scf $\left(36,000 \mathrm{~kJ} / \mathrm{m}^{3}\right)$ and the specific gravity relative to air was 0.665 . 


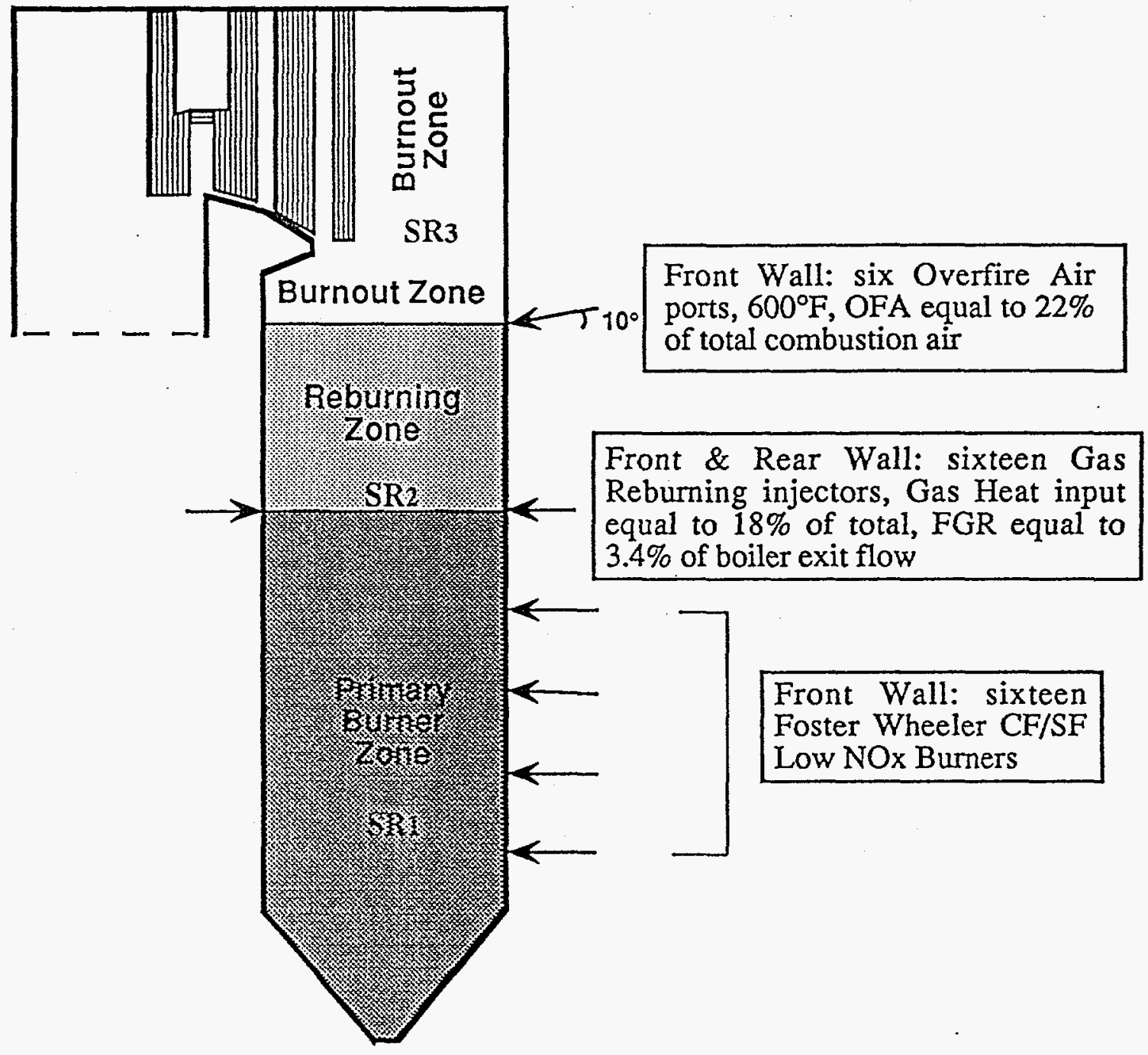

Figure 2-6. Cherokee Unit 3 Gas Reburning system injector specification 
TABLE 2-3. COAL AND NATURAL GAS COMPOSITION

\begin{tabular}{|c|c|c|c|}
\hline \multicolumn{4}{|c|}{ COAL (As Received) } \\
\hline Mine: Empire Energy & \multicolumn{3}{|c|}{ Location: Moffat County, State of Colorado } \\
\hline Proximate Analysis (\%): & & Ultimate Analysis (\%): & \\
\hline Total Moisture & 12.67 & Moisture & 12.67 \\
\hline Volatile Matter & 35.34 & Carbon & 60.36 \\
\hline Fixed Carbon & 43.59 & Hydrogen & 4.12 \\
\hline Ash & 8.40 & Oxygen & 12.98 \\
\hline & & Nitrogen & 1.12 \\
\hline HHV (Btu/lb) & 10,604 & Sulfur & 0.36 \\
\hline & & Ash & 8.40 \\
\hline Ash Chemical Analysis (\%): & & & \\
\hline $\mathrm{SiO} 2$ & 52.53 & Ash Fusion Temperatures $\left({ }^{\circ} \mathrm{F}\right)$ : & \\
\hline $\mathrm{A} 12 \mathrm{O} 3$ & 27.01 & Reducing & \\
\hline $\mathrm{TiO} 2$ & 0.86 & $\mathrm{mT}$ & 2380 \\
\hline $\mathrm{Fe} 2 \mathrm{O} 3$ & 5.11 & AST & 2400 \\
\hline $\mathrm{CaO}$ & 4.06 & AHT & 2480 \\
\hline $\mathrm{MgO}$ & 0.98 & AFT & 2590 \\
\hline $\mathrm{Na} 2 \mathrm{O}$ & 2.54 & Oxidizing & \\
\hline $\mathrm{K} 2 \mathrm{O}$ & 0.87 & $\mathrm{DT}$ & 2410 \\
\hline $\mathrm{P} 2 \mathrm{O} 5$ & 1.04 & AST & 2480 \\
\hline $\mathrm{SO} 3$ & 3.13 & AHT & 2590 \\
\hline Undetermined & 1.87 & AFT & 2680 \\
\hline
\end{tabular}

\begin{tabular}{|c|c|c|c|}
\hline \multicolumn{4}{|c|}{ NATURAL GAS } \\
\hline Constituent (Volume \%): & & & \\
CH4 & 80.81 & N2 & 6.37 \\
C2H6 & 7.70 & O2 & 1.90 \\
C3H8 & 1.15 & Specific Gravity & 0.665 \\
CO2 & 2.07 & HHV (Btu/SCF) & 966 \\
\hline
\end{tabular}




\subsubsection{Low NO Burners}

Installation of the LNBs was the responsibility of the Public Service Company of Colorado. EER had no direct involvement in the selection, procurement, or installation of the LNBs. After considering several burner suppliers, including Babcock \& Wilcox and Riley Stoker Corporation, Foster Wheeler Energy Corporation Controlled Flow/Split Flame burners were selected. The burner has dual air registers to stage the coal/air mixing and thereby control $\mathrm{NO}_{\mathrm{x}}$ emissions. It has a unique coal nozzle which splits the coal flow into four streams. Coal ignition and initial combustion take place in a fuel rich core. Air from the outer register is added to burnout the coal char under a normal burner excess air level. This arrangement of air input allows independent control of ignition and flame shaping. The burner has been installed on numerous other commercially operating utility boilers and was expected to achieve a minimum of $40 \% \mathrm{NO}_{x}$ reduction.

\subsubsection{Gas Reburning System}

The GR system was comprised of three subsystems: natural gas injection system, FGR injection system, and OFA injection system. These systems were integrated to provide the proper fuel, FGR and air flows into the appropriate regions of the furnace to reduce $\mathrm{NO}_{\mathrm{x}}$ and to supply the heat needed for steam generation at the units rated capacity.

In this application, the normal design natural gas flow was $5,600 \mathrm{scfm}\left(2.64 \mathrm{Nm}^{3} / \mathrm{s}\right)$ with a maximum of $7,300 \mathrm{scfm}\left(3.45 \mathrm{Nm}^{3} / \mathrm{s}\right)$. These flows corresponded to a normal reburning gas heat input of $327 \times 10^{6} \mathrm{Btu} / \mathrm{hr}\left(96 \mathrm{MW}_{\mathrm{e}}\right)$ and maximum heat input of $43010^{6} \mathrm{Btu} / \mathrm{hr}$ $\left(126 \mathrm{MW}_{\mathrm{e}}\right)$. A 6" $(15 \mathrm{~cm})$ tie-in to the main natural gas header transported the reburn natural gas to a flow metering and control station. The gas was then routed into two headers which delivered it to either the boiler front or rear wall injectors. The natural gas valve trains included manual shut-off valves, flow control valves, relief vent valves, flow meters, etc. Automatic safety shut-off and vent valves were located in a common pipe 
supplying both headers. The natural gas was then routed to sixteen feed lines, each of which were equipped with a manual shut-off valve to its corresponding injector. Natural gas, supplied at a pressure of $20 \mathrm{psig}(138 \mathrm{kPa})$ to the injector control valves, was then let down through the valves and mixed with FGR prior to injection into the furnace.

Design calculations indicated that a reburn zone gas temperature of $2200^{\circ} \mathrm{F}$ to $2600^{\circ} \mathrm{F}$ would be the most effective for GR operation. The higher temperatures produce higher chemical reaction rates which result in more rapid formation of hydrocarbon fragments and free radicals. This leads directly to higher rates of $\mathrm{NO}_{x}$ destruction. The level of completeness of the primary zone coal combustion process is indicated by the primary zone gas temperature of the combustion gas entering the reburn zone and $\mathrm{SR}_{1}$.

FGR was withdrawn from the breaching before the air heater inlet. This location was selected since the flue gas there is relatively low in $\mathrm{O}_{2}$, being upstream of the point of air heater leakage. The gas was routed to a multiclone which removed approximately $70 \%$ of particulate matter. The grain loading was decreased from approximately 2.5 to $3 \mathrm{gr} / \mathrm{dscf}$ $\left(5.7\right.$ to $\left.6.9 \mathrm{~g} / \mathrm{m}^{3}\right)$ to 0.75 to $0.9 \mathrm{gr} / \mathrm{dscf}\left(1.7\right.$ to $\left.2.1 \mathrm{~g} / \mathrm{m}^{3}\right)$. The flue gas was then routed to the high static fan, which boosted the pressure from approximately $-7^{\prime \prime}$ W.C. $(-2 \mathrm{kPa})$ to $+17^{\prime \prime}$ W.C. $(+4 \mathrm{kPa})$. This relatively high pressure was needed to inject the reburn fuel at sufficient velocity to penetrate fully into the furnace. The FGR fan was a centrifugal type with a speed of $1200 \mathrm{rpm}$, ensuring low erosion of the blades and housing. Shut-off dampers were placed at both upstream and downstream locations. The downstream damper was equipped with seal air supply to ensure worker safety during maintenance. FGR was then routed into two headers which supply the nozzles on the front and rear walls. Modulating dampers were used to balance the flow in these headers and each FGR nozzle supply line was equipped with a manually controlled damper.

OFA at a temperature of approximately $600^{\circ} \mathrm{F}\left(316^{\circ} \mathrm{C}\right)$ was withdrawn from two secondary air ducts. It was then routed to an OFA fan which boosted the pressure from 2" W.C. (0.5 
$\mathrm{kPa}$ ) to 12 " W.C. (3 kPa). Shut-off dampers were located both upstream and downstream of the OFA fan. The OFA was then routed to six ports located on the front wall of the furnace. Dampers were used to balance the flow to each port. The OFA injectors were tilted down at a $10^{\circ}$ angle to provide better penetration of the air into the furnace combustion gas, and to increase the furnace gas residence time in this burnout zone in order to enhance $\mathrm{CO}$ conversion to $\mathrm{CO}_{2}$. The OFA ports were cooled with an air supply from a small fan.

Pilot scale studies were conducted by EER to determine the effect of penetration and mixing in the reburn zone and the burnout zone. In the reburn zone, the study indicated that the natural gas had to be injected in such a way so that it would cover the crosssectional area normal to flue gas flow in order for the reburn process to be most effective. If the injection momentum of the natural gas is not of sufficient magnitude, the injected fuel simply follows a flow path adjacent to the boiler wall through which it was injected. This is much less effective in producing the uniform fuel-rich condition required for efficient $\mathrm{NO}_{\mathrm{x}}$ destruction. For the initial design of the gas injection system, recirculated flue gas was used as the carrier medium to inject the reburn gas into the furnace with sufficient momentum. The reburn gas injection system was designed with a sufficiently large range of recirculated flue gas flow rates in order to obtain good penetration and mixing performance at all boiler operating loads. The nominal reburn gas injection pressure of 3.83 inches W.C. was required in order to produce the desired system performance results.

The pilot scale studies also showed that to obtain the minimum $\mathrm{CO}$ emission levels leaving the burnout zone, the penetration and mixing of the OFA also had to cover the entire crosssectional area of the furnace perpendicular to the upward flowing furnace gas. To obtain the necessary penetration, the OFA injection pressure was increased to a nominal pressure of 3.95 inches W.C. by a booster fan and the angle of injection was set downward at negative $10^{\circ}$. The injection angle provided a longer time for penetration and mixing of the OFA into the upward flowing furnace gas. 


\subsubsection{Control System}

A Westinghouse Distributed Process Family (WDPF) control system was used to modulate the GR system and monitor/record process parameters. The control system included a series of permissives, specified conditions under which GR may be operated, and trips, conditions under which the GR system is shut-down.

\subsection{Expected Impacts of GR-LNB}

\subsubsection{Thermal Impacts}

The impacts of GR-LNB on boiler thermal performance were projected in the process design study. The projection included steam generation rate, steam temperature, attemperation spray rate, heat absorption by each heat exchanger, gas side temperatures, and boiler heat-loss efficiency. Table 2-4 summarizes heat transfer modeling results at $100 \%$ load under Baseline (prior to LNB retrofit), LNB and GR-LNB operation. Each case considered the coal higher heating value; the GR-LNB case considered $19 \%$ gas heat input.

Relatively minor changes in the main and reheat steam flows were calculated but the attemperation spray flow was expected to nearly double. The reduction in steam flows under GR are due to changes in the location of heat input to the furnace. These result from injection of reburn fuel (heat input) higher up in the furnace. GR was expected to roughly double attemperation spray flows in both the secondary superheat and reheat superheater cycles. This is again due to heat input higher up in the furnace, which leads to higher upper furnace gas temperatures. The changes in attemperation spray were well within the capacity of the attemperators. In each case, the final main steam temperature was projected to be $986^{\circ} \mathrm{F}\left(530^{\circ} \mathrm{C}\right)$, with a reheat steam temperature of $1002^{\circ} \mathrm{F}\left(539^{\circ} \mathrm{C}\right)$. 
TABLE 2-4. PROJECTED IMPACTS OF GR-LNB ON THERMAL PERFORMANCE

\begin{tabular}{|c|c|c|c|}
\hline & $\begin{array}{c}\text { Baseline } \\
100 \% \text { Load }\end{array}$ & $\begin{array}{c}\text { LNB } \\
100 \% \text { Load }\end{array}$ & $\begin{array}{c}\text { GR-LNB } \\
100 \% \text { Load }\end{array}$ \\
\hline \multicolumn{4}{|l|}{ Steam/Water Mass Flow (klb/hr) } \\
\hline Main Steam & 1,129 & 1,131 & 1,110 \\
\hline Reheat Steam & 926 & 931 & 919 \\
\hline \multicolumn{4}{|l|}{ Attemperation Spray (klb/hr) } \\
\hline Secondary Superheater & 10.7 & 22.0 & 41.3 \\
\hline Reheat Superheater & 2.7 & 5.7 & 10.9 \\
\hline \multicolumn{4}{|l|}{ Steam Side Temperature $\left({ }^{\circ} \mathrm{F}\right)$} \\
\hline Economizer Inlet & 488 & 487 & 487 \\
\hline Economizer Outlet & 500 & 500 & 502 \\
\hline Primary Superheater Inlet & 637 & 637 & 637 \\
\hline Primary Superheater Outlet & 793 & 799 & 819 \\
\hline Secondary Superheater Attemp. Outlet & 783 & 777 & 775 \\
\hline Secondary Superheater Outlet & 986 & 986 & 986 \\
\hline Reheat Attemperator Outlet & 644 & 639 & 630 \\
\hline Reheat Superheater Outlet & 1,002 & 1,002 & 1,002 \\
\hline \multicolumn{4}{|l|}{ Heat Transfer to Steam (MBtu/hr) } \\
\hline Furnace & 726 & 720 & 692 \\
\hline Secondary Superheater & 157 & 162 & 160 \\
\hline Reheat Superheater & 178 & 181 & 184 \\
\hline Primary Superheater & 228 & 231 & 238 \\
\hline Economizer & 17 & 17 & 18 \\
\hline \multicolumn{4}{|l|}{ Gas Side Exit Temperatures $\left({ }^{\circ} \mathrm{F}\right)$} \\
\hline Reheater & 1,294 & 1,305 & 1,314 \\
\hline Primary Superheater & 750 & 754 & 759 \\
\hline Economizer & 709 & 712 & 716 \\
\hline Air Preheater & 313 & 315 & 315 \\
\hline
\end{tabular}


Minor changes in heat absorption profiles were expected. GR results in a reduction in furnace heat absorption, but an increase in heat absorbed in the convective pass. This shift results in an increase in the heat absorbed by the reheat and primary superheaters and economizer. The upward shift in gas temperature under GR is also reflected in the flue gas exit temperatures listed. Relatively minor increases in temperature result with the air preheater exit temperature being roughly the same. The temperature at this location is used in the dry gas heat loss calculation; therefore, it has direct relevance to boiler efficiency.

Table 2-5 presents the impacts of Baseline, LNB, and GR-LNB on boiler efficiency. The boiler efficiency was projected to decrease by $1.0 \%$ using GR-LNB compared to LNB only operation. This is mainly due to an increase in heat loss associated with moisture from combustion. As long as the moisture is in the vapor phase its latent heat is a loss. A minor increase in unburned carbon-in-ash was also expected due to an expected small reduction in lower furnace gas temperature. A slight improvement in the moisture from fuel (coal) offsets these increases in heat loss. The total increase in heat loss is $1.0 \%$. The expected trend in the furnace gas temperature profile is shown in Figure 2-7. GR results in a decrease in the gas temperature in the burner region, then an upward shift in the reburn zone. Addition of OFA causes a significant dip in temperature, with the temperature in the convective pass being roughly equal under both conditions.

\subsubsection{Environmental Impacts}

Expected environmental impacts of applying GR-LNB to Cherokee Unit 3 were addressed in an Environmental Monitoring Plan (EMP), which called for a variety of measurements to ensure environmental acceptability of the project. The major environmental impacts were in the area of boiler emissions. Expected reductions in the emissions were $70 \%$ for $\mathrm{NO}_{\mathrm{x}}, 18 \%$ for $\mathrm{SO}_{2}, 8 \%$ for $\mathrm{CO}_{2}$, and up to $18 \%$ in particulate matter. Some of which result from a change in characteristics of fuels co-fired, since natural gas is free of sulfur, fuel 
TABLE 2-5. PROJECTED IMPACT OF GR-LNB ON GROSS BOILER EFFICIENCY

\begin{tabular}{|l|c|c|c|}
\hline & $\begin{array}{c}\text { Baseline } \\
100 \% \text { Load }\end{array}$ & $\begin{array}{c}\text { LNB } \\
100 \% \text { Load }\end{array}$ & $\begin{array}{c}\text { GR-LNB } \\
100 \% \text { Load }\end{array}$ \\
\hline Heat Loss (\%) & & & \\
Dry Gas & 5.11 & 5.12 & 5.02 \\
Moisture from Fuel & 1.69 & 1.70 & 1.38 \\
Moisture from Combustion & 4.15 & 4.15 & 5.38 \\
Combustible in Refuse & 0.44 & 0.38 & 0.60 \\
Radiation* & 0.22 & 0.22 & 0.22 \\
Unmeasured * & 1.50 & 1.50 & 1.50 \\
Total Losses & 13.12 & 13.08 & 14.09 \\
\hline & & & \\
Gross Efficiency (\%) & 86.88 & 86.92 & 85.91 \\
\hline
\end{tabular}

* Note: Value Taken From Design Data Sheet 


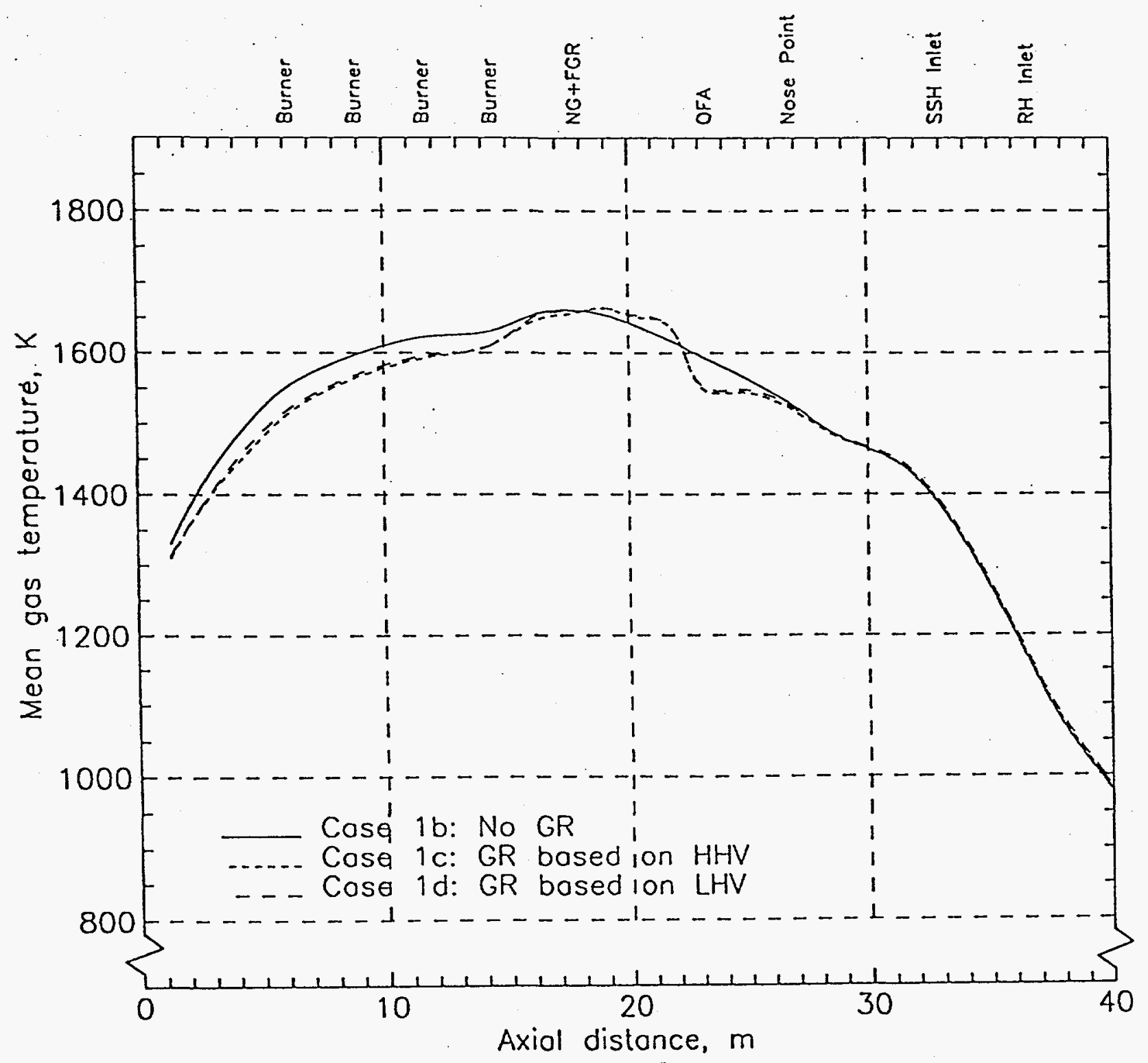

Figure 2-7. Predicted mean gas temperature profile for Unit \#3 with LNB and GR-LNB 
bound nitrogen, and ash and has a lower carbon-to-hydrogen molar ratio than coal. No change in emissions of $\mathrm{CO}$ was expected. Natural gas typically forms $\mathrm{CO}_{2}$ at a rate of 115 $\mathrm{lb} / 10^{6} \mathrm{Btu}\left(49.5 \mathrm{~g} / 10^{6} \mathrm{~J}\right)$, compared to approximately $205 \mathrm{lb} / 10^{6} \mathrm{Btu}\left(88.2 \mathrm{~g} / 10^{6} \mathrm{~J}\right)$ for coal. Therefore, firing natural gas at a rate corresponding to $18 \%$ of the heat input was expected to reduce $\mathrm{CO}_{2}$ by $8 \%$.

GR-LNB was expected to change the quantity but not the characteristics of fly ash from the boiler. A slight reduction in fly ash was expected to yield less stack particulate matter emissions, but the magnitude of the change was not predicted since baghouses are nearly constant removal devices. If particulate collection efficiency were to remain constant like that for ESPs, under GR operation a direct reduction in stack particulate emissions of $18 \%$ would be expected with $18 \%$ gas heat input.

No change in the rate of sluice water required to mix and carry fly ash to the polishing pond was expected. The makeup of this aqueous stream was not expected to change; therefore, the water discharged to the South Platte River was expected to have the same levels of constituents.

The plant operates under air emissions limits of $1.2 \mathrm{lb} \mathrm{SO}_{2} / 10^{6} \mathrm{Btu}\left(516 \mathrm{mg} / 10^{6} \mathrm{~J}\right)$ and opacity of $20 \%$ for six minute averages. These limits are imposed by the Colorado Air Pollution Control Division, and necessitate continuous flue gas monitoring to verify compliance. No problems in meeting these limits were anticipated.

The Colorado Water Quality Control Division imposes limits on the aqueous discharge including maximum temperature, $\mathrm{pH}$, oil \& grease, total suspended solids, ammonia, nitrate, phosphorus, chromium, zinc, copper, chlorine, and total flow. No change in these constituents was expected therefore full compliance with the limits was expected. 


\subsection{Proprietary Information}

The detail and control information on the GR-LNB technology concerning GR and OFA injection locations, orientations, and velocities, and furnace residence times between zones, are considered proprietary to the Energy and Environmental Research Corporation.

Reburning $\mathrm{NO}_{x}$ reduction performance depends on a range of different process parameters, which include the following: initial $\mathrm{NO}_{x}$ level, temperature at the reburn and burnout zones, $\mathrm{SR}_{1}, \mathrm{SR}_{2}, \mathrm{SR}_{3}$, residence times in the reburn and OFA zones, and mixing rates of the reburn fuel and OFA.

Data gathered during EER's various reburning demonstration programs have been reported in graphical format, where measured $\mathrm{NO}_{x}$ reduction performance has been compared with most of the above variable parameters, and where reasonably good correlations with individual parameters can be seen. However, given the rather complex inter-relationship between the various controlling parameters and reburning system performance, EER has elected not to present statistical correlations of the data.

EER believes that the use of such correlations can be misleading, particularly with respect to extrapolating system performance to other boilers and boundary conditions. To successfully correlate the data requires more complex process models, such as those used by EER during the development of designs for each of the different boiler applications.

These process/design models have been validated during the course of the demonstration project, and have been shown to accurately reflect performance trends as a function of the various process parameters for boilers of very different designs. For business reasons, and because of their importance in developing commercial guarantees, EER prefers not to make public any details of the process models. 


\subsection{Simplified Process Flow Diagram}

Figure 2-8 is a material balance for the GR process at full load. It considers a full load heat input of $1,66010^{6} \mathrm{Btu} / \mathrm{hr}\left(487 \mathrm{MW}_{\mathrm{e}}\right)$, for a net heat rate of $10,500 \mathrm{Btu} / \mathrm{kWhr}$. In this case, the natural gas heat input is $20 \%$, requiring a flow of $5,617 \mathrm{scfm}\left(2.65 \mathrm{Nm}^{3} / \mathrm{s}\right)$. A FGR flow rate of $10,230 \mathrm{scfm}\left(4.83 \mathrm{Nm}^{3} / \mathrm{s}\right)$ is used to inject the natural gas. The coal flow needed for $80 \%$ of the total heat input is $122,223 \mathrm{lb} / \mathrm{hr}(15.41 \mathrm{~kg} / \mathrm{s})$. The coal higher heating value is $10,904 \mathrm{Btu} / \mathrm{lb}(25,345 \mathrm{~kJ} / \mathrm{kg})$, as determined by bomb calorimetry for Yampa Valley Coal. The coal stoichiometric air requirement is $8.40 \mathrm{lb}$ air/lb coal; therefore, the burner air flow needed for $10 \%$ excess air operation is $1,129,340 \mathrm{lb} / \mathrm{hr}(142.4 \mathrm{~kg} / \mathrm{s})$. An OFA flow of $72,160 \mathrm{scfm}\left(34.08 \mathrm{Nm}^{3} / \mathrm{s}\right)$, corresponding to $23 \%$ of the total combustion air, is used to burnout coal and reburn fuels. The ash input is $10 \%$ of the total coal flow, with $80 \%$ of the ash leaving the furnace as fly ash and $20 \%$ as bottom ash. Air heater air leakage is approximately $7.5 \%$ of the total combustion air flow.

\section{$2.7 \quad$ Stream Data}

The heat energy balance presented in Figure 2-9 was performed with the computational heat transfer model, making use of a reduced heat input of $1,590 \times 10^{6} \mathrm{Btu} / \mathrm{hr}\left(466 \mathrm{MW}_{\mathrm{e}}\right)$. The final steam and feedwater conditions indicate that $86.83 \%$ of the total heat input is absorbed by steam/water. Approximately $47 \%$ is absorbed through the waterwall, $27 \%$ is transferred to the primary/secondary superheater, $11 \%$ is absorbed by the reheater, and $2 \%$ is absorbed by the economizer. The heat-loss method which does not consider the steam condition, but gross process parameters such as boiler exit temperature, fuel and ash composition, etc., indicates a boiler efficiency of $86.71 \%$. The most significant source of heat loss is associated with dry gas flow, accounting for a loss of $5.48 \%$. Moisture from combustion heat loss is also significant at $5.42 \%$. Other major sources of heat loss are associated with moisture in the coal, carbon-in-ash, and radiation. The total percentage of heat lost, i.e. not absorbed by steam, is $13.29 \%$. 


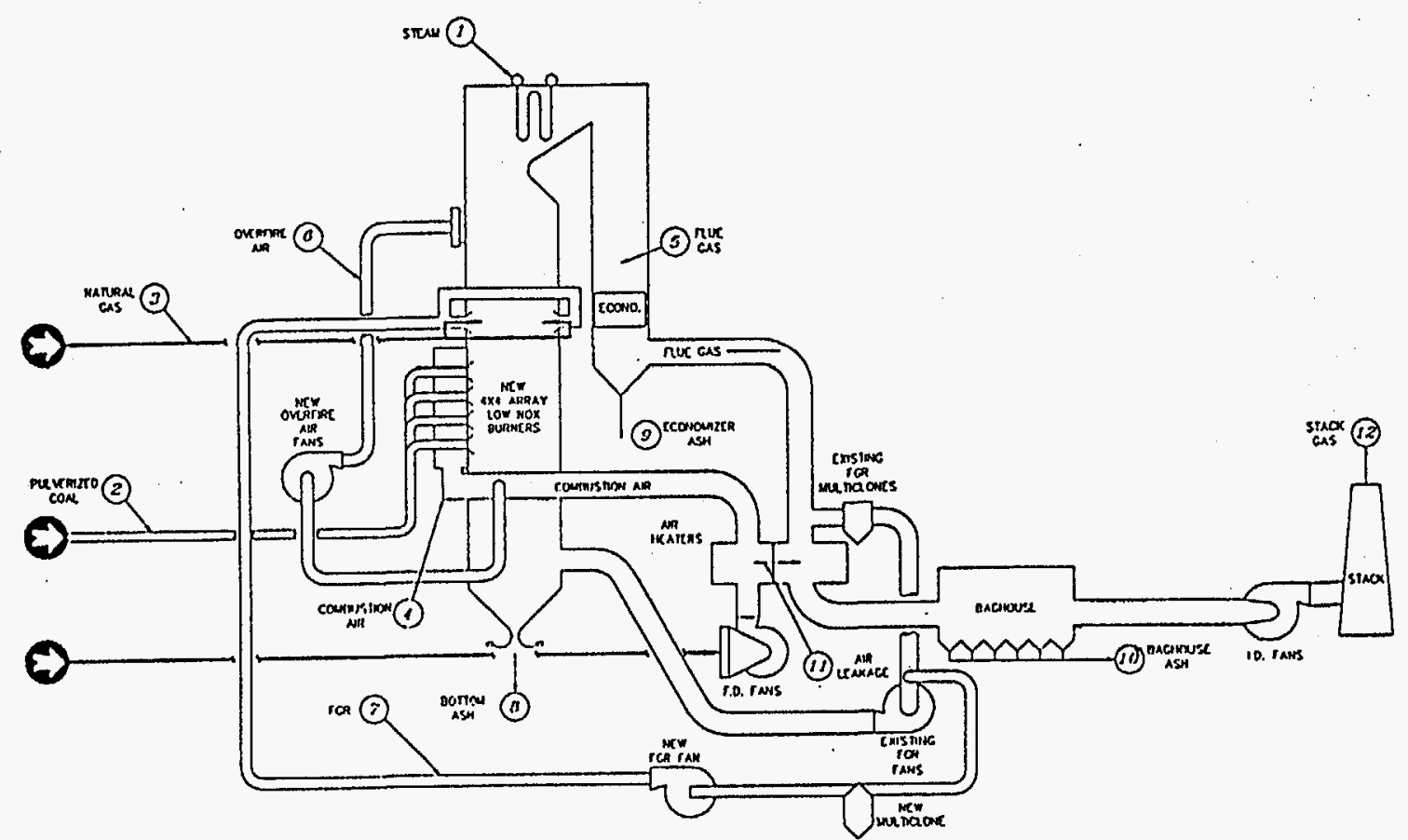

Gas Rebuming-Low NOx Bumer Materinl Balance: 172 MWc Gross

\begin{tabular}{|c|c|c|c|c|c|c|c|c|c|c|c|c|}
\hline & & 7 & $\pi$ & 4 & 5 & 6 & 7 & 8 & & 10 & & 12 \\
\hline Description & $\begin{array}{l}\frac{1}{\text { Stcam }} \\
\text { Flow }\end{array}$ & $\begin{array}{l}\text { Con } \\
\text { Flow }\end{array}$ & $\begin{array}{l}\text { Natural } \\
\text { Gas } \\
\text { Flow }\end{array}$ & $\begin{array}{c}\text { Coral } \\
\text { Combustion } \\
\text { Air }\end{array}$ & $\begin{array}{l}\text { Fiuc } \\
\text { Gas }\end{array}$ & $\begin{array}{c}\text { Overtire } \\
\text { Air }\end{array}$ & $\begin{array}{c}\text { FGTR } \\
\text { Gas } \\
\text { Injection }\end{array}$ & $\begin{array}{l}\text { Bottom } \\
\text { Ash }\end{array}$ & $\begin{array}{c}\text { Economizcr } \\
\text { Ash }\end{array}$ & $\begin{array}{c}\text { Baghousc } \\
\text { Ash }\end{array}$ & $\frac{\text { Air }}{\text { Leakage }}$ & $\begin{array}{l}\text { Stack } \\
\text { Gas }\end{array}$ \\
\hline \multicolumn{13}{|l|}{ Gas Side } \\
\hline Air (ID/hr) & & & & $1,129,340$ & & 331.288 & & & & & 110.000 & \\
\hline $\operatorname{Air}(\mathrm{sclm})$ & & & & 245,990 & & 72,160 & & & & & 23,960 & \\
\hline Natural Gas (b/hr) & & & 16.450 & & & & & & & & & \\
\hline Natura Gas (sc/m) & & & 5,617 & & & & & & & & & \\
\hline Flue Gas (1b/hr) & & & & & $1,587,042$ & & 47,611 & & & & & $1,475,803$ \\
\hline Fluc Gas (sclm) & & & & & 340,980 & & 10,230 & & & & & 317.405 \\
\hline $502(\mathrm{lb} / \mathrm{hr})$ & & & & & 1.208 & & & & & & & 1,208 \\
\hline SO2 (Ib/MiBLu) & & & & & 0.75 & & & & & & & 0.75 \\
\hline NOx $(16 / \mathrm{hr})$ & & & & & 338 & & & & & & & 338 \\
\hline NOx (IbMBiu) & & & & & 0.21 & & & & & & & 0.21 \\
\hline $1 \mathrm{H} 2 \mathrm{O}$ & $1,280,000$ & & & & & & & & & & & \\
\hline \multicolumn{13}{|l|}{ Solld Side } \\
\hline Coal $(\mathrm{lb} / \mathrm{hr})$ & & 109,964 & & & & & & & & & & \\
\hline Coal harts (Ib/hr) & & 12,259 & & & & & & 2,452 & 613 & 9.194 & & \\
\hline Total Solids (Ib/hr) & & 122,223 & & & & & & & & & & \\
\hline Temperalure ( $\mathrm{F})$ & 1005 & & & 602 & 727 & 602 & .727 & & & & & 270 \\
\hline Pressure & $1925 \mathrm{psig}$ & & & $2.75^{11}$ & $-3.6^{\prime \prime}$ & $10^{\prime \prime}$ & $40^{\prime \prime}$ & & & & & Atmos. \\
\hline
\end{tabular}

Figure 2-8. Cherokee Unit 3 GR material balance 


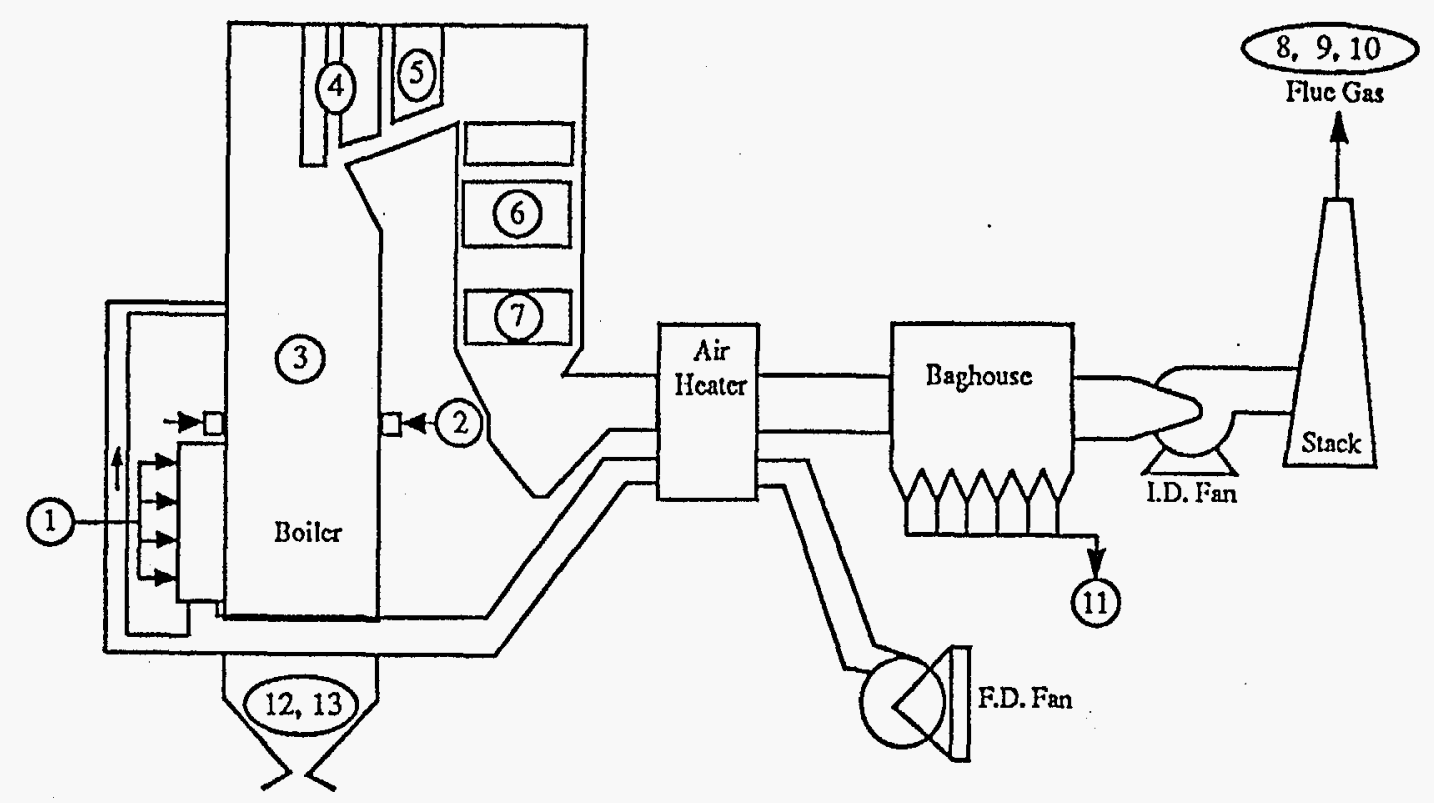

\begin{tabular}{|c|c|c|c|c|c|c|c|}
\hline No. & $\begin{array}{l}\text { Source/ } \\
\text { Device }\end{array}$ & $\begin{array}{l}\text { Heat Input } \\
(\mathrm{MBlu} / \mathrm{hr})\end{array}$ & $\begin{array}{l}\text { Heat Input } \\
\text { (\% of Total) }\end{array}$ & $\begin{array}{l}\text { Stcam Hcat Absorption } \\
\text { (MBtu/hr) }\end{array}$ & \begin{tabular}{|c} 
Stcam Hcat Absorption \\
(\% of inpul) \\
\end{tabular} & $\begin{array}{l}\text { Heat Loss } \\
(\mathrm{MBtu} / \mathrm{hr})\end{array}$ & $\begin{array}{l}\text { Heat Loss } \\
\text { (\% of input) }\end{array}$ \\
\hline 1 & Coal & 1304 & 82 & & & & \\
\hline 2 & Natural Gas & 286 & 18 & & & & \\
\hline 3 & Waterwall & & & 741 & 46.60 & & \\
\hline 4 & Secondary Superheater & & & 184 & 11.57 & & \\
\hline 5 & Rchcat Supcrheater & & & 180 & 11.32 & & \\
\hline 6 & Primary Supcrheater & & & 246 & 15.47 & & \\
\hline 7 & Economizer & & & 30 & 1.89 & & \\
\hline 8 & Dry Gas & & & & & 87 & 5.48 \\
\hline 9 & Moisture in Fuel & & & & & 15 & 0.92 \\
\hline 10 & Moisture from Combustion & & & & & 86 & 5.42 \\
\hline 11 & Carbon in Ash & & & & & 8 & 0.50 \\
\hline 12 & Radiation & & & & & 3 & 0.18 \\
\hline 13 & Unmeasured & & & & & 13 & 0.79 \\
\hline Total & & 1590 & 100 & 1381 & 86.86 & 211 & 13.29 \\
\hline
\end{tabular}

Figure 2-9. Gas reburning heat energy balance 


\subsection{Piping and Instrumentation Diagrams}

The piping and instrumentation diagrams for the GR are presented in Figures 2-10 through 2-12. During Second Generation GR, the system was modified by removing the FGR system. The piping and instrumentation diagrams for the modified system are presented in Figures 2-13 through 2-15. 


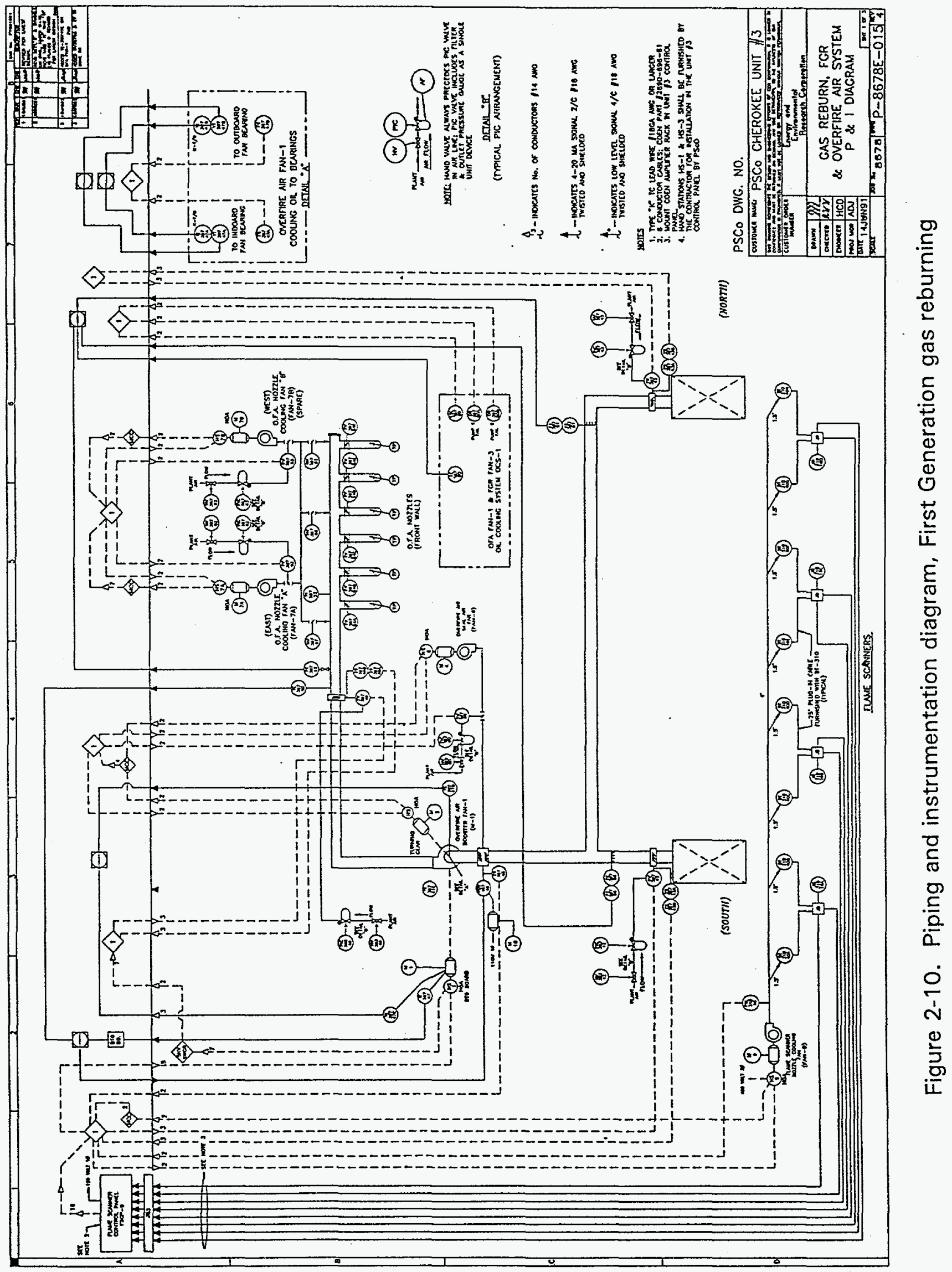




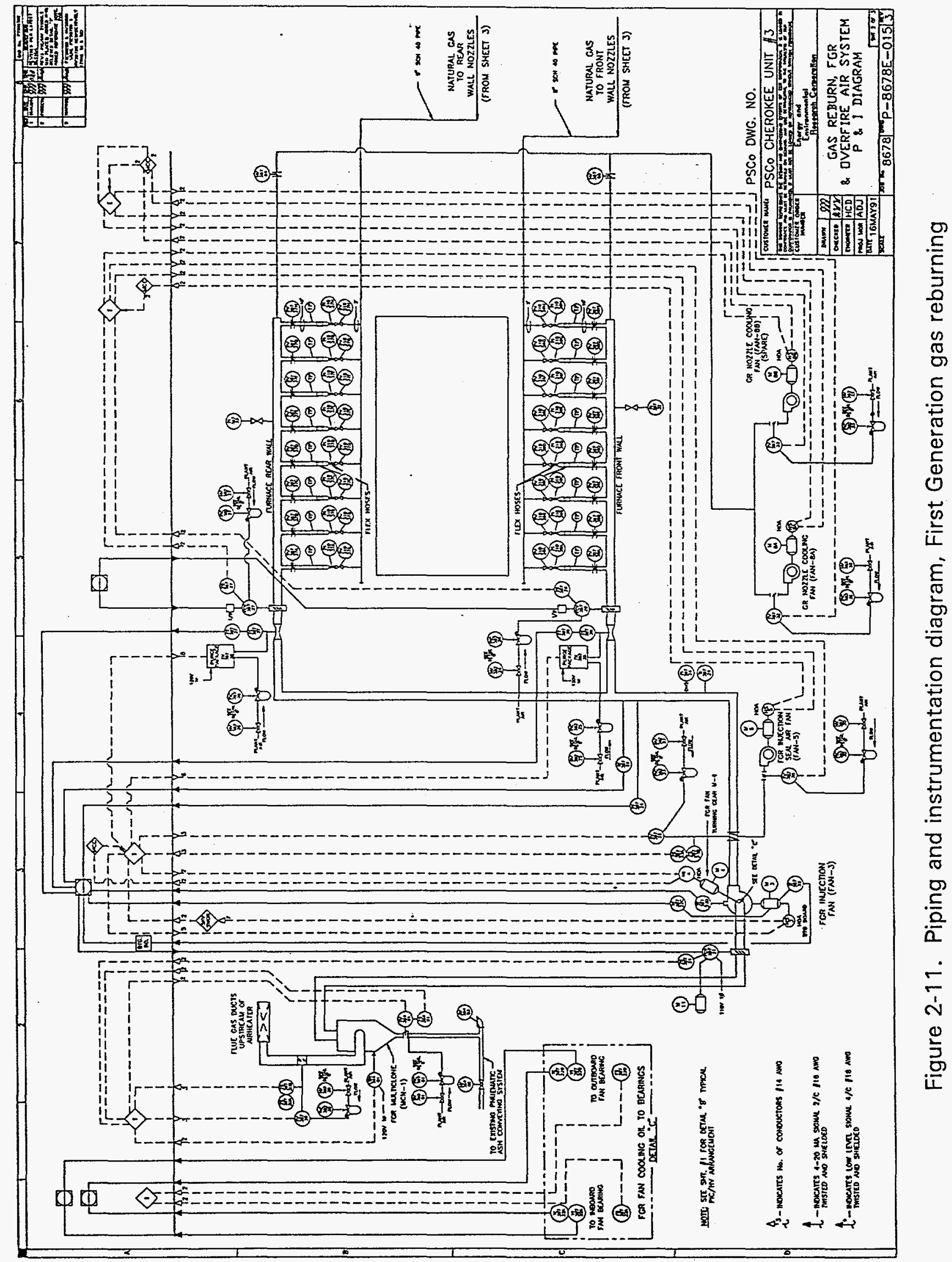




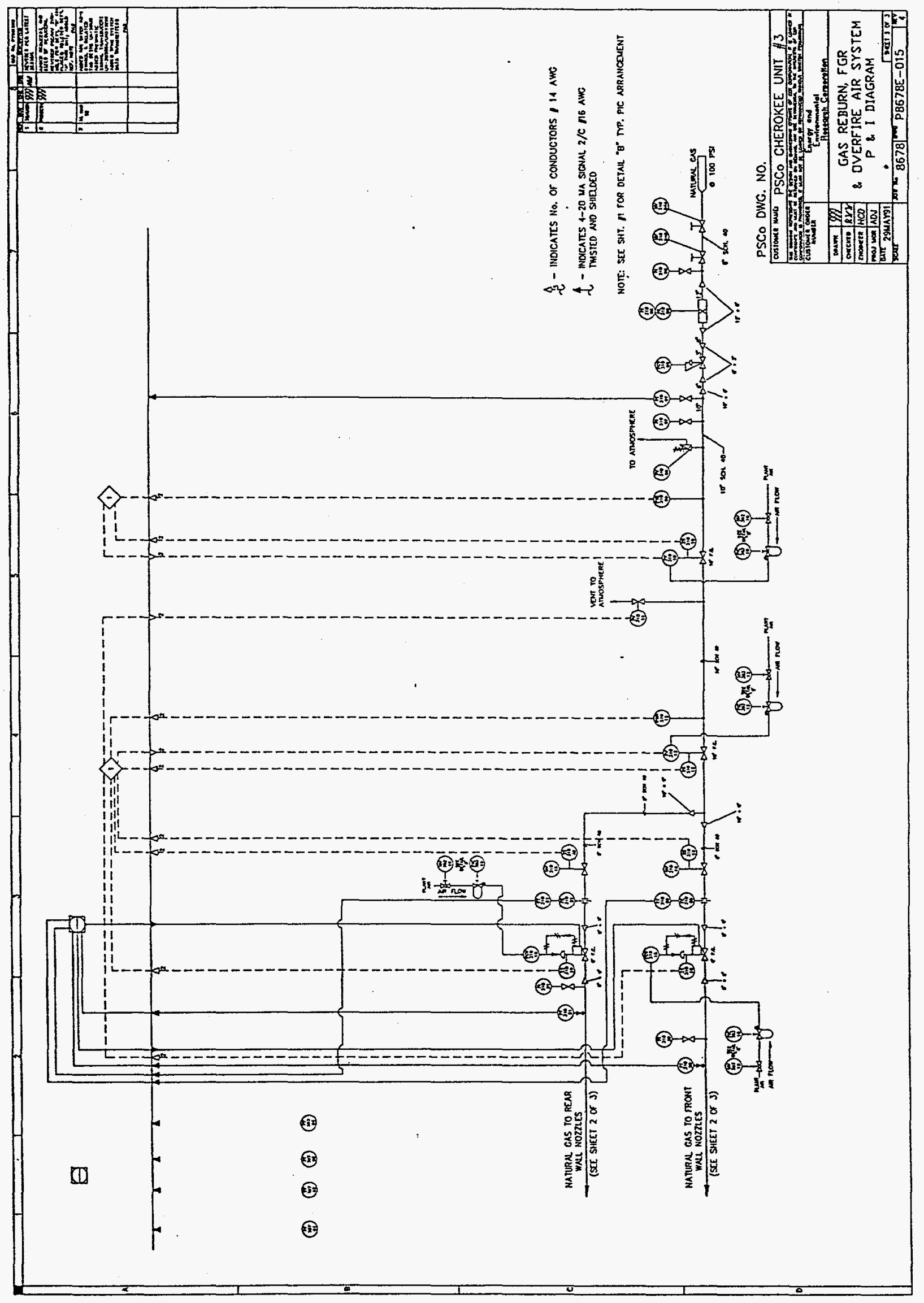

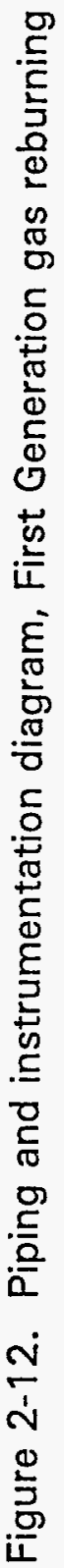




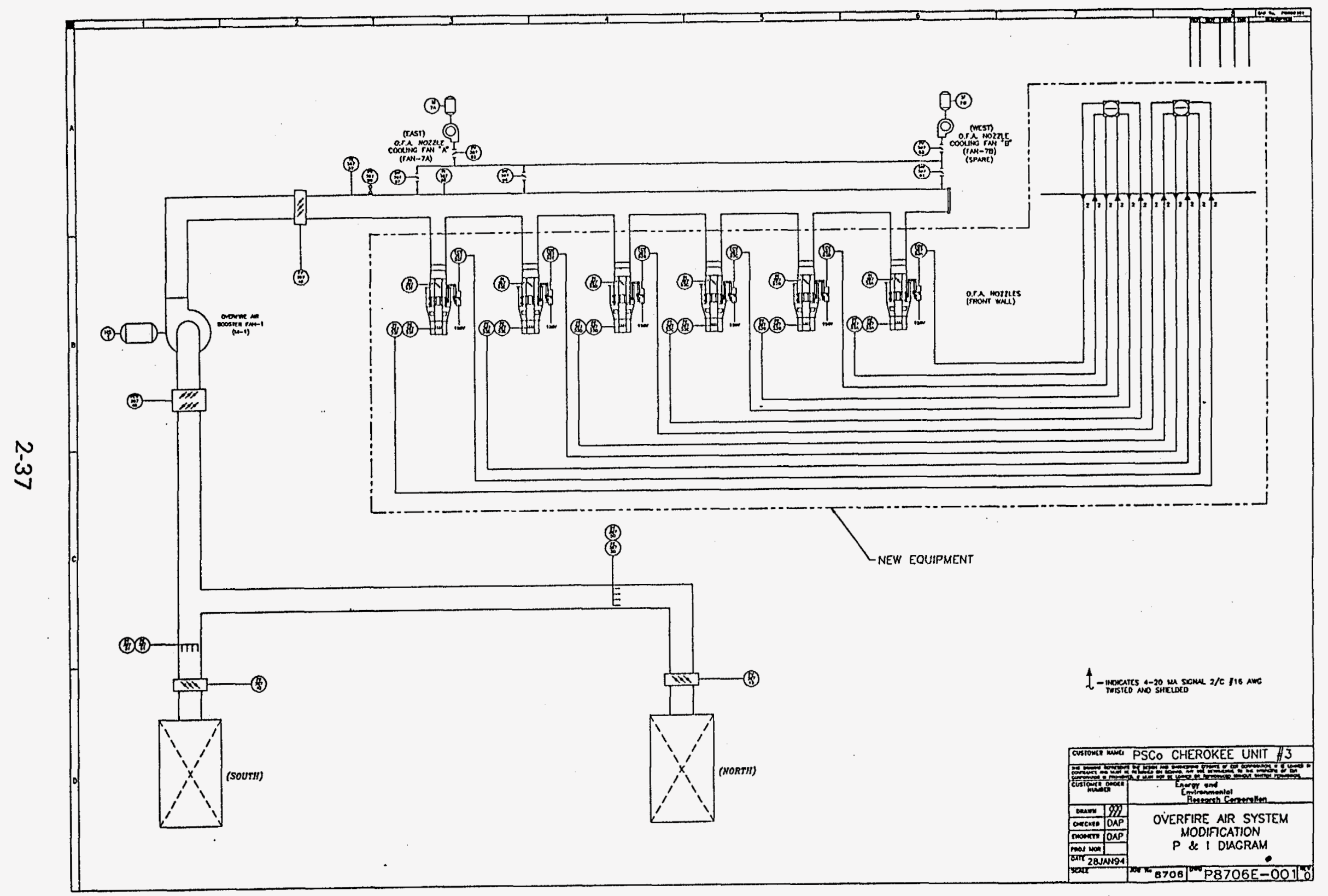

Figure 2-13. Piping and instrumentation diagram, Second Generation gas reburning 


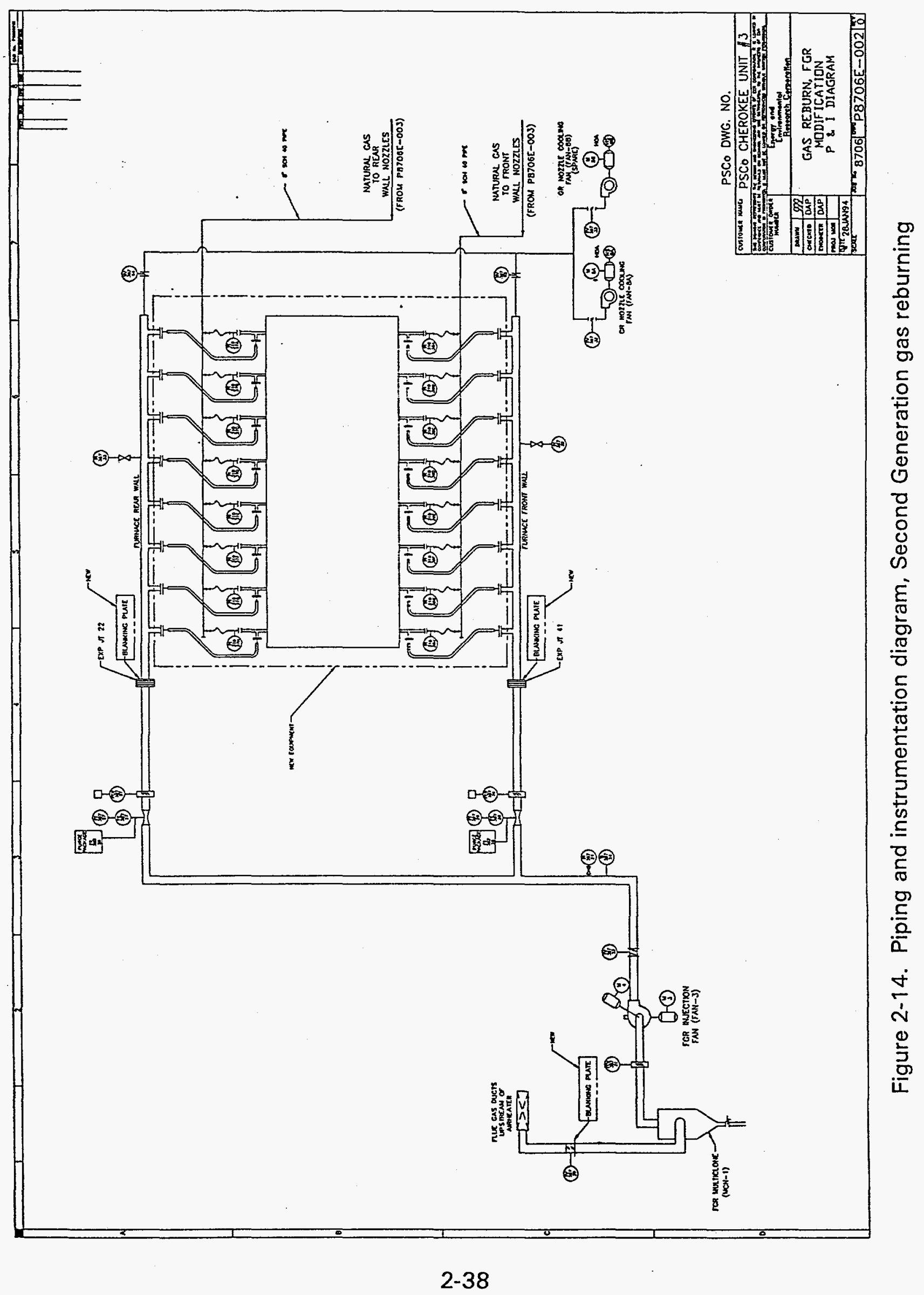




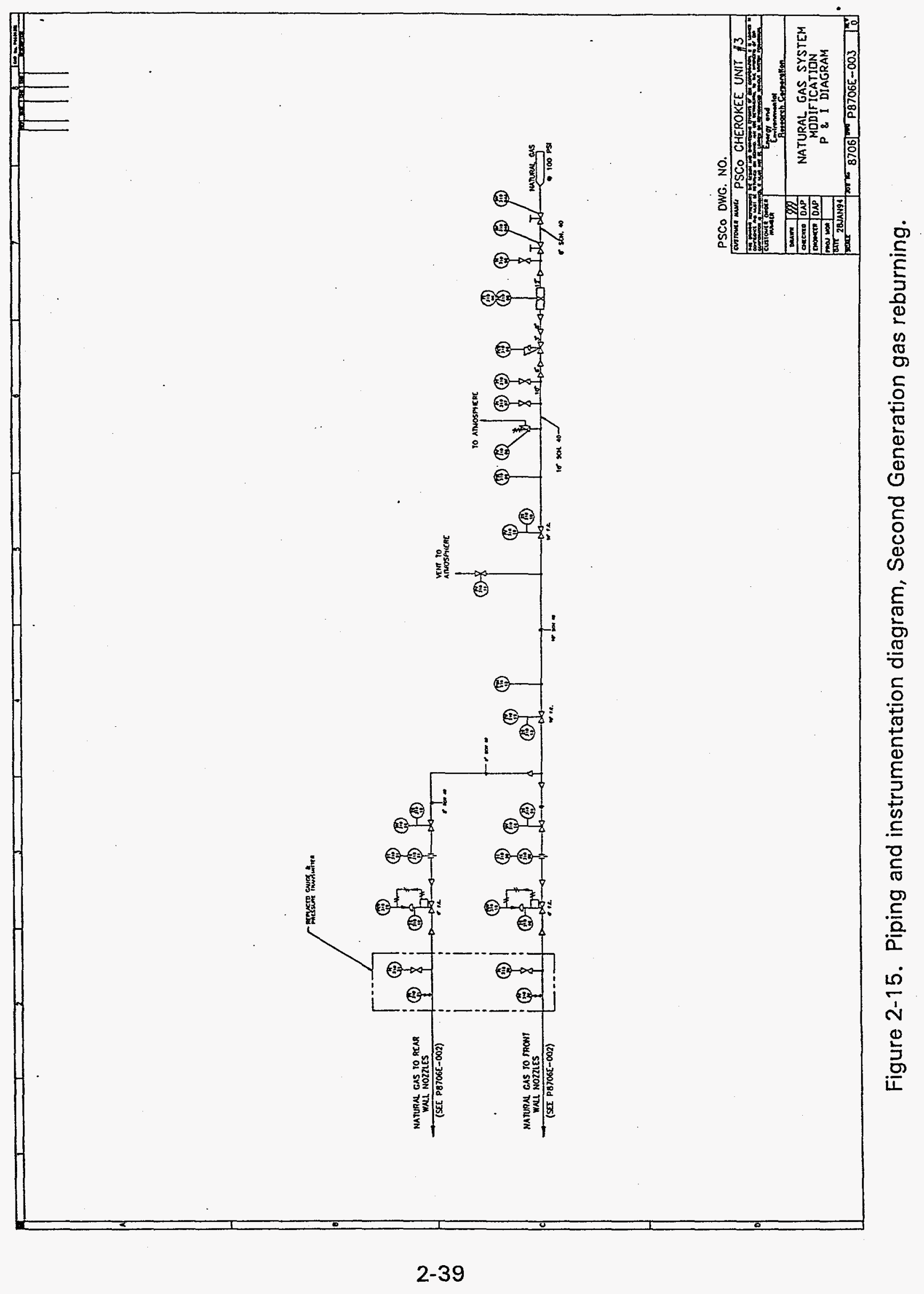




\subsection{UPDATE OF THE PUBLIC DESIGN REPORT}




\subsection{Design and Equipment Changes}

There is a significant amount of resistance in the utility industry to operating FGR systems. This attitude resulted from several serious accidents involving high temperature flue gas fans and the maintenance and operating cost issues associated with those fans. Testing has provided data that suggest a redesigned reburning fuel injector may perform quite well with greatly reduced or zero FGR. There would be no compromise made to the overall safety of the GR system if the FGR system were not utilized.

The GR-LNB system performance at Cherokee was evaluated continuously throughout the Optimization and Long-Term testing periods. The analyses focused on $\mathrm{NO}_{\mathrm{x}}$ reduction, process economic efficiency, combustion completion (CO emission and carbon-in-ash), thermal efficiency/heat rate, and other areas of boiler performance/operation. The analyses revealed that (1) $\mathrm{NO}_{x}$ reduction did not improve significantly at gas heat inputs above $10 \%$, (2) FGR had only a minor impact on $\mathrm{NO}_{x}$ reduction, and (3) CO emissions were significant in the "off-design" case of gas heat input below $18 \%$. The reason for elevated $\mathrm{CO}$ emissions was that under low gas inputs the OFA flows and injection velocities are also greatly reduced, preventing full burnout of fuels. EER therefore submitted a proposal to DOE to extend the project by incorporating modifications to the system to improve process economics and commercial attractiveness of GR. The economics were optimized by limiting the quantity of gas input in light of the gas-to-coal cost differential of $\$ 1.61 / 10^{6} \mathrm{Btu}$ at this site.

\subsubsection{Disposition of Flue Gas Recirculation System}

In the original GR system, FGR was used to enhance the penetration of the natural gas injected into the furnace. This was thought to be necessary since the total mass of natural 
gas was very small in comparison to the mass of flue gas from the burner region. The data analyses however revealed that $F G R$ had relatively little impact on $\mathrm{NO}_{x}$ reduction for $F G R$ flows of 4,000 to $14,000 \mathrm{scfm}\left(1.9\right.$ to $6.6 \mathrm{Nm}^{3} / \mathrm{s}$ ). This was most likely due to high process efficiency achieved by localized reducing areas in the furnace; i.e., uniform fuel rich conditions throughout the reburning zone were not necessary. Also, the reburn zone residence time was 0.50 seconds. EER has found that a residence time of this length is usually sufficient to obtain good $\mathrm{NO}_{\mathrm{x}}$ reduction. With $\mathrm{GR}$, as the residence time increases the effectiveness of FGR decreases.

For the reasons listed, the FGR system was eliminated from the GR system design. Elimination of $\mathrm{FGR}$ was expected to have minimal impact on $\mathrm{NO}_{x}$ control. It was also expected to have beneficial impacts on two areas: the steam attemperation spray rate and the total economics of the process. Since FGR increases the flue gas mass flow through

the upper furnace and convective pass, the result is higher heat transfer to the superheaters that necessitates a greater attemperation water spray rate. Therefore, elimination of $F G R$ would reduce the attemperation spray requirement at full load. Since the FGR system adds significantly to the capital cost of GR systems, its elimination would provide an installed cost savings of approximately $34 \%$ for GR applications. The equipment eliminated included ductwork, high static fan, control dampers, multiclone, and other miscellaneous small components.

\subsubsection{Reburning Fuel Injector Modification}

The reburning fuel injectors were replaced by high velocity gas jet injectors. The new injectors were designed with smaller flow areas to provide for a higher pressure drop, making greater use of the available natural gas pressure. The control system was also modified so that any combination of sixteen injectors could be selected for service. The gas heat input for the Second-Generation GR-LNB system would range from 5 to $10 \%$. In light of the gas-to-coal price differential, this significantly reduces the GR operating cost. 


\subsubsection{OFA System Modification}

First Generation GR testing demonstrated that a majority of the $\mathrm{NO}_{\mathrm{x}}$ reduction could be obtained with reburning gas consumption well below the $20 \%$ design value. Nearly $90 \%$ of the $\mathrm{NO}_{\mathrm{x}}$ reduction achieved with $20 \%$ reburning gas could be achieved by operating with only half that amount of reburning fuel $(10 \%)$. However, the installation could not be operated at the reduced reburning fuel inputs due to large amounts of carbon monoxide which were formed in the burnout zone due to poor mixing of the OFA with the reburning zone products. This was a result of the OFA jet velocity decreasing proportionally to the reburning fuel flow.

OFA ports were modified to allow on-line variation of the cross-sectional flow area of the port to provide optimum air jet velocities as the air flow rates changed. The goal of the OFA modification was to improve $\mathrm{CO}$ burnout over a wide range of OFA flows. The modified ports were of a double concentric design, with the inner port nominally supplying OFA up to $5 \%$ of the total combustion air. Any additional OFA flow would be added through the outer port. The design would achieve sufficient injection velocity and rapid mixing over a wide range of OFA flows. Improvement in the burnout of fuels, as indicated by $\mathrm{CO}$ emissions, was expected.

\subsection{Demonstration Plant Capital Cost Update}

The capital cost of the initial GR installation was as follows:

$\begin{array}{lr}\text { Project Management } & \$ 326,381 \\ \text { Engineering } & 623,522 \\ \text { Materials } & 4,707,282 \\ \text { Installation } & 5,032,928 \\ \text { Total } & \$ 10,690,113\end{array}$


The additional cost to convert the installation to Second Generation GR is as follows. Note that the cost includes removal of the FGR system:

$\begin{array}{lr}\text { Project Management } & \$ 60,424 \\ \text { Engineering } & 336,278 \\ \text { Material } & 95,563 \\ \text { Installation } & 314,055 \\ \text { Total } & \$ 806,320\end{array}$

These costs are not considered indicative of future, similar installations due to test-related equipment associated with the installation and design optimizing techniques employed.

The reader should refer to Section 7.0 for a detailed discussion of the current cost to install a GR system based on the Second Generation GR optimized technology.

\subsection{Demonstration Plant Operating Costs Update}

Table 3-1 presents the total annual fixed and variable operating costs for the reburning installation at Cherokee Unit 3. The fixed costs include operator labor, maintenance, and administrative support. The variable costs include gas-to-coal fuel cost differential and auxiliary power. The total annual fixed operation and maintenance cost is $\$ 59,169$. The total variable operating cost is $\$ 297 / \mathrm{hr}$ using a fuel differential of $\$ 1.60 / 10^{6}$ Btu and a natural gas heat input of $10 \%$. Assuming a $65 \%$ capacity factor, the annual total variable operating cost would be $\$ 1,689,152$. 


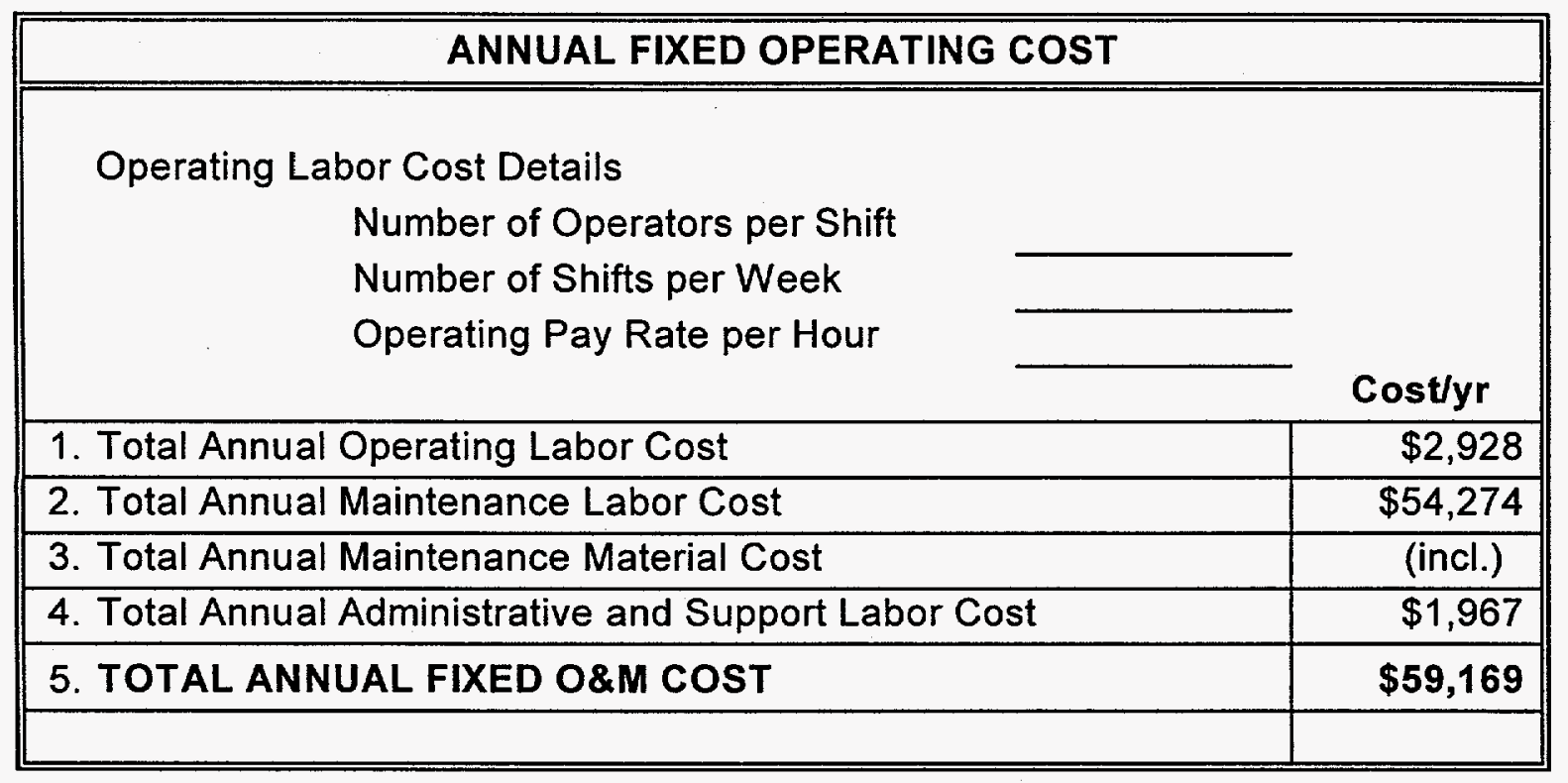

\begin{tabular}{|c|c|c|c|c|}
\hline \multicolumn{5}{|c|}{ VARIABLE OPERATING COST } \\
\hline Commodity & Unit & \$/Unit & Quantity/yr** & Cost/yr \\
\hline Fuel Differential (gas to coal) & $10^{6} \mathrm{Btu}$ & $\$ 1.60$ & 935,638 & $\$ 1,497,021$ \\
\hline Auxiliary Power & & & & $\$ 199,290$ \\
\hline Waste Disposal ${ }^{*}$ & ton & $\$ 9.29$ & $\overline{(695)}$ & $(\$ 6,459)$ \\
\hline & & & & \\
\hline & & & & \\
\hline & & & & \\
\hline TOTAL VARIABLE OPER & TING CC & & & $\$ 1,689,852$ \\
\hline
\end{tabular}

\section{Total Planned Operating Time for Demonstration}

* Credit based on $10 \%$ of total heat input as natural gas

* Based on a net heat rate of $10,400 \mathrm{Btu} / \mathrm{kWhr}, 10 \%$ gas and a $65 \%$ capacity factor 


\subsection{DEMONSTRATION PROGRAM}




\subsection{DEMONSTRATION PROGRAM}

The GR-LNB test program was designed initially to optimize the system with short parametric tests then operate it over a one-year demonstration period with the unit under dispatch load control. Testing was conducted according to a Phase III test plan prepared by EER and approved by project funders. In the midst of the long term testing, the GR system was modified to utilize Second Generation Reburning technology. The long term testing program was then completed.

\subsection{Test Plans}

The objective of the parametric/optimization test program was to identify the boiler set points or range of set points required to achieve both the targeted and optimal levels of $\mathrm{NO}_{\mathrm{x}}$ emissions reduction through the full load range of operation. This testing being done within the operability limits of the boiler. Parametric tests were performed to identify and quantify the impacts of various boiler and reburning system operating parameters. The information generated was used to fine tune (optimize) the reburning system in terms of $\mathrm{NO}_{x}$ reduction and operating costs. Further, boiler master curves were developed for the control system. The GR-LNB test plan sequence was as follows:

\footnotetext{
- Pre-construction baseline testing

- Post-construction baseline testing

- $\quad$ LNB optimization testing

- $\quad$ GR-LNB optimization testing (First Generation)

- Ultrasonic thickness inspection of tubes

- $\quad$ Long term testing

- $\quad$ GR-LNB optimization testing (Second Generation)

- Long term testing

- Ultrasonic thickness inspection of tubes
} 
Preliminary field tests were performed to identify the test conditions and procedures necessary to characterize the baseline operating conditions of the unit. The data documented the emissions and boiler performance characteristics and provided a basic set of boiler performance/operating data which were used in the process design studies and thermal performance analyses. Baseline unit performance and baseline emissions data were also obtained prior to the GR-LNB retrofit.

Following installation of the reburning equipment, a second baseline test was performed to assess the impact of the added equipment on boiler performance and flue gas emissions. Specifically, the $\mathrm{NO}_{x}$ and $\mathrm{CO}$ emissions were measured to determine the changes from the original baseline condition. Also, the impact of the OFA cooling air flow was assessed.

The performance of $\mathrm{LNBs}$ is very furnace specific. The degree of $\mathrm{NO}_{x}$ emissions reduction achievable with a burner retrofit to an existing furnace depends not only on the burner design, but also on other factors including:

- Initial $\mathrm{NO}_{x}$ level

- Coal type (fuel bound nitrogen and coal reactivity)

- Furnace burner spacing and firing depth

- Furnace volumetric heat release

- $\quad$ Retrofit constraints (e.g., diameter of original burner throat)

The manufacturer of the LNBs installed at Cherokee, Foster Wheeler Energy Corporation, (FWEC) conducted optimization tests of their burners. The focus of these tests was to adjust the combustion air registers to control the fuel/air distribution at the burner. This report documents only the $\mathrm{LNB} \mathrm{NO}_{\mathrm{x}}$ emissions reduction performance, since the FWEC burner adjusting techniques are proprietary and were not relayed on to EER. 
In GR there are several operating parameters that impact the $\mathrm{NO}_{x}$ reduction performance including:

- Primary zone stoichiometric ratio

- Reburn zone stoichiometric ratio

- Burnout (OFA) zone stoichiometric ratio

- Coal burner balance

- Reburn fuel distribution

- OFA distribution

A change in the primary zone stoichiometric ratio yields two separate effects on GR: a variation in initial NO levels and changes in the amount of reburning fuel (natural gas) that must be injected to achieve the targeted reburn zone stoichiometric ratio. Reburning data have shown that higher $\mathrm{NO}_{x}$ removal efficiencies occur with an increase in the initial $\mathrm{NO}_{x}$ concentration entering the reburn zone. At lower primary zone stoichiometric ratios, the initial $\mathrm{NO}_{\mathrm{x}}$ concentration entering the reburn zone decreases but as a system the overall $\mathrm{NO}_{x}$ reduction increases. When the primary stoichiometric ratio is high, a higher percentage of reburning fuel must be used to drive the reburn zone stoichiometric ratio down to the target value to achieve the $\mathrm{NO}_{x}$ emission level desired. This negatively affects the economics of the GR technology for the purchase price of natural gas will normally be quite higher than the parent coal.

Past tests have shown that for the GR technology, as the reburn zone stoichiometric ratio drops below 0.90 , the improvement in $\mathrm{NO}_{x}$ reduction levels off. In addition, the lower the stoichiometric ratio, the greater the potential for corrosion in the furnace, Therefore, the optimum reburn zone stoichiometric ratio was targeted at about 0.90 .

The burnout zone stoichiometric air to fuel ratio was established through injection of OFA to control $\mathrm{CO}$ and boiler efficiency. Higher ratios will result in greater dry gas losses, 
lowering the boiler efficiency. However, high ratios also result in better carbon burnout, increasing boiler efficiency. The parametric testing goal was to balance these two effects.

The furnace tubewalls could be susceptible to increased wastage due to the slightly fuel rich conditions in the reburn zone. To determine the wastage rate, ultrasonic thickness (UT) testing was performed on the tubes prior to and following long term GR-LNB testing. All areas of the boiler were tested including the waterwall, bullnose and division wall.

\subsubsection{Parametric/Optimization Testing}

The purpose of parametric testing was to define the relationships that exist between the controlling parameters and the boiler outputs. These relationships were then used to approximate the boiler set points required for optimum reburning performance. Optimization testing was used to fine tune the system. The test approach utilized a formalized test matrix consisting of a series of pre-planned tests that vary one parameter at a time (see Table 4-1). The parameters were as follows:

Load This parameter was varied from $60 \mathrm{MW}_{\mathrm{e}}$ to $150 \mathrm{MW}_{\mathrm{e}}$. The purpose of the variation was to establish the relationship between load and boiler emissions and performance with the reburning system in operation.

Boiler Excess $\mathrm{O}_{2}$ This parameter was varied from $2.50 \%$ to $4.00 \%$ (14\% - $24 \%$ excess air) at full load and higher levels at reduced loads (steam generation units are operated at increased excess air as load is reduced to increase the mass flow through the convective pass, thereby enhancing convective heat transfer). The purpose of the variation was to determine the minimum excess air operating point. Note that GR is most economical at lower primary zone stoichiometric ratios. However, the ratio must be balanced with respect to combustion completion, flame stability, slagging, and corrosion potential. 
TABLE 4-1. GR-LNB PARAMETRIC TEST MATRIX

\begin{tabular}{|c|c|c|c|c|c|c|c|c|c|c|c|c|}
\hline \multirow{2}{*}{$\begin{array}{c}\text { Test } \\
\text { ID }\end{array}$} & \multirow[t]{2}{*}{ Test Description } & \multirow{2}{*}{$\begin{array}{l}\text { Load } \\
(\mathrm{MWc})\end{array}$} & \multirow{2}{*}{$\begin{array}{c}\text { Mills } \\
\text { in } \\
\text { Scrvicc }\end{array}$} & \multirow{2}{*}{$\begin{array}{l}\text { Gas } \\
\text { Hcat } \\
\text { Input } \\
(\%)\end{array}$} & \multirow{2}{*}{$\begin{array}{c}\text { FGR . } \\
(\%)\end{array}$} & \multirow{2}{*}{$\begin{array}{l}\text { OFA } \\
\text { Flow } \\
\text { (scfm) }\end{array}$} & \multirow{2}{*}{$\begin{array}{c}\text { Excess } \\
\text { Oxygen } \\
(\%)\end{array}$} & \multirow{2}{*}{$\begin{array}{c}\text { Test } \\
\text { Duration } \\
\text { (min) }\end{array}$} & \multicolumn{4}{|c|}{ Measurements } \\
\hline & & & & & & & & & CEMS & HVT & $\begin{array}{c}\text { Carbon } \\
\text { in } \\
\text { Ash } \\
\end{array}$ & $\mathrm{N} 2 \mathrm{O}$ \\
\hline LNB - $1 \mathrm{~A}$ & Determine Minimum & 150 & $\mathrm{ABCD}$ & OFF & Cooling & Cooling & 2.50 & 60 & $x$ & & & \\
\hline LNB - 1B & Excess Air & 150 & $\mathrm{ABCD}$ & OFF & Cooling & Cooling & 3.00 & 120 & $\mathrm{x}$ & $\mathrm{x}$ & $\mathrm{x}$ & \\
\hline LNB - 1C & Operating Point & 150 & $\mathrm{ABCD}$ & OFF & Cooling & Cooling & 3.50 & 120 & $\mathrm{X}$ & & $x$ & \\
\hline LNB - 1D & & 150 & $\mathrm{ABCD}$ & OFF & Cooling & Cooling & 4.00 & 60 & $\mathrm{x}$ & & $x$ & \\
\hline LNB - $2 A$ & Detcrmine Minimum & 120 & $\mathrm{ABCD}$ & OFF & Cooling & Cooling & 2.75 & 60 & $x$ & & & \\
\hline $\mathrm{LNB}-2 \mathrm{~B}$ & Excess Air & 120 & $\mathrm{ABCD}$ & OFF & Cooling & Cooling & 3.25 & 120 & $X$ & $X$ & $\mathrm{X}$ & \\
\hline LNB - 2C & Operating Point & 120 & $\mathrm{ABCD}$ & $\overline{\mathrm{OFF}}$ & Cooling & Cooling & 4.00 & 120 & $\mathrm{X}$ & & $x$ & \\
\hline $\mathrm{LNB}-2 \mathrm{D}$ & & 120 & $\mathrm{ABCD}$ & OFF & Cooling & Cooling & 4.50 & 60 & $X$ & & $x$ & \\
\hline LNB - 2E & & 120 & $\mathrm{BCD}$ & OFF & Cooling & Cooling & 2.75 & 60 & $x$ & & & \\
\hline LNB - $2 F$ & & 120 & $\mathrm{BCD}$ & OFF & Cooling & Cooling & 3.25 & 60 & $\bar{x}$ & & & \\
\hline LNB - 2G & & 120 & $\mathrm{BCD}$ & OFF & Cooling & Cooling & 4.00 & 60 & $\mathrm{X}$ & & & \\
\hline $\mathrm{LNB}-2 \mathrm{H}$ & & 120 & $\mathrm{BCD}$ & OFF & Cooling & Cooling & 4.25 & 60 & $\mathrm{x}$ & & & \\
\hline $\mathrm{LNB}-3 \mathrm{~A}$ & Detcrmine Minimum & 90 & $\mathrm{BCD}$ & OFF & Cooling & Cooling & 3.50 & 120 & $x$ & $\mathrm{X}$ & $\mathrm{X}$ & \\
\hline LNB - 3B & Excess Air & 90 & $\overline{B C D}$ & OFF & Cooling & Cooling & 4.00 & 120 & $X$ & & $x$ & \\
\hline LNB - 3C & Operating Point & 90 & $\mathrm{BCD}$ & OFF & Cooling & Cooling & 4.50 & 60 & $\mathrm{X}$ & & $X$ & \\
\hline LNB - 3D & & 90 & $\mathrm{ABC}$ & OFF & Cooling & Cooling & 3.50 & 60 & $X$ & & & \\
\hline LNB - 3E & & 90 & $\overline{A B C}$ & OFF & Cooling & Cooling & 4.00 & 60 & $x$ & & & \\
\hline $\mathrm{LNB}-3 \mathrm{~F}$ & & 90 & $\mathrm{ABC}$ & OFF & Cooling & Cooling & 4.50 & 60 & $\mathrm{X}$ & & & \\
\hline$\overline{\mathrm{LNB}-4 \mathrm{~A}}$ & Detcrminc Minimum & 60 & $B C D$ & OFF & Cooling & Cooling & 4.50 & 120 & $\mathrm{X}$ & $\mathrm{X}$ & $\mathrm{X}$ & \\
\hline$L N B-4 B$ & Excess Air & 60 & $\mathrm{BCD}$ & OFF & Cooling & Cooling & 5.00 & 120 & $\mathrm{X}$ & & $\mathrm{X}$ & \\
\hline LNB - 4C & Opcrating Point & 60 & $\mathrm{BCD}$ & OFF & Cooling & Cooling & 5.50 & 60 & $x$ & & $X$ & \\
\hline LNB - 4D & & 60 & $A B C$ & OFF & Cooling & Cooling & 4.50 & 60 & $x$ & & & \\
\hline LNB - 4E & & 60 & $\mathrm{ABC}$ & OFF & Cooling & Cooling & 5.00 & 60 & $X$ & & & \\
\hline LNB - 4F & & 60 & $A B C$ & OFF & Cooling & Cooling & 5.50 & 60 & $x$ & & & \\
\hline
\end{tabular}


TABLE 4-1. GR-LNB PARAMETRIC TEST MATRIX (con't)

\begin{tabular}{|c|c|c|c|c|c|c|c|c|c|c|c|c|c|c|c|}
\hline \multirow{2}{*}{$\begin{array}{l}\text { Test } \\
\text { ID }\end{array}$} & \multirow[t]{2}{*}{ Test Description } & \multirow{2}{*}{$\begin{array}{l}\text { Load } \\
\text { (MWe) }\end{array}$} & \multirow{2}{*}{$\begin{array}{c}\text { Mills } \\
\text { in } \\
\text { Service }\end{array}$} & \multirow[b]{2}{*}{$\begin{array}{c}\text { Gas } \\
\text { Heat } \\
\text { Input } \\
(\%) \\
\end{array}$} & \multirow[b]{2}{*}{$\begin{array}{l}\text { FGR } \\
(\%) \\
\end{array}$} & \multirow[b]{2}{*}{$\begin{array}{l}\text { OFA } \\
\text { Flow } \\
\text { (scfm) }\end{array}$} & \multirow{2}{*}{$\begin{array}{c}\text { OFA } \\
\text { Vanc } \\
\text { Position }\end{array}$} & \multirow[b]{2}{*}{$\begin{array}{c}\text { Burner } \\
\text { Zone } \\
\text { Stoich } \\
\text { SR1 }\end{array}$} & \multirow{2}{*}{$\begin{array}{c}\text { Reburn } \\
\text { Zone } \\
\text { Stoich } \\
\text { SR2 } \\
\end{array}$} & \multirow[b]{2}{*}{$\begin{array}{c}\text { Burnout } \\
\text { Zone } \\
\text { Stoich } \\
\text { SR3 } \\
\end{array}$} & \multirow{2}{*}{$\begin{array}{c}\text { Tcst } \\
\text { Duration } \\
\text { (min) }\end{array}$} & \multicolumn{4}{|c|}{ Mcasurements } \\
\hline & & & & & & & & & & & & CEMS & HVT & $\begin{array}{c}\text { Carbon } \\
\text { in } \\
\text { Ash }\end{array}$ & $\mathrm{N} 2 \mathrm{O}$ \\
\hline$\overline{\text { LNB-OFA 5A }}$ & OFA Variation & 150 & $A B C D$ & $\overline{\mathrm{OFF}}$ & Cooling & $\overline{\text { OFF }}$ & Normal & 1.16 & 1.16 & 1.16 & 60 & $X$ & & & \\
\hline LNB-OFA $5 B$ & & 150 & $A B C D$ & OFF & Cooling & Cooling & Normal & 1.14 & 1.14 & 1.16 & 60 & $\mathrm{X}$ & & & \\
\hline LNB-OFA 5C & & 150 & $A B C D$ & OFF & Cooling & 10 & Normal & 1.12 & 1.12 & 1.16 & 120 & $\mathrm{X}$ & $X$ & & \\
\hline LNB-OFA 5D & & 150 & $\overline{\mathrm{ABCD}}$ & $\mathrm{OFF}$ & Cooling & 20 & Normal & 1.08 & 1.08 & 1.16 & 120 & $\mathrm{x}$ & & $\mathrm{x}$ & \\
\hline LNB-OFA 5E & & 150 & $\mathrm{ABCD}$ & OFF & Cooling & 30 & Normal & 1.05 & 1.05 & 1.16 & 120 & $X$ & $\mathrm{X}$ & & \\
\hline GR-LNB 6A & OFA Variation & 150 & $\mathrm{ABCD}$ & 20 & 3.4 & 65 & Normal & 1.15 & 0.92 & 1.16 & 120 & $x$ & & & \\
\hline GR-LNB 6B & w/Gas Reburning & 150 & $\mathrm{ABCD}$ & 20 & 3.4 & 70 & Normal & 1.12 & 0.90 & 1.16 & 120 & $X$ & & $\mathrm{X}$ & \\
\hline GR-LNB 6C & & 150 & $\mathrm{ABCD}$ & 20 & 3.4 & 75 & Normal & 1.10 & 0.88 & 1.16 & 120 & $X$ & $x$ & & \\
\hline GR-LNB 7A & Reburn Fucl & 150 & $A B C D$ & 5 & 3.4 & As Reqd & Normal & 1.10 & 1.04 & 1.16 & 120 & $\mathrm{X}$ & & $\mathrm{X}$ & \\
\hline GR-LNB 7B & Optimization & 150 & $\mathrm{ABCD}$ & 10 & 3.4 & As Reqd & Normal & 1.10 & 0.99 & 1.16 & 120 & $X$ & & & \\
\hline GR-LNB 7C & & 150 & $\mathrm{ABCD}$ & 15 & 3.4 & As Reqd & Normal & 1.10 & 0.93 & 1.16 & 120 & $\mathrm{X}$ & $\mathrm{X}$ & $\mathrm{X}$ & \\
\hline GR-LNB 7D & & 150 & $\mathrm{ABCD}$ & 20 & 3.4 & As Rcqd & Normal & 1.10 & 0.88 & 1.16 & 120 & $\mathrm{X}$ & & & \\
\hline GR-LNB 8A & FGR Variation & 150 & $\mathrm{ABCD}$ & 18 & 1 & As Reqd & Normal & 1.10 & 0.90 & 1.16 & 60 & $\mathrm{X}$ & & & \\
\hline GR-LNB 8B & & 150 & $A B C D$ & 18 & 2 & As Reqd & Normal & 1.10 & 0.90 & 1.16 & 60 & $x$ & & & \\
\hline GR-LNB 8C & & 150 & $\mathrm{ABCD}$ & 18 & 3 & As Reqd & Normal & 1.10 & 0.90 & 1.16 & 60 & $\mathrm{X}$ & & & \\
\hline GR-LNB 8D & & 150 & $\mathrm{ABCD}$ & 18 & Max. & As Reqd & Normal & 1.10 & 0.90 & 1.16 & 120 & $\mathrm{X}$ & & $\mathrm{X}$ & \\
\hline GR-LNB 9A & OFA Vane & 150 & $A B C D$ & Optim & Oplim & As Rcqd & Min & Optim & Optim & Oplim & 60 & $\mathrm{X}$ & & & \\
\hline GR-LNB 9B & Variation & 150 & $\mathrm{ABCD}$ & Optim & Optim & As Reqd & Max & Optim & Optim & Optim & 60 & $X$ & & & \\
\hline GR-LNB 10A & OFA Variation & 120 & $B C D$ & 20 & 3.4 & 60 & Normal & 1.17 & 0.93 & 1.21 & 120 & $X$ & & $\mathrm{x}$ & \\
\hline GR-LNB 10B & w/Reburning & 120 & $B C D$ & 20 & 3.4 & 65 & Normal & 1.14 & 0.91 & 1.21 & 120 & $X$ & & $\mathrm{x}$ & \\
\hline GR-LNB 10C & & 120 & $\mathrm{BCD}$ & 20 & 3.4 & 70 & Normal & 1.11 & 0.89 & 1.21 & 120 & $x$ & $\mathrm{x}$ & & \\
\hline GR-LNB 11A & Reburn Fucl & 120 & $\mathrm{BCD}$ & 5 & 3.4 & Optim & Normal & 1.12 & 1.06 & 1.21 & 120 & $\mathrm{X}$ & & $\mathrm{x}$ & \\
\hline GR-LNB 11B & Optimization & 120 & $\mathrm{BCD}$ & 10 & 3.4 & Optim & Normal & 1.12 & 1.01 & 1.21 & 60 & $X$ & & & \\
\hline GR-LNB 11C & & 120 & $B C D$ & 15 & 3.4 & Optim & Normal & 1.12 & 0.95 & 1.21 & 120 & $x$ & & $\mathrm{X}$ & \\
\hline GR-LNB 11D & & 120 & $\mathrm{BCD}$ & 20 & 3.4 & Optim & Normal & 1.12 & 0.90 & 1.21 & 120 & $x$ & & & \\
\hline
\end{tabular}


TABLE 4-1. GR-LNB PARAMETRIC TEST MATRIX (con't)

\begin{tabular}{|c|c|c|c|c|c|c|c|c|c|c|c|c|c|c|c|}
\hline \multirow{2}{*}{$\begin{array}{l}\text { Test } \\
\text { ID }\end{array}$} & \multirow[t]{2}{*}{ Test Description } & \multirow{2}{*}{$\begin{array}{l}\text { Load } \\
\text { (MWe) }\end{array}$} & \multirow{2}{*}{\begin{tabular}{|} 
Mills \\
in \\
Scrvice
\end{tabular}} & \multirow{2}{*}{$\begin{array}{l}\text { Gas } \\
\text { Heat } \\
\text { Input } \\
(\%) \\
\end{array}$} & \multirow{2}{*}{$\begin{array}{l}\text { FGR } \\
(\%)\end{array}$} & \multirow[b]{2}{*}{$\begin{array}{l}\text { OFA } \\
\text { Flow } \\
(\text { scfm })\end{array}$} & \multirow{2}{*}{$\begin{array}{c}\text { OFA } \\
\text { Vanc } \\
\text { Position }\end{array}$} & \multirow{2}{*}{$\begin{array}{c}\text { Burncr } \\
\text { Zone } \\
\text { Stoich } \\
\text { SR1 } \\
\end{array}$} & \multirow{2}{*}{$\begin{array}{c}\text { Reburn } \\
\text { Zonc } \\
\text { Stoich } \\
\text { SR2 }\end{array}$} & \multirow{2}{*}{$\begin{array}{c}\text { Burnout } \\
\text { Zone } \\
\text { Stoich } \\
\text { SR3 } \\
\end{array}$} & \multirow{2}{*}{$\begin{array}{c}\text { Test } \\
\text { Duration } \\
\text { (min) }\end{array}$} & \multicolumn{4}{|c|}{ Mcasurements } \\
\hline & & & & & & & & & & & & CEMS & HVT & $\begin{array}{c}\text { Carbon } \\
\text { in } \\
\text { Ash }\end{array}$ & $\mathrm{N} 2 \mathrm{O}$ \\
\hline GR-LNB 12A & OFA Variation & 90 & $B C D$ & 20 & 3.4 & 45 & Normal & 1.22 & 0.97 & 1.24 & 120 & $\mathrm{X}$ & & & \\
\hline GR-LNB 12B & w/Rcburning & 90 & $\mathrm{BCD}$ & 20 & 3.4 & 50 & Normal & 1.18 & 0.94 & 1.24 & 60 & $\mathrm{X}$ & & & \\
\hline GR-LNB 12C & & 90 & $\mathrm{BCD}$ & 20 & 3.4 & 55 & Normal & 1.14 & 0.91 & 1.24 & 120 & $X$ & & & \\
\hline GR-LNB 12D & & 90 & $\mathrm{BCD}$ & 20 & 3.4 & 60 & Normal & 1.10 & 0.88 & 1.24 & 120 & $\mathrm{X}$ & $\mathrm{x}$ & & \\
\hline GR-LNB 13A & Rcburn Fucl & 90 & $B C D$ & 10 & 3.4 & Optim & Normal & 1.14 & 1.03 & 1.24 & 120 & $\mathrm{x}$ & & $\mathrm{x}$ & \\
\hline GR-LNB 13B & Optimization & 90 & $B C D$ & 15 & 3.4 & Optim & Normal & 1.14 & 0.97 & 1.24 & 60 & $\mathrm{X}$ & & & \\
\hline GR-LNB 13C & & 90 & $B C D$ & 20 & 3.4 & Optim & Normal & 1.14 & 0.91 & 1.24 & 120 & $\mathrm{X}$ & & $\mathrm{x}$ & \\
\hline GR-LNB 13D & & 90 & $\mathrm{BCD}$ & 25 & 3.4 & Optim & Normal & 1.14 & 0.85 & 1.24 & 120 & $x$ & & & \\
\hline GR-LNB 14A & OFA Variation & 60 & $\mathrm{BCD}$ & 20 & 3.4 & 38 & Normal & 1.26 & 1.00 & 1.33 & 120 & $X$ & & $\mathrm{x}$ & \\
\hline GR-LNB 14B & w/Reburning & 60 & $B C D$ & 20 & 3.4 & 43 & Normal & 1.20 & 0.96 & 1.33 & 60 & $\mathrm{x}$ & & & \\
\hline GR-LNB 14C & & 60 & $\mathrm{BCD}$ & 20 & 3.4 & 48 & Normal & 1.15 & 0.92 & 1.33 & 120 & $X$ & & $\mathrm{x}$ & \\
\hline GR-LNB 14D & & 60 & $\mathrm{BCD}$ & 20 & 3.4 & 52 & Normal & 1.10 & 0.88 & 1.33 & 120 & $\mathrm{X}$ & $\mathrm{x}$ & & \\
\hline GR-LNB 15A & Reburn Fucl & 60 & $\mathrm{BCD}$ & 10 & 3.4 & Optim & Normal & 1.18 & 1.06 & 1.33 & 120 & $\mathrm{X}$ & & $x$ & \\
\hline GR-LNB 15B & Optimization & 60 & $\mathrm{BCD}$ & 15 & 3.4 & Optim & Normal & 1.18 & 1.00 & 1.33 & 60 & $\mathrm{X}$ & & & \\
\hline GR-LNB 15C & & 60 & $\mathrm{BCD}$ & 20 & 3.4 & Optim & Normal & 1.18 & 0.94 & 1.33 & 120 & $X$ & & $\mathrm{x}$ & \\
\hline GR-LNB 15D & & 60 & $B C D$ & 25 & 3.4 & Optim & Normal & 1.18 & 0.88 & 1.33 & 120 & $\mathrm{X}$ & & & \\
\hline
\end{tabular}


Gas Reburn Heat Input Natural gas was varied from $5 \%$ to $25 \%$ of the total heat input. During these tests, the primary zone stoichiometric ratio was fixed at 1.10. The reburn zone stoichiometric ratio increases as the gas heat input increases and creates reducing conditions. Overall $\mathrm{NO}_{\mathrm{x}}$ reductions are optimum when the reburn zone stoichiometric ratio is in the region of 0.90 . The purpose of varying the reburn fuel rate was to establish the relationship between the fuel rate and the boiler $\mathrm{NO}_{\mathrm{x}}$ emissions.

FGR Flowrate This parameter was varied from $1 \%$ to maximum capability. The FGR provides added momentum to the natural gas entering the furnace to aid in the mixing process with the flue gas from the primary zone. The purpose of the variation was to determine the impact on GR process efficiency.

OFA Flowrate This parameter was varied from 0 to $30 \mathrm{kscfm}$. Air was diverted from the LNBs to the OFA system, thereby reducing the primary zone stoichiometric ratio. It was desirable to minimize the overall excess air level in order to maintain the thermal efficiency of the unit. However, the OFA is required to minimize CO emissions and carbon-in-ash. The purpose of the variation was to establish the relationship between OFA flow and boiler emissions $\left(\mathrm{NO}_{\mathrm{x}}, \mathrm{CO}\right.$, etc.). Carbon-in-ash was also evaluated.

OFA Vane Position This parameter was varied from the maximum to minimum position. The purpose of varying the OFA vanes was to assess its impact on CO emissions and carbon burnout.

Following the parametric test program, optimization was performed to determine the reburning set points for optimum operation of the system. The testing was performed over the full range of boiler loads. 


\subsubsection{Long Term Testing}

A one year period of long-term GR-LNB testing was planned, with the unit operating under normal dispatch by PSCo staff. The data from the testing were used to establish the impacts of GR-LNB on long term boiler performance and economics. These impacts included furnace conditions such as slagging and waterwall corrosion rates, bottom ash characteristics and sluicing requirements, convective pass fouling, steam generation and final steam temperatures and pressures, process auxiliary power requirements, and impacts on the fabric filter dust collector (FFDC).

\subsubsection{Second Generation GR System Testing}

During long term testing, it was determined that the performance of the LNBs was not as good as expected, but could be improved with modifications. Also, it was determined that the performance and economics of the reburning system might be enhanced by converting it to Second Generation GR technology. Following adjustments to the LNBs and modifications to the GR system, the testing resumed with a parametric test program followed by load-following testing.

The parametric testing was based on a formalized test matrix consisting of a series of tests wherein one parameter was varied at a time (see Table 4-2). The parameters were as follows:

Load This parameter was varied from $90 \mathrm{MW}_{\mathrm{e}}$ to $150 \mathrm{MW}_{\mathrm{e}}$. The purpose of the variation was to establish the relationship between load and boiler emissions and performance with the reburning system in operation.

OFA Flowrate (w/o GR) -- This parameter was varied from 0 to $42 \mathrm{kscfm}$ at 150 $\mathrm{MW}_{\mathrm{e}}$ and 0 to $33 \mathrm{kscfm}$ at $120 \mathrm{MW}_{\mathrm{e}}$. As OFA flow increased, the secondary air to 
TABLE 4-2. SECOND GENERATION GR-LNB PARAMETRIC TEST MATRIX

\begin{tabular}{|c|c|c|c|c|c|c|c|c|c|c|c|c|c|c|c|c|}
\hline Test & Test & Load & Mills & Gas & Reburning & OFA & OrA & Bumer & Rebum & Burnout & OFA & 'Test & & Meast & rement & \\
\hline ID & Description & (MWe) & $\begin{array}{c}\text { in } \\
\text { Servioc }\end{array}$ & $\begin{array}{c}\text { Ileat } \\
\text { Input } \\
(\%)\end{array}$ & $\begin{array}{c}\text { Gas } \\
\text { Configuration } \\
\text { ID \# }\end{array}$ & Now & $\begin{array}{c}\text { Vane } \\
\text { Position }\end{array}$ & $\begin{array}{c}\text { Zone } \\
\text { Stoich } \\
\text { SR! }\end{array}$ & $\begin{array}{c}\text { Zone } \\
\text { Stoich } \\
\text { SR2 }\end{array}$ & \begin{tabular}{c|} 
Zone \\
Stoich \\
SR3
\end{tabular} & $(\%$, toll $)$ & $\begin{array}{l}\text { Dur. } \\
\text { (min) }\end{array}$ & CEMS & HVT & $\begin{array}{l}\text { Carbon } \\
\text { in } \\
\text { Ash }\end{array}$ & $\mathrm{N} 2 \mathrm{O}$ \\
\hline
\end{tabular}

\begin{tabular}{|l|c|c|c|c|c|c|c|c|c|c|c|c|c|c|c|c|}
\hline LNB-OFA 100A & FULL LOAD W/O GR & 150 & ABCD & OFF & OFF & OFF & Normal & 1.22 & 1.22 & 1.22 & 0.0 & 60 & $X$ & & $X$ & \\
LNB-OFA 100B & OFA VARIATION & 150 & ABCD & OFF & OFF & 10 & Normal & 1.18 & 1.18 & 1.22 & 3.3 & 60 & $X$ & & $X$ & \\
LNB-OFA 100C & & 150 & ABCD & OFF & OFF & 21 & Normal & 1.14 & 1.14 & 1.22 & 6.6 & 120 & $X$ & $X$ & $X$ & $X$ \\
LNB-OFA 100D & Performance Parameters: & 150 & ABCD & OFF & OFF & 31 & Normal & 1.10 & 1.10 & 1.22 & 9.8 & 60 & $X$ & & $X$ & \\
LNB-OFA 100E & NOx, CO \& Carbon-in-2sh & 150 & ABCD & OFF & OFF & 42 & Normal & 1.10 & 1.10 & 1.26 & 12.7 & 60 & $X$ & & $X$ & \\
\hline
\end{tabular}

\begin{tabular}{|c|c|c|c|c|c|c|c|c|c|c|c|c|c|c|}
\hline $\begin{array}{l}\text { LNB-OFA } 110 A \\
\text { LNB-OFA } 110 B\end{array}$ & $\begin{array}{l}\text { FULL LOAD OFA STAGING W/O GR } \\
\text { AIR SWIRL VARIATION } \\
\text {. }\end{array}$ & $\begin{array}{l}150 \\
150 \\
\end{array}$ & $\begin{array}{l}\triangle B C D \\
\triangle B C D\end{array}$ & $\begin{array}{l}\text { OFF } \\
\text { OFF }\end{array}$ & $\begin{array}{l}\text { OFF } \\
\text { OFF: }\end{array}$ & $\begin{array}{l}21 \\
21 \\
\end{array}$ & $\begin{array}{l}\text { Min } \\
\text { Max }\end{array}$ & $\begin{array}{l}1.14 \\
1.14 \\
\end{array}$ & $\begin{array}{l}1.14 \\
1.14 \\
\end{array}$ & $\begin{array}{l}1.22 \\
1.22 \\
\end{array}$ & $\begin{array}{l}6.6 \\
6.6 \\
\end{array}$ & $\begin{array}{l}60 \\
60 \\
\end{array}$ & $\begin{array}{l}X \\
X \\
\end{array}$ & $\begin{array}{l}x \\
x \\
\end{array}$ \\
\hline
\end{tabular}

\begin{tabular}{|l|c|c|c|c|c|c|c|c|c|c|c|c|c|c|c|c|}
\hline LNB-OFA 120A & MID LOAD W/O GR & 120 & ABCD & OFF & OFF & OFF & Normal & 1.24 & 1.24 & 1.24 & 0.0 & 60 & $\mathrm{X}$ & & $\mathrm{X}$ & \\
LNB-OFA 120B & OFA VARIATION & 120 & ABCD & OFF & OFF & 8 & Normal & 1.20 & 1.20 & 1.24 & 3.2 & 60 & $X$ & & $X$ & \\
LNB-OFA 120C & & 120 & ABCD & OFF & OFF & 17 & Nomal & 1.16 & 1.16 & 1.24 & 6.5 & 120 & $X$ & $X$ & $X$ & $X$ \\
LNB-OFA 120D & Performance Parameters: & 120 & ABCD & OFF & OFF & 25 & Nomal & 1.12 & 1.12 & 1.24 & 9.7 & 60 & $X$ & & $X$ & \\
LNB-OFA 120E & NOX, CO \& Carbon-in-ssh & 120 & ABCD & OFF & OFF & 33 & Normal & 1.12 & 1.12 & 1.28 & 12.5 & 60 & $X$ & & $X$ & \\
\hline
\end{tabular}

\begin{tabular}{|l|c|c|c|c|c|c|c|c|c|c|c|c|c|c|c|c|c|}
\hline LNB-OFA 130A & MID LOAD OFA STAGING W/O GR & 120 & ABCD & OFF & OFF & 17 & Min & 1.16 & 1.16 & 1.24 & 6.5 & 60 & $X$ & & $X$ & \\
\hline LNB-OFA 130B
\end{tabular}


TABLE 4-2. SECOND GENERATION GR-LNB PARAMETRIC TEST MATRIX (con't)

\begin{tabular}{|c|c|c|c|c|c|c|c|c|c|c|c|c|c|c|c|c|}
\hline Test & Test & Load & Mills & Gas & Rebuming & OFA & OFA & Bumet & Rebum & Bumout & OFA & Test & \multicolumn{4}{|c|}{ Measurement } \\
\hline ID & Description & $(M \dot{W C})$ & $\begin{array}{c}\text { in } \\
\text { Servicec }\end{array}$ & $\begin{array}{l}\text { Heat } \\
\text { Input } \\
(\%)\end{array}$ & $\begin{array}{c}\text { Gas } \\
\text { Configuration } \\
\text { ID\# }\end{array}$ & $\begin{array}{l}\text { Flow } \\
\text { (kscfm }\end{array}$ & $\begin{array}{c}\text { Vane } \\
\text { Position }\end{array}$ & $\begin{array}{c}\text { Zone } \\
\text { Stoich } \\
\text { SR1 } \\
\end{array}$ & \begin{tabular}{|c} 
Zone \\
Stoich \\
SR2 \\
\end{tabular} & $\begin{array}{c}\text { Zone } \\
\text { Stoich } \\
\text { SR3 } \\
\end{array}$ & $(\%$, , otl $)$ & $\begin{array}{l}\text { Dur. } \\
\text { (min) }\end{array}$ & CEMS & HVT & $\begin{array}{c}\text { Carbon } \\
\text { in } \\
\text { Ash }\end{array}$ & $\mathrm{N} 2 \mathrm{O}$ \\
\hline GR-LNB 140A & FULL LOAD GAS REBURNING & 150 & $A B C D$ & 10 & 14 & 50 & Optim & 1.14 & 1.03 & 1.22 & 15.9 & 60 & $\mathrm{x}$ & & $\mathrm{x}$ & \\
\hline GR-LNB 140B & SR1 \& OFA VARIATTON & 150 & $A B C D$ & 10 & 14 & 55 & Optim & 1.12 & 1.01 & 1.22 & 17.4 & 60 & $\mathrm{x}$ & & $\mathrm{x}$ & \\
\hline GR-LNB $140 \mathrm{C}$ & Performance Paramters: & 150 & $A B C D$ & 10 & 14 & 60 & Optim & 1.10 & 0.99 & 1.22 & 18.9 & 60 & $\mathrm{x}$ & & $\mathrm{x}$ & \\
\hline GR-LNB 140D & NOx, CO, C-in-ash, slagging, name stability & 150 & $\triangle B C D$ & 10 & 14 & 64 & Optim & 1.08 & 0.97 & 1.22 & 20.3 & 60 & $\mathrm{x}$ & & $x$ & \\
\hline
\end{tabular}

\begin{tabular}{|c|c|c|c|c|c|c|c|c|c|c|c|c|c|c|c|c|}
\hline GR-LNB I5OA & FULL LOAD GAS REBURNING & 150 & $\mathrm{ABCD}$ & 4 & 1 & 43 & Optim & 1.10 & 1.06 & 1.22 & 13.4 & 60 & $\mathrm{x}$ & & $\mathrm{x}$ & \\
\hline GR-LNB 150B & GAS HEAT INPUT AND INJECTOR-IN- & 150 & $A B C D$ & 4 & 2 & 43 & Optim & 1.10 & 1.06 & 1.22 & 13.4 & 60 & $\mathrm{x}$ & & $\mathrm{x}$ & \\
\hline GR-LNB $150 C$ & SERVICE VARIATTON & 150 & $A B C D$ & 6 & 3 & 48 & Optim & 1.10 & 1.03 & 1.22 & 15.2 & 60 & $\mathrm{x}$ & & $\mathrm{x}$ & \\
\hline GR-LNB 150D & & 150 & $A B C D$ & 6 & 4 & 48 & Optim & 1.10 & 1.03 & 1.22 & 15.2 & 60 & $\mathrm{x}$ & & $\mathrm{x}$ & \\
\hline GR-LNB 150E & SR1 NOMNNALLY SET AT 1.10 & 150 & $A B C D$ & 10 & 9 & 60 & Optim & 1.10 & 0.99 & 1.22 & 18.9 & 60 & $\mathrm{x}$ & & $\mathrm{x}$ & \\
\hline GR-LNB 150F & ACTUAL SRI DETERMINED FROM & .150 & $A B C D$ & 10 & 10 & 60 & Optim & 1.10 & 0.99 & 1.22 & 18.9 & 60 & $\mathrm{x}$ & & $\mathrm{x}$ & \\
\hline GR-LNB 150G & TESTS GR-LNB 140A -140D & 150 & $A B C D$ & 14 & 12 & 71 & Optim & 1.10 & 0.95 & 1.22 & 22.5 & 120 & $\mathrm{x}$ & $\mathrm{x}$ & $\mathrm{x}$ & $\mathrm{x}$ \\
\hline GR-LNB 150HI & Pefformance Paramters: & 150 & $A B C D$ & 14 & 13 & 71 & Optim & 1.10 & 0.95 & 1.22 & 22.5 & 60 & $\mathrm{x}$ & & $\mathrm{x}$ & \\
\hline GR-LNB 150I & NOx, CO, \& C-in-ash & 150 & $\triangle B C D$ & 18 & 14 & 83 & Optim & 1.10 & 0.90 & 1.22 & 26.1 & 120 & $\mathrm{x}$ & $x$ & $\underline{x}$ & $\underline{x}$ \\
\hline
\end{tabular}

\begin{tabular}{|c|c|c|c|c|c|c|c|c|c|c|c|c|c|c|}
\hline \multirow{3}{*}{$\begin{array}{l}\text { GR-LNB 160A } \\
\text { GR-LNB 160B } \\
\text { GR-LNB } 160 C\end{array}$} & \multirow{3}{*}{$\begin{array}{l}\text { FULL LOAD GAS REBURNING } \\
\text { SR3 VARIATION } \\
\text { SR1 NOMINALLY SET AT } 1.10\end{array}$} & \multirow{2}{*}{$\begin{array}{l}150 \\
150\end{array}$} & \multicolumn{2}{|l|}{$\triangle B C D$} & Optim & 65 & Optim & 1.10 & 0.99 & 1.24 & 20.2 & 60 & $\mathrm{x}$ & $\mathrm{x}$ \\
\hline & & & $A B C D$ & 10 & Optim & 70 & Optim & 1.10 & 0.99 & 1.26 & 21.4 & 60 & $\mathrm{x}$ & $\mathrm{x}$ \\
\hline & & 150 & $A B C D$ & 10 & Optim & 75 & Optim & 1.10 & 0.99 & 1.28 & 22.7 & 60 & $\mathrm{x}$ & $\mathrm{x}$ \\
\hline GR-LNB 160D & ACTUAL SRI FROM TESTS 140A - 140D & 150 & $\mathrm{ABCD}$ & 10 & Optim & 80 & Optim & 1.10 & 0.99 & 1.30 & 23.8 & 60 & $\mathrm{x}$ & $x$ \\
\hline
\end{tabular}

\begin{tabular}{|c|c|c|c|c|c|c|c|c|c|c|c|c|c|c|}
\hline \multirow[t]{2}{*}{$\begin{array}{l}\text { GR-LNB 170A } \\
\text { GR-LNB 170B }\end{array}$} & \multirow{2}{*}{$\begin{array}{l}\text { FULL LOAD GAS REBURNING } \\
\text { SIDE TO SIDE GAS INPUT TEST } \\
\text { nance Parameters: NOx, CO, C-in-ash }\end{array}$} & $\begin{array}{l}150 \\
150\end{array}$ & $\begin{array}{l}\mathrm{ABCD} \\
\mathrm{ABCD}\end{array}$ & $\begin{array}{l}8 \\
8 \\
\end{array}$ & $\begin{array}{l}7 \\
8 \\
\end{array}$ & $\begin{array}{r}54 \\
54 \\
\end{array}$ & $\begin{array}{l}\text { Optim } \\
\text { Optim }\end{array}$ & $\begin{array}{l}1.10 \\
1.10 \\
\end{array}$ & $\begin{array}{l}1.01 \\
1.01 \\
\end{array}$ & $\begin{array}{l}1.22 \\
1.22 \\
\end{array}$ & $\begin{array}{r}17.0 \\
17.0 \\
\end{array}$ & $\begin{array}{l}60 \\
60 \\
\end{array}$ & $\begin{array}{l}X \\
X \\
\end{array}$ & $\begin{array}{l}x \\
x \\
\end{array}$ \\
\hline & & & & & & & & & & & & & & \\
\hline $\begin{array}{l}\text { GR-LNB 180A } \\
\text { GR-LNB 180B } \\
\text { GR-LNB-180C }\end{array}$ & $\begin{array}{c}\text { 3 MILL - MAX LOAD GAS REBURNING } \\
\text { GAS HEAT INPUT VARIATION } \\
\text { Performance Paramters: NOx, CO, C-in-ash }\end{array}$ & $\begin{array}{l}\operatorname{Max} \\
\operatorname{Max} \\
\operatorname{Max}\end{array}$ & $\begin{array}{l}A B C \\
A B C \\
A B C\end{array}$ & $\begin{array}{c}14 \\
10 \\
4 \\
\end{array}$ & $\begin{array}{l}\text { Optim } \\
\text { Optim } \\
\text { Optim }\end{array}$ & \begin{tabular}{|l|} 
As Req \\
As Req \\
As Req
\end{tabular} & $\begin{array}{l}\text { Optim } \\
\text { Optim } \\
\text { Optim }\end{array}$ & $\begin{array}{l}1.10 \\
1.10 \\
1.10\end{array}$ & $\begin{array}{l}0.95 \\
0.99 \\
1.06\end{array}$ & $\begin{array}{l}1.22 \\
1.22 \\
1.22\end{array}$ & $\begin{array}{l}22.5 \\
18.9 \\
13.4 \\
\end{array}$ & $\begin{array}{l}60 \\
60 \\
60 \\
\end{array}$ & $\begin{array}{l}\mathrm{x} \\
\mathrm{x} \\
\mathrm{x} \\
\end{array}$ & $\begin{array}{l}\mathrm{x} \\
\mathrm{x} \\
\mathrm{x} \\
\end{array}$ \\
\hline
\end{tabular}


TABLE 4-2. SECOND GENERATION GR-LNB PARAMETRIC TEST MATRIX (con't)

\begin{tabular}{|c|c|c|c|c|c|c|c|c|c|c|c|c|c|c|c|c|}
\hline Test & Test & Load & Mills & Gas & Rebuming & OFA & OFA & Bumer & Rebum & Bumout & OFA & Test & \multicolumn{4}{|c|}{ Measurement } \\
\hline ID & Description & (MWe) & $\begin{array}{c}\text { in } \\
\text { Servicc } \\
\end{array}$ & $\begin{array}{l}\text { Heat } \\
\text { Input } \\
(\%)\end{array}$ & $\begin{array}{c}\text { Gas } \\
\text { Configuration } \\
\text { ID\# }\end{array}$ & $\begin{array}{l}\text { Fow } \\
\text { (kscfm) }\end{array}$ & $\begin{array}{c}\text { Vane } \\
\text { Position } \\
\end{array}$ & \begin{tabular}{|c} 
Zone \\
Stoich \\
SR1 \\
\end{tabular} & \begin{tabular}{|c} 
Zone \\
Stoich \\
SR2 \\
\end{tabular} & $\begin{array}{c}\text { Zone } \\
\text { Stoich } \\
\text { SR3 }\end{array}$ & $(\%$, , odu $)$ & $\begin{array}{l}\text { Dur. } \\
\text { (min }\end{array}$ & CEMS & HVT & $\begin{array}{l}\text { Carbon } \\
\text { in } \\
\text { Ash } \\
\end{array}$ & $\mathrm{N} 2 \mathrm{O}$ \\
\hline GR-LNB 190A & GAS REBURNING MID & 120 & $\mathrm{ABCD}$ & 10 & 14 & 41 & Normal & 1.16 & 1.04 & 1.24 & 15.8 & 60 & $\mathrm{x}$ & & $\mathrm{x}$ & \\
\hline GR-LNB 190B & SR1 \& OFA VARIATTION & 120 & $A B C D$ & 10 & 14 & 44 & Normal & 1.14 & 1.03 & 1.24 & 17.3 & 60 & $\mathrm{x}$ & & $\mathrm{x}$ & \\
\hline GR-LNB 190C & Perfomance Paramters: & 120 & $A B C D$ & 10 & 14 & 48 & Normal & 1.12 & 1.01 & 1.24 & 18.7 & 60 & $\mathrm{x}$ & & $\mathrm{x}$ & \\
\hline GR-LNB 190D & NOx, CO, C-in-ash, slagging, flame stability & 120 & $A B C D$ & 10 & 14 & 52 & Normal & 1.10 & 0.99 & 1.24 & 20.2 & 60 & $\mathrm{x}$ & & $\mathrm{x}$ & \\
\hline
\end{tabular}

\begin{tabular}{|c|c|c|c|c|c|c|c|c|c|c|c|c|c|c|}
\hline GR-LNB 200A & GAS REBURNING MID LOAD & 120 & $\mathrm{ABCD}$ & 4 & 1 & 34 & Normal & 1.12 & 1.08 & 1.24 & 13.3 & 60 & $\mathrm{x}$ & $\mathrm{x}$ \\
\hline GR-LNB 200B & GAS HEAT INPUT AND INJECTOR-IN- & 120 & $A B C D$ & 4 & 2 & 34 & Normal & 1.12 & 1.08 & 1.24 & 13.3 & 60 & $\mathrm{x}$ & $\mathrm{x}$ \\
\hline GR-LNB 200C & SERVICE VARIATION & 120 & $\mathrm{ABCD}$ & 6 & 3 & 39 & Normal & 1.12 & 1.05 & 1.24 & 15.1 & 60 & $\mathrm{x}$ & $\mathrm{x}$ \\
\hline GR-LNB 200D & & 120 & $A B C D$ & 6 & 4 & 39 & Nomal & 1.12 & 1.05 & 1.24 & 15.1 & 60 & $\mathrm{x}$ & $\mathrm{x}$ \\
\hline GR-LNB 200E & SR1 NOMINALLY SET AT 1.12 & 120 & $A B C D$ & 10 & 9 & 48 & Normal & 1.12 & 1.01 & 1.24 & 18.7 & 60 & $\mathrm{x}$ & $\mathrm{x}$ \\
\hline GR-LNB 200F & ACTUAL SRI DETERMINED FROM & 120 & $\mathrm{ABCD}$ & 10 & 10 & 48 & Normal & 1.12 & 1.01 & 1.24 & 18.7 & 60 & $\mathrm{x}$ & $\mathrm{x}$ \\
\hline GR-LNB 200G & TESTS GR-LNB 190A -190D & 120 & $A B C D$ & 14 & 12 & 57 & Normal & 1.12 & 0.96 & 1.24 & 22.3 & 60 & $\mathrm{x}$ & $\mathrm{x}$ \\
\hline GR-LNB 200H & Performance Paramters: & 120 & $\mathrm{ABCD}$ & 14 & 13 & 57 & Normal & 1.12 & 0.96 & 1.24 & 22.3 & 60 & $\mathrm{x}$ & $\mathrm{x}$ \\
\hline GR-LNB 2001 & NOx, CO, \& C-in-ash & 120 & $\triangle B C D$ & 18 & 14 & 67 & Normal & 1.12 & 0.92 & 1.24 & 25.9 & 60 & $\mathrm{x}$ & $\mathrm{x}$ \\
\hline
\end{tabular}

\begin{tabular}{|c|c|c|c|c|c|c|c|c|c|c|c|c|c|c|}
\hline \multirow{2}{*}{$\begin{array}{l}\text { GR-LNB } 210 A \\
\text { GR-LNB } 210 B\end{array}$} & 3 MILL - MID LOAD GAS REBURNING & 120 & $\mathrm{ABC}$ & 14 & Optim & 57 & Normal & 1.12 & 0.96 & 1.24 & 22.3 & 60 & $\mathrm{x}$ & $\mathrm{x}$ \\
\hline & GAS HEAT INPUT VARUATION & 120 & $A B C$ & 10 & Optim & 48 & Normal & 1.12 & 1.01 & 1.24 & 18.7 & $\infty$ & $\mathrm{x}$ & $\mathrm{x}$ \\
\hline GR-LNB $210 C$ & Performance Paramters: NOx, CO, \& C-in-ash & 120 & $A B C$ & 4 & Optim & 34 & Nomal & 1.12 & 1.08 & 1.21 & 13.3 & 60 & $\mathrm{x}$ & $\mathrm{x}$ \\
\hline
\end{tabular}

\begin{tabular}{|c|c|c|c|c|c|c|c|c|c|c|c|c|c|c|}
\hline \multirow{2}{*}{$\begin{array}{l}\text { GR-LNB 220A } \\
\text { GR-LNB 220B }\end{array}$} & GAS REBURNING LOW LOAD & 90 & $\triangle B C D$ & 10 & 14 & 42 & Nomal & 1.18 & 1.06 & 1.33 & 20.2 & 60 & $\mathrm{x}$ & $\mathrm{x}$ \\
\hline & SR1 \& OFA VARIATION & 90 & $\triangle B C D$ & 10 & 14 & 45 & Normal & 1.16 & 1.04 & 1.33 & 21.5 & $\infty$ & $\mathrm{x}$ & $\mathrm{x}$ \\
\hline GR-LNB 220C & Performance Paramiers: & 90 & $A B C D$ & 10 & 14 & 47 & Normal & 1.14 & 1.03 & 1.33 & 22.9 & 60 & $x$ & $\mathrm{x}$ \\
\hline GR-LNB 220D & NOx, CO, C-in-ash, slagging, flame stability & 90 & $A B C D$ & 10 & 14 & 50 & Normal & 1.12 & 1.01 & 1.33 & 24.2 & 60 & $\mathrm{x}$ & $\mathrm{x}$ \\
\hline
\end{tabular}

\begin{tabular}{|c|c|c|c|c|c|c|c|c|c|c|c|c|c|c|}
\hline GR-LNB 230A & GAS REBURNING LOW LOAD & 90 & $A B C D$ & 4 & 1 & 37 & Normal & 1.14 & 1.09 & 1.33 & 17.7 & 60 & $\mathrm{x}$ & $\mathrm{x}$ \\
\hline GR-LNB 230B & GAS HEAT INPUT AND INJECTOR-IN- & 90 & $\triangle B C D$ & 4 & 2 & 37 & Normal & 1.14 & 1.09 & 1.33 & 17.7 & 60 & $\mathrm{x}$ & $\mathrm{x}$ \\
\hline GR-LNB $230 \mathrm{C}$ & SERVICE VARIATION & 90 & $A B C D$ & 8 & 5 & 44 & Normal & 1.14 & 1.05 & 1.33 & 21.1 & 60 & $\mathrm{x}$ & $\mathrm{x}$ \\
\hline GR-LNB 230D & SR1 NOMINALLY 1.14, USE PREVIOUS TESTS & 90 & $A B C D$ & 8 & 0 & 44 & Normal & 1.14 & 1.05 & 1.33 & 21.1 & 60 & $\mathrm{x}$ & $\mathrm{x}$ \\
\hline GR-LNB 230E & ACTUAL FROM TESTS 220A - 220D & 90 & $\triangle B C D$ & 12 & 11 & 51 & Normal & 1.14 & 1.00 & 1.33 & 24.6 & 60 & $\mathrm{x}$ & $\mathrm{x}$ \\
\hline GR-LNB 230F & Performance Paramters: NOx, CO, \& C-in-nsh & 90 & $\triangle B C D$ & 18 & 14 & 62 & Normal & 1.14 & 0.93 & 1.33 & 29.7 & 60 & $\mathrm{x}$ & $\mathrm{x}$ \\
\hline
\end{tabular}


the LNBs decreased, which reduced the primary zone stoichiometric ratio from 1.22 to 1.10. The purpose of the variation was to assess the impact of OFA staging on $\mathrm{NO}_{\mathbf{x}}$ control and the extent of fuel burnout ( $\mathrm{CO}$ emissions and carbon-in-ash). Additional testing was performed to evaluate the impact of OFA air swirl. The OFA ports were equipped with swirl vanes, which would improve lateral coverage of the furnace flow field. The swirler position was varied from the minimum to maximum setting.

Gas Injector Configuration The number of reburning fuel injectors in service was varied using configurations 1 through 14 (Figure 4-1) to see which combination gave the best $\mathrm{NO}_{x}$ reduction. The natural gas heat input was varied from 4 to $18 \%$ depending on the number of injectors in service. Generally, even numbers of gas injector combinations were selected for evaluation since even numbers are required to maintain side-to-side symmetry in gas heat input.

OFA Flowrate ( $w / G R$ ) This parameter was varied from 50 to $80 \mathrm{kscfm}$ at $150 \mathrm{MW}_{\mathrm{e}}$ and 41 to $57 \mathrm{kscfm}$ at $120 \mathrm{MW}_{\mathrm{e}}$. The purpose of the variation was to establish the relationship between OFA flow and $\mathrm{CO}$ emissions. Carbon-in-ash was also evaluated.

Gas Injection Bias Tests were performed to determine if the injection of more gas into one side of the furnace than the other improved GR system performance. The same level of gas was input into either of two configurations to determine if $\mathrm{NO}_{x}$ reduction could be improved with gas injection into either the right or left side of the furnace.

Three Mill Operation Tests were performed to evaluate various levels of gas heat input under the maximum load achieved with three mills in service. Gas heat input was varied between 4 and $14 \%$ and the injectors placed in service were determined from the previous test series. While unit operators generally have all four mills in 

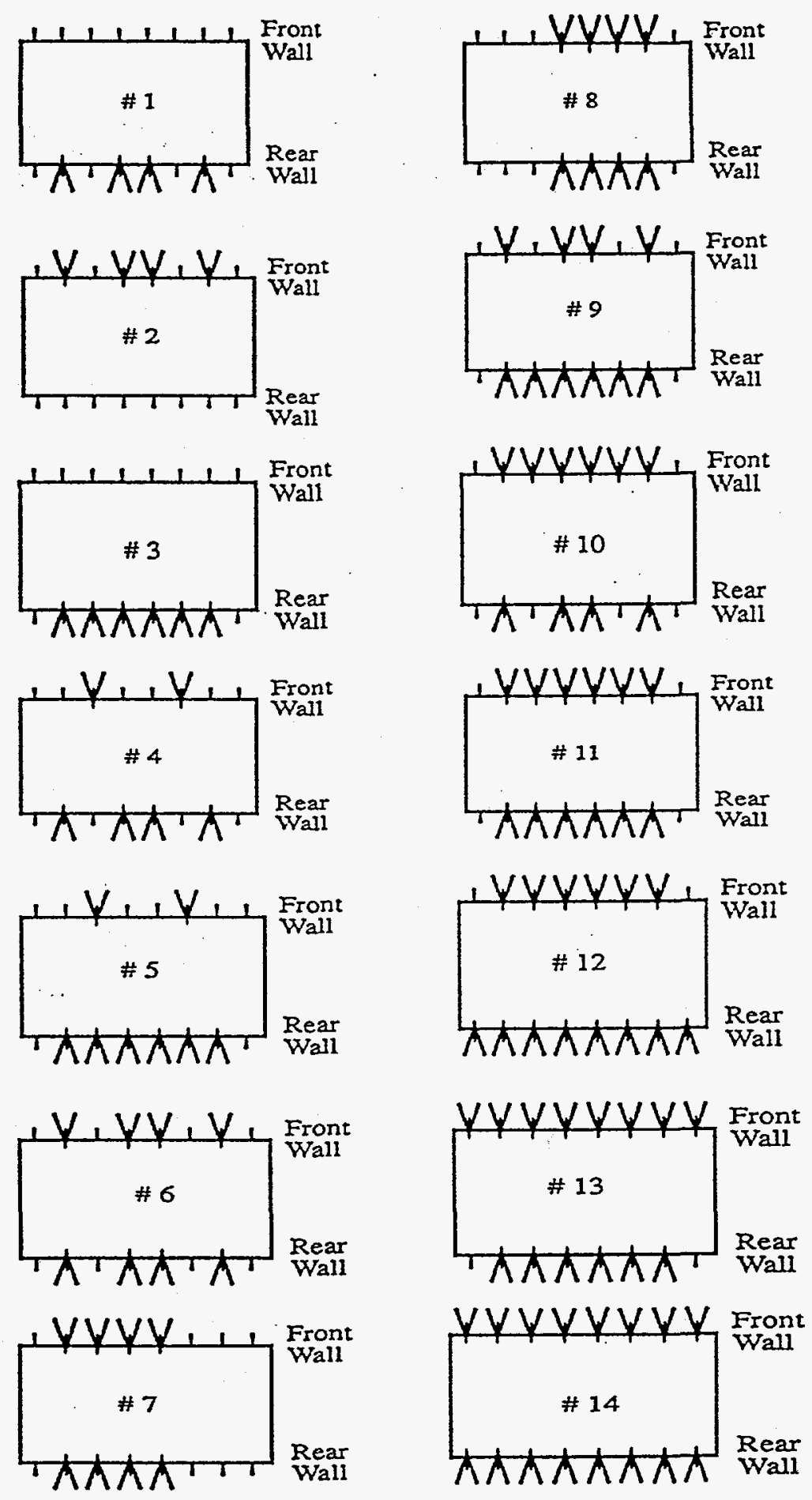

Figure 4-1. Reburn gas injector configurations 
service over a wide range of load, there are times when one is out of service for routine maintenance or due to an emergency trip. Under baseline operation the bottom row of burners (A mill) are taken out of service at loads of $90 \mathrm{MW}_{\mathrm{e}}$ and less.

\subsubsection{Gas Firing and Gas/Gas Reburning Testing}

Table 4-3 presents the parametric test matrix for the $100 \%$ gas firing and Gas/Gas Reburning testing. Significant reductions in boiler emissions including $\mathrm{NO}_{\mathrm{x}}, \mathrm{SO}_{2}, \mathrm{CO}_{2}$, and particulate matter were expected from firing a clean fuel such as natural gas.

In general, the primary and burnout zone stoichiometric ratios were much lower than that under coal firing. Burners firing natural gas typically operate at 5 to $10 \%$ excess air, compared to 15 to $20 \%$ for coal. The parameters were as follows:

Load This parameter was varied from $90 \mathrm{MW}_{\mathrm{e}}$ to $150 \mathrm{MW}_{\mathrm{e}}$. The purpose of the variation was to establish the relationship between load and boiler emissions and performance with the reburning system in operation.

Primary Zone Stoichiometric Ratio (SR) The SR was varied from 1.04 to 1.10 at full load and higher levels at reduced loads. The purpose of the variation was to determine the minimum excess air operating point as determined by carbon burnout.

Gas Reburn Heat Input Natural gas was varied from $5 \%$ to $25 \%$ of the total heat input. During the tests, the primary zone stoichiometric ratio was fixed at 1.06 . In this case the economic consideration of firing gas was eliminated, since there is no change in reburning fuel. However, a constraint against using higher levels of reburning gas is the formation of a fuel rich conditions in the furnace providing a 


\section{TABLE 4-3. $100 \%$ GAS FIRING AND GAS FIRING w/GR TEST MATRIX}

\begin{tabular}{|c|c|c|c|c|c|c|c|c|c|c|c|c|}
\hline $\begin{array}{l}\text { Test } \\
\text { ID }\end{array}$ & $\begin{array}{c}\text { Test } \\
\text { Description }\end{array}$ & $\begin{array}{l}\text { Load } \\
\text { MWe } \\
\text { (MWc) }\end{array}$ & $\begin{array}{c}\text { Reburming } \\
\text { Gas Heat } \\
\text { Input } \\
(\%) \\
\end{array}$ & $\begin{array}{l}\text { Reburning } \\
\text { Gas } \\
\text { Injectors } \\
\text { In Service }\end{array}$ & $\begin{array}{l}\text { OFA } \\
\text { Flow } \\
(\mathrm{kscfm})\end{array}$ & $\begin{array}{c}\text { OFA } \\
\text { Vane } \\
\text { Position }\end{array}$ & $\begin{array}{c}\text { Bumcr } \\
\text { Zone } \\
\text { Stoich } \\
\text { SR1 } \\
\end{array}$ & $\begin{array}{c}\text { Rebum } \\
\text { Zone } \\
\text { Stoich } \\
\text { SR2 } \\
\end{array}$ & $\begin{array}{c}\text { Burnout } \\
\text { Zonc } \\
\text { Stoich } \\
\text { SR3 } \\
\end{array}$ & $\begin{array}{c}\text { OFA } \\
(\%, \text { totl }) \\
\end{array}$ & $\begin{array}{l}\text { Test } \\
\text { Dur. } \\
(\min ) \\
\end{array}$ & CEMS \\
\hline $\begin{array}{l}\text { GLNB 100A } \\
\text { GLNB 100B } \\
\text { GLNB 100C }\end{array}$ & \begin{tabular}{|c} 
FULL LOAD W/O GR \\
EXCESS AIR VARIATION \\
Performance Parameters: NOx \& CO
\end{tabular} & $\begin{array}{l}150 \\
150 \\
150 \\
\end{array}$ & $\begin{array}{l}\text { OFF } \\
\text { OFF } \\
\text { OFF }\end{array}$ & $\begin{array}{l}\text { OFF } \\
\text { OFF } \\
\text { OFF }\end{array}$ & $\begin{array}{l}\text { OFF } \\
\text { OFF } \\
\text { OFF }\end{array}$ & $\begin{array}{l}\text { Optim } \\
\text { Optim } \\
\text { Optim }\end{array}$ & $\begin{array}{l}1.10 \\
1.07 \\
1.05\end{array}$ & $\begin{array}{l}1.10 \\
1.07 \\
1.05\end{array}$ & $\begin{array}{l}1.10 \\
1.07 \\
1.05\end{array}$ & $\begin{array}{l}0.0 \\
0.0 \\
0.0\end{array}$ & $\begin{array}{l}60 \\
60 \\
60\end{array}$ & $\begin{array}{l}\mathrm{X} \\
\mathrm{X} \\
\mathrm{X}\end{array}$ \\
\hline $\begin{array}{l}\text { GLNB-OFA 110A } \\
\text { GLNB-OFA 110B } \\
\text { GLNB-OFA 110C } \\
\end{array}$ & $\begin{array}{r}\text { FULL LOAD W/O GR } \\
\text { OFA VARIATION } \\
\text { Performance Parameters: NOx \& CO }\end{array}$ & $\begin{array}{l}150 \\
150 \\
150 \\
\end{array}$ & $\begin{array}{l}\text { OFF } \\
\text { OFF } \\
\text { OFF }\end{array}$ & $\begin{array}{l}\text { OFF } \\
\text { OFF } \\
\text { OFF }\end{array}$ & $\begin{array}{l}\text { OFF } \\
10 \\
16 \\
\end{array}$ & $\begin{array}{l}\text { Optim } \\
\text { Optim } \\
\text { Optim }\end{array}$ & $\begin{array}{l}1.08 \\
1.06 \\
1.04\end{array}$ & $\begin{array}{l}1.08 \\
1.06 \\
1.04\end{array}$ & $\begin{array}{l}1.10 \\
1.10 \\
1.10\end{array}$ & $\begin{array}{l}1.8 \\
3.6 \\
5.5\end{array}$ & $\begin{array}{l}60 \\
60 \\
60\end{array}$ & $\begin{array}{l}\mathrm{X} \\
\mathrm{X} \\
\mathrm{X}\end{array}$ \\
\hline $\begin{array}{l}\text { GLNB-GR 120A } \\
\text { GLNB-GR 120B } \\
\text { GLNB-GR 120C }\end{array}$ & $\begin{array}{c}\text { FULL LOAD GAS REBURNING } \\
\text { SR1 \& OFA VARIATION } \\
\text { Performance Parameters: NOx, CO, name stability }\end{array}$ & $\begin{array}{l}150 \\
150 \\
150 \\
\end{array}$ & $\begin{array}{l}20 \\
20 \\
20\end{array}$ & $\begin{array}{l}\text { All } \\
\text { All } \\
\text { All }\end{array}$ & $\begin{array}{l}61 \\
65 \\
70\end{array}$ & $\begin{array}{l}\text { Optim } \\
\text { Optim } \\
\text { Optim }\end{array}$ & $\begin{array}{l}1.08 \\
1.06 \\
1.04\end{array}$ & $\begin{array}{l}0.86 \\
0.85 \\
0.83\end{array}$ & $\begin{array}{l}1.10 \\
1.10 \\
1.10\end{array}$ & $\begin{array}{l}21.5 \\
22.9 \\
24.4\end{array}$ & $\begin{array}{l}60 \\
60 \\
60\end{array}$ & $\begin{array}{l}\mathrm{X} \\
\mathrm{X} \\
\mathrm{x}\end{array}$ \\
\hline $\begin{array}{l}\text { GLNB-GR 130A } \\
\text { GLNB-GR 130B } \\
\text { GLNB-GR 130C } \\
\text { GLNB-GR 130D }\end{array}$ & \begin{tabular}{|c} 
FULL LOAD GAS REBURNING \\
GAS INPUT VARIATION \\
SR1 NOMINALLY AT 1.06, ACTUAL FROM TESTS 120 \\
Performance Parametcrs: NOx \& CO \\
\end{tabular} & $\begin{array}{l}150 \\
150 \\
150 \\
150 \\
\end{array}$ & $\begin{array}{c}5 \\
10 \\
15 \\
25 \\
\end{array}$ & $\begin{array}{l}\text { Optim } \\
\text { Optim } \\
\text { Optim } \\
\text { Optim }\end{array}$ & $\begin{array}{l}24 \\
38 \\
52 \\
79 \\
\end{array}$ & $\begin{array}{l}\text { Optim } \\
\text { Optim } \\
\text { Optim } \\
\text { Optim }\end{array}$ & $\begin{array}{l}1.06 \\
1.06 \\
1.06 \\
1.06 \\
\end{array}$ & $\begin{array}{l}1.01 \\
0.95 \\
0.90 \\
0.80 \\
\end{array}$ & $\begin{array}{l}1.10 \\
1.10 \\
1.10 \\
1.10 \\
\end{array}$ & $\begin{array}{c}8.5 \\
13.3 \\
18.1 \\
27.7 \\
\end{array}$ & $\begin{array}{l}60 \\
60 \\
60 \\
60 \\
\end{array}$ & $\begin{array}{l}X \\
x \\
x \\
x \\
\end{array}$ \\
\hline $\begin{array}{l}\text { GLNB-GR 140A } \\
\text { GLNB-GR 140B } \\
\text { GLNB-GR 140C }\end{array}$ & $\begin{array}{l}\text { FULL LOAD GAS REBURNING } \\
\text { EXCESS AIR VARIATION } \\
\text { Performance Parameters: NOx \& CO }\end{array}$ & $\begin{array}{l}150 \\
150 \\
150\end{array}$ & $\begin{array}{l}20 \\
20 \\
20\end{array}$ & $\begin{array}{l}\text { All } \\
\text { All } \\
\text { All }\end{array}$ & $\begin{array}{l}55 \\
60 \\
71\end{array}$ & $\begin{array}{l}\text { Optim } \\
\text { Optim } \\
\text { Optim }\end{array}$ & $\begin{array}{l}1.06 \\
1.06 \\
1.06\end{array}$ & $\begin{array}{l}0.85 \\
0.85 \\
0.85\end{array}$ & $\begin{array}{l}1.06 \\
1.08 \\
1.12\end{array}$ & $\begin{array}{l}20.0 \\
21.5 \\
24.3\end{array}$ & $\begin{array}{l}60 \\
60 \\
60\end{array}$ & $\begin{array}{l}x \\
X \\
X\end{array}$ \\
\hline
\end{tabular}

Notc: Optimum Reburning Gas Injectors In Service and OFA Swirl Position Determined From Coal/Gas Reburning Tests 
TABLE 4-3. $100 \%$ GAS FIRING AND GAS FIRING w/GR TEST MATRIX (con't).

\begin{tabular}{|c|c|c|c|c|c|c|c|c|c|c|c|c|}
\hline $\begin{array}{c}\text { Test } \\
\text { ID }\end{array}$ & $\begin{array}{c}\text { Test } \\
\text { Description }\end{array}$ & $\begin{array}{l}\text { Load } \\
\text { (MWc) } \\
\end{array}$ & $\begin{array}{c}\text { Reburning } \\
\text { Gas Heat } \\
\text { Input } \\
(9 \%) \\
\end{array}$ & \begin{tabular}{|l} 
Reburning \\
Gas \\
Injectors \\
In Service
\end{tabular} & $\begin{array}{l}\text { OFA } \\
\text { Flow } \\
\text { (kscfm) }\end{array}$ & $\begin{array}{c}\text { OFA } \\
\text { Vanc } \\
\text { Position }\end{array}$ & $\begin{array}{c}\text { Bumcr } \\
\text { Zone } \\
\text { Stoich } \\
\text { SR1 } \\
\end{array}$ & $\begin{array}{c}\text { Rebum } \\
\text { Zone } \\
\text { Stoich } \\
\text { SR2 } \\
\end{array}$ & $\begin{array}{l}\text { Burnout } \\
\text { Zone } \\
\text { Stoich } \\
\text { SR3 }\end{array}$ & \begin{tabular}{c|} 
OFA \\
$(9$, tot $)$ \\
\end{tabular} & $\begin{array}{l}\text { Test } \\
\text { Dur. } \\
\text { (min) }\end{array}$ & CEMS \\
\hline $\begin{array}{l}\text { GLNB 150A } \\
\text { GLNB 150B } \\
\text { GLNB 150C }\end{array}$ & $\begin{array}{c}\text { MID LOAD W/O GR } \\
\text { EXCESS AIR VARIATION } \\
\text { Pcrformance Parameters: NOx \& CO } \\
\end{array}$ & $\begin{array}{l}120 \\
120 \\
120 \\
\end{array}$ & $\begin{array}{l}\text { OFF } \\
\text { OFF } \\
\text { OFF }\end{array}$ & $\begin{array}{l}\text { OFF } \\
\text { OFF } \\
\text { OFF }\end{array}$ & $\begin{array}{l}\text { OFF } \\
\text { OFF } \\
\text { OFF }\end{array}$ & $\begin{array}{l}\text { Optim } \\
\text { Optim } \\
\text { Optim }\end{array}$ & $\begin{array}{l}1.14 \\
1.11 \\
1.08\end{array}$ & $\begin{array}{l}1.14 \\
1.11 \\
1.08\end{array}$ & $\begin{array}{l}1.14 \\
1.11 \\
1.08 \\
\end{array}$ & $\begin{array}{l}0.0 \\
0.0 \\
0.0\end{array}$ & $\begin{array}{l}60 \\
60 \\
60\end{array}$ & $\begin{array}{l}x \\
x \\
x\end{array}$ \\
\hline $\begin{array}{l}\text { GLNB-OFA 160A } \\
\text { GLNB-OFA 160B } \\
\text { GLNB-OFA 160C }\end{array}$ & $\begin{array}{r}\text { MID LOAD W/O GR } \\
\text { OFA VARIATION } \\
\text { Performance Parameters: NOx \& CO }\end{array}$ & $\begin{array}{l}120 \\
120 \\
120 \\
\end{array}$ & $\begin{array}{l}\text { OFF } \\
\text { OFF } \\
\text { OFF }\end{array}$ & $\begin{array}{l}\text { OFF } \\
\text { OFF } \\
\text { OFF }\end{array}$ & $\begin{array}{l}\text { OFF } \\
12 \\
17\end{array}$ & $\begin{array}{l}\text { Optim } \\
\text { Optim } \\
\text { Optim }\end{array}$ & $\begin{array}{l}1.10 \\
1.08 \\
1.06 \\
\end{array}$ & $\begin{array}{l}1.10 \\
1.08 \\
1.06\end{array}$ & $\begin{array}{l}1.14 \\
1.14 \\
1.14\end{array}$ & $\begin{array}{l}3.5 \\
5.3 \\
7.0\end{array}$ & $\begin{array}{l}60 \\
60 \\
60\end{array}$ & $\begin{array}{l}x \\
x \\
x\end{array}$ \\
\hline $\begin{array}{l}\text { GLNB-GR 170A } \\
\text { GLNB-GR 170B } \\
\text { GLNB-GR 170C }\end{array}$ & $\begin{array}{c}\text { MID LOAD GAS REBURNING } \\
\text { SR1 \& OFA VARIATION } \\
\text { Performance Parameters: NOx, CO, flame stability }\end{array}$ & $\begin{array}{l}120 \\
120 \\
120\end{array}$ & $\begin{array}{l}20 \\
20 \\
20\end{array}$ & $\begin{array}{l}\text { All } \\
\text { All } \\
\text { All }\end{array}$ & $\begin{array}{l}54 \\
57 \\
61\end{array}$ & $\begin{array}{l}\text { Optim } \\
\text { Optim } \\
\text { Optim }\end{array}$ & $\begin{array}{l}1.10 \\
1.08 \\
1.06\end{array}$ & $\begin{array}{l}0.88 \\
0.86 \\
0.85\end{array}$ & $\begin{array}{l}1.14 \\
1.14 \\
1.14\end{array}$ & $\begin{array}{l}22.8 \\
24.2 \\
25.6\end{array}$ & $\begin{array}{l}60 \\
60 \\
60\end{array}$ & $\begin{array}{l}x \\
x \\
x\end{array}$ \\
\hline $\begin{array}{l}\text { GLNB-GR 180A } \\
\text { GLNB-GR 180B } \\
\text { GLNB-GR 180C } \\
\text { GLNB-GR 180D }\end{array}$ & \begin{tabular}{|l} 
MID LOAD GAS REBURNING \\
GAS INPUT VARIATION \\
SR1 NOMINALLY AT 1.08, ACTUAL FROM TESTS 170 \\
Performance Parameters: NOx \& CO \\
\end{tabular} & $\begin{array}{l}120 \\
120 \\
120 \\
120 \\
\end{array}$ & $\begin{array}{c}5 \\
10 \\
15 \\
25 \\
\end{array}$ & $\begin{array}{l}\text { Optim } \\
\text { Optim } \\
\text { Optim } \\
\text { Optim }\end{array}$ & $\begin{array}{l}24 \\
35 \\
46 \\
69 \\
\end{array}$ & $\begin{array}{l}\text { Optim } \\
\text { Optim } \\
\text { Optim } \\
\text { Optim }\end{array}$ & $\begin{array}{l}1.08 \\
1.08 \\
1.08 \\
1.08 \\
\end{array}$ & $\begin{array}{l}1.03 \\
0.97 \\
0.92 \\
0.81 \\
\end{array}$ & $\begin{array}{l}1.14 \\
1.14 \\
1.14 \\
1.14 \\
\end{array}$ & $\begin{array}{l}10.0 \\
14.7 \\
19.5 \\
28.9 \\
\end{array}$ & $\begin{array}{l}60 \\
60 \\
60 \\
60 \\
\end{array}$ & $\begin{array}{l}x \\
x \\
x \\
x \\
\end{array}$ \\
\hline $\begin{array}{l}\text { GLNB 190A } \\
\text { GLNB 190B } \\
\text { GLNB 190C }\end{array}$ & \begin{tabular}{|c} 
LOW LOAD W/O GR \\
EXCESS AIR VARIATION \\
Performance Parameters: NOx \& CO \\
\end{tabular} & $\begin{array}{l}90 \\
90 \\
90\end{array}$ & $\begin{array}{l}\text { OFF } \\
\text { OFF } \\
\text { OFF }\end{array}$ & $\begin{array}{l}\text { OFF } \\
\text { OFF } \\
\text { OFF }\end{array}$ & $\begin{array}{l}\text { OFF } \\
\text { OFF } \\
\text { OFF }\end{array}$ & $\begin{array}{l}\text { Optim } \\
\text { Optim } \\
\text { Optim }\end{array}$ & $\begin{array}{l}1.18 \\
1.14 \\
1.10\end{array}$ & $\begin{array}{l}1.18 \\
1.14 \\
1.10\end{array}$ & $\begin{array}{l}1.18 \\
1.14 \\
1.10 \\
\end{array}$ & $\begin{array}{l}0.0 \\
0.0 \\
0.0\end{array}$ & $\begin{array}{l}60 \\
60 \\
60 \\
\end{array}$ & $\begin{array}{l}x \\
x \\
x\end{array}$ \\
\hline $\begin{array}{l}\text { GLNB-OFA 200A } \\
\text { GLNB-OFA 200B } \\
\text { GLNB-OFA 200C }\end{array}$ & $\begin{array}{r}\text { LOW LOAD W/O GR } \\
\text { OFA VARIATION } \\
\text { Performance Parameters: NOx \& CO }\end{array}$ & $\begin{array}{l}90 \\
90 \\
90\end{array}$ & $\begin{array}{l}\text { OFF } \\
\text { OFF } \\
\text { OFF }\end{array}$ & $\begin{array}{l}\text { OFF } \\
\text { OFF } \\
\text { OFF }\end{array}$ & $\begin{array}{l}\text { OFF } \\
12 \\
16\end{array}$ & $\begin{array}{l}\text { Optim } \\
\text { Optim } \\
\text { Optim }\end{array}$ & $\begin{array}{l}1.12 \\
1.10 \\
1.08\end{array}$ & $\begin{array}{l}1.12 \\
1.10 \\
1.08\end{array}$ & $\begin{array}{l}1.18 \\
1.18 \\
1.18\end{array}$ & $\begin{array}{l}5.1 \\
6.8 \\
8.5\end{array}$ & $\begin{array}{l}60 \\
60 \\
60\end{array}$ & $\begin{array}{l}\mathrm{X} \\
\mathrm{X} \\
\mathrm{X}\end{array}$ \\
\hline $\begin{array}{l}\text { GLNB-GR 210A } \\
\text { GLNB-GR 210B } \\
\text { GINR-GR } 210 C\end{array}$ & $\begin{array}{c}\text { LOW LOAD GAS REBURNING } \\
\text { SR1 \& OFA VARIATION } \\
\text { Pcformatitit }\end{array}$ & $\begin{array}{l}90 \\
90 \\
90\end{array}$ & $\begin{array}{l}20 \\
20 \\
20\end{array}$ & $\begin{array}{l}\text { All } \\
\text { All } \\
\text { All }\end{array}$ & $\begin{array}{l}44 \\
47 \\
49\end{array}$ & $\begin{array}{l}\text { Optim } \\
\text { Optim } \\
\text { Optim }\end{array}$ & $\begin{array}{l}1.12 \\
1.10 \\
1.08\end{array}$ & $\begin{array}{l}0.90 \\
0.88 \\
0.86\end{array}$ & $\begin{array}{l}1.18 \\
1.18 \\
1.18\end{array}$ & $\begin{array}{l}24.1 \\
25.4 \\
26.8\end{array}$ & $\begin{array}{l}60 \\
60 \\
60\end{array}$ & $\begin{array}{l}X \\
X \\
X\end{array}$ \\
\hline
\end{tabular}

Note: Optimum Reburming Gas Injectors In Service and OFA Swirl Position Determined From Coal/Gas Reburning Tests 
potential for increased wastage of the waterwall. The purpose of the variation was to establish the relationship between reburn fuel level and boiler emissions.

OFA Flowrate This parameter was varied from 55 to $71 \mathrm{kscfm}$. During the tests, the natural gas heat input was fixed at $20 \%$. The purpose of the variation was to establish the relationship between OFA flow and boiler emissions $\left(\mathrm{NO}_{\mathrm{x}}, \mathrm{CO}\right.$, etc.). Carbon in the fly ash was also evaluated.

Gas Injection Bias Tests were completed to see if the injection of more gas on one side of the furnace would improve the GR system performance. The same level of gas was input into two configurations to see if improved $\mathrm{NO}_{x}$ reduction could be achieved with gas flowrate biasing to either the right or left side of the furnace.

\subsection{Operating Procedures}

The GR system is composed of three integrated systems: (1) natural gas injection, (2) FGR, and (3) OFA injection. The natural gas flow rate was controlled to the desired value for optimum $\mathrm{NO}_{x}$ destruction. The FGR flow was controlled to a value to give the natural gas momentum for optimum distribution in the furnace. The OFA was controlled to a value to complete combustion of all unburned fuel leaving the reburning zone. The three integrated systems were interlocked, operated and monitored by a Westinghouse Distributive Process Family (WDPF) control system.

The control logic for natural gas injection consisted of a flow controller which received a calculated set point from the boiler master and the natural gas flow transmitter. A comparison was made in the fuel controller between the set point and feedback signals and the controller output modulated the natural gas control valve to reduce any error to zero. The boiler master controlled gas flow with coal flow to obtain the heat input needed 
over the load range. A percentage of the boiler master signal was calculated and became the set point for the desired natural gas flow.

The desired FGR flow control set point was a calculated value determined from the boiler master signal. This set point signal was compared with the actual value of FGR flow rate in a PID controller which acted on any detected error signal. The WDPF automatically adjusted the FGR fan to reduce the error to zero.

Control of the OFA system consisted of sending a set point signal calculated from the boiler master signal to a controller where it was compared with the total of the two OFA air flows (one on each side of the boiler). The OFA nozzles were modulated to reduce any detected difference in the set point and total OFA flow to zero. The WDPF compared the two signals from the OFA flow transmitters to balance the flow of air.

Another control feature of the GR system was the cross limit between the OFA flow and natural gas flow. The set point for natural gas was compared with the OFA flow. If the natural gas flow set point was greater than the amount of OFA flow required for complete combustion of natural gas, the WDPF would decrease the natural gas set point to a value that permits complete combustion of the natural gas by the OFA. If the natural gas flow was greater than the OFA flow, the set point signal for OFA was increased to a value that would permit complete combustion of the natural gas. The above sequence is called cross limiting between the fuel (natural gas) and OFA and is very similar to the cross limiting features in the main combustion control between the coal feed and secondary air flow.

There was another cross limit between the FGR flow and the natural gas flow. If the FGR flow fell below a value that insured optimum penetration of the natural gas into the boiler (i.e., good mixing with the products of the coal combustion process), the set point for natural gas flow would be reduced to a safe value. Appendix $C$ contains the startup/shutdown procedures and the operator checklist. 


\subsubsection{Instrumentation and Data Acquisition}

Control and monitoring of the GR-LNB system was accomplished with a WDPF system. The system consisted of a variable mix of functional units (drops) communicating freely and rapidly via the WDPF data highway. The WDPF sent and received signals from various components in the GR-LNB system, in addition to interfacing with other microprocessors. The design of the GR-LNB control system was based on the following criteria:

- All normal operations that are required to start, stop, or modulate the various pieces of equipment shall be performed in the control room.

- Sufficient information shall be displayed in the control room to enable the operator to determine the status of all equipment. The operator interface shall be designed so that the above information is displayed in a manner to enable rapid understanding of system status.

- Certain operations shall be interlocked to prevent inadvertent operation of equipment when such operation may present an operating hazard or other undesirable condition.

- Certain shut-down procedures shall be initiated automatically by the control system when such operations are deemed necessary for safety or good operating practice.

- Microprocessor based technology shall be used for the controls and interlocks.

Operator interface shall be of the Keyboard-CRT type with custom graphics. 
- The system will readily interface with existing plant instrumentation and be of a design that will enable operator familiarity and understanding with a minimum of training.

Interlocks were included which were designed to start the equipment in an orderly fashion and prevent the operator from allowing the unit's safety to become compromised either through erroneous operation or due to equipment failure. All major commands issued by the WDPF control system were verified by a feedback signal. Trip signals were continuously monitored by the WDPF and would prevent startup or shutdown of equipment already in operation.

A Boiler Performance Monitoring System (BPMS) was used to monitor operating conditions, GR-LNB system performance, and unit thermal/steam production performance. The BPMS, developed by EER, is a state-of-the-art PC-based system which takes up to 300 inputs, updates these as often as every five seconds, and performs a variety of process calculations.

The Cherokee BPMS was customized to the GR-LNB application. The BPMS received data from plant instrumentation, GR system instrumentation, and continuous gas monitors, performed a series of calculations, and then output data in a prescribed format. The inputs to the Cherokee BPMS are listed in Table 4-4, while the outputs are listed in Table 4-5. The inputs included fuel characteristics (composition and heating value), design radiation and unmeasured heat losses for the boiler, ambient conditions, flue gas conditions at several locations, reburning gas and OFA flows, continuous flue gas analyses, combustion air temperature, superheat and reheat steam cycle data, and gross/net power generation. These data were then used to calculate heat absorption by each heat exchanger, heat loss efficiency, heat absorption ratios relative to baseline operation, furnace zone stoichiometries, and emissions in the form of volume concentration and on a mass per heat 
TABLE 4-4. INPUTS TO BPMS HEAT TRANSFER/COMBUSTION MODEL

\begin{tabular}{|c|c|}
\hline Class of Input & Input Data \\
\hline Fuel characteristics & $\begin{array}{l}\text { Proximate analysis } \\
\text { Ultimate analysis } \\
\text { Heating value }\end{array}$ \\
\hline ASME heat loss method & $\begin{array}{l}\text { Combustible in refuse } \\
\text { Radiation heat loss * } \\
\text { Unmeasured heat loss * }\end{array}$ \\
\hline Ambient conditions & $\begin{array}{l}\text { Relative humidity } \\
\text { Barometric pressure } \\
\text { Ambient temperature } \\
\end{array}$ \\
\hline $\begin{array}{l}\text { Boiler instrumentation - } \\
\text { flue gas side }\end{array}$ & $\begin{array}{l}\text { Total coal flow } \\
\text { Coal temperature } \\
\text { Combustion air temperature } \\
\text { Economizer outlet gas temperature } \\
\text { Air heater gas outlet temperature } \\
\text { FGR flow rate (hopper bottom) } \\
\text { Plant } 02\end{array}$ \\
\hline GR instrumentation & $\begin{array}{l}\text { Reburning FGR flow rate } \\
\text { Natural gas flow rate } \\
\text { Natural gas temperature } \\
\text { Overfire air flow rate }\end{array}$ \\
\hline Continuous emissions monitoring & $\begin{array}{l}\text { Gaseous concentrations of: } \\
\mathrm{CO} 2, \mathrm{CO}, \mathrm{NO}, \mathrm{SO} 2, \mathrm{O} 2 \text {, and } \mathrm{HCl}\end{array}$ \\
\hline Combustion air instrumentation & $\begin{array}{l}\text { Air heater air inlet temperature } \\
\text { Air heater air outlet temperature }\end{array}$ \\
\hline $\begin{array}{l}\text { Boiler instrumentation - } \\
\text { water/steam side }\end{array}$ & $\begin{array}{l}\text { Superheated steam } \\
\text { Feedwater pressure to economizer } \\
\text { Feedwater temperature to economizer } \\
\text { Feedwater flow rate to economizer } \\
\text { Outlet temperature of backpass to economizer wall } \\
\text { Boiler drum pressure } \\
\text { Outlet pressure of primary superheater } \\
\text { Outlet temperature of primary superheater } \\
\text { Superheater attemperator feedwater pressure } \\
\text { Superheater attemperator feedwater flow } \\
\text { Superheater attemperator outlet temperature } \\
\text { Steam pressure to turbine } \\
\text { Steam flow to turbine }\end{array}$ \\
\hline
\end{tabular}

* From boiler design performance data sheet 
TẢBLE 4-4. INPUTS TO BPMS HEAT TRANSFER/COMBUSTION MODEL (con't).

\begin{tabular}{|l|l|}
\hline Class of Input & Input Data \\
\hline Boiler instrumentation - & Reheat steam \\
& Cold reheat pressure \\
& Cold reheat temperature \\
& Cold reheat flow rate \\
& Reheater attemperator feedwater pressure \\
& Reheater attemperator feedwater flow \\
& Reheater attemperator outlet temperature \\
& Low temperature reheat inlet pressure \\
& Low temperature reheat inlet temperature \\
& High temperature reheat inlet pressure \\
& High temperature reheat inlet temperature \\
& Hot reheat steam flow \\
\hline Power generation & Generator gross power \\
& Generator net power \\
\hline
\end{tabular}


TAB́LE 4-5. OUTPUT DATA FROM BPMS HEAT TRANSFER/COMBUSTION MODEL

\begin{tabular}{|c|c|}
\hline Class of Input & Output Data \\
\hline Heat rate & $\begin{array}{l}\text { Total heat input } \\
\text { Heat input to burners } \\
\text { Reburn gas heat input }\end{array}$ \\
\hline Heat absorption & $\begin{array}{l}\text { Furnace } \\
\text { Secondary superheater } \\
\text { Reheat superheater } \\
\text { Primary superheater } \\
\text { Economizer } \\
\text { Air heater } \\
\end{array}$ \\
\hline $\begin{array}{l}\text { Boiler efficiency based on } \\
\text { ASME heat loss method }\end{array}$ & $\begin{array}{l}\text { Heat loss due to dry gas } \\
\text { Heat loss due to moisture in fuel } \\
\text { Heat loss due to } \mathrm{H} 2 \mathrm{O} \text { from combustion of } \mathrm{H} 2 \\
\text { Heat loss due to combustible in refuse } \\
\text { Heat loss due to radiation } \\
\text { Heat loss due to unmeasured sources }\end{array}$ \\
\hline $\begin{array}{l}\text { Boiler efficiency based on } \\
\text { heat absorption method }\end{array}$ & $\begin{array}{l}\text { Efficiency based on gross heating value } \\
\text { Efficiency based on lower heating value }\end{array}$ \\
\hline $\begin{array}{l}\text { Heat absorption ratio } \\
\text { (relative to baseline case) }\end{array}$ & \begin{tabular}{|l|} 
Furnace \\
Secondary superheater \\
Reheat superheater \\
Primary superheater \\
Economizer \\
Air heater \\
\end{tabular} \\
\hline Stoichiometric ratio & $\begin{array}{l}\text { Primary zone } \\
\text { Reburn zone } \\
\text { Burnout zone } \\
\end{array}$ \\
\hline Emissions control data & $\begin{array}{l}\text { Gaseous species concentrations of } \mathrm{CO} 2, \mathrm{CO}, \mathrm{NOx} \\
\mathrm{O} 2, \mathrm{SO} 2 \text {, and } \mathrm{HCl} \text { in the form of: Volume \% (ppm) } \\
\text { dry; corrected to } 3 \% \mathrm{O} 2 \text { and pounds per million heat } \\
\text { input. }\end{array}$ \\
\hline
\end{tabular}


input basis. The BPMS output average, maxima and minima for each performance parameter in reports with prescribed formats.

The Continuous Emissions Monitoring System (CEMS) is illustrated in Figure 4-2. Flue gas samples were drawn from a 16 point grid installed in twin economizer outlet ducts, as illustrated in Figure 4-3. Flue gas was withdrawn through stainless steel probes, then transported by heated sampling lines to individual rotameters in a heated enclosure. The rotameters were used to ensure even gas flow from each point of the gas extraction grid. The gas was then mixed in a manifold and carried by a heated Teflon sampling line into the test trailer. There moisture was removed with a chiller, then the gas was filtered and routed through a bypass pressure regulator to the analysis manifold. The gas was analyzed by the instruments listed in Table 4-6. These instruments were calibrated at least daily with zero and span gases.

\subsubsection{Test Methods}

EER measured a wide range of parameters using standard EPA, ASTM and ASME procedures as well as special procedures developed during previous boiler field evaluations. Measurement data obtained by EER were supplemented by available plant instrumentation.

The schedule of measurements performed on mills, coal and boiler are shown in Table 4-7. Coal sulfur, ash, moisture and higher heating values were determined by the plant using their normal methods. However, in addition to the daily samples extracted by the plant (which are difficult to relate precisely to a burn time) composite samples were extracted from the mill feeders. Special coal tests were performed by a commercial laboratory using ASTM procedures. 
Trailer

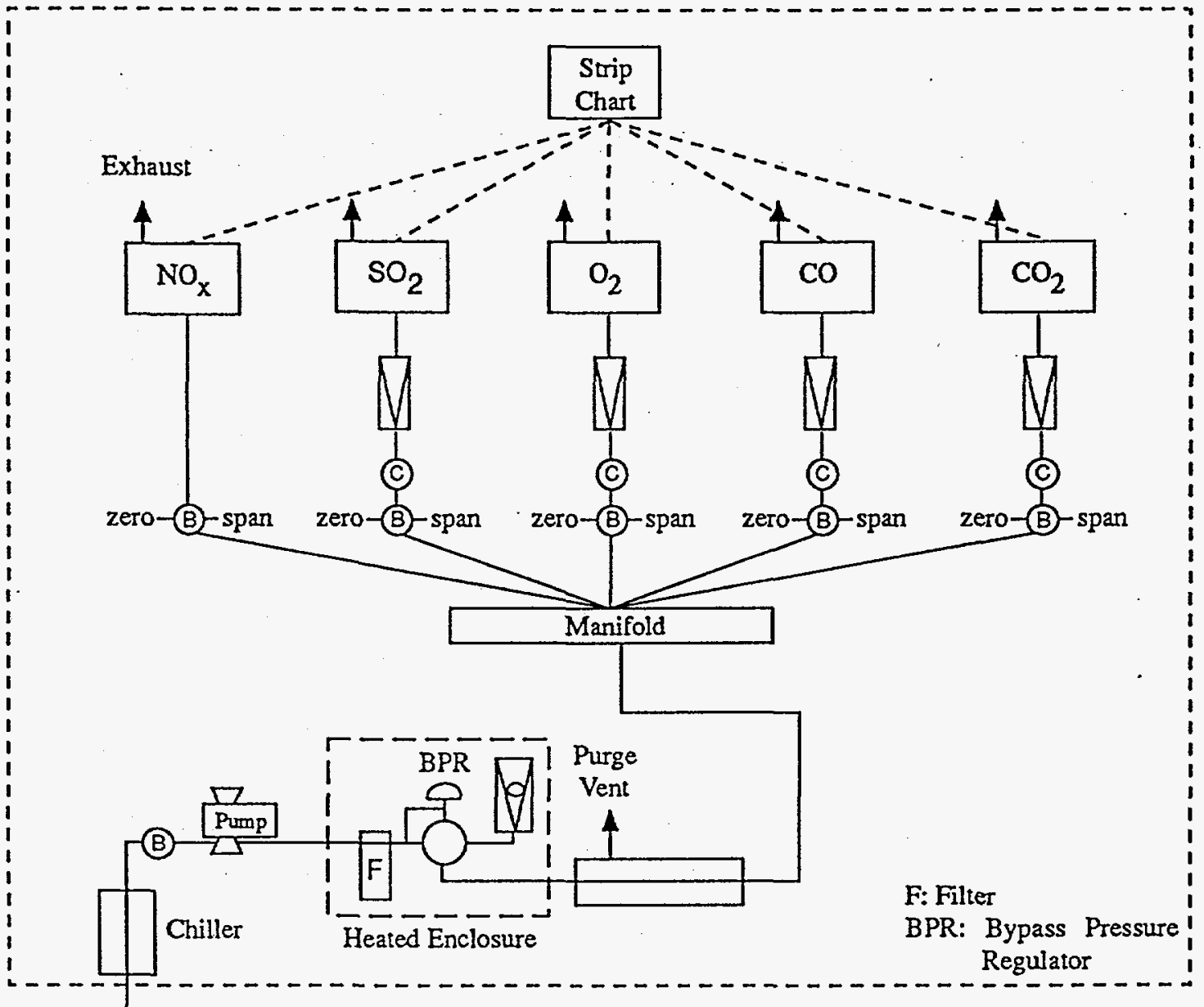

3/8" Heated Teflon Sample Line

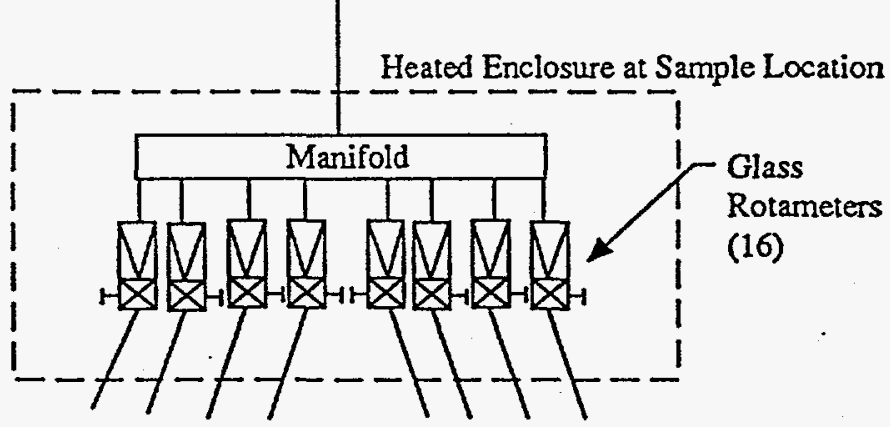

Heated Lines

From Sample Probes (16)

Figure 4-2. Schematic of continuous emissions monitoring system 

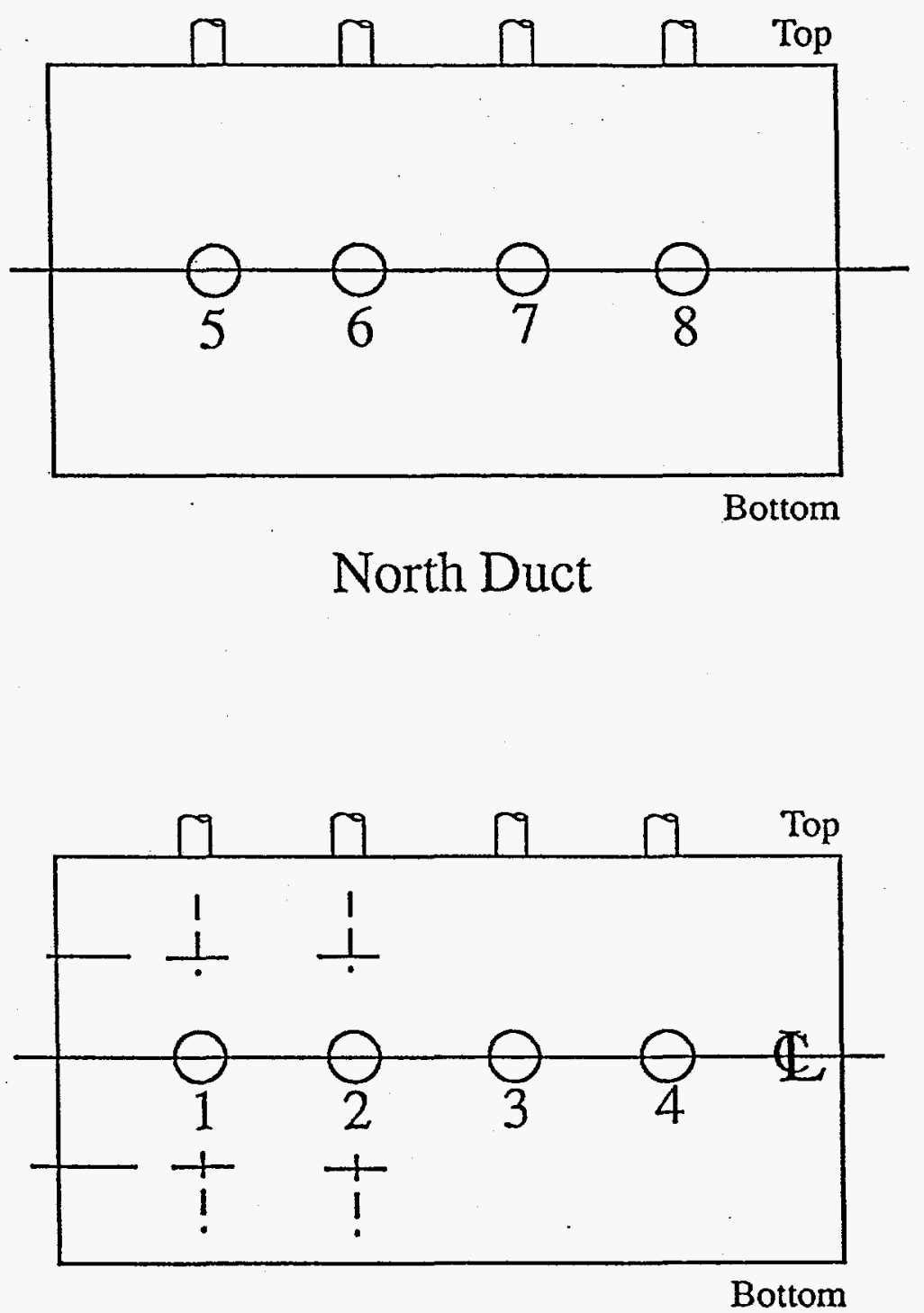

South Duct

Figure 4-3. Economizer exit gas sampling grid 
TABLE 4-6. CONTINUOUS EMISSIONS MONITORING SYSTEM (CEMS)

\begin{tabular}{|c|c|c|c|c|}
\hline Parameter & $\begin{array}{l}\text { Instrument } \\
\text { Manufacturer }\end{array}$ & $\begin{array}{l}\text { Model } \\
\text { Number }\end{array}$ & $\begin{array}{l}\text { Detection } \\
\text { Principle }\end{array}$ & $\begin{array}{l}\text { Measurement } \\
\text { Ranges }\end{array}$ \\
\hline NOx & Thermo Electron & $10 \mathrm{~A}$ & Chemilumiescence & $\begin{array}{l}0-2.5 \mathrm{ppm} \text { to } \\
0-10,000 \mathrm{ppm}\end{array}$ \\
\hline $\mathrm{CO}$ & ANARAD & $5000 R$ & Infrared & $\begin{array}{l}0-500 p p m \\
0-2000 p p m \\
0-2 \%\end{array}$ \\
\hline $\mathrm{CO} 2$ & ANARAD & $5000 R$ & Infrared & $0-25 \%$ \\
\hline $\mathrm{SO} 2$ & Western Research & 721AT & Ultraviolet & $\begin{array}{l}0-100 \mathrm{ppm} \text { to } \\
0-5000 \mathrm{ppm}\end{array}$ \\
\hline 02 & Taylor-Servomex & OA572 & Paramagnetism & $\begin{array}{l}0-5 \% \\
0-10 \% \\
0-25 \%\end{array}$ \\
\hline Hydrocarbons & Beckman & 402 & Flame lonization & $\begin{array}{l}0-5 \mathrm{ppm} \text { to } \\
0-25 \%\end{array}$ \\
\hline
\end{tabular}


TABLE 4-7. SAMPLING SCHEDULE

\begin{tabular}{|c|c|c|c|c|}
\hline $\begin{array}{l}\text { Measurement } \\
\text { Parameter }\end{array}$ & $\begin{array}{l}\text { Sampling } \\
\text { Location }\end{array}$ & $\begin{array}{l}\text { Sampling } \\
\text { Procedure }\end{array}$ & $\begin{array}{l}\text { Parametric } \\
\text { Frequency }\end{array}$ & $\begin{array}{l}\text { Long Term } \\
\text { Reference }\end{array}$ \\
\hline Coal & & & & \\
\hline Raw sample & At each mill & Grab sample & 1 per mill per test & 1 per mill per day \\
\hline $\begin{array}{l}\text { Proximate and } \\
\text { ultimate analysis } \\
\text { and grindability }\end{array}$ & $"$ & ASTM Procedures & 1 per month & 1 per month \\
\hline $\begin{array}{l}\text { Pulverized coal } \\
\text { size and flowrate } \\
\text { to each burner }\end{array}$ & $"$ & RotoProbe & 1 per month & 1 per month \\
\hline Mill setting & $"$ & Manual recording & Each test point & Daily \\
\hline $\begin{array}{c}\text { Furnace measurements } \\
\text { Gas temperature }\end{array}$ & Selected locations & Suction pyrometer & Selected condition & None \\
\hline Gas velocity & $"$ & Pitot tube & " & $"$ \\
\hline Fouling rate & $"$ & $\begin{array}{c}\text { Air cooled fouling } \\
\text { probe }\end{array}$ & $"$ & $"$ \\
\hline Gas composition & & & & \\
\hline 02 & Boiler outlet & $\begin{array}{c}\text { Extractive } \\
"\end{array}$ & Continuous & Continuous \\
\hline $\mathrm{SO} 2$ & or breeching & $"$ & " & $"$ \\
\hline $\begin{array}{l}\mathrm{CO} \\
\mathrm{CO} 2\end{array}$ & " & $"$ & $"$ & $"$ \\
\hline $\mathrm{NO}, \mathrm{NO} 2$ & $"$ & $"$ & $"$ & $"$ \\
\hline THC & $"$ & $"$ & $"$ & " \\
\hline $\begin{array}{l}\text { Hopper flyash } \\
\text { Elemental } \\
\text { Ash } \\
\quad \text { Elemental } \\
\quad \text { Fusion Temp. }\end{array}$ & $\begin{array}{c}\text { Slag tank, boiler } \\
\text { outlet hopper, } \\
\text { and } \mathrm{BH} \text { hopper } \\
\text { " }\end{array}$ & $\begin{array}{c}\text { Composite grab } \\
\text { sample } \\
" \\
"\end{array}$ & $\begin{array}{c}\text { Weekly } \\
" \\
" \\
"\end{array}$ & \\
\hline $\begin{array}{l}\text { In-situ flyash } \\
\text { Loading }\end{array}$ & $\begin{array}{c}\text { BH inlet and } \\
\text { outlet }\end{array}$ & $\begin{array}{c}\text { EPA Method } \\
5 \text { or } 7\end{array}$ & Daily & 1 per week \\
\hline $\begin{array}{l}\text { Particle size } \\
\text { distribution }\end{array}$ & BH outlet & Cascade impactor & As required & 1 per week \\
\hline Resistivity & BH outlet & Resistivity probe & As required & 1 per week \\
\hline Carbon & Economizer inlet & $\begin{array}{l}\text { Modified EPA } \\
\text { Method } 17\end{array}$ & Daily during GR & 1 per week \\
\hline Boiler performance & & BPMS Calculation & Continuously & Continuously \\
\hline $\mathrm{N} 2 \mathrm{O}$ & & Portable meter & As needed & As needed \\
\hline
\end{tabular}


TABLE 4-7. SAMPLING SCHEDULE (con't).

\begin{tabular}{|l|c|c|c|c|}
\hline $\begin{array}{l}\text { Measurement } \\
\text { Parameter }\end{array}$ & $\begin{array}{l}\text { Sampling } \\
\text { Location }\end{array}$ & $\begin{array}{c}\text { Sampling } \\
\text { Procedure }\end{array}$ & $\begin{array}{c}\text { Parametric } \\
\text { Frequency }\end{array}$ & $\begin{array}{c}\text { Long Term } \\
\text { Reference }\end{array}$ \\
\hline Control room readings & & Manual recording & Each test point & Daily \\
\hline Flame stability & & Visual observation & Each test point & Daily \\
\hline Economizer particulate & & 24-point traverse & As needed & As needed \\
\hline $\begin{array}{l}\text { Furnace velocities } \\
\begin{array}{l}\text { Incident heat flux at } \\
12 \text { furnace locations }\end{array}\end{array}$ & & Cooled pitot probe & As needed & As needed \\
\hline $\begin{array}{l}\text { Furnace wall co and } \\
\text { O2 at } 12 \text { locations }\end{array}$ & & Land fluxprobe & Selected condition & 1 per month \\
\hline $\begin{array}{l}\text { Temperature at gas } \\
\text { and overfire air } \\
\text { injection planes }\end{array}$ & & Portable meter & Selected condition & 1 per month \\
\hline
\end{tabular}


The boiler measurements made were divided into four classes: input measurement, boiler performance measurements, emissions measurements, and durability and operability measurements. Each of these categories is described below.

\subsubsection{Input Measurements}

Input are obtained by recording the parameters that dictate the unit operation. These parameters consisted of coal and natural gas properties and flow rates, the unit operation, and the GR-LNB operation.

A combined sample of the crushed coal being fed to each of the pulverizers was extracted

at least ten times per week during the entire program and more frequently (at least twice daily) during optimization testing. Once per week a sample was analyzed for nitrogen and heat contents. Pulverized coal size and mass distribution to the individual burners was determined using the International Standards Organization Draft Standard ISO/TC27/SC 4NGG N25 sampling method plus sieve analysis (50,100 and 200 mesh) of the samples. The rotating ISO-type probe, illustrated in Figure 4-4, extracts near-isokinetic samples from 64 equal-area points on a cross-section of each coal pipe. The results of these tests were used to determine whether the coal was being adequately pulverized and evenly distributed between the burners. A complete set of control room and boiler data were obtained at least once per hour during each steady-state test point and at least once per day during the long term demonstration. The data consisted mainly of:

- Sootblowing cycle

- Gross and net load

- Auxiliary power usage

- Fuel and air flow rates and excess air level

- Baghouse differential pressure 


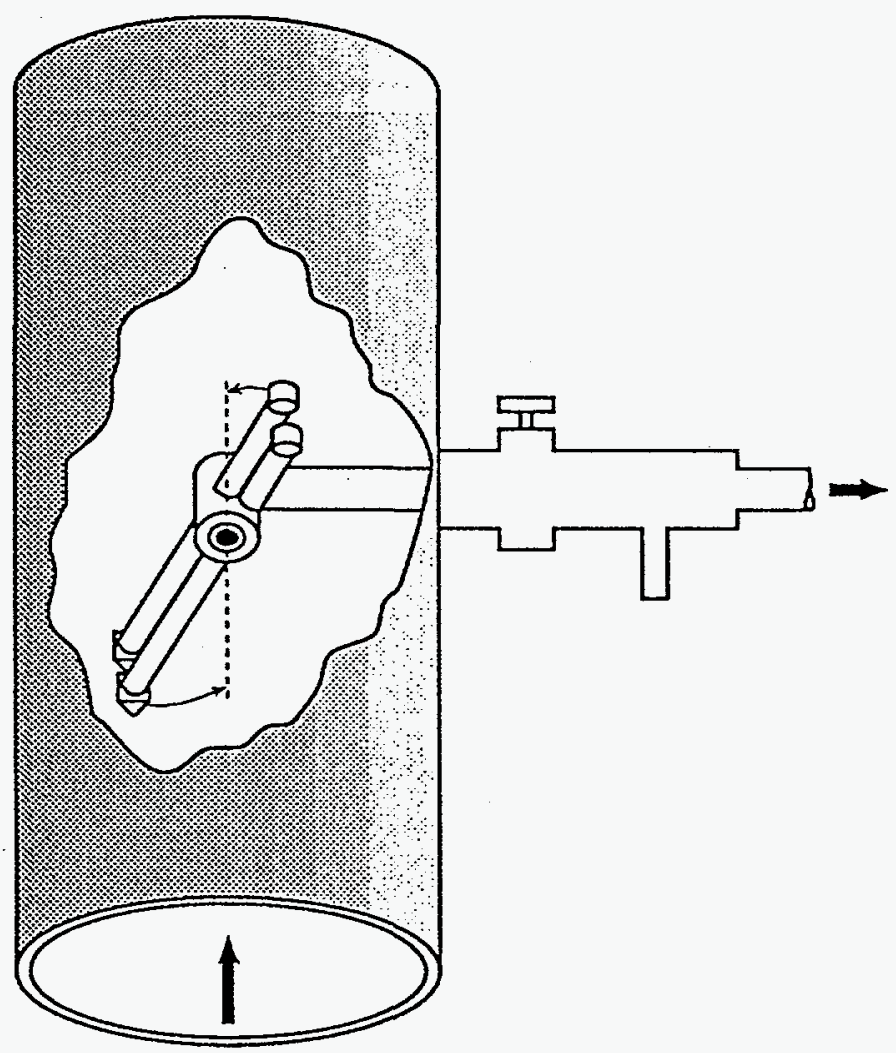

Figure 4-4. EER RotoProbe ${ }^{\mathrm{TM}}$ pulverized coal sampling probe 
The purpose of the data was to thoroughly record the operating conditions (1) for comparison between baseline and GR-LNB conditions, (2) to check for and diagnose variations in performance from day to day, and (3) to provide necessary inputs for the calibration of boiler performance.

The following GR-LNB conditions were monitored:

- $\quad$ Primary zone stoichiometric ratio (LNB setting)

- Reburn zone stoichiometric ratio (natural gas flow rate)

- $\quad$ Burnout (OFA) zone stoichiometric ratio

- $\quad$ Gas and air injector setting (mixing)

- $\quad$ FGR flow rate

The LNB setting was simply recorded and the measured excess $\mathrm{O}_{2}$ without the reburning was used to calculate the primary zone stoichiometric ratio. The reburn zone stoichiometric ratio was established by the natural gas flow rate. The gas flow rate was measured by a rate-of-flow meter, calibrated using a totalizing meter and stopwatch. The burnout zone stoichiometric ratio was controlled by the OFA flow rate and was measured by an Air Monitor ${ }^{\circledR}$ honeycomb flow meter with pitot rake. Overall uniformity of the fuel/air ratio was determined by traversing the economizer exit to determine excess oxygen.

\subsubsection{Boiler Performance Measurements}

The temperatures at the top of the furnace were measured once per hour throughout a full cycle from one routine sootblowing cycle until the next during baseline and optimization tests using a suction pyrometer with a radiation-shielded thermocouple (Figure 4-5). During the baseline tests temperatures were measured during normal unit dispatch including both steady state and transient conditions. During GR-LNB optimization tests, measurements were made under both steady state and load ramp conditions. 


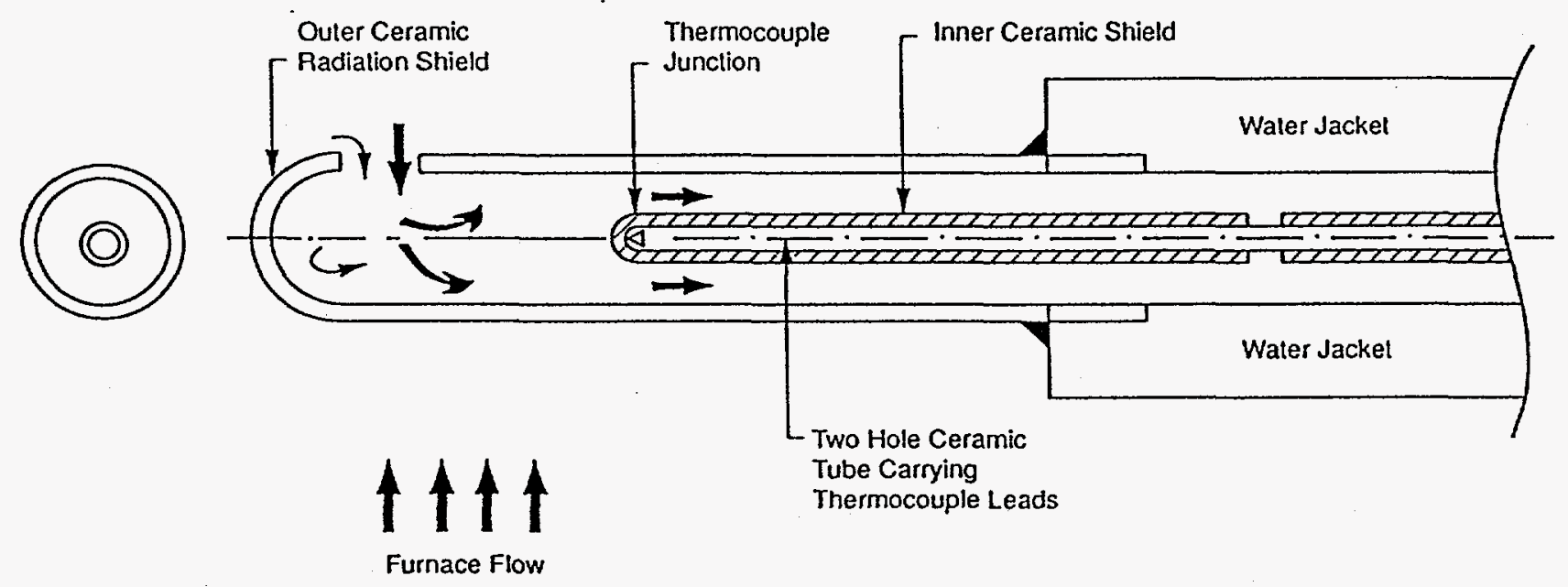

Figure 4-5. Suction pyrometer tip 
Concentrations of $\mathrm{CO}$ and $\mathrm{O}_{2}$ next to the furnace walls were measured in the reburn zone at maximum load for both baseline and GR conditions using a water-cooled probe. This information was used to assist in the tubewall wear analysis. Corrosion of furnace tubes is thought to be associated with low-melting ash components (particularly those containing iron) which exist under reducing conditions, and particularly in the presence of $\mathrm{H}_{2} \mathrm{~S}$. The concentration of $\mathrm{CO}$ was measured using the same continuous monitoring system employed for other gas analyses. For zones having $\mathrm{CO}$ concentrations over $500 \mathrm{ppm}$ next to the furnace wall, EPA Method 11 was used to determine $\mathrm{H}_{2} \mathrm{~S}$ concentration.

In addition to manual recording of control room data, boiler data were continuously logged by the BPMS. The data were used to estimate any changes in heat rate, ASME heat loss efficiency, and heat absorption distribution caused by GR-LNB.

Ash deposition amount and location in the furnace section of the boiler was recorded. Representative samples of the bottom ash collected in these tests were analyzed for. carbon burnout. Fouling factors were calculated for furnace sections in the boiler and displayed as a function of time.

At least three times per shift while optimization tests were being conducted, visual observations of deposits on the furnace walls were recorded. Deposition on boiler fireside heat transfer surfaces were quantified in terms of decreased heat transfer to those surfaces. This information was calculated on-line by the BPMS.

Although convective pass cleanliness was not expected to be affected by GR-LNB, fouling factors (FF) were calculated for individual heat transfer segments in the boiler and displayed as a function of time. Deposition was also inspected during boiler outages and deposition locations recorded. 
Fly ash size, composition and quantity was measured to provide an indication of combustion completeness. Mass balances of carbon, ash and sulfur were also performed.

\subsubsection{Emissions Measurements}

At selected test points, the conditions at the economizer exit were determined by analyzing samples extracted from a 16-point traverse of the flue gases at the economizer exit. The sampling ports are shown in Figure 4-6. The following species were measured:

$\begin{array}{ll}\text { - } & \mathrm{O}_{2} \\ \text { - } & \mathrm{CO}_{2} \\ \text { - } & \mathrm{CO} \\ \text { - } & \mathrm{SO}_{2} \\ \text { - } & \mathrm{NO}_{x} \\ \text { - } & \text { Hydrocarbons }\end{array}$

$\mathrm{SO}_{3}{ }{ }$ and $\mathrm{N}_{2} \mathrm{O}$ were also determined on occasion. The ash samples were extracted isokinetically at each location. This information was used to determine the following:

- Local stoichiometric ratio (indicative of overall fuel:air mixing)

- Local combustion efficiency

Although a certain amount of mixing occurred in the convective section of the boiler, nonuniformities remaining at the economizer exit often provided useful indications of mixing deficiencies in the furnace, where the combustion and reburning reactions predominantly occurred. This information was used for diagnostic purposes and to determine how closely ideal mixing had been achieved. 


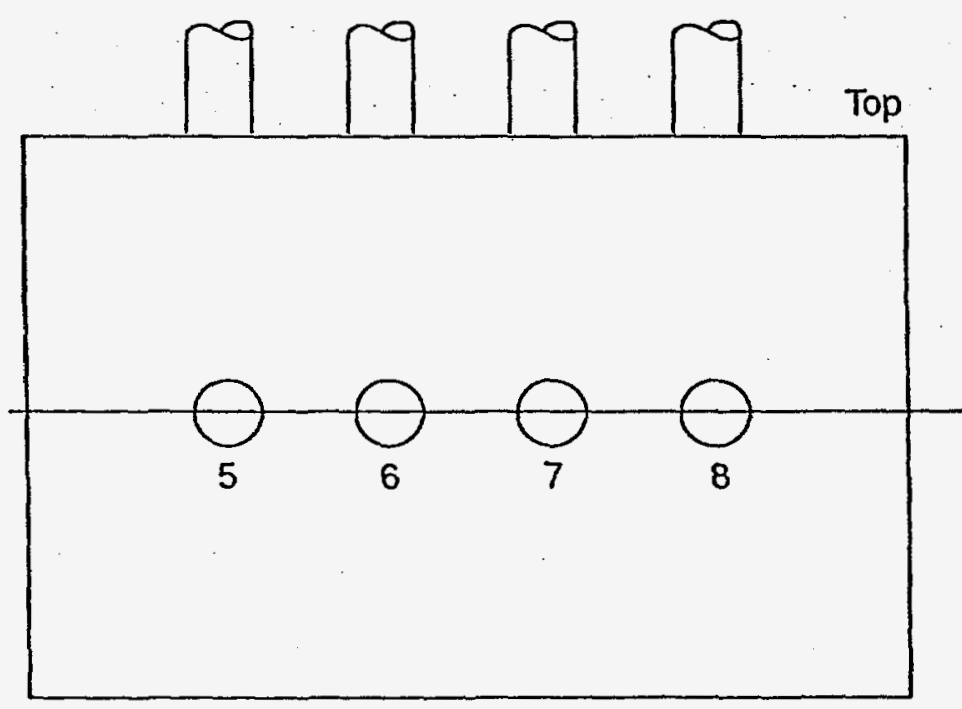

North Duct

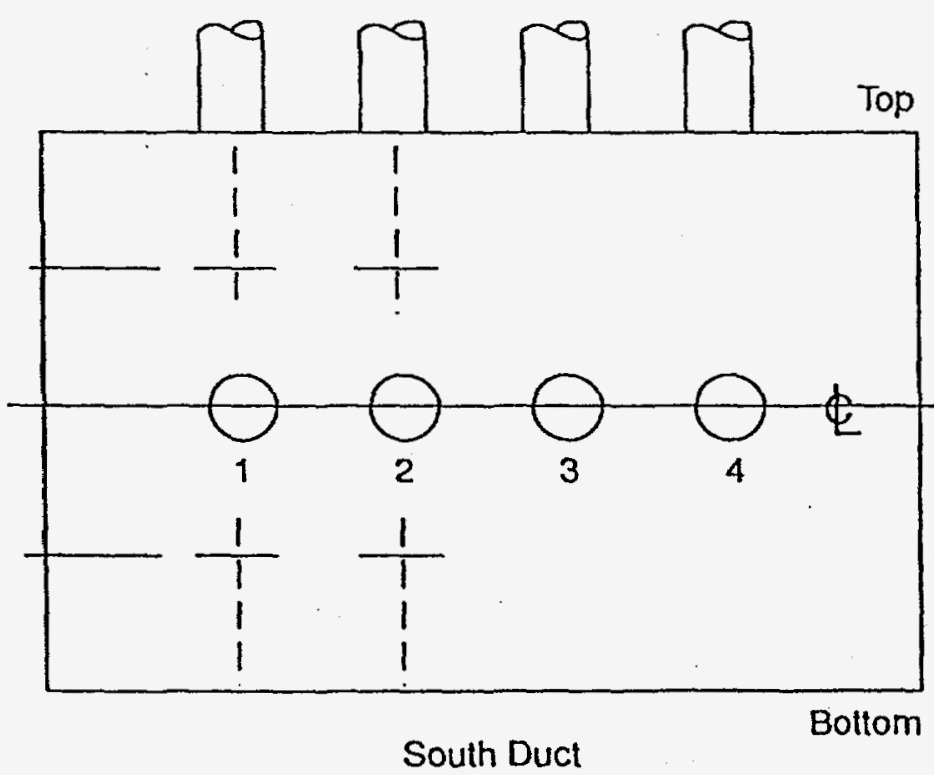

Figure 4-6. Economizer exit gas sampling grid 
Table 4-6 summarizes the continuous emissions monitoring system (CEMS). The $\mathrm{O}_{2}$ in the flue gas provided an indication of the boiler excess air and was used to convert the other emissions concentrations to a standard condition. The $\mathrm{CO}_{2}$ provided a means of checking the $\mathrm{O}_{2}$ measurements based on the fuel composition and a carbon mass balance. Carbon monoxide concentration provided a relative indication of combustion efficiency. The concentration of $\mathrm{CO}$ was typically below $200 \mathrm{ppm}$ in coal-fired boilers. It was monitored to determine whether GR-LNB caused a change in emissions or combustion completeness. Carbon monoxide and $\mathrm{O}_{2}$ stratification across the boiler exit was used as an indication of fuel/air mixing. Also, $\mathrm{SO}_{2}$ stratification combined with excess $\mathrm{O}_{2}$ was used as an indicator of fuel distribution.

A schematic diagram of the CEMS system used at Cherokee is shown (see Figure 4-2). The key features of the system included:

- Multiple probes

- Rotameters to provide accurate flow rate balancing

- Heating of components upstream of moisture removal equipment

- Sample filtration to remove fine particulate matter

- Use of a permeable membrane drier for moisture removal

A multiple array of sixteen probes was plumbed to a mixing manifold to obtain a representative sample. Glass rotameters were used to provide an on-line indication of each probe flow rate. Phase discrimination probes were used to provide inertial separation of particulate at the probe tip while minimizing the contacting of the gas with the particulate. All components outside the duct were heated to $250^{\circ} \mathrm{F}$ minimum and insulated to eliminate the possibility of condensation in the sample system.

EPA Reference Methods were used to verify the emissions measurements obtained with the CEMS. EPA Method 3 was used to verify $\mathrm{CO}_{2}$ and $\mathrm{O}_{2}$ measurements. Measurements 
of $\mathrm{SO}_{2}$ were verified using EPA Method 6 and $\mathrm{NO}_{x}$ measurements were verified with EPA Method 7. The Method 3 and Method 6 sampling was performed at both the air heater inlet (economizer outlet) and stack to verify the CEMS measurements.

The test port locations at the baghouse inlet are shown in Figures 4-7 and Figure 4-8. Both are consistent with U.S. EPA Method 1. Resistivity of the gases with particulate entering the baghouse was measured using a Wahlco cyclonic flow probe. Particulate loading at the inlet was measured using EPA Method 17. The velocity at the inlet was measured using EPA Method 2. The velocity information was used as input to Method 17 and to check the uniformity of flow.

The size of the particulate at the baghouse inlet was determined by single-point sampling with a Brinks cascade impactor, which is suitable for high dust loadings. The measurements were used to determine the efficiency of the baghouse and/or diagnose problems of baghouse efficiency.

Particulate emissions at the baghouse outlet were measured using EPA Method 17. Particulate emissions, together with particulate mass flux measured at the baghouse inlet, were used to calculate baghouse collection efficiency. Particulate size at the baghouse outlet was measured using an Andersen Mark-III cascade impactor.

\subsubsection{Durability and Operability}

U.T. testing was performed on the boiler tubewalls to collect data for the wear analysis following the recommendations in EPRI Report CS4633, "Fossil-Fired Boiler Tube Inspection." A digital thickness gauge and an oscilloscope were used to survey 4,150 points along the furnace wall. 


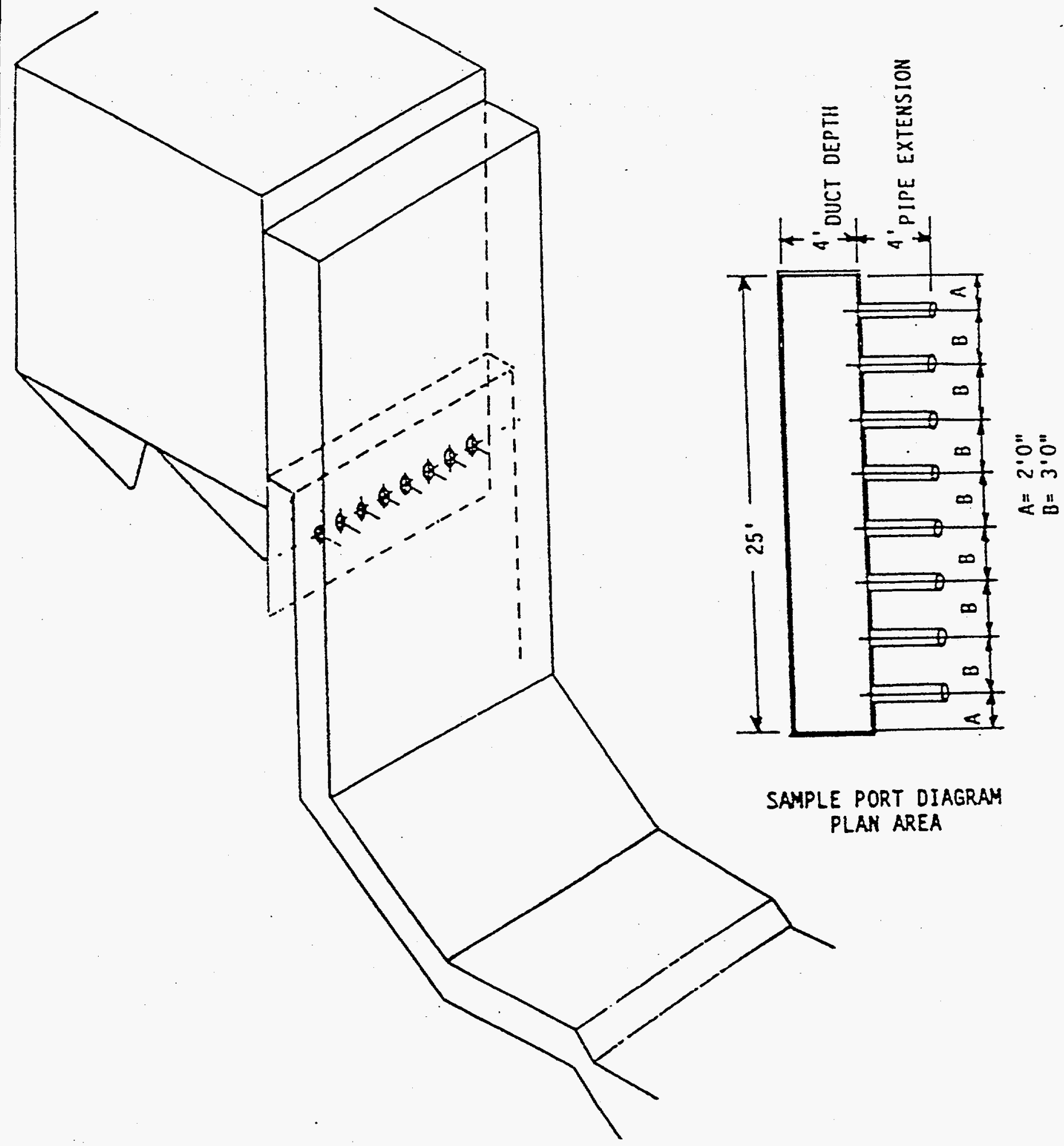

Figure 4-7. Baghouse inlet duct arrangement 


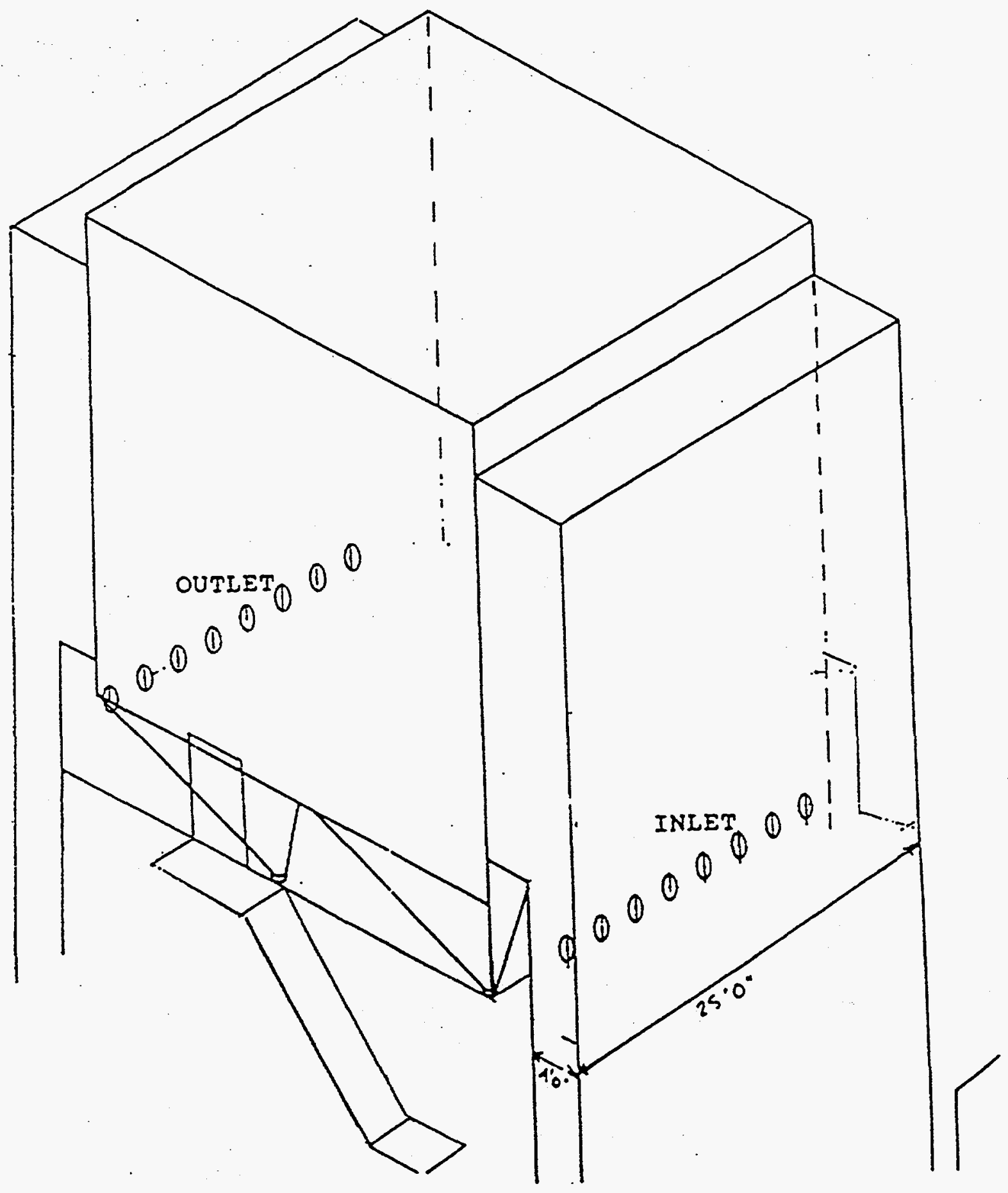

Figure 4-8. Baghouse sampling locations 


\subsection{Analyses of Feed Stocks, Products and Reagents}

The Cherokee Station fires coals from four Colorado mines. Ninety percent of the coal fired is from either the Yampa Valley or Empire Energy Mines (Table 4-8) operated by Cyprus Coal Company. These coals have a High Volatile $C$ Bituminous ranking. They typically contain 0.4 to $0.5 \%$ sulfur, 1.1 to $1.4 \%$ nitrogen, and have higher heating values of 10,600 to $10,900 \mathrm{Btu} / \mathrm{lb}$. They have good ignition characteristics as indicated by the fixed carbon/volatile matter ratio below 2.0 .

They have medium slagging propensity, as determined by ash fusion temperatures, and medium fouling propensity, as determined by the mineral content (sum of $\mathrm{Ca}, \mathrm{Mg}, \mathrm{Fe}$ in ash). They have relatively low grindability however, with an $\mathrm{HGl}$ of 41 to 47 . They have relatively low moisture and ash content and relatively high heating value, all of which are characteristics of this rank of coal. The coal ash fusion temperatures under oxidizing and reducing conditions indicate a medium slagging propensity. Therefore, minimal slag buildup would be expected under normal oxidizing conditions in a relatively large furnace.

The composition of the natural gas is shown in Appendix B.

4.4

Data Analysis Methodology

The performance of the $\mathrm{GR}$ system in controlling $\mathrm{NO}_{x}$ was evaluated through a standard technique described in this section. The three furnace stoichiometric ratios $\left(\mathrm{SR}_{1}, \mathrm{SR}_{2}\right.$, and $\mathrm{SR}_{3}$ ) are used to evaluate the $\mathrm{GR}$ process under fixed conditions. The process was fixed by holding process parameters constant, as will be illustrated. 
TABLE 4-8. ANALYSIS OF EMPIRE COAL FIRED ON CHEROKEE UNIT \#3

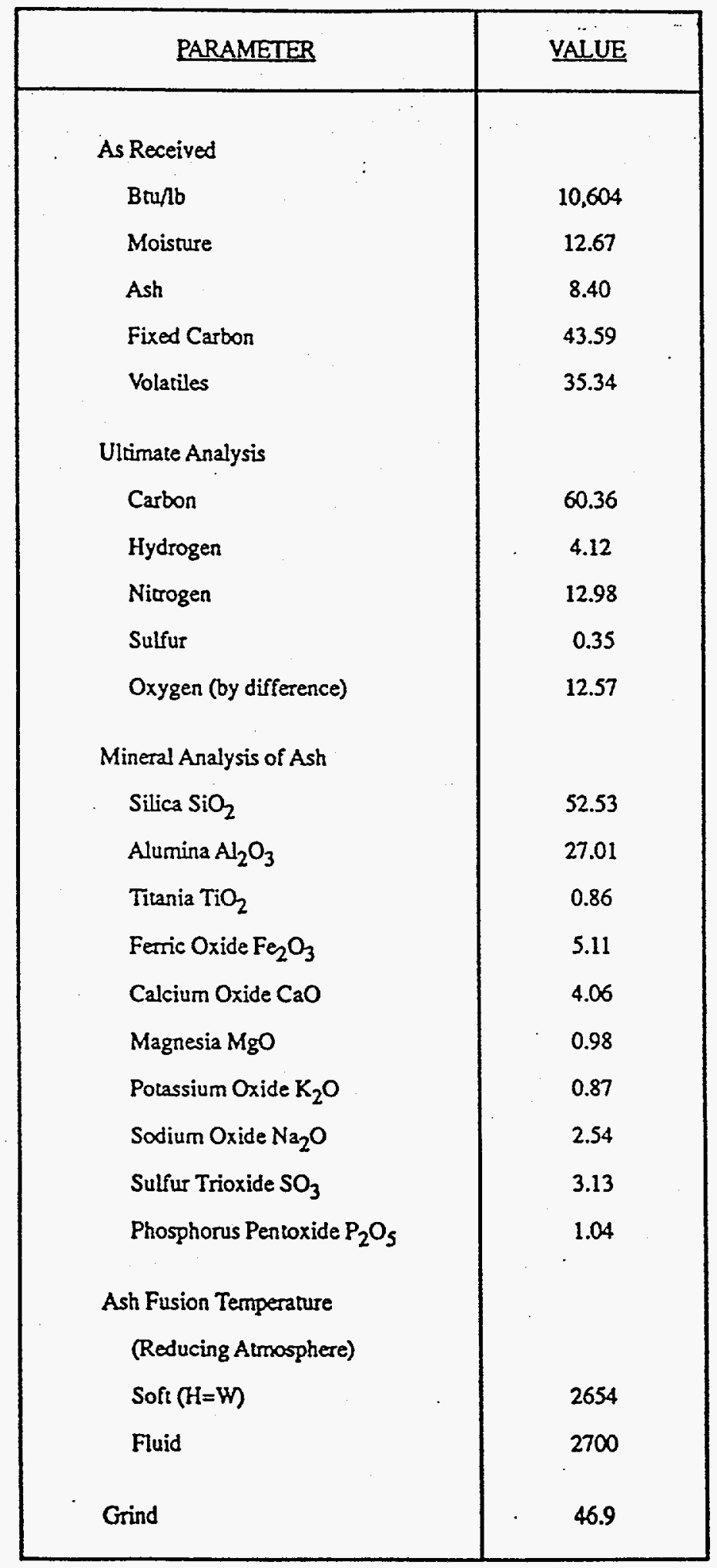


The stoichiometric ratios $\left(\mathrm{SR}_{1}, \mathrm{SR}_{2}\right.$, and $\left.\mathrm{SR}_{3}\right)$ are defined by the following equations:

$$
\begin{array}{ll}
\mathrm{SR}_{1} & =(T A-O F A) / C S A \\
\mathrm{SR}_{2} & =(T A-\text { OFA }) /(C S A+G S A) \\
\mathrm{SR}_{3} & =\mathrm{TA} /(\mathrm{CSA}+\mathrm{GSA})
\end{array}
$$

Where:

$$
\begin{aligned}
\text { TA } & =\text { Total Combustion Air, scfm } \\
\text { OFA } & =\text { Overfire Air, scfm } \\
\text { CSA } & =\text { Coal Stoichiometric Air, scfm } \\
& =(\text { Coal Theoretical Air, scf/lb) } \times(\text { Coal Flow, lb/min) } \\
\text { GSA } & =\text { NG Stoichiometric Air, scfm } \\
& =(\text { NG Theoretical Air, scf/scf) } \times(\text { NG Flow, scfm) }
\end{aligned}
$$

Several approximate equations may be derived from the above set of equations/definitions. These are only approximate but are useful in correlating results.

$$
\begin{aligned}
& \text { Coal Fraction = CSA } /(\mathrm{CSA}+\mathrm{GSA})=\mathrm{SR}_{2} / \mathrm{SR}_{1} \\
& \text { NG Fraction = } 1-\text { Coal Fraction }=\left(\mathrm{SR}_{1}-\mathrm{SR}_{2}\right) / \mathrm{SR}_{1} \\
& \text { Coal Air Fraction = }(\mathrm{TA}-\mathrm{OFA}) / \mathrm{TA}=\mathrm{SR}_{2} / \mathrm{SR}_{3} \\
& \text { OFA Fraction = OFA TA }=\left(\mathrm{SR}_{3}-\mathrm{SR}_{2}\right) / \mathrm{SR}_{3}
\end{aligned}
$$

The above four equations relate seven variables $\left(\mathrm{SR}_{1}, \mathrm{SR}_{2}, \mathrm{SR}_{3}\right.$, Coal Fraction, NG Fraction, Coal Air Fraction, and OFA Fraction). Therefore, for a given load the GR system is fixed if three of these process variables are fixed. Examples of sets of variables which fix the system are $\left(\mathrm{SR}_{1}, \mathrm{SR}_{2}\right.$, and $\left.\mathrm{SR}_{2}\right),\left(\mathrm{SR}_{1}, \mathrm{NG}\right.$ Fraction, and $\left.\mathrm{SR}_{3}\right)$, or $\left(\mathrm{SR}_{1}, \mathrm{NG}\right.$ Fraction, and OFA Fraction). When $\mathrm{NO}_{x}$ emissions are plotted as a function of one of these variables, two other variables must be held constant to see the effect of the variable. The following illustrates how $\mathrm{NO}_{x}$ data should be graphically displayed:

$$
\begin{array}{ll}
\text { Plot } & \text { Variables to be Fixed } \\
\mathrm{NO}_{x} \text { vs. } \mathrm{SR}_{2} & \left(\mathrm{SR}_{1}, \mathrm{SR}_{3}\right),(\mathrm{NG} \text { Fraction, OFA Fraction) } \\
& \left(\mathrm{SR}_{1}, \mathrm{OFA} \text { Fraction), or (NG Fraction, } \mathrm{SR}_{3}\right) \\
& \left(\mathrm{SR}_{1}, \mathrm{SR}_{3}\right),\left(\mathrm{SR}_{2}, \mathrm{SR}_{3}\right) \\
& \left(\mathrm { SR } _ { 1 } , \mathrm { OFA } \text { Fraction), or } \left(\mathrm{SR}_{2}, \mathrm{OFA}\right.\right. \text { Fraction) }
\end{array}
$$


The percentage of a parameter can be used in place of the fraction of a quantity (i.e. gas heat input may be used in place of NG Fraction).

The program quality assurance (QA) objectives for precision, accuracy and completeness are listed in Table 4-9 for each critical measurement. These $Q A$ objectives were based on the program requirements and the precision and accuracy levels achievable by the selected measurement methods. The results of previous methods evaluation studies and EER's experience were used to determine the anticipated precision and accuracy limits of each method. The values for precision are defined as the relative standard deviation (RSD), the ratio of the standard deviation to the mean, expressed as a percentage. Accuracy is the relative difference (expressed as a percentage) between the measured value and a known, or standard, reference value. Completeness is the percentage of the total data set which is accepted as valid.

\subsection{Data Summary}

Operating data collected during the parametric and long term testing are presented in Appendix A. The following data are included:

- $\quad$ LNB and LNB-OFA emissions data

- $\quad$ LNB and LNB-OFA operating conditions and steam data

- $\quad$ LNB and LNB-OFA heat transfer data

- GR-LNB emissions data

- $\quad$ GR-LNB operating conditions and steam data

- $\quad$ GR-LNB heat transfer data

- Modified LNB and LNB-OFA emissions data

- Modified LNB and LNB-OFA operating conditions and steam data

- Modified LNB and LNB-OFA heat transfer data

- $\quad$ Second Generation GR-LNB emissions data 
TABLE 4-9. PROGRAM OBJECTIVES FOR CRITICAL MEASUREMENT DATA

\begin{tabular}{|c|c|c|c|c|}
\hline $\begin{array}{c}\begin{array}{c}\text { Measurement } \\
\text { Parameter }\end{array} \\
\end{array}$ & Reference & $\begin{array}{l}\text { Precision } \\
\text { RDS }\end{array}$ & Accuracy & Completeness \\
\hline \multicolumn{5}{|l|}{ Coal } \\
\hline \multicolumn{5}{|l|}{ Proximate } \\
\hline Volatiles & ASTM D-3172 & $10 \%$ & $10 \%$ & $90 \%$ \\
\hline Fixed Carbion & ASTM D-3172 & $10 \%$ & $10 \%$ & $90 \%$ \\
\hline Moisture & ASTM D-3172 & $10 \%$ & $10 \%$ & $90 \%$ \\
\hline Ash & ASTM D-3172 & $10 \%$ & $10 \%$ & $90 \%$ \\
\hline \multicolumn{5}{|l|}{ Ultimate } \\
\hline Carbon & ASTM D-3176 & $2 \%$ & $2 \%$ & $90 \%$ \\
\hline Hydrogen & ASTM D-3176 & $5 \%$ & $5 \%$ & $90 \%$ \\
\hline Nitrogen & ASTM D-3176 & $10 \%$ & $10 \%$ & $90 \%$ \\
\hline Ash & ASTM D-3176 & $10 \%$ & $10 \%$ & $90 \%$ \\
\hline Sulfur & -..---.- & $10 \%$ & $10 \%$ & $90 \%$ \\
\hline \multicolumn{5}{|l|}{ Coal Ash } \\
\hline Elemental & ASTM D-2795 & $10 \%$ & $10 \%$ & $90 \%$ \\
\hline Fusion Temp. & ASTM D-1857 & $10 \%$ & $10 \%$ & $90 \%$ \\
\hline Heating Value & ASTM D-2015 & $2 \%$ & $2 \%$ & $90 \%$ \\
\hline \multicolumn{5}{|l|}{ Furnace measurements } \\
\hline Gas temperature & ---------- & $5 \%$ & $5 \%$ & $90 \%$ \\
\hline Gas velocity & ------- & $10 \%$ & $10 \%$ & $90 \%$ \\
\hline Fouling rate & --..-.---- & $10 \%$ & -------n-- & $90 \%$ \\
\hline \multicolumn{5}{|l|}{ Gas composition } \\
\hline $\mathrm{O} 2$ & EPA Method 3A & $2 \%$ & $20 \%$ & $90 \%$ \\
\hline SO2 & EPA Method 6C & $2 \%$ & $20 \%$ & $90 \%$ \\
\hline $\mathrm{CO}$ & --------- & $2 \%$ & $20 \%$ & $90 \%$ \\
\hline $\mathrm{CO} 2$ & EPA Method 3A & $2 \%$ & $20 \%$ & $90 \%$ \\
\hline $\mathrm{NO}, \mathrm{NO} 2$ & EPA Method 7E & $2 \%$ & $20 \%$ & $90 \%$ \\
\hline THC & EPA Method 25B & $5 \%$ & $20 \%$ & $80 \%$ \\
\hline \multicolumn{5}{|l|}{ Hopper flyash } \\
\hline Elemental & ASTM D-2785 & $10 \%$ & $10 \%$ & $90 \%$ \\
\hline Carbon & ASTM D-3176 & $10 \%$ & $10 \%$ & $90 \%$ \\
\hline Ash & ASTM D-3174 & $10 \%$ & $10 \%$ & $90 \%$ \\
\hline Elemental & ASTM D-2795 & $10 \%$ & $10 \%$ & $90 \%$ \\
\hline Fusion Temp. & ASTM D-1875 & $10 \%$ & $10 \%$ & $90 \%$ \\
\hline \multicolumn{5}{|l|}{ In-situ flyash } \\
\hline Loading & $\begin{array}{c}\text { EPA M5 or M17, } 40 \\
\text { CFR } 60, \text { App. A }\end{array}$ & $10 \%$ & $10 \%$ & $90 \%$ \\
\hline Carbon & $\begin{array}{l}\text { EPA M17 and } \\
\text { ASTM D-3172 }\end{array}$ & $10 \%$ & $10 \%$ & $10 \%$ \\
\hline
\end{tabular}


- $\quad$ Second Generation GR-LNB operating conditions and steam data

- $\quad$ Second Generation GR-LNB heat transfer data

- $100 \%$ gas firing emissions data

- $100 \%$ gas firing operating conditions and steam data

- $100 \%$ gas firing heat transfer data

Coal and natural gas analyses are presented in Appendix C. Graphs and analysis of the data are presented in Section 5.0.

\subsection{Operability and Reliability}

Following the parametric test program, the reburning system was converted to automatic mode. Hence, the system was operated with load following capability. The unit operated as designed in both manual and automatic modes. No problems were experienced. During long term testing, one incident caused the reburning system to be taken out of service for a duration of one week. Slag deposits were forming around the FGR/natural gas ports. Slagging was occurring around some of the FGR ports, however, the ports were not plugged. It was found that the shutoff damper on the discharge of a cooling air fan to the FGR ports (used when FGR is out of service) was not fully closing. The leakage of cold air was causing the slagging. The damper was subsequently repaired and testing resumed.

The LNBs, when operated without GR, did not reduce $\mathrm{NO}_{\mathrm{x}}$ emissions to degree anticipated by the utility. The average $\mathrm{NO}_{x}$ reduction was $37 \%$ compared to an expected $45 \%$. When EER terminated its activities at the site, Foster Wheeler (supplier of LNBs) was designing a system to route additional combustion (tertiary) air to the burners to improve the performance. There are currently no data available to assess the modification in this report. 


\subsubsection{Critical Component Failure Analysis}

All equipment in the GR system functioned as planned. There were no critical component failures. During the testing a fire destroyed some of the natural gas injection equipment, but the cause was unrelated to the reburning system. 


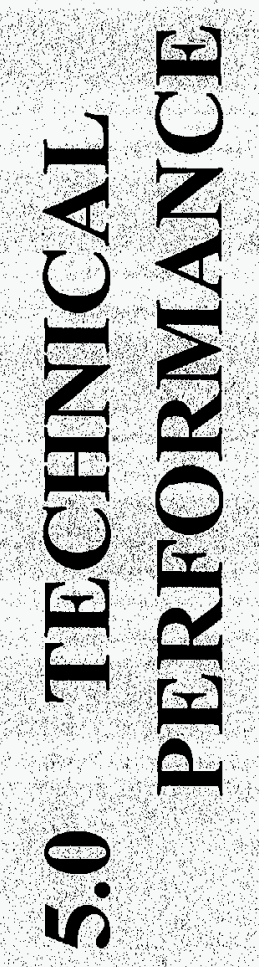


The objective of the test program was to demonstrate the effectiveness of combined GRLNB technology in reducing $\mathrm{NO}_{x}$ emissions from a wall-fired power generating unit. This section presents the results of the demonstration using data from both short-term parametric/optimization tests and long-term tests. The presentation includes First Generation and Second Generation GR plus the results of gas/gas reburning tests.

\subsection{Pre-Construction Baseline Testing}

Baseline testing of the Cherokee unit was conducted on July 9-26, 1991. The testing was designed to monitor daily operation of the boiler and auxiliary equipment during predetermined load conditions in a manner consistent with normal operation. The parameters which were varied during testing were excess $\mathrm{O}_{2}$ and load. No attempt was made to optimize the operation of the boiler before testing since the purpose was to document the "as found" condition.

A detailed Baseline Test Report was prepared during Phase I and submitted for record. The data from the report are summarized in Figures 5-1 through 5-3 which present $\mathrm{NO}_{\mathrm{x}}$ carbon-in-ash and $\mathrm{CO}$ results for the full load range, adjusted to a dry 3 percent $\mathrm{O}_{2}$ basis.

At full load (150 $\mathrm{MW}_{\mathrm{e}}$ net) the average emissions measured were:

$\begin{array}{ll}\mathrm{NO}_{x} & 541 \mathrm{ppm}\left(0.73 \mathrm{lb} / 10^{6} \mathrm{Btu}\right) \\ \mathrm{SO}_{2} & 355 \mathrm{ppm} \\ \mathrm{CO} & 67 \mathrm{ppm} \\ \text { Carbon-in-ash } & 4.4 \mathrm{wt} \%\end{array}$




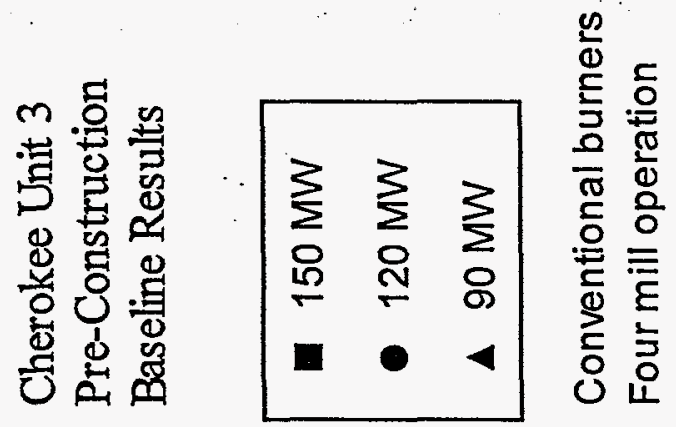

10

0
0
0
0
0
0
$\frac{1}{2}$
$\frac{0}{\pi}$
0
0

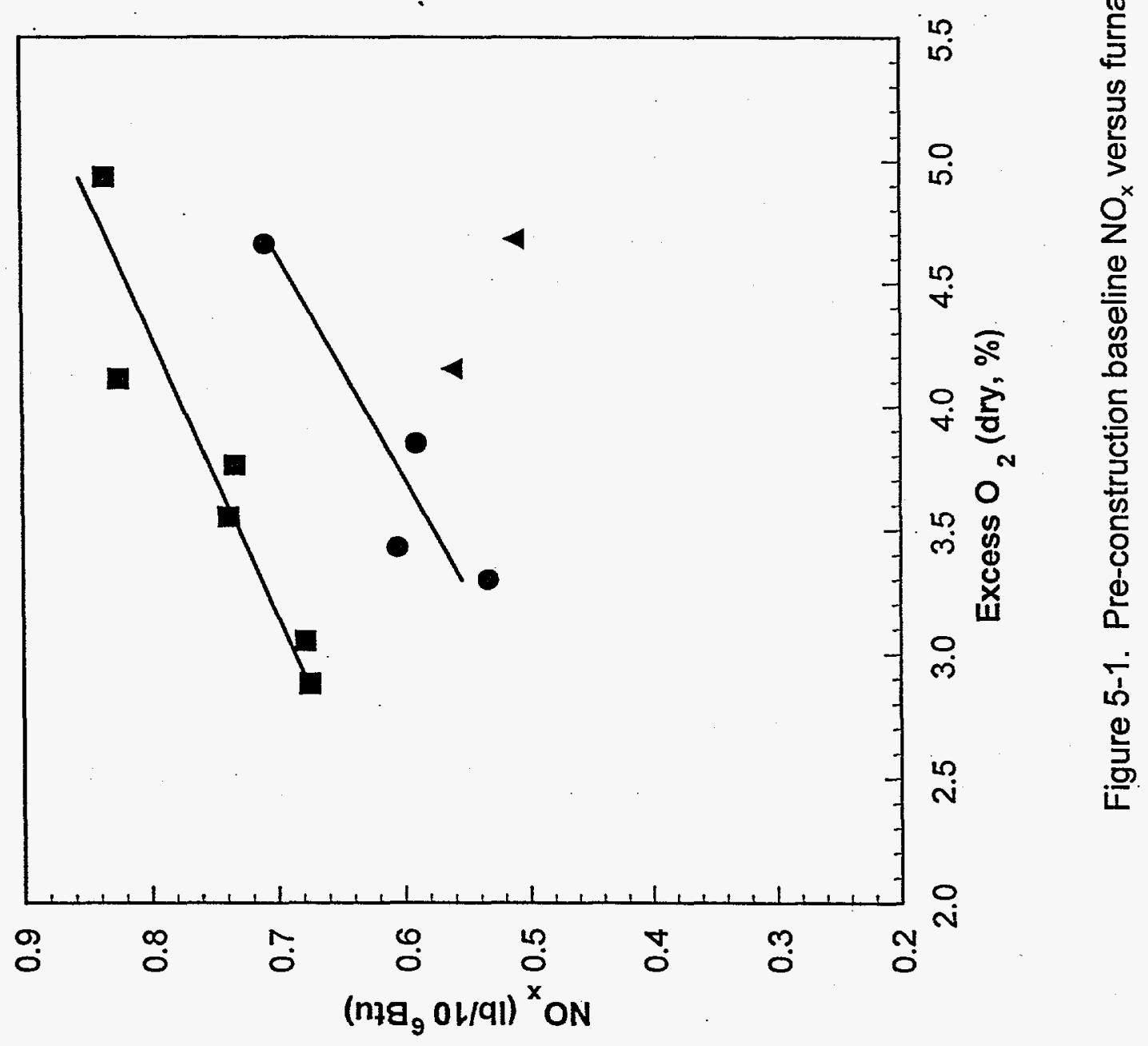

ก์ 


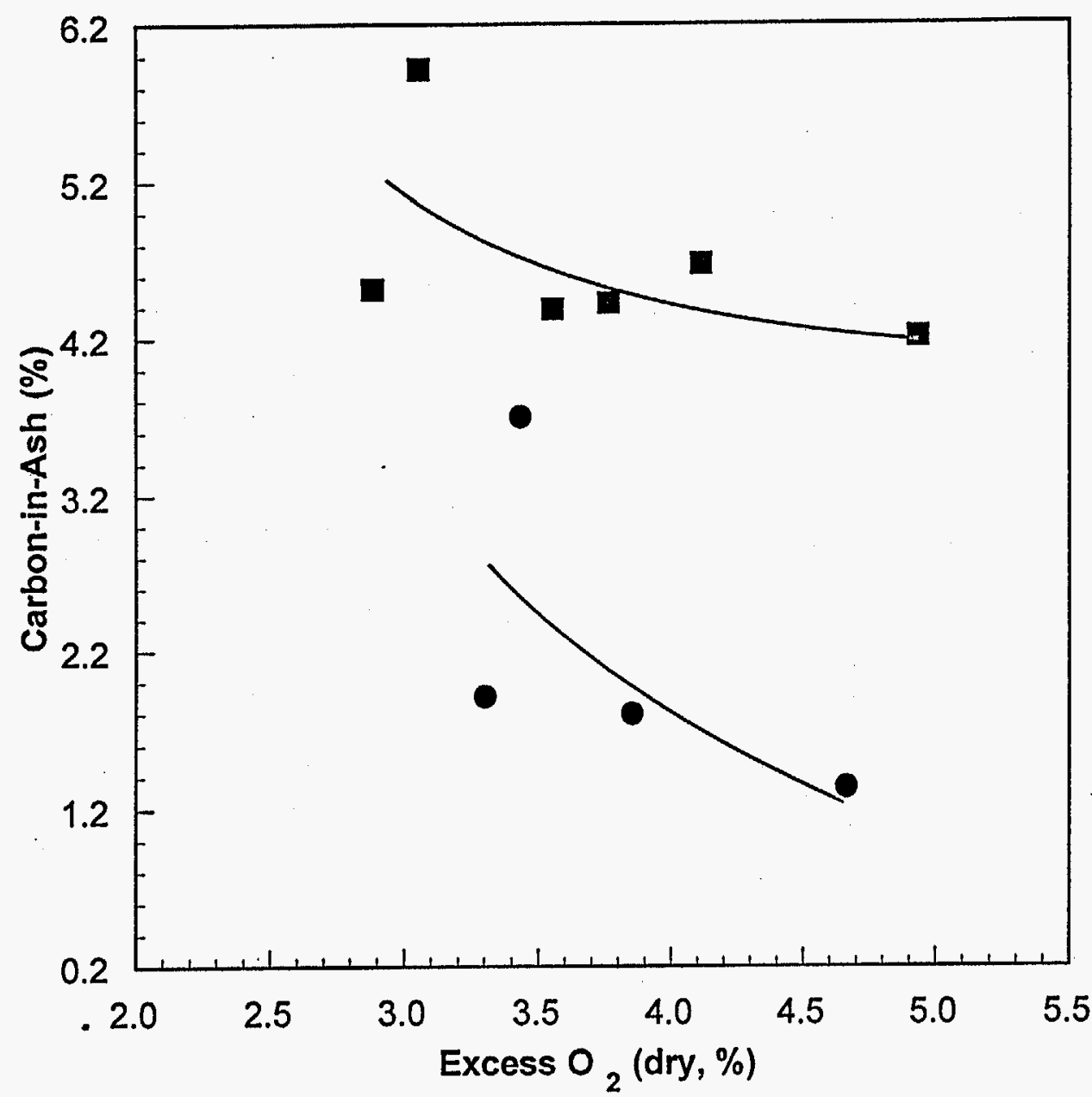

Cherokee Unit 3

Pre-Construction

Baseline Results

\section{- $150 \mathrm{MW}$ \\ - $120 \mathrm{MW}$}

Conventional burners

Four mill operation

Figure 5-2. Pre-construction baseline fly ash carbon versus furnace exit flue gas $\mathrm{O}_{2}$ 


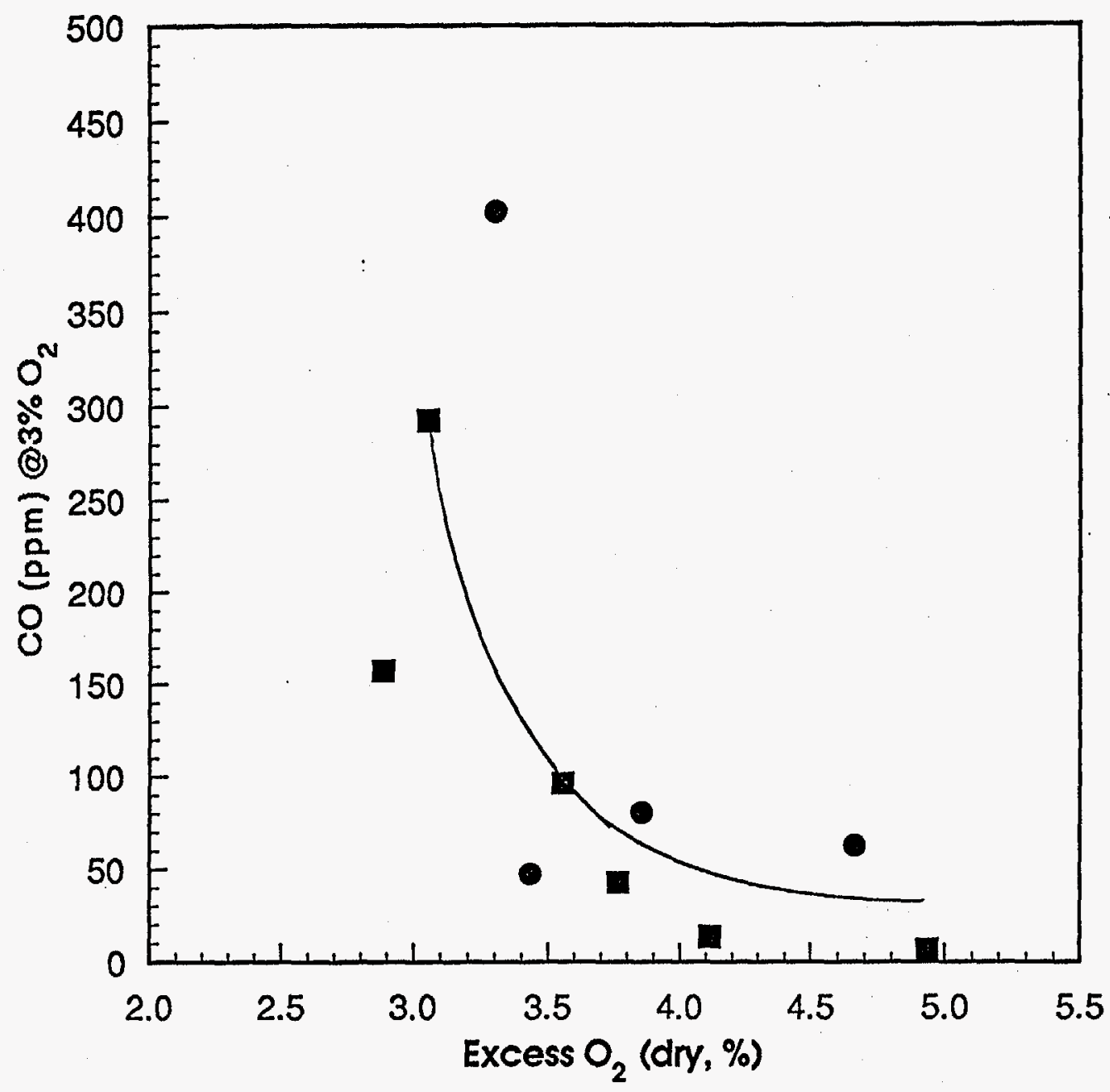

Cherokee Unit 3

Pre-Construction

Baseline Results

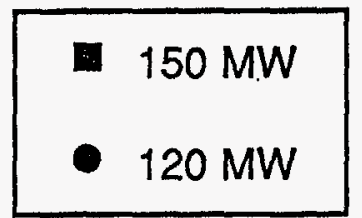

Conventional burners

Four mill operation

Figure 5-3. Pre-construction baseline $\mathrm{CO}$ versus furnace exit flue gas $\mathrm{O}_{2}$ 
$\mathrm{NO}_{x}$ The baseline $\mathrm{NO}_{x}$ emission levels were considered reasonable and comparable to other wall-fired units of similar design, size and age. As expected, $\mathrm{NO}_{\mathrm{x}}$ emissions increased as excess $\mathrm{O}_{2}$ increased.

$\underline{\mathrm{SO}}_{2}$ The baseline $\mathrm{SO}_{2}$ emission levels were reflective of the low-sulfur coal that was fired.

CO The baseline $\mathrm{CO}$ emission levels increased as excess $\mathrm{O}_{2}$ was decreased. During the tests, in some cases, the $\mathrm{CO}$ emission rates were high. It was believed that the high $\mathrm{CO}$ levels were caused by coal fineness out of specification on three of the four mills and the use of wet coal due to rain occurring during the test program.

$\mathrm{CO}_{2}$ The $\mathrm{CO}_{2}$ levels were typical for the fuel fired.

Carbon-in-ash The carbon-in-ash levels increased with decreasing excess air, but were generally less than $5 \%$.

\subsection{GR-LNB Optimization Testing (First Generation GR)}

The test program was designed to (1) evaluate the impacts of GR-LNB on gaseous emissions, boiler performance and operability, and operating costs, and (2) to determine the boiler set points required to reduce the $\mathrm{NO}_{x}$ emissions to the program goal of $70 \%$. This section presents the results of the parametric/optimization tests performed on the First Generation GR system. The plan for the testing was presented in Section 4.1.1.

Optimization of the GR system was accomplished by systematically varying the process parameters of the system which affect overall $\mathrm{NO}_{\mathrm{x}}$ emissions. The results of each parametric variation was used to establish the basis for the next parametric variation in succession. Thus the testing proceeded in logical fashion until all parameters were varied and their effects evaluated. 
The sequence of testing was as follows:

- LNB emissions were measured without GR in operation and compared to the original baseline.

- The excess air fired in the burners was varied to determine the minimum excess air level at which the burners could be operated commensurate with maintaining acceptable carbon loss and $\mathrm{CO}$ emissions. These tests were performed with and without the OFA system in operation.

- The natural gas was varied to determine the relationship between $\mathrm{NO}_{\mathrm{x}}$ emissions and gas heat input. The impact on carbon-in-ash was also assessed. The test series was used to study the effects of changes to the reburn zone stoichiometric ratio on reburn performance.

- The OFA was varied to determine the relationship between $\mathrm{CO}$ and excess air. The test series was used to identify the optimum overall excess air levels for reburn operation.

The majority of the tests were performed at full load $\left(150 \mathrm{MW}_{\mathrm{e}}\right)$. However, a significant number of tests were performed at reduced load (120 and $90 \mathrm{MW}_{\mathrm{e}}$ ).

\subsubsection{Low NO Burners}

The existing sixteen burners were replaced with FWEC internal fuel-staging LNBs. The burners employ dual combustion air registers which allow for control of air distribution at the burner, providing independent control of the ignition zone and flame shape. $A \mathrm{NO}_{x}$ reduction of $45 \%$ from baseline was projected at the full load condition. 


\subsubsection{1 $\quad$ LNB Baseline}

The purpose of the test series was to (1) compare the performance with that of the original boiler equipment, and (2) establish stabilized conditions at the start of each GR-LNB parametric test. Prior to each GR-LNB test, the performance of the boiler was recorded (see Appendix B).

The results of the test series are presented in Figures 5-4 through 5-6. $\mathrm{NO}_{\mathrm{x}}$, carbon-in-ash and $\mathrm{CO}$ are plotted against excess air. The following table summarizes the average results and compares them to the original equipment baseline:

$\begin{array}{cccc}\begin{array}{c}\text { Furnace exit } \mathrm{O}_{2} \\ \mathrm{NO}_{\times}\left(\mathrm{lb} / 10^{6} \mathrm{Btu}\right)\end{array} & \underline{3 \%} & \underline{4 \%} & \underline{5 \%} \\ \text { baseline } & 0.68 & 0.77 & 0.86 \\ \text { LNB } & 0.42 & 0.49 & 0.54 \\ \% \text { change } & -38 \% & -36 \% & -37 \% \\ \text { Carbon-in-ash } & & & \\ \text { baseline } & 5 \% & 5 \% & 4 \% \\ \text { LNB } & 8 \% & 5 \% & 2 \% \\ \text { CO (ppm) } & & & \\ \text { baseline } & <300 & <50 & <50 \\ \text { LNB } & <1000 & <500 & <100\end{array}$

The data show that the $\mathrm{LNBs}$ reduced $\mathrm{NO}_{x}$ emissions by about $37 \%$. However, carbon-inash and $\mathrm{CO}$ could not be maintained at acceptable levels at the normal excess air level $\left(\sim 3 \% \mathrm{O}_{2}\right)$. By boosting the excess air, the carbon-in-ash and $\mathrm{CO}$ could be lowered to approximately baseline conditions, but at the expense of higher $\mathrm{NO}_{x}$ emissions. Note that the targeted reduction in $\mathrm{NO}_{\mathrm{x}}$ emissions of $45 \%$ was not achieved. 


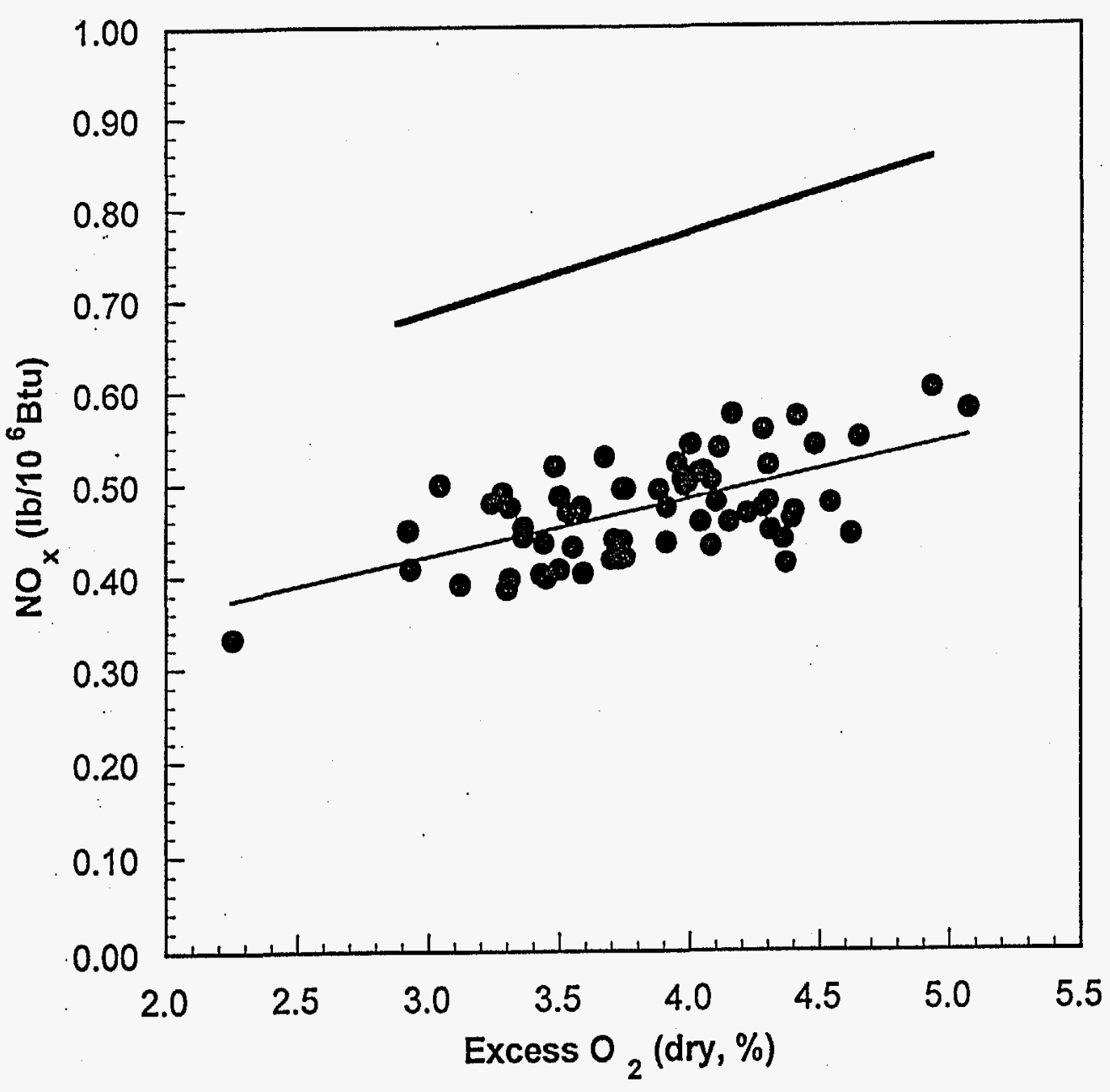

Cherokee Unit 3

First Generation GR

Low NOx Burners

LNB Baseline Results

- LNB

- Pre-Construction

140-160 MWe (net)

$0 \%$ Gas

O\% OFA

Figure 5-4. LNB baseline $\mathrm{NO}_{x}$ versus furnace exit flue gas $\mathrm{O}_{2}$ 

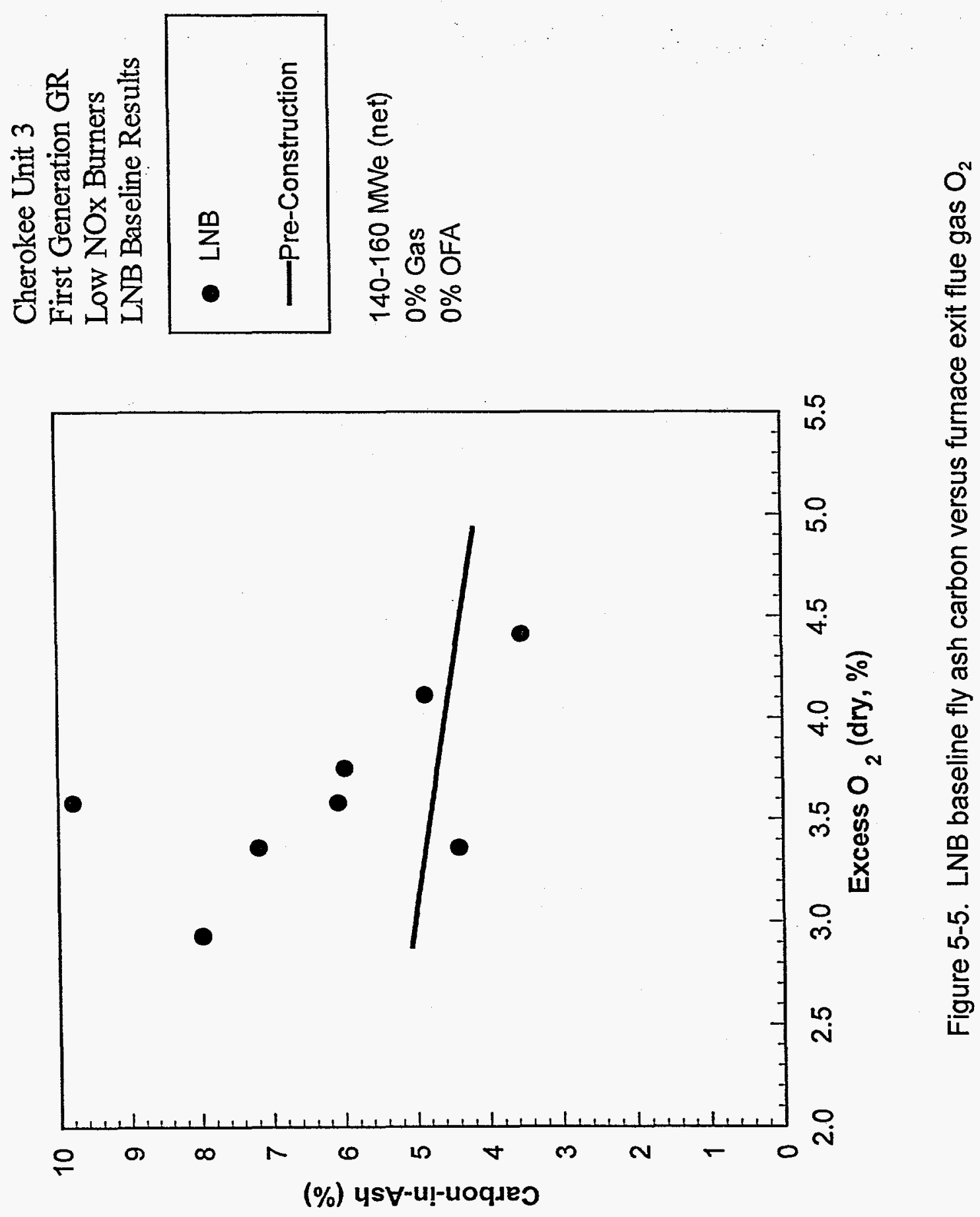

م) 

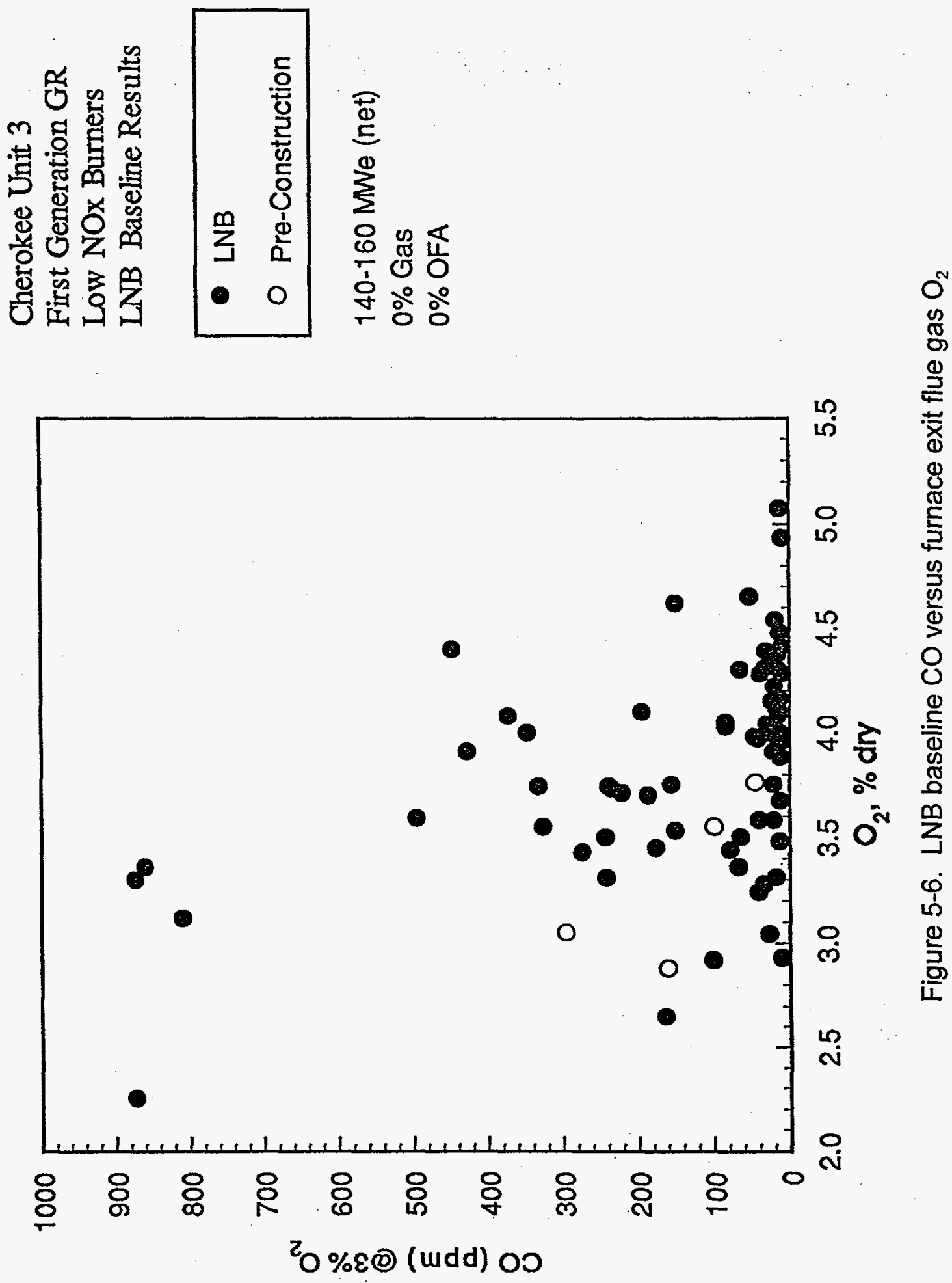


\subsubsection{Combustion Air Variation}

The purpose of varying combustion air to the LNBs was to establish the relationships between primary zone stoichiometric ratio $\left(\mathrm{SR}_{1}\right)$ and boiler emissions and performance. If this ratio could be reduced, the level of $\mathrm{NO}_{x}$ reduction per amount of reburn fuel added would increase. In addition, reducing $\mathrm{SR}_{1}$ results in lower $\mathrm{NO}_{x}$ emissions from the burners.

The normal operating $\mathrm{SR}_{1}$ for the LNBs was approximately 1.23 . If this ratio could be lowered, the result will be a reduced level of oxygen available to form fuel bound $\mathrm{NO}_{\mathrm{x}}$ and thermal $\mathrm{NO}_{\mathrm{x}}$ in the primary zone. $\mathrm{SR}_{1}$ has a lower limit (unique for each boiler) to avoid localized pockets of oxygen deficient flue gas, otherwise known as reducing atmospheres, which could result in accelerated corrosion in the lower furnace. It should be noted that there were no indications of reducing atmospheres in the burner zone of the furnace and no evidence of accelerated boiler tube corrosion rates at any time during the test program.

The results of the test series are displayed in Figures 5-7 and 5-8 for $\mathrm{NO}_{x}$, carbon-in-ash and $\mathrm{CO}$ versus $\mathrm{SR}_{1}$. As expected, $\mathrm{NO}_{x}$ emissions were lower when $\mathrm{SR}_{1}$ was reduced. The rate of reduction tapered off as $\mathrm{SR}_{1}$ fell below 1.10. CO for the most part remained below $150 \mathrm{ppm}$, demonstrating that as $\mathrm{SR}_{1}$ is reduced, $\mathrm{CO}$ can be controlled by the OFA ports. A negative impact was the higher level of carbon-in-ash (greater than 7\%). A goal of the GR technology was to avoid increasing the unburned carbon.

\subsubsection{Gas Reburning with Low NO $\times$ Burners}

This section discusses the impact of operating the gas reburning system with low $\mathrm{NO}_{\mathrm{x}}$ burners. Included in this section are discussions of the effects of varying the levels of gas heat input, OFA and FGR. 


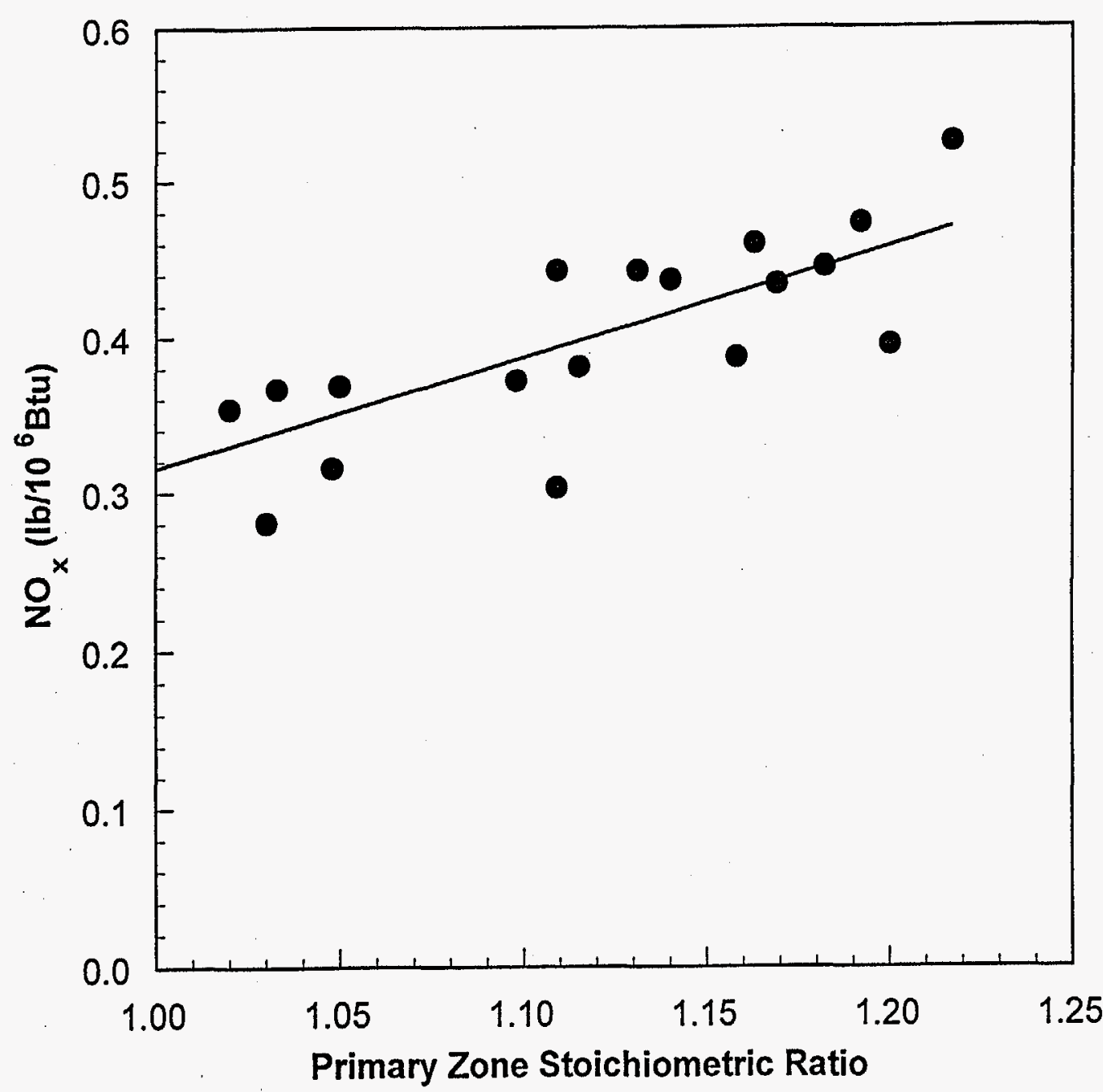

Cherokee Unit 3

First Generation GR

LNB-OFA

SR1 Variation Results

140-160 MWe (net)

$0 \%$ Gas

Figure 5-7. $\mathrm{LNB}$ w/OFA $\mathrm{NO}_{x}$ versus primary zone stoichiometric ratio $\left(\mathrm{SR}_{1}\right)$ 

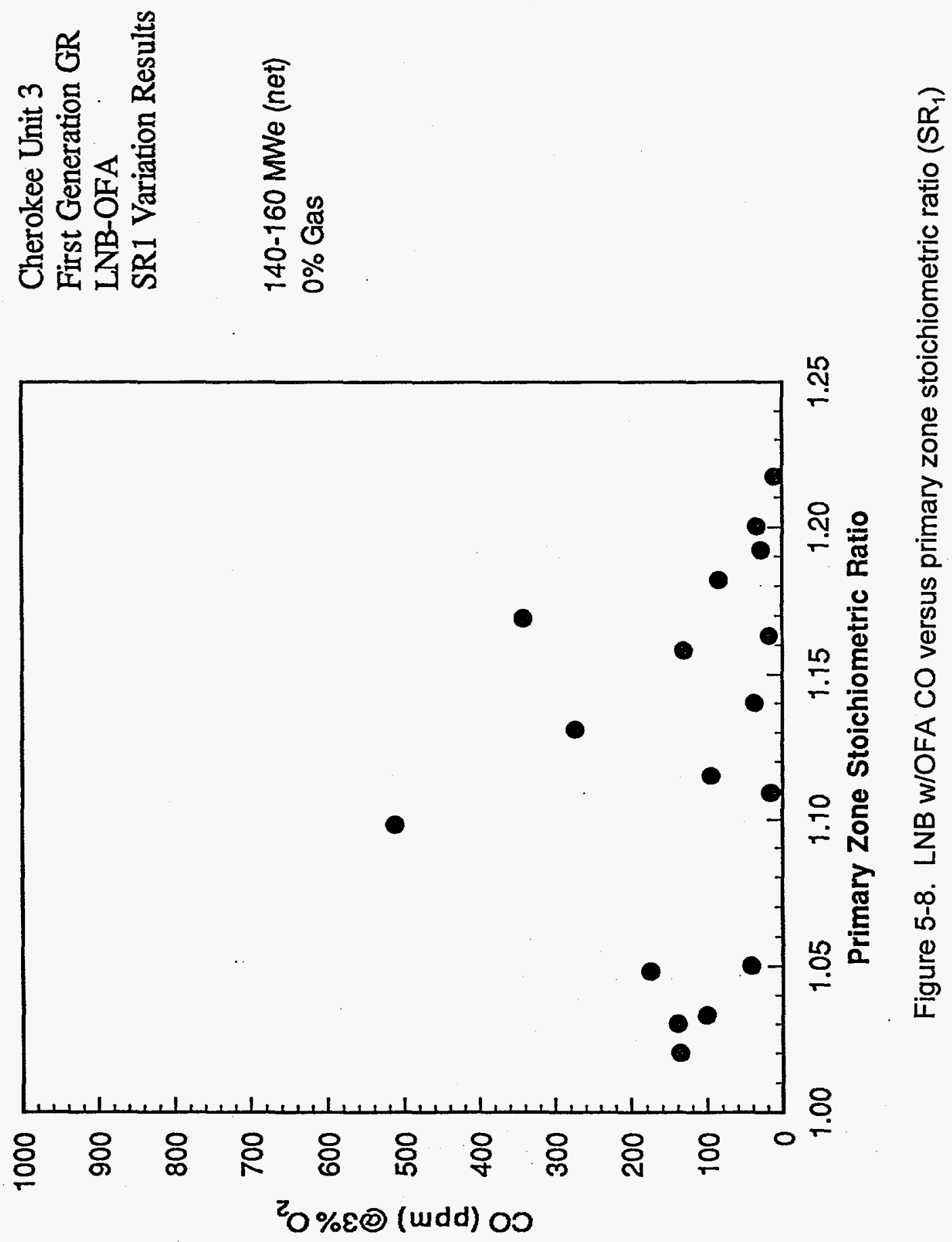


\subsubsection{Gas Heat Input Variation}

The tests of variable gas heat input were designed to establish its relationship with $\mathrm{NO}_{\mathrm{x}}$ emissions. $\mathrm{SR}_{2}$ is influenced by the amount of combustion air directed into the primary zone and the amount of gas injected into the reburn zone, measured as a percentage of total heat input to the boiler. Normally, the stoichiometric ratio of the flue gas exiting the primary zone is greater than 1.0. As natural gas is injected into the boiler, this ratio decreases and eventually creates a substoichiometric zone $\left(\mathrm{SR}_{2}<1.0\right)$ that is conducive to $\mathrm{NO}_{\mathrm{x}}$ reduction. The lower the stoichiometric ratio entering the reburn zone, the less gas required to reach the optimum reburn zone stoichiometric ratio. Note that $\mathrm{SR}_{2}$ is directly proportional to the gas heat input.

Small scale results have shown that overall $\mathrm{NO}_{x}$ reductions are highest when $\mathrm{SR}_{2}$ is in the region of 0.90 . Reducing the stoichiometric ratio below this level does not generally produce a significantly higher $\mathrm{NO}_{x}$ reduction. The natural gas flow rate is determined by (1) the lowest attainable operating SR level of the LNBs (including mills out-of-service), and (2) the boiler load.

Figure 5-9 presents the relationship between $\mathrm{NO}_{x}$ emission and gas heat input. Increasing the amount of reburn fuel lowers $\mathrm{NO}_{x}$ emissions. However, the greatest reburning benefit occurs within the first $10 \%$ of gas heat input. Figure 5-10 presents the relationship between $\mathrm{SO}_{2}$ emissions and gas heat input. The emission reduction here is due solely to replacement of coal with gas. Figure 5-11 shows the relationship between $\mathrm{CO}$ emissions and gas heat input. This chart is provided for information only, since final co levels are controlled with OFA.

Limited carbon-in-ash data are available. However, the results show that at the more desirable (lower) $\mathrm{SR}_{1}$ the carbon-in-ash is no worse than that of the LNBs. Also, lower values of carbon-in-ash were observed at the higher gas heat input levels. 


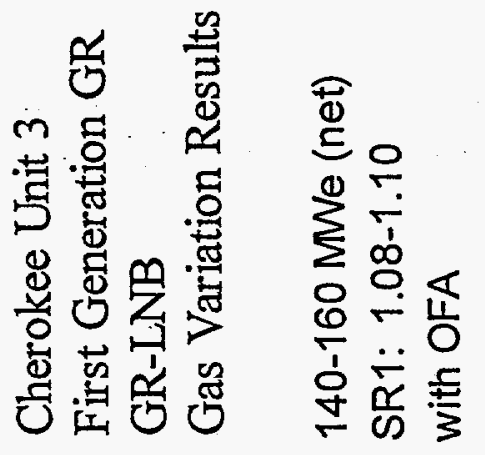

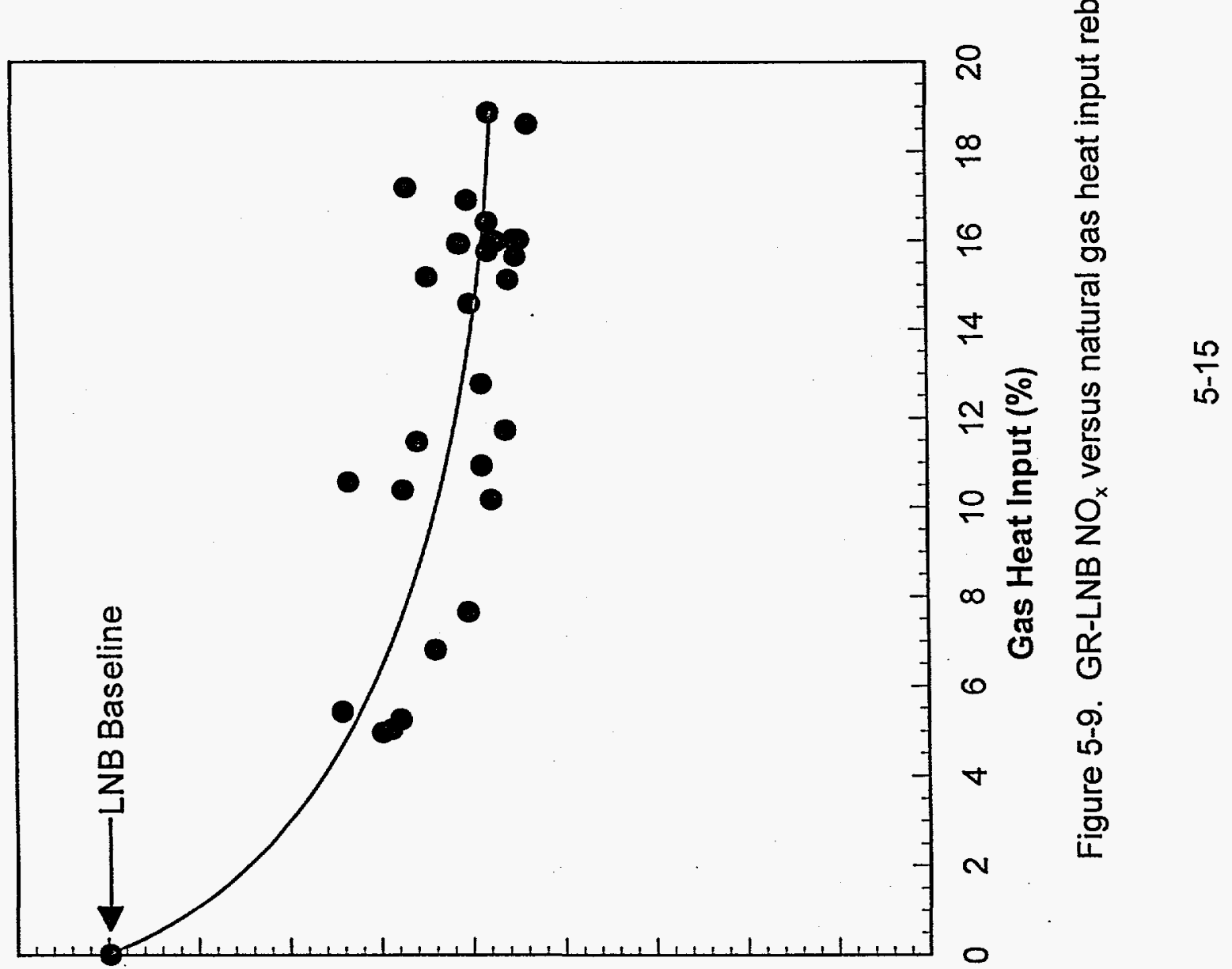

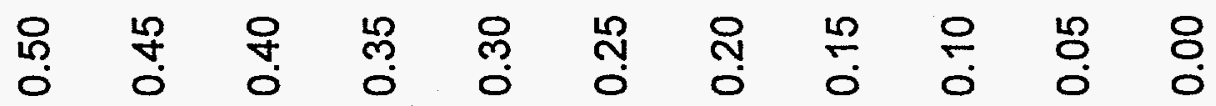
$\left(\mathrm{n}_{7} \mathrm{~g}_{9} \mathrm{OL/qI}\right)^{\times} \mathrm{ON}$ 


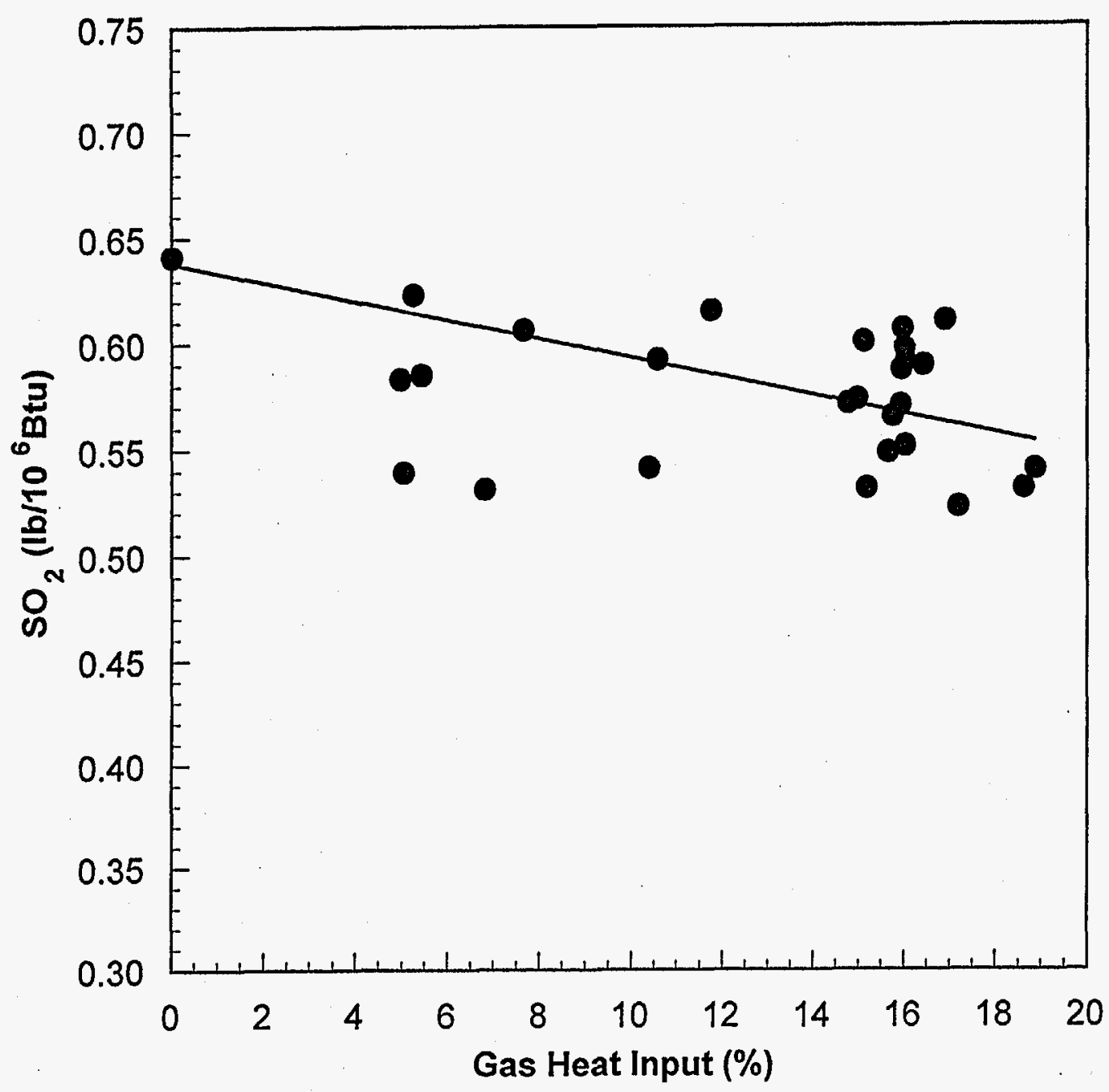

Cherokee Unit 3

First Generation GR

GR-LNB

Gas Variation Results

140-160 MWe (net)

SR1: $1.08-1.10$

with OFA

Figure 5-10. GR-LNB $\mathrm{SO}_{2}$ versus natural gas heat input reburn fuel 


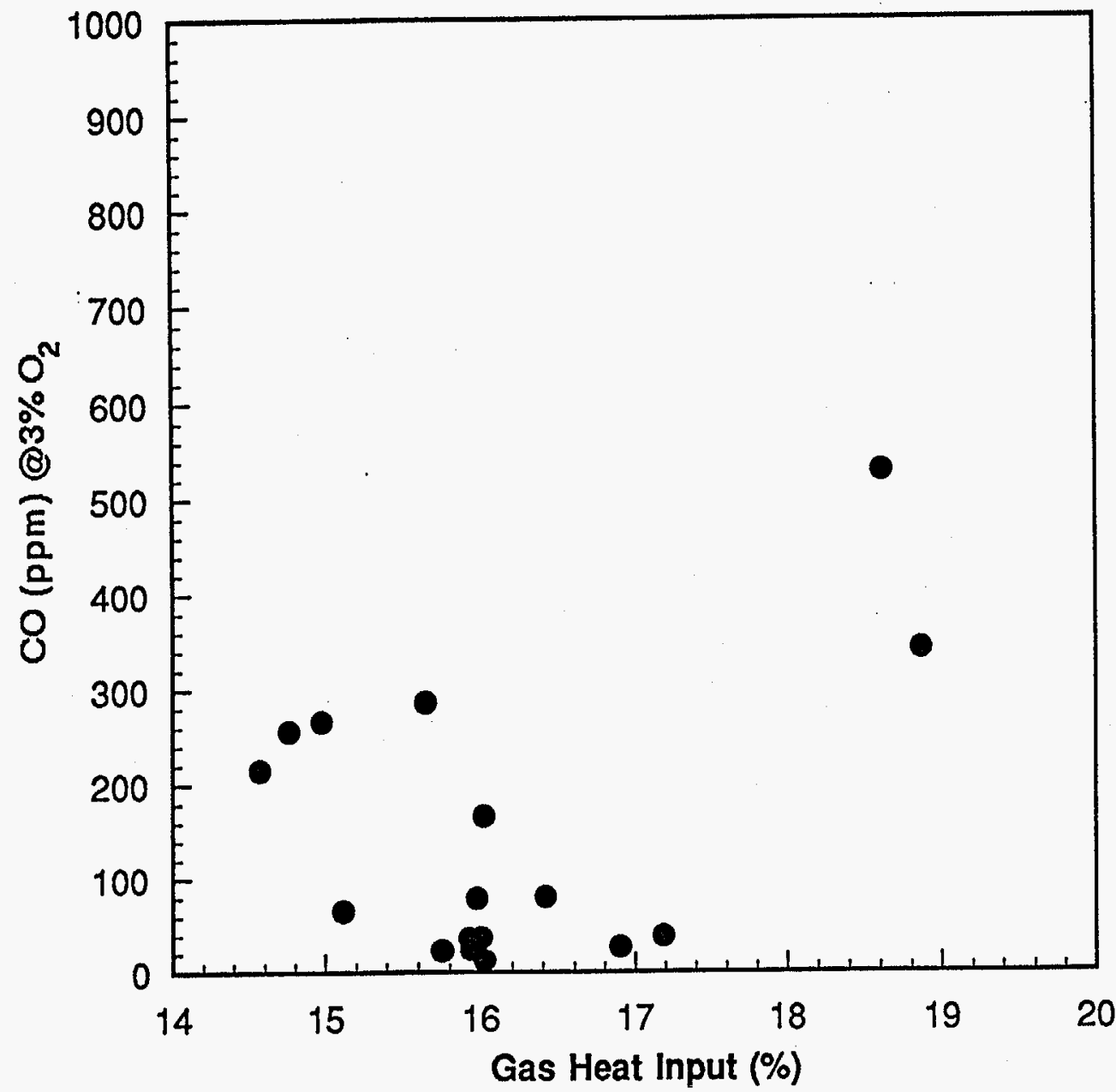

Cherokee Unit 3

First Generation GR GR-LNB

OFA Variation Results

140-160 MWe (net)

SR1: $1.08-1.10$

SR3: $1.10-1.20$

Figure 5-11. GR-LNB CO versus natural gas heat input reburn fuel 


\subsubsection{Overfire Air Variation}

OFA is injected into the boiler to complete combustion of the reburn fuel. OFA is typically 15-20 percent of the total air flow. When applying reburning, it is desirable to minimize the overall excess air level to maintain high thermal efficiencies. However, the OFA must also be adjusted to minimize $\mathrm{CO}$ emissions. The OFA flow capacity is bound by (1) the minimum air requirements to consume the remaining combustibles and (2) the maximum air available from the windbox.

Figures 5-12 through 5-14 present the results of the OFA variation tests. As anticipated, changes in $\mathrm{O}_{2}$ exhibited minimal effects on $\mathrm{NO}_{x}$ emissions. Although $\mathrm{NO}_{\mathrm{x}}$ emissions were reduced with lower $\mathrm{O}_{2}$, CO began to increase.

\subsubsection{Flue Gas Recirculation (FGR) Variation}

In the parametric tests the rate of carrier flue gas was varied from 4,000 to $14,000 \mathrm{scfm}$. The maximum design flow for the reburn fuel carrier flue gas was $3.4 \%$ of total boiler flue gas flow, nominally $12,000 \mathrm{scfm}$.

The effects of the FGR variation are displayed in Figure 5-15. The data show that the quantity of FGR which was injected into the reburn zone had little effect on $\mathrm{NO}_{x}$ emissions. In the initial stages of the parametric test program, $10,000 \mathrm{scfm}$ was identified as the optimum amount of FGR, but later tests showed that 4,000 scfm was sufficient for good penetration of the reburn fuel into the furnace. Use of the minimum $4,000 \mathrm{scfm}$ rate of FGR resulted in only slightly less $\mathrm{NO}_{x}$ reduction. It was demonstrated that any FGR rate in the range of $4,000 \mathrm{scfm}$ to $14,000 \mathrm{scfm}$ (maximum obtainable) could be used for the purpose of reburn fuel injection and for cost reasons, the lower the rate the better. The use of FGR resulted in higher steam attemperation water flow due to the release of heat higher up in the furnace. 

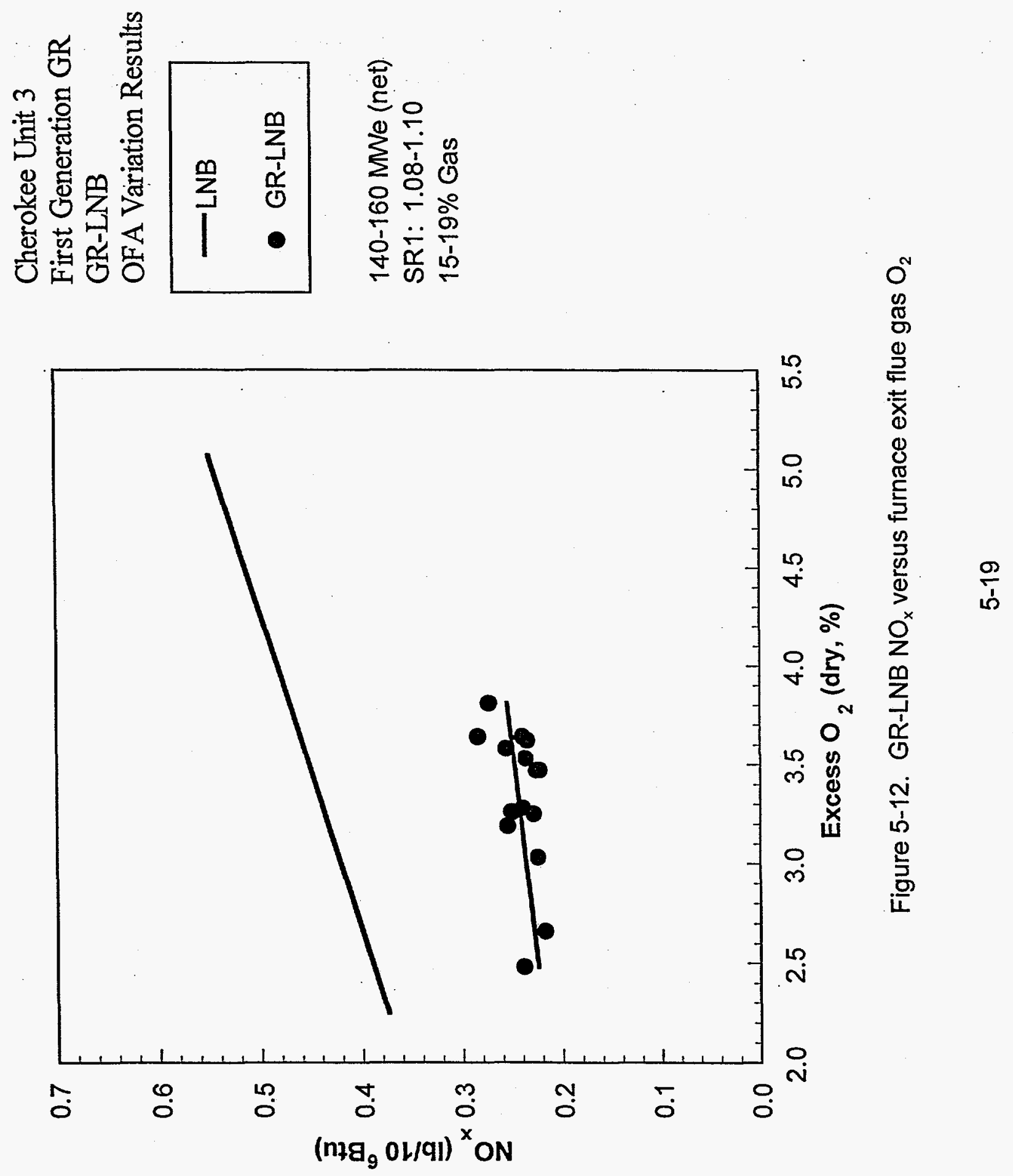

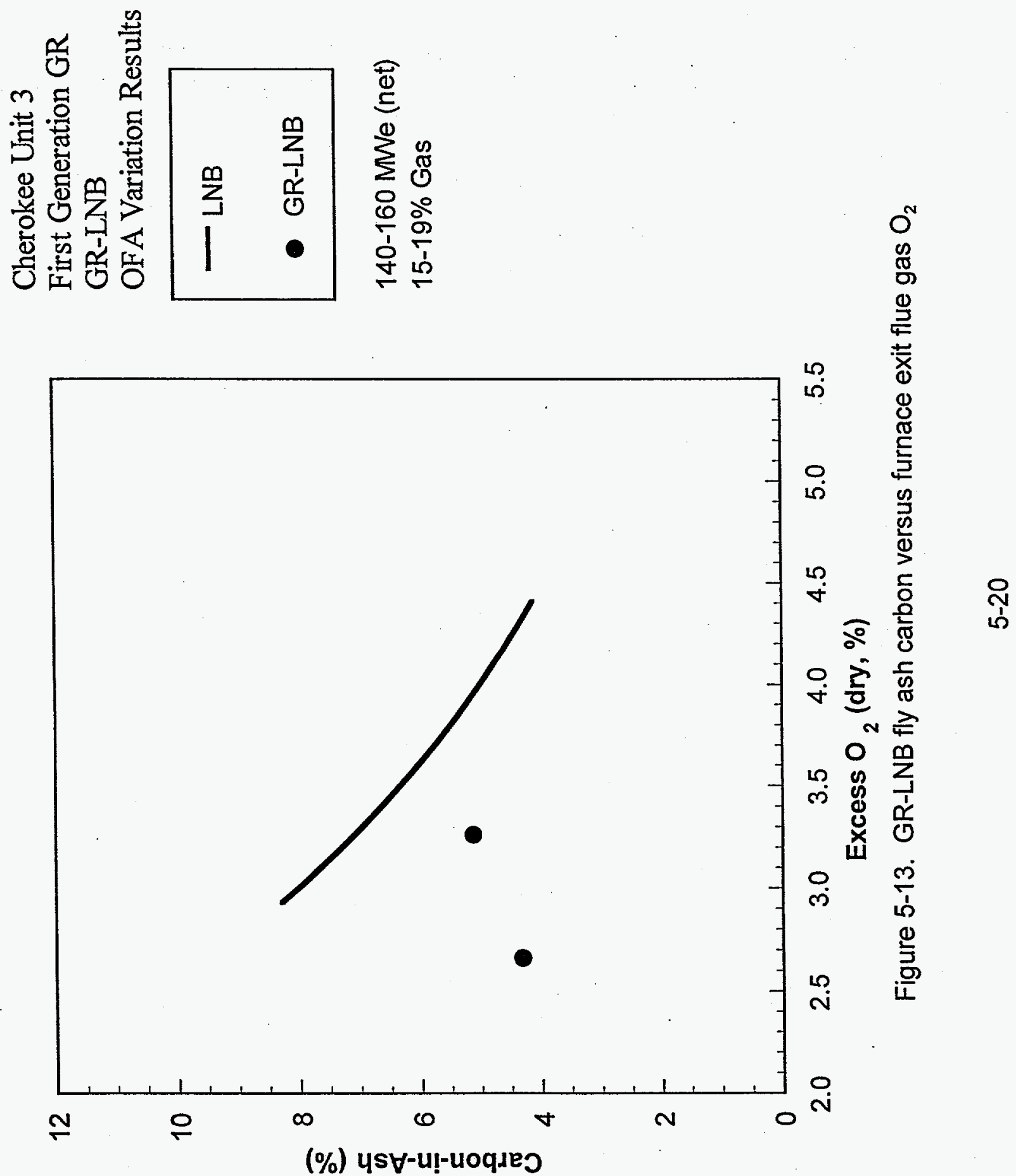


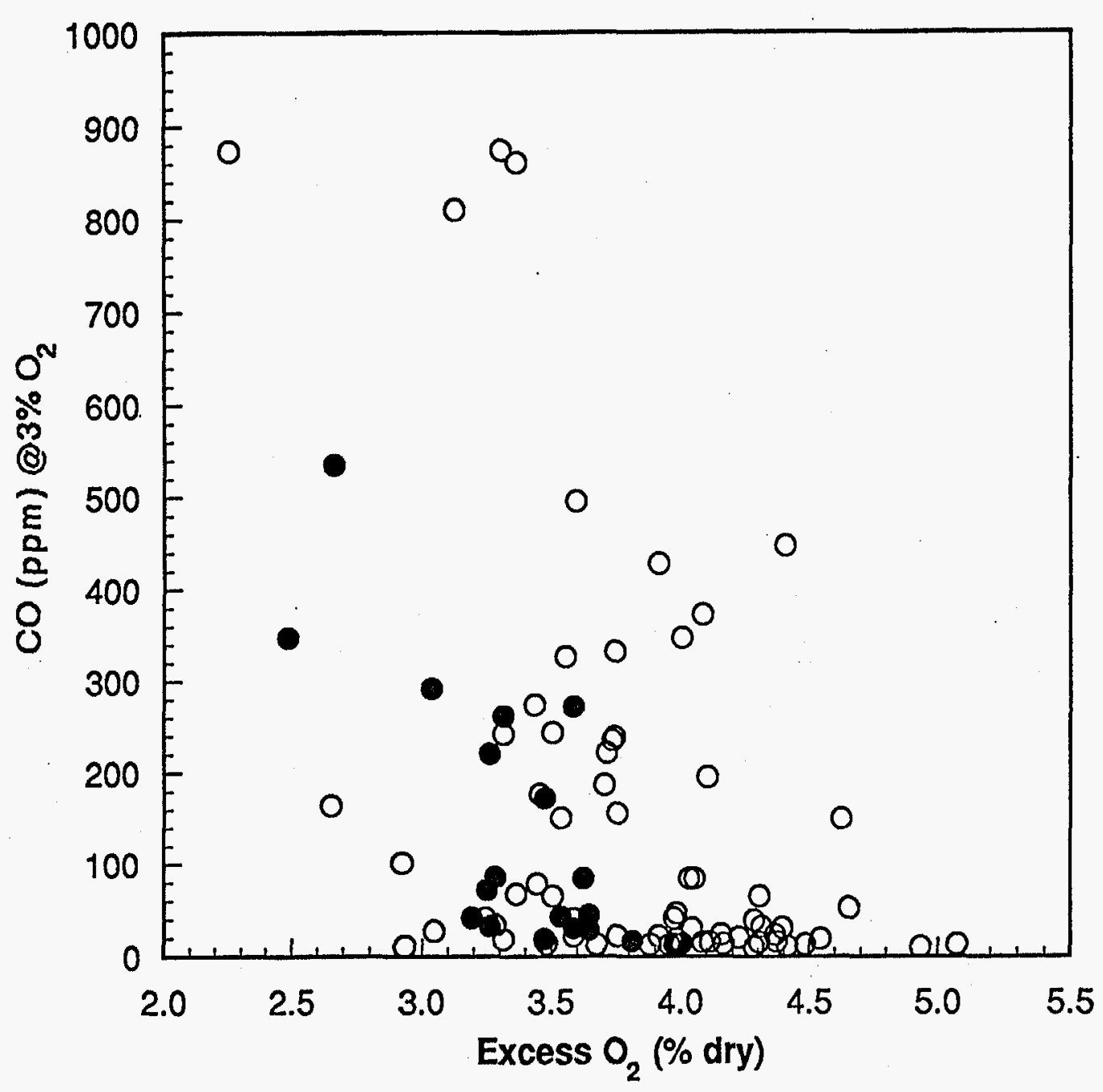

Cherokee Unit 3

First Generation GR

GR-LNB

OFA Variation Results

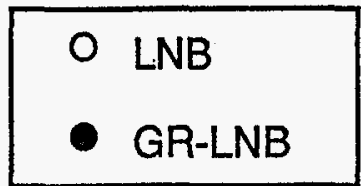

140-160 MWe (net)

$15-19 \%$ Gas

Figure 5-14. GR-LNB CO versus furnace exit flue gas $\mathrm{O}_{2}$ 


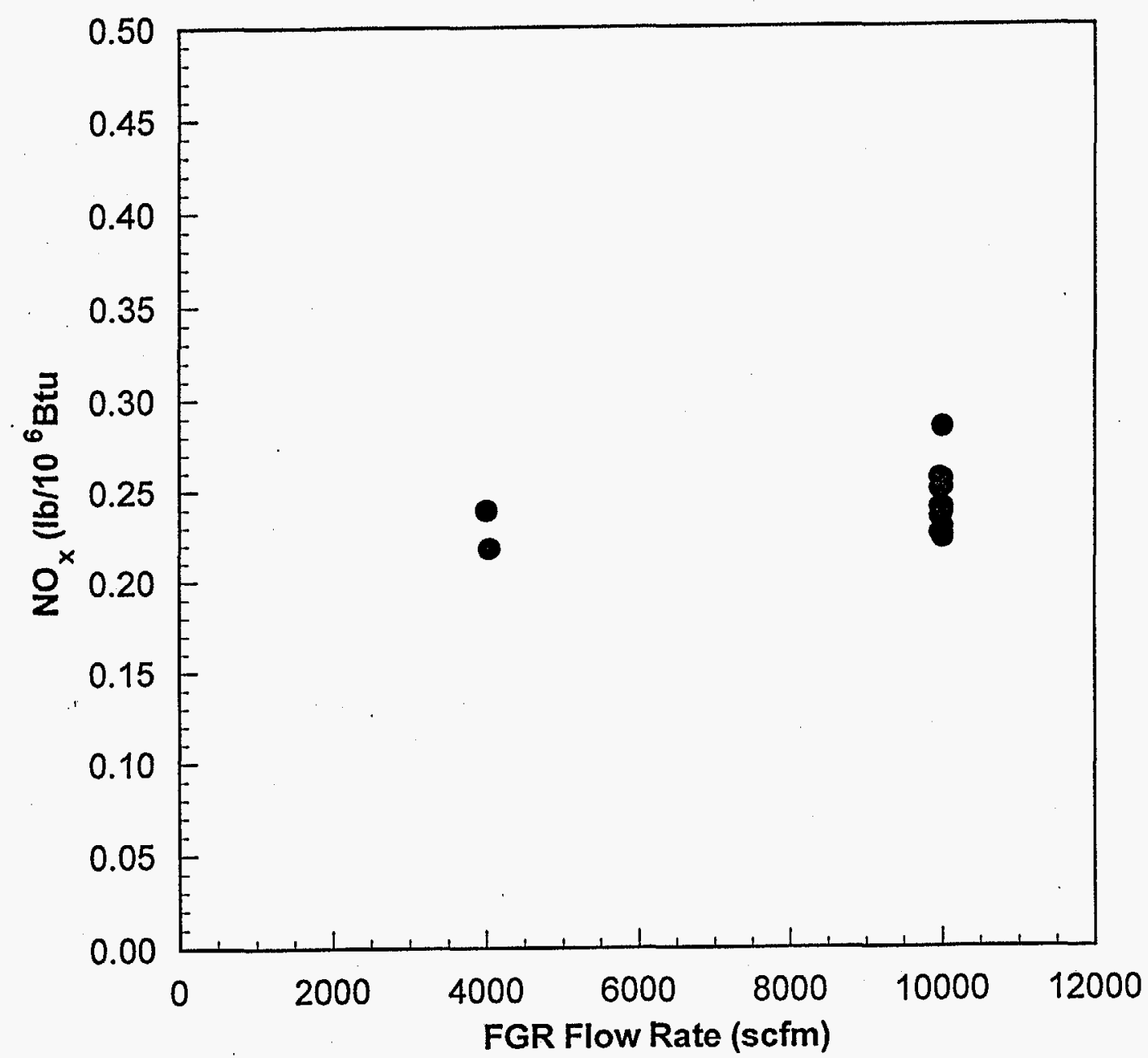

Cherokee Unit 3 First Generation GR GR-LNB

FGR Variation Results

140-160 MWe (net)

$15-19 \%$ Gas

Figure 5-15. GR-LNB NO ${ }_{x}$ versus $F G R$ flowrate 


\subsubsection{Assessment of Results}

The goals of the GR-LNB project were as follows:

- Reduce $\mathrm{NO}_{\mathrm{x}}$ emissions by $70 \%$ from baseline which corresponds to a $\mathrm{NO}_{\mathrm{x}}$ emissions level of $0.22 \mathrm{lb} / 10^{6} \mathrm{Btu}(94 \mathrm{mg} / \mathrm{MJ})$

- Maintain the operational integrity of the unit during operation of the GR-LNB system

- Hold CO emissions to acceptable levels (100 ppm or lower)

- Verify the long term operability of the combined technology while operating in the normal power generating mode of unit control by load dispatch over long periods of time

A series of parametric tests were performed to determine the optimum boiler set points that would achieve these goals. The parametric test results are discussed as they were used to establish these set points.

A series of tests were performed with LNBs only and with GR-LNB to determine the lower limit of $\mathrm{SR}_{1}$. Note that the lowest attainable level of $\mathrm{SR}_{1}$ results in the minimum natural gas usage required to reach the optimum $\mathrm{SR}_{2}$. However, $\mathrm{SR}_{1}$ is lowered at the expense of higher carbon-in-ash. The results of these tests indicated that the optimum $\mathrm{SR}_{1}$ was 1.08 with a carbon-in-ash level of $4.5 \mathrm{wt} \%$.

As expected, higher gas levels (15-19\%) were required to achieve the $\mathrm{NO}_{\mathrm{x}}$ reduction goal. Carbon-in-ash levels were also lower at higher gas levels. To achieve the targeted $\mathrm{SR}_{2}$ level of 0.90 , a gas heat input of $18 \%(4,850 \mathrm{scfm})$ was required. Although a $70 \%$ 
reduction in $\mathrm{NO}_{x}$ was achieved for short periods of time, the average was $65 \%$. Significantly higher gas heat inputs were required to consistently maintain a $70 \%$ reduction.

Tests of the OFA system indicated that CO was controllable to less than $100 \mathrm{ppm}$ with a $\mathrm{SR}_{3}$ of approximately 1.15 . This corresponds to an air flow of $68,000 \mathrm{scfm}$, which is about $30 \%$ of total air flow to the unit. At low gas flow, CO emissions were found to be high. Low gas operation requires reduced OFA flow, leading to reduced jet penetration and mixing and elevation of $\mathrm{CO}$ emissions. $\mathrm{CO}$ emissions were also high during operation with LNBs only.

The SR in each zone could vary by about \pm 0.02 with equally effective $\mathrm{NO}_{x}$ reduction results. The variation in SRs is primarily attributable to the process control systems on the unit. The output of the forced draft (FD) fans that supply combustion air to the unit could easily vary by $\pm 2 \%$ which could produce a variance of \pm 0.02 in the furnace zone SR's. This is not considered an abnormal condition and could occur in most power plants. During the controlled parametric tests, process outputs such as combustion air flow from the FD fans could be adjusted manually. In this way, the desired furnace SRs could be controlled to a target average. The results of the parametric testing were used to establish the operating conditions that would yield the desired test objectives. For full load, these conditions were as follows:

$\begin{array}{ll}\mathrm{SR}_{1} & 1.08 \\ \mathrm{SR}_{2} & 0.90 \\ \mathrm{SR}_{3} & 1.15 \\ \text { Gas heat input } & 18 \% \\ \mathrm{FGR} & 4,000-10,000 \mathrm{scfm} \\ \mathrm{OFA} & 68,000 \mathrm{scfm} \\ \mathrm{O}_{2} & 3.25 \% \\ \mathrm{NO}_{\mathrm{x}} & 0.25 \mathrm{lb} / 10^{6} \mathrm{Btu}(107 \mathrm{mg} / \mathrm{MJ}) \\ \mathrm{NO}_{\mathrm{x}} \text { reduction } & 66 \% \\ \text { CO } & 43 \mathrm{ppm} \\ \text { Carbon-in-ash } & 4.50 \%\end{array}$


The combined technology GR-LNB proved to be effective, but the total $\mathrm{NO}_{\mathrm{x}}$ reduction was not as great as could have been achieved with better LNB performance. LNBs reduced $\mathrm{NO}_{x}$ emissions by $37 \%$ but never achieved the anticipated reduction of $45 \%$ over the normal load range of 80 to $150 \mathrm{MW}_{\mathrm{e}}$. This diminished the potential $\mathrm{NO}_{\mathrm{x}}$ reduction that could be obtained for the combined GR-LNB system. An estimated $5 \%$ to $10 \%$ decline in the overall system $\mathrm{NO}_{x}$ reduction potential was attributable to the substandard LNB performance.

Also, the sluggish action of the combustion air control valve (old pneumatic type) did not keep the excess air at or near the desired levels during the long term test phase. This resulted in higher than desired excess air levels at times that yielded higher $\mathrm{NO}_{\mathrm{x}}$ emissions. Based on the results of the parametric tests, nominal operating conditions for long term testing were established as follows:

$\begin{array}{ll}\mathrm{SR}_{1} & 1.10 \\ \mathrm{SR}_{2} & 0.90 \\ \mathrm{SR}_{3} & 1.20 \\ \text { Gas heat input } & 18 \%\end{array}$

The long term test series lasted for approximately nine months. During this time the average $\mathrm{NO}_{x}$ reduction was $65 \%$ (Figure 5-16), while $\mathrm{CO}$ was maintained below an emission level of $100 \mathrm{ppm}$. The goal of $70 \% \mathrm{NO}_{x}$ reduction was achieved for short periods when the combustion controls were in manual mode for better control of excess air to the unit. When the unit was operated in the load-following mode, the nominal operating parameters were difficult to maintain and there was a continual variation from the desired operating conditions. The reaction time for changes in the GR set points was about 20 minutes after the demand signal was received. As mentioned, this was due to an antiquated pneumatic bellows arrangement on the combustion air flow valve that did not react quickly enough to changes in air flow demand. 


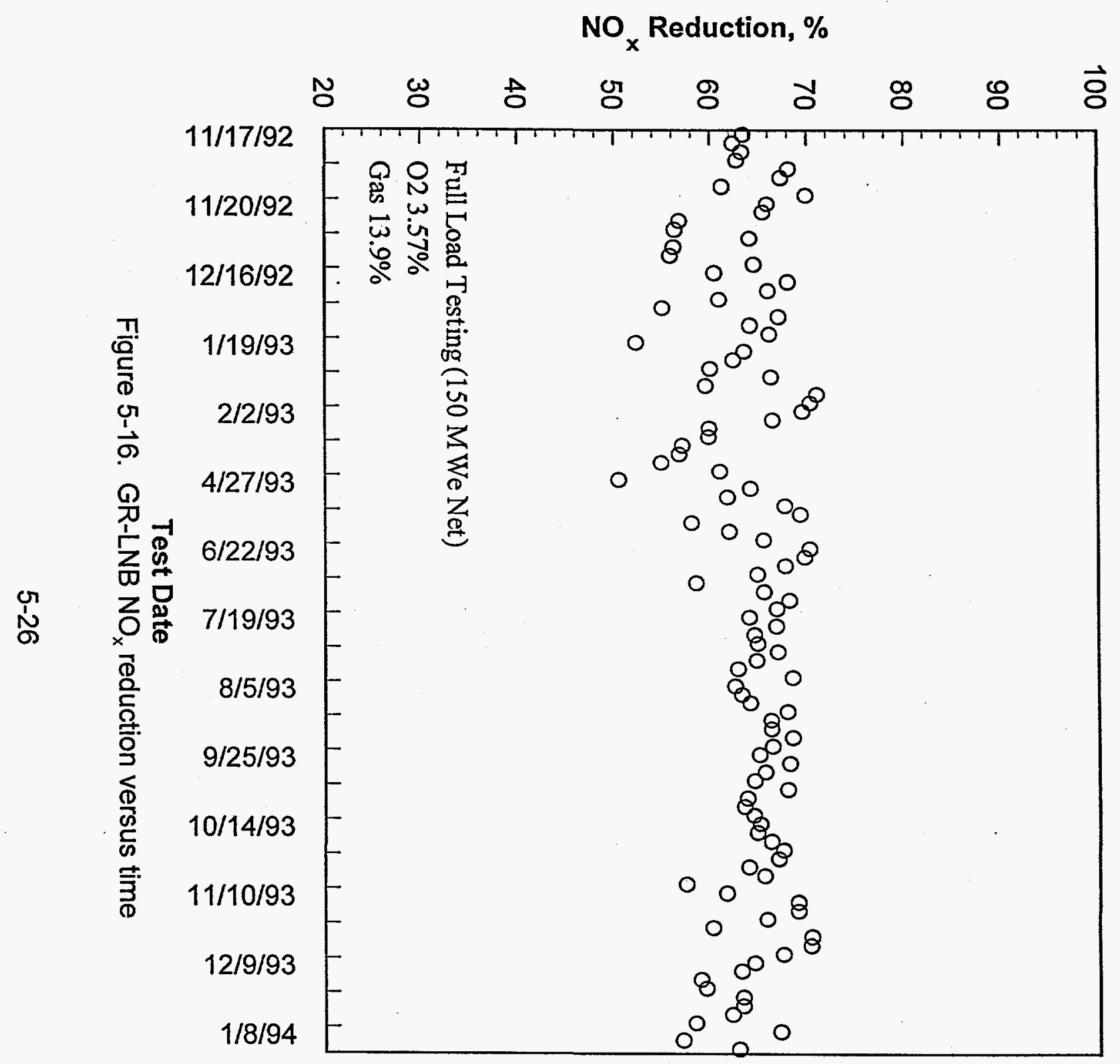




\subsubsection{Reduced Load Testing}

One objective of this project was to demonstrate a GR system that would be effective for $\mathrm{NO}_{x}$ reduction throughout the entire operating range of the boiler while in load-following mode under dispatch control. Optimization tests were conducted at loads from 60 to 150 $\mathrm{MW}_{\mathrm{e}}$, but it became apparent that the effective operating load range of the boiler was at loads of $70 \mathrm{MW}_{\mathrm{e}}$ and higher. The boiler load range for the practical operation of the GR system was 80 to $150 \mathrm{MW}_{\mathrm{e}}$. This was due to the difficulty in maintaining stable loads while operating below $80 \mathrm{MW}_{\mathrm{e}}$ and the necessity to operate the boiler at high levels of excess air to maintain final superheat and reheat steam temperatures.

Boiler load impacts GR performance in terms of the primary zone $\mathrm{NO}_{x}$ emission level and the furnace gas temperature profile. As load was reduced, the $\mathrm{NO}_{\mathrm{x}}$ formation in the primary zone was reduced as a result of less fuel being burned, and temperatures throughout the furnace were lower due to the reduced thermal input to the boiler. In order for the control room operators to maintain the main and reheat steam outlet temperatures at reduced loads, excess air was increased, shifting some of the heat transfer within the boiler from the radiant section (furnace tube walls) to the convection pass section (superheat and reheat tube banks).

Design data showed that lower $\mathrm{NO}_{\mathrm{x}}$ levels and lower gas temperatures entering the reburning zone resulted in a decrease in the overall $\mathrm{GR}$ system $\mathrm{NO}_{\mathrm{x}}$ reduction performance on a percentage basis from baseline levels. This was confirmed during the optimization testing.

Figure 5-17 shows $\mathrm{NO}_{x}$ emission levels as a function of gas heat input for the boiler operating load range. The results show that the percentage of $\mathrm{NO}_{x}$ emissions reduction decreased as load was reduced. However, $\mathrm{NO}_{\mathrm{x}}$ emission levels remained near $0.20 \mathrm{lb} / 10^{6}$ Btu. 


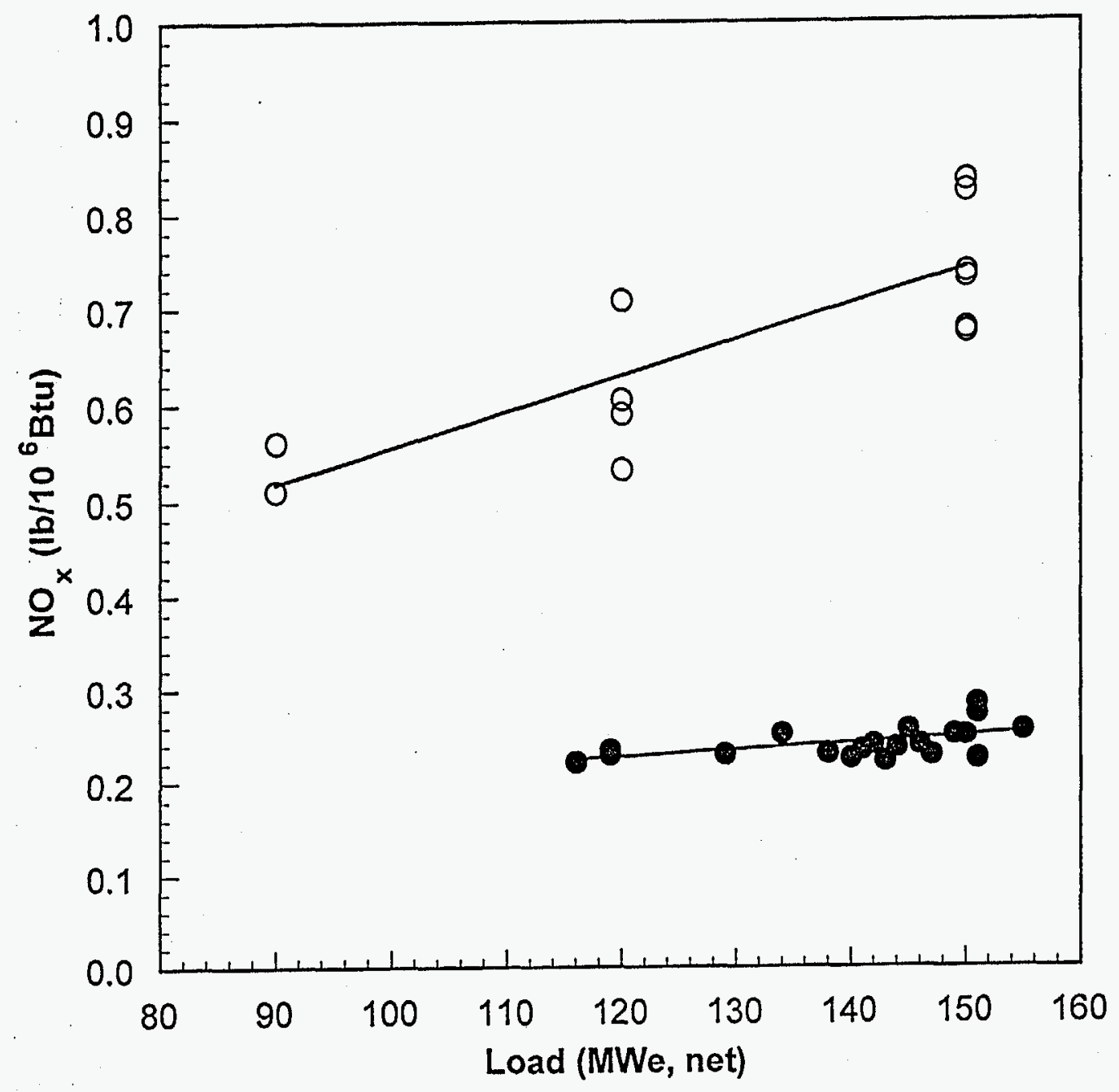

Cherokee Unit 3.

First Generation GR

GR-LNB

Reduced Load Results

\section{- GR-LNB}

- Pre-Construction Baseline

$15-19 \%$ Gas

Figure 5-17. $\mathrm{NO}_{x}$ versus load 
At Cherokee Unit \#3, the normal mode of operation is to have all four mills in service at full load and to have three mills in service for loads below $120 \mathrm{MW}_{\mathrm{e}}$. Operation with less than three mills resulted in unstable boiler operating conditions. The burners are fed by mills $\mathrm{D}$ to $A$, from the top row to the bottom row. Tests were conducted at $120 \mathrm{MW}_{\mathrm{e}}$ and 150 $\mathrm{MW}_{\mathrm{e}}$ with $\mathrm{D}$ mill and its associated top row of burners out of service to determine the operational effects of combustion staging in combination with GR. To obtain full load with D mill out of service, it was necessary to inject a total of about $20 \%$ natural gas in the GR system. The effect of combustion staging at full load was about a six percent improvement in $\mathrm{NO}_{x}$ reduction, from $66 \%$ with four mill operation to $72 \%$ with three mill operation. $\mathrm{A}$ greater $\mathrm{NO}_{x}$ reduction was expected from combustion staging with $\mathrm{GR}$, but the previously discussed performance problems with the LNBs probably prevented combustion staging from being more effective in reducing $\mathrm{NO}_{x}$ emissions. Also, excess air fluctuations were experienced during testing which probably had a negative impact on the results. An indication of combustion problems during the three mill operation test was high carbon-inash which ranged from 6 to $9 \%$.

Limited testing was conducted at three mill operation because of Unit \#3 operational problems and the requirement by dispatch management for full load operation during the time period scheduled for this testing.

\subsection{GR-LNB Optimization Testing (Second Generation GR)}

FGR was used initially to provide momentum to the natural gas to achieve optimum boiler penetration and mixing. However, as described in Section 5.2.2.3, it was determined that the FGR had minimal effect on $\mathrm{NO}_{x}$ emissions. Certain problems (see Section 5.6) associated with the FGR ash removal system made it attractive to consider a re-design of the gas injection system in order to eliminate the need for FGR altogether. The small amount of FGR required to transport the gas into the boiler, along with the lower amount of gas required for effective $\mathrm{NO}_{x}$ reduction, led to this decision. 
It was determined that a gas injection pressure in the range of 1 to 5 psig would adequately penetrate and cover the cross-sectional area of the furnace to provide the necessary reducing conditions in the reburn zone. This eliminated the need for the FGR booster fans, duct work, and the multiclone dust collectors. The elimination of FGR will result in significant cost savings on future GR system installations.

A second series of tests was added to evaluate the modified configuration and judge its impact (Section 4.1.3). This technology is referred to as Second Generation Gas Reburning and is described as follows:

- The FGR system, originally designed to provide momentum to the natural gas, was removed. The change would result in reduced capital costs on future designs.

- Natural gas injection was optimized at $13 \%$ gas heat input, compared to the First Generation operating value of $18 \%$. FGR elimination required incorporation of high velocity jet injectors that made good use of the available natural gas pressure. The change resulted in reduced operating cost due to lower gas usage.

- The OFA ports were modified to provide higher jet momentum, especially at low total flows.

- The OFA ports were also modified to provide air swirl capability and velocity control. The modification was designed to improve lateral coverage of the furnace and turbulence in mixing with unburned fuel. This change provided CO control at lower gas levels, which was a concern with the First Generation design. 
Prior to startup of the modified system, Foster Wheeler performed some modification work on the LNBs in an attempt to improve their $\mathrm{NO}_{x}$ reduction performance. The first tests following restart were to characterize the LNBs without GR in operation.

\subsubsection{Low NO Burners}

At the start of each Second Generation GR parametric test, the conditions of the boiler were stabilized before the data were taken. Data taken at the end of these startup periods were used as baseline data, since only LNBs were in operation during the start of each test. The results were used to compare the performance of originally-installed LNBs (see Section 5.2.1.1) with the modified LNBs.

Figure 5-18 presents a chart of $\mathrm{NO}_{x}$ versus excess air for $\mathrm{LNB}$ operation. Compared to the originally-installed LNB's and at an excess air level of $3.5 \%$, the $\mathrm{NO}_{x}$ emissions showed a favorable improvement of $11 \%$. Also, compared to the pre-construction burners at the same excess air, the $\mathrm{NO}_{x}$ emissions were reduced by $44 \%$, which was an improvement from the LNB baseline (see Section 5.2.1.1). However, the CO (see Figure 5-19) and carbon-in-ash levels were still unacceptably high. CO was in the 100-200 ppm range and carbon-in-ash was as high as $8 \%$. Also, long flames persisted in the upper furnace region.

Although the burner modifications now reduced $\mathrm{NO}_{x}$ emissions to the near target level of $45 \%$, the performance was unacceptable from a $\mathrm{CO}$ and carbon-in-ash standpoint.

\subsubsection{Gas Reburning with Low NO $x$ Burners}

The results of the Second Generation GR-LNB test series are displayed in Figures 5-20 through 5-23. The $\mathrm{NO}_{x}$ vs. gas heat input plot shows increased $\mathrm{NO}_{x}$ reduction as the level of gas increases, again similar to First Generation GR. At a gas heat input level of $12.5 \%$, the $\mathrm{NO}_{\mathrm{x}}$ level was $0.26 \mathrm{lb} / 10^{6} \mathrm{Btu}(64 \%$ reduction). Carbon-in-ash levels were at or below 


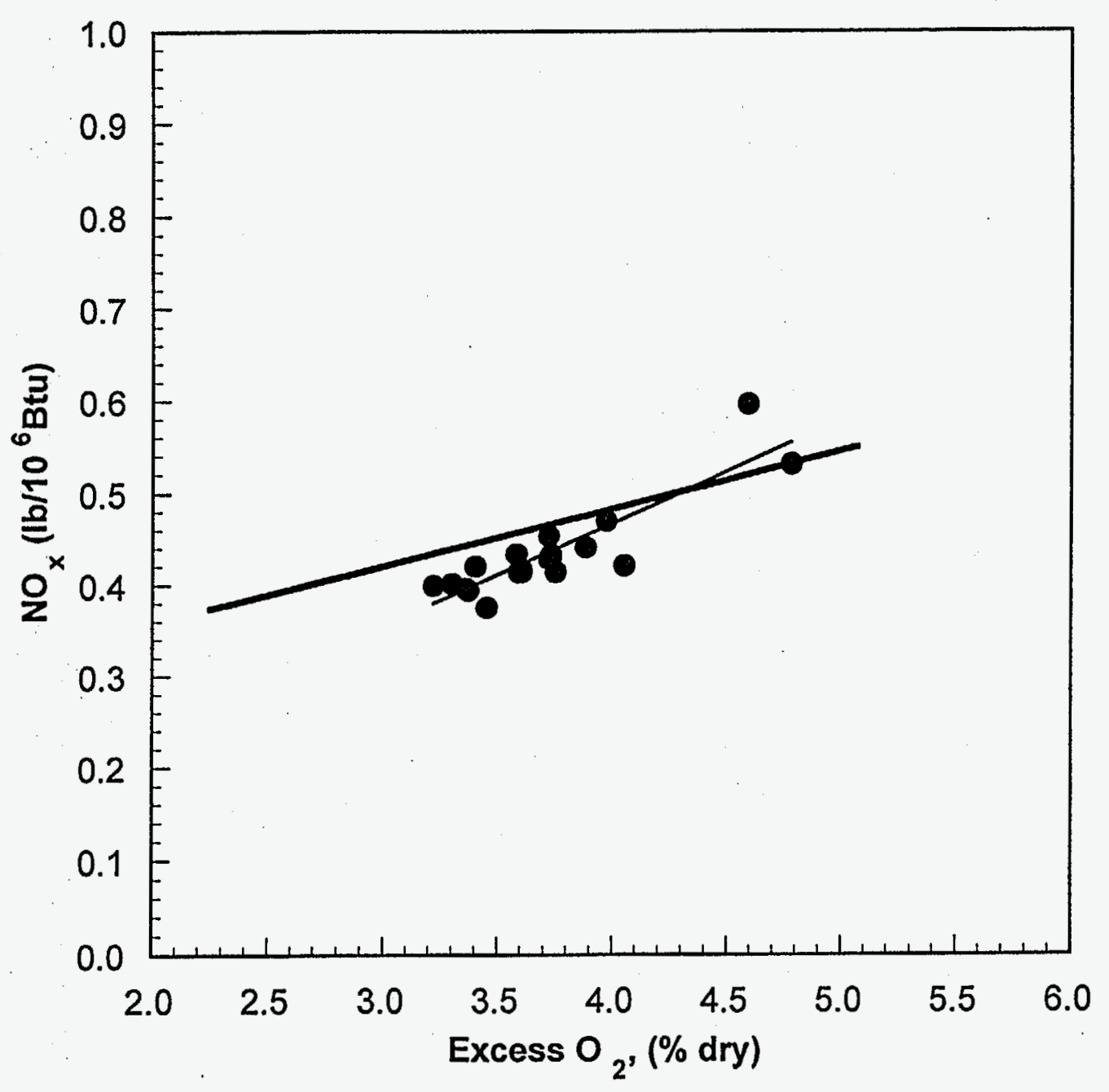

Cherokee Unit 3

Second Generation GR Low NOx Burners

LNB Baseline Results

- LNB-Modified

- LNB

140-160 MWe (Net)

$0 \%$ Gas

$0 \%$ OFA

Figure 5-18. LNB-Modified baseline $\mathrm{NO}_{x}$ versus furnace exit flue gas $\mathrm{O}_{2}$ 


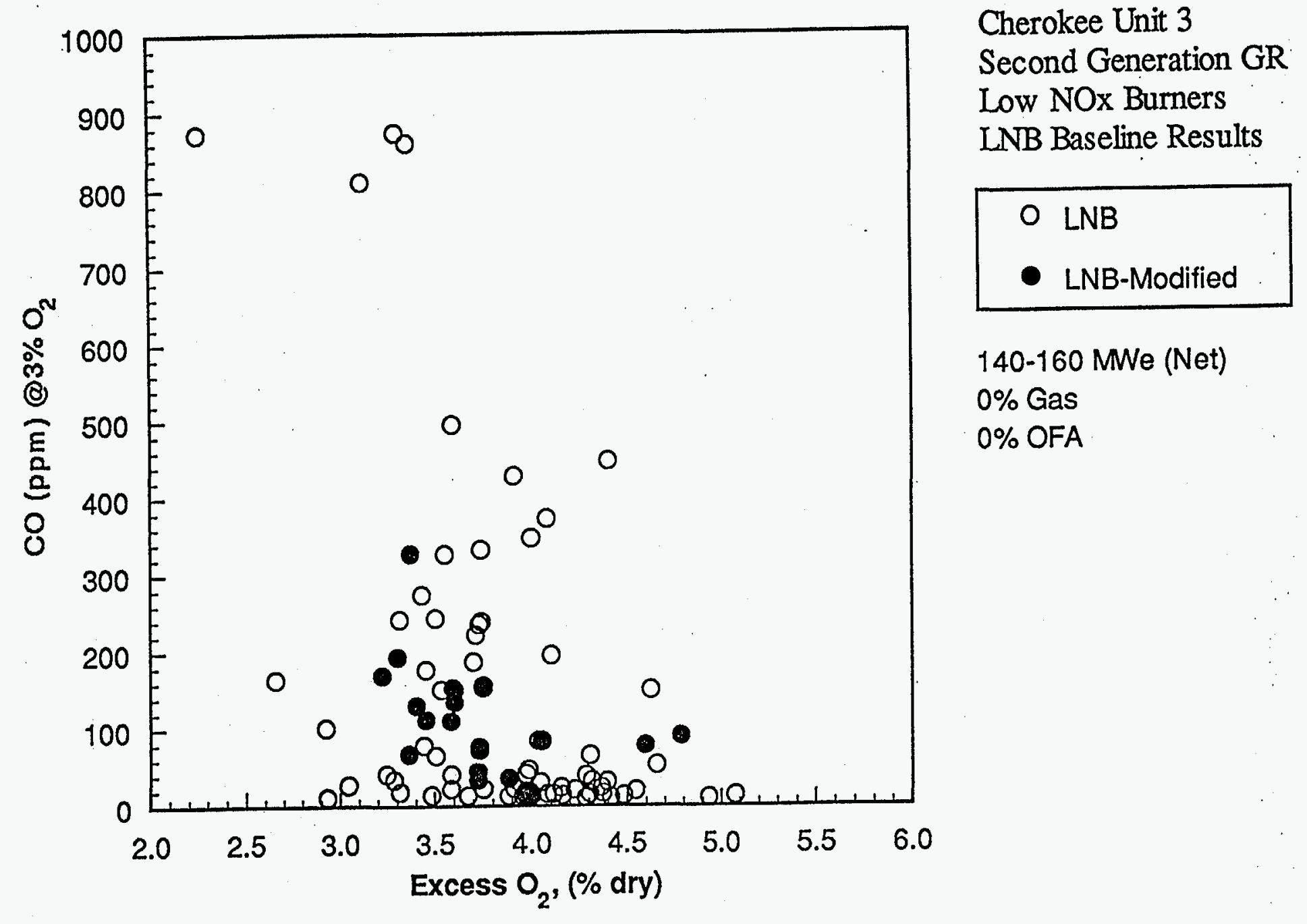

Figure 5-19. LNB-Modified baseline $\mathrm{CO}$ versus furnace exit flue gas $\mathrm{O}_{2}$ 


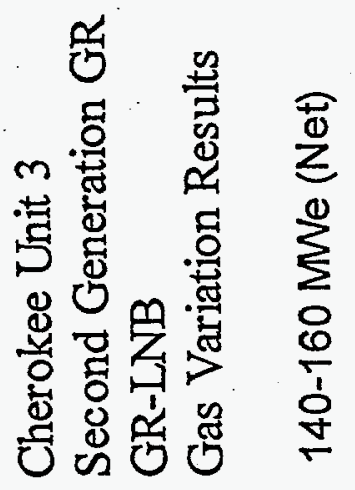

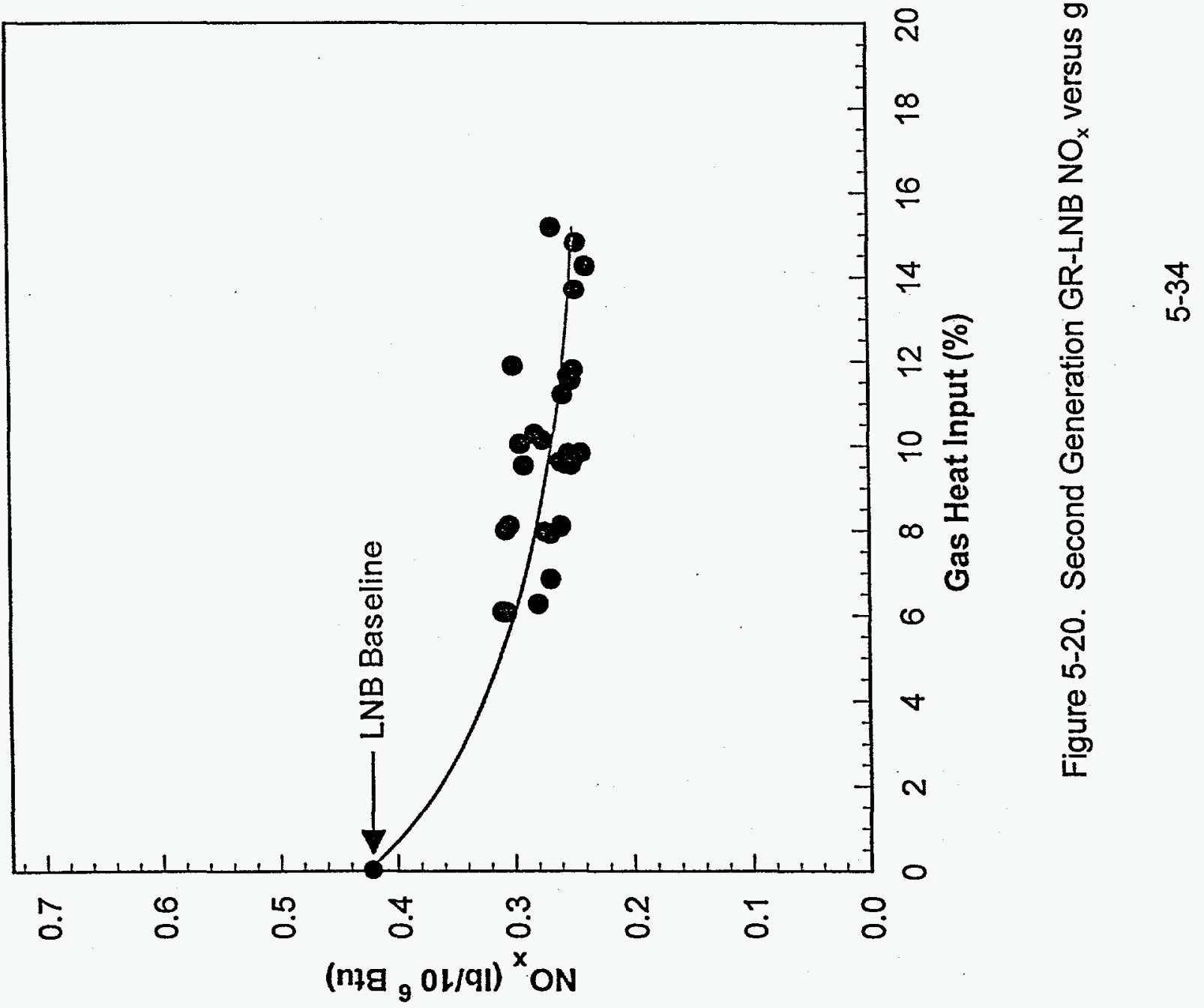




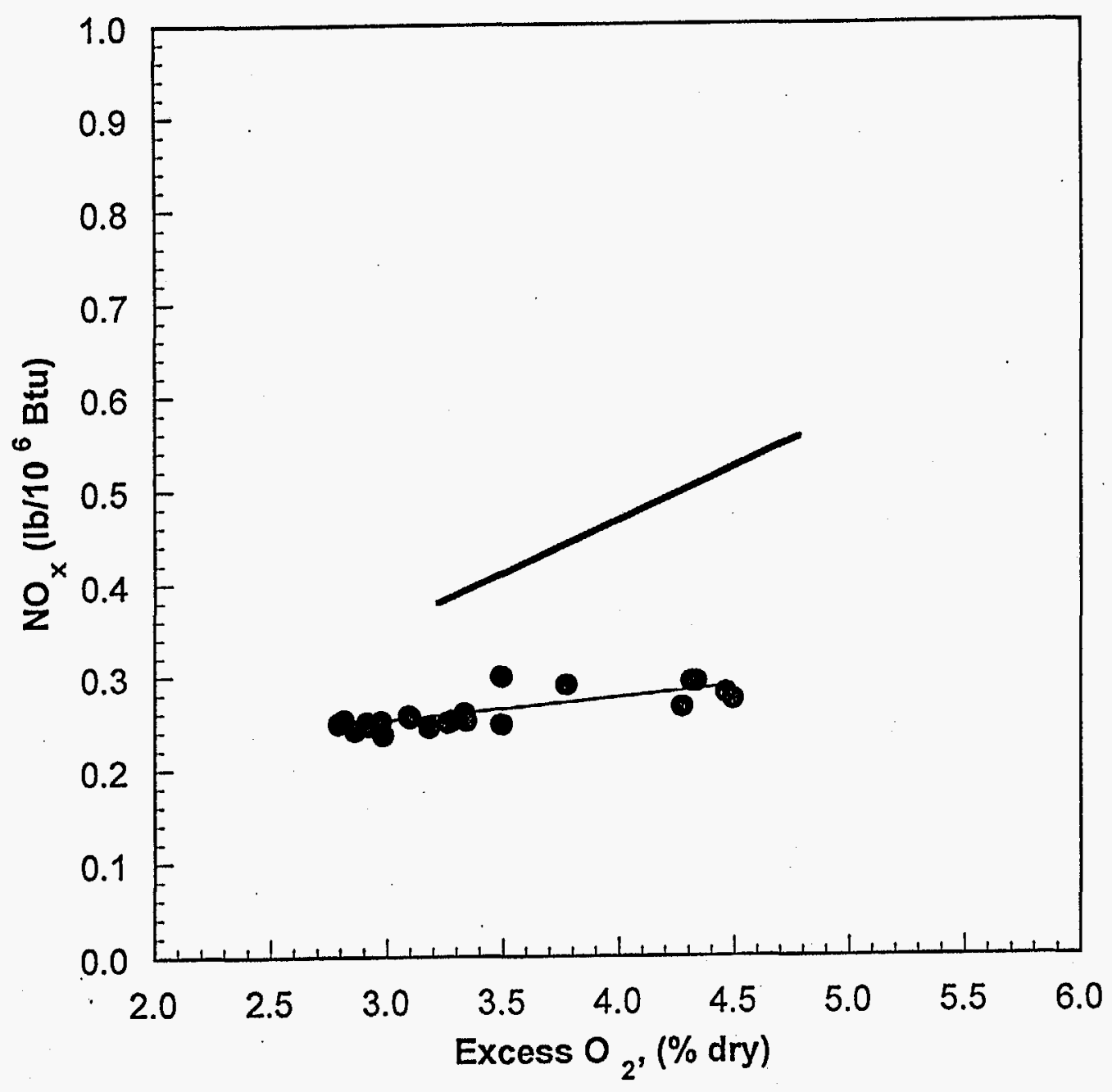

Cherokee Unit 3

Second Generation GR GR-LNB

2nd Generation Results

- GR-LNB

— LNB-Modified

140-160 MWe (Net)

$9-15 \%$ Gas

Figure 5-21. Second Generation GR-LNB NO $\mathrm{x}_{x}$ versus furnace exit flue gas $\mathrm{O}_{2}$ 


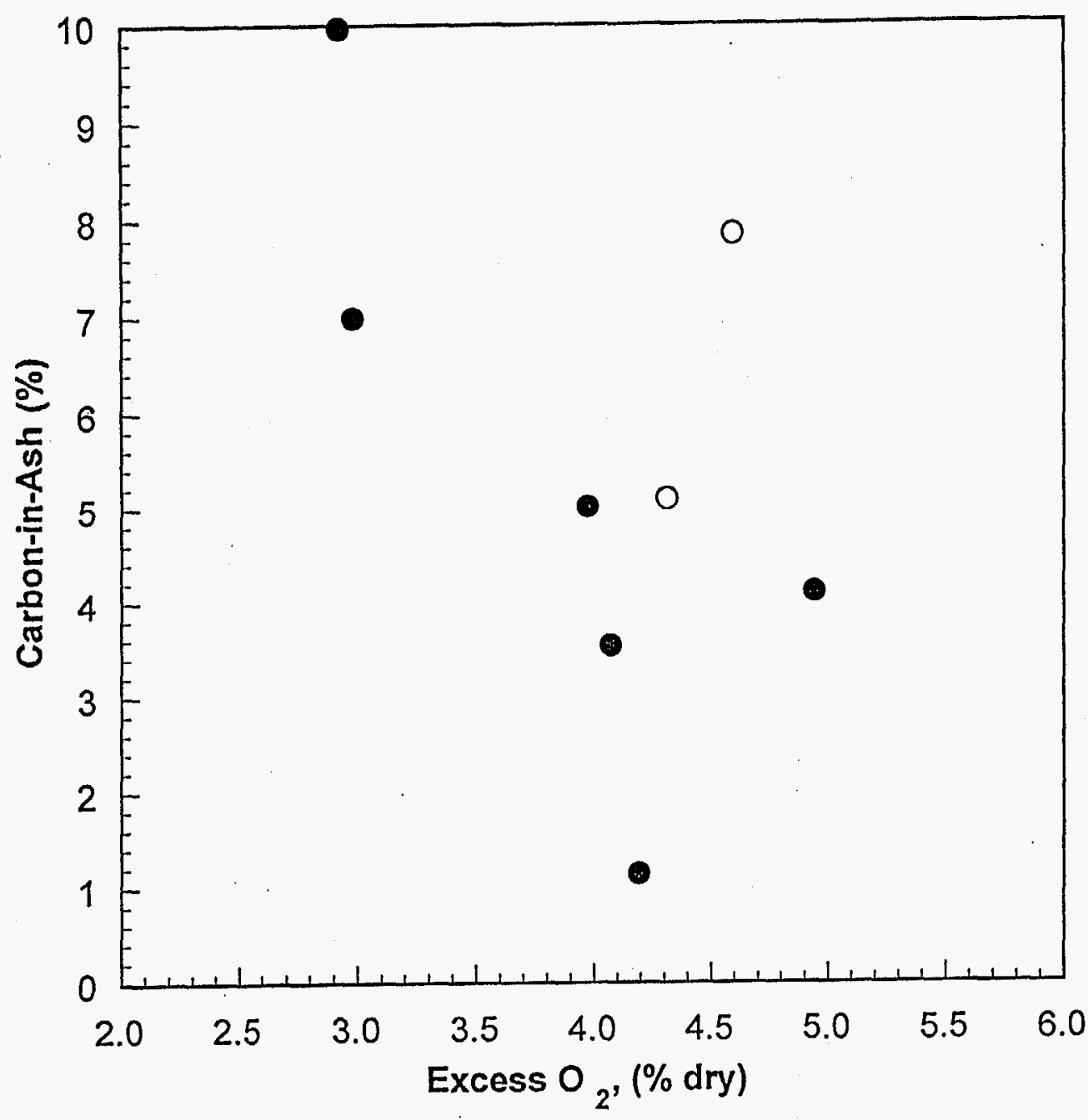

Cherokee Unit 3

Second Generation GR GR-LNB

2nd Generation Results

- GR-LNB

- LNB-Modified

140-160 MWe (net)

$9-15 \%$ Gas

Figure 5-22. Second Generation GR-LNB fly ash carbon versus furnace exit flue gas $\mathrm{O}_{2}$ 


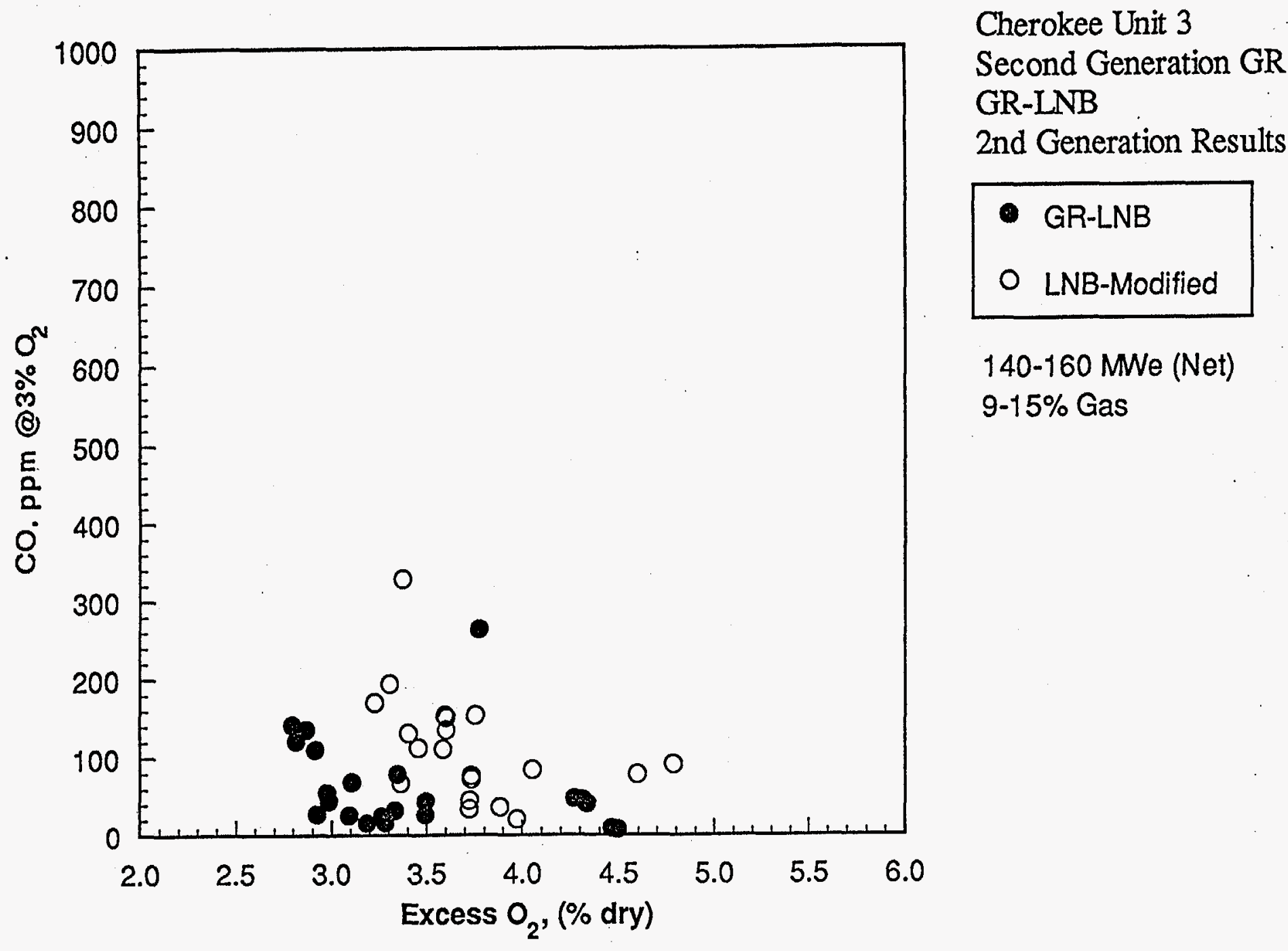

Figure 5-23. Second Generation GR-LNB CO versus furnace exit flue gas $\mathrm{O}_{2}$ 
the pre-construction baseline levels when the excess $\mathrm{O}_{2}$ was above $3.5 \%$. CO levels were somewhat higher than First Generation GR, but approximated the pre-construction levels when excess $\mathrm{O}_{2}$ was above $3.5 \%$.

An extended series of GR-LNB tests were conducted to verify the system performance. The tests were conducted both at constant loads and with the system under dispatch operation, where unit load was adjusted in order to meet the varying plant electrical output requirements. The load would vary from about 80 to $155 \mathrm{MW}_{\mathrm{e}}$ based on grid demand. The tests ranged in duration from one hour to several days. The results of the long term testing are presented in Figure 5-24. As the figure shows, there was no relative change in $\mathbf{N O}_{\mathbf{x}}$ emissions reduction between First and Second Generation GR, even with a reduced gas level.

\subsubsection{Assessment of Results}

FGR was used initially to provide momentum to the natural gas in order to achieve optimum boiler penetration. However, during the long term testing phase of the project, it was determined that the FGR had minimal effect on $\mathrm{NO}_{x}$ emissions. Therefore, a second series of tests was added to the project to evaluate the modified configuration and gage its impact. This Second Generation GR included:

- Removal of the FGR system.

- Installation of high velocity gas injectors coupled with reduced gas flow.

- Modifications to the OFA ports to provide higher jet momentum, air swirl capability and velocity control. The modifications were designed to improve furnace lateral coverage and turbulence in mixing with unburned fuel. This change provided $\mathrm{CO}$ control within acceptable limits at the lower gas levels. 


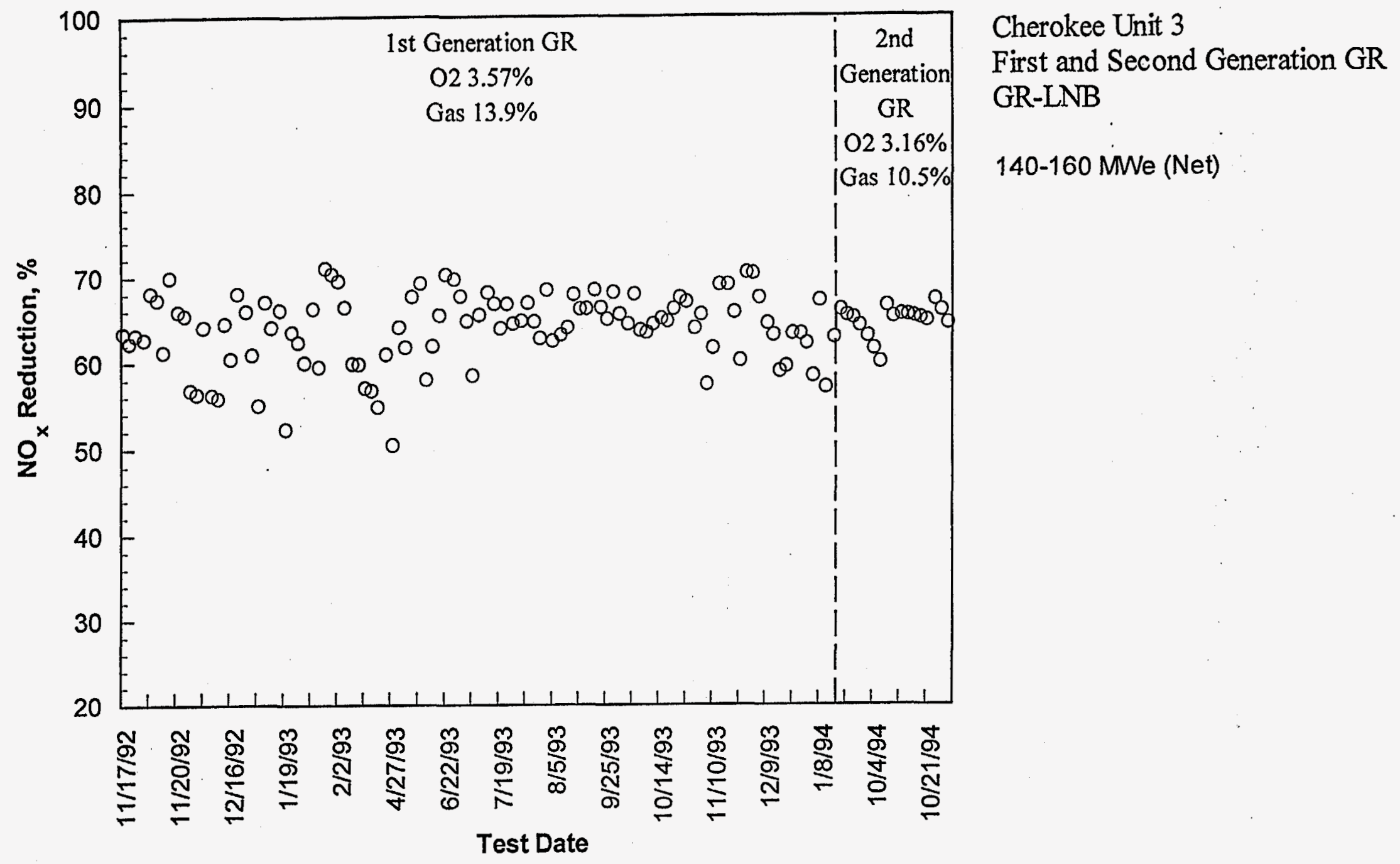

Figure 5-24. Second Generation GR-LNB NO ${ }_{x}$ reduction versus time 
The Second Generation GR was designed to provide performance and economic benefits compared to the First Generation GR. These include:

- Reduced capital cost through elimination of the FGR system

- Reduced operating cost through reduction in the gas heat input

- The same $\mathrm{NO}_{x}$ reduction as First Generation $\mathrm{GR}$ with less gas

- Reduced levels of $\mathrm{CO}$ at low natural gas flows

FWEC through LNB equipment modifications, achieved a slight reduction in $\mathrm{NO}_{x}$ emissions. No change was indicated in $\mathrm{CO}$ emissions (see Figure 5-19). There was only a slight reduction in GR-LNB NO ${ }_{x}$ emissions from an average of $65 \%$ to an average of $64 \%$ but with less natural gas due to better performance of the LNBs. At higher gas levels, $68 \%$ was achieved. A gas heat input of $12.5 \%$ was selected for Second Generation GR testing, which was a reduction of approximately $7 \%$ from First Generation GR. The $\mathrm{SR}_{2}$ setting of 0.90 was maintained, but $\mathrm{SR}_{1}$ was reduced to compensate for the reduced level of gas heat input. Compared to LNB only, $\mathrm{CO}$ emissions were reduced when the GR system was in service.

The results show that modified GR-LNB technology achieved excellent emissions reductions and all goals of the Second Generation GR system were achieved. The following table summarizes the results of the testing:

$\begin{array}{lcc} & \text { First Gen. } & \text { Second Gen. } \\ \text { Gas heat input } & 18 \% & 12.5 \% \\ \text { Baseline } \mathrm{NO}_{x} & 0.73 \mathrm{lb} / 10^{6} \mathrm{Btu} & 0.73 \mathrm{lb} / 10^{6} \mathrm{Btu} \\ \text { Average } \mathrm{NO}_{x} \text { reduction (LNB) } & 37 \% & 44 \% \\ \text { Average } \mathrm{NO}_{x} \text { reduction (GR-LNB) } & 65 \% & 64 \%\end{array}$




\section{$5.4 \quad$ Gas Gas/Reburning Testing}

A limited amount of GR testing was performed with the boiler operating on $100 \%$ natural gas (no coal) to determine the reduction in $\mathrm{NO}_{x}$ and assess the impact on $\mathrm{CO}$ emissions (see Section 4.1.4). The primary fuel (natural gas) was fired through the LNBs and gas also injected into the reburning zone. No equipment modifications were made to operate in this configuration.

The $\mathrm{NO}_{x}$ emissions results for full load are presented in Figures 5-25 and 5-26. The data show a reduction from a baseline of $0.30 \mathrm{lb} / 10^{6} \mathrm{Btu}$ to $0.17 \mathrm{lb} / 10^{6} \mathrm{Btu}(43 \%)$ at a reburning gas heat input of $7 \%$. For the most part, $\mathrm{CO}$ emissions were below $100 \mathrm{ppm}$ as shown in Figure $5-27$. The baseline (100\% gas/no reburning) and optimum gas/gas reburning conditions for full load were as follows:

$\mathrm{SR}_{1}$
$\mathrm{SR}_{2}$
$\mathrm{SR}_{3}$
$\mathrm{Reburn}$ Gas heat input
$\mathrm{O}_{2}$
$\mathrm{NO}_{x}$
$\mathrm{NO}_{x}$ reduction
$\mathrm{CO}$

\begin{tabular}{l} 
Baseline \\
\hline 1.15 \\
1.15 \\
1.16 \\
$0 \%$ \\
$3.06 \%$ \\
$0.30 \mathrm{lb} / 10^{6} \mathrm{Btu}$ \\
$0 \%$ \\
$2 \mathrm{ppm}$
\end{tabular}

\begin{tabular}{l} 
Optimum \\
\hline 1.03 \\
0.94 \\
1.17 \\
$7 \%$ \\
$2.36 \%$ \\
$0.17 \mathrm{lb} / 10^{6} \mathrm{Btu}$ \\
$43 \%$ \\
$32 \mathrm{ppm}$
\end{tabular}

At mid-load $\left(120 \mathrm{MW}_{\mathrm{e}}\right)$ the $\mathrm{NO}_{\mathrm{x}}$ was reduced from $0.22 \mathrm{lb} / 10^{6} \mathrm{Btu}$ to $0.11 \mathrm{lb} / 10^{6}$ Btu at $8 \%$ reburning gas heat input and $\mathrm{CO}$ at $80 \mathrm{ppm}$. At low load the $\mathrm{NO}_{\mathrm{x}}$ was reduced from 0.10 $\mathrm{lb} / 10^{6}$ Btu to $0.06 \mathrm{lb} / 10^{6} \mathrm{Btu}$ at $6 \%$ reburning gas heat input and $\mathrm{CO}$ at $52 \mathrm{ppm}$.

The normal test configuration was injection of reburning gas through the 8 rear wall injectors. However, some full-load injector biasing testing was performed. Shifting half of the gas to the front wall showed no change in $\mathrm{NO}_{\mathrm{x}}$ emissions, although an increase in $\mathrm{CO}$ was observed. When using all 16 injectors ( 8 front and 8 rear) and $12 \%$ gas, $\mathrm{NO}_{\mathrm{x}}$ 


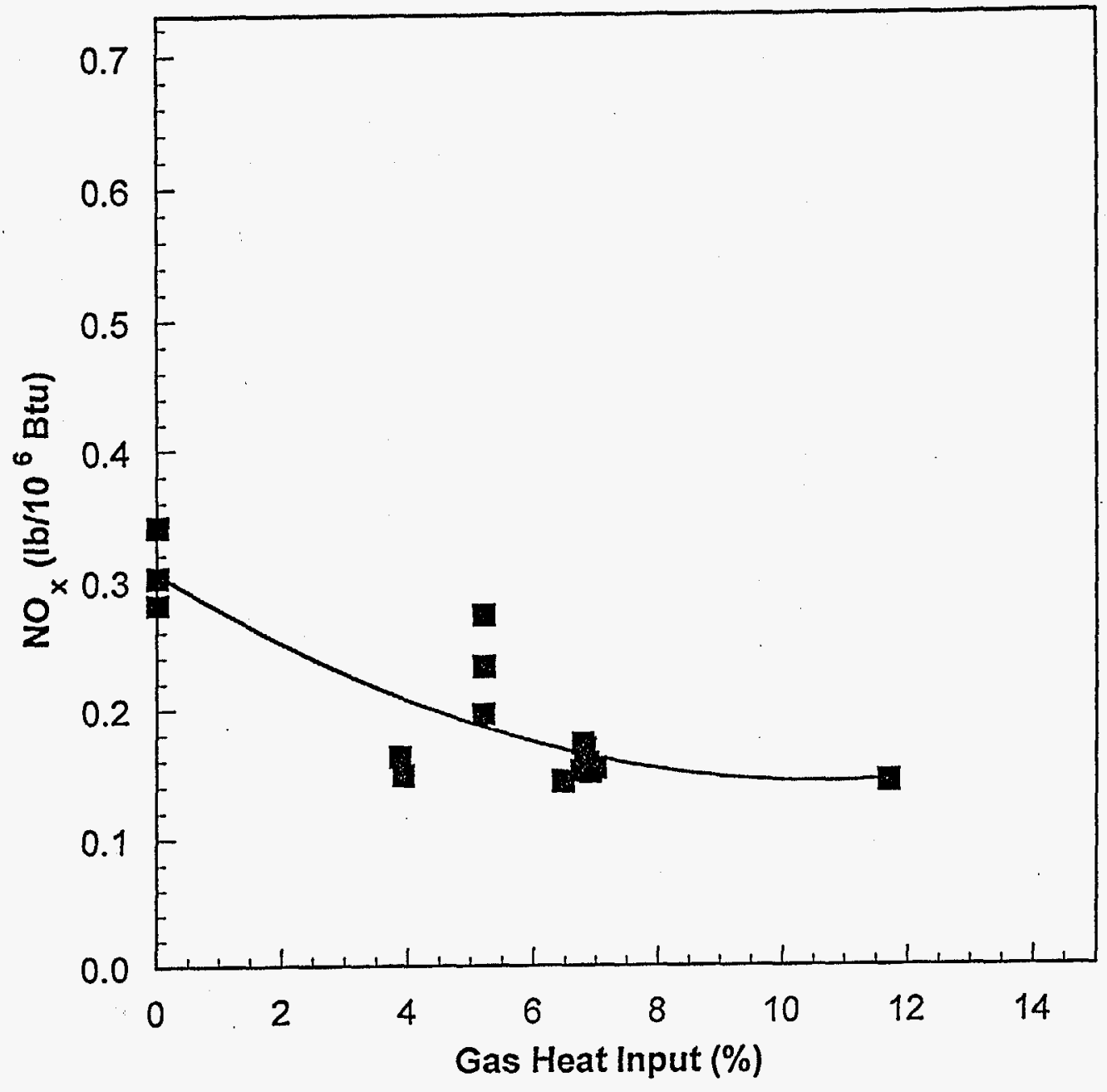

Cherokee Unit 3

Second Generation GR GR-LNB

$100 \%$ Gas Firing Results

140-160 MWe (Net)

Figure 5-25. GR-LNB 100\% gas w/GR NO ${ }_{x}$ versus gas heat input 

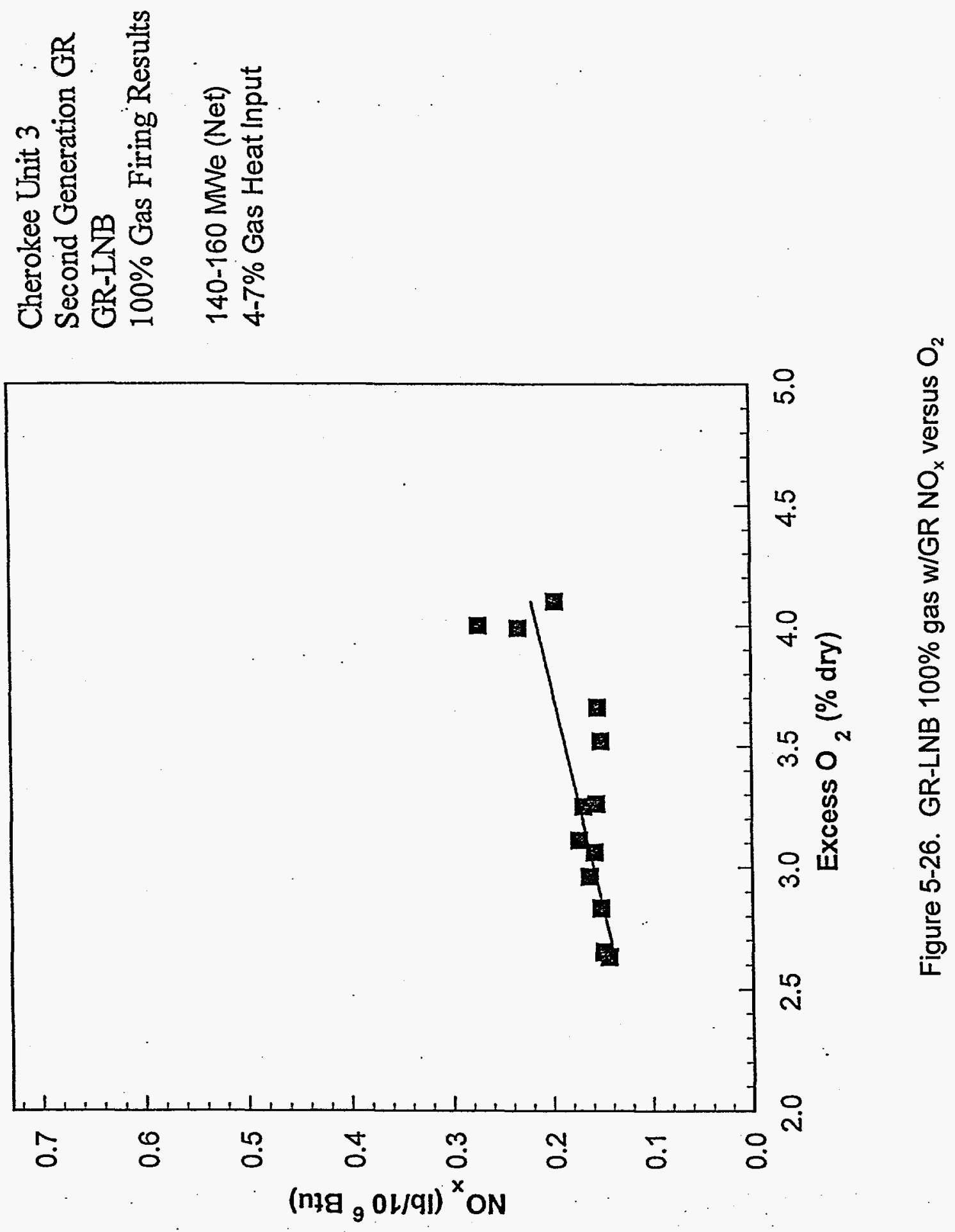


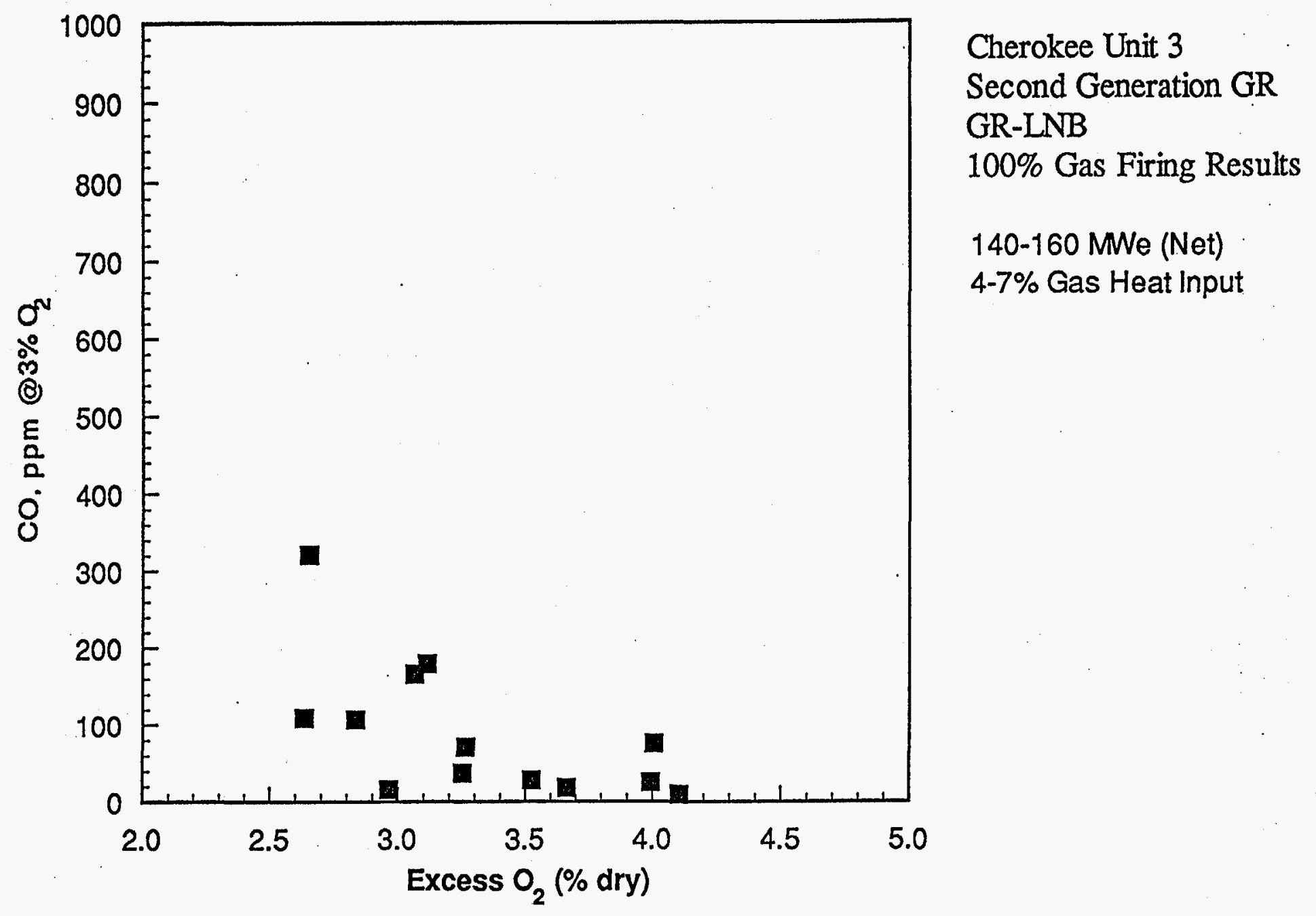

Figure 5-27. GR-LNB 100\% gas w/GR CO versus $\mathrm{O}_{2}$ 
emissions remained the same as for $7 \%$ gas, but the $\mathrm{CO}$ emissions increased dramatically. Lower load biasing tests showed similar results. Therefore, the optimum configuration was to use the 8 rear wall injectors only.

The results showed that a reduction in $\mathrm{NO}_{x}$ emissions can be achieved through reburning technology on a $100 \%$ gas system, while maintaining levels of $\mathrm{CO}$ emissions below 100 ppm.

\subsection{Boiler Impacts}

\subsubsection{Furnace Conditions}

GR operation did not exacerbate slagging in the furnace. Long term operation of the GR system did not show any trend toward additional slagging or fouling beyond that which occurred when operating without GR in service. Some slagging was noted around the LNBs, but this was attributed to the abnormal functioning of the burners. Later in the test program, one LNB (D3) nozzle and internals melted evidently due to combustion inside the burner.

In the reburn zone, slag formed around some of the gas injection nozzles on a random basis, but this did not cause a problem with the reburn gas injection system performance. The injection nozzles were designed with a removable inspection cover and clean out port to determine if the gas injection nozzle tip was plugged.

Generally, no more than two gas nozzles per wall would be plugged at a time, and usually only one nozzle per wall would require slag removal. When a nozzle did become plugged, it was a simple matter to "rod" out the nozzle and remove the slag from the nozzle orifice. 
In the OFA zone, heavy slag deposits formed around three of the six OFA injectors after about three months of operation. The initiation of the slag formation was attributed to higher flue gas temperatures in this area with the GR in operation. The air injected through the OFA ports would "chill" the slag so that it would solidify at this location. The unrestrained buildup of slag progressed over time due to a lack of sootblowers in this area of the furnace. Slag would build up on the refractory around the ports, and without sootblowers in place for removal, the deposits would continue to grow until a significant "eyebrow" would form and solidify around the port. These deposits were removed during regularly scheduled outages.

In the convection pass of the boiler, the bridging of slag deposits in the secondary superheater section occurred when flames from the LNBs swept up into this area. It was difficult to keep the LNB flames at the correct length, and they were generally too long and would bounce off the rear wall and continue up to the arch region at the exit of the furnace. When the FWEC personnel adjusted the burners for proper operation, this usually did not occur. It should be noted that the phenomenon of flames reaching the upper regions of the furnace occurred independent of GR operation.

The overall conclusion is that GR does not have a significant adverse impact upon boiler operation. The slagging and fouling that occurred did not significantly impact GR operation or performance. However, LNB operation did contribute to slagging in the primary burner zone and in the secondary superheater sections.

\subsubsection{Thermal Performance/Efficiency}

The impacts of GR-LNB on boiler thermal performance and efficiency were projected in the process design study (see Section 2.4.1). The study predicted that the unit would produce steam at its rated capacity during GR-LNB, but with a slightly lower thermal efficiency. Also, there would be minor changes in the heat absorption profile. 
During the parametric and long term testing, data were collected to compare GR-LNB results with baseline and also for comparison with the projections. Tables 5-1 through 5-3 present this data for both First and Second Generation LNB and GR-LNB operation over a range of boiler loads. The data were collected and evaluated to ensure that the unit operated at its rated capacity with proper steam temperatures and to verify that there were no adverse impacts on steam conditions/heat absorption.

Furnace Exit $\mathrm{O}_{2}$ The average $\mathrm{O}_{2}$ observed during non-test baseline conditions prior to installation of the GR-LNB system was $3.2 \%$. Following installation of the LNBs, the unit was operated at $2.85 \%$ but returned to the $3.2 \% \mathrm{O}_{2}$ level following modifications (in preparation for Second Generation GR testing) in an attempt to lower the $\mathrm{CO}$ emissions. GR-LNB operation was operated at $2.6 \% \mathrm{O}_{2}$, sufficiently low to control $\mathrm{CO}$ but not too high to jeopardize boiler efficiency.

Steam Side Temperatures As predicted in the process design, increases were observed in both the main and reheat steam temperatures. This was due to the modified heat distribution in the boiler when the GR system is in operation. The increase was lessened with Second Generation GR since the amount of gas heat input was reduced. Steam temperatures were adequately controlled through steam attemperation.

Heat Transfer GR operation can affect the thermal performance by altering the furnace heat release profile and by changing the local stoichiometric ratios and particulate loading resulting in minor changes in lower and upper furnace deposition patterns. Although heat transfer in the furnace was reduced and the heat transfer in the superheater and reheater increased during First Generation GR, the heat transfers improved considerably with the Second Generation GR. The furnace temperature in the reburn zone affects the rate of $\mathrm{NO}_{\mathrm{x}}$ reduction. Higher temperatures increase the rate of speed of the chemical reactions that result in $\mathrm{NO}_{x}$ destruction. The temperatures attained in the reburn zone were typically $2300^{\circ}$ to $2500^{\circ} \mathrm{F}$, which are consistent with the predicted reburn zone temperatures. 
TABLE 5-1. THERMAL PERFORMANCE SUMMARY (Full Load - $150 \mathrm{MW}_{\mathrm{e}}$ )

\begin{tabular}{|c|c|c|c|c|}
\hline \multirow[b]{2}{*}{ Thermal Parameters } & \multicolumn{2}{|c|}{ LNB } & \multicolumn{2}{|c|}{ GR-LNB } \\
\hline & 1st Gen. & 2nd Gen. & 1st Gen. & 2nd Gen. \\
\hline \multicolumn{5}{|l|}{ Process variables } \\
\hline Exit Plant $\mathrm{O} 2$ & 2.85 & 3.21 & 2.63 & 2.60 \\
\hline Gas heat input $(\%)$ & & & 13.72 & 10.23 \\
\hline OFA ( $\%$ total air) & & & 19.86 & 22.30 \\
\hline \multicolumn{5}{|l|}{ Steam side temperatures (deg. F) } \\
\hline Main steam temperature & 969 & 971 & 992 & 985 \\
\hline Hot reheat temperature & 945 & 946 & 984 & 964 \\
\hline Attemperator outlet temperature (deg. F) & 774 & 782 & 778 & 785 \\
\hline \multicolumn{5}{|l|}{ Heat transfer $\left(10^{\wedge} 6 \mathrm{Btu} / \mathrm{hr}\right)$} \\
\hline Furnace & 743 & 747 & 712 & 737 \\
\hline Secondary superheater & 164 & 160 & 173 & 165 \\
\hline Reheater & 163 & 157 & 169 & 153 \\
\hline Primary superheater & 231 & 238 & 231 & 239 \\
\hline Air heater & 193 & 192 & 190 & 184 \\
\hline Economizer & 29 & 30 & 29 & 31 \\
\hline \multicolumn{5}{|l|}{ Cleanliness factors } \\
\hline Furnace & 1.028 & 1.025 & 1.009 & 1.026 \\
\hline Secondary superheater & 1.038 & 0.999 & 1.118 & 1.045 \\
\hline Reheater & 0.901 & 0.861 & 0.958 & 0.849 \\
\hline Primary superheater & 1.034 & 1.053 & 1.067 & 1.077 \\
\hline Air heater & 1.045 & 1.032 & 1.061 & 1.005 \\
\hline Economizer & 1.022 & 1.047 & 1.024 & 1.075 \\
\hline Econ. gas outlet temp. (deg. F) & 699 & 707 & 713 & 707 \\
\hline \multicolumn{5}{|l|}{ Heat loss (\%) } \\
\hline Dry gas & 5.00 & 4.90 & 4.80 & 4.60 \\
\hline Moisture from fuel & 1.11 & 1.11 & 0.96 & 0.99 \\
\hline Moisture from combustion & 4.26 & 4.25 & 5.14 & 4.90 \\
\hline Combustible in refuse & 0.61 & 0.61 & 0.53 & 0.55 \\
\hline Radiation & 0.19 & 0.19 & 0.21 & 0.20 \\
\hline Unmeasured & 0.83 & 0.81 & 0.86 & 0.83 \\
\hline ASME' heat loss efficiency (\%) & 88.00 & 88.13 & 87.51 & 87.93 \\
\hline Net heat rate $(B t u / k W h)$ & 10,208 & 10,153 & 10,104 & 10,103 \\
\hline
\end{tabular}


TABLE 5-2. THERMAL PERFORMANCE SUMMARY (Mid Load - $120 \mathrm{MW}_{\mathrm{e}}$ )

\begin{tabular}{|c|c|c|c|c|}
\hline \multirow[b]{2}{*}{ Thermal Parameters. } & \multicolumn{2}{|c|}{ LNB } & \multicolumn{2}{|c|}{ GR-LNB } \\
\hline & 1st Gen. & 2nd Gen. & 1st Gen. & 2nd Gen. \\
\hline \multicolumn{5}{|l|}{ Process variables } \\
\hline Exit Plant $\mathrm{O} 2$ & 3.07 & 3.80 & 3.30 & 3.33 \\
\hline Gas heat input (\%) & & & 14.25 & 9.39 \\
\hline OFA (\% total air) & & & 21.32 & 22.87 \\
\hline \multicolumn{5}{|l|}{ Steam side temperatures (deg. F) } \\
\hline Main steam temperature & 974 & 964 & 989 & 969 \\
\hline Hot reheat temperature & 926 & 910 & 958 & 941 \\
\hline Attemperator outlet temperature (deg. F) & 760 & 777 & 773 & 771 \\
\hline \multicolumn{5}{|l|}{ Heat transfer $\left(10^{\wedge} 6 \mathrm{Btu} / \mathrm{hr}\right)$} \\
\hline Furnace & 608 & 585 & 595 & 660 \\
\hline Secondary superheater & 140 & 116 & 139 & 142 \\
\hline Reheater & 131 & 118 & 136 & 132 \\
\hline Primary superheater & 166 & 173 & 180 & 192 \\
\hline Air heater & 156 & 152 & 163 & 165 \\
\hline Economizer & 22 & 26 & 22 & 30 \\
\hline \multicolumn{5}{|l|}{ Cleanliness factors } \\
\hline Furnace & 1.046 & 1.039 & 1.024 & 1.052 \\
\hline Secondary superheater & 1.083 & 0.924 & 1.073 & 1.025 \\
\hline Reheater & 0.907 & 0.884 & 0.945 & 0.844 \\
\hline Primary superheater & 0.986 & 1.071 & 1.071 & 1.036 \\
\hline Air heater & 1.092 & 1.098 & 1.139 & 1.052 \\
\hline Economizer & 1.027 & 1.252 & 1.034 & 1.255 \\
\hline Econ. gas outlet temp. (deg. F) & 667 & 678 & 689 & 690 \\
\hline \multicolumn{5}{|l|}{ Heat loss $(\%)$} \\
\hline Dry gas & 5.06 & 4.88 & 5.04 & 4.43 \\
\hline Moisture from fuel & 1.11 & 1.10 & 0.95 & 0.99 \\
\hline Moisture from combustion & 4.26 & 4.24 & 5.17 & 4.82 \\
\hline Combustible in refuse & 0.61 & 0.61 & 0.52 & 0.50 \\
\hline Radiation & 0.29 & 0.31 & 0.29 & 0.26 \\
\hline Unmeasured & 1.12 & 1.16 & 1.13 & 1.03 \\
\hline ASME heat loss efficiency (\%) & 87.55 & 87.70 & 86.90 & 87.92 \\
\hline Net heat rate (Btu/kWh) & 10,303 & 10,143 & 10,275 & 10,617 \\
\hline
\end{tabular}


TABLE 5-3. THERMAL PERFORMANCE SUMMARY (Low Load - $90 \mathrm{MW}_{\mathrm{e}}$ )

\begin{tabular}{|c|c|c|c|c|}
\hline \multirow{2}{*}{ Thermal Parameters } & \multicolumn{2}{|c|}{ LNB } & \multicolumn{2}{|c|}{ GR-LNB } \\
\hline & 1st Gen. & 2nd Gen. & 1st Gen. & 2nd Gen. \\
\hline \multicolumn{5}{|l|}{ Process variables } \\
\hline Exit Plant $\mathrm{O} 2$ & 3.87 & 4.69 & 4.03 & 5.00 \\
\hline Gas heat input (\%) & & & 15.32 & 10.95 \\
\hline OFA ( $\%$ total air) & & & 23.55 & 25.86 \\
\hline \multicolumn{5}{|l|}{ Steam side temperatures (deg. F) } \\
\hline Main steam temperature & 956 & 998 & 978 & 980 \\
\hline Hot reheat temperature & 906 & 974 & 930 & 930 \\
\hline Attemperator outlet temperature (deg. F) & 752 & 782 & 760 & 772 \\
\hline \multicolumn{5}{|l|}{ Heat transfer $\left(10^{\wedge} 6 \mathrm{Btu} / \mathrm{hr}\right)$} \\
\hline Furnace & 486 & 483 & 474 & 497 \\
\hline Secondary superheater & 103 & 104 & 107 & 104 \\
\hline Reheater & 109 & 104 & 111 & 98 \\
\hline Primary superheater & 124 & 144 & 129 & 137 \\
\hline Air heater & 126 & 136 & 133 & 134 \\
\hline Economizer & 17 & 24 & 16 & 25 \\
\hline \multicolumn{5}{|l|}{ Cleanliness factors } \\
\hline Furnace & 4.040 & 1.036 & 1.027 & 1.049 \\
\hline Secondary superheater & 0.972 & 0.991 & 1.022 & 0.973 \\
\hline Reheater & 0.960 & 0.917 & 0.987 & 0.845 \\
\hline Primary superheater & 1.013 & 1.173 & 1.070 & 1.098 \\
\hline Air heater & 1.153 & 1.240 & 1.229 & 1.195 \\
\hline Economizer & 1.063 & 1.558 & 1.060 & 1.550 \\
\hline Econ. gas outlet temp. (deg. F) & 648 & 67 & 666 & 665 \\
\hline \multicolumn{5}{|l|}{ Heat loss $(\%)$} \\
\hline Dry gas & 5.28 & 4.67 & 5.59 & 4.73 \\
\hline Moisture from fuel & 1.11 & 1.09 & 0.94 & 0.97 \\
\hline Moisture from combustion & 4.26 & 4.21 & 5.25 & 4.90 \\
\hline Combustible in refuse & 0.61 & 0.61 & 0.52 & 0.54 \\
\hline Radiation & 0.37 & 0.37 & 0.38 & 0.37 \\
\hline Unmeasured & 1.37 & 1.37 & 1.38 & 1.35 \\
\hline ASME heat loss efficiency (\%) & 87.00 & 87.68 & 85.95 & 87.12 \\
\hline Net heat rate (Btu/kWh) & 10,954 & 10,871 & 10,858 & 11,182 \\
\hline
\end{tabular}


ASME Heat Loss A reduction in thermal efficiency was calculated using ASME Power Test Code 4.1 (heat loss method). A slight reduction in efficiency was observed with GRLNB as compared to LNB-only due to dry gas heat loss, moisture in fuel heat loss, and heat loss due to moisture from combustion. The decrease in heat absorption and resulting rise in the flue gas temperature increases the dry gas heat loss, especially for GR-LNB operation. Fuel switching, i.e. replacement of coal heat with heat from natural gas, results in a reduction in boiler efficiency due to increased fuel moisture heat loss. Since natural gas has a higher hydrogen-to-carbon ratio than coal, its combustion results in the formation of more moisture and consequently higher moisture from combustion heat loss. Nevertheless, the total reduction in efficiency was less than $1 \%$ for all conditions.

\subsubsection{Tubewear}

During reburning, a reducing of fuel-rich condition is established in the reburning zone. It is well known that fuel-rich conditions can enhance tube wastage due to two mechanisms:

- When fuels containing sulfur are burned under oxygen deficient conditions, some of the sulfur forms reduced sulfur species such as $\operatorname{COS}$ and $\mathrm{H}_{2} \mathrm{~S}$. These species react with iron in the tubes via $\mathrm{Fe}$ and $\mathrm{H}_{2} \mathrm{~S}-\mathrm{FeS}$. The FeS scales off the tube leading to wastage (corrosion).

- In normal fuel lean operation, the tubes are protected by a thin oxidized layer. Reducing conditions, particularly fluctuating (oxidizing/reducing) conditions, can continuously degrade this protective layer.

Normal rates of tube wastage in coal-fired boilers are normally in the range of 0.001 " to 0.003 " per year, however, some boilers inherently have massive tube wastage. As part of the field demonstration described above, the boiler tubes were subjected to nondestructive testing to determine if GR operation jeopardized the life of the tubes. Specific 
areas were targeted for investigation where the mechanisms listed above suggested a potential for significant tube wastage. The prime goal of the testing was to determine if there was a significant increase in tubewall wastage from GR-LNB. A secondary goal was to determine the incremental change in the tube thickness and project this change to the end of the boiler useful life.

Ultrasonic tube thickness measurements were obtained at two time points: in January 16, 1990 prior to GR startup, and in February 21, 1993 following parametric GR testing. Based on the accuracy of the measurement technique ( $\pm 0.005 ")$, no significant tube wastage was found. Given these results and the favorable results of two previous EER DOE-CCT projects involving GR, EER and the utility determined that no further testing was warranted.

\subsection{Additional Observations}

A multiclone mechanical dust collector system had been installed to remove the flyash from the FGR to prevent the ash from plugging the reburn gas injection system. However, one problem with this ash removal system was the recurring need to unplug the multiclone system periodically in order to remove the collected fly ash. The multiclone and associated piping were mounted at a second floor location which made periodic removal of the flyash very difficult. Also, during winter months when the ambient temperature was below $32^{\circ} \mathrm{F}$, moisture in the fly ash would freeze and plug the multiclone. This problem was later solved when the gas injection and OFA systems were redesigned and reinstalled during a unit outage in January of 1994. The new gas injection system eliminated FGR as the transport medium for the reburn fuel, thereby eliminating this problem entirely.

Full load temperature measurements were conducted to determine the gas temperature profile in the furnace at points leaving the primary zone, the reburn zone, and the burnout zone. A very limited number of boiler penetration locations were available for temperature 
measurement in the primary zone. The following average furnace gas temperature profiles were obtained from full load tests:

\section{Coal Firing (no GR) $\quad 19 \%$ Gas Heat Input (GR)}

Primary zone

Reburn zone

Burnout zone
$2541 \mathrm{~F}$

$2381 \mathrm{~F}$

$1840 \mathrm{~F}$
$2389 \mathrm{~F}$

$2453 \mathrm{~F}$

$1917 \mathrm{~F}$

The temperatures displayed for the various zones are the average of all temperatures measured for a given test. As shown from the above data, the gas temperature profile was shifted upwards in the furnace, with the GR system in operation. With GR in operation, the primary zone temperature dropped about $150 \mathrm{~F}$ while the reburn and burnout zones increased in gas temperature by about $70 \mathrm{~F}$ and $60 \mathrm{~F}$ respectively. This is the expected result with the GR system in operation, since some of the heat input is shifted from the primary zone to the reburn zone. The temperature profile tabulated above was recorded during the test with the greatest $\mathrm{NO}_{\mathrm{x}}$ reduction performance for the GR system.

\subsection{Coal and Natural Gas Analysis}

Initially, during the course of the GR-LNB demonstration program, it was determined through testing that the coal composition was fairly uniform and that the ash levels in the coal were consistently low. The average higher heating value of the coal was 11,268 $\mathrm{Btu} / \mathrm{lb}, \pm 600 \mathrm{Btu} / \mathrm{lb}$. After the initial period of baseline and optimization testing, coal was sampled on a less frequent basis. Likewise, the composition of the natural gas used as the reburn fuel did not change over the course of the test program, which is the normal expectation for natural gas. The higher heating value of the natural gas over the duration of testing varied by $\pm 2 \%$. 
Samples were taken from each of the two coal feeders per mill for the four mills and were tested for the following:

- Ultimate analysis

- $\quad$ Proximate analysis

- Heating value

- Ash composition

- Ash fusion temperature

Provided the design coal was being burned, fuel composition had little or no impact upon the performance of the GR, LNB, or the combined GR-LNB operation during this test program. At one point late in the test program, one train load of off-normal coal was burned which caused severe slagging in the boiler, and slag bridging occurred in the boiler which caused the shut down of the unit for cleaning. The coal analyses are shown in Tables 5-4.

Table 5-5 lists the annual average natural gas compositions from two stations that fed the Cherokee Station from 1992 through 1995. The natural gas composition was uniform during testing, and no problems were observed with the GR-LNB system due to the natural gas utilized during the test program. 
TABLE 5-4. ANALYSIS OF COAL FOR CHEROKEE UNIT \#3

\begin{tabular}{|c|c|c|c|c|c|c|c|c|c|c|c|c|c|c|}
\hline \multirow{2}{*}{$\begin{array}{l}\text { Date } \\
\text { Sampled }\end{array}$} & \multicolumn{4}{|c|}{ Proximate Composition (\%) } & \multicolumn{7}{|c|}{ Ultimate Composition (\%) } & \multirow{2}{*}{$\begin{array}{c}\text { Higher } \\
\text { Heating Value } \\
\text { (Btu/lb) }\end{array}$} & \multirow{2}{*}{$\begin{array}{c}\text { Theoretical } \\
\text { SO2 Emissions } \\
\text { (lb/MBu) }\end{array}$} & \multirow{2}{*}{$\begin{array}{l}\text { Stoichiometric } \\
\text { Air Requirement } \\
\text { (lb air/lb coal) }\end{array}$} \\
\hline & Moisture & $\begin{array}{l}\text { Volatile } \\
\text { Matter } \\
\end{array}$ & $\begin{array}{c}\text { Fixed } \\
\text { Carbon }\end{array}$ & Ash & Moisture & Carbon & Hydrogen & Nitrogen & Sulfur & Oxygen & Ash & & & \\
\hline $10 / 5 / 92$ & 10.34 & 35.15 & 44.06 & 10.45 & 10.34 & 62.79 & 4.84 & 1.54 & 0.43 & 9.61 & 10.45 & 11,029 & 0.78 & 8.51 \\
\hline $10 / 6 / 92$ & 10.82 & 35.52 & 44.11 & 9.55 & 10.82 & 62.52 & 4.21 & 1.34 & 0.45 & 11.11 & 9.55 & 11,000 & 0.82 & 8.20 \\
\hline $1 / 20 / 93$ & 10.51 & 35.27 & 45.58 & 8.64 & 10.51 & 64.37 & 4.30 & 1.60 & 0.39 & 10.19 & 8.64 & 11,293 & 0.69 & 8.48 \\
\hline $7 / 23 / 93$ & & & & & 10.31 & 63.01 & 4.48 & 1.72 & 0.44 & 9.23 & 10.81 & 11,089 & 0.79 & 8.43 \\
\hline $3 / 23 / 94$ & & & & & 8.55 & 68.24 & 4.28 & 1.51 & 0.46 & 9.08 & 7.86 & 11,866 & 0.78 & 8.97 \\
\hline $9 / 23 / 94$ & & & & & 10.98 & 62.87 & 4.34 & 1.55 & 0.44 & 9.15 & 10.67 & 10,994 & 0.80 & 8.37 \\
\hline $1 / 18 / 95$ & 10.21 & 34.81 & 46.63 & 8.35 & 10.21 & 64.68 & 4.62 & 1.43 & 0.55 & 10.16 & 8.35 & 11,621 & 0.95 & 8.63 \\
\hline $1 / 24 / 95$ & 10.39 & 34.06 & 45.89 & 9.66 & 10.39 & 64.47 & 4.50 & 1.53 & 0.44 & 9.01 & 9.66 & 11,186 & 0.79 & 8.61 \\
\hline $1 / 27 / 95$ & 9.63 & 33.98 & 45.80 & 10.59 & 9.63 & 65.11 & 4.56 & 1.33 & 0.44 & 8.34 & 10.59 & 11,331 & 0.78 & 8.73 \\
\hline Avg. & 10.32 & 34.80 & 45.35 & 9.54 & 10.19 & 64.23 & 4.46 & 1.51 & 0.45 & 9.54 & 9.62 & 11,268 & 0.80 & 8.55 \\
\hline Max. & 10.82 & 35.52 & 46.63 & 10.59 & 10.98 & 68.24 & 4.84 & 1.72 & 0.55 & 11.11 & 10.81 & 11,866 & 0.95 & 8.97 \\
\hline Min. & 9.63 & 33.98 & 44.06 & 8.35 & 8.55 & 62.52 & 4.21 & 1.33 & 0.39 & 8.34 & 7.86 & 10,994 & 0.69 & 8.20 \\
\hline St. Dev. & 0.39 & 0.65 & 1.04 & 0.91 & 0.72 & 1.78 & 0.20 & 0.12 & 0.04 & 0.83 & 1.11 & 302 & 0.07 & 0.22 \\
\hline
\end{tabular}


TABLE 5-5. ANNUAL AVERAGE NATURAL GAS COMPOSITIONS*

\begin{tabular}{|c|c|c|c|c|c|c|c|c|c|}
\hline $\begin{array}{c}\text { Component } \\
\text { (Mole \%) }\end{array}$ & $\begin{array}{c}1992 \\
\text { East } \\
\text { Denver } \\
\text { Control } \\
\end{array}$ & $\begin{array}{c}1992 \\
\text { 88th \& Platte }\end{array}$ & $\begin{array}{c}1993 \\
\text { East } \\
\text { Denver } \\
\text { Control } \\
\end{array}$ & $\begin{array}{c}1993 \\
\text { 88th \& Platte }\end{array}$ & $\begin{array}{c}1994 \\
\text { East } \\
\text { Denver } \\
\text { Control } \\
\end{array}$ & $\begin{array}{c}1994 \\
\text { 88th \& Platte }\end{array}$ & $\begin{array}{c}1995 \\
\text { East } \\
\text { Denver } \\
\text { Control } \\
\end{array}$ & $\begin{array}{c}1995 \\
\text { 88th \& Platte }\end{array}$ & $\begin{array}{l}\text { Overall } \\
\text { Average }\end{array}$ \\
\hline Carbon Dioxide & 1.327 & 2.287 & 1.292 & 2.383 & 1.757 & 2.332 & 1.628 & 2.048 & 1.882 \\
\hline Oxygen & 1.385 & 1.680 & 1.509 & 1.698 & 1.300 & 1.478 & 1.263 & 1.238 & 1.444 \\
\hline Nitrogen & 5.761 & 6.830 & 6.093 & 6.640 & 5.576 & 6.375 & 5.097 & 4.888 & 5.908 \\
\hline Methane & 85.164 & 80.314 & 84.167 & 80.938 & 84.162 & 81.127 & 85.656 & 85.628 & 83.395 \\
\hline Ethane & 5.373 & 7.782 & 5.796 & 7.114 & 5.990 & 7.449 & 5.252 & 5.416 & 6.272 \\
\hline Propane & 0.754 & 0.891 & 0.839 & 0.996 & 0.924 & 1.002 & 0.809 & 0.646 & 0.858 \\
\hline i-Butane & 0.069 & 0.068 & 0.083 & 0.077 & 0.089 & 0.079 & 0.099 & 0.048 & 0.077 \\
\hline n-Butane & 0.084 & 0.087 & 0.105 & 0.097 & 0.114 & 0.107 & 0.114 & 0.055 & 0.095 \\
\hline i-Pentane & 0.022 & 0.019 & 0.025 & 0.018 & 0.030 & 0.020 & 0.032 & 0.012 & 0.022 \\
\hline n-Pentane & 0.017 & 0.014 & 0.016 & 0.012 & 0.021 & 0.014 & 0.018 & 0.008 & 0.015 \\
\hline Hexanes Plus & 0.044 & 0.028 & 0.074 & 0.025 & 0.038 & 0.016 & 0.033 & 0.014 & 0.034 \\
\hline Total & 100.00 & 100.00 & 100.00 & 100.00 & 100.00 & 100.00 & 100.00 & 100.00 & 100.00 \\
\hline Compressibility & 0.99783 & 0.99773 & 0.99780 & 0.99774 & 0.99776 & 0.99770 & 0.99779 & 0.99781 & 0.9978 \\
\hline HHV (Btu/sc) & 982 & 978 & 964 & 976 & 994 & 989 & 993 & 986 & 983 \\
\hline Specific Gravity & 0.6366 & 0.6646 & 0.6425 & 0.6627 & 0.6450 & 0.6617 & 0.6369 & 0.6365 & 0.648 \\
\hline
\end{tabular}

* Two lines that feed the Cherokee Station 


\subsection{ENVIROMENTAL PERFORMANCE}




\subsection{Impact on the Environment}

Environmental measurements were outlined in an Environmental Monitoring Plan (EMP) previously submitted to the DOE. Environmental monitoring was conducted to ensure that environmental standards were met and to provide a data base for environmental impacts of the technology. The measurements were divided into two categories "Compliance" and "Supplemental" measurements. Compliance measurements were recorded by plant personnel to satisfy operating permit requirements of the Colorado Air Pollution Control Division (APCD) and the Colorado Water Quality Control Division (WQCD).

The plant operates under air emissions limits of $1.2 \mathrm{lb} \mathrm{SO} / 10^{6} \mathrm{Btu}\left(516 \mathrm{mg} / 10^{6} \mathrm{~J}\right)$ and an opacity limit of 20 percent averaged over six minute periods. To comply with these limits the plant uses continuous flue gas $\mathrm{SO}_{2}$ and opacity monitors and conducts fuel analyses to measure maximum theoretical $\mathrm{SO}_{2}$ emissions. The plant submits Excess Emissions Reports to the APCD on a quarterly basis which state the periods of emissions excursions and the likely reasons. The aqueous discharge to the South Platte River also has limits and daily-to-quarterly monitoring. National Pollutant Discharge Elimination System (NPDES) monitoring sheets are submitted on a monthly basis to the WQCD to demonstrate compliance with aqueous discharge limits.

Supplemental measurements were taken by EER to fully characterize the environmental impacts of the GR-LNB process and to demonstrate environmental acceptability per the cooperative agreement with DOE. Measurements were made in several areas including air emissions from the boiler $\left(\mathrm{NO}_{\mathrm{x}}, \mathrm{SO}_{2}, \mathrm{CO}, \mathrm{CO}_{2}\right.$, and $\left.\mathrm{O}_{2}\right)$, emissions of nitrous oxide $\left(\mathrm{N}_{2} \mathrm{O}\right)$, ambient suspended particulate matter with a diameter under 10 microns $\left(\mathrm{PM}_{10}\right)$, and worker area dust and noise levels. Boiler emissions at the economizer outlet were measured continuously by the CEMS and logged by the BPMS. Gas samples were 
extracted using a sixteen-point grid of stainless steel tubing, dried, then analyzed by instruments calibrated on a per test basis with zero, mid-span and span gases. Limited measurements of $\mathrm{N}_{2} \mathrm{O}$ emissions were made to verify that LNBs and GR-LNB do not increase the discharge of this species. $\mathrm{N}_{2} \mathrm{O}$ is believed to be involved in the depletion of stratospheric ozone. Measurements of $\mathrm{PM}_{10}$ were made at the border of the facility at both upwind and downwind locations to determine the ambient $\mathrm{PM}_{10}$ concentration. Worker area nuisance dust levels were measured in various areas of the boiler house. Noise levels in the boiler house were measured especially near GR equipment to determine the necessity for audiometric protection.

Average gaseous emissions for each GR-LNB testing period are summarized in Table 6-1. Optimization GR-LNB testing was conducted from November 11, 1992 though April 23, 1993. During this period, GR-LNB was evaluated for 107 hours. The average $\mathrm{NO}_{x}$ level was $0.261 \mathrm{lb} / 10^{6} \mathrm{Btu}\left(112 \mathrm{mg} / 10^{6} \mathrm{~J}\right)$, which is a reduction of $64 \%$ from the pre-project baseline of $0.73 \mathrm{lb} / 10^{6} \mathrm{Btu}\left(314 \mathrm{mg} / 10^{6} \mathrm{~J}\right)$. Emissions of CO averaged $149 \mathrm{ppm}$ (@ 3\% $\mathrm{O}_{2}$ ), which is below the typical standard of $200 \mathrm{ppm}$, and $\mathrm{CO}_{2}$ accounted for $15.7 \%$ of the flue gas volume. Emissions of $\mathrm{SO}_{2}$ averaged $0.554 \mathrm{lb} / 10^{6} \mathrm{Btu}\left(238 \mathrm{mg} / 10^{6} \mathrm{~J}\right)$, which is far below the $1.2 \mathrm{lb} / 10^{6} \mathrm{Btu}\left(516 \mathrm{mg} / 10^{6} \mathrm{~J}\right)$ limit.

During the long-term demonstration from April 27, 1993 to January 20, 1994, GR-LNB was evaluated for 2,913 hours. The gas heat input was reduced to an average of $12.89 \%$, compared to $17.03 \%$ for the Optimization Testing period. The $\mathrm{NO}_{x}$ level averaged 0.260 $\mathrm{lb} / 10^{6} \mathrm{Btu}\left(112 \mathrm{mg} / 10^{6} \mathrm{~J}\right)$, again a $64 \%$ reduction from the pre-project baseline. Emissions of $\mathrm{CO}$ averaged $160 \mathrm{ppm}$ and $\mathrm{CO}_{2}$ accounted for $16.1 \%$ of the flue gas volume. Emissions of $\mathrm{SO}_{2}$ averaged $0.571 \mathrm{lb} / 10^{6} \mathrm{Btu}\left(246 \mathrm{mg} / 10^{6} \mathrm{~J}\right)$, again were significantly below the standard of $1.2 \mathrm{lb} / 10^{6} \mathrm{Btu}\left(516 \mathrm{mg} / 10^{6} \mathrm{~J}\right)$.

The Second-Generation GR-LNB system was tested for 95 hours, from August 17, 1994 to January 27,1995 . This system used an average gas heat input of $10.22 \%$. The 
TABLE 6-1. AVERAGE EMISSIONS FOR CONDITIONS TESTED ON UNIT \#3.

\begin{tabular}{|c|c|c|c|c|c|c|c|c|c|c|}
\hline Test & Total & Net & Reburn & CEMS & COc & CO2c & NOxc & NOx & SO2c & SO2 \\
Condition & Duration & Power & Gas Heat & 02 & & & & \\
& (hours) & (MWe) & $(\%$, tot) $)$ & $(\%$, dry $)$ & $(\mathrm{ppm})$ & $(\%)$ & $(\mathrm{ppm})$ & $(\mathrm{bb} / \mathrm{MBtu})$ & $(\mathrm{ppm})$ & $(\mathrm{b} / \mathrm{MBtu})$ \\
\hline Optimization GR & 107 & 141 & 17.03 & 3.63 & 149 & 15.7 & 195 & 0.261 & 285 & 0.554 \\
Long-Term GR & 2913 & 133 & 12.89 & 4.17 & 160 & 16.1 & 193 & 0.260 & 304 & 0.571 \\
Second-Generation GR & 95 & 134 & 10.22 & 3.96 & 68 & 16.0 & 196 & 0.264 & 330 & 0.622 \\
100\% Gas Firing & $\#$ & 124 & 0.00 & 3.19 & 123 & 10.1 & 127 & 0.174 & 3 & 0.005 \\
Gas/Gas Reburning & $\#$ & 123 & 6.11 & 3.43 & 168 & 10.1 & 94 & 0.127 & 1 \\
\hline
\end{tabular}

Subscript c denotes correction to $3 \%$ O2

\#: Total duration of $100 \%$ Gas Firing \& Gas/Gas Rebuming Testing was 53 hours. 
average $\mathrm{NO}_{\mathrm{x}}$ level was $0.264 \mathrm{lb} / 10^{6} \mathrm{Btu}\left(114 \mathrm{mg} / 10^{6} \mathrm{~J}\right)$, which is a reduction of $64 \%$ from the pre-project baseline. Modifications of the OFA system resulted in an average emissions rate of $68 \mathrm{ppm}$, which is less than half of the levels measured previously. Emissions of $\mathrm{SO}_{2}$ were low, at $0.622 \mathrm{lb} / 10^{6} \mathrm{Btu}\left(267 \mathrm{mg} / 10^{6} \mathrm{~J}\right)$.

During a two week period in November, 1994, 100\% gas firing and Gas/Gas Reburning were tested over a cumulative period of 53 hours. The unit is capable of firing natural gas at a rate sufficient for full boiler load. Significant changes in emissions were measured since natural gas is free of fuel-bound nitrogen, sulfur, and ash, and because it has a lower carbon to hydrogen ratio. In $100 \%$ gas firing, $\mathrm{NO}_{x}$ emissions averaged $0.174 \mathrm{lb} / 10^{6} \mathrm{Btu}(75$ $\mathrm{mg} / 10^{6} \mathrm{~J}$ ), which is a reduction of $76 \%$ from the pre-project coal level. CO emissions averaged $123 \mathrm{ppm}$, while $\mathrm{CO}_{2}$ accounted for $10.1 \%$ of the flue gas volume. Emissions of $\mathrm{SO}_{2}$ were negligible. Gas/Gas Reburning was conducted with an average gas heat input of $6.11 \%$. This resulted in an average $\mathrm{NO}_{\mathrm{x}}$ emissions rate of $0.127 \mathrm{lb} / 10^{6} \mathrm{Btu}\left(55 \mathrm{mg} / 10^{6}\right.$ $\mathrm{J})$, corresponding to an $83 \%$ reduction from the pre-project coal baseline. CO emissions averaged $168 \mathrm{ppm}, \mathrm{CO}_{2}$ accounted for $10.1 \%$ of the flue gas volume, and there was virtually no $\mathrm{SO}_{2}$.

Limited measurements of $\mathrm{N}_{2} \mathrm{O}$ emissions were made during the Optimization Testing period. The results are presented in Table 6-2. The data indicate that LNB's result in a maximum $\mathrm{N}_{2} \mathrm{O}$ level of $5 \mathrm{ppm}$, while GR-LNB forms $\mathrm{N}_{2} \mathrm{O}$ at a level of $3 \mathrm{ppm}$. These are below the threshold level of $10 \mathrm{ppm}$ under which more extensive measurements were called for. Therefore the GR-LNB process does not increase the emissions of this species which is believed to result in depletion of stratospheric ozone.

The aqueous discharge to the South Platte River is regulated by the Colorado WQCD. Limits of the effluent discharge in the areas of flow rate, maximum temperature, minimum and maximum pH, Total Suspended Solids (TSS), Chromium, Zinc, Chlorine, Copper and Oil \& Grease are specified. Some parameters had no limits but required measurement and 
TABLE 6-2. MEASUREMENT OF $\mathrm{N}_{2} \mathrm{O}$ WITH LNB and GR-LNB OPERATION

\begin{tabular}{|c|c|c|c|c|c|c|}
\hline $\begin{array}{c}\text { Test } \\
\text { Date }\end{array}$ & $\begin{array}{c}\text { Test Duration } \\
\text { (hours) }\end{array}$ & $\begin{array}{c}\text { Operating } \\
\text { Condition }\end{array}$ & $\begin{array}{c}\text { Load } \\
(\mathrm{MWe}, \mathrm{net})\end{array}$ & $\begin{array}{c}\text { Gas Heat Input } \\
(\%, \text { total })\end{array}$ & $\begin{array}{c}\text { Boiler O2 } \\
(\%, \mathrm{dry})\end{array}$ & $\begin{array}{c}\text { Nitrous Oxide } \\
(\mathrm{ppm})\end{array}$ \\
\hline $4 / 15 / 93$ & 2.1 & LNB & 150 & 0 & 3.38 & 4.37 \\
$4 / 16 / 93$ & 6.0 & LNB & 150 & 0 & 4.05 & 5.14 \\
$4 / 19 / 93$ & 5.7 & GR-LNB & 150 & 20 & 4.19 & 3.33 \\
$4 / 20 / 93$ & 3.3 & LNB & 130 & 0 & 3.31 & 1.04 \\
$4 / 20 / 93$ & 2.8 & LNB & 120 & 0 & 4.51 & 1.01 \\
\hline
\end{tabular}


reporting of results. The limits varied with the monitoring period as the operating permit was adjusted. Oil \& Grease levels were never determined, since the measurement of this parameter is contingent upon visual observation of Oil \& Grease. The measurements as reported on the NPDES monitoring sheets are tabulated in Table 6-3. With the exception of one month in which the maximum temperature exceeded the $86^{\circ} \mathrm{F}$ limit, all aqueous discharge limits were met.

\subsection{Waste Streams and Their Disposal}

Limited characterization of fly ash was conducted to determine the extent of fuel burnout (carbon conversion). Fly ash was sampled with a high volume SLM sampler in the area of the air preheater exit. The fly ash was then analyzed for carbon content to evaluate combustion completion. Table 6-4 shows the results of these measurements. Ash carbon content was generally under $10 \%$. GR-LNB did not appear to impact the ash carbon level relative to that produced by LNB's.

The change in the quantity of fly ash generated was not measured. Since natural gas is free of ash, the change in quantity of total ash from the boiler should be equal to the gas heat input. Therefore, it was expected that ash disposal costs would be reduced by approximately 10 to $17 \%$, during the testing periods.

\subsection{Potential Environmental Concerns}

The major environmental concerns were in the areas of gaseous emissions from the boiler and the makeup of the aqueous discharge. The measurements presented above addressed these concerns, with the finding that the GR-LNB process did not adversely impact gaseous emissions or the aqueous discharge. In addition, other measurements were taken to ensure that the process did not affect the local environment. These include 
TABLE 6-3. AQUEOUS EFFLUENT MONITORING DATA

\begin{tabular}{|c|c|c|c|c|c|c|c|c|c|c|c|c|c|c|c|c|}
\hline \multirow{2}{*}{$\begin{array}{c}\text { Monitoring } \\
\text { Pcriod }\end{array}$} & \multirow{2}{*}{$\begin{array}{l}\text { Temp. } \\
\text { Max } \\
\text { (F) }\end{array}$} & \multicolumn{2}{|c|}{$\mathrm{pH}$} & \multicolumn{2}{|c|}{ TSS } & \multicolumn{2}{|c|}{ Chromiun } & \multicolumn{2}{|c|}{ Zinc } & \multicolumn{2}{|c|}{ Copper } & \multicolumn{2}{|c|}{ Flow } & \multicolumn{2}{|c|}{ Chlorine } & \multirow{2}{*}{$\begin{array}{c}\text { Oil \& Greasc } \\
\text { Visual } \\
\text { Ycs }=1 ; N o=0\end{array}$} \\
\hline & & Min & $\operatorname{Max}$ & $\begin{array}{c}\text { Avg } \\
(\mathrm{mg} /)\end{array}$ & $\begin{array}{l}\operatorname{Max} \\
(\mathrm{mg} / \mathrm{l})\end{array}$ & $\begin{array}{c}\text { Avg } \\
(m g /)\end{array}$ & $\begin{array}{l}\operatorname{Max} \\
(\mathrm{mg} / \mathrm{l})\end{array}$ & $\begin{array}{c}\text { Avg } \\
(\mathrm{mg} / \mathrm{l})\end{array}$ & $\begin{array}{r}\operatorname{Max} \\
(\mathrm{mg} / \mathrm{l}) \\
\end{array}$ & $\begin{array}{c}\text { Avg } \\
(\mathrm{mg} / \mathrm{n})\end{array}$ & $\begin{array}{l}\operatorname{Max} \\
(\mathrm{mg} / 1) \\
\end{array}$ & $\begin{array}{c}\text { Avg } \\
\text { (MGD) }\end{array}$ & $\begin{array}{c}\text { Max } \\
\text { (MGD) }\end{array}$ & $\begin{array}{l}\text { Avg } \\
(\mathrm{mg} / \mathrm{l}) \\
\end{array}$ & $\begin{array}{l}\operatorname{Max} \\
(\mathrm{mg} / \mathrm{l}) \\
\end{array}$ & \\
\hline Oct-92 & 75.5 & 6.890 & 8.430 & 14.400 & 19.200 & 0.007 & 0.007 & 0.027 & 0.027 & 0.044 & 0.044 & 2.413 & 3.320 & $<0.05$ & $<0.05$ & 0 \\
\hline Nov-92 & 60.5 & 6.950 & 8.180 & 3.500 & 6.400 & 0.031 & 0.031 & 0.030 & 0.030 & 0.026 & 0.026 & 2.301 & 4.360 & $<0.05$ & $<0.05$ & 0 \\
\hline Dec-92 & 54.2 & 7.290 & 8.100 & 6.400 & 9.600 & $<0.005$ & $<0.005$ & 0.023 & 0.023 & 0.021 & 0.021 & 3.094 & 4.770 & $<0.05$ & $<0.05$ & 0 \\
\hline $\operatorname{Jan}-93$ & 58.4 & 7.070 & 7.640 & 12.800 & 16.400 & $<0.005$ & $<0.005$ & 0.038 & 0.038 & 0.038 & 0.038 & 3.008 & 3.920 & $<0.05$ & $<0.05$ & 0 \\
\hline Feb-93 & 59.0 & 7.060 & 7.790 & 5.200 & 8.800 & $<0.005$ & $<0.005$ & 0.038 & 0.038 & 0.033 & 0.033 & 3.064 & 4.770 & $<0.05$ & $<0.05$ & 0 \\
\hline Mar-93 & 69.1 & 7.220 & 8.610 & 8.400 & 11.600 & $<0.005$ & $<0.005$ & 0.029 & 0.029 & 0.057 & 0.057 & 2.745 & 3.818 & $<0.05$ & $<0.05$ & 0 \\
\hline Apr-93 & 69.2 & 7.350 & 8.160 & 12.200 & 18.200 & $<0.005$ & $<0.005$ & 0.018 & 0.018 & 0.038 & 0.038 & 1.981 & 3.420 & $<0.05$ & $<0.05$ & 0 \\
\hline May-93 & 81.4 & 6.940 & 7.940 & 14.050 & 18.400 & $<0.005$ & $<0.005$ & 0.029 & 0.029 & 0.031 & 0.031 & 2.291 & 4.186 & $<0.05$ & $<0.05$ & 0 \\
\hline Jun-93 & 84.1 & 6.630 & 8.130 & 11.750 & 16.400 & $<0.005$ & $<0.005$ & 0.026 & 0.026 & 0.017 & 0.017 & 1.797 & 2.720 & $<0.05$ & $<0.05$ & 0 \\
\hline Limit & 86.0 & 6.500 & 9.000 & 30.000 & 100.000 & 0.110 & 0.110 & 0.230 & 0.460 & Report & Report & 5.600 & & 0.007 & 0.015 & \\
\hline
\end{tabular}

Note: 30 day averages, daily maxima 
TABLE 6-3. AQUEOUS EFFLUENT MONITORING DATA (con't).

\begin{tabular}{|c|c|c|c|c|c|c|c|c|c|c|c|c|c|c|c|c|c|c|c|c|c|c|c|c|c|}
\hline \multirow{2}{*}{$\begin{array}{c}\text { Monitoring } \\
\text { Period }\end{array}$} & \multicolumn{2}{|c|}{ Temperature } & \multicolumn{2}{|c|}{$\mathrm{pH}$} & \multicolumn{2}{|c|}{ TSS } & \multicolumn{2}{|c|}{ N/Ammonia } & \multicolumn{2}{|c|}{ N/Nitrate } & \multicolumn{2}{|c|}{ Phosphorus } & \multicolumn{2}{|c|}{ Cr/Trivalent } & \multicolumn{2}{|c|}{ Zinc } & \multicolumn{2}{|c|}{ Conper } & \multicolumn{2}{|c|}{ Cr/Hexavient } & \multicolumn{2}{|c|}{ Fow } & \multicolumn{2}{|c|}{ Chlorine } & \multirow{2}{*}{$\begin{array}{c}\text { Oil \& Grease } \\
\text { Visual } \\
\text { Yes }=1, \text { No }=0\end{array}$} \\
\hline & $\begin{array}{l}\text { Avg } \\
\text { (F) }\end{array}$ & Max & Min & $\operatorname{Max}$ & $\begin{array}{c}\text { Avg } \\
(m g / \Omega)\end{array}$ & $\begin{array}{l}\operatorname{Max} \\
(\mathrm{mg} /)\end{array}$ & $\begin{array}{c}\mathrm{Avg} \\
(\mathrm{mg} / \mathrm{N})\end{array}$ & $\begin{array}{l}\text { Max } \\
(\mathrm{mg} / \mathrm{I})\end{array}$ & $\begin{array}{c}\mathrm{Avg} \\
(\mathrm{mg} /)\end{array}$ & $\begin{array}{c}\operatorname{Max} \\
(\mathrm{mg} / 2)\end{array}$ & $\begin{array}{l}A \mathrm{vg} \\
(\mathrm{mg} /\end{array}$ & $\begin{array}{l}\operatorname{Max} \\
(\mathrm{mg} /)\end{array}$ & $\begin{array}{c}\mathrm{Avg} \\
(\mathrm{mg} /)\end{array}$ & $\begin{array}{c}\operatorname{Max} \\
(\mathrm{mg} / \mathrm{N})\end{array}$ & $\begin{array}{c}\Lambda \mathrm{vg} \\
(\mathrm{mg} \Omega)\end{array}$ & $\begin{array}{l}\operatorname{Max} \\
(\mathrm{mg} \Omega)\end{array}$ & $\begin{array}{l}\text { Avg } \\
(\mathrm{mg} /)\end{array}$ & $\begin{array}{l}\mathrm{Max} \\
(\mathrm{mg} / \mathrm{A})\end{array}$ & $\left|\begin{array}{c}A v g \\
(m g /)\end{array}\right|$ & $\begin{array}{l}\mathrm{Max} \\
(\mathrm{mg}, 1)\end{array}$ & $\begin{array}{l}\text { Avg } \\
\text { (MGD }\end{array}$ & $\operatorname{Max}$ & $\begin{array}{c}\mathrm{Avg} \\
(\mathrm{mg} \Omega)\end{array}$ & $\begin{array}{l}M \mathrm{ax} \\
(\mathrm{mg} /)\end{array}$ & \\
\hline Jul-93 & 80.38 & 85.50 & 6.78 & 7.64 & 17.84 & 31.60 & 0.24 & 0.24 & 4.20 & 4.20 & 0.40 & 0.40 & $<0.03$ & $<0.03$ & 0.031 & 0.039 & 0.033 & 0.055 & $<0.025$ & $<0.025$ & 1.96 & 3.28 & $<0.05$ & $<0.05$ & 0 \\
\hline Aug-93 & 78.51 & 3.30 & 6.95 & 7.79 & 18.84 & 27.80 & 0.07 & 0.07 & 10.40 & 10.40 & 0.60 & 0.60 & $<0.03$ & $<0.03$ & 0.076 & 0.134 & 0.042 & 0.049 & $<0.025 \mid$ & $<0.025$ & 2.12 & 3.75 & $<0.05$ & $<0.05$ & 0 \\
\hline Sep-93 & 69.27 & 79.70 & 7.10 & 7.69 & 7.00 & 7.40 & 0.11 & 0.11 & 10.60 & 10.60 & 0.30 & 0.30 & $<0.03$ & $<0.03$ & 0.035 & 0.048 & 0.025 & 0.034 & $<0.025$ & $<0.025$ & 1.83 & 3.75 & $<0.05$ & $<0.05$ & 0 \\
\hline Oct-93 & 65.87 & 74.50 & 6.74 & 7.75 & 13.20 & 21.20 & 0.20 & 0.20 & 12.30 & 12.30 & 0.95 & 0.95 & $<0.03$ & $<0.03$ & 0.043 & 0.060 & 0.032 & 0.043 & $<0.025 \mid$ & $<0.025$ & 2.19 & 3.66 . & $<0.05$ & $<0.05$ & 0 \\
\hline Nov-93 & 52.20 & 58.20 & 6.96 & 7.75 & 12.03 & 14.00 & 0.19 & 0.19 & 10.70 & 10.70 & 0.68 & 0.68 & $<0.03$ & $<0.03$ & 0.043 & 0.059 & 0.029 & 0.040 & $<0.025$ & $<0.025$ & 1.90 & 3.75 & $<0.05$ & $<0.05$ & 0 \\
\hline Dec-93 & 52.29 & 55.80 & 6.69 & 7.70 & 10.38 & 16.40 & 0.18 & 0.18 & 12.43 & 12.43 & 0.68 & 0.68 & $<0.03$ & $<0.03$ & 0.045 & 0.051 & 0.053 & 0.079 & $<0.025$ & $<0.025$ & 2.35 & 3.92 & $<0.05$ & $<0.05$ & 0 \\
\hline Jan-94 & 54.50 & 56.90 & 7.19 & 7.96 & 20.40 & 32.40 & 0.75 & 0.75 & 14.10 & 14.10 & 1.43 & 1.43 & $<0.03$ & $<0.03$ & 0.067 & 0.098 & 0.066 & 0.072 & $<0.025$ & $<0.025$ & 2.86 & 4.30 & $<0.05$ & $<0.05$ & 0 \\
\hline Feb-94 & 53.65 & 67.80 & 7.15 & 7.66 & 11.28 & 15.60 & 0.39 & 0.39 & 16.99 & 16.99 & 1.42 & 1.42 & $<0.03$ & $<0.03$ & 0.065 & 0.088 & 0.061 & 0.081 & $<0.025$ & $<0.025$ & 2.42 & 4.03 & $<0.05$ & $<0.05$ & 0 \\
\hline Mar-94 & 61.83 & 68.00 & 6.98 & 7.75 & 17.70 & 22.00 & 0.35 & 0.35 & 12.62 & 12.62 & 0.85 & 0.85 & $<0.03$ & $<0.03$ & 0.042 & 0.047 & 0.038 & 0.043 & $|<0.025|$ & $\mid<0.025$ & 2.50 & 3.76 & $<0.05$ & $<<.05$ & 0 \\
\hline Apr-94 & 65.15 & 74.60 & 7.09 & 7.76 & 19.65 & 23,60 & 0.19 & 0.19 & 12.37 & 12.37 & 1.13 & 1.13 & $<0.03$ & $<0.03$ & 0.067 & 0.105 & 0.068 & 0.115 & $|<0.025|$ & $<0.025$ & 2.62 & 3.74 & $<0.05$ & $<0.05$ & 0 \\
\hline May-94 & 68.45 & 75.60 & 7.10 & 7.62 & 20.56 & 35.60 & 0.18 & 0.18 & 7.88 & 7.88 & 0.56 & 0.56 & $<0.03$ & $<0.03$ & 0.035 & 0.045 & 0.029 & 0.040 & $<0.025$ & $<0.025$ & 1.91 & 2.66 & $<0.05$ & $<0.05$ & 0 \\
\hline Jun-94 & 79.85 & 84.90 & 6.76 & 7.54 & 10.20 & 19.80 & 0.10 & 0.10 & 2.15 & 2.15 & 0.20 & 0.20 & $<0.03$ & $<0.03$ & 0.031 & 0.080 & 0.022 & 0.027 & $<0.025$ & $<0.025$ & 2.43 & 3.14 & $<0.05$ & $<0.05$ & 0 \\
\hline Jul-94 & 76.88 & 84.60 & 6.86 & 8.19 & 7.05 & 8.00 & 0.19 & 0.19 & 5.06 & 5.06 & 0.27 & 0.27 & $<0.03$ & $<0.03$ & 0.036 & 0.054 & 0.020 & 0.031 & $<0.025$ & $<0.025$ & 2.23 & 3.96 & $<0.05$ & $<0.05$ & 0 \\
\hline Aug-94 & 80.90 & 86.80 & 6.86 & 8.11 & 6.48 & 11.60 & 0.28 & 0.28 & 13.35 & 13.35 & 0.33 & 0.33 & $<0.03$ & $<0.03$ & 0.041 & 0.068 & 0.033 & 0.045 & $|<0.025|$ & $<0.025$ & 2.08 & 3.52 & $<0.05$ & $<0.05$ & 0 \\
\hline Sep-94 & 74.28 & 79.70 & 6.96 & 8.00 & 8.00 & 13.00 & 0.21 & 0.21 & 12.95 & 12.95 & 0.20 & 0.20 & $<0.006$ & 0.009 & 0.066 & 0.089 & 0.044 & 0.051 & $<0.025 \mid$ & $<0.025$ & 1.38 & 2.33 & $<0.05$ & $<0.05$ & 0 \\
\hline Ocl-94 & 68.67 & 73.80 & 7.05 & 7.64 & 7.40 & 16.00 & 0.27 & 0.27 & $\mid 18.14$ & $\mid 18.14$ & 0.29 & 0.29 & $<0.007$ & 0.014 & 0.057 & 0.069 & 0.035 & 10.049 & $\mid<0.025$ & $<0.025$ & 1.65 & 2.73 & $<0.05 \mid$ & $<0.05$ & 0 \\
\hline Nov-94 & 58.61 & 65.30 & 7.20 & 7.94 & 10.00 & 14.00 & 0.23 & 0.23 & 21.03 & 21.03 & 0.23 & 0.23 & $<0.0058$ & 0.007 & 0.027 & 0.046 & 0.040 & 0.047 & $<0.025$ & $<0.025$ & 1.86 & 3.22 & $<0.05$ & $<0.05$ & 0 \\
\hline Dec-94 & 56.10 & 64.30 & 7.22 & 7.75 & 13.50 & 21.00 & $<0.02$ & $<0.02$ & 13.50 & 13.50 & 0.43 & 0.43 & $<0.0055$ & 0.007 & 0.032 & 0.045 & 0.043 & 0.043 & $<0.025$ & $<0.025$ & 1.89 & 2.96 & $<0.05$ & $<0.05$ & 0 \\
\hline Jan-95 & 54.93 & 58.80 & 6.89 & 7.83 & 13.40 & 17.00 & 0.52 & 0.52 & 21.90 & 21.90 & 0.53 & 0.53 & $<0.005$ & $<0.005$ & 0.036 & 0.086 & 0.025 & 0.053 & $\mid<0.025$ & $<0.025$ & 1.75 & 2.59 & $<0.05$ & $<0.05$ & 0 \\
\hline Limit & prt & 86.00 & 6.50 & 9.00 & $30 . \infty$ & 84.00 & Rprt & Rprt & Rprt & Rprt & Rprt & Rprt & $\mathrm{ptt}$ & 0.055 & 0.350 & 0.400 & 0.120 & 0.240 & Rprt & 0.018 & 3.10 & 5.50 & & 0.02 & \\
\hline
\end{tabular}


TABLE 6-4. UNIT \#3 FLY ASH CARBON DATA

\begin{tabular}{|c|c|c|c|c|c|c|c|c|c|c|}
\hline $\begin{array}{c}\text { Test } \\
\text { Condition }\end{array}$ & $\begin{array}{l}\text { Test } \\
\text { Date }\end{array}$ & $\begin{array}{l}\text { Gross } \\
\text { Power } \\
\text { (MWe) }\end{array}$ & $\begin{array}{c}\text { Net } \\
\text { Power } \\
(\mathrm{MWe})\end{array}$ & $\begin{array}{c}\text { CEMS } \\
02 \\
(\%, d r y) \\
\end{array}$ & $\begin{array}{c}\text { Gas } \\
\text { Heat } \\
(\%, \text { totl }) \\
\end{array}$ & $\begin{array}{l}\text { Coal } \\
\text { Zone } \\
\text { Stoich }\end{array}$ & $\begin{array}{l}\text { Reburn } \\
\text { Zone } \\
\text { Stoich } \\
\end{array}$ & $\begin{array}{l}\text { Exit } \\
\text { Zone } \\
\text { Stoich }\end{array}$ & OFA & $\begin{array}{c}\text { Carbon } \\
\text { In-Ash } \\
\text { (\%, As Rcvd) }\end{array}$ \\
\hline INB & $11 / 13 / 92$ & 166 & 155 & 4.41 & 0.00 & 1.259 & 1.259 & 1.259 & $0 \%$ & 3.54 \\
\hline LNB & $11 / 13 / 92$ & 162 & 151 & 4.18 & 0.00 & 1.182 & 1.184 & 1.242 & $5 \%$ & 7.47 \\
\hline LNB & $11 / 13 / 92$ & 162 & 151 & 3.75 & 0.00 & 1.098 & 1.100 & 1.212 & $9 \%$ & 11.43 \\
\hline GR-INB & $11 / 17 / 92$ & 162 & 150 & 3.52 & 20.86 & 1.201 & 0.965 & 1.194 & $20 \%$ & 4.18 \\
\hline GR-INB & $11 / 17 / 92$ & 161 & 150 & 3.57 & 21.08 & 1.162 & 0.932 & 1.197 & $23 \%$ & 2.71 \\
\hline GR-LNB & $11 / 18 / 92$ & 162 & 151 & 3.67 & 20.94 & 1.161 & 0.933 & 1.204 & $24 \%$ & 2.85 \\
\hline GR-LNB & $11 / 18 / 92$ & 161 & 149 & 3.79 & 15.96 & 1.117 & 0.953 & 1.213 & $23 \%$ & 3.27 \\
\hline GR-LNB & $11 / 19 / 92$ & 160 & 149 & 3.12 & 5.27 & 1.074 & 1.025 & 1.170 & $13 \%$ & 10.24 \\
\hline GR-INB & $11 / 19 / 92$ & 163 & 152 & 2.64 & 10.33 & 1.071 & .0 .969 & 1.139 & $15 \%$ & 7.82 \\
\hline GR-LNB & $11 / 19 / 92$ & 161 & 150 & 2.83 & 23.41 & 1.127 & 0.879 & 1.150 & $24 \%$ & 2.77 \\
\hline GR-INB & $11 / 20 / 92$ & 161 & 150 & 2.66 & 18.61 & 1.091 & 0.897 & 1.140 & $22 \%$ & 4.34 \\
\hline GR-LNB & $11 / 20 / 92$ & 161 & 150 & 3.60 & 20.51 & 1.156 & 0.933 & 1.199 & $24 \%$ & 4.93 \\
\hline GR-INB & $12 / 1 / 92$ & 129 & 120 & 4.07 & 21.03 & 1.165 & 0.937 & 1.231 & $25 \%$ & 2.75 \\
\hline GR-LNB & $12 / 1 / 92$ & 126 & 116 & 5.26 & 8.24 & 1.129 & 1.052 & 1.324 & $22 \%$ & 6.77 \\
\hline GR-INB & $12 / 7 / 92$ & 130 & 119 & 4.12 & 11.40 & 1.110 & 0.999 & 1.236 & $20 \%$ & 3.95 \\
\hline GR-INB & $12 / 7 / 92$ & 129 & 119 & 4.03 & 15.70 & 1.100 & 0.942 & 1.229 & $24 \%$ & 2.47 \\
\hline GR-LNB & $12 / 7 / 92$ & 130 & 119 & 3.90 & 20.85 & 1.119 & 0.903 & 1.219 & $27 \%$ & 1.62 \\
\hline GR-LNB & $12 / 8 / 92$ & 100 & 90 & 3.87 & 21.01 & 1.227 & 0.990 & 1.217 & $20 \%$ & 3.98 \\
\hline GR-LNB & $12 / 8 / 92$ & 98 & 88 & 5.10 & 21.24 & 1.164 & 0.941 & 1.308 & $30 \%$ & 1.22 \\
\hline GR-LNB & $12 / 8 / 92$ & 101 & 91 & 4.17 & 11.13 & 1.128 & 1.021 & 1.240 & $19 \%$ & 3.84 \\
\hline GR-LNB & $12 / 9 / 92$ & 99 & 89 & 4.68 & 20.87 & 1.097 & 0.891 & 1.275 & $32 \%$ & 1.77 \\
\hline GR-INB & $12 / 9 / 92$ & 102 & 92 & 4.19 & 20.99 & 1.106 & 0.896 & 1.239 & $29 \%$ & 10.29 \\
\hline GR-INB & $12 / 14 / 92$ & 159 & 150 & 3.87 & 5.42 & 1.085 & 1.035 & 1.219 & $16 \%$ & 8.75 \\
\hline GR-LNB & $12 / 16 / 92$ & 161 & 152 & 3.75 & 10.38 & 1.096 & 0.994 & 1.210 & $19 \%$ & 6.68 \\
\hline GR-INB & $1 / 15 / 93$ & 163 & 152 & 3.38 & 21.76 & 1.155 & 0.920 & 1.184 & $23 \%$ & 4.69 \\
\hline GR-LNB & $1 / 21 / 93$ & 163 & 152 & 3.15 & 22.48 & 1.137 & 0.896 & 1.168 & $24 \%$ & 3.51 \\
\hline
\end{tabular}


TABLE 6-4. UNIT \#3 FLY ASH CARBON DATA (con't)

\begin{tabular}{|c|c|c|c|c|c|c|c|c|c|c|}
\hline $\begin{array}{c}\text { Test } \\
\text { Condition }\end{array}$ & $\begin{array}{l}\text { Test } \\
\text { Date }\end{array}$ & $\begin{array}{l}\text { Gross } \\
\text { Power } \\
\text { (MWe) }\end{array}$ & $\begin{array}{l}\text { Net } \\
\text { Power } \\
(M W e) \\
\end{array}$ & $\begin{array}{c}\text { CEMS } \\
02 \\
(\%, d r y) \\
\end{array}$ & $\begin{array}{c}\text { Gas } \\
\text { Heat } \\
(\%, \text { totl }) \\
\end{array}$ & $\begin{array}{l}\text { Coal } \\
\text { Zone } \\
\text { Stoich } \\
\end{array}$ & $\begin{array}{c}\text { Reburn } \\
\text { Zone } \\
\text { Stoich } \\
\end{array}$ & $\begin{array}{l}\text { Exit } \\
\text { Zone } \\
\text { Stoich }\end{array}$ & OFA & $\begin{array}{c}\text { Carbon } \\
\text { In-Ash } \\
(\%, \text { As Rcvd })\end{array}$ \\
\hline GR-LNB & $2 / 2 / 93$ & 163 & 152 & 2.44 & 19.32 & 1.067 & 0.872 & 1.125 & $23 \%$ & 11.47 \\
\hline LNB & $3 / 8 / 93$ & 126 & 117 & 3.92 & 0.00 & 1.223 & 1.225 & 1.223 & $0 \%$ & 11.23 \\
\hline LNB & $3 / 8 / 93$ & 126 & 118 & 3.75 & 0.00 & 1.212 & 1.214 & 1.212 & $0 \%$ & 8.63 \\
\hline LNB & $3 / 9 / 93$ & 161 & 151 & 4.11 & 0.00 & 1.238 & 1.239 & 1.238 & $0 \%$ & 4.87 \\
\hline LNB & $3 / 9 / 93$ & 157 & 147 & 3.58 & 0.00 & 1.201 & 1.202 & 1.201 & $0 \%$ & 6.09 \\
\hline LNB & $3 / 10 / 93$ & 97 & 89 & 5.04 & 0.00 & 1.308 & 1.308 & 1.308 & $0 \%$ & 4.13 \\
\hline INB & $3 / 10 / 93$ & 98 & 90 & 4.61 & 0.00 & 1.274 & 1.274 & 1.274 & $0 \%$ & 4.81 \\
\hline INB & $3 / 11 / 93$ & 159 & 149 & 3.75 & 0.00 & 1.212 & 1.212 & 1.212 & $0 \%$ & 5.99 \\
\hline LNB & $3 / 11 / 93$ & 160 & 150 & 3.36 & 0.00 & 1.186 & 1.186 & 1.186 & $0 \%$ & 7.20 \\
\hline LNB & $4 / 23 / 93$ & 160 & 149 & 3.58 & 0.00 & 1.201 & 1.203 & 1.201 & $0 \%$ & 9.81 \\
\hline LNB & $4 / 23 / 93$ & 157 & 147 & 2.93 & 0.00 & 1.158 & 1.160 & 1.158 & $0 \%$ & 8.00 \\
\hline GR-INB & $11 / 9 / 93$ & 162 & 150 & 3.26 & 14.57 & 1.077 & 0.932 & 1.178 & $21 \%$ & 5.15 \\
\hline GR-INB & $11 / 10 / 93$ & 161 & 148 & 3.62 & 11.46 & 1.086 & 0.972 & 1.202 & $19 \%$ & $6.69,8.69$ \\
\hline LNB & $11 / 10 / 93$ & 158 & 146 & 3.36 & 0.00 & 1.186 & 1.186 & 1.186 & $0 \%$ & 4.41 \\
\hline GR-INB & $9 / 7 / 94$ & 150 & 138 & 4.94 & 10.17 & 1.174 & 1.059 & 1.296 & $18 \%$ & 4.12 \\
\hline GR-LNB & $9 / 7 / 94$ & 149 & 138 & 4.19 & 10.17 & 1.106 & 0.998 & 1.241 & $20 \%$ & 1.16 \\
\hline GR-LNB & $9 / 7 / 94$ & 150 & 138 & 4.07 & 10.20 & 1.096 & 0.989 & 1.231 & $20 \%$ & 3.56 \\
\hline LNB & $9 / 8 / 94$ & 149 & 138 & 4.31 & 0.00 & 1.251 & 1.251 & 1.251 & $0 \%$ & 5.11 \\
\hline GR-LNB & $9 / 8 / 94$ & 150 & 139 & 3.97 & 16.61 & 1.210 & 1.016 & 1.225 & $17 \%$ & 5.03 \\
\hline LNB & $1 / 24 / 95$ & 157 & 144 & 4.59 & 0.00 & 1.266 & 1.266 & 1.273 & $1 \%$ & 7.87 \\
\hline GR-LNB & $1 / 25 / 95$ & 159 & 146 & 2.98 & 14.25 & 1.055 & 0.909 & 1.160 & $22 \%$ & 7.01 \\
\hline GR-LNB & $1 / 26 / 95$ & 159 & 146 & 2.92 & 13.69 & 1.042 & 0.903 & 1.156 & $22 \%$ & 9.98 \\
\hline
\end{tabular}

Note: 9/7/94 Through 1/26/95 Data From Second-Generation GR-LNB System 
ambient air $\mathrm{PM}_{10}$ levels both downwind and upwind of the facility, worker area dust levels, and worker area noise levels.

Worker area dust levels were measured in several levels of the boiler house. The measurements were made using an Gilian Instruments Pump to ensure that the Department of Labor's Occupational Safety and Health Association (OSHA) standard of $15 \mathrm{mg} / \mathrm{m}^{3}$ was met. Table 6-5 shows the results, with very low dust levels determined. Ambient air sampling was conducted at the periphery of the plant at both upwind and downwind locations using General Metal high volume air samplers.

The results, including the plant contribution to $\mathrm{PM}_{10}$, are shown in Table 6-6. The plant contribution to ambient $\mathrm{PM}_{10}$ levels was small, with a maximum of $38 \mu \mathrm{g} / \mathrm{m}^{3}$. There was no correlation with either GR-LNB or LNB operation. Worker area noise levels were measured in several levels of the boiler house with a Larson Davis Model 710 Dosimeter. These were used to determine if the OSHA standard of 85 decibels, averaged over 8 hours, was exceeded. The measurements listed in Table 6-7 indicate that this level was exceeded in some areas. Therefore, audiometric protection would be required for workers spending lengthy periods in these areas. 
TABLE 6-5. WORKER AREA DUST LEVELS

\begin{tabular}{|c|c|c|c|c|c|c|}
\hline Test I.D. & $\begin{array}{l}\text { Sampling } \\
\text { Location }\end{array}$ & Datc & $\begin{array}{l}\text { Dust Collected } \\
\text { (mg) }\end{array}$ & $\begin{array}{l}\text { Time } \\
(\min )\end{array}$ & $\begin{array}{c}\text { Flow Rate, Avg. } \\
(1 / \mathrm{min})\end{array}$ & $\begin{array}{c}\text { Concentration } \\
\text { milligram/cubic meter }\end{array}$ \\
\hline Basclinc REP 1 & Sicmans Fan on & $1 / 26 / 93$ & 0.00 & 240 & 2.223 & 0.000 \\
\hline Bascline REP 2 & Ground Level & $1 / 29 / 93$ & 0.09 & 184 & 2.464 & 0.198 \\
\hline GR REP 1 & & $1 / 27 / 93$ & 0.01 & 180 & 2.219 & 0.025 \\
\hline Bascline REP 1 & 4th Floor, at & $1 / 26 / 93$ & 0.00 & 240 & 2.367 & 0.000 \\
\hline Bascline REP 2 & Gas Hcader & $1 / 29 / 93$ & 0.01 & 180 & 2.219 & 0.025 \\
\hline GR REP 1 & & $1 / 27 / 93$ & 0.02 & 180 & 2.406 & 0.046 \\
\hline Basclinc REP 1 & 5th Floor, Back & $1 / 27 / 93$ & 0.00 & 240 & 2.425 & 0.000 \\
\hline Basclinc REP 2 & Part of Injection & $1 / 28 / 93$ & 0.02 & 180 & 2.404 & 0.046 \\
\hline GR REP 1 & Arca (left of Elcv.) & $1 / 27 / 93$ & 0.11 & 213 & 2.397 & 0.215 \\
\hline Basclinc REP 1 & 5th Floor, Front & $1 / 27 / 93$ & 0.00 & 240 & 2.214 & 0.000 \\
\hline Bascline REP 2 & Part of Injection & $1 / 28 / 93$ & 0.04 & 180 & 2.247 & 0.099 \\
\hline GR REP 1 & Area (Right of Elcv.) & $1 / 27 / 93$ & 0.05 & 214 & 2.226 & 0.105 \\
\hline Baseline REP 1 & 5.5 Floor, Nozzlc & $1 / 28 / 93$ & 0.00 & 190 & 2.248 & 0.000 \\
\hline Bascline REP 2 & Cooling Fans & $1 / 29 / 93$ & 0.00 & 180 & 2.450 & 0.000 \\
\hline Baseline REP 1 & 6th Floor, Above & $1 / 28 / 93$ & 0.00 & 190 & 2.430 & 0.000 \\
\hline Baseline REP 2 & FGR Inlet & $1 / 29 / 93$ & 0.20 & 180 & 2.248 & 0.494 \\
\hline Bascline REP 1 & CEM Trailer Inside & $1 / 28 / 93$ & 0.05 & 247 & 2.413 & 0.084 \\
\hline Bascline REP 1 & CEM Trailer Outside & $1 / 28 / 93$ & 0.96 & 247 & 2.256 & 1.720 \\
\hline
\end{tabular}

Mcasurements Listed Are in Order of Elcvation (Ground Level First) 
TABLE 6-6. AMBIENT DUST LEVELS OUTSIDE OF PLANT

\begin{tabular}{|c|c|c|c|c|c|c|c|c|}
\hline \multicolumn{2}{|c|}{ Sampling Date } & \multicolumn{2}{|c|}{ Sampling Time } & \multirow{2}{*}{$\begin{array}{c}\text { Filter } \\
\text { Number }\end{array}$} & \multirow[t]{2}{*}{ Test I.D. } & \multirow{2}{*}{$\begin{array}{l}\text { Sampling } \\
\text { Location }\end{array}$} & \multirow{2}{*}{$\begin{array}{c}\text { TSP }<\text { PM10 } \\
\text { micrograms/cubic meter }\end{array}$} & \multirow{2}{*}{$\begin{array}{c}\text { Plant Contribution } \\
\text { micrograms/cubic meter }\end{array}$} \\
\hline Start & Finish & Start & Finish & & & & & \\
\hline $1 / 25 / 93$ & $1 / 25 / 93$ & $9: 00$ & $15: 02$ & 2000 & GR REP 1 & Upwind & 110.1 & \\
\hline $1 / 25 / 93$ & $1 / 25 / 93$ & 9:00 & $15: 12$ & 2001 & & Downwind & 148.2 & 38.1 \\
\hline $1 / 25 / 93$ & $1 / 26 / 93$ & $15: 05$ & $8: 00$ & 2003 & Bascline REP 1 & Upwind & 100.7 & \\
\hline $1 / 25 / 93$ & $1 / 26 / 93$ & $15: 15$ & $7: 53$ & 2002 & & Downwind & 118.6 & 17.9 \\
\hline $1 / 26 / 93$ & $1 / 26 / 93$ & $8: 16$ & $14: 45$ & 2004 & GR REP 2 & Upwind & 61.8 & \\
\hline $1 / 26 / 93$ & $1 / 26 / 93$ & $8: 15$ & $14: 55$ & 2005 & & Downwind & 77.2 & 15.4 \\
\hline $1 / 26 / 93$ & $1 / 27 / 93$ & $14: 52$ & $8: 25$ & 2006 & Baseline REP 2 & Upwind & 70.7 & \\
\hline $1 / 26 / 93$ & $1 / 27 / 93$ & $15: 00$ & $8: 15$ & 2007 & & Downwind & 77.2 & 6.5 \\
\hline $1 / 27 / 93$ & $1 / 27 / 93$ & $9: 28$ & $15: 28$ & 2009 & GR REP 3 & Upwind & 77.5 & \\
\hline $1 / 27 / 93$ & $1 / 27 / 93$ & $9: 23$ & $15: 23$ & 2008 & & Downwind & 93.1 & 15.6 \\
\hline $1 / 27 / 93$ & $1 / 28 / 93$ & $15: 40$ & $7: 56$ & 2010 & Baseline REP 3 & Upwind & 94.6 & \\
\hline $1 / 27 / 93$ & $1 / 28 / 93$ & $15: 30$ & $7: 46$ & 2011 & & Downwind & 105.6 & 11 \\
\hline $1 / 28 / 93$ & $1 / 28 / 93$ & $8: 01$ & $14: 38$ & 2013 & Basclinc REP 4 & Upwind & 35 & \\
\hline $1 / 28 / 93$ & $1 / 28 / 93$ & 8:05 & $14: 45$ & 2012 & & Downwind & 24.7 & -10.3 \\
\hline $1 / 28 / 93$ & $1 / 29 / 93$ & $14: 41$ & $10: 00$ & 2015 & Baseline REP 5 & Upwind & 21.3 & \\
\hline $1 / 28 / 93$ & $1 / 29 / 93$ & $14: 51$ & $10: 00$ & 2014 & & Downwind & 23.3 & 2 \\
\hline
\end{tabular}




\begin{tabular}{|c|c|c|c|}
\hline Test I.D. & $\begin{array}{c}\text { Measurement } \\
\text { Location }\end{array}$ & Date & $\begin{array}{c}\text { Noise Level } \\
(\mathrm{db})\end{array}$ \\
\hline Baseline REP 1 & Siemans Fan on & $1 / 26 / 93$ & 92 \\
Baseline REP 2 & Ground Level & $1 / 27 / 93$ & 90.4 \\
Baseline REP 3 & & $1 / 28 / 93$ & 89.4 \\
Baseline REP 4 & & $1 / 29 / 93$ & 92.4 \\
GR REP 1 & & $1 / 25 / 93$ & 91.4 \\
GR REP 2 & & $1 / 26 / 93$ & 91 \\
GR REP 3 & & $1 / 27 / 93$ & 91.9 \\
\hline Baseline REP 1 & 4th Floor, at & $1 / 26 / 93$ & 78.4 \\
Baseline REP 2 & Gas Header & $1 / 27 / 93$ & 78.4 \\
Baseline REP 3 & & $1 / 28 / 93$ & 79.9 \\
Baseline REP 4 & & $1 / 29 / 93$ & 77.9 \\
GR REP 1 & & $1 / 25 / 93$ & 90.6 \\
GR REP 2 & & $1 / 26 / 93$ & 84.9 \\
GR REP 3 & & $1 / 27 / 93$ & 89.4 \\
\hline Baseline REP 1 & 5th Floor, Scanner & $1 / 26 / 93$ & 81.9 \\
Baseline REP 2 & Cooling Fan (Maxon) & $1 / 27 / 93$ & 83.9 \\
Baseline REP 3 & & $1 / 28 / 93$ & 84.4 \\
Baseline REP 4 & & $1 / 29 / 93$ & 82.9 \\
GR REP 1 & & $1 / 25 / 93$ & 95.4 \\
GR REP 2 & & $1 / 26 / 93$ & 93 \\
GR REP 3 & & $1 / 27 / 93$ & 94.4 \\
\hline Baseline REP 1 & 5th Floor, Back Part & $1 / 26 / 93$ & 75.9 \\
Baseline REP 2 & of Injection Area & $1 / 27 / 93$ & 76.4 \\
Baseline REP 3 & (Left of Elevator) & $1 / 28 / 93$ & 78.4 \\
Baseline REP 4 & & $1 / 29 / 93$ & 75.9 \\
GR REP 1 & & $1 / 25 / 93$ & 94.4 \\
GR REP 2 & & $1 / 26 / 93$ & 92.9 \\
GR REP 3 & & $1 / 27 / 93$ & 92.9 \\
\hline
\end{tabular}


TABLE 6-7. NOISE LEVELS IN BOILER HOUSE (con't)

\begin{tabular}{|c|c|c|c|}
\hline Test I.D. & $\begin{array}{c}\text { Measurement } \\
\text { Location }\end{array}$ & Date & $\begin{array}{c}\text { Noise Level } \\
\text { (db) }\end{array}$ \\
\hline Baseline REP 1 & 5th Floor, Front Part & $1 / 26 / 93$ & 79.4 \\
Baseline REP 2 & of Injection Area & $1 / 27 / 93$ & 79.9 \\
Baseline REP 3 & (Right of Elevator) & $1 / 28 / 93$ & 79.9 \\
Baseline REP 4 & & $1 / 29 / 93$ & 79.1 \\
GR REP 1 & & $1 / 25 / 93$ & 97.9 \\
GR REP 2 & & $1 / 26 / 93$ & 93.9 \\
GR REP 3 & & $1 / 27 / 93$ & 95.4 \\
\hline Baseline REP 1 & 5.5 Floor, Nozzle & $1 / 26 / 93$ & 80 \\
Baseline REP 2 & Cooling Fans & $1 / 27 / 93$ & 80.8 \\
Baseline REP 3 & & $1 / 28 / 93$ & 83.4 \\
Baseline REP 4 & & $1 / 29 / 93$ & 80.4 \\
GR REP 1 & & $1 / 25 / 93$ & 89.9 \\
GR REP 2 & & $1 / 26 / 93$ & 89.9 \\
GR REP 3 & & $1 / 27 / 93$ & 90.4 \\
\hline Baseline REP 1 & 6th Floor, Above & $1 / 26 / 93$ & 81.9 \\
Baseline REP 2 & FGR Inlet & $1 / 27 / 93$ & 78.9 \\
Baseline REP 3 & & $1 / 28 / 93$ & 81 \\
Baseline REP 4 & & $1 / 29 / 93$ & 79.5 \\
GR REP 1 & & $1 / 25 / 93$ & 81.5 \\
GR REP 2 & & $1 / 26 / 93$ & 80.5 \\
GR REP 3 & & $1 / 27 / 93$ & 80.4 \\
\hline
\end{tabular}

Measurements Listed Are in Order of Elevation (Ground Level First) 


\subsection{ECONOMICS}




\subsection{ECONOMICS}

This section provides the estimated costs of installation, operation and performance for commercial installation of GR-LNB on a $300 \mathrm{MW}_{\mathrm{e}}$ wall-fired boiler. The estimate is based on mature technology; i.e., a so-called "nth" plant which incorporates process improvements resulting from experience gained in earlier installations. For a discussion on the actual costs involved in the $172 \mathrm{MW}_{\mathrm{e}}$ Cherokee demonstration see Section 3.0.

The capital and operating costs for the GR-LNB system for $\mathrm{NO}_{x}$ emissions reduction are based on a retrofit of a $300 \mathrm{MW}_{\mathrm{e}}$ wall-fired power plant. The degree of complexity regarding retrofit costs were factored based on the retrofit cost for the GR-LNB demonstration completed under this DOE contract.

\subsection{GR-LNB Economic Parameters}

The capital cost estimates presented summarize major equipment cost, approximate bulk material take-offs, and installation labor to arrive at direct construction costs. Construction indirects are added which include: field supervision, construction overhead and fee, and freight. In addition, costs for detailed engineering, project management, procurement, construction management, start-up, and contingency are included to develop the total installed system cost. All engineering and construction costs are representative of a turnkey contract arrangement. EER considers these estimates to be Class II, Preliminary Estimates. The estimates are expected to be representative of the actual cost $-10 \% /+15 \%$. This is based on the information available at this time which includes preliminary process design and conceptual engineering completed, recent major equipment quotes, bulk material takeoff's and average expected labor rates and productivity.

This section provides the basis for the estimating procedures, along with a list of assumptions used for estimating installation man-hours and costs. The cost estimates 
have been developed using the following sources of information for equipment pricing and for the development of labor costs:

- Richardson's Rapid System 1993 edition of Process Plant Construction Estimating Standards

- Questimate Cost Estimating software by Icarus Corp.

- Means Electrical Cost Data 1991 edition

- Vendor Quotations for Major Equipment

- $\quad$ EER's database of previous equipment purchases

Data from all of these sources were summarized using EER cost estimating software. Once the direct costs were determined, costs for field supervision, contractor overhead and fee, freight, engineering, project management, construction management, start-up, and contingency were added to determine the total installed cost. Table 7-1 shows the cost parameters for developing the capital cost of the installed retro-fit of the GR-LNB system on a $300 \mathrm{MW}_{\mathrm{e}}$ wall-fired unit. These values are commonly encountered in economic calculations and were used in recent studies of CCT processes by the U.S. Department of Energy. No changes were made to the parameters proposed by DOE.

\subsection{GR-LNB Capital Cost}

The design of the GR-LNB system included three integrated systems: 1) low $\mathrm{NO}_{x}$ burners, 2) natural gas injection and 3) OFA injection. It is further based on the Second Generation GR design wherein FGR is eliminated. Existing conventional burners are removed and replaced with low $\mathrm{NO}_{\mathrm{x}}$ burners. A natural gas header was assumed to exist at the station and a tie-in was made to this supply header to provide the natural gas for the GR system. The tie-in pipe supplied gas to a control and metering station and from this station natural gas was distributed to gas injection nozzles located above the low $\mathrm{NO}_{x}$ burners. The 


\section{TABLE 7-1. COST FACTORS}

\begin{tabular}{||l|c|c||}
\hline \multicolumn{1}{|c|}{ Item } & Units & Value \\
\hline Cost of debt & $\%$ & 8.5 \\
\hline Inflation rate & $\%$ & 4.0 \\
\hline Construction period & mos. & 9 \\
\hline Remaining life of power plant & - & 15 \\
\hline Year for cost presented in this report & - & 1996 \\
\hline Royalty allowance based on total process capital & $\%$ & 0.5 \\
\hline Capital charge factor - current dollars & - & 0.160 \\
\hline Capital charge factor - constant dollars & - & 0.124 \\
\hline O\&M cost levelization factor - current dollars & - & 1.314 \\
\hline O\&M cost levelization factor - constant dollars & - & 1.000 \\
\hline Power plant size & MW $(n e t)$ & 300 \\
\hline Power plant type & Wall-fired & - \\
\hline Power plant capacity factor & $\%$ & 65 \\
\hline Property Taxes and Insurance & $\%$ & 3 \\
\hline Sales tax rate & $\%$ & 5.0 \\
\hline Cost of freight & $\%$ & 2.0 \\
\hline Engineering/home office fees of total process capital & $\%$ & 10.0 \\
\hline
\end{tabular}

natural gas valve train, common to all of the injection nozzles, included flow metering and control equipment, and safety shut-off valves.

OFA was assumed supplied from the existing hot secondary combustion air windbox. The existing windbox pressure on a tangentially-fired units is normally inadequate, so booster fans were assumed required. The installation of the natural gas injectors and OFA ports 
requires furnace tubewall modifications. There are no unusual boiler access hindrances that would inhibit normal installation of equipment. No asbestos removal is required during installation. The reburning system is assumed to be installed during a normally scheduled plant outage, negating downtown costs. A list of the major equipment associated with the GR-LNB retro-fit in shown in Table 7-2. The sizes and quantities shown are for a standard $300 \mathrm{MW}_{\mathrm{e}}$ unit.

TABLE 7-2. MAJOR EQUIPMENT LIST

\begin{tabular}{|c|c|c|c|c|c|c|}
\hline \multirow{2}{*}{$\begin{array}{l}\text { Ttem } \\
\text { No. }\end{array}$} & \multirow[b]{2}{*}{ Item Name } & \multicolumn{2}{|c|}{ Number } & \multirow{2}{*}{$\begin{array}{c}\text { Unit } \\
\text { Capacity }\end{array}$} & \multirow{2}{*}{$\begin{array}{c}\text { Design } \\
\text { Conditions* }\end{array}$} & \multirow{2}{*}{$\begin{array}{l}\text { Material of } \\
\text { Construction }\end{array}$} \\
\hline & & In Use & Spare & & & \\
\hline 1 & Low NOx Burner & 30 & 0 & $\begin{array}{l}100 \times 10^{6} \\
\text { Btu/burner }\end{array}$ & & Steel \\
\hline $2 a$ & $\begin{array}{c}\text { Natural Gas } \\
\text { Delivery System } \\
\end{array}$ & 1 & 0 & $\begin{array}{l}3,840 \text { scfm } \\
60 \mathrm{psi}\end{array}$ & $\begin{array}{c}\text { National Electric Code } \\
\text { Class } 1 \text {, Division } 2\end{array}$ & Miscellaneous \\
\hline $2 b$ & $\begin{array}{c}\text { Natural Gas Cooling } \\
\text { Fan }\end{array}$ & 2 & 0 & $5,000 \mathrm{scfm}$ & & \\
\hline $2 c$ & Natural Gas Injector & 16 & 0 & $\begin{array}{l}240 \text { scfm/ } \\
\text { injector }\end{array}$ & & Steel \\
\hline $3 a$ & Overfire Air System & 1 & 0 & $200,000 \mathrm{scfm}$ & & Miscellaneous \\
\hline $3 b$ & $\begin{array}{c}\text { Overfire Air Booster } \\
\text { Fan }\end{array}$ & 1 & 0 & $200,000 \mathrm{scfm}$ & & \\
\hline $3 c$ & $\begin{array}{c}\text { Overfire Air Cooling } \\
\text { Fan }\end{array}$ & 5 & 0 & $20,000 \mathrm{scfm}$ & & \\
\hline $3 d$ & Overfire Air Injector & 8 & 0 & $\begin{array}{c}15,000 \mathrm{scfm} / \\
\text { injector }\end{array}$ & & Steel \\
\hline 4 & Control System & 1 & 0 & $\mathrm{n} / \mathrm{a}$ & & (Electronic) \\
\hline
\end{tabular}

Table 7-3 shows the major equipment costs. The total cost for the major equipment items of the GR-LNB system is $\$ 2.35$ million ( $\$ 2.5$ million for total equipment cost). Table $7-4$ presents the overall capital cost for the GR-LNB system. This cost includes both equipment and installation costs. The total cost, including a $15 \%$ project contingency, is estimated at $\$ 7.80$ million or $\$ 26.01 / \mathrm{kW}_{\mathrm{e}}$. The GR and LNB system capital costs can be easily separated from one another for they are independent systems. The capital cost for the GR system only is estimated at $\$ 3.64$ million or $\$ 12.14 / \mathrm{kW}_{\mathrm{e}}$, and the LNB system capital cost is estimated at $\$ 4.16$ million or $\$ 13.87 / \mathrm{kW}_{\mathrm{e}}$. 
TABLE 7-3. MAJOR EQUIPMENT COST

\begin{tabular}{|c|c|c|c|c|c|c|}
\hline \multirow[b]{2}{*}{$\begin{array}{l}\text { Item } \\
\text { No. }\end{array}$} & \multirow[b]{2}{*}{$\begin{array}{l}\text { Item } \\
\text { Name }\end{array}$} & \multicolumn{3}{|c|}{ Cost/Unit } & \multirow[b]{2}{*}{$\begin{array}{l}\text { No. of } \\
\text { Units }\end{array}$} & \multirow[b]{2}{*}{$\begin{array}{c}\text { Total } \\
\text { Cost } \\
\$ 1,000 \text { s }\end{array}$} \\
\hline & & $\begin{array}{c}\text { F.O.B. } \\
\text { Equipment }\end{array}$ & $\begin{array}{c}\text { Sales } \\
\text { Tax } \\
(5 \%)\end{array}$ & Total & & \\
\hline 1 & Low NOx Burners & 55.7 & 2.8 & 58.5 & 30 & $1,754.6$ \\
\hline $2 a$ & Natural Cooling Gas Fans & 4.5 & 0.2 & 4.7 & 2 & 9.5 \\
\hline $2 b$ & $\begin{array}{c}\text { Natural Gas Injectors \& } \\
\text { Tubewall Penetrations }\end{array}$ & 5.1 & 0.3 & 5.4 & 8 & 42.8 \\
\hline $3 a$ & Overfire Air Booster Fan & 351.8 & 17.6 & 369.4 & 1 & 369.4 \\
\hline $3 b$ & Overfire Air Cooling Fan & 11.8 & 0.6 & 12.4 & 2 & 24.8 \\
\hline $3 c$ & $\begin{array}{l}\text { Overfire Air Injectors \& } \\
\text { Tubewall Penetrations }\end{array}$ & 17.4 & 0.9 & 18.3 & 8 & 146.2 \\
\hline & Total & 446.3 & 22.3 & 468.6 & 1 & 2347.2 \\
\hline
\end{tabular}

\subsection{GR-LNB Operating Cost}

EER conducted analyses to evaluate the fixed and variable (operating) costs of a GR system for a $300 \mathrm{MW}_{\mathrm{e}}$ coal wall-fired power plant (net heat rate of $10,000 \mathrm{Btu} / \mathrm{kWhr}$ before GR-LNB); contributing cost factors were as follows:

1. Reburning Fuel Cost Differential Since gas costs more than coal on a heating value basis $\left(\$ / 10^{6} \mathrm{Btu}\right)$, there is a cost related to the amount of gas fired. This was calculated based on the delivered costs of gas and coal, the percentage of gas fired (12.5\% of the total heat input). A value of $\$ 1.00 / 10^{6} \mathrm{Btu}$ was used as the differential between the delivered price of natural gas $\left(\$ 2.47 / 10^{6} \mathrm{Btu}\right)$ and the delivered price of coal $\left(\$ 1.47 / 10^{6} \mathrm{Btu}\right)$.

2. Changes in Boiler Efficiency Since the boiler efficiency is lower when using gas as the reburning fuel there needs to be an increase in the amount of fuel fired to make up for the lower efficiency. This increase was based upon the boiler efficiency loss $\left(0.80 \%\right.$ w/12.5\% gas) for GR and a composite fuel cost of $\$ 1.67 / 10^{6} \mathrm{Btu}$. 


\section{Capital Cost}

\section{Category}

Equipment

Construction Labor

Construction Indirects

Other $(6 \%)$, Freight $(2 \%) \&$ Taxes $(5 \%)$

Gas Supply ${ }^{[1]}$

Gas Metering \& Reduction Station

Total Process Capital

Engineering ( $10 \%$ of process capital)

Project Management (8\%) /Owners Costs (5\%)

Project Contingency @ 15\%

Total Plant Cost

Allowance for Funds During Construction ${ }^{[2]}$

Total Plant Investment (TPI)

Royalty Fees @ 0.5\% of Total Process Capital

Startup Costs @ 3\% TPI

Working Capital @ 0.9\% TPI

Cost of Construction Downtime (28 days) ${ }^{[3]}$

Total Capital Requirement
$\$ 10^{6}$

2.50

1.25

0.77

0.32

0.00

0.45

5.29

0.53

0.69

0.98

7.48

0.00

7.48

0.03

0.22

0.07

0.00

7.80
$\$ / k W e$

8.32

4.17

2.57

1.08

0.00

1.50

17.64

1.76

2.29

3.25

24.95

0.00

24.95

0.09

0.75

0.22

0.00

26.01

[1] Gas supply availability at site assumed adequate

[2] No allowance included based on DOE guideline

[3] Assumed downtime to be during scheduled major outage 
3. Auxiliary Power Since the GR fuel contributes a significant portion of the boiler fuel, there is a corresponding percentage decreased load on the coal crushers. There is added power required however for the OFA booster fan and the natural gas and OFA cooling air fans. The electricity cost was based on an auxiliary power cost of $\$ 0.02 / \mathrm{kWhr}$.

4. Operating Labor All reburning system operation is performed in the automatic control mode. Therefore, no additional plant operators are required.

5. Maintenance Items/Spare Parts An allowance of $2 \%$ of the total plant investment was used for total maintenance, $40 \%$ of the $2 \%$ was allocated for maintenance items and spare parts. Since the LNBs are replacement units, no additional maintenance cost is included for this equipment.

6. Maintenance Labor An allowance of $2 \%$ of the total plant investment was used for total maintenance, $60 \%$ of the $2 \%$ was allocated for maintenance labor. No additional labor is required to operate the GR-LNB system; however, additional maintenance is required due to the added equipment.

7. Administration and General Overhead An allowance of $60 \%$ of plant labor was added to cover administration and general overhead.

8. Local Property Taxes and Insurance An allowance of $3 \%$ of total plant investment was used to cover taxes and insurance.

The total annual incremental gross operating cost for the GR-LNB system, excluding fixed charges to payback capital, is estimated at $\$ 2.66$ million (see Table 7-5). If an $\mathrm{SO}_{2}$ allowance credit is taken based on the reduction of fuel sulfur when firing natural gas, the net operating cost is estimated at about $\$ 2.17$ million. This $\mathrm{SO}_{2}$ credit was based on an allowance of $\$ 95 /$ ton (Feb. 1996). Variable operating cost for the GR-LNB is about $\$ 2.33$ million and the fixed cost, excluding fixed charges, is about $\$ 0.33$ million.

\subsection{Summary of Performance and Economics}

Based on the developed capital and fixed/variable operating costs, economic projections were made using current dollars which include an inflation rate of $4.0 \%$, and constant dollars which ignore inflation. The factors used in the development of the technology 


\title{
TABLE 7.5 ANNUAL INCREMENTAL OPERATING COST
}

\author{
Annual Incremental Operating Costs ${ }^{[1]}$
}

Annual Use

\section{Variable Costs}

Fuel:

Natural Gas

Supplemental Fuel

Utilities:

Electricity ${ }^{[4]}$

Ash Disposal Credit

Sub-Total
$2,135,25010^{6} \mathrm{Btu}$

$136,65610^{6} \mathrm{Btu}$

$2,18110^{3} \mathrm{kWhr}$

$(8,541)$ tons

$\$ 9.29$ /ton
Cost/Yr

$\$ 1.00 / 10^{6} \mathrm{Btu}^{[2]}$

$\$ 2,135,250$

$\$ 217,966$

$\$ 43,616$

$(\$ 79,346)$

$\$ 2,317,486$
$\$ 1.60 / 10^{6} \mathrm{Btu}^{[3]}$

Fixed Costs

Labor: ${ }^{[5]}$

Maintenance ( $2 \%$ of GR TPI $\times 60 \%$ )

$\$ 41,930$

Supervision ( $20 \%$ of Maintenance Labor)

$\$ 8,386$

Supplies:

Maintenance ( $2 \%$ of GR TPI $\times 40 \%$ )

$\$ 27,953$

Admin. and Gen. Ovhd. (60\% of total labor)

$\$ 5,032$

Local Taxes and Insurance @ $3 \%$ of TPI

$\$ 224,549$

Sub-Total

$\$ 307,850$

$\$ 2,625,337$

Total Gross Operating Cost

$(\$ 486,336)$

SO2 Allowance @ \$95/ton ${ }^{[6]}$

$\$ 2,139,001$

[1] $65 \%$ Capacity factor @ 300 MWe net capacity $(10,000 \mathrm{Btu} / \mathrm{kWhr}$ heat rate) $\mathrm{w} / 12.5 \%$ fuel heat input as natural gas

[2] Natural gas assumed delivered at $\$ 2.47 / \mathrm{MM} \mathrm{Btu}$; coal cost at $\$ 1.47 / \mathrm{MM}$ Btu

[3] Extra fuel added to make up for loss in efficiency $(0.80 \%)$ at same coal/gas ratio as reburn

[4] OFA booster and cooling fans power requirement ( $533 \mathrm{kWhr} @ 65 \%$ capacity), less pulverizer credit of $10 \mathrm{kWhr} / \mathrm{ton}$ coal

[5] Assumed no added operating labor and no incremental maintenance costs for LNBs since they are repalcement parts

[6] February 1996 Allowance Credit Value, reduction based on $4.8 \mathrm{lb} \mathrm{SO} 2 / \mathrm{MM}$ Btu for coal w/coal reduction of $12.5 \%$ 


\section{Summary of Data}

\section{Power Plant Attributes}

Plant capacity, net

Power produced, net

Capacity factor

Plant life

Coal feed

Sulfur in Coal

Units
$\mathrm{MWe}$
$10^{9} \mathrm{kWhr} / \mathrm{yr}$
$\%$
$\mathrm{yr}$
tons $/ \mathrm{yr}$
$\mathrm{wt} \%$

Value

300

1.71

65

15

683,280

3.0

Emissions Control Data

Removal efficiency

Units

NOx

Emissions standard (EPA 40 CFR Part 76 - 12/19/96)

$\%$

64.0

$\mathrm{lb} / 10^{6} \mathrm{Btu}$

0.46

Emissions without controls

$\mathrm{lb} / 10^{6} \mathrm{Btu}$

0.73

Emissions with GR-LNB control

$\mathrm{lb} / 10^{6} \mathrm{Btu}$

0.26

Amount reduced

tons/yr

3,990

\section{Capital Charge}

Fixed O\&M

Variable Operating Cost

Total Cost

$\mathrm{SO}_{2}$ Credits

Total Cost w/SO $\mathrm{S}_{2}$ Credits
Levelized Cost of Power

Current Dollars Factor

0.160

1.314

1.314

1.314
Mills/kWhr

0.73

0.25

1.79

2.77

(0.37)

2.40
Constant Dollars

Factor

0.124

1.000

1.000

1.000

Mills/kWhr

0.57

0.19

1.36

2.12

(0.28)

1.84

Levelized Cost - NOx Removal Basis

$\$$ iton

\$/ton

Factor

removed

Factor

removed

Capital Charge

0.160

313

0.124

242

Fixed O\&M

1.314

108

1.000

82

Variable Operating Cost

1.314

767

1.000

583

1187

908

$\mathrm{SO}_{2}$ Credits

1.314

(160)

1.000

(122)

1027

Total Cost w/SO 2 Credits

Basis: $64 \%$ NOx reduction assumed based on unit with 0.50 seconds Reburn zone residence time 
economics are shown in Table 7-1. Table 7-6 shows the performance and cost for a 300 $M W_{e}$ GR-LNB System that is retro-fitted to a wall-fired boiler. The table reflects the $\mathrm{NO}_{\mathrm{x}}$ reduction costs based a $65 \%$ capacity factor with $12.5 \%$ of the heat input supplied by natural gas at a gas to coal price differential of $\$ 1.00 /$ million Btu. The incremental increase in the levelized cost of power, including capital charges is estimated at $2.12 \mathrm{mills} / \mathrm{kWhr}$ in constant dollars and 2.77 mills/kWhr in current dollars.

If an $\mathrm{SO}_{2}$ credit is applied based on fuel sulfur reduction when firing natural gas, the net incremental increase in the levelized cost of power is estimated at $1.84 \mathrm{mills} / \mathrm{kWhr}$ in constant dollars and $2.40 \mathrm{mills} / \mathrm{kWhr}$ in current dollars. The levelized cost of $\mathrm{NO}_{x}$ removal is estimated at $\$ 908 /$ ton and $\$ 1187$ ton for current and constant dollar projections, respectively. If an $\mathrm{SO}_{2}$ credit is applied based on fuel sulfur reduction, the net levelized cost of $\mathrm{NO}_{x}$ removal is estimated at $\$ 786 /$ ton and $\$ 1,027 /$ ton for current and constant dollar projections, respectively.

Based on the levelized cost (in constant dollars) for reducing nitrogen oxides, excluding $\mathrm{SO}_{2}$ credits, the capital charge component made up around $27 \%$ of the total cost of $\mathrm{NO}_{\mathrm{x}}$ reduction. The fixed operation and maintenance costs represented only $9 \%$, and the variable cost made up the rest of the cost for removing $\mathrm{NO}_{\mathrm{x}}$. The cost of $\mathrm{NO}_{x}$ removal shows that the variable operating cost is the greatest cost component, making up some $64 \%$ of the $\mathrm{NO}_{x}$ reduction.

\subsection{Effect of Variables on Economics}

The economics developed for the $300 \mathrm{MW}_{\mathrm{e}}$ system were used to determine the economic effects of varying the selected parameters shown below:

- Fuel cost differential between gas and coal

- Wall-fired unit size 
- Onstream capacity factor

- Sulfur dioxide allowance credits

The GR-LNB capital costs developed for a range of power plant sizes was based on scaling the power plant cost based on a 0.75 power factor. The effects of the above variables are shown In Figures $7-1$ through $7-4$. The $\mathrm{NO}_{\mathrm{x}}$ reduction costs are based on constant dollars and includes the $\mathrm{SO}_{2}$ allowance credits.

Figure 7-1 Effect of plant size The size of plant on economics becomes less significant for unit sizes of $300 \mathrm{MW}_{\mathrm{e}}$ and greater. For example, the cost of $\mathrm{NO}_{\mathrm{x}}$ emissions for a 300 $\mathrm{MW}_{\mathrm{e}}$ unit is $\$ 72 /$ ton less than a $150 \mathrm{MW}_{\mathrm{e}}$ plant and when increasing the size to $450 \mathrm{MW}_{\mathrm{e}}$ the cost is reduced only $\$ 33 /$ ton.

Figure 7-2 Effect of capacity factor The onstream capacity factor impact is less significant as it increases above $65 \%$. For example, the cost of NOx emissions for a $65 \%$ capacity factor is $\$ 143 /$ ton less than that for $55 \%$, but when it increases from $65 \%$ to $75 \%$ the cost is reduced $\$ 101 /$ ton.

Figure 7-3 Effect of gas to coal price differential The price of natural gas has a linear effect on the NOx reduction costs. For every $\$ 0.25 / 10^{6}$ Btu change, either an increase or decrease in the gas to coal price differential, there is a corresponding $\$ 253 /$ ton cost effect.

Figure 7-4 Effect of $\mathrm{SO}_{2}$ allowance price The price of $\mathrm{SO}_{2}$ allowances also has a linear effect on the NOx reduction costs. For every $\$ 50 /$ ton change, either an increase or decrease in price, there is a corresponding $\$ 64 /$ ton effect.

Of the four parameters that were varied, clearly the price of natural gas is the most dominant parameter regarding the cost of NOx emission reductions. 


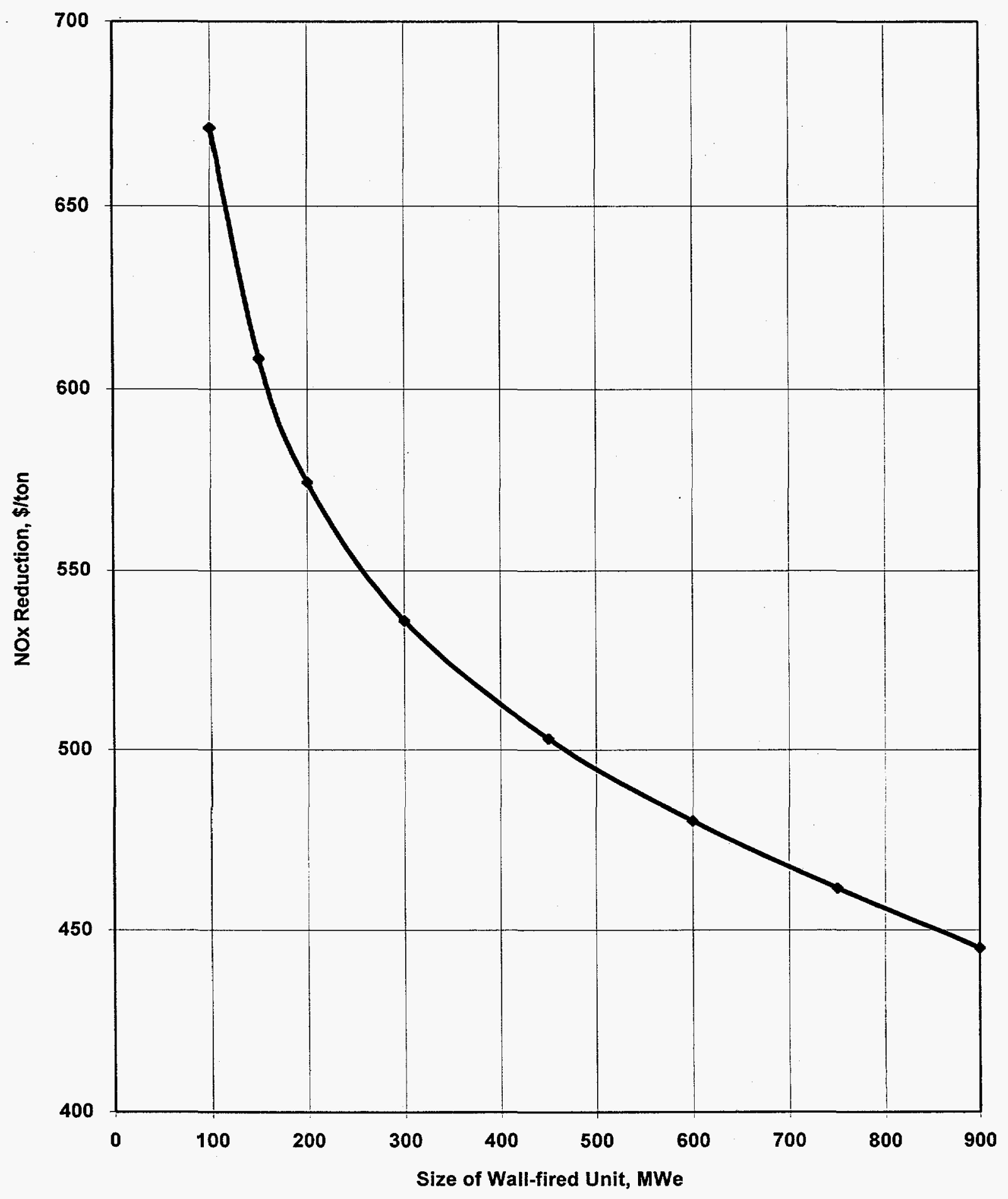

Figure 7-1. The effect of unit size on the cost of $\mathrm{NO}_{\mathbf{x}}$ reduction 


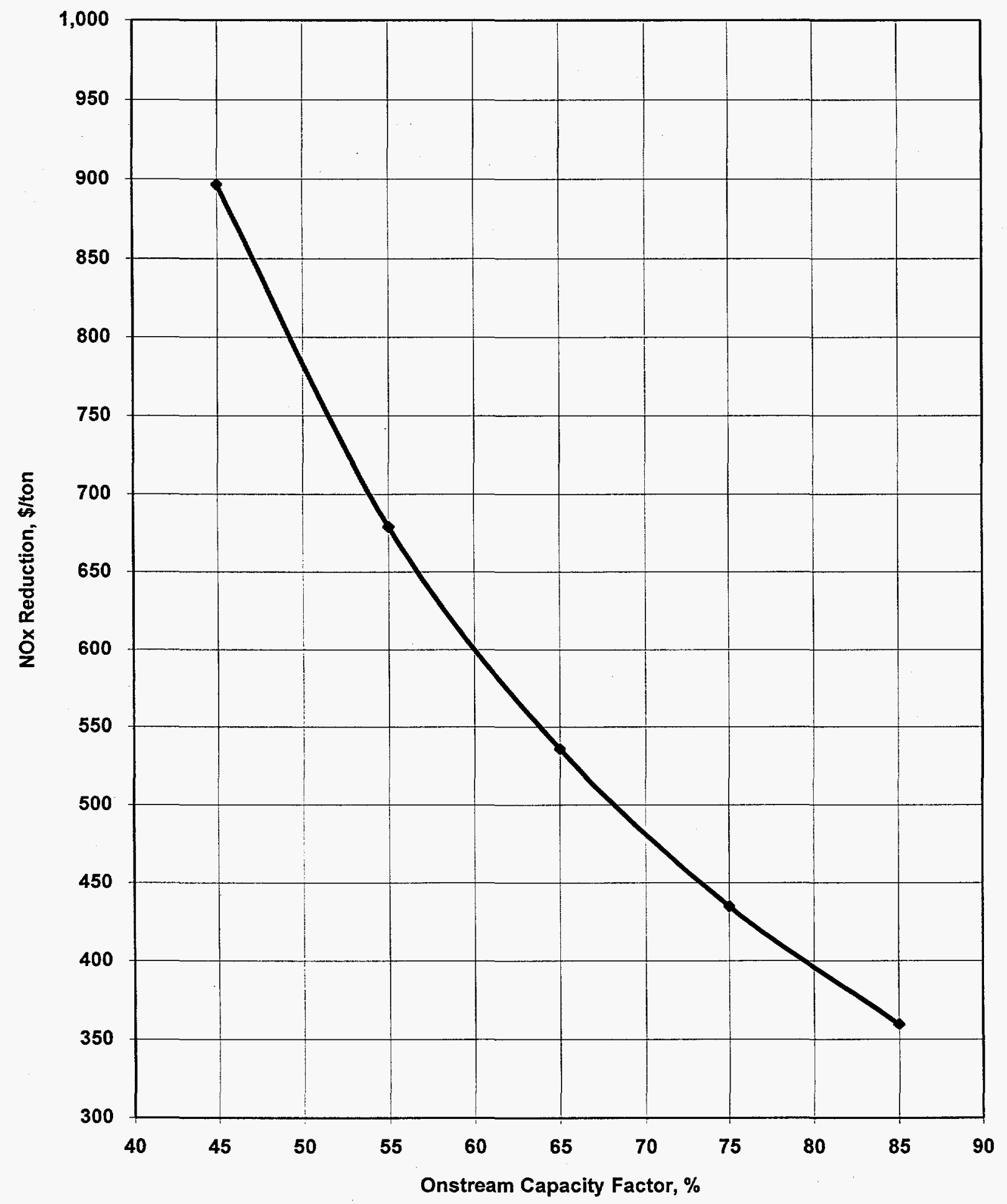

Figure 7-2. The effect of capacity factor on the cost of $\mathrm{NO}_{x}$ reduction 


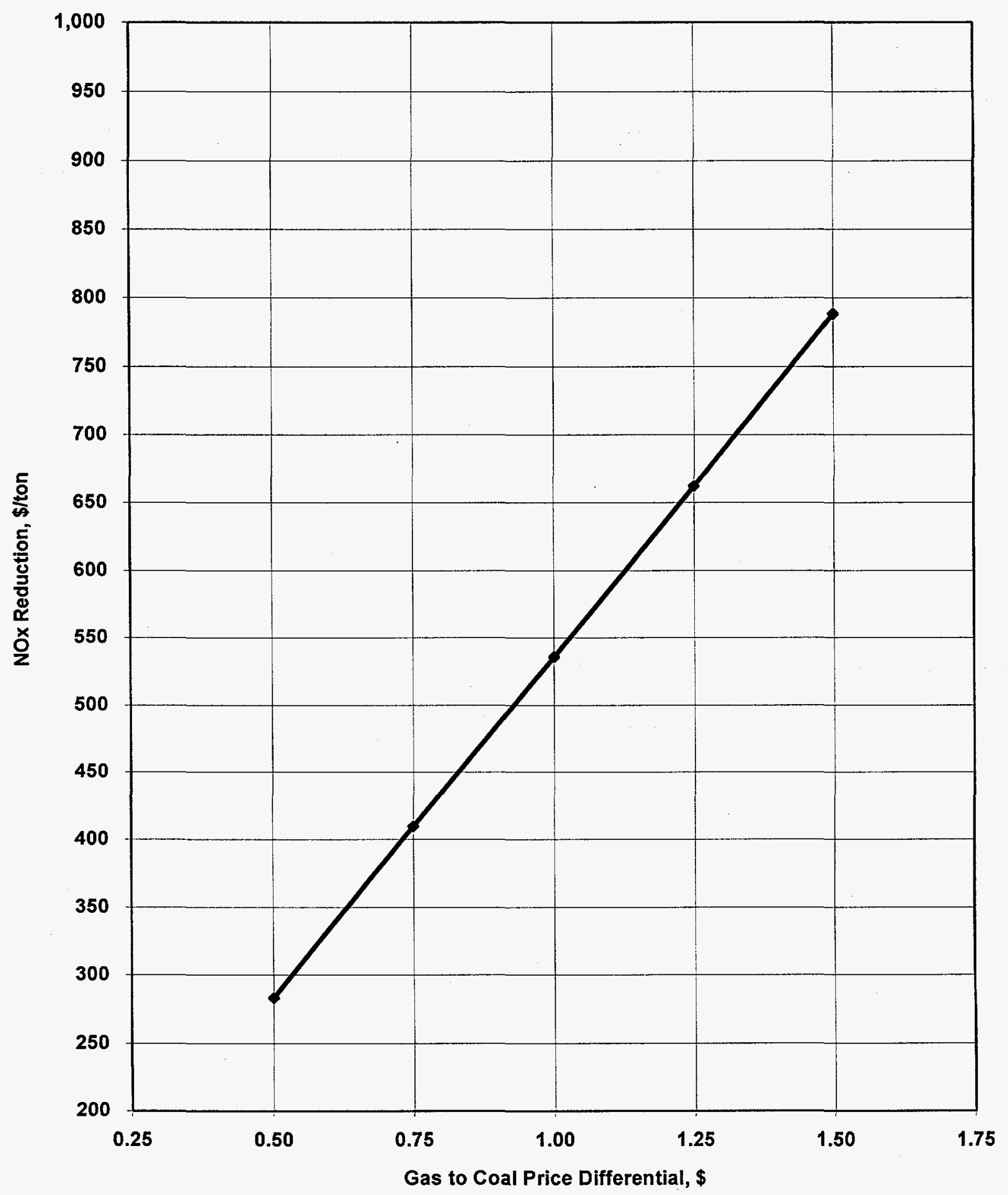

Figure 7-3. The effect of gas to coal price differential on the cost of $\mathrm{NO}_{x}$ reduction 


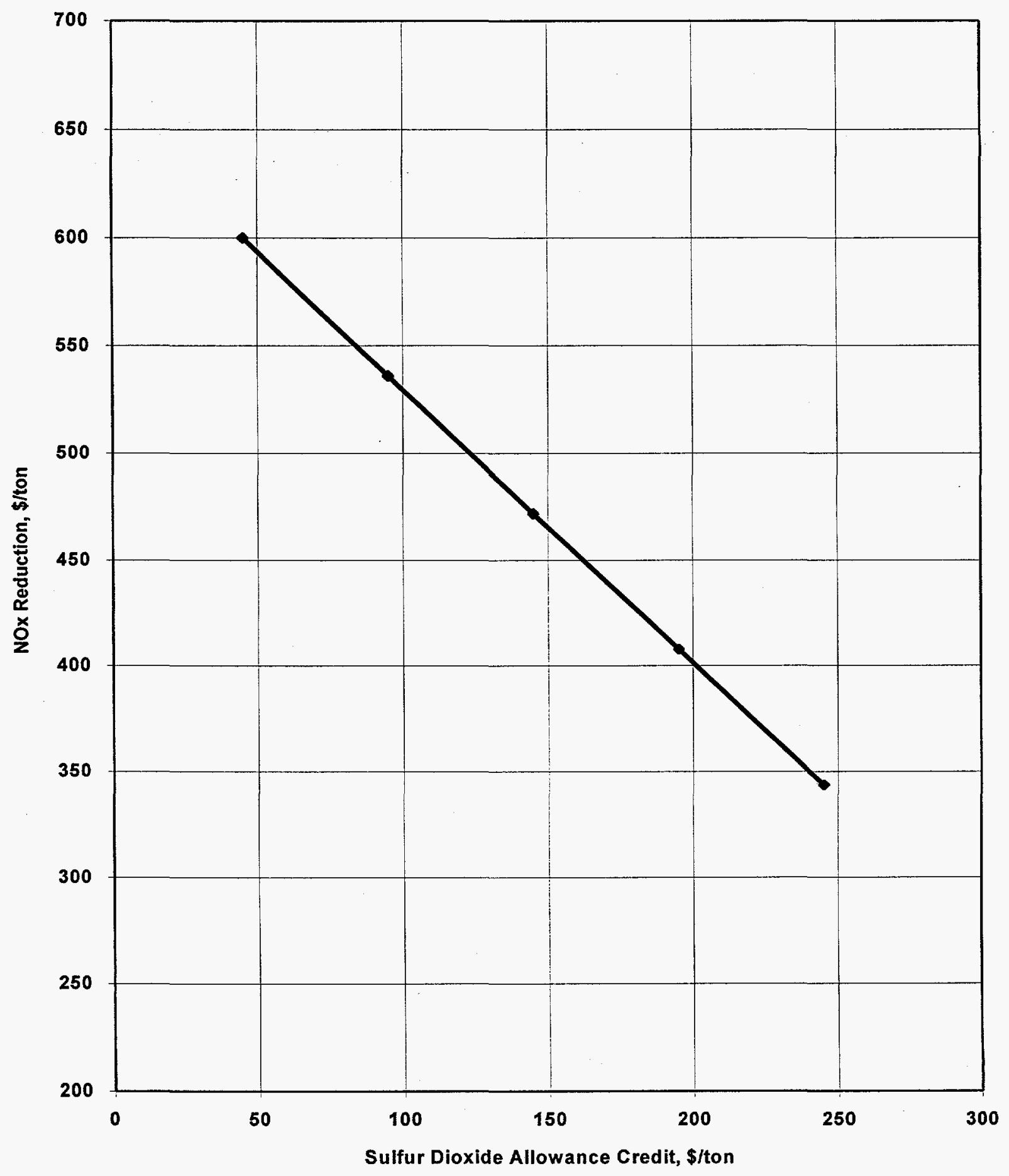

Figure 7-4. The effect of $\mathrm{SO}_{2}$ allowance price on the cost of $\mathrm{NO}_{x}$ reduction 


\subsection{COMMERCIALIZATION POTENTIAL AND PLANS}


In the recent past, the U.S. has experienced a very minimal increase in electric power generating capacity. Further, the new power plants that have been built have been of relatively low capacity. This past trend is predicted for the foreseeable future, so GR technologies, when applied, can be retrofitted to existing power plants.

Title IV of the 1990 Clean Air Act Amendments (CAAA) as specified in $\S 407(b)(2)$ provides for the reduction of $\mathrm{NO}_{x}$ emissions from coal-fired utility boilers. Under the CAAA, boilers were placed in two groups. For the Phase I Group 1 boilers (dry bottom wall-fired and tangentially-fired boilers), regulations were published in the Federal Register on April 13, 1995.

On December 19, 1996, the U.S. Environmental Protection Agency (EPA) set its regulations for Phase II Group 1 utility boilers and Phase II Group 2 utility boilers. Group 2 comprises the rest of the boiler types used by the utility industry (cyclone-fired, cell burner-fired, wet bottom, dry bottom vertically-fired, stoker-fired, and fluidized bed combustors). This regulations come into effect on January 1,2000 . The $\mathrm{NO}_{\mathrm{x}}$ reduction regulations are providing impetus to the electric utility industry to more seriously consider $\mathrm{GR}$ in its $\mathrm{NO}_{x}$ control strategy. The new utility boiler regulations for $\mathrm{NO}_{x}$ emission limits are shown in Table 8-1.

\subsection{Market Analysis}

Under the U.S. EPA regulations for Phase II Group 1 boilers (dry bottom wall-fired and tangentially-fired boilers), there are low cost retrofit technologies available that can be applied to meet the $\mathrm{NO}_{x}$ emission limits. Both of these boiler types can be brought into compliance with burner (low $\mathrm{NO}_{\mathrm{x}}$ ) retrofits, or burner retrofits with OFA. Therefore, even 
TABLE 8-1. U.S. EPA PROPOSED NO EMISSION REGULATIONS

(Annual Average Basis)

\begin{tabular}{||l|c|c||}
\hline \multicolumn{1}{|c|}{ Utility Boiler Type } & $\begin{array}{c}\text { PHASE I } \\
\text { Current Regulations } \\
\text { April } 13,1995\end{array}$ & $\begin{array}{c}\text { PHASE II } \\
\text { Proposed Regulations } \\
\text { January } 1,2000\end{array}$ \\
\hline Group 1: & $\mathrm{Ib} \mathrm{NO}_{x} / 10^{6} \mathrm{Btu}$ & $\mathrm{Ib} \mathrm{NO}_{x} / 10^{6} \mathrm{Btu}$ \\
\hline Wall-Fired (Dry Bottom) & 0.50 & 0.46 \\
\hline Tangentially-Fired & 0.45 & 0.40 \\
\hline Group 2: & - & 0.68 \\
\hline Cell Burner-Fired & - & 0.86 \\
\hline Cyclone-Fired & - & 0.84 \\
\hline Wet Bottom & - & 0.80 \\
\hline Vertically-Fired & & \\
\hline
\end{tabular}

Note: No regulations were proposed for stoker-fired units or fluidized bed boilers.

if these regulations are governing, for wall-fired units, rather than using GR-LNB, LNBs with OFA would be sufficient to meet these regulations.

In Group 2, cell burner-fired (36\%), wet bottom (13\%), and cyclone-fired (41\%) boilers make up some $90 \%$ of the generating capacity of the group. There are low cost burner replacement options for cell burner-fired boilers and staged combustion appears to be a low cost option for wet bottom boilers to meet the proposed $\mathrm{NO}_{\mathrm{x}}$ regulations. Cyclone-fired units present the best market potential for the GR technology based on the CAAA.

The market for the GR technology is difficult to assess at the present time in light of the recent Northeast State filings (states within the Northeast Ozone Transport Region) regarding $\mathrm{NO}_{x}$ emissions from other states. The Northeast States (NY, CT, PA, MA, RI, 
$M E, N H \& V T$ ) petitioned other states (AL, AR, DE, GA, IL, IN, IA, KY, LA, MA, MD, MI, MN, MS, MO, NC, NH, NY, PA, OH, RI, SC, TN, VA, WV \& WI) to reduce power plant (units $\geq 250$ million Btu/hr) $\mathrm{NO}_{x}$ emissions. The petitions varied, but most are asking that the named states reduce their $\mathrm{NO}_{x}$ emissions by $85 \%$ or down to a level of 0.15 $\mathrm{lb} / 10^{6} \mathrm{Btu}$, whichever is less stringent. If the targeted states implement regulations to meet these levels it could open a market for $\mathrm{GR}$; however, the $\mathrm{NO}_{\mathrm{x}}$ emission level is so low that GR would have to be used in combination with other technologies such as selective catalytic reduction (SCR) or selective non-catalytic reduction (SNCR). It is unlikely that combined GR-LNB technology would be used in this case for the two combined technologies could not meet the requested $\mathrm{NO}_{\mathrm{x}}$ emission levels. A third technology such as SCR or SNCR would have to be added.

In addition to the SIP call, there are proposed new National Ambient Air Quality Standards (NAAQS) that would reduce ambient ozone levels by $50 \%$. If these proposed regulations become law there will be more ozone non-attainment areas in the U.S. putting added pressure on the electric utilities to reduce their $\mathrm{NO}_{x}$ emissions (a precursor to ozone production). These three initiatives to reduce $\mathrm{NO}_{x}$ emissions has created a high degree of confusion regarding what standards a certain power plant will have to meet. It has delayed the electric utility industry from making decisions regarding the reduction of $\mathrm{NO}_{\mathrm{x}}$ emissions.

\subsubsection{Applicability of the Technology}

The GR technology is applicable to any type of boiler. A gas injector retrofit requires very little space; this is especially true with the new gas injection system developed by EER. The new system, which was demonstrated under this CCT project, does not require the use of FGR with fuel gas injection. Any type of fuel gas can be used for the GR system, natural gas, propane, landfill gas, etc. With GR, an OFA system is required and in applications to cyclone-fired units, the air pressure in the specific boiler windbox is 
sufficient for the OFA system, so additional air booster fans would not be required. This may not be the case for other types of boilers, and booster fans could be required.

As stated previously, in light of the existing and proposed new regulations, it is unlikely that there will be a market for combined GR-LNB technology. However, each technology individually will be marketable.

\subsubsection{Market Size}

The potential size of the market for GR technology is dependent on environmental regulations; the more stringent the $\mathrm{NO}_{x}$ emission limits to a point, the greater the market size will be. The three initiatives which are now operative will set the size of the market. All three of the above discussed initiatives result in different $\mathrm{NO}_{x}$ emission levels. Which one is controlling will set the technologies that will be used in the future based a technology's $\mathrm{NO}_{x}$ reduction potential.

Currently there are thirteen states in the Northeast that are included in the Ozone Transport Region (OTR). They have a cooperative agreement under the Northeastern States Cooperative Air Usage Management (NESCAUM) group to reduce $\mathrm{NO}_{\mathrm{x}}$ emissions. The member states are Connecticut, Delaware, District of Columbia, Maine, Maryland, Massachusetts, New Hampshire, New Jersey, New York, Pennsylvania, Rhode Island, Vermont, and Virginia.

In these thirteen states there are 463 boilers, that in 1990 emitted some 1 million tons of $\mathrm{NO}_{x}$ to the atmosphere. The average $\mathrm{NO}_{x}$ emissions rate for these boilers was 0.649 $\mathrm{lb} / 10^{6} \mathrm{Btu}$ in 1990. In 1999 these boilers will have to meet a five month control average of $0.20 \mathrm{lb} / 10^{6} \mathrm{Btu}$, and in the year 2003 will have to meet $0.15 \mathrm{lb} / 10^{6} \mathrm{Btu}$. Under the SIP call another 13 states would be added to this group. If the requested emission levels dictated in the SIP calls prevail, the market for reburning should increase dramatically; how much it increases will be determined by the lowest $\mathrm{NO}_{x}$ emissions allowable by law. 
Also, based on the proposed U.S. EPA limits, a new market is specifically opening for the use of reburning technology on cyclone-fired units. The reason for this market is that there are not many cost effective $\mathrm{NO}_{\mathrm{x}}$ reduction options available for cyclone-fired boilers. The U.S. EPA regulation for cyclone-fired units $\left(>155 \mathrm{MW}_{\mathrm{e}}\right)$ is $0.86 \mathrm{lb} \mathrm{NO} / 10^{6} \mathrm{Btu}$, and there are some 55 cyclone-fired units in the United States to which GR could be applied to put these units into compliance. In addition to cyclone units, power plants in the existing OTR are good marketing targets.

\subsubsection{Market Barriers}

In the case of the GR technology, a critical capital cost item concerns the availability of natural gas. If natural gas is available at the site to supply a sufficient volume, the capital cost will be much less than that compared to a plant that did not have gas on-site. The capital cost differential between sites is related to the pipeline distance required to bring gas to the power plant.

Another factor that affects the capital cost is the existing combustion air windbox pressure. If there is adequate windbox pressure (4-6 in. W.C. or greater) then a booster OFA fan would not be required. The air pressure required is also dependent on the size of the unit; the larger the size, the higher the air pressure required for optimum furnace penetration with the OFA.

GR is most effective where furnace temperatures are hot $\left(2600+^{\circ} \mathrm{F}\right)$ and residence times in the reburning (reducing) zones are long enough to effectively reduce $\mathrm{NO}_{\mathrm{x}}$ emissions. The hotter the reburning zone and the longer the residence time, the greater the $\mathrm{NO}_{\mathrm{x}}$ reduction will be for the same rate of gas fired as a reburning fuel.

The biggest economic factor concerning the use of the GR technology to reduce $\mathrm{NO}_{\mathrm{x}}$ emissions at a specific power plant is the price differential between the reburning fuel 
(natural gas) and the primary fuel (coal). The smaller the price differential, the more attractive the GR system will become.

Another economic factor is $\mathrm{SO}_{2}$ allowance credits. Since natural gas, containing no sulfur, replaces coal with sulfur, the higher the $\mathrm{SO}_{2}$ credits are selling for, the better the economics of a gas reburn system will look.

\subsubsection{Economic Comparison with Competing Technologies}

Methods for controlling $\mathrm{NO}_{\mathrm{x}}$ from coal-fired utility boilers include combustion modifications and post combustion treatment of the flue gas. Combustion modifications involve operating the primary combustion zone under fuel rich conditions (and therefore reduced temperatures), cooling the flame at a higher rate, and dilution of the flame to reduce adiabatic flame temperatures. Gas residence times in the high temperature zone as well as excess air levels are reduced, inhibiting the formation of fuel and thermal $\mathrm{NO}_{\mathrm{x}}$.

The combustion modification techniques that can be applied depends on the type of boiler and method of firing the fuel. Low $\mathrm{NO}_{x}$ burner technology with OFA has been successfully applied to wall and tangentially fired pulverized coal units. Low $\mathrm{NO}_{x}$ burner technology, however, cannot be applied to cyclone units due to the configuration of the cyclone furnaces. The importance of OFA as it relates to staging the combustion process has been determined in testing of low $\mathrm{NO}_{x}$ burner retrofits and demonstrations. This information has promoted the addition of OFA to conventional firing systems as a stand alone alternative to low $\mathrm{NO}_{x}$ burners for utilities requiring moderate reductions.

OFA systems may be "close-coupled" to the existing burner assemblies on tangentially fired units, or separated higher into the furnace on both tangentially and wall fired designs for deeper staging and increased $\mathrm{NO}_{\mathrm{x}}$ reductions. Staged combustion with OFA also cannot be applied to cyclone-fired units with high sulfur coal feedstocks. Industry 
experience indicates that this combustion modification technique for high sulfur feedstocks results in high levels of corrosion in the cyclone barrels.

Post combustion techniques include reburning, selective catalytic reduction (SCR), and selective non-catalytic reduction (SNCR). The reburning process using natural gas as the reburning fuel is described elsewhere in this manual. Coal and coal water slurry (CWS) have also been proposed as reburning fuels. In Table 8-2 below, a relative comparison is made between the cost, design, and operating factors associated with the three reburning fuels.

TABLE 8-2. REBURNING FUEL COMPARISON

\begin{tabular}{||c|c|c|c||}
\hline & Natural Gas & Coal & CWS \\
\hline Reburning Fuel Cost & Highest & None & Low \\
\hline Capital Cost & Lowest & Highest & Low \\
\hline $\mathrm{SO}_{2}$ Reduction & Yes & None & Varies \\
\hline Injector Size & Small & Large & Small \\
\hline Auxiliary Power & Low & High & Moderate \\
\hline Residence Time Requirement & Low & Moderate & Moderate \\
\hline
\end{tabular}

Natural gas is the most expensive reburning fuel, with the differential above coal averaging $\$ 1.00$ to $\$ 1.50 / 10^{6} \mathrm{Btu}$. Coal reburning involves no differential fuel cost since the total heat input to the unit does not change. The cost of CWS is site specific depending on the cost and the availability of the coal fines used to formulate the slurry. CWS may be produced by wet milling the primary coal ( $\$ 4 /$ ton), using the minus 100 mesh froth cell product from coal cleaning plants, or recovering coal fines from coal preparation plant ponds with advanced coal cleaning techniques (delivered cost could be less than primary coal cost or higher depending on ownership of resource, quality of impounded coal and distance from 
power plant). Other fuels, like fuel oil and Orimulsion ${ }^{\circledast}$, a Venezuelan bitumen-water emulsion can also be used as effective reburning fuels.

If gas is available at the power plant, GR offers the lowest capital cost investment since there are no fuel preparation or handling equipment requirements. Coal reburning will require the addition of coal handling and milling equipment, milling equipment upgrading, or storage and handling equipment for coal fines produced elsewhere. Reburning with slurry requires CWS feeding equipment, added air compression for CWS atomization, and either onsite CWS storage or CWS formulation equipment for delivered coal fines filter cake.

Since natural gas contains no sulfur, GR offers an additional $\mathrm{SO}_{2}$ reduction over that provided by $\mathrm{SI}$ or other processes since gas replaces coal containing sulfur. For normal GR applications gas would replace coal and $\mathrm{SO}_{2}$ would be reduced by some $20 \%$.

Auxiliary power requirements for GR are relatively lower since fuel handling and preparation equipment is not necessary as it is with reburning using coal or CWS as the reburn fuels. Demonstrations of GR with FGR have shown that, with most furnace designs and adequate natural gas pressures available, the FGR may not be necessary to promote adequate mixing of the natural gas with the furnace gases. In such a case, the FGR fan can be eliminated, further reducing the auxiliary power requirements.

Consideration of the furnace geometry and available residence time may be critical in the selection of the reburning fuel. Natural gas requires the shortest residence time for the reburning process since the fuel "particle" size is at the molecular level. Coal, having larger particle sizes will require longer residence times.

Selective catalytic and non-catalytic reduction are post combustion treatment methods. In the selective catalytic reduction process, ammonia vapor and preheated air are mixed 
and injected into the flue gas at the boiler exit. The optimum temperature window for this process is 550 to $750^{\circ} \mathrm{F}$. Flue gas at this temperature is generally available upstream of the unit's air heater. A catalytic converter is installed in the duct work at this location. $\mathrm{NO}_{\mathrm{x}}$ is reduced by the process to diatomic nitrogen in the converter. SCR systems are better suited for installation downstream of a hot side precipitator since dust buildup and catalyst fouling are reduced. On systems installed upstream of a cold side precipitator, the catalyst mesh size must be increased to reduce dust build-up and catalyst fouling. The larger mesh size dictates a larger converter to provide the necessary surface area.

Ammonia slip (un-reacted $\mathrm{NH}_{3}$ ) is a major operating consideration with $\mathrm{SCR}$ systems. As the catalyst is expended, ammonia slip increases. Ammonia passing through the converter forms ammonium sulfate in particulate form which may foul equipment downstream such as air heaters, draft fans, or precipitators. Sulfates may also form in the catalyst pores to deactivate the catalyst if the flue gas temperature drops below $500^{\circ} \mathrm{F}$. Un-reacted ammonia may also be adsorbed by the fly ash and increase the leachability of metals in the ash, affecting the salability of the fly ash.

In the SNCR process, ammonia or urea based reagents are injected into the upper furnace at locations where flue gas temperatures range from 1600 to $2000^{\circ} \mathrm{F}$. With this process the required high activation energy is provided by the temperature of the flue gas, and a converter with catalyst is not necessary.

An independent study completed for the U.S. EPA (Contract No. 68-D2-0168) "Investigation of Performance and Cost of $\mathrm{NO}_{x}$ Controls as Applied to Group 2 Boilers", compared the costs of competing $\mathrm{NO}_{x}$ control technologies. The costs for various $\mathrm{NO}_{\mathrm{x}}$ reduction systems applied to boilers were developed as part of this study. The values for GR system are slightly different than those developed by EER due to different cost assumptions. Although actual costs vary, the relative costs for the technologies evaluated should be valid. In Table 8-3, the cost of GR, GR-LNB, Coal Reburning, Selective Non- 
Catalytic Reduction (SNCR) and Selective Catalytic Reduction (SCR), based on $\$ / k W_{e}$ and $\$$ /ton of $\mathrm{NO}_{\mathrm{x}}$ removed are shown for $400 \mathrm{MW}_{\mathrm{e}}$ units where the secondary air pressure is high enough not to require a booster fan for GR. As shown in the table, the boiler $\mathrm{NO}_{\mathrm{x}}$ control technologies show a cost per ton of $\mathrm{NO}_{x}$ removed that ranges from approximately $\$ 490$ to $\$ 718$. Based on this comparison Coal Reburning is the least expensive and GRLNB and SNCR are the most expensive. GR and SCR are near equal when the price differential between natural gas and the primary coal is $\$ 1.00 / 10^{6} \mathrm{Btu}$. The $\mathrm{NO}_{\mathrm{x}}$ reduction for SCR assumed for this study was low, only $50 \%$.

TABLE 8-3. $400 \mathrm{MW}_{\mathrm{e}}$ UNIT NO $\mathrm{N}_{\mathrm{x}}$ CONTROL COMPARISON

\begin{tabular}{||l|c|c|c||}
\hline \multicolumn{1}{|c|}{ Technology } & $\begin{array}{c}\text { NO } \\
\%\end{array}$ & $\begin{array}{c}\text { Capital Cost } \\
\$ / k W_{e}\end{array}$ & $\begin{array}{c}\text { NO }_{x} \text { Removed }^{5} \\
\$ / \text { ton }\end{array}$ \\
\hline GR $^{1}$ & 60 & 15.2 & 590 \\
\hline GR-LNB $^{2}$ & 64 & 24.2 & 718 \\
\hline Coal Reburning & 50 & 52.7 & 490 \\
\hline SNCR $^{3}$ & 35 & 7.3 & 690 \\
\hline $\mathrm{SCR}^{4}$ & 50 & 40.0 & 575 \\
\hline
\end{tabular}

(1) Natural Gas @ \$2.47/10 Btu and Coal @ $\$ 1.47 / 10^{6}$ Btu

(2) With $12.5 \%$ natural gas and a gas to coal price differential of $\$ 1 / 10^{6} \mathrm{Btu}$, same as GR

(3) $50 \%$ Urea solution @ \$0.50/gal

(4) Anhydrous Ammonia @ \$162/ton \& SCR catalyst replacement (3 yr life) @ \$350/ft

(5) Incremental operating cost, including cost of capital

However, SCR systems have achieved $85 \%+$ reductions with increased catalyst volume. For $\mathrm{NO}_{\mathrm{x}}$ reduction beyond what is possible by a particular technology, it is possible to combine some technologies for deeper reduction. For an example, Advanced GR is currently being marketed involving the simultaneous application of GR and SNCR. Overall $\mathrm{NO}_{\mathrm{x}}$ reduction is expected to be in the range of 75 to 90 percent. GR has also been demonstrated with low $\mathrm{NO}_{\mathrm{x}}$ burners, under this CCT project, achieving overall $\mathrm{NO}_{\mathrm{x}}$ reductions of up to 70 percent (64 to $65 \%$ average). 


\subsection{Commercialization Plans}

EER is taking the lead in the commercialization of the GR technology. Much of the marketing efforts of the Corporation are targeted to Reburning technology. EER has presented numerous papers on the $\mathrm{NO}_{\mathrm{x}}$ reduction results achieved with the $\mathrm{GR}$ technology under the CCT demonstrations. It has developed brochures and has presented seminars to prospective utilities which are solely dedicated to the commercialization of Reburning technology.

EER installed and successfully started up a GR system on a glass furnace (Anchor) and a GR system that it installed on a $108 \mathrm{MW}_{\mathrm{e}}$ tangentially-fired unit (New York State Electric \& Gas). Several other proposals are outstanding for installation of GR on other electric utility boilers. EER also installed and successfully started up a micronized coal reburning system on a $50 \mathrm{MW}_{e}$ cyclone-fired unit (Kodak) in the fall of 1996.

In 1998, EER installed a GR system on the Tennessee Valley Authority's Memphis Unit $\# 1$, a $330 \mathrm{MW}_{\mathrm{e}}$ cyclone-fired unit. At the time of the writing this report, it was being started up and preliminary testing indicate that the $\mathrm{NO}_{x}$ reduction guarantees will be met. EER, at the time of the issuance of this report, is designing two GR systems for Baltimore Gas and Electric, Crane Units \#1 and \#2, both $190 \mathrm{MW}_{\mathrm{e}}$ cyclone-fired units.

The impetus provided by the new U.S. EPA regulations for Group 2 utility boilers has been the key to EER's successful commercialization of the technology. Clearly, the commercialization of all of the $\mathrm{NO}_{x}$ reduction technologies is driven by environmental regulations. 


\subsection{CONCLUSIONS AND RECOMMENDATIONS}


The objective of this project was to demonstrate the commercial readiness of the GR-LNB technology for application to pre-NSPS utility boilers. The specific goal was to demonstrate that high levels of $\mathrm{NO}_{\mathrm{x}}$ reductions could be achieved over the long term with minor impacts on other areas of unit operation including combustion completion (quantified by unburned carbon-in-ash), furnace slagging or corrosion, convective pass fouling, steam capacity and final steam conditions, and other areas of unit performance. The target was a reduction of 70 percent in $\mathrm{NO}_{x}$ emissions.

\section{Technical Performance Summary}

The new LNBs, installed by FWEC reduced $\mathrm{NO}_{x}$ emissions from a pre-construction baseline level of $0.73 \mathrm{lb} / 10^{6} \mathrm{Btu}$ to $0.46 \mathrm{lb} / 10^{6} \mathrm{Btu}$ at $3.5 \% \mathrm{O}_{2}$. This was a reduction of $37 \%$, which was below the targeted reduction of $45 \%$. Also, carbon-in-ash and CO could not be maintained at acceptable levels.

During parametric testing, when $\mathrm{GR}$ was introduced the $\mathrm{NO}_{x}$ emissions level dropped to an average of $0.25 \mathrm{lb} / 10^{6} \mathrm{Btu}$ at $3.25 \% \mathrm{O}_{2}$ which was a reduction of $66 \%$. The gas heat input was $18 \%$. Both carbon-in-ash and CO were at acceptable levels. The $70 \%$ reduction target could not be achieved without significant levels of gas heat input due to the substandard performance of the LNBs.

Following installation of the Second Generation equipment, the system achieved similar reductions in $\mathrm{NO}_{\times}$emissions, but with only $12.5 \%$ gas heat input. Again, both carbon-inash and $\mathrm{CO}$ were at acceptable levels. The LNBs were modified and achieved a $44 \% \mathrm{NO}_{x}$ reduction which helped toward reducing the reburn gas required. 
The reburning zone operates under reducing, slightly fuel rich conditions. This suggests the possibility of increased tube wastage due to removal of the protective oxide layer and/or sulfide attack. Accordingly, the field evaluations included a comprehensive program of non-destructive (ultrasonic tube thickness) evaluations. The evaluations showed no evidence of increased tube wastage attributable to GR.

Slag formed around some of the gas injection nozzles on a random basis, but this did not cause a problem with the reburn gas injection system performance. In the OFA zone, heavy slag deposits formed around three of the six OFA injectors after about three months of operation. The initiation of the slag formation was attributed to higher flue gas temperatures in this area. Deposits were removed during regularly scheduled outages.

As predicted, there was a minor change in the heat absorption profile. Increases were observed in both the main and reheat steam temperatures due to the modified heat distribution in the boiler when the GR system was in operation. With the Second Generation GR system since the amount of gas heat input was reduced, the impact on reheat temperatures was less. Nonetheless, steam temperatures were controlled through water spray steam attemperation. There was a reduction in thermal efficiency of less than $1 \%$ due to increased moisture from the combustion of the natural gas. The reason for this is that natural gas has a higher $\mathrm{H}: \mathrm{C}$ ratio than coal which yields more water vapor per million Btus of energy released.

Although not considered a part of this project, the opportunity presented itself to perform testing with natural gas as the primary fuel coupled with gas reburning. The gas/gas reburning testing demonstrated a reduction in $\mathrm{NO}_{x}$ emissions of $43 \%\left(0.30 \mathrm{lb} / 10^{6} \mathrm{Btu}\right.$ reduced to $0.17 \mathrm{lb} / 10^{6} \mathrm{Btu}$ ) using $7 \%$ gas heat input as a reburn fuel. 


\section{Economics Summary}

The cost and performance data from the Cherokee project were used to estimate the costs of installation, operation and performance for commercial installation of GR-LNB onto a $300 \mathrm{MW}_{\mathrm{e}}$ power plant. The estimate is based on mature technology; i.e., a so-called "nth" plant which incorporates process improvements resulting from experience gained in earlier installations. The results of the economic analysis are as follows:

GR-LNB

Total installation cost

Capital requirement

Operation and maintenance cost

$\mathrm{NO}_{x}$ removal cost - current dollars

$\mathrm{NO}_{x}$ removal cost - constant dollars
$\$ 7.48$ million

$\$ 7.80$ million

$\$ 2.14$ million

$\$ 1,027 /$ ton

$\$ 786 /$ ton

The analysis is based on a coal-to-gas differential of $\$ 1.00 / 10^{6} \mathrm{Btu}$, a $64 \% \mathrm{NO}_{\mathrm{x}}$ removal efficiency at $12.5 \%$ gas heat input, Second Generation Gas Reburning technology, and a sulfur dioxide credit of $\$ 95 /$ ton.

\section{Conclusions}

The following can be highlighted from the GR-LNB demonstration:

- GR-LNB was installed and operated successfully on a wall-fired unit.

- The project goal of $70 \% \mathrm{NO}_{x}$ reduction could be achieved. With First Generation $\mathrm{GR}$, a NO reduction of $65 \%$ was achieved with $18 \%$ gas heat input. $\mathrm{ANO}_{x}$ reduction of $64 \%$ was achieved at $12.5 \%$ gas heat input using Second Generation GR. On occasion, a $70 \%$ reduction was reached. The $\mathrm{NO}_{\mathrm{x}}$ reduction performance was diminished somewhat due to the less than projected performance from the LNB's. 
- The system was operated consistently and reliably. The GR-LNB system was fully functional in automatic mode. No boiler trips were experienced during the testing phase due to failure of project equipment.

- $\quad$ Carbon-in-ash and $\mathrm{CO}$ can be controlled to acceptable levels.

- Existing boiler equipment experienced no mechanical degradation or failure.

\section{Recommendations}

GR technology is recommended for any type of utility boiler. A gas injector retrofit requires very little space; this is especially true with the new gas injection system developed by EER which does not require FGR. Any type of fuel gas can be used for the GR system, natural gas, propane, landfill gas, etc. On a purely performance basis, natural gas is the preferred reburning fuel offering the advantages of no ash, no sulfur, no bound nitrogen, and $100 \%$ volatiles. With GR, an OFA system will also be required. In certain applications, the air pressure in the boiler windbox will be sufficient for the OFA system, so additional air booster fans will not be required and the GR installed cost will be less.

When considering GR-LNB, certain capital and operating economic cost considerations should be evaluated. A critical capital cost item concerns the availability of natural gas. If natural gas is available at the site to supply a sufficient volume, the capital cost would be much less than that compared to a plant that did not have gas on-site. The capital cost differential between the sites would be related to the pipeline distance required to bring gas to the power plant. The biggest economic operating cost factor is the cost differential between the reburning fuel (natural gas) and the primary fuel (coal). The smaller the cost differential, the more attractive the GR system will become. Regarding the GR-LNB technology, regulatory requirements will dictate whether a GR-LNB system would be considered by an electric utility. At present, LNBs with OFA could meet the 1990 CAAA regulations. However, the GR-LNB could not meet the proposed OTR limits. 


\section{BIBLIOGRAPHY OF OTHER PROJECT REPORTS}

Environmental Monitoring Plan, October 1991.

Public Design Report, April 1992.

Baseline Test Report, June 1992.

Phase III Test Plan, September 1992.

Results of Environmental Monitoring Testing, March 1993.

Environmental Monitoring Report, Optimization Testing Period, June 1995.

Environmental Monitoring Report, Long-Term Testing Period, June 1995.

Environmental Monitoring Plan, July 1993. 


\section{APPENDIX A}

Instrument and Component List 
REVISION DATE 08-10-92 by DAP

\begin{tabular}{|c|c|c|c|c|c|c|c|c|}
\hline NSG & OYOFER & 6ro & 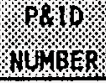 & Yorogase & YANUYOSURER & 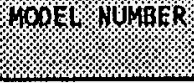 & IISIALINTION & RANGE \\
\hline & $\begin{array}{l}\text { EXAMPLE } \\
\text { FT }-31017\end{array}$ & $\begin{array}{l}\text { CHEROKEE UNIT\#3 INSTRUMENT TAG NUA } \\
\text { FT- FUNCTIONAL INDENTIFIERS } \\
\text { 3- UNIT NUMBER ( } \$ 3 \text { ) } \\
\text { 10- SYSTEM IDENTIFIER (NATURAL GAS) } \\
\text { 17- INSTRUMENT LOOP NUMBER } \\
\text { 82- SYS ID. INST. \& SERVICE AIR } \\
\text { 87- SYS ID. BOILER AIR \& FLUE GAS }\end{array}$ & & & & & & \\
\hline
\end{tabular}

NATURAL GAS SYSTEM INSTRUMENTS \& COMPONENTS

\begin{tabular}{|c|c|c|c|c|c|c|c|c|c|}
\hline$U A-38101$ & & DI & INSTR. AIR DRYER SYSTEM ALARM & $P 8678 E-015 / 3$ & 47252 & PNEU. PROD. CO. & 150DHA-SA.4B-1S-F01-D-0 & & 0.150 \\
\hline HV-31004A & BV $-304 A$ & & $\begin{array}{l}\text { NATURAL GAS ISOLATION } \\
\text { PLUG VALVE "A" (MANUAL OPERATE) }\end{array}$ & P8678E $-015 / 3$ & 47707 & $\begin{array}{c}\text { DEZURIK } \\
\text { MCSTAY \& ASSOC. }\end{array}$ & $\begin{array}{l}\text { 6" PLUG VALVE W/GEAR } \\
\text { ACruATOR, FIG. } 118\end{array}$ & $A 8678 E-036 / 2$ & \\
\hline HV-31004B & BV-304B & & $\begin{array}{l}\text { NATURAL GAS ISOLATION } \\
\text { PLUG VALVE "B" (MANUAL OPERATE) }\end{array}$ & $P 8678 E-015 / 3$ & 47707 & $\begin{array}{c}\text { DEZURIK } \\
\text { MCSIAY \& ASSOC. } \\
\end{array}$ & $\begin{array}{l}\text { 6" PLUG VALVE H/GEAR } \\
\text { ACTUATOR, FIG. } 118\end{array}$ & A8678E $-036 / 2$ & \\
\hline$F E-31005$ & & & $\begin{array}{c}\text { MATURAL GAS FLOW METER } \\
\text { PRIMARY ELEMENT } \\
\end{array}$ & P8678E-015 & $\begin{array}{c}70230- \\
8706 \\
\end{array}$ & $\begin{array}{c}\text { EQUIMETER (rockwel l) } \\
\text { J.F. GOOD } \\
\end{array}$ & $\begin{array}{l}\text { MODELL \# T-140 } \\
12 " \text { TURBOMETER } \\
\end{array}$ & $A 8678 E-036 / 4$ & $\begin{array}{l}861 \mathrm{ksch} \\
275 \mathrm{psi}\end{array}$ \\
\hline$F 1-31005$ & & & $\begin{array}{l}\text { NATURAL GAS FLOW METER } \\
\text { FLOW INDICATOR / TOTALIZER }\end{array}$ & P8678E-015 & $\begin{array}{c}70230- \\
8706\end{array}$ & $\begin{array}{c}\text { EQUIMETER (rockwell) } \\
\text { J.F. GOOD }\end{array}$ & $\begin{array}{l}\text { MOOEL \# } 1163113110 \\
\text { ELECTROCORRECTOR }\end{array}$ & A8678E-036/4 & \\
\hline$P 1-31005$ & PI-301 & & $\begin{array}{l}\text { NATURAL GAS SUPPLY } \\
\text { PRESSURE INDICATOR }\end{array}$ & P8678E-015/3 & 47821 & $\begin{array}{l}\text { ASHCROFT } \\
\text { J.F. GOOD }\end{array}$ & $4-1 / 2 " 1279 A S$ & $\begin{array}{c}\text { A8678E }-036 / 2 \\
\text { STD }-143 / 1\end{array}$ & $\begin{array}{c}0 \cdot 160 \\
\text { PSIG }\end{array}$ \\
\hline PCV-31006 & PRV -302 & & $\begin{array}{c}\text { NATURAL GAS PRESSURE } \\
\text { REDUCING VALVE }\end{array}$ & P8678E-015/3 & 47781 & $\begin{array}{c}\text { FISHER } \\
\text { A.E. EHRKE }\end{array}$ & $311-125 \#$ TYPE 399 & A8678E-036/2 & $\begin{array}{l}10-125 \\
\text { PSIG }\end{array}$ \\
\hline PI-31007 & PI -303 & - & $\begin{array}{l}\text { NATURAL GAS CONTROLLED } \\
\text { PRESSURE INDICATOR }\end{array}$ & P8678E-015/3 & 47821 & $\begin{array}{l}\text { ASHCROFT } \\
\text { J.F. GOOD } \\
\end{array}$ & 4-1/2" 1279AS & $\begin{array}{c}\text { A8678E }-036 / 2 \\
\text { STD }-143 / 1 \\
\end{array}$ & $\begin{array}{c}0-30 \\
\text { PSIG } \\
\end{array}$ \\
\hline PI-31007 & PT -303 & Al & $\begin{array}{l}\text { NATURAL GAS CONTROLLED } \\
\text { PRESSURE TRANSMITTER } \\
\end{array}$ & P8678E $-0.15 / 3$ & 47817 & $\begin{array}{l}\text { ROSEMOUNT } \\
\text { INC. }\end{array}$ & $\begin{array}{c}\text { 1151GP651281 } \\
\text { CALIBRATE } 0-25 \text { PSIG } \\
\end{array}$ & $\begin{array}{c}\text { A8678E }-036 / 2 \\
\text { STD }-143 / 4 \\
\end{array}$ & $\begin{array}{c}0 \cdot 100 \\
\text { PSIG } \\
\end{array}$ \\
\hline PV-31008 & PSV-304 & & $\begin{array}{l}\text { NATURAL GAS RELIEF VENT } \\
\text { VALVE }\end{array}$ & P8678E-015/3 & 47781 & $\begin{array}{c}\text { FISHER } \\
\text { A.E. EHRKE } \\
\end{array}$ & $6 " 1$ - 125\# TYPE 63EG & $A 8678 E-036 / 2$ & $\begin{array}{c}10-40 \\
\text { PSIG } \\
\end{array}$ \\
\hline PSL-31009 & PSL-305 & DI & $\begin{array}{l}\text { NATURAL GAS LOW } \\
\text { PRESSURE SWITCH } \\
\end{array}$ & P8678E-015/3 & 47821 & $\begin{array}{c}\text { ASCO } \\
\text { J.F. GOOD } \\
\end{array}$ & SB210/TD20A11 & $\begin{array}{c}\text { A8678E }-036 / 2 \\
\text { STD }-143 / 2 \\
\end{array}$ & $\begin{array}{l}1-18 \\
\text { PSIG } \\
\end{array}$ \\
\hline $\begin{array}{l}F V-31010 \\
2 S-31010\end{array}$ & $\begin{array}{l}\text { SSV-307 } \\
\text { 2SC-307 }\end{array}$ & $\begin{array}{l}\text { DO } \\
\text { DI }\end{array}$ & $\begin{array}{l}\text { NATURAL GAS SAFETY } \\
\text { SHUT-OFF VALVE W/CLOSED LIMIT }\end{array}$ & $P 8678 E-015 / 3$ & 47797 & $\begin{array}{c}\text { DEZURIK } \\
\text { MCSTAY \& ASSOC. }\end{array}$ & 10" BUTTERFLY VALVE & A8678E $-036 / 2$ & \\
\hline
\end{tabular}


INSTRUMENT \& COMPONENT LIST CHEROKEE CCT UNIT 3

\begin{tabular}{|c|c|c|c|c|c|c|c|c|c|}
\hline & & & & & & & REVISION DATE 08-10-92 by DAP & & \\
\hline PSOY 196 & $000 \mathrm{EER}$ & 1roc & $S \mathrm{EVOE}$ & Wuto & 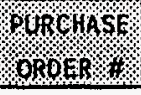 & W6NUEOSURER & 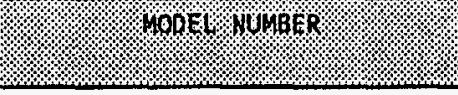 & 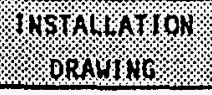 & RANG \\
\hline$H V-38210$ & BV -307 & & $\begin{array}{c}\text { MANUAL BALL VALVE } \\
\text { FOR } \quad \text { FV- } 31010 \\
\end{array}$ & $P 8678 E-015 / 3$ & 47782 & $\begin{array}{l}\text { WORCESTER CON. } \\
\text { A.E. EHRKE }\end{array}$ & 4846 RSE with $1 / 0-1 / 4 "$ NPT & A8678E-036/2 & \\
\hline PIC-38210 & $\begin{array}{l}\text { AF }-307 \\
\text { PI }-307 \\
\text { PRV }-307 \\
\end{array}$ & & $\begin{array}{l}\text { AIR PRESSURE FILTER } \\
\text { REGULATOR FOR FV-31010 }\end{array}$ & $P 8678 E-015 / 3$ & 47782 & $\begin{array}{l}\text { FISHER } \\
\text { A.E. EHRKE } \\
\end{array}$ & $\begin{array}{c}\text { TYPE } 67 \text { AFR-239 w/FILTER \& } \\
0-100 \text { psi PRESSURE GAUGE } \\
\text { with } 1 / 0-1 / 4 " \text { NPT }\end{array}$ & A8678E-036/2 & \\
\hline PV-31011 & SV-310 & DO & NATURAL GAS VENT VALVE & $P 8678 E-015 / 3$ & 47821 & ASCO / J.F. GOOD & EF8215C83 (2" 120VAC) & A8678E-036/2 & \\
\hline PSH-31012 & PSH -308 & DI & $\begin{array}{l}\text { NATURAL GAS HIGH } \\
\text { PRESSURE SWITCH } \\
\end{array}$ & P8678E-015/3 & 47821 & $\begin{array}{c}\text { ASCO } \\
\text { J.F. COOD } \\
\end{array}$ & SB210/TE20A11 & $\begin{array}{c}\text { A8678E-036/2 } \\
\text { STD }-143 / 2 \\
\end{array}$ & $\begin{array}{c}1.5-36 \\
\text { PSIG }\end{array}$ \\
\hline $\begin{array}{l}F V-31013 \\
2 S-31013 \\
\end{array}$ & $\begin{array}{l}\text { SSV-309 } \\
2 S C-309 \\
\end{array}$ & $\begin{array}{l}\text { DO } \\
\text { DI }\end{array}$ & $\begin{array}{l}\text { NATURAL GAS SAFETY } \\
\text { SHUT-OFF VALVE W/CLOSED LIMIT } \\
\end{array}$ & P8678E-015/3 & 47797 & $\begin{array}{c}\text { DEZURIK } \\
\text { MCSTAY \& ASSOC. }\end{array}$ & 10" BUTTERFLY VALVE & $A 8678 E-036 / 2$ & \\
\hline HV -38213 & $8 V-309$ & & $\begin{array}{c}\text { MANUAL BALL VALVE } \\
\text { FOR FV- } 31013 \\
\end{array}$ & $P 8678 E-015 / 3$ & 47782 & $\begin{array}{c}\text { WORCESTER CON. } \\
\text { A.E. EHRKE }\end{array}$ & 4846 RSE with $1 / 0-1 / 41$ NPT & $A 8678 E-036 / 2$ & \\
\hline PIC-38213 & $\begin{array}{l}\text { AF }-309 \\
\text { PI }-309 \\
\text { PRV-309 }\end{array}$ & & $\begin{array}{l}\text { AIR PRESSURE FILTER } \\
\text { REGULATOR FOR FV-31013 }\end{array}$ & $P 8678 E-015 / 3$ & 47782 & $\begin{array}{c}\text { FISHER } \\
\text { A.E. EHRKE } \\
\end{array}$ & $\begin{array}{c}\text { TYPE } 67 \text { AFR-239 w/FILTER \& } \\
0-100 \text { psi PRESSURE GAUGE } \\
\text { with } 1 / 0-1 / 4 " \text { NPT }\end{array}$ & $A 8678 E-036 / 2$ & \\
\hline $\begin{array}{l}\text { HV }-31014 \\
2 S-31014\end{array}$ & $\begin{array}{l}\text { MV }-322 \\
2 S C-322\end{array}$ & DI & $\begin{array}{l}\text { FRONT WALL MATURAL GAS } \\
\text { CONTROL VALVE W/CLOSED LIMIT } \\
\text { MANUAL OPERATION }\end{array}$ & $P 8678 E-015 / 3$ & 47797 & $\begin{array}{l}\text { DEZURIK } \\
\text { MCSTAY \& ASSOC. }\end{array}$ & 8" PLUG VALVE & A8678E $-036 / 2$ & \\
\hline $\begin{array}{l}H V-31015 \\
2 S-31015\end{array}$ & $\begin{array}{l}M V-323 \\
2 s c-323\end{array}$ & DI & $\begin{array}{l}\text { REAR WALL NATURAL GAS } \\
\text { CONTROL VALVE W/CLOSED LIMIT } \\
\text { MANUAL OPERATION }\end{array}$ & $P 8678 E-015 / 3$ & 47797 & $\begin{array}{l}\text { DEZURIK } \\
\text { MCSTAY \& ASSOC. }\end{array}$ & 8" PLUG VALVE & A8678E-036/2 & \\
\hline $\begin{array}{c}F C V-31018 \\
2 S-31018 \\
\end{array}$ & $\begin{array}{r}c V-321 \\
2 s c-321 \\
\end{array}$ & $\begin{array}{l}\text { AO } \\
\text { DI }\end{array}$ & $\begin{array}{l}\text { NORTH - NATURAL GAS FLOW } \\
\text { CONTROL VALVE W/ CLOSED LIMIT }\end{array}$ & $P 8678 E-015 / 3$ & 47781 & $\begin{array}{c}\text { FISHER } \\
\text { A.E. EHRKE } \\
\end{array}$ & $\begin{array}{l}\text { 6" TYPE 1052-V150 with I/P } \\
3620 \mathrm{~J} \text { POSIIIONER (4-20ma) }\end{array}$ & $\begin{array}{l}\text { A8678E-036/2 } \\
E 8678 E-011 / 2 \\
\end{array}$ & \\
\hline HV-38218 & BV-321 & & $\begin{array}{l}\text { MANUAL BALL VALVE } \\
\text { FOR FC V-31018 } \\
\end{array}$ & P8678E $-015 / 3$ & 47782 & $\begin{array}{l}\text { WORCESTER CON. } \\
\text { A.E. EHRKE } \\
\end{array}$ & 4846 RSE with $1 / 0-1 / 41$ NPT & $\begin{array}{l}\text { AB678E-036/2 } \\
E 8678 E-011 / 2 \\
\end{array}$ & \\
\hline PIC-38218 & $\begin{array}{l}\text { AF }-321 \\
\text { PI }-321 \\
\text { PRV }-321 \\
\end{array}$ & & $\begin{array}{l}\text { AIR PRESSURE FILTER } \\
\text { REGULATOR FOR FCV-31018 }\end{array}$ & $P 8678 E-015 / 3$ & 47782 & $\begin{array}{l}\text { FISHER } \\
\text { A.E. EHRKE } \\
\end{array}$ & $\begin{array}{c}\text { TYPE 67AFR-239 W/FILTER \& } \\
0-60 \text { psig PRESSURE GAUGE } \\
\text { with } 1 / 0-1 / 4 " \mathrm{NPr} \\
\end{array}$ & $\begin{array}{l}A 8678 E-036 / 2 \\
E 8678 E-011 / 2\end{array}$ & \\
\hline $\begin{array}{r}\text { FCV-31019 } \\
2 S-31019 \\
\end{array}$ & $\begin{array}{r}\mathrm{CV}-311 \\
2 \mathrm{sc}-311 \\
\end{array}$ & $\begin{array}{l}\text { AO } \\
\text { DI }\end{array}$ & $\begin{array}{l}\text { SOUTH - NATURAL GAS FLOW } \\
\text { CONTROL VALVE W/ CLOSED LIMIT }\end{array}$ & P8678E-015/3 & 47781 & $\begin{aligned} \text { FISHER } \\
\text { A.E. EHRKE } \\
\end{aligned}$ & $\begin{array}{l}\text { 6" TYPE } 1052-\text { V150 with I/P } \\
3620 \mathrm{~J} \text { POSITIONER (4-20ma) }\end{array}$ & $\begin{array}{l}A B 678 E-036 / 2 \\
E 8678 E-011 / 2 \\
\end{array}$ & \\
\hline HV-38219 & BV-311 & & $\begin{array}{l}\text { MANUAL BALL VALVE } \\
\text { FOR FCV-31019 } \\
\end{array}$ & P8678E-015/3 & 47782 & $\begin{array}{l}\text { WORCESTER CON. } \\
\text { A.E. EHRKE } \\
\end{array}$ & 4846 RSE with $1 / 0 \cdot 1 / 4 "$ NPT & $\begin{array}{l}\text { A8678E }-036 / 2 \\
E 8678 E-011 / 2 \\
\end{array}$ & \\
\hline P1C-38219 & $\begin{array}{l}\text { AF }-311 \\
\text { PI }-311 \\
\text { PRV-311 }\end{array}$ & & $\begin{array}{l}\text { AIR PRESSURE FILTER } \\
\text { REGULATOR FOR FCV-31019 }\end{array}$ & $P 8678 E-015 / 3$ & 47782 & $\begin{array}{c}\text { FISHER } \\
\text { A.E. EHRKE } \\
\end{array}$ & $\begin{array}{c}\text { TYPE 67AFR-239 w/FILTER \& } \\
0-60 \text { psig PRESSURE GAUGE } \\
\text { with } 1 / 0-1 / 4 " \text { NPT }\end{array}$ & $\begin{array}{l}\text { A8678E-036/2 } \\
E 8678 E-011 / 2\end{array}$ & \\
\hline
\end{tabular}

CHKINST.XLS

Page 2 


\begin{tabular}{|c|c|c|c|c|c|c|c|c|c|}
\hline & & & & & & & REVISION DATE 08-10-92 by DA & & \\
\hline PSQYAQ & OLOEER & 1\%o: & SERYY & 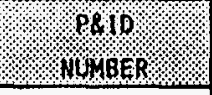 & $\begin{array}{l}\text { PURCAASF } \\
\text { OROER }\end{array}$ & MONUFACURS & অ. & 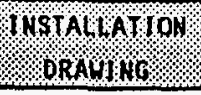 & OANGE \\
\hline PI-31020 & PI-319 & & $\begin{array}{l}\text { NORTH - NATURAL GAS NOZZLE } \\
\text { HEADER PRESSURE GAUGE }\end{array}$ & $P 8678 E-015 / 3$ & 47821 & $\begin{array}{r}\text { DWYER } \\
\text { J.F. GOOD } \\
\end{array}$ & 2205 & $\begin{array}{c}\text { AB678E-036/2 } \\
\text { STD-143/1 }\end{array}$ & $\begin{array}{l}0 \cdot 5 \\
\text { PSIG }\end{array}$ \\
\hline PT-31020 & PT -320 & A! & $\begin{array}{l}\text { NORTH - NATURAL GAS NOZZLE } \\
\text { HEADER PRESSURE TRANSMITIER } \\
\end{array}$ & P8678E-015/3 & 47817 & $\begin{array}{l}\text { ROSEMOUNT } \\
\text { INC. }\end{array}$ & $\begin{array}{c}11516 P 451281 \\
\text { CALIBRAIE } 0-5 \text { PSIG } \\
\end{array}$ & $\begin{array}{l}A B 678 E-036 / 2 \\
E B 678 E-011 / 2\end{array}$ & $\begin{array}{l}1-150 \\
\text { INWC }\end{array}$ \\
\hline PI-31021 & $\mathrm{Pl}-312$ & & $\begin{array}{l}\text { SOUTH - NATURAL GAS NOZZLE } \\
\text { HEADER PRESSURE GAUGE }\end{array}$ & P8678E-015/3 & 47821 & $\begin{array}{l}\text { DWYER } \\
\text { J.F. GOOD } \\
\end{array}$ & 2205 & $\begin{array}{c}A B 678 E-036 / 2 \\
\text { STD-143/1 }\end{array}$ & $\begin{array}{r}0-5 \\
\text { PSIG } \\
\end{array}$ \\
\hline PT-31021 & PT-312 & A! & $\begin{array}{l}\text { SOUTH - NATURAL GAS NOZZLE } \\
\text { HEADER PRESSURE TRANSMITIER }\end{array}$ & P8678E-015/3 & 47817 & $\begin{array}{l}\text { ROSEMOUNT } \\
\text { INC. }\end{array}$ & $\begin{array}{c}\text { 1151GP4S1281 } \\
\text { CALIBRATE } 0-5 \text { PSIG } \\
\end{array}$ & $\begin{array}{l}A 8678 E-036 / 2 \\
E 8678 E-011 / 2 \\
\end{array}$ & $\begin{array}{c}1-150 \\
\text { INWC } \\
\end{array}$ \\
\hline P1-31036A & $P 1-313 A$ & & $\begin{array}{l}\text { NATURAL GAS NOZZLE } \\
\text { PRESSURE GAUGE "36A" } \\
\end{array}$ & $P 8678 E-015 / 2$ & 47821 & $\begin{array}{r}\text { DWYER } \\
\text { J.F. GOOD } \\
\end{array}$ & 2205 & $\begin{array}{c}\text { AB678E-036/1 } \\
\text { STD-143/1 } \\
\end{array}$ & $\begin{array}{l}0-5 \\
\text { PSIG } \\
\end{array}$ \\
\hline Pl-31036B & $P I-313 B$ & & $\begin{array}{l}\text { NATURAL GAS NOZZLE } \\
\text { PRESSURE GAUGE "36B" }\end{array}$ & $P 8678 E-015 / 2$ & 47821 & $\begin{array}{l}\text { DWYER } \\
\text { J.F. GOOD } \\
\end{array}$ & 2205 & $\begin{array}{c}\text { AB678E-036/1 } \\
\text { STD- } 143 / 1 \\
\end{array}$ & $\begin{array}{l}0-5 \\
\text { PSIG }\end{array}$ \\
\hline PI-31036C & PI-313C & & $\begin{array}{l}\text { NATURAL GAS NOZZLE } \\
\text { PRESSURE GAUGE "36C" }\end{array}$ & P8678E-015/2 & 47821 & $\begin{array}{l}\text { OWYER } \\
\text { J.F. GOOD } \\
\end{array}$ & 2205 & $\begin{array}{c}\text { AB678E-036/1 } \\
\text { STD- } 143 / 1\end{array}$ & $\begin{array}{l}0-5 \\
\text { PSIC }\end{array}$ \\
\hline PI-310360 & PI-3130 & & $\begin{array}{l}\text { NATURAL GAS NOZZLE } \\
\text { PRESSURE GAUGE "360" }\end{array}$ & P8678E-015/2 & 47821 & $\begin{array}{l}\text { DWYER } \\
\text { J.F. GOOD } \\
\end{array}$ & 2205 & $\begin{array}{c}\text { A8678E-036/1 } \\
\text { STD }-143 / 1 \\
\end{array}$ & $\begin{array}{l}0-5 \\
\text { PSIG } \\
\end{array}$ \\
\hline Pl-31036E & PI-313E & & $\begin{array}{l}\text { NATURAL GAS NOZZLE } \\
\text { PRESSURE GAUGE "36E" }\end{array}$ & P8678E-0.15/2 & 47821 & $\begin{array}{l}\text { DWYER } \\
\text { J.F. GOOD } \\
\end{array}$ & 2205 & $\begin{array}{c}A 8678 E-036 / 1 \\
S T 0-143 / 1 \\
\end{array}$ & $\begin{array}{l}0-5 \\
\text { PSIG }\end{array}$ \\
\hline P1-31036F & $P I-313 F$ & & $\begin{array}{l}\text { NATURAL GAS NOZZLE } \\
\text { PRESSURE GAUGE "36F" }\end{array}$ & P8678E-015/2 & 47821 & $\begin{array}{c}\text { DWYER } \\
\text { J.F. GOOD } \\
\end{array}$ & 2205 & $\begin{array}{c}A 8678 E-036 / 1 \\
\text { STD- } 143 / 1 \\
\end{array}$ & $\begin{array}{l}0-5 \\
\text { PSIG } \\
\end{array}$ \\
\hline PI-31036G & $P I-313 G$ & & $\begin{array}{l}\text { NATURAL GAS NOZZLE } \\
\text { PRESSURE GAUGE "36G" }\end{array}$ & $P 8678 E-015 / 2$ & 47821 & $\begin{array}{c}\text { DWYER } \\
\text { J.F. GOOD }\end{array}$ & 2205 & $\begin{array}{c}\text { A8678E }-036 / 1 \\
\text { STD }-143 / 1\end{array}$ & $\begin{array}{l}0-5 \\
\text { PSIG }\end{array}$ \\
\hline PI-31036H & PI-313H & & $\begin{array}{l}\text { NATURAL GAS NOZZLE } \\
\text { PRESSURE GAUGE "36H" }\end{array}$ & P8678E-015/2 & 47821 & $\begin{array}{l}\text { DWYER } \\
\text { J.F. GOOD } \\
\end{array}$ & 2205 & $\begin{array}{c}\text { A8678E-036/1 } \\
\text { STD }-143 / 1 \\
\end{array}$ & $\begin{array}{l}0=5 \\
\text { PSIG }\end{array}$ \\
\hline PV-31036A & $C V-314 A$ & & $\begin{array}{l}\text { NATURAL GAS NOZZLE } \\
\text { SHUT-OFF VALVE "36A" (MANUAL) }\end{array}$ & P8678E-015/2 & 47707 & $\begin{array}{c}\text { DEZURIK } \\
\text { MCSTAY \& ASSOC. }\end{array}$ & $\begin{array}{l}\text { 3" PLUG VALVE } \\
\text { SCREWED ENDS, FIG. } 425\end{array}$ & $\begin{array}{l}A 8678 E-036 / 1 \\
D 8678 E-125 / 3\end{array}$ & \\
\hline PV-310368 & $C V-314 B$ & & $\begin{array}{l}\text { NATURAL GAS NOZZLE } \\
\text { SHUT-OFF VALVE "36B" (MANUAL) }\end{array}$ & P8678E-015/2 & 47707 & $\begin{array}{c}\text { DEZURIK } \\
\text { MCSTAY \& ASSOC. }\end{array}$ & $\begin{array}{l}\text { 3" PLUG VALVE } \\
\text { SCREWED ENOS, FIG. } 425\end{array}$ & $\begin{array}{l}A 8678 E-036 / 1 \\
08678 E-125 / 3\end{array}$ & \\
\hline PV-31036C & $C V-314 C$ & & $\begin{array}{l}\text { NATURAL GAS NOZZLE } \\
\text { SHUT-OFF VALVE "36C" (MANUAL) }\end{array}$ & P8678E-015/2 & 47707 & $\begin{array}{c}\text { DEZURIK } \\
\text { MCSTAY \& ASSOC. }\end{array}$ & $\begin{array}{l}\text { 3" PLUG VALVE } \\
\text { SCREWED ENDS, FIG. } 425\end{array}$ & $\begin{array}{l}A 8678 E-036 / 1 \\
D 8678 E-125 / 3 \\
\end{array}$ & \\
\hline PV -310360 & $C V-3140$ & & $\begin{array}{l}\text { NATURAL GAS NOZZLE } \\
\text { SHUT-OFF VALVE "360" (MANUAL) }\end{array}$ & P8678E-015/2 & 47707 & $\begin{array}{c}\text { DEZUR IK } \\
\text { MCSTAY \& ASSOC. }\end{array}$ & $\begin{array}{l}\text { 3" PLUG VALVE } \\
\text { SCREWED ENDS, FIG. } 425\end{array}$ & $\begin{array}{l}A 8678 E-036 / 1 \\
08678 E-125 / 3\end{array}$ & \\
\hline PV-31036E & CV-314E & & $\begin{array}{l}\text { NATURAL GAS NOZZLE } \\
\text { SHUT-OFF VALVE "36E" (MANUAL) }\end{array}$ & P8678E-015/2 & 47707 & $\begin{array}{c}\text { DEZURIK } \\
\text { MCSTAY \& ASSOC. }\end{array}$ & $\begin{array}{l}\text { 3" PLUG VALVE } \\
\text { SCREWED ENDS, FIG. } 425\end{array}$ & $\begin{array}{l}A 8678 E-036 / 1 \\
08678 E-125 / 3\end{array}$ & \\
\hline
\end{tabular}


INSTRUMENT \& COMPONENT LIST CHEROKEE CCT UNIT 3

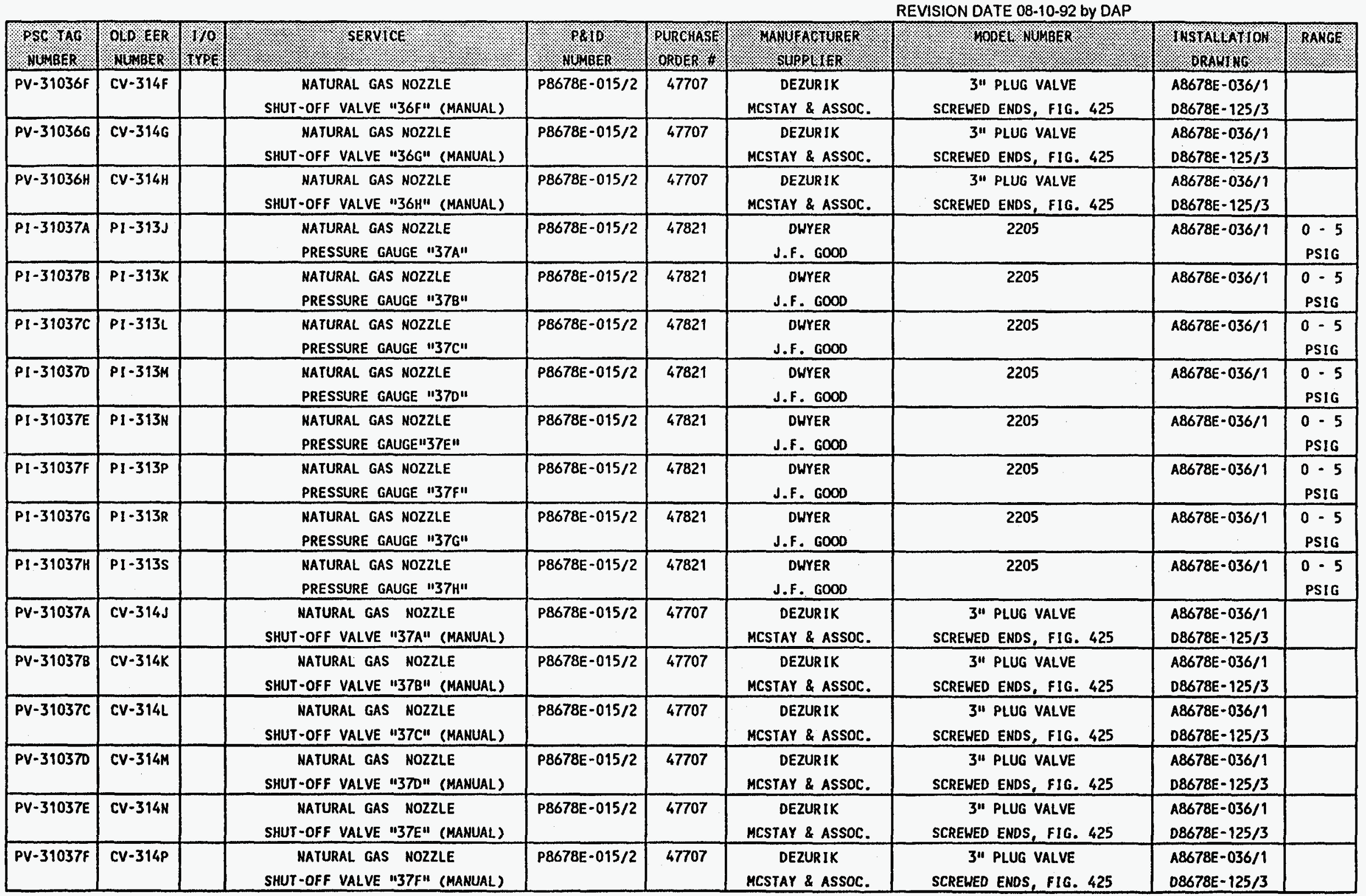




\begin{tabular}{|c|c|c|c|c|c|c|c|c|c|}
\hline & & & & & & & VISION DATE 08-10-92 by DAF & & \\
\hline PSOPA & OLOEE & roe & SERY Le? & roroser. & PURCHA H & 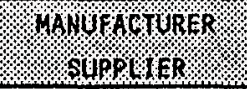 & $100 \% 2 \%$ & WOSTALATOOH & RAHGE \\
\hline PV-31037G & $C V-314 R$ & & $\begin{array}{l}\text { NATURAL GAS NOZZLE } \\
\text { SHUT-OFF VALVE "37G" (MANUAL) }\end{array}$ & $P 8678 E-015 / 2$ & 47707 & $\begin{array}{c}\text { DEZURIK } \\
\text { MCSTAY \& ASSOC. }\end{array}$ & $\begin{array}{l}\text { 3" PLUG VALVE } \\
\text { SCREWED ENDS, FIG. } 425\end{array}$ & $\begin{array}{l}\text { A8678E-036/1 } \\
D 8678 E-125 / 3\end{array}$ & \\
\hline PV-31037H & CV-314S & & $\begin{array}{l}\text { MATURAL GAS NOZZLE } \\
\text { SHUT-OFF VALVE "37H" (MANUAL) }\end{array}$ & P8678E-015/2 & 47707 & $\begin{array}{c}\text { DEZURIK } \\
\text { MCSTAY \& ASSOC. }\end{array}$ & $\begin{array}{l}\text { 3" PLUG VALVE } \\
\text { SCREWED ENDS, FIG. } 425\end{array}$ & $\begin{array}{l}\text { A8678E-036/1 } \\
D 8678 E-125 / 3\end{array}$ & \\
\hline $\mathrm{BT}-31040 \mathrm{~A}$ & $A E-316 A$ & DI & $\begin{array}{l}\text { NORTH FLAME SCANNER "A" } \\
\text { ELEVATION 5183' (BURNER 3D2) }\end{array}$ & $P 8678 E-015 / 1$ & 47926 & $\begin{array}{l}\text { COEN COMPANY } \\
\text { PROCESS ALTERN. }\end{array}$ & $\begin{array}{c}\text { IR7200A SCANNER } \\
\text { IRTO00A SIGNAL PROCESSOR }\end{array}$ & $E 8678 E-011 / 6$ & \\
\hline BT -310408 & $A E-316 B$ & DI & $\begin{array}{l}\text { SOUTH FLAME SCANMER "B" } \\
\text { ELEVATION } 5183 \text { ' (BURNER 304) }\end{array}$ & $P 8678 E-015 / 1$ & 47926 & $\begin{array}{l}\text { COEN COMPANY } \\
\text { PROCESS ALTERN. }\end{array}$ & $\begin{array}{c}\text { IR7200A SCANNER } \\
\text { IR7000A SIGNAL PROCESSOR }\end{array}$ & $E 8678 E-011 / 6$ & \\
\hline $8 T-31040 \mathrm{C}$ & $A E-316 C$ & DI & $\begin{array}{l}\text { NORTH FLAME SCANNER "C" } \\
\text { ELEVATION } 5175 \text { ' (BURNER } 3 C 1 \text { ) }\end{array}$ & $P 8678 E-015 / 1$ & 47926 & $\begin{array}{l}\text { COEN COMPANY } \\
\text { PROCESS ALTERN. }\end{array}$ & $\begin{array}{c}\text { IR7200A SCANNER } \\
\text { IR7000A SIGNAL PROCESSOR }\end{array}$ & E8678E-011/6 & \\
\hline BT -310400 & $A E-3160$ & DI & $\begin{array}{l}\text { SOUTH FLAME SCANNER "D" } \\
\text { ELEVATION } 5175 \text { (BURNER } 3 \mathrm{C3} \text { ) }\end{array}$ & $P 8678 E-015 / 1$ & 47926 & $\begin{array}{l}\text { COEN COMPANY } \\
\text { PROCESS ALTERN. }\end{array}$ & $\begin{array}{c}\text { IR7200A SCANNER } \\
\text { IR7000A SIGNAL PROCESSOR }\end{array}$ & $E 8678 E-011 / 6$ & \\
\hline BT-31040E & $A E-316 E$ & DI & $\begin{array}{l}\text { NORTH FLAME SCANNER "E" } \\
\text { ELEVATION } 5167 \text { ' (BURMER 3B2) }\end{array}$ & P8678E-015/1 & 47926 & $\begin{array}{l}\text { COEN COMPANY } \\
\text { PROCESS ALTERN. }\end{array}$ & $\begin{array}{c}\text { IR7200A SCANNER } \\
\text { IR7000A SIGNAL. PROCESSOR }\end{array}$ & $E 8678 E-011 / 6$ & \\
\hline $8 \mathrm{~T}-31040 \mathrm{~F}$ & $A E-316 F$ & DI & $\begin{array}{l}\text { SOUTH FLAME SCANNER "F" } \\
\text { ELEVATION } 5167 \text { (BURNER 3B4) }\end{array}$ & P8678E-015/1 & 47926 & $\begin{array}{l}\text { COEN COMPANY } \\
\text { PROCESS ALTERN. }\end{array}$ & $\begin{array}{c}\text { IR7200A SCANNER } \\
\text { IR7000A SIGNAL PROCESSOR }\end{array}$ & $E 8678 E-011 / 6$ & \\
\hline BT-31040G & $A E-316 G$ & DI & $\begin{array}{l}\text { NORTH FLAME SCANNER "G" } \\
\text { ELEVATION 5159. (BURNER 3A1) }\end{array}$ & P8678E-015/1 & 47926 & $\begin{array}{l}\text { COEN COMPANY } \\
\text { PROCESS ALTERN. }\end{array}$ & $\begin{array}{c}\text { IR7200A SCANKER } \\
\text { IR7000A SIGNAL PROCESSOR }\end{array}$ & EB678E-011/6 & \\
\hline 8T-31040H & $A E-316 H$ & 01 & $\begin{array}{l}\text { SOUTH FLAME SCANMER "H" } \\
\text { ELEVATION } 51591 \quad \text { (BURNER 3A3) }\end{array}$ & P8678E-015/1 & 47926 & $\begin{array}{l}\text { COEN COMPANY } \\
\text { PROCESS ALTERN. }\end{array}$ & $\begin{array}{c}\text { IR7200A SCANNER } \\
\text { IR7000A SIGNAL PROCESSOR }\end{array}$ & $E 8678 E-011 / 6$ & \\
\hline PSL-31040 & PSL-318 & DI & $\begin{array}{l}\text { FLAME SCANNERS COOLING AIR } \\
\text { LOW PRESSURE SWITCH }\end{array}$ & $P 8678 E-015 / 1$ & 47821 & $\begin{array}{c}\text { ASCO } \\
\text { J.F. GOOD }\end{array}$ & $S B 410-T A 41 A 11$ & $E 8678 E-011 / 6$ & $\begin{array}{l}0-12 " \\
\text { HATER }\end{array}$ \\
\hline$F E-31050$ & & & $\begin{array}{l}\text { REAR HALL - NAT. GAS FLOW } \\
\text { PRIMARY ELEMENT }\end{array}$ & P8678E-015 & $\begin{array}{c}70230- \\
8706\end{array}$ & $\begin{array}{l}\text { AI TKEN } \\
\text { J.F. GOOD }\end{array}$ & $\begin{array}{l}\text { CONCENTRIC ORIFICE PLATE } \\
\text { 8" LINE }\end{array}$ & $A 8678 E-036 / 2$ & \\
\hline FT -31050 & & AI & $\begin{array}{l}\text { REAR WALL - GAS FLOW } \\
\text { TRANSMITTER }\end{array}$ & P8678E-015 & $\begin{array}{c}70224- \\
8706\end{array}$ & $\begin{array}{l}\text { ROSEMOUNT } \\
\text { ROSEMOUNT }\end{array}$ & MODEL \# 1151DP3S12B1 & $A 8678 E-036 / 2$ & $\begin{array}{l}0-30 \\
\text { inwc }\end{array}$ \\
\hline FE-31051 & & & $\begin{array}{l}\text { FRONT WALL - NAT. GAS FLOW } \\
\text { PRIMARY ELEMENT }\end{array}$ & P8678E-015 & $\begin{array}{c}70230- \\
8706\end{array}$ & $\begin{array}{l}\text { AI TKEN } \\
\text { J.F. GOOD }\end{array}$ & $\begin{array}{c}\text { CONCENTRIC ORIFICE PLATE } \\
\text { g" LINE }\end{array}$ & $A 8678 E-036 / 2$ & \\
\hline FT-31051 & . & AI & $\begin{array}{l}\text { FRONT WALL - GAS FLOW } \\
\text { TRANSMITIER }\end{array}$ & P8678E-015. & $\begin{array}{c}70224- \\
8706\end{array}$ & $\begin{array}{l}\text { ROSEMOUNT } \\
\text { ROSEMOUNT }\end{array}$ & MODEL \# 11510P3S1281 & A8678E-036/2 & $\begin{array}{l}0.30 \\
\text { inwe }\end{array}$ \\
\hline
\end{tabular}

ASH HANDLING SYSTEM INSTRUMENTS \& COMPONENTS

\begin{tabular}{|c|c|c|c|c|c|c|c|c|}
\hline $\begin{array}{l}\text { FV }-36401 \\
2 S-36401\end{array}$ & $\begin{array}{l}C D-626 \\
25 C-626\end{array}$ & DI & $\begin{array}{l}\text { FGR MULTICLONE HOPPER } \\
\text { SLIDE GATE H/CLOSED LIMIT SW }\end{array}$ & P8678E-015/2 & 47819 & $\begin{array}{l}\text { UNITED COHVEY. } \\
\text { WATSON PWR EQ }\end{array}$ & $\begin{array}{c}8^{11}-1804-5 / 1803-41 / 1802-64 \\
1814-51 / 3531-23 / 1701-324-3 F\end{array}$ & $\begin{array}{c}\text { A867BE-030/1 } \\
\text { E8678E-012 }\end{array}$ \\
\hline
\end{tabular}


INSTRUMENT \& COMPONENT LIST CHEROKEE CCT UNIT 3

REVISION DATE 08-10-92 by DAP

\begin{tabular}{|c|c|c|c|c|c|c|c|c|c|}
\hline YSO WUAGER & OLO NGER & 110 & seRYuce & Meraser. & guRchase & Y.WURS TURER & $100 \mathrm{D} \bigcirc \mathrm{NU} / \mathrm{BER}$ & YYSTALIATION & उANGE \\
\hline$H V-38201$ & BV - 626 & & $\begin{array}{l}\text { MANUAL BALL VALVE } \\
\text { FOR FV-36401 }\end{array}$ & P8678E-015/2 & 47782 & $\begin{array}{l}\text { WORCESTER } \\
\text { A.E. EHRKE }\end{array}$ & 4846 RSE with $1 / 0-1 / 41$ NPT & $\begin{array}{c}A 8678 E-030 / 1 \\
E 8678 E-012\end{array}$ & \\
\hline PIC-38201 & $\begin{array}{l}\text { AF }-626 \\
\text { PI }-626 \\
\text { PRV }-626\end{array}$ & & $\begin{array}{l}\text { AIR PRESSURE FILTER } \\
\text { REGULATOR FOR } \\
\text { FV }-36401\end{array}$ & $P 8678 E-015 / 2$ & 47782 & $\begin{array}{l}\text { FISHER } \\
\text { A.E. EHRKE }\end{array}$ & $\begin{array}{c}\text { TYPE 67AFR W/FILTER \& } \\
0-60 \text { psig PRESSURE GAUGE } \\
1 / 0-1 / 4 " \text { NPT }\end{array}$ & $\begin{array}{c}A 8678 E-030 / 1 \\
E 8678 E-012 \\
E 8678 E-005\end{array}$ & \\
\hline LSH-36401 & LSH-615 & DI & $\begin{array}{c}\text { MULTICLONE HOPPER HIGH } \\
\text { LEVEL SWITCH }\end{array}$ & $P 8678 E-015 / 2$ & 47927 & $\begin{array}{l}\text { DYNATROL } \\
\text { AUTO. PROD. INC. }\end{array}$ & $\begin{array}{l}\text { CL-10DJT LEVEL DET. } \\
\text { W/EC-501A CONTROL UNIT }\end{array}$ & $\begin{array}{l}E 8678 E-012 \\
E 8678 E-005\end{array}$ & \\
\hline HV -36402 & $C D-627$ & & $\begin{array}{l}\text { FGR MULTICLONE AIR INTAKE } \\
\text { SHUT-OFF VALVE }\end{array}$ & P8678E-015/2 & 47819 & $\begin{array}{l}\text { UNITED CONVEY. } \\
\text { WATSON PWR EQ }\end{array}$ & $6^{\prime 1}-1904-11 / 6^{11}-1701-398-17 \mathrm{~B}$ & A8678E-030/1 & \\
\hline AV -36403 & & & $\begin{array}{l}\text { FGR MULTICLONE AIR INTAKE } \\
\text { CHECK VALVE }\end{array}$ & $P 8678 E-015 / 2$ & 47819 & $\begin{array}{l}\text { UNITED CONVEY. } \\
\text { WATSON PHR EQ }\end{array}$ & $\begin{array}{l}\text { 611-1801-24 W/18255-3 } \\
\text { CONN. 1701-293-LA }\end{array}$ & A8678E-030/1 & \\
\hline HV-38202 & $B V-627$ & & $\begin{array}{l}\text { MANUAL BALL VALVE } \\
\text { (SPARE / NOT REQUIRED) }\end{array}$ & $\begin{array}{l}\text { SPARE / NOT } \\
\text { REQUIRED }\end{array}$ & 47782 & $\begin{array}{l}\text { WORCESTER } \\
\text { A.E. EHRKE }\end{array}$ & 4846 RSE with I/O - 1/4" NPT & & \\
\hline PIC-38202 & $\begin{array}{l}\text { AF- } 627 \\
\text { PI-627 } \\
\text { PRV-627 }\end{array}$ & & $\begin{array}{l}\text { AIR PRESSURE FILTER } \\
\text { REGULATOR } \\
\text { (SPARE / NOT REOUIRED) }\end{array}$ & $\begin{array}{l}\text { SPARE } \\
/ \text { NOT } \\
\text { REQUIREO }\end{array}$ & 47782 & $\begin{array}{l}\text { FISHER } \\
\text { A.E. EHRKE }\end{array}$ & $\begin{array}{c}\text { TYPE 67AFR w/FILIER \& } \\
0-60 \text { psig PRESSURE GAUGE } \\
1 / 0-1 / 4 " \text { NPT }\end{array}$ & & \\
\hline
\end{tabular}

BOILER AIR AND FLUE GAS SYSTEM INSTRUMENTS \& COMPONENTS

\begin{tabular}{|c|c|c|c|c|c|c|c|c|}
\hline FT -38701 & & Al & AIR FLOW TRANSMITTER/NORTH & P8678E-015/3 & & ROSEMOUNT & 1151DR2F12B1 & STD 143-6 \\
\hline $\mathrm{FT}-38702$ & & AI & AIR FLOW TRANSMITTER/SOUTH & P8678E-015/3 & & ROSEMOUNT & 1151DR2F12B1 & STD $143-6$ \\
\hline $\mathrm{FT}-38703$ & & AI & GAS RECIRC. FLOW/NORTH & P8678E-015/3 & & ROSEMOUNT & 11510R2F12B1 & STD143-6 \\
\hline FT038704 & & AI & GAS RECIRC. FLOW/SOUTH & P8678E-015/3 & & ROSEMOUNT & 1151DR2F 12B1 $0-0.5 / 6^{11 W C}$ & STD143-6 \\
\hline $\begin{array}{l}F V-38720 \\
2 S-38720 A \\
Z S-387208 \\
\end{array}$ & $\begin{array}{l}C D-608 \\
2 S C-608 \\
2 S 0-608 \\
\end{array}$ & $\begin{array}{l}2-00 \\
2-01\end{array} \mid$ & $\begin{array}{l}\text { FGR MULTICLONE INLET } \\
\text { ISOLATION DAMPER WITH } \\
\text { OPEN \& CLOSED LIMIT SWITCHS }\end{array}$ & P8678E-015/2 & 42535 & $\begin{array}{l}\text { MADER DAMPERS } \\
\text { HUGHES \& ASSOC. }\end{array}$ & $\begin{array}{l}56 " \times \text { 85" DAMPER } \\
\text { DUAL COIL }\end{array}$ & $\begin{array}{c}08678 E-125 / 4 \\
E 8678 E-012 \\
E 8678 E-005 \\
\end{array}$ \\
\hline HV -38220 & $B V-608$ & & $\begin{array}{c}\text { MANUAL BALL VALVE } \\
\text { FOR FV- } 38720 \\
\end{array}$ & P8678E-015/2 & 47782 & $\begin{array}{l}\text { WORCESTER CON. } \\
\text { A.E. EHRKE }\end{array}$ & 4846 RSE with $1 / 0-1 / 4 " \mathrm{NPT}$ & $\begin{array}{c}08678 E-125 / 4 \\
E 8678 E-012 \\
\end{array}$ \\
\hline PIC-38220 & $\begin{array}{l}\text { AF }-608 \\
\text { PI }-608 \\
\text { PRV }-608 \\
\end{array}$ & & $\begin{array}{l}\text { AIR PRESSURE FILTER } \\
\text { REGULATOR FOR FV-38720 }\end{array}$ & P8678E-015/2 & 47782 & $\begin{array}{l}\text { FISHER } \\
\text { A.E. EHRKE } \\
\end{array}$ & $\begin{array}{c}\text { TYPE 67AFR W/FILTER \& } \\
0-60 \text { psig PRESSURE GAUGE } \\
1 / 0-1 / 4 " \mathrm{NPT} \\
\end{array}$ & $\begin{array}{c}08678 E-125 / 4 \\
E 8678 E-012 \\
E 8678 E-005 \\
\end{array}$ \\
\hline $\begin{array}{c}\text { FCV }-38721 \\
25-38721\end{array}$ & $\begin{array}{l}C D-601 \\
2 S C-601\end{array}$ & $\begin{array}{l}\text { AO } \\
\text { DI }\end{array}$ & $\begin{array}{l}\text { FGR INJECTION FAN INLET } \\
\text { CONIROL DAMPER FOR FAN-3 } \\
\text { W/CLOSED LIMIT SWITCH }\end{array}$ & P8678E-015/2 & 42524 & $\begin{array}{l}\text { BARRON } \\
\text { FLO-TECH } \\
\text { INC. }\end{array}$ & $\begin{array}{l}30 " \times 126 " \text { DAMPER } \\
\text { W/ BECK DRIVE } \\
\text { FURNISHED W/ FAN-3 }\end{array}$ & $\begin{array}{c}08678 E-125 / 4 \\
E 8678 E-012 \\
E 8678 E-005\end{array}$ \\
\hline
\end{tabular}


INSTRUMENT \& COMPONENT LIST CHEROKEE CCT UNIT 3

REVISION DATE 08-10-92 by DAP

\begin{tabular}{|c|c|c|c|c|c|c|c|c|c|}
\hline PSO & OW0 & 110 & $S E R Y O$ & $\begin{array}{l}\text { Q10\% } \\
\text { NUABER }\end{array}$ & OURCHAsE & 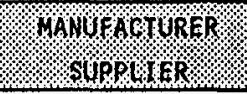 & \% $/$, & 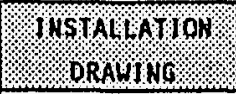 & rANGE \\
\hline $1 T-38722$ & $1 T-616$ & Al & $\begin{array}{l}\text { FGR FAN CURRENT } \\
\text { TRANSMITITER FOR } M-3\end{array}$ & $P 8678 E-015 / 2$ & 42568 & MAGNETEK & $\begin{array}{l}\text { PART OF FAN-3 } \\
5 \mathrm{KV} \text { SWITCHGEAR }\end{array}$ & $\begin{array}{c}D 8678 E-125 / 4 \\
E 8678 E-005\end{array}$ & \\
\hline FS-38722A & FS $-613 A$ & DI & $\begin{array}{l}\text { FGR FAN INBOARD BEARING } \\
\text { OIL FLOW SWITCH }\end{array}$ & P8678E-015/2 & 42524 & $\begin{array}{l}\text { BARRON } \\
\text { FLO-TECH, INC. }\end{array}$ & INCLUDED W/ OCS-1 & E8678E-005 & \\
\hline FS-387228 & FS-613B & DI & $\begin{array}{l}\text { FGR FAN OUTBOARD BEARING } \\
\text { OIL FLOW SWITCH } \\
\end{array}$ & P8678E-015/2 & 42524 & $\begin{array}{c}\text { BARRON } \\
\text { FLO-TECH, INC. }\end{array}$ & INCLUDED W/ OCS-1 & $E 8678 E-005$ & \\
\hline TE-38722A & $T E-613 A$ & $A I-T C$ & $\begin{array}{l}\text { FGR FAN INBOARD BEARING TEMP. } \\
\text { ELEMENT, TYPE "K" THERMOCOUPLE }\end{array}$ & $P 8678 E-015 / 2$ & 42524 & $\begin{array}{c}\text { BARRON } \\
\text { FLO-YECH, INC. }\end{array}$ & INCLUDED W/ FAN & $\begin{array}{c}D 8678 E-125 / 4 \\
E 8678 E-012 \\
\end{array}$ & \\
\hline TE-38722B & TE-613B & $A I-T C$ & $\begin{array}{l}\text { FGR FAN OUTBOARD BEARING TEMP. } \\
\text { ELEMENT, TYPE "K" THERMOCOUPLE }\end{array}$ & P8678E-015/2 & 42524 & $\begin{array}{c}\text { BARRON } \\
\text { FLO-TECH, INC. }\end{array}$ & INCLUDED W/ FAN & $\begin{array}{c}D 8678 E-125 / 4 \\
E 8678 E-012\end{array}$ & \\
\hline TE-38722C & TE-613C & $A 1-I C$ & $\begin{array}{l}\text { FGR FAN MOTOR STATOR TEMP. } \\
\text { ELEMENT, TYPE "K" THERMOCOUPLE }\end{array}$ & P8678E-015/2 & 42524 & $\begin{array}{c}\text { BARRON } \\
\text { FLO-TECH, INC. }\end{array}$ & INCLUDED W/ FAN & $\begin{array}{c}D 8678 E-125 / 4 \\
E 8678 E-012\end{array}$ & \\
\hline TE-38722D & TE-613D & $A I-T C$ & $\begin{array}{l}\text { FGR FAN HOUSING TEMPERATURE } \\
\text { ELEMENT, TYPE "K" THERMOCOUPLE }\end{array}$ & $P 8678 E-015 / 2$ & 42524 & $\begin{array}{c}\text { BARRON } \\
\text { FLO-TECH, INC. }\end{array}$ & INCLUDED W/ FAN & $\begin{array}{c}\text { D8678E- } 125 / 4 \\
E 8678 E-012\end{array}$ & \\
\hline$r T-38722 A$ & $V E-614 A$ & AI & $\begin{array}{c}\text { FGR FAN INBOARD BEARING } \\
\text { VIBRATION SENSOR }\end{array}$ & P8678E-015/2 & 42524 & $\begin{array}{c}\text { BARRON } \\
\text { FLO-TECH, INC. }\end{array}$ & INCLUDED W/ FAN & $\begin{array}{c}D 8678 E-125 / 4 \\
E B 678 E-012 \\
\end{array}$ & \\
\hline$Y T-38722 B$ & VE-614B & Al & $\begin{array}{c}\text { FGR FAN OUTBOARD BEARING } \\
\text { VIBRATION SENSOR } \\
\end{array}$ & P8678E-015/2 & 42524 & $\begin{array}{c}\text { BARRON } \\
\text { FLO-TECH, INC. }\end{array}$ & INCLUDED W/ FAN & $\begin{array}{c}08678 E-125 / 4 \\
E 8678 E-012 \\
\end{array}$ & \\
\hline $\begin{array}{l}\text { FV }-38723 \\
2 S-38723 A \\
2 S-38723 B \\
\end{array}$ & $\begin{array}{l}C D-606 \\
2 S C-606 \\
2 S 0-606\end{array}$ & $\begin{array}{l}2-D 0 \\
2-D 1\end{array} \mid$ & $\begin{array}{l}\text { FGR INJECTION FAN DISCHARGE } \\
\text { ISOLATION DAMPER WITH } \\
\text { OPEN \& CLOSED LIMIT SHITCHS }\end{array}$ & P8678E-015/2 & 42535 & $\begin{array}{l}\text { MADER DAMPERS } \\
\text { HUGHES \& ASSOC. }\end{array}$ & $\begin{array}{l}\text { 42" DAMPER INCLUDES } \\
\text { FV-38730, FAN-5 AND } M-5 \\
\text { DUAL COIL }\end{array}$ & $\begin{array}{c}\text { D8678E- } 125 / 3,4 \\
E 8678 E-012\end{array}$ & \\
\hline HV-38223 & BV. 606 & & $\begin{array}{l}\text { MANUAL BALL VALVE } \\
\text { FOR FV-38723 }\end{array}$ & P8678E-015/2 & 47782 & $\begin{array}{l}\text { WORCESTER CON. } \\
\text { A.E. EHRKE }\end{array}$ & 4846 RSE with $1 / 0-1 / 411 \mathrm{NPT}$ & $\begin{array}{c}D 8678 E-125 / 3,4 \\
E 8678 E-012 \\
\end{array}$ & \\
\hline PIC-38223 & $\begin{array}{l}\text { AF }=606 \\
\text { PI }-606 \\
\text { PRV-606 }\end{array}$ & & $\begin{array}{l}\text { AIR PRESSURE FILTER } \\
\text { REGULATOR FOR } \\
\text { FV }-38723\end{array}$ & P8678E-015/2 & 47782 & $\begin{array}{l}\text { FISHER } \\
\text { A.E. EHRKE } \\
\end{array}$ & $\begin{array}{c}\text { TYPE 67AFR W/FILTER \& } \\
0 \cdot 60 \text { psig PRESSURE GAUGE } \\
1 / 0-1 / 4^{\prime \prime} \text { NPT }\end{array}$ & $\begin{array}{c}D 8678 E-125 / 4 \\
E 8678 E-012\end{array}$ & \\
\hline $\mathrm{TI}-38724$ & $T 1-603$ & & $\begin{array}{l}\text { FGR GAS TEMPERATURE } \\
\text { INDICATOR } \\
\end{array}$ & P8678E-015/2 & 47255 & $\begin{array}{l}\text { ASHCROFT } \\
\text { J.F. GOOO }\end{array}$ & 5" 50EI60E090 W/ WELL & $\begin{array}{c}\text { D8678E-125/3 } \\
\text { STD }-143 / 3 \\
\end{array}$ & $\begin{array}{l}200-1000 \\
\text { DEG F. }\end{array}$ \\
\hline TE-38724 & TE -603 & AI $-\mathrm{TC}$ & $\begin{array}{l}\text { FGR DUCT GAS TEMPERATURE } \\
\text { ELEMENT, TYPE "K" THERMOCOUPLE }\end{array}$ & P8678E-015/2 & 477220 & $\begin{array}{c}\text { T-TEC } \\
\text { A.0. GRUMNEY } \\
\end{array}$ & $\begin{array}{ll}1020-K-(23-1 / 2)-1-S-A-U & (T / C) \\
3 / 4-260 S-(22-1 / 2)-304 & (W E L L)\end{array}$ & $D 8678 E-125 / 3$ & \\
\hline $\mathrm{PI}-38724$ & PI-604 & & $\begin{array}{l}\text { FGR GAS INJECTION PORTS } \\
\text { HEADER PRESSURE INDICATOR }\end{array}$ & $P 8678 E-015 / 2$ & 47821 & $\begin{array}{c}\text { DWYER } \\
\text { J.F. GOOD } \\
\end{array}$ & 2030 & $\begin{array}{c}\text { D8678E-125/3 } \\
\text { STD-143/1 }\end{array}$ & $\begin{array}{l}0 \text { - } 30 " 1 \\
\text { WATER }\end{array}$ \\
\hline PT-38724 & PT - 623 & AI & $\begin{array}{l}\text { FGR INJECTION HEADER } \\
\text { PRESSURE TRANSMITTER }\end{array}$ & P8678E-015/2 & 47817 & $\begin{array}{l}\text { ROSEMOUNT } \\
\text { INC. }\end{array}$ & $\begin{array}{c}\text { 1151GP4S1281 } \\
\text { CALIBRATE } 0-30 \text { INHC }\end{array}$ & $\begin{array}{c}\text { D8678E-125/3 } \\
\text { STD }-143 / 4\end{array}$ & $\begin{array}{c}1-150 \\
\text { INWC }\end{array}$ \\
\hline
\end{tabular}


INSTRUMENT \& COMPONENT LIST CHEROKEE CCT UNIT 3

\begin{tabular}{|c|c|c|c|c|c|c|c|c|c|}
\hline & & & & & & & REVISION DATE 08-10-92 by DAP & & \\
\hline $150 \%$ & $\begin{array}{l}01 \mathrm{EER} \\
\mathrm{NHABR}\end{array}$ & $1 \%$ & SERYIR & MHBer & rURCHASE & 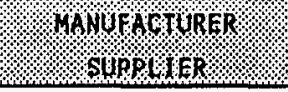 & MopeV WuMBen & WSTALATON & RAMG \\
\hline FK- 38225 & $P R-1 A$ & $3-D 0$ & $\begin{array}{c}\text { FGR VENTURI PURGE PANEL } \\
\text { FOR FE-38726 } \\
\end{array}$ & P8678E-015/2 & 47905 & RBB SYSTEMS, INC. & $\begin{array}{l}\text { PURGE PANEL UNIT } \\
\text { EER DWG. STD-106 } \\
\end{array}$ & $\begin{array}{c}\text { D8678E-125/3,4 } \\
E 8678 E-012 \\
\end{array}$ & \\
\hline$H V-38225$ & BV-PR 1A & & $\begin{array}{l}\text { MANUAL BALL VALVE } \\
\text { FOR FK-38225 }\end{array}$ & P8678E-015/2 & 47782 & $\begin{array}{l}\text { WORCESTER } \\
\text { A.E. EHRKE }\end{array}$ & 4846 RSE with $1 / 0-1 / 411$ NPT & $\begin{array}{c}D 8678 E-125 / 3,4 \\
E 8678 E-012\end{array}$ & \\
\hline PIC-38225 & $\begin{array}{r}\text { AF-PR 1A } \\
\text { PI }-P R 1 A \\
\text { PRV-PR1A } \\
\end{array}$ & & $\begin{array}{l}\text { AIR PRESSURE FILTER } \\
\text { REGULATOR FOR FK-38225 }\end{array}$ & $P 8678 E-015 / 2$ & 47782 & $\begin{array}{l}\text { FISHER } \\
\text { A.E. EHRKE } \\
\end{array}$ & $\begin{array}{c}\text { TYPE 67AFR w/FILTER \& } \\
0-60 \mathrm{psig} \text { PRESSURE GAUGE } \\
1 / 0-1 / 4^{\prime \prime} \mathrm{NPT}\end{array}$ & $\begin{array}{c}\text { D8678E-125/3.4 } \\
E 8678 E-012\end{array}$ & \\
\hline FE -38726 & $F E-627 A$ & & FGR VENTURI FLOW ELEMENT & $P 8678 E-015 / 2$ & $\ldots \ldots \ldots$ & B\&W & & $\begin{array}{c}D 8678 E-125 / 3,4 \\
E 8678 E-012\end{array}$ & \\
\hline$F T+38726$ & FT - 627A & AI & $\begin{array}{l}\text { FGR VENTURI FLOW DELTA-P } \\
\text { TRANSMITTER (FRONT WALL) }\end{array}$ & $P 8678 E-015 / 2$ & 47817 & $\begin{array}{l}\text { ROSEMOUNT } \\
\text { INC. }\end{array}$ & $\begin{array}{c}\text { 11510R2F12B1 } \\
\text { CALIB. } 0-2.4 " \text { WAIER }\end{array}$ & $\begin{array}{c}8678 E-125 / 3,4 \\
E 8678 E-012\end{array}$ & $\begin{array}{l}0-6 " \\
\text { WATER }\end{array}$ \\
\hline $\begin{array}{c}\text { FCV-38726 } \\
25 \cdot 38726 \\
\end{array}$ & $C D-6178$ & $\begin{array}{l}\text { AO } \\
\text { DI }\end{array}$ & $\begin{array}{l}\text { FGR HEADER CONTROL DAMPER } \\
\text { W/CLOSED LIMIT SWITCH (EAST) }\end{array}$ & P8678E-015/2 & 42535 & $\begin{array}{l}\text { MADER OAMPERS } \\
\text { HUGHES \& ASSOC. }\end{array}$ & $\begin{array}{l}\text { 30" MODULATING BUTTERFLY } \\
\text { DAMPER W/ CLOSED LIMIT }\end{array}$ & $\begin{array}{c}\text { D8678E- } 125 / 3,4 \\
E 8678 E-012 \\
\end{array}$ & \\
\hline$H V-38226$ & $B V-617 B$ & & $\begin{array}{l}\text { MANUAL BALL VALVE } \\
\text { FOR FCV- } 38726 \\
\end{array}$ & $P 8678 E-015 / 2$ & 47782 & $\begin{array}{l}\text { WORCESTER CON. } \\
\text { A.E. EHRKE } \\
\end{array}$ & 4846 RSE with $1 / 0-1 / 4 "$ NPT & $\begin{array}{c}08678 E-125 / 3,4 \\
E 8678 E-012 \\
\end{array}$ & \\
\hline PIC-38226 & $\begin{array}{l}\text { AF }-617 B \\
\text { PI }-617 B \\
\text { PRV }-617 B\end{array}$ & & $\begin{array}{l}\text { AIR PRESSURE FILTER } \\
\text { REGULATOR FOR FCV-38726 }\end{array}$ & $P 8678 E-015 / 2$ & 47782 & $\begin{array}{c}\text { FISHER } \\
\text { A.E. EHRKE }\end{array}$ & $\begin{array}{c}\text { TYPE 67AFR W/ FILTER \& } \\
0-60 \text { psig PRESSURE GAUGE } \\
1 / 0-1 / 4 " \mathrm{NPT}\end{array}$ & $\begin{array}{c}\text { D8678E-125/3,4 } \\
E 8678 E-012\end{array}$ & \\
\hline FE-38727 & $F E-6278$ & & FGR VENTURI FLOW ELEMENT & P8678E-015/2 & -.......... & $B \& W$ & & $\begin{array}{c}\text { D8678E-125/3,4 } \\
E 8678 E-012\end{array}$ & \\
\hline FT-38727 & $F T-627 B$ & AI & $\begin{array}{l}\text { FGR VENTURI FLOW DELTA-P } \\
\text { TRANSMITTER (REAR WALL) }\end{array}$ & P8678E-015/2 & 47817 & $\begin{array}{l}\text { ROSEMOUNT } \\
\text { INC. }\end{array}$ & $\begin{array}{c}\text { 11510R2F12B1 } \\
\text { CAL IBRATE } 0-2.4 " \text { WATER }\end{array}$ & $\begin{array}{c}\text { D8678E-125/3,4 } \\
E B 678 E-012 \\
\end{array}$ & $\begin{array}{c}0-6 " 1 \\
\text { WATER }\end{array}$ \\
\hline $\begin{array}{r}\text { FCV }-38727 \\
2 S-38727 \\
\end{array}$ & $C D-617 A$ & $\begin{array}{l}\text { AO } \\
\text { DI }\end{array}$ & $\begin{array}{l}\text { FGR HEADER CONTROL DAMPER } \\
\text { W/CLOSED LIMIT SWITCH (WEST) }\end{array}$ & P8678E-015/2 & 42535 & $\begin{array}{l}\text { MADER DAMPERS } \\
\text { HUGHES \& ASSOC. }\end{array}$ & $\begin{array}{l}\text { 30" MODULATING BUTTERFLY } \\
\text { DAMPER W/ CLOSED LIMIT }\end{array}$ & $\begin{array}{c}D 8678 E-125 / 3,4 \\
E 8678 E-012\end{array}$ & \\
\hline$H V-38227$ & BV-617A & & $\begin{array}{l}\text { MANUAL BALL VALVE } \\
\text { FOR FCV- } 38727 \\
\end{array}$ & P8678E-015/2 & 47782 & $\begin{array}{l}\text { WORCESTER CON. } \\
\text { A.E. EHRKE }\end{array}$ & 4846 RSE with $1 / 0-1 / 4 "$ NPT & $\begin{array}{c}D 8678 E-125 / 3,4 \\
E 8678 E-012\end{array}$ & \\
\hline PIC-38227 & $\begin{array}{l}A F-617 A \\
P I-617 A \\
P R V-617 A\end{array}$ & & $\begin{array}{l}\text { AIR PRESSURE FILTER } \\
\text { REGULATOR FOR FCV-38727 }\end{array}$ & P8678E-015/2 & 47782 & $\begin{array}{c}\text { FISHER } \\
\text { A.E. EHRKE }\end{array}$ & $\begin{array}{c}\text { TYPE G7AFR W/ FILTER \& } \\
\text { PRESSURE GAUGE } \\
1 / 0-1 / 4 " \text { NPT }\end{array}$ & $\begin{array}{c}\text { D8678E-125/3,4 } \\
\text { EB678E-012 }\end{array}$ & \\
\hline FK-38228 & $P R-1 A$ & $3-00$ & $\begin{array}{l}\text { FGR VENTURI PURGE PANEL } \\
\text { FOR FE-38727 } \\
\end{array}$ & PB678E-015/2 & 47905 & RBB SYSTEMS, INC. & $\begin{array}{l}\text { PURGE PANEL UNIT } \\
\text { EER DWG. STD-106 } \\
\end{array}$ & $\begin{array}{c}\mathrm{D} 8678 E-125 / 3,4 \\
E 8678 E-012 \\
\end{array}$ & \\
\hline HV-38228 & $B V-P R 1 B$ & & $\begin{array}{c}\text { MANUAL BALL VALVE } \\
\text { FOR FK-38228 }\end{array}$ & P8678E-015/2 & 47782 & $\begin{array}{l}\text { WORCESTER CON. } \\
\text { A.E. EHRKE }\end{array}$ & 4846 RSE with $1 / 0-1 / 4$ " NPT & $\begin{array}{c}\text { D8678E-125/3,4 } \\
E 8678 E-012\end{array}$ & \\
\hline
\end{tabular}


INSTRUMENT \& COMPONENT LIST CHEROKEE CCT UNIT 3

\begin{tabular}{|c|c|c|c|c|c|c|c|c|c|}
\hline & & & & & & & REVISION DATE $08-10-92$ by DAP & & \\
\hline 850 & oun & $10 \%$ & SERYC & \%स⿴囗\% & POQWUSE & 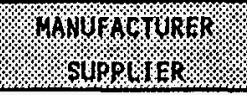 & V. & 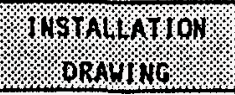 & RAUGS \\
\hline PIC-38228 & $\begin{array}{l}\text { AF-PR1B } \\
\text { PI -PR1B } \\
\text { PRV-PR1B }\end{array}$ & & $\begin{array}{c}\text { AIR PRESSURE FILTER } \\
\text { REGULATOR FOR } \\
\text { FK- } 38228\end{array}$ & P8678E-015/2 & 47782 & $\begin{array}{l}\text { FISHER } \\
\text { A.E. EHRKE }\end{array}$ & $\begin{array}{c}\text { TYPE 67AFR w/FILTER \& } \\
0-60 \text { psig PRESSURE GAUGE } \\
1 / 0-1 / 4^{\prime \prime} \mathrm{NPT}\end{array}$ & $\begin{array}{c}D 8678 E-125 / 3,4 \\
E B 678 E-012\end{array}$ & \\
\hline FV-38730 & $C D-610$ & DO & $\begin{array}{c}\text { FGR DISCHARGE DAMPER SEAL AIR } \\
\text { FAN SHUT - OFF DAMPER }\end{array}$ & P8678E-015/2 & 42535 & $\begin{array}{l}\text { MADER DAMPERS } \\
\text { HUGHES \& ASSOC. }\end{array}$ & $\begin{array}{c}\text { INTERGAL PART OF } \\
\text { FV }-38723 \\
\end{array}$ & $\begin{array}{c}D 8678 E-125 / 3,4 \\
E 8678 E-012 \\
\end{array}$ & \\
\hline HV -38230 & BV -610 & & $\begin{array}{l}\text { MANUAL BALL VALVE } \\
\text { FOR FV- } 38730\end{array}$ & P8678E-015/2 & 47782 & $\begin{array}{l}\text { WORCESTER CON. } \\
\text { A.E. EHRKE }\end{array}$ & 4846 RSE with $1 / 0-1 / 4 "$ MPT & $\begin{array}{c}D 8678 E-125 / 3,4 \\
E 8678 E-012\end{array}$ & \\
\hline PIC-38230 & $\begin{array}{l}\text { AF }-610 \\
\text { PI }-610 \\
\text { PRV- } 610\end{array}$ & & $\begin{array}{l}\text { AIR PRESSURE FILTER } \\
\text { REGULATOR FOR FV-38730 }\end{array}$ & P8678E-015/2 & 47782 & $\begin{array}{c}\text { FISHER } \\
\text { A.E. EHRKE } \\
\end{array}$ & $\begin{array}{c}\text { TYPE 67AFR W/ FILTER \& } \\
0-60 \text { psig PRESSURE GAUGE } \\
\text { I/0 }-1 / 4 " \text { NPT }\end{array}$ & $\begin{array}{c}\text { D8678E-125/3,4 } \\
E 8678 E-012\end{array}$ & \\
\hline PI-38732 & $\mathrm{PI}-605 \mathrm{~A}$ & & $\begin{array}{l}\text { FRONT WALL GAS REBURN } \\
\text { HEADER PRESSURE INOICATOR }\end{array}$ & P8678E-015/2 & 47821 & $\begin{array}{l}\text { DWYER } \\
\text { J.F. } 6000\end{array}$ & 2030 & $\begin{array}{c}A 8678 E-125 / 4 \\
E 8678 E-005\end{array}$ & $\begin{array}{l}0-30^{\prime \prime} \\
\text { WATER }\end{array}$ \\
\hline FV-38732 & CV-607A & Do & $\begin{array}{l}\text { GR NOZZLE COOLING AIR FAN } \\
\text { SHUT- OFF DAMPER "A" }\end{array}$ & P8678E-015/2 & 42535 & $\begin{array}{l}\text { MADER DAMPERS } \\
\text { HUGHES \& ASSOC. }\end{array}$ & 16" DAMPER & $\begin{array}{c}\text { AB678E- } 125 / 4 \\
E 8678 E-005\end{array}$ & \\
\hline HV- 38232 & BV-607A & & $\begin{array}{c}\text { MANUAL BALL VALVE } \\
\text { FOR FV- } 38732 \\
\end{array}$ & P8678E-015/2 & 47782 & $\begin{array}{l}\text { WORCESTER CON. } \\
\text { A.E. EHRKE }\end{array}$ & 4846 RSE with $1 / 0-1 / 4 "$ MPT & $\begin{array}{c}A 8678 E-125 / 4 \\
E 8678 E-005\end{array}$ & \\
\hline PIC-38232 & $\begin{array}{l}\text { AF-607A } \\
\text { PI-607A } \\
\text { PRV-607A }\end{array}$ & & $\begin{array}{l}\text { AIR PRESSURE FILTER } \\
\text { REGULATOR FOR FV- } 38732\end{array}$ & P8678E-015/2 & 47782 & $\begin{array}{l}\text { FISHER } \\
\text { A.E. EHRKE }\end{array}$ & $\begin{array}{c}\text { TYPE } 67 \text { AFR w/FILIER \& } \\
0-60 \text { psig PRESSURE GAUGE } \\
1 / 0-1 / 4 " \text { NPT }\end{array}$ & $\begin{array}{c}A 8678 E-125 / 4 \\
E 8678 E-005\end{array}$ & \\
\hline PI-38733 & PI-605B & & $\begin{array}{l}\text { REAR WALL GAS REBURN } \\
\text { HEADER PRESSURE INDICATOR } \\
\end{array}$ & $P 8678 E-015 / 2$ & 47821 & $\begin{array}{l}\text { DWYER } \\
\text { J.F. } \text { GOOD } \\
\end{array}$ & 2030 & $\begin{array}{c}\text { A8678E- } 125 / 4 \\
E 8678 E-005 \\
\end{array}$ & $\begin{array}{l}0-30^{\prime \prime} \\
\text { HATER }\end{array}$ \\
\hline$F V-38733$ & CV-607B & DO & $\begin{array}{l}\text { GR NOZZLE COOLING AIR FAN } \\
\text { SHUT-OFF DAMPER "B" }\end{array}$ & P8678E-015/2 & 42535 & $\begin{array}{l}\text { MADER DAMPERS } \\
\text { HUGHES \& ASSOC. } \\
\end{array}$ & 16" DAMPER & $\begin{array}{c}A 8678 E-125 / 4 \\
E 8678 E-005 \\
\end{array}$ & \\
\hline HV-38233 & BV-607B & & $\begin{array}{l}\text { MANUAL BALL VALVE } \\
\text { FOR FV- } 38733 \\
\end{array}$ & P8678E-015/2 & 47782 & $\begin{array}{l}\text { WORCESTER CON. } \\
\text { A.E. EHRKE } \\
\end{array}$ & 4846 RSE with $1 / 0-1 / 4 "$ MPT & $\begin{array}{c}A 8678 E-125 / 4 \\
E 8678 E-005\end{array}$ & \\
\hline PIC-38233 & $\begin{array}{l}\text { AF-607B } \\
\text { PI-607B } \\
\text { PRV-6078 }\end{array}$ & & $\begin{array}{l}\text { AIR PRESSURE FILIER } \\
\text { REGULATOR FOR FV-38733 }\end{array}$ & P8678E-015/2 & 47782 & $\begin{array}{l}\text { FISHER } \\
\text { A.E. EHRKE }\end{array}$ & $\begin{array}{c}\text { TYPE 67AFR w/FILIER \& } \\
0-60 \text { psig PRESSURE GAUGE } \\
1 / 0-1 / 4^{11} \text { NPT }\end{array}$ & $\begin{array}{c}\text { A8678E- } 125 / 4 \\
E 8678 E-005\end{array}$ & \\
\hline PV-38736A & $C V-609 A$ & & $\begin{array}{l}\text { MANUAL FGR INJECTION FLOW } \\
\text { BALANCING DAMPER "36A" }\end{array}$ & P8678E-015/2 & 42536 & $\begin{array}{l}\text { OLSON TECH. } \\
\text { HUGHES \& ASSOC. }\end{array}$ & $\begin{array}{c}\text { 10" DAMPER } \\
\text { FIG.\# 25 AW-22 HM-L } \\
\end{array}$ & E8678E-005 & \\
\hline PV-38736B & $C V-609 B$ & & $\begin{array}{l}\text { MANUAL FGR INJECTION FLOW } \\
\text { BALANCING DAMPER "368" }\end{array}$ & P8678E-015/2 & 42536 & $\begin{array}{l}\text { OLSON TECH. } \\
\text { HUGHES \& ASSOC. }\end{array}$ & $\begin{array}{l}\text { 10" DAMPER } \\
\text { FIG.\# } 25 \text { AH-22 HM-L }\end{array}$ & E8678E-005 & \\
\hline PV-38736C & $C V-609 C$ & & $\begin{array}{l}\text { MANUAL FGR INJECTION FLOW } \\
\text { BALANCING DAMPER "36C" }\end{array}$ & P8678E-015/2 & 42536 & $\begin{array}{l}\text { OLSON TECH. } \\
\text { HUGHES \& ASSOC. }\end{array}$ & $\begin{array}{c}\text { 10" DAMPER } \\
\text { FIG.\#25 AW-22 HM-L. }\end{array}$ & $E 8678 E-005$ & \\
\hline
\end{tabular}


INSTRUMENT \& COMPONENT LIST CHEROKEE CCT UNIT 3

\begin{tabular}{|c|c|c|c|c|c|c|c|c|c|}
\hline & & & & & & & REVISION DATE 08-10-92 by DAP & & \\
\hline $19 \mathrm{SO} / \mathrm{AO}$ & OYOH & 109 & SERUYC & Nolorar. & PORQRASE & 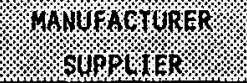 & $100 \% 4 \%$ & WORAG & RANGF \\
\hline$P V-387360$ & $C V-6090$ & & $\begin{array}{l}\text { MANUAL FGR INJECTION FLOW } \\
\text { BALANCING DAMPER "36D" }\end{array}$ & P8678E-015/2 & 42536 & $\begin{array}{l}\text { OLSON TECH. } \\
\text { HUGHES \& ASSOC. }\end{array}$ & $\begin{array}{c}\text { 10" DAMPER } \\
\text { F1G.\#25 AW-22 HM-L }\end{array}$ & $E 8678 E-005$ & \\
\hline PV-38736E & CV-609E & & $\begin{array}{l}\text { MANUAL FGR INJECTION FLOW } \\
\text { BALANCING DAMPER "36E" }\end{array}$ & P8678E-015/2 & 42536 & $\begin{array}{l}\text { OLSON TECH. } \\
\text { HUGHES \& ASSOC. }\end{array}$ & $\begin{array}{c}\text { 10" DAMPER } \\
\text { FIG. \#25 AW-22 HM-L }\end{array}$ & E8678E-005 & \\
\hline$P V-38736 F$ & CV-609f & & $\begin{array}{l}\text { MANUAL FGR INJECTION FLOW } \\
\text { BALANCING DAMPER "36F" }\end{array}$ & P8678E-015/2 & 42536 & $\begin{array}{l}\text { OLSON TECH. } \\
\text { HUGHES \& ASSOC. }\end{array}$ & $\begin{array}{c}\text { 10" DAMPER } \\
\text { FIG.\#25 AH-22 HM-L }\end{array}$ & $E 8678 E-005$ & \\
\hline PV-38736G & CV-609G & & $\begin{array}{l}\text { MANUAL FGR INJECTION FLOW } \\
\text { BALANCING DAMPER "36G" }\end{array}$ & P8678E-015/2 & 42536 & $\begin{array}{l}\text { OLSON TECH. } \\
\text { HUGHES \& ASSOC. }\end{array}$ & $\begin{array}{c}\text { 10" DAMPER } \\
\text { FIG. \#25 AW-22 HM-L }\end{array}$ & E8678E-005 & \\
\hline PV-38736H & CV-609H & & $\begin{array}{l}\text { MANUAL FGR INJECTION FLOW } \\
\text { BALANCING DAMPER "36H" }\end{array}$ & P8678E-015/2 & 42536 & $\begin{array}{l}\text { OLSON TECH. } \\
\text { HUGHES \& ASSOC. }\end{array}$ & $\begin{array}{c}\text { 10" DAMPER } \\
\text { FIG.\# } 25 \text { AW-22 HM-L }\end{array}$ & E8678E-005 & \\
\hline$P V-38737 A$ & $C V-609 \mathrm{~J}$ & & $\begin{array}{l}\text { MANUAL FGR INJECTION FLOW } \\
\text { BALANCING DAMPER "37A" }\end{array}$ & P8678E-015/2 & 42536 & $\begin{array}{l}\text { OLSON TECH. } \\
\text { HUGHES \& ASSOC. }\end{array}$ & $\begin{array}{l}\text { 10" DAMPER } \\
\text { FIG.\# } 25 \text { AW-22 HM-L }\end{array}$ & E8678E-005 & \\
\hline PV-38737B & $C V-609 K$ & & $\begin{array}{l}\text { MANUAL FGR INJECTION FLOW } \\
\text { BALANCING DAMPER "37B" }\end{array}$ & P8678E-015/2 & 42536 & $\begin{array}{l}\text { OLSON TECH. } \\
\text { HUGHES \& ASSOC. }\end{array}$ & $\begin{array}{c}\text { 10" DAMPER } \\
\text { FIG.\#25 AW-22 HM-L }\end{array}$ & $E 8678 E-005$ & \\
\hline PV-38737C & $C V-609 L$ & & $\begin{array}{l}\text { MANUAL FGR INJECTION FLOW } \\
\text { BALANCING DAMPER " } 37 \mathrm{C} "\end{array}$ & P8678E-015/2 & 42536 & $\begin{array}{l}\text { OLSON TECH. } \\
\text { HUGHES \& ASSOC. }\end{array}$ & $\begin{array}{c}\text { 10" DAMPER } \\
\text { FIG.\# } 25 \text { AW-22 HM-L }\end{array}$ & $E 8678 E \cdot 005$ & \\
\hline$P V-387370$ & $C V-609 M$ & & $\begin{array}{l}\text { MANUAL FGR INJECTION FLOW } \\
\text { BALANCING DAMPER "37D" }\end{array}$ & P8678E-015/2 & 42536 & $\begin{array}{l}\text { OLSON TECH. } \\
\text { HUGHES \& ASSOC. }\end{array}$ & $\begin{array}{c}\text { 10" DAMPER } \\
\text { FIG.\#25 AW-22 HM-L }\end{array}$ & E8678E-005 & \\
\hline PV-38737E & CV-609N & & $\begin{array}{l}\text { MANUAL FGR INJECTION FLOW } \\
\text { BALANCING DAMPER "37E" }\end{array}$ & P8678E-015/2 & 42536 & $\begin{array}{l}\text { OLSON TECH. } \\
\text { HUGHES \& ASSOC. }\end{array}$ & $\begin{array}{c}\text { 10" DAMPER } \\
\text { FIG.\# } 25 \text { AW-22 HM-L }\end{array}$ & E8678E-005 & \\
\hline PV-38737F & $C V-609 P$ & & $\begin{array}{l}\text { MANUAL FGR INJECTION FLOW } \\
\text { BALANCING DAMPER "37F" }\end{array}$ & P8678E-015/2 & 42536 & $\begin{array}{l}\text { OLSON TECH. } \\
\text { HUGHES \& ASSOC. }\end{array}$ & $\begin{array}{c}\text { 10" DAMPER } \\
\text { FIG.\#25 AW-22 HM-L }\end{array}$ & $E 8678 E-005$ & \\
\hline PV-38737G & $C V-609 R$ & & $\begin{array}{l}\text { MANUAL FGR INJECTION FLOW } \\
\text { BALANCING DAMPER "37G" }\end{array}$ & P8678E-015/2 & 42536 & $\begin{array}{l}\text { OLSON TECH. } \\
\text { HUGHES \& ASSOC. }\end{array}$ & $\begin{array}{c}\text { 10" DAMPER } \\
\text { FIG.\#25 AW-22 HM-L }\end{array}$ & $E 8678 E-005$ & \\
\hline PV-38737H & CV-609S & & $\begin{array}{l}\text { MANUAL FGR INJECTION FLOW } \\
\text { BALANCING DAMPER "37H" }\end{array}$ & P8678E-015/2 & 42536 & $\begin{array}{l}\text { OLSON TECH. } \\
\text { HUGHES \& ASSOC. }\end{array}$ & $\begin{array}{l}\text { 10" DAMPER } \\
\text { FIG.\# } 25 \text { AW-22 HM-L }\end{array}$ & $E 8678 E-005$ & \\
\hline $\begin{array}{r}F V-38742 \\
2 S-38742 A \\
2 S-38742 B \\
\end{array}$ & $\begin{array}{r}C D-404 B \\
2 S C-404 B \\
250-404 B \\
\end{array}$ & $\begin{array}{l}2-D O \\
2-D I\end{array}$ & $\begin{array}{l}\text { OVER-FIRE AIR INTAKE } \\
\text { ISOLATION DAMPER (SOUTH) } \\
\text { W/ OPEN \& CLOSED LIMIT SWITCHS }\end{array}$ & P8678E-015/1 & 42535 & $\begin{array}{l}\text { MADER DAMPERS } \\
\text { HUGHES \& ASSOC. }\end{array}$ & $\begin{array}{c}\text { 42" } \times \text { 84" DAMPER } \\
\text { W/ FISHER ACTUATOR \#1061 } \\
\text { DUAL COIL. }\end{array}$ & $\begin{array}{c}A 8678 E-045 / 1,3 \\
E 8678 E-005 \\
E 8678 E-011 / 2 \\
\end{array}$ & \\
\hline HV-38242 & $8 V-404 B$ & & $\begin{array}{l}\text { MANUAL BALL VALVE FOR } \\
\text { FOR FV-38742 } \\
\end{array}$ & P8678E-015/1 & 47782 & $\begin{array}{l}\text { WORCESTER CON. } \\
\text { A.E. EHRKE } \\
\end{array}$ & 4846 RSE with $1 / 0-1 / 4 "$ NPT & $\begin{array}{c}A 8678 E-045 / 1,3 \\
E 8678 E-011 / 2\end{array}$ & \\
\hline PIC-38242 & $\begin{array}{l}\text { AF }-404 B \\
\text { PI }-404 B \\
\text { PRV-404B }\end{array}$ & & $\begin{array}{l}\text { AIR PRESSURE FILTER } \\
\text { REGULATOR FOR FV- } 38742\end{array}$ & P8678E-015/1 & 47782 & $\begin{array}{l}\text { FISHER } \\
\text { A.E. EHRKE }\end{array}$ & $\begin{array}{c}\text { TYPE 67AFR W/FILTER \& } \\
0-60 \text { psig PRESSURE GAUGE } \\
1 / 0-1 / 4 " \text { NPT }\end{array}$ & $\begin{array}{c}A B 678 E-045 / 1,3 \\
E 8678 E-005 \\
E 8678 E-011 / 2\end{array}$ & \\
\hline
\end{tabular}


INSTRUMENT \& COMPONENT LIST CHEROKEE CCT UNIT 3

REVISION DATE 08-10-92 by DAP

\begin{tabular}{|c|c|c|c|c|c|c|c|c|c|}
\hline YSSTAG & $010 \%$ & $1 \%$ & $\mathrm{SERYSO}$ & Nomiser. & POROAASE & 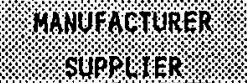 & $100 \mathrm{O} \% 4 \mathrm{MBSR}$ & THSTARAJYON & RANGE \\
\hline $\begin{array}{l}F V-38743 \\
2 S-38743 A \\
2 S-38743 B\end{array}$ & $\begin{array}{l}C D-404 A \\
2 S C-404 A \\
2 S 0-404 A\end{array}$ & $\begin{array}{l}2-D 0 \\
2-01\end{array}$ & $\begin{array}{l}\text { OVER-FIRE AIR INTAKE } \\
\text { ISOLATION DAMPER (NORTH) } \\
\text { W/ OPEN \& CLOSED LIMIT SWITCHS }\end{array}$ & $P 8678 E-015 / 1$ & 42535 & $\begin{array}{l}\text { MADER DAMPERS } \\
\text { HUGHES \& ASSOC. }\end{array}$ & $\begin{array}{l}\text { 42" } \times \text { 84" DAMPER } \\
\text { W/ FISHER ACTUATOR \#1061 } \\
\text { DUAL COIL }\end{array}$ & $\begin{array}{c}A 8678 E-045 / 1 \\
E 8678 E-005 \\
E 8678 E-011 / 2\end{array}$ & \\
\hline HV-38243 & BV-404A & & $\begin{array}{c}\text { MANUAL BALL VALVE FOR } \\
\text { FV }-38743\end{array}$ & PB678E-015/1 & 47782 & $\begin{array}{l}\text { WORCESTER CON. } \\
\text { A.E. EHRKE }\end{array}$ & 4846 RSE with $1 / 0 \cdot 1 / 4 "$ MPT & $\begin{array}{l}A 8678 E-045 / 1 \\
E 8678 E-011 / 2\end{array}$ & \\
\hline PIC-38243 & $\begin{array}{l}\text { AF-404A } \\
\text { PI }-404 A \\
\text { PRV-404A }\end{array}$ & & $\begin{array}{l}\text { AIR PRESSURE FILTER } \\
\text { REGULATOR FOR FV }-38743\end{array}$ & $P 8678 E-015 / 1$ & 47782 & $\begin{array}{l}\text { FISHER } \\
\text { A.E. EHRKE }\end{array}$ & $\begin{array}{c}\text { TYPE 67AFR W/FILTER \& } \\
0-60 \text { psig PRESSURE GAUGE } \\
1 / 0-1 / 4 " \text { NPT }\end{array}$ & $\begin{array}{c}A 8678 E-045 / 1 \\
E 8678 E-005 \\
E 8678 E-011 / 2\end{array}$ & \\
\hline $\begin{array}{l}\text { FCV }-38745 \\
2 S-38745 A\end{array}$ & $\begin{array}{l}\mathrm{CD}-403 \\
2 \mathrm{SC}-403\end{array}$ & $\begin{array}{l}\text { AO } \\
01\end{array}$ & $\begin{array}{l}\text { OVER-FIRE AIR BOOSTER FAN } \\
\text { CONTROL DAMPER } \\
\text { W/CLOSED LIMIT SWITCH }\end{array}$ & PB678E $-015 / 1$ & 42524 & $\begin{array}{l}\text { BARRON } \\
\text { FLO-TECH } \\
\text { INC. }\end{array}$ & $\begin{array}{l}\text { 60" } \times 105 " \text { ZERO LEAKAGE } \\
\text { DAMPER W/ BECK DRIVE } \\
\& \text { CLOSED LIMIT SWITCH }\end{array}$ & $\begin{array}{c}A 8678 E-045 / 2,3 \\
E 8678 E-005\end{array}$ & \\
\hline $17-38747$ & $1 T-408$ & AI & $\begin{array}{l}\text { OVERFIRE AIR FAN CURRENT } \\
\text { TRANSHITTER FOR } M-1 \\
\end{array}$ & P8678E-015/1 & 42568 & MAGNETEK & $\begin{array}{c}\text { PART OF FAN-1 } \\
5 \mathrm{KV} \text { SWITCHGEAR } \\
\end{array}$ & $\begin{array}{c}\text { A8678E-045/1 } \\
E 8678 E-005\end{array}$ & \\
\hline FS-38747A & FS-622A & DI & $\begin{array}{l}\text { OFA FAN INBOARD BEARING } \\
\text { OIL FLOW SWITCH }\end{array}$ & PB678E $-015 / 1$ & 42524 & $\begin{array}{l}\text { BARRON } \\
\text { FLO-TECH, INC. }\end{array}$ & INCLUDED W/ OCS-1 & $\begin{array}{c}\text { A8678E-045/1 } \\
\text { E867BE-005 }\end{array}$ & \\
\hline FS-38747B & FS-6228 & DI & $\begin{array}{l}\text { OFA FAN OUTBOARD BEARING } \\
\text { OIL FLOW SWITCH }\end{array}$ & P8678E $-015 / 1$ & 42524 & $\begin{array}{c}\text { BARRON } \\
\text { FLO-TECH, INC. }\end{array}$ & INCLUDED W/ OCS-1 & $\begin{array}{c}A 8678 E-045 / 1 \\
\varepsilon 8678 E-005\end{array}$ & \\
\hline TE-38747A & TE-622A & AI $-\mathrm{TC}$ & $\begin{array}{l}\text { OFA FAN INBOARD BEARING TEMP. } \\
\text { ELEMENT, TYPE "K" THERMOCOUPLE }\end{array}$ & $P 8678 E-015 / 1$ & 42524 & $\begin{array}{l}\text { BARRON } \\
\text { FLO-TECH, INC. }\end{array}$ & INCLUDED W/ FAN & $\begin{array}{c}\text { A8678E-045/1 } \\
E 8678 E-005\end{array}$ & \\
\hline TE-38747B & TE-622B & $A I-T C$ & $\begin{array}{l}\text { OFA FAN OUTBOARD BEARING TEMP } \\
\text { ELEMENT, TYPE "K" THERMOCOUPLE }\end{array}$ & P8678E $-015 / 1$ & 42524 & $\begin{array}{c}\text { BARRON } \\
\text { FLO-TECH, INC. }\end{array}$ & INCLUDED W/ FAN & $\begin{array}{c}A 8678 E-045 / 1 \\
E 8678 E-005\end{array}$ & \\
\hline TE-38747C & TE-622C & $A I-T C$ & $\begin{array}{l}\text { OFA FAN MOTOR STATOR TEMP. } \\
\text { ELEMENT, TYPE "K" THERMOCOUPLE }\end{array}$ & $P 8678 E-015 / 1$ & 42524 & $\begin{array}{c}\text { BARRON } \\
\text { FLO-TECH, INC. }\end{array}$ & INCLUDED W/ FAN & $\begin{array}{c}\text { A8678E-045/1 } \\
E 8678 E-005 \\
\end{array}$ & \\
\hline TE-387470 & TE-6220 & $|A I-T C|$ & $\begin{array}{l}\text { OFA FAN HOUSING TEMPERATURE } \\
\text { ELEMENT, TYPE "K" THERMOCOUPLE }\end{array}$ & $P 8678 E-015 / 1$ & 42524 & $\begin{array}{c}\text { BARRON } \\
\text { FLO-TECH, INC. }\end{array}$ & INCLUDED H/ FAN & $\begin{array}{c}\text { A8678E-045/1 } \\
E 8678 E-005 \\
\end{array}$ & \\
\hline YT-38747A & $V E-622 A$ & AI & $\begin{array}{l}\text { OFA FAN INBOARD BEARING } \\
\text { VIBRATION SENSOR } \\
\end{array}$ & $P 8678 E-015 / 1$ & 42524 & $\begin{array}{c}\text { BARRON } \\
\text { FLO-TECH, INC. }\end{array}$ & INCLUDED W/ FAN & $\begin{array}{c}\text { A8678E-045/1 } \\
E 8678 E-005 \\
\end{array}$ & \\
\hline YT-38747B & VE-622B & A! & $\begin{array}{l}\text { OFA FAN OUTBOARD BEARING } \\
\text { VIBRATION SENSOR }\end{array}$ & P8678E-015/1 & 42524 & $\begin{array}{c}\text { BARRON } \\
\text { FLO-TECH, INC. }\end{array}$ & INCLUDED W/ FAN & $\begin{array}{c}A 8678 E-045 / 1 \\
E 8678 E-005\end{array}$ & \\
\hline $\begin{array}{l}F V-38749 \\
2 S-38749 A \\
2 S-387498 \\
\end{array}$ & $\begin{array}{l}C D-405 \\
2 S C-405 \\
2 S 0-405 \\
\end{array}$ & $\begin{array}{l}2.00 \\
2-01\end{array}$ & $\begin{array}{c}\text { OVER-FIRE AIR DISCHARGE } \\
\text { ISOLATION DAMPER } \\
\text { W/OPEN \& CLOSED LIMIT SHITCHES }\end{array}$ & $P 8678 E-015 / 1$ & 42535 & $\begin{array}{l}\text { MADER DAMPERS } \\
\text { HUGHES \& ASSOC. }\end{array}$ & $\begin{array}{l}54 " \times 120 " \text { DAMPER } \\
\text { DUAL COLL }\end{array}$ & $\begin{array}{c}\text { A8678E-045/1 } \\
E 8678 E-005 \\
E 8678 E-011 / 5\end{array}$ & \\
\hline HV- 38249 & BV -405 & & $\begin{array}{l}\text { MANUAL BALL VALVE } \\
\text { FOR FV-38749 }\end{array}$ & P8678E-015/1 & 47782 & $\begin{array}{l}\text { WORCESTER CON. } \\
\text { A.E. EHRKE }\end{array}$ & 4846 RSE with $1 / 0-1 / 4 "$ NPT & $\begin{array}{l}\text { A8678E-045/1 } \\
\text { E8678E-011/5 }\end{array}$ & \\
\hline
\end{tabular}


INSTRUMENT \& COMPONENT LIST CHEROKEE CCT UNIT 3

REVISION DATE 08-10-92 by DAP

\begin{tabular}{|c|c|c|c|c|c|c|c|c|c|}
\hline & OHOHER & 1\%o & SERYO & 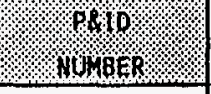 & PUROASE & 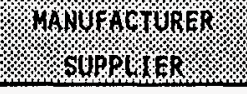 & 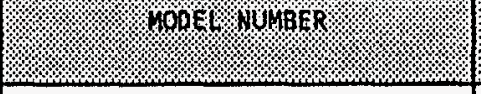 & 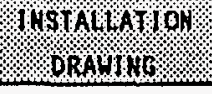 & RANGS \\
\hline PIC-38249 & $\begin{array}{l}\text { AF }-405 \\
\text { PI }-405 \\
\text { PRV }-405\end{array}$ & & $\begin{array}{l}\text { AIR PRESSURE FILTER } \\
\text { REGULATOR FOR FV38749 }\end{array}$ & $P 8678 E-015 / 1$ & 47782 & $\begin{array}{l}\text { FISHER } \\
\text { A.E. EHRKE } \\
\end{array}$ & $\begin{array}{c}\text { TYPE } 67 \text { AFR w/FILTER \& } \\
0-60 \text { psig PRESSURE GUAGE } \\
1 / 0-1 / 4 " \text { NPT } \\
\end{array}$ & $\begin{array}{c}A 8678 E-045 / 1 \\
E 8678 E-005 \\
E 8678 E-011 / 5 \\
\end{array}$ & \\
\hline FE -38750 & FE-401B & & $\begin{array}{l}\text { SOUTH OVER-FIRE AIR FLOW } \\
\text { GRID PITOT TUBE }\end{array}$ & P8678E-015/1 & 47818 & $\begin{array}{l}\text { AIR MONITOR } \\
\text { H.R. BOWERS CO. }\end{array}$ & $\begin{array}{c}\text { MODEL CA } \\
12^{\prime \prime}-36^{\prime \prime} \times 70^{\prime \prime} \\
\end{array}$ & $\begin{array}{l}A 8678 E-045 / 1 \\
E 8678 E-011 / 2 \\
\end{array}$ & \\
\hline FT -38750 & FT $-401 B$ & Al & $\begin{array}{c}\text { SOUTH OVER-FIRE AIR FLOW } \\
\text { TRANSMITTER }\end{array}$ & P8678E-015/1 & 47817 & $\begin{array}{l}\text { ROSEMOUNT } \\
\text { INC. }\end{array}$ & $\begin{array}{c}\text { 11510R2F12B1 } \\
\text { CALIB. } 0-0.77 " \text { WATER }\end{array}$ & $\begin{array}{l}A 8678 E-045 / 1 \\
E 8678 E-011 / 2 \\
\end{array}$ & $\begin{array}{l}0-6^{\prime \prime} \\
\text { HATER }\end{array}$ \\
\hline$F E=38751$ & FE- $401 A$ & & $\begin{array}{c}\text { NORTH OVER-FIRE AIR FLOW } \\
\text { GRID PITOY TUBE } \\
\end{array}$ & PB678E-015/1 & 47818 & $\begin{array}{c}\text { AIR MONITOR } \\
\text { H.R. BOWERS CO. }\end{array}$ & $\begin{array}{c}\text { MOOEL CA } \\
12^{\prime \prime}-36^{\prime \prime} \times 70^{\prime \prime} \\
\end{array}$ & $\begin{array}{l}A 8678 E-045 / 1 \\
E 8678 E-011 / 2 \\
\end{array}$ & \\
\hline FT -38751 & FT-401A & Al & $\begin{array}{l}\text { NORTH OVER-FIRE AIR FLOW } \\
\text { TRANSMITTER }\end{array}$ & P8678E-015/1 & 47817 & $\begin{array}{l}\text { ROSEMOUNT } \\
\text { INC. } \\
\end{array}$ & $\begin{array}{c}\text { 11510R2F12B1 } \\
\text { CALIB. } 0-0.77 " \text { WATER }\end{array}$ & $\begin{array}{l}\text { A8678E-045/1 } \\
E 8678 E-011 / 2 \\
\end{array}$ & $\begin{array}{l}0-6 " \\
\text { HATER }\end{array}$ \\
\hline TE-38752 & $\mathrm{TT}-402$ & $A I-T C$ & $\begin{array}{l}\text { OVER-FIRE AIR TEMPERATURE } \\
\text { ELEMENT, TYPE "K" THERMOCOUPLE }\end{array}$ & PB678E-015/1 & 47220 & $\begin{array}{c}\text { T-TEC } \\
\text { A.O. GRUMNEY } \\
\end{array}$ & $\begin{array}{ll}1020-K-(23-1 / 2)-1-S-A-U & (T / C) \\
3 / 4-260 S-(22-1 / 2)-304 & (H E L L)\end{array}$ & $A 8678 E-045 / 1$ & \\
\hline PI-38752 & PI -407 & & $\begin{array}{c}\text { OVER-FIRE AIR HEADER } \\
\text { PRESSURE INDICATOR } \\
\end{array}$ & PB678E-015/1 & 47821 & $\begin{array}{c}\text { DWYER } \\
\text { J.F. GOOO } \\
\end{array}$ & 2030 & $\begin{array}{c}\text { A8678E-045/1 } \\
\text { STO- } 143 / 1 \\
\end{array}$ & $\begin{array}{l}0-30 " 1 \\
\text { WATER }\end{array}$ \\
\hline PT-38752 & PT -407 & AI & $\begin{array}{l}\text { OVER-FIRE AIR HEADER } \\
\text { PRESSURE TRANSMITTER } \\
\end{array}$ & PB678E-015/1 & 47817 & $\begin{array}{l}\text { ROSEMOUNT } \\
\text { INC. }\end{array}$ & $\begin{array}{c}11516 P 451281 \\
\text { CALIBRATE } 0-30 \text { INWC } \\
\end{array}$ & $\begin{array}{l}\text { A8678E-045/1 } \\
E 8678 E-011 / 5 \\
\end{array}$ & $\begin{array}{c}1-150 \\
\text { INWC } \\
\end{array}$ \\
\hline FV $-38754 A$ & CV-409A & & $\begin{array}{c}\text { OVER-FIRE AIR MANUAL } \\
\text { INJECTION BALANCING DAMPER "A" }\end{array}$ & $P 8678 E-015 / 1$ & 42535 & $\begin{array}{l}\text { MADER DAMPERS } \\
\text { HUGHES \& ASSOC. }\end{array}$ & $\begin{array}{l}16 " \times 21 " \text { BUTTERFLY } \\
\text { DAMPER }\end{array}$ & $\begin{array}{c}\text { A8678E-045/1 } \\
\text { E8678E-005 }\end{array}$ & \\
\hline FV $-38754 B$ & CV-409B & & $\begin{array}{l}\text { OVER-FIRE AIR MANUAL } \\
\text { INJECTION BALANCING DAMPER "B" }\end{array}$ & P8678E-015/1 & 42535 & $\begin{array}{c}\text { MADER } \\
\text { HUGHES \& ASSOC. }\end{array}$ & $\begin{array}{c}16 " \times 21 " \text { BUTTERFLY } \\
\text { DAMPER }\end{array}$ & $\begin{array}{c}A 8678 E-045 / 1 \\
E 8678 E-005 \\
\end{array}$ & \\
\hline FV $-38754 \mathrm{C}$ & CV-409C & & $\begin{array}{c}\text { OVER-FIRE AIR MANUAL } \\
\text { INJECTION BALANCING DAMPER "C" }\end{array}$ & PB678E-015/1 & 42535 & $\begin{array}{c}\text { MADER } \\
\text { HUGHES \& ASSOC. } \\
\end{array}$ & $\begin{array}{c}16 " \times 21 " \text { BUTTERFLY } \\
\text { DAMPER }\end{array}$ & $\begin{array}{c}\text { A8678E-045/1 } \\
E 8678 E-005 \\
\end{array}$ & \\
\hline FV-387540 & $C V-4090$ & & $\begin{array}{l}\text { OVER-FIRE AIR MANUAL } \\
\text { INJECTION BALANCING DAMPER "D" }\end{array}$ & P8678E-015/1 & 42535 & $\begin{array}{c}\text { MADER } \\
\text { HUGHES \& ASSOC. }\end{array}$ & $\begin{array}{c}16 " \times 2111 \text { BUTTERFLY } \\
\text { DAMPER }\end{array}$ & $\begin{array}{c}\text { A8678E-045/1 } \\
E 8678 E-005 \\
\end{array}$ & \\
\hline FV-38754E & CV-409E & & $\begin{array}{l}\text { OVER-FIRE AIR MANUAL } \\
\text { INJECTION BALANCING DAMPER "E" }\end{array}$ & PB678E-015/1 & 42535 & $\begin{array}{c}\text { MADER } \\
\text { HUGHES \& ASSOC. }\end{array}$ & $\begin{array}{c}16 " \times 21 " \text { BUTTERFLY } \\
\text { DAMPER } \\
\end{array}$ & $\begin{array}{c}A 8678 E-045 / 1 \\
E 8678 E-005 \\
\end{array}$ & \\
\hline FV-38754F & CV-409F & & $\begin{array}{l}\text { OVER-FIRE AIR MANUAL } \\
\text { INJECTION BALANCING DAMPER "F" }\end{array}$ & P8678E-015/1 & 42535 & $\begin{array}{c}\text { MADER } \\
\text { HUGHES \& ASSOC. }\end{array}$ & $\begin{array}{l}16 " \times 21^{\prime \prime} \text { BUTTERFLY } \\
\text { DAMPER }\end{array}$ & $\begin{array}{c}A 8678 E-045 / 1 \\
E 8678 E-005\end{array}$ & \\
\hline FV -38760 & $C D-410$ & DO & $\begin{array}{l}\text { OFA INLET CONTROL DAMPER } \\
\text { SEAL AIR FAN SHUT-OFF DAMPER }\end{array}$ & P8678E-015/1 & 42524 & $\begin{array}{c}\text { BARRON } \\
\text { FLO-TECH, INC. }\end{array}$ & $\begin{array}{l}\text { W/OFA FAN-1 } \\
\text { SEAL AIR FAN-6 }\end{array}$ & $\begin{array}{c}\text { A8678E-045/2 } \\
E 8678 E-005 \\
\end{array}$ & \\
\hline$H V-38260$ & BV -410 & & $\begin{array}{l}\text { MANUAL BALL VALVE } \\
\text { FOR FV-38760 }\end{array}$ & $P 8678 E-015 / 1$ & 47782 & $\begin{array}{l}\text { WORCESTER CON. } \\
\text { A.E. EHRKE }\end{array}$ & 4846RSE with $1 / 0-1 / 4 " \mathrm{NPT}$ & $\begin{array}{c}A 8678 E-045 / 2 \\
E 8678 E-005\end{array}$ & \\
\hline
\end{tabular}


INSTRUMENT \& COMPONENT LIST CHEROKEE CCT UNIT 3

REVISION DATE 08-10-92 by DAP

\begin{tabular}{|c|c|c|c|c|c|c|c|c|c|}
\hline $18 \% 1 A B$ & OLOFER & 110 & $S E R \cup Y C$ & Noto & OUR ORDER $\%$ & YHWUFATURER & MODE $/ \mathrm{UMBR}$ & YWSTALA OLON & RAYGS \\
\hline PIC-38260 & $\begin{array}{l}\text { AF }-410 \\
\text { PI }-410 \\
\text { PRV }-410\end{array}$ & & $\begin{array}{l}\text { AIR PRESSURE FILTER } \\
\text { REGULATOR FOR FV-38760 }\end{array}$ & P8678E $-015 / 1$ & 47782 & $\begin{array}{l}\text { FISHER } \\
\text { A.E. EHRKE }\end{array}$ & $\begin{array}{c}\text { TYPE 67AFR W/FILTER \& } \\
0-60 \text { psig PRESSURE GAUGE } \\
\text { I/0 - 1/4" NPT }\end{array}$ & $\begin{array}{c}A 8678 E-045 / 2 \\
E 8678 E-005\end{array}$ & \\
\hline$H V-38761$ & $C D-461$ & & $\begin{array}{l}\text { OVER-FIRE AIR NOZZLE COOLING FAN } \\
\text { MANUAL ISOLATION DAMPER - NORTH }\end{array}$ & P8678E-015/1 & 42535 & $\begin{array}{l}\text { MADER DAMPERS } \\
\text { HUGHES \& ASSOC. }\end{array}$ & 16" DAMPER & $\begin{array}{c}\text { A8678E-045/1 } \\
\text { E8678E-005 }\end{array}$ & \\
\hline FV - 38762 & $C D-406 B$ & DO & $\begin{array}{l}\text { OVER-FIRE AIR NOZZLE COOLING } \\
\text { FAN SHUT-OFF DAMPER (EAST) }\end{array}$ & $P 8678 E-015 / 1$ & 42535 & $\begin{array}{l}\text { MADER DAMPERS } \\
\text { HUGHES \& ASSOC. }\end{array}$ & 18" DAMPER & $\begin{array}{c}A 8678 E-045 / 1 \\
E 8678 E-005\end{array}$ & \\
\hline HV -38262 & $B V-406 B$ & & $\begin{array}{l}\text { MANUAL BALL VALVE } \\
\text { FOR FV- } 38762 \\
\end{array}$ & P8678E-015/1 & 47782 & $\begin{array}{l}\text { WORCESTER CON. } \\
\text { A.E. EHRKE }\end{array}$ & 4846 RSE with $1 / 0-1 / 4 "$ NPT & $\begin{array}{c}A 8678 E-045 / 1 \\
E 8678 E-005\end{array}$ & \\
\hline PIC-38262 & $\begin{array}{l}\text { AF }-406 B \\
\text { PI }-406 B \\
P R V-406 B\end{array}$ & & $\begin{array}{l}\text { AIR PRESSURE FILTER } \\
\text { REGULATOR FOR FV } 38762\end{array}$ & P8678E-015/1 & 47782 & $\begin{array}{c}\text { FISHER } \\
\text { A.E. EHRKE } \\
\end{array}$ & $\begin{array}{c}\text { TYPE } 67 A F R \text { W/FILTER \& } \\
0-60 \text { psig PRESSURE GAUGE } \\
1 / 0-1 / 4^{\prime \prime} \text { NPT }\end{array}$ & $\begin{array}{c}A 8678 E-045 / 2 \\
E 8678 E-005 \\
E 8678 E-011 / 5\end{array}$ & \\
\hline FV -38763 & $C D-406 A$ & DO & $\begin{array}{l}\text { OVER-FIRE AIR NOZZLE COOLING } \\
\text { FAN SHUT-OFF DAMPER (WEST) }\end{array}$ & P8678E-015/1 & 42535 & $\begin{array}{l}\text { MADER DAMPERS } \\
\text { HUGHES \& ASSOC. }\end{array}$ & 18" DAMPER & $\begin{array}{c}A 8678 E-045 / 1 \\
E 8678 E-005\end{array}$ & \\
\hline$H V-38263$ & $B V-406 A$ & & $\begin{array}{c}\text { MANUAL BALL VALVE } \\
\text { FOR FV-38763 } \\
\end{array}$ & $P 8678 E-015 / 1$ & 47782 & $\begin{array}{l}\text { WORCESTER CON. } \\
\text { A.E. EHRKE } \\
\end{array}$ & 4846 RSE with $1 / 0-1 / 4 "$ NPT & $\begin{array}{c}A 8678 E-045 / 1 \\
E 8678 E-005\end{array}$ & \\
\hline PIC-38263 & $\begin{array}{l}\text { AF }-406 A \\
\text { PI-406A } \\
\text { PRV-406A }\end{array}$ & & $\begin{array}{l}\text { AIR PRESSURE FILTER } \\
\text { REGULATOR FOR FV-38763 }\end{array}$ & $P 8678 E-015 / 1$ & 47782 & $\begin{array}{c}\text { FISHER } \\
\text { A.E. EHRKE } \\
\end{array}$ & $\begin{array}{c}\text { TYPE 67AFR W/FILTER \& } \\
0-60 \text { psig PRESSURE GAUGE } \\
1 / 0-1 / 4 " \text { NPT }\end{array}$ & $\begin{array}{c}A 8678 E-045 / 2 \\
E 8678 E-005 \\
E 8678 E-011 / 5\end{array}$ & \\
\hline$H V-38764$ & $C D-628$ & & $\begin{array}{l}\text { GR NOZZLE COOLING FAN MANUAL } \\
\text { ISOLATION DAMPER (REAR WALL) }\end{array}$ & P8678E-015/2 & 42536 & $\begin{array}{l}\text { OLSON TECH. } \\
\text { HUGHES \& ASSOC. }\end{array}$ & $\begin{array}{l}\text { 12" DAMPER } \\
\text { FIG. \# } 25 \text { AW-22 HM-L }\end{array}$ & $\begin{array}{c}D 8678 E-125 / 3 \\
E 8678 E-005\end{array}$ & \\
\hline HV -38765 & CD -629 & & $\begin{array}{l}\text { GR NOZZLE COOLING FAN MANUAL } \\
\text { ISOLATION DAMPER (FRONT WALL) }\end{array}$ & P8678E-015/2 & 42536 & $\begin{array}{l}\text { OLSON TECH. } \\
\text { HUGHES \& ASSOC. }\end{array}$ & $\begin{array}{l}\text { 12" DAMPER } \\
\text { FIG. \#25 AW-22 HM-L }\end{array}$ & $\begin{array}{c}\text { D8678E-125/3 } \\
E 8678 E-005\end{array}$ & \\
\hline HV -38766 & CD-629 & & $\begin{array}{l}\text { OFA NOZZLE COOLING FAN MANUAL } \\
\text { ISOLATION DAMPER (CENTER) }\end{array}$ & P8678E-015/1 & 70039 & $\begin{array}{l}\text { OLSON TECH. } \\
\text { HUGHES \& ASSOC. }\end{array}$ & 16" DAMPER & SK-010792 & \\
\hline$H V-38767$ & $\mathrm{CD}-629$ & & $\begin{array}{l}\text { OFA NOZZLE COOLING FAN MANUAL } \\
\text { ISOLATION DAMPER (SOUTH) }\end{array}$ & P8678E-015/1 & 70039 & $\begin{array}{l}\text { OLSON TECH. } \\
\text { HUGHES \& ASSOC. }\end{array}$ & 12" DAMPER & SK-010792 & \\
\hline HS -38770 & SIEMERSD & DI & EMERGENCY GR SHUT DOWN & & & & PUSH-PULL HAND SWITCH & & \\
\hline TE-38780 & & $A I-T C$ & $\begin{array}{l}\text { OIL COOLING SYS. RESERVOIR TEMP } \\
\text { ELEMENT, TYPE "K" THERMOCOUPLE }\end{array}$ & P8678E-015/1 & 42524 & $\begin{array}{c}\text { BARRON } \\
\text { FLO-TECH, INC. }\end{array}$ & INCLUDED W/ OCS-1 & $\begin{array}{c}A 8678 E-045 / 1 \\
E 8678 E-005\end{array}$ & $\begin{array}{l}0-300 \\
\text { DEGF }\end{array}$ \\
\hline LSL- 38780 & & DI & $\begin{array}{l}\text { OIL COOLING SYSTEM RESERVOIR } \\
\text { LOW OIL LEVEL SHITCH }\end{array}$ & P8678E-015/1 & 42524 & $\begin{array}{c}\text { BARRON } \\
\text { FLO-TECH, INC. }\end{array}$ & INCLUDED W/ OCS-1 & $\begin{array}{c}A 8678 E-045 / 1 \\
E 8678 E-005 \\
\end{array}$ & \\
\hline CR-38780A & & DI & $\begin{array}{l}\text { OIL COOLING SYSTEM } \\
\text { \#1 PUMP FAIL SWITCH }(T R-1)\end{array}$ & P8678E-015/1 & 42524 & $\begin{array}{c}\text { BARRON } \\
\text { FLO-TECH, INC. }\end{array}$ & INCLUDED W/ OCS-1 & $\begin{array}{c}A 8678 E-045 / 1 \\
E 8678 E-005\end{array}$ & \\
\hline
\end{tabular}




\section{INSTRUMENT \& COMPONENT LIST CHEROKEE CCT UNIT 3}

REVISION DATE 08-10-92 by DAP

\begin{tabular}{|c|c|c|c|c|c|c|c|c|c|}
\hline PSC 1 OHAR & OLDER & 10 & SERYSE & NUABER & ougnas & 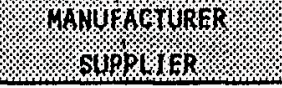 & MODEOYOMBER & 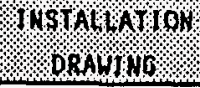 & KAHG \\
\hline CR-38780B & & DI & $\begin{array}{l}\text { OIL COOLING SYSTEM } \\
\text { \#2 PUMP FAIL SHITCH (TR-2) }\end{array}$ & P8678E-015/1 & 42524 & $\begin{array}{c}\text { BARRON } \\
\text { FLO-TECH, INC. }\end{array}$ & INCLUDED W/ OCS-1 & $\begin{array}{c}\text { A8678E-045/1 } \\
E 8678 E-005\end{array}$ & \\
\hline UM-39320A & & Al & $\begin{array}{l}\text { BOILER MASIER SIGNAL } \\
\text { TRANSDUCER }(P / 1)\end{array}$ & P8678E-055 & 47820 & $\begin{array}{c}\text { BELLOFRAM } \\
\text { PROC. VALVE \& EQ. }\end{array}$ & $\begin{array}{c}\text { TYPE } 5000 \mathrm{P} / \mathrm{I} \\
\text { P/N } 241-964-201-000 \\
\end{array}$ & P8678E-055 & $\begin{array}{l}3-27 p s i g \\
4-20 \mathrm{ma}\end{array}$ \\
\hline UM-39320B & & AO & $\begin{array}{l}\text { REBURN GAS FLOW SIGNAL } \\
\text { TRANSDUCER ( I/P ) }\end{array}$ & P8678E-055 & 47820 & $\begin{array}{l}\text { BELLOFRAM } \\
\text { PROC. VALVE \& EQ. }\end{array}$ & $\begin{array}{c}\text { TYPE } 10001 / P \\
P / N \quad 221-961-074-000\end{array}$ & P8678E-055 & $\begin{array}{l}4-20 \mathrm{ma} \\
3-27 p s i g\end{array}$ \\
\hline
\end{tabular}

EXISTING SYSTEM INPUTS FOR BPMS TO BE DEFINED LATER

\begin{tabular}{|c|c|}
\hline $\mathrm{BAHE}$ & REVISION WSINO \\
\hline $6 / 04 / 1991$ & added psc tag numbers \\
\hline $8 / 19 / 1991$ & update p.o. \#, descrip, model, manuf./suplr. \\
\hline $8 / 30 / 1991$ & $\begin{array}{l}\text { update p.o. \#, descrip, model, manuf./suplr. } \\
\text { added fgr gas temp TE-603 \& TT-603 }\end{array}$ \\
\hline $9 / 02 / 1991$ & $\begin{array}{l}\text { update descrip, model, manuf./suplr. } \\
\text { remove existing system inputs list }\end{array}$ \\
\hline $9 / 27 / 1991$ & added av-36403, deleted $\mathrm{tt}-38724, \mathrm{tt}-38752$ \\
\hline $12 / 06 / 1991$ & update p.o.\#, correct um-39320a \& um-39320b \\
\hline & added oil cooling system ??-38780's, suplr. \\
\hline $12 / 09 / 1991$ & added fs-38722a/b \& fs-38747a/b switches \\
\hline $12 / 19 / 1991$ & added burner \#'s to scanners, misc. changes \\
\hline $01 / 29 / 1992$ & reformat, added ua-38101, add installation dwg \\
\hline $02 / 25 / 1992$ & added bpms xmtrs, ft-38701/4, wh \\
\hline $04 / 01 / 1992$ & added hs-38770 \\
\hline 04/08/1992 & added hv-38766, hv-38767 \\
\hline 08/10/1992 & $\begin{array}{l}\text { added fe-31005, fi-31005, fe-31050,51, ft-31050,51 } \\
\text { deleted fe-31016,17, ft-31016,17 }\end{array}$ \\
\hline
\end{tabular}




\section{APPENDIX B}

First Generation Gas Reburning Test Data 
Pre Modification

\begin{tabular}{|c|c|c|c|c|c|c|c|c|c|c|c|c|c|c|c|c|c|c|c|}
\hline 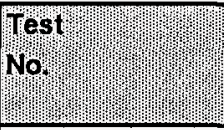 & Date & Dury & $\begin{array}{l}\text { CEMS } \\
\text { O2 } \\
\text { \% Dry }\end{array}$ & "rpant! & poc & Co2c & Noxç & $\begin{array}{l}\text { NOx } \\
\text { formbsqu }\end{array}$ & SOPY? & 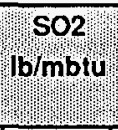 & $\begin{array}{l}\text { Reb } \\
\text { Gas } \\
\text { sctum }\end{array}$ & West! & $\begin{array}{l}\text { East: } \\
\text { OFfy } \\
\text { scfm }\end{array}$ & $\begin{array}{l}\text { FGR! } \\
\text { scm!m! } \\
\text { scy! }\end{array}$ & 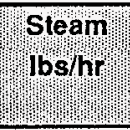 & Mill & Mill & Mill! & Mill! \\
\hline Base Cond. (OFA off) & $11 / 11 / 92$ & $8: 42$ & 4.00 & 3.19 & 125 & 16.72 & 253 & .345 & 320 & .610 & 0 & 0 & 0 & 776 & 805808 & 0 & 0 & 0 & 0 \\
\hline GR & $11 / 11 / 92$ & $1: 01$ & 3.38 & 2.90 & 256 & 15.55 & 208 & .278 & 276 & .515 & 5569 & 31902 & 32282 & 10075 & 1239194 & 0 & 0 & 0 & 0 \\
\hline Base Cond. (OFA off) & $11 / 11 / 92$ & $4: 25$ & 4.00 & 3.13 & 9 & 16.70 & 397 & .543 & 337 & .645 & 0 & 0 & 0 & 1740 & 1243929 & 0 & 0 & 0 & 0 \\
\hline Base Cond. OFA off & $11 / 12 / 92$ & $0: 45$ & 3.24 & 2.76 & 36 & 16.9 & 352 & .480 & 330 & .629 & 0 & 0 & 0 & 2782 & 1257174 & 0 & 0 & 0 & 0 \\
\hline BPMS GR 4 & $11 / 12 / 92$ & $1: 05$ & 3.85 & 3.09 & 29 & 15.5 & 227 & .303 & 269 & .503 & 5269 & 33996 & 33892 & 10212 & 1230455 & 0 & 0 & 0 & 0 \\
\hline Base Cond. OFA off & $11 / 12 / 92$ & $1: 15$ & 3.95 & 3.23 & 8 & 16.6 & 383 & .523 & 331 & .631 & 0 & 0 & 0 & 2060 & 1243684 & 0 & 0 & 0 & 0 \\
\hline BPMS Base Cond. 5 & $11 / 13 / 92$ & $2: 55$ & 4.41 & 3.59 & 6 & 16.6 & 420 & .573 & 329 & .628 & 0 & 0 & 0 & 796 & 1254148 & 0 & 0 & 0 & 0 \\
\hline BPMS Base Cond. 6 & $11 / 13 / 92$ & 1.00 & 4.18 & 3.56 & 85 & 16.6 & 327 & .446 & 334 & .638 & $\overline{0}$ & 7233 & 8547 & 2250 & 1268525 & 0 & $\overline{0}$ & 0 & 0 \\
\hline BPMS Base Cond. 7 & $11 / 13 / 92$ & $1: 00$ & 3.75 & 3.51 & 513 & 16.7 & 274 & .373 & 333 & .636 & 0 & 15101 & 15019 & 2707 & 1278852 & 0 & 0 & 0 & 0 \\
\hline Base Cond. $.1 \mathrm{~d}$ & $11 / 16 / 92$ & 1.00 & 4.28 & 3.27 & 5 & 16.7 & 410 & .559 & 339 & .646 & 0 & 0 & 0 & 2531 & 1165455 & 0 & 0 & $\overline{0}$ & 0 \\
\hline GR-10c & $11 / 16 / 92$ & 1.00 & 3.46 & 3.56 & 154 & 16.7 & 317 & .432 & 354 & .676 & 0 & 6212 & 5770 & 2871 & 1231148 & 0 & 0 & 0 & 0 \\
\hline GR-10d & $11 / 16 / 92$ & 1.00 & 3.69 & 3.31 & 274 & 16.7 & 326 & .444 & 364 & .695 & 0 & 9737 & 9975 & 2943 & 1233115 & 0 & 0 & 0 & 0 \\
\hline Base Cond. OFA off & $11 / 17 / 92$ & $1: 15$ & 4.16 & 3.49 & 9 & 16.7 & 422 & .576 & 341 & .650 & 0 & 0 & 0 & 7809 & 1245526 & 0 & 0 & 0 & 0 \\
\hline GR-11c & $11 / 17 / 92$ & $1: 00$ & 3.52 & 3.14 & 86 & 15.5 & 206 & .274 & 280 & .521 & 5502 & 30489 & 30297 & 10595 & 1199836 & 0 & 0 & 0 & 0 \\
\hline GR-11d & $11 / 17 / 92$ & $1: 00$ & 3.57 & 2.79 & 13 & 15.5 & 200 & .266 & 278 & .517 & 5521 & 35105 & 34771 & 10732 & 1190179 & 0 & 0 & 0 & 0 \\
\hline Base Cond. OFA off & $11 / 17 / 92$ & $0: 20$ & 4.93 & 3.79 & 5 & 16.5 & 443 & .604 & 345 & .657 & 0 & 0 & 0 & 3102 & 1170476 & 0 & 0 & 0 & 0 \\
\hline Base Cond. OFA off & $11 / 18 / 92$ & $0: 28$ & 3.28 & 2.66 & 29 & 16.7 & 360 & .491 & 338 & .645 & 0 & 0 & 0 & 2267 & 1219655 & 0 & 0 & 0 & 0 \\
\hline GR-110 & $11 / 18 / 92$ & $1: 04$ & 3.67 & 2.89 & 14 & 15.4 & 201 & .268 & 281 & .523 & 5517 & 35902 & 35882 & 10794 & 1203538 & 0 & 0 & 0 & 0 \\
\hline GR-12b & $11 / 18 / 92$ & $1: 05$ & 3.79 & 2.97 & 31 & 15.7 & 203 & .272 & 306 & .573 & 4168 & 34344 & 34271 & 10957 & 1199394 & 0 & 0 & 0 & 0 \\
\hline Base Cond. OFA oft & $11 / 18 / 92$ & $0: 35$ & 4.05 & 3.44 & 79 & 16.7 & 377 & .514 & 353 & .674 & 0 & 0 & 0 & 3020 & 1190000 & 0 & 0 & 0 & 0 \\
\hline GR-12 (5\% Gas) & $11 / 19 / 92$ & $1: 00$ & 3.12 & 3.06 & 986 & 16.3 & 208 & .282 & 338 & .641 & 1385 & 18886 & 20014 & 10324 & 1237049 & 0 & 0 & $\overline{0}$ & 0 \\
\hline GR-12a (10\% Gas) & $11 / 19 / 92$ & $1: 00$ & 2.64 & 2.41 & 955 & 16.0 & 176 & .238 & 326 & .614 & 2740 & 22246 & 23343 & 10348 & 1222295 & 0 & 0 & 0 & 0 \\
\hline GR-12c (23\% Gas) & $11 / 19 / 92$ & $1: 00$ & 2.83 & 2.24 & 92 & 15.2 & 175 & .232 & 275 & .511 & 6063 & 35104 & 35381 & 15051 & 1172295 & 0 & 0 & 0 & 0 \\
\hline Base Cond. OFA off & $11 / 19 / 92$ & $0: 20$ & 3.98 & 3.33 & 14 & 16.4 & 373 & .509 & 340 & .649 & 0 & 0 & 0 & 7364 & 1172857 & 0 & 0 & 0 & 0 \\
\hline GR-13A; $18 \%$ Gas & $11 / 20 / 92$ & $0 ; 58$ & 2.66 & 2.19 & 530 & 15.7 & 164 & .219 & 285 & .532 & 4850 & 30837 & 31822 & 4063 & 1191695 & 0 & 0 & 0 & 0 \\
\hline GR-13D; $18 \%$ Gas & $11 / 20 / 92$ & 1.00 & 3.25 & 2.33 & 43 & 15.7 & 186 & .248 & 291 & .544 & 4822 & 33657 & 34629 & 11943 & 1175082 & 0 & 0 & 0 & 0 \\
\hline GR-14B; $20 \%$ Gas & $11 / 20 / 92$ & $1: 00$ & 3.60 & 2.46 & 32 & 15.5 & 189 & .251 & 281 & .525 & 5305 & 33962 & 34994 & 10075 & 1170984 & 0 & 0 & 0 & 0 \\
\hline Base Cond. OFA off & $11 / 30 / 92$ & $1: 50$ & 3.74 & 3.13 & 234 & 16.7 & 363 & .495 & 343 & .654 & 0 & 0 & 0 & 2008 & 1214054 & 0 & 0 & 0 & 0 \\
\hline GR-BFr & $11 / 30 / 92$ & $0: 26$ & 4.39 & 3.56 & 162 & 15.9 & 236 & .318 & 315 & .593 & 2783 & 35407 & 34997 & 12754 & 1207407 & 0 & 0 & 0 & 0 \\
\hline GR-BFI & $11 / 30 / 92$ & $0: 27$ & 4.58 & 3.51 & 41 & 15.9 & 234 & .315 & 314 & .593 & 2736 & 34383 & 34410 & 11483 & 1195357 & 0 & 0 & 0 & 0 \\
\hline GR-21C & $12 / 1 / 92$ & $1: 06$ & 4.07 & 2.97 & 34 & 15.4 & 168 & .224 & 271 & .504 & 4377 & 30188 & 31048 & 10570 & 924946 & 0 & $\overline{0}$ & 0 & 0 \\
\hline GR-22 & $12 / 1 / 92$ & $0: 50$ & 5.26 & 4.19 & 11 & 16.0 & 208 & .281 & 310 & .585 & 1697 & 28007 & 29199 & 10663 & 939580 & 0 & 0 & 0 & 0 \\
\hline Bias Firing & $12 / 1 / 92$ & $0: 10$ & 4.11 & 2.80 & 45 & 15.4 & 168 & .224 & 279 & .519 & 4539 & 28229 & 29327 & 12196 & 919221 & 0 & 0 & 0 & 0 \\
\hline Base Cond. OFA on & $12 / 1 / 92$ & $0: 50$ & 3.63 & 3.80 & 272 & 16.70 & 212 & .288 & 324 & .617 & 0 & 9215 & 13085 & 6438 & 952541 & 0 & 0 & 0 & 0 \\
\hline Base Cond. OFA off & $12 / 1 / 92$ & $0: 40$ & 4.06 & 3.47 & 90 & 16.76 & 298 & .407 & 341 & .650 & 0 & 0 & 0 & 1606 & 1008774 & 0 & 0 & 0 & 0 \\
\hline Base Cond. OFA off & $12 / 2 / 92$ & $3: 55$ & 3.91 & 3.57 & 17 & 16.6 & 348 & .475 & 373 & .711 & 0 & 0 & 0 & 0 & 1184549 & 0 & 0 & 0 & 0 \\
\hline Base Cond. OFA off & $12 / 4 / 92$ & $0: 55$ & 4.26 & 3.18 & 69 & 16.8 & 257 & .350 & 464 & .884 & 0 & 0 & 0 & 0 & 964976 & 0 & 0 & 0 & 0 \\
\hline OFA Test & $12 / 4 / 92$ & $2: 10$ & 4.57 & 4.24 & 167 & 16.7 & 208 & .283 & 455 & .867 & 0 & 11958 & 15882 & 0 & 901188 & 0 & 0 & 0 & 0 \\
\hline Base Cond. OFA off & $12 / 7 / 92$ & $2: 10$ & 4.48 & 3.37 & 152 & 16.8 & 297 & .405 & 353 & .673 & 0 & 0 & 0 & 0 & 979707 & 0 & 0 & 0 & 0 \\
\hline GR-22A & $12 / 7 / 92$ & $1: 05$ & 4.12 & 3.78 & 671 & 16.0 & 175 & .236 & 320 & .602 & 2440 & 25023 & 26622 & 12026 & 960300 & $\overline{0}$ & $\overline{0}$ & 0 & $\overline{0}$ \\
\hline
\end{tabular}


Cherokee Unit 3, Average Test Data

Pre Modification

\begin{tabular}{|c|c|c|c|c|c|c|c|c|c|c|c|c|c|c|c|c|c|c|c|}
\hline Topt & Date: & Dur & $\begin{array}{l}\text { CEMS } \\
\text { OO Dry } \\
\text { \% }\end{array}$ & "Plant] & pom & ${ }^{\mathrm{co}} \mathrm{c}$ & NOxc & rón/mox & $\mathrm{so} p$ & 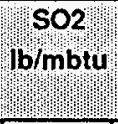 & $\begin{array}{l}\begin{array}{l}\text { Reb } \\
\text { Gas } \\
\text { scim }\end{array} \\
\end{array}$ & West! & 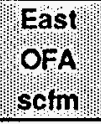 & 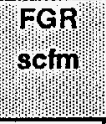 & steam & mill & Mily & Mill & Mill \\
\hline GR-22B & $12 / 7 / 92$ & $1: 00$ & 4.03 & 3.50 & 23 & 15.8 & 173 & .231 & 302 & .566 & 3332 & 29743 & 31158 & 10291 & 948854 & 0 & 0 & 0 & 0 \\
\hline GR-22C & $12 / 7 / 92$ & 1.00 & 3.90 & 3.17 & 8 & 15.5 & 163 & .217 & 281 & .524 & 4429 & 32849 & 34158 & 11935 & 948973 & 0 & 0 & 0 & 0 \\
\hline Base Cond. OFA off & $12 / 8 / 92$ & $0: 27$ & 3.58 & 2.51 & 826 & 16.6 & 236 & .321 & 345 & .657 & 0 & 0 & 0 & 3757 & 741704 & 0 & 0 & 0 & 0 \\
\hline GR-31C & $12 / 8 / 92$ & $1: 00$ & 3.87 & 3.18 & 202 & 15.4 & 158 & .210 & 281 & .523 & 3575 & 18244 & 21244 & 12085 & 744738 & 0 & 0 & 0 & 0 \\
\hline GR-3IF & $12 / 8 / 92$ & $1: 23$ & 5.10 & 4.07 & 8 & 15.1 & 183 & .242 & 275 & .512 & 3600 & 30965 & 32115 & 12243 & 746411 & 0 & 0 & 0 & 0 \\
\hline GR-32A & $12 / 8 / 92$ & $1: 00$ & 4.17 & 3.67 & 240 & 15.9 & 168 & .227 & 304 & .573 & 1892 & 17900 & 20712 & 12444 & 750449 & 0 & 0 & 0 & 0 \\
\hline Base Cond. OFA off & $12 / 9 / 92$ & $0: 41$ & 3.08 & 2.54 & 256 & 16.8 & 223 & .304 & 339 & .646 & 0 & 0 & 0 & 4971 & 763638 & 0 & 0 & 0 & 0 \\
\hline GR-32C & $12 / 9 / 92$ & $1: 00$ & 4.68 & 3.74 & 17 & 15.3 & 171 & .226 & 262 & .489 & 3494 & 32821 & 32536 & 12564 & 730910 & 0 & 0 & 0 & 0 \\
\hline GR-32C; 3Mills & $12 / 9 / 92$ & $0: 56$ & 4.19 & 3.64 & 13 & 15.3 & 146 & .194 & 265 & .494 & 3590 & 29831 & 29860 & 12776 & 753483 & 0 & 0 & 0 & 1 \\
\hline Base Cond. OFA off & $12 / 9 / 92$ & $0: 15$ & 4.94 & 4.22 & 15 & 16.4 & 303 & .412 & 342 & .652 & 0 & 0 & 0 & 2255 & 800406 & 0 & 0 & 0 & 0 \\
\hline Base Cond. OFA off & $12 / 14 / 92$ & $2: 00$ & 4.40 & 3.59 & 69 & 16.5 & 335 & .456 & 346 & .659 & 0 & 0 & 0 & 0 & 1073140 & 0 & 0 & 0 & 0 \\
\hline GR-12Z & $12 / 14 / 92$ & $1: 02$ & 3.87 & 3.24 & 326 & 16.0 & 237 & .322 & 309 & .586 & 1428 & 23928 & 25198 & 10074 & 1195714 & 0 & 0 & 0 & 0 \\
\hline GR $2.7 \%$ Gas & $12 / 14 / 92$ & $0: 17$ & 4.12 & 3.44 & 54 & 16.2 & 235 & .319 & 314 & .597 & 696 & 30334 & 31860 & 10062 & 1193333 & 0 & 0 & 0 & 0 \\
\hline Base Cond. OFA off & $12 / 15 / 92$ & $1: 37$ & 3.74 & 3.08 & 327 & 16.7 & 323 & .439 & 339 & .646 & 0 & 0 & 0 & 0 & 1171486 & 0 & 0 & 0 & 0 \\
\hline GR $20 \%$ Gas & $12 / 15 / 92$ & $0: 36$ & 3.54 & 2.89 & 53 & 15.5 & 194 & .258 & 263 & .490 & 5002 & 34687 & 34800 & 10892 & 1181622 & 0 & 0 & 0 & 0 \\
\hline Base Cond. OFA off & $12 / 16 / 92$ & $0: 48$ & 3.97 & 3.64 & 9 & 16.6 & 371 & .506 & 317 & .604 & 0 & 0 & 0 & 0 & 1190000 & 0 & 0 & 0 & 0 \\
\hline GR-12A1 & $12 / 16 / 92$ & $2: 19$ & 3.75 & 3.18 & 74 & 16.0 & 214 & .288 & 288 & .542 & 2725 & 27872 & 29125 & 10690 & 1216071 & 0 & 0 & 0 & 0 \\
\hline Test C1 & $1 / 15 / 93$ & $1: 00$ & 4.02 & 3.16 & 31 & 16.29 & 242 & .328 & 292 & .553 & 1996 & 22497 & 24181 & 13462 & 1220000 & 0 & 0 & 0 & 0 \\
\hline Tost C2 & $1 / 15 / 93$ & 1.00 & 3.89 & 2.96 & 17 & 16.02 & 212 & .285 & 282 & .531 & 3256 & 29561 & 30316 & 13509 & 1219508 & 0 & 0 & 0 & 0 \\
\hline Test C3 & $1 / 15 / 93$ & $0: 58$ & 3.67 & 2.44 & 13 & 15.74 & 185 & .248 & 275 & .514 & 4545 & 35040 & 35272 & 13849 & 1219153 & 0 & 0 & 0 & 0 \\
\hline Test C4 & $1 / 15 / 93$ & $0: 50$ & 3.38 & 2.12 & 77 & 15.49 & 175 & .233 & 262 & .488 & 5786 & 35093 & 35485 & 13941 & 1220000 & 0 & 0 & 0 & 0 \\
\hline Test Bi & $1 / 15 / 93$ & $0: 59$ & 4.16 & 3.63 & 43 & 16.77 & 271 & .370 & 338 & .644 & 0 & 24531 & 25480 & 2681 & 1239167 & 0 & 0 & 0 & 0 \\
\hline Test B3 & $1 / 15 / 93$ & $1: 01$ & 3.66 & 3.43 & 138 & 16.86 & 260 & .355 & 342 & .652 & 0 & 23602 & 24718 & 2461 & 1238871 & 0 & 0 & 0 & 0 \\
\hline Base Cond. OFA off & $1 / 18 / 93$ & $0: 45$ & 3.48 & 2.81 & 9 & 16.89 & 381 & .520 & 332 & .632 & 0 & 0 & 0 & 0 & 1262609 & 0 & 0 & 0 & 0 \\
\hline Tost B5 & $1 / 18 / 93$ & $1: 01$ & 3.60 & 3.28 & 102 & 16.87 & 270 & .368 & 342 & .652 & 0 & 20653 & 23758 & 0 & 1270323 & 0 & 0 & 0 & 0 \\
\hline Base Cond. OFA cooling & $1 / 19 / 93$ & $0: 39$ & 4.00 & 3.79 & 7 & 16.85 & 385 & .523 & 332 & .634 & 0 & 0 & 7531 & 2946 & 1272000 & 0 & 0 & 0 & 0 \\
\hline GR-12R & $1 / 19 / 93$ & $1: 00$ & 4.56 & 3.84 & 20 & 16.44 & 256 & .348 & 310 & .589 & 1352 & 31531 & 33639 & 12599 & 1254754 & 0 & 0 & 0 & 0 \\
\hline GR-13E & $1 / 19 / 93$ & $1: 00$ & 3.42 & 2.39 & 33 & 15.75 & 185 & .247 & 269 & .503 & 4865 & 33584 & 35609 & 10066 & 1205738 & 0 & 0 & 0 & 0 \\
\hline GR-13C & $1 / 20 / 93$ & $1: 10$ & 3.50 & 2.42 & 28 & 15.77 & 199 & .266 & 277 & .518 & 4844 & 35894 & 36507 & 9901 & 1231000 & 0 & 0 & 0 & 0 \\
\hline GR-12D & $1 / 20 / 93$ & $1: 05$ & 3.81 & 2.61 & 12 & 15.86 & 204 & .274 & 283 & .532 & 4070 & 35814 & 36201 & 11463 & 1230484 & 0 & 0 & 0 & 0 \\
\hline GR-12E & $1 / 20 / 93$ & $0: 59$ & 3.52 & 2.69 & 57 & 16.21 & 216 & .292 & 312 & .589 & 2633 & 28992 & 29776 & 12031 & 1233833 & 0 & 0 & 0 & 0 \\
\hline Base Cond. OFA off & $1 / 20 / 93$ & $0: 15$ & 2.92 & 2.34 & 96 & 16.95 & 332 & .451 & 338 & .643 & 0 & 0 & 0 & 2659 & 1243750 & 0 & 0 & 0 & 0 \\
\hline 150 MWn Max NOx Red & $1 / 21 / 93$ & $1: 05$ & 3.15 & 2.00 & 54 & 15.57 & 185 & .246 & 269 & .500 & 6076 & 36261 & 36094 & 10201 & 1224091 & 0 & 0 & 0 & 0 \\
\hline Base Cond. OFA cooling & $1 / 21 / 93$ & $1: 30$ & 3.42 & 3.14 & 20 & 16.98 & 340 & .463 & 339 & .646 & 0 & 0 & 4339 & 5341 & 1221429 & 0 & 0 & 0 & 0 \\
\hline $120 \mathrm{MWn}$ Max NOx Red & $1 / 21 / 93$ & 1.00 & 3.47 & 2.49 & 13 & 15.49 & 160 & .213 & 255 & .473 & 5272 & 29726 & 29847 & 10044 & 971677 & 0 & 0 & 0 & 0 \\
\hline GR Environ.\#1 & $1 / 25 / 93$ & 5:10 & 4.42 & 3.21 & 8 & 15.63 & 218 & .291 & 278 & .520 & 4396 & 33399 & 34070 & 11142 & 1152283 & 0 & 0 & 0 & 0 \\
\hline Base Cond. OFA cooling & $1 / 26 / 93$ & $0: 55$ & 4.28 & 3.64 & 44 & 16.79 & 302 & .412 & 321 & .611 & 0 & 486 & 9414 & 3670 & 1140357 & 0 & 0 & 0 & 0 \\
\hline GR Environ. Test \#2 & $1 / 26 / 93$ & $5: 22$ & 3.95 & 3.11 & 22 & 15.79 & 197 & .263 & 283 & .530 & 4108 & 34163 & 34076 & 12804 & 1132215 & 0 & 0 & 0 & 0 \\
\hline Environ. \#3 & $1 / 27 / 93$ & $5: 55$ & 4.03 & 3.18 & 31 & 15.69 & 220 & .295 & 276 & .517 & 4242 & 34388 & 34265 & 12240 & 1220225 & 0 & 0 & 0 & 0 \\
\hline Environ. \#4 (No GR) & $1 / 27 / 93$ & $6: 00$ & 3.50 & 3.11 & 60 & 16.59 & 357 & .487 & 325 & .621 & 0 & 0 & 0 & 2182 & $\$ 157591$ & 0 & 0 & 0 & 0 \\
\hline
\end{tabular}


Cherokee Unit 3, Average Test Data

Pre Modification

\begin{tabular}{|c|c|c|c|c|c|c|c|c|c|c|c|c|c|c|c|c|c|c|c|}
\hline $\begin{array}{l}\text { Test } \\
\text { No. }\end{array}$ & Date: & Dur. & $\begin{array}{l}\text { CEMS } \\
\text { O2 } \\
\% \text { Dry }\end{array}$ & $\begin{array}{l}\text { Plant } \\
\text { o2 } \\
\% \text { wet }\end{array}$ & $\begin{array}{l}\text { coc } \\
\text { ppm }\end{array}$ & corc & $\begin{array}{l}\text { NOxc } \\
\text { ppmp }\end{array}$ & $\begin{array}{c}\text { NOx } \\
1 \mathrm{~b} / \mathrm{mbtu}\end{array}$ & $\begin{array}{l}\mathrm{SO} 2 \mathrm{c} \\
\mathrm{ppm}\end{array}$ & 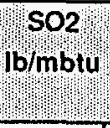 & $\begin{array}{l}\text { Reb } \\
\text { Gas } \\
\text { sctm }\end{array}$ & $\begin{array}{l}\text { West } \\
\text { OFA } \\
\text { sctm }\end{array}$ & $\begin{array}{l}\text { Eas! } \\
\text { OFA } \\
\text { scfm }\end{array}$ & FGR & $\begin{array}{l}\text { Steam } \\
\text { Ibshrhr }\end{array}$ & Mill & $\begin{array}{l}\text { Mill } \\
\text { B } \\
0=0\end{array}$ & Mill & Mill \\
\hline Environ, *55 (No GR) & $1 / 28 / 93$ & $6: 04$ & 3.67 & 3.17 & 8 & 17.04 & 389 & .530 & 320 & .610 & 0 & 0 & 0 & 610 & 1248877 & 0 & \begin{tabular}{l|l}
0 \\
\end{tabular} & 0 & 0 \\
\hline Base Cond. & $2 / 2 / 93$ & $0: 17$ & 3.31 & 3.00 & 13 & 16.89 & 348 & .475 & & & 0 & 0 & 0 & 1087 & 1221514 & 0 & 0 & 0 & 0 \\
\hline LNB 120MW \#1 & $3 / 8 / 93$ & $2: 00$ & 3.92 & 3.36 & 277 & 16.54 & 263 & 359 & 367 & 699 & 0 & 0 & 0 & 2097 & 962185 & 0 & 0 & 0 & 0 \\
\hline LNB 120MW \#2 & $3 / 8 / 93$ & $2: 00$ & 3.75 & 2.89 & 342 & 16.50 & 249 & .339 & 368 & .703 & 0 & 0 & 0 & 2985 & 954153 & 0 & 0 & 0 & 0 \\
\hline LNB 150NW *1 & 3/9/93 & $2: 00$ & 4.11 & 3.56 & 10 & 16.54 & 395 & .539 & 347 & .661 & 0 & 0 & 0 & 1726 & 1238182 & 0 & 0 & 0 & 0 \\
\hline LNB 150NW \#2 & $3 / 9 / 93$ & $2: 00$ & 3.58 & 2.88 & 35 & 16.59 & 346 & .472 & 347 & .662 & 0 & 0 & 0 & 2244 & 1227898 & 0 & 0 & 0 & 0 \\
\hline LNB 90MW \#1 & $3 / 10 / 93$ & $2: 00$ & 5.04 & 4.40 & 32 & 16.44 & 346 & .471 & 320 & .610 & 0 & 0 & 0 & 304 & 747371 & 0 & 0 & 0 & 0 \\
\hline LNB 90MW \#2 & $3 / 10 / 93$ & $1: 58$ & 4.61 & 4.29 & 69 & 16.44 & 329 & .448 & 316 & 603 & 0 & 0 & 0 & 209 & 748097 & 0 & 0 & 0 & 0 \\
\hline LNB 150MW \#3 & $3 / 11 / 93$ & $2: 00$ & 3.75 & 3.38 & 17 & 16.59 & 363 & .495 & 308 & .587 & 0 & 0 & 0 & 0 & 1190331 & 0 & 0 & 0 & 0 \\
\hline LNB 150MW \#4 & $3 / 11 / 93$ & $2: 00$ & 3.36 & 3.13 & 62 & 16.62 & 333 & .454 & 304 & .580 & 0 & 0 & 0 & 0 & 1211074 & 0 & 0 & 0 & 0 \\
\hline $3 M_{1}$ & $3 / 22 / 93$ & $1: 02$ & 2.53 & 1.89 & 158 & 15.64 & 150 & .200 & 280 & .523 & 5156 & 32799 & 32127 & 10248 & 1218254 & 0 & 0 & 0 & 1 \\
\hline 3 3M2 & $3 / 22 / 93$ & $1: 03$ & 2.27 & 1.68 & 144 & 15.58 & 150 & .200 & 272 & .507 & 5174 & 29745 & 29125 & 10278 & 1210156 & 0 & 0 & 0 & 1 \\
\hline 3 M3 & $3 / 2293$ & $0: 59$ & 2.87 & 2.38 & 16 & 15.53 & 181 & .241 & 271 & .504 & 5183 & 29132 & 28952 & 10258 & 1206667 & 0 & 0 & 0 & 1 \\
\hline 3 Mill 7 & $4 / 13 / 93$ & $1: 00$ & 3.44 & 3.10 & 104 & 16.64 & 230 & .314 & 348 & .664 & 0 & 0 & 0 & 1276 & 963564 & 0 & 0 & 0 & 1 \\
\hline 3 Mill 6 & $4 / 13 / 93$ & $1: 00$ & 3.02 & 2.70 & 281 & 16.77 & 211 & .287 & 356 & .680 & 0 & 0 & 0 & 1496 & 972327 & 0 & 0 & 0 & 1 \\
\hline Level 6 1/2 & $4 / 15 / 93$ & $2: 05$ & 3.70 & 2.28 & 182 & 16.82 & 307 & .419 & 335 & 639 & 0 & 0 & 0 & 130 & 1190873 & 0 & 0 & 0 & 0 \\
\hline Level 4 & $4 / 15 / 93$ & $1: 10$ & 3.75 & 2.32 & 151 & 16.79 & 308 & .421 & 335 & 639 & 0 & 0 & 0 & 67 & 1190704 & 0 & 0 & 0 & 0 \\
\hline Level 3 & $4 / 15 / 93$ & $0: 53$ & 3.73 & 2.19 & 230 & 16.82 & 307 & .419 & 331 & 631 & 0 & 0 & 0 & 393 & 1191296 & 0 & 0 & 0 & 0 \\
\hline Level 5 5/2 & $4 / 15 / 93$ & $1: 58$ & 3.3 .1 & 2.31 & 237 & 16.77 & 292 & .398 & 329 & 628 & 0 & 0 & 0 & 1173 & 1195042 & 0 & 0 & 0 & $\overline{0}$ \\
\hline Base Cond & $4 / 15 / 93$ & $5: 25$ & 3.50 & 2.28 & 238 & 16.78 & 299 & .408 & 331 & .632 & 0 & 0 & 0 & 644 & 1192178 & 0 & 0 & 0 & 0 \\
\hline Level $51 / 2$ & $4 / 16 / 93$ & $1: 47$ & 4.03 & 3.20 & 79 & 16.74 & 375 & .512 & 332 & 635 & 0 & 0 & 0 & 775 & 1204194 & 0 & 0 & 0 & 0 \\
\hline Level $61 / 2$ & $4 / 16 / 93$ & 1:19 & 3.88 & 3.11 & 8 & 16.76 & 362 & .494 & 341 & .649 & 0 & 0 & 0 & 2339 & 1212250 & 0 & 0 & 0 & 0 \\
\hline Level 3 & $4 / 16 / 93$ & $0: 44$ & 3.99 & 3.16 & 8 & 16.70 & 367 & .501 & 347 & .662 & 0 & 0 & 0 & 2497 & 1210222 & 0 & 0 & 0 & 0 \\
\hline Level 4 & $4 / 16 / 93$ & $1: 00$ & 3.98 & 3.14 & 8 & 16.70 & 366 & .499 & 347 & .662 & 0 & 0 & 0 & 2533 & 1211967 & 0 & 0 & 0 & 0 \\
\hline North out. South in & $4 / 16 / 93$ & 0.20 & 4.71 & 3.23 & 321 & 16.66 & 405 & .552 & 330 & .633 & 0 & 0 & 0 & 790 & 1201429 & 0 & 0 & 0 & 0 \\
\hline South out, North in & $4 / 16 / 93$ & $0: 20$ & 3.81 & 3.21 & 9 & 16.79 & 358 & .488 & 339 & .646 & 0 & 0 & 0 & 787 & 1202381 & 0 & 0 & 0 & 0 \\
\hline Baso Cond & $4 / 16 / 93$ & 6.25 & 3.98 & 3.14 & 41 & 16.73 & 367 & .500 & 341 & .651 & 0 & 0 & 0 & 1989 & 1210081 & 0 & 0 & 0 & 0 \\
\hline Level 4 & $4 / 19 / 93$ & $0: 56$ & 3.69 & 2.81 & 59 & 15.75 & 220 & 293 & 386 & .720 & 4996 & 31169 & 31190 & 12318 & 1191228 & 0 & 0 & 0 & 0 \\
\hline Level 3 & $4 / 19 / 93$ & $0: 52$ & 3.68 & 2.80 & 58 & 15.75 & 219 & .292 & 385 & .720 & 4996 & 31175 & 31209 & 12323 & 1190566 & 0 & 0 & 0 & 0 \\
\hline Lovel $51 / 2$ & $4 / 49 / 93$ & $2: 29$ & 4.18 & 3.23 & 9 & 15.74 & 236 & .315 & 371 & .693 & 5021 & 33682 & 33472 & 12180 & 1180600 & 0 & 0 & 0 & 0 \\
\hline Lovel $61 / 2$ & $4 / 19 / 93$ & 1:10 & 4.27 & 3.25 & 9 & 15.84 & 246 & .329 & 383 & .716 & 5040 & 34184 & 33691 & 12391 & 1180000 & 0 & 0 & 0 & 0 \\
\hline Base Cond. OFA on & $4 / 19 / 93$ & $1: 00$ & 4.97 & 4.26 & 16 & 16.56 & 325 & .444 & 456 & 870 & 0 & 23654 & 23943 & 12375 & 1193770 & 0 & 0 & 0 & 0 \\
\hline GR & $4 / 19 / 93$ & $5: 42$ & 4.10 & 3.16 & 12 & 15.76 & 235 & .313 & 376 & .702 & 5020 & 33651 & 33434 & 12254 & 1180644 & 0 & 0 & 0 & 0 \\
\hline Lovel 6 1/2 & $4 / 20 / 93$ & $1: 47$ & 3.30 & 2.84 & 68 & 16.72 & 259 & .353 & 406 & .773 & 0 & 0 & 0 & 233 & 1079815 & 0 & 0 & 0 & 1 \\
\hline Base Cond $130 \mathrm{MW}$ & $4 / 20 / 93$ & 3:35 & 3.24 & 2.81 & 113 & 16.71 & 252 & .343 & 413 & .788 & 0 & 0 & 0 & 484 & 1079537 & 0 & 0 & 0 & 0 \\
\hline Base Cond 120MW & $4 / 20 / 93$ & $2: 55$ & 4.48 & 3.25 & 68 & 16.52 & 292 & .398 & 427 & .814 & 0 & 0 & 0 & 1260 & 962761 & 0 & 0 & 0 & 0 \\
\hline Base Cond. OFA off & $4 / 21 / 93$ & $7: 40$ & 3.98 & 2.99 & 380 & 16.38 & 271 & .370 & 477 & .910 & 0 & 0 & 0 & 1689 & 936625 & 0 & 0 & 0 & 0 \\
\hline Base Cond. OFA off & 4/23/93 & $0: 30$ & 3.58 & 2.68 & 17 & 16.89 & 348 & .476 & 355 & .677 & 0 & 0 & 0 & 2645 & 1200645 & 0 & 0 & 0 & 0 \\
\hline 4M12 (OFA off) & $4 / 23 / 93$ & $1: 00$ & 2.93 & 1.92 & 6 & 15.96 & 299 & .409 & 296 & .565 & 0 & 0 & 0 & 2856 & 1216721 & 0 & 0 & 0 & 0 \\
\hline $4 \mathrm{M} 13 \mathrm{a}(78,000 \mathrm{sctm}$ OFA & 4/23/93 & 0:20 & 3.68 & 3.25 & 50 & 15.70 & 193 & .263 & 291 & .556 & 0 & 39940 & 38135 & 2871 & 1259524 & 0 & 0 & 0 & 0 \\
\hline
\end{tabular}


Pre Modification

\begin{tabular}{|c|c|c|c|c|c|c|c|c|c|c|c|c|c|c|c|c|c|c|c|}
\hline Test & Date & Dur & $\begin{array}{l}\text { CEMS } \\
\text { O2 } \\
\% \text { Dry }\end{array}$ & $\begin{array}{l}\text { Plant } \\
\text { o2 } \\
\% \text { Wot }\end{array}$ & coc & $\begin{array}{c}\mathrm{CO} 2 \mathrm{c} \\
\%\end{array}$ & $\begin{array}{l}\text { Noxe } \\
\text { ppm }\end{array}$ & 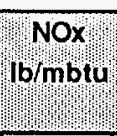 & $\begin{array}{l}\text { so2c } \\
\text { ppm }\end{array}$ & $\begin{array}{l}\text { so2 } \\
\text { b/mbro }\end{array}$ & $\begin{array}{l}\text { Reb } \\
\text { Gas } \\
\text { scrm }\end{array}$ & $\begin{array}{l}\text { West } \\
\text { OFA } \\
\text { sctm }\end{array}$ & $\begin{array}{l}\text { East } \\
\text { OFA } \\
\text { sctm }\end{array}$ & $\begin{array}{l}F G R \\
\text { sccm }\end{array}$ & Steam & Mill & $\begin{array}{l}M \text { Mint } \\
\text { B } \\
0=c\end{array}$ & Mill & Mill \\
\hline $4 \mathrm{M} 13 \mathrm{~b}(70,000 \mathrm{scim}$ OF & $4 / 23 / 93$ & $0: 50$ & 3.79 & 3.07 & 33 & 15.73 & 214 & .293 & 286 & .545 & 0 & 35404 & 34049 & 2766 & 1267308 & 0 & 0 & 0 & \\
\hline Base Cond. OFAOn & $4 / 27 / 93$ & $0: 30$ & 4.81 & 3.62 & 11 & 16.59 & 386 & .526 & 340 & .647 & 0 & 8540 & 9861 & 5545 & 1221613 & 0 & 0 & $\overline{0}$ & 0 \\
\hline GR on $150 \mathrm{MW}, 11 \%$ Gas & $4 / 27 / 93$ & $0: 53$ & 3.99 & 3.00 & 25 & 16.09 & 268 & .361 & 299 & .564 & 2987 & 18389 & 18339 & 10001 & 1208519 & 0 & 0 & 0 & $\overline{0}$ \\
\hline GR on $150 M W, 17 \%$ Gas & $4 / 27 / 93$ & $2: 48$ & 3.64 & 2.81 & 40 & 15.76 & 213 & .285 & 280 & .523 & 4459 & 36218 & 35490 & 10001 & 1208037 & 0 & 0 & 0 & 0 \\
\hline Base Cond. OFA on & $4 / 28 / 93$ & $0: 44$ & 4.90 & 3.87 & 10 & 16.64 & 355 & .484 & 335 & .639 & 0 & 7132 & 9195 & 4686 & 1137333 & 0 & $\overline{0}$ & 0 & 0 \\
\hline GR on Auto & $4 / 28 / 93$ & $6: 35$ & 3.74 & 2.86 & 6 & 15.80 & 191 & .256 & 284 & .533 & 3933 & 33171 & 32485 & 9995 & 1097551 & 0 & 0 & 0 & 0 \\
\hline GR on Auto & $5 / 3 / 93$ & $7: 00$ & 4.19 & 3.65 & 7 & 15.50 & 222 & .297 & 287 & .537 & 4270 & 35646 & 34442 & 9996 & 1138217 & 0 & 0 & 0 & $\overline{0}$ \\
\hline Base Cond. OFA on & $5 / 6 / 93$ & $2: 45$ & 4.85 & 3.32 & 31 & 16.48 & 344 & .470 & 353 & .673 & 0 & 6985 & 8367 & 4146 & 1163494 & 0 & 0 & 0 & 0 \\
\hline GR on Auto & $5 / 6 / 93$ & $1: 15$ & 3.91 & 2.91 & 20 & 15.70 & 204 & .274 & 292 & .547 & 3774 & 32268 & 31261 & 10005 & 3947 & 0 & 0 & 0 & 0 \\
\hline Base Cond. OFA off & $5 / 6 / 93$ & $0: 21$ & 4.43 & 2.12 & 772 & 16.39 & 292 & .398 & 342 & .653 & 0 & 0 & 0 & 3601 & 970203 & 0 & 0 & 0 & $\overline{0}$ \\
\hline GR on Auto $150 \mathrm{MW}$ & $5 / 7 / 93$ & $4: 26$ & 3.74 & 2.94 & 11 & 15.57 & 196 & .262 & 315 & .589 & 4553 & 36388 & 35798 & 10000 & 1206418 & 0 & 0 & 0 & $\overline{0}$ \\
\hline GR on Auto $160 \mathrm{MW}$ & $5 / 7 / 93$ & 1.59 & 3.49 & 2.70 & 8 & 15.58 & 208 & .278 & 323 & .605 & 4836 & 37227 & 36368 & 9989 & 1295750 & 0 & 0 & $\overline{0}$ & $\overline{0}$ \\
\hline GR on Auto $140 \mathrm{MW}$ & $5 / 7 / 93$ & $4: 50$ & 4.06 & 3.19 & 7 & 15.41 & 208 & .278 & 338 & .632 & 4248 & 35014 & 34787 & 10004 & 1122062 & co & 0 & 0 & 0 \\
\hline Base Cond. OFA off & $5 / 7 / 93$ & $0: 35$ & 4.48 & 3.20 & 8 & 16.20 & 398 & .542 & 361 & .690 & 0 & 0 & 0 & 1400 & 9167 & 0 & 0 & 0 & 0 \\
\hline GR on Auto & $5 / 11 / 93$ & 6.08 & 4.86 & 3.64 & 7 & 15.52 & 209 & .280 & 298 & .558 & 4071 & 34084 & 33708 & 10003 & 1089265 & 0 & 0 & 0 & 0 \\
\hline GR 13 & $5 / 25 / 93$ & $15: 04$ & 3.98 & 3.25 & 7 & 15.70 & 208 & .279 & 297 & .557 & 4233 & 34644 & 35080 & 10004 & 1164920 & 0 & 0 & 0 & $\overline{0}$ \\
\hline GR 14 & $5 / 25 / 93$ & $1: 25$ & 5.04 & 4.06 & 5 & 15.40 & 224 & .300 & 296 & .554 & 2961 & 29291 & 29684 & 9972 & & 0 & $\mathrm{c}$ & 0 & 0 \\
\hline GR 15 & $5 / 26 / 93$ & $1: 29$ & 5.06 & 4.10 & 5 & 15.38 & 207 & .276 & 296 & .553 & 3118 & 29027 & 30011 & 9992 & 219 & 0 & 0 & 0 & 0 \\
\hline LNB-OFA & $5 / 26 / 93$ & $0: 42$ & 6.41 & 5.47 & 25 & 15.99 & 283 & .390 & 346 & .659 & 0 & 18890 & 20768 & 8231 & 741474 & 0 & 0 & 0 & 0 \\
\hline NB & $5 / 26 / 93$ & $9: 44$ & 3.61 & 2.62 & 161 & 16.58 & 304 & .415 & 357 & .680 & 0 & 0 & & 2053 & 1128501 & 0 & 0 & 0 & 0 \\
\hline $\mathrm{NB}$ & $5 / 27 / 93$ & $0: 10$ & 4.07 & 2.78 & 329 & 16.62 & 264 & .359 & 361 & .688 & 0 & 0 & & 5694 & 917407 & 0 & 0 & 0 & 0 \\
\hline LNB-OFA & $5 / 27 / 93$ & $0: 45$ & 4.60 & 3.65 & 38 & 16.58 & 321 & .438 & 366 & .699 & 0 & 18427 & 15737 & 8930 & 1199783 & 0 & 0 & 0 & 0 \\
\hline GR-LNB 16 & $5 / 27 / 93$ & $13: 40$ & 4.19 & 3.43 & 7 & 15.68 & 222 & .298 & 302 & .565 & 3964 & 33655 & 32673 & 9997 & 0676 & $c$ & 0 & 0 & 0 \\
\hline GR-LNB 17 & $5 / 28 / 93$ & $2: 57$ & 5.47 & 4.41 & 6 & 15.45 & 221 & .297 & 300 & .563 & 2883 & 28577 & 28796 & 9789 & & 0 & 0 & 0 & $\overline{0}$ \\
\hline $\mathrm{NB}$ & $5 / 28 / 93$ & $1: 23$ & 6.01 & 5.10 & 10 & 16.22 & 301 & .410 & 346 & .660 & 0 & 0 & 0 & 3066 & 699170 & 0 & $\overline{0}$ & 0 & 0 \\
\hline GR-LNB 20b & $6 / 3 / 93$ & $8: 51$ & 3.29 & 2.40 & 18 & 16.22 & 176 & .236 & 301 & .564 & 4103 & 34468 & 33864 & 9991 & 1126804 & 0 & $\overline{0}$ & 0 & $\overline{0}$ \\
\hline LNB & $6 / 3 / 93$ & 1.05 & 5.50 & 4.25 & 30 & 17.05 & 341 & .467 & 357 & .680 & 0 & 0 & 0 & 2084 & 761725 & 0 & 0 & 0 & 0 \\
\hline LNB (low bad) & $6 / 4 / 93$ & 6.52 & 5.91 & 4.56 & 18 & 16.80 & 365 & .497 & 357 & .682 & 0 & 7 & 7 & 1828 & 723239 & $\mathrm{c}$ & 0 & 0 & 0 \\
\hline LNB (high load) & $6 / 4 / 93$ & $5: 25$ & 4.22 & 3.06 & 15 & 17.39 & 343 & .468 & 369 & .704 & 0 & 0 & 0 & 1331 & 9289 & 7 & 0 & 0 & 0 \\
\hline LNB-OFA & $6 / 4 / 93$ & $2: 31$ & 4.16 & 3.44 & 96 & 16.59 & 280 & .382 & 361 & .688 & 0 & 17155 & 15601 & 5952 & 1269880 & c & $\mathrm{c}$ & 0 & 0 \\
\hline GR.LNB & $6 / 4 / 93$ & $7: 42$ & 3.07 & 2.29 & 37 & 15.72 & 176 & .235 & 301 & .564 & 4228 & 35531 & 34075 & 10001 & 1164427 & 0 & 0 & 0 & 0 \\
\hline LNB & $6 / 8 / 93$ & $1: 35$ & 4.32 & 3.13 & 34 & 16.42 & 331 & .452 & 349 & .666 & 0 & 0 & 0 & 2428 & 1128646 & 0 & 0 & 0 & 0 \\
\hline NB-OFA & $6 / 8 / 93$ & $1: 40$ & 4.79 & 3.54 & 135 & 16.63 & 310 & .422 & 371 & .707 & 0 & 9617 & 7060 & 4718 & 1139901 & I & 0 & 0 & 0 \\
\hline GR-LNB 22a & $6 / 8 / 93$ & 6.21 & 4.54 & 3.46 & 16 & 15.79 & 198 & .265 & 310 & .580 & 3922 & 33702 & 32454 & 10001 & 1054627 & 0 & 0 & 0 & 0 \\
\hline GP-LNB 22b & $6 / 8 / 93$ & $5: 30$ & 3.05 & 2.55 & 87 & 16.07 & 167 & .224 & 306 & .573 & 4340 & 36153 & 34706 & 9998 & 1160091 & $\mathrm{c}$ & 0 & 0 & 0 \\
\hline GR-LNB 23a & $6 / 9 / 93$ & $1: 16$ & 3.70 & 2.93 & 49 & 16.19 & 157 & .211 & 307 & .576 & 3130 & 29755 & 29425 & 10008 & 890215 & 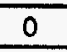 & 0 & 0 & 0 \\
\hline LNB-OFA & $6 / 9 / 93$ & $0: 30$ & 5.56 & 4.50 & 59 & 16.83 & 184 & .251 & 358 & .683 & 0 & 17162 & 18085 & 5358 & 688972 & $\mathrm{c}$ & 0 & 0 & 0 \\
\hline NB & $6 / 9 / 93$ & $16: 03$ & 4.71 & 3.41 & 107 & 17.10 & 295 & .402 & 362 & .690 & 0 & 0 & 0 & 2719 & 950036 & 0 & 0 & 0 & 0 \\
\hline GR-LNB 23b & $6 / 9 / 93$ & $4: 28$ & 4.84 & 4.03 & 6 & 16.07 & 232 & .311 & 308 & .576 & 4052 & 34395 & 33067 & 10000 & 1090496 & 0 & 0 & 0 & 0 \\
\hline LNB & $6 / 10 / 93$ & $8: 47$ & 4.41 & 3.20 & 518 & 17.15 & 239 & .326 & 363 & .693 & 0 & 0 & 0 & 2474 & 920397 & 0 & 0 & 0 & 0 \\
\hline
\end{tabular}




\begin{tabular}{|c|c|c|c|c|c|c|c|c|c|c|c|c|c|c|c|c|c|c|c|}
\hline Test & 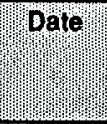 & Dow & 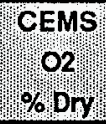 & 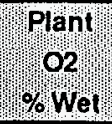 & popm! & 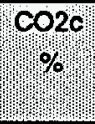 & Noxc & 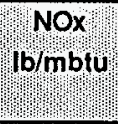 & sorc & (1) so2 & $\begin{array}{l}\text { Reb } \\
\text { Gas } \\
\text { sctm }\end{array}$ & $\begin{array}{l}\text { West } \\
\text { ofpat }\end{array}$ & $\begin{array}{l}\text { East" } \\
\text { OFas } \\
\text { sctm }\end{array}$ & $\begin{array}{l}\text { FGR } \\
\text { scfim } \\
\text { ş⿻ }\end{array}$ & Steam! & Mill & Mill" & Mill! & Mill \\
\hline LNB-OFA & $6 / 10 / 93$ & $1: 16$ & 5.03 & 3.68 & 35 & 17.16 & 291 & .396 & 366 & .698 & 0 & 14739 & 12660 & 5820 & 1218442 & 0 & 0 & 0 & 0 \\
\hline GR-LNB 24 & $6 / 10 / 93$ & $2: 57$ & 4.54 & 3.55 & 11 & 15.69 & 229 & .306 & 309 & .577 & 4417 & 36757 & 34841 & 10001 & 1165749 & 0 & 0 & 0 & 0 \\
\hline LNB & $6 / 10 / 93$ & $0: 37$ & 4.08 & 3.07 & 10 & 16.63 & 370 & .504 & 380 & .724 & 0 & 0 & 0 & 3177 & 1230000 & 0 & 0 & 0 & 0 \\
\hline GR-LNB 25a & $6 / 11 / 93$ & $5: 28$ & 3.91 & 3.11 & 18 & 15.59 & 192 & .258 & 337 & .632 & 3635 & 32240 & 30812 & 9997 & 1044157 & 0 & 0 & 0 & 0 \\
\hline GR-LNB 25b & $6 / 11 / 93$ & $9: 06$ & 3.79 & 2.98 & 15 & 15.56 & 207 & .278 & 342 & .641 & 4101 & 35111 & 33049 & 10003 & 1166323 & 0 & 0 & 0 & 0 \\
\hline GR-LNB 26a & $6 / 12 / 93$ & $11: 22$ & 3.42 & 2.68 & 44 & 15.69 & 179 & .240 & 335 & .628 & 3718 & 33199 & 31983 & 9995 & 1068493 & 0 & 0 & 0 & 0 \\
\hline GR-LNB 26b & $6 / 12 / 93$ & $2: 13$ & 5.19 & 4.32 & 31 & 15.69 & 256 & .344 & 349 & .659 & 1437 & 20377 & 21102 & 7909 & 717418 & 0 & 0 & 0 & 0 \\
\hline LNB-OFA & $6 / 12 / 93$ & $7: 11$ & 3.61 & 2.26 & 764 & 16.49 & 269 & .367 & 396 & .756 & 0 & 13517 & 10477 & 6584 & 1117982 & 0 & 0 & 0 & 0 \\
\hline LNB-OFA & $6 / 13 / 93$ & $9: 43$ & 5.87 & 4.07 & 136 & 16.44 & 396 & .540 & 385 & .734 & 0 & 3874 & 7030 & 5970 & 665303 & 0 & 0 & 0 & 0 \\
\hline GR-LNB 28 & $6 / 14 / 93$ & $4: 06$ & 3.26 & 2.69 & 28 & 16.02 & 188 & .252 & 327 & .611 & 4365 & 36577 & 34514 & 10000 & 1192146 & 0 & 0 & 0 & 0 \\
\hline LNB & $6 / 14 / 93$ & $1: 59$ & 3.95 & 2.48 & 364 & 16.87 & 268 & .365 & 385 & .735 & 0 & 0 & 0 & 3153 & 1066859 & 0 & 0 & 0 & 0 \\
\hline LNB & $6 / 18 / 93$ & $0: 38$ & 3.41 & 2.92 & 27 & 16.85 & 310 & .422 & 361 & .689 & 0 & 0 & 0 & 4902 & 1067799 & 0 & 0 & 0 & 0 \\
\hline GR-LNB 29 & $6 / 18 / 93$ & $14: 24$ & 3.76 & 3.16 & 8 & 15.77 & 197 & .263 & 322 & .601 & 4340 & 34953 & 34502 & 9998 & 1127750 & 0 & 0 & 0 & 0 \\
\hline GR-LNB 30a & $6 / 19 / 93$ & $0: 30$ & 5.24 & 4.03 & 4 & 15.44 & 244 & .324 & 320 & .598 & 3384 & 29882 & 30161 & 10001 & 815086 & 0 & 0 & 0 & 0 \\
\hline LNB & $6 / 19 / 93$ & $9: 15$ & 5.08 & 4.06 & 247 & 16.56 & 410 & .559 & 387 & .737 & 0 & 0 & 0 & 2536 & 690957 & 0 & 0 & 0 & 0 \\
\hline GA-LNB 30b & $6 / 19 / 93$ & $11: 53$ & 3.01 & 2.34 & 59 & 15.85 & 162 & .217 & 325 & .608 & 4587 & 36895 & 35211 & 10002 & 1137486 & 0 & 0 & 0 & 0 \\
\hline GR-LNB $30 \mathrm{C}$ & $6 / 19 / 93$ & $1: 33$ & 4.56 & 3.33 & 6 & 15.67 & 203 & .270 & 318 & .595 & 2921 & 29301 & 28696 & 9837 & 775014 & 0 & 0 & 0 & 0 \\
\hline GR-LNB 23 & $6 / 23 / 93$ & $7: 35$ & 2.99 & 1.91 & 35 & 15.75 & 165 & .221 & 317 & .593 & 4697 & 37616 & 35636 & 9998 & 1187149 & 0 & 0 & 0 & 0 \\
\hline GR-LNB 32b & $6 / 23 / 93$ & $1: 09$ & 3.65 & 2.39 & 18 & 15.84 & 173 & .231 & 292 & .546 & 3872 & 33770 & 32415 & 10011 & 1012043 & 0 & 0 & 0 & 0 \\
\hline LNB-OFA cooling & $6 / 24 / 93$ & $6: 25$ & 4.65 & 3.80 & 164 & 16.87 & 337 & .459 & 381 & .726 & 0 & 3779 & 7686 & 4923 & 687386 & 0 & 0 & 0 & 0 \\
\hline GR-LNB 33a & $6 / 24 / 93$ & $6: 00$ & 3.61 & 2.96 & 6 & 15.82 & 188 & .251 & 346 & .649 & 3638 & 32322 & 31113 & 10006 & 968909 & 0 & 0 & 0 & 0 \\
\hline GR-LNB 33 & $6 / 24 / 93$ & $11: 22$ & 2.98 & 2.39 & 12 & 15.78 & 176 & .235 & 335 & .626 & 4612 & 36864 & 35541 & 10002 & 1165609 & 0 & 0 & 0 & 0 \\
\hline GR-LNB 34a & $6 / 25 / 93$ & $1: 52$ & 5.57 & 4.30 & 3 & 15.68 & 330 & .443 & 348 & .653 & 2150 & 24838 & 25094 & 9048 & 674211 & 0 & 0 & 0 & 0 \\
\hline LNB-OFA & $6 / 25 / 93$ & $4: 03$ & 5.74 & 4.57 & 42 & 16.57 & 358 & .487 & 391 & .746 & 0 & 11767 & 14803 & 6053 & 685403 & 0 & 0 & 0 & 0 \\
\hline GR-LNB 34 & $6 / 25 / 93$ & $8: 00$ & 3.23 & 2.67 & 17 & 15.94 & 178 & .238 & 353 & .661 & 4192 & 34905 & 34235 & 9997 & 1119480 & 0 & 0 & 0 & 0 \\
\hline LNB (some OFA) & $6 / 28 / 93$ & $1: 03$ & 3.44 & 2.52 & 73 & 16.87 & 321 & .437 & 366 & .697 & 0 & 558 & 0 & 327 & 1214844 & 0 & 0 & 0 & 0 \\
\hline LNB (some OFA) & $6 / 29 / 93$ & $12: 15$ & 3.41 & 2.66 & 429 & 16.81 & 285 & .389 & 385 & .733 & 0 & 7879 & 0 & 1872 & 1036440 & 0 & 0 & 0 & 0 \\
\hline LNB & $6 / 30 / 93$ & $11: 51$ & 3.86 & 3.14 & 428 & 16.99 & 278 & .378 & 386 & .736 & 0 & 0 & 0 & 1295 & 945475 & 0 & 0 & 0 & 0 \\
\hline GR.LNB 35 & $6 / 30 / 93$ & $1: 48$ & 3.71 & 2.74 & 46 & 15.71 & 191 & .256 & 325 & .608 & 4311 & 36183 & 34437 & 9992 & 1202018 & 0 & 0 & 0 & 0 \\
\hline GR-LNB 35a & $6 / 30 / 93$ & 6.05 & 4.48 & 3.31 & 5 & 15.59 & 226 & .303 & 318 & .596 & 4250 & 36009 & 34027 & 9998 & 1187541 & 0 & 0 & 0 & 0 \\
\hline GR-LNB 35b & $6 / 30 / 93$ & $1: 53$ & 5.18 & 3.82 & 4 & 15.49 & 231 & .309 & 304 & .570 & 3802 & 33177 & 31397 & 10017 & 1053950 & 0 & 0 & 0 & 0 \\
\hline GR-OLNB 36a & $7 / 1 / 93$ & $8: 22$ & 6.32 & 4.99 & 19 & 15.42 & 276 & .371 & 320 & .602 & 2070 & 24474 & 24227 & 8739 & 734912 & 0 & 0 & 0 & 0 \\
\hline GR-LNB 36 & $7 / 1 / 93$ & $15: 37$ & 3.62 & 2.55 & 80 & 15.68 & 176 & .236 & 324 & .607 & 3933 & 34216 & 32307 & 9999 & 1138706 & 0 & 0 & 0 & 0 \\
\hline GR 37a & $7 / 2 / 93$ & $14: 55$ & 4.39 & 2.88 & 444 & 15.56 & 179 & .240 & 323 & .607 & 3058 & 29847 & 28438 & 9714 & 926914 & 0 & 0 & 0 & 0 \\
\hline GR 37 & $7 / 2 / 93$ & $7: 05$ & 3.71 & 2.66 & 45 & 15.68 & 188 & .251 & 331 & .619 & 4255 & 36003 & 33902 & 10002 & 1210316 & 0 & 0 & 0 & 0 \\
\hline GR-LNB 38 & $7 / 3 / 93$ & $7: 46$ & 3.63 & 2.59 & 90 & 15.54 & 173 & .232 & 325 & .608 & 4032 & 34453 & 32853 & 10001 & 1177277 & 0 & 0 & 0 & 0 \\
\hline GR-LNB 38a & $7 / 3 / 93$ & $8: 43$ & 3.47 & 2.62 & 43 & 15.29 & 159 & .238 & 304 & .570 & 3953 & 33798 & 32878 & 9996 & 1143061 & 0 & 0 & 0 & 0 \\
\hline GR-LNB 39a & $7 / 4 / 93$ & $17: 27$ & 4.23 & 3.35 & 21 & 15.14 & 155 & .249 & 328 & .617 & 2523 & 26426 & 26360 & 9236 & 872129 & 0 & 0 & 0 & 0 \\
\hline GR-LNB 39 & $7 / 4 / 93$ & $6: 33$ & 3.16 & 2.33 & 11 & 15.29 & 152 & .242 & 323 & .607 & 3887 & 32822 & 32136 & 9998 & 1173866 & 0 & 0 & 0 & 0 \\
\hline GR-LNB 40a & $7 / 5 / 93$ & $11: 52$ & 4.84 & 3.94 & 7 & 15.07 & 165 & .279 & 332 & .626 & 1926 & 23418 & 23603 & 8514 & 768092 & 0 & 0 & 0 & 0 \\
\hline
\end{tabular}


Cherokee Unit 3, Average Test Data

Pre Moditication

\begin{tabular}{|c|c|c|c|c|c|c|c|c|c|c|c|c|c|c|c|c|c|c|c|}
\hline Test & 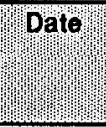 & pwp & $\begin{array}{l}\text { CEMS } \\
\text { O2, } \\
\text { \% DY }\end{array}$ & Prant" & poca & $\mathrm{CO}^{2} \mathrm{c}$ & Noxce & $\begin{array}{l}\text { NOx } \\
\text { Ib/mbtu }\end{array}$ & po2c & 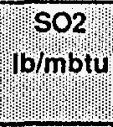 & पृeb & 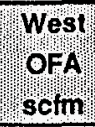 & $\begin{array}{l}\text { East } \\
\text { OF } \\
\text { scfm }\end{array}$ & 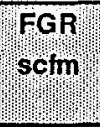 & Steam & Mill & Mill: & Mill! & Mill \\
\hline GR-LNB 40 & $7 / 5 / 93$ & $12: 08$ & 3.48 & 2.63 & 6 & 15.11 & 142 & .238 & 329 & .617 & 3628 & 31924 & 30822 & 9996 & 1118801 & 0 & 0 & 0 & 0 \\
\hline GR-LNB 52a & $7 / 17 / 93$ & $8: 31$ & 5.27 & 3.62 & 0 & 15.38 & 198 & .266 & 311 & .583 & 2936 & 28931 & 30044 & 9587 & 815654 & 0 & 0 & 0 & 0 \\
\hline GR-LNB 52 & $7 / 17 / 93$ & $5: 45$ & 3.99 & 2.89 & 0 & 15.82 & 188 & .251 & 320 & .599 & 4181 & 33584 & 34666 & 10003 & 1146028 & 0 & 0 & 0 & 0 \\
\hline LNB & $7 / 19 / 93$ & $1: 53$ & 3.64 & 2.79 & & 16.57 & 211 & .287 & 378 & .721 & 0 & 0 & 0 & 166 & 918704 & 0 & 0 & 0 & 0 \\
\hline LNB-OFA & $7 / 19 / 93$ & $0: 22$ & 3.76 & 3.27 & & 16.45 & 205 & .281 & 384 & .732 & 0 & 10140 & 9012 & 564 & 970186 & 0 & 0 & 0 & 0 \\
\hline GR-LNB 53a & $7 / 19 / 93$ & $3: 29$ & 3.79 & 3.23 & & 15.66 & 176 & .236 & 316 & .592 & 3396 & 29845 & 31116 & 9886 & 955417 & 0 & 0 & 0 & 0 \\
\hline GR-LNB 53 & $7 / 19 / 93$ & $7: 06$ & 3.72 & 2.85 & & 15.66 & 196 & .263 & 312 & .585 & 4301 & 34294 & 35259 & 9997 & 1189204 & 0 & 0 & 0 & 0 \\
\hline LNB & $7 / 21 / 93$ & $8: 34$ & 4.63 & 4.17 & 0 & 16.27 & 351 & .478 & 348 & .664 & 0 & 0 & 0 & 0 & 658291 & 0 & 0 & 0 & 0 \\
\hline GA-LNB 54 & $7 / 21 / 93$ & $4: 52$ & 3.69 & 3.00 & 0 & 15.82 & 194 & .260 & 308 & .576 & 4192 & 33366 & 34909 & 10004 & 1144957 & 0 & 0 & 0 & 0 \\
\hline LNB & $7 / 23 / 93$ & $2: 35$ & 4.41 & 3.73 & 53 & 16.66 & 299 & .407 & 358 & .682 & 0 & 0 & 0 & 13 & 763630 & 0 & 0 & 0 & 0 \\
\hline GR-LNB 55 & $7 / 23 / 93$ & $4: 53$ & 4.37 & 3.24 & 7 & 15.58 & 210 & .281 & 336 & .630 & 4136 & 33640 & 34384 & 9994 & 1151463 & 0 & 0 & 0 & 0 \\
\hline GR-LNB 55a & $7 / 23 / 93$ & $1: 08$ & 4.64 & 3.58 & 10 & 15.53 & 193 & .259 & 338 & .633 & 3649 & 31303 & 32213 & 10012 & 1027666 & 0 & 0 & 0 & 0 \\
\hline LNB & $7 / 23 / 93$ & $3: 55$ & 4.47 & 3.61 & 583 & 16.38 & 232 & .317 & 377 & .719 & 0.00 & 1668 & 0 & 0 & 650024 & 0 & 0 & 0 & 0 \\
\hline LNB & $7 / 24 / 93$ & $1: 52$ & 5.44 & 3.47 & 454 & 15.97 & 231 & .316 & 309 & .588 & 0 & 0 & 0 & 0 & 675137 & 0 & 0 & 0 & 0 \\
\hline LNB-OFA & $7 / 24 / 93$ & $0: 36$ & 6.78 & 4.74 & 121 & 15.85 & 253 & .345 & 354 & .675 & 0 & 14115 & 13297 & 446 & 746830 & 0 & 0 & 0 & 0 \\
\hline GR-LNB 56 & $7 / 24 / 93$ & $7: 45$ & 4.20 & 3.12 & 12 & 15.57 & 190 & .254 & 321 & .600 & 4118 & 33628 & 34167 & 10008 & 1142849 & 0 & 0 & 0 & 0 \\
\hline GR-LNB 56a & $7 / 24 / 93$ & $2: 09$ & 5.65 & 4.17 & 7 & 15.39 & 269 & .360 & 312 & .585 & 2664 & 27341 & 27876 & 8334 & 767608 & 0 & 0 & 0 & 0 \\
\hline GR-LNB 57a & $7 / 25 / 93$ & $1: 10$ & 6.85 & 5.06 & 5 & 15.02 & 364 & .489 & 303 & .569 & 2193 & 24105 & 25090 & 7051 & 625994 & 0 & 0 & 0 & 0 \\
\hline LNB-OFA & $7 / 25 / 93$ & $5: 52$ & 6.41 & 5.37 & 11 & 16.24 & 267 & .364 & 363 & .693 & 0 & 26373 & 27358 & 8162 & 715693 & 0 & 0 & 0 & 0 \\
\hline GR-LNB 57b & $7 / 25 / 93$ & $10: 19$ & 5.03 & 3.64 & 9 & 15.62 & 210 & .281 & 319 & .598 & 3579 & 31520 & 32176 & 9704 & 994774 & 0 & 0 & 0 & 0 \\
\hline GR-LNB 57 & $7 / 25 / 93$ & $6: 14$ & 3.73 & 2.70 & 11 & 15.81 & 181 & .242 & 319 & .597 & 4239 & 35128 & 34744 & 10003 & 1198755 & 0 & 0 & 0 & 0 \\
\hline GR-LNB 58a & $7 / 26 / 93$ & $10: 15$ & 6.08 & 4.14 & 8 & 15.29 & 237 & .317 & 312 & .584 & 3067 & 29204 & 30414 & 9444 & 873265 & 0 & 0 & 0 & 0 \\
\hline GR-LNB 58 & $7 / 26 / 93$ & $8: 34$ & 3.89 & 2.54 & 6 & 15.74 & 193 & .259 & 304 & .570 & 4169 & 34676 & 34556 & 10000 & 1206515 & 0 & 0 & 0 & 0 \\
\hline GR-LNB 58b & $7 / 26 / 93$ & $5: 09$ & 4.83 & 3.09 & 6 & 15.65 & 201 & .269 & 288 & .539 & 3592 & 31628 & 31619 & 9983 & 1062357 & 0 & 0 & 0 & 0 \\
\hline GR-LNB 59a & $7 / 27 / 93$ & $10: 48$ & 5.72 & 4.01 & 5 & 15.55 & 245 & .327 & 294 & .552 & 2992 & 29052 & 29511 & 8908 & 879577 & 0 & 0 & 0 & 0 \\
\hline LNG-OFA & $7 / 27 / 93$ & $3: 21$ & 3.25 & 2.39 & 482 & 17.07 & 301 & .410 & 382 & .729 & 0 & 5383 & 196 & 1459 & 1271436 & 0 & 0 & 0 & 0 \\
\hline GR-LNB 59 & $7 / 27 / 93$ & $9: 16$ & 3.98 & 3.00 & 10 & 15.84 & 190 & .255 & 314 & .589 & 3766 & 32201 & 31721 & 10010 & 1089309 & 0 & 0 & 0 & 0 \\
\hline GR-LNB 60a & $7 / 28 / 93$ & $11: 06$ & 4.33 & 3.32 & 7 & 15.88 & 191 & .256 & 317 & .595 & 3414 & 29808 & 30879 & .9957 & 994650 & 0 & 0 & 0 & 0 \\
\hline GA-LNB 60b & $7 / 28 / 93$ & $2: 02$ & 3.57 & 2.50 & 13 & 15.82 & 195 & .261 & 309 & .579 & 4467 & 36181 & 35864 & 10007 & 1268293 & 0 & 0 & 0 & 0 \\
\hline LNB-OFA & $7 / 28 / 93$ & $2: 21$ & 3.29 & 2.24 & 386 & 16.72 & 332 & .452 & 377 & .720 & 0 & 8128 & 41 & 3904 & 1284085 & 0 & 0 & 0 & 0 \\
\hline GR-LNB 60 & $7 / 28 / 93$ & $8: 10$ & 3.19 & 2.50 & 37 & 15.82 & 191 & .256 & 305 & .571 & 4342 & 35842 & 35083 & 10002 & 1270102 & 0 & 0 & 0 & 0 \\
\hline GR-LNB 61a & $7 / 29 / 93$ & $15: 55$ & 3.58 & 2.82 & 26 & 15.80 & 192 & .257 & 314 & .588 & 4069 & 33739 & 33869 & 9994 & 1180275 & 0 & 0 & 0 & 0 \\
\hline GR-LNB 61 & $7 / 29 / 93$ & $8: 04$ & 3.28 & 2.38 & 81 & 15.75 & 180 & .241 & 315 & .590 & 4198 & 35071 & 34330 & 9997 & 1182536 & 0 & 0 & 0 & 0 \\
\hline GR-LNB 62 & $7 / 30 / 93$ & $10: 04$ & 3.47 & 2.54 & 168 & 15.80 & 169 & .227 & 316 & .592 & 3928 & 32711 & 33077 & 9999 & 1132029 & 0 & 0 & 0 & 0 \\
\hline LNB-OFA & $7 / 30 / 93$ & $4: 32$ & 4.07 & 3.01 & 342 & 16.75 & 319 & .435 & 381 & .727 & 0 & 11829 & 5626 & 3879 & 1236007 & 0 & 0 & 0 & 0 \\
\hline GR-LNB 62a & $7 / 30 / 93$ & $9: 00$ & 4.19 & 3.05 & 43 & 15.84 & 203 & .271 & 308 & .577 & 4132 & 33977 & 34618 & 9997 & 1190684 & 0 & 0 & 0 & 0 \\
\hline GR-LNB 63a & $7 / 31 / 93$ & $17: 10$ & 3.53 & 2.54 & 38 & 15.93 & 178 & .238 & 319 & .598 & 4078 & 33569 & 34189 & 10005 & 1179568 & 0 & 0 & 0 & 0 \\
\hline GR-LNB 63b & $7 / 31 / 93$ & $6: 49$ & 3.25 & 2.23 & 67 & 15.93 & 172 & .230 & 320 & .601 & 3898 & 32584 & 32554 & 10000 & 1195410 & 0 & 0 & 0 & 0 \\
\hline GR-LNB 64a & $8 / 1 / 93$ & $1: 25$ & 3.81 & 2.62 & 30 & 15.83 & 169 & .226 & 315 & .591 & 3541 & 30740 & 31067 & 9989 & 1052532 & 0 & 0 & 0 & 0 \\
\hline GR-LNB 64b & $8 / 1 / 93$ & $10: 21$ & 5.20 & 4.02 & 6 & 15.70 & 229 & .308 & 306 & .574 & 2771 & 27501 & 29408 & 9017 & 823827 & 0 & 0 & 0 & 0 \\
\hline
\end{tabular}


Pre Modification

\begin{tabular}{|c|c|c|c|c|c|c|c|c|c|c|c|c|c|c|c|c|c|c|c|}
\hline Test & Date" & purm & $\begin{array}{l}\text { CEMS } \\
\text { O2 } \\
\text { \% bry }\end{array}$ & $\begin{array}{l}\text { Plant } \\
\text { o2 Wet } \\
\text { 9 We }\end{array}$ & ponm & cosc & Noxc & $\begin{array}{l}\text { nox } \\
\text { lb/mbtu } \\
\end{array}$ & po2c & Ib/mbtu & $\begin{array}{l}\text { Reb } \\
\text { Gas } \\
\text { scrim }\end{array}$ & West & $\begin{array}{l}\text { East } \\
\text { of A A } \\
\text { scfm }\end{array}$ & FGR & steam! & Mill! & ${ }^{\mathrm{Mill}}$ & Mill & Mill \\
\hline GR-LNB 640 & $8 / 1 / 93$ & $12: 14$ & 3.64 & 2.61 & 24 & 15.88 & 180 & .241 & 302 & .566 & 3938 & 32749 & 34103 & 10001 & 1156441 & 0 & 0 & 0 & 0 \\
\hline GR-LNB 65a & $8 / 2 / 93$ & $8: 55$ & 5.73 & 4.17 & 5 & 15.32 & 234 & .314 & 287 & .538 & 2601 & 26353 & 28721 & 8422 & 790952 & 0 & 0 & 0 & 0 \\
\hline LNB-OFA & $8 / 2 / 93$ & $1: 23$ & 3.98 & 2.25 & 425 & 16.84 & 289 & .395 & 362 & .691 & 0 & 1680 & 4992 & 2352 & 1234365 & 0 & 0 & 0 & 0 \\
\hline GR-LNB 65b & $8 / 2 / 93$ & $6: 02$ & 3.47 & 2.26 & 14 & 15.73 & 167 & .224 & 295 & .552 & 4058 & 32292 & 34857 & 10002 & 1173016 & 0 & 0 & 0 & 0 \\
\hline GR.LNB 65c & $8 / 2 / 93$ & $7: 14$ & 3.66 & 2.49 & 9 & 15.01 & 173 & .232 & & & 3977 & 32303 & 34498 & 9965 & 1126852 & 0 & 0 & 0 & 0 \\
\hline GR-LNB 66a & $8 / 3 / 93$ & $8: 29$ & 6.17 & 4.48 & 4 & 15.11 & 255 & .342 & & & 2520 & 26065 & 29515 & 8775 & 721769 & 0 & 0 & 0 & 0 \\
\hline GR-LNB 66b & $8 / 3 / 93$ & $9: 34$ & 4.39 & 3.10 & 4 & 15.87 & 193 & .258 & & & 3984 & 30990 & 34863 & 9994 & 1119411 & 0 & 0 & 0 & 0 \\
\hline GR-LNB 66c & $8 / 3 / 93$ & $5: 55$ & 3.68 & 2.50 & 6 & 15.92 & 181 & .243 & & & 4107 & 31654 & 35389 & 9998 & 1172640 & 0 & 0 & 0 & 0 \\
\hline GR-LNB 67 & $8 / 4 / 93$ & 24.00 & 4.23 & 2.75 & 8 & 15.80 & 188 & .252 & & & 3628 & 29591 & 33640 & 9964 & 1078102 & 0 & 0 & 0 & 0 \\
\hline GR.LNB 68a & $8 / 5 / 93$ & $7: 39$ & 4.76 & 3.38 & 7 & 15.73 & 178 & .239 & & & 2975 & 27352 & 31903 & 9999 & 907097 & 0 & 0 & 0 & 0 \\
\hline GR-LNB 68b & $8 / 5 / 93$ & $15: 50$ & 4.05 & 2.45 & 8 & 15.82 & 204 & .274 & & & 3997 & 29936 & 34829 & 9999 & 1193868 & 0 & 0 & 0 & 0 \\
\hline GR-LNB 69 & $8 / 6 / 93$ & $9: 48$ & 3.74 & 2.86 & 7 & 15.75 & 189 & .253 & & & 3575 & 27908 & 33577 & 9982 & 1084174 & 0 & 0 & 0 & 0 \\
\hline LNB & $8 / 6 / 93$ & $7: 58$ & 3.55 & 2.27 & 321 & 16.54 & 317 & .432 & & & 0 & 0 & 0 & 0 & 1211591 & 0 & 0 & 0 & 0 \\
\hline LNB-OFA & $8 / 6 / 93$ & $5: 04$ & 3.70 & 2.29 & 199 & 16.49 & 331 & .451 & & & 0 & 3977 & 0 & 0 & 1250695 & 0 & 0 & 0 & 0 \\
\hline LNB & $8 / 7 / 93$ & $3: 04$ & 3.12 & 1.68 & 805 & 16.54 & 288 & .392 & & & 0 & 2 & 0 & 63 & 1186157 & 0 & 0 & 0 & 0 \\
\hline GR-LNB 70 & $8 / 7 / 93$ & 3.53 & 3.61 & 2.41 & 875 & 15.98 & 184 & .249 & & & 1815 & 16491 & 20425 & 7457 & 1086542 & 0 & 0 & 0 & 0 \\
\hline LNB-OFA & $8 / 7 / 93$ & $8: 05$ & 3.86 & 2.37 & 362 & 16.38 & 305 & .415 & & & 0 & 2653 & 1581 & 14 & 1213040 & 0 & 0 & 0 & 0 \\
\hline LNB & $8 / 7 / 93$ & $6: 28$ & 3.71 & 2.38 & 217 & 16.46 & 323 & .440 & & & 0 & 0 & 0 & 0 & 1234851 & 0 & 0 & 0 & 0 \\
\hline LNB & $8 / 9 / 93$ & $8: 04$ & 4.16 & 2.85 & 248 & 16.71 & 288 & .393 & & & 0 & 0 & 0 & 0 & 1139708 & 0 & 0 & 0 & 0 \\
\hline GR-LNB 71 (10\% Gas) & $8 / 9 / 93$ & $13: 45$ & 3.91 & 2.81 & 15 & 16.20 & 199 & .268 & & & 2762 & 27917 & 29863 & 9999 & 1226985 & 0 & 0 & 0 & 0 \\
\hline GR-LNB $72 a(10 \%)$ & $8 / 10 / 93$ & $7: 48$ & 3.96 & 2.70 & 48 & 16.23 & 195 & .263 & & & 2446 & 25681 & 29001 & 9992 & 1185288 & 0 & 0 & 0 & 0 \\
\hline LNB & $8 / 10 / 93$ & $7: 27$ & 4.31 & 2.60 & 27 & 16.74 & 330 & .450 & & & 0 & 1 & 0 & 0 & 1216526 & 0 & 0 & 0 & 0 \\
\hline GR-LNB $72 b(10 \%)$ & $8 / 10 / 93$ & $7: 25$ & 4.29 & 3.07 & 14 & 16.22 & 204 & .275 & & & 2455 & 25926 & 29000 & 10002 & 1167690 & 0 & 0 & 0 & 0 \\
\hline GR-LNB 73 & $8 / 11 / 93$ & 3.22 & 4.65 & 3.64 & 9 & 16.00 & 217 & .294 & & & 2380 & 24891 & 28634 & 9995 & 1120389 & 0 & 0 & 0 & 0 \\
\hline LNB-OFA & $8 / 11 / 93$ & $9: 49$ & 3.90 & 2.35 & 172 & 16.74 & 282 & .384 & & & 0 & 5042 & 0 & 0 & 1271288 & 0 & 0 & 0 & 0 \\
\hline LNB & $8 / 11 / 93$ & $2: 45$ & 4.37 & 2.96 & 11 & 16.68 & 304 & .414 & & & 0 & 0 & 0 & 0 & 1205723 & 0 & 0 & 0 & 0 \\
\hline LNB & $8 / 12 / 93$ & $7: 36$ & 4.45 & 3.34 & 105 & 16.69 & 248 & .338 & & & 0 & 0 & 0 & 0 & 893989 & 0 & 0 & 0 & 0 \\
\hline GR-LNB 74 & $8 / 1293$ & $14: 33$ & 4.07 & 2.80 & 9 & 16.22 & 194 & .262 & & & 2552 & 26538 & 30326 & 9997 & 1203784 & 0 & 0 & 0 & 0 \\
\hline GR-LNB 75 & $8 / 13 / 93$ & $18: 16$ & 4.26 & 2.83 & 11 & 15.99 & 205 & .276 & & & 2584 & 26141 & 30856 & 9996 & 1182245 & 0 & 0 & 0 & 0 \\
\hline GR-LNB 76a & $8 / 14 / 93$ & $4: 54$ & 4.85 & 3.18 & 46 & 15.83 & 188 & .254 & & & 1899 & 20598 & 25294 & 9999 & 925040 & 0 & 0 & 0 & 0 \\
\hline LNB & $8 / 14 / 93$ & $1: 46$ & 7.18 & 4.91 & 106 & 15.74 & 326 & .445 & & & 0 & 0 & 0 & 0 & 679285 & 0 & 0 & 0 & 0 \\
\hline GR-LNB 76b & $8 / 14 / 93$ & $11: 05$ & 4.75 & 3.01 & 10 & 15.91 & 199 & .268 & & & 2513 & 25381 & 30722 & 9996 & 1158368 & 0 & 0 & 0 & 0 \\
\hline GR-LNB 77 & $8 / 15 / 93$ & $1: 10$ & 5.35 & 3.36 & 24 & 15.79 & 199 & .271 & & & 1798 & 19760 & 25005 & 9696 & 887753 & 0 & 0 & 0 & 0 \\
\hline LNB & $8 / 15 / 93$ & $14: 44$ & 4.80 & 3.03 & 575 & 16.38 & 271 & .370 & & & 0 & 1258 & 786 & 129 & 913531 & 0 & 0 & 0 & 0 \\
\hline LNB & $8 / 15 / 93$ & $6: 58$ & 3.73 & 1.84 & 223 & 16.63 & 290 & .396 & & & 0 & 1987 & 0 & 0 & 1239884 & 0 & 0 & 0 & 0 \\
\hline LNB (low load) & $8 / 16 / 93$ & $7: 38$ & 4.90 & 3.07 & 786 & 16.38 & 236 & .322 & & & 0 & 0 & 0 & 0 & 812318 & 0 & 0 & 0 & 0 \\
\hline LNB (150 MWe) & $8 / 16 / 93$ & $3: 21$ & 4.28 & 2.85 & 34 & 16.70 & 348 & .474 & & & 0 & 0 & 0 & 31 & 1263073 & 0 & 0 & 0 & 0 \\
\hline LNB-OFA cooling & $8 / 16 / 93$ & $11: 40$ & 3.88 & 2.14 & 70 & 16.57 & 340 & .464 & & & 0 & 6499 & 0 & 172 & 1291641 & 0 & 0 & 0 & 0 \\
\hline LNB & $8 / 17 / 93$ & $9: 07$ & 4.14 & 2.46 & 384 & 16.58 & 279 & .381 & & & 0 & 0 & 0 & 0 & 949955 & 0 & 0 & 0 & 0 \\
\hline $100 \%$ Gas (plant tost) & $8 / 17 / 93$ & $0: 34$ & 2.85 & 1.89 & 971 & 10.16 & 76 & .104 & & & 0 & 0 & 0 & 0 & 566196 & 0 & 0 & 0 & 0 \\
\hline
\end{tabular}


Pre Modification

\begin{tabular}{|c|c|c|c|c|c|c|c|c|c|c|c|c|c|c|c|c|c|c|c|}
\hline $\begin{array}{l}\text { Test } \\
\text { Nop } \\
\end{array}$ & Date? & Dow & 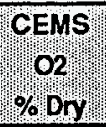 & 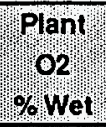 & cort & cosç & Noxc & 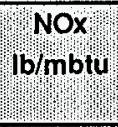 & so2c & 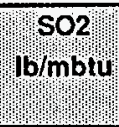 & 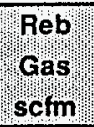 & West' & 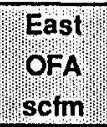 & FGR! & Steam & Mill & Miil! & Mill & Mill \\
\hline LNB (OFA cooling) & $8 / 17 / 93$ & $8: 59$ & 3.60 & 2.27 & 314 & 16.70 & 313 & .427 & & & 0 & 6435 & 0 & 0 & 0 & 0 & 0 & 0 & 0 \\
\hline LNB & $8 / 17 / 93$ & $3: 05$ & 3.43 & 2.08 & 269 & 16.80 & 296 & .403 & & & 0 & 0 & 0 & 0 & 0 & 0 & 0 & 0 & 0 \\
\hline LNB (low load) & $8 / 18 / 93$ & $9: 42$ & 3.87 & 2.47 & 775 & 16.62 & 234 & .320 & & & 0 & 0 & 0 & 0 & 0 & 0 & 0 & 0 & 0 \\
\hline LNB $150 \mathrm{MW}$ & $8 / 18 / 93$ & $14: 16$ & 4.04 & 2.53 & 25 & 16.77 & 336 & .459 & & & 0 & 2 & 0 & 0 & 0 & 0 & 0 & 0 & 0 \\
\hline GR-LNB 78 & $8 / 24 / 93$ & $3: 25$ & 3.47 & 2.41 & 141 & 16.05 & 174 & .234 & & & 2712 & 26959 & 31890 & 10010 & 1129806 & 0 & 0 & 0 & 0 \\
\hline LNB OFA cooling & $8 / 24 / 93$ & $10: 38$ & 4.12 & 2.35 & 227 & 16.68 & 320 & .436 & & & 0 & 8003 & 0 & 5 & 1156672 & 0 & 0 & 0 & 0 \\
\hline LNB OFA cooling & $8 / 25 / 93$ & $2: 06$ & 4.00 & 2.75 & 528 & 16.56 & 250 & .341 & & & 0 & 4689 & 0 & 0 & 881699 & 0 & 0 & 0 & 0 \\
\hline LNB & $8 / 25 / 93$ & $8: 38$ & 4.16 & 2.65 & 738 & 16.73 & 248 & .338 & & & 0 & 0 & 0 & 0 & 848417 & 0 & 0 & 0 & 0 \\
\hline LNB & $8 / 25 / 93$ & 13.08 & 4.54 & 2.99 & 14 & 17.11 & 351 & .479 & & & 0 & 0 & 0 & 0 & 1151539 & 0 & 0 & 0 & 0 \\
\hline LNB & $8 / 26 / 93$ & $21: 16$ & 5.44 & 3.65 & 222 & 18.16 & 301 & .411 & & & 0 & 0 & 0 & 10 & 879914 & 0 & 0 & 0 & 0 \\
\hline LNB & $8 / 26 / 93$ & $2: 42$ & 4.39 & 3.03 & 26 & 16.95 & 339 & .462 & & & 0 & 0 & 0 & 0 & 1209141 & 0 & 0 & 0 & 0 \\
\hline LNB & $8 / 27 / 93$ & $8: 26$ & 5.27 & 3.98 & 38 & 17.94 & 345 & .469 & & & 0 & 0 & 0 & 0 & 817252 & 0 & 0 & 0 & 0 \\
\hline LNB & $8 / 27 / 93$ & $6: 17$ & 4.36 & 2.90 & 18 & 16.92 & 322 & .440 & & & 0 & 0 & 0 & 0 & 1193794 & 0 & 0 & 0 & 0 \\
\hline GR-LNB 79 & $9 / 8 / 93$ & $11: 15$ & 3.94 & 2.89 & 52 & 16.50 & 183 & .246 & & & 3348 & 25986 & 31999 & 9996 & 1191746 & 0 & 0 & 0 & 0 \\
\hline GR-LNB 79a & $9 / 8 / 93$ & $1: 49$ & 4.82 & 3.54 & 72 & 17.42 & 176 & .236 & & & 2994 & 24836 & 31141 & 9992 & 969489 & 0 & 0 & 0 & 0 \\
\hline GR-LNB 80a & $9 / 9 / 93$ & $6: 55$ & 5.17 & 3.97 & 69 & 17.83 & 198 & .266 & & & 2757 & 24239 & 30756 & 9466 & 867451 & 0 & 0 & 0 & 0 \\
\hline LNB-OFA & $9 / 9 / 93$ & $1: 46$ & 6.52 & 4.50 & 93 & 19.50 & 300 & .409 & & & 0 & 692 & 10904 & 9370 & 699534 & 0 & 0 & 0 & 0 \\
\hline GR-LNB 80 & $9 / 9 / 93$ & $14: 15$ & 4.17 & 3.16 & 202 & 16.75 & 169 & .227 & & & 3350 & 26718 & 31944 & 9977 & 1085308 & 0 & 0 & 0 & 0 \\
\hline LNB-OFA & $9 / 10 / 93$ & $4: 50$ & 7.18 & 4.45 & 137 & 20.45 & 403 & .549 & & & 0 & 769 & 6815 & 3080 & 651164 & 0 & 0 & 0 & 0 \\
\hline GR-LNB 81 & $9 / 10 / 93$ & $1: 46$ & 4.99 & 3.68 & 15 & 17.61 & 180 & .240 & & & 2960 & 26769 & 31123 & 9760 & 852630 & 0 & 0 & 0 & 0 \\
\hline LNB & $9 / 10 / 93$ & $13: 30$ & 4.62 & 2.72 & 145 & 17.20 & 327 & .445 & & & 0 & 6 & 0 & 0 & 1170095 & 0 & 0 & 0 & 0 \\
\hline LNB & $9 / 11 / 93$ & $19: 30$ & 4.45 & 3.03 & 548 & 17.01 & 290 & .396 & & & 0 & 1072 & 0 & 0 & 1081220 & 0 & 0 & 0 & 0 \\
\hline GR-LNB 82 & $9 / 11 / 93$ & $4: 10$ & 4.88 & 2.96 & 25 & 17.48 & 201 & .270 & & & 3642 & 28192 & 32487 & 9998 & 1191334 & 0 & 0 & 0 & 0 \\
\hline GR-LNB 83a & $9 / 12 / 93$ & $11: 51$ & 5.39 & 3.46 & 15 & 18.07 & 190 & .256 & & & 3132 & 26150 & 31407 & 9960 & 1013296 & 0 & 0 & 0 & 0 \\
\hline GR-LNB 83 & $9 / 12 / 93$ & $12: 09$ & 4.04 & 2.22 & 52 & 16.59 & 183 & .246 & & & 3519 & 27123 & 32187 & 10002 & 1251152 & 0 & 0 & 0 & 0 \\
\hline GR-LNB 84a & $9 / 13 / 93$ & $5: 35$ & 5.67 & 3.68 & 13 & 18.42 & 190 & .255 & & & 2802 & 24327 & 30811 & 9626 & 916612 & 0 & 0 & 0 & 0 \\
\hline GR-LNB 84 & $9 / 13 / 93$ & $18: 03$ & 4.63 & 3.28 & 54 & 17.21 & 195 & .262 & & & 2706 & 21575 & 31415 & 10001 & 1155926 & 0 & 0 & 0 & 0 \\
\hline GR-LNB 85a & $9 / 14 / 93$ & $4: 15$ & 4.57 & 3.39 & 135 & 17.14 & 173 & .233 & & & 2702 & 22127 & 30843 & 9997 & 1019116 & 0 & 0 & 0 & 0 \\
\hline LNB & $9 / 14 / 93$ & $11: 05$ & 4.69 & 3.62 & 255 & 17.28 & 306 & .416 & & & 0 & 0 & 0 & 0 & 959581 & 0 & 0 & 0 & 0 \\
\hline LNB-OFA & $9 / 14 / 93$ & 1.06 & 4.59 & 3.64 & 337 & 17.15 & 297 & .405 & & & 0 & 1957 & 9647 & 75 & 1226119 & 0 & 0 & 0 & 0 \\
\hline GR-LN日 85 & $9 / 14 / 93$ & $6: 55$ & 3.19 & 2.69 & 28 & 15.80 & 171 & .230 & & & 3115 & 24319 & 32107 & 10002 & 1163822 & 0 & 0 & 0 & 0 \\
\hline GR-LNB 86a & $9 / 15 / 93$ & $0: 50$ & 3.92 & 3.23 & 15 & 16.48 & 167 & .224 & & & 2925 & 23514 & 31543 & 10008 & 1046613 & 0 & 0 & 0 & 0 \\
\hline LNB & $9 / 15 / 93$ & 3.07 & 4.72 & 3.16 & 329 & 17.32 & 278 & .379 & & & 0 & 0 & 0 & 35 & 810045 & 0 & 0 & 0 & 0 \\
\hline GR-LNB 96b & $9 / 15 / 93$ & $4: 26$ & 4.14 & 3.38 & 18 & 16.73 & 178 & .239 & & & 2808 & 23148 & 31322 & 9940 & 971915 & 0 & 0 & 0 & 0 \\
\hline GR-LNB 86 & $9 / 15 / 93$ & $11: 20$ & 3.33 & 2.72 & 12 & 15.93 & 182 & .245 & & & 3153 & 24447 & 32230 & 10003 & 1150475 & 0 & 0 & 0 & 0 \\
\hline GR-LNB 87a & $9 / 16 / 93$ & $5: 46$ & 4.32 & 3.58 & 7 & 16.92 & 194 & .260 & & & 2740 & 22996 & 31181 & 9379 & 963288 & 0 & 0 & 0 & 0 \\
\hline GR-LNB 87 & $9 / 16 / 93$ & $15: 24$ & 4.87 & 3.14 & 15 & 17.48 & 191 & .256 & & & 2889 & 22666 & 32109 & 10002 & 1087587 & 0 & 0 & 0 & 0 \\
\hline GR-LNB 88a & $9 / 17 / 93$ & $5: 31$ & 4.80 & 3.21 & 13 & 17.40 & 174 & .233 & & & 2920 & 23877 & 31699 & 9859 & 999394 & 0 & 0 & 0 & 0 \\
\hline GR-LNB 88 & $9 / 17 / 93$ & $18: 28$ & 3.83 & 2.73 & 23 & 16.40 & 179 & .241 & & & 3046 & 23613 & 32303 & 9997 & 1157526 & 0 & 0 & 0 & 0 \\
\hline GR-LNB B9 & $9 / 18 / 93$ & $24: 00$ & 3.61 & 2.86 & 63 & 16.19 & 173 & .232 & & & 2820 & 22544 & 31568 & 10003 & 1122638 & 0 & 0 & 0 & 0 \\
\hline
\end{tabular}


Cherokee Unit 3, Average Test Data

Pre Modification

\begin{tabular}{|c|c|c|c|c|c|c|c|c|c|c|c|c|c|c|c|c|c|c|c|}
\hline Test & "Date & Dyrm & 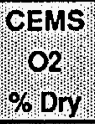 & "ront & ppm & $\int^{c o}{ }^{c}{ }^{\prime}$ & Noxc: & (b/mox & popm & Ib/mblu & $\begin{array}{l}\text { peb } \\
\text { Gas } \\
\text { setm }\end{array}$ & Wwest" & "East & FraR & Steam & Mill! & Mill & Mill' & Mill \\
\hline GR-LNB 90a & $9 / 19 / 93$ & $10: 06$ & 4.07 & 3.08 & 23 & 16.64 & 173 & .233 & & & 2639 & 21476 & 30777 & 10000 & 1020960 & 0 & \begin{tabular}{l|l}
0 & \\
\end{tabular} & 0 & 0 \\
\hline GR-LNB 90 & $9 / 19 / 93$ & $13: 54$ & 3.48 & 2.81 & 22 & 16.07 & 182 & .245 & & & 2759 & 21902 & 31645 & 10008 & 1179188 & 0 & 0 & 0 & 0 \\
\hline GR-LNB 91 & 9/20/93 & $24: 00$ & 3.19 & 2.52 & 192 & 15.80 & 165 & .222 & & & 3063 & 24230 & 31646 & 10000 & 1124284 & 0 & 0 & 0 & 0 \\
\hline GR-LNB 92a & $9 / 21 / 93$ & $3: 00$ & 4.01 & 3.03 & 256 & 16.61 & 166 & .223 & & & 2904 & 25267 & 30735 & 9860 & 931802 & 0 & 0 & 0 & 0 \\
\hline GR-LNB 92 & $9 / 21 / 93$ & $17: 56$ & 3.74 & 2.63 & 135 & 16.31 & 168 & .225 & 199 & .374 & 3255 & 25975 & 31436 & 9999 & 1139502 & 0 & 0 & 0 & 0 \\
\hline GR-LNB 3 Mill a & $9 / 22 / 93$ & $7: 59$ & 4.93 & 3.50 & 35 & 17.53 & 154 & .206 & 284 & .533 & 2933 & 25081 & 30671 & 10008 & 900782 & 0 & 0 & 0 & 1 \\
\hline GR-LNB 3 Mill b & $9 / 22 / 93$ & $8: 25$ & 4.53 & 2.87 & 18 & 15.91 & 160 & .215 & 287 & .540 & 2944 & 24580 & 30769 & 9976 & 972294 & 0 & 0 & 0 & 1 \\
\hline GR.LNB 3 Mill C & $9 / 23 / 93$ & $24: 00$ & 4.52 & 3.13 & 16 & 15.73 & 165 & .221 & 329 & .618 & 2980 & 24403 & 31080 & 10001 & 982953 & 0 & 0 & 0 & 1 \\
\hline GR-LNB 3 Mill d & $9 / 24 / 93$ & 1.58 & 5.63 & 3.96 & 8 & 15.40 & 165 & .221 & 306 & .574 & 2598 & 23971 & 30157 & 8874 & 791465 & 0 & 0 & 0 & 1 \\
\hline LNB-OFA 3 Mill & $9 / 24 / 93$ & $3: 33$ & 7.73 & 5.83 & 32 & 15.65 & 226 & .308 & 351 & .669 & 0 & 18759 & 24561 & 7142 & 636951 & 0 & 0 & 0 & 1 \\
\hline GR-LNB 3 Mill 0 & $9 / 24 / 93$ & $6: 10$ & 4.97 & 3.72 & 12 & 15.76 & 174 & .234 & 311 & .584 & 2863 & 23530 & 31072 & 9997 & 988715 & 0 & 0 & 0 & 1 \\
\hline GR-LNB 93 & $9 / 24 / 93$ & $12: 09$ & 4.63 & 3.38 & 10 & 16.08 & 192 & .258 & 320 & .601 & 2926 & 23587 & 31459 & 10002 & 1115514 & 0 & 0 & 0 & 0 \\
\hline GR-LNB 94a & $9 / 25 / 93$ & $2: 12$ & 4.70 & 3.44 & 9 & 16.01 & 169 & .228 & 314 & .590 & 2783 & 23317 & 30654 & 9990 & 972449 & 0 & 0 & 0 & 0 \\
\hline LNB-OFA & $9 / 25 / 93$ & $2: 24$ & 6.51 & 5.05 & 9 & 16.36 & 218 & .298 & 355 & .677 & 0 & 23399 & 30302 & 7976 & 807992 & 0 & 0 & 0 & 0 \\
\hline GR-LNB 94 & $9 / 25 / 93$ & $19: 05$ & 4.01 & 2.86 & 12 & 16.16 & 190 & .255 & 326 & .614 & 2966 & 23405 & 31870 & 9997 & 1191631 & 0 & 0 & 0 & 0 \\
\hline GR-LNB 95a & $9 / 26 / 93$ & $4: 15$ & 4.74 & 3.49 & 9 & 16.17 & 171 & .229 & 304 & .571 & 2919 & 24257 & 31129 & 9991 & 952879 & 0 & 0 & 0 & 0 \\
\hline LNB-OFA & $9 / 26 / 93$ & $2: 55$ & 7.19 & 5.70 & 13 & 16.55 & 251 & .341 & 350 & .667 & 0 & 23968 & 30323 & 6819 & 785818 & 0 & 0 & 0 & 0 \\
\hline GR-LNB 95 & $9 / 26 / 93$ & $16: 33$ & 4.48 & 3.36 & 7 & 16.01 & 191 & .256 & 319 & .601 & 3042 & 24139 & 31945 & 9996 & 1112300 & 0 & 0 & 0 & 0 \\
\hline GR-LNB 96a & 9/27/93 & $2: 53$ & 5.10 & 3.81 & 7 & 15.70 & 187 & .251 & 312 & .586 & 2944 & 23763 & 31827 & 10003 & 1008787 & 0 & 0 & 0 & 0 \\
\hline LNB & $9 / 27 / 93$ & $19: 45$ & 4.62 & 3.28 & 45 & 16.79 & 373 & .508 & 375 & .715 & 0 & 1531 & 0 & 10 & 1200767 & 0 & 0 & 0 & 0 \\
\hline GR-LNB 96b & 9/27/93 & $0: 57$ & 4.36 & 3.12 & 26 & 15.95 & 163 & .218 & 316 & .593 & 3147 & 27716 & 32450 & 9966 & 986342 & 0 & 0 & 0 & 0 \\
\hline GR-LNB 97a & $9 / 28 / 93$ & $9: 13$ & 4.81 & 3.58 & 8 & 15.99 & 187 & .250 & 313 & .589 & 3055 & 24969 & 31696 & 9967 & 1037986 & 0 & 0 & 0 & 0 \\
\hline LNB & 9/28/93 & $4: 27$ & 2.25 & 1.20 & 868 & 17.18 & 245 & .334 & 375 & .716 & 0 & 0 & 0 & 9997 & 1220446 & 0 & 0 & 0 & 0 \\
\hline GR-LNB 97 & $9 / 28 / 93$ & $5: 58$ & 3.49 & 2.42 & 30 & 16.32 & 172 & .232 & 333 & .629 & 2702 & 25173 & 32083 & 10000 & 1184986 & 0 & 0 & 0 & 0 \\
\hline GR-LNB 97b & $9 / 28 / 93$ & $2: 48$ & 4.57 & 3.14 & 8 & 16.20 & 184 & .248 & 326 & .615 & 2133 & 21533 & 27849 & 9945 & 974067 & 0 & 0 & 0 & 0 \\
\hline GR-LNB 98a & $9 / 29 / 93$ & $5: 22$ & 5.23 & 3.81 & 6 & 16.03 & 204 & .275 & 322 & .607 & 1898 & 19930 & 26018 & 9624 & 884053 & 0 & 0 & 0 & 0 \\
\hline GA-LNB 98 & $9 / 29 / 93$ & $18: 37$ & 3.89 & 2.74 & 14 & 16.15 & 186 & .251 & 325 & .611 & 3027 & 25188 & 31946 & 10003 & 1189487 & 0 & 0 & 0 & 0 \\
\hline GR-LNB 99a & $9 / 30 / 93$ & $5: 32$ & 5.49 & 4.01 & 6 & 15.51 & 204 & .273 & 305 & .573 & 2808 & 25547 & 30337 & 9499 & 890779 & 0 & 0 & 0 & 0 \\
\hline GR-LNB 99 & $9 / 30 / 93$ & $13: 24$ & 4.15 & 2.92 & 9 & 16.06 & 193 & .259 & 321 & .603 & 3351 & 26070 & 32041 & 10000 & 1181229 & 0 & 0 & 0 & 0 \\
\hline GA-LNB 996 & $9 / 30 / 93$ & $2: 27$ & 5.07 & 3.42 & 7 & 15.85 & 183 & .246 & 311 & .583 & 3265 & 27085 & 31292 & 9979 & 995361 & 0 & 0 & 0 & 0 \\
\hline LNB-OFA & $9 / 30 / 93$ & $2: 27$ & 6.35 & 5.05 & 305 & 16.39 & 370 & .505 & 352 & .672 & 0 & 1636 & 6437 & 897 & 669649 & 0 & 0 & 0 & 0 \\
\hline GR-LNB $100 \mathrm{a}$ & $10 / 1 / 93$ & $11: 00$ & 6.13 & 4.46 & 7 & 15.76 & 223 & .299 & 287 & .538 & 2628 & 26189 & 30307 & 9347 & 816223 & 0 & 0 & 0 & 0 \\
\hline GR-LNB 100 & $10 / 1 / 93$ & $9: 12$ & 4.68 & 3.20 & 7 & 16.07 & 174 & .234 & 278 & .522 & 3009 & 25908 & 30576 & 9999 & 983329 & 0 & 0 & 0 & 0 \\
\hline GR-LNB 101 & $10 / 2 / 93$ & $24: 00$ & 5.29 & 3.60 & 6 & 16.29 & 184 & .247 & 289 & .542 & 2909 & 25906 & 30694 & 9990 & 963831 & 0 & 0 & 0 & 0 \\
\hline GR-LNB 102 & $10 / 3 / 93$ & $24: 00$ & 5.56 & 3.85 & 6 & 16.14 & 195 & .262 & 287 & .540 & 2737 & 26269 & 29985 & 9750 & 911766 & 0 & 0 & 0 & 0 \\
\hline GR-LNB 103 & $10 / 4 / 93$ & $24: 00$ & 4.95 & 3.45 & 7 & 15.96 & 181 & .243 & 291 & .545 & 3122 & 27549 & 31218 & 9993 & 977555 & 0 & 0 & 0 & 0 \\
\hline GR-LNB 104 & $10 / 5 / 93$ & $24: 00$ & 5.11 & 3.55 & 6 & 15.79 & 189 & .254 & 305 & .571 & 3436 & 27513 & 31632 & 9990 & 998394 & 0 & 0 & 0 & 0 \\
\hline QR-LNB 105 & $10 / 6 / 93$ & $10: 15$ & 4.69 & 3.35 & 10 & 15.96 & 188 & .252 & 307 & .577 & 3383 & 26196 & 32154 & 10000 & 1137382 & 0 & 0 & 0 & 0 \\
\hline GR-LNB 106 & $10 / 8 / 93$ & $8: 45$ & 3.63 & 2.58 & 18 & 16.60 & 174 & .234 & 309 & .582 & 3173 & 25180 & 31649 & 10002 & 1186027 & 0 & 0 & 0 & 0 \\
\hline GR-LNB 107 & $10 / 9 / 93$ & $24: 00$ & 4.59 & 3.13 & 12 & 16.52 & 197 & .264 & 308 & .581 & 3085 & 24385 & 31839 & 10005 & 1182794 & 0 & 0 & 0 & 0 \\
\hline
\end{tabular}


Pre Modification

\begin{tabular}{|c|c|c|c|c|c|c|c|c|c|c|c|c|c|c|c|c|c|c|c|}
\hline Nost No $^{2}$ & Dote & Dur? & CEMS & $\begin{array}{l}\text { Plant of } \\
\text { Wet } \\
\text { Wet }\end{array}$ & poc & consc & Noxp & 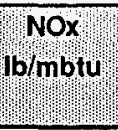 & so2c & 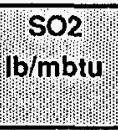 & Reb & West & $\begin{array}{l}\text { East } \\
\text { of } \\
\text { sctm! }\end{array}$ & FGR! & 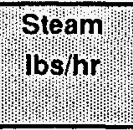 & Mill & Mill & Milll & Mill \\
\hline GR-LNB 108 & $10 / 10 / 93$ & $11: 00$ & 4.65 & 3.15 & 32 & 16.35 & 198 & .266 & 311 & .585 & 3096 & 24362 & 31937 & 9997 & 1184866 & 0 & \begin{tabular}{l|l}
0 & \\
\end{tabular} & 0 & 0 \\
\hline GR-LNB 109a & $10 / 13 / 93$ & $4: 07$ & 4.24 & 2.42 & 18 & 16.47 & 193 & .259 & 310 & .582 & 3647 & 31684 & 30645 & 10000 & 1195887 & 0 & 0 & 0 & 0 \\
\hline GR-LNB 1096 & $10 / 13 / 93$ & 2.02 & 4.93 & 3.08 & 12 & 16.31 & 188 & .252 & 311 & .584 & 2968 & 29485 & 29602 & 10002 & 986307 & 0 & 0 & 0 & 0 \\
\hline GR-LNB $110 \mathrm{a}$ & $10 / 14 / 93$ & $6: 02$ & 4.86 & 2.99 & 20 & 16.36 & 190 & .255 & 312 & .586 & 3217 & 29854 & 30095 & 10009 & 1040627 & 0 & 0 & 0 & 0 \\
\hline GR-LNB 110 & $10 / 14 / 93$ & $14: 56$ & 4.19 & 2.39 & 18 & 16.36 & 190 & .255 & 307 & .575 & 4022 & 33654 & 33411 & 9997 & 1173059 & 0 & 0 & 0 & 0 \\
\hline GR-LNB $110 b$ & $10 / 14 / 93$ & $3: 00$ & 5.35 & 3.27 & 8 & 15.96 & 201 & .269 & 294 & .550 & 3805 & 32522 & 32481 & 9980 & 951225 & 0 & 0 & 0 & 0 \\
\hline GR-LNB 111 & $10 / 15 / 93$ & $12: 49$ & 4.45 & 2.51 & 63 & 16.39 & 174 & .233 & 311 & .582 & 3691 & 31735 & 32152 & 9998 & 1066641 & 0 & 0 & 0 & 0 \\
\hline GR-LNB 3 Mill a & $10 / 15 / 93$ & $2: 58$ & 3.46 & 1.83 & 30 & 16.56 & 178 & .239 & 315 & .591 & 3765 & 31716 & 31998 & 10000 & 1151508 & 0 & 0 & 1 & 0 \\
\hline GR-LNB 3 Mill b & $10 / 15 / 93$ & $7: 05$ & 4.45 & 2.71 & 16 & 16.54 & 191 & .257 & 316 & .593 & 3261 & 29959 & 30343 & 10000 & 1065767 & 0 & 0 & 1 & 0 \\
\hline GR-LNB 3 Mill o & $10 / 16 / 93$ & 12:05 & 5.90 & 4.11 & 5 & 16.16 & 212 & .285 & 315 & .591 & 2735 & 28856 & 29543 & 9896 & 856244 & 0 & 0 & 1 & 0 \\
\hline GR-LNB 3 Mill d & $10 / 16 / 93$ & $10: 28$ & 4.04 & 2.45 & 16 & 16.58 & 198 & .265 & 317 & .595 & 4054 & 34099 & 33851 & 10004 & 1240715 & 0 & 0 & 1 & 0 \\
\hline GR-LNB 3 Mill $\theta$ & $10 / 16 / 93$ & $1: 25$ & 4.32 & 2.34 & 31 & 16.55 & 158 & .213 & 312 & .586 & 3513 & 30086 & 30936 & 10008 & 1093256 & 0 & 0 & 1 & 0 \\
\hline GR-LNB 3 Mill & $10 / 17 / 93$ & $23: 46$ & 4.40 & 2.30 & 164 & 16.34 & 161 & .215 & 310 & .581 & 3438 & 30122 & 30651 & 9994 & 1035016 & 0 & 0 & 1 & 0 \\
\hline LNB-OFA 3 Mill & $10 / 18 / 93$ & $11: 10$ & 5.47 & 3.18 & 169 & 17.07 & 184 & .251 & 364 & .693 & 0 & 22983 & 24415 & 7645 & 838204 & 0 & 0 & 1 & 0 \\
\hline GR-LNB 3 Mill g & $10 / 19 / 93$ & $15: 35$ & 4.87 & 3.17 & 20 & 15.69 & 172 & .231 & 284 & .533 & 3251 & 29408 & 30579 & 9998 & 1008201 & 0 & 0 & 1 & 0 \\
\hline GR-LNB 3 Mill $h$ & $10 / 20 / 93$ & $7: 35$ & 5.02 & 3.10 & 14 & 15.79 & 171 & .229 & 238 & .445 & 3265 & 29130 & 30593 & 10000 & 1003963 & 0 & 0 & 1 & 0 \\
\hline GR-LNB 112 & $10 / 20 / 93$ & $4: 09$ & 5.41 & 3.69 & 22 & 16.10 & 196 & .263 & 270 & .507 & 3037 & 28893 & 30578 & 9998 & 951590 & 0 & 0 & 0 & 0 \\
\hline LNB-OFA & $10 / 20 / 93$ & 0.56 & 5.91 & 4.16 & 61 & 16.46 & 273 & .371 & 335 & .640 & 0 & 26411 & 27589 & 8222 & 1075664 & 0 & 0 & 0 & 0 \\
\hline GR-LNB 113 & $10 / 20 / 93$ & $10: 42$ & 4.55 & 3.04 & 16 & 15.72 & 192 & .257 & 296 & .555 & 3846 & 31426 & 33526 & 9992 & 1180964 & 0 & 0 & 0 & 0 \\
\hline GR-LNB 113 & $10 / 21 / 93$ & $24: 00$ & 4.25 & 3.10 & 93 & 15.72 & 184 & .246 & 303 & .568 & 4089 & 33130 & 35144 & 10002 & 1168787 & 0 & 0 & 0 & 0 \\
\hline GR-LNB 114 & $10 / 22 / 93$ & $24: 00$ & 4.16 & 3.11 & 96 & 15.67 & 176 & .235 & 312 & .584 & 4029 & 33036 & 34593 & 10000 & 1138196 & 0 & 0 & 0 & 0 \\
\hline GR-LNB 115 & $10 / 23 / 93$ & $24: 00$ & 4.29 & 3.08 & 74 & 15.63 & 17 & .237 & 311 & .583 & 4094 & 33662 & 34816 & 10001 & 1186652 & 0 & 0 & 0 & 0 \\
\hline GR-LNB 116 & $10 / 24 / 93$ & 14.00 & 4.32 & 3.09 & 91 & 15.62 & 174 & .233 & 313 & .587 & 3884 & 32233 & 33537 & 9999 & 1164111 & 0 & 0 & 0 & 0 \\
\hline GR-LNB 116a & $10 / 24 / 93$ & $10: 00$ & 4.17 & 2.91 & 103 & 15.46 & & & 310 & .579 & 4050 & 33729 & 34365 & 10002 & 1187424 & 0 & 0 & 0 & 0 \\
\hline GR-LNB 117a & $10 / 25 / 93$ & $4: 55$ & 5.13 & 3.48 & 19 & 15.34 & & & 312 & .586 & 3012 & 28619 & 30001 & 9822 & 946111 & 0 & 0 & 0 & 0 \\
\hline GR-LNB 117 & $10 / 25 / 93$ & $19: 04$ & 4.10 & 2.89 & 68 & 15.79 & & & 307 & .576 & 3836 & 32010 & 32868 & 9999 & 1163105 & 0 & 0 & 0 & 0 \\
\hline GR-LNB 118 & $10 / 26 / 93$ & $24: 00$ & 3.89 & 2.81 & 47 & 16.03 & & & 312 & .585 & 3786 & 31721 & 32722 & 10002 & 1157913 & 0 & 0 & 0 & 0 \\
\hline GR-LNB 119 & $10 / 27 / 93$ & $14: 25$ & 3.58 & 2.44 & 267 & 15.87 & & & 306 & .574 & 3822 & 31745 & 32808 & 10002 & 1194679 & 0 & 0 & 0 & 0 \\
\hline GR-LNB 119a & $10 / 27 / 93$ & $9: 34$ & 3.00 & 2.44 & & 15.56 & & & 311 & .583 & 3710 & 31517 & 31771 & 10006 & 1167386 & 0 & 0 & 0 & 0 \\
\hline GR-LNB 120a & $10 / 28 / 93$ & $7: 21$ & 3.55 & 2.74 & & 15.39 & & & 311 & .583 & 3396 & 30547 & 30776 & 10001 & 1105049 & 0 & 0 & 0 & 0 \\
\hline GA-LNB 120 & $10 / 28 / 93$ & $16: 38$ & 3.31 & 2.55 & 257 & 16.11 & & & 305 & .572 & 3700 & 31258 & 31701 & 10000 & 1169499 & 0 & 0 & 0 & 0 \\
\hline GR-LNB 121 & $10 / 29 / 93$ & $24: 00$ & 4.07 & 2.62 & 211 & 16.40 & & & 300 & .563 & 3725 & 30717 & 32584 & 9999 & 1162158 & 0 & 0 & 0 & 0 \\
\hline GR-LNB 122 & $10 / 30 / 93$ & $24: 00$ & 3.88 & 2.49 & 95 & 16.36 & & & 317 & .595 & 3853 & 31919 & 33273 & 10005 & 1201700 & 0 & 0 & 0 & 0 \\
\hline GR-LNB 123 & $10 / 31 / 93$ & $24: 00$ & 3.93 & 2.50 & 55 & 16.13 & & & 331 & .621 & 3801 & 31826 & 32642 & 10000 & 1177015 & 0 & 0 & 0 & 0 \\
\hline GR.LNB 124 & $11 / 1 / 93$ & $6: 18$ & 3.92 & 2.71 & & 16.36 & & & 328 & .616 & 2909 & 29009 & 29846 & 10006 & 1151387 & 0 & 0 & 0 & 0 \\
\hline LNB.OFA & $11 / 1 / 93$ & 1.08 & 4.88 & 3.67 & & 17.25 & & & 371 & .709 & 0 & 19684 & 22513 & 8362 & 939449 & 0 & 0 & 0 & 0 \\
\hline GR-LNB 125a & $11 / 293$ & $8: 15$ & 2.96 & 2.26 & & 16.90 & & & 324 & .611 & 2806 & 28763 & 30384 & 9997 & 1177218 & 0 & 0 & 0 & 0 \\
\hline LNB & $11 / 2 / 93$ & $0: 29$ & 2.97 & 2.24 & & 16.80 & & & 318 & .599 & 2766 & 28844 & 29778 & 9909 & 1168762 & 0 & 0 & 0 & 0 \\
\hline GR-LNB 125 & $11 / 2 / 93$ & $10: 09$ & 2.96 & 2.23 & & 16.79 & & & 317 & .597 & 2802 & 28984 & 29924 & 10007 & 1168297 & 0 & 0 & 0 & 0 \\
\hline GR-LNB 126a & $11 / 4 / 93$ & $1: 40$ & 2.57 & 2.22 & & 16.43 & & & & & 2523 & 26835 & 28941 & 10014 & 1135867 & 0 & 0 & 0 & 0 \\
\hline
\end{tabular}


Pre Modification

\begin{tabular}{|c|c|c|c|c|c|c|c|c|c|c|c|c|c|c|c|c|c|c|c|}
\hline Test. & Date & Dur: & $\begin{array}{l}\text { CEMS } \\
\text { O2 } \\
\% \text { Dry }\end{array}$ & $\begin{array}{l}\text { Plant } \\
\text { o2 } \\
\% \text { Wet }\end{array}$ & $\begin{array}{l}\text { coc } \\
\text { ppm }\end{array}$ & $\mathrm{cos}^{\mathrm{co}}$ & $\begin{array}{l}\text { NOXxc } \\
\text { ppm }\end{array}$ & $\begin{array}{l}\text { NOx } \\
\text { lb/mbtu }\end{array}$ & $\begin{array}{l}\mathrm{SO} 2 \mathrm{c} \\
\mathrm{ppm}\end{array}$ & $\begin{array}{l}\mathrm{SO} 2 \\
\text { lb/mbtu }\end{array}$ & $\begin{array}{l}\text { Reb } \\
\text { Gas } \\
\text { sctm }\end{array}$ & $\begin{array}{l}\text { West } \\
\text { OFA } \\
\text { scfm }\end{array}$ & $\begin{array}{l}\text { East } \\
\text { OFA } \\
\text { scfm }\end{array}$ & $\begin{array}{l}\text { FGR } \\
\text { scrmin }\end{array}$ & $\begin{array}{l}\text { Steam } \\
\text { Tbs/hr }\end{array}$ & Mill & $\begin{array}{l}\text { Mill } \\
\mathrm{B} \\
0=0\end{array}$ & Mill & $\int_{\mathrm{Dill}}$ \\
\hline GR-LNB 126 & $11 / 4 / 93$ & $13: 29$ & 3.36 & 2.45 & & 16.78 & 179 & .241 & & & 2522 & 27084 & 29025 & 10002 & 1158195 & 0 & 0 & 0 & 0 \\
\hline GA-LNB 127a & $11 / 5 / 93$ & $7: 20$ & 6.00 & 2.99 & & 17.45 & 192 & .259 & & & 2300 & 24624 & 27869 & 10002 & 1081003 & 0 & 0 & 0 & 0 \\
\hline GA-LNB 127 & $11 / 5 / 93$ & $5: 54$ & 3.94 & 2.93 & & 15.06 & 178 & .240 & & & 2623 & 27270 & 30504 & 9999 & 1215775 & 0 & 0 & 0 & 0 \\
\hline GR-LNB 128 & $11 / 8 / 93$ & $4: 55$ & 3.76 & 2.93 & 244 & 16.44 & 195 & .263 & & & 3752 & 30677 & 32862 & 9998 & 1178015 & 0 & 0 & 0 & 0 \\
\hline GR-LNB 129 & $11 / 9 / 93$ & $8: 30$ & 3.26 & 2.50 & 216 & 15.80 & 186 & .251 & & & 3781 & 31136 & 32644 & 9990 & 1215592 & 0 & 0 & 0 & 0 \\
\hline GR-LNB 129a & $11 / 9 / 93$ & $5: 29$ & 3.86 & 3.30 & 123 & 15.87 & 230 & .311 & & & 3269 & 28567 & 30900 & 10004 & 1280032 & 0 & 0 & 0 & 0 \\
\hline GA-LNB 130 & $11 / 10 / 93$ & $15: 43$ & 3.62 & 2.89 & 405 & 16.09 & 207 & .280 & & & 2960 & 28559 & 30907 & 10002 & 1213151 & 0 & 0 & 0 & 0 \\
\hline LNB & $11 / 10 / 93$ & $7: 50$ & 3.36 & 2.86 & 855 & 16.82 & 329 & .444 & & & 0 & 0 & 0 & 0 & 1232191 & 0 & 0 & 0 & 0 \\
\hline LNB & $11 / 11 / 93$ & $2: 00$ & 4.37 & 3.55 & 265 & 16.63 & 365 & .493 & & & 0 & 0 & 0 & 0 & 1150603 & 0 & 0 & 0 & 0 \\
\hline LNB 3 Mill a & $11 / 11 / 93$ & $3: 34$ & 4.09 & 2.36 & 976 & 16.68 & 248 & .335 & & & 0 & 0 & 0 & 0 & 889428 & 1 & 0 & 0 & 0 \\
\hline LNB 3 Mill b & $11 / 11 / 93$ & $9: 20$ & 4.87 & 2.83 & 297 & 16.52 & 290 & .392 & 305 & .582 & 0 & 0 & 0 & 0 & 896590 & 1 & 0 & 0 & 0 \\
\hline LNB 3 Mill c & $11 / 12 / 93$ & $12: 30$ & 4.57 & 2.82 & 184 & 16.14 & 310 & .418 & 284 & .542 & 0 & 0 & 0 & 0 & 974764 & 1 & 0 & 0 & 0 \\
\hline LNB 3 Milld & $11 / 12 / 93$ & $11: 29$ & 2.61 & 2.01 & 486 & 17.20 & 296 & .399 & 288 & .549 & 0 & 0 & 0 & 0 & 1224797 & 1 & 0 & 0 & 0 \\
\hline LNB 3 Mill e & $11 / 13 / 93$ & $14: 30$ & 3.70 & 2.92 & 83 & 17.18 & 358 & .484 & 282 & .538 & 0 & 0 & 0 & 0 & 1192612 & 1 & 0 & 0 & 0 \\
\hline LNB 3 Millf & $11 / 13 / 93$ & 9:29 & 2.62 & 2.13 & 341 & 17.33 & & & 298 & .568 & 0 & 0 & 0 & 0 & 1227895 & 1 & 0 & 0 & 0 \\
\hline LNB 3 Mill & $11 / 14 / 93$ & $24: 00$ & 3.07 & 2.67 & 190 & 17.57 & & & 282 & .539 & 0 & 0 & 0 & 0 & 1172791 & 1 & 0 & 0 & 0 \\
\hline LNB & $11 / 15 / 93$ & $1: 39$ & 2.65 & 2.59 & 159 & 17.79 & & & $2 \pi 7$ & .528 & 0 & 0 & 0 & 0 & 1189100 & 0 & 0 & 0 & 0 \\
\hline GR-LNB 131 & $11 / 15 / 93$ & $13: 00$ & 3.16 & 3.06 & 17 & 15.93 & 191 & .257 & 243 & .457 & 3614 & 29963 & 32813 & 10004 & 1169471 & 0 & 0 & 0 & 0 \\
\hline GA-LNB 132 & $11 / 16 / 93$ & $7: 42$ & 3.02 & 3.09 & 15 & 15.95 & $1 \pi$ & .239 & 255 & .479 & 3385 & 28551 & 31680 & 10005 & 1128226 & 0 & 0 & 0 & 0 \\
\hline GR-LNB 132a & $11 / 16 / 93$ & $16: 17$ & 5.58 & 3.18 & 14 & 15.64 & 181 & .245 & 225 & .423 & 3186 & 28414 & 30801 & 9974 & 1045179 & 0 & 0 & 0 & 0 \\
\hline GA-LNB 133 & $11 / 17 / 93$ & $0: 40$ & 5.65 & 3.28 & 8 & 15.72 & 167 & .225 & 239 & .450 & 2986 & 28195 & 31101 & 9977 & 1003996 & 0 & 0 & 0 & 0 \\
\hline LNB & $11 / 17 / 93$ & $8: 40$ & 5.35 & 2.70 & 304 & 16.64 & 249 & .336 & 280 & .534 & 0 & 0 & 0 & 0 & 983988 & 0 & 0 & 0 & 0 \\
\hline LNB & $12 / 3 / 93$ & $5: 15$ & 4.00 & 3.02 & 342 & 17.01 & & & 315 & .602 & 0 & 0 & 0 & 0 & 1201392 & 0 & 0 & 0 & 0 \\
\hline LNB & $12 / 6 / 93$ & $2: 33$ & 4.29 & 3.36 & 932 & 15.87 & & & 296 & .564 & 0 & 0 & 0 & 0 & 870724 & 0 & 0 & 0 & 0 \\
\hline LNB & $12 / 6 / 93$ & $3: 00$ & 3.97 & 3.03 & 36 & 15.80 & & & 304 & .579 & 0 & 0 & 0 & 0 & 1269337 & 0 & 0 & 0 & 0 \\
\hline LNB & $12 / 6 / 93$ & $1: 55$ & 4.30 & 3.36 & 10 & 15.71 & 381 & .520 & 295 & .562 & 0 & 0 & 0 & 0 & 1271638 & 0 & 0 & 0 & 0 \\
\hline LNB & $12 / 7 / 93$ & $6: 45$ & 4.10 & 3.04 & 190 & 17.18 & 352 & .480 & 309 & .590 & 0 & 0 & 0 & 0 & 1294655 & 0 & 0 & 0 & 0 \\
\hline LNB & $12 / 8 / 93$ & $4: 03$ & 4.65 & 3.59 & 47 & 17.01 & 403 & .550 & 322 & .614 & 0 & 0 & 0 & 2 & 1264918 & 0 & 0 & 0 & 0 \\
\hline GA-LNB 134 & $12 / 8 / 93$ & $3: 40$ & 3.03 & 2.22 & 287 & 16.22 & 169 & .226 & 293 & .549 & 4200 & 33105 & 33616 & 10002 & 1261376 & 0 & 0 & 0 & 0 \\
\hline GR-LNB 134a & $12 / 8 / 93$ & $0: 46$ & 3.30 & 2.85 & 239 & 16.86 & 214 & .290 & 329 & .624 & 1400 & 19258 & 20738 & 10001 & 1268511 & 0 & 0 & 0 & 0 \\
\hline GR-LNB 134b & $12 / 8 / 93$ & $2: 44$ & 2.32 & 2.18 & 806 & 17.07 & 184 & .249 & 331 & .628 & 1402 & 19366 & 20690 & 9982 & 1258909 & 0 & 0 & 0 & 0 \\
\hline GR-LNB $134 c$ & $12 / 8 / 93$ & $3: 31$ & 1.76 & 1.72 & 934 & 17.07 & 167 & .226 & 329 & .623 & 1402 & 19146 & 20966 & 10015 & 1257547 & 0 & 0 & 0 & 0 \\
\hline GR-LNB 135 & $12 / 9 / 93$ & $12: 00$ & 2.26 & 2.06 & 828 & 16.96 & 168 & .228 & 317 & .601 & 1277 & 18190 & 20991 & 9999 & 1154113 & 0 & 0 & 0 & 0 \\
\hline GR-LNB 135a & $12 / 9 / 93$ & $2: 59$ & 3.08 & 2.39 & 377 & 17.05 & 199 & .269 & 301 & .571 & 1373 & 19049 & 20954 & 10002 & 1210333 & 0 & 0 & 0 & 0 \\
\hline GA-LNB 135b & $12 / 9 / 93$ & $7: 10$ & 4.71 & 3.81 & 27 & 16.94 & 249 & .338 & 263 & .498 & 1193 & 17976 & 20945 & 9891 & 1143046 & 0 & 0 & 0 & 0 \\
\hline GR-LNB 136 & $12 / 10 / 93$ & $11: 35$ & 4.39 & 3.58 & 87 & 16.97 & 233 & .316 & 272 & .516 & 1202 & 17739 & 21020 & 10000 & 1182535 & 0 & 0 & 0 & 0 \\
\hline GR-LNB 137 & $12 / 11 / 93$ & $16: 15$ & 3.83 & 3.06 & 124 & 16.44 & 205 & .278 & 294 & .557 & 1120 & 16157 & 21833 & 10001 & 1117980 & 0 & 0 & 0 & 0 \\
\hline GA-LNB 137a & $12 / 11 / 93$ & $7: 44$ & 3.64 & 3.04 & & 16.10 & 221 & .300 & 308 & .584 & 1328 & 16685 & 23322 & 9997 & 1271054 & 0 & 0 & 0 & 0 \\
\hline GR-LNB 138 & $12 / 12 / 93$ & 24:00 & 3.47 & 2.93 & & 15.87 & 218 & .295 & 285 & .540 & 1352 & 16215 & 23771 & 10003 & 1277488 & 0 & 0 & 0 & 0 \\
\hline GR-LNB 139 & $12 / 13 / 93$ & $7: 48$ & 3.17 & 2.66 & & 16.33 & 197 & .268 & 249 & .473 & 1342 & 15208 & 24858 & 9995 & 1275586 & 0 & 0 & 0 & 0 \\
\hline
\end{tabular}


Cherokee Unit 3, Average Test Data

Pre Modification

\begin{tabular}{|c|c|c|c|c|c|c|c|c|c|c|c|c|c|c|c|c|c|c|c|}
\hline Nostw. & Dat? & Dur & 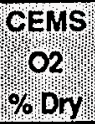 & Plant" & prom & corc & Noxc & (Nox & ppp & 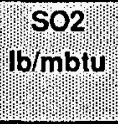 & $\begin{array}{l}\text { Reb } \\
\text { Gas! } \\
\text { sctm }\end{array}$ & West! & $\begin{array}{l}\text { East } \\
\text { OFA_ } \\
\text { sctm }\end{array}$ & FGA & 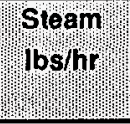 & MiIIII & 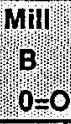 & Mill! & Mili \\
\hline GR-LNB 139a & $12 / 13 / 93$ & $4: 18$ & 3.65 & 2.68 & 183 & 16.65 & 197 & .268 & 240 & .454 & 1350 & 14257 & 25801 & 10000 & 1261888 & 0 & 0 & 0 & 0 \\
\hline LNB & $12 / 13 / 93$ & $5: 18$ & 4.30 & 2.90 & 60 & 16.96 & 353 & .481 & 308 & .588 & 0 & 0 & 0 & 24 & 1220439 & 0 & 0 & 0 & 0 \\
\hline LNB-OFA & $12 / 14 / 93$ & $1: 55$ & 4.98 & 3.31 & 17 & 16.68 & 223 & .304 & 321 & .612 & 0 & 21463 & 29880 & 10030 & 1278835 & 0 & 0 & 0 & 0 \\
\hline GR-LNB 140 & $12 / 14 / 93$ & $1: 18$ & 3.68 & 2.52 & 868 & 16.59 & 203 & .276 & 310 & .588 & 1383 & 20291 & 19521 & 9535 & 1269747 & 0 & 0 & 0 & 0 \\
\hline LNB & $12 / 14 / 93$ & $8: 30$ & 3.45 & 2.18 & 172 & 16.95 & 293 & .399 & 316 & .602 & 0 & 0 & 0 & 3 & 1256579 & 0 & 0 & 0 & 0 \\
\hline LNB & $12 / 15 / 93$ & $9: 28$ & 4.15 & 3.02 & 18 & 16.71 & 337 & .459 & 302 & .576 & 0 & 0 & 0 & 0 & 1247133 & 0 & 0 & 0 & 0 \\
\hline LNB-OFA & $12 / 15 / 93$ & $5: 29$ & 4.45 & 3.70 & 132 & 16.50 & 284 & .388 & 302 & .575 & 0 & 12277 & 14828 & 1056 & 1265273 & 0 & 0 & 0 & 0 \\
\hline GR-LNB 141 & $12 / 15 / 93$ & $5: 15$ & 3.70 & 2.73 & 461 & 16.24 & 195 & .265 & 285 & .540 & 1272 & 18316 & 20573 & 9951 & 1113543 & 0 & 0 & 0 & 0 \\
\hline LNB & $12 / 15 / 93$ & $2: 50$ & 5.84 & 4.53 & 21 & 15.83 & 347 & .472 & 268 & .512 & 0 & 0 & 0 & 0 & 745605 & 0 & 0 & 0 & 0 \\
\hline LNB & $12 / 16 / 93$ & 15.05 & 4.40 & 2.68 & 442 & 16.69 & 345 & .470 & 291 & .556 & 0 & 0 & 0 & 0 & 1175991 & 0 & 0 & 0 & 0 \\
\hline GR-LNB 142 & $12 / 16 / 93$ & $6: 14$ & 4.30 & 2.75 & 685 & 16.68 & 224 & .303 & 274 & .520 & 1424 & 19258 & 20992 & 10010 & 1261200 & 0 & 0 & 0 & 0 \\
\hline GR-LNB 142a & $12 / 16 / 93$ & $1: 15$ & 4.83 & 3.10 & 848 & 16.53 & 172 & .233 & 261 & .494 & 1083 & 17145 & 20277 & 9990 & 849694 & 0 & 0 & 0 & 0 \\
\hline GR-LNB 143 & $12 / 17 / 93$ & $2: 10$ & 5.25 & 3.72 & 848 & 16.42 & 172 & .233 & 262 & .496 & 1066 & 16822 & 20435 & 10001 & 823936 & 0 & 0 & 0 & 0 \\
\hline LNB-OFA & $12 / 17 / 93$ & $0: 40$ & 8.68 & 6.73 & 13 & 15.74 & 492 & .669 & 247 & .472 & 0 & 15944 & 19979 & 7066 & 464254 & 0 & 0 & 0 & 0 \\
\hline LNB & $12 / 17 / 93$ & $6: 10$ & 4.08 & 2.78 & 367 & 17.00 & 317 & .433 & 303 & .578 & 0 & 0 & 0 & 0 & 1214380 & 0 & 0 & 0 & 0 \\
\hline LNB & $12 / 20 / 93$ & $2: 25$ & 4.97 & 3.51 & 199 & 16.70 & 354 & .482 & 308 & .588 & 0 & 0 & 0 & 0 & 1062739 & 0 & 0 & 0 & 0 \\
\hline $100 \%$ Gas Firing & $12 / 20 / 93$ & $0: 34$ & 6.39 & 4.20 & 19 & 10.20 & 125 & .170 & 49 & .093 & 0 & 0 & 0 & 0 & 693795 & 0 & 0 & 0 & 0 \\
\hline LNB & $12 / 22 / 93$ & $2: 35$ & 5.22 & 3.65 & 497 & 16.58 & 308 & .420 & 256 & .488 & 0 & 0 & 0 & 2148 & 984811 & 0 & 0 & 0 & 0 \\
\hline LNB & $1 / 5 / 94$ & $2: 24$ & 3.53 & 2.73 & 146 & 16.92 & 344 & .470 & 306 & .583 & 0 & 0 & 0 & 0 & 1192621 & 0 & 0 & 0 & 0 \\
\hline LNB-OFA & $1 / 5 / 94$ & $2: 26$ & 4.05 & 3.68 & 729 & 16.79 & 303 & .413 & 294 & .559 & 0 & 5894 & 5319 & 7587 & 1200884 & 0 & 0 & 0 & 0 \\
\hline LNB-OFA & $1 / 5 / 94$ & $9: 15$ & 4.21 & 3.42 & 888 & 16.87 & 248 & .339 & 320 & .610 & 0 & 57 & 5725 & 3966 & 1042703 & 0 & 0 & 0 & 0 \\
\hline LNB-OFA & $1 / 6 / 94$ & $8: 47$ & 4.68 & 3.51 & 1016 & 16.77 & 215 & .293 & 316 & .603 & 0 & 0 & 5143 & 2872 & 797140 & 0 & 0 & 0 & 0 \\
\hline LNB & $1 / 6 / 94$ & 15:12 & 3.59 & 2.22 & 490 & 17.05 & 296 & .404 & 314 & .599 & 0 & 0 & 0 & 0 & 1178087 & 0 & 0 & 0 & 0 \\
\hline LNB & $1 / 7 / 94$ & $6: 55$ & 4.00 & 2.81 & 587 & 17.14 & 242 & .330 & 319 & .608 & 0 & 0 & 0 & 0 & 958594 & 0 & 0 & 0 & 0 \\
\hline LNB-OFA & $1 / 7 / 94$ & 1.09 & 4.35 & 3.59 & 850 & 16.94 & 194 & .264 & 310 & .593 & 0 & 12141 & 18034 & 0 & 989174 & 0 & 0 & 0 & 0 \\
\hline GR-LNB 144 & $1 / 7 / 94$ & $15: 40$ & 3.79 & 2.79 & 849 & 16.35 & 197 & .267 & 286 & .542 & 1368 & 18898 & 21049 & 9994 & 1126768 & 0 & 0 & 0 & 0 \\
\hline GR-LNB 145a & $1 / 8 / 94$ & $8: 20$ & 3.69 & 2.44 & 917 & 16.39 & 162 & .220 & 281 & .534 & 1226 & 18058 & 20744 & 10000 & 993975 & 0 & 0 & 0 & 0 \\
\hline GR-LNB 145 & $1 / 8 / 94$ & $15: 39$ & 3.06 & 1.77 & 1001 & 16.36 & 177 & .239 & 283 & .537 & 1396 & 19041 & 21022 & 10002 & 1174058 & 0 & 0 & 0 & 0 \\
\hline GR-LNB 146a & $1 / 9 / 94$ & $2: 10$ & 2.70 & 1.40 & 983 & 16.15 & 157 & .213 & 282 & .534 & 1399 & 18374 & 21546 & 9995 & 1137267 & 0 & 0 & 0 & 0 \\
\hline GR-LNB 146b & $1 / 9 / 94$ & $8: 39$ & 3.75 & 2.26 & 956 & 16.13 & 157 & .213 & 276 & .523 & 1114 & 17179 & 20841 & 9963 & 901363 & 0 & 0 & 0 & 0 \\
\hline GR-LNB 146 & $1 / 9 / 94$ & 9.02 & 3.89 & 2.76 & 880 & 16.13 & 196 & .266 & 269 & .510 & 1357 & 18815 & 21051 & 9988 & 1087677 & 0 & 0 & 0 & 0 \\
\hline LNB & $1 / 9 / 94$ & $3: 35$ & 4.09 & 2.96 & 817 & 16.52 & 219 & .299 & 285 & .544 & 0 & 0 & 38 & 47 & 940925 & 0 & 0 & 0 & 0 \\
\hline LNB & $1 / 10 / 94$ & 3.50 & 4.51 & 2.52 & 740 & 17.09 & 238 & .324 & 298 & .569 & 0 & 0 & 20 & 28 & 1040174 & 0 & 0 & 0 & 0 \\
\hline GR-LNB 147 & $1 / 10 / 94$ & $2: 40$ & 4.32 & 2.36 & 822 & 16.88 & 221 & .300 & 289 & .548 & 1404 & 19352 & 20681 & 9991 & 1248369 & 0 & 0 & 0 & 0 \\
\hline GR-LNB 147a & $1 / 10 / 94$ & $4: 04$ & 5.19 & 3.14 & 364 & 16.66 & 194 & .262 & 278 & .526 & 1462 & 19597 & 21281 & 9971 & 974260 & 0 & 0 & 0 & 0 \\
\hline GR-LNB 1476 & $1 / 10 / 94$ & $4: 54$ & 5.39 & 3.52 & 209 & 16.65 & 201 & .272 & 268 & .507 & 1448 & 18816 & 21905 & 9999 & 980778 & 0 & 0 & 0 & 0 \\
\hline GR-LNB 148a & $1 / 11 / 94$ & $6: 32$ & 5.93 & 4.04 & 48 & 16.47 & 208 & .281 & 268 & .507 & 1350 & 17.867 & 22029 & 9972 & 860045 & 0 & 0 & 0 & 0 \\
\hline GR-LNB 148 & $1 / 11 / 94$ & $14: 38$ & 4.13 & 3.12 & 541 & 16.39 & 232 & .313 & 273 & .516 & 1775 & 20985 & 22888 & 9996 & 1238948 & 0 & 0 & 0 & 0 \\
\hline GR-LNB 148b & $1 / 11 / 94$ & $2: 48$ & 4.39 & 3.21 & 393 & 16.42 & 188 & .254 & 275 & .521 & 1358 & 18743 & 21145 & 9966 & 1015828 & 0 & 0 & 0 & 0 \\
\hline GR-LNB 149a & $1 / 12 / 94$ & $6: 14$ & 4.41 & 3.31 & 437 & 16.51 & 210 & .285 & 266 & .503 & 1433 & 18680 & 21677 & 10008 & 1062151 & 0 & 0 & 0 & 0 \\
\hline
\end{tabular}


Cherokee Unit 3, Average Test Data

Pre Modification

\begin{tabular}{|c|c|c|c|c|c|c|c|c|c|c|c|c|c|c|c|c|c|c|c|}
\hline & Date & Dury & 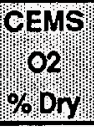 & $\begin{array}{l}\text { Planty } \\
\text { gon } \\
\text { g wet }\end{array}$ & popm & con & Noxp ppon & 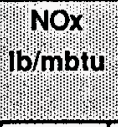 & so2c & 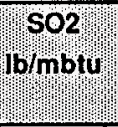 & $\begin{array}{l}\text { Reb } \\
\text { Gas } \\
\text { sctm }\end{array}$ & West] & E़ast & 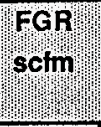 & 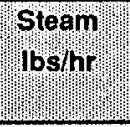 & Min & Mill & Mill & Mili \\
\hline GA-LNB 149 & $1 / 12 / 94$ & $13: 30$ & 4.18 & 3.09 & 553 & 16.40 & 220 & \begin{tabular}{|l|}
.298 \\
\end{tabular} & 266 & .503 & 1550 & 19639 & 21999 & 10011 & 1142102 & 0 & \begin{tabular}{l|l}
0 & \\
\end{tabular} & 0 & 0 \\
\hline GA-LNB A Mill off & $1 / 12 / 94$ & 1.09 & 4.05 & 3.05 & 717 & 16.36 & 206 & .279 & 267 & .505 & 1444 & 18905 & 21690 & 10002 & 1029804 & 0 & 0 & 0 & 0 \\
\hline GR-LNB D Mill off & $1 / 12 / 94$ & $1: 39$ & 3.15 & 2.36 & 791 & 16.24 & 161 & .218 & 266 & .503 & 2060 & 22512 & 24896 & 7923 & 1071712 & 0 & 0 & 0 & 1 \\
\hline GA-LNB D Mill off line & $1 / 13 / 94$ & $4: 23$ & 3.70 & 2.48 & 844 & 16.18 & 138 & .186 & 266 & .503 & 1401 & 18359 & 21403 & 8862 & 841565 & 0 & 0 & 0 & 1 \\
\hline GA-LNB 150 & $1 / 13 / 94$ & $7: 15$ & 3.55 & 2.53 & 1023 & 16.40 & 200 & .271 & 281 & .532 & 1786 & 21134 & 22719 & 9994 & 1217306 & 0 & 0 & 0 & 0 \\
\hline GA-LNB D Mill off line & $1 / 13 / 94$ & $1: 13$ & 3.23 & 2.12 & 970 & 16.22 & 153 & .207 & 281 & .531 & 1940 & 22816 & 24213 & 9045 & 1067973 & 0 & 0 & 0 & 1 \\
\hline GA-LNB 150a & $1 / 13 / 94$ & 6.00 & 4.15 & 3.02 & 619 & 16.37 & 189 & .256 & 274 & .519 & 1567 & 20166 & 21808 & 10004 & 1074955 & 0 & 0 & 0 & 0 \\
\hline GR-LNB 1512 & $1 / 14 / 94$ & $7: 25$ & 4.91 & 3.56 & 200 & 16.21 & 180 & .243 & 272 & .514 & 1241 & 18501 & 20545 & 9571 & 852590 & 0 & 0 & 0 & 0 \\
\hline GR-LNB, ABC & $1 / 14 / 94$ & $7: 50$ & 3.70 & 2.03 & 1023 & 16.51 & 163 & .220 & 283 & .536 & 1405 & 19212 & 20780 & 10006 & 1033877 & 0 & 0 & 0 & 1 \\
\hline GR-LNB 151 & $1 / 14 / 94$ & $7: 54$ & 3.75 & 2.78 & 612 & 16.58 & 190 & .257 & 281 & .532 & 1413 & 19093 & 21170 & 9995 & 1042914 & 0 & 0 & 0 & 0 \\
\hline GR-LNB 156 & $1 / 19 / 94$ & $24: 00$ & 4.15 & 3.45 & 643 & 16.52 & 175 & .237 & 312 & .591 & 1342 & 18138 & 21655 & 9831 & 925175 & 0 & 0 & 0 & 0 \\
\hline GR-LNB 157a & $1 / 20 / 94$ & $6: 38$ & 4.04 & 3.31 & 486 & 16.86 & 163 & .220 & 314 & .594 & 1281 & 16416 & 22981 & 9762 & 884252 & 0 & 0 & 0 & 0 \\
\hline GR-LNB 157 & $1 / 20 / 94$ & 3.50 & 3.55 & 2.50 & 674 & 16.55 & 187 & .253 & $\overline{321}$ & .607 & 1865 & 19514 & 25301 & 10010 & 1142670 & 0 & 0 & 0 & 0 \\
\hline
\end{tabular}


Pre Modification

\begin{tabular}{|c|c|c|c|c|c|c|c|c|c|c|c|c|c|c|c|c|c|}
\hline Test & Wpate & Durf & $\begin{array}{l}\text { (coal } \\
\text { (folow } \\
\text { (bs/hr } \\
\end{array}$ & 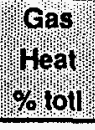 & $\begin{array}{l}\text { Coal } \\
\text { Storch }\end{array}$ & $\begin{array}{l}\text { Reburn } \\
\text { stolch! }\end{array}$ & SFit & $\begin{array}{l}\text { Gross } \\
\text { Power } \\
\text { MWe }\end{array}$ & $\begin{array}{l}\text { Net } \\
\text { power! } \\
\text { nwe }\end{array}$ & 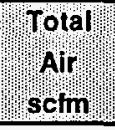 & Steam & $\begin{array}{l}\text { Main } \\
\text { Steam } \\
\text { Temp }\end{array}$ & 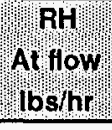 & $\begin{array}{l}\text { SH } \\
\text { At fow } \\
\text { ibshth }\end{array}$ & 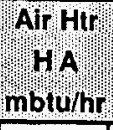 & Ebic/n & Frurn \\
\hline Base Cond. (OFA off) & $11 / 11 / 92$ & $8: 42$ & 95421 & 0.0 & 1.229 & 1.230 & 1.229 & 110 & 100 & 192210 & 805808 & 987 & 950 & 2102 & 137 & 18 & 515 \\
\hline GR & $11 / 11 / 92$ & $1: 01$ & 113190 & 20.6 & 1.176 & 0.948 & 1.185 & 168 & 157 & 230148 & 1239194 & 994 & 2675 & 18217 & 200 & 29 & 713 \\
\hline Base Cond. (OFA off) & $11 / 11 / 92$ & $4: 25$ & 140720 & 0.0 & 1.229 & 1.231 & 1.229 & 164 & 153 & 248175 & 1243929 & 968 & 1038 & 4539 & 203 & 29 & 744 \\
\hline Base Cond. OFA off & $11 / 12 / 92$ & $0: 45$ & 139961 & 0.00 & 1.18 & 1.18 & 1.18 & 162 & 151 & 243139 & 1257174 & 947 & 1030 & 1285 & 191 & 30 & 758 \\
\hline BPMS GR 4 & $11 / 12 / 92$ & 1.05 & 114695 & 19.50 & 1.18 & 0.97 & 1.22 & 167 & 156 & 232694 & 1230455 & 1001 & 3117 & 18272 & 207 & 29 & 710 \\
\hline Base Cond. OFA off & $11 / 12 / 92$ & $1: 15$ & 140390 & 0.00 & 1.23 & 1.23 & 1.23 & 163 & 152 & 248446 & 1243684 & 967 & 1038 & 3535 & 204 & 30 & 742 \\
\hline BPMS Base Cond. 5 & $11 / 13 / 92$ & $2: 55$ & 142362 & 0.00 & 1.259 & 1.259 & 1.259 & 166 & 155 & 254849 & 1254148 & 979 & 1045 & 3565 & 211 & 30 & 742 \\
\hline BPMS Base Cond. 6 & $11 / 13 / 92$ & $1: 00$ & 141044 & 0.00 & 1.182 & 1.184 & 1.242 & 162 & 151 & 242242 & 1268525 & 945 & 1049 & 1275 & 199 & 31 & 763 \\
\hline BPMS Base Cond. 7 & $11 / 13 / 92$ & 1.00 & 141483 & 0.00 & 1.098 & 1.100 & 1.212 & 162 & 151 & 236964 & 1278852 & 937 & 1074 & 1287 & 193 & 31 & 770 \\
\hline Base Cond. -1d & $11 / 16 / 92$ & 1.00 & 131564 & 0.00 & 1.249 & 1.251 & 1.249 & 153 & 143 & 237391 & 1165455 & 973 & 1023 & 1494 & 190 & 28 & 695 \\
\hline GR-10c & $11 / 16 / 92$ & $1: 00$ & 137268 & 0.00 & 1.146 & 1.147 & 1.192 & 157 & 147 & 236962 & 1231148 & 938 & 1079 & 1345 & 182 & 30 & 750 \\
\hline GR-10d & $11 / 16 / 92$ & 1.00 & 137421 & 0.00 & 1.131 & 1.133 & 1.207 & 157 & 146 & 235031 & 1233115 & 939 & 1079 & 1387 & 184 & 30 & 750 \\
\hline Base Cond. OFA off & $11 / 17 / 92$ & $1: 15$ & 140413 & 0.00 & 1.240 & 1.246 & 1.240 & 162 & 151 & 251397 & 1245526 & 966 & 1058 & 1513 & 202 & 30 & 747 \\
\hline GR-11c & $11 / 17 / 92$ & $1: 00$ & 110086 & 20.86 & 1.201 & 0.965 & 1.194 & 162 & 150 & 224777 & 1199836 & 993 & 1064 & 9438 & 192 & 29 & 709 \\
\hline GR-11d. & $11 / 17 / 92$ & $1: 00$ & 108995 & 21.08 & 1.162 & 0.932 & 1.197 & 161 & 150 & 222068 & 1190179 & 994 & 1077 & 10305 & 192 & 28 & 702 \\
\hline Base Cond. OFA off & $11 / 17 / 92$ & $0: 20$ & 134059 & 0.00 & 1.299 & 1.301 & 1.299 & 156 & 145 & 247246 & 1170476 & 974 & 1079 & 6496 & 202 & 28 & 700 \\
\hline Base Cond. OFA off & $11 / 18 / 92$ & $0: 28$ & 136025 & 0.00 & 1.180 & 1.181 & 1.180 & 159 & 148 & 244558 & 1219655 & 962 & 1059 & 1348 & 188 & 29 & 734 \\
\hline GR-110 & $11 / 18 / 92$ & $1: 04$ & 109854 & 20.94 & 1.161 & 0.933 & 1.204 & 162 & 151 & 226522 & 1203538 & 996 & 1040 & 15022 & 197 & 29 & 702 \\
\hline GR-12b & $11 / 18 / 92$ & $1: 05$ & 115754 & 15.96 & 1.117 & 0.953 & 1.213 & 161 & 149 & 225788 & 1199394 & 987 & 1045 & 11622 & 196 & 29 & 705 \\
\hline Base Cond. OFA off & $11 / 18 / 92$ & $0: 35$ & 135727 & 0.00 & 1.233 & 1.235 & 1.233 & 157 & 147 & 245788 & 1190000 & 973 & 1054 & 5829 & 197 & 29 & 714 \\
\hline GR-12 (5\% Gas) & $11 / 19 / 92$ & 1.00 & 131242 & 5.27 & 1.074 & 1.025 & 1.170 & 160 & 149 & 228005 & 1237049 & 953 & 1050 & 1259 & 186 & 30 & 747 \\
\hline GR-12a (10\% Gas) & $11 / 19 / 92$ & $1: 00$ & 125387 & 10.33 & 1.071 & 0.969 & 1.139 & 163 & 152 & 224106 & 1222295 & 990 & 1053 & 2987 & 184 & 29 & 729 \\
\hline GR-12c (23\% Gas) & $11 / 19 / 92$ & $1: 00$ & 104612 & 23.41 & 1.127 & 0.879 & 1.150 & 161 & 150 & 218445 & 1172295 & 1003 & 2197 & 26121 & 184 & 27 & 674 \\
\hline Base Cond. OFA off & $11 / 19 / 92$ & $0: 20$ & 135016 & 0.00 & 1.228 & 1.233 & 1.228 & 158 & 147 & 244664 & 1172857 & 984 & 1081 & 4779 & 193 & 28 & 705 \\
\hline GR-13A; $18 \%$ Gas & $11 / 20 / 92$ & $0: 58$ & 111898 & 18.61 & 1.091 & 0.897 & 1.140 & 161 & 150 & 217317 & 1191695 & 997 & 948 & 11693 & 187 & 28 & 702 \\
\hline GR-13D; $18 \%$ Gas & $11 / 20 / 92$ & $1: 00$ & 110655 & 18.69 & 1.106 & 0.913 & 1.176 & 161 & 150 & 219718 & 1175082 & 1002 & 949 & 17611 & 194 & 28 & 683 \\
\hline GR-14B; $20 \%$ Gas & $11 / 20 / 92$ & $1: 00$ & 108464 & 20.51 & 1.156 & 0.933 & 1.199 & 161 & 150 & 220152 & 1170984 & 1006 & 1078 & 18921 & 198 & 28 & 680 \\
\hline Base Cond. OFA off & $11 / 30 / 92$ & $1: 50$ & 138225 & 0.00 & 1.211 & 1.212 & 1.211 & 161 & 150 & 243850 & 1214054 & 981 & 968 & 1430 & 193 & 29 & 729 \\
\hline GA-BFr & $11 / 30 / 92$ & $0: 26$ & 124321 & 10.56 & 1.094 & 0.992 & 1.256 & 161 & 150 & 226601 & 1207407 & 988 & 1036 & 2659 & 202 & 29 & 723 \\
\hline GR-BFf & $11 / 30 / 92$ & $0: 27$ & 123102 & 10.49 & 1.112 & 1.009 & 1.270 & 159 & 148 & 226345 & 1195357 & 980 & 1039 & 1433 & 200 & 29 & 722 \\
\hline GR-21C & $12 / 1 / 92$ & 1.06 & 86699 & 21.03 & 1.165 & 0.937 & 1.231 & 129 & 120 & 191800 & 924946 & 1001 & 1031 & 11535 & 154 & 21 & 564 \\
\hline GR-22 & $12 / 1 / 92$ & $0: 50$ & 99718 & 8.24 & 1.129 & 1.052 & 1.324 & 126 & 116 & 201618 & 939580 & 955 & 991 & 1486 & 162 & 22 & 592 \\
\hline Bias Firing & $12 / 1 / 92$ & $0: 10$ & 85602 & 21.85 & 1.203 & 0.959 & 1.234 & 127 & 118 & 193233 & 919221 & 999 & 979 & 8263 & 153 & 21 & 573 \\
\hline Base Cond. OFA on & $12 / 1 / 92$ & 0.50 & 108167 & 0.00 & 1.131 & 1.137 & 1.241 & 125 & 116 & 202208 & 952541 & 937 & 1038 & 1556 & 150 & 22 & 605 \\
\hline Base Cond. OFA off & $12 / 1 / 92$ & $0: 40$ & 116558 & 0.00 & 1.217 & 1.218 & 1.217 & 137 & 127 & 221698 & 1008774 & 985 & 1004 & 1475 & 165 & 23 & 624 \\
\hline Base Cond. OFA off & $12 / 2 / 92$ & $3: 55$ & 134387 & 0.00 & 1.223 & 1.223 & 1.223 & 157 & 146 & 244387 & 1184549 & 974 & 972 & 1509 & 194 & 29 & 715 \\
\hline Base Cond. OFA off & $12 / 4 / 92$ & $0: 55$ & 113673 & 0.00 & 1.248 & 1.248 & 1.248 & 130 & 120 & 218621 & 964976 & 987 & 937 & 3501 & 167 & 22 & 603 \\
\hline OFA Test & $12 / 4 / 92$ & $2: 10$ & 105538 & 0.00 & 1.129 & 1.129 & 1.271 & 122 & 111 & 205575 & 901188 & 988 & 948 & 3539 & 156 & 21 & 566 \\
\hline Base Cond. OFA off & $12 / 7 / 92$ & $2: 10$ & 114409 & 0.00 & 1.264 & 1.264 & 1.264 & 132 & 122 & 223175 & 979707 & 997 & 1089 & 9564 & 171 & 22 & 599 \\
\hline GR-22A & $12 / 7 / 92$ & 1.05 & 100069 & 11.40 & 1.110 & 0.999 & 1.236 & 130 & 119 & 203782 & 960300 & 997 & 1100 & 14016 & 164 & 22 & 581 \\
\hline
\end{tabular}


Pre Modification

\begin{tabular}{|c|c|c|c|c|c|c|c|c|c|c|c|c|c|c|c|c|c|}
\hline Nosp & Date & Durm & בcoal" & 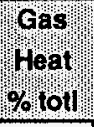 & coal & Reburn & Stoxich & $\begin{array}{l}\text { Gross } \\
\text { Power } \\
\text { nwwe }\end{array}$ & $\begin{array}{l}\text { net Net } \\
\text { Power } \\
\text { nwe }\end{array}$ & Tolal air & steamm & $\begin{array}{l}\text { Main } \\
\text { Steam } \\
\text { Temp }\end{array}$ & 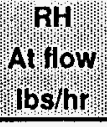 & 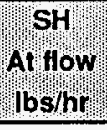 & 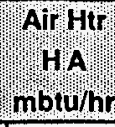 & ["fon A & 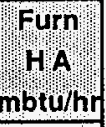 \\
\hline GA-22B & $127 / 92$ & $1: 00$ & 94323 & 15.70 & 1.100 & 0.942 & 1.229 & 129 & 119 & 200290 & 948854 & 1000 & 1097 & 19490 & 162 & 21 & 568 \\
\hline GR-22C & $12 / 7 / 92$ & 1.00 & 88644 & 20.85 & 1.119 & 0.903 & 1.219 & 130 & 119 & 194496 & 948973 & 999 & 1097 & 21111 & 162 & 21 & 565 \\
\hline Base Cond. OFA off & $12 / 8 / 92$ & $0: 27$ & 87540 & 0.00 & 1.200 & 1.204 & 1.200 & 99 & 89 & 184147 & 741704 & 989 & 1098 & 7096 & 122 & 16 & 471 \\
\hline GR-31C & $12 / 8 / 92$ & $1: 00$ & 70866 & 21.01 & 1.227 & 0.990 & 1.217 & 100 & 90 & 170678 & 744738 & 1001 & 1095 & 15093 & 128 & 16 & 461 \\
\hline GR-31F & $12 / 8 / 92$ & $1: 23$ & 70399 & 21.24 & 1.164 & 0.941 & 1.308 & 98 & 88 & 173095 & 746411 & 998 & 1094 & 15852 & 138 & 16 & 456 \\
\hline GR-32A & $12 / 8 / 92$ & $1: 00$ & 79710 & 11.13 & 1.128 & 1.021 & 1.240 & 101 & 91 & 173693 & 750449 & 998 & 1084 & 7135 & 130 & 16 & 475 \\
\hline Base Cond. OFA off & $12 / 9 / 92$ & $0: 41$ & 90429 & 0.00 & 1.167 & 1.171 & 1.167 & 101 & 91 & 187241 & 763638 & 992 & 1144 & 3412 & 120 & 17 & 491 \\
\hline GR-32C & $12 / 9 / 92$ & 1.00 & 69844 & 20.87 & 1.097 & 0.891 & 1.275 & 99 & 89 & 166006 & 730910 & 998 & 1149 & 12399 & 130 & 16 & 456 \\
\hline GR-32C; 3Mills & $12 / 9 / 92$ & 0.56 & 71250 & 20.99 & 1.106 & 0.896 & 1.239 & 102 & 92 & 176241 & 753483 & 997 & 1141 & 17862 & 127 & 16 & 463 \\
\hline Base Cond. OFA off & $12 / 9 / 92$ & $0: 15$ & 95016 & 0.00 & 1.299 & 1.302 & 1.299 & 108 & 98 & 205862 & 800406 & 999 & 1147 & 11640 & 143 & 17 & 497 \\
\hline Base Cond. OFA off & $12 / 14 / 92$ & $2: 00$ & 127673 & 0.00 & 1.258 & 1.258 & 1.258 & 145 & 137 & 234352 & 1073140 & 981 & 1092 & 1422 & 187 & 26 & 666 \\
\hline GR-12Z & $12 / 14 / 92$ & 1.02 & 131479 & 5.42 & 1.085 & 1.035 & 1.219 & 159 & 150 & 229446 & 1195714 & 979 & 1122 & 1375 & 199 & 29 & 727 \\
\hline GR $2.7 \%$ Gas & $12 / 14 / 92$ & $0: 17$ & 134689 & 2.65 & 1.020 & 1.001 & 1.237 & 159 & 150 & 227458 & 1193333 & 980 & 1143 & 1351 & 202 & 29 & 723 \\
\hline Base Cond. OFA off & $12 / 15 / 92$ & $1: 37$ & 129836 & 0.00 & 1.211 & 1.211 & 1.211 & 155 & 146 & 237785 & 1171486 & 964 & 1163 & 1407 & 184 & 28 & 717 \\
\hline GR 20\% Gas & $12 / 15 / 92$ & $0: 36$ & 108043 & 19.62 & 1.128 & 0.921 & 1.195 & 161 & 152 & 223123 & 1181622 & 996 & 1166 & 8993 & 186 & 28 & 708 \\
\hline Base Cond. OFA of & $12 / 16 / 92$ & $0: 48$ & 135250 & 0.00 & 1.227 & 1.227 & 1.227 & 157 & 149 & 243911 & 1190000 & 960 & 1166 & 1380 & 195 & 29 & 727 \\
\hline GR-12A1 & $12 / 16 / 92$ & $2: 19$ & 124136 & 10.38 & 1.096 & 0.994 & 1.210 & 161 & 152 & 227194 & 1216071 & 975 & 1165 & 1389 & 197 & 30 & 734 \\
\hline Test C1 & $1 / 15 / 93$ & 1.00 & 129234 & 7.53 & 1.134 & 1.062 & 1.233 & 161 & 150 & 231773 & 1220000 & 990 & 1519 & 2415 & 200 & 29 & 722 \\
\hline Tost C2 & $1 / 15 / 93$ & $1: 00$ & 122975 & 12.25 & 1.121 & 0.997 & 1.219 & 162 & 151 & 228682 & 1219508 & 997 & 1537 & 10620 & 199 & 29 & 710 \\
\hline Test C3 & $1 / 15 / 93$ & $0: 58$ & 116628 & 17.05 & 1.118 & 0.943 & 1.204 & 162 & 151 & 221631 & 1219153 & 999 & 1553 & 17440 & 197 & 29 & 703 \\
\hline Tost $\mathrm{C}_{4}$ & $1 / 15 / 93$ & 0.50 & 109761 & 21.76 & 1.155 & 0.920 & 1.184 & 163 & 152 & 219438 & 1220000 & 997 & 1544 & 23365 & 194 & 28 & 696 \\
\hline Tost B1 & $1 / 15 / 93$ & $0: 59$ & 139887 & 0.00 & 1.050 & 1.052 & 1.241 & 160 & 149 & 235867 & 1239167 & 972 & 1542 & 1950 & 199 & 30 & 738 \\
\hline Tost B3 & $1 / 15 / 93$ & $1: 01$ & 139538 & 0.00 & 1.020 & 1.022 & 1.206 & 160 & 149 & 234121 & 1238871 & 973 & 1545 & 2067 & 193 & 30 & 738 \\
\hline Base Cond. OFA off & $1 / 18 / 93$ & $0: 45$ & 142799 & 0.00 & 1.194 & 1.194 & 1.194 & 166 & 156 & 249671 & 1262609 & 992 & 1520 & 2318 & 204 & 30 & 745 \\
\hline Test B5 & $1 / 18 / 93$ & $1: 01$ & 141516 & 0.00 & 1.033 & 1.033 & 1.202 & 164 & 152 & 236019 & 1270323 & 971 & 1515 & 1763 & 198 & 31 & 753 \\
\hline Base Cond. OFA cooling & $1 / 19 / 93$ & $0: 39$ & 142187 & 0.00 & 1.199 & 1.201 & 1.227 & 165 & 154 & 251230 & 1272000 & 974 & 1516 & 4040 & 211 & 31 & 749 \\
\hline GR-12R & $1 / 19 / 93$ & $1: 00$ & 132746 & 5.10 & 1.071 & 1.029 & 1.272 & 161 & 149 & 235829 & 1254754 & 963 & 1518 & 2614 & 213 & 30 & 743 \\
\hline GR-13E & $1 / 19 / 93$ & $1: 00$ & 112787 & 18.54 & 1.114 & 0.921 & 1.187 & 160 & 149 & 218946 & 1205738 & 997 & 1519 & 13008 & 199 & 29 & 703 \\
\hline GR-13C & $1 / 20 / 93$ & $1: 10$ & 115745 & 18.08 & 1.108 & 0.921 & 1.192 & 163 & 152 & 234599 & 1231000 & 997 & 1544 & 14459 & 200 & 29 & 713 \\
\hline GR-12D & $1 / 20 / 93$ & $1: 05$ & 120063 & 15.17 & 1.102 & 0.948 & 1.216 & 163 & 151 & 226863 & 1230484 & 994 & 1546 & 11826 & 204 & 29 & 717 \\
\hline GR-12E & $1 / 20 / 93$ & $0: 59$ & 127283 & 9.84 & 1.073 & 0.978 & 1.195 & 162 & 150 & 229434 & 1233833 & 991 & 1554 & 7575 & 198 & 30 & 725 \\
\hline Base Cond. OFA off & $1 / 20 / 93$ & $0: 15$ & 140760 & 0.00 & 1.156 & 1.158 & 1.156 & 161 & 150 & 240941 & 1243750 & 976 & 1584 & 2988 & 192 & 30 & 741 \\
\hline 150 MWn Max NOx Red & $1 / 21 / 93$ & $1: 05$ & 109132 & 22.48 & 1.137 & 0.896 & 1.168 & 163 & 152 & 220284 & 1224091 & 997 & 1946 & 27916 & 193 & 28 & 694 \\
\hline Base Cond. OFA cooling & $1 / 21 / 93$ & $1: 30$ & 139004 & 0.00 & 1.173 & 1.176 & 1.190 & 158 & 147 & 240390 & 1221429 & 981 & 1592 & 2544 & 191 & 29 & 730 \\
\hline $120 \mathrm{MWn}$ Max NOx Red & $1 / 21 / 93$ & $1: 00$ & 85199 & 24.62 & 1.188 & 0.913 & 1.190 & 132 & 122 & 190749 & 971677 & 999 & 1542 & 12743 & 154 & 22 & 583 \\
\hline GR Environ. & $1 / 25 / 93$ & $5: 10$ & 109308 & 17.50 & 1.180 & 0.990 & 1.257 & 155 & 144 & 223404 & 1152283 & 997 & 1548 & 13797 & 195 & 27 & 673 \\
\hline Base Cond. OFA cooling & $1 / 26 / 93$ & $0: 55$ & 128790 & 0.00 & 1.208 & 1.211 & 1.250 & 149 & 139 & 232800 & 1140357 & 978 & 1537 & 2292 & 186 & 27 & 685 \\
\hline GR Environ. Test \#2 & $1 / 26 / 93$ & $5: 22$ & 108980 & 16.61 & 1.121 & 0.951 & 1.223 & 152 & 141 & 216046 & 1132215 & 997 & 1536 & 13875 & 184 & 26 & 664 \\
\hline Environ. $* 3$ & $1 / 27 / 93$ & $5: 55$ & 116374 & 16.15 & 1.14 & 0.97 & 1.23 & 162 & 151 & 229275 & 1220225 & 995 & 1599 & 13395 & 201 & 29 & 706 \\
\hline Environ. 44 (No GR) & $1 / 27 / 93$ & $6: 00$ & 131023 & 0.00 & 1.20 & 1.20 & 1.20 & 151 & 141 & 239155 & 1157591 & 967 & 1619 & 3643 & 183 & 27 & 698 \\
\hline
\end{tabular}


Cherokee Unit 3, Average Test [

Pre Modification

\begin{tabular}{|c|c|c|c|c|c|c|c|c|c|c|c|c|c|c|c|c|c|}
\hline no & Date! & purn & rooal & "Gas & copal & Reburn & Stoich & $\begin{array}{l}\text { Gross } \\
\text { Power } \\
\text { nwe }\end{array}$ & $\begin{array}{l}\text { Net } \\
\text { power } \\
\text { puwe }\end{array}$ & Thotal & Steam & Main" & 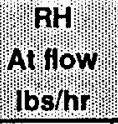 & At frow & $\begin{array}{l}\text { Air Hty } \\
\text { mbtu/hr } \\
\end{array}$ & 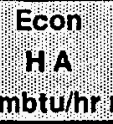 & 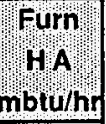 \\
\hline Environ. $: 5$ (No GA) & $1 / 28 / 93$ & $6: 04$ & 139606 & 0.00 & 1.206 & 1.206 & 1.206 & 163 & 152 & 249938 & 1248877 & 981 & 1600 & 1984 & 199 & 30 & 740 \\
\hline Base Cond. & $2 / 2 / 93$ & $0: 17$ & 138217 & 0.00 & 1.183 & 1.183 & 1.183 & 157 & 147 & 242538 & 1221514 & 978 & 1856 & 1868 & 188 & 29 & 734 \\
\hline LNB 120MW\#\# & $3 / 8 / 93$ & 2.00 & 112721 & 0.00 & 1.223 & 1.225 & 1.223 & 126 & 117 & 213576 & 962185 & 932 & 0 & 3393 & 151 & 23 & 633 \\
\hline LNB 120MW \#2 & $3 / 8 / 93$ & $2: 00$ & 113254 & 0.00 & 1.212 & 1.214 & 1.212 & 126 & 118 & 211837 & 954153 & 950 & 0 & 3416 & 152 & 23 & 628 \\
\hline LNB 150MW \#1 & $3 / 9 / 93$ & $2: 00$ & 144518 & 0.00 & 1.238 & 1.239 & 1.238 & 161 & 151 & 251015 & 1238182 & 967 & 0 & 3357 & 208 & 31 & 764 \\
\hline LNB 150MW \#2 & $3 / 9 / 93$ & $2: 00$ & 142136 & 0.00 & 1.201 & 1.202 & 1.201 & 157 & 147 & 243876 & 1227898 & 947 & 0 & 3331 & 195 & 30 & 768 \\
\hline LNB 9OMW *1 & $3 / 10 / 93$ & $2: 00$ & 88914 & 0.00 & 1.308 & 1.308 & 1.308 & 97 & 89 & 194021 & 747371 & 921 & 0 & 2758 & 129 & 17 & 513 \\
\hline LNB 9OMW *2 & $3 / 10 / 93$ & $1: 58$ & 89253 & 0.00 & 1.274 & 1.274 & 1.274 & 98 & 90 & 190408 & 748097 & 928 & 0 & 2654 & 127 & 17 & 512 \\
\hline LNB $150 \mathrm{MW}$ *3 & $3 / 11 / 93$ & 2.00 & 140628 & 0.00 & 1.212 & 1.212 & 1.212 & 159 & 149 & 244440 & 1190331 & 980 & 0 & 3192 & 203 & 29 & 741 \\
\hline LNB $150 M W: 4$ & $3 / 11 / 93$ & $2: 00$ & 141453 & 0.00 & 1.186 & 1.186 & 1.186 & 160 & 150 & 242136 & 1211074 & 970 & 0 & 3190 & 199 & 30 & 754 \\
\hline $3 M_{1}$ & 3/22/93 & 1.02 & 107276 & 20.22 & 1.08 & 0.88 & 1.13 & 157 & 147 & 213141 & 1218254 & 942 & 0 & 3443 & 168 & 30 & 750 \\
\hline $3 M 2$ & $3 / 22 / 93$ & 1.03 & 106881 & 20.34 & 1.09 & 0.88 & 1.12 & 157 & 147 & 214502 & 1210156 & 952 & 0 & 3467 & 165 & 29 & 744 \\
\hline $3 M_{3}$ & $3 / 22 / 93$ & $0: 59$ & 107574 & 20.26 & 1.14 & 0.93 & 1.15 & 158 & 148 & 221879 & 1206667 & 962 & 0 & 3484 & 172 & 29 & 740 \\
\hline 3 Mill 7 & $4 / 13 / 93$ & 1.00 & 107272 & 0.00 & 1.192 & 1.193 & 1.192 & 125 & 116 & 217012 & 963564 & 923 & 0 & 3395 & 138 & 23 & 624 \\
\hline 3 Mill 6 & $4 / 13 / 93$ & 1.00 & 108328 & 0.00 & 1.163 & 1.164 & 1.163 & 127 & 117 & 216033 & 972327 & 932 & 0 & 3436 & 136 & 23 & 628 \\
\hline Level 6 1/2 & $4 / 15 / 93$ & $2: 05$ & 132176 & 0.00 & 1.209 & 1.209 & 1.209 & 157 & 147 & 236762 & 1190873 & 966 & 0 & 3453 & 185 & 29 & 729 \\
\hline Level 4 & $4 / 15 / 93$ & $1: 10$ & 132081 & 0.00 & 1.212 & 1.212 & 1.212 & 157 & 147 & 236963 & 1190704 & 965 & 0 & 3449 & 186 & 29 & 729 \\
\hline Level 3 & $4 / 15 / 93$ & $0: 53$ & 132366 & 0.00 & 1.210 & 1.210 & 1.210 & 158 & 147 & 236303 & 1191296 & 967 & 0 & 3461 & 186 & 29 & 729 \\
\hline Level 5 1/2 & $4 / 15 / 93$ & $1: 58$ & 132167 & 0.00 & 1.182 & 1.183 & 1.182 & 157 & 146 & 235825 & 1195042 & 957 & 0 & 3395 & 180 & 29 & 733 \\
\hline Base Cond & $4 / 15 / 93$ & $5: 25$ & 132182 & 0.00 & 1.195 & 1.195 & 1.195 & 157 & 147 & 236260 & 1192178 & 963 & 0 & 3437 & 183 & 29 & 731 \\
\hline Level 5 1/2 & $4 / 16 / 93$ & $1: 47$ & 135162 & 0.00 & 1.232 & 1.232 & 1.232 & 161 & 151 & 247500 & 1204194 & 984 & 0 & 3650 & 196 & 29 & 731 \\
\hline Level 6 1/2 & $4 / 16 / 93$ & $1: 19$ & 135361 & 0.00 & 1.220 & 1.222 & 1.220 & 161 & 150 & 247523 & 1212250 & 974 & 0 & 3599 & 193 & 29 & 736 \\
\hline \begin{tabular}{|l} 
Level 3 \\
\end{tabular} & $4 / 16 / 93$ & $0: 44$ & 135550 & 0.00 & 1.230 & 1.231 & 1.230 & 161 & 150 & 248308 & 1210222 & 974 & 0 & 3680 & 194 & 29 & 737 \\
\hline Level 4 & $4 / 16 / 93$ & $1: 00$ & 135705 & 0.00 & 1.229 & 1.231 & 1.229 & 161 & 150 & 248259 & 1211967 & 974 & 0 & 3670 & 194 & 29 & 737 \\
\hline North out, South in & $4 / 16 / 93$ & 0.20 & 135478 & 0.00 & 1.281 & 1.282 & 1.281 & 161 & 151 & 247553 & 1201429 & 985 & 0 & 3664 & 205 & 29 & 731 \\
\hline South out, North in & $4 / 16 / 93$ & $0: 20$ & 134606 & 0.00 & 1.216 & 1.217 & 1.216 & 161 & 150 & 247562 & 1202381 & 982 & 0 & 3633 & 192 & 29 & 729 \\
\hline Base Cond & $4 / 16 / 93$ & $6: 25$ & 135460 & 0.00 & 1.228 & 1.230 & 1.228 & 161 & 150 & 247714 & 1210081 & 976 & 0 & 3635 & 194 & 29 & 735 \\
\hline Level 4 & $4 / 19 / 93$ & $0: 56$ & 108837 & 19.50 & 1.178 & 0.964 & 1.205 & 162 & 151 & 225868 & 1191228 & 997 & 0 & 11697 & 189 & 29 & 706 \\
\hline Level 3 & $4 / 19 / 93$ & $0: 52$ & 108733 & 19.51 & 1.177 & 0.963 & 1.204 & 162 & 151 & 225729 & 1190566 & 997 & 0 & 11653 & 189 & 29 & 706 \\
\hline Level 5 1/2 & $4 / 19 / 93$ & $2: 29$ & 107787 & 19.73 & 1.196 & 0.977 & 1.239 & 161 & 150 & 229197 & 1180600 & 997 & 0 & 16114 & 195 & 28 & 694 \\
\hline Level $61 / 2$ & 4/19/93 & $1: 10$ & 108196 & 19.72 & 1.204 & 0.984 & 1.247 & 162 & 151 & 230268 & 1180000 & 997 & 0 & 16411 & 198 & 28 & 695 \\
\hline Base Cond. OFA on & $4 / 19 / 93$ & 1.00 & 132138 & 0.00 & 1.109 & 1.120 & 1.302 & 156 & 145 & 236365 & 1193770 & 951 & 0 & 3721 & 197 & 29 & 728 \\
\hline GR & $4 / 19 / 93$ & $5: 42$ & 107835 & 19.71 & 1.191 & 0.973 & 1.234 & 161 & 150 & 228332 & 1180644 & 997 & 0 & 15645 & 194 & 28 & 695 \\
\hline Lovel $61 / 2$ & $4 / 20 / 93$ & $1: 47$ & 118536 & 0.00 & 1.183 & 1.183 & 1.183 & 140 & 130 & 224896 & 1079815 & 927 & 0 & 3288 & 158 & 26 & 680 \\
\hline Base Cond 130MW & $4 / 20 / 93$ & $3: 35$ & 118485 & 0.00 & 1.178 & 1.178 & 1.178 & 140 & 130 & 224650 & 1079537 & 928 & 0 & 3294 & 156 & 26 & 680 \\
\hline Base Cond $120 \mathrm{MW}$ & $4 / 20 / 93$ & $2: 55$ & 110982 & 0.00 & 1.265 & 1.266 & 1.265 & 132 & 123 & 218887 & 962761 & 991 & 0 & 5572 & 160 & 22 & 603 \\
\hline Base Cond. OFA off & $4 / 21 / 93$ & $7: 40$ & 107591 & 0.00 & 1.229 & 1.230 & 1.229 & 128 & 118 & 211507 & 936625 & 980 & 0 & 4237 & 149 & 22 & 594 \\
\hline Base Cond. OFA off & $4 / 23 / 93$ & $0: 30$ & 134843 & 0.00 & 1.201 & 1.203 & 1.201 & 160 & 149 & 243990 & 1200645 & 981 & 0 & 3565 & 185 & 29 & 729 \\
\hline $4 \mathrm{M} 12$ (OFA off) & $4 / 23 / 93$ & $1: 00$ & 133541 & 0.00 & 1.158 & 1.160 & 1.158 & 157 & 147 & 240464 & 1216721 & 945 & 0 & 3541 & 172 & 29 & 745 \\
\hline $4 \mathrm{M} 13 \mathrm{a}(78,000 \mathrm{scfm}$ OFA & $4 / 23 / 93$ & $0: 20$ & 135843 & 0.00 & 0.900 & 0.902 & 1.206 & 157 & 146 & 230443 & 1259524 & 909 & 0 & 3511 & 179 & 31 & 777 \\
\hline
\end{tabular}


Cherokee Unit 3, Average Test L

Pre Modification

\begin{tabular}{|c|c|c|c|c|c|c|c|c|c|c|c|c|c|c|c|c|c|}
\hline Test No & Date & Durp & Coral & 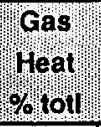 & Coalm & Reburn & Storich & Gross & Power & Total Air? & $\begin{array}{l}\text { Steam } \\
\text { losshrint }\end{array}$ & $\begin{array}{l}\text { Main } \\
\text { Steam } \\
\text { Temp }\end{array}$ & Affrow & 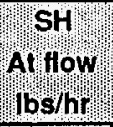 & 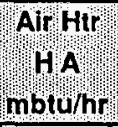 & Econ & 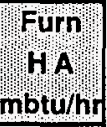 \\
\hline 4M 13b $(70,000 \mathrm{sefm}$ OFA & $4 / 23 / 93$ & 0.50 & 135673 & 0.00 & 0.944 & 0.945 & 1.215 & 157 & 146 & 233023 & 1267308 & 904 & 0 & 3545 & \begin{tabular}{|l|}
178 \\
\end{tabular} & 31 & 780 \\
\hline \begin{tabular}{|l|l} 
Base Cond. OFA On \\
\end{tabular} & $4 / 27 / 93$ & $0: 30$ & 137393 & 0.00 & 1.217 & 1.222 & 1.289 & 162 & 150 & 249563 & 1221613 & 991 & 0 & 5772 & 205 & 30 & 733 \\
\hline GR on $150 \mathrm{MW}, 11 \%$ Gas & $4 / 27 / 93$ & 0.53 & 121810 & 11.43 & 1.218 & 1.091 & 1.227 & 161 & 150 & 235246 & 1208519 & 995 & 0 & 5238 & 193 & 29 & 729 \\
\hline GR on $150 \mathrm{MW}, 17 \%$ Gas & $4 / 27 / 93$ & $2: 48$ & 113324 & 17.18 & 1.104 & 0.927 & 1.202 & 162 & 151 & 226405 & 1208037 & 997 & 0 & 7450 & 188 & 29 & 722 \\
\hline Base Cond. OFA on & $4 / 28 / 93$ & $0: 44$ & 128025 & 0.00 & 1.228 & 1.233 & 1.297 & 149 & 138 & 238462 & 1137333 & 966 & 0 & 3617 & 189 & 27 & 703 \\
\hline GR on Auto & $4 / 28 / 93$ & $6: 35$ & 105563 & 16.42 & 1.106 & 0.938 & 1.209 & 149 & 138 & 216279 & 1097551 & 996 & 0 & 7627 & 174 & 26 & 670 \\
\hline GR on Auto & $5 / 3 / 93$ & $7: 00$ & 109090 & 17.13 & 1.144 & 0.962 & 1.240 & 153 & 142 & 228883 & 1138217 & 996 & 0 & 7358 & 185 & 27 & 693 \\
\hline Base Cond. OFA on & $5 / 6 / 93$ & $2: 45$ & 128448 & 0.00 & 1.229 & 1.233 & 1.293 & 149 & 139 & 237273 & 1163494 & 937 & 0 & 2943 & 183 & 28 & 720 \\
\hline GR on Auto & $5 / 6 / 93$ & $1: 15$ & 109881 & 15.34 & 1.125 & 0.965 & 1.221 & 153 & 142 & 218626 & 1143947 & 981 & 0 & 3561 & 178 & 27 & 697 \\
\hline Base Cond. OFA off & $5 / 6 / 93$ & 0.21 & 111951 & 0.00 & 1.261 & 1.264 & 1.261 & 132 & 122 & 217774 & 970203 & 989 & 0 & 3435 & 155 & 23 & 615 \\
\hline GR on Auto $150 \mathrm{MW}$ & $5 / 7 / 93$ & $4: 26$ & 112649 & 17.57 & 1.113 & 0.931 & 1.208 & 159 & 148 & 223455 & 1206418 & 974 & 0 & 3979 & 186 & 29 & 735 \\
\hline Gh on Auto 160MW & $5 / 7 / 93$ & $1: 59$ & 121216 & 17.39 & 1.110 & 0.929 & 1.192 & 171 & 159 & 231918 & 1295750 & 986 & 0 & 3295 & 199 & 32 & 778 \\
\hline GR on Auto $140 \mathrm{MW}$ & $5 / 7 / 93$ & $4: 50$ & 106629 & 17.36 & 1.129 & 0.947 & 1.232 & 151 & 140 & 217963 & 1122062 & 990 & 0 & 4270 & 180 & 27 & 690 \\
\hline Base Cond. OFA oft & $5 / 7 / 93$ & $0: 35$ & 133176 & 0.00 & 1.264 & 1.265 & 1.264 & 156 & 146 & 243468 & 1179167 & 974 & 0 & 3174 & 193 & 28 & 724 \\
\hline GR on Auto & $5 / 11 / 93$ & 6.08 & 104108 & 17.10 & 1.198 & 1.010 & 1.291 & 150 & 139 & 218598 & 1089265 & 996 & 0 & 9325 & 185 & 26 & 660 \\
\hline GR 13 & $5 / 25 / 93$ & $15: 04$ & 110684 & 16.79 & 1.126 & 0.951 & 1.226 & 158 & 147 & 225159 & 1164920 & 996 & 0 & 8647 & 187 & 28 & 699 \\
\hline GR 14 & $5 / 25 / 93$ & $1: 25$ & 81198 & 16.15 & 1.158 & 0.990 & 1.306 & 113 & 103 & 185230 & 823513 & 971 & 0 & 4070 & 140 & 19 & 530 \\
\hline GR 15 & $5 / 26 / 93$ & $1: 29$ & 84832 & 16.24 & 1.176 & 1.004 & 1.306 & 119 & 109 & 192062 & 862219 & 982 & 0 & 4397 & 147 & 20 & 549 \\
\hline LNB-OFA & $5 / 26 / 93$ & $0: 42$ & 85765 & 0.00 & 1.184 & 1.199 & 1.432 & 99 & 90 & 186468 & 741474 & 931 & 0 & 3984 & 133 & 16 & 485 \\
\hline LNB & $5 / 26 / 93$ & $9: 44$ & 125678 & 0.00 & 1.204 & 1.206 & 1.204 & 146 & 137 & 229683 & 1128501 & 952 & 0 & 3937 & 168 & 27 & 695 \\
\hline LNB & $5 / 27 / 93$ & $0: 10$ & 103797 & 0.00 & 1.236 & 1.241 & 1.236 & 124 & 114 & 212013 & 917407 & 972 & 0 & 4177 & 141 & 21 & 573 \\
\hline LNB-OFA & $5 / 27 / 93$ & $0: 45$ & 135091 & 0.00 & 1.140 & 1.147 & 1.274 & 158 & 147 & 241483 & 1199783 & 980 & 0 & 4461 & 195 & 29 & 726 \\
\hline GR-LNB 16 & $5 / 27 / 93$ & $13: 40$ & 110253 & 15.93 & 1.147 & 0.978 & 1.241 & 154 & 144 & 227015 & 1140676 & 995 & 0 & 7485 & 184 & 27 & 688 \\
\hline GR-LNB 17 & $5 / 28 / 93$ & $2: 57$ & 86180 & 14.87 & 1.209 & 1.049 & 1.341 & 118 & 108 & 197193 & 865399 & 973 & 0 & 4505 & 149 & 20 & 551 \\
\hline LNB & $5 / 28 / 93$ & $1: 23$ & 81863 & 0.00 & 1.393 & 1.399 & 1.393 & 93 & 84 & 192218 & 699170 & 942 & 0 & 4155 & 123 & 15 & 460 \\
\hline GR-LNB 20b & $6 / 3 / 93$ & $8: 51$ & 107116 & 16.83 & 1.069 & 0.901 & 1.181 & 153 & 142 & 210403 & 1126804 & 993 & 0 & 10859 & 173 & 27 & 679 \\
\hline LNB & $6 / 3 / 93$ & 1.05 & 88649 & 0.00 & 1.347 & 1.350 & 1.347 & 103 & 95 & 196080 & 761725 & 959 & 0 & 4230 & 132 & 17 & 492 \\
\hline LNB (low load) & $6 / 4 / 93$ & $6: 52$ & 84677 & 0.00 & 1.385 & 1.388 & 1.385 & 97 & 89 & 190380 & 723239 & 951 & 0 & 4567 & 128 & 16 & 471 \\
\hline LNB (high load) & $6 / 4 / 93$ & $5: 25$ & 133437 & 0.00 & 1.246 & 1.247 & 1.246 & 157 & 146 & 241367 & 1199289 & 955 & 0 & 4418 & 191 & 29 & 731 \\
\hline LNB-OFA & $6 / 4 / 93$ & $2: 31$ & 137915 & 0.00 & 1.115 & 1.119 & 1.242 & 159 & 149 & 238263 & 1269880 & 924 & 0 & 4132 & 189 & 31 & 775 \\
\hline GR-LNB & $6 / 4 / 93$ & $7: 42$ & 110334 & 16.81 & 1.053 & 0.888 & 1.165 & 157 & 147 & 213422 & 1164427 & 995 & 0 & 9843 & 176 & 28 & 700 \\
\hline LNB & $6 / 8 / 93$ & $1: 35$ & 127379 & 0.00 & 1.253 & 1.255 & 1.253 & 149 & 139 & 236646 & 1128646 & 955 & 0 & 3709 & 179 & 27 & 701 \\
\hline LNB-OFA & $6 / 8 / 93$ & $1: 40$ & 127822 & 0.00 & 1.218 & 1.223 & 1.288 & 149 & 138 & 235405 & 1139901 & 949 & 0 & 3713 & 183 & 27 & 708 \\
\hline GR-LNB 22a & $6 / 8 / 93$ & $6: 21$ & 101957 & 16.86 & 1.171 & 0.989 & 1.269 & 145 & 134 & 212158 & 1054627 & 992 & 0 & 7486 & 176 & 25 & 649 \\
\hline GR-LNB 22b & $6 / 8 / 93$ & 5:30 & 110084 & 17.23 & 1.053 & 0.884 & 1.164 & 158 & 147 & 215138 & 1160091 & 997 & 0 & 11450 & 175 & 28 & 699 \\
\hline GR.LNB 23a & $6 / 9 / 93$ & $1: 16$ & 87779 & 15.82 & 1.063 & 0.909 & 1.207 & 125 & 115 & 187305 & 890215 & 997 & 0 & 10693 & 138 & 20 & 559 \\
\hline LNB-OFA & $6 / 9 / 93$ & $0: 30$ & 81446 & 0.00 & 1.122 & 1.131 & 1.355 & 94 & 85 & 171211 & 688972 & 956 & 0 & 4469 & 118 & 15 & 458 \\
\hline LNB & $6 / 9 / 93$ & $16: 03$ & 108345 & 0.00 & 1.284 & 1.287 & 1.284 & 126 & 116 & 214188 & 950036 & 952 & 0 & 5018 & 153 & 22 & 601 \\
\hline GR-LNB 23b & $6 / 9 / 93$ & 4:28 & 105101 & 16.90 & 1.199 & 1.013 & 1.289 & 149 & 138 & 223166 & 1090496 & 992 & 0 & 6716 & 183 & 26 & 669 \\
\hline LNB & $6 / 10 / 93$ & $8: 47$ & 105994 & 0.00 & 1.260 & 1.262 & 1.260 & 125 & 115 & 211843 & 920397 & 977 & 0 & 5348 & 148 & 21 & 582 \\
\hline
\end{tabular}


Cherokee Unit 3, Average Test C

Pre Modification

\begin{tabular}{|c|c|c|c|c|c|c|c|c|c|c|c|c|c|c|c|c|c|}
\hline restrły & Datem & pur & $\begin{array}{l}\text { Coal } \\
\text { Frond } \\
\text { [losh }\end{array}$ & 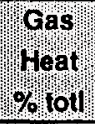 & $\begin{array}{l}\text { coal } \\
\text { Storytat }\end{array}$ & fépurn & $\begin{array}{l}\text { Exit } \\
\text { Stolch } \\
\text { (y) }\end{array}$ & $\begin{array}{l}\text { Gross } \\
\text { power } \\
\text { nwe }\end{array}$ & $\begin{array}{l}\text { Net } \\
\text { Power } \\
\text { puw }\end{array}$ & 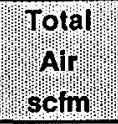 & Steam & $\begin{array}{l}\text { Main } \\
\text { Steam } \\
\text { Temp }\end{array}$ & 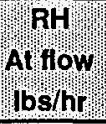 & $\begin{array}{l}\text { SH } \\
\text { Affow } \\
\text { (bsihr }\end{array}$ & 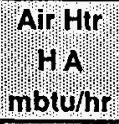 & $\begin{array}{l}\text { Econ } \\
\text { mbtu/hr } \\
\text { mbth }\end{array}$ & $\begin{array}{l}\text { Furn } \\
\text { mbtuan } \\
\text { mbtum }\end{array}$ \\
\hline LNB-OFA & $6 / 10 / 93$ & $1: 16$ & 135703 & 0.00 & 1.200 & 1.205 & 1.307 & 159 & 148 & 240132 & 1218442 & 953 & 0 & 4156 & 201 & 30 & 742 \\
\hline GR-LNB 24 & $6 / 10 / 93$ & $2: 57$ & 110517 & 17.42 & 1.178 & 0.988 & 1.266 & 158 & 148 & 228295 & 1165749 & 996 & 0 & 10355 & 195 & 28 & 698 \\
\hline LNB & $6 / 10 / 93$ & 0,37 & 136793 & 0.00 & 1.235 & 1.237 & 1.235 & 159 & 149 & 245179 & 1230000 & 943 & 0 & 4320 & 187 & 30 & 751 \\
\hline GR-LNB 25a & $6 / 11 / 93$ & $5: 28$ & 101493 & 15.87 & 1.114 & 0.952 & 1.222 & 144 & 134 & 209043 & 1046837 & 994 & 0 & 12835 & 166 & 24 & 634 \\
\hline GR-LNB 25b & $6 / 11 / 93$ & $9: 06$ & 112279 & 16.16 & 1.117 & 0.950 & 1.212 & 159 & 148 & 222755 & 1166549 & 996 & 0 & 12950 & 184 & 28 & 696 \\
\hline GR-LNB 26a & $6 / 12 / 93$ & $11: 22$ & 103242 & 15.88 & 1.068 & 0.911 & 1.188 & 147 & 136 & 205936 & 1068493 & 995 & 0 & 16439 & 167 & 25 & 640 \\
\hline GR.LNB $26 b$ & $6 / 12 / 93$ & $2: 13$ & 77735 & 8.74 & 1.156 & 1.071 & 1.318 & 99 & 89 & 173515 & 717418 & 978 & 0 & 5247 & 123 & 16 & 468 \\
\hline LNB-OFA & $6 / 12 / 93$ & $7: 11$ & 125768 & 0.00 & 1.106 & 1.111 & 1.207 & 147 & 137 & 221490 & 1117982 & 961 & 0 & 4900 & 166 & 27 & 689 \\
\hline LNB-OFA & $6 / 13 / 93$ & $9: 43$ & 76903 & 0.00 & 1.305 & 1.316 & 1.381 & 87 & 79 & 171221 & 665303 & 920 & 0 & 5061 & 114 & 14 & 440 \\
\hline GR-LNB 28 & $6 / 14 / 93$ & $4: 06$ & 113195 & 16.90 & 1.077 & 0.907 & 1.177 & 160 & 149 & 221655 & 1192146 & 994 & 0 & 7366 & 180 & 29 & 717 \\
\hline LNB. & $6 / 14 / 93$ & $1: 59$ & 120039 & 0.00 & 1.227 & 1.230 & 1.227 & 138 & 129 & 221993 & 1066859 & 941 & 0 & 5113 & 161 & 25 & 670 \\
\hline LNB & $6 / 18 / 93$ & $0: 38$ & 121009 & 0.00 & 1.188 & 1.192 & 1.188 & 145 & 136 & 232919 & 1067799 & 1000 & 0 & 16158 & 165 & 25 & 637 \\
\hline GR-LNB 29 & $6 / 18 / 93$ & $14: 24$ & 105693 & 17.81 & 1.109 & 0.926 & 1.211 & 153 & 142 & 218273 & 1127750 & 997 & 108 & 20667 & 178 & 26 & 663 \\
\hline GR-LNB 30a & $6 / 19 / 93$ & $0: 30$ & 78474 & 18.54 & 1.197 & 0.995 & 1.319 & 114 & 104 & 186016 & 815086 & 1001 & 0 & 14343 & 143 & 18 & 506 \\
\hline LNB & $6 / 19 / 93$ & $9: 15$ & 81061 & 0.00 & 1.318 & 1.322 & 1.319 & 94 & 85 & 181229 & 690957 & 977 & 0 & 8147 & 117 & 15 & 441 \\
\hline GR-LNB 30b & $6 / 19 / 93$ & $11: 53$ & 105584 & 18.64 & 1.054 & 0.870 & 1.161 & 155 & 144 & 212397 & 1137486 & 997 & 1157 & 32235 & 173 & 26 & 658 \\
\hline GR-LNB $30 c$ & $6 / 19 / 93$ & $1: 33$ & 77325 & 16.62 & 1.109 & 0.943 & 1.269 & 108 & 98 & 174718 & 775014 & 995 & 40 & 10996 & 131 & 17 & 490 \\
\hline GR-LNB 23 & $6 / 23 / 93$ & $7: 35$ & 110131 & 18.35 & 1.060 & 0.877 & 1.160 & 159 & 149 & 216811 & 1187149 & 997 & 0 & 15566 & 175 & 28 & 703 \\
\hline GA-LNB 32b & $6 / 23 / 93$ & $1: 09$ & 96516 & 17.45 & 1.081 & 0.907 & 1.203 & 139 & 129 & 197925 & 1012043 & 993 & 0 & 12113 & 157 & 24 & 618 \\
\hline LNB-OFA cooling & $6 / 24 / 93$ & 6.25 & 80146 & 0.00 & 1.202 & 1.208 & 1.278 & 93 & 85 & 172577 & 687386 & 968 & 0 & 5900 & 113 & 15 & 446 \\
\hline GR-LNB 33a & $6 / 24 / 93$ & $6: 00$ & 92834 & 17.10 & 1.075 & 0.905 & 1.202 & 134 & 124 & 196457 & 968909 & 997 & 23 & 15011 & 151 & 22 & 585 \\
\hline GR-LNB 33 & $6 / 24 / 93$ & $11: 22$ & 108227 & 18.35 & 1.054 & 0.873 & 1.160 & 158 & 148 & 215139 & 1165609 & 996 & 29 & 17183 & 173 & 27 & 688 \\
\hline GR-LNB 34a & $6 / 25 / 93$ & $1: 52$ & 68421 & 14.11 & 1.173 & 1.030 & 1.349 & 92 & 83 & 166204 & 674211 & 981 & 0 & 6936 & 119 & 15 & 432 \\
\hline LNB-OFA & $6 / 25 / 93$ & $4: 03$ & 78347 & 0.00 & 1.185 & 1.196 & 1.369 & 89 & 79 & 173363 & 685403 & 926 & 0 & 5899 & 115 & 15 & 448 \\
\hline GR-LNB 34 & $6 / 25 / 93$ & $8: 00$ & 104912 & 17.42 & 1.060 & 0.888 & 1.175 & 151 & 141 & 209807 & 1119480 & 994 & 0 & 13915 & 171 & 26 & 665 \\
\hline LNB (some OFA) & $6 / 28 / 93$ & $1: 03$ & 137238 & 0.00 & 1.189 & 1.189 & 1.191 & 160 & 148 & 240977 & 1214844 & 978 & 0 & 5405 & 182 & 29 & 736 \\
\hline LNB (some OFA) & $6 / 29 / 93$ & $12: 15$ & 117110 & 0.00 & 1.154 & 1.155 & 1.189 & 136 & 124 & 218918 & 1036440 & 961 & 0 & 6328 & 152 & 24 & 640 \\
\hline LNB & $6 / 30 / 93$ & $11: 51$ & 108672 & 0.00 & 1.220 & 1.221 & 1.220 & 127 & 116 & 210612 & 945475 & 985 & 0 & 8344 & 148 & 22 & 584 \\
\hline GR-LNB 35 & $6 / 30 / 93$ & $1: 48$ & 114578 & 16.56 & 1.112 & 0.941 & 1.207 & 161 & 149 & 225995 & 1202018 & 997 & 0 & 14300 & 185 & 29 & 712 \\
\hline GR-LNB 35a & $6 / 30 / 93$ & $6: 05$ & 113256 & 16.52 & 1.175 & 0.996 & 1.262 & 160 & 147 & 233001 & 1187541 & 997 & 0 & 15340 & 192 & 28 & 699 \\
\hline GR-LNB 35b & $6 / 30 / 93$ & $1: 53$ & 101543 & 16.47 & 1.229 & 1.044 & 1.317 & 143 & 131 & 223189 & 1053950 & 996 & 10 & 13473 & 179 & 25 & 632 \\
\hline GR-OLNB 36a & $7 / 1 / 93$ & $8: 22$ & 75163 & 12.30 & 1.266 & 1.132 & 1.418 & 99 & 88 & 183412 & 734912 & 966 & 0 & 7199 & 131 & 16 & 468 \\
\hline GP-LNB 36 & $7 / 1 / 93$ & $15: 37$ & 109011 & 15.97 & 1.099 & 0.937 & 1.202 & 153 & 141 & 214425 & 1138706 & 994 & 17 & 18764 & 174 & 27 & 671 \\
\hline GR 37a & $7 / 2 / 93$ & $14: 55$ & 91390 & 14.78 & 1.131 & 0.980 & 1.259 & 126 & 115 & 192716 & 926914 & 988 & 15 & 19794 & 147 & 21 & 564 \\
\hline GR 37 & $7 / 2 / 93$ & $7: 05$ & 115392 & 16.28 & 1.116 & 0.947 & 1.208 & 161 & 149 & 224382 & 1210316 & 997 & 62 & 20901 & 188 & 29 & 709 \\
\hline GR-LNB 38 & $7 / 3 / 93$ & $7: 46$ & 112169 & 15.94 & 1.106 & 0.943 & 1.202 & 159 & 147 & 219199 & 1177277 & 987 & 78 & 33089 & 182 & 27 & 679 \\
\hline GR-LNB 38a & $7 / 3 / 93$ & $8: 43$ & 110737 & 15.84 & 1.265 & 1.081 & 1.341 & 155 & 143 & 214154 & 1143061 & 997 & 25 & 23503 & 199 & 27 & 672 \\
\hline GR-LNB 39a & $7 / 4 / 93$ & $17: 27$ & 89454 & 12.57 & 1.387 & 1.235 & 1.495 & 119 & 108 & 186634 & 872129 & 986 & 3 & 13189 & 170 & 20 & 541 \\
\hline GA-LNB 39 & $7 / 4 / 93$ & $6: 33$ & 114795 & 15.16 & 1.338 & 1.153 & 1.399 & 159 & 147 & 219205 & 1173866 & 997 & 0 & 20363 & 215 & 28 & 692 \\
\hline GR-LNB 40a & $7 / 5 / 93$ & $11: 52$ & 81700 & 10.62 & 1.517 & 1.381 & 1.634 & 105 & 95 & 177264 & 768092 & 983 & 0 & 10126 & 164 & 17 & 488 \\
\hline
\end{tabular}


Cherokee Unit 3, Average Test [

Pre Modification

\begin{tabular}{|c|c|c|c|c|c|c|c|c|c|c|c|c|c|c|c|c|c|}
\hline Test & Date्य) & מצy. & Coral & 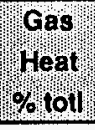 & Coal & Reburn & Strolch & $\begin{array}{l}\text { Gross } \\
\text { Power } \\
\text { nwe }\end{array}$ & $\begin{array}{l}\text { Net } \\
\text { Powerl } \\
\text { nwo }\end{array}$ & WTotal & Steam & $\begin{array}{l}\text { Main } \\
\text { Steam } \\
\text { Temp }\end{array}$ & 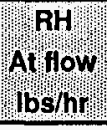 & $\begin{array}{l}\text { Shy } \\
\text { At now } \\
\text { Ibs/hy }\end{array}$ & 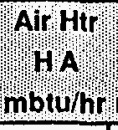 & 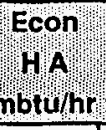 & Furn \\
\hline GR-LNB 40 & $7 / 5 / 93$ & $12: 08$ & 110736 & 14.71 & 1.444 & 1.252 & 1.497 & 152 & 140 & 213890 & 1118801 & 993 & 83 & 18898 & 219 & 26 & 666 \\
\hline GR-LNB 52a & $7 / 17 / 93$ & $8: 31$ & 79101 & 16.36 & 1.174 & 1.002 & 1.328 & 108 & 97 & 179699 & 815654 & 961 & 0 & 8745 & 135 & 18 & 516 \\
\hline GR-LNB 52 & $7 / 17 / 93$ & $5: 45$ & 107944 & 16.95 & 1.129 & 0.952 & 1.226 & 154 & 141 & 219497 & 1146028 & 997 & 99 & 24861 & 181 & 26 & 670 \\
\hline LNB & $7 / 19 / 93$ & $1: 53$ & 106496 & 0.00 & 1.204 & 1.204 & 1.204 & 124 & 114 & 213817 & 918704 & 996 & 0 & 7616 & 138 & 21 & 582 \\
\hline LNB-OFA & $7 / 19 / 93$ & $0: 22$ & 110577 & 0.00 & 1.122 & 1.123 & 1.214 & 128 & 117 & 216790 & 970186 & 983 & 0 & 6550 & 141 & 22 & 613 \\
\hline GR-LNB 53a & $7 / 19 / 93$ & $3: 29$ & 93598 & 16.05 & 1.088 & 0.927 & 1.213 & 130 & 119 & 198618 & 955417 & 995 & 0 & 17783 & 147 & 22 & 587 \\
\hline GR-LNB 53 & $7 / 19 / 93$ & $7: 06$ & 113352 & 16.68 & 1.117 & 0.943 & 1.208 & 159 & 146 & 223835 & 1189204 & 997 & 250 & 19969 & 181 & 28 & 706 \\
\hline LNB & $7 / 21 / 93$ & $8: 34$ & 76228 & 0.00 & 1.278 & 1.278 & 1.278 & 86 & 75 & 175788 & 658291 & 940 & 0 & 6567 & 104 & 14 & 428 \\
\hline GR.LNB 54 & $7 / 21 / 93$ & $4: 52$ & 108745 & 16.89 & 1.111 & 0.937 & 1.207 & 152 & 140 & 219369 & 1144957 & 997 & 3 & 17092 & 170 & 27 & 677 \\
\hline LNB & $7 / 23 / 93$ & $2: 35$ & 91398 & 0.00 & 1.260 & 1.260 & 1.260 & 96 & 85 & 181205 & 763630 & 898 & 0 & 7180 & 124 & 19 & 505 \\
\hline GR-LNB 55 & $7 / 23 / 93$ & $4: 53$ & 110471 & 16.48 & 1.167 & 0.989 & 1.254 & 155 & 143 & 224082 & 1151463 & 997 & 27 & 16973 & 186 & 27 & 684 \\
\hline GR-LNB 55a & $7 / 23 / 93$ & $1: 08$ & 100763 & 16.06 & 1.177 & 1.004 & 1.277 & 139 & 127 & 208479 & 1027666 & 989 & 0 & 9683 & 171 & 24 & 636 \\
\hline LNB & $7 / 23 / 93$ & $3: 55$ & 75018 & 0.00 & 1.254 & 1.254 & 1.266 & 82 & 72 & 173970 & 650024 & 911 & 0 & 6680 & 98 & 14 & 437 \\
\hline LNB & $7 / 24 / 93$ & $1: 52$ & 78094 & 0.00 & 1.344 & 1.344 & 1.344 & 87 & 77 & 182387 & 675137 & 928 & 0 & 7533 & 107 & 14 & 446 \\
\hline LNB-OFA & $7 / 24 / 93$ & 0.36 & 88171 & 0.00 & 1.301 & 1.301 & 1.464 & 99 & 89 & 186576 & 746830 & 951 & 0 & 6168 & 137 & 17 & 491 \\
\hline GA-LNB 56 & $7 / 24 / 93$ & $7: 45$ & 109225 & 16.60 & 1.151 & 0.974 & 1.242 & 154 & 141 & 220171 & 1142849 & 996 & 0 & 18945 & 185 & 27 & 676 \\
\hline GA-LNB 56a & $7 / 24 / 93$ & $2: 09$ & 76098 & 15.60 & 1.206 & 1.037 & 1.357 & 102 & 91 & 173585 & 767608 & 946 & 0 & 7085 & 131 & 17 & 497 \\
\hline GR-LNB 57a & $7 / 25 / 93$ & $1: 10$ & 62811 & 15.55 & 1.318 & 1.136 & 1.473 & 82 & 72 & 161845 & 625994 & 941 & 0 & 6634 & 115 & 13 & 415 \\
\hline LNB-OFA & $7 / 25 / 93$ & $5: 52$ & 81925 & 0.00 & 1.080 & 1.095 & 1.429 & 92 & 82 & 175681 & 715693 & 909 & 0 & 6281 & 124 & 16 & 470 \\
\hline GR-LNB 570 & $7 / 25 / 93$ & $10: 19$ & 95992 & 16.35 & 1.194 & 1.017 & 1.307 & 134 & 122 & 203531 & 994774 & 986 & 40 & 13611 & 166 & 23 & 603 \\
\hline GR-LNB 57 & $7 / 25 / 93$ & $6: 14$ & 114215 & 16.37 & 1.115 & 0.945 & 1.209 & 160 & 148 & 222568 & 1198755 & 996 & 0 & 14591 & 186 & 28 & 709 \\
\hline GR-LNB 58a & $7 / 26 / 93$ & $10: 15$ & 85467 & 15.90 & 1.274 & 1.093 & 1.399 & 118 & 107 & 193771 & 873265 & 988 & 6 & 11136 & 156 & 20 & 539 \\
\hline GA-LNB 58 & $7 / 26 / 93$ & $8: 34$ & 114931 & 16.06 & 1.127 & 0.959 & 1.219 & 160 & 147 & 224715 & 1206515 & 996 & 23 & 18228 & 189 & 28 & 709 \\
\hline GA-LNB 58b & $7 / 26 / 93$ & $5: 09$ & 103155 & 15.49 & 1.190 & 1.021 & 1.290 & 143 & 131 & 210698 & 1062357 & 990 & 91 & 13659 & 176 & 25 & 642 \\
\hline GR-LN8 59a & $7 / 27 / 93$ & $10: 48$ & 86014 & 15.43 & 1.235 & 1.064 & 1.368 & 118 & 106 & 192711 & 879577 & 978 & 23 & 10341 & 154 & 20 & 542 \\
\hline LNB-OFA & $7 / 27 / 93$ & $3: 21$ & 141613 & 0.00 & 1.158 & 1.159 & 1.179 & 164 & 151 & 242944 & 1271436 & 970 & 0 & 5939 & 189 & 31 & 769 \\
\hline GA-LNB 59 & $7 / 27 / 93$ & $9: 16$ & 106270 & 15.74 & 1.129 & 0.965 & 1.226 & 146 & 134 & 213115 & 1089309 & 995 & 2 & 11296 & 174 & 26 & 664 \\
\hline GR-LNB 60a & $7 / 28 / 93$ & $11: 06$ & 97255 & 15.61 & 1.140 & 0.977 & 1.252 & 136 & 124 & 203508 & 994650 & 996 & 0 & 16462 & 164 & 23 & 604 \\
\hline GR-LNB 600 & $7 / 28 / 93$ & $2: 02$ & 120122 & 16.42 & 1.108 & 0.938 & 1.197 & 169 & 156 & 228036 & 1268293 & 996 & 2784 & 26570 & 197 & 30 & 731 \\
\hline LNB-OFA & $7 / 28 / 93$ & $2: 21$ & 143731 & 0.00 & 1.151 & 1.153 & 1.181 & 166 & 153 & 247702 & 1284085 & 977 & 11 & 6047 & 190 & 31 & 771 \\
\hline GR-LNB 60 & $7 / 28 / 93$ & $8: 10$ & 120987 & 15.92 & 1.079 & 0.919 & 1.173 & 168 & 155 & 227971 & 1270102 & 996 & 74 & 18139 & 192 & 30 & 742 \\
\hline GR.LNB 61a & $7 / 29 / 93$ & $15: 55$ & 113186 & 15.93 & 1.102 & 0.939 & 1.199 & 158 & 145 & 221114 & 1180275 & 997 & 405 & 20169 & 184 & 28 & 695 \\
\hline GR-LNB 61 & $7 / 29 / 93$ & $8: 04$ & 112810 & 16.41 & 1.080 & 0.915 & 1.179 & 159 & 146 & 218047 & 1182536 & 997 & 1161 & 26560 & 180 & 28 & 689 \\
\hline GR-LNB 62 & $7 / 30 / 93$ & $10: 04$ & 108598 & 16.02 & 1.089 & 0.927 & 1.191 & 153 & 140 & 211712 & 1132029 & 997 & 580 & 24781 & 174 & 26 & 666 \\
\hline LNB-OFA & $7 / 30 / 93$ & $4: 32$ & 138517 & 0.00 & 1.169 & 1.172 & 1.235 & 159 & 146 & 242314 & 1236007 & 972 & 0 & 6207 & 189 & 30 & 749 \\
\hline GR-LNB 62a & $7 / 30 / 93$ & $9: 00$ & 114381 & 16.00 & 1.152 & 0.981 & 1.241 & 158 & 145 & 225616 & 1190684 & 997 & 76 & 15248 & 191 & 28 & 705 \\
\hline GR.LNB 63a & $7 / 31 / 93$ & $17: 10$ & 112988 & 16.00 & 1.098 & 0.935 & 1.195 & 157 & 144 & 216384 & 1179568 & 996 & 229 & 17322 & 181 & 28 & 699 \\
\hline GR-LNB 636 & $7 / 31 / 93$ & $6: 49$ & 115516 & 15.11 & 1.084 & 0.932 & 1.177 & 160 & 147 & 216882 & 1195410 & 996 & 18 & 21189 & 182 & 28 & 702 \\
\hline GR-LNB 64a & $8 / 1 / 93$ & $1: 25$ & 102747 & 15.38 & 1.109 & 0.952 & 1.214 & 143 & 131 & 204553 & 1052532 & 996 & 116 & 21342 & 168 & 24 & 629 \\
\hline GA-LNB 64b & $8 / 1 / 93$ & 10:21 & 81407 & 15.22 & 1.170 & 1.010 & 1.320 & 110 & 99 & 183972 & 823827 & 974 & 0 & 9809 & 139 & 18 & 519 \\
\hline
\end{tabular}


Cherokee Unit 3, Average Test $\mathrm{C}$

Pre Modification

\begin{tabular}{|c|c|c|c|c|c|c|c|c|c|c|c|c|c|c|c|c|c|}
\hline Test & Date & Dur: & $\begin{array}{l}\text { CoalII } \\
\text { Flow } \\
\text { Tbsthr }\end{array}$ & $\begin{array}{l}\text { Gas } \\
\text { Heat } \\
\text { \% rotl }\end{array}$ & $\begin{array}{l}\text { Coal } \\
\text { stoich }\end{array}$ & Reburn & $\begin{array}{l}\text { Exit } \\
\text { Stiolch }\end{array}$ & $\begin{array}{l}\text { Gross } \\
\text { Power } \\
\text { MWe }\end{array}$ & $\begin{array}{l}\text { Net } \\
\text { Power } \\
\text { uwe }\end{array}$ & $\begin{array}{l}\text { Total } \\
\text { Air } \\
\text { sctm }\end{array}$ & $\begin{array}{l}\text { Steam } \\
\text { lbs } / \mathrm{hr}\end{array}$ & $\begin{array}{l}\text { Main } \\
\text { Steam } \\
\text { Temp }\end{array}$ & $\begin{array}{l}\text { RH } \\
\text { At flow } \\
\text { ibsthr }\end{array}$ & 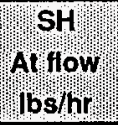 & $\begin{array}{l}\text { Air Htr } \\
\text { म н A } \\
\text { mbtulht }\end{array}$ & $\begin{array}{l}\text { Ecoon" } \\
\text { HAA } \\
m b+\mathrm{hr}\end{array}$ & $\begin{array}{l}\text { Furn } \\
\text { HA A } \\
\text { mbtu/hr }\end{array}$ \\
\hline GR-LNB $64 C$ & $8 / 1 / 93$ & $12: 14$ & 111057 & 15.75 & 1.100 & 0.939 & 1.203 & 155 & 142 & 217308 & 1156441 & 996 & 11 & \begin{tabular}{|l|}
21748 \\
\end{tabular} & \begin{tabular}{|l|}
184 \\
\end{tabular} & \begin{tabular}{|l|}
27 \\
\end{tabular} & 678 \\
\hline GR-LNB 65a & $8 / 293$ & $8: 55$ & 78544 & 14.83 & 1.216 & 1.055 & 1.364 & 105 & 93 & 179557 & 790952 & 965 & 0 & 8166 & 138 & 18 & 503 \\
\hline LNB-OFA & $8 / 293$ & $1: 23$ & 138466 & 0.00 & 1.203 & 1.205 & 1.229 & 160 & 148 & 237609 & 1234365 & 986 & 0 & 6720 & 195 & 30 & 744 \\
\hline GR-LNB 655 & $8 / 293$ & $6: 02$ & 112140 & 16.02 & 1.091 & 0.929 & 1.191 & 156 & 143 & 213646 & 1173016 & 997 & 51 & 13594 & 182 & 28 & 700 \\
\hline GR-LNB $65 \mathrm{C}$ & $8 / 293$ & $7: 14$ & 107432 & 16.30 & 1.098 & 0.932 & 1.205 & 150 & 138 & 211496 & 1126852 & 993 & 115 & 18594 & 177 & 26 & 669 \\
\hline GR-LNB 6Ga & $8 / 3 / 93$ & 8.29 & 71855 & 15.61 & 1.238 & 1.067 & 1.402 & 97 & 86 & 173390 & 721769 & 975 & 0 & 7203 & 132 & 16 & 465 \\
\hline GR.LNB $66 \mathrm{~b}$ & $8 / 3 / 93$ & $9: 34$ & 106999 & 16.40 & 1.163 & 0.987 & 1.256 & 151 & 138 & 216394 & 1119411 & 997 & 83 & 18890 & 184 & 26 & 665 \\
\hline GR-LNB 66c & $8 / 3 / 93$ & $5: 55$ & 111634 & 16.25 & 1.110 & 0.942 & 1.205 & 157 & 145 & 217833 & 1172640 & 997 & 209 & 19994 & 186 & 27 & 690 \\
\hline GR-LNB 67 & $8 / 4 / 93$ & $24: 00$ & 104594 & 15.46 & 1.138 & 0.977 & 1.245 & 145 & 133 & 208422 & 1078102 & 993 & 19 & 16089 & 176 & 25 & 646 \\
\hline GR-LNB 68a & $8 / 5 / 93$ & $7: 39$ & 90167 & 14.82 & 1.145 & 0.992 & 1.283 & 124 & 112 & 191039 & 907097 & 992 & 0 & 10075 & 153 & 21 & 565 \\
\hline GR-LNB 686 & $8 / 5 / 93$ & $15: 50$ & 114545 & 15.55 & 1.147 & 0.982 & 1.230 & 160 & 147 & 220991 & 1193868 & 997 & 248 & 22391 & 193 & 28 & 697 \\
\hline GR-LNB 69 & $8 / 6 / 93$ & $9: 48$ & 105202 & 15.18 & 1.105 & 0.950 & 1.211 & 146 & 134 & 208024 & 1084174 & 995 & 145 & 16609 & 174 & 25 & 649 \\
\hline LNB & $8 / 6 / 93$ & $7: 58$ & 135507 & 0.00 & 1.199 & 1.199 & 1.199 & 156 & 144 & 235303 & 1211591 & 967 & 0 & 6387 & 182 & 29 & 737 \\
\hline LNB-OFA & $8 / 6 / 93$ & $5: 04$ & 139200 & 0.00 & 1.193 & 1.193 & 1.208 & 160 & 147 & 240153 & 1250695 & 965 & 0 & 5946 & 187 & 30 & 758 \\
\hline LNB & $8 / 793$ & $3: 04$ & 133043 & 0.00 & 1.170 & 1.170 & 1.170 & 154 & 142 & 230595 & 1186157 & 975 & 0 & 6181 & 176 & 28 & 722 \\
\hline GA-LNB 70 & $8 / 793$ & $3: 53$ & 115672 & 7.62 & 1.127 & 1.050 & 1.203 & 147 & 135 & 207263 & 1086542 & 996 & 2815 & 15760 & 176 & 25 & 652 \\
\hline LNB.OFA & $8 / 7 / 93$ & $8: 05$ & 136082 & 0.00 & 1.203 & 1.203 & 1.220 & 157 & 145 & 235797 & 1213040 & 978 & 4 & 7841 & 185 & 29 & 732 \\
\hline LNB & $8 / 7 / 93$ & $6: 28$ & 137961 & 0.00 & 1.209 & 1.209 & 1.209 & 159 & 146 & 239395 & 1234851 & 971 & 0 & 7092 & 186 & 30 & 746 \\
\hline LNB & $8 / 9 / 93$ & $8: 04$ & 127397 & 0.00 & 1.241 & 1.241 & 1.241 & 146 & 134 & 229959 & 1139708 & 955 & 0 & 6246 & 175 & 27 & 701 \\
\hline GR-LNB 71 (10\% Gas) & $8 / 9 / 93$ & 13:45 & 124813 & 10.44 & 1.116 & 1.010 & 1.221 & 160 & 147 & 224046 & 1226985 & 995 & 40 & 10619 & 192 & 29 & 731 \\
\hline GR-LNB 72a (10\%) & $8 / 10 / 93$ & $7: 48$ & 121811 & 9.58 & 1.113 & 1.017 & 1.225 & 157 & 144 & 219910 & 1185288 & 996 & 152 & 20808 & 187 & 27 & 703 \\
\hline LNB & $8 / 10 / 93$ & $7: 27$ & 138553 & 0.00 & 1.252 & 1.252 & 1.252 & 156 & 144 & 243708 & 1216526 & 949 & 0 & 6127 & 191 & 30 & 759 \\
\hline GA-LNB $72 b(10 \%)$ & $8 / 10 / 93$ & $7: 25$ & 119944 & 9.73 & 1.135 & 1.036 & 1.249 & 153 & 140 & 220653 & 1167690 & 993 & 0 & 8292 & 185 & 28 & 704 \\
\hline GR-LNB 73 & $8 / 11 / 93$ & 3:22 & 114651 & 9.87 & 1.164 & 1.062 & 1.278 & 148 & 135 & 220455 & 1120389 & 991 & 11 & 9183 & 180 & 26 & 675 \\
\hline LNB-OFA & $8 / 11 / 93$ & $9: 49$ & 141129 & 0.00 & 1.205 & 1.205 & 1.224 & 161 & 149 & 245466 & 1271288 & 965 & 0 & 6040 & 192 & 31 & 765 \\
\hline LNB & $8 / 11 / 93$ & $2: 45$ & 134064 & 0.00 & 1.255 & 1.255 & 1.255 & 153 & 141 & 241401 & 1205723 & 956 & 0 & 6297 & 187 & 29 & 733 \\
\hline LNB & $8 / 12 / 93$ & $7: 36$ & 102169 & 0.00 & 1.263 & 1.263 & 1.263 & 116 & 104 & 203969 & 893989 & 951 & 0 & 6646 & 140 & 20 & 569 \\
\hline GR-LNB 74 & $8 / 12 / 93$ & $14: 33$ & 122857 & 9.87 & 1.116 & 1.017 & 1.233 & 158 & 145 & 222362 & 1203784 & 996 & 16 & 13802 & 191 & 29 & 712 \\
\hline GR-LNB 75 & $8 / 13 / 93$ & $18: 16$ & 120404 & 10.12 & 1.132 & 1.030 & 1.247 & 155 & 143 & 220957 & 1182245 & 992 & 38 & 15043 & 189 & 28 & 699 \\
\hline GR.LNB 76a & $8 / 14 / 93$ & $4: 54$ & 97749 & 9.27 & 1.171 & 1.077 & 1.292 & 126 & 114 & 192824 & 925040 & 998 & 0 & 18081 & 155 & 21 & 563 \\
\hline LNB & $8 / 14 / 93$ & $1: 46$ & 80714 & 0.00 & 1.508 & 1.508 & 1.508 & 89 & 80 & 187627 & 679285 & 959 & 0 & 6501 & 129 & 15 & 443 \\
\hline GR-LNB 76b & $8 / 14 / 93$ & $11: 05$ & 118872 & 10.02 & 1.171 & 1.066 & 1.283 & 153 & 141 & 219864 & 1158368 & 994 & 73 & 13927 & 191 & 27 & 690 \\
\hline GR-LNB 77 & $8 / 15 / 93$ & $1: 10$ & 94016 & 9.10 & 1.214 & 1.120 & 1.339 & 120 & 108 & 187601 & 887753 & 989 & 0 & 12358 & 154 & 20 & 551 \\
\hline LNB & $8 / 15 / 93$ & 14:44 & 104787 & 0.00 & 1.287 & 1.287 & 1.299 & 120 & 109 & 203571 & 913531 & 964 & 0 & 7850 & 147 & 21 & 572 \\
\hline LNB & $8 / 15 / 93$ & $6: 58$ & 139032 & 0.00 & 1.204 & 1.204 & 1.211 & 160 & 148 & 237720 & 1239884 & 982 & 0 & 6317 & 189 & 30 & 747 \\
\hline LNB (low load) & $8 / 16 / 93$ & $7: 38$ & 94604 & 0.00 & 1.302 & 1.302 & 1.302 & 109 & 98 & 193269 & 812318 & 982 & 0 & 9256 & 139 & 18 & 511 \\
\hline LNB (150 MWe) & $8 / 16 / 93$ & 3:21 & 140409 & 0.00 & 1.250 & 1.250 & 1.250 & 162 & 150 & 246741 & 1263073 & 976 & 0 & 6768 & 202 & 30 & 755 \\
\hline LNB-OFA cooling & $8 / 16 / 93$ & $11: 40$ & 142241 & 0.00 & 1.197 & 1.197 & 1.221 & 162 & 150 & 244498 & 1291641 & 946 & 0 & 5830 & 192 & 31 & 781 \\
\hline LNB & $8 / 17 / 93$ & $9: 07$ & 124002 & 0.00 & 1.240 & 1.240 & 1.240 & 142 & 130 & 224890 & 949955 & 953 & 0 & 6374 & 171 & 26 & 679 \\
\hline $100 \%$ Gas (plant test) & $8 / 17 / 93$ & $0: 34$ & 73951 & 0.00 & 1.156 & 1.156 & 1.156 & 80 & 71 & 170693 & 566196 & 880 & 0 & 6423 & 88 & 14 & 439 \\
\hline
\end{tabular}


Pre Modiflcation

\begin{tabular}{|c|c|c|c|c|c|c|c|c|c|c|c|c|c|c|c|c|c|}
\hline 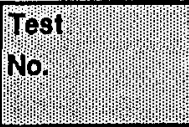 & Date" & Dep & 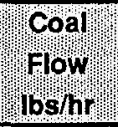 & 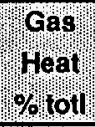 & 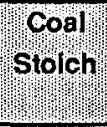 & sqeburn & $\begin{array}{l}\text { Exit } \\
\text { Stoich }\end{array}$ & $\begin{array}{l}\text { Gross } \\
\text { Power } \\
\text { nwe: }\end{array}$ & $\begin{array}{l}\text { Net } \\
\text { Power: } \\
\text { Mwo }\end{array}$ & 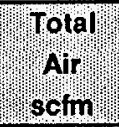 & YYsteam & $\begin{array}{l}\text { Main] } \\
\text { Stram } \\
\text { Temp }\end{array}$ & $\begin{array}{l}\text { [nH } \\
\text { At fow } \\
\text { Ibs/hI] }\end{array}$ & 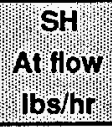 & 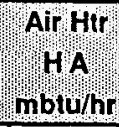 & 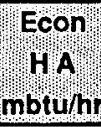 & 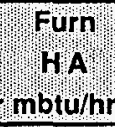 \\
\hline LNB (OFA cooling) & $8 / 17 / 93$ & $8: 59$ & 148384 & 0.00 & 1.180 & 1.180 & 1.202 & 161 & 148 & 242598 & 0 & 951 & 0 & 6048 & 200 & 31 & 771 \\
\hline LNB & $8 / 17 / 93$ & $3: 05$ & 145491 & 0.00 & 1.191 & 1.191 & 1.191 & 158 & 146 & 238257 & 0 & 957 & 0 & 6373 & 194 & 30 & 756 \\
\hline LNB (low load) & $8 / 18 / 93$ & $9: 42$ & 111224 & 0.00 & 1.223 & 1.223 & 1.223 & 122 & 110 & 204399 & 0 & 962 & 0 & 8394 & 152 & 21 & 581 \\
\hline LNB $150 \mathrm{MWe}$ & $8 / 18 / 93$ & $14: 16$ & 148284 & 0.00 & 1.233 & 1.233 & 1.233 & 160 & 147 & 244593 & 0 & 938 & 0 & 5958 & 204 & 31 & 774 \\
\hline GR-LNB 78 & $8 / 24 / 93$ & $3: 25$ & 117053 & 10.89 & 1.066 & 0.961 & 1.191 & 159 & 147 & 216487 & 1129806 & 997 & 42 & 26186 & 172 & 24 & 699 \\
\hline LNB OFA cooling & $8 / 24 / 93$ & $10: 38$ & 134604 & 0.00 & 1.208 & 1.208 & 1.239 & 160 & 148 & 242758 & 1156672 & 989 & 237 & 7947 & 181 & 25 & 743 \\
\hline LNB OFA cooling & $8 / 25 / 93$ & $2: 06$ & 105315 & 0.00 & 1.206 & 1.206 & 1.229 & 126 & 116 & 214667 & 881699 & 998 & 0 & 9695 & 135 & 18 & 586 \\
\hline LNB & $8 / 25 / 93$ & $8: 38$ & 100894 & 0.00 & 1.241 & 1.241 & 1.241 & 120 & 110 & 209651 & 848417 & 990 & 0 & 11845 & 133 & 18 & 562 \\
\hline LNB & $8 / 25 / 93$ & 13:08 & 132513 & 0.00 & 1.268 & 1.268 & 1.268 & 157 & 146 & 247077 & 1151539 & 975 & 0 & 5801 & 186 & 25 & 740 \\
\hline LNB & $8 / 26 / 93$ & $21: 16$ & 100277 & 0.00 & 1.344 & 1.344 & 1.344 & 114 & 103 & 205520 & 879914 & 934 & 0 & 7243 & 146 & 20 & 559 \\
\hline LNB & $8 / 26 / 93$ & $2: 42$ & 135579 & 0.00 & 1.258 & 1.258 & 1.258 & 157 & 145 & 244242 & 1209141 & 969 & 0 & 6768 & 191 & 29 & 730 \\
\hline LNB & $8 / 27 / 93$ & $8: 26$ & 93838 & 0.00 & 1.329 & 1.329 & 1.329 & 107 & 97 & 197534 & 817252 & 936 & 0 & 7077 & 135 & 18 & 524 \\
\hline LNB & $8 / 27 / 93$ & $6: 17$ & 132554 & 0.00 & 1.256 & 1.256 & 1.256 & 154 & 142 & 238653 & 1193794 & 949 & 0 & 6686 & 186 & 29 & 728 \\
\hline GR-LNB 79 & $9 / 8 / 93$ & $11: 15$ & 117756 & 13.04 & 1.138 & 1.002 & 1.223 & 158 & 146 & 219460 & 1191746 & 991 & 0 & 5420 & 188 & 29 & 718 \\
\hline CR-LNB 79a & 9/8/93 & $1: 49$ & 96950 & 14.13 & 1.180 & 1.030 & 1.288 & 130 & 119 & 194649 & 969489 & 982 & 0 & 3646 & 161 & 23 & 609 \\
\hline GR-LNB 60a & $9 / 9 / 93$ & $6: 55$ & 86601 & 14.55 & 1.186 & 1.031 & 1.317 & 118 & 106 & 184430 & 867451 & 988 & 0 & 6488 & 147 & 20 & 543 \\
\hline LNB-OFA & $9 / 9 / 93$ & $1: 46$ & 81879 & 0.00 & 1.364 & 1.382 & 1.441 & 92 & 81 & 176686 & 699534 & 947 & 0 & 3407 & 127 & 16 & 461 \\
\hline GR-LNB 80 & $9 / 9 / 93$ & 14:15 & 106284 & 14.33 & 1.144 & 0.994 & 1.241 & 146 & 134 & 207267 & 1085308 & 994 & 0 & 10513 & 174 & 26 & 653 \\
\hline LNB-OFA & $9 / 10 / 93$ & $4: 50$ & 75788 & 0.00 & 1.457 & 1.464 & 1.511 & 85 & 75 & 169294 & 651164 & 938 & 0 & 3426 & 122 & 14 & 427 \\
\hline GR-LNB 81 & $9 / 10 / 93$ & $1: 46$ & 84099 & 15.66 & 1.162 & 0.999 & 1.301 & 117 & 106 & 180373 & 852630 & 996 & 0 & 8314 & 148 & 19 & 531 \\
\hline LNB & $9 / 10 / 93$ & $13: 30$ & 130674 & 0.00 & 1.276 & 1.276 & 1.276 & 151 & 140 & 237494 & 1170095 & 959 & 0 & 4397 & 186 & 28 & 713 \\
\hline LNB & $9 / 11 / 93$ & $19: 30$ & 121777 & 0.00 & 1.259 & 1.259 & 1.263 & 141 & 129 & 224267 & 1081220 & 963 & 0 & 4194 & 171 & 26 & 666 \\
\hline GR-LNB 82 & $9 / 11 / 93$ & $4: 10$ & 116087 & 14.21 & 1.223 & 1.064 & 1.293 & 157 & 144 & 220738 & .1191334 & 978 & 0 & 3901 & 197 & 29 & 722 \\
\hline GR-LNB 83a & $9 / 12 / 93$ & 11.51 & 100367 & 14.18 & 1.239 & 1.081 & 1.335 & 137 & 125 & 204346 & 1013296 & 984 & 0 & 5650 & 174 & 24 & 625 \\
\hline GR-LNB 83 & $9 / 12 / 93$ & $12: 09$ & 123161 & 13.10 & 1.156 & 1.016 & 1.230 & 166 & 153 & 222367 & 1251152 & 995 & 4 & 8779 & 198 & 30 & 742 \\
\hline GR-LNB 84a & $9 / 13 / 93$ & $5: 35$ & 91790 & 13.90 & 1.244 & 1.089 & 1.359 & 125 & 113 & 192148 & 916612 & 991 & 0 & 6494 & 163 & 21 & 571 \\
\hline GR-LNB 84 & $9 / 13 / 93$ & $18: 03$ & 116688 & 10.91 & 1.179 & 1.063 & 1.274 & 157 & 144 & 219520 & 1155926 & 994 & 0 & 8995 & 195 & 28 & 692 \\
\hline GR-LNB 85a & $9 / 14 / 93$ & $4: 15$ & 102703 & 12.26 & 1.160 & 1.032 & 1.270 & 140 & 128 & 199390 & 1019116 & 996 & 0 & 11985 & 171 & 24 & 619 \\
\hline LNB & $9 / 14 / 93$ & $11: 05$ & 109330 & 0.00 & 1.281 & 1.281 & 1.281 & 128 & 117 & 216210 & 959581 & 966 & 0 & 4382 & 157 & 22 & 602 \\
\hline LNB-OFA & $9 / 14 / 93$ & 1.06 & 136479 & 0.00 & 1.226 & 1.226 & 1.272 & 160 & 148 & 240505 & 1226119 & 969 & 0 & 3277 & 195 & 30 & 743 \\
\hline GR-LNB B5 & $9 / 14 / 93$ & $6: 55$ & 115131 & 12.49 & 1.072 & 0.949 & 1.174 & 158 & 145 & 215025 & 1163822 & 996 & 0 & 13699 & 176 & 28 & 691 \\
\hline GR-LNB 86a & $9 / 15 / 93$ & $0: 50$ & 104429 & 12.89 & 1.114 & 0.983 & 1.223 & 143 & 131 & 202384 & 1046613 & 995 & 0 & 12049 & 168 & 25 & 636 \\
\hline LNB & $9 / 15 / 93$ & $3: 07$ & 92960 & 0.00 & 1.284 & 1.284 & 1.284 & 110 & 99 & 199104 & 810045 & 974 & 0 & 13233 & 130 & 18 & 508 \\
\hline GR-LNB 86b & $9 / 15 / 93$ & $4: 26$ & 96768 & 13.57 & 1.118 & 0.980 & 1.240 & 134 & 122 & 195843 & 971915 & 997 & 0 & 14525 & 159 & 22 & 588 \\
\hline GR-LNB 86 & $9 / 15 / 93$ & $11: 20$ & 113876 & 12.76 & 1.084 & 0.957 & 1.183 & 156 & 144 & 216897 & 1150475 & 996 & 0 & 14998 & 176 & 27 & 682 \\
\hline GR-LNB 87a & $9 / 16 / 93$ & $5: 46$ & 95779 & 13.35 & 1.126 & 0.990 & 1.253 & 131 & 119 & 195838 & 963288 & 977 & 0 & 14051 & 155 & 22 & 587 \\
\hline GR-LNB 87 & $9 / 16 / 93$ & $15: 24$ & 109303 & 12.33 & 1.198 & 1.065 & 1.293 & 148 & 136 & 211933 & 1087587 & 996 & 0 & 14439 & 185 & 26 & 649 \\
\hline GR-LNB 88a & $9 / 17 / 93$ & $5: 31$ & 99764 & 13.45 & 1.178 & 1.036 & 1.289 & 137 & 125 & 199621 & 999394 & 996 & 0 & 15091 & 169 & 23 & 603 \\
\hline GR-LNB 88 & $9 / 17 / 93$ & $18: 28$ & 115080 & 12.26 & 1.119 & 0.994 & 1.216 & 157 & 144 & 216191 & 1157526 & 996 & 0 & 17557 & 185 & 27 & 682 \\
\hline GR-LNB 89 & $9 / 18 / 93$ & 24.00 & 112388 & 11.72 & 1.095 & 0.978 & 1.201 & 153 & 140 & 211284 & 1122638 & 996 & 0 & 16604 & 176 & 26 & 666 \\
\hline
\end{tabular}


Cherokee Unit 3, Average Test C

Pre Modification

\begin{tabular}{|c|c|c|c|c|c|c|c|c|c|c|c|c|c|c|c|c|c|}
\hline Test No N & Date & Durn & 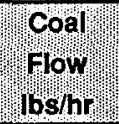 & $\begin{array}{l}\text { Gas } \\
\text { Yreat } \\
\text { \% lot! }\end{array}$ & Coal!" & $\begin{array}{l}\text { Reburn } \\
\text { Storch }\end{array}$ & Exit Ex/ch & $\begin{array}{l}\text { Gross } \\
\text { Powe; } \\
\text { nwe }\end{array}$ & Powed & Trotal| & Siteam & $\begin{array}{l}\text { Main } \\
\text { Steam } \\
\text { Temp }\end{array}$ & $\begin{array}{l}\text { RHWW" } \\
\text { Al flow } \\
\text { Ibshr }\end{array}$ & 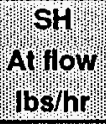 & 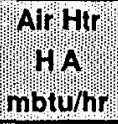 & Econ: & 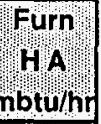 \\
\hline GA-LNB 90a & $9 / 19 / 93$ & $10: 06$ & 102865 & 11.99 & 1.120 & 0.999 & 1.234 & 141 & 129 & 199891 & 1020960 & 997 & 0 & 19034 & \begin{tabular}{|l|}
166 \\
\end{tabular} & 23 & 610 \\
\hline GA-LNB 90 & $9 / 19 / 93$ & 13.54 & 118596 & 10.93 & 1.092 & 0.983 & 1.193 & 160 & 147 & 219053 & 1179188 & 996 & 3 & 20274 & 183 & 28 & 689 \\
\hline GA-LNB 91 & $9 / 20 / 93$ & $24: 00$ & 110995 & 12.72 & 1.069 & 0.944 & 1.174 & 154 & 141 & 210599 & 1124284 & 996 & 46 & 26227 & 172 & 26 & 654 \\
\hline GR-LNB 92a & $9 / 21 / 93$ & $3: 00$ & 92301 & 14.45 & 1.097 & 0.953 & 1.230 & 127 & 116 & 187661 & 931802 & 993 & 0 & 12842 & 150 & 21 & 569 \\
\hline GR-LNB 92 & $9 / 21 / 93$ & $17: 56$ & 112357 & 13.27 & 1.116 & 0.980 & 1.210 & 153 & 141 & 211239 & 1139502 & 992 & 2 & 12408 & 178 & 27 & 681 \\
\hline GA.LNB 3 Mill a & $9 / 22 / 93$ & $7: 59$ & 89138 & 14.84 & 1.177 & 1.019 & 1.297 & 123 & 112 & 188060 & 900782 & 994 & 0 & 8495 & 151 & 21 & 560 \\
\hline GR-LNB 3 Mill b & $9 / 22 / 93$ & $8: 25$ & 95611 & 14.03 & 1.152 & 1.006 & 1.266 & 131 & 120 & 195196 & 972294 & 983 & 0 & 7698 & 155 & 23 & 603 \\
\hline GR-LNB 3 Mill C & $9 / 23 / 93$ & $24: 00$ & 96702 & 14.02 & 1.154 & 1.008 & 1.265 & 132 & 122 & 199335 & 982953 & 985 & 0 & 6644 & 158 & 23 & 608 \\
\hline GR-LNB 3 Mill d & $9 / 24 / 93$ & $1: 58$ & 78987 & 14.88 & 1.212 & 1.051 & 1.358 & 107 & 97 & 176006 & 791465 & 986 & 0 & 5183 & 138 & 18 & 505 \\
\hline LNB-OFA 3 Mill & $9 / 24 / 93$ & $3: 33$ & 70772 & 0.00 & 1.241 & 1.260 & 1.573 & 75 & 66 & 162304 & 636951 & 842 & 0 & 3496 & 114 & 14 & 432 \\
\hline GR-LNB 3 Mill 0 & $9 / 24 / 93$ & $6: 10$ & 97473 & 13.47 & 1.192 & 1.048 & 1.300 & 131 & 120 & 202006 & 988715 & 966 & 0 & 3463 & 161 & 23 & 621 \\
\hline GR-LNB 93 & $9 / 24 / 93$ & 12.09 & 111231 & 12.24 & 1.180 & 1.049 & 1.275 & 148 & 136 & 213502 & 1115514 & 980 & 0 & 4723 & 183 & 27 & 680 \\
\hline GR-LNB 94a & $9 / 25 / 93$ & $2: 12$ & 98036 & 13.13 & 1.166 & 1.028 & 1.279 & 132 & 121 & 192762 & 972449 & 990 & 0 & 5022 & 165 & 23 & 605 \\
\hline LNB-OFA & $9 / 25 / 93$ & $2: 24$ & 93154 & 0.00 & 1.130 & 1.144 & 1.442 & 108 & 97 & 182642 & 807992 & 962 & 0 & 3748 & 150 & 18 & 516 \\
\hline GR-LNB 94 & $9 / 25 / 93$ & $19: 05$ & 119198 & 11.64 & 1.136 & 1.016 & 1.229 & 160 & 147 & 217890 & 1191631 & 994 & 34 & 10765 & 192 & 29 & 707 \\
\hline GR-LNB 95a & $9 / 26 / 93$ & $4: 15$ & 95006 & 14.03 & 1.168 & 1.021 & 1.283 & 131 & 119 & 191570 & 952879 & 998 & 4 & 9133 & 162 & 22 & 586 \\
\hline LNB-OFA & $9 / 26 / 93$ & $2: 55$ & 88733 & 0.00 & 1.179 & 1.192 & 1.509 & 99 & 89 & 178143 & 785818 & 892 & 0 & 3315 & 144 & 18 & 518 \\
\hline GR-LNB 95 & $9 / 26 / 93$ & $16: 33$ & 110855 & 12.73 & 1.167 & 1.032 & 1.264 & 150 & 138 & 210955 & 1112300 & 993 & 0 & 8549 & 183 & 26 & 670 \\
\hline GR-LNB 96a & $9 / 27 / 93$ & $2: 53$ & 99821 & 13.53 & 1.207 & 1.060 & 1.311 & 136 & 124 & 201088 & 1008787 & 981 & 0 & 7246 & 172 & 24 & 621 \\
\hline LNB & $9 / 27 / 93$ & $19: 45$ & 133431 & 0.00 & 1.270 & 1.270 & 1.276 & 154 & 142 & 243127 & 1200767 & 949 & 0 & 3468 & 191 & 29 & 733 \\
\hline GR-LNB 96b & $9 / 27 / 93$ & $0: 57$ & 97262 & 14.56 & 1.126 & 0.977 & 1.255 & 133 & 121 & 189650 & 986342 & 983 & 0 & 6438 & 161 & 23 & 613 \\
\hline GR-LNB 97a & $9 / 28 / 93$ & $9: 13$ & 103105 & 13.59 & 1.186 & 1.040 & 1.288 & 141 & 129 & 204855 & 1037986 & 993 & 0 & 9458 & 176 & 24 & 630 \\
\hline LNB & $9 / 28 / 93$ & $4: 27$ & 135363 & 0.00 & 1.117 & 1.121 & 1.117 & 159 & 147 & 230272 & 1220446 & 977 & 0 & 3575 & 172 & 30 & 740 \\
\hline GR-LNB 97 & $9 / 28 / 93$ & $5: 58$ & 119429 & 10.66 & 1.075 & 0.971 & 1.194 & 159 & 147 & 213319 & 1184986 & 997 & 0 & 17711 & 185 & 28 & 695 \\
\hline GR-LNB 97b & $9 / 28 / 93$ & $2: 48$ & 101042 & 9.99 & 1.146 & 1.045 & 1.272 & 133 & 122 & 194464 & 974067 & 995 & 0 & 13239 & 162 & 22 & 593 \\
\hline GR-LNB 98a & $9 / 29 / 93$ & $5: 22$ & 92861 & 9.67 & 1.194 & 1.095 & 1.324 & 122 & 111 & 188531 & 884053 & 998 & 0 & 10722 & 155 & 20 & 545 \\
\hline GR-LNB 98 & $9 / 29 / 93$ & $18: 37$ & 118547 & 11.91 & 1.122 & 1.000 & 1.221 & 158 & 146 & 217802 & 1189487 & 991 & 51 & 10254 & 188 & 29 & 708 \\
\hline GR-LNB 99a & $9 / 30 / 93$ & $5: 32$ & 88275 & 14.42 & 1.219 & 1.061 & 1.345 & 119 & 108 & 187077 & 890779 & 969 & 0 & 4263 & 153 & 21 & 563 \\
\hline GR.LNB 99 & $9 / 30 / 93$ & $13: 24$ & 116759 & 13.15 & 1.154 & 1.015 & 1.238 & 157 & 146 & 218364 & 1181229 & 992 & 0 & 5489 & 189 & 28 & 711 \\
\hline GR-LNB 99b & 9/30/93 & $2: 27$ & 97960 & 14.97 & 1.212 & 1.047 & 1.308 & 134 & 123 & 197604 & 995361 & 978 & 0 & 6963 & 169 & 23 & 616 \\
\hline LNB-OFA & $9 / 30 / 93$ & $2: 27$ & 76313 & 0.00 & 1.371 & 1.373 & 1.429 & 83. & 73 & 168982 & 669649 & 873 & 0 & 3750 & 113 & 15 & 451 \\
\hline GR-LNB to0a & $10 / 1 / 93$ & $11: 00$ & 81763 & 14.60 & 1.255 & 1.092 & 1.400 & 111 & 100 & 181919 & 816223 & 983 & 0 & 5612 & 151 & 18 & 516 \\
\hline GR-LNB 100 & $10 / 1 / 93$ & $9: 12$ & 98068 & 13.94 & 1.170 & 1.022 & 1.278 & 135 & 124 & 196599 & 983329 & 998 & 0 & 12991 & 165 & 23 & 598 \\
\hline GR-LNB 101 & $10 / 2 / 93$ & $24: 00$ & 96512 & 13.73 & 1.215 & 1.065 & 1.327 & 132 & 121 & 196058 & 963831 & 994 & 0 & 9652 & 170 & 22 & 591 \\
\hline GR-LNB 102 & $10 / 3 / 93$ & $24: 00$ & 92146 & 13.54 & 1.227 & 1.079 & 1.351 & 125 & 115 & 192393 & 911766 & 998 & 0 & 10313 & 163 & 21 & 561 \\
\hline GR-LNB 103 & $10 / 4 / 93$ & $24: 00$ & 96999 & 14.51 & 1.189 & 1.033 & 1.300 & 134 & 123 & 198625 & 977555 & 994 & 0 & 12590 & 168 & 23 & 596 \\
\hline GR-LNB 104 & $10 / 5 / 93$ & $24: 00$ & 97825 & 15.65 & 1.222 & 1.048 & 1.311 & 136 & 125 & 202754 & 998394 & 995 & 0 & 10261 & 173 & 23 & 610 \\
\hline GR-LNB 105 & $10 / 6 / 93$ & $10: 15$ & 112323 & 13.71 & 1.195 & 1.046 & 1.278 & 154 & 142 & 216460 & 1137382 & 994 & 0 & 9357 & 192 & 27 & 682 \\
\hline GR-LNB 106 & $10 / 8 / 93$ & $8: 45$ & 117155 & 12.51 & 1.106 & 0.979 & 1.202 & 159 & 146 & 215108 & 1186027 & 990 & 0 & 6285 & 187 & 29 & 714 \\
\hline GR-LNB 107 & $10 / 9 / 93$ & $24: 00$ & 117345 & 12.23 & 1.182 & 1.051 & 1.272 & 159 & 147 & 218954 & 1182794 & 992 & 17 & 7886 & 200 & 28 & 708 \\
\hline
\end{tabular}


Pre Modification

\begin{tabular}{|c|c|c|c|c|c|c|c|c|c|c|c|c|c|c|c|c|c|}
\hline Test & 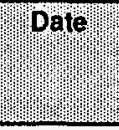 & Durfin & 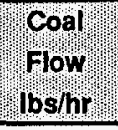 & 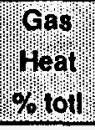 & $\begin{array}{l}\text { Coral } \\
\text { Stolch }\end{array}$ & Reburn & $\begin{array}{l}\text { Exit } \\
\text { Sioich }\end{array}$ & $\begin{array}{l}\text { Gross: } \\
\text { power! } \\
\text { MWe }\end{array}$ & $\begin{array}{l}\text { Net } \\
\text { Power } \\
\text { MWe }\end{array}$ & $\begin{array}{l}\text { Trotal II } \\
\text { Ancm }\end{array}$ & Steam & $\begin{array}{l}\text { Main } \\
\text { Steam } \\
\text { Temp }\end{array}$ & 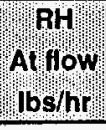 & $\begin{array}{l}\text { Sh } \\
\text { At fow } \\
\text { ibs/hy }\end{array}$ & 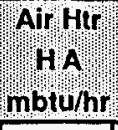 & $\begin{array}{l}\text { Ecoñ } \\
\text { mbtu/hr } \\
\end{array}$ & 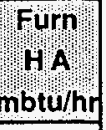 \\
\hline GR-LNB 108 & $10 / 10 / 93$ & $11: 00$ & 118041 & 12.19 & 1.187 & 1.056 & 1.275 & 160 & 147 & 219289 & 1184866 & 995 & 64 & 10205 & 201 & 28 & 705 \\
\hline GR-LNB $109 \mathrm{a}$ & $10 / 13 / 93$ & $4: 07$ & 115981 & 14.23 & 1.155 & 1.004 & 1.244 & 158 & 146 & 217498 & 1195887 & 980 & 0 & 7811 & 190 & 29 & 720 \\
\hline GR-LNB 1096 & $10 / 13 / 93$ & $2: 02$ & 98246 & 13.75 & 1.171 & 1.027 & 1.298 & 133 & 121 & 195799 & 986307 & 979 & 0 & 4616 & 166 & 23 & 616 \\
\hline GR-LNB 110a & $10 / 14 / 93$ & $6: 02$ & 102633 & 14.17 & 1.183 & 1.031 & 1.292 & 143 & 131 & 205061 & 1040627 & 997 & 5 & 14721 & 178 & 24 & 625 \\
\hline GR-LNB 110 & $10 / 14 / 93$ & $14: 56$ & 111767 & 15.94 & 1.145 & 0.977 & 1.241 & 159 & 147 & 216301 & 1173059 & 996 & 100 & 20327 & 191 & 28 & 687 \\
\hline GR-LNB $110 b$ & $10 / 14 / 93$ & $3: 00$ & 90211 & 18.19 & 1.226 & 1.023 & 1.332 & 129 & 117 & 193348 & 951225 & 984 & 10 & 8301 & 166 & 22 & 589 \\
\hline GR-LNB 111 & $10 / 15 / 93$ & $12: 49$ & 102263 & 16.00 & 1.154 & 0.985 & 1.260 & 146 & 134 & 205285 & 1066641 & 996 & 74 & 19628 & 178 & 25 & 633 \\
\hline GR-LNB 3 Mill a & $10 / 15 / 93$ & $2: 58$ & 110532 & 15.23 & 1.087 & 0.934 & 1.190 & 154 & 142 & 213940 & 1151508 & 996 & 0 & 6596 & 173 & 28 & 696 \\
\hline GR-LNB 3 Mill b & $10 / 15 / 93$ & $7: 05$ & 104279 & 14.15 & 1.149 & 1.001 & 1.260 & 143 & 131 & 209026 & 1065767 & 983 & 0 & 5721 & 172 & 25 & 656 \\
\hline GR-LNB 3 Mill C & $10 / 16 / 93$ & 12.05 & 85759 & 14.41 & 1.236 & 1.078 & 1.380 & 117 & 105 & 191574 & 856244 & 988 & 0 & 6575 & 157 & 19 & 539 \\
\hline GR-LNB 3 Mill d & $10 / 16 / 93$ & $10: 28$ & 118518 & 15.28 & 1.136 & 0.976 & 1.230 & 165 & 152 & 224874 & 1240715 & 988 & 49 & 9051 & 199 & 30 & 738 \\
\hline GR-LNB 3 Mill $\theta$ & $10 / 16 / 93$ & $1: 25$ & 106901 & 14.78 & 1.150 & 0.995 & 1.249 & 147 & 135 & 204794 & 1093256 & 986 & 0 & 3918 & 179 & 26 & 673 \\
\hline GR-LNB 3 Mill & $10 / 17 / 93$ & $23: 46$ & 99865 & 15.36 & 1.146 & 0.985 & 1.256 & 140 & 130 & 203394 & 1035016 & 991 & 0 & 10384 & 166 & 24 & 631 \\
\hline LNB-OFA 3 Mill & $10 / 18 / 93$ & $11: 10$ & 96210 & 0.00 & 1.075 & 1.086 & 1.346 & 114 & 103 & 187027 & 838204 & 978 & 0 & 8181 & 142 & 19 & 529 \\
\hline GR-LNB 3 Mill $\mathrm{g}$ & $10 / 19 / 93$ & $15: 35$ & 97978 & 14.92 & 1.180 & 1.020 & 1.292 & 134 & 122 & 204933 & 1008201 & 970 & 0 & 3705 & 162 & 24 & 631 \\
\hline GR-LNB 3 Mill h & $10 / 20 / 93$ & $7: 35$ & 98242 & 14.92 & 1.194 & 1.033 & 1.304 & 135 & 123 & 204782 & 1003963 & 987 & 0 & 4075 & 168 & 24 & 625 \\
\hline GR-LNB 112 & $10 / 20 / 93$ & $4: 09$ & 94572 & 14.47 & 1.211 & 1.054 & 1.335 & 130 & 118 & 199263 & 951590 & 996 & 0 & 8780 & 170 & 22 & 586 \\
\hline LNB-OFA & $10 / 20 / 93$ & 0.56 & 121545 & 0.00 & 1.140 & 1.150 & 1.381 & 144 & 132 & 224156 & 1075664 & 989 & 0 & 8756 & 194 & 25 & 646 \\
\hline GR-LNB 113 & $10 / 20 / 93$ & $10: 42$ & 113856 & 15.13 & 1.176 & 1.013 & 1.267 & 158 & 145 & 220076 & 1180964 & 991 & 9 & 10722 & 198 & 28 & 704 \\
\hline GR-LNB 113 & $10 / 21 / 93$ & $24: 00$ & 111346 & 16.22 & 1.147 & 0.976 & 1.246 & 157 & 145 & 220403 & 1168787 & 995 & 84 & 14942 & 190 & 28 & 692 \\
\hline GR-LNB 114 & $10 / 22 / 93$ & $24: 00$ & 108366 & 16.38 & 1.137 & 0.965 & 1.239 & 154 & 141 & 216629 & 1138196 & 994 & 119 & 15353 & 183 & 27 & 677 \\
\hline GR-LNB 115 & $10 / 23 / 93$ & $24: 00$ & 112995 & 16.04 & 1.152 & 0.981 & 1.248 & 159 & 147 & 221084 & 1186652 & 994 & 80 & 12726 & 191 & 28 & 705 \\
\hline GR-LNB 116 & $10 / 24 / 93$ & $14: 00$ & 111670 & 15.48 & 1.154 & 0.990 & 1.250 & 157 & 144 & 218947 & 1164111 & 994 & 32 & 13513 & 190 & 28 & 692 \\
\hline GR-LNB 116a & $10 / 24 / 93$ & $10: 00$ & 113536 & 15.83 & 1.142 & 0.975 & 1.239 & 159 & 147 & 220654 & 1187424 & 994 & 0 & 12601 & 190 & 28 & 705 \\
\hline GR-LNB 117a & $10 / 25 / 93$ & $4: 55$ & 93260 & 14.43 & 1.189 & 1.035 & 1.317 & 127 & 116 & 195229 & 946111 & 983 & 0 & 9111 & 160 & 22 & 585 \\
\hline GR-LNB 117 & $10 / 25 / 93$ & $19: 04$ & 111542 & 15.35 & 1.136 & 0.976 & 1.234 & 157 & 145 & 218580 & 1163105 & 996 & 16 & 18161 & 188 & 27 & 685 \\
\hline GR-LNB 118 & $10 / 26 / 93$ & $24: 00$ & 111142 & 15.22 & 1.117 & 0.960 & 1.220 & 156 & 144 & 215759 & 1157913 & 994 & 11 & 13753 & 185 & 27 & 690 \\
\hline GR-LNB 119 & $10 / 27 / 93$ & $14: 25$ & 114505 & 14.97 & 1.098 & 0.946 & 1.200 & 161 & 149 & 218216 & 1194679 & 995 & 214 & 16685 & 188 & 28 & 704 \\
\hline GR-LNB 119a & $10 / 27 / 93$ & $9: 34$ & 113018 & 14.76 & 1.054 & 0.910 & 1.161 & 157 & 145 & 213987 & 1167386 & 994 & 8 & 14049 & 175 & 28 & 696 \\
\hline GR-LNB 120a & $10 / 28 / 93$ & $7: 21$ & 108008 & 14.18 & 1.082 & 0.941 & 1.198 & 149 & 136 & 208779 & 1105049 & 990 & 7 & 10614 & 171 & 26 & 668 \\
\hline GR-LNB 120 & $10 / 28 / 93$ & $16: 38$ & 112702 & 14.76 & 1.076 & 0.929 & 1.181 & 158 & 146 & 217868 & 1169499 & 995 & 22 & 17451 & 181 & 28 & 691 \\
\hline GR-LNB 121 & $10 / 29 / 93$ & $24: 00$ & 111329 & 15.01 & 1.134 & 0.977 & 1.233 & 157 & 145 & 217065 & 1162158 & 995 & 91 & 21872 & 193 & 27 & 683 \\
\hline GR-LNB 122 & $10 / 30 / 93$ & $24: 00$ & 114860 & 15.02 & 1.120 & 0.965 & 1.220 & 162 & 149 & 221186 & 1201700 & 994 & 181 & 19621 & 196 & 28 & 705 \\
\hline GR-LNB 123 & $10 / 31 / 93$ & $24: 00$ & 113177 & 15.04 & 1.124 & 0.968 & 1.223 & 159 & 147 & 219332 & 1177015 & 995 & 8 & 17788 & 189 & 28 & 695 \\
\hline GR-LNB 124 & $11 / 1 / 93$ & $6: 18$ & 115166 & 11.75 & 1.102 & 0.985 & 1.222 & 155 & 143 & 215363 & 1151387 & 994 & 40 & 13427 & 186 & 27 & 688 \\
\hline LNB-OFA & $11 / 1 / 93$ & $1: 08$ & 106797 & 0.00 & 1.082 & 1.091 & 1.298 & 125 & 114 & 200469 & 939449 & 982 & 0 & 6439 & 158 & 21 & 585 \\
\hline GR-LNB 125a & $11 / 2 / 93$ & $8: 15$ & 116997 & 11.23 & 1.026 & 0.920 & 1.158 & 159 & 147 & 214569 & 1177218 & 995 & 33 & 24736 & 179 & 28 & 687 \\
\hline LNB & $11 / 2 / 93$ & 0.29 & 116783 & 11.10 & 1.029 & 0.924 & 1.160 & 158 & 145 & 214638 & 1168762 & 995 & 87 & 22462 & 175 & 27 & 686 \\
\hline GR-LNB 125 & $11 / 2 / 93$ & $10: 09$ & 116526 & 11.25 & 1.029 & 0.923 & 1.159 & 158 & 145 & 214404 & 1168297 & 995 & 89 & 22754 & 175 & 27 & 686 \\
\hline GR-LNB 126a & $11 / 4 / 93$ & $1: 40$ & 114620 & 10.38 & 1.001 & 0.906 & 1.136 & 154 & 141 & 209490 & 1135867 & 996 & 102 & 18389 & 170 & 27 & 674 \\
\hline
\end{tabular}


Cherokee Unit 3, Average Test [

Pre Modification

\begin{tabular}{|c|c|c|c|c|c|c|c|c|c|c|c|c|c|c|c|c|c|}
\hline Test Wh & Date & Dur: & $\begin{array}{l}\text { coal } \\
\text { flow } \\
\text { bshth }\end{array}$ & $\begin{array}{l}\text { Gas } \\
\text { hea } \\
\text { \%orl }\end{array}$ & $\begin{array}{l}\text { Coal } \\
\text { Storch }\end{array}$ & $\begin{array}{l}\text { Reburn } \\
\text { sionch } \\
\text { fy. }\end{array}$ & $\begin{array}{l}\text { Exit } \\
\text { Storch }\end{array}$ & $\begin{array}{l}\text { Gross } \\
\text { Power } \\
\text { nwe }\end{array}$ & $\begin{array}{l}\text { Net: } \\
\text { Power } \\
\text { uwe }\end{array}$ & $\begin{array}{l}\text { Total } \\
\text { air } \\
\text { sctm }\end{array}$ & $\begin{array}{l}\text { Steam } \\
\text { grshr }\end{array}$ & $\begin{array}{l}\text { Main } \\
\text { Sieam } \\
\text { Temp } \\
\end{array}$ & Al fow & $\begin{array}{l}\text { SH } \\
\text { At fow } \\
\text { los/hr }\end{array}$ & $\begin{array}{l}\text { Air } \mathrm{Htr} \\
\mathrm{H} \\
\mathrm{mb}\end{array}$ & $\begin{array}{l}\text { Econ } \\
\text { HA } \\
\text { nbuthr }\end{array}$ & $\begin{array}{c}\text { Furn } \\
\text { HA } \\
\text { mbtu/hr }\end{array}$ \\
\hline GR-LNB 126 & $11 / 4 / 93$ & $13: 29$ & 117149 & 10.20 & 1.057 & 0.960 & 1.186 & 156 & 143 & 213649 & 1158195 & 994 & 45 & 13128 & \begin{tabular}{|l|}
181 \\
\end{tabular} & 27 & 692 \\
\hline GR-LNB 127a & $11 / 5 / 93$ & 7:20 & 111238 & 9.79 & 1.282 & 1.174 & 1.393 & 145 & 133 & 208091 & 1081003 & 986 & 0 & 8391 & 201 & 26 & 660 \\
\hline GP.LNB 127 & $11 / 5 / 93$ & $5: 54$ & 122263 & 10.16 & 1.103 & 1.002 & 1.225 & 160 & 147 & 221892 & 1215775 & 980 & 0 & 4859 & 194 & 29 & 736 \\
\hline GR-LNB 128 & $11 / 8 / 93$ & $4: 55$ & 113732 & 14.82 & 1.112 & 0.960 & 1.211 & 159 & 147 & 219770 & 1178015 & 996 & 21 & 13339 & 187 & 28 & 700 \\
\hline GR-LNB 129 & $11 / 9 / 93$ & $8: 30$ & 116930 & 14.57 & 1.077 & 0.932 & 1.178 & 162 & 150 & 222588 & 1215592 & 993 & 3 & 13544 & 186 & 29 & 718 \\
\hline GR-LNB 129a & $11 / 9 / 93$ & $5: 29$ & 125401 & 12.09 & 1.123 & 0.998 & 1.217 & 167 & 154 & 234137 & 1280032 & 974 & 0 & 4125 & 199 & 31 & 767 \\
\hline GR-LNB 130 & $11 / 10 / 93$ & $15: 43$ & 120549 & 11.46 & 1.086 & 0.972 & 1.202 & 161 & 148 & 225277 & 1213151 & 987 & 0 & 9191 & 188 & 29 & 725 \\
\hline LNB & $11 / 10 / 93$ & $7: 50$ & 136104 & 0.00 & 1.186 & 1.186 & 1.186 & 158 & 146 & 243412 & 1232191 & 960 & 0 & 3799 & 181 & 30 & 752 \\
\hline LNB & $11 / 11 / 93$ & 2:00 & 128349 & 0.00 & 1.257 & 1.257 & 1.257 & 150 & 138 & 240911 & 1150603 & 962 & 0 & 4121 & 181 & 28 & 709 \\
\hline LNB 3 Mill a & $11 / 11 / 93$ & $3: 34$ & 101986 & 0.00 & 1.236 & 1.236 & 1.236 & 118 & 108 & 208283 & 889428 & 982 & 0 & 4844 & 137 & 20 & 566 \\
\hline LNB 3 Millb & $11 / 11 / 93$ & $9: 20$ & 102041 & 0.00 & 1.295 & 1.295 & 1.295 & 117 & 106 & 211771 & 896590 & 960 & 0 & 3495 & 143 & 21 & 576 \\
\hline LNB 3 Mill C & $11 / 1293$ & 12:30 & 109663 & 0.00 & 1.272 & 1.272 & 1.272 & 127 & 116 & 221314 & 974764 & 960 & 0 & 3587 & 155 & 23 & 617 \\
\hline LNB 3 Mill d & $11 / 12 / 93$ & $11: 29$ & 134370 & 0.00 & 1.140 & 1.140 & 1.140 & 157 & 145 & 239384 & 1224797 & 955 & 0 & 3560 & 174 & 30 & 749 \\
\hline LNB 3 Mill 0 & $11 / 13 / 93$ & 14:30 & 131971 & 0.00 & 1.210 & 1.210 & 1.210 & 154 & 142 & 241735 & 1192612 & 960 & 0 & 3879 & 182 & 29 & 730 \\
\hline LNB 3 Mill f & 11/13/93 & $9: 29$ & 134978 & 0.00 & 1.139 & 1.139 & 1.139 & 158 & 146 & 238693 & 1227895 & 959 & 0 & 3478 & 174 & 30 & 751 \\
\hline LNB 3 Mill & $11 / 14 / 93$ & 24:00 & 129746 & 0.00 & 1.169 & 1.169 & 1.169 & 152 & 140 & 237224 & 1172791 & 964 & 0 & 3732 & 174 & 28 & 720 \\
\hline LNB & $11 / 15 / 93$ & 1:39 & 131242 & 0.00 & 1.141 & 1.141 & 1.141 & 154 & 143 & 238277 & 1189100 & 967 & 0 & 3386 & 175 & 29 & 727 \\
\hline GR-LNB 131 & $11 / 15 / 93$ & $13: 00$ & 112669 & 14.44 & 1.060 & 0.918 & 1.172 & 157 & 144 & 224019 & 1169471 & 992 & 8 & 11858 & 180 & 28 & 697 \\
\hline GR-LNB 132 & 11/16/93 & $7: 42$ & 109648 & 14.00 & 1.047 & 0.911 & 1.163 & 152 & 140 & 217597 & 1128226 & 993 & 0 & 11845 & 174 & 27 & 678 \\
\hline GR-LNB 132a & 11/16/93 & $16: 17$ & 102674 & 14.01 & 1.248 & 1.091 & 1.351 & 140 & 128 & 205351 & 1045179 & 977 & 0 & 11422 & 184 & 24 & 638 \\
\hline GP-LNB 133 & $11 / 17 / 93$ & $0: 40$ & 100222 & 13.66 & 1.239 & 1.087 & 1.354 & 135 & 123 & 203232 & 1003996 & 991 & 0 & 8011 & 180 & 23 & 621 \\
\hline LNB & $11 / 17 / 93$ & $8: 40$ & 110887 & 0.00 & 1.339 & 1.339 & 1.339 & 127 & 116 & 212617 & 984433 & 945 & 0 & 3448 & 169 & 23 & 626 \\
\hline LNB & $12 / 3 / 93$ & 5:15 & 133061 & 0.00 & 1.231 & 1.231 & 1.231 & 154 & 142 & 240232 & 1201392 & 964 & 0 & 3691 & 190 & 29 & 733 \\
\hline LNB & $12 / 6 / 93$ & $2: 33$ & 99047 & 0.00 & 1.251 & 1.251 & 1.251 & 112 & 101 & 201062 & 870724 & 952 & 0 & 4646 & 142 & 20 & 559 \\
\hline LNB & $12 / 6 / 93$ & $3: 00$ & 138996 & 0.00 & 1.228 & 1.228 & 1.228 & 161 & 148 & 247314 & 1269337 & 948 & 0 & 3230 & 197 & 31 & 773 \\
\hline LNB & $12 / 6 / 93$ & $1: 55$ & 139695 & 0.00 & 1.251 & 1.251 & 1.251 & 162 & 149 & 251332 & 1271638 & 947 & 0 & 3302 & 201 & 31 & 775 \\
\hline LNB & $127 / 93$ & $6: 45$ & 141062 & 0.00 & 1.236 & 1.236 & 1.236 & 162 & 149 & 249915 & 1294655 & 933 & 0 & 3419 & 199 & 32 & 788 \\
\hline LNB & $12 / 8 / 93$ & 4:03 & 140531 & 0.00 & 1.277 & 1.277 & 1.277 & 163 & 150 & 255401 & 1264918 & 966 & 0 & 3421 & 208 & 31 & 765 \\
\hline GR-LNB 134 & $12 / 8 / 93$ & $3: 40$ & 119433 & 15.65 & 1.076 & 0.918 & 1.164 & 164 & 151 & 221915 & 1261376 & 985 & 1 & 5166 & 189 & 31 & 759 \\
\hline GR-LNB 134a & $12 / 8 / 93$ & $0: 46$ & 133141 & 5.25 & 1.086 & 1.037 & 1.182 & 162 & 149 & 230147 & 1268511 & 961 & 0 & 3577 & 190 & 31 & 771 \\
\hline GR-LNB 134b & $12 / 8 / 93$ & $2: 44$ & 133004 & 5.27 & 1.022 & 0.974 & 1.121 & 164 & 151 & 225616 & 1258909 & 983 & 11 & 4878 & 180 & 31 & 759 \\
\hline GP.LNB 134C & $12 / 8 / 93$ & $3: 31$ & 132393 & 5.29 & 0.987 & 0.939 & 1.089 & 167 & 154 & 223579 & 1257547 & 994 & 26 & 16467. & 179 & 30 & 739 \\
\hline GR-LNB 135 & 12/9/93 & $12: 00$ & 122705 & 5.20 & 1.006 & 0.960 & 1.118 & 154 & 142 & 214665 & 1154113 & 993 & 35 & 17121 & 169 & 27 & 685 \\
\hline GP-LNB 135a & $12 / 9 / 93$ & $2: 59$ & 128403 & 5.34 & 1.066 & 1.016 & 1.167 & 162 & 149 & 225977 & 1210333 & 993 & 48 & 15507 & 188 & 29 & 714 \\
\hline GR-LNB 135b & $12 / 9 / 93$ & $7: 10$ & 120972 & 4.93 & 1.171 & 1.124 & 1.282 & 147 & 134 & 224404 & 1143046 & 948 & 0 & 5054 & 187 & 28 & 702 \\
\hline GR-LNB 136 & $12 / 10 / 93$ & 11:35 & 125344 & 4.81 & 1.155 & 1.109 & 1.259 & 153 & 140 & 227625 & 1182535 & 961 & 0 & 4135 & 190 & 29 & 722 \\
\hline GR-LNB 137 & $12 / 11 / 93$ & $16: 15$ & 119739 & 4.70 & 1.105 & 1.062 & 1.218 & 147 & 134 & 216505 & 1117980 & 976 & 0 & 8189 & 178 & 27 & 682 \\
\hline GR-LNB 137a & $12 / 11 / 93$ & $7: 44$ & 134330 & 4.96 & 1.104 & 1.058 & 1.203 & 165 & 152 & 233215 & 1271054 & 973 & 0 & 3724 & 197 & 31 & 765 \\
\hline GR-LNB 138 & $12 / 12 / 93$ & $24: 00$ & 134660 & 5.03 & 1.095 & 1.048 & 1.193 & 166 & 152 & 232940 & 1277488 & 972 & 0 & 3878 & 197 & 31 & 767 \\
\hline GR-LNB 139 & 12/13/93 & $7: 48$ & 135122 & 4.98 & 1.073 & 1.027 & 1.173 & 168 & 155 & 228791 & 1275586 & 991 & 3 & 6147 & 196 & 31 & 759 \\
\hline
\end{tabular}


Cherokee Unit 3, Average Test C

Pre Modification

\begin{tabular}{|c|c|c|c|c|c|c|c|c|c|c|c|c|c|c|c|c|c|}
\hline Test & pare & Durm & "roal & $\begin{array}{l}\text { Gas } \\
\text { Heat } \\
\text { croti }\end{array}$ & Ycoaln & Re burn & 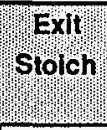 & $\begin{array}{l}\text { Gross } \\
\text { Power } \\
\text { Mwe }\end{array}$ & $\begin{array}{l}\text { Net } \\
\text { powerp } \\
\text { Mwe }\end{array}$ & 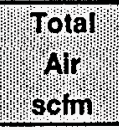 & 'steam & $\begin{array}{l}\text { Whain! } \\
\text { Steam } \\
\text { Temp }\end{array}$ & at flow & 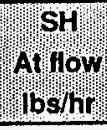 & 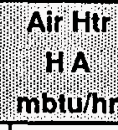 & $\begin{array}{l}\text { Econ } \\
\text { mbturn }\end{array}$ & 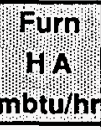 \\
\hline GR-LNB 139a & $12 / 13 / 93$ & $4: 18$ & 134009 & 5.05 & 1.106 & 1.058 & 1.205 & 167 & 153 & 227653 & 1261888 & 993 & 0 & 6437 & 200 & 31 & 752 \\
\hline LNB & $12 / 13 / 93$ & $5: 18$ & 133870 & 0.00 & 1.253 & 1.253 & 1.253 & 157 & 144 & 243245 & 1220439 & 949 & 0 & 14433 & 193 & 29 & 731 \\
\hline LNB.OFA & $12 / 14 / 93$ & $1: 55$ & 141974 & 0.00 & 1.109 & 1.117 & 1.303 & 166 & 152 & 230943 & 1278835 & 974 & 0 & 3325 & 216 & 31 & 768 \\
\hline GR-LNB 140 & $12 / 14 / 93$ & $1: 18$ & 135497 & 5.12 & 1.114 & 1.065 & 1.208 & 168 & 154 & 230530 & 1269747 & 992 & 0 & 5085 & 198 & 31 & 761 \\
\hline LNB & $12 / 14 / 93$ & $8: 30$ & 139333 & 0.00 & 1.192 & 1.192 & 1.192 & 162 & 149 & 239735 & 1256579 & 967 & 0 & 3354 & 192 & 31 & 763 \\
\hline LNB & $12 / 15 / 93$ & $9: 28$ & 137698 & 0.00 & 1.241 & 1.241 & 1.241 & 160 & 148 & 244378 & 1247133 & 958 & 0 & 3190 & 199 & 30 & 759 \\
\hline LNB-OFA & $12 / 15 / 93$ & $5: 29$ & 139287 & 0.00 & 1.158 & 1.159 & 1.262 & 162 & 149 & 240166 & 1265273 & 955 & 0 & 3214 & 204 & 31 & 768 \\
\hline GR-LNB 141 & $12 / 15 / 93$ & $5: 15$ & 119469 & 5.34 & 1.096 & 1.047 & 1.211 & 147 & 133 & 213125 & 1113543 & 983 & 29 & 6617 & 178 & 26 & 683 \\
\hline LNB & $12 / 15 / 93$ & $2: 50$ & 86246 & 0.00 & 1.388 & 1.388 & 1.388 & 98 & 87 & 199225 & 745605 & 994 & 0 & 9958 & 133 & 16 & 474 \\
\hline LNB & $12 / 16 / 93$ & $15: 05$ & 132676 & 0.00 & 1.260 & 1.260 & 1.260 & 156 & 143 & 242540 & 1175991 & 977 & 0 & 3635 & 194 & 27 & 733 \\
\hline GR-LNB 142 & $12 / 16 / 93$ & $6: 14$ & 135161 & 5.27 & 1.157 & 1.105 & 1.251 & 168 & 154 & 236507 & 1261200 & 992 & 948 & 4896 & 210 & 30 & 772 \\
\hline GR-LNB 142a & $12 / 16 / 93$ & $1: 15$ & 94213 & 5.74 & 1.150 & 1.098 & 1.290 & 115 & 104 & 179796 & 849694 & 980 & 0 & 4768 & 150 & 19 & 554 \\
\hline GR.LNB 143 & $12 / 17 / 93$ & $2: 10$ & 91390 & 5.80 & 1.181 & 1.128 & 1.323 & 112 & 101 & 182796 & 823936 & 994 & 0 & 6119 & 149 & 18 & 530 \\
\hline LNB-OFA & $12 / 17 / 93$ & $0: 40$ & 55318 & 0.00 & 1.337 & 1.364 & 1.688 & 57 & 47 & 121691 & 464254 & 877 & 0 & 3039 & 105 & 10 & 326 \\
\hline LNB & $12 / 17 / 93$ & $6: 10$ & 136809 & 0.00 & 1.236 & 1.236 & 1.236 & 163 & 150 & 243507 & 1214380 & 984 & 0 & 4441 & 197 & 28 & 752 \\
\hline LNB & $12 / 20 / 93$ & $2: 25$ & 121446 & 0.00 & 1.317 & 1.317 & 1.317 & 144 & 132 & 233768 & 1062739 & 988 & 0 & 6793 & 187 & 25 & 662 \\
\hline $100 \%$ Gas Firing & $12 / 20 / 93$ & $0: 34$ & 80058 & 0.00 & 1.435 & 1.435 & 1.435 & 92 & 83 & 208245 & 693795 & 975 & 0 & 5164 & 126 & 15 & 448 \\
\hline LNB & $12 / 2293$ & $2: 35$ & 113294 & 0.00 & 1.322 & 1.325 & 1.322 & 133 & 122 & 226092 & 984811 & 984 & 0 & 5659 & 176 & 22 & 621 \\
\hline LNB & $1 / 5 / 94$ & $2: 24$ & 135271 & 0.00 & 1.196 & 1.196 & 1.196 & 159 & 147 & 243031 & 1192621 & 984 & 0 & 3685 & 184 & 28 & 742 \\
\hline LNB-OFA & $1 / 5 / 94$ & $2: 26$ & 135407 & 0.00 & 1.189 & 1.194 & 1.233 & 159 & 146 & 240631 & 1200884 & 971 & 0 & 3688 & 191 & 28 & 748 \\
\hline LNB-OFA & $1 / 5 / 94$ & $9: 15$ & 119495 & 0.00 & 1.218 & 1.222 & 1.244 & 140 & 128 & 218178 & 1042703 & 977 & 0 & 4077 & 171 & 24 & 661 \\
\hline LNB-OFA & $1 / 6 / 94$ & $8: 47$ & 93312 & 0.00 & 1.255 & 1.259 & 1.284 & 107 & 96 & 184621 & 797140 & 976 & 0 & 9765 & 138 & 18 & 514 \\
\hline LNB & $1 / 6 / 94$ & 15:12 & 133673 & 0.00 & 1.201 & 1.201 & 1.201 & 159 & 147 & 237896 & 1178087 & 987 & 0 & 4910 & 190 & 28 & 730 \\
\hline LNB & $1 / 7 / 94$ & $6: 55$ & 110162 & 0.00 & 1.231 & 1.231 & 1.231 & 129 & 118 & 209883 & 958594 & 983 & 0 & 5586 & 159 & 22 & 610 \\
\hline LNB-OFA & $1 / 7 / 94$ & $1: 09$ & 113386 & 0.00 & 1.119 & 1.119 & 1.260 & 134 & 122 & 204185 & 989174 & 982 & 0 & 10220 & 169 & 22 & 621 \\
\hline GR-LNB 144 & $1 / 7 / 94$ & $15: 40$ & 121635 & 5.61 & 1.107 & 1.054 & 1.214 & 154 & 142 & 220257 & 1126768 & 994 & 102 & 12035 & 184 & 26 & 690 \\
\hline GR-LNB 145a & $1 / 8 / 94$ & $8: 20$ & 107935 & 5.64 & 1.084 & 1.033 & 1.208 & 137 & 125 & 199257 & 993975 & 996 & 0 & 19271 & 163 & 22 & 607 \\
\hline GR-LNB 145 & $1 / 8 / 94$ & $15: 39$ & 125471 & 5.56 & 1.060 & 1.009 & 1.166 & 161 & 148 & 220472 & 1174058 & 995 & 490 & 25884 & 186 & 27 & 697 \\
\hline GR-LNB 146a & $1 / 9 / 94$ & $2: 10$ & 120661 & 5.77 & 1.032 & 0.980 & 1.143 & 157 & 145 & 213181 & 1137267 & 995 & 0 & 36933 & 174 & 25 & 666 \\
\hline GR-LNB 146b & $1 / 9 / 94$ & $8: 39$ & 98416 & 5.63 & 1.071 & 1.022 & 1.211 & 126 & 114 & 189715 & 901363 & 998 & 17 & 30082 & 153 & 19 & 541 \\
\hline GR-LNB 146 & $1 / 9 / 94$ & $9: 02$ & 117435 & 5.76 & 1.109 & 1.055 & 1.221 & 150 & 138 & 216733 & 1087677 & 995 & 107 & 18453 & 181 & 25 & 659 \\
\hline LNB & $1 / 9 / 94$ & $3: 35$ & 108271. & 0.00 & 1.238 & 1.238 & 1.238 & 125 & 114 & 201739 & 940925 & 966 & 0 & 3700 & 155 & 22 & 608 \\
\hline LNB & $1 / 10 / 94$ & $3: 50$ & 119039 & 0.00 & 1.269 & 1.269 & 1.269 & 142 & 130 & 216822 & 1040174 & 996 & 88 & 14220 & 179 & 24 & 637 \\
\hline GR-LNB 147 & $1 / 10 / 94$ & $2: 40$ & 134381 & 5.22 & 1.159 & 1.108 & 1.252 & 168 & 155 & 233086 & 1248369 & 992 & 597 & 9077 & 212 & 29 & 759 \\
\hline GR-LNB 147a & $1 / 10 / 94$ & $4: 04$ & 105585 & 6.84 & 1.201 & 1.133 & 1.319 & 132 & 120 & 200523 & 974260 & 987 & 0 & 7282 & 173 & 22 & 615 \\
\hline GR-LNB 1476 & $1 / 10 / 94$ & $4: 54$ & 106168 & 6.74 & 1.220 & 1.152 & 1.335 & 133 & 121 & 204128 & 980778 & 983 & 0 & 8432 & 177 & 22 & 619 \\
\hline GR-LNB 148a & $1 / 11 / 94$ & $6: 32$ & 93894 & 7.06 & 1.254 & 1.183 & 1.383 & 118 & 106 & 194218 & 860045 & 997 & 0 & 10158 & 164 & 19 & 542 \\
\hline GR-LNB 148 & $1 / 11 / 94$ & $14: 38$ & 130318 & 6.70 & 1.143 & 1.077 & 1.238 & 164 & 151 & 234355 & 1238948 & 973 & 0 & 4073 & 202 & 29 & 765 \\
\hline GR-LNB $148 b$ & $1 / 11 / 94$ & $2: 48$ & 108570 & 6.22 & 1.139 & 1.080 & 1.257 & 133 & 121 & 203986 & 1015828 & 949 & 0 & 3754 & 165 & 23 & 653 \\
\hline GR-LNB 149a & $1 / 12 / 94$ & $6: 14$ & 114624 & 6.20 & 1.150 & 1.090 & 1.259 & 145 & 132 & 216406 & 1062151 & 990 & 4 & 7050 & 181 & 24 & 663 \\
\hline
\end{tabular}


Cherokee Unit 3, Average Test C

Pre Modification

\begin{tabular}{|c|c|c|c|c|c|c|c|c|c|c|c|c|c|c|c|c|c|}
\hline nos & Date & Dur & Proal & 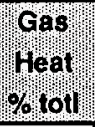 & sopaln" & Reburn & Storich & Gross & $\begin{array}{l}\text { Net } \\
\text { Power } \\
\text { nwe }\end{array}$ & 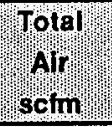 & Steam & $\begin{array}{l}\text { Main } \\
\text { Steam } \\
\text { Temp }\end{array}$ & 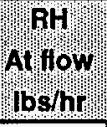 & $\begin{array}{l}\text { sh } \\
\text { Atfow } \\
\text { Ibshr.h }\end{array}$ & Atr & EcoñI" & 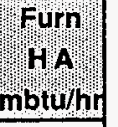 \\
\hline GR-LNB 149 & $1 / 12 / 94$ & $13: 30$ & 122024 & 6.29 & 1.137 & 1.076 & 1.241 & 154 & 141 & 224520 & 1142102 & 986 & 14 & 7113 & 189 & 27 & 706 \\
\hline GR-LNB A Mill off & $1 / 12 / 94$ & $1: 09$ & 110619 & 6.45 & 1.118 & 1.056 & 1.233 & 142 & 130 & 214568 & 1029804 & 998 & 321 & 22215 & 172 & 23 & 623 \\
\hline GR-LNB D Mill off & $1 / 12 / 94$ & $1: 39$ & 111431 & 8.88 & 1.054 & 0.969 & 1.173 & 148 & 136 & 211571 & 1071712 & 999 & 0 & 24362 & 169 & 24 & 643 \\
\hline GA-LNB D Mill off line & $1 / 13 / 94$ & $4: 23$ & 90176 & 7.45 & 1.065 & 0.997 & 1.209 & 116 & 106 & 181847 & 841565 & 995 & 0 & 24408 & 135 & 18 & 516 \\
\hline GR-LNB 150 & $1 / 13 / 94$ & $7: 15$ & 128758 & 6.80 & 1.100 & 1.035 & 1.198 & 165 & 153 & 229501 & 1217306 & 994 & 1276 & 23810 & 197 & 28 & 724 \\
\hline GR-LNB D Mill off line & $1 / 13 / 94$ & $1: 13$ & 111747 & 8.41 & 1.055 & 0.975 & 1.176 & 149 & 137 & 212931 & 1067973 & 998 & 138 & 36523 & 168 & 24 & 629 \\
\hline GR-LNB 150a & $1 / 13 / 94$ & $6: 00$ & 115289 & 6.70 & 1.129 & 1.064 & 1.240 & 146 & 133 & 213233 & 1074955 & 984 & 231 & 12399 & 180 & 25 & 665 \\
\hline GR-LNB 151a & $1 / 14 / 94$ & $7: 25$ & 93341 & 6.57 & 1.161 & 1.099 & 1.298 & 115 & 103 & 186662 & 852590 & 976 & 15 & 9084 & 148 & 19 & 548 \\
\hline GR-LNB, ABC & $1 / 14 / 94$ & $7: 50$ & 110912 & 6.26 & 1.093 & 1.035 & 1.208 & 143 & 132 & 212467 & 1033877 & 998 & 0 & 27821 & 164 & 23 & 620 \\
\hline GR-LNB 151 & $1 / 14 / 94$ & $7: 54$ & 112463 & 6.25 & 1.097 & 1.039 & 1.212 & 143 & 131 & 210589 & 1042914 & 994 & 40 & 18587 & 170 & 24 & 637 \\
\hline GR-LNB 156 & $1 / 19 / 94$ & 24.00 & 100531 & 6.59 & 1.113 & 1.051 & 1.241 & 126 & 114 & 195405 & 925175 & 988 & 1 & 10075 & 153 & 21 & 584 \\
\hline GR-LNB 157a & $1 / 20 / 94$ & $6: 38$ & 95851 & 6.59 & 1.094 & 1.034 & 1.233 & 122 & 111 & 188348 & 884252 & 998 & 0 & 18640 & 150 & 19 & 547 \\
\hline GA-LNB 157 & $1 / 20 / 94$ & $3: 50$ & 119466 & 7.65 & 1.089 & 1.015 & 1.196 & 157 & 145 & 217610 & 1142670 & 996 & 129 & 29647 & 189 & 26 & 675 \\
\hline
\end{tabular}


Cherokee Unit 3, Average Test L

Pre Modification

\begin{tabular}{|c|c|c|c|c|c|c|c|c|c|c|c|c|c|c|c|c|c|c|}
\hline Tost & Date: & Dur & Writ & $\begin{array}{l}\text { PSH } \\
\text { HA } \\
\text { mburh }\end{array}$ & $\begin{array}{c}\mathrm{SSH} \\
\mathrm{HA} \\
\mathrm{mbru} / \mathrm{h}\end{array}$ & Trotal & $\begin{array}{l}\text { Tolal } \\
\text { Heat In } \\
\text { mbtorh }\end{array}$ & $\begin{array}{c}\text { GrosshV } \\
\text { Boileft } \\
\% \%\end{array}$ & $\begin{array}{l}\text { LowHV } \\
\text { Boiletf } \\
\text { Y \% }\end{array}$ & $\begin{array}{l}\text { HiLoss } \\
\text { Bolleff } \\
\text { Yo }\end{array}$ & $\begin{array}{l}\text { Furn } \\
\text { clean } \\
\text { Fact }\end{array}$ & $\begin{array}{l}\text { PSH } \\
\text { Clean } \\
\text { Fact }\end{array}$ & $\begin{array}{l}\text { SSH } \\
\text { Clean } \\
\text { Fact }\end{array}$ & $\begin{array}{l}\mathrm{RH} \\
\text { Clean } \\
\mathrm{Fact}\end{array}$ & $\begin{array}{l}\text { ECON } \\
\text { Clean } \\
\text { Fac }\end{array}$ & $\begin{array}{l}\text { Airttr } \\
\text { Clean } \\
\text { ract }\end{array}$ & $\begin{array}{l}\text { Ht lon } \\
\text { Burners } \\
\text { mbtu/hy }\end{array}$ & 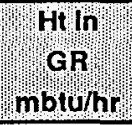 \\
\hline Base Cond. (OFA off) & $11 / 11 / 92$ & $8: 42$ & 126 & 140 & 116 & 915 & 1051 & 87.06 & 90.55 & 85.09 & 1.04 & 1.05 & 1.05 & 1.04 & 1.05 & 1.16 & 1051 & 0 \\
\hline$G R$ & $11 / 11 / 92$ & $1: 01$ & 209 & 242 & 178 & 1371 & 1570 & 87.31 & 91.95 & 85.76 & 0.99 & 1.09 & 1.13 & 1.16 & 1.03 & 1.09 & 1247 & 324 \\
\hline Base Cond. (OFA off) & $11 / 11 / 92$ & $4: 25$ & 189 & 239 & 160 & 1362 & 1550 & 87.87 & 91.39 & 87.13 & 1.02 & 1.05 & 1.00 & 1.03 & 1.01 & 1.08 & 1550 & 0 \\
\hline Base Cond OFA off & $11 / 1292$ & $0: 45$ & 186 & 222 & 165 & 1362 & 1542 & 88.35 & 91.89 & 88.58 & 1.02 & 0.97 & 1.02 & 1.00 & 1.03 & 1.01 & 1542 & 0 \\
\hline BPMS GR 4 & $11 / 12 / 92$ & $1: 05$ & 205 & 252 & 171 & 1368 & 1569 & 87.17 & 91.74 & 87.32 & 0.99 & 1.14 & 1.09 & 1.14 & 1.03 & 1.13 & 1263 & 306 \\
\hline Base Cond. OFA off & $11 / 12 / 92$ & $1: 15$ & 188 & 241 & 156 & 1358 & 1546 & 87.83 & 91.35 & 88.02 & 1.02 & 1.07 & 0.98 & 1.02 & 1.03 & 1.09 & 1546 & 0 \\
\hline BPMS Base Cond. 5 & $11 / 13 / 92$ & $2: 55$ & 195 & 245 & 164 & 137 & 1568 & 87.79 & 91.31 & 87.98 & 1.01 & 1.07 & 1.02 & 1.06 & 1.03 & 1.12 & 1568 & 0 \\
\hline BPMS Base Cond. 8 & $11 / 13 / 92$ & $1: 00$ & 185 & 230 & 159 & 1367 & 1554 & 87.98 & 91.51 & 88.17 & 1.02 & 0.99 & 0.97 & 0.98 & 1.02 & 1.04 & 1554 & 0 \\
\hline BPMS Base Cond. 7 & $11 / 13 / 92$ & $1: 00$ & 183 & 227 & 160 & 1372 & 1558 & 88.05 & 91.58 & 88.25 & 1.02 & 0.97 & 0.97 & 0.97 & 1.02 & 1.00 & 1558 & 0 \\
\hline Base Cond.1d & $11 / 16 / 92$ & $1: 00$ & 178 & 214 & 156 & 1270 & 1449 & 87.66 & 91.17 & 87.85 & 1.02 & 1.03 & 1.03 & 1.04 & 1.04 & 1.10 & 1449 & 0 \\
\hline GA-10c & $11 / 16 / 92$ & 1.00 & 178 & 216 & 157 & 1331 & 1512 & 88.02 & 91.55 & 88.22 & 1.03 & 0.95 & 0.98 & 0.97 & 1.03 & 0.97 & 1512 & 0 \\
\hline GR-10d & $11 / 16 / 92$ & $1: 00$ & 177 & 217 & 157 & 1331 & 1514 & 87.94 & 91.46 & 88.15 & 1.03 & 0.96 & 0.98 & 0.96 & 1.02 & 0.99 & 1514 & 0 \\
\hline Base Cond. OFA off & $11 / 17 / 92$ & 1:15 & 188 & 236 & 162 & 1362 & 1547 & 88.09 & 91.62 & 88.27 & 1.02 & 1.03 & 1.01 & 1.02 & 1.03 & 1.08 & 1547 & 0 \\
\hline GR-11c & $11 / 17 / 92$ & 1.00 & 194 & 237 & 166 & 1334 & 1532 & 87.09 & 91.74 & 87.26 & 1.01 & 1.10 & 1.07 & 1.10 & 1.03 & 1.07 & 1213 & 320 \\
\hline GR-11d & 11/17/92 & $1: 00$ & 193 & 236 & 164 & 1323 & 1521 & 86.94 & 91.59 & 87.11 & 1.01 & 1.10 & 1.07 & 1.10 & 1.03 & 1.08 & 1201 & 321 \\
\hline Base Cond. OFA off & $11 / 1792$ & $0: 20$ & 184 & 228 & 150 & 1289 & 1477 & 87.31 & 90.81 & 87.46 & 1.01 & 1.08 & 0.99 & 1.06 & 1.03 & 1.15 & 1477 & 0 \\
\hline Base Cond. OFA off & $11 / 18 / 92$ & $0: 28$ & 179 & 228 & 155 & 1325 & 1498 & 88.43 & 91.98 & 88.61 & 1.02 & 1.03 & 0.99 & 1.00 & 1.03 & 1.03 & 1498 & 0 \\
\hline GR-110 & $11 / 18 / 92$ & 1.04 & 193 & 245 & 163 & 1332 & 1530 & 87.03 & 91.68 & 87.17 & 1.00 & 1.14 & 1.06 & 1.10 & 1.03 & 1.10 & 1210 & 320 \\
\hline GA-120 & 11/188/92 & 1.05 & 189 & 240 & 159 & 1322 & 1517 & 87.13 & 91.51 & 87.30 & 1.00 & 1.11 & 1.03 & 1.08 & 1.03 & 1.10 & 1275 & 242 \\
\hline Base Cond. OFA off & $11 / 18 / 92$ & $0: 35$ & 183 & 233 & 152 & 1310 & 1495 & 87.64 & 91.15 & 87.83 & 1.02 & 1.08 & 0.98 & 1.04 & 1.03 & 1.10 & 1495 & 0 \\
\hline GA-12 (5\% Gas) & $11 / 19 / 92$ & 1.00 & 183 & 217 & 168 & 1344 & 1526 & 88.10 & 91.92 & 88.28 & 1.02 & 0.96 & 1.05 & 1.00 & 1.03 & 1.00 & 1446 & 80 \\
\hline GA-12a (10\% Gas) & $11 / 19 / 92$ & 1.00 & 189 & 234 & 171 & 1353 & 1540 & 87.88 & 91.97 & 88.04 & 1.02 & 1.06 & 1.09 & 1.05 & 1.03 & 1.01 & 1381 & 159 \\
\hline GR-12c (23\% Gas) & $11 / 19 / 92$ & $1: 00$ & 200 & 218 & 189 & 1309 & 1504 & 87.01 & 91.80 & 87.14 & 0.99 & 1.05 & 1.26 & 1.17 & 1.02 & 1.07 & 1152 & 352 \\
\hline OFA off & & $0: 20$ & 187 & 227 & 159 & 1306 & 1487 & 87.83 & 91.35 & 87.96 & 1.02 & 1.07 & 1.04 & 1.08 & 1.03 & 1.10 & 1487 & 0 \\
\hline GR-13A; $18 \%$ Gas & $11 / 20 / 92$ & $0: 58$ & 191 & 233 & 170 & 1326 & 1514 & 87.54 & 92.08 & 87.72 & 1.01 & 1.09 & 1.11 & 1.09 & 1.03 & 1.05 & 1232 & 282 \\
\hline GR-13D; $18 \%$ Gas & $11 / 20 / 92$ & $1: 00$ & 195 & 236 & 167 & 1309 & 1499 & 87.30 & 91.84 & 87.48 & 1.00 & 1.13 & 1.11 & 1.13 & 1.03 & 1.12 & 1219 & 280 \\
\hline GR-14B; $20 \%$ Gas & $11 / 20 / 92$ & $1: 00$ & 197 & 237 & 168 & 1309 & 1503 & 87.11 & 91.74 & 87.27 & 0.99 & 1.14 & 1.12 & 1.15 & 1.03 & 1.15 & 1195 & 308 \\
\hline Base Cond. OFA off & & $1: 50$ & 184 & 233 & 162 & 1338 & 1522 & 87.86 & 91.38 & 88.06 & 1.02 & 1.06 & 1.03 & 1.03 & 1.03 & 1.06 & 1522 & 0 \\
\hline GA-BFt & & $0: 26$ & 186 & 242 & 156 & 1336 & 1531 & 87.26 & 34 & 87.6 & 1.01 & 1.11 & 1.00 & 4 & 1.03 & 1.12 & 1369 & 162 \\
\hline GA-BFI & $11 / 30 / 92$ & $0: 27$ & 182 & 229 & 160 & 1323 & 1515 & 87.33 & 91.41 & 87.47 & 1.02 & 1.06 & 1.03 & 1.03 & 1.03 & 1.11 & 1356 & 159 \\
\hline GR-21C & $12 / 1 / 92$ & 1.06 & 154 & 173 & 136 & 1048 & 1209 & 86.71 & 91.34 & 86.84 & 1.02 & 1.10 & 1.10 & 1.13 & 1.04 & 1.14 & 955 & 254 \\
\hline GA-22 & $12 / 1 / 92$ & $0: 50$ & 143 & 170 & 116 & 1043 & 1197 & 87.11 & 91.06 & 87.24 & 1.04 & 1.04 & 0.91 & 1.02 & 1.04 & 1.16 & 1098 & 99 \\
\hline Bias Firing & $12 / 1 / 92$ & $0: 10$ & 147 & 177 & 130 & 1048 & 1207 & 86.89 & 91.58 & 87.05 & 1.03 & 1.12 & 1.05 & 1.06 & 1.04 & 1.12 & 943 & 264 \\
\hline Base Cond. OFA on & & $0: 50$ & 15 & 151 & 129 & 1047 & 1191 & 87.86 & 91.38 & 88.19 & 1.05 & 0.91 & 1.01 & 0.97 & 1.03 & 1.06 & 1191 & 0 \\
\hline Base Cond. OFA off & $12 / 1 / 92$ & $0: 40$ & 15 & 188 & 137 & 1127 & 1284 & 87.79 & 91.31 & 87.93 & 1.04 & 1.07 & 1.03 & 1.04 & 1.04 & 1.10 & 1284 & 0 \\
\hline Base Cond. OFA off & $12 / 2 / 92$ & $3: 55$ & 180 & 233 & 147 & 1304 & 1480 & 88.09 & 91.62 & 88.24 & 1.02 & 1.09 & 0.96 & 1.03 & 1.03 & 1.09 & 1480 & 0 \\
\hline Base Cond. OFA off & $12 / 4 / 92$ & $0: 55$ & 160 & 178 & 135 & 1099 & 1252 & 87.80 & 91.32 & 88.01 & 1.04 & 1.06 & 1.05 & 1.11 & 1.03 & 1.16 & 1252 & 0 \\
\hline OFA Test & $12 / 4 / 92$ & 2:10 & 143 & 170 & 121 & 1021 & 1162 & 87.80 & 91.32 & 87.99 & 1.04 & 1.11 & 0.99 & 1.06 & 1.04 & 1.17 & 1162 & 0 \\
\hline sse Cond. OFA off & $12 / 7 / 92$ & 2:10 & 159 & 175 & 150 & 1105 & 1260 & 87.67 & 91.18 & 87.88 & 1.02 & 1.03 & 1.16 & 1.09 & 1.03 & 1.19 & 1260 & 0 \\
\hline GR-22A & $12 / 7 / 92$ & 1.05 & 161 & 179 & 141 & 1085 & 1244 & 87.20 & 91.32 & 87.38 & 1.01 & 1.09 & 1.11 & 1.14 & 1.03 & 1.16 & 1102 & 142 \\
\hline
\end{tabular}


Cherokee Unit 3, Average Test [

Pre Modification

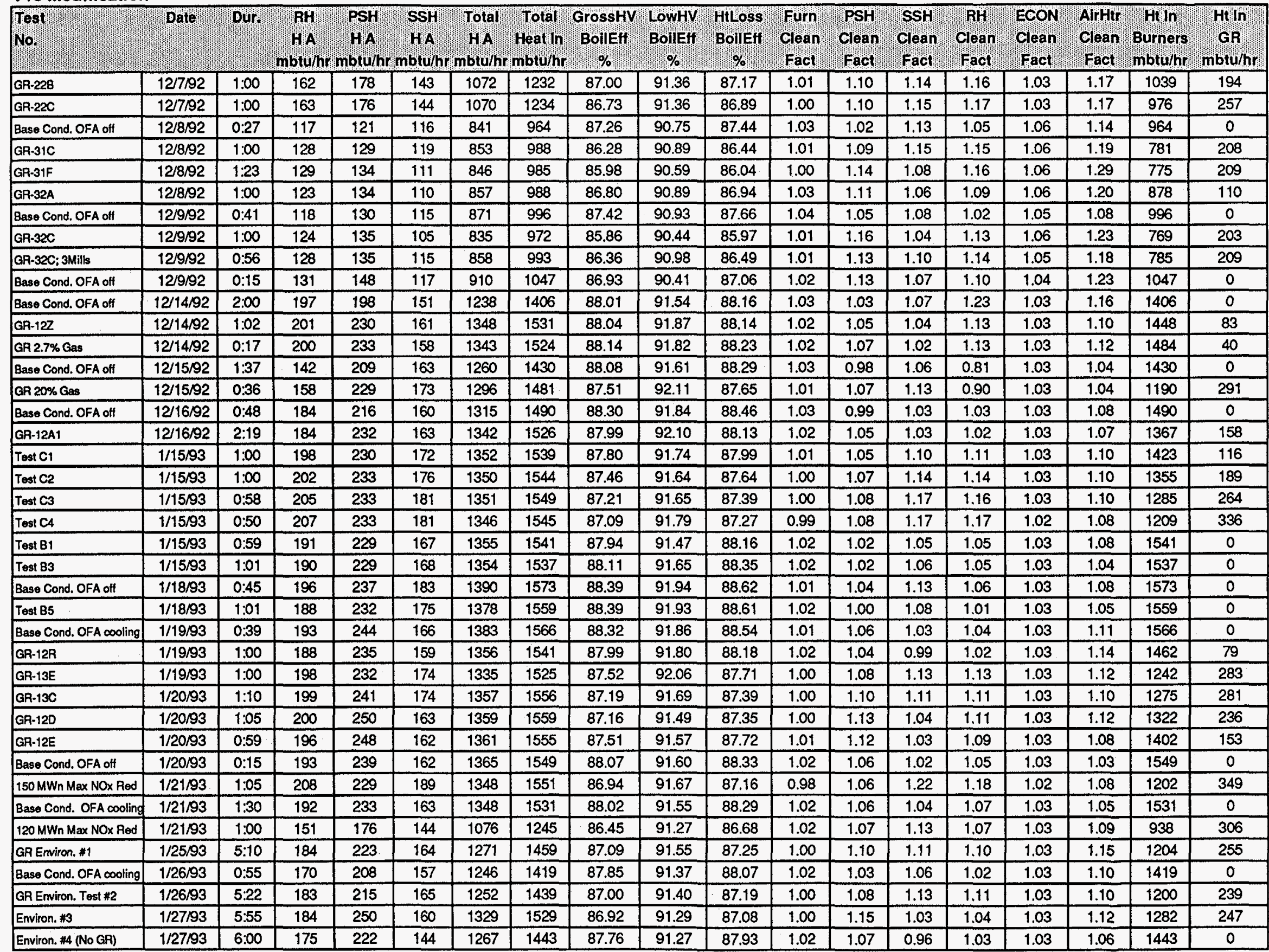


Cherokee Unit 3, Average Test [

Pre Modification

\begin{tabular}{|c|c|c|c|c|c|c|c|c|c|c|c|c|c|c|c|c|c|c|}
\hline Testim & Date & Dur. & $\begin{array}{c}\begin{array}{c}\mathrm{BH} \\
\mathrm{H}\end{array} \\
\text { mbtu/hr } \\
\end{array}$ & $\begin{array}{l}\text { PSH } \\
\text { HAN } \\
\text { bruth }\end{array}$ & $\begin{array}{r}\text { SSH } \\
\mathrm{HA} \\
\mathrm{nbtu/h} \\
\end{array}$ & $\begin{array}{l}\text { Total } \\
\mathrm{H} / \mathrm{A}\end{array}$ & $\begin{array}{l}\text { Total } \\
\text { Heat } / \text { h } \\
\text { mbtu/hr }\end{array}$ & $\begin{array}{l}\text { GrossHV } \\
\text { Boiferf } \\
\text { \% }\end{array}$ & $\begin{array}{l}\text { Lowhy } \\
\text { Boifef } \\
\%\end{array}$ & $\begin{array}{l}\text { HtLoss } \\
\text { BoifEff }\end{array}$ & $\begin{array}{l}\text { Furn } \\
\text { Clean } \\
\text { Fact }\end{array}$ & $\begin{array}{l}\text { PSH } \\
\text { Clean } \\
\text { Fact }\end{array}$ & $\begin{array}{l}\text { SSH } \\
\text { Clean } \\
\text { Fach }\end{array}$ & $\begin{array}{l}\text { RH } \\
\text { clean } \\
\text { ract }\end{array}$ & $\begin{array}{l}\text { ECON } \\
\text { Clean } \\
\text { Fac }\end{array}$ & $\begin{array}{l}\text { Airhtr } \\
\text { Cean } \\
\text { react }\end{array}$ & $\begin{array}{l}\text { Hi ln } \\
\text { Burners } \\
\text { mblu/hr }\end{array}$ & $\begin{array}{c}\mathrm{Ht} \ln \\
\mathrm{GR} \\
\mathrm{mbtu}\end{array}$ \\
\hline Environ. \#5 (No GR) & $1 / 28 / 93$ & $6: 04$ & 177 & 244 & 161 & 1352 & 1538 & 87.93 & 91.45 & 88.21 & 1.02 & 1.08 & 1.01 & 0.97 & 1.03 & 1.07 & \begin{tabular}{|l|}
1538 \\
\end{tabular} & \\
\hline Base Cond. & $2 / 2 / 93$ & $0: 17$ & 181 & 223 & 172 & 1340 & 1522 & 88.02 & 91.55 & 88.26 & 1.02 & 1.01 & 1.10 & 1.01 & 1.03 & 1.03 & 1522 & 0 \\
\hline LNB 120MW \#1 & $3 / 8 / 93$ & $2: 00$ & 139 & 150 & 140 & 1085 & 1241 & 87.44 & 90.95 & 87.61 & 1.06 & 0.86 & 1.06 & 0.93 & 1.02 & 1.02 & 1241 & 0 \\
\hline LNB 120MW \#2 & 3/8/93 & $2: 00$ & 138 & 160 & 139 & 1088 & 1247 & 87.25 & 90.75 & 87.42 & 1.05 & 0.92 & 1.05 & 0.94 & 1.02 & 1.03 & 1247 & 0 \\
\hline LNB 150MW \#1 & $3 / 9 / 93$ & 2.00 & 194 & 248 & 156 & 1393 & 1592 & 87.54 & 91.05 & 87.70 & 1.03 & 1.07 & 0.96 & 1.04 & 1.02 & 1.09 & 1592 & 0 \\
\hline LNB 150MW \#2 & $3 / 9 / 93$ & $2: 00$ & 187 & 230 & 157 & 1373 & 1565 & 87.69 & 91.21 & 87.87 & 1.03 & 0.99 & 0.97 & 1.00 & 1.02 & 1.03 & 1565 & 0 \\
\hline LNB 90MW *1 & $3 / 10 / 93$ & $2: 00$ & 108 & 112 & 104 & 854 & 979 & 87.18 & 90.68 & 87.31 & 1.07 & 0.87 & 0.96 & 0.92 & 1.04 & 1.13 & 979 & 0 \\
\hline LNB 90MW *2 & $3 / 10 / 93$ & $1: 58$ & 109 & 116 & 104 & 857 & 983 & 87.16 & 90.65 & 87.29 & 1.07 & 0.90 & 0.96 & 0.93 & 1.04 & 1.12 & 983 & $\overline{0}$ \\
\hline LNB 150MW *3 & 3/11/93 & $2: 00$ & 194 & 239 & 160 & 1364 & 1549 & 88.03 & 91.56 & 88.19 & 1.03 & 1.07 & 1.01 & 1.07 & 1.02 & 1.10 & 1549 & 0 \\
\hline LNB 150MW \#4 & 3/11/93 & $2: 00$ & 190 & 235 & 163 & 1373 & 1558 & 88.13 & 91.66 & 88.30 & 1.03 & 1.03 & 1.02 & 1.03 & 1.02 & 1.06 & 1558 & 0 \\
\hline $3 M 1$ & $3 / 2293$ & 1.02 & 147 & 209 & 164 & 1299 & 1481 & 87.67 & 92.31 & 87.85 & 1.03 & 0.93 & 1.03 & 0.80 & 1.02 & 0.91 & 1182 & 300 \\
\hline 3M2 & $3 / 2293$ & $1: 03$ & 146 & 211 & 165 & 1296 & 1478 & 87.71 & 92.36 & 87.88 & 1.03 & 0.95 & 1.05 & 0.81 & 1.02 & 0.90 & 1177 & 301 \\
\hline 3M3 & $3 / 2293$ & $0: 59$ & 149 & 224 & 159 & 1301 & 1486 & 87.54 & 92.18 & 87.70 & 1.03 & 1.01 & 1.01 & 0.83 & 1.02 & 0.94 & 1185 & 301 \\
\hline 3 Mill 7 & $4 / 13 / 93$ & $1: 00$ & 116 & 144 & 135 & 1042 & 1182 & 88.15 & 91.68 & 88.31 & 1.06 & 0.84 & 1.03 & 0.79 & 1.02 & 0.95 & 1182 & 0 \\
\hline 3 Mill 6 & $4 / 13 / 93$ & $1: 00$ & 116 & 147 & 140 & 1054 & 1193 & 88.36 & 91.90 & 88.55 & 1.05 & 0.85 & 1.06 & 0.79 & 1.02 & 0.92 & 1193 & 0 \\
\hline Level $61 / 2$ & $4 / 15 / 93$ & $2: 05$ & 141 & 212 & 169 & 1281 & 1456 & 87.96 & 91.49 & 88.19 & 1.03 & 0.97 & 1.09 & 0.79 & 1.02 & 1.03 & 1456 & 0 \\
\hline Level 4 & $4 / 15 / 93$ & 1:10 & 141 & 212 & 169 & 1280 & 1455 & 87.96 & 91.49 & 88.19 & 1.03 & 0.97 & 1.09 & 0.79 & 1.02 & 1.03 & 1455 & 0 \\
\hline Level 3 & $4 / 15 / 93$ & $0: 53$ & 142 & 213 & 170 & 1282 & 1458 & 87.93 & 91.46 & 88.17 & 1.03 & 0.97 & 1.09 & 0.80 & 1.02 & 1.03 & 1458 & 0 \\
\hline Level $51 / 2$ & $4 / 15 / 93$ & $1: 58$ & 142 & 212 & 164 & 1281 & 1456 & 87.97 & 91.49 & 88.18 & 1.03 & 0.97 & 1.05 & 0.79 & 1.02 & 0.99 & 1456 & 0 \\
\hline Base Cond & $4 / 15 / 93$ & $5: 25$ & 142 & 212 & 167 & 1281 & 1456 & 87.97 & 91.50 & 88.20 & 1.03 & 0.97 & 1.07 & 0.80 & 1.02 & 1.01 & 1456 & 0 \\
\hline Level $51 / 2$ & $4 / 16 / 93$ & $1: 47$ & 147 & 238 & 161 & 1306 & 1489 & 87.70 & 91.21 & 87.92 & 1.02 & 1.08 & 1.03 & 0.82 & 1.03 & 1.08 & 1489 & 0 \\
\hline Loval $61 / 2$ & $4 / 16 / 93$ & 1:19 & 148 & 236 & 158 & 1307 & 1491 & 87.68 & 91.19 & 87.90 & 1.02 & 1.06 & 1.00 & 0.82 & 1.03 & 1.05 & 1491 & 0 \\
\hline Levol 3 & $4 / 16 / 93$ & $0: 44$ & 148 & 238 & 156 & 1308 & 1493 & 87.60 & 91.11 & 87.81 & 1.02 & 1.07 & 0.99 & 0.82 & 1.03 & 1.06 & 1493 & 0 \\
\hline Level 4 & $4 / 16 / 93$ & $1: 00$ & 149 & 238 & 156 & 1309 & 1495 & 87.60 & 91.11 & 87.81 & 1.02 & 1.07 & 0.99 & 0.82 & 1.03 & 1.06 & 1495 & 0 \\
\hline North out, South in & $4 / 16 / 93$ & $0: 20$ & 147 & 239 & 160 & 1305 & 1492 & 87.48 & 90.99 & 87.69 & 1.02 & 1.08 & 1.02 & 0.82 & 1.03 & 1.12 & 1492 & 0 \\
\hline South out, North in & $4 / 16 / 93$ & $0: 20$ & 147 & 237 & 159 & 1301 & 1483 & 87.74 & 91.26 & 87.97 & 1.02 & 1.08 & 1.01 & 0.82 & 1.03 & 1.06 & 1483 & 0 \\
\hline Base Cond & $4 / 16 / 93$ & $6: 25$ & 148 & 237 & 158 & 1308 & 1492 & 87.65 & 91.17 & 87.87 & 1.02 & 1.07 & 1.00 & 0.82 & 1.03 & 1.06 & 1492 & 0 \\
\hline Level 4 & 4/19/93 & $0: 56$ & 157 & 236 & 168 & 1296 & 1489 & 87.06 & 91.63 & 87.28 & 1.00 & 1.09 & 1.09 & 0.89 & 1.03 & 1.06 & 1199 & 290 \\
\hline Level 3 & $4 / 19 / 93$ & $0: 52$ & 157 & 236 & 168 & 1295 & 1488 & 87.06 & 91.63 & 87.28 & 1.00 & 1.09 & 1.09 & 0.89 & 1.03 & 1.06 & 1198 & 290 \\
\hline Level $51 / 2$ & $4 / 199 / 93$ & $2: 29$ & 160 & 238 & 163 & 1284 & 1479 & 86.81 & 91.38 & 87.04 & 1.00 & 1.12 & 1.07 & 0.92 & 1.03 & 1.11 & 1187 & 292 \\
\hline Level $61 / 2$ & $4 / 19 / 93$ & 1:10 & 161 & 241 & 162 & 1288 & 1485 & 86.76 & 91.32 & 87.02 & 1.00 & 1.13 & 1.06 & 0.92 & 1.03 & 1.12 & 1192 & 293 \\
\hline Base Cond. OFA on & $4 / 19 / 93$ & 1:00 & 149 & 224 & 146 & 1277 & 1455 & 87.71 & 91.23 & 87.88 & 1.02 & 1.02 & 0.94 & 0.83 & 1.03 & 1.09 & 1455 & 0 \\
\hline GR & $4 / 19 / 93$ & $5: 42$ & 160 & 238 & 164 & 1285 & 1479 & 86.83 & 91.40 & 87.07 & 1.00 & 1.12 & 1.07 & 0.92 & 1.03 & 1.10 & 1188 & 292 \\
\hline Level 6 1/2 & $4 / 20 / 93$ & $1: 47$ & 130 & 171 & 146 & 1154 & 1306 & 88.35 & 91.89 & 88.53 & 1.04 & 0.88 & 1.02 & 0.80 & 1.02 & 0.96 & 1306 & 0 \\
\hline Base Cond 130MW & $4 / 20 / 93$ & $3: 35$ & 129 & 171 & 147 & 1153 & 1305 & 88.35 & 91.89 & 88.53 & 1.04 & 0.87 & 1.02 & 0.79 & 1.02 & 0.96 & 1305 & 0 \\
\hline Base Cond 120MW & 4/20/93 & $2: 55$ & 126 & 171 & 144 & 1067. & 1222 & 87.32 & 90.82 & 87.48 & 1.04 & 1.02 & 1.12 & 0.88 & 1.03 & 1.11 & 1222 & 0 \\
\hline Base Cond. OFA off & $4 / 21 / 93$ & $7: 40$ & 120 & 159 & 140 & 1035 & 1185 & 87.31 & 90.81 & 87.43 & 1.04 & 0.98 & 1.11 & 0.85 & 1.03 & 1.07 & 1185 & 0 \\
\hline Base Cond. OFA off & 4/23/93 & $0: 30$ & 150 & 231 & 161 & 1301 & 1485 & 87.58 & 91.09 & 87.84 & 1.02 & 1.06 & 1.03 & 0.84 & 1.03 & 1.02 & 1485 & 0 \\
\hline 4M:12 (OFA off) & $4 / 23 / 93$ & $1: 00$ & 148 & 214 & 160 & 1295 & 1471 & 88.07 & 91.60 & 88.07 & 1.03 & 0.96 & 1.01 & 0.81 & 1.02 & 0.93 & 1471 & 0 \\
\hline $4 \mathrm{M} 13 \mathrm{a}$ (78,000 sofm OFA & 4/23/93 & $0: 20$ & 147 & 213 & 150 & 1318 & 1496 & 88.07 & 91.60 & 87.98 & 1.03 & 0.91 & 0.91 & 0.78 & 1.02 & 0.93 & 1496 & 0 \\
\hline
\end{tabular}


Cherokee Unit 3, Average Test [

Pre Modification

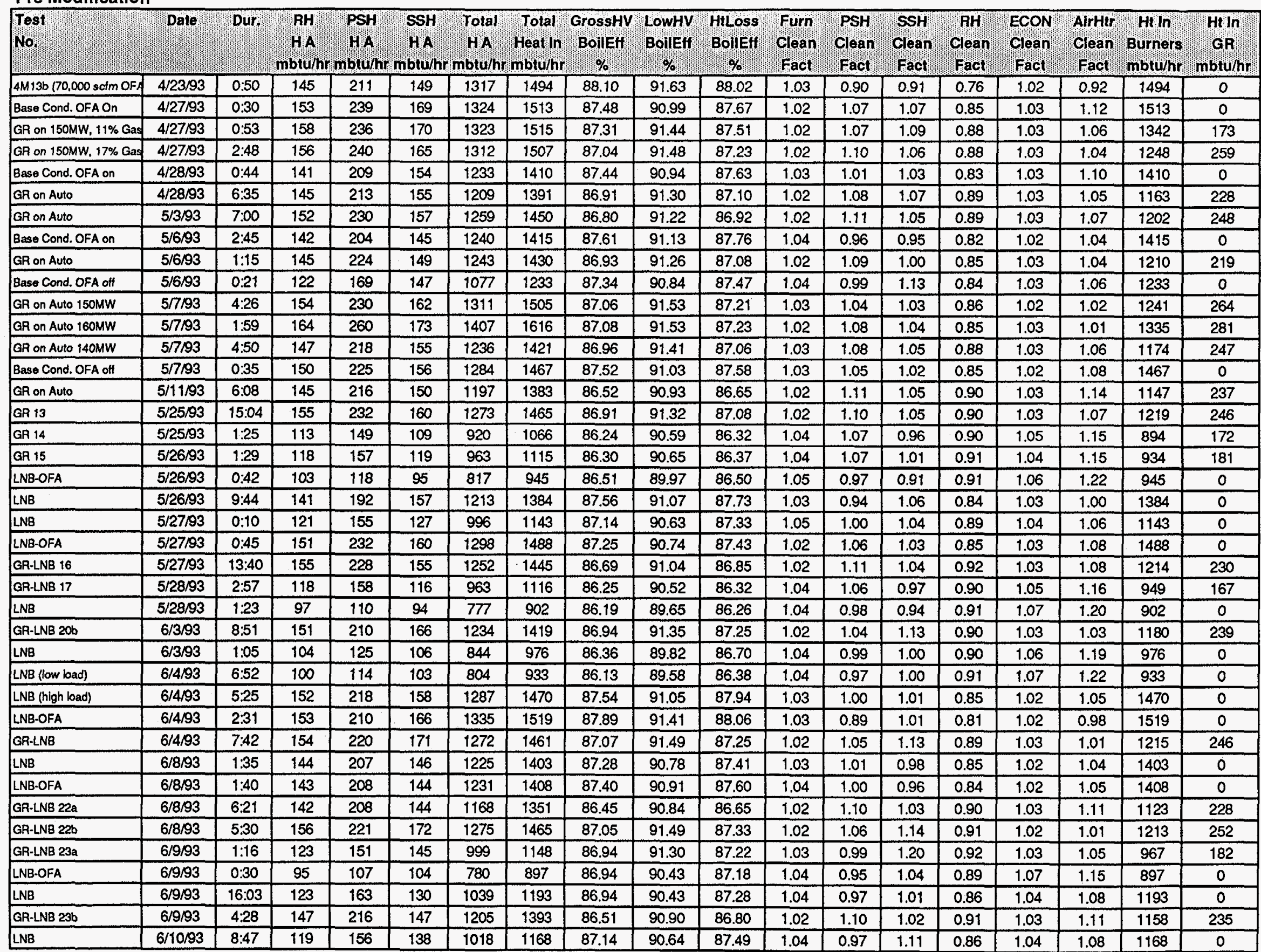


Cherokee Unit 3, Average Test C

Pre Modification

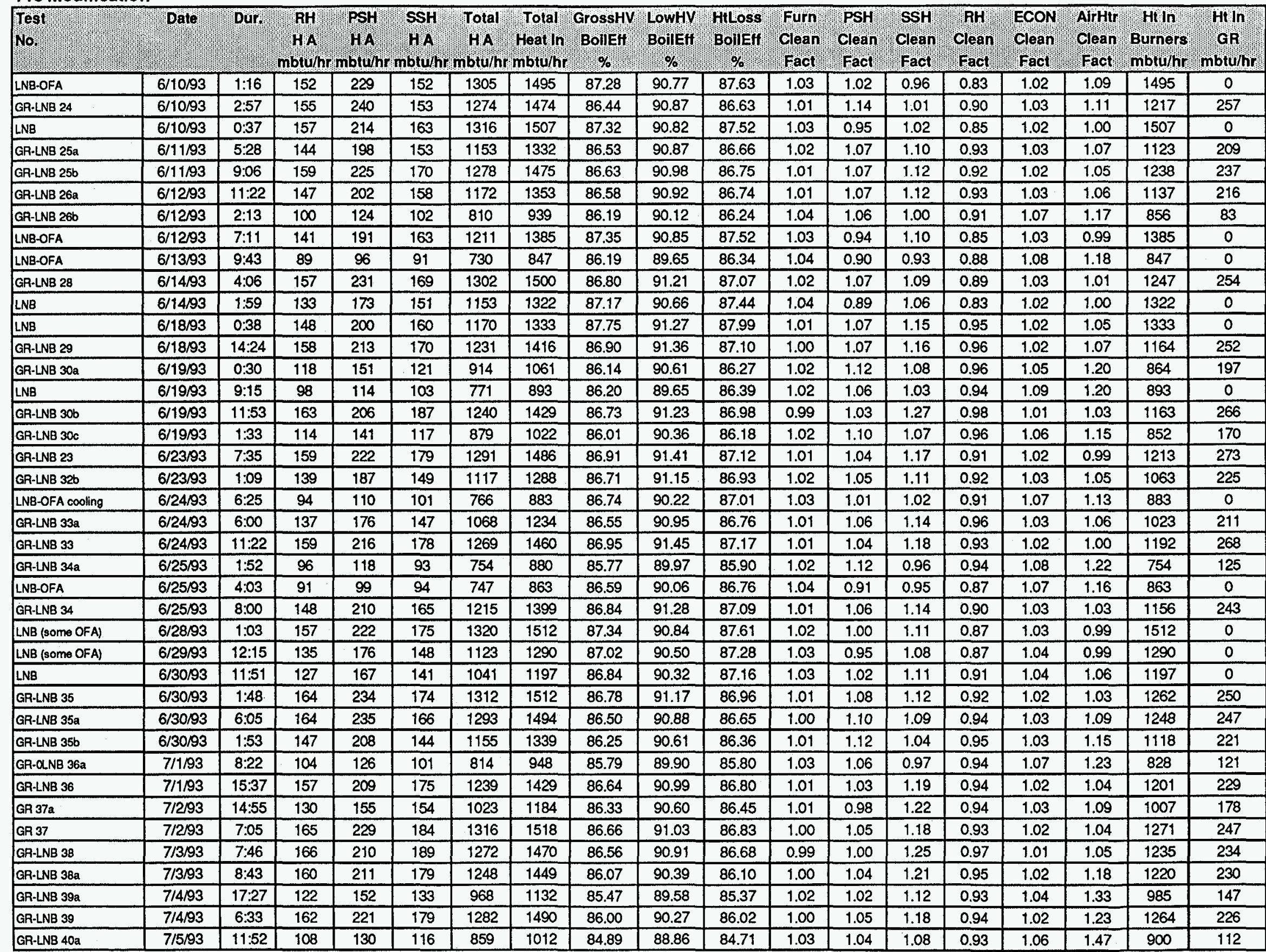


Cherokee Unit 3, Average Test [

Pre Modification

\begin{tabular}{|c|c|c|c|c|c|c|c|c|c|c|c|c|c|c|c|c|c|c|}
\hline \begin{tabular}{|l|} 
Test \\
No.
\end{tabular} & Date & Dur & $\begin{array}{c}\mathrm{RH} \\
\mathrm{HA} \\
\mathrm{mb} \\
\mathrm{mbuh}\end{array}$ & PSSH & $\begin{array}{l}\mathrm{SSH} \\
\mathrm{H} A \mathrm{~A} \\
\mathrm{nbtuh}\end{array}$ & $\begin{array}{l}\text { Total } \\
\text { HA } \\
\text { mbtu/hr }\end{array}$ & $\begin{array}{l}\text { Total } \\
\text { Heat hn } \\
\text { moluhr }\end{array}$ & $\begin{array}{l}\text { GrossHV } \\
\text { BoilEf } \\
\text { \% }\end{array}$ & LowHY & Holloss & $\begin{array}{l}\text { Furn } \\
\text { Clean } \\
\text { Fact }\end{array}$ & $\begin{array}{l}\text { PSH } \\
\text { Clean } \\
\text { Fact }\end{array}$ & $\begin{array}{l}\text { SSH } \\
\text { clean } \\
\text { ract }\end{array}$ & $\begin{array}{l}\text { RH } \\
\text { Clean } \\
\text { Fact }\end{array}$ & $\begin{array}{l}\text { ECON } \\
\text { Clean } \\
\text { Fact }\end{array}$ & $\begin{array}{l}\text { AirHtr } \\
\text { Clean } \\
\text { Fact }\end{array}$ & $\begin{array}{l}\text { Ht ln } \\
\text { Burners } \\
\text { mbturhr }\end{array}$ & $\begin{array}{l}\mathrm{Ht} \mathrm{ln} \\
\mathrm{GR} \\
\mathrm{mbru}\end{array}$ \\
\hline GR-LNB 40 & $7 / 5 / 93$ & $12: 08$ & 154 & 208 & 169 & 1223 & 1430 & 85.47 & 89.69 & 85.40 & 1.01 & 1.04 & 1.16 & 0.93 & 1.02 & 1.32 & 1220 & 211 \\
\hline GA-LNB 52a & $7 / 17 / 93$ & $8: 31$ & 111 & 137 & 115 & 897 & 1042 & 86.04 & 90.38 & 86.11 & 1.04 & 1.00 & 1.02 & 0.90 & 1.05 & 1.14 & 871 & 171 \\
\hline GR-LNB 52 & $7 / 17 / 93$ & $5: 45$ & 158 & 212 & 176 & 1242 & 1432 & 86.74 & 91.15 & 86.96 & 1.00 & 1.05 & 1.19 & 0.95 & 1.02 & 1.08 & 1189 & 243 \\
\hline LNB & $7 / 19 / 93$ & $1: 53$ & 119 & 161 & 143 & 1027 & 1173 & 87.55 & 91.06 & 87.71 & 1.04 & 1.02 & 1.15 & 0.86 & 1.03 & 1.01 & 1173 & 0 \\
\hline LNB-OFA & $7 / 19 / 93$ & $0: 22$ & 119 & 157 & 157 & 1070 & 1218 & 87.81 & 91.33 & 87.94 & 1.05 & 0.92 & 1.21 & 0.82 & 1.02 & 0.98 & 1218 & 0 \\
\hline GP-LNB 53a & $7 / 19 / 93$ & $3: 29$ & 135 & 173 & 150 & 1067 & 1228 & 86.80 & 91.17 & 86.95 & 1.02 & 1.04 & 1.17 & 0.95 & 1.03 & 1.04 & 1031 & 197 \\
\hline GR-LNB 53 & $7 / 19 / 93$ & $7: 06$ & 163 & 230 & 176 & 1304 & 1498 & 86.99 & 91.40 & 87.15 & 1.01 & 1.07 & 1.15 & 0.93 & 1.02 & 1.02 & 1249 & 250 \\
\hline LNB & $7 / 21 / 93$ & $8: 34$ & 90 & 97 & 93 & 723 & 840 & 86.03 & 89.48 & 86.12 & 1.03 & 0.96 & 0.98 & 0.90 & 1.08 & 1.10 & 840 & 0 \\
\hline GA-LNB 54 & $7 / 21 / 93$ & $4: 52$ & 154 & 227 & 159 & 1244 & 1441 & 86.31 & 90.70 & 86.53 & 1.01 & 1.12 & 1.08 & 0.92 & 1.02 & 1.00 & 1198 & 243 \\
\hline LNB & $7 / 23 / 93$ & $2: 35$ & 132 & 147 & 69 & 873 & 1007 & 86.69 & 90.16 & 86.90 & 1.01 & 1.09 & 0.62 & 1.07 & 1.07 & 1.04 & 1007 & 0 \\
\hline GR-LNB 55 & $7 / 23 / 93$ & $4: 53$ & 159 & 226 & 165 & 1261 & 1457 & 86.57 & 90.95 & 86.71 & 1.01 & 1.10 & 1.11 & 0.94 & 1.02 & 1.09 & 1217 & 240 \\
\hline GR-LNB 55a & $7 / 23 / 93$ & 1.08 & 138 & 198 & 146 & 1142 & 1322 & 86.33 & 90.67 & 86.44 & 1.02 & 1.07 & 1.06 & 0.89 & 1.03 & 1.11 & 1110 & 213 \\
\hline LNB & $7 / 23 / 93$ & $3: 55$ & 86 & 75 & 103 & 715 & 826 & 86.58 & 90.05 & 86.71 & 1.05 & 0.73 & 1.09 & 0.86 & 1.07 & 1.03 & 826 & 0 \\
\hline LNB & $7 / 24 / 93$ & $1: 52$ & 91 & 89 & 104 & 744 & 860 & 86.53 & 89.99 & 86.53 & 1.05 & 0.81 & 1.07 & 0.88 & 1.07 & 1.08 & 860 & 0 \\
\hline LNB-OFA & $7 / 24 / 93$ & 0.36 & 101 & 123 & 104 & 834 & 971 & 85.92 & 89.37 & 85.87 & 1.04 & 0.99 & 0.98 & 0.88 & 1.05 & 1.24 & 971 & 0 \\
\hline GR-LNB 56 & $7 / 24 / 93$ & $7: 45$ & 156 & 226 & 163 & 1248 & 1442 & 86.52 & 90.90 & 86.65 & 1.01 & 1.11 & 1.10 & 0.93 & 1.02 & 1.09 & 1203 & 239 \\
\hline GR-LNB 56a & $7 / 24 / 93$ & $2: 09$ & 105 & 125 & 108 & 853 & 993 & 85.81 & 90.10 & 85.87 & 1.03 & 0.97 & 0.99 & 0.90 & 1.06 & 1.15 & 838 & 155 \\
\hline GA-LNB 57a & $7 / 25 / 93$ & $1: 10$ & 87 & 96 & 86 & 698 & 819 & 85.20 & 89.46 & 85.12 & 1.03 & 0.99 & 0.94 & 0.91 & 1.09 & 1.26 & 692 & 127 \\
\hline LNB-OFA & $7 / 25 / 93$ & $5: 52$ & 97 & 107 & 90 & 780 & 902 & 86.39 & 89.86 & 86.47 & 1.05 & 0.91 & 0.89 & 0.88 & 1.06 & 1.18 & 902 & 0 \\
\hline GR-LNB 57b & $7 / 25 / 93$ & $10: 19$ & 138 & 185 & 143 & 1091 & 1265 & 86.16 & 90.50 & 86.31 & 1.02 & 1.07 & 1.08 & 0.94 & 1.03 & 1.14 & 1057 & 208 \\
\hline GR-LNB 57 & $7 / 25 / 93$ & $6: 14$ & 163 & 231 & 174 & 1305 & 1504 & 86.72 & 91.10 & 86.93 & 1.01 & 1.07 & 1.13 & 0.93 & 1.02 & 1.04 & 1258 & 246 \\
\hline GR-LNB 58a & $7 / 26 / 93$ & $10: 15$ & 120 & 162 & 120 & 961 & 1119 & 85.73 & 90.03 & 85.76 & 1.03 & 1.11 & 1.01 & 0.93 & 1.05 & 1.24 & 941 & 178 \\
\hline GA-LNB 58 & $7 / 26 / 93$ & $8: 34$ & 163 & 232 & 174 & 1307 & 1508 & 86.70 & 91.06 & 86.88 & 1.01 & 1.08 & 1.13 & 0.93 & 1.02 & 1.06 & 1266 & 242 \\
\hline GA-LNB $58 b$ & $7 / 26 / 93$ & $5: 09$ & 144 & 203 & 148 & 1161 & 1345 & 86.32 & 90.63 & 86.47 & 1.02 & 1.09 & 1.06 & 0.92 & 1.03 & 1.13 & 1136 & 209 \\
\hline GR-LNB 59a & $7 / 27 / 93$ & $10: 48$ & 120 & 164 & 117 & 964 & 1121 & 85.85 & 90.13 & 85.96 & 1.03 & 1.11 & 0.97 & 0.92 & 1.05 & 1.21 & 947 & 174 \\
\hline LNB-OFA & $7 / 27 / 93$ & $3: 21$ & 157 & 238 & 172 & 1367 & 1560 & 87.61 & 91.12 & 87.94 & 1.03 & 1.02 & 1.05 & 0.84 & 1.02 & 0.98 & 1560 & 0 \\
\hline GR-LNB 59 & $7 / 27 / 93$ & $9: 16$ & 148 & 211 & 154 & 1202 & 1389 & 86.50 & 90.83 & 86.71 & 1.02 & 1.09 & 1.07 & 0.91 & 1.03 & 1.07 & 1171 & 219 \\
\hline GR-LNB 60a & $7 / 28 / 93$ & $11: 06$ & 138 & 190 & 142 & 1097 & 1270 & 86.37 & 90.69 & 86.59 & 1.02 & 1.10 & 1.08 & 0.94 & 1.03 & 1.12 & 1071 & 198 \\
\hline GA-LNB 606 & $7 / 28 / 93$ & $2: 02$ & 177 & 237 & 198 & 1372 & 1583 & 86.66 & 91.04 & 86.88 & 0.99 & 1.04 & 1.23 & 0.96 & 1.01 & 1.04 & 1323 & 260 \\
\hline LNB-OFA & $7 / 28 / 93$ & $2: 21$ & 163 & 240 & 180 & 1386 & 1583 & 87.57 & 91.08 & 87.80 & 1.02 & 1.02 & 1.09 & 0.86 & 1.02 & 0.98 & 1583 & 0 \\
\hline GR-LNB 60 & $7 / 28 / 93$ & $8: 10$ & 170 & 245 & 187 & 1375 & 1585 & 86.78 & 91.13 & 86.98 & 1.00 & 1.06 & 1.15 & 0.91 & 1.02 & 1.01 & 1333 & 252 \\
\hline GR-LNB $61 \mathrm{a}$ & $7 / 29 / 93$ & $15: 55$ & 162 & 229 & 171 & 1285 & 1483 & 86.65 & 91.00 & 86.85 & 1.01 & 1.09 & 1.12 & 0.94 & 1.02 & 1.05 & 1247 & 236 \\
\hline GR-LNB 61 & $7 / 29 / 93$ & $8: 04$ & 166 & 220 & 184 & 1287 & 1486 & 86.57 & 90.94 & 86.76 & 1.00 & 1.04 & 1.21 & 0.96 & 1.02 & 1.03 & 1243 & 244 \\
\hline GR-LNB 62 & $7 / 30 / 93$ & $10: 04$ & 157 & 205 & 179 & 1234 & 1424 & 86.62 & 90.97 & 86.82 & 1.00 & 1.03 & 1.22 & 0.95 & 1.02 & 1.04 & 1196 & 228 \\
\hline LNB-OFA & $7 / 30 / 93$ & $4: 32$ & 156 & 230 & 167 & 1332 & 1526 & 87.31 & 90.81 & 87.56 & 1.03 & 1.02 & 1.05 & 0.85 & 1.02 & 1.02 & 1526 & 0 \\
\hline GR-LNB 62a & $7 / 30 / 93$ & $9: 00$ & 162 & 234 & 168 & 1297 & 1500 & 86.50 & 90.84 & 86.72 & 1.01 & 1.09 & 1.10 & 0.92 & 1.02 & 1.08 & 1260 & 240 \\
\hline GR-LNB 63a & $7 / 31 / 93$ & $17: 10$ & 159 & 220 & 178 & 1284 & 1481 & 86.65 & 91.01 & 86.89 & 1.01 & 1.04 & 1.17 & 0.92 & 1.02 & 1.03 & 1244 & 237 \\
\hline GR-LNB 63b & $7 / 31 / 93$ & $6: 49$ & 163 & 224 & 182 & 1298 & 1499 & 86.63 & 90.93 & 86.86 & 1.00 & 1.05 & 1.18 & 0.93 & 1.02 & 1.02 & 1272 & 226 \\
\hline GR-LNB 64a & $8 / 1 / 93$ & $1: 25$ & 147 & 199 & 156 & 1155 & 1338 & 86.36 & 90.66 & 86.56 & 1.01 & 1.08 & 1.13 & 0.95 & 1.02 & 1.08 & 1132 & 206 \\
\hline GR-LNB 646 & $8 / 1 / 93$ & $10: 21$ & 112 & 147 & 113 & 909 & 1058 & 85.93 & 90.20 & 86.09 & 1.03 & 1.07 & 0.99 & 0.90 & 1.05 & 1.16 & 897 & 161 \\
\hline
\end{tabular}


Cherokee Unit 3, Average Test [

Pre Modification

\begin{tabular}{|c|c|c|c|c|c|c|c|c|c|c|c|c|c|c|c|c|c|c|}
\hline Test & Date & Dur & $\begin{array}{l}\text { RH } \\
\text { HA } \\
\text { mbturh }\end{array}$ & $\begin{array}{l}P S H \\
\text { netur }\end{array}$ & SSH & motal & $\begin{array}{l}\text { Totolal } \\
\text { feat } \\
\text { mbtuht }\end{array}$ & $\begin{array}{l}\text { Grosshy } \\
\text { Boileff }\end{array}$ & $\begin{array}{l}\text { Lowhy } \\
\text { BoilEfy } \\
\text { \% }\end{array}$ & 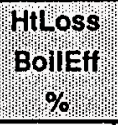 & $\begin{array}{l}\text { Furn } \\
\text { clean } \\
\text { Fact }\end{array}$ & $\begin{array}{l}\text { PSH } \\
\text { clean } \\
\text { Fact }\end{array}$ & $\begin{array}{l}\text { Ssh } \\
\text { Clean } \\
\text { Fact }\end{array}$ & $\begin{array}{l}\text { RH } \\
\text { clean } \\
\text { ract }\end{array}$ & $\begin{array}{c}\text { ECON } \\
\text { Clean } \\
\text { Fact }\end{array}$ & $\begin{array}{l}\text { Airthr } \\
\text { Clean } \\
\text { ract }\end{array}$ & $\begin{array}{l}\text { Ht in } \\
\text { Burners } \\
\text { mbtu/hr }\end{array}$ & 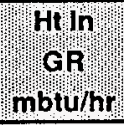 \\
\hline GR-LNB 64C & $8 / 1 / 93$ & $12: 14$ & 159 & 226 & 166 & 1257 & 1452 & 86.54 & 90.87 & 86.76 & 1.00 & 1.10 & 1.11 & 0.94 & 1.02 & 1.07 & 1223 & 229 \\
\hline GR-LNB 65a & $8 / 2 / 93$ & $8: 55$ & 106 & 136 & 109 & 872 & 1016 & 85.74 & 89.98 & 85.76 & 1.04 & 1.04 & 0.98 & 0.89 & 1.05 & 1.19 & 865 & 151 \\
\hline LNB.OFA & $8 / 293$ & $1: 23$ & 154 & 230 & 176 & 1333 & 1525 & 87.43 & 90.94 & 87.70 & 1.03 & 1.02 & 1.11 & 0.85 & 1.02 & 1.05 & 1525 & 0 \\
\hline GR-LNB 65b & $8 / 2 / 93$ & 6.02 & 154 & 224 & 171 & 1276 & 1471 & 86.77 & 91.13 & 86.95 & 1.02 & 1.06 & 1.13 & 0.89 & 1.02 & 1.04 & 1235 & 236 \\
\hline GR-LNB $65 \mathrm{C}$ & $8 / 293$ & $7: 14$ & 152 & 210 & 169 & 1226 & 1414 & 86.65 & 91.02 & 86.61 & 1.01 & 1.05 & 1.15 & 0.91 & 1.02 & 1.06 & 1183 & 231 \\
\hline GR-LNB 66a & $8 / 3 / 93$ & $8: 29$ & 99 & 125 & 99 & 803 & 938 & 85.65 & 89.93 & 85.62 & 1.04 & 1.08 & 0.97 & 0.90 & 1.07 & 1.26 & 791 & 146 \\
\hline GR-LNB 666 & $8 / 3 / 93$ & $9: 34$ & 153 & 214 & 163 & 1221 & 1410 & 86.56 & 90.93 & 86.78 & 1.01 & 1.08 & 1.13 & 0.93 & 1.02 & 1.12 & 1179 & 231 \\
\hline GR-LNB 666 & $8 / 3 / 93$ & $5: 55$ & 159 & 229 & 168 & 1273 & 1468 & 86.73 & 91.10 & 86.96 & 1.01 & 1.09 & 1.11 & 0.93 & 1.02 & 1.07 & 1230 & 239 \\
\hline GR-LNB 67 & $8 / 493$ & $24: 00$ & 147 & 207 & 154 & 1179 & 1363 & 86.52 & 90.84 & 86.71 & 1.01 & 1.09 & 1.09 & 0.93 & 1.03 & 1.11 & 1152 & 211 \\
\hline GR-LNB 68a & $8 / 5 / 93$ & $7: 39$ & 124 & 167 & 129 & 1007 & 1166 & 86.32 & 90.59 & 86.47 & 1.03 & 1.08 & 1.06 & 0.92 & 1.04 & 1.14 & 993 & 173 \\
\hline GR-LNB 68b & $8 / 5 / 93$ & $15: 50$ & 163 & 229 & 177 & 1294 & 1494 & 86.65 & 90.98 & 86.85 & 1.00 & 1.08 & 1.15 & 0.94 & 1.02 & 1.09 & 1262 & 232 \\
\hline GR-LNB 69 & $8 / 6 / 93$ & $9: 48$ & 148 & 207 & 156 & 1185 & 1366 & 86.72 & 91.03 & 86.88 & 1.02 & 1.08 & 1.10 & 0.93 & 1.02 & 1.09 & 1159 & 208 \\
\hline LNB & $8 / 6 / 93$ & $7: 58$ & 152 & 217 & 168 & 1304 & 1492 & 87.36 & 90.86 & 87.54 & 1.03 & 0.99 & 1.07 & 0.85 & 1.02 & 1.00 & 1492 & 0 \\
\hline LNB-OFA & $8 / 6 / 93$ & $5: 04$ & 155 & 219 & 178 & 1340 & 1533 & 87.39 & 90.89 & 87.55 & 1.03 & 0.96 & 1.11 & 0.84 & 1.02 & 0.99 & 1533 & 0 \\
\hline LNB & $8 / 793$ & $3: 04$ & 153 & 222 & 159 & 1284 & 1465 & 87.60 & 91.11 & 87.79 & 1.03 & 1.04 & 1.03 & 0.87 & 1.02 & 0.99 & 1465 & 0 \\
\hline GA-LNB 70 & $8 / 793$ & $3: 53$ & 156 & 218 & 148 & 1199 & 1380 & 86.85 & 90.75 & 87.00 & 1.01 & 1.13 & 1.04 & 0.97 & 1.03 & 1.10 & 1274 & 106 \\
\hline LNB-OFA & $8 / 793$ & $8: 05$ & 153 & 216 & 177 & 1308 & 1499 & 87.25 & 90.75 & 87.39 & 1.03 & 0.99 & 1.13 & 0.86 & 1.02 & 1.02 & 1499 & 0 \\
\hline LNB & $8 / 7 / 93$ & $6: 28$ & 155 & 222 & 175 & 1327 & 1520 & 87.33 & 90.83 & 87.49 & 1.03 & 0.99 & 1.10 & 0.85 & 1.02 & 1.00 & 1520 & 0 \\
\hline LNB & $8 / 9 / 93$ & $8: 04$ & 142 & 197 & 157 & 1224 & 1403 & 87.20 & 90.69 & 87.43 & 1.04 & 0.95 & 1.05 & 0.84 & 1.02 & 1.02 & 1403 & 0 \\
\hline GR-LNB 71 (10\% Gas) & $8 / 9 / 93$ & $13: 45$ & 160 & 239 & 173 & 1333 & 1535 & 86.81 & 90.86 & 87.05 & 1.02 & 1.08 & 1.10 & 0.89 & 1.02 & 1.04 & 1375 & 160 \\
\hline GR-LNB 72a (10\%) & $8 / 10 / 93$ & $7: 48$ & 159 & 222 & 178 & 1289 & 1484 & 86.87 & 90.88 & 87.10 & 1.02 & 1.05 & 1.17 & 0.92 & 1.01 & 1.07 & 1342 & 142 \\
\hline LNB & $8 / 10 / 93$ & $7: 27$ & 154 & 220 & 168 & 1331 & 1526 & 87.21 & 90.70 & 87.44 & 1.03 & 0.96 & 1.04 & 0.83 & 1.02 & 1.02 & 1526 & 0 \\
\hline GR-LNB $72 b(10 \%)$ & $8 / 10 / 93$ & $7: 25$ & 153 & 220 & 168 & 1273 & 1464 & 86.94 & 90.96 & 87.16 & 1.02 & 1.05 & 1.11 & 0.89 & 1.03 & 1.06 & 1321 & 143 \\
\hline GR-LNB 73 & $8 / 11 / 93$ & $3: 22$ & 150 & 214 & 154 & 1219 & 1401 & 86.99 & 91.02 & 87.14 & 1.02 & 1.08 & 1.06 & 0.91 & 1.03 & 1.09 & 1263 & 138 \\
\hline LNB-OFA & $8 / 11 / 93$ & $9: 49$ & 158 & 232 & 173 & 1358 & 1554 & 87.36 & 90.86 & 87.60 & 1.02 & 1.00 & 1.06 & 0.84 & 1.02 & 1.01 & 1554 & 0 \\
\hline LNB & $8 / 11 / 93$ & $2: 45$ & 151 & 219 & 156 & 1287 & $147 \pi$ & 87.18 & 90.67 & 87.40 & 1.03 & 1.00 & 1.00 & 0.84 & 1.02 & 1.03 & 1477 & 0 \\
\hline LNB & $8 / 1293$ & $7: 36$ & 116 & 141 & 131 & 976 & 1125 & 86.69 & 90.16 & 86.91 & 1.05 & 0.91 & 1.07 & 0.86 & 1.03 & 1.06 & 1125 & 0 \\
\hline GR-LNB 74 & $8 / 1293$ & $14: 33$ & 160 & 232 & 173 & 1307 & 1501 & 87.02 & 91.05 & 87.25 & 1.01 & 1.07 & 1.12 & 0.91 & 1.02 & 1.07 & 1353 & 148 \\
\hline GR-LNB 75 & $8 / 13 / 93$ & 18:16 & 158 & 226 & 170 & 1282 & 1476 & 86.80 & 90.83 & 86.96 & 1.01 & 1.06 & 1.12 & 0.91 & 1.02 & 1.08 & 1326 & 150 \\
\hline GR-LNB 76a & $8 / 14 / 93$ & $4: 54$ & 132 & 166 & 144 & 1025 & 1187 & 86.29 & 90.26 & 86.39 & 1.02 & 1.06 & 1.16 & 0.96 & 1.03 & 1.15 & 1077 & 110 \\
\hline LNB & $8 / 14 / 93$ & $1: 46$ & 96 & 107 & 98 & 759 & 889 & 85.42 & 88.84 & 85.31 & 1.04 & 1.00 & 1.01 & 0.93 & 1.07 & 1.31 & 889 & 0 \\
\hline GR-LNB 76b & $8 / 14 / 93$ & $11: 05$ & 155 & 223 & 165 & 1260 & 1455 & 86.60 & 90.62 & 86.74 & 1.01 & 1.08 & 1.10 & 0.91 & 1.02 & 1.11 & 1309 & 146 \\
\hline GA-LNB 77 & $8 / 15 / 93$ & $1: 10$ & 120 & 158 & 132 & 982 & 1140 & 86.10 & 90.04 & 86.17 & 1.03 & 1.05 & 1.09 & 0.91 & 1.04 & 1.19 & 1036 & 104 \\
\hline LNB & $8 / 15 / 93$ & $14: 44$ & 120 & 147 & 141 & 1001 & 1154 & 86.54 & 90.00 & 86.67 & 1.04 & 0.92 & 1.13 & 0.88 & 1.04 & 1.11 & 1154 & 0 \\
\hline LNB & $8 / 15 / 93$ & $6: 58$ & 154 & 223 & 184 & 1337 & 1531 & 87.32 & 90.82 & 87.52 & 1.02 & 0.99 & 1.15 & 0.84 & 1.02 & 1.01 & 1531 & 0 \\
\hline LNB (low bad) & $8 / 16 / 93$ & $7: 38$ & 110 & 141 & 118 & 898 & 1042 & 86.11 & 89.56 & 86.27 & 1.03 & 1.05 & 1.06 & 0.91 & 1.05 & 1.18 & 1042 & 0 \\
\hline LNB (150 MWe) & $8 / 16 / 93$ & $3: 21$ & 155 & 238 & 171 & 1349 & 1547 & 87.26 & 90.75 & 87.48 & 1.02 & 1.04 & 1.05 & 0.84 & 1.02 & 1.07 & 1547 & 0 \\
\hline LNB-OFA cooling & $8 / 16 / 93$ & $11: 40$ & 158 & 221 & 177 & 1369 & 1567 & 87.35 & 90.86 & 87.54 & 1.03 & 0.93 & 1.07 & 0.83 & 1.02 & 0.98 & 1567 & 0 \\
\hline LNB & $8 / 17 / 93$ & $9: 07$ & 137 & 198 & 150 & 1190 & 1366 & 87.10 & 90.59 & 87.30 & 1.04 & 1.01 & 1.04 & 0.84 & 1.02 & 1.04 & 1366 & 0 \\
\hline $100 \%$ Gas (plant tosti) & $8 / 17 / 93$ & $0: 34$ & 86 & 79 & 94 & 711 & 815 & 87.29 & 90.79 & 84.82 & 1.05 & 0.76 & 0.99 & 0.86 & 1.06 & 0.92 & 815 & 0 \\
\hline
\end{tabular}


Cherokee Unit 3, Average Test C

Pre Modification

\begin{tabular}{|c|c|c|c|c|c|c|c|c|c|c|c|c|c|c|c|c|c|c|}
\hline Test!I!' & Date & Dur & 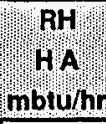 & חIPSH: & $\begin{array}{l}\text { SSH } \\
\text { mbtu/h } \\
\end{array}$ & 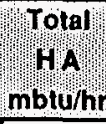 & 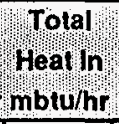 & $\begin{array}{c}\text { Grosshy } \\
\text { Boileff } \\
\end{array}$ & $\begin{array}{l}\text { CowHY } \\
\text { Boileff } \\
\text { \% \% }\end{array}$ & Hooss & $\begin{array}{l}\text { Furn } \\
\text { Clean } \\
\text { Fact }\end{array}$ & $\begin{array}{l}\text { PSH } \\
\text { Clean } \\
\text { Fact }\end{array}$ & $\begin{array}{l}\text { CYSHY } \\
\text { Clean } \\
\text { Fact }\end{array}$ & 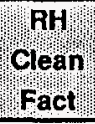 & $\begin{array}{l}\text { ECON } \\
\text { Clean } \\
\text { Fact }\end{array}$ & $\begin{array}{l}\text { Airhitr } \\
\text { Clean } \\
\text { Fact }\end{array}$ & $\begin{array}{l}\text { But ln } \\
\text { Burners } \\
\text { mbtu/hr }\end{array}$ & 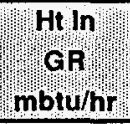 \\
\hline LNB (OFA cooling) & $8 / 17 / 93$ & $8: 59$ & 157 & 299 & 170 & 1428 & 1634 & \begin{tabular}{|l|}
87.35 \\
\end{tabular} & 90.85 & 87.58 & 1.03 & 1.28 & 1.04 & 0.83 & 1.02 & 1.04 & 1634 & 0 \\
\hline LNB & $8 / 17 / 93$ & 3.05 & 153 & 292 & 170 & 1401 & 1602 & 87.46 & 90.96 & 87.71 & 1.03 & 1.28 & 1.06 & 0.83 & 1.02 & 1.03 & 1602 & 0 \\
\hline LNB (low load) & $8 / 18 / 93$ & $9: 42$ & 121 & 210 & 130 & 1063 & 1225 & 86.70 & 90.18 & 86.93 & 1.04 & 1.32 & 1.04 & 0.88 & 1.03 & 1.11 & 1225 & 0 \\
\hline LNB $150 \mathrm{MWe}$ & $8 / 18 / 93$ & $14: 16$ & 159 & 297 & 166 & 1427 & 1633 & 87.40 & 90.90 & 87.64 & 1.03 & 1.27 & 1.01 & 0.84 & 1.02 & 1.06 & 1633 & 0 \\
\hline GR-LNB 78 & $8 / 24 / 93$ & $3: 25$ & 159 & 206 & 171 & 1259 & 1447 & 87.02 & 91.11 & 87.21 & 1.08 & 1.07 & 1.20 & 0.98 & 0.95 & 1.06 & 1289 & 158 \\
\hline LNB OFA cooling & $8 / 24 / 93$ & $10: 38$ & 150 & 214 & 160 & 1293 & 1483 & 87.18 & 90.67 & 87.40 & 1.11 & 1.05 & 1.09 & 0.89 & 0.96 & 1.07 & 1483 & 0 \\
\hline LNB OFA cooling & $8 / 25 / 93$ & 2.06 & 118 & 144 & 145 & 1012 & 1160 & 87.21 & 90.71 & 87.39 & 1.11 & 0.98 & 1.22 & 0.91 & 0.98 & 1.06 & 1160 & 0 \\
\hline LNB & $8 / 25 / 93$ & $8: 38$ & 116 & 141 & 132 & 968 & 1111 & 87.08 & 90.57 & 87.31 & 1.10 & 1.01 & 1.16 & 0.93 & 0.98 & 1.08 & 1111 & 0 \\
\hline LNB & $8 / 25 / 93$ & $13: 08$ & 147 & 221 & 140 & 1273 & 1460 & 87.21 & 90.70 & 87.54 & 1.11 & 1.10 & 0.95 & 0.88 & 0.97 & 1.11 & 1460 & 0 \\
\hline LNB & $8 / 26 / 93$ & $21: 16$ & 114 & 140 & 122 & 955 & 1105 & 86.41 & 89.87 & 87.08 & 1.04 & 0.91 & 1.01 & 0.86 & 1.04 & 1.12 & 1105 & 0 \\
\hline LNB & $8 / 26 / 93$ & $2: 42$ & 155 & 228 & 160 & 1303 & 1493 & 87.23 & 90.73 & 87.53 & 1.02 & 1.03 & 1.02 & 0.86 & 1.03 & 1.05 & 1493 & 0 \\
\hline LNB & $8 / 27 / 93$ & $8: 26$ & 109 & 127 & 115 & 894 & 1034 & 86.40 & 89.87 & 87.00 & 1.04 & 0.90 & 1.02 & 0.88 & 1.05 & 1.12 & 1034 & 0 \\
\hline LNB & $8 / 27 / 93$ & $6: 17$ & 150 & 209 & 160 & 1276 & 1460 & 87.42 & 90.92 & 87.70 & 1.03 & 0.96 & 1.03 & 0.85 & 1.02 & 1.03 & 1460 & 0 \\
\hline GR.LNB 79 & $9 / 8 / 93$ & $11: 15$ & 154 & 236 & 160 & 1297 & 1492 & 86.97 & 91.17 & 87.32 & 1.02 & 1.09 & 1.03 & 0.87 & 1.03 & 1.05 & 1297 & 195 \\
\hline GR-LNB 79a & $9 / 8 / 93$ & $1: 49$ & 128 & 180 & 135 & 1075 & 1242 & 86.49 & 90.73 & 87.11 & 1.03 & 1.05 & 1.02 & 0.87 & 1.04 & 1.11 & 1068 & 174 \\
\hline GR-LNB 80a & $9 / 9 / 93$ & $6: 55$ & 117 & 161 & 120 & 962 & 1114 & 86.31 & 90.56 & 87.04 & 1.03 & 1.10 & 1.01 & 0.90 & 1.05 & 1.16 & 954 & 160 \\
\hline LNB-OFA & $9 / 9 / 93$ & $1: 46$ & 95 & 114 & 93 & 778 & 902 & 86.25 & 89.71 & 87.25 & 1.04 & 1.00 & 0.92 & 0.88 & 1.07 & 1.24 & 902 & 0 \\
\hline GR-LNB 80 & $9 / 9 / 93$ & $14: 15$ & 144 & 208 & 153 & 1183 & 1365 & 86.64 & 90.90 & 87.09 & 1.02 & 1.08 & 1.07 & 0.90 & 1.03 & 1.08 & 1171 & 195 \\
\hline LNB-OFA & $9 / 10 / 93$ & $4: 50$ & 88 & 100 & 86 & 716 & 835 & 85.74 & 89.18 & 87.04 & 1.03 & 0.99 & 0.91 & 0.88 & 1.09 & 1.31 & 835 & 0 \\
\hline GR-LNB 81 & $9 / 10 / 93$ & $1: 46$ & 117 & 162 & 117 & 947 & 1098 & 86.16 & 90.47 & 86.86 & 1.02 & 1.14 & 1.00 & 0.92 & 1.05 & 1.19 & 926 & 172 \\
\hline LNB & $9 / 10 / 93$ & $13: 30$ & 147 & 211 & 155 & 1254 & 1439 & 87.11 & 90.60 & 87.49 & 1.03 & 0.99 & 1.01 & 0.85 & 1.03 & 1.06 & 1439 & 0 \\
\hline LNB & $9 / 11 / 93$ & $19: 30$ & 136 & 195 & 144 & 1166 & 1341 & 86.88 & 90.37 & 87.22 & 1.03 & 1.01 & 1.01 & 0.84 & 1.03 & 1.06 & 1341 & 0 \\
\hline GR-LNB 82 & $9 / 11 / 93$ & $4: 10$ & 151 & 235 & 152 & 1289 & 1491 & 86.50 & 90.75 & 87.17 & 1.02 & 1.08 & 0.98 & 0.85 & 1.03 & 1.10 & 1279 & 212 \\
\hline GR-LNB 83a & $9 / 12 / 93$ & $11: 51$ & 134 & 194 & 135 & 1112 & 1288 & 86.36 & 90.60 & 87.17 & 1.03 & 1.08 & 1.00 & 0.89 & 1.04 & 1.15 & 1106 & 182 \\
\hline GR-LNB 83 & $9 / 12 / 93$ & $12: 09$ & 162 & 245 & 176 & 1355 & 1561 & 86.82 & 91.02 & 87.21 & 1.01 & 1.07 & 1.09 & 0.88 & 1.03 & 1.05 & 1357 & 204 \\
\hline GR-LNB 84a & $9 / 13 / 93$ & $5: 35$ & 124 & 172 & 127 & 1015 & 1174 & 86.42 & 90.65 & 87.28 & 1.03 & 1.10 & 1.02 & 0.90 & 1.05 & 1.20 & 1011 & 163 \\
\hline GR-LNB 84 & $9 / 13 / 93$ & $18: 03$ & 153 & 229 & 157 & 1259 & 1442 & 87.24 & 91.34 & 87.73 & 1.01 & 1.10 & 1.05 & 0.90 & 1.03 & 1.13 & 1285 & 157 \\
\hline GR-LNB 85a & $9 / 14 / 93$ & $4: 15$ & 138 & 190 & 150 & 1121 & 1288 & 87.04 & 91.20 & 87.53 & 1.02 & 1.07 & 1.11 & 0.92 & 1.03 & 1.13 & 1131 & 157 \\
\hline LNB & $9 / 14 / 93$ & $11: 05$ & 125 & 170 & 132 & 1051 & 1204 & 87.20 & 90.69 & 87.57 & 1.04 & 1.00 & 1.02 & 0.87 & 1.04 & 1.10 & 1204 & 0 \\
\hline LNB-OFA & $9 / 14 / 93$ & 1.06 & 153 & 231 & 161 & 1317 & 1503 & 87.63 & 91.14 & 87.97 & 1.02 & 1.03 & 1.01 & 0.84 & 1.03 & 1.05 & 1503 & 0 \\
\hline GR-LNB 85 & $9 / 14 / 93$ & $6: 55$ & 155 & 222 & 169 & 1266 & 1449 & 87.35 & 91.54 & 87.48 & 1.01 & 1.07 & 1.12 & 0.91 & 1.03 & 1.02 & 1268 & 181 \\
\hline GR-LNB 86a & $9 / 15 / 93$ & 0.50 & 139 & 195 & 155 & 1149 & 1320 & 87.03 & 91.23 & 87.36 & 1.02 & 1.05 & 1.12 & 0.89 & 1.03 & 1.08 & 1150 & 170 \\
\hline LNB & $9 / 15 / 93$ & 3.07 & 111 & 119 & 138 & 895 & 1024 & 87.38 & 90.88 & 87.74 & 1.03 & 0.89 & 1.24 & 0.92 & 1.04 & 1.10 & 1024 & 0 \\
\hline GR-LNB 86b & $9 / 15 / 93$ & $4: 26$ & 133 & 186 & 140 & 1068 & 1229 & 86.79 & 91.02 & 87.20 & 1.01 & 1.11 & 1.07 & 0.92 & 1.04 & 1.12 & 1066 & 163 \\
\hline GR-LNB 86 & $9 / 15 / 93$ & $11: 20$ & 155 & 221 & 166 & 1252 & 1437 & 87.09 & 91.29 & 87.27 & 1.01 & 1.08 & 1.12 & 0.92 & 1.03 & 1.03 & 1254 & 183 \\
\hline GR-LNB 87a & $9 / 16 / 93$ & $5: 46$ & 132 & 176 & 137 & 1053 & 1214 & 86.69 & 90.90 & 87.15 & 1.01 & 1.05 & 1.06 & 0.92 & 1.04 & 1.10 & 1055 & 159 \\
\hline GR-LNB 87 & $9 / 16 / 93$ & $15: 24$ & 148 & 210 & 155 & 1188 & 1372 & 86.61 & 90.76 & 87.23 & 1.01 & 1.10 & 1.09 & 0.93 & 1.03 & 1.15 & 1204 & 168 \\
\hline GR-LNB 88a & $9 / 17 / 93$ & $5: 31$ & 139 & 187 & 148 & 1099 & 1268 & 86.64 & 90.86 & 87.24 & 1.01 & 1.08 & 1.11 & 0.94 & 1.03 & 1.15 & 1099 & 170 \\
\hline GR-LNB 88 & $9 / 17 / 93$ & $18: 28$ & 157 & 222 & 169 & 1258 & 1444 & 87.08 & 91.24 & 87.38 & 1.00 & 1.07 & 1.13 & 0.92 & 1.03 & 1.07 & 1268 & 177 \\
\hline GR-LNB 89 & $9 / 18 / 93$ & $24: 00$ & 153 & 212 & 167 & 1223 & 1402 & 87.25 & 91.40 & 87.48 & 1.01 & 1.06 & 1.14 & 0.92 & 1.03 & 1.06 & 1238 & 164 \\
\hline
\end{tabular}


Pre Modification

\begin{tabular}{|c|c|c|c|c|c|c|c|c|c|c|c|c|c|c|c|c|c|c|}
\hline Test No & 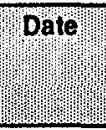 & Durf: & 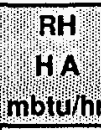 & 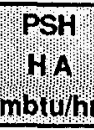 & 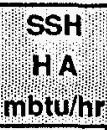 & $\begin{array}{l}\text { Total: } \\
\text { YH A } \\
\text { mbtu/hr }\end{array}$ & $\begin{array}{l}\text { Total } \\
\text { Heat In } \\
\text { mbtu/ht }\end{array}$ & GrossHV & $\begin{array}{l}\text { LOWHV } \\
\text { BoiIEff } \\
\text { \% }\end{array}$ & $\begin{array}{l}\text { Hiloss } \\
\text { Bolletf } \\
\text { क\% }\end{array}$ & $\begin{array}{l}\text { Furn } \\
\text { clean } \\
\text { ract }\end{array}$ & $\begin{array}{l}\text { PSH! } \\
\text { Clean } \\
\text { Fact! }\end{array}$ & $\begin{array}{l}\text { ssh } \\
\text { Clean } \\
\text { ract }\end{array}$ & Rlean! & $\begin{array}{l}\text { ECON } \\
\text { Clean! } \\
\text { fract }\end{array}$ & Alean! & $\begin{array}{l}\text { Cut ln } \\
\text { Burners } \\
\text { mbtu/hr }\end{array}$ & 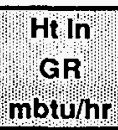 \\
\hline GR-LNB $90 \mathrm{a}$ & 9/19/93 & $10: 06$ & 142 & 187 & 156 & 1119 & \begin{tabular}{|l|}
1286 \\
\end{tabular} & \begin{tabular}{|l|}
86.96 \\
\end{tabular} & 91.10 & 87.32 & 1.01 & 1.06 & 1.16 & 0.94 & 1.03 & 1.11 & 1133 & 153 \\
\hline GR-LNB 90 & $9 / 19 / 93$ & 13.54 & 161 & 224 & 176 & 1278 & 1467 & 87.15 & 91.24 & 87.33 & 1.00 & 1.06 & 1.16 & 0.93 & 1.02 & 1.04 & 1306 & 160 \\
\hline GR-LNB 91 & 9/20/93 & $24: 00$ & 156 & 209 & 174 & 1219 & 1401 & 87.02 & 91.21 & 87.16 & 0.99 & 1.05 & 1.20 & 0.95 & 1.02 & 1.04 & 1223 & 178 \\
\hline GR-LNB 92a & $9 / 21 / 93$ & $3: 00$ & 128 & 176 & 133 & 1027 & 1186 & 86.54 & 90.80 & 86.94 & 1.02 & 1.11 & 1.05 & 0.92 & 1.04 & 1.10 & 1017 & 169 \\
\hline GA-LNB 92 & $9 / 21 / 93$ & $17: 56$ & 150 & 215 & 166 & 1239 & 1427 & 86.83 & 91.04 & 87.14 & 1.01 & 1.05 & 1.12 & 0.89 & 1.03 & 1.05 & 1238 & 189 \\
\hline GR-LNB 3 Mill a & 9/22/93 & $7: 59$ & 122 & 164 & 132 & 998 & 1152 & 86.59 & 90.88 & 87.23 & 1.03 & 1.07 & 1.08 & 0.90 & 1.04 & 1.14 & 982 & 170 \\
\hline GR-LNB 3 Mill b & $9 / 22 / 93$ & $8: 25$ & 126 & 175 & 139 & 1066 & 1224 & 87.05 & 91.31 & 87.22 & 1.03 & 1.04 & 1.07 & 0.87 & 1.04 & 1.08 & 1053 & 171 \\
\hline GR-LNB 3 Mill C & 9/23/93 & $24: 00$ & 128 & 183 & 135 & 1078 & 1238 & 87.05 & 91.31 & 87.18 & 1.03 & 1.07 & 1.03 & 0.88 & 1.04 & 1.08 & 1065 & 173 \\
\hline GR-LNB 3 Mill d & $9 / 24 / 93$ & $1: 58$ & 106 & 147 & 108 & 883 & 1021 & 86.44 & 90.73 & 86.49 & 1.03 & 1.11 & 0.97 & 0.88 & 1.06 & 1.19 & 870 & 151 \\
\hline LNB-OFA 3 Mill & 9/24/93 & $3: 33$ & 81 & 68 & 79 & 674 & 780 & 86.47 & 89.93 & 86.33 & 1.05 & 0.67 & 0.84 & 0.82 & 1.08 & 1.22 & 780 & 0 \\
\hline GR-LNB 3 Mill e & $9 / 24 / 93$ & $6: 10$ & 126 & 183 & 127 & 1079 & 1240 & 87.04 & 91.28 & 87.18 & 1.04 & 1.05 & 0.95 & 0.85 & 1.03 & 1.09 & 1074 & 166 \\
\hline GR-LNB 93 & 9/24/93 & $12: 09$ & 143 & 217 & 145 & 1212 & 1395 & 86.84 & 91.00 & 87.06 & 1.02 & 1.08 & 0.99 & 0.86 & 1.03 & 1.10 & 1225 & 170 \\
\hline GR-LNB 94a & $9 / 25 / 93$ & $2: 12$ & 128 & 189 & 130 & 1075 & 1241 & 86.57 & 90.76 & 86.79 & 1.03 & 1.11 & 1.00 & 0.88 & 1.04 & 1.14 & 1080 & 162 \\
\hline LNB-OFA & 9/25/93 & $2: 24$ & 105 & 148 & 99 & 887 & 1026 & 86.44 & 89.90 & 86.55 & 1.04 & 1.09 & 0.88 & 0.86 & 1.06 & 1.27 & 1026 & 0 \\
\hline GR-LNB 94 & $9 / 25 / 93$ & $19: 05$ & 155 & 237 & 163 & 1291 & 1485 & 86.89 & 91.02 & 87.13 & 1.01 & 1.10 & 1.06 & 0.88 & 1.03 & 1.08 & 1313 & 172 \\
\hline GR-LNB 95a & $9 / 26 / 93$ & $4: 15$ & 129 & 181 & 135 & 1054 & 1216 & 86.64 & 90.89 & 86.91 & 1.02 & 1.10 & 1.06 & 0.91 & 1.04 & 1.15 & 1046 & 170 \\
\hline LNB-OFA & $9 / 26 / 93$ & $2: 55$ & 101 & 113 & 96 & 845 & 977 & 86.43 & 89.89 & 86.60 & 1.05 & 0.85 & 0.87 & 0.84 & 1.05 & 1.23 & 977 & 0 \\
\hline GR-LNB 95 & $9 / 26 / 93$ & $16: 33$ & 146 & 216 & 155 & 1213 & 1398 & 86.78 & 90.96 & 86.99 & 1.02 & 1.09 & 1.06 & 0.89 & 1.03 & 1.11 & 1221 & 177 \\
\hline GR-LNB 96a & 9/27/93 & $2: 53$ & 132 & 189 & 134 & 1100 & 1270 & 86.53 & 90.74 & 86.65 & 1.03 & 1.08 & 1.01 & 0.88 & 1.04 & $t .15$ & 1099 & 171 \\
\hline LNB & $9 / 27 / 93$ & $19: 45$ & 149 & 220 & 151 & 1282 & 1470 & 87.22 & 90.72 & 87.47 & 1.03 & 1.00 & 0.97 & 0.83 & 1.03 & 1.05 & 1470 & 0 \\
\hline GA-LNB 96b & 9/27/93 & $0: 57$ & 128 & 189 & 133 & 1085 & 1254 & 86.48 & 90.74 & 86.69 & 1.03 & 1.09 & 1.00 & 0.86 & 1.04 & 1.10 & 1071 & 183 \\
\hline GR-LNB 97a & $9 / 28 / 93$ & $9: 13$ & 138 & 201 & 142 & 1137 & 1313 & 86.54 & 90.76 & 86.76 & 1.02 & 1.10 & 1.04 & 0.90 & 1.04 & 1.14 & 1136 & 177 \\
\hline LNB & 9/28/93 & $4: 27$ & 147 & 218 & 178 & 1313 & 1491 & 88.03 & 91.56 & 88.37 & 1.03 & 0.98 & 1.13 & 0.81 & 1.03 & 0.93 & 1491 & 0 \\
\hline GR-LNB 97 & 9/28/93 & $5: 58$ & 157 & 226 & 176 & 1281 & 1472 & 87.01 & 91.09 & 87.27 & 1.00 & 1.06 & 1.15 & 0.90 & 1.03 & 1.05 & 1315 & 157 \\
\hline GR-LNB 97b & 9/28/93 & $2: 48$ & 133 & 180 & 144 & 1072 & 1237 & 86.62 & 90.64 & 86.84 & 1.02 & 1.07 & 1.11 & 0.92 & 1.04 & 1.13 & 1113 & 124 \\
\hline GA-LNB 9Ba & 9/29/93 & $5: 22$ & 121 & 164 & 128 & 979 & 1133 & 86.34 & 90.33 & 86.51 & 1.02 & 1.10 & 1.07 & 0.92 & 1.05 & 1.20 & 1023 & 110 \\
\hline GR-LNB 98 & $9 / 29 / 93$ & $18: 37$ & 155 & 231 & 166 & 1289 & 1482 & 86.97 & 91.11 & 87.20 & 1.01 & 1.08 & 1.07 & 0.88 & 1.03 & 1.06 & 1306 & 176 \\
\hline GR-LNB 99a & 9/30/93 & $5: 32$ & 117 & 160 & 119 & 979 & 1135 & 86.20 & 90.44 & 86.28 & 1.04 & 1.05 & 0.98 & 0.88 & 1.05 & 1.16 & 973 & 163 \\
\hline GP-LNB 99 & $9 / 30 / 93$ & 13:24 & 152 & 232 & 160 & 1285 & 1481 & 86.77 & 90.97 & 87.00 & 1.02 & 1.09 & 1.04 & 0.87 & 1.03 & 1.06 & 1286 & 195 \\
\hline GR-LNB 99b & $9 / 30 / 93$ & $2: 27$ & 131 & 189 & 133 & 1092 & 1269 & 86.09 & 90.36 & 86.30 & 1.03 & 1.07 & 1.00 & 0.88 & 1.04 & 1.14 & 1079 & 190 \\
\hline LNB-OFA & 9/30/93 & $2: 27$ & 89 & 79 & 90 & 723 & 841 & 86.03 & 89.47 & 86.16 & 1.05 & 0.73 & 0.92 & 0.86 & 1.07 & 1.15 & 841 & 0 \\
\hline GR-LNB 100a & $10 / 1 / 93$ & $11: 00$ & 109 & 155 & 106 & 904 & 1053 & 85.83 & 90.07 & 86.00 & 1.03 & 1.13 & 0.94 & 0.89 & 1.06 & 1.26 & 901 & 153 \\
\hline GA-LNB 100 & $10 / 1 / 93$ & $9: 12$ & 136 & 182 & 147 & 1085 & 1255 & 86.41 & 90.63 & 86.65 & 1.02 & 1.07 & 1.12 & 0.93 & 1.03 & 1.14 & 1080 & 175 \\
\hline GR-LNB 101 & $10 / 2 / 93$ & $24: 00$ & 131 & 183 & 135 & 1064 & 1232 & 86.31 & 90.52 & 86.63 & 1.02 & 1.10 & 1.05 & 0.92 & 1.04 & 1.19 & 1063 & 169 \\
\hline GA-LNB 102 & $10 / 3 / 93$ & $24: 00$ & 126 & 172 & 130 & 1010 & 1174 & 86.02 & 90.21 & 86.30 & 1.02 & 1.11 & 1.05 & 0.93 & 1.04 & 1.22 & 1015 & 159 \\
\hline GR-LNB 103 & $10 / 4 / 93$ & $24: 00$ & 134 & 186 & 139 & 1078 & 1250 & 86.21 & 90.46 & 86.44 & 1.02 & 1.10 & 1.06 & 0.92 & 1.03 & 1.16 & 1068 & 181 \\
\hline GR-LNB 104 & $10 / 5 / 93$ & $24: 00$ & 136 & 192 & 139 & 1100 & 1277 & 86.13 & 90.44 & 86.33 & 1.02 & 1.10 & 1.05 & 0.91 & 1.04 & 1.17 & 1078 & 200 \\
\hline GR-LNB 105 & $10 / 6 / 93$ & $10: 15$ & 152 & 223 & 157 & 1241 & 1434 & 86.59 & 90.82 & 86.81 & 1.01 & 1.09 & 1.06 & 0.91 & 1.03 & 1.13 & 1237 & 196 \\
\hline GR-LNB 106 & $10 / 8 / 93$ & $8: 45$ & 154 & 231 & 163 & 1291 & 1475 & 87.56 & 91.76 & 87.89 & 1.02 & 1.07 & 1.06 & 0.88 & 1.03 & 1.05 & 1290 & 184 \\
\hline GR-LNB 107 & $10 / 9 / 93$ & $24: 00$ & 156 & 233 & 162 & 1286 & 1472 & 87.39 & 91.57 & 87.71 & 1.01 & 1.09 & 1.05 & 0.89 & 1.03 & 1.13 & 1293 & 179 \\
\hline
\end{tabular}


Cherokee Unit 3, Average Test $\mathbf{C}$

Pre Modification

\begin{tabular}{|c|c|c|c|c|c|c|c|c|c|c|c|c|c|c|c|c|c|c|}
\hline Test & Date! & 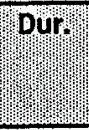 & 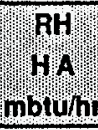 & Prast & ח'sshy! & 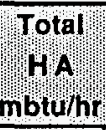 & $\begin{array}{l}\text { Total"m } \\
\text { Heat In } \\
\text { mblums }\end{array}$ & $\begin{array}{l}\text { GrosshV } \\
\text { BoilEtf } \\
\end{array}$ & LowHV & $\begin{array}{l}\text { Heloss } \\
\text { Bolfeff } \\
\text { \% }\end{array}$ & 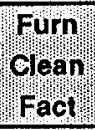 & $\begin{array}{l}\text { PSH } \\
\text { Clean } \\
\text { ract }\end{array}$ & $\begin{array}{l}\text { SsH! } \\
\text { clean! } \\
\text { ract! }\end{array}$ & 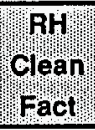 & 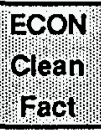 & $\begin{array}{l}\text { Air } \\
\text { cleary } \\
\text { Cract }\end{array}$ & 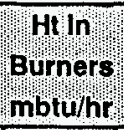 & 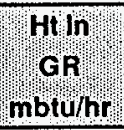 \\
\hline GR.LNB 108 & $10 / 10 / 93$ & $11: 00$ & 158 & 233 & 166 & 1290 & 1480 & 87.18 & 91.35 & 87.46 & 1.01 & 1.09 & 1.08 & 0.90 & 1.03 & 1.13 & 1300 & 180 \\
\hline GR-LNB 109a & $10 / 13 / 93$ & $4: 07$ & 155 & 223 & 169 & 1296 & 1489 & 87.02 & 91.29 & 87.38 & 1.02 & 1.03 & 1.09 & 0.88 & 1.03 & 1.06 & 1277 & 212 \\
\hline GR-LNB 109b & $10 / 13 / 93$ & $2: 02$ & 130 & 182 & 136 & 1088 & 1255 & 86.65 & 90.87 & 86.95 & 1.03 & 1.05 & 1.02 & 0.88 & 1.04 & 1.12 & 1082 & 173 \\
\hline GR-LNB 110a & $10 / 14 / 93$ & 6.02 & 143 & 198 & 152 & 1142 & 1317 & 86.67 & 90.92 & 87.00 & 1.01 & 1.08 & 1.11 & 0.93 & 1.03 & 1.16 & 1131 & 187 \\
\hline GR-LNB 110 & $10 / 14 / 93$ & $14: 56$ & 160 & 221 & 178 & 1272 & 1465 & 86.88 & 91.24 & 87.23 & 1.00 & 1.05 & 1.18 & 0.93 & 1.02 & 1.10 & 1231 & 234 \\
\hline GR-LNB $110 \mathrm{~b}$ & $10 / 14 / 93$ & $3: 00$ & 126 & 178 & 133 & 1048 & 1215 & 86.25 & 90.71 & 86.53 & 1.02 & 1.07 & 1.03 & 0.88 & 1.04 & 1.18 & 994 & 221 \\
\hline GR-LNB 111 & $10 / 15 / 93$ & $12: 49$ & 146 & 198 & 162 & 1163 & 1341 & 86.73 & 91.09 & 87.09 & 1.00 & 1.06 & 1.16 & 0.93 & 1.03 & 1.13 & 1126 & 214 \\
\hline GR-LNB 3 Mill a & $10 / 15 / 93$ & $2: 58$ & 148 & 213 & 172 & 1257 & 1436 & 87.50 & 91.86 & 87.86 & 1.02 & 1.03 & 1.15 & 0.87 & 1.03 & 1.00 & 1217 & 219 \\
\hline GR-LNB 3 MiII b & $10 / 15 / 93$ & $7: 05$ & 138 & 200 & 147 & 1166 & 1338 & 87.11 & 91.38 & 87.46 & 1.03 & 1.05 & 1.04 & 0.87 & 1.03 & 1.08 & 1149 & 189 \\
\hline GR-LNB 3 Mill C & $10 / 16 / 93$ & $12: 05$ & 117 & 163 & 114 & 952 & 1104 & 86.22 & 90.46 & 86.50 & 1.03 & 1.13 & 0.97 & 0.91 & 1.05 & 1.25 & 945 & 159 \\
\hline GR-LNB 3 Mill d & $10 / 16 / 93$ & $10: 28$ & 161 & 245 & 168 & 1341 & 1541 & 87.04 & 91.37 & 87.44 & 1.01 & 1.09 & 1.05 & 0.88 & 1.03 & 1.07 & 1305 & 235 \\
\hline GA-LNB 3 Mill a & $10 / 16 / 93$ & $1: 25$ & 143 & 207 & 152 & 1201 & 1382 & 86.97 & 91.27 & 87.35 & 1.03 & 1.05 & 1.05 & 0.88 & 1.03 & 1.09 & 1177 & 204 \\
\hline GR-LNB 3 Millf & $10 / 17 / 93$ & $23: 46$ & 137 & 186 & 157 & 1135 & 1300 & 87.31 & 91.66 & 87.62 & 1.02 & 1.02 & 1.15 & 0.89 & 1.03 & 1.08 & 1100 & 200 \\
\hline LNB-OFA 3 Mill & $10 / 18 / 93$ & $11: 10$ & 112 & 140 & 128 & 929 & 1060 & 87.65 & 91.16 & 87.93 & 1.03 & 0.99 & 1.11 & 0.89 & 1.05 & 1.15 & 1060 & 0 \\
\hline GR-LNB 3 Mill 9 & $10 / 19 / 93$ & $15: 35$ & 131 & 183 & 137 & 1106 & 1268 & 87.17 & 91.48 & 87.29 & 1.04 & 1.02 & 1.01 & 0.87 & 1.03 & 1.07 & 1079 & 189 \\
\hline GR-LNB 3 Mill h & $10 / 20 / 93$ & $7: 35$ & 133 & 189 & 139 & 1110 & 1272 & 87.26 & 91.58 & 87.41 & 1.03 & 1.07 & 1.04 & 0.89 & 1.04 & 1.12 & 1082 & 190 \\
\hline GR-LNB 112 & $10 / 20 / 93$ & $4: 09$ & 131 & 185 & 130 & 1055 & 1218 & 86.62 & 90.89 & 86.88 & 1.02 & 1.13 & 1.02 & 0.92 & 1.04 & 1.21 & 1042 & 176 \\
\hline LNB-OFA & $10 / 20 / 93$ & $0: 56$ & 144 & 214 & 138 & 1167 & 1339 & 87.15 & 90.65 & 87.30 & 1.02 & 1.13 & 0.98 & 0.91 & 1.03 & 1.23 & 1339 & 0 \\
\hline GR-LNB 113 & $10 / 20 / 93$ & $10: 42$ & 158 & 231 & 163 & 1285 & 1478 & 86.96 & 91.28 & 87.11 & 1.01 & 1.09 & 1.07 & 0.90 & 1.03 & 1.12 & 1254 & 223 \\
\hline GR-LNB 113 & $10 / 21 / 93$ & $24: 00$ & 160 & 226 & 169 & 1273 & 1464 & 86.98 & 91.37 & 87.15 & 1.01 & 1.08 & 1.12 & 0.93 & 1.03 & 1.09 & 1226 & 238 \\
\hline GR-LNB 114 & $10 / 22 / 93$ & $24: 00$ & 155 & 216 & 166 & 1242 & 1428 & 86.95 & 91.34 & 87.11 & 1.01 & 1.06 & 1.13 & 0.93 & 1.03 & 1.08 & 1194 & 234 \\
\hline GA-LNB 115 & $10 / 23 / 93$ & $24: 00$ & 159 & 227 & 171 & 1290 & 1482 & 87.04 & 91.42 & 87.18 & 1.01 & 1.06 & 1.12 & 0.91 & 1.03 & 1.08 & 1245 & 238 \\
\hline GR-LNB 116 & $10 / 24 / 93$ & $14: 00$ & 157 & 225 & 165 & 1267 & 1455 & 87.05 & 91.39 & 87.17 & 1.01 & 1.08 & 1.10 & 0.92 & 1.03 & 1.10 & 1230 & 226 \\
\hline GR-LNB 116a & $10 / 24 / 93$ & $10: 00$ & 159 & 230 & 169 & 1292 & 1486 & 86.94 & 91.30 & 87.03 & 1.01 & 1.08 & 1.10 & 0.91 & 1.03 & 1.07 & 1251 & 235 \\
\hline GR-LNB 117a & $10 / 25 / 93$ & $4: 55$ & 129 & 170 & 137 & 1042 & 1202 & 86.67 & 90.93 & 86.68 & 1.03 & 1.04 & 1.07 & 0.91 & 1.04 & 1.15 & 1027 & 175 \\
\hline GR-LNB 117 & $10 / 25 / 93$ & $19: 04$ & 159 & 221 & 172 & 1266 & 1451 & 87.20 & 91.54 & 87.37 & 1.00 & 1.06 & 1.15 & 0.93 & 1.02 & 1.09 & 1229 & 223 \\
\hline GR-LNB 118 & $10 / 26 / 93$ & $24: 00$ & 156 & 220 & 169 & 1262 & 1444 & 87.42 & 91.76 & 87.64 & 1.01 & 1.06 & 1.13 & 0.91 & 1.03 & 1.07 & 1224 & 220 \\
\hline GR-LNB 119 & $10 / 27 / 93$ & $14: 25$ & 161 & 226 & 179 & 1298 & 1483 & 87.53 & 91.88 & 87.72 & 1.00 & 1.05 & 1.17 & 0.92 & 1.02 & 1.06 & 1261 & 222 \\
\hline GR-LNB 119a & $10 / 27 / 93$ & $9: 34$ & 158 & 219 & 175 & 1276 & 1460 & 87.40 & 91.72 & 87.52 & 1.01 & 1.04 & 1.16 & 0.92 & 1.02 & 1.00 & 1245 & 216 \\
\hline GR-LNB 120a & $10 / 28 / 93$ & $7: 21$ & 147 & 205 & 164 & 1210 & 1387 & 87.23 & 91.51 & 87.30 & 1.02 & 1.03 & 1.13 & 0.89 & 1.03 & 1.03 & 1190 & 197 \\
\hline GR-LNB 120 & $10 / 28 / 93$ & $16: 38$ & 160 & 220 & 176 & 1275 & 1456 & 87.55 & 91.88 & 87.79 & 1.01 & 1.05 & 1.17 & 0.93 & 1.02 & 1.04 & 1241 & 215 \\
\hline GR-LNB 121 & $10 / 29 / 93$ & $24: 00$ & 160 & 217 & 178 & 1264 & 1443 & 87.64 & 91.99 & 87.95 & 1.00 & 1.05 & 1.19 & 0.94 & 1.02 & 1.12 & 1226 & 216 \\
\hline GR-LNB 122 & $10 / 30 / 93$ & $24: 00$ & 164 & 229 & 179 & 1305 & 1489 & 87.64 & 91.99 & 87.94 & 1.00 & 1.06 & 1.16 & 0.93 & 1.02 & 1.09 & 1265 & 224 \\
\hline GR-LNB 123 & $10 / 31 / 93$ & $24: 00$ & 161 & 223 & 176 & 1282 & 1467 & 87.38 & 91.71 & 87.63 & 1.00 & 1.06 & 1.16 & 0.93 & 1.02 & 1.08 & 1247 & 221 \\
\hline GR-LNB 124 & $11 / 1 / 93$ & $6: 18$ & 155 & 217 & 172 & 1259 & 1437 & 87.58 & 91.75 & 87.84 & 1.01 & 1.05 & 1.15 & 0.91 & 1.03 & 1.08 & 1268 & 169 \\
\hline LNB-OFA & $11 / 1 / 93$ & $1: 08$ & 125 & 167 & 134 & 1033 & 1176 & 87.75 & 91.27 & 88.07 & 1.04 & 1.03 & 1.06 & 0.89 & 1.04 & 1.14 & 1176 & 0 \\
\hline GP-LNB 125a & $11 / 2 / 93$ & $8: 15$ & 161 & 214 & 188 & 1277 & 1452 & 87.94 & 92.09 & 88.30 & 1.00 & 1.02 & 1.24 & 0.93 & 1.02 & 1.03 & 1289 & 163 \\
\hline LNB & $11 / 2 / 93$ & $0: 29$ & 158 & 213 & 185 & 1270 & 1447 & 87.75 & 91.88 & 88.10 & 1.00 & 1.02 & 1.22 & 0.92 & 1.02 & 1.01 & 1286 & 161 \\
\hline GR-LNB 125 & $11 / 2 / 93$ & $10: 09$ & 158 & 213 & 185 & 1269 & 1446 & 87.74 & 91,88 & 88.09 & 1.00 & 1.02 & 1.23 & 0.92 & 1.02 & 1.01 & 1283 & 163 \\
\hline GR-LNB 126a & $11 / 4 / 93$ & $1: 40$ & 154 & 207 & 178 & 1239 & 1409 & 87.91 & 92.02 & 88.16 & 1.01 & 1.02 & 1.21 & 0.92 & 1.02 & 1.01 & 1262 & 146 \\
\hline
\end{tabular}


Pre Modification

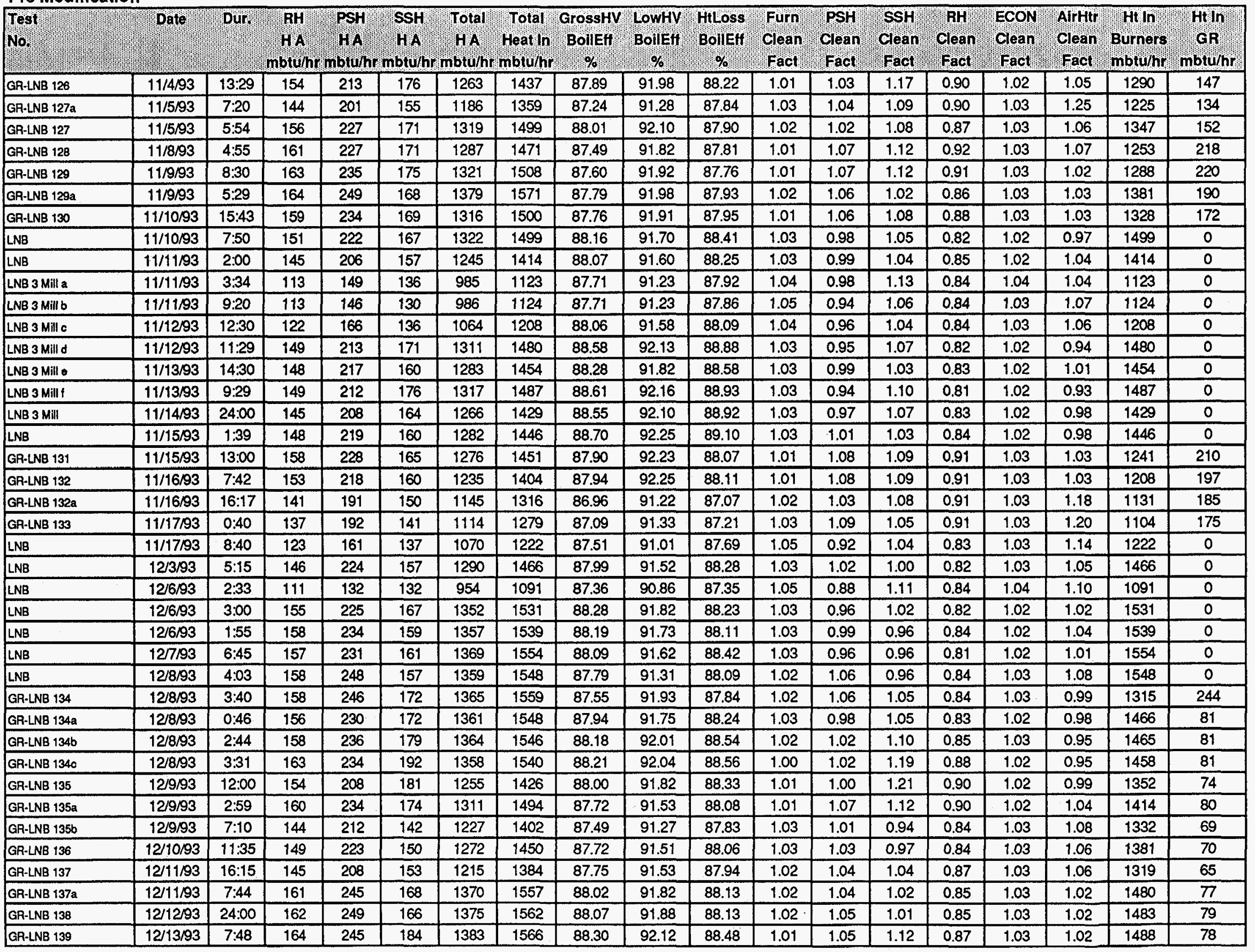


Pre Modification

\begin{tabular}{|c|c|c|c|c|c|c|c|c|c|c|c|c|c|c|c|c|c|c|}
\hline Test & Date & Durf & 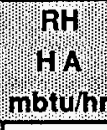 & Pasp] & 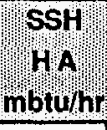 & 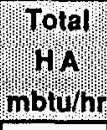 & 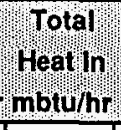 & GrosshV & 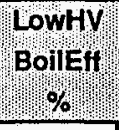 & Hilooss & Furn & $\begin{array}{l}\text { PSPH } \\
\text { clean } \\
\text { Fact }\end{array}$ & (çeañ & Clean! & Econ & AirHel & $\begin{array}{l}\text { He In } \\
\text { Burners } \\
\text { mbtu/hr }\end{array}$ & 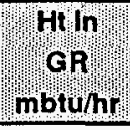 \\
\hline GR-LNB 139a & $12 / 13 / 93$ & $4: 18$ & 163 & 245 & 180 & 1370 & 1555 & 88.15 & 91.97 & 88.39 & 1.01 & 1.06 & 1.11 & 0.87 & 1.03 & 1.05 & 1476 & 78 \\
\hline LNB & $12 / 13 / 93$ & $5: 18$ & 157 & 213 & 168 & 1298 & 1475 & 88.05 & 91.58 & 88.31 & 1.01 & 0.96 & 1.07 & 0.87 & 1.02 & 1.06 & 1475 & 0 \\
\hline LNB-OFA & $12 / 14 / 93$ & $1: 55$ & 160 & 245 & 172 & 1376 & 1564 & 87.98 & 91.50 & 88.17 & 1.02 & 1.04 & 1.04 & 0.84 & 1.03 & 1.11 & 1564 & 0 \\
\hline GR-LNB 140 & $12 / 14 / 93$ & $1: 18$ & 164 & 238 & 189 & 1383 & 1573 & 87.93 & 91.74 & 88.19 & 1.02 & 1.02 & 1.15 & 0.87 & 1.03 & 1.03 & 1492 & 81 \\
\hline LNB & $12 / 14 / 93$ & $8: 30$ & 155 & 229 & 175 & 1353 & 1535 & 88.18 & 91.71 & 88.44 & 1.02 & 0.98 & 1.08 & 0.83 & 1.02 & 1.01 & 1535 & 0 \\
\hline LNB & $12 / 15 / 93$ & $9: 28$ & 155 & 228 & 166 & 1338 & 1517 & 88.23 & 91.76 & 88.42 & 1.03 & 0.99 & 1.03 & 0.84 & 1.02 & 1.05 & 1517 & 0 \\
\hline LNB-OFA & $12 / 15 / 93$ & $5: 29$ & 157 & 239 & 160 & 1355 & 1534 & 88.29 & 91.83 & 88.43 & 1.02 & 1.02 & 0.97 & 0.83 & 1.02 & 1.06 & 1534 & 0 \\
\hline GR-LNB 141 & $12 / 15 / 93$ & $5: 15$ & 147 & 204 & 163 & 1223 & 1390 & 87.92 & 91.74 & 88.07 & 1.03 & 1.01 & 1.12 & 0.89 & 1.03 & 1.07 & 1316 & 74 \\
\hline LNB & $12 / 15 / 93$ & $2: 50$ & 101 & 135 & 104 & 829 & 950 & 87.04 & 90.53 & 86.96 & 1.04 & 1.18 & 0.98 & 0.90 & 1.09 & 1.29 & 950 & 0 \\
\hline LNB & $12 / 16 / 93$ & $15: 05$ & 151 & 218 & 160 & 1289 & 1461 & 88.21 & 91.74 & 88.40 & 1.06 & 1.03 & 1.05 & 0.87 & 1.00 & 1.10 & 1461 & 0 \\
\hline GR-LNB 142 & $12 / 16 / 93$ & $6: 14$ & 164 & 246 & 173 & 1385 & 1571 & 88.13 & 91.95 & 88.39 & 1.05 & 1.08 & 1.07 & 0.89 & 1.00 & 1.12 & 1489 & 83 \\
\hline GR-LNB 142a & $12 / 16 / 93$ & $1: 15$ & 114 & 152 & 121 & 960 & 1101 & 87.20 & 91.01 & 87.46 & 1.06 & 1.04 & 1.03 & 0.89 & 1.03 & 1.19 & 1038 & 63 \\
\hline GR-LNB 143 & $12 / 17 / 93$ & $2: 10$ & 114 & 143 & 125 & 931 & 1069 & 87.09 & 90.90 & 87.32 & 1.05 & 1.04 & 1.11 & 0.92 & 1.03 & 1.23 & 1007 & 62 \\
\hline LNB-OFA & $12 / 17 / 93$ & $0: 40$ & 65 & 57 & 61 & 519 & 609 & 85.17 & 88.58 & 85.04 & 1.01 & 0.87 & 0.80 & 0.87 & 1.19 & 1.54 & 609 & 0 \\
\hline LNB & $12 / 17 / 93$ & $6: 10$ & 154 & 228 & 167 & 1330 & 1507 & 88.27 & 91.81 & 88.54 & 1.06 & 1.04 & 1.07 & 0.86 & 1,00 & 1.09 & 1507 & 0 \\
\hline LNB & $12 / 20 / 93$ & $2: 25$ & 140 & 208 & 140 & 1174 & 1338 & 87.66 & 91.17 & 87.84 & 1.05 & 1.12 & 0.99 & 0.89 & 1.02 & 1.21 & 1338 & 0 \\
\hline $100 \%$ Gas Firing & $12 / 20 / 93$ & $0: 34$ & 96 & 120 & 91 & 770 & 882 & 87.18 & 90.67 & 84.48 & 1.05 & 1.12 & 0.92 & 0.93 & 1.08 & 1.30 & 882 & 0 \\
\hline LNB & $12 / 22 / 93$ & $2: 35$ & 131 & 188 & 130 & 1092 & 1248 & 87.49 & 90.99 & 87.67 & 1.05 & 1.10 & 0.99 & 0.89 & 1.02 & 1.21 & 1248 & 0 \\
\hline LNB & $1 / 5 / 94$ & $2: 24$ & 152 & 224 & 166 & 1312 & 1490 & 88.04 & 91.57 & 88.29 & 1.05 & 1.04 & 1.08 & 0.86 & 1.01 & 1,03 & 1490 & 0 \\
\hline LNB-OFA & $1 / 5 / 94$ & 2.26 & 152 & 229 & 155 & 1312 & 1491 & 87.93 & 91.46 & 88.17 & 1.06 & 1.05 & 1.00 & 0.85 & 1.00 & 1.06 & 1491 & 0 \\
\hline LNB-OFA & $1 / 5 / 94$ & $9: 15$ & 135 & 190 & 145 & 1156 & 1316 & 87.76 & 91.28 & 88.03 & 1.06 & 1.03 & 1.05 & 0.87 & 1.01 & 1.10 & 1316 & 0 \\
\hline LNB-OFA & $1 / 6 / 94$ & $8: 47$ & 109 & 135 & 122 & 896 & 1028 & 87.07 & 90.56 & 87.32 & 1.05 & 1.01 & 1.09 & 0.90 & 1.04 & 1.18 & 1028 & 0 \\
\hline LNB & $1 / 6 / 94$ & $15: 12$ & 152 & 223 & 164 & 1296 & 1472 & 88.05 & 91.58 & 88.34 & 1.05 & 1.05 & 1.08 & 0.88 & 1.01 & 1.08 & 1472 & 0 \\
\hline LNB & $1 / 7 / 94$ & $6: 55$ & 125 & 169 & 140 & 1065 & 1213 & 87.71 & 91.23 & 88.03 & 1.06 & 1.02 & 1.09 & 0.87 & 1.02 & 1.13 & 1213 & 0 \\
\hline LNB-OFA & $1 / 7 / 94$ & 1.09 & 132 & 180 & 141 & 1096 & 1249 & 87.71 & 91.23 & 87.99 & 1.05 & 1.04 & 1.07 & 0.90 & 1.01 & 1.16 & 1249 & 0 \\
\hline GR-LNB 144 & $1 / 7 / 94$ & $15: 40$ & 153 & 213 & 163 & 1244 & 1419 & 87.66 & 91.49 & 87.86 & 1.04 & 1.07 & 1.12 & 0.92 & 1.01 & 1.10 & 1340 & 79 \\
\hline GR-LNB 145a & $1 / 8 / 94$ & $8: 20$ & 139 & 174 & 159 & 1101 & 1260 & 87.39 & 91.20 & 87.61 & 1.03 & 1.02 & 1.22 & 0.95 & 1.01 & 1.12 & 1189 & 71 \\
\hline GA-LNB 145 & $1 / 8 / 94$ & $15: 39$ & 162 & 212 & 186 & 1285 & 1463 & 87.80 & 91.62 & 88.00 & 1.02 & 1.02 & 1.24 & 0.95 & 1.00 & 1.08 & 1382 & 81 \\
\hline GR-LNB 146a & $1 / 9 / 94$ & $2: 10$ & 159 & 179 & 211 & 1241 & 1410 & 87.98 & 91.82 & 88.12 & 1.01 & 0.90 & 1.46 & 0.97 & 0.99 & 1.05 & 1329 & 81 \\
\hline GR-LNB 146b & $1 / 9 / 94$ & $8: 39$ & 134 & 156 & 151 & 1001 & 1149 & 87.16 & 90.97 & 87.31 & 1.01 & 1.03 & 1.27 & 1.01 & 1.01 & 1.18 & 1084 & 65 \\
\hline GR-LNB 146 & $1 / 9 / 94$ & $9: 02$ & 152 & 202 & 164 & 1201 & 1372 & 87.53 & 91.36 & 87.68 & 1.03 & 1.06 & 1.16 & 0.95 & 1.01 & 1.13 & 1293 & 79 \\
\hline LNB & $1 / 9 / 94$ & $3: 35$ & 121 & 160 & 136 & 1046 & 1193 & 87.64 & 91.15 & 87.80 & 1.06 & 0.96 & 1.07 & 0.86 & 1.02 & 1.10 & 1193 & 0 \\
\hline LNB & $1 / 10 / 94$ & $3: 50$ & 141 & 186 & 161 & 1149 & 1311 & 87.58 & 91.09 & 87.90 & 1.04 & 1.02 & 1.19 & 0.93 & 1.01 & 1.18 & 1311 & 0 \\
\hline GR-LNB 147 & $1 / 10 / 94$ & $2: 40$ & 164 & 246 & 169 & 1368 & 1562 & 87.61 & 91.41 & 87.96 & 1.04 & 1.09 & 1.06 & 0.90 & 1.01 & 1.14 & 1480 & 82 \\
\hline GR-LNB 147a & $1 / 10 / 94$ & $4: 04$ & 131 & 178 & 141 & 1086 & 1248 & 86.98 & 90.85 & 87.29 & 1.05 & 1.04 & 1.08 & 0.90 & 1.02 & 1.20 & 1163 & 85 \\
\hline GR-LNB 147b & $1 / 10 / 94$ & $4: 54$ & 132 & 180 & 138 & 1092 & 1253 & 87.05 & 90.91 & 87.35 & 1.05 & 1.05 & 1.05 & 0.90 & 1.02 & 1.22 & 1169 & 84 \\
\hline GR-LNB 148a & $1 / 11 / 94$ & $6: 32$ & 121 & 161 & 122 & 965 & 1112 & 86.75 & 90.62 & 87.00 & 1.04 & 1.12 & 1.04 & 0.95 & 1.03 & 1.31 & 1034 & 78 \\
\hline GR-LNB 148 & $1 / 11 / 94$ & $14: 38$ & 158 & 239 & 158 & 1350 & 1538 & 87.74 & 91.62 & 87.96 & 1.05 & 1.06 & 0.99 & 0.87 & 1.00 & 1.09 & 1435 & 103 \\
\hline GR-LNB 148b & $1 / 11 / 94$ & $2: 48$ & 129 & 174 & 136 & 1115 & 1275 & 87.41 & 91.26 & 87.63 & 1.07 & 0.96 & 1.00 & 0.85 & 1.01 & 1.09 & 1196 & 79 \\
\hline GR-LNB 149a & $1 / 12 / 94$ & $6: 14$ & 142 & 206 & 143 & 1178 & 1346 & 87.51 & 91.36 & 87.75 & 1.05 & 1.10 & 1.02 & 0.90 & 1.01 & 1.15 & 1263 & 83 \\
\hline
\end{tabular}


Cherokee Unit 3, Average Test C

Pre Modification

\begin{tabular}{|c|c|c|c|c|c|c|c|c|c|c|c|c|c|c|c|c|c|c|}
\hline Tesp & Whate & pur & $\begin{array}{l}\text { RHIIIIIII } \\
\text { mbturht }\end{array}$ & mbromp & mbsh" & 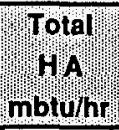 & 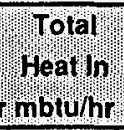 & Grosshy & LowHY & Hoileft & 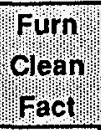 & 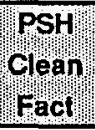 & (Clesp) & 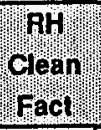 & Econ & Airfytr & 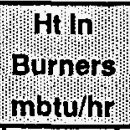 & 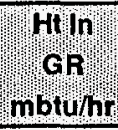 \\
\hline GR-LNB 149 & $1 / 12 / 94$ & $13: 30$ & 151 & 220 & 154 & 1257 & 1434 & 87.63 & 91.49 & 87.84 & 1.05 & 1.08 & 1.04 & 0.89 & 1.01 & 1.11 & 1344 & 90 \\
\hline GR-LNB A Mill of & $1 / 12 / 94$ & 1.09 & 146 & 193 & 154 & 1139 & 1302 & 87.42 & 91.28 & 87.63 & 1.03 & 1.09 & 1.14 & 0.97 & 1.01 & 1.14 & 1218 & 84 \\
\hline GA-LNB D Mill off & $1 / 12 / 94$ & $1: 39$ & 150 & 195 & 169 & 1181 & 1346 & 87.69 & 91.70 & 87.90 & 1.02 & 1.05 & 1.22 & 0.96 & 1.00 & 1.07 & 1227 & 119 \\
\hline GR-LNB D Mill off line & $1 / 13 / 94$ & $4: 23$ & 121 & 133 & 149 & 938 & 1075 & 87.23 & 91.14 & 87.41 & 1.02 & 0.96 & 1.31 & 0.97 & 1.02 & 1.12 & 993 & 81 \\
\hline GR-LNB 150 & $1 / 13 / 94$ & $7: 15$ & 168 & 229 & 184 & 1333 & 1522 & 87.60 & 91.49 & 87.85 & 1.02 & 1.05 & 1.18 & 0.95 & 1.00 & 1.09 & 1418 & 104 \\
\hline GR.LNB O Mill off line & $1 / 13 / 94$ & $1: 13$ & 156 & 186 & 182 & 1177 & 1344 & 87.62 & 91.60 & 87.83 & 1.01 & 1.01 & 1.32 & 1.00 & 0.99 & 1.08 & 1231 & 113 \\
\hline GR-LNB 150a & $1 / 13 / 94$ & $6: 00$ & 146 & 203 & 151 & 1189 & 1361 & 87.34 & 91.21 & 87.56 & 1.04 & 1.06 & 1.07 & 0.91 & 1.01 & 1.12 & 1270 & 91 \\
\hline GR-LNB 151a & $1 / 14 / 94$ & $7: 25$ & 117 & 149 & 124 & 956 & 1100 & 86.85 & 90.69 & 87.02 & 1.05 & 1.03 & 1.05 & 0.91 & 1.03 & 1.18 & 1028 & 72 \\
\hline GR.LNB, ABC & $1 / 14 / 94$ & $7: 50$ & 146 & 178 & 174 & 1141 & 1303 & 87.58 & 91.44 & 87.84 & 1.02 & 1.00 & 1.29 & 0.97 & 1.00 & 1.09 & 1222 & 82 \\
\hline GR-LNB 151 & $1 / 14 / 94$ & $7: 54$ & 145 & 193 & 157 & 1155 & 1321 & 87.40 & 91.25 & 87.67 & 1.03 & 1.06 & 1.15 & 0.94 & 1.01 & 1.11 & 1239 & 82 \\
\hline GR-LNB 156 & $1 / 19 / 94$ & 24.00 & 127 & 165 & 137 & 1033 & 1185 & 87.15 & 91.01 & 87.41 & 1.05 & 1.04 & 1.10 & 0.92 & 1.02 & 1.13 & 1107 & 78 \\
\hline GR-LNB 157a & $1 / 20 / 94$ & $6: 38$ & 126 & 154 & 141 & 988 & 1130 & 87.38 & 91.24 & 87.70 & 1.03 & 1.04 & 1.19 & 0.97 & 1.02 & 1.17 & 1056 & 74 \\
\hline GR.LNB 157 & $1 / 20 / 94$ & $3: 50$ & 160 & 212 & 177 & 1251 & 1425 & 87.78 & 91.72 & 88.04 & 1.02 & 1.06 & 1.21 & 0.97 & 1.00 & 1.13 & 1316 & 109 \\
\hline
\end{tabular}


Cherokee Unit 3, Average Test L

Pre Modification

\begin{tabular}{|c|c|c|c|c|c|c|c|c|c|c|c|c|c|c|c|c|c|c|}
\hline Test nop & Date & Dur & $\begin{array}{l}\text { co } \\
\text { rawy } \\
\text { ppm }\end{array}$ & 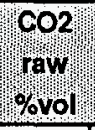 & nox & $\begin{array}{l}\mathrm{so2} \\
\mathrm{raw} \\
\mathrm{ppm}\end{array}$ & $\begin{array}{l}\text { Econ } \\
\text { nuegf } \\
\text { Deg }\end{array}$ & 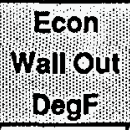 & $\begin{array}{l}\text { Cold RH } \\
\text { Flow } \\
\text { (bs/hr }\end{array}$ & $\begin{array}{l}\text { Hot } \\
\text { RH } \\
\text { DegF }\end{array}$ & 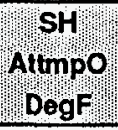 & 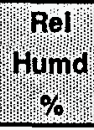 & (Pross & $\begin{array}{l}\text { Amb } \\
\text { Temp: } \\
\text { Deg F }\end{array}$ & $\begin{array}{l}\text { NG } \\
\text { Temp } \\
\text { Def F }\end{array}$ & Coal & 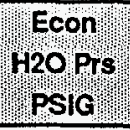 & 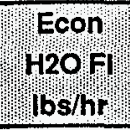 \\
\hline Base Cond. (OFA off) & $11 / 11 / 92$ & $8: 42$ & 119 & 10.73 & 239 & 302 & 468 & 489 & 736460 & 920 & 768 & 50.5 & 29.9 & 50 & 80 & 80 & 1924 & 768683 \\
\hline GR & $11 / 11 / 92$ & $1: 01$ & 250 & 10.76 & 204 & 270 & 513 & 533 & 1139355 & 1004 & 780 & 50.5 & 29.9 & 49 & 80 & 80 & 2043 & 1173710 \\
\hline Base Cond. (OFA off) & $11 / 11 / 92$ & $4: 25$ & 8 & 13.07 & 376 & 319 & 508 & 527 & 1129821 & 953 & 781 & 50.5 & 29.9 & 55 & 80 & 80 & 2042 & 1210615 \\
\hline Base Cond. OFA off & $11 / 12 / 92$ & $0: 45$ & 35 & 16.68 & 348 & 325 & 505 & 525 & 1129565 & 927 & 764 & 50.5 & 27.1 & 47 & 80 & 80 & 2047 & 1230000 \\
\hline BPMS GR 4 & $11 / 12 / 92$ & $1: 05$ & 27 & 14.80 & 217 & 257 & 513 & 533 & 1133636 & 1005 & 791 & 50.5 & 24.0 & 53 & 80 & 80 & 2040 & 1168939 \\
\hline Base Cond. OFA off & $11 / 12 / 92$ & $1: 15$ & 8 & 15.75 & 363 & 313 & 508 & 528 & 1130000 & 950 & 784 & 50.5 & 23.8 & 56 & 80 & 80 & 2043 & 1210000 \\
\hline BPMS Base Cond. 5 & $11 / 13 / 92$ & $2: 55$ & 5 & 15.33 & 387 & 303 & 510 & 530 & 1140852 & 970 & 786 & 50.5 & 22.8 & 53 & 80 & 80 & 2048 & 1216648 \\
\hline BPMS Base Cond. 6 & $11 / 13 / 92$ & 1.00 & 79 & 15.54 & 305 & 312 & 506 & 526 & 1140000 & 922 & 769 & 50.5 & 25.1 & 63 & 80 & 80 & 2050 & 1240328 \\
\hline BPMS Base Cond. 7 & $11 / 13 / 92$ & $1: 00$ & 502 & 15.96 & 262 & 319 & 506 & 526 & 1147869 & 910 & 764 & 50.5 & 25.1 & 68 & 80 & 80 & 2054 & 1252951 \\
\hline Base Cond.-1d & $11 / 16 / 92$ & 1.00 & 5 & 15.47 & 381 & 314 & 506 & 526 & 1055152 & 958 & 776 & 50.5 & 25.0 & 59 & 80 & 80 & 2015 & 1124848 \\
\hline GR-10C & $11 / 16 / 92$ & $1: 00$ & 150 & 16.26 & 309 & 345 & 503 & 523 & 1108525 & 909 & 761 & 50.5 & 25.0 & 74 & 80 & 80 & 2040 & 1209672 \\
\hline GR-10d & $11 / 16 / 92$ & $1: 00$ & 266 & 16.07 & 313 & 350 & 503 & 523 & 1109344 & 906 & 762 & 50.5 & 25.0 & 75 & 80 & 80 & 2043 & 1210492 \\
\hline Base Cond. OFA off & $11 / 17 / 92$ & $1: 15$ & 9 & 15.58 & 395 & 319 & 508 & 528 & 1128289 & 948 & 779 & 50.5 & 25.0 & 58 & 80 & 80 & 2046 & 1218158 \\
\hline GR-11c & $11 / 17 / 92$ & 1.00 & 83 & 15.05 & 200 & 271 & 508 & 528 & 1102459 & 988 & 786 & 50.5 & 25.0 & 65 & 80 & 80 & 2033 & 1153934 \\
\hline GR-11d & $11 / 17 / 92$ & 1.00 & 13 & 14.96 & 194 & 269 & 508 & 528 & 1098393 & 987 & 787 & 50.5 & 25.0 & 68 & 80 & 80 & 2030 & 1141429 \\
\hline Base Cond. OFA off & $11 / 17 / 92$ & $0: 20$ & 5 & 14.70 & 395 & 308 & 505 & 525 & 1071905 & 959 & 784 & 50.5 & 25.0 & 70 & 80 & 80 & 2023 & 1130000 \\
\hline Base Cond. OFA off & $11 / 18 / 92$ & $0: 28$ & 29 & 16.46 & 355 & 333 & 504 & 524 & 1099655 & 932 & 777 & 50.5 & 25.0 & 47 & 80 & 80 & 2037 & 1184483 \\
\hline GR-110 & $11 / 18 / 92$ & $1: 04$ & 13 & 14.83 & 194 & 270 & 510 & 530 & 1103846 & 989 & 792 & 50.5 & 25.0 & 60 & 80 & 80 & 2033 & 1147385 \\
\hline GR-12b & $11 / 18 / 92$ & 1.05 & 30 & 15.05 & 194 & 292 & 508 & 528 & 1099848 & 974 & 789 & 50.5 & 25.0 & 65 & 80 & 80 & 2032 & 1148636 \\
\hline Base Cond. OFA off & $11 / 18 / 92$ & $0: 35$ & 74 & 15.68 & 355 & 333 & 506 & 526 & 1084722 & 954 & 785 & 50.5 & 25.0 & 65 & 80 & 80 & 2025 & 1155556 \\
\hline GR-12 (5\% Gas) & $11 / 19 / 92$ & 1.00 & 980 & 16.19 & 207 & 336 & 505 & 525 & 1113443 & 930 & 762 & 50.5 & 25.0 & 77 & 80 & 80 & 2040 & 1210000 \\
\hline GR-12a (10\% Gas) & $11 / 19 / 92$ & 1.00 & 974 & 16.31 & 180 & 332 & 507 & 527 & 1116721 & 974 & 783 & 50.5 & 25.0 & $\pi$ & 80 & 80 & 2039 & 1185082 \\
\hline GR-12c (23\% Gas) & $11 / 19 / 92$ & $1: 00$ & 93 & 15.36 & 176 & 278 & 509 & 529 & 1085082 & 1009 & 763 & 50.5 & 24.9 & 77 & 80 & 80 & 2022 & 1098852 \\
\hline Base Cond. OFA off & $11 / 19 / 92$ & 0.20 & 14 & 15.54 & 353 & 322 & 504 & 524 & 1072381 & 973 & 784 & 50.5 & 24.9 & $\pi 7$ & 80 & 80 & 2019 & 1138095 \\
\hline GR-13A; $18 \%$ Gas & $11 / 20 / 92$ & $0: 58$ & 543 & 15.96 & 167 & 290 & 507 & 527 & 1093220 & 988 & 783 & 50.5 & 24.8 & 49 & 80 & 80 & 2029 & 1141356 \\
\hline GR-13D; $18 \%$ Gas & $11 / 20 / 92$ & $1: 00$ & 43 & 15.47 & 183 & 287 & 508 & 528 & 1082623 & 1001 & 787 & 50.5 & 24.8 & 48 & 80 & 80 & 2023 & 1112295 \\
\hline GA-14B; $20 \%$ Gas & $11 / 20 / 92$ & $1: 00$ & 31 & 14.96 & 182 & 272 & 509 & 529 & 1081803 & 1007 & 788 & 50.5 & 24.7 & 48 & 80 & 80 & 2022 & 1108033 \\
\hline Base Cond. OFA off & $11 / 30 / 92$ & $1: 50$ & 226 & 16.00 & 348 & 329 & 506 & 526 & 1108468 & 959 & 784 & 50.5 & 25.0 & 60 & 80 & 80 & 2033 & 1181712 \\
\hline GA-BFr & $11 / 30 / 92$ & $0: 26$ & 150 & 14.69 & 218 & 290 & 509 & 528 & 1104444 & 969 & 794 & 50.5 & 25.0 & 61 & 80 & 80 & 2033 & 1175556 \\
\hline GR-BFt & $11 / 30 / 92$ & $0: 27$ & 38 & 14.53 & 213 & 287 & 506 & 526 & 1090357 & 957 & 783 & 50.5 & 25.0 & 60 & 80 & 80 & 2030 & 1168929 \\
\hline GR-21C & $12 / 1 / 92$ & $1: 06$ & 32 & 14.45 & 158 & 254 & 486 & 506 & 856025 & 971 & 775 & 50.5 & 25.1 & 56 & 80 & 80 & 1951 & 872653 \\
\hline GR-22 & $12 / 1 / 92$ & $0: 50$ & 10 & 14.00 & 182 & 271 & 483 & 503 & 852769 & 906 & 774 & 50.5 & 25.1 & 56 & 80 & 80 & 1952 & 910222 \\
\hline Bias Firing & $12 / 1 / 92$ & $0: 10$ & 43 & 14.48 & 158 & 262 & 485 & 505 & 847234 & 947 & 783 & 50.5 & 25.1 & 56 & 80 & 80 & 1954 & 882677 \\
\hline Base Cond. OFA on & $12 / 1 / 92$ & $0: 50$ & 263 & 16.11 & 204 & 312 & 481 & 501 & 857056 & 878 & 747 & 50.5 & 25.1 & 54 & 80 & 80 & 1955 & 924722 \\
\hline Base Cond. OFA off & $12 / 1 / 92$ & $0: 40$ & 85 & 15.77 & 280 & 321 & 489 & 509 & 923356 & 941 & 780 & 50.5 & 25.1 & 55 & 80 & 80 & 1973 & 971791 \\
\hline Base Cond. OFA off & $12 / 292$ & $3: 55$ & 16 & 15.74 & 330 & 354 & 505 & 525 & 1076534 & 950 & 790 & 50.5 & 25.0 & 43 & 80 & 80 & 2020 & 1154807 \\
\hline Base Cond. OFA off & $12 / 4 / 92$ & $0: 55$ & 65 & 15.61 & 239 & 431 & 485 & 505 & 887952 & 957 & 777 & 50.5 & 25.3 & 35 & 80 & 80 & 1960 & 931117 \\
\hline OFA Test & $12 / 4 / 92$ & $2: 10$ & 157 & 15.22 & 189 & 414 & 480 & 500 & 788182 & 950 & 784 & 50.5 & 25.3 & 36 & 80 & 80 & 1942 & 864610 \\
\hline Base Cond. OFA off & $12 / 7 / 92$ & $2: 10$ & 141 & 15.37 & 272 & 324 & 489 & 509 & 864629 & 976 & 765 & 50.5 & 25.0 & 37 & 80 & 80 & 1958 & 930989 \\
\hline GR-22A & $12 / 7 / 92$ & $1: 05$ & 634 & 14.99 & 164 & 300 & 490 & 510 & 849507 & 988 & 773 & 50.5 & 25.0 & 45 & 80 & 80 & 1954 & 904634 \\
\hline
\end{tabular}


Cherokee Unit 3, Average Test L

Pre Modification

\begin{tabular}{|c|c|c|c|c|c|c|c|c|c|c|c|c|c|c|c|c|c|c|}
\hline Trop & Daten & Dup & $\begin{array}{l}\text { com } \\
\text { pawn } \\
\text { ppm }\end{array}$ & ray & $\begin{array}{l}\text { Nox } \\
\text { rawn } \\
\text { ppm }\end{array}$ & $\begin{array}{l}\mathrm{SO}_{2} \\
\text { raw } \\
\mathrm{ppm}\end{array}$ & In Econ: & $\begin{array}{l}\text { Econ } \\
\text { Wail ouf } \\
\text { Degs }\end{array}$ & 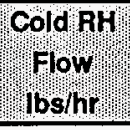 & $\begin{array}{l}\text { Whot } \\
\text { Degf } \\
\text { Degh }\end{array}$ & 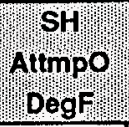 & 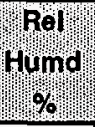 & Apross & 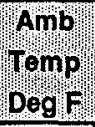 & 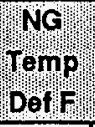 & $\begin{array}{l}\text { Coal } \\
\text { Demp } \\
\text { Deg }\end{array}$ & "Econ 20 & 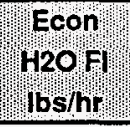 \\
\hline GR-22B & $12 / 7 / 92$ & $1: 00$ & 22 & 14.87 & 162 & 285 & 490 & 510 & 842418 & 992 & 769 & 50.5 & 25.0 & 45 & 80 & 80 & 1953 & 884639 \\
\hline GR-22C & $12 / 7 / 92$ & $1: 00$ & 7 & 14.69 & 155 & 267 & 490 & 510 & 843079 & 995 & 767 & 50.5 & 25.0 & 45 & 80 & 80 & 1952 & 880215 \\
\hline Base Cond. OFA off & $12 / 8 / 92$ & $0: 27$ & 800 & 16.03 & 228 & 333 & 464 & 484 & 650326 & 929 & 751 & 50.5 & 24.9 & 44 & 80 & 80 & 1903 & 696312 \\
\hline GA-31C & $12 / 8 / 92$ & $1: 00$ & 195 & 14.69 & 150 & 267 & 468 & 488 & 657968 & 971 & 756 & 50.5 & 24.8 & 51 & 80 & 80 & 1903 & 685888 \\
\hline GR-31F & $12 / 8 / 92$ & $1: 23$ & 7 & 13.32 & 161 & 243 & 470 & 490 & 660274 & 971 & 765 & 50.5 & 24.8 & 52 & 80 & 80 & 1902 & 682228 \\
\hline GR-32A & $12 / 8 / 92$ & 1.00 & 227 & 14.86 & 157 & 284 & 464 & 484 & 651399 & 955 & 770 & 50.5 & 24.8 & 50 & 80 & 80 & 1907 & 702563 \\
\hline Base Cond. OFA off & $12 / 9 / 92$ & $0: 41$ & 256 & 16.77 & 222 & 337 & 463 & 483 & 660379 & 928 & 763 & 50.5 & 24.8 & 63 & 80 & 80 & 1913 & 725266 \\
\hline GR-32C & $12 / 9 / 92$ & $1: 00$ & 16 & 13.83 & 154 & 238 & 465 & 485 & 636338 & 964 & 772 & 50.5 & 24.8 & 67 & 80 & 80 & 1906 & 675228 \\
\hline GR-32C; 3 Mills & $12 / 9 / 92$ & $0: 56$ & 12 & 14.31 & 136 & 247 & 468 & 488 & 658136 & 967 & 761 & 50.5 & 24.8 & 67 & 80 & 80 & 1910 & 690765 \\
\hline Base Cond. OFA off & $12 / 9 / 92$ & $0: 15$ & 13 & 14.65 & 270 & 305 & 472 & 492 & 698101 & 959 & 773 & 50.5 & 24.8 & 65 & 80 & 80 & 1921 & 746623 \\
\hline Base Cond. OFA off & $12 / 14 / 92$ & $2: 00$ & 64 & 15.24 & 309 & 319 & 495 & 515 & 1158182 & 947 & 774 & 50.5 & 24.9 & 41 & 80 & 80 & 1993 & 1050661 \\
\hline GA-12Z & $12 / 14 / 92$ & $1: 02$ & 314 & 15.24 & 226 & 294 & 504 & 524 & 1200000 & 955 & 782 & 50.5 & 24.8 & 44 & 80 & 80 & 2032 & 1174127 \\
\hline GR 2.7\% Gas & $12 / 14 / 92$ & $0: 17$ & 51 & 15.16 & 220 & 294 & 505 & 525 & 1200000 & 955 & 786 & 50.5 & 24.8 & 39 & 80 & 80 & 2031 & 1169444 \\
\hline Base Cond. OFA off & $12 / 15 / 92$ & $1: 37$ & 326 & 16.06 & 309 & 325 & 501 & 521 & 875993 & 928 & 766 & 50.5 & 24.7 & 46 & 80 & 80 & 2022 & 1149189 \\
\hline GR 20\% Gas & $12 / 15 / 92$ & $0: 36$ & 51 & 15.03 & 188 & 255 & 506 & 526 & 896641 & 985 & 780 & 50.5 & 24.6 & 50 & 80 & 80 & 2033 & 1147838 \\
\hline Baso Cond. OFA off & $12 / 16 / 92$ & $0: 48$ & 9 & 15.70 & 351 & 300 & 502 & 522 & 1100000 & 935 & 769 & 50.5 & 25.0 & 36 & 80 & 80 & 2028 & 1169592 \\
\hline GR.12A1 & $12 / 16 / 92$ & $2: 19$ & 71 & 15.29 & 205 & 276 & 506 & 526 & 1100000 & 952 & 781 & 50.5 & 24.9 & 39 & 80 & 80 & 2040 & 1191000 \\
\hline Test C1 & $1 / 15 / 93$ & $1: 00$ & 30 & 15.37 & 228 & 276 & 508 & 528 & 1150000 & 978 & 780 & 50.5 & 25.0 & 52 & 80 & 80 & 2036 & 1177213 \\
\hline Test C2 & $1 / 15 / 93$ & 1.00 & 17 & 15.23 & 201 & 268 & 509 & 529 & 1150000 & 991 & 779 & 50.5 & 25.0 & 61 & 80 & 80 & 2036 & 1160000 \\
\hline Test C3 & $1 / 15 / 93$ & 0.58 & 12 & 15.15 & 178 & 264 & 509 & 529 & 1150000 & 998 & 776 & 50.5 & 24.9 & 64 & 80 & 80 & 2036 & 1150000 \\
\hline Tost C4 & $1 / 15 / 93$ & $0: 50$ & 75 & 15.16 & 171 & 257 & 510 & 530 & 1150000 & 1000 & 773 & 50.5 & 24.9 & 64 & 80 & 80 & 2036 & 1142353 \\
\hline Tost B1 & $1 / 15 / 93$ & $0: 59$ & 41 & 15.69 & 253 & 316 & 506 & 526 & 1150000 & 951 & 775 & 50.5 & 25.0 & 64 & 80 & 80 & 2042 & 1199667 \\
\hline Tost B3 & $1 / 15 / 93$ & $1: 01$ & 132 & 16.23 & 251 & 329 & 506 & 526 & 1150000 & 950 & 775 & 50.5 & 25.0 & 62 & 80 & 80 & 2043 & 1200323 \\
\hline Base Cond. OFA off & $1 / 18 / 93$ & $0: 45$ & 9 & 16.44 & 371 & 323 & 511 & 530 & 1150000 & 981 & 778 & 50.5 & 25.0 & 36 & 80 & 80 & 2051 & 1219783 \\
\hline Test B5 & $1 / 18 / 93$ & 1.01 & 99 & 16.30 & 261 & 331 & 509 & 529 & 1150000 & 948 & 772 & 50.5 & 25.0 & 45 & 80 & 80 & 2052 & 1232097 \\
\hline Base Cond. OFA cooling & $1 / 19 / 93$ & $0: 39$ & 7 & 15.91 & 363 & 314 & 511 & 531 & 1150000 & 960 & 782 & 50.5 & 24.9 & 34 & 80 & 80 & 2045 & 1229500 \\
\hline GR-12R & $1 / 19 / 93$ & $1: 00$ & 18 & 15.00 & 234 & 283 & 509 & 529 & 1150000 & 939 & 778 & 50.5 & 24.9 & 34 & 80 & 80 & 2039 & 1211967 \\
\hline GR-13E & $1 / 19 / 93$ & $1: 00$ & 32 & 15.38 & 180 & 263 & 509 & 529 & 1150000 & 983 & 780 & 50.5 & 24.9 & 35 & 80 & 80 & 2025 & 1143443 \\
\hline GR-13C & $1 / 20 / 93$ & $1: 10$ & 27 & 15.33 & 193 & 269 & 511 & 531 & 1150000 & 990 & 783 & 50.5 & 24.9 & 59 & 80 & 80 & 2032 & 1167800 \\
\hline GR.12D & $1 / 20 / 93$ & 1.05 & 12 & 15.14 & 195 & 270 & 511 & 531 & 1150000 & 988 & 793 & 50.5 & 24.9 & 64 & 80 & 80 & 2031 & 1172097 \\
\hline GR-12E & $1 / 20 / 93$ & 0.59 & 55 & 15.74 & 210 & 303 & 509 & 529 & 1150000 & 979 & 793 & 50.5 & 24.9 & 64 & 80 & 80 & 2032 & 1182167 \\
\hline Base Cond. OFA off & $1 / 20 / 93$ & $0: 15$ & 97 & 17.02 & 333 & 340 & 507 & 527 & 1150000 & 963 & 783 & 50.5 & 24.9 & 64 & 80 & 80 & 2033 & 1203750 \\
\hline 150 MWn Max NOx Red & $1 / 21 / 93$ & $1: 05$ & 54 & 15.45 & 183 & 267 & 511 & 531 & 1150000 & 1003 & 766 & 50.5 & 25.0 & 66 & 80 & 80 & 2026 & 1137727 \\
\hline Base Cond. OFA cooling & $1 / 21 / 93$ & $1: 30$ & 19 & 16.58 & 332 & 331 & 506 & 526 & 1150000 & 961 & 783 & 50.5 & 25.1 & 66 & 80 & 80 & 2023 & 1181209 \\
\hline $120 \mathrm{MWn}$ Max NOx Red & $1 / 21 / 93$ & $1: 00$ & 13 & 15.08 & 156 & 248 & 489 & 509 & 843012 & 972 & 771 & 50.5 & 25.1 & 70 & 80 & 80 & 1950 & 906540 \\
\hline GR Emiron. \#1 & $1 / 25 / 93$ & $5: 10$ & 7 & 14.40 & 200 & 256 & 507 & 527 & 1030000 & 991 & 781 & 50.5 & 25.1 & 53 & 80 & 80 & 2003 & 1090129 \\
\hline Base Cond. OFA cooling & $1 / 26 / 93$ & $0: 55$ & 41 & 15.59 & 281 & 298 & 502 & 522 & 1030000 & 945 & 774 & 50.5 & 25.2 & 50 & 80 & 80 & 1995 & 1097143 \\
\hline GA Environ. Test *2 & $1 / 26 / 93$ & $5: 22$ & 21 & 14.95 & 186 & 268 & 505 & 525 & 1030000 & 987 & 777 & 50.5 & 25.2 & 65 & 80 & 80 & 1995 & 1069815 \\
\hline Environ. \#3 & $1 / 27 / 93$ & $5: 55$ & 30 & 14.79 & 208 & 260 & 512 & 532 & 1030000 & 998 & 795 & 50.5 & 25.0 & 66 & 80 & 80 & 2027 & 1159101 \\
\hline Environ. \#4 (No GA) & $1 / 27 / 93$ & $6: 00$ & 61 & 16.13 & 346 & 316 & 501 & 521 & 1030000 & 946 & 783 & 50.5 & 25.0 & 60 & 80 & 80 & 2004 & 1115616 \\
\hline
\end{tabular}


Cherokee Unit 3, Average Test [

Pre Modification

\begin{tabular}{|c|c|c|c|c|c|c|c|c|c|c|c|c|c|c|c|c|c|c|}
\hline Tost No & Date: & Dur: & paw & (co2 & Nox & $\begin{array}{l}\text { So2 } \\
\text { paw } \\
\text { ppm }\end{array}$ & $\begin{array}{l}\text { Econ } \\
\text { nury } 20 \\
\text { Deg F }\end{array}$ & $\begin{array}{l}\text { Econ } \\
\text { Wals out } \\
\text { Degf }\end{array}$ & 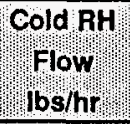 & $\begin{array}{l}\text { Hot: } \\
\text { Degh }\end{array}$ & 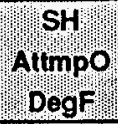 & "rel]") & $\begin{array}{l}\text { Amb } \\
\text { Press } \\
\text { Mros }\end{array}$ & Ampenp & $\begin{array}{l}\text { NG } \\
\text { Temp } \\
\text { Def }\end{array}$ & Coal & 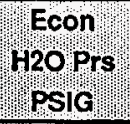 & Econ \\
\hline Environ. \#5 (No GR) & $1 / 28 / 93$ & $6: 04$ & 8 & 16.41 & 374 & 308 & 509 & 529 & 1030000 & 973 & 788 & 50.5 & 25.2 & 50 & 80 & 80 & 2036 & 1207233 \\
\hline Base Cond. & $2 / 2 / 93$ & $0: 17$ & 13 & 16.60 & 342 & & 505 & 525 & 1090010 & 955 & 772 & 50.5 & 25.0 & 57 & 80 & 80 & 2022 & 1189688 \\
\hline LNB 120MW \#1 & $3 / 8 / 93$ & $2: 00$ & 263 & 15.69 & 249 & 348 & 478 & 498 & 845008 & 875 & 739 & 50.5 & 25.1 & 72 & 80 & 80 & 2002 & 965239 \\
\hline LNB 120MW \#2 & $3 / 8 / 93$ & 2.00 & 327 & 15.81 & 238 & 353 & 479 & 499 & 845008 & 889 & 750 & 50.5 & 25.0 & 80 & 80 & 80 & 1999 & 957829 \\
\hline LN8 150MW :1 & $3 / 9 / 93$ & 2.00 & 9 & 15.51 & 371 & 325 & 505 & 525 & 1150000 & 950 & 787 & 50.5 & 25.0 & 71 & 80 & 80 & 2076 & 1235372 \\
\hline LNB $150 \mathrm{MW} \# 2$ & $3 / 9 / 93$ & $2: 00$ & 34 & 16.05 & 335 & 336 & 502 & 522 & 1150000 & 920 & 770 & 50.5 & 25.0 & 73 & 80 & 80 & 2057 & 1232308 \\
\hline LNB 9OMW \#1 & $3 / 10 / 93$ & $2: 00$ & 29 & 14.57 & 306 & 283 & 456 & 476 & 649998 & 843 & 734 & 50.5 & 25.2 & 49 & 80 & 80 & 1907 & 744413 \\
\hline LNB 90MW *2 & $3 / 10 / 93$ & $1: 58$ & 63 & 14.96 & 299 & 288 & 456 & 476 & 649998 & 854 & 738 & 50.5 & 25.2 & 49 & 80 & 80 & 1912 & 743794 \\
\hline LNB $150 \mathrm{MW}$ *3 & $3 / 11 / 93$ & $2: 00$ & 16 & 15.89 & 348 & 295 & 503 & 523 & 1150000 & 956 & 787 & 50.5 & 25.1 & 41 & 80 & 80 & 2063 & 1194545 \\
\hline LNB $150 M W * 4$ & $3 / 11 / 93$ & $2: 00$ & 61 & 16.29 & 327 & 298 & 504 & 524 & 1150000 & 944 & 779 & 50.5 & 25.1 & 43 & 80 & 80 & 2060 & 1215620 \\
\hline $3 M_{1}$ & $3 / 22 / 93$ & $1: 02$ & 162 & 16.05 & 154 & 288 & 501 & 521 & 917092 & 909 & 756 & 50.5 & 25.1 & 65 & 80 & 80 & 2057 & 1202540 \\
\hline $3 M 2$ & $3 / 22 / 93$ & $1: 03$ & 150 & 16.22 & 156 & 283 & 501 & 521 & 910551 & 918 & 760 & 50.5 & 25.1 & 68 & 80 & 80 & 2049 & 1191563 \\
\hline $3 M 3$ & $3 / 22 / 93$ & 0.59 & 16 & 15.64 & 182 & 273 & 502 & 522 & 908560 & 935 & 773 & 50.5 & 25.1 & 69 & 80 & 80 & 2050 & 1187000 \\
\hline 3 Mill 7 & $4 / 13 / 93$ & 1.00 & 101 & 16.23 & 224 & 340 & 479 & 499 & 739351 & 858 & 734 & 50.5 & 24.8 & 63 & 80 & 80 & 1961 & 947076 \\
\hline 3 Mill 6 & $4 / 13 / 93$ & 1.00 & 281 & 16.75 & 211 & 356 & 480 & 500 & 744881 & 865 & 735 & 50.5 & 24.8 & 64 & 80 & 80 & 1966 & 958825 \\
\hline Lovel 6 1/2 & $4 / 15 / 93$ & $2: 05$ & 177 & 16.16 & 295 & 322 & 501 & 521 & 896884 & 921 & 764 & 50.5 & 25.0 & 51 & 80 & 80 & 2059 & 1170397 \\
\hline Lovel 4 & $4 / 15 / 93$ & $1: 10$ & 145 & 16.09 & 295 & 321 & 501 & 521 & 897005 & 920 & 764 & 50.5 & 25.0 & 51 & 80 & 80 & 2059 & 1170000 \\
\hline Level 3 & $4 / 15 / 93$ & $0: 53$ & 224 & 16.13 & 294 & 317 & 502 & 522 & 897065 & 923 & 765 & 50.5 & 25.0 & 53 & 80 & 80 & 2061 & 1170926 \\
\hline Level 5 1/2 & $4 / 15 / 93$ & $1: 58$ & 233 & 16.48 & 287 & 323 & 501 & 521 & 900446 & 914 & 763 & 50.5 & 24.9 & 60 & 80 & 80 & 2061 & 1175882 \\
\hline Base Cond & $4 / 15 / 93$ & $5: 25$ & 232 & 16.32 & 290 & 322 & 501 & 521 & 898146 & 919 & 764 & 50.5 & 25.0 & 55 & 80 & 80 & 2060 & 1172638 \\
\hline Lovel 5 1/2 & $4 / 16 / 93$ & $1: 47$ & 72 & 15.78 & 353 & 313 & 505 & 525 & 906870 & 949 & 788 & 50.5 & 24.9 & 59 & 80 & 80 & 2061 & 1181398 \\
\hline Lovel 6 1/2 & $4 / 16 / 93$ & $1: 19$ & 8 & 15.93 & 344 & 324 & 505 & 525 & 912032 & 941 & 784 & 50.5 & 24.9 & 66 & 80 & 80 & 2060 & 1190750 \\
\hline Level 3 & $4 / 16 / 93$ & $0: 44$ & 7 & 15.78 & 346 & 327 & 505 & 525 & 911503 & 943 & 786 & 50.5 & 24.9 & 69 & 80 & 80 & 2057 & 1191556 \\
\hline Level 4 & $4 / 16 / 93$ & $1: 00$ & 7 & 15.79 & 346 & 328 & 505 & 525 & 912350 & 944 & 786 & 50.5 & 24.9 & 69 & 80 & 80 & 2059 & 1191311 \\
\hline North out, South in & $4 / 16 / 93$ & $0: 20$ & 290 & 15.07 & 367 & 298 & 505 & 525 & 905155 & 951 & 789 & 50.5 & 24.9 & 59 & 80 & 80 & 2057 & 1179048 \\
\hline South out. North in & $4 / 16 / 93$ & $0: 20$ & 9 & 16.02 & 341 & 323 & 505 & 525 & 905330 & 949 & 788 & 50.5 & 24.9 & 61 & 80 & 80 & 2055 & 1177143 \\
\hline Base Cond & $4 / 16 / 93$ & $6: 25$ & 38 & 15.81 & 346 & 322 & 505 & 525 & 910902 & 944 & 785 & 50.5 & 24.9 & 65 & 80 & 80 & 2060 & 1188329 \\
\hline Lovel 4 & $4 / 19 / 93$ & $0: 56$ & 58 & 15.14 & 211 & 371 & 509 & 529 & 897676 & 988 & 786 & 50.5 & 24.8 & 63 & 80 & 80 & 2052 & 1149825 \\
\hline Level 3 & $4 / 19 / 93$ & $0: 52$ & 56 & 15.15 & 211 & 371 & 509 & 529 & 897370 & 988 & 786 & 50.5 & 24.8 & 63 & 80 & 80 & 2051 & 1148679 \\
\hline Level $51 / 2$ & $4 / 19 / 93$ & $2: 29$ & 8 & 14.71 & 221 & 347 & 510 & 530 & 892484 & 995 & 788 & 50.5 & 24.9 & 64 & 80 & 80 & 2051 & 1132267 \\
\hline Level 6 1/2 & $4 / 19 / 93$ & $1: 10$ & 8 & 14.72 & 229 & 356 & 511 & 531 & 893750 & 998 & 791 & 50.5 & 24.9 & 63 & 80 & 80 & 2053 & 1130000 \\
\hline Base Cond. OFA on & $4 / 19 / 93$ & $1: 00$ & 14 & 14.74 & 289 & 406 & 505 & 525 & 898922 & 929 & 776 & 50.5 & 24.8 & 60 & 80 & 80 & 2042 & 1174426 \\
\hline GR & $4 / 19 / 93$ & $5: 42$ & 12 & 14.79 & 220 & 353 & 510 & 530 & 892305 & 995 & 788 & 50.5 & 24.9 & 64 & 80 & 80 & 2051 & 1132678 \\
\hline Lovel $61 / 2$ & $4 / 20 / 93$ & $1: 47$ & 67 & 16.43 & 254 & 399 & 492 & 512 & 819065 & 876 & 743 & 50.5 & 25.2 & 49 & 80 & 80 & 2003 & 1063426 \\
\hline Base Cond 130MW & $4 / 20 / 93$ & $3: 35$ & 112 & 16.49 & 248 & 408 & 491 & 511 & 818653 & 876 & 743 & 50.5 & 25.2 & 51 & 80 & 80 & 2002 & 1062500 \\
\hline Base Cond $120 \mathrm{MW}$ & $4 / 20 / 93$ & $2: 55$ & 62 & 15.16 & 268 & 392 & 486 & 506 & 736009 & 951 & 767 & 50.5 & 25.2 & 61 & 80 & 80 & 1973 & 929630 \\
\hline Base Cond. OFA off & $4 / 21 / 93$ & $7: 40$ & 363 & 15.48 & 256 & 452 & 482 & 502 & 717584 & 927 & 759 & 50.5 & 25.2 & 65 & 80 & 80 & 1959 & 907662 \\
\hline Base Cond. OFA off & $4 / 23 / 93$ & $0: 30$ & 17 & 16.35 & 337 & 344 & 505 & 525 & 902553 & 961 & 783 & 50.5 & 24.7 & 81 & 80 & 80 & 2045 & 1175484 \\
\hline 4M+2 (OFA off) & $4 / 23 / 93$ & $1: 00$ & 6 & 16.02 & 301 & 297 & 502 & 522 & 914437 & 915 & 761 & 50.5 & 24.7 & 80 & 80 & 80 & 2054 & 1195574 \\
\hline $4 \mathrm{M} 13 \mathrm{a}(78,000 \mathrm{scfm}$ OFd & $4 / 23 / 93$ & $0: 20$ & 49 & 15.10 & 186 & 280 & 502 & 522 & 943441 & 878 & 751 & 50.5 & 24.7 & 81 & 80 & 80 & 2062 & 1247143 \\
\hline
\end{tabular}


Cherokee Unit 3, Average Test [

Pre Modification

\begin{tabular}{|c|c|c|c|c|c|c|c|c|c|c|c|c|c|c|c|c|c|c|}
\hline Test' & 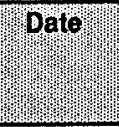 & Durd & ppop & (co2) & nox & so2! & 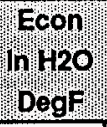 & $\begin{array}{l}\text { Econ } \\
\text { Wal out } \\
\text { peg }\end{array}$ & 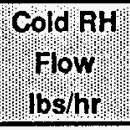 & 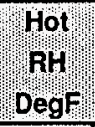 & $\begin{array}{l}\text { SHHYW } \\
\text { Atrompo } \\
\text { Dog }\end{array}$ & 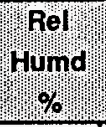 & Pamb & $\begin{array}{l}\text { Amb } \\
\text { Demp } \\
\text { Deg }\end{array}$ & Derge & $\begin{array}{l}\text { coal!" } \\
\text { Temp: } \\
\text { Deg] }\end{array}$ & $\begin{array}{l}\text { Econ } \\
\text { } 2 \text { OPrs } \\
\text { psig. }\end{array}$ & Econ \\
\hline $4 \mathrm{M} 13 \mathrm{~b}(70,000$ sefm OFA & $4 / 23 / 93$ & $0: 50$ & 32 & 15.04 & 205 & 274 & 502 & 522 & 949171 & 864 & 750 & 50.5 & 24.7 & 83 & 80 & 80 & 2071 & 1252692 \\
\hline Base Cond. OFA On & $4 / 27 / 93$ & $0: 30$ & 10 & 14.91 & 347 & 305 & 507 & 527 & 913394 & 970 & 785 & 50.5 & 25.1 & 66 & 80 & 80 & 2061 & 1193548 \\
\hline GR on $150 M W, 11 \%$ Gas & $4 / 27 / 93$ & $0: 53$ & 24 & 15.20 & 253 & 283 & 506 & 526 & 904519 & 988 & 785 & 50.5 & 25.1 & 67 & 80 & 80 & 2043 & 1179444 \\
\hline GA on $150 M W, 17 \%$ Gas & $4 / 27 / 93$ & $2: 48$ & 38 & 15.17 & 207 & 270 & 507 & 527 & 906973 & 986 & 790 & 50.5 & 25.0 & 74 & 80 & 80 & 2036 & 1167353 \\
\hline Base Cond. OFA on & $4 / 28 / 93$ & $0: 44$ & 9 & 14.88 & 317 & 300 & 499 & 519 & 856414 & 932 & 771 & 50.5 & 25.1 & 66 & 80 & 80 & 2025 & 1117778 \\
\hline GR on Auto & $4 / 28 / 93$ & $6: 35$ & 5 & 15.15 & 183 & 273 & 499 & 519 & 831638 & 976 & 784 & 50.5 & 25.1 & 76 & 80 & 80 & 2005 & 1063636 \\
\hline GR on Auto & $5 / 3 / 93$ & $7: 00$ & 7 & 14.47 & 207 & 268 & 502 & 522 & 860313 & 980 & 791 & 50.5 & 24.9 & 81 & 80 & 80 & 2055 & 1112167 \\
\hline Base Cond. OFA on & $5 / 6 / 93$ & $2: 45$ & 28 & 14.78 & 308 & 316 & 496 & 516 & 860901 & 900 & 762 & 50.5 & 24.8 & 72 & 80 & 80 & 2050 & 1141386 \\
\hline GR on Auto & $5 / 6 / 93$ & $1: 15$ & 19 & 14.91 & 194 & 277 & 500 & 520 & 851644 & 950 & 788 & 50.5 & 24.8 & 78 & 80 & 80 & 2066 & 1115526 \\
\hline Base Cond. OFA off & $5 / 6 / 93$ & $0: 21$ & 711 & 15.08 & 269 & 315 & 486 & 506 & 730814 & 943 & 763 & 50.5 & 24.8 & 80 & 80 & 80 & 1944 & 942245 \\
\hline GR on Auto $150 \mathrm{MW}$ & $5 / 7 / 93$ & $4: 26$ & 11 & 14.93 & 188 & 302 & 502 & 522 & 894600 & 956 & 780 & 50.5 & 24.7 & 74 & 80 & 80 & 2072 & 1183209 \\
\hline GR on Auto $160 \mathrm{MW}$ & $5 / 7 / 93$ & 1.59 & 7 & 15.15 & 202 & 315 & 509 & 529 & 955102 & 976 & 790 & 50.5 & 24.7 & 80 & 80 & 80 & 2104 & 1275667 \\
\hline GR on Auto 140MW & $5 / 7 / 93$ & $4: 50$ & 7 & 14.50 & 195 & 318 & 498 & 518 & 837812 & 968 & 785 & 50.5 & 24.7 & 67 & 80 & 80 & 2041 & 1097589 \\
\hline Base Cond. OFA off & $5 / 7 / 93$ & $0: 35$ & 7 & 14.87 & 365 & 331 & 500 & 520 & 875041 & 954 & 780 & 50.5 & 24.7 & 66 & 80 & 80 & 2051 & 1157778 \\
\hline GR on Auto & $5 / 11 / 93$ & $6: 08$ & 6 & 13.91 & 187 & 267 & 499 & 519 & 825740 & 976 & 788 & 50.5 & 25.3 & 72 & 80 & 80 & 2018 & 1050617 \\
\hline GR 13 & $5 / 25 / 93$ & $15: 04$ & 7 & 14.84 & 197 & 281 & 505 & 525 & 890012 & 985 & 789 & 50.5 & 25.2 & 70 & 80 & 80 & 2029 & 1124878 \\
\hline GR 14 & $5 / 25 / 93$ & $1: 25$ & 4 & 13.64 & 198 & 262 & 474 & 494 & 651233 & 922 & 772 & 50.5 & 25.2 & 73 & 80 & 80 & 1932 & 794645 \\
\hline GR 15 & $5 / 26 / 93$ & $1: 29$ & 5 & 13.61 & 183 & 261 & 477 & 497 & 679763 & 932 & 774 & 50.5 & 25.1 & 71 & 80 & 80 & 1944 & 832471 \\
\hline LNB-OFA & $5 / 26 / 93$ & $0: 42$ & 20 & 12.94 & 228 & 280 & 461 & 481 & 590620 & 882 & 747 & 50.5 & 25.1 & 70 & 80 & 80 & 1904 & 711114 \\
\hline LNB & $5 / 26 / 93$ & $9: 44$ & 157 & 16.02 & 294 & 345 & 494 & 514 & 872218 & 913 & 756 & 50.5 & 25.1 & 73 & 80 & 80 & 2035 & 1102654 \\
\hline LNB & $5 / 27 / 93$ & $0: 10$ & 310 & 15.63 & 248 & 339 & 477 & 497 & 719552 & 918 & 761 & 50.5 & 25.0 & 82 & 80 & 80 & 1939 & 866804 \\
\hline LNB-OFA & $5 / 27 / 93$ & $0: 45$ & 34 & 15.10 & 293 & 334 & 504 & 525 & 922635 & 950 & 784 & 50.5 & 25.0 & 85 & 80 & 80 & 2049 & 1171087 \\
\hline GR-LNB 16 & $5 / 27 / 93$ & $13: 40$ & 6 & 14.64 & 207 & 281 & 503 & 523 & 883820 & 982 & 791 & 50.5 & 25.0 & 84 & 80 & 80 & 2036 & 1105230 \\
\hline GR-LNB 17 & $5 / 28 / 93$ & $2: 57$ & 5 & 13.32 & 190 & 258 & 478 & 498 & 682029 & 928. & 772 & 50.5 & 25.0 & 75 & 80 & 80 & 1938 & 837593 \\
\hline LNB & $5 / 28 / 93$ & $1: 23$ & 8 & 13.50 & 249 & 288 & 455 & 475 & 556886 & 878 & 746 & 50.5 & 25.0 & 75 & 80 & 80 & 1902 & 667571 \\
\hline GR-LNB 206 & $6 / 3 / 93$ & $8: 51$ & 18 & 15.96 & 173 & 296 & 501 & 521 & 873118 & 974 & 773 & 50.5 & 24.9 & 73 & 80 & 80 & 2022 & 1084260 \\
\hline LNB & $6 / 3 / 93$ & 1.05 & 26 & 14.68 & 293 & 307 & 462 & 482 & 604599 & 895 & 753 & 50.5 & 25.0 & 70 & 80 & 80 & 1929 & 727079 \\
\hline LNB (low load) & $6 / 4 / 93$ & 6.52 & 15 & 14.09 & 301 & 300 & 458 & 478 & 573344 & 891 & 745 & 50.5 & 25.0 & 67 & 80 & 80 & 1914 & 690770 \\
\hline LNB (high load) & $6 / 4 / 93$ & $5: 25$ & 14 & 16.20 & 320 & 344 & 502 & 522 & 923027 & 927 & 769 & 50.5 & 25.1 & 60 & 80 & 80 & 2069 & 1174094 \\
\hline LNB-OFA & $6 / 4 / 93$ & $2: 31$ & 90 & 15.51 & 262 & 337 & 503 & 523 & 973283 & 893 & 749 & 50.5 & 25.0 & 71 & 80 & 80 & 2073 & 1250544 \\
\hline GR-LNB & $6 / 4 / 93$ & $7: 42$ & 37 & 15.67 & 175 & 300 & 503 & 523 & 899583 & 976 & 776 & 50.5 & 24.9 & 74 & 80 & 80 & 2033 & 1122824 \\
\hline LNB & $6 / 8 / 93$ & $1: 35$ & 32 & 15.21 & 307 & 323 & 496 & 516 & 872973 & 918 & 771 & 50.5 & 24.8 & 77 & 80 & 80 & 2038 & 1111354 \\
\hline LNB-OFA & $6 / 8 / 93$ & $1: 40$ & 122 & 14.97 & 279 & 334 & 497 & 517 & 880816 & 910 & 769 & 50.5 & 24.8 & 78 & 80 & 80 & 2032 & 1122277 \\
\hline GR-LNB 22a & $6 / 8 / 93$ & $6: 21$ & 15 & 14.44 & 180 & 283 & 496 & 516 & 820143 & 963 & 787 & 50.5 & 24.9 & 80 & 80 & 80 & 2005 & 1023977 \\
\hline GR-LNB 220 & $6 / 8 / 93$ & $5: 30$ & 87 & 16.03 & 167 & 305 & 503 & 523 & 897541 & 982 & 777 & 50.5 & 24.9 & 77 & 80 & 80 & 2034 & 1122266 \\
\hline GR-LNB 23a & $6 / 9 / 93$ & $1: 16$ & 48 & 15.56 & 151 & 295 & 480 & 500 & 700903 & 951 & 754 & 50.5 & 25.1 & 69 & 80 & 80 & 1953 & 849520 \\
\hline LNB-OFA & $6 / 9 / 93$ & $0: 30$ & 51 & 14.42 & 157 & 307 & 459 & 478 & 548749 & 900 & 740 & 50.5 & 25.1 & 71 & 80 & 80 & 1898 & 665477 \\
\hline LNB & $6 / 9 / 93$ & $16: 03$ & 95 & 15.47 & 267 & 327 & 479 & 499 & 741448 & 899 & 754 & 50.5 & 25.1 & 75 & 80 & 80 & 1972 & 926623 \\
\hline GR.LNB 23b & $6 / 9 / 93$ & $4: 28$ & 6 & 14.42 & 208 & 276 & 499 & 519 & 845506 & 970 & 790 & 50.5 & 25.1 & 79 & 80 & 80 & 2009 & 1060322 \\
\hline LNB & $6 / 10 / 93$ & $8: 47$ & 477 & 15.80 & 220 & 335 & 478 & 499 & 721156 & 917 & 756 & 50.5 & 25.1 & 71 & 80 & 80 & 1970 & 890153 \\
\hline
\end{tabular}


Cherokee Unit 3, Average Test $\mathrm{C}$

Pre Modiflcation

\begin{tabular}{|c|c|c|c|c|c|c|c|c|c|c|c|c|c|c|c|c|c|c|}
\hline Nost & Datr & 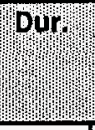 & raw & $\begin{array}{l}\text { cos } \\
\text { ray } \\
\text { \% }\end{array}$ & Nox" & so2! & 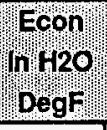 & 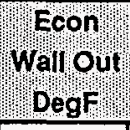 & cold AH & $\begin{array}{l}\text { Hot } \\
\text { Deg } \\
\text { Deg }\end{array}$ & 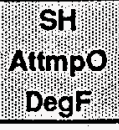 & nomp & "amb & Amb & $\begin{array}{l}\text { Na } \\
\text { Temp? } \\
\text { Def? }\end{array}$ & 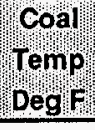 & Creon & Econ \\
\hline LNB-OFA & $6 / 10 / 93$ & $1: 16$ & 31 & 15.21 & 258 & 324 & 504 & 524 & 938467 & 923 & 775 & 50.5 & 25.2 & 77 & 80 & 80 & 2063 & 1197273 \\
\hline GR-LNB 24 & $6 / 10 / 93$ & $2: 57$ & 10 & 14.34 & 209 & 282 & 506 & 526 & 901521 & 978 & 797 & 50.5 & 25.1 & 84 & 80 & 80 & 2041 & 1126527 \\
\hline LNB & $6 / 10 / 93$ & $0: 37$ & 9 & 15.62 & 348 & 357 & 503 & 523 & 950099 & 919 & 759 & 50.5 & 25.1 & 89 & 80 & 80 & 2077 & 1210000 \\
\hline GR-LNB 25a & $6 / 11 / 93$ & $5: 28$ & 17 & 14.81 & 183 & 320 & 495 & 515 & 817068 & 969 & 776 & 50.5 & 24.9 & 91 & 80 & 80 & 2019 & 1002441 \\
\hline GR-LNB 25b & $6 / 11 / 93$ & $9: 06$ & 14 & 14.87 & 198 & 327 & 505 & 525 & 904153 & 984 & 780 & 50.5 & 24.9 & 94 & 80 & 80 & 2065 & 1123265 \\
\hline GR-LNB 26a & $6 / 12 / 93$ & 11:22 & 44 & 15.32 & 175 & 328 & 497 & 517 & 832651 & 974 & 773 & 50.5 & 25.0 & 89 & 80 & 80 & 2020 & 1016721 \\
\hline GR-LNB 26b & $6 / 12 / 93$ & $2: 13$ & 28 & 13.76 & 223 & 306 & 462 & 482 & 570488 & 915 & 763 & 50.5 & 25.0 & 79 & 80 & 80 & 1917 & 686907 \\
\hline LNB-OFA & $6 / 12 / 93$ & $7: 11$ & 755 & 15.93 & 257 & 383 & 494 & 514 & 867137 & 925 & 755 & 50.5 & 25.0 & 96 & 80 & 80 & 2018 & 1091225 \\
\hline LNB-OFA & $6 / 13 / 93$ & $9: 43$ & 119 & 13.82 & 330 & 323 & 448 & 468 & 528734 & 843 & 731 & 50.5 & 25.1 & 79 & 80 & 80 & 1885 & 632203 \\
\hline GR-LNB 28 & $6 / 14 / 93$ & $4: 06$ & 28 & 15.79 & 185 & 322 & 506 & 526 & 920485 & 977 & 783 & 50.5 & 25.1 & 94 & 80 & 80 & 2050 & 1156883 \\
\hline LNB & $6 / 14 / 93$ & $1: 59$ & 341 & 15.98 & 253 & 365 & 491 & 510 & 829895 & 894 & 745 & 50.5 & 25.1 & 89 & 80 & 80 & 2007 & 1048433 \\
\hline LNB & $6 / 18 / 93$ & $0: 38$ & 26 & 16.47 & 303 & 353 & 495 & 515 & 829648 & 978 & 773 & 50.5 & 25.2 & 63 & 80 & 80 & 2036 & 1008632 \\
\hline GP-LNB 29 & $6 / 18 / 93$ & $14: 24$ & 8 & 15.11 & 188 & 308 & 503 & 523 & 874443 & 992 & 771 & 50.5 & 25.2 & 68 & 80 & 80 & 2027 & 1065390 \\
\hline GR-LNB 30a & $6 / 19 / 93$ & $0: 30$ & 3 & 13.51 & 213 & 280 & 479 & 499 & 644654 & 966 & 771 & 50.5 & 25.2 & 67 & 80 & 80 & 1903 & 764250 \\
\hline LNB & $6 / 19 / 93$ & $9: 15$ & 239 & 14.66 & 354 & 342 & 456 & 476 & 547037 & 920 & 751 & 50.5 & 25.2 & 71 & 80 & 80 & 1892 & 646084 \\
\hline GR-LNB 306 & $6 / 19 / 93$ & $11: 53$ & 59 & 15.85 & 162 & 325 & 505 & 525 & 884859 & 997 & 755 & 50.5 & 25.1 & 85 & 80 & 80 & 2037 & 1059484 \\
\hline GR-LNB $30 c$ & $6 / 19 / 93$ & $1: 33$ & 5 & 14.31 & 184 & 290 & 473 & 493 & 614874 & 957 & 768 & 50.5 & 25.2 & 84 & 80 & 80 & 1949 & 737235 \\
\hline GP-LNB 23 & $6 / 23 / 93$ & $7: 35$ & 35 & 15.76 & 165 & 317 & 506 & 526 & 919235 & 987 & 772 & 50.5 & 24.8 & 90 & 80 & 80 & 2029 & 1133311 \\
\hline GR-LNB 326 & $6 / 23 / 93$ & $1: 09$ & 18 & 15.26 & 166 & 281 & 494 & 514 & 790735 & 970 & 771 & 50.5 & 24.9 & 80 & 80 & 80 & 1970 & 970630 \\
\hline LNB-OFA cooling & $6 / 24 / 93$ & $6: 25$ & 151 & 15.32 & 305 & 346 & 456 & 476 & 547641 & 898 & 749 & 50.5 & 25.1 & 71 & 80 & 80 & 1903 & 647867 \\
\hline GR-LNB 33a & $6 / 24 / 93$ & $6: 00$ & 6 & 15.28 & 181 & 335 & 489 & 509 & 760134 & 970 & 767 & 50.5 & 25.1 & 83 & 80 & 80 & 1998 & 914695 \\
\hline GR-LNB 33 & $6 / 24 / 93$ & $11: 22$ & 12 & 15.80 & 176 & 336 & 505 & 525 & 902696 & 987 & 769 & 50.5 & 25.1 & 83 & 80 & 80 & 2045 & 1109437 \\
\hline GR-LNB 34a & $6 / 25 / 93$ & $1: 52$ & 3 & 13.43 & 281 & 298 & 460 & 479 & 537754 & 922 & 767 & 50.5 & 25.2 & 78 & 80 & 80 & 1897 & 632393 \\
\hline LNB-OFA & $6 / 25 / 93$ & 4.03 & 37 & 14.04 & 301 & 331 & 453 & 473 & 545712 & 847 & 732 & 50.5 & 25.2 & 72 & 80 & 80 & 1885 & 648434 \\
\hline GR-LNB 34 & $6 / 25 / 93$ & $8: 00$ & 17 & 15.74 & 175 & 349 & 500 & 520 & 867914 & 966 & 773 & 50.5 & 25.2 & 77 & 80 & 80 & 2046 & 1066600 \\
\hline LNB (some OFA) & $6 / 28 / 93$ & $1: 03$ & 72 & 16.45 & 313 & 357 & 505 & 525 & 936878 & 959 & 770 & 50.5 & 24.9 & 96 & 80 & 80 & 2059 & 1185469 \\
\hline LNB (some OFA) & $6 / 29 / 93$ & $12: 15$ & 415 & 16.43 & 279 & 376 & 489 & 509 & 806771 & 924 & 753 & 50.5 & 24.8 & 102 & 80 & 80 & 1980 & 1002311 \\
\hline LNB & $6 / 30 / 93$ & $11: 51$ & 405 & 16.18 & 265 & 367 & 481 & 501 & 737768 & 943 & 761 & 50.5 & 25.0 & 83 & 80 & 80 & 1977 & 905836 \\
\hline GR-LNB 35 & $6 / 30 / 93$ & $1: 48$ & 46 & 15.09 & 184 & 312 & 508 & 528 & 926725 & 994 & 781 & 50.5 & 25.0 & 91 & 80 & 80 & 2047 & 1155138 \\
\hline GR-LNB 35a & $6 / 30 / 93$ & 6.05 & 4 & 14.30 & 207 & 292 & 509 & 529 & 918051 & 996 & 785 & 50.5 & 25.0 & 93 & 80 & 80 & 2041 & 1134344 \\
\hline GR-LNB 35b & $6 / 30 / 93$ & $1: 53$ & 4 & 13.61 & 203 & 267 & 499 & 519 & 821865 & 984 & 787 & 50.5 & 25.0 & 87 & 80 & 80 & 1989 & 1003674 \\
\hline GA-OLNB 36a & $7 / 1 / 93$ & $8: 22$ & 15 & 12.56 & 223 & 260 & 464 & 484 & 583597 & 913 & 760 & 50.5 & 25.0 & 83 & 80 & 80 & 1919 & 692337 \\
\hline GR-LNB 36 & $7 / 1 / 93$ & $15: 37$ & 79 & 15.14 & 170 & 313 & 503 & 523 & 883595 & 985 & 765 & 50.5 & 24.9 & 95 & 80 & 80 & 2028 & 1078611 \\
\hline GR 37a & $7 / 2 / 93$ & $14: 55$ & 426 & 14.36 & 164 & 298 & 484 & 504 & 729430 & 958 & 746 & 50.5 & 24.8 & 95 & 80 & 80 & 1954 & 869968 \\
\hline GR 37 & $7 / 2 / 93$ & $7: 05$ & 43 & 15.06 & 180 & 317 & 509 & 529 & 933226 & 996 & 770 & 50.5 & 24.9 & 96 & 80 & 80 & 2038 & 1152749 \\
\hline GR-LNB 38 & $7 / 3 / 93$ & $7: 46$ & 87 & 14.99 & 167 & 313 & 507 & 527 & 913864 & 993 & 752 & 50.5 & 24.6 & 98 & 80 & 80 & 2037 & 1099083 \\
\hline GR-LNB 38a & $7 / 3 / 93$ & $8: 43$ & 37 & 13.17 & 153 & 262 & 504 & 524 & 886851 & 994 & 763 & 50.5 & 24.7 & 90 & 80 & 80 & 2021 & 1078573 \\
\hline GR-LNB 39a & $7 / 4 / 93$ & $17: 27$ & 16 & 11.68 & 142 & 253 & 478 & 498 & 686497 & 949 & 756 & 50.5 & 24.8 & 79 & 80 & 80 & 1928 & 823572 \\
\hline GR-LNB 39 & $7 / 4 / 93$ & $6: 33$ & 9 & 12.60 & 149 & 267 & 506 & 526 & 906893 & 994 & 769 & 50.5 & 24.8 & 84 & 80 & 80 & 2039 & 1116149 \\
\hline GR-LNB 40a & $7 / 5 / 93$ & 11:52 & 5 & 10.62 & 145 & 234 & 467 & 487 & 607726 & 933 & 754 & 50.5 & 24.9 & 79 & 80 & 80 & 1897 & 724089 \\
\hline
\end{tabular}


Cherokee Unit 3, Average Test $\mathrm{C}$

Pre Modification

\begin{tabular}{|c|c|c|c|c|c|c|c|c|c|c|c|c|c|c|c|c|c|c|}
\hline ress & Datepty & Durn & rapl & ro.2: & pox & $\begin{array}{l}\text { so2 } \\
\text { raw } \\
\text { ppmp }\end{array}$ & $\begin{array}{l}\text { Econ } \\
\text { WH2O } \\
\text { DegF }\end{array}$ & 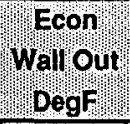 & Cold RH & $\begin{array}{l}\text { Hot } \\
\text { pert } \\
\text { pegr }\end{array}$ & 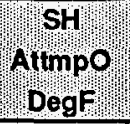 & 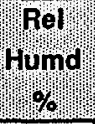 & Prop & $\begin{array}{l}\text { amb! } \\
\text { Demp } \\
\text { Deg }\end{array}$ & 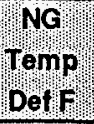 & $\begin{array}{l}\text { Coal } \\
\text { Temp } \\
\text { Degl }\end{array}$ & 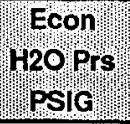 & ¿दcon \\
\hline GR-LNB 40 & $7 / 5 / 93$ & $12: 08$ & 4 & 11.63 & 136 & 253 & 501 & 521 & 867106 & 983 & 767 & 50.5 & 24.9 & 88 & 80 & 80 & 2013 & 1062573 \\
\hline GR-LNB 52a & $7 / 17193$ & $8: 31$ & & 13.44 & 172 & 272 & 469 & 489 & 638795 & 909 & 753 & 50.5 & 25.1 & 81 & 80 & 80 & 1922 & 772233 \\
\hline GR-LNB 52 & $7 / 17 / 93$ & $5: 45$ & & 14.95 & 177 & 302 & 503 & 523 & 884308 & 993 & 765 & 50.5 & 25.2 & 76 & 80 & 80 & 2009 & 1071428 \\
\hline LNB & $7 / 19 / 93$ & $1: 53$ & & 15.98 & 204 & 365 & 479 & 499 & 712207 & 938 & 762 & 50.5 & 25.2 & 85 & 80 & 80 & 1957 & 885393 \\
\hline LNB-OFA & $7 / 19 / 93$ & $0: 22$ & & 15.75 & 197 & 368 & 482 & 502 & 751461 & 918 & 747 & 50.5 & 25.2 & 86 & 80 & 80 & 1958 & 940635 \\
\hline GR-LNB 53a & $7 / 19 / 93$ & $3: 29$ & & 14.98 & 168 & 302 & 486 & 506 & 741326 & 976 & 761 & 50.5 & 25.1 & 85 & 80 & 80 & 1960 & 906746 \\
\hline GR-LNB 53 & $7 / 19 / 93$ & $7: 06$ & & 15.04 & 188 & 300 & 505 & 525 & 912719 & 997 & 775 & 50.5 & 25.1 & 90 & 80 & 80 & 2030 & 1135691 \\
\hline LNB & $7 / 21 / 93$ & $8: 34$ & & 14.79 & 316 & 316 & 447 & 467 & 515482 & 869 & 736 & 50.5 & 25.0 & 85 & 80 & 80 & 1900 & 616574 \\
\hline GR-LNB 54 & $7 / 21 / 93$ & $4: 52$ & & 15.21 & 186 & 296 & 503 & 523 & 878017 & 985 & 785 & 50.5 & 24.9 & 91 & 80 & 80 & 2022 & 1085269 \\
\hline LNB & $7 / 23 / 93$ & $2: 35$ & 49 & 15.35 & 276 & 330 & 487 & 508 & 589773 & 949 & 773 & 50.5 & 25.0 & 86 & 80 & 80 & 1887 & 775029 \\
\hline GR-LNB 55 & $7 / 23 / 93$ & $4: 53$ & 7 & 14.39 & 194. & 311 & 503 & 523 & 883503 & 992 & 782 & 50.5 & 24.9 & 92 & 80 & 80 & 2050 & 1098871 \\
\hline GR-LNB 55a & $7 / 23 / 93$ & 1.08 & 9 & 14.12 & 175 & 307 & 494 & 514 & 792893 & 964 & 778 & 50.5 & 24.9 & 92 & 80 & 80 & 2002 & 996774 \\
\hline LNB & $7 / 23 / 93$ & 3.55 & 544 & 15.03 & 211 & 346 & 444 & 464 & 508626 & 836 & 706 & 50.5 & 24.9 & 91 & 80 & 80 & 1854 & 618671 \\
\hline LNB & $7 / 24 / 93$ & $1: 52$ & 395 & 13.80 & 199 & 266 & 446 & 466 & 525455 & 857 & 714 & 50.5 & 25.0 & 87 & 80 & 80 & 1825 & 635911 \\
\hline LNB-OFA & $7 / 24 / 93$ & $0: 36$ & 96 & 12.50 & 199 & 279 & 460 & 480 & 580655 & 885 & 751 & 50.5 & 25.0 & 92 & 80 & 80 & 1938 & 718518 \\
\hline GR-LNB 56 & $7 / 24 / 93$ & $7: 45$ & 11 & 14.53 & 177 & 299 & 502 & 522 & 875177 & 984 & 782 & 50.5 & 25.0 & 93 & 80 & 80 & 2052 & 1087740 \\
\hline GR-LNB 56a & $7 / 24 / 93$ & $2: 09$ & 6 & 13.11 & 227 & 266 & 464 & 484 & 597143 & 899 & 744 & 50.5 & 25.1 & 87 & 80 & 80 & 1916 & 737877 \\
\hline GR-LNB 57a & $7 / 25 / 93$ & $1: 10$ & 4 & 11.79 & 285 & 237 & 448 & 468 & 488979 & 880 & 739 & 50.5 & 25.1 & 85 & 80 & 80 & 1867 & 590518 \\
\hline LNB-OFA & $7 / 25 / 93$ & $5: 52$ & 9 & 13.15 & 215 & 294 & 455 & 475 & 558063 & 845 & 735 & 50.5 & 25.1 & 79 & 80 & 80 & 1896 & 682022 \\
\hline GR.LNB 57b & $7 / 25 / 93$ & $10: 19$ & 8 & 13.85 & 185 & 283 & 488 & 508 & 765797 & 965 & 770 & 50.5 & 25.1 & 89 & 80 & 80 & 1979 & 940986 \\
\hline GA-LNB 57 & $7 / 25 / 93$ & $6: 14$ & 11 & 15.17 & 173 & 306 & 506 & 526 & 917103 & 992 & 779 & 50.5 & 25.0 & 97 & 80 & 80 & 2056 & 1145384 \\
\hline GR-LNB 58a & $7 / 26 / 93$ & $10: 15$ & 7 & 12.68 & 194 & 258 & 477 & 497 & 676807 & 949 & 775 & 50.5 & 25.0 & 82 & 80 & 80 & 1907 & 820445 \\
\hline GR-LNB 58 & $7 / 26 / 93$ & 8.34 & 6 & 14.95 & 184 & 289 & 507 & 527 & 923416 & 997 & 777 & 50.5 & 24.9 & 96 & 80 & 80 & 2021 & 1143938 \\
\hline GR-LNB 58b & $7 / 26 / 93$ & $5: 09$ & 5 & 14.06 & 180 & 258 & 495 & 515 & 818260 & 976 & 778 & 50.5 & 25.0 & 88 & 80 & 80 & 1958 & 1008551 \\
\hline GR-LNB 59a & $7 / 27 / 93$ & $10: 48$ & 4 & 13.21 & 206 & 250 & 476 & 496 & 680842 & 936 & 775 & 50.5 & 25.1 & 81 & 80 & 80 & 1942 & 829835 \\
\hline LNB-OFA & $7 / 27 / 93$ & $3: 21$ & 479 & 16.83 & 296 & 377 & 506 & 526 & 966641 & 949 & 774 & 50.5 & 25.1 & 93 & 80 & 80 & 2057 & 1242178 \\
\hline GA-LNB 59 & $7 / 27 / 93$ & $9: 16$ & 9 & 14.97 & 180 & 297 & 497 & 517 & 836351 & 980 & 781 & 50.5 & 25.1 & 93 & 80 & 80 & 1988 & 1049247 \\
\hline GR-LNB 60a & $7 / 28 / 93$ & $11: 06$ & 6 & 14.70 & 176 & 294 & 491 & 511 & 767861 & 977 & 776 & 50.5 & 25.2 & 81 & 80 & 80 & 1948 & 939032 \\
\hline GR-LNB 606 & $7 / 28 / 93$ & 2.02 & 12 & 15.32 & 189 & 299 & 511 & 531 & 965784 & 1004 & 765 & 50.5 & 25.2 & 94 & 80 & 80 & 2063 & 1194553 \\
\hline LNB-OFA & $7 / 28 / 93$ & $2: 21$ & 381 & 16.45 & 327 & 371 & 508 & 528 & 975491 & 963 & 774 & 50.5 & 25.1 & 101 & 80 & 80 & 2083 & 1255070 \\
\hline GR-LNB 60 & $7 / 28 / 93$ & $8: 10$ & 37 & 15.66 & 189 & 301 & 511 & 531 & 967666 & 996 & 777 & 50.5 & 25.1 & 100 & 80 & 80 & 2068 & 1214155 \\
\hline GR-LNB 61a & $7 / 29 / 93$ & $15: 55$ & 25 & 15.29 & 186 & 304 & 506 & 526 & 902996 & 997 & 778 & 50.5 & 25.2 & 92 & 80 & 80 & 2016 & 1118932 \\
\hline GR-LNB 61 & $7 / 29 / 93$ & 8.04 & 80 & 15.50 & 177 & 310 & 507 & 527 & 909884 & 1002 & 764 & 50.5 & 25.1 & 103 & 80 & 80 & 2022 & 1112619 \\
\hline GR-LNB 62 & $7 / 30 / 93$ & $10: 04$ & 165 & 15.39 & 165 & 307 & 503 & 523 & 872604 & 995 & 759 & 50.5 & 25.2 & 91 & 80 & 80 & 1995 & 1063028 \\
\hline LNB-OFA & $7 / 30 / 93$ & 4:32 & 325 & 15.75 & 300 & 358 & 505 & 525 & 943801 & 956 & 774 & 50.5 & 25.2 & 101 & 80 & 80 & 2027 & 1204982 \\
\hline GR-LNB 62a & $7 / 30 / 93$ & $9: 00$ & 41 & 14.79 & 189 & 288 & 507 & 527 & 913819 & 994 & 783 & 50.5 & 25.2 & 92 & 80 & 80 & 2029 & 1138872 \\
\hline GR-LNB 63a & $7 / 31 / 93$ & $17: 10$ & 37 & 15.46 & 172 & 310 & 505 & 525 & 906250 & 992 & 769 & 50.5 & 25.2 & 94 & 80 & 80 & 2009 & 1122978 \\
\hline GR-LNB 63b & $7 / 31 / 93$ & $6: 49$ & 67 & 15.71 & 169 & 316 & 507 & 527 & 919098 & 995 & 769 & 50.5 & 25.2 & 103 & 80 & 80 & 2037 & 1133217 \\
\hline GR-LNB 64a & $8 / 1 / 93$ & $1: 25$ & 29 & 15.12 & 161 & 301 & 498 & 518 & 816297 & 990 & 770 & 50.5 & 25.2 & 95 & 80 & 80 & 1960 & 991175 \\
\hline GR-LNB 64b & $8 / 1 / 93$ & $10: 21$ & 6 & 13.78 & 200 & 269 & 473 & 493 & 643164 & 926 & 765 & 50.5 & 25.3 & 85 & 80 & 80 & 1893 & 779138 \\
\hline
\end{tabular}


Cherokee Unit 3, Average Test 5

Pre Modification

\begin{tabular}{|c|c|c|c|c|c|c|c|c|c|c|c|c|c|c|c|c|c|c|}
\hline Test) & 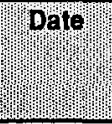 & pwpy & raw & (roz) & row & $\begin{array}{l}\text { so2 } \\
\text { raw } \\
\text { ppm }\end{array}$ & $\begin{array}{l}\text { Econ } \\
\text { DegF } \\
\text { Deg }\end{array}$ & $\begin{array}{l}\text { Econ } \\
\text { Wail ou! } \\
\text { Deg Fy }\end{array}$ & 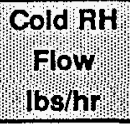 & $\begin{array}{l}\text { Whot } \\
\text { Degh } \\
\text { Deg }\end{array}$ & $\begin{array}{l}\text { SH. } \\
\text { Attmpo } \\
\text { DegF }\end{array}$ & 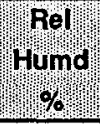 & Amb" & $\begin{array}{l}\text { Amb! } \\
\text { Demp } \\
\text { Deg }\end{array}$ & प्NG & $\begin{array}{l}\text { Coal" } \\
\text { Temp: } \\
\text { Deg }\end{array}$ & सcon & 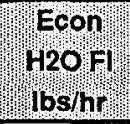 \\
\hline GR-LNB 64C & $8 / 1 / 93$ & $12: 14$ & 23 & 15.31 & 173 & 291 & 505 & 525 & 889735 & 994 & 779 & 50.5 & 25.3 & 90 & 80 & 80 & 2023 & 1092870 \\
\hline GR-LNB 65a & $8 / 2 / 93$ & $8: 55$ & 5 & 12.99 & 197 & 243 & 468 & 488 & 616394 & 906 & 758 & 50.5 & 25.2 & 84 & 80 & 80 & 1905 & 750168 \\
\hline LNB-OFA & $8 / 2 / 93$ & $1: 23$ & 404 & 15.92 & 273 & 343 & 506 & 525 & 939354 & 966 & 774 & 50.5 & 25.2 & 81 & 80 & 80 & 2024 & 1196910 \\
\hline GA-LNB 656 & $8 / 293$ & $6: 02$ & 14 & 15.33 & 163 & 290 & 504 & 524 & 898630 & 983 & 777 & 50.5 & 25.2 & 84 & 80 & 80 & 2010 & 1122469 \\
\hline GR-LNB 65c & $8 / 2 / 93$ & $7: 14$ & 8 & 14.45 & 167 & & 501 & 521 & 865854 & 983 & 769 & 50.5 & 25.2 & 84 & 80 & 80 & 1989 & 1068595 \\
\hline GR-LNB 66a & $8 / 3 / 93$ & $8: 29$ & 4 & 12.43 & 210 & & 462 & 482 & 564511 & 916 & 763 & 50.5 & 25.3 & 74 & 80 & 80 & 1856 & 681123 \\
\hline GR-LNB 66b & $8 / 3 / 93$ & $9: 34$ & 4 & 14.64 & 178 & & 501 & 521 & 859935 & 990 & 775 & 50.5 & 25.3 & 75 & 80 & 80 & 1987 & 1058443 \\
\hline GR-LNB 66c & $8 / 3 / 93$ & 5.55 & 6 & 15.32 & 174 & & 505 & 525 & 899680 & 995 & 779 & 50.5 & 25.3 & 79 & 80 & 80 & 2010 & 1109886 \\
\hline GR-LNB 67 & $8 / 4 / 93$ & $24: 00$ & 8 & 14.72 & 175 & & 497 & 517 & 829130 & 978 & 777 & 50.5 & 25.2 & 80 & 80 & 80 & 1999 & 1023701 \\
\hline GR-LNB 68a & $8 / 5 / 93$ & $7: 39$ & 7 & 14.19 & 161 & & 482 & 502 & 702850 & 954 & 773 & 50.5 & 25.2 & 75 & 80 & 80 & 1932 & 861996 \\
\hline GR-LNB 68b & $8 / 5 / 93$ & 15:50 & 7 & 14.90 & 192 & & 507 & 527 & 914005 & 998 & 774 & 50.5 & 25.2 & 81 & 80 & 80 & 2026 & 1127368 \\
\hline GR-LNB 69 & $8 / 6 / 93$ & $9: 48$ & 7 & 15.10 & 181 & & 497 & 517 & 833590 & 983 & 776 & 50.5 & 25.2 & 73 & 80 & 80 & 1984 & 1027219 \\
\hline LNB & $8 / 6 / 93$ & $7: 58$ & 312 & 16.03 & 307 & & 502 & 522 & 924066 & 948 & 765 & 50.5 & 25.1 & 86 & 80 & 80 & 2018 & 1178269 \\
\hline LNB.OFA & $8 / 6 / 93$ & $5: 04$ & 191 & 15.85 & 318 & & 504 & 524 & 952122 & 946 & 760 & 50.5 & 25.1 & 93 & 80 & 80 & 2031 & 1217781 \\
\hline LNB & $8 / 7 / 93$ & $3: 04$ & 798 & 16.43 & 286 & & 501 & 521 & 905338 & 960 & 776 & 50.5 & 25.0 & 81 & 80 & 80 & 2000 & 1149042 \\
\hline GR-LNB 70 & $8 / 7 / 93$ & $3: 53$ & 850 & 15.43 & 178 & & 499 & 519 & 834073 & 999 & 788 & 50.5 & 25.0 & 79 & 80 & 80 & 1974 & 1033833 \\
\hline LNB.OFA & $8 / 793$ & $8: 05$ & 348 & 15.60 & 290 & & 503 & 523 & 925837 & 959 & 764 & 50.5 & 25.0 & 91 & 80 & 80 & 2026 & 1174140 \\
\hline LNB & $8 / 7 / 93$ & $6: 28$ & 210 & 15.81 & 310 & & 504 & 524 & 941014 & 953 & 766 & 50.5 & 25.0 & 91 & 80 & 80 & 2037 & 1200396 \\
\hline LNB & $8 / 9 / 93$ & $8: 04$ & 234 & 15.63 & 269 & & 495 & 515 & 869472 & 922 & 758 & 50.5 & 25.2 & 82 & 80 & 80 & 2005 & 1107058 \\
\hline GA-LNB 71 (10\% Gas) & $8 / 9 / 93$ & $13: 45$ & 14 & 15.38 & 189 & & 507 & 527 & 934273 & 988 & 783 & 50.5 & 25.3 & 98 & 80 & 80 & 2033 & 1181731 \\
\hline GR-LNB $72 a(10 \%)$ & $8 / 10 / 93$ & $7: 48$ & 46 & 15.37 & 184 & & 499 & 519 & 914960 & 991 & 769 & 50.5 & 25.2 & 88 & 80 & 80 & 2003 & 1117394 \\
\hline LNB & $8 / 10 / 93$ & $7: 27$ & 25 & 15.52 & 306 & & 503 & 523 & 948745 & 926 & 759 & 50.5 & 25.2 & 92 & 80 & 80 & 2053 & 1219610 \\
\hline GR-LNB $72 b(10 \%)$ & $8 / 10 / 93$ & $7: 25$ & 13 & 15.06 & 189 & & 502 & 522 & 888649 & 977 & 777 & 50.5 & 25.3 & 82 & 80 & 80 & 2030 & 1125736 \\
\hline GR-LNB 73 & $8 / 11 / 93$ & 3.22 & 9 & 14.53 & 197 & & 497 & 518 & 853475 & 974 & 782 & 50.5 & 25.2 & 80 & 80 & 80 & 2011 & 1072260 \\
\hline LNB-OFA & $8 / 11 / 93$ & $9: 49$ & 171 & 15.90 & 267 & & 506 & 526 & 963069 & 946 & 769 & 50.5 & 25.1 & 94 & 80 & 80 & 2060 & 1236831 \\
\hline LNB & $8 / 11 / 93$ & $2: 45$ & 10 & 15.40 & 281 & & 501 & 521 & 916336 & 933 & 769 & 50.5 & 25.2 & 90 & 80 & 80 & 2028 & 1170904 \\
\hline LNB & $8 / 12 / 93$ & $7: 36$ & 97 & 15.33 & 228 & & 473 & 493 & 688915 & 898 & 743 & 50.5 & 25.2 & 84 & 80 & 80 & 1942 & 857299 \\
\hline GR-LNB 74 & $8 / 1293$ & $14: 33$ & 9 & 15.25 & 183 & & 506 & 526 & 916026 & 992 & 780 & 50.5 & 25.2 & 81 & 80 & 80 & 2038 & 1150589 \\
\hline GR-LNB 75 & $8 / 13 / 93$ & $18: 16$ & 11 & 14.87 & 190 & & 504 & 524 & 900509 & 985 & 776 & 50.5 & 25.1 & 91 & 80 & 80 & 2037 & 1126591 \\
\hline GP-LNB 76a & $8 / 14 / 93$ & $4: 54$ & 41 & 14.19 & 168 & & 484 & 504 & 715491 & 975 & 761 & 50.5 & 25.0 & 90 & 80 & 80 & 1964 & 865469 \\
\hline LNB & $8 / 14 / 93$ & $1: 46$ & 82 & 12.07 & 249 & & 453 & 473 & 526616 & 905 & 746 & 50.5 & 25.1 & 89 & 80 & 80 & 1917 & 641834 \\
\hline GR-LNB 766 & $8 / 14 / 93$ & $11: 05$ & 9 & 14.36 & 179 & & 502 & 522 & 882874 & 983 & 779 & 50.5 & 25.1 & 89 & 80 & 80 & 2030 & 1106385 \\
\hline GR-LNB 77 & $8 / 15 / 93$ & $1: 10$ & 22 & 13.73 & 171 & & 480 & 500 & 685299 & 950 & 764 & 50.5 & 25.1 & 83 & 80 & 80 & 1943 & 843335 \\
\hline LNB & $8 / 15 / 93$ & $14: 44$ & 534 & 14.76 & 239 & & 474 & 494 & 701217 & 917 & 744 & 50.5 & 25.1 & 84 & 80 & 80 & 1966 & 872200 \\
\hline LNB & $8 / 15 / 93$ & $6: 58$ & 217 & 15.95 & 278 & & 504 & 524 & 940260 & 959 & 767 & 50.5 & 25.1 & 91 & 80 & 80 & 2058 & 1202964 \\
\hline LNB (low load) & $8 / 16 / 93$ & $7: 38$ & 710 & 14.65 & 210 & & 468 & 488 & 627800 & 929 & 761 & 50.5 & 25.1 & 80 & 80 & 80 & 1940 & 765506 \\
\hline LNB $(150 \mathrm{MWo})$ & $8 / 16 / 93$ & $3: 21$ & 32 & 15.50 & 323 & & 506 & 526 & 954522 & 952 & 778 & 50.5 & 25.1 & 82 & 80 & 80 & 2064 & 1223021 \\
\hline LNB-OFA cooling & $8 / 16 / 93$ & $11: 40$ & 67 & 15.76 & 324 & & 505 & 525 & 977554 & 925 & 756 & 50.5 & 25.0 & 100 & 80 & 80 & 2074 & 1261213 \\
\hline LNB & $8 / 17 / 93$ & 9.07 & 363 & 15.52 & 261 & & 491 & 511 & 838400 & 914 & 759 & 50.5 & 25.1 & 86 & 80 & 80 & 2012 & 1064869 \\
\hline $100 \%$ Gas (plant test) & $8 / 17 / 93$ & $0: 34$ & 979 & 10.24 & 77 & & 441 & 461 & 503186 & 811 & 702 & 50.5 & 25.1 & 86 & 80 & 80 & 1882 & 614471 \\
\hline
\end{tabular}


Pre Modification

\begin{tabular}{|c|c|c|c|c|c|c|c|c|c|c|c|c|c|c|c|c|c|c|}
\hline Nos & Date: & Dup & $\begin{array}{l}\text { cop } \\
\text { rawn } \\
\text { ppm }\end{array}$ & con & Nox" & 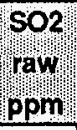 & Econ & $\begin{array}{l}\text { Econ } \\
\text { Walnout } \\
\text { OeY }\end{array}$ & Cold RH! & $\begin{array}{l}\text { Hot:m } \\
\text { Degh }\end{array}$ & 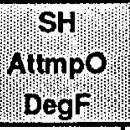 & पroin" & Press & $\begin{array}{l}\text { Amb } \\
\text { Temp: } \\
\text { Deg }\end{array}$ & $\begin{array}{l}\text { ¿ng } \\
\text { Temp } \\
\text { Deff }\end{array}$ & $\begin{array}{l}\text { Coal! } \\
\text { Temp } \\
\text { Deg }\end{array}$ & Wecon! & 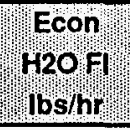 \\
\hline LNB (OFA cooling) & $8 / 17 / 93$ & $8: 59$ & 309 & 16.14 & 302 & & 505 & 525 & 963717 & 932 & 765 & 50.5 & 25.1 & 99 & 80 & 80 & 2060 & 1243185 \\
\hline LNB & $8 / 17 / 93$ & $3: 05$ & 266 & 16.40 & 287 & & 503 & 523 & 944875 & 933 & 765 & 50.5 & 25.1 & 90 & 80 & 80 & 2054 & 1214202 \\
\hline LNB (low load) & $8 / 18 / 93$ & $9: 42$ & 738 & 15.81 & 223 & & 477 & 497 & 711620 & 915 & 756 & 50.5 & 25.1 & 87 & 80. & 80 & 1960 & 884230 \\
\hline LNB 150 MWe & $8 / 18 / 93$ & $14: 16$ & 24 & 15.79 & 317 & & 504 & 524 & 965559 & 923 & 761 & 50.5 & 25.2 & 87 & 80 & 80 & 2062 & 1248041 \\
\hline GR-LNB 78 & $8 / 24 / 93$ & $3: 25$ & 138 & 15.63 & 169 & & 459 & 479 & 936348 & 983 & 764 & 50.5 & 25.1 & 95 & 80 & 80 & 2017 & 1031452 \\
\hline LNB OFA cooling & $8 / 24 / 93$ & $10: 38$ & 218 & 15.63 & 299 & & 457 & 477 & 958038 & 953 & 777 & 50.5 & 25.0 & 99 & 80 & 80 & 2028 & 1093474 \\
\hline LNB OFA cooling & $8 / 25 / 93$ & $2: 06$ & 499 & 15.63 & 236 & & 435 & 455 & 736333 & 933 & 749 & 50.5 & 25.0 & 91 & 80 & 80 & 1947 & 824576 \\
\hline LNB & $8 / 25 / 93$ & $8: 38$ & 694 & 15.63 & 232 & & 432 & 452 & 709272 & 928 & 752 & 50.5 & 25.0 & 88 & 80 & 80 & 1945 & 788327 \\
\hline LNB & $8 / 25 / 93$ & $13: 08$ & 13 & 15.63 & 321 & & 456 & 476 & 951552 & 934 & 789 & 50.5 & 25.0 & 83 & 80 & 80 & 2029 & 1088036 \\
\hline LNB & $8 / 26 / 93$ & $21: 16$ & 195 & 15.63 & 257 & & 474 & 494 & 682870 & 874 & 742 & 50.5 & 25.2 & 83 & 80 & 80 & 1950 & 847754 \\
\hline LNB & $8 / 26 / 93$ & $2: 42$ & 24 & 15.63 & 313 & & 505 & 525 & 920314 & 950 & 776 & 50.5 & 25.2 & 81 & 80 & 80 & 2049 & 1178896 \\
\hline LNB & $8 / 27 / 93$ & $8: 26$ & 34 & 15.63 & 298 & & 467 & 487 & 636402 & 878 & 740 & 50.5 & 25.3 & 76 & 80 & 80 & 1936 & 782992 \\
\hline LNB & $8 / 27 / 93$ & $6: 17$ & 17 & 15.63 & 298 & & 502 & 522 & 910390 & 924 & 760 & 50.5 & 25.3 & 74 & 80 & 80 & 2038 & 1166460 \\
\hline GR-LNB 79 & $9 / 8 / 93$ & 11:15 & 49 & 15.63 & 174 & & 507 & 527 & 910146 & 971 & 790 & 50.5 & 25.1 & 85 & 80 & 80 & 2044 & 1161124 \\
\hline GR-LNB 79a & $9 / 8 / 93$ & $1: 49$ & 67 & 15.63 & 158 & & 489 & 509 & 749933 & 941 & 775 & 50.5 & 25.1 & 81 & 80 & 80 & 1977 & 946036 \\
\hline GR-LNB 80a & 9/9/93 & $6: 55$ & 64 & 15.63 & 173 & & 479 & 499 & 674509 & 939 & $7 \pi$ & 50.5 & 25.2 & 76 & 80 & 80 & 1955 & 830995 \\
\hline LNB-OFA & $9 / 9 / 93$ & $1: 46$ & 77 & 15.63 & 239 & & 458 & 478 & 550030 & 881 & 752 & 50.5 & 25.1 & 77 & 80 & 80 & 1908 & 671739 \\
\hline GR-LNB 80 & $9 / 9 / 93$ & $14: 15$ & 195 & 15.63 & 158 & & 500 & 520 & 835861 & 969 & 781 & 50.5 & 25.3 & 85 & 80 & 80 & 2003 & 1040148 \\
\hline LNB-OFA & $9 / 10 / 93$ & $4: 50$ & 114 & 15.63 & 305 & & 450 & 470 & 512090 & 863 & 744 & 50.5 & 25.3 & 78 & 80 & 80 & 1894 & 616942 \\
\hline GR-LNB 81 & $9 / 10 / 93$ & $1: 46$ & 13 & 15.63 & 159 & & 481 & 501 & 663604 & 949 & 784 & 50.5 & 25.3 & 71 & 80 & 80 & 1942 & 809001 \\
\hline LNB & 9/10/93 & $13: 30$ & 134 & 15.63 & 297 & & 501 & 521 & 894549 & 930 & 768 & 50.5 & 25.1 & 86 & 80 & 80 & 2028 & 1140871 \\
\hline LNB & $9 / 11 / 93$ & 19:30 & 501 & 15.63 & 267 & & 493 & 513 & 829857 & 921 & 768 & 50.5 & 25.0 & 89 & 80 & 80 & 2005 & 1054475 \\
\hline GR-LNB 82 & $9 / 11 / 93$ & $4: 10$ & 22 & 15.63 & 180 & & 506 & 526 & 910079 & 955 & 789 & 50.5 & 24.9 & 93 & 80 & 80 & 2037 & 1166076 \\
\hline GR-LNB 83a & $9 / 12 / 93$ & $11: 51$ & 13 & 15.63 & 165 & & 493 & 513 & 783090 & 950 & 783 & 50.5 & 24.8 & 82 & 80 & 80 & 1981 & 980065 \\
\hline GR-LNB 83 & $9 / 12 / 93$ & $12: 09$ & 50 & 15.63 & 172 & & 512 & 532 & 954513 & 985 & 785 & 50.5 & 24.7 & 96 & 80 & 80 & 2058 & 1212694 \\
\hline GA-LNB 84a & 9/13/93 & $5: 35$ & 12 & 15.63 & 160 & & 485 & 505 & 711459 & 950 & 780 & 50.5 & 25.0 & 64 & 80 & 80 & 1952 & 880016 \\
\hline GR-LNB 84 & $9 / 13 / 93$ & $18: 03$ & 50 & 15.63 & 177 & & 506 & 526 & 885199 & 980 & 789 & 50.5 & 25.1 & 51 & 80 & 80 & 2021 & 1114655 \\
\hline GR-LNB 85a & $9 / 14 / 93$ & $4: 15$ & 125 & 15.63 & 158 & & 496 & 516 & 788833 & 971 & 773 & 50.5 & 25.2 & 55 & 80 & 80 & 1980 & 975182 \\
\hline LNB & $9 / 14 / 93$ & $11: 05$ & 231 & 15.63 & 277 & & 484 & 504 & 742577 & 921 & 764 & 50.5 & 25.2 & 62 & 80 & 80 & 1965 & 928489 \\
\hline LNB-OFA & 9/14/93 & 1.06 & 308 & 15.63 & 271 & & 507 & 527 & 933237 & 946 & 778 & 50.5 & 25.1 & 75 & 80 & 80 & 2049 & 1202090 \\
\hline GR-LNB 85 & $9 / 14 / 93$ & $6: 55$ & 28 & 15.63 & 169 & & 506 & 526 & 892118 & 985 & 777 & 50.5 & 25.1 & 73 & 80 & 80 & 2025 & 1114591 \\
\hline GR-LNB 86a & $9 / 15 / 93$ & $0: 50$ & 14 & 15.63 & 158 & & 498 & 518 & 809649 & 967 & 772 & 50.5 & 25.1 & 66 & 80 & 80 & 1986 & 1002451 \\
\hline LNB & $9 / 15 / 93$ & $3: 07$ & 301 & 15.63 & 250 & & 472 & 492 & 636515 & 923 & 732 & 50.5 & 25.1 & 66 & 80 & 80 & 1943 & 760575 \\
\hline GR-LNB 86b & $9 / 15 / 93$ & $4: 26$ & 17 & 15.63 & 166 & & 491 & 511 & 752988 & 964 & 778 & 50.5 & 25.1 & 66 & 80 & 80 & 1984 & 920529 \\
\hline GR-LNB 86 & 9/15/93 & $11: 20$ & 12 & 15.63 & 179 & & 506 & 526 & 884075 & 985 & 779 & 50.5 & 25.0 & 84 & 80 & 80 & 2028 & 1100045 \\
\hline GR-LNB 87a & $9 / 16 / 93$ & $5: 46$ & 7 & 15.63 & 179 & & 489 & 509 & 746772 & 948 & 766 & 50.5 & 25.1 & 73 & 80 & 80 & 1970 & 916784 \\
\hline GR-LNB 87 & $9 / 16 / 93$ & $15: 24$ & 14 & 15.63 & 171 & & 501 & 521 & 837790 & 981 & 780 & 50.5 & 25.1 & 74 & 80 & 80 & 2009 & 1036682 \\
\hline GR-LNB 88a & $9 / 17 / 93$ & $5: 31$ & 12 & 15.63 & 156 & & 494 & 514 & 774856 & 975 & 772 & 50.5 & 25.2 & 68 & 80 & 80 & 1974 & 946807 \\
\hline GR-LNB 88 & $9 / 17 / 93$ & $18: 28$ & 22 & 15.63 & 170 & & 507 & 527 & 888723 & 989 & 776 & 50.5 & 25.1 & 71 & 80 & 80 & 2026 & 1101554 \\
\hline GR-LNB 89 & $9 / 18 / 93$ & $24: 00$ & 61 & 15.63 & 167 & & 504 & 524 & 863809 & 985 & 773 & 50.5 & 25.0 & 65 & 80 & 80 & 2013 & 1068203 \\
\hline
\end{tabular}


Cherokee Unlt 3, Average Test $\mathrm{C}$

Pre Modification

\begin{tabular}{|c|c|c|c|c|c|c|c|c|c|c|c|c|c|c|c|c|c|c|}
\hline Test' & Date & Durn & raw & (cos) & $\begin{array}{l}\text { Nox } \\
\text { raw } \\
\text { ppm }\end{array}$ & raw! & Decon & $\begin{array}{l}\text { Econ } \\
\text { Wallowt } \\
\text { Degf }\end{array}$ & 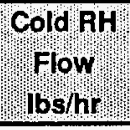 & $\begin{array}{l}\text { Hot } \\
\text { Degr } \\
\text { Degr }\end{array}$ & 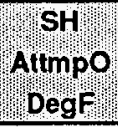 & 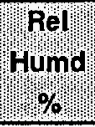 & Pramb" & $\begin{array}{l}\text { Amb! } \\
\text { pemp } \\
\text { pog }\end{array}$ & 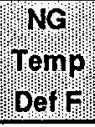 & Coal & 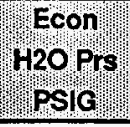 & Econ \\
\hline GR-LNB 90a & 9/19/93 & $10: 06$ & 23 & 15.63 & 163 & & 496 & 516 & 791457 & 980 & 765 & 50.5 & 25.0 & 63 & 80 & 80 & 1983 & 961743 \\
\hline GR-LNB 90 & $9 / 19 / 93$ & $13: 54$ & 22 & 15.63 & 177 & & 509 & 529 & 905264 & 994 & 772 & 50.5 & 25.0 & 76 & 80 & 80 & 2029 & 1118543 \\
\hline GR-LNB 91 & $9 / 20 / 93$ & $24: 00$ & 192 & 15.63 & 163 & & 505 & 525 & 867530 & 992 & 764 & 50.5 & 25.0 & 76 & 80 & 80 & 2014 & 1053315 \\
\hline GR-LNB 92a & $9 / 21 / 93$ & $3: 00$ & 253 & 15.63 & 156 & & 488 & 508 & 724919 & 959 & 777 & 50.5 & 25.0 & 74 & 80 & 80 & 1959 & 884737 \\
\hline GR-LNB 92 & $9 / 21 / 93$ & $17: 56$ & 130 & 15.63 & 161 & 190 & 504 & 524 & 875506 & 972 & 775 & 50.5 & 25.0 & 82 & 80 & 80 & 2023 & 1094892 \\
\hline GR-LNB 3 Mill a & $9 / 2293$ & $7: 59$ & 32 & 15.63 & 137 & 254 & 484 & 504 & 701841 & 949 & 771 & 50.5 & 25.0 & 69 & 80 & 80 & 1948 & 859668 \\
\hline GR-LNB 3 Mill b & $9 / 22 / 93$ & $8: 25$ & 17 & 14.56 & 146 & 263 & 489 & 509 & 753668 & 938 & 769 & 50.5 & 25.0 & 68 & 80 & 80 & 1964 & 934756 \\
\hline GR-LNB 3 Mill C & 9/23/93 & $24: 00$ & 15 & 14.40 & 151 & 302 & 490 & 510 & 760768 & 944 & 777 & 50.5 & 25.0 & 68 & 80 & 80 & 1965 & 946917 \\
\hline GR-LNB 3 Mill d & $9 / 24 / 93$ & $1: 58$ & 7 & 13.16 & 140 & 261 & 474 & 494 & 618280 & 929 & 777 & 50.5 & 25.0 & 67 & 80 & 80 & 1911 & 758238 \\
\hline LNB-OFA 3 Mill & $9 / 24 / 93$ & $3: 33$ & 23 & 11.52 & 166 & 258 & 440 & 460 & 500236 & 745 & 702 & 50.5 & 25.0 & 66 & 80 & 80 & 1881 & 613038 \\
\hline GR-LNB 3 Mill o & $9 / 24 / 93$ & $6: 10$ & 10 & 14.04 & 155 & 277 & 488 & 508 & 762679 & 917 & 776 & 50.5 & 25.1 & 65 & 80 & 80 & 1969 & 961735 \\
\hline GR-LNB 93 & $9 / 24 / 93$ & $12: 09$ & 9 & 14.62 & 175 & 291 & 500 & 520 & 857716 & 951 & 786 & 50.5 & 25.1 & 72 & 80 & 80 & 2005 & 1084221 \\
\hline GR-LNB 94a & $9 / 25 / 93$ & $2: 12$ & 8 & 14.49 & 153 & 284 & 491 & 511 & 755004 & 948 & 786 & 50.5 & 25.1 & 66 & 80 & 80 & 1962 & 942488 \\
\hline LNB-OFA & $9 / 25 / 93$ & $2: 24$ & 8 & 13.16 & 175 & 285 & 472 & 492 & 634724 & 897 & 777 & 50.5 & 25.1 & 65 & 80 & 80 & 1920 & 775205 \\
\hline GR-LNB 94 & 9/25/93 & 19.05 & 11 & 15.25 & 179 & 308 & 508 & 528 & 913886 & 979 & 788 & 50.5 & 25.1 & $\pi$ & 80 & 80 & 2030 & 1147317 \\
\hline GR-LNB 95a & $9 / 26 / 93$ & $4: 15$ & 8 & 14.61 & 154 & 275 & 490 & 510 & 742394 & 964 & 781 & 50.5 & 25.3 & 65 & 80 & 80 & 1954 & 911722 \\
\hline LNB-OFA & $9 / 26 / 93$ & $2: 55$ & 10 & 12.68 & 191 & 268 & 464 & 484 & 617885 & 819 & 732 & 50.5 & 25.4 & 63 & 80 & 80 & 1911 & 763717 \\
\hline GR-LNB 95 & 9/26/93 & $16: 33$ & 7 & 14.69 & 175 & 293 & 502 & 522 & 854891 & 971 & 784 & 50.5 & 25.3 & 71 & 80 & 80 & 2004 & 1072051 \\
\hline GR-LNB 96a & 9/27/93 & $2: 53$ & 6 & 13.86 & 165 & 275 & 492 & 512 & 782263 & 941 & 779 & 50.5 & 25.3 & 67 & 80 & 80 & 1977 & 971849 \\
\hline LNB & 9/27/93 & $19: 45$ & 44 & 15.28 & 338 & 341 & 503 & 523 & 917473 & 921 & 770 & 50.5 & 25.3 & 82 & 80 & 80 & 2032 & 1178328 \\
\hline GR-LNB 96b & $9 / 27 / 93$ & 0.57 & 25 & 14.75 & 150 & 292 & 492 & 511 & 762962 & 940 & 781 & 50.5 & 25.2 & $\pi$ & 80 & 80 & 1967 & 955576 \\
\hline GR-LNB 97a & 9/28/93 & $9: 13$ & 7 & 14.38 & 168 & 282 & 496 & 516 & 802460 & 964 & 785 & 50.5 & 25.3 & 70 & 80 & 80 & 1984 & 995126 \\
\hline LNB & $9 / 28 / 93$ & $4: 27$ & 907 & 17.90 & 255 & 391 & 506 & 525 & 931357 & 942 & 765 & 50.5 & 25.4 & 73 & 80 & 80 & 2035 & 1193829 \\
\hline GR-LNB 97 & 9/28/93 & $5: 58$ & 29 & 15.87 & 167 & 324 & 509 & 529 & 909780 & 986 & 774 & 50.5 & 25.3 & 78 & 80 & 80 & 2025 & 1129304 \\
\hline GR-LNB 97b & $9 / 28 / 93$ & $2: 48$ & 7 & 14.78 & 168 & 297 & 492 & 512 & 757785 & 964 & 771 & 50.5 & 25.4 & 72 & 80 & 80 & 1959 & 927068 \\
\hline GR-LNB 98a & 9/29/93 & $5: 22$ & 6 & 14.04 & 178 & 282 & 484 & 504 & 691681 & 956 & 775 & 50.5 & 25.3 & 69 & 80 & 80 & 1940 & 837834 \\
\hline GR-LNB 98 & 9/29/93 & $18: 37$ & 13 & 15.35 & 177 & 309 & 508 & 528 & 911287 & 976 & 783 & 50.5 & 25.2 & $\pi$ & 80 & 80 & 2028 & 1147567 \\
\hline GR-LNB 99a & 9/30/93 & $5: 32$ & 5 & 13.36 & 175 & 263 & 480 & 500 & 694998 & 917 & 770 & 50.5 & 25.1 & 73 & 80 & 80 & 1944 & 860032 \\
\hline GR-LNB 99 & 9/30/93 & $13: 24$ & 8 & 15.03 & 180 & 300 & 507 & 527 & 904585 & 971 & 788 & 50.5 & 25.0 & 86 & 80 & 80 & 2030 & 1148508 \\
\hline GR-LNB 99b & $9 / 30 / 93$ & $2: 27$ & 6 & 14.03 & 162 & 275 & 493 & 513 & 772983 & 943 & 778 & 50.5 & 25.0 & 90 & 80 & 80 & 1973 & 962985 \\
\hline LNB-OFA & $9 / 30 / 93$ & $2: 27$ & 259 & 13.34 & 298 & 286 & 447 & 467 & 530406 & 794 & 710 & 50.5 & 25.0 & 88 & 80 & 80 & 1895 & 645540 \\
\hline GR-LNB $100 \mathrm{a}$ & $10 / 1 / 93$ & $11: 00$ & 6 & 13.01 & 184 & 237 & 475 & 495 & 638714 & 923 & 784 & 50.5 & 25.2 & 70 & 80 & 80 & 1936 & 780747 \\
\hline GR-LNB 100 & $10 / 1 / 93$ & $9: 12$ & 6 & 14.57 & 158 & 252 & 493 & 513 & 764884 & 973 & 771 & 50.5 & 25.0 & 77 & 80 & 80 & 1975 & 935314 \\
\hline GR-LNB 101 & $10 / 293$ & $24: 00$ & 5 & 14.21 & 160 & 252 & 491 & 511 & 749864 & 963 & 780 & 50.5 & 25.3 & 69 & 80 & 80 & 1970 & 921644 \\
\hline GR-LNB 102 & $10 / 3 / 93$ & $24: 00$ & 5 & 13.84 & 166 & 246 & 486 & 506 & 712297 & 963 & 779 & 50.5 & 25.2 & 78 & 80 & 80 & 1957 & 867220 \\
\hline GR-LNB 103 & $10 / 4 / 93$ & $24: 00$ & 7 & 14.23 & 161 & 259 & 492 & 512 & 761373 & 966 & 778 & 50.5 & 25.2 & 81 & 80 & 80 & 1974 & 931726 \\
\hline GR-LNB 104 & $10 / 5 / 93$ & $24: 00$ & 5 & 13.94 & 167 & 269 & 494 & 514 & 775329 & 968 & 782 & 50.5 & 25.2 & 83 & 80 & 80 & 1978 & 955790 \\
\hline GR-LNB 105 & $10 / 6 / 93$ & $10: 15$ & 9 & 14.46 & 170 & 278 & 504 & 524 & 874510 & 980 & 786 & 50.5 & 25.1 & 75 & 80 & 80 & 2024 & 1096262 \\
\hline GR-LNB 106 & $10 / 8 / 93$ & $8: 45$ & 18 & 16.02 & 167 & 298 & 506 & 526 & 907830 & 975 & 785 & 50.5 & 25.2 & 54 & 80 & 80 & 2032 & 1153156 \\
\hline GR-LNB 107 & $10 / 9 / 93$ & $24: 00$ & 11 & 15.06 & 179 & 281 & 507 & 527 & 904641 & 980 & 787 & 50.5 & 25.3 & 48 & 80 & 80 & 2029 & 1146133 \\
\hline
\end{tabular}


Pre Modification

\begin{tabular}{|c|c|c|c|c|c|c|c|c|c|c|c|c|c|c|c|c|c|c|}
\hline Test & parqu & Dum & $\begin{array}{l}\text { co } \\
\text { raw } \\
\text { ppm }\end{array}$ & 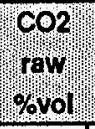 & nox & so2 & Econ & 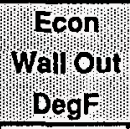 & cold & $\begin{array}{l}\text { Hot } \\
\text { Deft! } \\
\text { DegF }\end{array}$ & 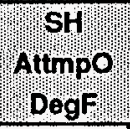 & पrampl & $\begin{array}{l}\text { (amb' } \\
\text { press } \\
\text { HgA }\end{array}$ & $\begin{array}{l}\text { Amb } \\
\text { Temp } \\
\text { Deg }\end{array}$ & 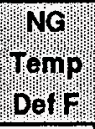 & $\begin{array}{l}\text { coal! } \\
\text { Temp: } \\
\text { Deg F }\end{array}$ & $\begin{array}{l}\text { Econ } \\
\text { Hesprs } \\
\text { psig }\end{array}$ & Econ \\
\hline GR-LNB 108 & $10 / 10 / 93$ & $11: 00$ & 29 & 14.84 & 180 & 282 & 508 & 528 & 907114 & 987 & 785 & 50.5 & 25.2 & 51 & 80 & 80 & 2035 & 1143835 \\
\hline GR-LNB $109 \mathrm{a}$ & $10 / 13 / 93$ & $4: 07$ & 17 & 15.32 & 180 & 288 & 506 & 526 & 916372 & 964 & 773 & 50.5 & 25.1 & 75 & 80 & 80 & 2044 & 1162903 \\
\hline GR.LNB 109b & $10 / 13 / 93$ & $2: 02$ & 11 & 14.55 & 167 & 277 & 490 & 510 & 764606 & 940 & 774 & 50.5 & 25.1 & 70 & 80 & 80 & 1977 & 960169 \\
\hline GR-LNB 110a & $10 / 14 / 93$ & $6: 02$ & 18 & 14.67 & 170 & 279 & 497 & 517 & 805622 & 978 & 776 & 50.5 & 25.1 & 65 & 80 & 80 & 1994 & 988613 \\
\hline GR-LNB 110 & $10 / 14 / 93$ & $14: 56$ & 17 & 15.28 & 177 & 287 & 508 & 528 & 901962 & 992 & 770 & 50.5 & 25.0 & 69 & 80 & 80 & 2031 & 1113023 \\
\hline GA-LNB 1100 & $10 / 14 / 93$ & $3: 00$ & 7 & 13.87 & 174 & 256 & 488 & 508 & 739921 & 941 & 775 & 50.5 & 25.0 & 68 & 80 & 80 & 1976 & 915835 \\
\hline GA-LNB 111 & $10 / 15 / 93$ & $12: 49$ & 59 & 15.07 & 160 & 286 & 500 & 520 & 824142 & 980 & 767 & 50.5 & 25.0 & 63 & 80 & 80 & 1990 & 1007217 \\
\hline GA-LNB 3 Mill a & $10 / 15 / 93$ & $2: 58$ & 30 & 16.14 & 174 & 307 & 504 & 524 & 881517 & 971 & 773 & 50.5 & 25.0 & 73 & 80 & 80 & 2013 & 1116145 \\
\hline GA-LNB 3 Mill b & $10 / 15 / 93$ & $7: 05$ & 15 & 15.20 & 175 & 290 & 496 & 516 & 820278 & 949 & 777 & 50.5 & 25.0 & 69 & 80 & 80 & 1983 & 1033302 \\
\hline GR-LNB 3 Mill c & $10 / 16 / 93$ & $12: 05$ & 4 & 13.55 & 177 & 264 & 480 & 500 & 667340 & 943 & 783 & 50.5 & 25.0 & 64 & 80 & 80 & 1923 & 818698 \\
\hline GR-LNB 3 Mill d & $10 / 16 / 93$ & $10: 28$ & 15 & 15.62 & 187 & 299 & 511 & 531 & 944598 & 979 & 786 & 50.5 & 25.0 & 72 & 80 & 80 & 2042 & 1202878 \\
\hline GR-LNB 3 Mill e & $10 / 16 / 93$ & $1: 25$ & 29 & 15.33 & 147 & 289 & 498 & 518 & 839565 & 958 & 779 & 50.5 & 25.0 & 66 & 80 & 80 & 2012 & 1066369 \\
\hline GA-LNB 3 Mill I & $10 / 17 / 93$ & $23: 46$ & 152 & 15.06 & 148 & 286 & 495 & 515 & 801669 & 958 & 765 & 50.5 & 24.9 & 59 & 80 & 80 & 1992 & 992905 \\
\hline LNB-OFA 3 Mill & $10 / 18 / 93$ & $11: 10$ & 148 & 14.72 & 158 & 314 & 475 & 495 & 656702 & 920 & 753 & 50.5 & 25.0 & 56 & 80 & 80 & 1944 & 800074 \\
\hline GR-LNB 3 Mill g & $10 / 19 / 93$ & $15: 35$ & 18 & 14.06 & 154 & 255 & 489 & 509 & 779809 & 930 & 771 & 50.5 & 25.1 & 66 & 80 & 80 & 1987 & 982222 \\
\hline GR-LNB 3 Mill h & $10 / 20 / 93$ & $7: 35$ & 12 & 14.01 & 151 & 211 & 491 & 511 & 776541 & 953 & 780 & 50.5 & 25.3 & 54 & 80 & 80 & 1987 & 974539 \\
\hline GR-LNB 112 & $10 / 20 / 93$ & $4: 09$ & 19 & 13.94 & 169 & 234 & 490 & 510 & 738441 & 967 & 786 & 50.5 & 25.4 & 52 & 80 & 80 & 1970 & 910495 \\
\hline LNB-OFA & $10 / 20 / 93$ & $0: 56$ & 52 & 13.79 & 229 & 280 & 496 & 516 & 829004 & 961 & 793 & 50.5 & 25.4 & 55 & 80 & 80 & 2008 & 1026356 \\
\hline GR-LNB 113 & $10 / 20 / 93$ & $10: 42$ & 15 & 14.36 & 175 & 270 & 506 & 526 & 903570 & 983 & 784 & 50.5 & 25.3 & 58 & 80 & 80 & 2039 & 1138509 \\
\hline GR-LNB 113 & $10 / 21 / 93$ & $24: 00$ & 89 & 14.62 & 171 & 282 & 506 & 526 & 896565 & 992 & 779 & 50.5 & 25.3 & 63 & 80 & 80 & 2033 & 1117907 \\
\hline GR-LNB 114 & $10 / 22 / 93$ & $24: 00$ & 91 & 14.66 & 164 & 292 & 504 & 524 & 875357 & 986 & 775 & 50.5 & 25.3 & 68 & 80 & 80 & 2020 & 1086784 \\
\hline GR-LNB 115 & $10 / 23 / 93$ & $24: 00$ & 70 & 14.51 & 164 & 289 & 507 & 527 & 909758 & 987 & 778 & 50.5 & 25.3 & 70 & 80 & 80 & 2033 & 1139602 \\
\hline GR-LNB 116 & $10 / 24 / 93$ & $14: 00$ & 85 & 14.47 & 161 & 290 & 506 & 526 & 893249 & 988 & 780 & 50.5 & 25.2 & 66 & 80 & 80 & 2023 & 1114402 \\
\hline GR-LNB 116a & $10 / 24 / 93$ & $10: 00$ & 97 & 14.45 & & 289 & 507 & 527 & 910574 & 989 & 781 & 50.5 & 25.1 & $\pi$ & 80 & 80 & 2034 & 1140962 \\
\hline GR-LNB $117 a$ & $10 / 25 / 93$ & $4: 55$ & 18 & 13.53 & & 275 & 485 & 505 & 735278 & 948 & 767 & 50.5 & 25.1 & 65 & 80 & 80 & 1963 & 906400 \\
\hline GR-LNB 117 & $10 / 25 / 93$ & $19: 04$ & 65 & 14.83 & & 288 & 506 & 526 & 893753 & 993 & 774 & 50.5 & 25.3 & 62 & 80 & 80 & 2025 & 1105426 \\
\hline GR-LNB 118 & $10 / 26 / 93$ & $24: 00$ & 46 & 15.24 & & 297 & 505 & 525 & 888159 & 986 & 775 & 50.5 & 25.4 & 54 & 80 & 80 & 2023 & 1109376 \\
\hline GR-LNB 119 & $10 / 27 / 93$ & $14: 25$ & 263 & 15.35 & & 296 & 508 & 528 & 914767 & 992 & 772 & 50.5 & 25.3 & 53 & 80 & 80 & 2041 & 1141615 \\
\hline GR-LNB 119a & $10 / 27 / 93$ & $9: 34$ & & 15.57 & & 311 & 505 & 525 & 895662 & 988 & 771 & 50.5 & 25.0 & 73 & 80 & 80 & 2034 & 1121570 \\
\hline GR-LNB 120a & $10 / 28 / 93$ & $7: 21$ & & 14.92 & & 301 & 498 & 519 & 849435 & 967 & 770 & 50.5 & 24.9 & 71 & 80 & 80 & 2023 & 1064614 \\
\hline GR-LNB 120 & $10 / 28 / 93$ & $16: 38$ & 254 & 15.84 & & 300 & 506 & 526 & 896947 & 992 & 771 & 50.5 & 24.9 & 57 & 80 & 80 & 2032 & 1115740 \\
\hline GA-LNB 121 & $10 / 29 / 93$ & $24: 00$ & 203 & 15.43 & & 282 & 505 & 525 & 892054 & 992 & 767 & 50.5 & 25.2 & 33 & 80 & 80 & 2027 & 1100690 \\
\hline GR-LNB 122 & $10 / 30 / 93$ & $24: 00$ & 92 & 15.55 & & 301 & 508 & 528 & 920269 & 993 & 772 & 50.5 & 25.2 & 41 & 80 & 80 & 2039 & 1143870 \\
\hline GR-LNB 123 & $10 / 31 / 93$ & $24: 00$ & 52 & 15.29 & & 313 & 506 & 526 & 904259 & 992 & 772 & 50.5 & 25.0 & 58 & 80 & 80 & 2034 & 1122829 \\
\hline GR-LNB 124 & $11 / 1 / 93$ & $6: 18$ & & 15.53 & & 311 & 504 & 524 & 883998 & 983 & 773 & 50.5 & 25.2 & 50 & 80 & 80 & 2029 & 1106832 \\
\hline LNB-OFA & $11 / 1 / 93$ & 1.08 & & 15.44 & & 332 & 481 & 502 & 728828 & 934 & 768 & 50.5 & 25.3 & 45 & 80 & 80 & 1965 & 900387 \\
\hline GR-LNB 125a & $11 / 2 / 93$ & $8: 15$ & & 16.94 & & 325 & 506 & 526 & 903684 & 994 & 759 & 50.5 & 25.3 & 47 & 80 & 80 & 2023 & 1110101 \\
\hline LNB & $11 / 2 / 93$ & $0: 29$ & & 16.83 & & 318 & 506 & 526 & 898793 & 990 & 761 & 50.5 & 25.2 & 62 & 80 & 80 & 2020 & 1106317 \\
\hline GR-LNB 125 & $11 / 2 / 93$ & $10: 09$ & & 16.82 & & 318 & 506 & 526 & 898530 & 990 & 761 & 50.5 & 25.2 & 62 & 80 & 80 & 2020 & 1105218 \\
\hline GR-LNB 126a & $11 / 4 / 93$ & $1: 40$ & & 16.82 & & & 503 & 523 & 874776 & 985 & 763 & 50.5 & 25.0 & 50 & 80 & 80 & 2017 & 1079213 \\
\hline
\end{tabular}


Cherokee Unit 3, Average Test C

Pre Modiflcation

\begin{tabular}{|c|c|c|c|c|c|c|c|c|c|c|c|c|c|c|c|c|c|c|}
\hline Tost No & 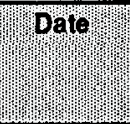 & "Dur" & raw" & חק & rox & row & "Econ! & 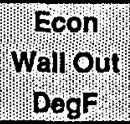 & 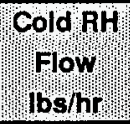 & $\begin{array}{l}\text { पhot } \\
\text { RH' } \\
\text { beg }\end{array}$ & $\begin{array}{l}\text { SH } \\
\text { Attmp } \\
\text { Deg } \\
\text { Deg }\end{array}$ & 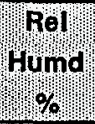 & Prosing & $\begin{array}{l}\text { Amb" } \\
\text { Demp } \\
\text { Deg }\end{array}$ & 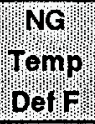 & 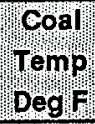 & $\begin{array}{l}\text { Econ } \\
\text { h2o prs } \\
\text { psig }\end{array}$ & सcon \\
\hline GR-LNB 126 & $11 / 4 / 93$ & $13: 29$ & & 16.44 & 173 & & 503 & 523 & 888852 & 980 & 768 & 50.5 & 25.2 & 45 & 80 & 80 & 2028 & 1111931 \\
\hline GR-LNB 127a & $11 / 5 / 93$ & $7: 20$ & & 14.50 & 158 & & 496 & 516 & 830193 & 964 & 773 & 50.5 & 25.3 & 37 & 80 & 80 & 2001 & 1043887 \\
\hline GR-LNB 127 & $11 / 5 / 93$ & $5: 54$ & & 14.27 & 167 & & 505 & 525 & 926081 & 964 & 775 & 50.5 & 25.3 & 39 & 80 & 80 & 2047 & 1186535 \\
\hline GR-LNB 128 & $11 / 8 / 93$ & $4: 55$ & 238 & 15.74 & 185 & & 506 & 526 & 902556 & 993 & 779 & 50.5 & 25.2 & 55 & 80 & 80 & 2033 & 1129743 \\
\hline GR-LNB 129 & $11 / 9 / 93$ & $8: 30$ & 213 & 15.56 & 182 & & 508 & 528 & 929341 & 991 & 779 & 50.5 & 25.3 & 62 & 80 & 80 & 2052 & 1168399 \\
\hline GR-LNB 129a & $11 / 9 / 93$ & $5: 29$ & 117 & 15.11 & 217 & & 510 & 530 & 973667 & 964 & 784 & 50.5 & 25.3 & 57 & 80 & 80 & 2075 & 1254645 \\
\hline GR-LNB 130 & $11 / 10 / 93$ & $15: 43$ & 395 & 15.53 & 198 & & 507 & 527 & 927457 & 977 & 780 & 50.5 & 25.2 & 57 & 80 & 80 & 2041 & 1175109 \\
\hline LNB & $11 / 10 / 93$ & $7: 50$ & 839 & 16.48 & 319 & & 504 & 524 & 942393 & 930 & 767 & 50.5 & 25.1 & 68 & 80 & 80 & 2050 & 1208894 \\
\hline LNB & $11 / 11 / 93$ & $2: 00$ & 246 & 15.36 & 334 & & 499 & 519 & 881764 & 932 & 766 & 50.5 & 25.0 & 51 & 80 & 80 & 2026 & 1126630 \\
\hline LNB 3 Mill a & $11 / 11 / 93$ & $3: 34$ & 918 & 15.66 & 232 & & 478 & 498 & 693531 & 912 & 756 & 50.5 & 24.9 & 65 & 80 & 80 & 1953 & 858258 \\
\hline LNB 3 Mill b & $11 / 11 / 93$ & $9: 20$ & 269 & 14.80 & 259 & 274 & 476 & 496 & 698408 & 889 & 751 & 50.5 & 24.8 & 60 & 80 & 80 & 1957 & 870796 \\
\hline LNB 3 Mill o & $11 / 12 / 93$ & $12: 30$ & 170 & 14.71 & 281 & 258 & 483 & 503 & 754027 & 901 & 757 & 50.5 & 24.6 & 46 & 80 & 80 & 1975 & 948076 \\
\hline LNB 3 Mill d & $11 / 12 / 93$ & $11: 29$ & 505 & 17.58 & 299 & 294 & 502 & 522 & 934460 & 921 & 759 & 50.5 & 24.7 & 51 & 80 & 80 & 2059 & 1202493 \\
\hline LNB 3 Mill $\theta$ & $11 / 13 / 93$ & $14: 30$ & 82 & 16.50 & 340 & 271 & 501 & 521 & 911229 & 931 & 768 & 50.5 & 24.9 & 50 & 80 & 80 & 2033 & 1168930 \\
\hline LNB 3 Millf & $11 / 13 / 93$ & $9: 29$ & 351 & 17.70 & & 304 & 503 & 523 & 936780 & 925 & 758 & 50.5 & 24.8 & 51 & 80 & 80 & 2057 & 1206649 \\
\hline LNB 3 Mill & $11 / 14 / 93$ & $24: 00$ & 192 & 17.50 & & 281 & 499 & 519 & 895562 & 931 & 764 & 50.5 & 25.1 & 41 & 80 & 80 & 2035 & 1148491 \\
\hline LNB & $11 / 15 / 93$ & $1: 39$ & 163 & 18.14 & & 282 & 501 & 521 & 907330 & 935 & 773 & 50.5 & 25.2 & 36 & 80 & 80 & 2042 & 1163600 \\
\hline GR-LNB 131 & $11 / 15 / 93$ & $13: 00$ & 18 & 15.79 & 188 & 241 & 505 & 525 & 894782 & 985 & 782 & 50.5 & 25.1 & 43 & 80 & 80 & 2033 & 1125170 \\
\hline GR-LNB 132 & $11 / 16 / 93$ & $7: 42$ & 15 & 15.93 & 175 & 255 & 501 & 521 & 864824 & 981 & 781 & 50.5 & 25.1 & 41 & 80 & 80 & 2020 & 1084106 \\
\hline GR-LNB 132a & $11 / 16 / 93$ & $16: 17$ & 12 & 13.40 & 154 & 193 & 493 & 513 & 805245 & 955 & 767 & 50.5 & 25.2 & 52 & 80 & 80 & 1990 & 1003988 \\
\hline GR-LNB 133 & $11 / 17 / 93$ & $0: 40$ & 7 & 13.40 & 140 & 204 & 490 & 510 & 773733 & 961 & 781 & 50.5 & 25.3 & 46 & 80 & 80 & 1985 & 965928 \\
\hline LNB & $11 / 17 / 93$ & $8: 40$ & 277 & 14.43 & 214 & 243 & 482 & 502 & 758497 & 891 & 750 & 50.5 & 25.3 & 44 & 80 & 80 & 1969 & 961648 \\
\hline LNB & $12 / 3 / 93$ & $5: 15$ & 321 & 16.06 & & 298 & 503 & 523 & 915010 & 930 & 774 & 50.5 & 14.3 & 53 & 80 & 80 & 2033 & 1177595 \\
\hline LNB & $12 / 6 / 93$ & $2: 33$ & 859 & 14.72 & & 274 & 472 & 492 & 675505 & 885 & 739 & 50.5 & 14.3 & 41 & 80 & 80 & 1951 & 840999 \\
\hline LNB & $12 / 6 / 93$ & 3.00 & 34 & 14.95 & & 287 & 505 & 525 & 961915 & 925 & 763 & 50.5 & 14.3 & 43 & 80 & 80 & 2053 & 1248398 \\
\hline LNB & $12 / 6 / 93$ & $1: 55$ & 10 & 14.56 & 353 & 273 & 506 & 526 & 964390 & 931 & 770 & 50.5 & 14.3 & 47 & 80 & 80 & 2046 & 1251810 \\
\hline LNB & $12 / 7 / 93$ & $6: 45$ & 178 & 16.12 & 331 & 290 & 506 & 526 & 982732 & 909 & 763 & 50.5 & 14.3 & 58 & 80 & 80 & 2077 & 1279360 \\
\hline LNB & $12 / 8 / 93$ & $4: 03$ & 43 & 15.45 & 366 & 293 & 509 & 529 & 960348 & 950 & 785 & 50.5 & 14.3 & 60 & 80 & 80 & 2047 & 1242254 \\
\hline GR-LNB 134 & $12 / 8 / 93$ & $3: 40$ & 290 & 16.19 & 168 & 293 & 509 & 529 & 960566 & 967 & 784 & 50.5 & 14.3 & 72 & 80 & 80 & 2055 & 1233704 \\
\hline GR-LNB 134a & $12 / 8 / 93$ & 0.46 & 237 & 16.58 & 210 & 323 & 507 & 527 & 965218 & 943 & 767 & 50.5 & 14.3 & 71 & 80 & 80 & 2050 & 1247447 \\
\hline GR-LNB 134b & $12 / 8 / 93$ & $2: 44$ & 839 & 17.72 & 191 & 344 & 508 & 528 & 958599 & 966 & 775 & 50.5 & 14.3 & 71 & 80 & 80 & 2050 & 1231152 \\
\hline GR-LNB $134 c$ & $12 / 8 / 93$ & $3: 31$ & 999 & 18.25 & 178 & 351 & 511 & 531 & 960391 & 985 & 768 & 50.5 & 14.3 & 66 & 80 & 80 & 2051 & 1206368 \\
\hline GR-LNB 135 & $12 / 9 / 93$ & $12: 00$ & 866 & 17.67 & 175 & 330 & 503 & 523 & 886318 & 980 & 761 & 50.5 & 14.3 & 61 & 80 & 80 & 2025 & 1101725 \\
\hline GR-LNB 135a & $12 / 9 / 93$ & $2: 59$ & 378 & 16.98 & 198 & 300 & 509 & 529 & 926560 & 986 & 778 & 50.5 & 14.3 & 70 & 80 & 80 & 2036 & 1159006 \\
\hline GR-LNB 135b & $12 / 9 / 93$ & $7: 10$ & 25 & 15.32 & 225 & 238 & 498 & 518 & 876032 & 919 & 771 & 50.5 & 14.3 & 64 & 80 & 80 & 2020 & 1120113 \\
\hline GR-LNB 136 & $12 / 10 / 93$ & $11: 35$ & 84 & 15.66 & 214 & 251 & 502 & 522 & 902290 & 935 & 777 & 50.5 & 14.3 & 61 & 80 & 80 & 2036 & 1158928 \\
\hline GR-LNB 137 & $12 / 11 / 93$ & $16: 15$ & 120 & 15.68 & 195 & 280 & 499 & 519 & 857776 & 951 & 773 & 50.5 & 14.3 & 58 & 80 & 80 & 2009 & 1084228 \\
\hline GR-LNB 137a & $12 / 11 / 93$ & $7: 44$ & & 15.52 & 213 & 297 & 510 & 530 & 967143 & 959 & 781 & 50.5 & 14.3 & 60 & 80 & 80 & 2071 & 1249054 \\
\hline GR-LNB 138 & $12 / 12 / 93$ & $24: 00$ & & 15.45 & 212 & 277 & 511 & 531 & 973075 & 958 & 783 & 50.5 & 14.3 & 59 & 80 & 80 & 2074 & 1255267 \\
\hline GR-LNB 139 & $12 / 13 / 93$ & $7: 48$ & & 16.17 & 195 & 247 & 512 & 532 & 969476 & 981 & 780 & 50.5 & 14.3 & 47 & 80 & 80 & 2082 & 1245991 \\
\hline
\end{tabular}


Cherokee Unit 3, Average Test C

Pre Modification

\begin{tabular}{|c|c|c|c|c|c|c|c|c|c|c|c|c|c|c|c|c|c|c|}
\hline אosp & Date & pur & $\begin{array}{l}\text { com } \\
\text { raw } \\
\text { ppm }\end{array}$ & $\begin{array}{l}\mathrm{co}_{2} \\
\text { ray }\end{array}$ & Nox & so2 & "Econ & $\begin{array}{l}\text { Econ } \\
\text { Wall out } \\
\text { DegF }\end{array}$ & 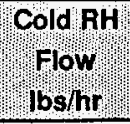 & $\begin{array}{l}\text { hot } \\
\text { Rert: } \\
\text { DegF }\end{array}$ & 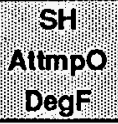 & "rel" & $\begin{array}{l}\text { Amb } \\
\text { press } \\
\text { pha A }\end{array}$ & 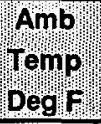 & पemp & $\begin{array}{l}\text { coaply } \\
\text { Temp } \\
\text { Dege }\end{array}$ & 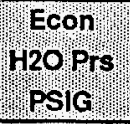 & Hasp \\
\hline GR-LNB 139a & $12 / 13 / 93$ & $4: 18$ & 177 & 16.04 & 190 & 231 & 512 & 532 & 959305 & .984 & 782 & 50.5 & 14.3 & 47 & 80 & 80 & 2061 & 1231245 \\
\hline LNB & $12 / 13 / 93$ & $5: 18$ & 57 & 15.72 & 327 & 286 & 505 & 525 & 932560 & 935 & 756 & 50.5 & 14.3 & 53 & 80 & 80 & 2053 & 1180972 \\
\hline LNB-OFA & $12 / 14 / 93$ & $1: 55$ & 15 & 14.83 & 198 & 285 & 511 & 531 & 969707 & 957 & 780 & 50.5 & 14.3 & 52 & 80 & 80 & 2076 & 1257184 \\
\hline GR-LNB 140 & $12 / 14 / 93$ & $1: 18$ & 833 & 15.96 & 196 & 298 & 510 & 530 & 964012 & 983 & 775 & 50.5 & 14.3 & 63 & 80 & 80 & 2070 & 1242405 \\
\hline LNB & $12 / 14 / 93$ & $8: 30$ & 171 & 16.53 & 285 & 308 & 506 & 526 & 955330 & 943 & 768 & 50.5 & 14.3 & 55 & 80 & 80 & 2069 & 1236159 \\
\hline LNB & $12 / 15 / 93$ & $9: 28$ & 17 & 15.63 & 315 & 282 & 505 & 525 & 947026 & 936 & 769 & 50.5 & 14.3 & 40 & 80 & 80 & 2062 & 1226517 \\
\hline LNB-OFA & $12 / 15 / 93$ & $5: 29$ & 122 & 15.17 & 261 & 277 & 507 & 527 & 959812 & 934 & 776 & 50.5 & 14.3 & 43 & 80 & 80 & 2068 & 1247848 \\
\hline GR-LNB 141 & $12 / 15 / 93$ & $5: 15$ & 449 & 15.61 & 188 & 274 & 493 & 512 & 866460 & 936 & 768 & 50.5 & 14.3 & 43 & 80 & 80 & 2025 & 1081017 \\
\hline LNB & $12 / 15 / 93$ & $2: 50$ & 18 & 13.38 & 290 & 227 & 454 & 474 & 592909 & 944 & 766 & 50.5 & 14.3 & 40 & 80 & 80 & 1691 & 690629 \\
\hline LNB & $12 / 16 / 93$ & $15: 05$ & 420 & 15.38 & 317 & 268 & 486 & 506 & 929122 & 950 & 776 & 50.5 & 14.3 & 37 & 80 & 80 & 2043 & 1138641 \\
\hline GR-LNB 142 & $12 / 16 / 93$ & $6: 14$ & 637 & 15.46 & 207 & 254 & 493 & 513 & 993458 & 975 & 787 & 50.5 & 14.3 & 37 & 80 & 80 & 2068 & 1219253 \\
\hline GR-LNB 142a & $12 / 16 / 93$ & $1: 15$ & 768 & 14.84 & 154 & 234 & 466 & 486 & 682221 & 927 & 767 & 50.5 & 14.3 & 40 & 80 & 80 & 1939 & 821732 \\
\hline GR-LNB 143 & $12 / 17 / 93$ & $2: 10$ & 742 & 14.36 & 150 & 229 & 464 & 484 & 662344 & 942 & 764 & 50.5 & 14.3 & 39 & 80 & 80 & 1945 & 785103 \\
\hline LNB-OFA & $12 / 17 / 93$ & $0: 40$ & 9 & 10.75 & 333 & 169 & 422 & 442 & 370078 & 832 & 715 & 50.5 & 14.3 & 41 & 80 & 80 & 1861 & 446786 \\
\hline LNB & $12 / 17 / 93$ & $6: 10$ & 347 & 15.98 & 298 & 285 & 489 & 509 & 957819 & 961 & 779 & 50.5 & 14.3 & 38 & 80 & 80 & 2039 & 1174380 \\
\hline LNB & $12 / 20 / 93$ & $2: 25$ & 186 & 14.91 & 310 & 274 & 484 & 504 & 842268 & 959 & 789 & 50.5 & 14.3 & 35 & 80 & 80 & 1977 & 1021855 \\
\hline $100 \%$ Gas Firing & $12 / 20 / 93$ & 0.34 & 15 & 8.27 & 102 & 39 & 448 & 468 & 561119 & 910 & 769 & 50.5 & 14.3 & 39 & 80 & 80 & 1844 & 645929 \\
\hline LNB & $12 / 22 / 93$ & $2: 35$ & 434 & 14.53 & 270 & 224 & 477 & 497 & 783556 & 941 & 784 & 50.5 & 14.3 & 44 & 80 & 80 & 1983 & 944581 \\
\hline LNB & $1 / 5 / 94$ & $2: 24$ & 142 & 16.42 & 334 & 297 & 489 & 509 & 942168 & 955 & 778 & 50.5 & 14.3 & 68 & 80 & 80 & 2055 & 1158414 \\
\hline LNB-OFA & $1 / 5 / 94$ & $2: 26$ & 688 & 15.80 & 285 & 276 & 489 & 509 & 948672 & 942 & 781 & 50.5 & 14.3 & 67 & 80 & 80 & 2049 & 1168027 \\
\hline LNB-OFA & $1 / 5 / 94$ & $9: 15$ & 830 & 15.74 & 232 & 298 & 478 & 498 & 827853 & 935 & 772 & 50.5 & 14.3 & 54 & 80 & 80 & 1999 & 1009498 \\
\hline LNB-OFA & $1 / 6 / 94$ & $8: 47$ & 924 & 15.21 & 194 & 286 & 457 & 477 & 636605 & 918 & 751 & 50.5 & 14.3 & 49 & 80 & 80 & 1942 & 758069 \\
\hline LNB & $1 / 6 / 94$ & $15: 12$ & 475 & 16.49 & 286 & 304 & 489 & 509 & 929193 & 962 & 780 & 50.5 & 14.3 & 43 & 80 & 80 & 2038 & 1139017 \\
\hline LNB & $1 / 7 / 94$ & $6: 55$ & 552 & 16.19 & 229 & 301 & 472 & 492 & 761517 & 931 & 765 & 50.5 & 14.3 & 30 & 80 & 80 & 1975 & 920629 \\
\hline LNB-OFA & $1 / 7 / 94$ & 1.09 & 793 & 15.66 & 179 & 287 & 477 & 496 & 786503 & 942 & 768 & 50.5 & 14.3 & 36 & 80 & 80 & 1971 & 942272 \\
\hline GR-LNB 144 & $1 / 7 / 94$ & $15: 40$ & 815 & 15.63 & 188 & 273 & 489 & 509 & 891406 & 978 & 776 & 50.5 & 14.3 & 53 & 80 & 80 & 2021 & 1074773 \\
\hline GR-LNB 145a & $1 / 8 / 94$ & $8: 20$ & 886 & 15.76 & 156 & 271 & 480 & 500 & 792116 & 971 & 756 & 50.5 & 14.3 & 51 & 80 & 80 & 1986 & 930650 \\
\hline GR-LNB 145 & $1 / 8 / 94$ & $15: 39$ & 997 & 16.31 & 176 & 283 & 493 & 513 & 928565 & 990 & 759 & 50.5 & 14.3 & 51 & 80 & 80 & 2037 & 1096957 \\
\hline GR-LNB 146a & $1 / 9 / 94$ & 2:10 & 1000 & 16.42 & 160 & 287 & 491 & 511 & 903039 & 991 & 729 & 50.5 & 14.3 & 42 & 80 & 80 & 2018 & 1041872 \\
\hline GR-LNB $146 \mathrm{~b}$ & 1/9/94 & $8: 39$ & 919 & 15.46 & 150 & 264 & 477 & 497 & 722449 & 984 & 744 & 50.5 & 14.3 & 44 & 80 & 80 & 1958 & 819845 \\
\hline GR-LNB 146 & $1 / 9 / 94$ & 9:02 & 838 & 15.33 & 187 & 256 & 487 & 507 & 863592 & 984 & 768 & 50.5 & 14.3 & 51 & 80 & 80 & 2012 & 1023610 \\
\hline LNB & $1 / 9 / 94$ & $3: 35$ & 765 & 15.52 & 206 & 268 & 469 & 489 & 749786 & 912 & 755 & 50.5 & 14.3 & 48 & 80 & 80 & 1968 & 913339 \\
\hline LNB & $1 / 10 / 94$ & $3: 50$ & 673 & 15.65 & 218 & 273 & 481 & 501 & 824039 & 968 & 762 & 50.5 & 14.3 & 46 & 80 & 80 & 2001 & 982931 \\
\hline GR-LNB 147 & $1 / 10 / 94$ & $2: 40$ & 762 & 15.63 & 205 & 268 & 495 & 515 & 981185 & 982 & 787 & 50.5 & 14.3 & 54 & 80 & 80 & 2052 & 1199787 \\
\hline GA-LNB 147a & $1 / 10 / 94$ & $4: 04$ & 322 & 14.62 & 170 & 244 & 476 & 496 & 774915 & 948 & 769 & 50.5 & 14.3 & 53 & 80 & 80 & 1973 & 934278 \\
\hline GA-LNB 1476 & $1 / 10 / 94$ & $4: 54$ & 186 & 14.43 & 175 & 232 & 477 & 497 & 780534 & 945 & 771 & 50.5 & 14.3 & 47 & 80 & 80 & 1974 & 938847 \\
\hline GR-LNB 148a & $1 / 11 / 94$ & $6: 32$ & 41 & 13.77 & 174 & 224 & 470 & 490 & 687297 & 957 & 778 & 50.5 & 14.3 & 42 & 80 & 80 & 1943 & 812438 \\
\hline GR-LNB 148 & $1 / 11 / 94$ & $14: 38$ & 511 & 15.35 & 217 & 255 & 492 & 512 & 975550 & 955 & 784 & 50.5 & 14.3 & 55 & 80 & 80 & 2058 & 1202950 \\
\hline GR-LNB 148b & $1 / 11 / 94$ & $2: 48$ & 373 & 15.15 & 174 & 254 & 474 & 494 & 808167 & 900 & 757 & 50.5 & 14.3 & 55 & 80 & 80 & 1981 & 986733 \\
\hline GA-LNB 149a & $1 / 12 / 94$ & $6: 14$ & 408 & 15.21 & 193 & 245 & 483 & 503 & 842118 & 961 & 785 & 50.5 & 14.3 & 48 & 80 & 80 & 1997 & 1021819 \\
\hline
\end{tabular}


Cherokee Unit 3, Average Test C

Pre Modification

\begin{tabular}{|c|c|c|c|c|c|c|c|c|c|c|c|c|c|c|c|c|c|c|}
\hline Tost & Dato & purm & popy & row & nox & rap & $\begin{array}{l}\text { Econ } \\
\text { ne H2O } \\
\text { DegF }\end{array}$ & 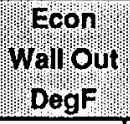 & Cold RH & $\begin{array}{l}\text { hot } \\
\text { RegF } \\
\text { DegF }\end{array}$ & $\begin{array}{l}\text { SH } \\
\text { Atmp } \\
\text { Degf }\end{array}$ & 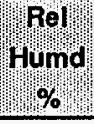 & $\begin{array}{l}\text { Amb: } \\
\text { Press } \\
\text { Whg }\end{array}$ & $\begin{array}{l}\text { Amb } \\
\text { Temp } \\
\text { Deg F }\end{array}$ & $\begin{array}{l}\text { Na } \\
\text { Domp } \\
\text { Dof F }\end{array}$ & $\begin{array}{l}\text { coal } \\
\text { Tomp } \\
\text { Deg F }\end{array}$ & $\begin{array}{l}\text { Econ } \\
\text { (2o prs } \\
\text { pslg }\end{array}$ & (Ecor \\
\hline GR-LNB 149 & $1 / 12 / 94$ & 13:30 & 521 & 15.32 & 206 & 248 & 488 & 508 & 902397 & 964 & 783 & 50.5 & 14.3 & 52 & 80 & 80 & 2023 & 1100096 \\
\hline GP-LNB A Mill off & $1 / 12 / 94$ & 1.09 & 680 & 15.40 & 194 & 251 & 485 & 505 & 820001 & 984 & 769 & 50.5 & 14.3 & 53 & 80 & 80 & 1974 & 958837 \\
\hline GR-LNB D Mill off & $1 / 12 / 94$ & $1: 39$ & 791 & 16.10 & 159 & 264 & 488 & 508 & 852270 & 986 & 761 & 50.5 & 14.3 & 54 & 80 & 80 & 2007 & 997742 \\
\hline GA.LNB D Mill off line & $1 / 13 / 94$ & $4: 23$ & 820 & 15.55 & 132 & 255 & 469 & 489 & 675626 & 961 & 735 & 50.5 & 14.3 & 55 & 80 & 80 & 1936 & 770077 \\
\hline GP.LNB 150 & $1 / 13 / 94$ & $7: 15$ & 991 & 15.89 & 194 & 272 & 496 & 516 & 960179 & 994 & 768 & 50.5 & 14.3 & 59 & 80 & 80 & 2044 & 1146067 \\
\hline GR-LNB D Mill off line & $1 / 13 / 94$ & $1: 13$ & 957 & 16.02 & 151 & 277 & 489 & 509 & 852250 & 1000 & 744 & 50.5 & 14.3 & 60 & 80 & 80 & 1993 & 978561 \\
\hline GR-LNB 150a & $1 / 13 / 94$ & $6: 00$ & 589 & 15.32 & 177 & 257 & 484 & 504 & 853029 & 960 & 774 & 50.5 & 14.3 & 59 & 80 & 80 & 2007 & 1029683 \\
\hline GR-LNB 151a & $1 / 14 / 94$ & $7: 25$ & 187 & 14.48 & 160 & 243 & 466 & 486 & 682966 & 925 & 761 & 50.5 & 14.3 & 59 & 80 & 80 & 1944 & 813316 \\
\hline GR-LNB, ABC & $1 / 14 / 94$ & $7: 50$ & 983 & 15.87 & 156 & 272 & 486 & 506 & 825014 & 985 & 746 & 50.5 & 14.3 & 64 & 80 & 80 & 1987 & 956780 \\
\hline GR-LNB 151 & $1 / 14 / 94$ & $7: 54$ & 592 & 15.89 & 182 & 269 & 484 & 504 & 830754 & 975 & 767 & 50.5 & 14.3 & 62 & 80 & 80 & 1996 & 981919 \\
\hline GR-LNB 156 & $1 / 19 / 94$ & $24: 00$ & 610 & 15.46 & 163 & 292 & 473 & 493 & 739252 & 948 & 765 & 50.5 & 14.3 & 63 & 80 & 80 & 1964 & 881044 \\
\hline GR-LNB 157a & $1 / 20 / 94$ & $6: 38$ & 469 & 15.88 & 153 & 295 & 473 & 493 & 706935 & 966 & 756 & 50.5 & 14.3 & 38 & 80 & 80 & 1946 & 822271 \\
\hline GR-LNB 157 & $1 / 20 / 94$ & $3: 50$ & 654 & 16.04 & 182 & 311 & 493 & 513 & 904599 & 993 & 762 & 50.5 & 14.3 & 38 & 80 & 80 & 2021 & 1058977 \\
\hline
\end{tabular}




\section{Pre Modification}

\begin{tabular}{|c|c|c|c|c|c|c|c|c|c|c|c|c|c|c|c|c|c|}
\hline Test & Date: & pur & $\begin{array}{l}\text { prum } \\
\text { Press } \\
\text { Psic }\end{array}$ & $\begin{array}{l}\text { Psh } \\
\text { owit } \\
\text { psic }\end{array}$ & $\begin{array}{l}\text { Sheam } \\
\text { To Turb } \\
\text { Psic }\end{array}$ & $\begin{array}{l}\text { RH } \\
\text { Press } \\
\text { PSIG }\end{array}$ & $\begin{array}{l}\text { RH } \\
\text { Temp } \\
\text { Deg F }\end{array}$ & $\begin{array}{l}\text { Hot RH } \\
\text { OutPrs } \\
\text { PSIG }\end{array}$ & $\begin{array}{l}\text { PryGas } \\
\text { fulss } \\
\% \%\end{array}$ & $\begin{array}{l}\text { Moist } \\
\text { Huss } \\
\text { P.s. }\end{array}$ & CombH2O & Pefuse & $\begin{array}{l}\text { Radiat } \\
\text { ftrss } \\
\%\end{array}$ & Unmeas & $\begin{array}{l}\text { Total } \\
\text { fitss } \\
\text { \% }\end{array}$ & $\begin{array}{l}\text { Comb } \\
\text { Arr } \\
\text { Temp }\end{array}$ & $\begin{array}{l}\text { Econ } \\
\text { Gas out } \\
\text { Temp }\end{array}$ \\
\hline Base Cond. (OFA off) & $11 / 11 / 92$ & $8: 42$ & 1905 & 1860 & 1815 & 280 & 590 & 271 & 7.26 & 1.11 & 4.27 & 0.61 & 0.35 & 1.31 & 14.91 & 80 & 658 \\
\hline GR & $11 / 11 / 92$ & 1:01 & 2010 & 1918 & 1826 & 438 & 660 & 424 & 6.29 & 0.88 & 5.57 & 0.48 & 0.20 & 0.83 & 14.24 & 80 & 719 \\
\hline Base Cond. (OFA off) & $11 / 11 / 92$ & $4: 25$ & 2006 & 1915 & 1821 & 430 & 639 & 413 & 5.90 & 1.11 & 4.26 & 0.61 & 0.19 & 0.81 & 12.87 & 80 & 703 \\
\hline Base Cond. OFA off & $11 / 12 / 92$ & $0: 45$ & 2011 & 1918 & 1826 & 433 & 619 & 420 & 4.50 & 1.10 & 4.24 & 0.61 & 0.18 & 0.79 & 11.42 & 80 & 686 \\
\hline BPMS GR 4 & $11 / 1292$ & 1:05 & 2007 & 1916 & 1824 & 435 & 664 & 420 & 4.76 & 0.89 & 5.50 & 0.49 & 0.20 & 0.84 & 12.68 & 80 & 726 \\
\hline Base Cond. OFA off & $11 / 12 / 92$ & 1:15 & 2008 & 1916 & 1823 & 429 & 637 & 412 & 5.01 & 1.11 & 4.26 & 0.61 & 0.19 & 0.81 & 11.98 & 80 & 708 \\
\hline BPMS Base Cond. 5 & $11 / 13 / 92$ & $2: 55$ & 2013 & 1919 & 1825 & 437 & 649 & 421 & 5.06 & 1.11 & 4.25 & 0.61 & 0.19 & 0.80 & 12.02 & 80 & 702 \\
\hline BPMS Base Cond. 6 & $11 / 13 / 92$ & $1: 00$ & 2015 & 1920 & 1824 & 430 & 619 & 410 & 4.92 & 1.10 & 4.25 & 0.61 & 0.18 & 0.78 & 11.83 & 80 & 693 \\
\hline BPMS Base Cond. 7 & $11 / 13 / 92$ & $1: 00$ & 2019 & 1922 & 1825 & 431 & 612 & 409 & 4.85 & 1.11 & 4.25 & 0.61 & 0.17 & 0.76 & 11.75 & 80 & 691 \\
\hline Base Cond.-1d & $11 / 16 / 92$ & $1: 00$ & 1985 & 1904 & 1824 & 400 & 640 & 383 & 5.05 & 1.11 & 4.26 & 0.61 & 0.22 & 0.91 & 12.15 & 80 & 686 \\
\hline GR-10c & $11 / 16 / 92$ & $1: 00$ & 2003 & 1913 & 1823 & 414 & 608 & 391 & 4.81 & 1.11 & 4.26 & 0.61 & 0.19 & 0.81 & 11.78 & 80 & 684 \\
\hline GR-10d & $11 / 16 / 92$ & 1:00 & 2005 & 1916 & 1825 & 413 & 608 & 389 & 4.88 & 1.11 & 4.26 & 0.61 & 0.19 & 0.81 & 11.85 & 80 & 686 \\
\hline Base Cond. OFA off & $11 / 17 / 92$ & 1:15 & 2009 & 1918 & 1826 & 429 & 636 & 411 & 4.79 & 1.10 & 4.24 & 0.61 & 0.19 & 0.80 & 11.73 & 80 & 706 \\
\hline GR-11c & $11 / 17 / 92$ & $1: 00$ & 2000 & 1912 & 1825 & 416 & 655 & 395 & 4.71 & 0.88 & 5.60 & 0.48 & 0.21 & 0.86 & 12.74 & 80 & 713 \\
\hline GA-11d & $11 / 17 / 92$ & $1: 00$ & 1996 & 1910 & 1824 & 412 & 656 & 390 & 4.83 & 0.87 & 5.62 & 0.48 & 0.21 & 0.88 & 12.89 & 80 & 715 \\
\hline Base Cond. OFA off & $11 / 17 / 92$ & $0: 20$ & 1990 & 1905 & 1823 & 401 & 636 & 378 & 5.44 & 1.11 & 4.27 & 0.61 & 0.22 & 0.90 & 12.54 & 80 & 711 \\
\hline Base Cond. OFA off & $11 / 18 / 92$ & $0: 28$ & 2003 & 1913 & 1825 & 419 & 626 & 404 & 4.41 & 1.10 & 4.23 & 0.61 & 0.20 & 0.84 & 11.39 & 80 & 694 \\
\hline GR-110 & $11 / 18 / 92$ & $1: 04$ & 2001 & 1913 & 1825 & 422 & 659 & 406 & 4.80 & 0.87 & 5.60 & 0.48 & 0.21 & 0.87 & 12.83 & 80 & 725 \\
\hline GA-12b & $11 / 18 / 92$ & 1:05 & 2000 & 1912 & 1825 & 417 & 650 & 399 & 4.89 & 0.93 & 5.29 & 0.51 & 0.21 & 0.87 & 12.70 & 80 & 721 \\
\hline Base Cond. OFA off & $11 / 18 / 92$ & $0: 35$ & 1993 & 1909 & 1821 & 411 & 636 & 393 & 5.11 & 1.11 & 4.27 & 0.61 & 0.21 & 0.87 & 12.17 & 80 & 713 \\
\hline GR-12 (5\% Gas) & 11/19/92 & $1: 00$ & 2007 & 1915 & 1823 & 422 & 622 & 404 & 4.52 & 1.04 & 4.58 & 0.58 & 0.19 & 0.81 & 11.72 & 80 & 697 \\
\hline GR-12a (10\% Gas) & $11 / 19 / 92$ & $1: 00$ & 2006 & 1915 & 1824 & 422 & 654 & 402 & 4.48 & 0.99 & 4.91 & 0.55 & 0.20 & 0.84 & 11.96 & 80 & 702 \\
\hline GR-120 (23\% Gas) & $11 / 19 / 92$ & $1: 00$ & 1993 & 1908 & 1824 & 411 & 661 & 390 & 4.65 & 0.85 & 5.77 & 0.47 & 0.22 & 0.91 & 12.86 & 80 & 716 \\
\hline Base Cond. OFA off & $11 / 19 / 92$ & $0: 20$ & 1988 & 1904 & 1818 & 404 & 644 & 383 & 4.97 & 1.10 & 4.25 & 0.61 & 0.21 & 0.89 & 12.04 & 80 & 703 \\
\hline GR-13A; 18\% Gas & $11 / 20 / 92$ & $0: 58$ & 2000 & 1913 & 1825 & 417 & 657 & 401 & 4.37 & 0.90 & 5.44 & 0.50 & 0.21 & 0.88 & 12.28 & 80 & 712 \\
\hline GR-13D; 18\% Gas & $11 / 20 / 92$ & $1: 00$ & 1994 & 1909 & 1824 & 414 & 661 & 398 & 4.56 & 0.90 & 5.45 & 0.50 & 0.22 & 0.90 & 12.52 & 80 & 724 \\
\hline GR-148; $20 \%$ Gas & $11 / 20 / 92$ & $1: 00$ & 1994 & 1909 & 1824 & 414 & 664 & 399 & 4.68 & 0.88 & 5.57 & 0.48 & 0.22 & 0.91 & 12.73 & 80 & 725 \\
\hline Base Cond. OFA off & $11 / 30 / 92$ & $1: 50$ & 1987 & 1903 & 1819 & 419 & 646 & 402 & 4.92 & 1.11 & 4.26 & 0.61 & 0.20 & 0.84 & 11.94 & 80 & 697 \\
\hline GR-BFr & $11 / 30 / 92$ & $0: 26$ & 1987 & 1904 & 1820 & 417 & 652 & 397 & 5.07 & 0.99 & 4.94 & 0.54 & 0.20 & 0.85 & 12.59 & 80 & 719 \\
\hline GR-BFI & $11 / 30 / 92$ & 0.27 & 1986 & 1903 & 1821 & 412 & 642 & 392 & 5.01 & 0.99 & 4.92 & 0.55 & 0.20 & 0.86 & 12.53 & 80 & 708 \\
\hline GR-21C & $12 / 1 / 92$ & 1:06 & 1923 & 1870 & 1816 & 325 & 626 & 312 & 4.72 & 0.87 & 5.59 & 0.48 & 0.31 & 1.18 & 13.16 & 80 & 686 \\
\hline GA-22 & $12 / 1 / 92$ & $0: 50$ & 1922 & 1868 & 1814 & 323 & 586 & 309 & 4.98 & 1.01 & 4.76 & 0.56 & 0.30 & 1.15 & 12.76 & 80 & 679 \\
\hline Bias Firing & $12 / 1 / 92$ & $0: 10$ & 1925 & 1871 & 1819 & 320 & 615 & 306 & 4.51 & 0.86 & 5.62 & 0.48 & 0.31 & 1.17 & 12.95 & 80 & 684 \\
\hline Base Cond. OFA on & $12 / 1 / 92$ & $0: 50$ & 1925 & 1870 & 1815 & 325 & 570 & 312 & 4.45 & 1.10 & 4.23 & 0.61 & 0.30 & 1.13 & 11.81 & 80 & 661 \\
\hline Base Cond. OFA off & $12 / 1 / 92$ & $0: 40$ & 1941 & 1879 & 1816 & 349 & 621 & 335 & 4.76 & 1.10 & 4.24 & 0.61 & 0.28 & 1.08 & 12.07 & 80 & 681 \\
\hline Base Cond. OFA off & $12 / 2 / 92$ & $3: 55$ & 1981 & 1899 & 1817 & 413 & 635 & 401 & 4.72 & 1.10 & 4.24 & 0.61 & 0.21 & 0.87 & 11.76 & 80 & 699 \\
\hline Base Cond. OFA off & $12 / 4 / 92$ & $0: 55$ & 1932 & 1874 & 1815 & 335 & 612 & 332 & 4.64 & 1.10 & 4.23 & 0.61 & 0.29 & 1.12 & 11.99 & 80 & 671 \\
\hline OFA Test & $12 / 4 / 92$ & 2:10 & 1917 & 1866 & 1814 & 312 & 602 & 309 & 4.57 & 1.10 & 4.22 & 0.61 & 0.32 & 1.20 & 12.01 & 80 & 670 \\
\hline Base Cond. OFA off & $12 / 7 / 92$ & 2:10 & 1931 & 1871 & 1811 & 336 & 626 & 325 & 4.77 & 1.10 & 4.23 & 0.61 & 0.29 & 1.12 & 12.12 & 80 & 681 \\
\hline GR-22A & $12 / 7 / 92$ & $1: 05$ & 1927 & 1869 & 1811 & 328 & 625 & 315 & 4.70 & 0.98 & 4.97 & 0.54 & 0.30 & 1.14 & 12.62 & 80 & 698 \\
\hline
\end{tabular}


Cherokee Unit 3, Average Test [

Pre Modification

\begin{tabular}{|c|c|c|c|c|c|c|c|c|c|c|c|c|c|c|c|c|c|}
\hline 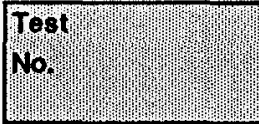 & חpantem & Durp & prum) & $\begin{array}{l}\text { PSH } \\
\text { OpsI }\end{array}$ & $\begin{array}{l}\text { Sterm } \\
\text { forturb } \\
\text { Psig }\end{array}$ & RHYln & $\begin{array}{l}\text { RH In } \\
\text { Demp } \\
\text { Deg }\end{array}$ & $\begin{array}{l}\text { Hot RH } \\
\text { outprsp } \\
\text { PSIG }\end{array}$ & DryGas & Moist & Combriş & Refuse & Radiat: & Unmoas & Total" & 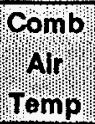 & $\begin{array}{l}\text { Econ } \\
\text { Gaspout } \\
\text { Tempemp. }\end{array}$ \\
\hline GA-22B & $12 / 7 / 92$ & $1: 00$ & 1927 & 1870 & 1813 & 324 & 625 & 310 & 4.68 & 0.93 & 5.24 & 0.51 & 0.30 & 1.16 & 12.83 & 80 & 702 \\
\hline GR-22C. & $12 / 7 / 92$ & 1.00 & 1926 & 1869 & 1812 & 325 & 625 & 312 & 4.70 & 0.87 & 5.58 & 0.48 & 0.31 & 1.16 & 13.11 & 80 & 704 \\
\hline Base Cond. OFA off & $12 / 8 / 92$ & $0: 27$ & 1881 & 1844 & 1808 & 250 & 583 & 242 & 4.83 & 1.11 & 4.25 & 0.61 & 0.38 & 1.39 & 12.56 & 80 & 656 \\
\hline GR-31C & $12 / 8 / 92$ & $1: 00$ & 1882 & 1845 & 1808 & 252 & 595 & 241 & 4.83 & 0.87 & 5.61 & 0.48 & 0.38 & 1.39 & 13.56 & 80 & 679 \\
\hline GR-31F & $12 / 8 / 92$ & $1: 23$ & 1881 & 1844 & 1806 & 252 & 595 & 240 & 5.22 & 0.87 & 5.61 & 0.48 & 0.38 & 1.39 & 13.96 & 80 & 690 \\
\hline GR-32A & $12 / 8 / 92$ & $1: 00$ & 1886 & 1848 & 1810 & 247 & 590 & 235 & 4.82 & 0.98 & 4.96 & 0.54 & 0.38 & 1.38 & 13.06 & 80 & 677 \\
\hline Base Cond. OFA off & $12 / 9 / 92$ & $0: 41$ & 1891 & 1851 & 1810 & 244 & 583 & 227 & 4.65 & 1.11 & 4.25 & 0.61 & 0.37 & 1.36 & 12.34 & 80 & 661 \\
\hline GR-32C & $12 / 9 / 92$ & $1: 00$ & 1885 & 1848 & 1810 & 235 & 588 & 217 & 5.27 & 0.88 & 5.61 & 0.48 & 0.39 & 1.41 & 14.03 & 80 & 684 \\
\hline GR-32C; 3Milis & $12 / 9 / 92$ & $0: 56$ & 1889 & 1849 & 1810 & 242 & 591 & 222 & 4.81 & 0.87 & 5.59 & 0.48 & 0.38 & 1.38 & 13.51 & 80 & 687 \\
\hline Base Cond. OFA off & $12 / 9 / 92$ & $0: 15$ & 1899 & 1857 & 1810 & 255 & 597 & 233 & 5.29 & 1.11 & 4.25 & 0.61 & 0.36 & 1.32 & 12.94 & 80 & 689 \\
\hline Base Cond. OFA off & $12 / 14 / 92$ & $2: 00$ & 1962 & 1891 & 1821 & 377 & 624 & 367 & 4.67 & 1.10 & 4.22 & 0.61 & 0.25 & 0.99 & 11.84 & 80 & 687 \\
\hline GR-12Z & $12 / 14 / 92$ & 1.02 & 1997 & 1911 & 1824 & 413 & 639 & 397 & 4.62 & 1.04 & 4.57 & 0.58 & 0.20 & 0.85 & 11.86 & 80 & 706 \\
\hline GR $2.7 \%$ Gas & $12 / 14 / 92$ & $0: 17$ & 1996 & 1910 & 1824 & 413 & 640 & 398 & 4.66 & 1.07 & 4.39 & 0.59 & 0.20 & 0.86 & 11.77 & 80 & 709 \\
\hline Base Cond. OFA off & $12 / 15 / 92$ & $1: 37$ & 1988 & 1906 & 1823 & 403 & 622 & 387 & 4.66 & 1.10 & 4.24 & 0.61 & 0.21 & 0.88 & 11.71 & 80 & 696 \\
\hline GR $20 \%$ Gas & $12 / 15 / 92$ & $0: 36$ & 1999 & 1913 & 1829 & 411 & 653 & 393 & 4.42 & 0.88 & 5.48 & 0.49 & 0.21 & 0.87 & 12.35 & 80 & 708 \\
\hline Base Cond. OFA off & $12 / 16 / 92$ & $0: 48$ & 1995 & 1910 & 1825 & 411 & 621 & 397 & 4.55 & 1.10 & 4.22 & 0.61 & 0.20 & 0.86 & 11.54 & 80 & 694 \\
\hline GR-12A1 & $12 / 16 / 92$ & $2: 19$ & 2006 & 1917 & 1828 & 420 & 638 & 405 & 4.44 & 0.98 & 4.88 & 0.55 & 0.20 & 0.83 & 11.87 & 80 & 705 \\
\hline Test C1 & $1 / 15 / 93$ & $1: 00$ & 2005 & 1914 & 1823 & 417 & 654 & 397 & 4.67 & 1.02 & 4.72 & 0.56 & 0.20 & 0.85 & 12.01 & 80 & 707 \\
\hline Test C2 & $1 / 15 / 93$ & $1: 00$ & 2006 & 1915 & 1824 & 417 & 660 & 394 & 4.76 & 0.97 & 5.03 & 0.53 & 0.20 & 0.86 & 12.36 & 80 & 715 \\
\hline Test C3 & $1 / 15 / 93$ & $0: 58$ & 2005 & 1915 & 1824 & 416 & 662 & 391 & 4.77 & 0.92 & 5.35 & 0.51 & 0.21 & 0.86 & 12.61 & 80 & 716 \\
\hline Tost C4 & $1 / 15 / 93$ & $0: 50$ & 2005 & 1915 & 1825 & 417 & 662 & 391 & 4.66 & 0.87 & 5.65 & 0.48 & 0.21 & 0.87 & 12.73 & 80 & 716 \\
\hline Tost B1 & $1 / 15 / 93$ & $0: 59$ & 2008 & 1915 & 1822 & 415 & 639 & 389 & 4.86 & 1.10 & 4.25 & 0.61 & 0.19 & 0.82 & 11.84 & 80 & 707 \\
\hline Test B3 & $1 / 15 / 93$ & 1.01 & 2008 & 1915 & 1823 & 415 & 640 & 388 & 4.68 & 1.10 & 4.24 & 0.61 & 0.19 & 0.82 & 11.65 & 80 & 706 \\
\hline Base Cond. OFA off & $1 / 18 / 93$ & $0: 45$ & 2016 & 1920 & 1825 & 437 & 661 & 420 & 4.46 & 1.10 & 4.23 & 0.61 & 0.18 & 0.80 & 11.38 & 80 & 709 \\
\hline Test B5 & $1 / 18 / 93$ & $1: 01$ & 2016 & 1921 & 1826 & 437 & 641 & 420 & 4.48 & 1.10 & 4.23 & 0.61 & 0.18 & 0.79 & 11.39 & 80 & 704 \\
\hline Base Cond. OFA cooling & $1 / 19 / 93$ & $0: 39$ & 2011 & 1914 & 1816 & 439 & 645 & 423 & 4.55 & 1.10 & 4.23 & 0.61 & 0.18 & 0.79 & 11.46 & 80 & 720 \\
\hline GR-12R & $1 / 19 / 93$ & $1: 00$ & 2005 & 1910 & 1817 & 430 & 632 & 414 & 4.66 & 1.04 & 4.55 & 0.58 & 0.19 & 0.81 & 11.82 & 80 & 718 \\
\hline GR-13E & $1 / 19 / 93$ & $1: 00$ & 1996 & 1907 & 1818 & 421 & 658 & 406 & 4.40 & 0.90 & 5.42 & 0.50 & 0.21 & 0.87 & 12.29 & 80 & 718 \\
\hline GR-13C & $1 / 20 / 93$ & $1: 10$ & 1999 & 1907 & 1814 & 422 & 663 & 400 & 4.74 & 0.91 & 5.42 & 0.50 & 0.20 & 0.84 & 12.61 & 80 & 724 \\
\hline GR-12D & $1 / 20 / 93$ & 1.05 & 1998 & 1905 & 1812 & 420 & 661 & 396 & 4.92 & 0.94 & 5.24 & 0.52 & 0.20 & 0.84 & 12.65 & 80 & 728 \\
\hline GR-12E & $1 / 20 / 93$ & $0: 59$ & 2000 & 1905 & 1811 & 416 & 658 & 389 & 4.81 & 1.00 & 4.89 & 0.55 & 0.20 & 0.83 & 12.28 & 80 & 722 \\
\hline Base Cond. OFA off & $1 / 20 / 93$ & $0: 15$ & 2000 & 1905 & 1809 & 417 & 648 & 389 & 4.69 & 1.11 & 4.26 & 0.61 & 0.19 & 0.81 & 11.67 & 80 & 714 \\
\hline 150 MWn Max NOx Red & $1 / 21 / 93$ & $1: 05$ & 1994 & 1904 & 1813 & 421 & 663 & 396 & 4.72 & 0.86 & 5.72 & 0.47 & 0.21 & 0.86 & 12.84 & 80 & 721 \\
\hline Base Cond. OFA cooling & $1 / 21 / 93$ & $1: 30$ & 1990 & 1899 & 1807 & 413 & 647 & 388 & 4.70 & 1.11 & 4.25 & 0.61 & 0.20 & 0.84 & 11.71 & 80 & 708 \\
\hline 120 MWn Max NOx Red & $1 / 21 / 93$ & $1: 00$ & 1925 & 1865 & 1804 & 331 & 631 & 311 & 4.74 & 0.84 & 5.85 & 0.46 & 0.30 & 1.14 & 13.32 & 80 & 688 \\
\hline GR Emviron.\#1 & $1 / 25 / 93$ & $5: 10$ & 1975 & 1892 & 1809 & 398 & 653 & 378 & 4.82 & 0.91 & 5.36 & 0.50 & 0.23 & 0.93 & 12.75 & 80 & 714 \\
\hline Base Cond. OFA cooling & $1 / 26 / 93$ & $0: 55$ & 1966 & 1886 & 1806 & 390 & 633 & 374 & 4.81 & 1.10 & 4.24 & 0.61 & 0.23 & 0.94 & 11.93 & 80 & 696 \\
\hline GR Emiron. Tost \#2 & $1 / 26 / 93$ & $5: 22$ & 1967 & 1887 & 1808 & 391 & 651 & 370 & 4.87 & 0.92 & 5.32 & 0.51 & 0.24 & 0.96 & 12.81 & 80 & 706 \\
\hline Environ, \#3 & $1 / 27 / 93$ & $5: 55$ & 1994 & 1903 & 1812 & 420 & 661 & 397 & 5.11 & 0.93 & 5.31 & 0.51 & 0.20 & 0.85 & 12.92 & 80 & 729 \\
\hline Environ. \#4 (No GR) & $1 / 27 / 93$ & $6: 00$ & 1971 & 1889 & 1806 & 390 & 625 & 368 & 4.96 & 1.11 & 4.26 & 0.61 & 0.22 & 0.91 & 12.07 & 80 & 703 \\
\hline
\end{tabular}


Cherokee Unit 3, Average Test [

Pre Modification

\begin{tabular}{|c|c|c|c|c|c|c|c|c|c|c|c|c|c|c|c|c|c|}
\hline rest. & Date & Dur & $\begin{array}{l}\text { Drum } \\
\text { Press } \\
\text { psia }\end{array}$ & $\begin{array}{l}\text { PSH } \\
\text { Puy } \\
\text { Psig }\end{array}$ & $\begin{array}{l}\text { Steam } \\
\text { To turb } \\
\text { PsiG }\end{array}$ & $\begin{array}{l}\text { RHIn } \\
\text { press } \\
\text { PSIG }\end{array}$ & $\begin{array}{l}\text { RHIn } \\
\text { Temp } \\
\text { Deg } \mathrm{F} \\
\end{array}$ & $\begin{array}{l}\text { Hot RH } \\
\text { Out Prs } \\
\text { Psia }\end{array}$ & $\begin{array}{l}\text { DryGas } \\
\text { htuss } \\
\text { ato }\end{array}$ & $\begin{array}{l}\text { Moist } \\
\text { homss } \\
\text { \% }\end{array}$ & 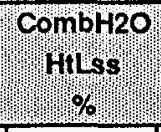 & 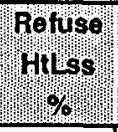 & $\begin{array}{l}\text { Radiat } \\
\text { hitus } \\
\text { pyos }\end{array}$ & $\begin{array}{l}\text { Unmeas } \\
\text { puss } \\
\text { mos }\end{array}$ & $\begin{array}{l}\text { Total } \\
\text { ptiss } \\
\text { rog }\end{array}$ & $\begin{array}{l}\text { Comb } \\
\text { Ar } \\
\text { Temp }\end{array}$ & $\begin{array}{l}\text { Econ } \\
\text { Gas out } \\
\text { Temp }\end{array}$ \\
\hline Environ, 籼 (No GR) & $1 / 28 / 93$ & $6: 04$ & 2001 & 1907 & 1813 & 428 & 650 & 408 & 4.81 & 1.11 & 4.26 & 0.61 & 0.19 & 0.81 & 11.79 & 80 & 710 \\
\hline Base Cond. & $2 / 2 / 93$ & $0: 17$ & 1992 & 1899 & 1806 & 414 & 642 & 393 & 4.73 & 1.11 & 4.26 & 0.61 & 0.20 & 0.84 & 11.74 & 80 & 694 \\
\hline LNB 120MW*11 & $3 / 8 / 93$ & $2: 00$ & 1932 & 1888 & 1844 & 307 & 563 & 274 & 5.05 & 1.11 & 4.26 & 0.61 & 0.28 & 1.09 & 12.39 & 80 & 662 \\
\hline LNB 120MW \#2 & $3 / 8 / 93$ & $2: 00$ & 1928 & 1885 & 1842 & 304 & 577 & 269 & 5.21 & 1.11 & 4.28 & 0.61 & 0.28 & 1.09 & 12.58 & 80 & 671 \\
\hline LNB 150MW *1 & $3 / 9 / 93$ & $2: 00$ & 1997 & 1919 & 1841 & 404 & 632 & 368 & 5.34 & 1.11 & 4.28 & 0.61 & 0.18 & 0.78 & 12.30 & 80 & 716 \\
\hline LNB 150MW \#2 & $3 / 9 / 93$ & $2: 00$ & 1979 & 1897 & 1815 & 387 & 614 & 349 & 5.17 & 1.11 & 4.28 & 0.61 & 0.18 & 0.78 & 12.13 & 80 & 703 \\
\hline LNB 90MW *1 & $3 / 10 / 93$ & $2: 00$ & 1846. & 1821 & 1796 & 235 & 524 & 210 & 5.05 & 1.10 & 4.24 & 0.61 & 0.36 & 1.34 & 12.69 & 80 & 637 \\
\hline LNB 9OMW \#2 & $3 / 10 / 93$ & $1: 58$ & 1850 & 1825 & 1800 & 236 & 532 & 213 & 5.05 & 1.10 & 4.25 & 0.61 & 0.36 & 1.34 & 12.71 & 80 & 640 \\
\hline LNB 150MW *3 & $3 / 11 / 93$ & $2: 00$ & 1989 & 1916 & 1843 & 401 & 638 & 373 & 4.82 & 1.10 & 4.25 & 0.61 & 0.19 & 0.83 & 11.81 & 80 & 708 \\
\hline LNB $150 M W * 4$ & $3 / 11 / 93$ & $2: 00$ & 1985 & 1910 & 1834 & 406 & 633 & 376 & 4.74 & 1.10 & 4.25 & 0.61 & 0.19 & 0.80 & 11.70 & 80 & 704 \\
\hline $3 \mathrm{M} 1$ & $3 / 22 / 93$ & $1: 02$ & 1978 & 1905 & 1831 & 398 & 609 & 360 & 4.24 & 0.88 & 5.53 & 0.49 & 0.19 & 0.82 & 12.15 & 80 & 689 \\
\hline 3M2 & $3 / 22 / 93$ & $1: 03$ & 1971 & 1898 & 1825 & 394 & 617 & 356 & 4.20 & 0.88 & 5.54 & 0.49 & 0.20 & 0.83 & 12.12 & 80 & 689 \\
\hline $3 \mathrm{M3}$ & $3 / 2293$ & $0: 59$ & 1972 & 1899 & 1826 & 394 & 626 & 354 & 4.37 & 0.88 & 5.54 & 0.49 & 0.20 & 0.83 & 12.30 & 80 & 697 \\
\hline 3 Mill 7 & $4 / 13 / 93$ & $1: 00$ & 1898 & 1851 & 1804 & 311 & 560 & 282 & 4.37 & 1.10 & 4.22 & 0.61 & 0.29 & 1.11 & 11.69 & 80 & 654 \\
\hline 3 Mill 6 & $4 / 13 / 93$ & $1: 00$ & 1902 & 1854 & 1807 & 314 & 569 & 284 & 4.16 & 1.09 & 4.21 & 0.61 & 0.28 & 1.09 & 11.45 & 80 & 654 \\
\hline Lovel $61 / 2$ & $4 / 15 / 93$ & 2.05 & 1988 & 1916 & 1843 & 397 & 625 & 369 & 4.78 & 1.10 & 4.25 & 0.61 & 0.20 & 0.85 & 11.81 & 80 & 695 \\
\hline Level 4 & $4 / 15 / 93$ & $1: 10$ & 1988 & 1915 & 1843 & 398 & 624 & 370 & $\overline{79}$ & 1.10 & 4.25 & 0.61 & 0.20 & 0.85 & 11.81 & 80 & 695 \\
\hline Level 3 & $4 / 15 / 93$ & $0: 53$ & 1990 & 1917 & 1844 & 398 & 625 & 369 & 4.81 & 1.11 & 4.25 & 0.61 & 0.20 & 0.85 & 11.83 & 80 & 695 \\
\hline Levol 5 1/2 & $4 / 15 / 93$ & $1: 58$ & 1990 & 1916 & 1842 & 396 & 617 & 365 & 4.79 & 1.11 & 4.26 & 0.61 & 0.20 & 0.85 & 11.82 & 80 & 697 \\
\hline Base Cond & $4 / 15 / 93$ & $5: 25$ & 1989 & 1915 & 1842 & 397 & 622 & 367 & 4.78 & 1.11 & 4.26 & 0.61 & 0.20 & 0.85 & 11.80 & 80 & 696 \\
\hline Level $51 / 2$ & $4 / 16 / 93$ & $1: 47$ & 1989 & 1913 & 1838 & 404 & 644 & 373 & 5.06 & 1.11 & 4.26 & 0.61 & 0.20 & 0.84 & 12.08 & 80 & 717 \\
\hline Lovel 6 1/2 & $4 / 16 / 93$ & $1: 19$ & 1986 & 1911 & 1835 & 403 & 637 & 370 & 5.08 & 1.11 & 4.27 & 0.61 & 0.20 & 0.83 & 12.10 & 80 & 714 \\
\hline Level 3 & $4 / 16 / 93$ & $0: 44$ & 1982 & 1906 & 1830 & 401 & 637 & 366 & 5.17 & 1.11 & 4.27 & 0.61 & 0.20 & 0.83 & 12.19 & 80 & 716 \\
\hline Level 4 & $4 / 16 / 93$ & $1: 00$ & 1984 & 1908 & 1832 & 401 & 637 & 366 & 5.17 & 1.11 & 4.27 & 0.61 & 0.20 & 0.83 & 12.19 & 80 & 716 \\
\hline North out, South in & $4 / 16 / 93$ & $0: 20$ & 1985 & 1910 & 1835 & 403 & 645 & 372 & 5.29 & 1.11 & 4.27 & 0.61 & 0.20 & 0.84 & 12.31 & 80 & 717 \\
\hline South out. North in & $4 / 16 / 93$ & $0: 20$ & 1983 & 1908 & 1833 & 402 & 643 & 371 & 5.00 & 1.11 & 4.27 & 0.61 & 0.20 & 0.84 & 12.03 & 80 & 717 \\
\hline Base Cond & $4 / 16 / 93$ & $6: 25$ & 1986 & 1911 & 1835 & 403 & 639 & 370 & 5.12 & 1.11 & 4.27 & 0.61 & 0.20 & 0.83 & 12.13 & 80 & 716 \\
\hline Lovel 4 & $4 / 19 / 93$ & $0: 56$ & 1976 & 1905 & 1833 & 402 & 657 & 370 & 4.75 & 0.89 & 5.51 & 0.49 & 0.21 & 0.87 & 12.72 & 80 & 722 \\
\hline Level 3 & $4 / 19 / 93$ & $0: 52$ & 1976 & 1905 & 1833 & 402 & 657 & 370 & 4.75 & 0.89 & 5.51 & 0.49 & 0.21 & 0.87 & 12.72 & 80 & 722 \\
\hline Level $51 / 2$ & $4 / 19 / 93$ & $2: 29$ & 1977 & 1906 & 1836 & 400 & 656 & 366 & 4.95 & 0.89 & 5.53 & 0.49 & 0.21 & 0.88 & 12.96 & 80 & 731 \\
\hline Lovel $61 / 2$ & $4 / 19 / 93$ & $1: 10$ & 1979 & 1908 & 1838 & 399 & 657 & 364 & 4.98 & 0.89 & 5.53 & 0.49 & 0.21 & 0.88 & 12.98 & 80 & 734 \\
\hline Base Cond. OFA on & $4 / 19 / 93$ & $1: 00$ & 1965 & 1894 & 1824 & 396 & 618 & 365 & 5.12 & 1.10 & 4.24 & 0.61 & 0.20 & 0.85 & 12.12 & 80 & 711 \\
\hline GR & $4 / 19 / 93$ & $5: 42$ & 1976 & 1906 & 1836 & 399 & 657 & 366 & 4.92 & 0.89 & 5.53 & 0.49 & 0.21 & 0.88 & 12.93 & 80 & 730 \\
\hline Level $61 / 2$ & $4 / 20 / 93$ & $1: 47$ & 1932 & 1875 & 1819 & 358 & 579 & 334 & 4.32 & 1.10 & 4.22 & 0.61 & 0.24 & 0.97 & 11.47 & 80 & 675 \\
\hline Base Cond 130MW & $4 / 20 / 93$ & $3: 35$ & 1931 & 1874 & 1817 & 357 & 579 & 332 & & 1.1 & 4.22 & 0.61 & 0.24 & 0.98 & 11.47 & 80 & 674 \\
\hline Base Cond 120MW & $4 / 20 / 93$ & $2: 55$ & 1907 & 1861 & 1815 & 322 & 622 & 295 & 5.14 & 1.11 & 4.26 & 0.61 & 0.29 & 1.12 & 12.52 & 80 & 678 \\
\hline Base Cond. OFA off & $4 / 21 / 93$ & $7: 40$ & 1894 & 1850 & 1807 & 310 & 608 & 282 & 5.13 & 1.11 & 4.26 & 0.61 & 0.30 & 1.15 & 12.57 & 80 & 669 \\
\hline Base Cond. OFA off & $4 / 23 / 93$ & $0: 30$ & 1970 & 1895 & 1820 & 401 & 646 & 367 & 5.11 & 1.11 & 4.28 & 0.61 & 0.20 & 0.85 & 12.16 & 80 & 706 \\
\hline 4M12 (OFA off) & $4 / 23 / 93$ & 1.00 & 1979 & 1904 & 1829 & 400 & 612 & 366 & 4.94 & 1.11 & 4.26 & 0.61 & 0.19 & 0.83 & 11.93 & 80 & 693 \\
\hline 4M13a 78,000 scim OFA & $4 / 23 / 93$ & $0: 20$ & 1984 & 1905 & 1825 & 410 & 589 & 376 & 5.11 & 1.11 & 4.25 & 0.61 & 0.17 & 0.76 & 12.02 & 80 & 693 \\
\hline
\end{tabular}


Cherokee Unit 3, Average Test C

Pre Modification

\begin{tabular}{|c|c|c|c|c|c|c|c|c|c|c|c|c|c|c|c|c|c|}
\hline тев & Dapien: & 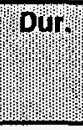 & prum & Powit & צ'steam! & RPY & RHIIn & 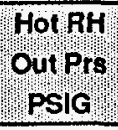 & Dry Gas & Moist & CombH2o & pefuse & padiat & unmers & Trotal & comb: & 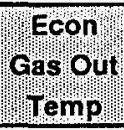 \\
\hline $4 \mathrm{M} 13 \mathrm{~b}(70,000 \mathrm{scfm}$ OFA & $4 / 23 / 93$ & $0: 50$ & 1993 & 1913 & 1833 & 411 & 581 & 376 & 5.09 & 1.10 & 4.25 & 0.61 & 0.17 & 0.76 & 11.98 & 80 & 694 \\
\hline Base Cond. OFA On & $4 / 27 / 93$ & $0: 30$ & 1985 & 1909 & 1833 & 411 & 655 & 380 & 5.33 & 1.11 & 4.26 & 0.61 & 0.19 & 0.83 & 12.33 & 80 & 718 \\
\hline GR on $150 \mathrm{MW}, 11 \%$ Gas & $4 / 27 / 93$ & $0: 53$ & 1967 & 1892 & 1817 & 408 & 659 & 378 & 4.94 & 0.98 & 5.00 & 0.54 & 0.20 & 0.84 & 12.49 & 80 & 711 \\
\hline GA on $150 \mathrm{MW}, 17 \%$ Gas & $4 / 27 / 93$ & $2: 48$ & 1962 & 1886 & 1810 & 407 & 661 & 374 & 4.92 & 0.92 & 5.38 & 0.50 & 0.20 & 0.85 & 12.77 & 80 & 716 \\
\hline Base Cond. OFA on & $4 / 28 / 93$ & $0: 44$ & 1954 & 1888 & 1822 & 379 & 621 & 350 & 5.26 & 1.11 & 4.26 & 0.61 & 0.22 & 0.91 & 12.37 & 80 & 704 \\
\hline GR on Auto & $4 / 28 / 93$ & $6: 35$ & 1937 & 1874 & 1811 & 368 & 645 & 337 & 4.93 & 0.93 & 5.32 & 0.51 & 0.24 & 0.97 & 12.90 & 80 & 707 \\
\hline GR on Auto & $5 / 3 / 93$ & $7: 00$ & 1982 & 1917 & 1853 & 387 & 646 & 359 & 5.15 & 0.92 & 5.37 & 0.50 & 0.22 & 0.91 & 13.08 & 80 & 716 \\
\hline Base Cond. OFA on & $5 / 6 / 93$ & $2: 45$ & 1977 & 1913 & 1849 & 387 & 590 & 366 & 5.18 & 1.10 & 4.25 & 0.61 & 0.21 & 0.89 & 12.24 & 80 & 688 \\
\hline GR on Auto & $5 / 6 / 93$ & $1: 15$ & 1992 & 1930 & 1868 & 385 & 627 & 362 & 5.06 & 0.94 & 5.26 & 0.52 & 0.22 & 0.92 & 12.92 & 80 & 703 \\
\hline Base Cond. OFA off & $5 / 6 / 93$ & $0: 21$ & 1878 & 1833 & 1787 & 325 & 623 & 304 & 5.16 & 1.11 & 4.26 & 0.61 & 0.29 & 1.11 & 12.53 & 80 & 671 \\
\hline GR on Auto $150 \mathrm{MW}$ & $5 / 7 / 93$ & $4: 26$ & 1998 & 1927 & 1856 & 406 & 631 & 382 & 4.94 & 0.91 & 5.40 & 0.50 & 0.20 & 0.84 & 12.79 & 80 & 705 \\
\hline GR on Auto $160 \mathrm{MW}$ & $5 / 7 / 93$ & $1: 59$ & 2024 & 1941 & 1859 & 435 & 653 & 407 & 5.05 & 0.92 & 5.40 & 0.50 & 0.16 & 0.73 & 12.77 & 80 & 717 \\
\hline GA on Auto 140MW & $5 / 7 / 93$ & $4: 50$ & 1969 & 1909 & 1848 & 382 & 636 & 361 & 4.99 & 0.91 & 5.37 & 0.50 & 0.23 & 0.94 & 12.94 & 80 & 702 \\
\hline Base Cond. OFA off & $5 / 7 / 93$ & $0: 35$ & 1978 & 1910 & 1843 & 399 & 630 & 380 & 5.36 & 1.11 & 4.26 & 0.61 & 0.21 & 0.87 & 12.42 & 80 & 703 \\
\hline GR on Auto & $5 / 11 / 93$ & $6: 08$ & 1950 & 1891 & 1833 & 372 & 642 & 346 & 5.33 & 0.92 & 5.37 & 0.51 & 0.25 & 0.98 & 13.35 & 80 & 709 \\
\hline GR 13 & $5 / 25 / 93$ & 15:04 & 1960 & 1891 & 1822 & 399 & 655 & 374 & 5.02 & 0.92 & 5.35 & 0.51 & 0.22 & 0.90 & 12.92 & 80 & 714 \\
\hline GR 14 & $5 / 25 / 93$ & $1: 25$ & 1876 & 1844 & 1812 & 275 & 587 & 253 & 5.33 & 0.93 & 5.30 & 0.51 & 0.34 & 1.28 & 13.68 & 80 & 671 \\
\hline GA 15 & $5 / 26 / 93$ & $1: 29$ & 1886 & 1851 & 1815 & 290 & 598 & 269 & 5.33 & 0.93 & 5.30 & 0.51 & 0.33 & 1.24 & 13.63 & 80 & 675 \\
\hline LNB-OFA & $5 / 26 / 93$ & $0: 42$ & 1850 & 1826 & 1802 & 245 & 544 & 226 & 5.80 & 1.10 & 4.24 & 0.61 & 0.38 & 1.37 & 13.50 & 80 & 649 \\
\hline LNB & $5 / 26 / 93$ & $9: 44$ & 1967 & 1903 & 1839 & 379 & 605 & 355 & 5.12 & 1.11 & 4.27 & 0.61 & 0.23 & 0.93 & 12.27 & 80 & 677 \\
\hline LNB & $5 / 27 / 93$ & $0: 10$ & 1879 & 1838 & 1797 & 302 & 596 & 276 & 5.17 & 1.11 & 4.27 & 0.61 & 0.32 & 1.20 & 12.67 & 80 & 663 \\
\hline LNB-OFA & $5 / 27 / 93$ & $0: 45$ & 1977 & 1904 & 1832 & 402 & 642 & 372 & 5.51 & 1.11 & 4.28 & 0.61 & 0.20 & 0.85 & 12.57 & 80 & 711 \\
\hline GR-LNB 16 & $5 / 27 / 93$ & $13: 40$ & 1965 & 1900 & 1835 & 386 & 650 & 355 & 5.25 & 0.93 & 5.31 & 0.51 & 0.23 & 0.92 & 13.15 & 80 & 712 \\
\hline GR-LNB 17 & $5 / 28 / 93$ & $2: 57$ & 1878 & 1843 & 1808 & 291 & 595 & 269 & 5.45 & 0.94 & 5.21 & 0.52 & 0.33 & 1.23 & 13.68 & 80 & 673 \\
\hline LNB & $5 / 28 / 93$ & $1: 23$ & 1847 & 1828 & 1808 & 230 & 540 & 212 & 5.93 & 1.11 & 4.27 & 0.61 & 0.39 & 1.42 & 13.74 & 80 & 636 \\
\hline GR-LNB 2Ob & $6 / 3 / 93$ & $8: 51$ & 1951 & 1888 & 1826 & 386 & 647 & 360 & 4.78 & 0.92 & 5.36 & 0.51 & 0.23 & 0.94 & 12.75 & 80 & 702 \\
\hline LNB & $6 / 3 / 93$ & $1: 05$ & 1871 & 1847 & 1823 & 256 & 562 & 240 & 5.58 & 1.11 & 4.28 & 0.61 & 0.37 & 1.36 & 13.30 & 80 & 647 \\
\hline LNB (low load) & $6 / 4 / 93$ & 6.52 & 1858 & 1836 & 1815 & 243 & 553 & 227 & 5.84 & 1.11 & 4.28 & 0.61 & 0.38 & 1.40 & 13.62 & 80 & 636 \\
\hline LNB (high load) & $6 / 4 / 93$ & $5: 25$ & 1996 & 1927 & 1858 & 411 & 618 & 392 & 5.02 & 1.11 & 4.27 & 0.61 & 0.20 & 0.85 & 12.06 & 80 & 690 \\
\hline LNB-OFA & $6 / 4 / 93$ & $2: 31$ & 1996 & 1918 & 1841 & 426 & 600 & 402 & 5.03 & 1.11 & 4.26 & 0.61 & 0.17 & 0.76 & 11.94 & 80 & 686 \\
\hline GA-LNB & $6 / 4 / 93$ & $7: 42$ & 1961 & 1894 & 1827 & 399 & 653 & 374 & 4.85 & 0.92 & 5.36 & 0.51 & 0.22 & 0.90 & 12.75 & 80 & 704 \\
\hline LNB & $6 / 8 / 93$ & $1: 35$ & 1970 & 1909 & 1847 & 380 & 608 & 355 & 5.44 & 1.11 & 4.28 & 0.61 & 0.23 & 0.92 & 12.59 & 80 & 685 \\
\hline LNB-OFA & $6 / 8 / 93$ & $1: 40$ & 1962 & 1900 & 1837 & 381 & 604 & 355 & 5.29 & 1.11 & 4.26 & 0.61 & 0.22 & 0.91 & 12.40 & 80 & 689 \\
\hline GR-LNB 22a & $6 / 8 / 93$ & $6: 21$ & 1939 & 1885 & 1830 & 357 & 634 & 330 & 5.29 & 0.92 & 5.36 & 0.51 & 0.26 & 1.01 & 13.35 & 80 & 703 \\
\hline GR-LNB 22b & $6 / 8 / 93$ & $5: 30$ & 1963 & 1897 & 1832 & 395 & 653 & 365 & 4.74 & 0.92 & 5.39 & 0.50 & 0.22 & 0.90 & 12.67 & 80 & 705 \\
\hline GR-LNB 23a & $6 / 9 / 93$ & $1: 16$ & 1893 & 1857 & 1821 & 303 & 614 & 282 & 4.55 & 0.93 & 5.26 & 0.51 & 0.32 & 1.21 & 12.78 & 80 & 668 \\
\hline LNB-OFA & $6 / 9 / 93$ & $0: 30$ & 1844 & 1826 & 1806 & 229 & 565 & 210 & 5.07 & 1.10 & 4.23 & 0.61 & 0.39 & 1.42 & 12.82 & 80 & 638 \\
\hline LNB & $6 / 9 / 93$ & $16: 03$ & 1907 & 1864 & 1822 & 317 & 583 & 294 & 5.31 & 1.11 & 4.27 & 0.61 & 0.29 & 1.13 & 12.72 & 80 & 662 \\
\hline GR-LNB 23b & $6 / 9 / 93$ & $4: 28$ & 1939 & 1882 & 1825 & 370 & 639 & 342 & 5.19 & 0.92 & 5.36 & 0.51 & 0.24 & 0.97 & 13.20 & 80 & 703 \\
\hline LNB & $6 / 10 / 93$ & $8: 47$ & 1907 & 1868 & 1829 & 310 & 600 & 290 & 5.05 & 1.11 & 4.26 & 0.61 & 0.31 & 1.17 & 12.51 & 80 & 659 \\
\hline
\end{tabular}


Cherokee Unit 3, Average Test [

Pre Modiflcation

\begin{tabular}{|c|c|c|c|c|c|c|c|c|c|c|c|c|c|c|c|c|c|}
\hline 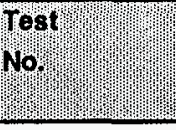 & 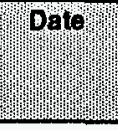 & pur & Drum: & Psh & 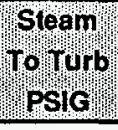 & PH & $\begin{array}{l}\text { RH In } \\
\text { Temp: } \\
\text { Dege }\end{array}$ & (hot ph & Dry Gas & Moist & combring & Refuss & Padjat & Unmeas & 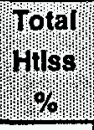 & $\begin{array}{l}\text { comb: } \\
\text { Afr] } \\
\text { Tenp }\end{array}$ & 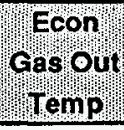 \\
\hline LNB-OFA & $6 / 10 / 93$ & $1: 16$ & 1988 & 1917 & 1847 & 410 & 619 & 385 & 5.36 & 1.11 & 4.27 & 0.61 & 0.19 & 0.82 & 12.37 & 80 & 705 \\
\hline GR-LNB 24 & $6 / 10 / 93$ & $2: 57$ & 1968 & 1903 & 1837 & 396 & 653 & 366 & 5.42 & 0.92 & 5.41 & 0.50 & 0.22 & 0.89 & 13.37 & 80 & 725 \\
\hline LNB & $6 / 10 / 93$ & $0: 37$ & 1998 & 1928 & 1857 & 409 & 610 & 376 & 5.47 & 1.12 & 4.29 & 0.61 & 0.19 & 0.81 & 12.48 & 80 & 686 \\
\hline GR-LNB 25a & $6 / 11 / 93$ & $5: 28$ & 1944 & 1895 & 1847 & 352 & 634 & 321 & 5.29 & 0.94 & 5.30 & 0.51 & 0.26 & 1.03 & 13.34 & 80 & 701 \\
\hline GR-LNB 25b & $6 / 11 / 93$ & $9: 06$ & 1985 & 1924 & 1863 & 393 & 651 & 359 & 5.35 & 0.94 & 5.33 & 0.51 & 0.22 & 0.90 & 13.25 & 80 & 714 \\
\hline GR-LNB 26a & $6 / 12 / 93$ & $11: 22$ & 1943 & 1893 & 1843 & 362 & 639 & 333 & 5.22 & 0.94 & 5.32 & 0.51 & 0.26 & 1.01 & 13.26 & 80 & 708 \\
\hline GR-LNB 26b & $6 / 12 / 93$ & $2: 13$ & 1853 & 1836 & 1819 & 238 & 576 & 216 & 5.58 & 1.01 & 4.83 & 0.56 & 0.38 & 1.40 & 13.76 & 80 & 657 \\
\hline LNB-OFA & $6 / 1293$ & $7: 11$ & 1936 & 1880 & 1823 & 368 & 616 & 333 & 5.30 & 1.11 & 4.29 & 0.61 & 0.23 & 0.94 & 12.48 & 80 & 682 \\
\hline LNB-OFA & $6 / 13 / 93$ & $9: 43$ & 1821 & 1809 & 1797 & 213 & 517 & 192 & 5.81 & 1.11 & 4.27 & 0.61 & 0.40 & 1.46 & 13.66 & 80 & 634 \\
\hline GR-LNB 28 & $6 / 14 / 93$ & $4: 06$ & 1967 & 1902 & 1837 & 398 & 655 & 362 & 5.04 & 0.93 & 5.39 & 0.51 & 0.21 & 0.86 & 12.93 & 80 & 710 \\
\hline LNB & $6 / 14 / 93$ & $1: 59$ & 1927 & 1879 & 1829 & 350 & 591 & 317 & 5.31 & 1.11 & 4.29 & 0.61 & 0.25 & 0.99 & 12.56 & 80 & 666 \\
\hline LNB & $6 / 18 / 93$ & $0: 38$ & 1966 & 1915 & 1864 & 371 & 639 & 352 & 4.76 & 1.11 & 4.26 & 0.61 & 0.26 & 1.02 & 12.01 & 80 & 695 \\
\hline GR-LNB 29 & $6 / 18 / 93$ & $14: 24$ & 1955 & 1896 & 1837 & 392 & 649 & 369 & 4.89 & 0.91 & 5.41 & 0.50 & 0.24 & 0.95 & 12.90 & 80 & 708 \\
\hline GR-LNB 30a & $6 / 19 / 93$ & $0: 30$ & 1844 & 1815 & 1786 & 281 & 614 & 261 & 5.24 & 0.90 & 5.44 & 0.50 & 0.35 & 1.30 & 13.73 & 80 & 681 \\
\hline LNB & $6 / 19 / 93$ & $9: 15$ & 1836 & 1816 & 1797 & 232 & 571 & 215 & 5.76 & 1.11 & 4.29 & 0.61 & 0.40 & 1.44 & 13.61 & 80 & 641 \\
\hline GR-LNB 306 & $6 / 19 / 93$ & $11: 53$ & 1965 & 1905 & 1845 & 389 & 649 & 358 & 4.95 & 0.91 & 5.50 & 0.50 & 0.23 & 0.95 & 13.02 & 80 & 717 \\
\hline GR-LNB $30 c$ & $6 / 19 / 93$ & $1: 33$ & 1887 & 1863 & 1839 & 258 & 601 & 232 & 5.34 & 0.93 & 5.35 & 0.51 & 0.36 & 1.33 & 13.82 & 80 & 674 \\
\hline GR-LNB 23 & $6 / 23 / 93$ & $7: 35$ & 1952 & 1885 & 1818 & 400 & 660 & 365 & 4.91 & 0.91 & 5.47 & 0.50 & 0.21 & 0.88 & 12.88 & 80 & 703 \\
\hline GR-LNB 326 & $6 / 23 / 93$ & 1.09 & 1899 & 1852 & 1805 & 341 & 636 & 310 & 4.91 & 0.92 & 5.39 & 0.50 & 0.27 & 1.07 & 13.07 & 80 & 690 \\
\hline LNB-OFA cooling & $6 / 24 / 93$ & $6: 25$ & 1842 & 1826 & 1810 & 227 & 563 & 207 & 5.17 & 1.11 & 4.26 & 0.61 & 0.40 & 1.44 & 12.99 & 80 & 646 \\
\hline GR-LNB 33a & $6 / 24 / 93$ & 6.00 & 1930 & 1888 & 1847 & 328 & 626 & 300 & 5.01 & 0.92 & 5.38 & 0.51 & 0.29 & 1.13 & 13.24 & 80 & 690 \\
\hline GR-LNB 33 & $6 / 24 / 93$ & $11: 22$ & 1971 & 1907 & 1844 & 399 & 654 & 370 & 4.84 & 0.91 & 5.46 & 0.50 & 0.22 & 0.91 & 12.83 & 80 & 706 \\
\hline GR-LNB 34a & $6 / 25 / 93$ & $1: 52$ & 1838 & 1822 & 1807 & 222 & 576 & 200 & 5.59 & 0.95 & 5.18 & 0.52 & 0.40 & 1.46 & 14.10 & 80 & 657 \\
\hline LNB-OFA & $6 / 25 / 93$ & 4.03 & 1828 & 1812 & 1796 & 224 & 524 & 205 & 5.43 & 1.10 & 4.25 & 0.61 & 0.40 & 1.44 & 13.24 & 80 & 638 \\
\hline GA-LNB 34 & $6 / 25 / 93$ & 8.00 & 1974 & 1916 & 1858 & 383 & 642 & 357 & 4.89 & 0.92 & 5.40 & 0.50 & 0.24 & 0.96 & 12.91 & 80 & 711 \\
\hline LNB (some OFA) & $6 / 28 / 93$ & 1.03 & 1980 & 1911 & 1841 & 407 & 643 & 374 & 5.34 & 1.12 & 4.30 & 0.61 & 0.20 & 0.83 & 12.39 & 80 & 691 \\
\hline LNB (some OFA) & $6 / 29 / 93$ & $12: 15$ & 1906 & 1855 & 1805 & 336 & 607 & 298 & 5.38 & 1.12 & 4.31 & 0.61 & 0.26 & 1.04 & 12.72 & 80 & 666 \\
\hline LNB & $6 / 30 / 93$ & $11: 51$ & 1909 & 1867 & 1826 & 316 & 612 & 289 & 5.36 & 1.12 & 4.30 & 0.61 & 0.30 & 1.15 & 12.84 & 80 & 666 \\
\hline GR-LNB 35 & $6 / 30 / 93$ & $1: 48$ & 1970 & 1901 & 1832 & 405 & 661 & 370 & 5.18 & 0.93 & 5.36 & 0.51 & 0.20 & 0.86 & 13.04 & 80 & 708 \\
\hline GR-LNB 35a & $6 / 30 / 93$ & 6.05 & 1965 & 1898 & 1831 & 400 & 660 & 364 & 5.47 & 0.93 & 5.36 & 0.51 & 0.21 & 0.88 & 13.35 & 80 & 713 \\
\hline GR-LNB 35b & $6 / 30 / 93$ & $1: 53$ & 1918 & 1865 & 1813 & 355 & 642 & 323 & 5.57 & 0.93 & 5.34 & 0.51 & 0.26 & 1.03 & 13.64 & 80 & 705 \\
\hline GR-OL.NB 36a & $7 / 1 / 93$ & $8: 22$ & 1859 & 1838 & 1817 & 240 & 569 & 215 & 5.87 & 0.97 & 5.05 & 0.53 & 0.38 & 1.39 & 14.20 & 80 & 655 \\
\hline GR-LNB 36 & $7 / 1 / 93$ & $15: 37$ & 1955 & 1893 & 1831 & 382 & 650 & 347 & 5.26 & 0.94 & 5.33 & 0.51 & 0.23 & 0.94 & 13.20 & 80 & 701 \\
\hline GR $37 \mathrm{a}$ & $7 / 2 / 93$ & $14: 55$ & 1886 & 1848 & 1810 & 306 & 618 & 273 & 5.37 & 0.95 & 5.23 & 0.52 & 0.31 & 1.18 & 13.55 & 80 & 676 \\
\hline GR 37 & $7 / 2 / 93$ & $7: 05$ & 1960 & 1891 & 1821 & 408 & 662 & 372 & 5.32 & 0.93 & 5.35 & 0.51 & 0.20 & 0.85 & 13.17 & 80 & 712 \\
\hline GR-LNB 38 & $7 / 3 / 93$ & $7: 46$ & 1960 & 1897 & 1833 & 397 & 649 & 361 & 5.41 & 0.94 & 5.33 & 0.51 & 0.22 & 0.90 & 13.32 & 80 & 712 \\
\hline GR-LNB 38a & $7 / 3 / 93$ & $8: 43$ & 1946 & 1886 & 1826 & 391 & 654 & 361 & 5.97 & 0.94 & 5.32 & 0.51 & 0.23 & 0.93 & 13.90 & 80 & 705 \\
\hline GR-LNB 39a & $7 / 4 / 93$ & $17: 27$ & 1865 & 1832 & 1799 & 298 & 608 & 277 & 6.48 & 0.97 & 5.08 & 0.53 & 0.33 & 1.23 & 14.63 & 80 & 670 \\
\hline GR-LNB 39 & $7 / 4 / 93$ & 6.33 & 1966 & 1902 & 1838 & 404 & 657 & 378 & 6.14 & 0.94 & 5.26 & 0.52 & 0.22 & 0.89 & 13.98 & 80 & 708 \\
\hline GR-LNB 40a & $7 / 5 / 93$ & $11: 52$ & 1839 & 1814 & 1790 & 259 & 591 & 240 & 7.09 & 0.99 & 4.95 & 0.54 & 0.37 & 1.35 & 15.29 & 80 & 658 \\
\hline
\end{tabular}


Pre Modiflcation

\begin{tabular}{|c|c|c|c|c|c|c|c|c|c|c|c|c|c|c|c|c|c|}
\hline & Date! & WDW" & prum & out: & 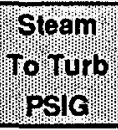 & 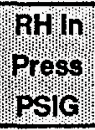 & 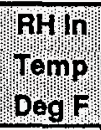 & $\begin{array}{l}\text { Hot RH } \\
\text { out P s s } \\
\text { PSIG }\end{array}$ & Dryasas & Moist & combins" & Refuse & Radiat & 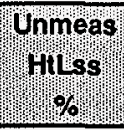 & 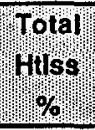 & $\begin{array}{l}\text { comb" } \\
\text { Tomp }\end{array}$ & 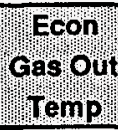 \\
\hline GR-LNB 40 & $7 / 5 / 93$ & $12: 08$ & 1943 & 1884 & 1824 & 382 & 646 & 355 & 6.70 & 0.95 & 5.24 & 0.52 & 0.24 & 0.96 & 14.60 & 80 & 703 \\
\hline GR-LNB 52a & $7 / 17 / 93$ & 8.31 & 1862 & 1833 & 1804 & 268 & 576 & 244 & 5.49 & 0.93 & 5.32 & 0.51 & 0.35 & 1.30 & 13.89 & 80 & 661 \\
\hline GR-LNB 52 & $7 / 17 / 93$ & $5: 45$ & 1941 & 1878 & 1815 & 394 & 655 & 369 & 5.08 & 0.92 & 5.37 & 0.51 & 0.23 & 0.94 & 13.04 & 80 & 711 \\
\hline LNB & $7 / 19 / 93$ & $1: 53$ & 1894 & 1855 & 1815 & 304 & 617 & 277 & 4.84 & 1.10 & 4.25 & 0.61 & 0.31 & 1.17 & 12.29 & 80 & 669 \\
\hline LNB-OFA & $7 / 19 / 93$ & $0: 22$ & 1893 & 1848 & 1804 & 319 & 615 & 289 & 4.71 & 1.10 & 4.24 & 0.61 & 0.29 & 1.11 & 12.06 & 80 & 667 \\
\hline GA-LNB 53a & $7 / 19 / 93$ & $3: 29$ & 1895 & 1853 & 1810 & 321 & 628 & 292 & 4.89 & 0.93 & 5.29 & 0.51 & 0.30 & 1.14 & 13.05 & 80 & 686 \\
\hline GA-LNB 53 & $7 / 19 / 93$ & $7: 06$ & 1956 & 1887 & 1819 & 401 & 659 & 367 & 4.99 & 0.92 & 5.34 & 0.51 & 0.21 & 0.87 & 12.85 & 80 & 710 \\
\hline LNB & $7 / 21 / 93$ & $8: 34$ & 1842 & 1828 & 1813 & 210 & 530 & 189 & 5.95 & 1.12 & 4.30 & 0.61 & 0.41 & 1.48 & 13.88 & 80 & 628 \\
\hline GA-LNB 54 & $7 / 21 / 93$ & $4: 52$ & 1948 & 1886 & 1823 & 382 & 653 & 348 & 5.46 & 0.93 & 5.41 & 0.51 & 0.23 & 0.93 & 13.47 & 80 & 721 \\
\hline LNB & $7 / 23 / 93$ & $2: 35$ & 1826 & 1804 & 1781 & 240 & 519 & 215 & 5.45 & 1.11 & 4.28 & 0.61 & 0.35 & 1.30 & 13.10 & 80 & 673 \\
\hline GA-LNB 55 & $7 / 23 / 93$ & $4: 53$ & 1977 & 1913 & 1850 & 387 & 650 & 354 & 5.36 & 0.93 & 5.35 & 0.51 & 0.22 & 0.92 & 13.29 & 80 & 711 \\
\hline GR-LNB 55a & $7 / 23 / 93$ & $1: 08$ & 1933 & 1883 & 1833 & 340 & 632 & 306 & 5.49 & 0.93 & 5.32 & 0.51 & 0.26 & 1.04 & 13.56 & 80 & 697 \\
\hline LNB & $7 / 23 / 93$ & 3.55 & 1796 & 1782 & 1768 & 199 & 508 & 173 & 5.41 & 1.11 & 4.27 & 0.61 & 0.41 & 1.48 & 13.29 & 80 & 609 \\
\hline LNB & $7 / 24 / 93$ & $1: 52$ & 1768 & 1750 & 1734 & 213 & 523 & 191 & 5.64 & 1.11 & 4.26 & 0.61 & 0.40 & 1.46 & 13.47 & 80 & 610 \\
\hline LNB-OFA & $7 / 24 / 93$ & $0: 36$ & 1879 & 1857 & 1835 & 238 & 550 & 213 & 6.41 & 1.11 & 4.27 & 0.61 & 0.37 & 1.36 & 14.13 & 80 & 644 \\
\hline GR-LNB 56 & $7 / 24 / 93$ & $7: 45$ & 1980 & 1917 & 1855 & 383 & 647 & 350 & 5.39 & 0.93 & 5.36 & 0.51 & 0.23 & 0.93 & 13.35 & 80 & 716 \\
\hline GR-LNB 56a & $7 / 24 / 93$ & $2: 09$ & 1855 & 1831 & 1806 & 247 & 557 & 221 & 5.70 & 0.94 & 5.27 & 0.51 & 0.36 & 1.34 & 14.13 & 80 & 649 \\
\hline GR-LNB 57a & $7 / 25 / 93$ & $1: 10$ & 1811 & 1798 & 1785 & 196 & 532 & 174 & 6.24 & 0.94 & 5.26 & 0.51 & 0.42 & 1.51 & 14.88 & 80 & 629 \\
\hline LNB-OFA & $7 / 25 / 93$ & $5: 52$ & 1839 & 1820 & 1802 & 229 & 513 & 208 & 5.78 & 1.10 & 4.25 & 0.61 & 0.39 & 1.40 & 13.53 & 80 & 639 \\
\hline GR-LNB 57b & $7 / 25 / 93$ & $10: 19$ & 1912 & 1865 & 1817 & 331 & 621 & 302 & 5.53 & 0.93 & 5.33 & 0.51 & 0.29 & 1.10 & 13.69 & 80 & 689 \\
\hline GR-LNB 57 & $7 / 25 / 93$ & $6: 14$ & 1979 & 1911 & 1842 & 399 & 657 & 361 & 5.20 & 0.93 & 5.35 & 0.51 & 0.21 & 0.87 & 13.07 & 80 & 711 \\
\hline GR-LNB 58a & $7 / 26 / 93$ & $10: 15$ & 1844 & 1809 & 1774 & 291 & 608 & 267 & 5.93 & 0.93 & 5.29 & 0.51 & 0.33 & 1.24 & 14.24 & 80 & 679 \\
\hline GR-LNB 58 & $7 / 26 / 93$ & $8: 34$ & 1945 & 1874 & 1804 & 403 & 663 & 367 & 5.28 & 0.94 & 5.33 & 0.51 & 0.21 & 0.87 & 13.12 & 80 & 714 \\
\hline GR-LNB 58b & $7 / 26 / 93$ & $5: 09$ & 1886 & 1832 & 1778 & 353 & 640 & 320 & 5.51 & 0.94 & 5.28 & 0.51 & 0.26 & 1.02 & 13.53 & 80 & 699 \\
\hline GR-LNB 59a & $7 / 27 / 93$ & $10: 48$ & 187 & 1841 & 1806 & 291 & 597 & 266 & 5.76 & 0.94 & 5.27 & 0.52 & 0.33 & 1.23 & 14.04 & 80 & 682 \\
\hline LNB-OFA & $7 / 27 / 93$ & $3: 21$ & 1977 & 1899 & 1821 & 421 & 643 & 387 & 5.10 & 1.12 & 4.29 & 0.61 & 0.18 & 0.77 & 12.06 & 80 & 708 \\
\hline GR-LNB 59 & $7 / 27 / 93$ & $9: 16$ & 1915 & 1858 & 1801 & 359 & 645 & 324 & 5.30 & 0.94 & 5.31 & 0.51 & 0.25 & 0.98 & 13.29 & 80 & 702 \\
\hline GR-LNB 60a & $7 / 28 / 93$ & 11.06 & 1882 & 1836 & 1790 & 336 & 634 & 311 & 5.28 & 0.94 & 5.29 & 0.51 & 0.28 & 1.10 & 13.41 & 80 & 700 \\
\hline GR-LNB 60b & $7 / 28 / 93$ & $2: 02$ & 1985 & 1908 & 1832 & 430 & 661 & 396 & 5.32 & 0.93 & 5.37 & 0.51 & 0.18 & 0.80 & 13.12 & 80 & 721 \\
\hline LNB-OFA & $7 / 28 / 93$ & $2: 21$ & 2001 & 1922 & 1843 & 422 & 649 & 383 & 5.25 & 1.12 & 4.30 & 0.61 & 0.17 & 0.75 & 12.20 & 80 & 705 \\
\hline GR-LNB 60 & $7 / 28 / 93$ & $8: 10$ & 1985 & 1909 & 1832 & 422 & 666 & 382 & 5.26 & 0.94 & 5.34 & 0.51 & 0.18 & 0.79 & 13.02 & 80 & 719 \\
\hline GR-LNB 61a & $7 / 29 / 93$ & $15: 55$ & 1939 & 1873 & 1807 & 397 & 658 & 364 & 5.27 & 0.94 & 5.33 & 0.51 & 0.22 & 0.89 & 13.15 & 80 & 716 \\
\hline GR-LNB 61 & $7 / 29 / 93$ & $8: 04$ & 1943 & 1878 & 1813 & 395 & 658 & 356 & 5.31 & 0.94 & 5.37 & 0.51 & 0.22 & 0.89 & 13.24 & 80 & 711 \\
\hline GR-LNB 62 & $7 / 30 / 93$ & $10: 04$ & 1919 & 1860 & 1802 & 383 & 654 & 352 & 5.21 & 0.94 & 5.33 & 0.51 & 0.24 & 0.95 & 13.18 & 80 & 704 \\
\hline LNB-OFA & $7 / 30 / 93$ & $4: 32$ & 1944 & 1871 & 1799 & 406 & 644 & 368 & 5.42 & 1.12 & 4.29 & 0.61 & 0.19 & 0.81 & 12.44 & 80 & 699 \\
\hline GR-LNB 62a & $7 / 30 / 93$ & $9: 00$ & 1951 & 1884 & 1818 & 401 & 660 & 369 & 5.42 & 0.94 & 5.33 & 0.51 & 0.21 & 0.87 & 13.28 & 80 & 714 \\
\hline GR-LNB 63a & $7 / 31 / 93$ & $17: 10$ & 1931 & 1866 & 1800 & 397 & 660 & 364 & 5.22 & 0.94 & 5.33 & 0.51 & 0.22 & 0.89 & 13.11 & .80 & 706 \\
\hline GA-LNB 63b & $7 / 31 / 93$ & $6: 49$ & 1955 & 1889 & 1823 & 397 & 661 & 357 & 5.30 & 0.95 & 5.29 & 0.52 & 0.21 & 0.87 & 13.14 & 80 & 712 \\
\hline GR-LNB 64a & $8 / 1 / 93$ & $1: 25$ & 1886 & 1835 & 1784 & 351 & 647 & 317 & 5.38 & 0.95 & 5.30 & 0.52 & 0.26 & 1.04 & 13.44 & 80 & 705 \\
\hline GR-LNB 64b & $8 / 1 / 93$ & $10: 21$ & 1828 & 1800 & 1772 & 269 & 592 & 243 & 5.56 & 0.94 & 5.26 & 0.52 & 0.35 & 1.29 & 13.91 & 80 & 671 \\
\hline
\end{tabular}


Cherokee Unit 3, Average Test 5

Pre Modification

\begin{tabular}{|c|c|c|c|c|c|c|c|c|c|c|c|c|c|c|c|c|c|}
\hline Tost & Daten & Dur & prum & $\begin{array}{l}\text { Psh! } \\
\text { ouf } \\
\text { psig }\end{array}$ & 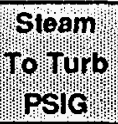 & RHYh & RH/W & $\begin{array}{l}\text { Hot RH } \\
\text { oypprs } \\
\text { PsIG }\end{array}$ & 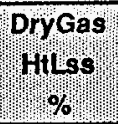 & Moist & CombH2o & Refuse & Radiat: & Unmess & 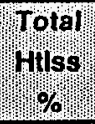 & comb & 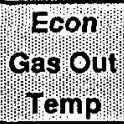 \\
\hline GR-LNB $64 c$ & $8 / 1 / 93$ & $12: 14$ & 1947 & 1884 & 1821 & 390 & 656 & 357 & 5.32 & 0.94 & 5.32 & 0.51 & 0.22 & 0.92 & 13.24 & 80 & 723 \\
\hline GR-LNB 65a & $8 / 2 / 93$ & $8: 55$ & 1842 & 1816 & 1791 & 257 & 574 & 234 & 5.86 & 0.95 & 5.23 & 0.52 & 0.36 & 1.32 & 14.24 & 80 & 666 \\
\hline LNB-OFA & $8 / 2 / 93$ & $1: 23$ & 1946 & 1872 & 1798 & 415 & 657 & 387 & 5.28 & 1.11 & 4.29 & 0.61 & 0.19 & 0.82 & 12.30 & 80 & 711 \\
\hline GR.LNB 65b & $8 / 2 / 93$ & $6: 02$ & 1935 & 1869 & 1803 & 395 & 659 & 366 & 5.17 & 0.94 & 5.33 & 0.51 & 0.22 & 0.90 & 13.05 & 80 & 715 \\
\hline GR-LNB 65c & $8 / 2 / 93$ & $7: 14$ & 1917 & 1855 & 1793 & 380 & 652 & 349 & 5.42 & 0.93 & 5.34 & 0.51 & 0.24 & 0.95 & 13.39 & 80 & 711 \\
\hline GR-LNB 66a & $8 / 3 / 93$ & $8: 29$ & 1799 & 1778 & 1758 & 237 & 577 & 219 & 5.88 & 0.93 & 5.27 & 0.51 & 0.39 & 1.41 & 14.38 & 80 & 662 \\
\hline GR-LNB 66b & $8 / 3 / 93$ & $9: 34$ & 1917 & 1857 & 1796 & 384 & 653 & 361 & 5.24 & 0.93 & 5.34 & 0.51 & 0.24 & 0.96 & 13.22 & 80 & 713 \\
\hline GR-LNB 66c & $8 / 3 / 93$ & $5: 55$ & 1938 & 1872 & 1805 & 402 & 660 & 376 & 5.13 & 0.93 & 5.34 & 0.51 & 0.22 & 0.90 & 13.04 & 80 & 722 \\
\hline GA-LNB 67 & $8 / 4 / 93$ & $24: 00$ & 1931 & 1875 & 1819 & 365 & 641 & 340 & 5.29 & 0.94 & 5.28 & 0.52 & 0.25 & 1.01 & 13.29 & 80 & 710 \\
\hline GR-LNB 68a & $8 / 5 / 93$ & $7: 39$ & 1871 & 1833 & 1795 & 305 & 616 & 284 & 5.33 & 0.95 & 5.23 & 0.52 & 0.32 & 1.20 & 13.53 & 80 & 686 \\
\hline GR-LNB 68b & $8 / 5 / 93$ & $15: 50$ & 1955 & 1886 & 1816 & 407 & 661 & 380 & 5.31 & 0.94 & 5.29 & 0.51 & 0.21 & 0.88 & 13.15 & 80 & 724 \\
\hline GA-LNB 69 & $8 / 6 / 93$ & $9: 48$ & 1918 & 1861 & 1803 & 370 & 645 & 347 & 5.15 & 0.94 & 5.26 & 0.52 & 0.25 & 1.00 & 13.12 & 80 & 712 \\
\hline LNB & $8 / 6 / 93$ & $7: 58$ & 1942 & 1870 & 1798 & 402 & 638 & 372 & 5.40 & 1.12 & 4.30 & 0.61 & 0.20 & 0.84 & 12.46 & 80 & 689 \\
\hline LNB-OFA & $8 / 6 / 93$ & 5.04 & 1954 & 1876 & 1798 & 410 & 640 & 375 & 5.44 & 1.12 & 4.30 & 0.61 & 0.18 & 0.80 & 12.45 & 80 & 688 \\
\hline LNB & $8 / 7 / 93$ & 3.04 & 1926 & 1857 & 1787 & 398 & 642 & 370 & 5.12 & 1.11 & 4.29 & 0.61 & 0.21 & 0.87 & 12.21 & 80 & 693 \\
\hline GR-LNB 70 & $8 / 7 / 93$ & $3: 53$ & 1906 & 1848 & 1789 & 372 & 645 & 347 & 5.38 & 1.03 & 4.79 & 0.56 & 0.25 & 0.99 & 13.00 & 80 & 716 \\
\hline LNB-OFA & $8 / 7 / 93$ & $8: 05$ & 1950 & 1877 & 1805 & 401 & 646 & 367 & 5.55 & 1.12 & 4.30 & 0.61 & 0.20 & 0.84 & 12.61 & 80 & 690 \\
\hline LNB & $8 / 7 / 93$ & $6: 28$ & 1959 & 1885 & 1810 & 409 & 643 & 375 & 5.48 & 1.12 & 4.30 & 0.61 & 0.19 & 0.82 & 12.51 & 80 & 689 \\
\hline LNB & $8 / 9 / 93$ & 8.04 & 1931 & 1869 & 1808 & 376 & 614 & 350 & 5.42 & 1.11 & 4.29 & 0.61 & 0.23 & 0.92 & 12.57 & 80 & 674 \\
\hline GR-LNB 71 (10\% Gas) & $8 / 9 / 93$ & $13: 45$ & 1954 & 1880 & 1805 & 403 & 664 & 365 & 5.40 & 1.00 & 4.98 & 0.55 & 0.20 & 0.83 & 12.95 & 80 & 710 \\
\hline GR-LNB $72 a(10 \%)$ & $8 / 10 / 93$ & $7: 48$ & 1927 & 1859 & 1791 & 401 & 663 & 369 & 5.32 & 1.01 & 4.91 & 0.55 & 0.22 & 0.89 & 12.90 & 80 & 708 \\
\hline LNB & $8 / 10 / 93$ & $7: 27$ & 1972 & 1874 & 1772 & 407 & 621 & 372 & 5.56 & 1.12 & 4.30 & 0.61 & 0.18 & 0.79 & 12.56 & 80 & 685 \\
\hline GR-LNB 72b (10\%) & $8 / 10 / 93$ & $7: 25$ & 1955 & 1893 & 1831 & 388 & 651 & 356 & 5.26 & 1.00 & 4.91 & 0.55 & 0.22 & 0.90 & 12.84 & 80 & 699 \\
\hline GR.LNB 73 & $8 / 11 / 93$ & $3: 22$ & 1940 & 1883 & 1827 & 376 & 641 & 350 & 5.22 & 1.00 & 4.90 & 0.55 & 0.24 & 0.96 & 12.86 & 80 & 696 \\
\hline LNB-OFA & $8 / 11 / 93$ & $9: 49$ & 1980 & 1905 & 1830 & 414 & 639 & 377 & 5.43 & 1.12 & 4.30 & 0.61 & 0.18 & 0.77 & 12.40 & 80 & 693 \\
\hline LNB & $8 / 11 / 93$ & $2: 45$ & 1950 & 1885 & 1820 & 396 & 624 & 364 & 5.54 & 1.11 & 4.29 & 0.61 & 0.20 & 0.85 & 12.60 & 80 & 689 \\
\hline LNB & $8 / 12 / 93$ & $7: 36$ & 1878 & 1846 & 1815 & 289 & 576 & 265 & 5.55 & 1.11 & 4.29 & 0.61 & 0.32 & 1.20 & 13.09 & 80 & 648 \\
\hline GR-LNB 74 & $8 / 12 / 93$ & $14: 33$ & 1964 & 1898 & 1832 & 407 & 661 & 379 & 5.22 & 1.00 & 4.92 & 0.55 & 0.21 & 0.86 & 12.75 & 80 & 711 \\
\hline GR-LNB 75 & $8 / 13 / 93$ & $18: 16$ & 1963 & 1899 & 1835 & 395 & 653 & 364 & 5.44 & 1.00 & 4.94 & 0.55 & 0.22 & 0.89 & 13.04 & 80 & 711 \\
\hline GR-LNB 76a & $8 / 14 / 93$ & $4: 54$ & 1899 & 1865 & 1831 & 307 & 623 & 280 & 5.67 & 1.01 & 4.88 & 0.55 & 0.31 & 1.18 & 13.61 & 80 & 684 \\
\hline LNB & $8 / 14 / 93$ & $1: 46$ & 1857 & 1846 & 1834 & 213 & 549 & 189 & 6.83 & 1.11 & 4.28 & 0.61 & 0.40 & 1.45 & 14.69 & 80 & 629 \\
\hline GR-LNB 76b & $8 / 14 / 93$ & $11: 05$ & 1957 & 1896 & 1835 & 387 & 651 & 355 & 5.64 & 1.00 & 4.94 & 0.55 & 0.22 & 0.91 & 13.26 & 80 & 708 \\
\hline GR-LNB 77 & $8 / 15 / 93$ & $1: 10$ & 1880 & 1848 & 1817 & 293 & 613 & 268 & 5.85 & 1.01 & 4.87 & 0.55 & 0.32 & 1.22 & 13.83 & 80 & 679 \\
\hline LNB & $8 / 15 / 93$ & $14: 44$ & 1902 & 1867 & 1832 & 298 & 587 & 274 & 5.81 & 1.12 & 4.29 & 0.61 & 0.31 & 1.19 & 13.33 & 80 & 654 \\
\hline LNB & $8 / 15 / 93$ & 6.58 & 1981 & 1910 & 1839 & 407 & 650 & 371 & 5.45 & 1.12 & 4.30 & 0.61 & 0.19 & 0.81 & 12.48 & 80 & 691 \\
\hline LNB (low load) & $8 / 16 / 93$ & $7: 38$ & 1880 & 1855 & 1831 & 267 & 589 & 246 & 6.04 & 1.12 & 4.31 & 0.61 & 0.35 & 1.31 & 13.73 & 80 & 664 \\
\hline LNB (150 MWo) & $8 / 16 / 93$ & $3: 21$ & 1988 & 1914 & 1841 & 422 & 646 & 395 & 5.53 & 1.12 & 4.29 & 0.61 & 0.18 & 0.79 & 12.52 & 80 & 709 \\
\hline LNB-OFA cooling & $8 / 16 / 93$ & $11: 40$ & 1991 & 1916 & 1840 & 417 & 623 & 379 & 5.52 & 1.12 & 4.30 & 0.61 & 0.17 & 0.75 & 12.46 & 80 & 690 \\
\hline LNB & $8 / 17 / 93$ & 9.07 & 1938 & 1752 & 1564 & 360 & 604 & 333 & 5.48 & 1.11 & 4.29 & 0.61 & 0.24 & 0.97 & 12.70 & 80 & 680 \\
\hline $100 \%$ Gas (plant test) & $8 / 17 / 93$ & $0: 34$ & 1824 & 1699 & 1574 & 199 & 482 & 178 & 7.33 & 1.11 & 4.26 & 0.61 & 0.41 & 1.47 & 15.18 & 80 & 606 \\
\hline
\end{tabular}


Cherokee Unit 3, Average Test C

Pre Modification

\begin{tabular}{|c|c|c|c|c|c|c|c|c|c|c|c|c|c|c|c|c|c|}
\hline Testwp. pow & Date & Dur & $\begin{array}{l}\text { Drum } \\
\text { Press } \\
\text { PSiG }\end{array}$ & $\begin{array}{l}\text { PSH } \\
\text { Out } \\
\text { PSIG }\end{array}$ & $\begin{array}{l}\text { Steam } \\
\text { To Turb } \\
\text { Psig }\end{array}$ & $\begin{array}{l}\text { RHIh } \\
\text { Press } \\
\text { PSIG } \\
\end{array}$ & $\begin{array}{l}\text { RHIn } \\
\text { Temp } \\
\text { Deg F }\end{array}$ & $\begin{array}{l}\text { Hot RH } \\
\text { Out Prs } \\
\text { PSIG }\end{array}$ & $\begin{array}{l}\text { DryGas } \\
\text { putss } \\
\%\end{array}$ & $\begin{array}{l}\text { Moist } \\
\text { nutss } \\
\%\end{array}$ & 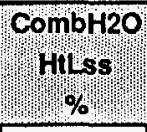 & $\begin{array}{l}\text { Refuse } \\
\text { putss } \\
\text { \% }\end{array}$ & $\begin{array}{l}\text { nadiat } \\
\text { quss } \\
\text { \% }\end{array}$ & $\begin{array}{l}\text { Unmeas } \\
\text { phuss } \\
\text { fyos }\end{array}$ & $\begin{array}{l}\text { Total } \\
\text { ntss } \\
\text { To. }\end{array}$ & $\begin{array}{l}\text { Comb } \\
\text { Arr } \\
\text { Temp }\end{array}$ & $\begin{array}{l}\text { Econ } \\
\text { Gas ouf } \\
\text { Temp }\end{array}$ \\
\hline LNB (OFA cooling) & $8 / 17 / 93$ & $8: 59$ & 1978 & 989 & 0 & 412 & 626 & 374 & 5.45 & 1.12 & 4.30 & 0.61 & 0.17 & 0.77 & 12.42 & 80 & 695 \\
\hline LNB & $8 / 17 / 93$ & $3: 05$ & 1974 & 987 & 0 & 409 & 628 & 377 & 5.29 & 1.12 & 4.30 & 0.61 & 0.19 & 0.80 & 12.29 & 80 & 693 \\
\hline LNB (low load) & $8 / 18 / 93$ & $9: 42$ & 1894 & 947 & 0 & 301 & 589 & 275 & 5.56 & 1.12 & 4.30 & 0.61 & 0.31 & 1.17 & 13.07 & 80 & 670 \\
\hline LNB $150 \mathrm{MWe}$ & $8 / 18 / 93$ & 14:16 & 1982 & 991 & 0 & 420 & 615 & 389 & 5.41 & 1.11 & 4.29 & 0.61 & 0.17 & 0.76 & 12.36 & 80 & 691 \\
\hline GR-LNB 78 & $8 / 24 / 93$ & $3: 25$ & 1947 & 1887 & 1826 & 408 & 664 & 373 & 5.05 & 0.99 & 4.98 & 0.54 & 0.25 & 0.98 & 12.79 & 80 & 693 \\
\hline LNB OFA cooling & $8 / 24 / 93$ & $10: 38$ & 1952 & 1888 & 1824 & 407 & 658 & 367 & 5.42 & 1.11 & 4.29 & 0.61 & 0.23 & 0.93 & 12.60 & 80 & 680 \\
\hline LNB OFA cooling & $8 / 25 / 93$ & $2: 06$ & 1881 & 1848 & 1815 & 306 & 624 & 274 & 5.07 & 1.11 & 4.26 & 0.61 & 0.33 & 1.24 & 12.61 & 80 & 645 \\
\hline LNB & $8 / 25 / 93$ & $8: 38$ & 1881 & 1852 & 1822 & 297 & 614 & 271 & 5.08 & 1.11 & 4.26 & 0.61 & 0.34 & 1.28 & 12.69 & 80 & 645 \\
\hline LNB & $8 / 25 / 93$ & 13:08 & 1956 & 1895 & 1833 & 414 & 644 & 386 & 5.29 & 1.11 & 4.28 & 0.61 & 0.23 & 0.94 & 12.46 & 80 & 688 \\
\hline LNB & $8 / 26 / 93$ & $21: 16$ & 1887 & 1855 & 1822 & 285 & 556 & 261 & 5.37 & 1.11 & 4.28 & 0.61 & 0.32 & 1.22 & 12.92 & 80 & 653 \\
\hline LNB & $8 / 26 / 93$ & $2: 42$ & 1972 & 1904 & 1835 & 402 & 633 & 374 & 5.42 & 1.11 & 4.29 & 0.61 & 0.20 & 0.84 & 12.47 & 80 & 693 \\
\hline LNB & $8 / 27 / 93$ & $8: 26$ & 1877 & 1849 & 1822 & 268 & 548 & 248 & 5.36 & 1.11 & 4.28 & 0.61 & 0.35 & 1.29 & 13.00 & 80 & 642 \\
\hline LNB & $8 / 27 / 93$ & $6: 17$ & 1965 & 1898 & 1831 & 399 & 613 & 375 & 5.25 & 1.11 & 4.28 & 0.61 & 0.20 & 0.85 & 12.30 & 80 & 682 \\
\hline GR-LNB 79 & $9 / 8 / 93$ & 11:15 & 1969 & 1902 & 1834 & 401 & 651 & 372 & 5.00 & 0.97 & 5.12 & 0.53 & 0.21 & 0.86 & 12.68 & 80 & 712 \\
\hline GR-LNB 79a & $9 / 8 / 93$ & $1: 49$ & 1907 & 1867 & 1826 & 325 & 615 & 301 & 4.85 & 0.95 & 5.18 & 0.52 & 0.29 & 1.11 & 12.89 & 80 & 683 \\
\hline GR-LNB 80a & 9/9/93 & 6.55 & 1891 & 1860 & 1828 & 292 & 604 & 272 & 4.74 & 0.95 & 5.19 & 0.52 & 0.33 & 1.24 & 12.96 & 80 & 676 \\
\hline LNB-OFA & $9 / 9 / 93$ & $1: 46$ & 1847 & 1832 & 1817 & 228 & 546 & 211 & 4.98 & 1.11 & 4.25 & 0.61 & 0.39 & 1.42 & 12.75 & 80 & 644 \\
\hline GR-LNB 80 & 9/9/93 & 14:15 & 1933 & 1877 & 1821 & 363 & 642 & 333 & 4.99 & 0.95 & 5.20 & 0.52 & 0.25 & 0.99 & 12.91 & 80 & 701 \\
\hline LNB-OFA & $9 / 10 / 93$ & $4: 50$ & 1838 & 1824 & 1811 & 209 & 529 & 191 & 5.09 & 1.11 & 4.26 & 0.61 & 0.41 & 1.48 & 12.96 & 80 & 632 \\
\hline GR-LNB 81 & $9 / 10 / 93$ & $1: 46$ & 1882 & 1851 & 1821 & 289 & 610 & 270 & 4.82 & 0.94 & 5.28 & 0.51 & 0.34 & 1.26 & 13.14 & 80 & 686 \\
\hline LNB & $9 / 10 / 93$ & 13:30 & 1954 & 1889 & 1824 & 386 & 620 & 356 & 5.40 & 1.11 & 4.29 & 0.61 & 0.21 & 0.89 & 12.51 & 80 & 685 \\
\hline LNB & $9 / 11 / 93$ & 19:30 & 1932 & 1876 & 1821 & 355 & 610 & 325 & 5.52 & 1.12 & 4.30 & 0.61 & 0.25 & 0.98 & 12.78 & 80 & 677 \\
\hline GR-LNB 82 & $9 / 11 / 93$ & $4: 10$ & 1957 & 1891 & 1825 & 395 & 641 & 362 & 5.08 & 0.96 & 5.21 & 0.52 & 0.20 & 0.86 & 12.83 & 80 & 711 \\
\hline GR-LNB 83a & $9 / 12 / 93$ & $11: 51$ & 1909 & 1864 & 1819 & 339 & 623 & 313 & 4.83 & 0.95 & 5.18 & 0.52 & 0.27 & 1.07 & 12.83 & 80 & 691 \\
\hline GR-LNB 83 & $9 / 12 / 93$ & 12:09 & 1975 & 1901 & 1827 & 415 & 665 & 377 & 5.17 & 0.97 & 5.14 & 0.53 & 0.18 & 0.80 & 12.79 & 80 & 713 \\
\hline GR-LNB 84a & $9 / 13 / 93$ & $5: 35$ & 1886 & 1851 & 1816 & 314 & 616 & 298 & 4.61 & 0.95 & 5.14 & 0.52 & 0.31 & 1.18 & 12.72 & 80 & 679 \\
\hline GR-LNB 84 & $9 / 13 / 93$ & $18: 03$ & 1946 & 1882 & 1819 & 391 & 652 & 363 & 4.66 & 0.98 & 4.95 & 0.54 & 0.22 & 0.91 & 12.27 & 80 & 708 \\
\hline GR-LNB 85a & $9 / 14 / 93$ & $4: 15$ & 1910 & 1861 & 1814 & 340 & 637 & 311 & 4.60 & 0.97 & 5.03 & 0.53 & 0.27 & 1.07 & 12.47 & 80 & 693 \\
\hline LNB & $9 / 14 / 93$ & $11: 05$ & 1896 & 1854 & 1812 & 313 & 599 & 285 & 5.03 & 1.11 & 4.26 & 0.61 & 0.29 & 1.13 & 12.43 & 80 & 663 \\
\hline LNB-OFA & $9 / 14 / 93$ & $1: 06$ & 1965 & 1895 & 1825 & 401 & 637 & 366 & 5.05 & 1.11 & 4.26 & 0.61 & 0.19 & 0.82 & 12.03 & 80 & 699 \\
\hline GR-LNB 85 & $9 / 14 / 93$ & $6: 55$ & 1944 & 1882 & 1820 & 388 & 655 & 354 & 4.83 & 0.97 & 5.07 & 0.53 & 0.22 & 0.90 & 12.52 & 80 & 708 \\
\hline GR-LNB 86a & $9 / 15 / 93$ & 0.50 & 1911 & 1863 & 1814 & 349 & 640 & 318 & 4.76 & 0.96 & 5.09 & 0.53 & 0.26 & 1.03 & 12.64 & 80 & 699 \\
\hline LNB & $9 / 15 / 93$ & $3: 07$ & 1876 & 1852 & 1829 & 264 & 585 & 237 & 4.66 & 1.10 & 4.23 & 0.61 & 0.35 & 1.31 & 12.26 & 80 & 649 \\
\hline GR-LNB 86b & $9 / 15 / 93$ & $4: 26$ & 1913 & 1872 & 1830 & 323 & 627 & 293 & 4.77 & 0.96 & 5.13 & 0.53 & 0.29 & 1.12 & 12.80 & 80 & 698 \\
\hline GR-LNB 86 & $9 / 15 / 93$ & $11: 20$ & 1949 & 1887 & 1826 & 379 & 653 & 339 & 4.98 & $0 . \overline{97}$ & 5.10 & 0.53 & 0.23 & 0.92 & 12.73 & 80 & 711 \\
\hline GR-LNB 87a & $9 / 16 / 93$ & $5: 46$ & 1901 & 1859 & 1816 & 314 & 611 & 279 & 4.82 & 0.96 & 5.12 & 0.53 & 0.29 & 1.13 & 12.85 & 80 & 689 \\
\hline GR-LNB 87 & $9 / 16 / 93$ & 15:24 & 1938 & 1881 & 1824 & 359 & 644 & 324 & 4.95 & 0.97 & 5.07 & 0.53 & 0.25 & 0.99 & 12.77 & 80 & 709 \\
\hline GR-LNB 88a & 9/17/93 & $5: 31$ & 1914 & 1866 & 1819 & 330 & 633 & 298 & 4.77 & 0.96 & 5.12 & 0.53 & 0.28 & 1.09 & 12.76 & 80 & 695 \\
\hline GR-LNB 88 & $9 / 17 / 93$ & $18: 28$ & 1954 & 1889 & 1825 & 386 & 654 & 351 & 4.92 & 0.97 & 5.06 & 0.53 & 0.22 & 0.91 & 12.62 & 80 & 714 \\
\hline GR-LNB 89 & $9 / 18 / 93$ & $24: 00$ & 1943 & 1882 & 1821 & 376 & 650 & 344 & 4.80 & 0.98 & 5.01 & 0.54 & 0.24 & 0.95 & 12.52 & 80 & 705 \\
\hline
\end{tabular}


Cherokee Unit 3, Average Test C

Pre Modification

\begin{tabular}{|c|c|c|c|c|c|c|c|c|c|c|c|c|c|c|c|c|c|}
\hline Test No & Date & חown & $\begin{array}{l}\text { Drum } \\
\text { Press } \\
\text { Pssig }\end{array}$ & 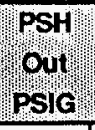 & 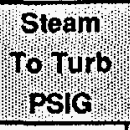 & RH In & $\begin{array}{l}\text { RH In } \\
\text { Temp } \\
\text { Deg }\end{array}$ & $\begin{array}{l}\text { Hot RH } \\
\text { optprs pre } \\
\text { Psic }\end{array}$ & 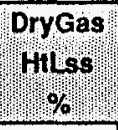 & Moist & CombH2O & $\begin{array}{l}\text { Rofuse: } \\
\text { Htyss }\end{array}$ & Radiat & 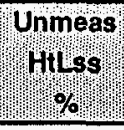 & $\begin{array}{l}\text { Total } \\
\text { Thtss } \\
\text { \% }\end{array}$ & Comb & 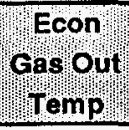 \\
\hline GR-LNB 90a & $9 / 19 / 93$ & $10: 06$ & 1919 & 1869 & 1819 & 342 & 638 & 313 & 4.80 & 0.97 & 5.03 & 0.54 & 0.28 & 1.07 & 12.68 & 80 & 697 \\
\hline GR-LNB 90 & $9 / 19 / 93$ & $13: 54$ & 1960 & 1890 & 1821 & 394 & 658 & 358 & 5.04 & 0.99 & 4.98 & 0.54 & 0.22 & 0.89 & 12.67 & 80 & 712 \\
\hline GR-LNB 91 & $9 / 20 / 93$ & $24: 00$ & 1945 & 1884 & 1823 & 376 & 651 & 341 & 5.03 & 0.97 & 5.10 & 0.53 & 0.24 & 0.96 & 12.84 & 80 & 712 \\
\hline GR-LNB 92a & $9 / 21 / 93$ & $3: 00$ & 1895 & 1854 & 1814 & 308 & 623 & 278 & 4.91 & 0.95 & 5.21 & 0.52 & 0.31 & 1.17 & 13.06 & 80 & 690 \\
\hline GR-LNB 92 & $9 / 21 / 93$ & $17: 56$ & 1950 & 1888 & 1826 & 379 & 648 & 345 & 5.07 & 0.97 & 5.14 & 0.53 & 0.23 & 0.93 & 12.86 & 80 & 706 \\
\hline GR-LNB 3 Mill a & $9 / 22 / 93$ & $7: 59$ & 1886 & 1851 & 1815 & 303 & 616 & 281 & 4.59 & 0.94 & 5.20 & 0.52 & 0.32 & 1.20 & 12.77 & 80 & 680 \\
\hline GR-LNB 3 Mill b & $9 / 22 / 93$ & $8: 25$ & 1901 & 1857 & 1813 & 327 & 617 & 305 & 4.77 & 0.95 & 5.13 & 0.52 & 0.29 & 1.12 & 12.78 & 80 & 680 \\
\hline GR-LNB 3 Mill c & $9 / 23 / 93$ & $24: 00$ & 1903 & 1857 & 1811 & 330 & 621 & 308 & 4.83 & 0.95 & 5.13 & 0.52 & 0.29 & 1.10 & 12.82 & 80 & 687 \\
\hline GR-LNB 3 Mill d & $9 / 24 / 93$ & $1: 58$ & 1857 & 1829 & 1801 & 264 & 598 & 245 & 5.20 & 0.94 & 5.18 & 0.52 & 0.36 & 1.32 & 13.51 & 80 & 669 \\
\hline LNB-OFA 3 Mill & $9 / 24 / 93$ & $3: 33$ & 1830 & 1817 & 1803 & 198 & 443 & 183 & 5.86 & 1.09 & 4.21 & 0.61 & 0.41 & 1.49 & 13.67 & 80 & 615 \\
\hline GR-LNB 3 Mill e & $9 / 24 / 93$ & $6: 10$ & 1908 & 1861 & 1815 & 331 & 603 & 310 & 4.89 & 0.95 & 5.09 & 0.53 & 0.28 & 1.09 & 12.82 & 80 & 681 \\
\hline GR-LNB 93 & $9 / 24 / 93$ & $12: 09$ & 1938 & 1877 & 1815 & 374 & 635 & 347 & 5.20 & 0.97 & 5.05 & 0.53 & 0.23 & 0.95 & 12.94 & 80 & 701 \\
\hline GR-LNB 94a & $9 / 25 / 93$ & $2: 12$ & 1900 & 1853 & 1806 & 320 & 625 & 288 & 5.21 & 0.96 & 5.11 & 0.53 & 0.29 & 1.11 & 13.21 & 80 & 692 \\
\hline LNB-OFA & $9 / 25 / 93$ & $2: 24$ & 1863 & 1833 & 1804 & 259 & 576 & 231 & 5.83 & 1.10 & 4.25 & 0.61 & 0.35 & 1.30 & 13.45 & 80 & 671 \\
\hline GR-LNB 94 & $9 / 25 / 93$ & $19: 05$ & 1960 & 1888 & 1816 & 396 & 658 & 360 & 5.23 & 0.98 & 5.04 & 0.54 & 0.21 & 0.87 & 12.87 & 80 & 718 \\
\hline GR-LNB 95a & $9 / 26 / 93$ & $4: 15$ & 1894 & 1849 & 1804 & 317 & 630 & 287 & 5.02 & 0.95 & 5.16 & 0.52 & 0.30 & 1.14 & 13.09 & 80 & 690 \\
\hline LNB-OFA & $9 / 26 / 93$ & $2: 55$ & 1855 & 1829 & 1803 & 249 & 511 & 226 & 5.78 & 1.10 & 4.24 & 0.61 & 0.36 & 1.31 & 13.40 & 80 & 646 \\
\hline GR-LNB 95 & $9 / 26 / 93$ & $16: 33$ & 1937 & 1874 & 1811 & 370 & 646 & 337 & 5.22 & 0.97 & 5.09 & 0.53 & 0.24 & 0.96 & 13.01 & 80 & 703 \\
\hline GR-LNB 96a & 9/27/93 & 2.53 & 1913 & 1863 & 1814 & 333 & 619 & 304 & 5.38 & 0.96 & 5.13 & 0.53 & 0.28 & 1.08 & 13.35 & 80 & 693 \\
\hline LNB & $9 / 27 / 93$ & $19: 45$ & 1957 & 1886 & 1815 & 391 & 617 & 355 & 5.48 & 1.11 & 4.28 & 0.61 & 0.20 & 0.84 & 12.53 & 80 & 689 \\
\hline GR-LNB 966 & $9 / 27 / 93$ & 0.57 & 1898 & 1852 & 1806 & 322 & 621 & 288 & 5.25 & 0.95 & 5.22 & 0.52 & 0.28 & 1.09 & 13.31 & 80 & 691 \\
\hline GR-LNB 97a & $9 / 28 / 93$ & $9: 13$ & 1915 & 1864 & 1813 & 346 & 636 & 315 & 5.30 & 0.96 & 5.15 & 0.53 & 0.27 & 1.05 & 13.24 & 80 & 701 \\
\hline LNB & $9 / 28 / 93$ & $4: 27$ & 1962 & 1889 & 1815 & 403 & 645 & 371 & 4.61 & 1.11 & 4.28 & 0.61 & 0.19 & 0.83 & 11.63 & 80 & 696 \\
\hline GR-LNB 97 & $9 / 28 / 93$ & $5: 58$ & 1956 & 1885 & 1815 & 396 & 660 & 360 & 5.11 & 1.00 & 4.98 & 0.54 & 0.21 & 0.88 & 12.73 & 80 & 717 \\
\hline GR.LNB 97b & $9 / 28 / 93$ & $2: 48$ & 1898 & 1852 & 1805 & 323 & 631 & 292 & 5.28 & 1.00 & 4.92 & 0.55 & 0.29 & 1.12 & 13.16 & 80 & 691 \\
\hline GR-LNB 98a & $9 / 29 / 93$ & $5: 22$ & 1880 & 1843 & 1807 & 293 & 619 & 265 & 5.50 & 1.00 & 4.89 & 0.55 & 0.33 & 1.22 & 13.49 & 80 & 685 \\
\hline GR-LNB 98 & $9 / 29 / 93$ & $18: 37$ & 1956 & 1885 & 1815 & 396 & 655 & 361 & 5.15 & 0.98 & 5.05 & 0.54 & 0.21 & 0.87 & 12.80 & 80 & 712 \\
\hline GA-LNB 99a & $9 / 30 / 93$ & $5: 32$ & 1881 & 1845 & 1809 & 289 & 592 & 260 & 5.54 & 0.95 & 5.19 & 0.52 & 0.32 & 1.20 & 13.72 & 80 & 672 \\
\hline GR-LNB 99 & $9 / 30 / 93$ & 13:24 & 1957 & 1888 & 1819 & 391 & 653 & 356 & 5.28 & 0.97 & 5.14 & 0.53 & 0.21 & 0.88 & 13.00 & 80 & 708 \\
\hline GR-LNB 996 & $9 / 30 / 93$ & $2: 27$ & 1908 & 1861 & 1813 & 327 & 620 & 294 & 5.61 & 0.95 & 5.26 & 0.52 & 0.28 & 1.08 & 13.70 & 80 & 694 \\
\hline LNB-OFA & $9 / 30 / 93$ & $2: 27$ & 1840 & 1825 & 1809 & 205 & 476 & 180 & 6.01 & 1.11 & 4.27 & 0.61 & 0.40 & 1.45 & 13.84 & 80 & 621 \\
\hline GR-LNB $100 a$ & $10 / 1 / 93$ & $11: 00$ & 1878 & 1848 & 1818 & 267 & 594 & 242 & 5.69 & 0.95 & 5.20 & 0.52 & 0.35 & 1.29 & 14.00 & 80 & 679 \\
\hline GR-LNB 100 & $10 / 1 / 93$ & $9: 12$ & 1912 & 1865 & 1818 & 325 & 634 & 291 & 5.29 & 0.96 & 5.17 & 0.52 & 0.29 & 1.11 & 13.35 & 80 & 694 \\
\hline GR-LNB 101 & $10 / 2 / 93$ & $24: 00$ & 1909 & 1864 & 1818 & 319 & 628 & 288 & 5.32 & 0.96 & 5.15 & 0.53 & 0.29 & 1.13 & 13.37 & 80 & 696 \\
\hline GR.LNB 102 & $10 / 3 / 93$ & $24: 00$ & 1895 & 1855 & 1816 & 299 & 624 & 267 & 5.56 & 0.96 & 5.15 & 0.53 & 0.31 & 1.19 & 13.70 & 80 & 692 \\
\hline GA-LNB 103 & $10 / 4 / 93$ & $24: 00$ & 1909 & 1864 & 1819 & 321 & 630 & 287 & 5.47 & 0.95 & 5.22 & 0.52 & 0.29 & 1.11 & 13.56 & 80 & 701 \\
\hline GR-LNB 104 & $10 / 5 / 93$ & $24: 00$ & 1910 & 1864 & 1819 & 333 & 633 & 303 & 5.55 & 0.94 & 5.29 & 0.51 & 0.28 & 1.09 & 13.67 & 80 & 703 \\
\hline GR-LNB 105 & $10 / 6 / 93$ & $10: 15$ & 1949 & 1889 & 1830 & 387 & 650 & 361 & 5.38 & 0.96 & 5.16 & 0.53 & 0.23 & 0.93 & 13.19 & 80 & 714 \\
\hline GR-LNB 106 & $10 / 8 / 93$ & $8: 45$ & 1958 & 1889 & 1820 & 396 & 653 & 364 & 4.49 & 0.96 & 5.05 & 0.53 & 0.21 & 0.87 & 12.11 & 80 & 705 \\
\hline GR-LNB 107 & $10 / 9 / 93$ & $24: 00$ & 1961 & 1891 & 1822 & 398 & 654 & 369 & 4.69 & 0.97 & 5.02 & 0.53 & 0.21 & 0.88 & 12.29 & 80 & 709 \\
\hline
\end{tabular}


Pre Modification

\begin{tabular}{|c|c|c|c|c|c|c|c|c|c|c|c|c|c|c|c|c|c|}
\hline 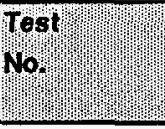 & Date: & pwp & $\begin{array}{l}\text { Drum } \\
\text { presss } \\
\text { prsig }\end{array}$ & "rst! & 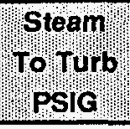 & חRHIn & Rerpla & $\begin{array}{c}\text { Hotsh } \\
\text { oytprs } \\
\text { psiG }\end{array}$ & DryGas! & $\begin{array}{l}\text { Moist } \\
\text { Whoss } \\
\text { \% }\end{array}$ & comb & 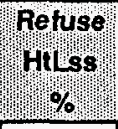 & Radiat & Unmeas & Trotal & 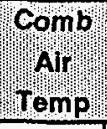 & $\begin{array}{l}\text { Econ } \\
\text { Gas out } \\
\text { tempem }\end{array}$ \\
\hline GR-LNB 108 & $10 / 10 / 93$ & 11.00 & 1965 & 1895 & 1824 & 399 & 658 & 368 & 4.91 & 0.97 & 5.03 & 0.53 & 0.21 & 0.88 & 12.54 & 80 & 711 \\
\hline GR-LNB $109 \mathrm{a}$ & $10 / 13 / 93$ & $4: 07$ & 1968 & 1899 & 1829 & 393 & 645 & 356 & 4.91 & 0.95 & 5.18 & 0.52 & 0.20 & 0.86 & 12.62 & 80 & 699 \\
\hline GR-LNB 1096 & $10 / 13 / 93$ & $2: 02$ & 1911 & 1865 & 1818 & 321 & 616 & 287 & 5.06 & 0.95 & 5.14 & 0.53 & 0.28 & 1.09 & 13.05 & 80 & 681 \\
\hline GA-LNB 110a & $10 / 14 / 93$ & $6: 02$ & 1927 & 1875 & 1824 & 347 & 640 & 316 & 5.05 & 0.95 & 5.17 & 0.52 & 0.27 & 1.05 & 13.00 & 80 & 700 \\
\hline GA-LNB 110 & $10 / 14 / 93$ & $14: 56$ & 1959 & 1892 & 1825 & 393 & 657 & 359 & 4.92 & 0.93 & 5.29 & 0.51 & 0.22 & 0.90 & 12.77 & 80 & 712 \\
\hline GR-LNB $110 b$ & $10 / 14 / 93$ & 3.00 & 1912 & 1868 & 1825 & 311 & 615 & 280 & 5.21 & 0.91 & 5.43 & 0.50 & 0.30 & 1.14 & 13.47 & 80 & 685 \\
\hline GR-LNB 111 & $10 / 15 / 93$ & $12: 49$ & 1924 & 1869 & 1814 & 360 & 644 & 330 & 4.90 & 0.93 & 5.29 & 0.51 & 0.26 & 1.02 & 12.91 & 80 & 704 \\
\hline GR-LNB 3 Mill a & $10 / 15 / 93$ & $2: 58$ & 1944 & 1878 & 1811 & 382 & 654 & 348 & 4.35 & 0.93 & 5.21 & 0.52 & 0.22 & 0.91 & 12.14 & 80 & 698 \\
\hline GA-LNB 3 Mill $b$ & $10 / 15 / 93$ & $7: 05$ & 1918 & 1861 & 1804 & 349 & 630 & 316 & 4.67 & 0.95 & 5.15 & 0.52 & 0.25 & 1.00 & 12.54 & 80 & 694 \\
\hline GR-LNB 3 Mill C & $10 / 16 / 93$ & $12: 05$ & 1866 & 1830 & 1795 & 278 & 604 & 249 & 5.28 & 0.94 & 5.17 & 0.52 & 0.33 & 1.25 & 13.50 & 80 & 683 \\
\hline GR-LNB 3 Mill d & $10 / 16 / 93$ & $10: 28$ & 1967 & 1890 & 1812 & 410 & 659 & 373 & 4.85 & 0.94 & 5.25 & 0.52 & 0.19 & 0.81 & 12.56 & 80 & 718 \\
\hline GR-LNB 3 Mill $\theta$ & $10 / 16 / 93$ & $1: 25$ & 1943 & 1884 & 1825 & 358 & 635 & 324 & 4.78 & 0.94 & 5.21 & 0.52 & 0.24 & 0.97 & 12.65 & 80 & 696 \\
\hline GR-LNB 3 Mill $f$ & $10 / 17 / 93$ & $23: 46$ & 1928 & 1875 & 1823 & 345 & 633 & 316 & 4.42 & 0.93 & 5.20 & 0.52 & 0.27 & 1.05 & 12.38 & 80 & 687 \\
\hline LNB-OFA 3 Mill & $10 / 18 / 93$ & $11: 10$ & 1888 & 1855 & 1821 & 273 & 592 & 246 & 4.56 & 1.09 & 4.20 & 0.61 & 0.34 & 1.27 & 12.07 & 80 & 658 \\
\hline GR-LNB 3 Mill g & $10 / 19 / 93$ & $15: 35$ & 1924 & 1874 & 1824 & 331 & 609 & 301 & 4.74 & 0.93 & 5.17 & 0.52 & 0.27 & 1.07 & 12.71 & 80 & 678 \\
\hline GR-LNB 3 Mill h & $10 / 20 / 93$ & $7: 35$ & 1925 & 1875 & 1826 & 334 & 625 & 306 & 4.63 & 0.93 & 5.16 & 0.52 & 0.28 & 1.07 & 12.59 & 80 & 682 \\
\hline GR-LNB 112 & $10 / 20 / 93$ & $4: 09$ & 1911 & 1867 & 1822 & 318 & 626 & 293 & 5.05 & 0.94 & 5.17 & 0.52 & 0.30 & 1.14 & 13.12 & 80 & 692 \\
\hline LNB-OFA & $10 / 20 / 93$ & 0.56 & 1944 & 1886 & 1827 & 359 & 631 & 333 & 5.47 & 1.10 & 4.25 & 0.61 & 0.26 & 1.01 & 12.70 & 80 & 702 \\
\hline GR-LNB 113 & $10 / 20 / 93$ & $10: 42$ & 1970 & 1900 & 1830 & 397 & 653 & 367 & 5.11 & 0.94 & 5.23 & 0.52 & 0.21 & 0.88 & 12.89 & 80 & 710 \\
\hline GR-LNB 113 & $10 / 21 / 93$ & $24: 00$ & 1965 & 1896 & 1828 & 394 & 655 & 363 & 4.99 & 0.93 & 5.30 & 0.51 & 0.22 & 0.90 & 12.85 & 80 & 710 \\
\hline GR-LNB 114 & $10 / 22 / 93$ & $24: 00$ & 1952 & 1887 & 1822 & 382 & 650 & 349 & 4.98 & 0.93 & 5.31 & 0.51 & 0.23 & 0.93 & 12.89 & 80 & 705 \\
\hline GR-LNB 115 & $10 / 23 / 93$ & $24: 00$ & 1960 & 1890 & 1821 & 399 & 656 & 366 & 5.00 & 0.93 & 5.29 & 0.51 & 0.21 & 0.88 & 12.82 & 80 & 709 \\
\hline GR-LNB 116 & $10 / 24 / 93$ & $14: 00$ & 1950 & 1885 & 1820 & 395 & 655 & 367 & 5.00 & 0.93 & 5.25 & 0.51 & 0.22 & 0.90 & 12.83 & 80 & 709 \\
\hline GR-LNB 116a & $10 / 24 / 93$ & 10.00 & 1959 & 1890 & 1822 & 398 & 659 & 364 & 5.15 & 0.93 & 5.29 & 0.51 & 0.21 & 0.88 & 12.97 & 80 & 711 \\
\hline GR-LNB $117 \mathrm{a}$ & $10 / 25 / 93$ & $4: 55$ & 1898 & 1856 & 1815 & 313 & 613 & 285 & 5.23 & 0.94 & 5.17 & 0.52 & 0.30 & 1.15 & 13.32 & 80 & 677 \\
\hline GR-LNB 117 & $10 / 25 / 93$ & $19: 04$ & 1955 & 1888 & 1822 & 393 & 657 & 363 & 4.82 & 0.93 & 5.23 & 0.52 & 0.22 & 0.91 & 12.63 & 80 & 709 \\
\hline GR-LNB 118 & $10 / 26 / 93$ & $24: 00$ & 1955 & 1888 & 1820 & 389 & 654 & 359 & 4.57 & 0.93 & 5.21 & 0.52 & 0.22 & 0.91 & 12.36 & 80 & 704 \\
\hline GR-LNB 119 & $10 / 27 / 93$ & $14: 25$ & 1972 & 1900 & 1828 & 404 & 659 & 374 & 4.55 & 0.94 & 5.20 & 0.52 & 0.21 & 0.87 & 12.28 & 80 & 710 \\
\hline GR-LNB 119a & $10 / 27 / 93$ & $9: 34$ & 1967 & 1896 & 1826 & 387 & 654 & 350 & 4.70 & 0.94 & 5.21 & 0.52 & 0.22 & 0.90 & 12.48 & 80 & 704 \\
\hline GR-LNB 120a & $10 / 28 / 93$ & $7: 21$ & 1960 & 1896 & 1832 & 362 & 639 & 326 & 4.86 & 0.95 & 5.17 & 0.52 & 0.24 & 0.96 & 12.70 & 80 & 696 \\
\hline GR-LNB 120 & $10 / 28 / 93$ & $16: 38$ & 1965 & 1896 & 1825 & 392 & 655 & 358 & 4.45 & 0.94 & 5.19 & 0.52 & 0.22 & 0.90 & 12.21 & 80 & 707 \\
\hline GR-LNB 121 & $10 / 29 / 93$ & $24: 00$ & 1961 & 1894 & 1827 & 397 & 653 & 372 & 4.29 & 0.93 & 5.18 & 0.52 & 0.22 & 0.91 & 12.05 & 80 & 709 \\
\hline GR-LNB 122 & $10 / 30 / 93$ & $24: 00$ & 1970 & 1899 & 1827 & 411 & 657 & 385 & 4.36 & 0.93 & 5.19 & 0.52 & 0.21 & 0.86 & 12.06 & 80 & 714 \\
\hline GR-LNB 123 & $10 / 31 / 93$ & $24: 00$ & 1966 & 1896 & 1826 & 397 & 656 & 365 & 4.61 & 0.94 & 5.21 & 0.52 & 0.22 & 0.89 & 12.37 & 80 & 710 \\
\hline GR-LNB 124 & $11 / 1 / 93$ & $6: 18$ & 1962 & 1895 & 1828 & 385 & 652 & 353 & 4.53 & 0.97 & 4.99 & 0.54 & 0.22 & 0.91 & 12.16 & 80 & 706 \\
\hline LNB-OFA & $11 / 1 / 93$ & $1: 08$ & 1905 & 1861 & 1818 & 308 & 605 & 281 & 4.54 & 1.10 & 4.22 & 0.61 & 0.30 & 1.16 & 11.93 & 80 & 671 \\
\hline GR-LNB 125a & $11 / 2 / 93$ & $8: 15$ & 1956 & 1887 & 1817 & 399 & 658 & 371 & 4.12 & 0.98 & 4.95 & 0.54 & 0.22 & 0.90 & 11.70 & 80 & 708 \\
\hline LNB & $11 / 2 / 93$ & 0.29 & 1953 & 1883 & 1813 & 390 & 657 & 356 & 4.30 & 0.98 & 4.95 & 0.54 & 0.22 & 0.90 & 11.90 & 80 & 706 \\
\hline GR-LNB 125 & $11 / 2 / 93$ & $10: 09$ & 1953 & 1883 & 1813 & 390 & 657 & 355 & 4.31 & 0.98 & 4.96 & 0.54 & 0.22 & 0.90 & 11.91 & 80 & 706 \\
\hline GR-LNB 126a & $11 / 4 / 93$ & $1: 40$ & 1950 & 1885 & 1819 & 380 & 652 & 348 & 4.24 & 0.99 & 4.90 & 0.55 & 0.23 & 0.94 & 11.84 & 80 & 702 \\
\hline
\end{tabular}


Cherokee Unit 3, Average Test C

Pre Modification

\begin{tabular}{|c|c|c|c|c|c|c|c|c|c|c|c|c|c|c|c|c|c|}
\hline Nost Nop̧ & patp] & Durn & Prum & Psh' & $\begin{array}{l}\text { Stoam } \\
\text { tofturb } \\
\text { Psic }\end{array}$ & $\begin{array}{l}\text { RHIIn } \\
\text { Presss: } \\
\text { PSIG }\end{array}$ & $\begin{array}{l}\text { RH In } \\
\text { Temp } \\
\text { Deg FI }\end{array}$ & $\begin{array}{l}\text { Hot BH } \\
\text { out prs } \\
\text { psig }\end{array}$ & DryGas & Moist & Combrita & Refuse! & Radiat & 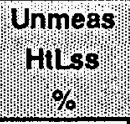 & पTotal & Comb & 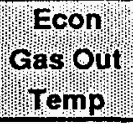 \\
\hline GR-LNB 126 & $11 / 4 / 93$ & 13:29 & 1961 & 1893 & 1826 & 390 & 652 & 360 & 4.24 & 0.99 & \begin{tabular}{|l|} 
\\
\end{tabular} & 0.55 & 0.22 & 0.91 & 11.78 & 80 & 701 \\
\hline GR.LNB 127a & $11 / 5 / 93$ & $7: 20$ & 1937 & 1879 & 1821 & 364 & 634 & 340 & 4.55 & 0.99 & 4.84 & 0.55 & 0.25 & 0.99 & 12.16 & 80 & 694 \\
\hline GR.LNB 127 & $11 / 5 / 93$ & $5: 54$ & 1975 & 1902 & 1828 & 409 & 645 & 384 & 4.68 & 0.98 & 4.86 & 0.55 & 0.20 & 0.83 & 12.10 & 80 & 702 \\
\hline GR-LNB 128 & $11 / 8 / 93$ & $4: 55$ & 1967 & 1896 & 1825 & 397 & 657 & 367 & 4.44 & 0.94 & 5.19 & 0.52 & 0.21 & 0.89 & 12.19 & 80 & 710 \\
\hline GR-LNB 129 & $11 / 9 / 93$ & $8: 30$ & 1983 & 1907 & 1832 & 408 & 660 & 375 & 4.56 & 0.94 & 5.18 & 0.52 & 0.20 & 0.84 & 12.24 & 80 & 714 \\
\hline GR-LNB 129a & $11 / 9 / 93$ & $5: 29$ & 2001 & 1918 & 1835 & 424 & 647 & 390 & 4.63 & 0.97 & 5.01 & 0.54 & 0.17 & 0.76 & 12.07 & 80 & 712 \\
\hline GR.LNB 130 & $11 / 10 / 93$ & $15: 43$ & 1971 & 1896 & 1821 & 405 & 654 & 373 & 4.52 & 0.97 & 4.97 & 0.54 & 0.20 & 0.84 & 12.05 & 80 & 709 \\
\hline LNB & $11 / 10 / 93$ & $7: 50$ & 1975 & 1900 & 1823 & 401 & 629 & 363 & 4.63 & 1.10 & 4.25 & 0.61 & 0.19 & 0.81 & 11.59 & 80 & 691 \\
\hline LNB & $11 / 11 / 93$ & $2: 00$ & 1957 & 1891 & 1825 & 377 & 620 & 345 & 4.70 & 1.10 & 4.23 & 0.61 & 0.22 & 0.90 & 11.75 & 80 & 681 \\
\hline LNB 3 Mill a & $11 / 11 / 93$ & 3:34 & 1894 & 1856 & 1818 & 285 & 598 & 255 & 4.62 & 1.10 & 4.23 & 0.61 & 0.32 & 1.21 & 12.08 & 80 & 658 \\
\hline LNB 3 Mill b & $11 / 11 / 93$ & $9: 20$ & 1897 & 1859 & 1821 & 287 & 579 & 257 & 4.71 & 1.10 & 4.22 & 0.61 & 0.32 & 1.19 & 12.14 & 80 & 654 \\
\hline LNB 3 Mill c & $11 / 1293$ & $12: 30$ & 1912 & 1866 & 1821 & 319 & 591 & 293 & 4.60 & 1.09 & 4.21 & 0.61 & 0.29 & 1.10 & 11.91 & 80 & 662 \\
\hline LNB 3 Mill d & $11 / 12 / 93$ & $11: 29$ & 1987 & 1912 & 1837 & 402 & 622 & 370 & 4.18 & 1.10 & 4.23 & 0.61 & 0.19 & 0.82 & 11.12 & 80 & 684 \\
\hline LNB 3 Mill & $11 / 13 / 93$ & $14: 30$ & 1963 & 1891 & 1818 & 392 & 625 & 360 & 4.43 & 1.10 & 4.23 & 0.61 & 0.20 & 0.85 & 11.42 & 80 & 686 \\
\hline LNB 3 Millf & $11 / 13 / 93$ & $9: 29$ & 1985 & 1909 & 1833 & 403 & 626 & 370 & 4.13 & 1.10 & 4.23 & 0.61 & 0.19 & 0.81 & 11.07 & 80 & 682 \\
\hline LNB 3 Mill & $11 / 14 / 93$ & $24: 00$ & 1967 & 1898 & 1829 & 388 & 624 & 360 & 4.07 & 1.10 & 4.22 & 0.61 & 0.21 & 0.88 & 11.08 & 80 & 683 \\
\hline LNB & $11 / 15 / 93$ & $1: 39$ & $\$ 974$ & 1903 & 1831 & 396 & 628 & 369 & 3.91 & 1.10 & 4.22 & 0.61 & 0.21 & 0.86 & 10.90 & 80 & 691 \\
\hline GR-LNB 131 & $11 / 15 / 93$ & $13: 00$ & 1968 & 1897 & 1826 & 394 & 652 & 365 & 4.21 & 0.94 & 5.14 & 0.52 & 0.22 & 0.89 & 11.93 & 80 & 710 \\
\hline GR-LNB 132 & $11 / 16 / 93$ & $7: 42$ & 1956 & 1891 & 1826 & 380 & 647 & 352 & 4.15 & 0.94 & 5.11 & 0.52 & 0.23 & 0.94 & 11.89 & 80 & 706 \\
\hline GR-LNB 132a & $11 / 16 / 93$ & $16: 17$ & 1929 & 1872 & 1816 & 346 & 622 & 316 & 5.04 & 0.94 & 5.12 & 0.52 & 0.26 & 1.03 & 12.93 & 80 & 690 \\
\hline GR-LNB 133 & $11 / 17 / 93$ & $0: 40$ & 1926 & 1875 & 1823 & 335 & 626 & 307 & 4.88 & 0.95 & 5.09 & 0.53 & 0.28 & 1.08 & 12.79 & 80 & 687 \\
\hline LNB & $11 / 17 / 93$ & $8: 40$ & 1911 & 1862 & 1813 & 320 & 582 & 295 & 5.00 & 1.10 & 4.23 & 0.61 & 0.28 & 1.09 & 12.31 & 80 & 658 \\
\hline LNB & $12 / 3 / 93$ & $5: 15$ & 1963 & 1888 & 1814 & 393 & 629 & 362 & 4.72 & 1.10 & 4.24 & 0.61 & 0.20 & 0.84 & 11.72 & 80 & 690 \\
\hline LNB & $12 / 6 / 93$ & $2: 33$ & 1894 & 1858 & 1822 & 282 & 570 & 260 & 5.14 & 1.10 & 4.25 & 0.61 & 0.33 & 1.23 & 12.65 & 80 & 651 \\
\hline LNB & $12 / 6 / 93$ & 3.00 & 1980 & 1898 & 1817 & 420 & 623 & 391 & 4.89 & 1.10 & 4.23 & 0.61 & 0.17 & 0.76 & 11.77 & 80 & 688 \\
\hline LNB & $12 / 6 / 93$ & $1: 55$ & 1973 & 1891 & 1808 & 420 & 623 & 390 & 5.02 & 1.10 & 4.23 & 0.61 & 0.17 & 0.76 & 11.89 & 80 & 691 \\
\hline LNB & $12 / 7 / 93$ & $6: 45$ & 2003 & 1918 & 1833 & 422 & 611 & 387 & 4.73 & 1.10 & 4.25 & 0.61 & 0.16 & 0.73 & 11.58 & 80 & 688 \\
\hline LNB & $12 / 8 / 93$ & $4: 03$ & 1974 & 1892 & 1810 & 418 & 640 & 385 & 5.00 & 1.10 & 4.25 & 0.61 & 0.18 & 0.77 & 11.91 & 80 & 700 \\
\hline GR-LNB 134 & $12 / 8 / 93$ & $3: 40$ & 1980 & 1898 & 1816 & 416 & 657 & 379 & 4.50 & 0.93 & 5.26 & 0.51 & 0.18 & 0.78 & 12.16 & 80 & 708 \\
\hline GR-LNB 134a & $12 / 8 / 93$ & $0: 46$ & 1973 & 1892 & 1810 & 414 & 638 & 376 & 4.60 & 1.05 & 4.59 & 0.58 & 0.17 & 0.76 & 11.76 & 80 & 700 \\
\hline GR-LNB 134b & $12 / 8 / 93$ & $2: 44$ & 1975 & 1893 & 1810 & 413 & 655 & 375 & 4.29 & 1.05 & 4.59 & 0.58 & 0.18 & 0.78 & 11.46 & 80 & 701 \\
\hline GR-LNB 134c & $12 / 8 / 93$ & $3: 31$ & 1978 & 1897 & 1815 & 418 & 666 & 380 & 4.23 & 1.05 & 4.60 & 0.58 & 0.18 & 0.80 & 11.44 & 80 & 713 \\
\hline GR-LNB 135 & $12 / 9 / 93$ & $12: 00$ & 1957 & 1888 & 1820 & 384 & 651 & 350 & 4.32 & 1.05 & 4.59 & 0.58 & 0.22 & 0.92 & 11.67 & 80 & 705 \\
\hline GR-LNB $135 a$ & $12 / 9 / 93$ & $2: 59$ & 1965 & 1890 & 1814 & 401 & 660 & 364 & 4.63 & 1.05 & 4.61 & 0.58 & 0.20 & 0.85 & 11.92 & 80 & 723 \\
\hline GR-LNB 135b & $12 / 9 / 93$ & $7: 10$ & 1951 & 1883 & 1816 & 373 & 609 & 339 & 4.85 & 1.05 & 4.56 & 0.58 & 0.22 & 0.91 & 12.17 & 80 & 699 \\
\hline GR-LNB 136 & $12 / 10 / 93$ & $11: 35$ & 1966 & 1894 & 1823 & 388 & 624 & 356 & 4.69 & 1.05 & 4.55 & 0.58 & 0.21 & 0.87 & 11.94 & 80 & 700 \\
\hline GR-LNB 137 & $12 / 11 / 93$ & $16: 15$ & 1941 & 1878 & 1814 & 369 & 630 & 338 & 4.71 & 1.05 & 4.54 & 0.58 & 0.23 & 0.94 & 12.06 & 80 & 699 \\
\hline GR-LNB 137a & $12 / 11 / 93$ & $7: 44$ & 1995 & 1912 & 1830 & 421 & 646 & 387 & 4.75 & 1.05 & 4.56 & 0.58 & 0.17 & 0.76 & 11.87 & 80 & 708 \\
\hline GR-LNB 138 & $12 / 1293$ & $24: 00$ & 1998 & 1914 & 1831 & 423 & 646 & 388 & 4.75 & 1.05 & 4.57 & 0.58 & 0.17 & 0.76 & 11.87 & 80 & 711 \\
\hline GR-LNB 139 & $12 / 13 / 93$ & $7: 48$ & 2007 & 1924 & 1841 & 427 & 662 & 395 & 4.41 & 1.04 & 4.55 & 0.58 & 0.17 & 0.76 & 11.52 & 80 & 708 \\
\hline
\end{tabular}


Pre Moditication

\begin{tabular}{|c|c|c|c|c|c|c|c|c|c|c|c|c|c|c|c|c|c|}
\hline 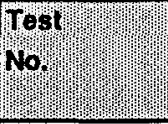 & Date & Dury" & $\begin{array}{l}\text { prum } \\
\text { Press } \\
\text { psic }\end{array}$ & PSHI & 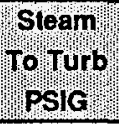 & 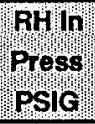 & $\begin{array}{l}\text { RHIn } \\
\text { Deg } \\
\text { Demp }\end{array}$ & $\begin{array}{l}\text { Hotrus } \\
\text { Outprs } \\
\text { PsslG }\end{array}$ & Dryasas & Hoist & Comb & Refuse & 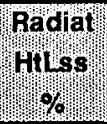 & 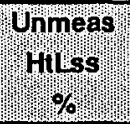 & Total & 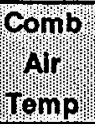 & 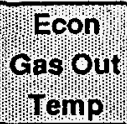 \\
\hline GR-LNB 139a & $12 / 13 / 93$ & $4: 18$ & 1988 & 1906 & 1824 & 424 & 664 & 393 & 4.47 & 1.04 & 4.55 & 0.58 & 0.18 & 0.78 & 11.61 & 80 & 707 \\
\hline LNB & $12 / 13 / 93$ & $5: 18$ & 1982 & 1907 & 1833 & 403 & 618 & 371 & 4.72 & 1.10 & 4.24 & 0.61 & 0.19 & 0.83 & 11.69 & 80 & 692 \\
\hline LNB-OFA & $12 / 14 / 93$ & $1: 55$ & 2001 & 1918 & 1835 & 426 & 647 & 396 & 4.96 & 1.10 & 4.24 & 0.61 & 0.17 & 0.76 & 11.83 & 80 & 708 \\
\hline GR-LNB 140 & $12 / 14 / 93$ & $1: 18$ & 1995 & 1913 & 1831 & 424 & 662 & 390 & 4.67 & 1.05 & 4.58 & 0.58 & 0.18 & 0.77 & 11.81 & 80 & 701 \\
\hline LNB & $12 / 14 / 93$ & $8: 30$ & 1994 & 1915 & 1835 & 415 & 637 & 382 & 4.65 & 1.10 & 4.25 & 0.61 & 0.18 & 0.78 & 11.56 & 80 & 689 \\
\hline LNB & $12 / 15 / 93$ & $9: 28$ & 1989 & 1911 & 1833 & 415 & 628 & 387 & 4.67 & 1.10 & 4.23 & 0.61 & 0.18 & 0.79 & 11.58 & 80 & 686 \\
\hline LNB-OFA & $12 / 15 / 93$ & $5: 29$ & 1994 & 1914 & 1833 & 420 & 627 & 391 & 4.70 & 1.10 & 4.22 & 0.61 & 0.17 & 0.77 & 11.57 & 80 & 694 \\
\hline GR-LNB 141 & $12 / 15 / 93$ & $5: 15$ & 1958 & 1893 & 1829 & 378 & 618 & 348 & 4.56 & 1.04 & 4.57 & 0.58 & 0.24 & 0.95 & 11.93 & 80 & 690 \\
\hline LNB & $12 / 15 / 93$ & $2: 50$ & 1637 & 1604 & 1574 & 247 & 614 & 225 & 5.34 & 1.10 & 4.22 & 0.61 & 0.38 & 1.39 & 13.04 & 80 & 643 \\
\hline LNB & $12 / 16 / 93$ & $15: 05$ & 1974 & 1904 & 1834 & 405 & 643 & 378 & 4.57 & 1.10 & 4.22 & 0.61 & 0.21 & 0.89 & 11.60 & 80 & 681 \\
\hline GR-LNB 142 & $12 / 16 / 93$ & $6: 14$ & 1995 & 1914 & 1832 & 440 & 665 & 411 & 4.46 & 1.04 & 4.56 & 0.58 & 0.18 & 0.80 & 11.61 & 80 & 708 \\
\hline GR-LNB 142a & $12 / 16 / 93$ & $1: 15$ & 1883 & 1849 & 1813 & 290 & 605 & 265 & 4.76 & 1.04 & 4.60 & 0.57 & 0.33 & 1.25 & 12.54 & 80 & 669 \\
\hline GR-LNB 143 & $12 / 17 / 93$ & $2: 10$ & 1890 & 1858 & 1826 & 281 & 610 & 258 & 4.84 & 1.03 & 4.60 & 0.57 & 0.35 & 1.29 & 12.68 & 80 & 664 \\
\hline LNB-OFA & $12 / 17 / 93$ & $0: 40$ & 1814 & 1810 & 1804 & 143 & 487 & 124 & 6.85 & 1.10 & 4.24 & 0.61 & 0.47 & 1.67 & 14.96 & 80 & 611 \\
\hline LNB & $12 / 17 / 93$ & $6: 10$ & 1970 & 1894 & 1819 & 422 & 657 & 395 & 4.48 & 1.10 & 4.22 & 0.61 & 0.20 & 0.85 & 11.46 & 80 & 687 \\
\hline LNB & $12 / 20 / 93$ & $2: 25$ & 1914 & 1855 & 1795 & 368 & 643 & 342 & 4.95 & 1.10 & 4.23 & 0.61 & 0.26 & 1.02 & 12.16 & 80 & 695 \\
\hline $100 \%$ Gas Fining & $12 / 20 / 93$ & $0: 34$ & 1794 & 1768 & 1747 & 228 & 577 & 205 & 7.78 & 1.09 & 4.20 & 0.61 & 0.40 & 1.45 & 15.52 & 80 & 635 \\
\hline LNB & $12 / 22 / 93$ & $2: 35$ & 1924 & 1874 & 1824 & 333 & 622 & 305 & 5.00 & 1.10 & 4.23 & 0.61 & 0.29 & .1 .11 & 12.33 & 80 & 684 \\
\hline LNB & $1 / 5 / 94$ & $2: 24$ & 1981 & 1911 & 1840 & 405 & 650 & 371 & 4.67 & 1.10 & 4.25 & 0.61 & 0.21 & 0.87 & 11.71 & 80 & 688 \\
\hline LNB-OFA & $1 / 5 / 94$ & $2: 26$ & 1976 & 1904 & 1832 & 406 & 641 & 371 & 4.81 & 1.10 & 4.25 & 0.61 & 0.20 & 0.85 & 11.83 & 80 & 702 \\
\hline LNB-OFA & $1 / 5 / 94$ & $9: 15$ & 1933 & 1879 & 1825 & 351 & 625 & 320 & 4.73 & 1.10 & 4.24 & 0.61 & 0.26 & 1.03 & 11.97 & 80 & 685 \\
\hline LNB-OFA & $1 / 6 / 94$ & $8: 47$ & 1885 & 1854 & 1824 & 264 & 588 & 238 & 5.04 & 1.10 & 4.25 & 0.61 & 0.36 & 1.31 & 12.68 & 80 & 663 \\
\hline LNB & $1 / 6 / 94$ & $15: 12$ & 1968 & 1898 & 1828 & 405 & 653 & 376 & 4.60 & 1.10 & 4.25 & 0.61 & 0.21 & 0.89 & 11.66 & 80 & 694 \\
\hline LNB & $1 / 7 / 94$ & 6.55 & 1914 & 1868 & 1823 & 326 & 617 & 302 & 4.59 & 1.10 & 4.24 & 0.61 & 0.30 & 1.13 & 11.97 & 80 & 663 \\
\hline LNB-OFA & $1 / 7 / 94$ & $1: 09$ & 1909 & 1860 & 1811 & 336 & 622 & 310 & 4.68 & 1.10 & 4.23 & 0.61 & 0.29 & 1.10 & 12.01 & 80 & 680 \\
\hline GA-LNB 144 & $1 / 7 / 94$ & $15: 40$ & 1955 & 1889 & 1823 & 383 & 653 & 349 & 4.73 & 1.04 & 4.61 & 0.58 & 0.24 & 0.95 & 12.14 & 80 & 705 \\
\hline GR-LNB 145a & $1 / 8 / 94$ & $8: 20$ & 1925 & 1875 & 1826 & 337 & 636 & 305 & 4.77 & 1.04 & 4.61 & 0.57 & 0.29 & 1.11 & 12.39 & 80 & 692 \\
\hline GR-LNB 145 & $1 / 8 / 94$ & $15: 39$ & 1967 & 1898 & 1830 & 406 & 660 & 374 & 4.64 & 1.04 & 4.61 & 0.58 & 0.22 & 0.91 & 12.00 & 80 & 717 \\
\hline GR-LNB 146a & $1 / 9 / 94$ & $2: 10$ & 1952 & 1889 & 1826 & 396 & 658 & 367 & 4.46 & 1.04 & 4.61 & 0.57 & 0.24 & 0.96 & 11.88 & 80 & 702 \\
\hline GR-LNA 146b & $1 / 9 / 94$ & $8: 39$ & 1899 & 1861 & 1822 & 309 & 629 & 283 & 4.90 & 1.04 & 4.62 & 0.57 & 0.32 & 1.22 & 12.69 & 80 & 699 \\
\hline GR-LNB 146 & $1 / 9 / 94$ & $9: 02$ & 1947 & 1887 & 1827 & 372 & 650 & 338 & 4.84 & 1.04 & 4.62 & 0.57 & 0.25 & 1.00 & 12.32 & 80 & 708 \\
\hline LNB & $1 / 9 / 94$ & 3.35 & 1907 & 1862 & 1818 & 312 & 602 & 281 & 4.80 & 1.10 & 4.24 & 0.61 & 0.30 & 1.14 & 12.20 & 80 & 670 \\
\hline LNB & $1 / 10 / 94$ & $3: 50$ & 1938 & 1882 & 1827 & 355 & 641 & 326 & 4.82 & 1.10 & 4.24 & 0.61 & 0.27 & 1.05 & 12.10 & 80 & 695 \\
\hline GR-LNB 147 & $1 / 10 / 94$ & $2: 40$ & 1979 & 1899 & 1818 & 427 & 666 & 391 & 4.83 & 1.05 & 4.59 & 0.58 & 0.19 & 0.81 & 12.04 & 80 & 724 \\
\hline GR-LNB 147a & $1 / 10 / 94$ & $4: 04$ & 1910 & 1861 & 1813 & 326 & 626 & 293 & 5.03 & 1.03 & 4.68 & 0.57 & 0.29 & 1.12 & 12.71 & 80 & 681 \\
\hline GR.LNB 147b & $1 / 10 / 94$ & $4: 54$ & 1912 & 1864 & 1815 & 329 & 623 & 298 & 4.99 & 1.03 & 4.67 & 0.57 & 0.29 & 1.11 & 12.65 & 80 & 686 \\
\hline GR.LNB 148a & $1 / 11 / 94$ & $6: 32$ & 1885 & 1850 & 1814 & 289 & 618 & 263 & 5.14 & 1.02 & 4.68 & 0.57 & 0.34 & 1.25 & 13.00 & 80 & 680 \\
\hline GR-LNB 148 & $1 / 11 / 94$ & $14: 38$ & 1985 & 1906 & 1827 & 419 & 649 & 383 & 4.77 & 1.03 & 4.67 & 0.57 & 0.19 & 0.82 & 12.04 & 80 & 710 \\
\hline GR-LNB 148b & $1 / 11 / 94$ & $2: 48$ & 1918 & 1865 & 1811 & 333 & 597 & 297 & 4.80 & 1.03 & 4.64 & 0.57 & 0.27 & 1.06 & 12.37 & 80 & 675 \\
\hline GR-LNB 149a & $1 / 12 / 94$ & $6: 14$ & 1933 & 1875 & 1816 & 358 & 641 & 324 & 4.74 & 1.03 & 4.63 & 0.57 & 0.26 & 1.02 & 12.25 & 80 & 700 \\
\hline
\end{tabular}


Cherokee Unit 3, Average Test [

Pre Modification

\begin{tabular}{|c|c|c|c|c|c|c|c|c|c|c|c|c|c|c|c|c|c|}
\hline Nos/ & 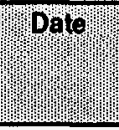 & Dury & Prum & psy & 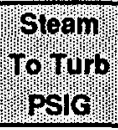 & RH In & $\begin{array}{l}\text { RHII } \\
\text { Demp } \\
\text { Degle }\end{array}$ & $\begin{array}{l}\text { Hotph } \\
\text { oup prs } \\
\text { (psla }\end{array}$ & Drygas & Moist & 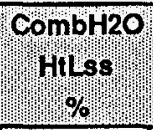 & Retuse & nadiat & Unmess & 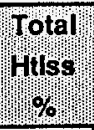 & Comb" & 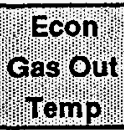 \\
\hline GR-LNB 149 & $1 / 12 / 94$ & $13: 30$ & 1954 & 1887 & 1820 & 387 & 648 & 352 & 4.75 & 1.03 & 4.64 & 0.57 & 0.23 & 0.93 & 12.16 & 80 & 705 \\
\hline GR-LNB A Mill off & $1 / 12 / 94$ & 1.09 & 1912 & 1857 & 1804 & 349 & 646 & 315 & 4.76 & 1.03 & 4.66 & 0.57 & 0.28 & 1.07 & 12.37 & 80 & 706 \\
\hline GR-LNB D Mill off & $1 / 12 / 94$ & $1: 39$ & 1944 & 1886 & 1828 & 365 & 651 & 330 & 4.45 & 1.00 & 4.81 & 0.56 & 0.26 & 1.03 & 12.10 & 80 & 708 \\
\hline GA-LNB D Mill off line & $1 / 13 / 94$ & $4: 23$ & 1880 & 1846 & 1812 & 280 & 617 & 248 & 4.66 & 1.02 & 4.72 & 0.56 & 0.35 & 1.28 & 12.59 & 80 & 673 \\
\hline GA-LNB 150 & $1 / 13 / 94$ & $7: 15$ & 1975 & 1898 & 1821 & 415 & 664 & 377 & 4.80 & 1.03 & 4.70 & 0.57 & 0.20 & 0.86 & 12.15 & 80 & 723 \\
\hline GR-LNB D Mill off line & $1 / 13 / 94$ & $1: 13$ & 1932 & 1873 & 1815 & 363 & 653 & 325 & 4.53 & 1.01 & 4.78 & 0.56 & 0.26 & 1.03 & 12.17 & 80 & 712 \\
\hline GR-LNB 150a & $1 / 13 / 94$ & $6: 00$ & 1943 & 1882 & 1821 & 360 & 636 & 323 & 4.90 & 1.03 & 4.68 & 0.57 & 0.25 & 1.00 & 12.44 & 80 & 702 \\
\hline GR-LNB 151a & $1 / 14 / 94$ & $7: 25$ & 1889 & 1852 & 1815 & 278 & 598 & 244 & 5.13 & 1.03 & 4.67 & 0.57 & 0.33 & 1.25 & 12.98 & 80 & 667 \\
\hline GR-LNB, ABC & $1 / 14 / 94$ & $7: 50$ & 1926 & 1871 & 1816 & 349 & 648 & 313 & 4.58 & 1.03 & 4.64 & 0.57 & 0.27 & 1.07 & 12.16 & 80 & 699 \\
\hline GR-LNB 151 & $1 / 14 / 94$ & $7: 54$ & 1933 & 1878 & 1822 & 354 & 643 & 320 & 4.75 & 1.04 & 4.66 & 0.57 & 0.27 & 1.05 & 12.33 & 80 & 704 \\
\hline GR-LNB 156 & $1 / 19 / 94$ & $24: 00$ & 1903 & 1860 & 1818 & 306 & 619 & 272 & 4.83 & 1.03 & 4.67 & 0.57 & 0.31 & 1.17 & 12.59 & 80 & 682 \\
\hline GR-LNB 157a & $1 / 20 / 94$ & $6: 38$ & 1887 & 1850 & 1813 & 301 & 623 & 275 & 4.49 & 1.03 & 4.65 & 0.57 & 0.33 & 1.23 & 12.30 & 80 & 685 \\
\hline GR-LNB 157 & $1 / 20 / 94$ & $3: 50$ & 1955 & 1890 & 1825 & 398 & 658 & 370 & 4.47 & 1.02 & 4.73 & 0.56 & 0.23 & 0.95 & 11.96 & 80 & 720 \\
\hline
\end{tabular}


Cherokee Unit 3, Average Test C

Pre Modification

\begin{tabular}{|c|c|c|c|c|c|c|c|c|c|c|c|c|c|c|}
\hline 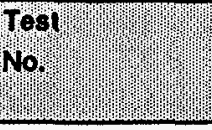 & Datel & Dup & АН Gas & 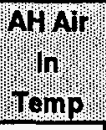 & Arifil & Calc Coal) & 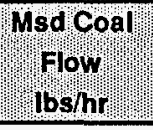 & Galct TAII & 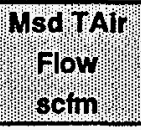 & 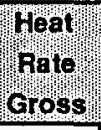 & Theat! & "Boffier: & orp & carbon \\
\hline Base Cond. (OFA ofi) & $11 / 11 / 92$ & $8: 42$ & 311 & 50 & 612 & 95421 & N/A & 219588 & 192210 & 9521 & 10471 & 85.09 & N/A & \\
\hline GA & $11 / 11 / 92$ & 1.01 & 299 & 49 & 626 & 113190 & $\mathrm{~N} / \mathrm{A}$ & 313411 & 230148 & 9343 & 10021 & 85.76 & $\mathrm{~N} / \mathrm{A}$ & \\
\hline Base Cond. (OFA off) & $11 / 11 / 92$ & $4: 25$ & 305 & 55 & 620 & 140720 & N/A & 323921 & 248175 & 9477 & 10149 & 87.13 & N/A & \\
\hline Base Cond. OFA off & $11 / 12 / 92$ & $0: 45$ & 295 & 47 & 606 & 139961 & 149248 & 309088 & 243139 & 9515 & 10212 & 88.58 & $0.00 \%$ & \\
\hline BPMS GR 4 & $11 / 12 / 92$ & $1: 05$ & 302 & 53 & 630 & 114695 & 123794 & 322842 & 232694 & 9377 & 10066 & 87.32 & $21.03 \%$ & \\
\hline Base Cond. OFA off & $11 / 12 / 92$ & $1: 15$ & 307 & 56 & 624 & 140390 & 148999 & 323563 & 248446 & 9479 & 10153 & 88.02 & $0.00 \%$ & \\
\hline BPMS Baso Cond. 5 & $11 / 13 / 92$ & $2: 55$ & 304 & 53 & 617 & 142362 & 148467 & 337232 & 254849 & 9439 & 10108 & 87.98 & $0.00 \%$ & 3.54 \\
\hline BPMS Base Cond. 6 & $11 / 13 / 92$ & $1: 00$ & 300 & 63 & 608 & 141044 & 148922 & 328990 & 242242 & 9562 & 10266 & 88.17 & $4.87 \%$ & 7.47 \\
\hline BPMS Base Cond. 7 & $11 / 13 / 92$ & $1: 00$ & 303 & 68 & 608 & 141483 & 148650 & 321988 & 236964 & 9598 & 10305 & 88.25 & $9.28 \%$ & 11.43 \\
\hline Base Cond.-1d & $11 / 16 / 92$ & $1: 00$ & 305 & 59 & 613 & 131564 & 138735 & 308732 & 237391 & 9457 & 10153 & 87.85 & $0.00 \%$ & \\
\hline GR-10c & $11 / 16 / 92$ & $1: 00$ & 305 & 74 & 607 & 137268 & 146919 & 307396 & 236962 & 9605 & 10320 & 88.22 & $3.80 \%$ & \\
\hline GR-10d & $11 / 16 / 92$ & 1.00 & 306 & 75 & 608 & 137421 & 137259 & 311632 & 235031 & 9625 & 10343 & 88.15 & $6.35 \%$ & \\
\hline Base Cond. OFA off & $11 / 17 / 92$ & $1: 15$ & 295 & 58 & 616 & 140413 & 150342 & 327111 & 251397 & 9519 & 10218 & 88.27 & $0.00 \%$ & \\
\hline GR-11C & $11 / 17 / 92$ & $1: 00$ & 305 & 65 & 626 & 110086 & 119373 & 309070 & 224777 & 9481 & 10181 & 87.26 & $19.62 \%$ & 4.18 \\
\hline GR-11d & $11 / 17 / 92$ & $1: 00$ & 309 & 68 & 629 & 108995 & 119678 & 307719 & 222068 & 9465 & 10168 & 87.11 & $23.19 \%$ & 2.71 \\
\hline Base Cond. OFA off & $11 / 17 / 92$ & $0: 20$ & 311 & 70 & 626 & 134059 & 146628 & 326970 & 247246 & 9461 & 10154 & 87.46 & $0.00 \%$ & \\
\hline Base Cond. OFA off & $11 / 18 / 92$ & $0: 28$ & 288 & 47 & 609 & 136025 & 147633 & 301466 & 244558 & 9437 & 10144 & 88.61 & $0.00 \%$ & \\
\hline GR-110 & $11 / 18 / 92$ & $1: 04$ & 306 & 60 & 632 & 109854 & 121891 & 311275 & 226522 & 9428 & 10129 & 87.17 & $23.56 \%$ & 2.85 \\
\hline GR.12b & $11 / 18 / 92$ & $1: 05$ & 308 & 65 & 631 & 115754 & 128210 & 311550 & 225788 & 9450 & 10162 & 87.30 & $22.58 \%$ & 3.27 \\
\hline Base Cond. OFA off & $11 / 18 / 92$ & $0: 35$ & 311 & 65 & 629 & 135727 & 148463 & 314236 & 245788 & 9494 & 10183 & 87.83 & $0.00 \%$ & \\
\hline GR-12 (5\% Gas) & $11 / 19 / 92$ & $1: 00$ & 297 & 77 & 610 & 131242 & 142706 & 303658 & 228005 & 9546 & 10259 & 88.28 & $12.62 \%$ & 10.24 \\
\hline GA-12a (10\% Gas) & $11 / 19 / 92$ & $1: 00$ & 301 & 77 & 616 & 125397 & 133940 & 297806 & 224106 & 9472 & 10164 & 88.04 & $15.23 \%$ & 7.82 \\
\hline GR-120 (23\% Gas) & $11 / 19 / 92$ & $1: 00$ & 309 & $\pi$ & 631 & 104612 & 112632 & 291978 & 218445 & 9334 & 10019 & 87.14 & $24.49 \%$ & 2.77 \\
\hline Base Cond. OFA off & $11 / 19 / 92$ & $0: 20$ & 303 & $\pi$ & 619 & 135016 & 148181 & 311396 & 244664 & 9441 & 10129 & 87.96 & $0.00 \%$ & \\
\hline GR-13A; $18 \%$ Gas & $11 / 20 / 92$ & 0.58 & 298 & 49 & 626 & 111898 & 119919 & 291967 & 217317 & 9399 & 10087 & 87.72 & $21.63 \%$ & 4.34 \\
\hline GR-13D; $18 \%$ Gas & $11 / 20 / 92$ & $1: 00$ & 301 & 48 & 634 & 110655 & 123400 & 298249 & 219718 & 9318 & 10008 & 87.48 & $23.64 \%$ & \\
\hline GR-14B; $20 \%$ Gas & $11 / 20 / 92$ & $1: 00$ & 301 & 48 & 636 & 108464 & 122185 & 304511 & 220152 & 9326 & 10014 & 87.27 & $23.65 \%$ & 4.93 \\
\hline Base Cond. OFA off & $11 / 30 / 92$ & $1: 50$ & 307 & 60 & 619 & 138225 & 147065 & 311795 & 243850 & 9452 & 10124 & 88.06 & $0.00 \%$ & \\
\hline GR-BFr & $11 / 30 / 92$ & $0: 26$ & 306 & 61 & 625 & 124321 & 127957 & 323701 & 226601 & 9486 & 10194 & 87.41 & $22.13 \%$ & \\
\hline GR-BFf & $11 / 30 / 92$ & $0: 27$ & 300 & 60 & 616 & 123102 & 127166 & 323842 & 226345 & 9519 & 10239 & 87.47 & $21.99 \%$ & \\
\hline GR-21C & $12 / 1 / 92$ & 1.06 & 297 & 56 & 616 & 86699 & 87553 & 249070 & 191800 & 9363 & 10086 & 86.84 & $25.40 \%$ & 2.75 \\
\hline GR-22 & $12 / 1 / 92$ & $0: 50$ & 290 & 56 & 604 & 99718 & 105288 & 266603 & 201618 & 9511 & 10279 & 87.24 & $22.09 \%$ & 6.77 \\
\hline Bias Firing & $12 / 1 / 92$ & $0: 10$ & 288 & 56 & 611 & 85602 & 92460 & 249034 & 193233 & 9508 & 10255 & 87.05 & $24.26 \%$ & \\
\hline Base Cond. OFA on & $12 / 1 / 92$ & $0: 50$ & 287 & 54 & 593 & 108167 & 109430 & 252098 & 202208 & 9528 & 10285 & 88.19 & $8.85 \%$ & \\
\hline Base Cond. OFA off & $12 / 1 / 92$ & $0: 40$ & 296 & 55 & 613 & 116558 & 125800 & 266216 & 221698 & 9402 & 10128 & 87.93 & $0.00 \%$ & \\
\hline Base Cond. OFA off & $12 / 2 / 92$ & $3: 55$ & 294 & 43 & 619 & 134387 & 146291 & 304530 & 244387 & 9435 & 10116 & 88.24 & $0.00 \%$ & \\
\hline Base Cond. OFA off & $12 / 4 / 92$ & $0: 55$ & 288 & 35 & 609 & 113673 & 130350 & 262484 & 218621 & 9608 & 10437 & 88.01 & $0.00 \%$ & \\
\hline OFA Tost & $12 / 4 / 92$ & $2: 10$ & 281 & 36 & 604 & 105538 & 126214 & 248353 & 205575 & 9546 & 10446 & 87.99 & $10.97 \%$ & \\
\hline Base Cond. OFA off & $12 / 7 / 92$ & $2: 10$ & 291 & 37 & 615 & 114409 & 125310 & 267802 & 223175 & 9544 & 10354 & 87.88 & $0.00 \%$ & \\
\hline GA-22A & $12 / 7 / 92$ & $1: 05$ & 294 & 45 & 621 & 100069 & 109350 & 257614 & 203782 & 9562 & 10418 & 87.38 & $19.72 \%$ & 3.95 \\
\hline
\end{tabular}


Cherokee Unit 3, Average Test [

Pre Modification

\begin{tabular}{|c|c|c|c|c|c|c|c|c|c|c|c|c|c|c|}
\hline nos) & Date & Dwr & AH Gas & AH Air & Ałpyir & calc coal & Msdcoal & calc TAir & Msd & $\begin{array}{l}\text { Heat } \\
\text { Grop) } \\
\text { Gross }\end{array}$ & Heat & Boiler! & OFA & Carbon \\
\hline GR-22B & $12 / 7 / 92$ & 1.00 & 295 & 45 & 625 & 94323 & 100862 & 253349 & 200290 & 9522 & 10381 & 87.17 & $23.90 \%$ & 2.47 \\
\hline GR-22C & $12 / 7 / 92$ & $1: 00$ & 299 & 45 & 629 & 88644 & 95311 & 250894 & 194496 & 9515 & 10369 & 86.89 & $26.85 \%$ & 1.62 \\
\hline Base Cond. OFA off & $12 / 8 / 92$ & $0: 27$ & 304 & 44 & 611 & 87540 & 92405 & 194790 & 184147 & 9760 & 10843 & 87.44 & $0.00 \%$ & \\
\hline GR-31C & $12 / 8 / 92$ & $1: 00$ & 305 & 51 & 624 & 70866 & 73803 & 200947 & 170678 & 9890 & 10984 & 86.44 & $19.82 \%$ & 3.98 \\
\hline GR-31F & $12 / 8 / 92$ & 1:23 & 302 & 52 & 630 & 70399 & 77769 & 215285 & 173095 & 10054 & 11210 & 86.04 & $29.93 \%$ & 1.22 \\
\hline GR-32A & $12 / 8 / 92$ & $1: 00$ & 298 & 50 & 621 & 79710 & 86022 & 205526 & 173693 & 9817 & 10901 & 86.94 & $18.67 \%$ & 3.84 \\
\hline Base Cond. OFA off & $12 / 9 / 92$ & $0: 41$ & 304 & 63 & 613 & 90429 & 94963 & 196880 & 187241 & 9874 & 10937 & 87.66 & $0.00 \%$ & \\
\hline GA-32C & $12 / 9 / 92$ & $1: 00$ & 312 & 67 & 628 & 69844 & 75170 & 208499 & 166006 & 9856 & 10967 & 85.97 & $32.34 \%$ & 1.77 \\
\hline GR-32C; 3 Mills & $12 / 9 / 92$ & 0.56 & 299 & 67 & 623 & 71250 & 80115 & 206995 & 176241 & 9762 & 10801 & 86.49 & $29.03 \%$ & 10.29 \\
\hline Base Cond. OFA off & $12 / 9 / 92$ & $0: 15$ & 304 & 65 & 624 & 95016 & 101770 & 230457 & 205862 & 9704 & 10663 & 87.06 & $0.00 \%$ & \\
\hline Base Cond, OFA off & $12 / 14 / 92$ & $2: 00$ & 286 & 41 & 610 & 127673 & 139474 & 297553 & 234352 & 9689 & 10240 & 88.16 & $0.00 \%$ & \\
\hline GR-12Z & $12 / 14 / 92$ & $1: 02$ & 288 & 44 & 617 & 131479 & 144100 & 313498 & 229446 & 9631 & 10210 & 88.14 & $15.98 \%$ & 8.75 \\
\hline GA $2.7 \%$ Gas & $12 / 14 / 92$ & $0: 17$ & 286 & 39 & 617 & 134689 & 147684 & 316719 & 227458 & 9561 & 10139 & 88.23 & $20.07 \%$ & \\
\hline Base Cond. OFA off & $12 / 15 / 92$ & $1: 37$ & 296 & 46 & 617 & 129836 & 144850 & 291733 & 237785 & 9235 & 9771 & 88.29 & $0.00 \%$ & \\
\hline GR 20\% Gas & $12 / 15 / 92$ & $0: 36$ & 289 & 50 & 618 & 108043 & 120207 & 295711 & 223123 & 9191 & 9734 & 87.65 & $23.98 \%$ & \\
\hline Base Cond. OFA off & $12 / 16 / 92$ & $0: 48$ & 286 & 36 & 610 & 135250 & 150817 & 307145 & 243911 & 9459 & 10009 & 88.46 & $0.00 \%$ & \\
\hline GR-12A1 & 12/16/92 & 2:19 & 285 & 39 & 615 & 124136 & 137087 & 309062 & 227194 & 9449 & 10005 & 88.13 & $18.73 \%$ & 6.68 \\
\hline Test C1 & $1 / 15 / 93$ & $1: 00$ & 293 & 52 & 619 & 129234 & 126697 & 318993 & 231773 & 9562 & 10276 & 87.99 & $14.63 \%$ & \\
\hline Tost C2 & $1 / 15 / 93$ & $1: 00$ & 301 & 61 & 627 & 122975 & 123840 & 316589 & 228682 & 9539 & 10247 & 87.64 & $18.91 \%$ & \\
\hline Test C3 & $1 / 15 / 93$ & 0.58 & 305 & 64 & 631 & 116628 & 117907 & 313534 & 221631 & 9533 & 10232 & 87.39 & $22.43 \%$ & \\
\hline Test C4 & $1 / 15 / 93$ & 0.50 & 305 & 64 & 633 & 109761 & 112246 & 307057 & 219438 & 9495 & 10186 & 87.27 & $22.99 \%$ & 4.69 \\
\hline Tost B1 & $1 / 15 / 93$ & $0: 59$ & 300 & 64 & 617 & 139887 & 144035 & 323987 & 235867 & 9632 & 10354 & 88.16 & $15.44 \%$ & \\
\hline Test B3 & $1 / 15 / 93$ & $1: 01$ & 298 & 62 & 617 & 139538 & 146413 & 313779 & 234121 & 9617 & 10335 & 88.35 & $15.40 \%$ & \\
\hline Base Cond. OFA off & $1 / 18 / 93$ & $0: 45$ & 290 & 36 & 621 & 142799 & 146807 & 315639 & 249671 & 9462 & 10115 & 88.62 & $0.00 \%$ & \\
\hline Test B5 & $1 / 18 / 93$ & $1: 01$ & 290 & 45 & 614 & 141516 & 147902 & 315377 & 236019 & 9525 & 10226 & 88.61 & $14.08 \%$ & \\
\hline Base Cond. OFA cooling & $1 / 19 / 93$ & $0: 39$ & 289 & 34 & 625 & 142187 & 154259 & 322910 & 251230 & 9468 & 10167 & 88.54 & $2.33 \%$ & \\
\hline GR-12R & $1 / 19 / 93$ & $1: 00$ & 286 & 34 & 621 & 132746 & 145890 & 328366 & 235829 & 9579 & 10318 & 88.18 & $19.85 \%$ & \\
\hline GR-13E & $1 / 19 / 93$ & $1: 00$ & 292 & 35 & 632 & 112787 & 120224 & 301800 & 218946 & 9505 & 10210 & 87.71 & $22.93 \%$ & \\
\hline GR-13C & $1 / 20 / 93$ & $1: 10$ & 307 & 59 & 638 & 115745 & 121859 & 311284 & 234599 & 9546 & 10253 & 87.39 & $23.26 \%$ & \\
\hline GR-12D & $1 / 20 / 93$ & 1.05 & 309 & 64 & 639 & 120063 & 127012 & 318836 & 226863 & 9592 & 10304 & 87.35 & $22.59 \%$ & \\
\hline GR-12E & $1 / 20 / 93$ & $0: 59$ & 308 & 64 & 634 & 127283 & 139859 & 313531 & 229434 & 9621 & 10338 & 87.72 & $18.74 \%$ & \\
\hline Base Cond. OFA off & $1 / 20 / 93$ & $0: 15$ & 309 & 64 & 633 & 140760 & 149755 & 303339 & 240941 & 9619 & 10292 & 88.33 & $0.00 \%$ & \\
\hline $150 \mathrm{MWn}$ Max NOx Red & $1 / 21 / 93$ & $1: 05$ & 313 & 66 & 639 & 109132 & 117113 & 304221 & 220284 & 9528 & 10223 & 87.16 & $23.78 \%$ & 3.51 \\
\hline Base Cond. OFA cooling & $1 / 21 / 93$ & $1: 30$ & 304 & 66 & 624 & 139004 & 151266 & 308885 & 240390 & 9682 & 10399 & 88.29 & $1.40 \%$ & \\
\hline $120 \mathrm{MWn}$ Max NOx Red & $1 / 21 / 93$ & $1: 00$ & 310 & 70 & 626 & 85199 & 94476 & 248955 & 190749 & 9425 & 10212 & 86.68 & $23.93 \%$ & \\
\hline GR Environ. \#1 & $1 / 25 / 93$ & $5: 10$ & 297 & 53 & 627 & 109308 & 119855 & 307256 & 223404 & 9423 & 10143 & 87.25 & $21.96 \%$ & \\
\hline Base Cond. OFA cooling & $1 / 26 / 93$ & $0: 55$ & 296 & 50 & 612 & 128790 & 135478 & 298826 & 232800 & 9490 & 10224 & 88.07 & $3.31 \%$ & \\
\hline GR Environ. Tost \#2 & $1 / 26 / 93$ & 5:22 & 306 & 65 & 625 & 108980 & 121438 & 296303 & 216046 & 9482 & 10203 & 87.19 & $23.03 \%$ & \\
\hline Environ. \#3 & $1 / 27 / 93$ & $5: 55$ & 314 & 66 & 639 & 116374 & 126034 & 316272 & 229275 & 9418 & 10117 & 87.08 & $21.71 \%$ & \\
\hline Environ. 44 (No GR) & $1 / 27 / 93$ & $6: 00$ & 309 & 60 & 626 & 131023 & 138086 & 292160 & 239155 & 9570 & 10281 & 87.93 & $0.00 \%$ & \\
\hline
\end{tabular}


Cherokee Unit 3, Average Test $\mathrm{C}$

Pre Modification

\begin{tabular}{|c|c|c|c|c|c|c|c|c|c|c|c|c|c|c|}
\hline Test Now & & oury & $\begin{array}{l}\text { AH Gas } \\
\text { Toup } \\
\text { Temp }\end{array}$ & AHAir & $\begin{array}{l}\text { AHAir } \\
\text { Oüt? } \\
\text { Temp }\end{array}$ & "Galc Coal & $\begin{array}{l}\text { Msd Coal } \\
\text { Flow } \\
\text { lbs/hr }\end{array}$ & Calc TAir & 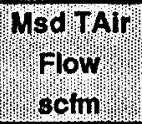 & $\begin{array}{l}\text { Theat } \\
\text { prote } \\
\text { Gross }\end{array}$ & $\begin{array}{l}\text { Heat } \\
\text { Rate } \\
\text { Net }\end{array}$ & Bofiler & 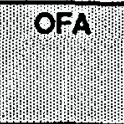 & сатьоро \\
\hline Environ. $* 5$ (No GR) & $1 / 28 / 93$ & $6: 04$ & 306 & 50 & 625 & 139606 & 147180 & 312665 & 249938 & 9432 & 10101 & 88.21 & $0.00 \%$ & \\
\hline Base Cond. & $2 / 2 / 93$ & $0: 17$ & 305 & 57 & 616 & 138217 & 140728 & 304125 & 242538 & 9667 & 10350 & 88.26 & $0.00 \%$ & \\
\hline LNB 120MW \#1 & $3 / 8 / 93$ & 2.00 & 308 & 72 & 601 & 112721 & 121832 & 258180 & 213576 & 9853 & 10576 & 87.61 & $0.00 \%$ & 11.23 \\
\hline LNB 120MW *2 & $3 / 8 / 93$ & $2: 00$ & 318 & 80 & 611 & 113254 & 122881 & 258302 & 211837 & 9882 & 10602 & 87.42 & $0.00 \%$ & 8.63 \\
\hline LNB $150 M W * 1$ & $3 / 9 / 93$ & $2: 00$ & 318 & 71 & 630 & 144518 & 153587 & 334835 & 251015 & 9868 & 10562 & 87.70 & $0.00 \%$ & 4.87 \\
\hline LNB $150 \mathrm{MW} * 2$ & $3 / 9 / 93$ & $2: 00$ & 318 & 73 & 623 & 142136 & 156992 & 319930 & 243876 & 9943 & 10651 & 87.87 & $0.00 \%$ & 6.09 \\
\hline LNB 9OMW \#1 & $3 / 10 / 93$ & 2.00 & 292 & 49 & 589 & 88914 & 101579 & 215864 & 194021 & 10080 & 11025 & 87.31 & $0.00 \%$ & 4.13 \\
\hline LNB 9OMW *2 & $3 / 10 / 93$ & 1.58 & 298 & 49 & 595 & 89253 & 100139 & 211036 & 190408 & 10034 & 10964 & 87.29 & $0.00 \%$ & 4.81 \\
\hline LNB $150 M W * 3$ & $3 / 11 / 93$ & $2: 00$ & 301 & 41 & 623 & 140628 & 149725 & 315744 & 244440 & 9727 & 10406 & 88.19 & $0.00 \%$ & 5.99 \\
\hline LNB 150MW :4 & $3 / 11 / 93$ & 2.00 & 302 & 43 & 621 & 141453 & 158012 & 310936 & 242136 & 9736 & 10417 & 88.30 & $0.00 \%$ & 7.20 \\
\hline $3 M_{1}$ & $3 / 22 / 93$ & $1: 02$ & 294 & 65 & 604 & 107276 & 116948 & 281586 & 213141 & 9408 & 10083 & 87.85 & $23.06 \%$ & \\
\hline $3 M 2$ & $3 / 22 / 93$ & 1.03 & 294 & 68 & 605 & 106881 & 119073 & 277476 & 214502 & 9400 & 10085 & 87.88 & $21.22 \%$ & \\
\hline $3 \mathrm{M} 3$ & $3 / 22 / 93$ & $0: 59$ & 295 & 69 & 609 & 107574 & 119279 & 288225 & 221879 & 9381 & 10062 & 87.70 & $20.15 \%$ & \\
\hline 3 Mill 7 & $4 / 13 / 93$ & 1.00 & 284 & 63 & 588 & 107272 & 134388 & 238431 & 217012 & 9433 & 10200 & 88.31 & $0.00 \%$ & \\
\hline 3 Mill 6 & $4 / 13 / 93$ & $1: 00$ & 280 & 64 & 586 & 108328 & 135251 & 235134 & 216033 & 9419 & 10174 & 88.55 & $0.00 \%$ & \\
\hline Level $61 / 2$ & $4 / 15 / 93$ & 2.05 & 302 & 51 & 616 & 132176 & 159181 & 296998 & 236762 & 9245 & 9897 & 88.19 & $0.00 \%$ & \\
\hline Levol 4 & $4 / 15 / 93$ & $1: 10$ & 302 & 51 & 616 & 132081 & 159312 & 297397 & 236963 & 9240 & 9892 & 88.19 & $0.00 \%$ & \\
\hline Level 3 & $4 / 15 / 93$ & $0: 53$ & 303 & 53 & 617 & 132366 & 158899 & 298147 & 236303 & 9250 & 9898 & 88.17 & $0.00 \%$ & \\
\hline Lovol 5 1/2 & $4 / 15 / 93$ & $1: 58$ & 307 & 60 & 619 & 132167 & 159566 & 290952 & 235825 & 9282 & 9937 & 88.18 & $0.00 \%$ & \\
\hline Base Cond & $4 / 15 / 93$ & $5: 25$ & 304 & 55 & 617 & 132182 & 159378 & 293836 & 236260 & 9260 & 9911 & 88.20 & $0.00 \%$ & \\
\hline Lovel 5 1/2 & 4/16/93 & $1: 47$ & 310 & 59 & 630 & 135162 & 160046 & 309954 & 247500 & 9223 & 9871 & 87.92 & $0.00 \%$ & \\
\hline Lovel 6 1/2 & $4 / 16 / 93$ & $1: 19$ & 313 & 66 & 629 & 135361 & 161663 & 308524 & 247523 & 9270 & 9925 & 87.90 & $0.00 \%$ & \\
\hline Level 3 & $4 / 16 / 93$ & $0: 44$ & 315 & 69 & 630 & 135550 & 164101 & 311653 & 248308 & 9296 & 9954 & 87.81 & $0.00 \%$ & \\
\hline Leveld & $4 / 16 / 93$ & 1.00 & 315 & 69 & 630 & 135705 & 163807 & 311884 & 248259 & 9297 & 9954 & 87.81 & $0.00 \%$ & \\
\hline North out, South in & $4 / 16 / 93$ & $0: 20$ & 310 & 59 & 631 & 135478 & 160538 & 323244 & 247553 & 9257 & 9907 & 87.69 & $0.00 \%$ & \\
\hline South out, North in & $4 / 16 / 93$ & $0: 20$ & 310 & 61 & 630 & 134606 & 160878 & 304846 & 247562 & 9208 & 9857 & 87.97 & $0.00 \%$ & \\
\hline Base Cond & 4/16/93 & $6: 25$ & 313 & 65 & 630 & 135460 & 161809 & 310573 & 247714 & 9267 & 9921 & 87.87 & $0.00 \%$ & \\
\hline Level 4 & $4 / 19 / 93$ & $0: 56$ & 306 & 63 & 629 & 108837 & 127394 & 301200 & 225868 & 9201 & 9877 & 87.28 & $20.70 \%$ & \\
\hline Level 3 & 4/19/93 & $0: 52$ & 306 & 63 & 629 & 108733 & 127295 & 300860 & 225729 & 9195 & 9870 & 87.28 & $20.74 \%$ & \\
\hline Level 5 1/2 & $4 / 19 / 93$ & $2: 29$ & 310 & 64 & 636 & 107787 & 125604 & 307713 & 229197 & 9157 & 9838 & 87.04 & $21.82 \%$ & \\
\hline Level $61 / 2$ & 4/19/93 & $1: 10$ & 311 & 63 & 639 & 108196 & 125345 & 310904 & 230268 & 9173 & 9851 & 87.02 & $21.83 \%$ & \\
\hline Base Cond. OFA on & 4/19/93 & $1: 00$ & 298 & 60 & 615 & 132138 & 151710 & 320537 & 236365 & 9303 & 10023 & 87.88 & $14.85 \%$ & \\
\hline GA & 4/19/93 & $5: 42$ & 310 & 64 & 636 & 107835 & 125698 & 306573 & 228332 & 9163 & 9842 & 87.07 & $21.88 \%$ & \\
\hline Level 6 1/2 & $4 / 20 / 93$ & $1: 47$ & 284 & 49 & 598 & 118536 & 134468 & 260175 & 224896 & 9335 & 10046 & 88.53 & $0.00 \%$ & \\
\hline Base Cond 130MW & 4/20/93 & $3: 35$ & 285 & 51 & 597 & 118485 & 134726 & 259183 & 224650 & 9340 & 10053 & 88.53 & $0.00 \%$ & \\
\hline Base Cond $120 \mathrm{MW}$ & $4 / 20 / 93$ & $2: 55$ & 305 & 61 & 612 & 110982 & 125821 & 261474 & 218887 & 9235 & 9901 & 87.48 & $0.00 \%$ & \\
\hline Base Cond. OFA off & 4/21/93 & $7: 40$ & 310 & 65 & 610 & 107591 & 124093 & 246885 & 211507 & 9268 & 10035 & 87.43 & $0.00 \%$ & \\
\hline Base Cond. OFA off & $4 / 23 / 93$ & $0: 30$ & 319 & 81 & 625 & 134843 & 162342 & 305081 & 243990 & 9310 & 9958 & 87.84 & $0.00 \%$ & 9.81 \\
\hline 4M12 (OFA off) & $4 / 23 / 93$ & $1: 00$ & 308 & 80 & 613 & 133541 & 134012 & 291323 & 240464 & 9383 & 10023 & 88.07 & $0.00 \%$ & 8.00 \\
\hline $4 \mathrm{M} 13 \mathrm{a}(78,000 \mathrm{scim}$ OFA & $4 / 23 / 93$ & $0: 20$ & 303 & 81 & 602 & 135843 & 138591 & 308665 & 230443 & 9531 & 10248 & 87.98 & $25.29 \%$ & \\
\hline
\end{tabular}


Cherokee Unit 3, Average Test [

Pre Modification

\begin{tabular}{|c|c|c|c|c|c|c|c|c|c|c|c|c|c|c|}
\hline rest & perpan & 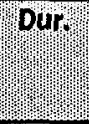 & AH Gss & Ahrain & AHAir & 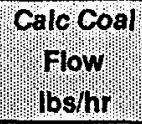 & 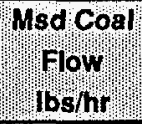 & Calc Tair & 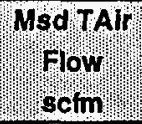 & $\begin{array}{l}\text { Meat } \\
\text { Gerem } \\
\text { Gross }\end{array}$ & Heat! & Boller & OFAצ' & Carbon \\
\hline $4 \mathrm{M} 13 \mathrm{~b}(70,000 \mathrm{sctm}$ OFA & $4 / 23 / 93$ & $0: 50$ & 301 & 83 & 600 & 135673 & 137289 & 311028 & 233023 & 9543 & 10259 & 88.02 & $22.33 \%$ & \\
\hline Base Cond. OFA On & $4 / 27 / 93$ & $0: 30$ & 310 & 66 & 625 & 137393 & 163077 & 330669 & 249563 & 9360 & 10056 & 87.67 & $5.56 \%$ & \\
\hline GR on $150 \mathrm{MW}, 11 \%$ Gas & $4 / 27 / 93$ & 0.53 & 307 & 67 & 622 & 121810 & 143288 & 313796 & 235246 & 9398 & 10084 & 87.51 & $11.70 \%$ & \\
\hline GR on $150 \mathrm{MW}, 17 \%$ Gas & $4 / 27 / 93$ & $2: 48$ & 313 & 74 & 627 & 113324 & 136540 & 306297 & 226405 & 9316 & 10004 & 87.23 & $23.41 \%$ & \\
\hline Base Cond. OFA on & $4 / 28 / 93$ & $0: 44$ & 306 & 66 & 617 & 128025 & 147200 & 309999 & 238462 & 9481 & 10224 & 87.63 & $5.27 \%$ & \\
\hline GR on Auto & $4 / 28 / 93$ & $6: 35$ & 311 & 76 & 625 & 105563 & 124223 & 284692 & 216279 & 9367 & 10097 & 87.10 & $23.06 \%$ & \\
\hline GA on Auto & $5 / 3 / 93$ & $7: 00$ & 312 & 81 & 626 & 109090 & 126679 & 305069 & 228883 & 9459 & 10204 & 86.92 & $22.97 \%$ & \\
\hline Base Cond. OFA on & $5 / 6 / 93$ & $2: 45$ & 301 & 72 & 604 & 128448 & 147181 & 311053 & 237273 & 9469 & 10203 & 87.76 & $4.94 \%$ & \\
\hline GR on Auto & $5 / 6 / 93$ & $1: 15$ & 313 & 78 & 621 & 109881 & 123762 & 295850 & 218626 & 9364 & 10077 & 87.08 & $21.47 \%$ & \\
\hline Base Cond. OFA off & $5 / 6 / 93$ & $0: 21$ & 305 & 80 & 605 & 111951 & 125645 & 265709 & 217774 & 9340 & 10070 & 87.47 & $0.00 \%$ & \\
\hline GR on Auto $150 \mathrm{MW}$ & $5 / 793$ & $4: 26$ & 310 & 74 & 619 & 112649 & 125465 & 307406 & 223455 & 9451 & 10162 & 87.21 & $23.48 \%$ & \\
\hline GR on Auto $160 \mathrm{MW}$ & $5 / 7 / 93$ & $1: 59$ & 318 & 80 & 627 & 121216 & 135030 & 326859 & 231918 & 9471 & 10148 & 87.23 & $22.52 \%$ & \\
\hline GR on Auto $140 \mathrm{MW}$ & $5 / 7 / 93$ & $4: 50$ & 306 & 67 & 617 & 106629 & 118424 & 294642 & 217963 & 9387 & 10118 & 87.06 & $23.69 \%$ & \\
\hline Base Cond. OFA off & $5 / 7 / 93$ & 0.35 & 310 & 66 & 621 & 133176 & 147419 & 314300 & 243468 & 9387 & 10072 & 87.58 & $0.00 \%$ & \\
\hline GR on Auto & $5 / 11 / 93$ & $6: 08$ & 312 & 72 & 625 & 104108 & 121603 & 301282 & 218598 & 9240 & 9960 & 86.65 & $22.50 \%$ & \\
\hline GR 13 & $5 / 25 / 93$ & 15.04 & 312 & 70 & 627 & 110684 & 133638 & 302823 & 225159 & 9279 & 9956 & 87.08 & $23.02 \%$ & \\
\hline GR 14 & $5 / 25 / 93$ & $1: 25$ & 306 & 73 & 611 & 81198 & 97285 & 235120 & 185230 & 9449 & 10333 & 86.32 & $25.08 \%$ & \\
\hline GR 15 & $5 / 26 / 93$ & $1: 29$ & 306 & 71 & 611 & 84832 & 102103 & 245649 & 192062 & 9395 & 10239 & 86.37 & $24.03 \%$ & \\
\hline LNB-OFA & $5 / 26 / 93$ & $0: 42$ & 298 & 70 & 595 & 85765 & 103731 & 229497 & 186468 & 9574 & 10513 & 86.50 & $17.28 \%$ & \\
\hline LNB & $5 / 26 / 93$ & $9: 44$ & 316 & 73 & 611 & 125678 & 149916 & 282354 & 229683 & 9462 & 10142 & 87.73 & $0.00 \%$ & \\
\hline LNB & $5 / 27 / 93$ & $0: 10$ & 312 & 82 & 608 & 103797 & 128327 & 241565 & 212013 & 9248 & 10030 & 87.33 & $0.00 \%$ & \\
\hline LNB-OFA & $5 / 27 / 93$ & $0: 45$ & 320 & 85 & 623 & 135091 & 157739 & 325151 & 241483 & 9407 & 10097 & 87.43 & $10.51 \%$ & \\
\hline GR-LNB 16 & $5 / 27 / 93$ & $13: 40$ & 318 & 84 & 626 & 110253 & 126788 & 304984 & 227015 & 9364 & 10060 & 86.85 & $21.75 \%$ & \\
\hline GR-LNB 17 & $5 / 28 / 93$ & $2: 57$ & 305 & 75 & 607 & 86180 & 98305 & 252690 & 197193 & 9464 & 10332 & 86.32 & $22.70 \%$ & \\
\hline LNB & $5 / 28 / 93$ & $1: 23$ & 312 & 75 & 595 & 81863 & 95551 & 213575 & 192218 & 9694 & 10709 & 86.26 & $0.00 \%$ & \\
\hline GR-LNB 20b & $6 / 3 / 93$ & $8: 51$ & 316 & 73 & 625 & 107116 & 127768 & 282557 & 210403 & 9285 & 9967 & 87.25 & $24.18 \%$ & \\
\hline LNB & $6 / 3 / 93$ & $1: 05$ & 316 & 70 & 603 & 88649 & 106473 & 222910 & 196080 & 9541 & 10361 & 86.70 & $0.00 \%$ & \\
\hline LNB (low load) & $6 / 4 / 93$ & $6: 52$ & 317 & 67 & 598 & 84677 & 100776 & 217567 & 190380 & 9663 & 10551 & 86.38 & $0.00 \%$ & \\
\hline LNB (high load) & $6 / 4 / 93$ & $5: 25$ & 313 & 60 & 617 & 133437 & 156584 & 309642 & 241367 & 9388 & 10043 & 87.94 & $0.00 \%$ & \\
\hline LNB-OFA & $6 / 4 / 93$ & $2: 31$ & 305 & 71 & 603 & 137915 & 163045 & 320582 & 238263 & 9534 & 10231 & 88.06 & $10.22 \%$ & \\
\hline GR-LNB & $6 / 4 / 93$ & $7: 42$ & 316 & 74 & 625 & 110334 & 131376 & 287430 & 213422 & 9297 & 9965 & 87.25 & $24.22 \%$ & \\
\hline LNB & $6 / 8 / 93$ & $1: 35$ & 319 & 77 & 615 & 127379 & 144516 & 299745 & 236646 & 9416 & 10127 & 87.41 & $0.00 \%$ & \\
\hline LNB-OFA & $6 / 8 / 93$ & $1: 40$ & 309 & 78 & 610 & 127822 & 148618 & 309610 & 235405 & 9432 & 10181 & 87.60 & $5.39 \%$ & \\
\hline GR-LNB 22a & $6 / 8 / 93$ & $6: 21$ & 317 & 80 & 625 & 101957 & 117116 & 291093 & 212158 & 9335 & 10079 & 86.65 & $22.73 \%$ & \\
\hline GR-LNB 22b & $6 / 8 / 93$ & $5: 30$ & 316 & 77 & 624 & 110084 & 128249 & 288750 & 215138 & 9268 & 9929 & 87.33 & $24.54 \%$ & \\
\hline GR-LNB 23a & $6 / 9 / 93$ & $1: 16$ & 298 & 69 & 604 & 87779 & 101362 & 233663 & 187305 & 9212 & 10015 & 87.22 & $25.33 \%$ & \\
\hline LNB-OFA & $6 / 9 / 93$ & $0: 30$ & 291 & 71 & 589 & 81446 & 88693 & 206327 & 171211 & 9475 & 10513 & 87.18 & $17.08 \%$ & \\
\hline LNB & $6 / 9 / 93$ & 16.03 & 316 & 75 & 606 & 108345 & 123012 & 259188 & 214188 & 9523 & 10378 & 87.28 & $0.00 \%$ & \\
\hline GR-LNB 236 & $6 / 9 / 93$ & $4: 28$ & 313 & 79 & 620 & 105101 & 121378 & 304466 & 223166 & 9366 & 10121 & 86.80 & $22.16 \%$ & \\
\hline LNB & $6 / 10 / 93$ & $8: 47$ & 310 & 71 & 603 & 105994 & 122276 & 249527 & 211843 & 9352 & 10147 & 87.49 & $0.00 \%$ & \\
\hline
\end{tabular}


Cherokee Unit 3, Average Test C

Pre Modification

\begin{tabular}{|c|c|c|c|c|c|c|c|c|c|c|c|c|c|c|}
\hline 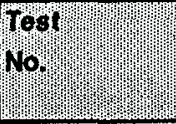 & Datep & Dow & 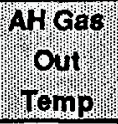 & 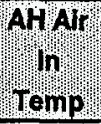 & Nhair & Calc coal" & 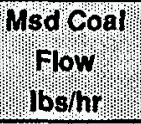 & Galc TAir & Msd & 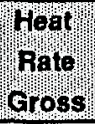 & Heat & Bone" & 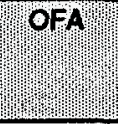 & carbon \\
\hline LNB-OFA & $6 / 10 / 93$ & $1: 16$ & 315 & 77 & 621 & 135703 & 156185 & 333008 & 240132 & 9427 & 10111 & 87.63 & $8.23 \%$ & \\
\hline GR-LNB 24 & $6 / 10 / 93$ & 2.57 & 323 & 84 & 637 & 110517 & 129533 & 317340 & 228295 & 9313 & 9989 & 86.63 & $22.56 \%$ & \\
\hline LNB & $6 / 10 / 93$ & $0: 37$ & 326 & 89 & 615 & 136793 & 155000 & 320293 & 245179 & 9454 & 10101 & 87.52 & $0.00 \%$ & \\
\hline GR-LNB 25a & $6 / 11 / 93$ & $5: 28$ & 322 & 91 & 626 & 101957 & 114675 & 278267 & 209279 & 9260 & 9959 & 86.66 & $22.66 \%$ & \\
\hline GR-LNB 25b & $6 / 11 / 93$ & 9.06 & 327 & 94 & 632 & 112416 & 126248 & 307218 & 222800 & 9296 & 9951 & 86.75 & $22.19 \%$ & \\
\hline GR-LNB 26a & $6 / 12 / 93$ & $11: 22$ & 327 & 89 & 635 & 103242 & 117561 & 274365 & 205936 & 9228 & 9925 & 86.74 & $23.76 \%$ & \\
\hline GR-LNB 26b. & $6 / 12 / 93$ & $2: 13$ & 312 & 79 & 608 & 77735 & 80993 & 210382 & 173515 & 9485 & 10502 & 86.24 & $19.72 \%$ & \\
\hline LNB-OFA & $6 / 12 / 93$ & $7: 11$ & 323 & 96 & 613 & 125768 & 149855 & 287453 & 221490 & 9450 & 10174 & 87.52 & $8.35 \%$ & \\
\hline LNB-OFA & $6 / 13 / 93$ & $9: 43$ & 312 & 79 & 595 & 76903 & 90810 & 198932 & 171221 & 9772 & 10812 & 86.34 & $5.48 \%$ & \\
\hline GR-LNB 28 & $6 / 14 / 93$ & $4: 06$ & 327 & 94 & 628 & 113195 & 135219 & 303259 & 221655 & 9393 & 10060 & 87.07 & $23.44 \%$ & \\
\hline LNB & $6 / 14 / 93$ & $1: 59$ & 324 & 89 & 608 & 120039 & 139502 & 278747 & 221993 & 9557 & 10283 & 87.44 & $0.00 \%$ & \\
\hline LNB & $6 / 18 / 93$ & $0: 38$ & 305 & 63 & 620 & 121009 & 140139 & 268164 & 232919 & 9172 & 9774 & 87.99 & $0.00 \%$ & \\
\hline GR-LNB 29 & $6 / 18 / 93$ & $14: 24$ & 310 & 68 & 624 & 105693 & 131749 & 288491 & 218273 & 9272 & 9954 & 87.10 & $24.08 \%$ & \\
\hline GR-LNB 30a & $6 / 19 / 93$ & $0: 30$ & 303 & 67 & 615 & 78474 & 102170 & 235465 & 186016 & 9292 & 10187 & 86.27 & $25.50 \%$ & \\
\hline LNB & $6 / 19 / 93$ & $9: 15$ & 322 & 71 & 605 & 81061 & 107893 & 196978 & 181229 & 9602 & 10686 & 86.39 & $0.00 \%$ & \\
\hline GA-LNB $30 b$ & $6 / 19 / 93$ & $11: 53$ & 325 & 85 & 637 & 105584 & 135338 & 282259 & 212397 & 9246 & 9910 & 86.98 & $25.55 \%$ & \\
\hline GR-LNB $30 c$ & $6 / 19 / 93$ & $1: 33$ & 318 & 84 & 620 & 77325 & 90969 & 219651 & 174718 & 9463 & 10409 & 86.18 & $26.40 \%$ & \\
\hline GA-LNB 23 & $6 / 23 / 93$ & $7: 35$ & 321 & 90 & 623 & 110131 & 136188 & 294849 & 216811 & 9341 & 10003 & 87.12 & $24.84 \%$ & \\
\hline GR-LNB 32b & $6 / 23 / 93$ & 1.09 & 313 & 80 & 620 & 96516 & 115763 & 262244 & 197925 & 9285 & 9989 & 86.93 & $25.24 \%$ & \\
\hline LNB-OFA cooling & $6 / 24 / 93$ & $6: 25$ & 309 & 71 & 602 & 80146 & 97092 & 191678 & 172577 & 9526 & 10443 & 87.01 & $5.98 \%$ & \\
\hline GR-LNB 33a & $6 / 24 / 93$ & 6.00 & 318 & 83 & 622 & 92834 & 110361 & 251472 & 196457 & 9216 & 9955 & 86.76 & $25.23 \%$ & \\
\hline GA-LNB 33 & $6 / 24 / 93$ & $11: 22$ & 319 & 83 & 625 & 108227 & 134555 & 287684 & 215139 & 9219 & 9875 & 87.17 & $25.17 \%$ & \\
\hline GR-LNB 34a & $6 / 25 / 93$ & $1: 52$ & 312 & 78 & 610 & 68421 & 81307 & 200840 & 166204 & 9542 & 10660 & 85.90 & $24.86 \%$ & \\
\hline LNB-OFA & $6 / 25 / 93$ & $4: 03$ & 300 & 72 & 592 & 78347 & 96415 & 200423 & 173363 & 9720 & 10909 & 86.76 & $13.26 \%$ & \\
\hline GR-LNB 34 & $6 / 25 / 93$ & $8: 00$ & 319 & 77 & 632 & 104912 & 124594 & 278148 & 209807 & 9255 & 9953 & 87.09 & $24.86 \%$ & \\
\hline LNB (some OFA) & $6 / 28 / 93$ & $1: 03$ & 332 & 96 & 621 & 137238 & 158831 & 311915 & 240977 & 9472 & 10221 & 87.61 & $0.18 \%$ & \\
\hline LNB (some OFA) & $6 / 29 / 93$ & $12: 15$ & 334 & 102 & 611 & 117110 & 136939 & 267207 & 218918 & 9528 & 10413 & 87.28 & $2.95 \%$ & \\
\hline LNB & $6 / 30 / 93$ & $11: 51$ & 330 & 83 & 615 & 108672 & 129149 & 249030 & 210612 & 9437 & 10372 & 87.16 & $0.00 \%$ & \\
\hline GR-LNB 35 & $6 / 30 / 93$ & $1: 48$ & 323 & 91 & 624 & 114578 & 131099 & 312689 & 225995 & 9398 & 10178 & 86.96 & $22.58 \%$ & \\
\hline GR-LNB 35a & $6 / 30 / 93$ & 6.05 & 323 & 93 & 626 & 113256 & 127039 & 323285 & 233001 & 9360 & 10150 & 86.65 & $21.66 \%$ & \\
\hline GR-LNB 35b & $6 / 30 / 93$ & $1: 53$ & 316 & 87 & 622 & 101543 & 115123 & 300326 & 223189 & 9347 & 10202 & 86.36 & $21.50 \%$ & \\
\hline GR-OLNB 36a & $7 / 1 / 93$ & $8: 22$ & 307 & 83 & 600 & 75163 & 85948 & 227877 & 183412 & 9583 & 10794 & 85.80 & $21.37 \%$ & \\
\hline GR-LNB 36 & $7 / 1 / 93$ & $15: 37$ & 326 & 95 & 626 & 109011 & 123691 & 294930 & 214425 & 9341 & 10142 & 86.80 & $22.56 \%$ & \\
\hline GA 37a & $7 / 2 / 93$ & $14: 55$ & 318 & 95 & 613 & 91390 & 105540 & 255425 & 192716 & 9411 & 10360 & 86.45 & $22.82 \%$ & \\
\hline GR 37 & $7 / 2 / 93$ & $7: 05$ & 328 & 96 & 630 & 115392 & 132985 & 315965 & 224382 & 9415 & 10194 & 86.83 & $22.12 \%$ & \\
\hline GR-LNB 38 & $7 / 3 / 93$ & $7: 46$ & 331 & 98 & 633 & 112169 & 127237 & 305047 & 219199 & 9260 & 10023 & 86.68 & $22.06 \%$ & \\
\hline GR-LNB 38a & $7 / 3 / 93$ & $8: 43$ & 325 & 90 & 629 & 110737 & 125133 & 332351 & 214154 & 9346 & 10133 & 86.10 & $20.06 \%$ & \\
\hline GR-LNB 39a & $7 / 4 / 93$ & $17: 27$ & 314 & 79 & 612 & 89454 & 99692 & 286123 & 186634 & 9496 & 10500 & 85.37 & $18.45 \%$ & \\
\hline GR-LNB 39 & $7 / 4 / 93$ & $6: 33$ & 321 & 84 & 628 & 114795 & 129375 & 355054 & 219205 & 9387 & $10+62$ & 86.02 & $18.30 \%$ & \\
\hline GA-LNB 40a & $7 / 5 / 93$ & $11: 52$ & 311 & 79 & 607 & 81700 & 89000 & 280221 & 177264 & 9653 & 10723 & 84.71 & $16.78 \%$ & \\
\hline
\end{tabular}


Cherokee Unit 3, Average Test [

Pre Moditication

\begin{tabular}{|c|c|c|c|c|c|c|c|c|c|c|c|c|c|c|}
\hline 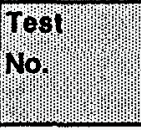 & Datel & purp & 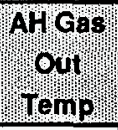 & 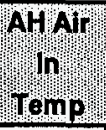 & 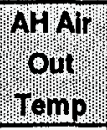 & Galc coal & 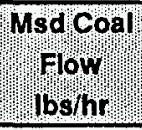 & calc TAir & MsdThal & 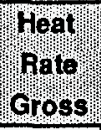 & Heat & Boingler & 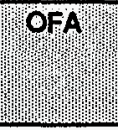 & Carbon \\
\hline GR-LNB 40 & $7 / 5 / 93$ & $12: 08$ & 323 & 88 & 627 & 110736 & 121149 & 365433 & 213890 & 9443 & 10257 & 85.40 & $17.17 \%$ & \\
\hline GR-LNB 52a & $7 / 1793$ & $8: 31$ & 309 & 81 & 604 & 79101 & 93020 & 233042 & 179699 & 9660 & 10802 & 86.11 & $25.31 \%$ & \\
\hline GR-LNB 52 & $7 / 17 / 93$ & $5: 45$ & 316 & 76 & 626 & 107944 & 128357 & 296938 & 219497 & 9329 & 10135 & 86.96 & $22.98 \%$ & \\
\hline LNB & $7 / 19 / 93$ & $1: 53$ & 302 & 85 & 598 & 106496 & 125543 & 242125 & 213817 & 9479 & 10313 & 87.71 & $0.00 \%$ & \\
\hline LNB-OFA & $7 / 19 / 93$ & $0: 22$ & 294 & 86 & 588 & 110577 & 132874 & 253703 & 216790 & 9502 & 10421 & 87.94 & $7.55 \%$ & \\
\hline GR-LNB 53a & $7 / 19 / 93$ & 3.29 & 307 & 85 & 606 & 93598 & 108145 & 253075 & 198618 & 9439 & 10375 & 86.95 & $24,09 \%$ & \\
\hline GR-LNB 53 & $7 / 19 / 93$ & $7: 06$ & 313 & 90 & 615 & 113352 & 135716 & 309678 & 223835 & 9454 & 10254 & 87.15 & $22.46 \%$ & \\
\hline LNB & $7 / 21 / 93$ & $8: 34$ & 334 & 85 & 594 & 76228 & 87944 & 183344 & 175788 & 9841 & 11279 & 86.12 & $0.00 \%$ & \\
\hline GR-LNB 54 & $7 / 21 / 93$ & $4: 52$ & 337 & 91 & 603 & 108745 & 131321 & 297865 & 219369 & 9462 & 10292 & 86.53 & $22.92 \%$ & \\
\hline LNB & $7 / 23 / 93$ & $2: 35$ & 321 & 86 & 599 & 91398 & 105394 & 217672 & 181205 & 10482 & 11819 & 86.90 & $0.00 \%$ & \\
\hline GR-LNB 55 & $7 / 23 / 93$ & 4.53 & 320 & 92 & 627 & 110471 & 129216 & 312881 & 224082 & 9383 & 10223 & 86.71 & $21.74 \%$ & \\
\hline GR-LNB 55a & $7 / 23 / 93$ & 1.08 & 320 & 92 & 624 & 100763 & 113980 & 288603 & 208479 & 9508 & 10432 & 86.44 & $22.01 \%$ & \\
\hline LNB & $7 / 23 / 93$ & 3.55 & 315 & 91 & 579 & 75018 & 92037 & 180400 & 173970 & 10029 & 11447 & 86.71 & $0.92 \%$ & \\
\hline LNB & $7 / 24 / 93$ & $1: 52$ & 306 & 87 & 568 & 78094 & 95440 & 199109 & 182387 & 9970 & 11250 & 86.53 & $0.00 \%$ & \\
\hline LNB-OFA & $7 / 24 / 93$ & $0: 36$ & 314 & 92 & 596 & 88171 & 104569 & 245401 & 186576 & 9807 & 10957 & 85.87 & $11.17 \%$ & \\
\hline GR-LNB 56 & $7 / 24 / 93$ & $7: 45$ & 323 & 93 & 633 & 109225 & 128540 & 306685 & 220171 & 9374 & 10213 & 86.65 & $22.11 \%$ & \\
\hline GR-LNB 56a & $7 / 24 / 93$ & 2.09 & 313 & 87 & 601 & 76098 & 84126 & 228334 & 173585 & 9746 & 10988 & 85.87 & $24.18 \%$ & \\
\hline GR-LNB 57a & $7 / 25 / 93$ & $1: 10$ & 309 & 85 & 589 & 62811 & 70494 & 205563 & 161845 & 10025 & 11442 & 85.12 & $23.93 \%$ & \\
\hline LNB-OFA & $7 / 25 / 93$ & 5.52 & 301 & 79 & 587 & 81925 & 92005 & 219864 & 175681 & 9810 & 11081 & 86.47 & $24,44 \%$ & \\
\hline GR-LNB 57b & $7 / 25 / 93$ & $10: 19$ & 318 & 89 & 619 & 95992 & 112530 & 280533 & 203531 & 9433 & 10391 & 86.31 & $22.71 \%$ & \\
\hline GR-LNB 57 & $7 / 25 / 93$ & $6: 14$ & 325 & 97 & 629 & 114215 & 132522 & 313346 & 222568 & 9384 & 10195 & 86.93 & $22.30 \%$ & \\
\hline GR-LNB 58a & $7 / 26 / 93$ & $10: 15$ & 313 & 82 & 615 & 85467 & 98283 & 262961 & 193771 & 9478 & 10536 & 85.76 & $22.67 \%$ & \\
\hline GR-LNB 58 & $7 / 26 / 93$ & $8: 34$ & 324 & 96 & 631 & 114931 & 130539 & 316485 & 224715 & 9432 & 10251 & 86.88 & $21.88 \%$ & \\
\hline GR-LNB 58b & $7 / 26 / 93$ & 5.09 & 320 & 88 & 624 & 103155 & 113917 & 294895 & 210698 & 9418 & 10322 & 86.47 & $21.45 \%$ & \\
\hline GR-LNB 59a & $7 / 27 / 93$ & $10: 48$ & 315 & 81 & 617 & 86014 & 95322 & 256860 & 192711 & 9518 & 10683 & 85.96 & $22.80 \%$ & \\
\hline LNB-OFA & $7 / 27 / 93$ & $3: 21$ & 327 & 93 & 626 & 141613 & 160374 & 317689 & 242944 & 9522 & 10323 & 87.94 & $1.76 \%$ & \\
\hline GR-LNB 59 & $7 / 27 / 93$ & $9: 16$ & 325 & 93 & 627 & 106270 & 119460 & 292285 & 213115 & 9498 & 10385 & 86.71 & $21.87 \%$ & \\
\hline GR-LNB 60a & $7 / 28 / 93$ & $11: 06$ & 320 & 81 & 628 & 97255 & 109445 & 269493 & 203508 & 9356 & 10227 & 86.59 & $22,52 \%$ & \\
\hline GR-LNB 606 & $7 / 28 / 93$ & $2: 02$ & 333 & 94 & 636 & 120122 & 138525 & 325557 & 228036 & 9370 & 10160 & 86.88 & $22.13 \%$ & \\
\hline LNB-OFA & $7 / 28 / 93$ & $2: 21$ & 329 & 101 & 624 & 143731 & 160010 & 325566 & 247702 & 9521 & 10315 & 87.80 & $2.51 \%$ & \\
\hline GR-LNB 60 & $7 / 28 / 93$ & $8: 10$ & 334 & 100 & 635 & 120987 & 134997 & 321416 & 227971 & 9448 & 10247 & 86.98 & $22.07 \%$ & \\
\hline GR-LNB 61a & $7 / 29 / 93$ & $15: 55$ & 329 & 92 & 635 & 113186 & 127894 & 304762 & 221114 & 9390 & 10217 & 86.85 & $22.18 \%$ & \\
\hline GR-LNB 61 & $7 / 29 / 93$ & $8: 04$ & 335 & 103 & 634 & 112810 & 131783 & 303893 & 218047 & 9377 & 10197 & 86.76 & $22.84 \%$ & \\
\hline GR-LNB 62 & $7 / 30 / 93$ & $10: 04$ & 328 & 91 & 630 & 108598 & 124443 & 290349 & 211712 & 9339 & 10180 & 86.82 & $22.66 \%$ & \\
\hline LNB.OFA & $7 / 30 / 93$ & $4: 32$ & 326 & 101 & 618 & 138517 & 165217 & 328322 & 242314 & 9600 & 10445 & 87.56 & $5.32 \%$ & \\
\hline GR-LNB 62a & $7 / 30 / 93$ & $9: 00$ & 328 & 92 & 630 & 114381 & 130376 & 319178 & 225616 & 9479 & 10322 & 86.72 & $21.49 \%$ & \\
\hline GR-LNB 63a & $7 / 31 / 93$ & $17: 10$ & 329 & 94 & 628 & 112988 & 128949 & 304343 & 216384 & 9431 & 10260 & 86.89 & $22.26 \%$ & \\
\hline GR-LNB 63b & $7 / 31 / 93$ & $6: 49$ & 336 & 103 & 635 & 115516 & 124145 & 306271 & 216882 & 9391 & 10200 & 86.86 & $21.27 \%$ & \\
\hline GR-LNB 64a & $8 / 1 / 93$ & $1: 25$ & 331 & 95 & 635 & 102747 & 113573 & 278895 & 204553 & 9354 & 10234 & 86.56 & $22.16 \%$ & \\
\hline GR-LNB 64b & $8 / 1 / 93$ & $10: 21$ & 317 & 85 & 614 & 81407 & 90176 & 236379 & 183972 & 9604 & 10764 & 86.09 & $24.08 \%$ & \\
\hline
\end{tabular}


Cherokee Unit 3, Average Test 5

Pre Modification

\begin{tabular}{|c|c|c|c|c|c|c|c|c|c|c|c|c|c|c|}
\hline rosp & 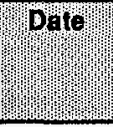 & pur & 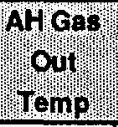 & Whälim & Aн Ain' & Calc coal & 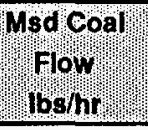 & Calc TfIII! & 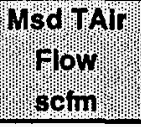 & $\begin{array}{l}\text { Heat } \\
\text { Rete } \\
\text { Gross }\end{array}$ & Heat) & Boiler & (of A & carbon \\
\hline GR-LNB 64c & $8 / 1 / 93$ & $12: 14$ & 332 & 90 & 642 & 111057 & 125008 & 298343 & 217308 & 9388 & 10216 & 86.76 & $22.41 \%$ & \\
\hline GR-LNB 65a & $8 / 2 / 93$ & $8: 55$ & 316 & 84 & 611 & 78544 & 84685 & 234870 & 179557 & 9716 & 10936 & 85.76 & $23.45 \%$ & \\
\hline LNB-OFA & $8 / 2 / 93$ & $1: 23$ & 322 & 81 & 629 & 138466 & 157723 & 320343 & 237609 & 9508 & 10321 & 87.70 & $2.08 \%$ & \\
\hline GR-LNB 65b & $8 / 2 / 93$ & $6: 02$ & 325 & 84 & 634 & 112140 & 128465 & 297910 & 213646 & 9443 & 10277 & 86.95 & $22.54 \%$ & \\
\hline GR-LNB 650 & $8 / 2 / 93$ & $7: 14$ & 324 & 84 & 632 & 107432 & 125688 & 290205 & 211496 & 9423 & 10292 & 86.61 & $23.02 \%$ & \\
\hline GR-LNB 66a & $8 / 3 / 93$ & $8: 29$ & 308 & 74 & 608 & 71855 & 82153 & 222335 & 173390 & 9658 & 10946 & 85.62 & $25.00 \%$ & \\
\hline GR-LNB 66b & $8 / 3 / 93$ & $9: 34$ & 318 & 75 & 630 & 106999 & 126516 & 298918 & 216394 & 9355 & 10213 & 86.78 & $22.03 \%$ & \\
\hline GR-LNB 660 & $8 / 3 / 93$ & $5: 55$ & 323 & 79 & 638 & 111634 & 130251 & 300029 & 217833 & 9333 & 10152 & 86.96 & $22.35 \%$ & \\
\hline GR-LNB 67 & $8 / 4 / 93$ & $24: 00$ & 321 & 80 & 632 & 104594 & 115911 & 286945 & 208422 & 9399 & 10292 & 86.71 & $22.04 \%$ & \\
\hline GR-LNB 68a & $8 / 5 / 93$ & $7: 39$ & 313 & 75 & 620 & 90167 & 96583 & 252926 & 191039 & 9427 & 10430 & 86.47 & $23.43 \%$ & \\
\hline GA-LNB 68b & $8 / 5 / 93$ & $15: 50$ & 324 & 81 & 637 & 114545 & 127578 & 312197 & 220991 & 9365 & 10176 & 86.85 & $20.75 \%$ & \\
\hline GR-LNB 69 & $8 / 6 / 93$ & $9: 48$ & 319 & 73 & 633 & 105202 & 115261 & 279028 & 208024 & 9374 & 10254 & 86.88 & $22.04 \%$ & \\
\hline LNB & $8 / 6 / 93$ & $7: 58$ & 329 & 86 & 620 & 135507 & 152301 & 307106 & 235303 & 9582 & 10390 & 87.54 & $0.00 \%$ & \\
\hline LNB-OFA & $8 / 6 / 93$ & $5: 04$ & 329 & 93 & 617 & 139200 & 156646 & 319811 & 240153 & 9606 & 10405 & 87.55 & $1.24 \%$ & \\
\hline LNB & $8 / 7 / 93$ & 3.04 & 323 & 81 & 623 & 133043 & 152559 & 293279 & 230595 & 9490 & 10309 & 87.79 & $0.00 \%$ & \\
\hline GR-LNB 70 & $8 / 7 / 93$ & 3.53 & 328 & 79 & 641 & 115672 & 129955 & 281698 & 207263 & 9362 & 10223 & 87.00 & $13.11 \%$ & \\
\hline LNB-OFA & $8 / 7 / 93$ & 8.05 & 329 & 91 & 619 & 136082 & 151935 & 315462 & 235797 & 9534 & 10341 & 87.39 & $1.34 \%$ & \\
\hline LNB & $8 / 7 / 93$ & $6: 28$ & 330 & 91 & 618 & 137961 & 152516 & 316815 & 239395 & 9577 & 10375 & 87.49 & $0.00 \%$ & \\
\hline LNB & $8 / 9 / 93$ & 8.04 & 324 & 82 & 610 & 127397 & 143447 & 298101 & 229959 & 9624 & 10490 & 87.43 & $0.00 \%$ & \\
\hline GR-LNB 71 (10\% Gas) & $8 / 9 / 93$ & $13: 45$ & 331 & 98 & 629 & 124813 & 141025 & 323971 & 224046 & 9577 & 10416 & 87.05 & $17.84 \%$ & \\
\hline GA-LNB 72a $(10 \%)$ & $8 / 10 / 93$ & $7: 48$ & 325 & 88 & 628 & 121811 & 136004 & 311569 & 219910 & 9441 & 10274 & 87.10 & $17.55 \%$ & \\
\hline LNB & $8 / 10 / 93$ & $7: 27$ & 328 & 92 & 614 & 138553 & 159493 & 329661 & 243708 & 9775 & 10614 & 87.44 & $0.00 \%$ & \\
\hline GR-LNB $72 b(10 \%)$ & $8 / 10 / 93$ & $7: 25$ & 319 & 82 & 617 & 119944 & 136607 & 311369 & 220653 & 9585 & 10463 & 87.16 & $17.64 \%$ & \\
\hline GA-LNB 73 & $8 / 11 / 93$ & $3: 22$ & 308 & 80 & 614 & 114651 & 133712 & 304084 & 220455 & 9486 & 10370 & 87.14 & $17.60 \%$ & \\
\hline LNB-OFA & $8 / 11 / 93$ & $9: 49$ & 328 & 94 & 619 & 141129 & 162624 & 328878 & 245466 & 9648 & 10454 & 87.60 & $1.53 \%$ & \\
\hline LNB & $8 / 11 / 93$ & $2: 45$ & 326 & 90 & 617 & 134064 & 149499 & 319320 & 241401 & 9657 & 10494 & 87.40 & $0.00 \%$ & \\
\hline LNB & $8 / 12 / 93$ & $7: 36$ & 325 & 84 & 602 & 102169 & 114134 & 243465 & 203969 & 9710 & 10817 & 86.91 & $0.00 \%$ & \\
\hline GR-LNB 74 & $8 / 12 / 93$ & $14: 33$ & 319 & 81 & 627 & 122857 & 141508 & 315138 & 222362 & 9486 & 10325 & 87.25 & $18.04 \%$ & \\
\hline GR-LNB 75 & $8 / 13 / 93$ & $18: 16$ & 324 & 91 & 629 & 120404 & 143834 & 316033 & 220957 & 9505 & 10366 & 86.96 & $18.04 \%$ & \\
\hline GR-LNB 76a & $8 / 14 / 93$ & $4: 54$ & 322 & 90 & 621 & 97749 & 113733 & 262877 & 192824 & 9396 & 10379 & 86.39 & $17.46 \%$ & \\
\hline LNB & $8 / 14 / 93$ & $1: 46$ & 321 & 89 & 592 & 80714 & 90963 & 230800 & 187627 & 9938 & 11150 & 85.31 & $0.00 \%$ & \\
\hline GR-LNB 76b & $8 / 14 / 93$ & $11: 05$ & 325 & 89 & 627 & 118872 & 139606 & 319917 & 219864 & 9494 & 10357 & 86.74 & $17.54 \%$ & \\
\hline GR-LNB 77 & $8 / 15 / 93$ & $1: 10$ & 320 & 83 & 619 & 94016 & 107749 & 259165 & 187601 & 9530 & 10560 & 86.17 & $17.27 \%$ & \\
\hline LNB & $8 / 15 / 93$ & $14: 44$ & 326 & 84 & 605 & 104787 & 124717 & 252824 & 203571 & 9703 & 10740 & 86.67 & $0.81 \%$ & \\
\hline LNB & $8 / 15 / 93$ & $6: 58$ & 330 & 91 & 621 & 139032 & 164521 & 319722 & 237720 & 9575 & 10366 & 87.52 & $0.62 \%$ & \\
\hline LNB (low load) & $8 / 16 / 93$ & $7: 38$ & 335 & 80 & 620 & 94604 & 111147 & 230812 & 193269 & 9625 & 10737 & 86.27 & $0.00 \%$ & \\
\hline LNB (150 MWe) & $8 / 16 / 93$ & 3.21 & 327 & 82 & 631 & 140409 & 163924 & 330826 & 246741 & 9540 & 10340 & 87.48 & $0.00 \%$ & \\
\hline LNB-OFA cooling & $8 / 16 / 93$ & $11: 40$ & 331 & 100 & 616 & 142241 & 164060 & 332982 & 244498 & 9655 & 10465 & 87.54 & $1.95 \%$ & \\
\hline LNB & $8 / 17 / 93$ & $9: 07$ & 325 & 86 & 615 & 124002 & 137788 & 290545 & 224890 & 9658 & 10554 & 87.30 & $0.00 \%$ & \\
\hline $100 \%$ Gas (plant test) & $8 / 17 / 93$ & $0: 34$ & 304 & 86 & 577 & 73951 & 0 & 161443 & 170693 & 10238 & 11428 & 84.82 & $0.00 \%$ & \\
\hline
\end{tabular}


Cherokee Unit 3, Average Test C

Pre Modification

\begin{tabular}{|c|c|c|c|c|c|c|c|c|c|c|c|c|c|c|}
\hline Testạt & palp & pur & AH Gas & 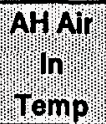 & $\begin{array}{l}\text { AH Air } \\
\text { rowt } \\
\text { remp }\end{array}$ & Calccoal & $\begin{array}{l}\text { Msd Coal } \\
\text { Flow } \\
\text { lbs/hr }\end{array}$ & Calç TÁ, & Mso' TAT & $\begin{array}{l}\text { Teat } \\
\text { Yrate } \\
\text { Gross }\end{array}$ & חeat & בroter & $\int^{O F A}$ & Carbon \\
\hline LNB (OFA cooling) & $8 / 17 / 93$ & $8: 59$ & 333 & 99 & 623 & 148384 & 158004 & 341536 & 242598 & 10176 & 11031 & 87.58 & $1.88 \%$ & \\
\hline LNB & $8 / 17 / 93$ & $3: 05$ & 329 & 90 & 621 & 145491 & 153659 & 328978 & 238257 & 10131 & 10989 & 87.71 & $0.00 \%$ & \\
\hline LNB (low load) & $8 / 18 / 93$ & $9: 42$ & 334 & 87 & 619 & 111224 & 119253 & 256656 & 204399 & 10101 & 11172 & 86.93 & $0.00 \%$ & \\
\hline LNB $150 \mathrm{MWe}$ & $8 / 18 / 93$ & $14: 16$ & 326 & 87 & 618 & 148284 & 157239 & 345915 & 244593 & 10211 & 11080 & 87.64 & $0.00 \%$ & \\
\hline GR-LNB 78 & $8 / 24 / 93$ & $3: 25$ & 318 & 95 & 615 & 117053 & 147575 & 296876 & 216487 & 9071 & 9838 & 87.21 & $19.82 \%$ & \\
\hline LNB OFA cooling & $8 / 24 / 93$ & $10: 38$ & 324 & 99 & 609 & 134604 & 162076 & 319508 & 242758 & 9267 & 10020 & 87.40 & $2.50 \%$ & \\
\hline LNB OFA cooling & $8 / 25 / 93$ & $2: 06$ & 309 & 91 & 587 & 105315 & 129722 & 245925 & 214667 & 9233 & 10024 & 87.39 & $1.91 \%$ & \\
\hline LNB & $8 / 25 / 93$ & $8: 38$ & 310 & 88 & 591 & 100894 & 124726 & 237139 & 209651 & 9280 & 10123 & 87.31 & $0.00 \%$ & \\
\hline LNB & $8 / 25 / 93$ & 13.08 & 318 & 83 & 612 & 132513 & 159731 & 316824 & 247077 & 9284 & 9984 & 87.54 & $0.00 \%$ & \\
\hline LNB & $8 / 26 / 93$ & 21:16 & 322 & 83 & 603 & 100277 & 113516 & 252716 & 205520 & 9731 & 10848 & 87.08 & $0.00 \%$ & \\
\hline LNB & $8 / 26 / 93$ & $2: 42$ & 324 & 81 & 618 & 135579 & 149582 & 321161 & 244242 & 9492 & 10284 & 87.53 & $0.00 \%$ & \\
\hline LNB & $8 / 27 / 93$ & $8: 26$ & 321 & 76 & 599 & 93838 & 109436 & 232628 & 197534 & 9722 & 10760 & 87.00 & $0.00 \%$ & \\
\hline LNB & $8 / 27 / 93$ & $6: 17$ & 316 & 74 & 612 & 132554 & 148689 & 312143 & 238653 & 9507 & 10317 & 87.70 & $0.00 \%$ & \\
\hline GR-LNB 79 & $9 / 8 / 93$ & $11: 15$ & 318 & 85 & 629 & 117756 & 130192 & 311182 & 219460 & 9439 & 10248 & 87.32 & $18.63 \%$ & \\
\hline GR-LNB 79a & $9 / 8 / 93$ & $1: 49$ & 312 & 81 & 616 & 96950 & 103679 & 271189 & 194649 & 9526 & 10482 & 87.11 & $20.64 \%$ & \\
\hline GR-LNB BOa & $9 / 9 / 93$ & 6.55 & 307 & 76 & 613 & 86601 & 94789 & 246725 & 184430 & 9478 & 10524 & 87.04 & $22.29 \%$ & \\
\hline LNB-OFA & 9/9/93 & $1: 46$ & 303 & $\pi$ & 596 & 81879 & 90390 & 221179 & 176686 & 9795 & 11126 & 87,25 & $5.24 \%$ & \\
\hline GR-LNB 80 & $9 / 9 / 93$ & $14: 15$ & 319 & 85 & 627 & 106284 & 118889 & 287894 & 207267 & 9352 & 10204 & 87.09 & $20.38 \%$ & \\
\hline LNB-OFA & $9 / 10 / 93$ & $4: 50$ & 308 & 78 & 593 & 75788 & 84546 & 213997 & 169294 & 9913 & 11266 & 87.04 & $3.54 \%$ & \\
\hline GR-LNB 81 & $9 / 10 / 93$ & $1: 46$ & 312 & 71 & 626 & 84099 & 92785 & 240680 & 180373 & 9366 & 10392 & 86.86 & $24.05 \%$ & \\
\hline LNB & 9/10/93 & 13.30 & 323 & 86 & 617 & 130674 & 144896 & 315148 & 237494 & 9512 & 10319 & 87.49 & $0.00 \%$ & \\
\hline LNB & $9 / 11 / 93$ & $19: 30$ & 329 & 89 & 618 & 121777 & 132188 & 291420 & 224267 & 9541 & 10450 & 87.22 & $0.37 \%$ & \\
\hline GR-LNB 82 & $9 / 11 / 93$ & $4: 10$ & 323 & 93 & 629 & 116087 & 122810 & 330669 & 220738 & 9500 & 10335 & 87.17 & $18.35 \%$ & \\
\hline GR-LNB 83a & $9 / 12 / 93$ & $11: 51$ & 311 & 82 & 618 & 100367 & 103309 & 291989 & 204346 & 9411 & 10335 & 87.17 & $19.71 \%$ & \\
\hline GR-LNB 83 & $9 / 12 / 93$ & $12: 09$ & 326 & 96 & 632 & 123161 & 123174 & 331210 & 222367 & 9413 & 10193 & 87.21 & $17.91 \%$ & \\
\hline GR-LNB 84a & $9 / 13 / 93$ & $5: 35$ & 300 & 64 & 612 & 91790 & 90344 & 267381 & 192148 & 9390 & 10442 & 87.28 & $20.62 \%$ & \\
\hline GR-LNB 84 & $9 / 13 / 93$ & $18: 03$ & 300 & 51 & 622 & 116688 & 127576 & 308293 & 219520 & 9202 & 10008 & 87.73 & $17.19 \%$ & \\
\hline GR-LNB 85a & $9 / 14 / 93$ & $4: 15$ & 298 & 55 & 619 & 102703 & 111036 & 274184 & 199390 & 9202 & 10077 & 87.53 & $19.32 \%$ & \\
\hline LNB & $9 / 14 / 93$ & $11: 05$ & 307 & 62 & 605 & 109330 & 123501 & 260591 & 216210 & 9417 & 10357 & 87.57 & $0.00 \%$ & \\
\hline LNB-OFA & $9 / 14 / 93$ & $1: 06$ & 307 & 75 & 616 & 136479 & 164492 & 325728 & 240505 & 9376 & 10181 & 87.97 & $3.56 \%$ & \\
\hline GR-LNB 85 & $9 / 14 / 93$ & $6: 55$ & 310 & 73 & 626 & 115131 & 137398 & 287766 & 215025 & 9194 & 9988 & 87.48 & $19.61 \%$ & \\
\hline GR-LNB 86a & $9 / 15 / 93$ & $0: 50$ & 307 & 66 & 624 & 104429 & 123752 & 272160 & 202384 & 9231 & 10089 & 87.36 & $20.23 \%$ & \\
\hline LNB & $9 / 15 / 93$ & $3: 07$ & 290 & 66 & 593 & 92960 & 114937 & 222813 & 199104 & 9276 & 10306 & 87.74 & $0.00 \%$ & \\
\hline GR-LNB $86 b$ & $9 / 15 / 93$ & $4: 26$ & 307 & 66 & 626 & 96768 & 114013 & 255614 & 195843 & 9230 & 10166 & 87.20 & $21.31 \%$ & \\
\hline GR.LNB 86 & $9 / 15 / 93$ & $11: 20$ & 317 & 84 & 630 & 113876 & 126174 & 289789 & 216897 & 9208 & 10012 & 87.27 & $19.56 \%$ & \\
\hline GR-LNB 87a & $9 / 16 / 93$ & $5: 46$ & 310 & 73 & 619 & 95779 & 102457 & 255311 & 195838 & 9315 & 10289 & 87.15 & $21.22 \%$ & \\
\hline GR-LNB 87 & $9 / 16 / 93$ & $15: 24$ & 315 & 74 & 629 & 109303 & 116804 & 299788 & 211933 & 9251 & 10099 & 87.23 & $18.27 \%$ & \\
\hline GR-LNB B8a & $9 / 17 / 93$ & $5: 31$ & 307 & 68 & 622 & 99764 & 105406 & 274834 & 199621 & 9242 & 10144 & 87.24 & $20.22 \%$ & \\
\hline GR-LNB 88 & $9 / 17 / 93$ & $18: 28$ & 313 & 71 & 631 & 115080 & 121003 & 297014 & 216191 & 9204 & 10002 & 87.38 & $18.83 \%$ & \\
\hline GR-LNB 89 & $9 / 18 / 93$ & $24: 00$ & 307 & 65 & 625 & 112388 & 120938 & 283716 & 211284 & 9177 & 9987 & 87.48 & $19.07 \%$ & \\
\hline
\end{tabular}


Cherokee Unit 3, Average Test C

Pre Modification

\begin{tabular}{|c|c|c|c|c|c|c|c|c|c|c|c|c|c|c|}
\hline 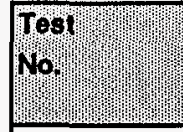 & Date: & Dup & $\begin{array}{l}\text { AHGas } \\
\text { Oowfy } \\
\text { Temp }\end{array}$ & $\begin{array}{l}\text { AHAir } \\
\text { In } \\
\text { Temp }\end{array}$ & $\begin{array}{l}\text { AH Alr } \\
\text { Out } \\
\text { Tomp }\end{array}$ & Calc Coal & $\begin{array}{l}\text { Msd Coal } \\
\text { Wrilow } \\
\text { Wloshr }\end{array}$ & $\begin{array}{l}\text { Calc TAir } \\
\text { Flow } \\
\text { sctm }\end{array}$ & $\begin{array}{l}\text { Msd TAif } \\
\text { Flow } \\
\text { scm }\end{array}$ & $\begin{array}{l}\text { Heat } \\
\text { Reter } \\
\text { Ross }\end{array}$ & $\begin{array}{l}\text { heat } \\
\text { nase } \\
\text { ner }\end{array}$ & Boiler & OFA & $\begin{array}{l}\text { Carbon } \\
\text { Tin } \\
\text { Ash } \%\end{array}$ \\
\hline GR.LNB 90a & 9/19/93 & $10: 06$ & 307 & 63 & 624 & 102865 & 113334 & 266803 & 199891 & 9143 & 10005 & 87.32 & $19.58 \%$ & \\
\hline GA-LNB 90 & 9/19/93 & $13: 54$ & 318 & 76 & 630 & 118596 & 142137 & 296715 & 219053 & 9171 & 9952 & 87.33 & $18.05 \%$ & \\
\hline GA-LNB 91 & 9/20/93 & $24: 00$ & 320 & 76 & 633 & 110995 & 132963 & 278774 & 210599 & 9122 & 9918 & 87.16 & $20.04 \%$ & \\
\hline GR-LNB 92a & $9 / 21 / 93$ & $3: 00$ & 316 & 74 & 625 & 92301 & 105678 & 244816 & 187661 & 9327 & 10241 & 86.94 & $22.88 \%$ & \\
\hline GR-LNB 92 & $9 / 21 / 93$ & $17: 56$ & 322 & 82 & 628 & 112357 & 125848 & 294045 & 211239 & 9346 & 10156 & 87.14 & $19.52 \%$ & \\
\hline GR-LNB 3 Mill a & $9 / 22 / 93$ & $7: 59$ & 300 & 69 & 612 & 89138 & 99840 & 251669 & 188060 & 9350 & 10254 & 87.23 & $22.15 \%$ & \\
\hline GR-LNB 3 Mill b & $9 / 22 / 93$ & $8: 25$ & 293 & 68 & 605 & 95611 & 104796 & 260884 & 195196 & 9370 & 10198 & 87.22 & $21.22 \%$ & \\
\hline GR-LNB 3 Mill C & 9/23/93 & $24: 00$ & 294 & 68 & 608 & 96702 & 104347 & 264056 & 199335 & 9360 & 10176 & 87.18 & $21.01 \%$ & \\
\hline GA-LNB 3 Mill d & 9/24/93 & $1: 58$ & 291 & 67 & 604 & 78987 & 84017 & 231855 & 176006 & 9517 & 10533 & 86.49 & $23.35 \%$ & \\
\hline LNB-OFA 3 Mill & $9 / 24 / 93$ & $3: 33$ & 277 & 66 & 563 & 70772 & 77449 & 206672 & 162304 & 10372 & 11963 & 86.33 & $20.96 \%$ & \\
\hline GR-LNB 3 Mill $\theta$ & 9/24/93 & $6: 10$ & 291 & 65 & 602 & 97473 & 102655 & 271215 & 202006 & 9488 & 10338 & 87.18 & $20.13 \%$ & \\
\hline GR-LNB 93 & $9 / 24 / 93$ & 12:09 & 311 & 72 & 621 & 111231 & 121077 & 300291 & 213502 & 9418 & 10250 & 87.06 & $18.33 \%$ & \\
\hline GR-LNB 942 & 9/25/93 & $2: 12$ & 311 & 66 & 624 & 98036 & 99753 & 266967 & 192762 & 9379 & 10290 & 86.79 & $20.22 \%$ & \\
\hline LNB-OFA & $9 / 25 / 93$ & $2: 24$ & 302 & 65 & 608 & 93154 & 97849 & 249736 & 182642 & 9540 & 10593 & 86.55 & $21.50 \%$ & \\
\hline GA-LNB 94 & $9 / 25 / 93$ & $19: 05$ & 322 & 77 & 637 & 119198 & 127311 & 309538 & 217890 & 9313 & 10109 & 87.13 & $17.86 \%$ & \\
\hline GA-LNB 95a & 9/26/93 & $4: 15$ & 305 & 65 & 622 & 95006 & 99184 & 261787 & 191570 & 9280 & 10209 & 86.91 & $21.16 \%$ & \\
\hline LNB-OFA & $9 / 26 / 93$ & $2: 55$ & 293 & 63 & 587 & 88733 & 91670 & 249052 & 178143 & 9832 & 11009 & 86.60 & $21.80 \%$ & \\
\hline GR-LNB 95 & 9/26/93 & $16: 33$ & 314 & 71 & 625 & 110855 & 118588 & 297667 & 210955 & 9331 & 10166 & 86.99 & $18.84 \%$ & \\
\hline GR-LNB 96a & 9/27/93 & $2: 53$ & 309 & 67 & 620 & 99821 & 105124 & 280347 & 201088 & 9361 & 10275 & 86.65 & $19.83 \%$ & \\
\hline LNB & $9 / 27 / 93$ & 19:45 & 321 & 82 & 616 & 133431 & 141215 & 321673 & 243127 & 9529 & 10345 & 87.47 & $0.48 \%$ & \\
\hline GR-LNB 966 & 9/27/93 & $0: 57$ & 318 & 77 & 623 & 97262 & 98280 & 265294 & 189650 & 9454 & 10394 & 86.69 & $22.68 \%$ & \\
\hline GR-LNB 97a & 9/28/93 & $9: 13$ & 313 & 70 & 626 & 103105 & 105331 & 285040 & 204855 & 9309 & 10189 & 86.76 & $19.88 \%$ & \\
\hline LNB & 9/28/93 & 4:27 & 317 & 73 & 621 & 135363 & 144545 & 283410 & 230272 & 9385 & 10160 & 88.37 & $0.00 \%$ & \\
\hline GR-LNB 97 & 9/28/93 & $5: 58$ & 324 & 78 & 636 & 119429 & 127251 & 298510 & 213319 & 9240 & 10022 & 87.27 & $19.18 \%$ & \\
\hline GR-LNB 976 & 9/28/93 & $2: 48$ & 315 & 72 & 624 & 101042 & 104569 & 265526 & 194464 & 9272 & 10161 & 86.84 & $18: 60 \%$ & \\
\hline GR-LNB 98a & $9 / 29 / 93$ & $5: 22$ & 313 & 69 & 622 & 92861 & 96888 & 252731 & 188531 & 9319 & 10234 & 86.51 & $18.18 \%$ & \\
\hline GR-LNB 98 & 9/29/93 & 18:37 & 320 & 77 & 630 & 118547 & 125216 & 306753 & 217802 & 9354 & 10148 & 87.20 & $18.63 \%$ & \\
\hline GR-LNB 99a & 9/30/93 & $5: 32$ & 308 & 73 & 609 & 88275 & 92069 & 256767 & 187077 & 9544 & 10510 & 86.28 & $21.76 \%$ & \\
\hline GR-LNB 99 & 9/30/93 & 13:24 & 323 & 86 & 628 & 116759 & 123327 & 313075 & 218364 & 9414 & 10151 & 87.00 & $18.56 \%$ & \\
\hline GR-LNB 996 & $9 / 30 / 93$ & $2: 27$ & 323 & 90 & 626 & 97960 & 107255 & 283061 & 197604 & 9462 & 10308 & 86.30 & $20.62 \%$ & \\
\hline LNB-OFA & $9 / 30 / 93$ & $2: 27$ & 312 & 88 & 583 & 76313 & 83239 & 205945 & 168982 & 10133 & 11511 & 86.16 & $3.92 \%$ & \\
\hline GR-LNB 100a & $10 / 1 / 93$ & $11: 00$ & 309 & 70 & 617 & 81763 & 89706 & 247973 & 181919 & 9540 & 10562 & 86.00 & $22.78 \%$ & \\
\hline GR-LNB 100 & $10 / 1 / 93$ & $9: 12$ & 316 & 77 & 625 & 98068 & 110264 & 271831 & 196599 & 9292 & 10104 & 86.65 & $20.78 \%$ & \\
\hline GR-LNB 101 & $10 / 2 / 93$ & $24: 00$ & 312 & 69 & 625 & 96512 & 106063 & 275524 & 196058 & 9323 & 10162 & 86.63 & $20.54 \%$ & \\
\hline GR-LNB 102 & $10 / 3 / 93$ & $24: 00$ & 316 & 78 & 625 & 92146 & 98804 & 267998 & 192393 & 9372 & 10264 & 86.30 & $20.99 \%$ & \\
\hline GA-LNB 103 & $10 / 4 / 93$ & $24: 00$ & 319 & 81 & 630 & 96999 & 102332 & 275709 & 198625 & 9339 & 10156 & 86.44 & $21.31 \%$ & \\
\hline GP-LNB 104 & $10 / 5 / 93$ & $24: 00$ & 320 & 83 & 630 & 97825 & 102543 & 284706 & 202754 & 9378 & 10197 & 86.33 & $20.77 \%$ & \\
\hline GR-LNB 105 & $10 / 6 / 93$ & $10: 15$ & 319 & 75 & 632 & 112323 & 116453 & 310244 & 216460 & 9327 & 10131 & 86.81 & $18.81 \%$ & \\
\hline GR-LNB 106 & $10 / 8 / 93$ & $8: 45$ & 298 & 54 & 622 & 117155 & 135993 & 297606 & 215108 & 9297 & 10093 & 87.89 & $19.10 \%$ & \\
\hline GR-LNB 107 & $10 / 9 / 93$ & 24:00 & 294 & 48 & 623 & 117345 & 133682 & 313617 & 218954 & 9238 & 10032 & 87.71 & $17.93 \%$ & \\
\hline
\end{tabular}


Cherokee Unlt 3, Average Test [

Pre Modiflcation

\begin{tabular}{|c|c|c|c|c|c|c|c|c|c|c|c|c|c|c|}
\hline 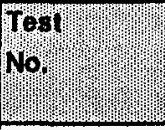 & Date & pur & 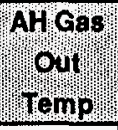 & AH Air & Ä & Calc Coal & Msd Cos/ & çalc Tair & Msdraty & $\begin{array}{l}\text { חreat } \\
\text { Wpate } \\
\text { Gross }\end{array}$ & "reat" & Boiler & OFA & Carbon \\
\hline GR-LNB 108 & $10 / 10 / 93$ & $11: 00$ & 302 & 51 & 625 & 118041 & 128091 & 316616 & 219289 & 9248 & 10038 & 87.46 & $17.78 \%$ & \\
\hline GR.LNB 109a & $10 / 13 / 93$ & $4: 07$ & 311 & 75 & 621 & 115981 & 129226 & 313634 & 217498 & 9411 & 10197 & 87.38 & $19.87 \%$ & \\
\hline GR-LNB $109 b$ & $10 / 13 / 93$ & $2: 02$ & 305 & 70 & 615 & 98246 & 106626 & 274169 & 195799 & 9436 & 10346 & 86.95 & $21.55 \%$ & \\
\hline GR-LNB 110a & $10 / 14 / 93$ & 6.02 & 307 & 65 & 627 & 102633 & 115612 & 286453 & 205061 & 9253 & 10091 & 87.00 & $20.93 \%$ & \\
\hline GR-LNB 110 & $10 / 14 / 93$ & $14: 56$ & 312 & 69 & 632 & 111767 & 129883 & 306409 & 216301 & 9219 & 9984 & 87.23 & $21.89 \%$ & \\
\hline GR-LNB $110 b$ & $10 / 14 / 93$ & $3: 00$ & 306 & 68 & 619 & 90211 & 120374 & 271236 & 193348 & 9444 & 10393 & 86.53 & $23.97 \%$ & \\
\hline GR-LNB 111 & $10 / 15 / 93$ & $12: 49$ & 308 & 63 & 630 & 102263 & 119322 & 283641 & 205285 & 9203 & 9984 & 87.09 & $22.52 \%$ & \\
\hline GR-LNB 3 Mill a & $10 / 15 / 93$ & 2.58 & 295 & 73 & 613 & 110532 & 136622 & 288876 & 213940 & 9302 & 10082 & 87.86 & $22.06 \%$ & \\
\hline GR-LNB 3 Mill b & $10 / 15 / 93$ & $7: 05$ & 297 & 69 & 614 & 104279 & 118149 & 284230 & 209026 & 9380 & 10236 & 87.46 & $21.22 \%$ & \\
\hline GR-LNB 3 Mill $C$ & $10 / 16 / 93$ & 12:05 & 300 & 64 & 617 & 85759 & 97988 & 255616 & 191574 & 9421 & 10512 & 86.50 & $22.85 \%$ & \\
\hline GR-LNB 3 Mill d & $10 / 16 / 93$ & $10 ; 28$ & 313 & 72 & 633 & 118518 & 140119 & 320142 & 224874 & 9359 & 10138 & 87.44 & $21.22 \%$ & \\
\hline GR-LNB 3 Mill $\theta$ & $10 / 16 / 93$ & $1: 25$ & 305 & 66 & 622 & 106901 & 123907 & 290672 & 204794 & 9406 & 10204 & 87.35 & $20.99 \%$ & \\
\hline GR-LNB 3 Mill $f$ & $10 / 17 / 93$ & 23:46 & 286 & 59 & 607 & 99865 & 125496 & 273930 & 203394 & 9258 & 10020 & 87.62 & $22.19 \%$ & \\
\hline LNB-OFA 3 Mill & $10 / 18 / 93$ & 11:10 & 273 & 56 & 589 & 96210 & 118422 & 240654 & 187027 & 9354 & 10303 & 87.93 & $19.70 \%$ & \\
\hline GR-LNB 3 Mill $\mathrm{g}$ & $10 / 19 / 93$ & 15:35 & 286 & 66 & 597 & 97978 & 119772 & 275683 & 204933 & 9456 & 10391 & 87.29 & $21.76 \%$ & \\
\hline GR-LNB 3 Mill $h$ & $10 / 20 / 93$ & $7: 35$ & 280 & 54 & 599 & 98242 & 120293 & 277647 & 204782 & 9386 & 10311 & 87.41 & $21.51 \%$ & \\
\hline GR-LNB 112 & $10 / 20 / 93$ & $4: 09$ & 297 & 52 & 618 & 94572 & 109509 & 272188 & 199263 & 9359 & 10291 & 86.88 & $21.85 \%$ & \\
\hline LNB-OFA & $10 / 20 / 93$ & 0.56 & 299 & 55 & 618 & 121545 & 147347 & 311624 & 224156 & 9314 & 10188 & 87.30 & $17.33 \%$ & \\
\hline GR-LNB 113 & $10 / 20 / 93$ & $10: 42$ & 307 & 58 & 626 & 113856 & 133983 & 314262 & 220076 & 9366 & 10158 & 87.11 & $20.67 \%$ & \\
\hline GR-LNB 113 & $10 / 21 / 93$ & 24.00 & 307 & 63 & 624 & 111346 & 131855 & 306643 & 220403 & 9296 & 10088 & 87.15 & $22.26 \%$ & \\
\hline GR-LNB 114 & $10 / 22 / 93$ & $24: 00$ & 307 & 68 & 622 & 108366 & 130087 & 297819 & 216629 & 9287 & 10095 & 87.11 & $22.71 \%$ & \\
\hline GR-LNB 115 & $10 / 23 / 93$ & $24: 00$ & 305 & 70 & 623 & 112995 & 132397 & 311785 & 221084 & 9313 & 10101 & 87.18 & $21.96 \%$ & \\
\hline GR-LNB 116 & $10 / 24 / 93$ & $14: 00$ & 304 & 66 & 625 & 111670 & 126462 & 306451 & 218947 & 9294 & 10090 & 87.17 & $21.46 \%$ & \\
\hline GR-LNB 116a & $10 / 24 / 93$ & $10: 00$ & 311 & 77 & 627 & 113536 & 130629 & 311704 & 220654 & 9332 & 10118 & 87.03 & $21.85 \%$ & \\
\hline GR-LNB $117 \mathrm{a}$ & $10 / 25 / 93$ & $4: 55$ & 298 & 65 & 610 & 93260 & 103392 & 264784 & 195229 & 9473 & 10453 & 86.68 & $22.14 \%$ & \\
\hline GR.LNB 117 & $10 / 25 / 93$ & $19: 04$ & 301 & 62 & 624 & 111542 & 125820 & 301084 & 218580 & 9221 & 10004 & 87.37 & $21.55 \%$ & \\
\hline GR-LNB 118 & $10 / 26 / 93$ & $24: 00$ & 294 & 54 & 619 & 111142 & 124392 & 295072 & 215759 & 9251 & 10044 & 87.64 & $21.84 \%$ & \\
\hline GR-LNB 119 & $10 / 27 / 93$ & $14: 25$ & 295 & 53 & 622 & 114505 & 127229 & 298178 & 218216 & 9209 & 9977 & 87.72 & $21.65 \%$ & \\
\hline GR-LNB $119 \mathrm{a}$ & $10 / 27 / 93$ & $9: 34$ & 306 & 73 & 623 & 113018 & 125818 & 286643 & 213987 & 9282 & 10062 & 87.52 & $22.08 \%$ & \\
\hline GR-LNB 120a & $10 / 28 / 93$ & $7: 21$ & 304 & 71 & 620 & 108008 & 116546 & 280066 & 208779 & 9356 & 10190 & 87.30 & $21.90 \%$ & \\
\hline GR-LNB 120 & $10 / 28 / 93$ & $16: 38$ & 297 & 57 & 622 & 112702 & 125883 & 288823 & 217868 & 9208 & 9982 & 87.79 & $21.80 \%$ & \\
\hline GR-LNB 121 & $10 / 29 / 93$ & $24: 00$ & 284 & 33 & 621 & 111329 & 127834 & 296779 & 217065 & 9173 & 9951 & 87.95 & $21.33 \%$ & \\
\hline GR-LNB 122 & $10 / 30 / 93$ & $24: 00$ & 288 & 41 & 624 & 114860 & 131394 & 303485 & 221186 & 9203 & 9979 & 87.94 & $21.48 \%$ & \\
\hline GR-LNB 123 & $10 / 31 / 93$ & 24,00 & 297 & 58 & 624 & 113177 & 130201 & 301169 & 219332 & 9236 & 10017 & 87.64 & $21.41 \%$ & \\
\hline GR-LNB 124 & $11 / 1 / 93$ & $6: 18$ & 293 & 50 & 621 & 115166 & 130933 & 294416 & 215363 & 9284 & 10084 & 87.84 & $19.99 \%$ & \\
\hline LNB-OFA & $11 / 1 / 93$ & 1.08 & 281 & 45 & 602 & 106797 & 129293 & 256263 & 200469 & 9423 & 10408 & 88.07 & $16.47 \%$ & \\
\hline GR-LNB 125a & $11 / 2 / 93$ & $8: 15$ & 290 & 47 & 622 & 116997 & 134508 & 281875 & 214569 & 9120 & 9883 & 88.30 & $20.98 \%$ & \\
\hline LNB & $11 / 2 / 93$ & $0: 29$ & 298 & 62 & 622 & 116783 & 139863 & 282619 & 214638 & 9180 & 9950 & 92.33 & $20.74 \%$ & \\
\hline GR-LNB 125 & $11 / 2 / 93$ & $10: 09$ & 298 & 62 & 622 & 116526 & 139622 & 282392 & 214404 & 9177 & 9947 & 88.09 & $20.86 \%$ & \\
\hline GR-LNB 126a & $11 / 4 / 93$ & $1: 40$ & 294 & 50 & 621 & 114620 & 129573 & 268652 & 209490 & 9182 & 9970 & 88.16 & $20.76 \%$ & \\
\hline
\end{tabular}


Cherokee Unit 3, Average Test $\mathrm{C}$

Pre Modification

\begin{tabular}{|c|c|c|c|c|c|c|c|c|c|c|c|c|c|c|}
\hline 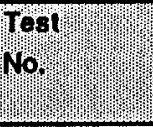 & 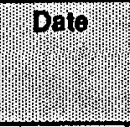 & our & AH cras & 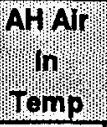 & $\begin{array}{l}\text { AH Air } \\
\text { out } \\
\text { Temp }\end{array}$ & calccoplal & Msdcoal & Calctair & Msd Taly & (feat) & חקeat" & Boffer" & ог & car bon \\
\hline GA-LNB 126 & $11 / 4 / 93$ & 13:29 & 289 & 45 & 617 & 117149 & 129402 & 285562 & 213649 & 9239 & 10029 & 88.22 & $19.65 \%$ & \\
\hline GR-LNB 127a & $11 / 5 / 93$ & $7: 20$ & 281 & 37 & 613 & 111238 & 122209 & 315809 & 208091 & 9404 & 10266 & 87.84 & $16.62 \%$ & \\
\hline GR-LNB 127 & $11 / 5 / 93$ & $5: 54$ & 282 & 39 & 611 & 122263 & 134412 & 307363 & 221892 & 9382 & 10176 & 87.90 & $18.80 \%$ & \\
\hline GR-LNB 128 & $11 / 8 / 93$ & $4: 55$ & 295 & 55 & 622 & 113732 & 130624 & 298782 & 219770 & 9256 & 10034 & 87.81 & $21.27 \%$ & \\
\hline GA-LNB 129 & $11 / 9 / 93$ & $8: 30$ & 298 & 62 & 625 & 116930 & 124003 & 298549 & 222588 & 9277 & 10047 & 87.76 & $21.36 \%$ & 5.15 \\
\hline GR-LNB 129a & $11 / 9 / 93$ & $5: 29$ & 293 & 57 & 617 & 125401 & 128619 & 321398 & 234137 & 9419 & 10201 & 87.93 & $18.50 \%$ & \\
\hline GR-LNB 130 & $11 / 10 / 93$ & $15: 43$ & 293 & 57 & 618 & 120549 & 125906 & 303160 & 225277 & 9323 & 10107 & 87.95 & $19.62 \%$ & $6.69,8.69$ \\
\hline LNB & $11 / 10 / 93$ & $7: 50$ & 300 & 68 & 609 & 136104 & 145758 & 301606 & 243412 & 9462 & 10236 & 88.41 & $0.00 \%$ & 4.41 \\
\hline LNB & $11 / 11 / 93$ & $2: 00$ & 288 & 51 & 599 & 128349 & 135371 & 299460 & 240911 & 9439 & 10249 & 88.25 & $0.00 \%$ & \\
\hline LNB 3 Mill a & $11 / 11 / 93$ & $3: 34$ & 289 & 65 & 593 & 101986 & 112835 & 235266 & 208283 & 9496 & 10431 & 87.92 & $0.00 \%$ & \\
\hline LNB 3 Mill b & $11 / 11 / 93$ & $9: 20$ & 282 & 60 & 587 & 102041 & 112696 & 246076 & 211771 & 9586 & 10595 & 87.86 & $0.00 \%$ & \\
\hline LN8 3 Mill c & $11 / 12 / 93$ & $12: 30$ & 276 & 46 & 588 & 109663 & 114823 & 258292 & 221314 & 9522 & 10469 & 88.09 & $0.00 \%$ & \\
\hline LNB 3 Mill d & $11 / 1293$ & $11: 29$ & 290 & 51 & 603 & 134370 & 155369 & 284489 & 239384 & 9436 & 10202 & 88.88 & $0.00 \%$ & \\
\hline LNB 3 Mill $\theta$ & $11 / 13 / 93$ & $14: 30$ & 289 & 50 & 604 & 131971 & 150696 & 296454 & 241735 & 9443 & 10232 & 88.58 & $0.00 \%$ & \\
\hline LNB 3 Mill $f$ & $11 / 13 / 93$ & $9: 29$ & 289 & 51 & 601 & 134978 & 156313 & 285566 & 238693 & 9430 & 10193 & 88.93 & $0.00 \%$ & \\
\hline LNB 3 Mill & $11 / 14 / 93$ & $24: 00$ & 283 & 41 & 601 & 129746 & 155474 & 280712 & 237224 & 9404 & 10191 & 88.92 & $0.00 \%$ & \\
\hline LNB & $11 / 15 / 93$ & $1: 39$ & 282 & 36 & 608 & 131242 & 159456 & 277134 & 238277 & 9372 & 10140 & 89.10 & $0.00 \%$ & \\
\hline GR-LNB 131 & $11 / 15 / 93$ & $13: 00$ & 284 & 43 & 616 & 112669 & 138420 & 283991 & 224019 & 9254 & 10059 & 88.07 & $22.10 \%$ & \\
\hline GR-LNB 132 & $11 / 16 / 93$ & $7: 42$ & 282 & 41 & 616 & 109648 & 130996 & 272787 & 217597 & 9257 & 10075 & 88.11 & $22.08 \%$ & \\
\hline GR-LNB $132 a$ & $11 / 16 / 93$ & $16: 17$ & 289 & 52 & 612 & 102674 & 123870 & 296917 & 205351 & 9468 & 10382 & 87.07 & $19.94 \%$ & \\
\hline GR-LNB 133 & $11 / 17 / 93$ & $0: 40$ & 282 & 46 & 608 & 100222 & 118692 & 289250 & 203232 & 9447 & 10333 & 87.21 & $20.50 \%$ & \\
\hline LNB & $11 / 17 / 93$ & $8: 40$ & 288 & 44 & 597 & 110962 & 132037 & 275124 & 212695 & 9659 & 10604 & 87.69 & $0.00 \%$ & \\
\hline LNB & $12 / 3 / 93$ & $5: 15$ & 298 & 53 & 613 & 133061 & 144983 & 306408 & 240232 & 9499 & 10311 & 88.28 & $0.00 \%$ & \\
\hline LNB & $12 / 6 / 93$ & $2: 33$ & 300 & 41 & 599 & 99047 & 114617 & 229904 & 201062 & 9775 & 10911 & 87.35 & $0.00 \%$ & \\
\hline LNB & $12 / 6 / 93$ & 3.00 & 291 & 43 & 605 & 138996 & 156760 & 317723 & 247314 & 9506 & 10323 & 88.23 & $0.00 \%$ & \\
\hline LNB & $12 / 6 / 93$ & $1: 55$ & 292 & 47 & 606 & 139695 & 160134 & 325883 & 251332 & 9517 & 10332 & 88.11 & $0.00 \%$ & \\
\hline LNB & $12 / 7 / 93$ & $6: 45$ & 299 & 58 & 607 & 141062 & 157127 & 327194 & 249915 & 9580 & 10396 & 88.42 & $0.00 \%$ & \\
\hline LNB & $12 / 8 / 93$ & $4: 03$ & 303 & 60 & 616 & 140531 & 158838 & 337084 & 255401 & 9497 & 10306 & 88.09 & $0.00 \%$ & \\
\hline GR-LNB 134 & $12 / 8 / 93$ & $3: 40$ & 304 & 72 & 620 & 119433 & 138275 & 310189 & 221915 & 9485 & 10300 & 87.84 & $21.51 \%$ & \\
\hline GR-LNB 134a & $12 / 8 / 93$ & $0: 46$ & 304 & 71 & 615 & 133141 & 153853 & 314035 & 230147 & 9524 & 10356 & 88.24 & $12.74 \%$ & \\
\hline GR-LNB 134b & $12 / 8 / 93$ & $2: 44$ & 303 & 71 & 616 & 133004 & 155466 & 297357 & 225616 & 9424 & 10233 & 88.54 & $13.47 \%$ & \\
\hline GR-LNB $134 c$ & $12 / 8 / 93$ & $3: 31$ & 306 & 66 & 628 & 132393 & 155085 & 286586 & 223579 & 9246 & 10025 & 88.56 & $14.00 \%$ & \\
\hline GR-LNB 135 & $12 / 9 / 93$ & $12: 00$ & 304 & 61 & 624 & 122705 & 140171 & 270912 & 214665 & 9242 & 10040 & 88.33 & $14.46 \%$ & \\
\hline GR-LNB 135a & $12 / 9 / 93$ & 2.59 & 310 & 70 & 635 & 128403 & 150762 & 298901 & 225977 & 9249 & 10051 & 88.08 & $13.38 \%$ & \\
\hline GR-LNB 135b & $12 / 9 / 93$ & $7: 10$ & 299 & 64 & 614 & 120972 & 138699 & 305484 & 224404 & 9577 & 10531 & 87.83 & $12.74 \%$ & \\
\hline GR-LNB 136 & $12 / 10 / 93$ & $11: 35$ & 296 & 61 & 613 & 125344 & 140522 & 310645 & 227625 & 9500 & 10389 & 88.06 & $12.48 \%$ & \\
\hline GR-LNB 137 & $12 / 11 / 93$ & $16: 15$ & 297 & 58 & 618 & 119739 & 131712 & 286350 & 216505 & 9398 & 10294 & 87.94 & $13.27 \%$ & \\
\hline GR-LNB 137a & $12 / 11 / 93$ & $7: 44$ & 298 & 60 & 618 & 134330 & 153111 & 318604 & 233215 & 9420 & 10242 & 88.13 & $12.56 \%$ & \\
\hline GR-LNB 138 & $12 / 12 / 93$ & $24: 00$ & 298 & 59 & 620 & 134660 & 156753 & 316683 & 232940 & 9436 & 10253 & 88.13 & $12.63 \%$ & \\
\hline GR-LNB 139 & $12 / 13 / 93$ & $7: 48$ & 291 & 47 & 617 & 135122 & 154517 & 310301 & 228791 & 9325 & 10118 & 88.48 & $12.91 \%$ & \\
\hline
\end{tabular}


Cherokee Unlt 3, Average Test [

Pre Modification

\begin{tabular}{|c|c|c|c|c|c|c|c|c|c|c|c|c|c|c|}
\hline Tesp & 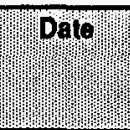 & purn & 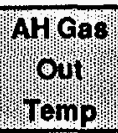 & 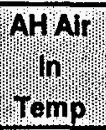 & 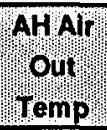 & Calc coall & Msd Coal: & Calct TAir & Msdraty & 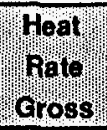 & $\begin{array}{l}\text { Treat } \\
\text { Tratec } \\
\text { Nej }\end{array}$ & Boffer & POFA & Carbon \\
\hline GR-LNB 139a & $12 / 13 / 93$ & $4: 18$ & 291 & 47 & 617 & 134009 & 155833 & 316307 & 227653 & 9331 & 10132 & 88.39 & $12.66 \%$ & \\
\hline LNB & $12 / 13 / 93$ & $5: 18$ & 293 & 53 & 610 & 133870 & 161547 & 313051 & 243245 & 9416 & 10251 & 88.31 & $0.00 \%$ & \\
\hline LNB-OFA & $12 / 14 / 93$ & $1: 55$ & 292 & 52 & 614 & 141974 & 164709 & 345848 & 230943 & 9439 & 10291 & 88.17 & $14.85 \%$ & \\
\hline GR-LNB 140 & $12 / 14 / 93$ & $1: 18$ & 300 & 63 & 615 & 135497 & 161124 & 323814 & 230530 & 9389 & 10201 & 88.19 & $12.29 \%$ & \\
\hline LNB & $12 / 14 / 93$ & $8: 30$ & 300 & 55 & 613 & 139333 & 160556 & 310898 & 239735 & 9459 & 10273 & 88.44 & $0.00 \%$ & \\
\hline LNB & $12 / 15 / 93$ & $9: 28$ & 290 & 40 & 606 & 137698 & 157104 & 317610 & 244378 & 9457 & 10285 & 88.42 & $0.00 \%$ & \\
\hline LNB-OFA & $12 / 15 / 93$ & $5: 29$ & 286 & 43 & 607 & 139287 & 156081 & 327352 & 240166 & 9466 & 10318 & 88.43 & $8.28 \%$ & \\
\hline GR-LNB 141 & $12 / 15 / 93$ & $5: 15$ & 290 & 43 & 612 & 119469 & 136657 & 282099 & 213125 & 9526 & 10513 & 88.07 & $13.79 \%$ & \\
\hline LNB & $12 / 15 / 93$ & $2: 50$ & 284 & 40 & 591 & 86246 & 98420 & 216323 & 199225 & 9842 & 11400 & 86.96 & $0.00 \%$ & \\
\hline LNB & $12 / 16 / 93$ & $15: 05$ & 283 & 37 & 601 & 132676 & 147937 & 310580 & 242540 & 9392 & 10233 & 88.40 & $0.00 \%$ & \\
\hline GR-LNB 142 & $12 / 16 / 93$ & $6: 14$ & 284 & 37 & 613 & 135161 & 161828 & 330708 & 236507 & 9357 & 10181 & 88.39 & $12.17 \%$ & \\
\hline GR-LNB 142a & $12 / 16 / 93$ & $1: 15$ & 290 & 40 & 609 & 94213 & 107402 & 238760 & 179796 & 9570 & 10616 & 87.46 & $15.67 \%$ & \\
\hline GR-LNB 143 & $12 / 17 / 93$ & $2: 10$ & 287 & 39 & 605 & 91390 & 106748 & 237891 & 182796 & 9509 & 10553 & 87.32 & $15.66 \%$ & \\
\hline LNB-OFA & $12 / 17 / 93$ & $0: 40$ & 296 & 41 & 587 & 55318 & 58055 & 173521 & 121691 & 10676 & 13015 & 85.04 & $20.70 \%$ & \\
\hline LNB & $12 / 17 / 93$ & $6: 10$ & 286 & 38 & 605 & 136809 & 162222 & 314239 & 243507 & 9267 & 10043 & 88.54 & $0.00 \%$ & \\
\hline LNB & $12 / 20 / 93$ & $2: 25$ & 289 & 35 & 614 & 121446 & 121607 & 291998 & 233768 & 9323 & 10200 & 87.84 & $0.00 \%$ & \\
\hline $100 \%$ Gas Firing & $12 / 20 / 93$ & $0: 34$ & 269 & 39 & 579 & 80058 & 51 & 211676 & 208245 & 9671 & 10827 & 84.48 & $0.00 \%$ & \\
\hline LNB & $12 / 22 / 93$ & $2: 35$ & 290 & 44 & 613 & 113294 & 135333 & 278646 & 226092 & 9393 & 10249 & 87.67 & $0.00 \%$ & \\
\hline LNB & $1 / 5 / 94$ & $2: 24$ & 300 & 68 & 609 & 135271 & 147520 & 305738 & 243031 & 9354 & 10116 & 88.29 & $0.00 \%$ & \\
\hline LNB-OFA & $1 / 5 / 94$ & $2: 26$ & 300 & 67 & 614 & 135407 & 148526 & 314930 & 240631 & 9404 & 10213 & 88.17 & $3.56 \%$ & \\
\hline LNB-OFA & $1 / 5 / 94$ & $9: 15$ & 295 & 54 & 610 & 119495 & 131794 & 277569 & 218178 & 9419 & 10316 & 88.03 & $2.08 \%$ & \\
\hline LNB-OFA & $1 / 6 / 94$ & $8: 47$ & 301 & 49 & 609 & 93312 & 103863 & 221133 & 184621 & 9716 & 10854 & 87.32 & $2.33 \%$ & \\
\hline LNB & $1 / 6 / 94$ & $15: 12$ & 298 & 43 & 616 & 133673 & 150891 & 298747 & 237896 & 9273 & 10030 & 88.34 & $0.00 \%$ & \\
\hline LNB & $1 / 7 / 94$ & 6.55 & 294 & 30 & 605 & 110162 & 119364 & 250528 & 209883 & 9431 & 10333 & 88.03 & $0.00 \%$ & \\
\hline LNB-OFA & $1 / 7 / 94$ & $1: 09$ & 291 & 36 & 613 & 113386 & 120699 & 264088 & 204185 & 9342 & 10249 & 87.99 & $11.43 \%$ & \\
\hline GR-LNB 144 & $1 / 7 / 94$ & $15: 40$ & 299 & 53 & 622 & 121635 & 138358 & 291560 & 220257 & 9221 & 10025 & 87.86 & $13.70 \%$ & \\
\hline GR-LNB 145a & $1 / 8 / 94$ & $8: 20$ & 302 & 51 & 623 & 107935 & 122836 & 257051 & 199257 & 9195 & 10079 & 87.61 & $15.10 \%$ & \\
\hline GR-LNB 145 & $1 / 8 / 94$ & $15: 39$ & 304 & 51 & 632 & 125471 & 146527 & 288542 & 220472 & 9109 & 9878 & 88.00 & $13.88 \%$ & \\
\hline GA-LNB 146a & $1 / 9 / 94$ & $2: 10$ & 297 & 42 & 622 & 120661 & 140531 & 271657 & 213181 & 8987 & 9757 & 88.12 & $14.69 \%$ & \\
\hline GR-LNB 146b & $1 / 9 / 94$ & $8: 39$ & 305 & 44 & 634 & 98416 & 111365 & 234644 & 189715 & 9153 & 10104 & 87.31 & $16.20 \%$ & \\
\hline GR-LNB 146 & $1 / 9 / 94$ & $9: 02$ & 300 & 51 & 627 & 117435 & 138971 & 283261 & 216733 & 9162 & 9983 & 87.68 & $14.07 \%$ & \\
\hline LNB & $1 / 9 / 94$ & $3: 35$ & 295 & 48 & 608 & 108271 & 123120 & 248750 & 201739 & 9544 & 10548 & 87.80 & $0.02 \%$ & \\
\hline LNB & $1 / 10 / 94$ & $3: 50$ & 298 & 46 & 621 & 119039 & 137666 & 280676 & 216822 & 9286 & 10127 & 87.90 & $0.01 \%$ & \\
\hline GR-LNB 147 & $1 / 10 / 94$ & $2: 40$ & 303 & 54 & 631 & 134381 & 155998 & 331291 & 233086 & 9298 & 10073 & 87.96 & $12.08 \%$ & \\
\hline GR-LNB $147 a$ & $1 / 10 / 94$ & $4: 04$ & 299 & 53 & 613 & 105585 & 121044 & 278133 & 200523 & 9447 & 10421 & 87.29 & $14.70 \%$ & \\
\hline GR-LNB $147 b$ & $1 / 10 / 94$ & $4: 54$ & 295 & 47 & 614 & 106168 & 120307 & 281723 & 204128 & 9428 & 10388 & 87.35 & $14.45 \%$ & \\
\hline GR-LNB 148a & $1 / 11 / 94$ & $6: 32$ & 291 & 42 & 615 & 93894 & 107394 & 258805 & 194218 & 9431 & 10535 & 87.00 & $15.42 \%$ & \\
\hline GR-LNB 148 & $1 / 11 / 94$ & $14: 38$ & 298 & 55 & 618 & 130318 & 143563 & 322907 & 234355 & 9400 & 10205 & 87.96 & $13.59 \%$ & \\
\hline GR-LNB 1486 & $1 / 11 / 94$ & $2: 48$ & 295 & 55 & 605 & 108570 & 112420 & 270954 & 203986 & 9550 & 10520 & 87.63 & $14.72 \%$ & \\
\hline GR-LNB 149a & $1 / 12 / 94$ & $6: 14$ & 294 & 48 & 619 & 114624 & 122689 & 286050 & 216406 & 9312 & 10190 & 87.75 & $14.11 \%$ & \\
\hline
\end{tabular}


Cherokee Unit 3, Average Test C

Pre Modification

\begin{tabular}{|c|c|c|c|c|c|c|c|c|c|c|c|c|c|c|}
\hline 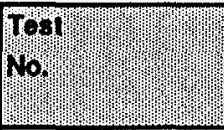 & 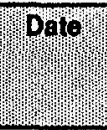 & Duwn & 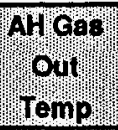 & 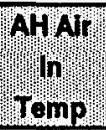 & AH Air & calcospl & 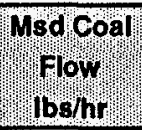 & Calctaly & 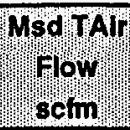 & 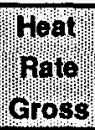 & 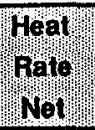 & Eopler & 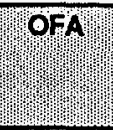 & Carbon \\
\hline GR-LNB 149 & $1 / 12 / 94$ & $13: 30$ & 296 & 52 & 619 & 122024 & 132348 & 301048 & 224520 & 9317 & 10155 & 87.84 & $13.83 \%$ & \\
\hline GR-LNB A Mill off & $1 / 12 / 94$ & 1.09 & 298 & 53 & 625 & 110619 & 125459 & 271576 & 214568 & 9167 & 10028 & 87.63 & $14.95 \%$ & \\
\hline GR-LNB D Mill off & $1 / 12 / 94$ & $1: 39$ & 295 & 54 & 623 & 111431 & 124105 & 267114 & 211571 & 9081 & 9883 & 87.90 & $17.75 \%$ & \\
\hline GR-LNB D Mill off line & $1 / 13 / 94$ & $4: 23$ & 296 & 55 & 612 & 90176 & 96301 & 219087 & 181847 & 9270 & 10206 & 87.41 & $18.15 \%$ & \\
\hline GR-LNB 150 & $1 / 13 / 94$ & $7: 15$ & 307 & 59 & 632 & 128758 & 142794 & 309661 & 229501 & 9196 & 9974 & 87.85 & $14.16 \%$ & \\
\hline GR-LNB D Mill off line & $1 / 13 / 94$ & $1: 13$ & 298 & 60 & 625 & 111747 & 129950 & 268350 & 212931 & 9013 & 9815 & 87.83 & $17.53 \%$ & \\
\hline GR-LNB 150a & $1 / 13 / 94$ & $6: 00$ & 303 & 59 & 624 & 115289 & 126753 & 285904 & 213233 & 9351 & 10241 & 87.56 & $14.68 \%$ & \\
\hline GR-LNB 151a & $1 / 14 / 94$ & $7: 25$ & 301 & 59 & 610 & 93341 & 97495 & 242118 & 186662 & 9590 & 10693 & 87.02 & $16.13 \%$ & \\
\hline GR-LNB, ABC & $1 / 14 / 94$ & $7: 50$ & 296 & 64 & 616 & 110912 & 122235 & 268284 & 212467 & 9120 & 9874 & 87.84 & $14.91 \%$ & \\
\hline GR-LNB 151 & $1 / 14 / 94$ & $7: 54$ & 304 & 62 & 626 & 112463 & 119481 & 272095 & 210589 & 9214 & 10079 & 87.67 & $14.80 \%$ & \\
\hline GR-LNB 156 & $1 / 19 / 94$ & $24: 00$ & 302 & 63 & 615 & 100531 & 106606 & 250306 & 195405 & 9416 & 10396 & 87.41 & $15.90 \%$ & \\
\hline GR-LNB 157a & $1 / 20 / 94$ & $6: 38$ & 291 & 38 & 619 & 95851 & 100031 & 233990 & 188348 & 9264 & 10191 & 87.70 & $16.84 \%$ & \\
\hline GR-LNB 157 & $1 / 20 / 94$ & $3: 50$ & 294 & 38 & 633 & 119466 & 127123 & 286592 & 217610 & 9067 & 9858 & 88.04 & $15.64 \%$ & \\
\hline
\end{tabular}




\section{APPENDIX C}

Second Generation Gas Reburning Test Data 
Post Modification

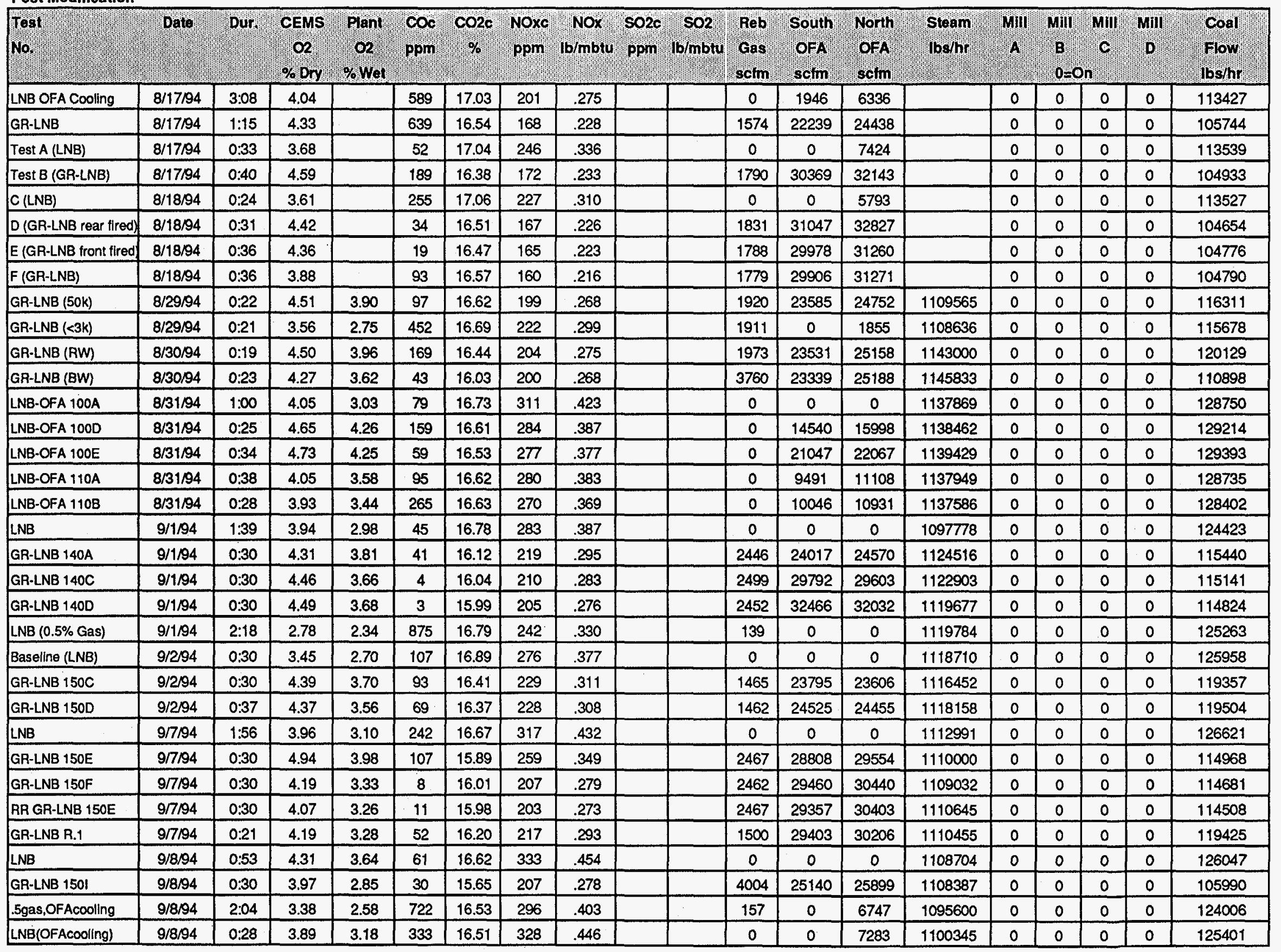


Post Modification

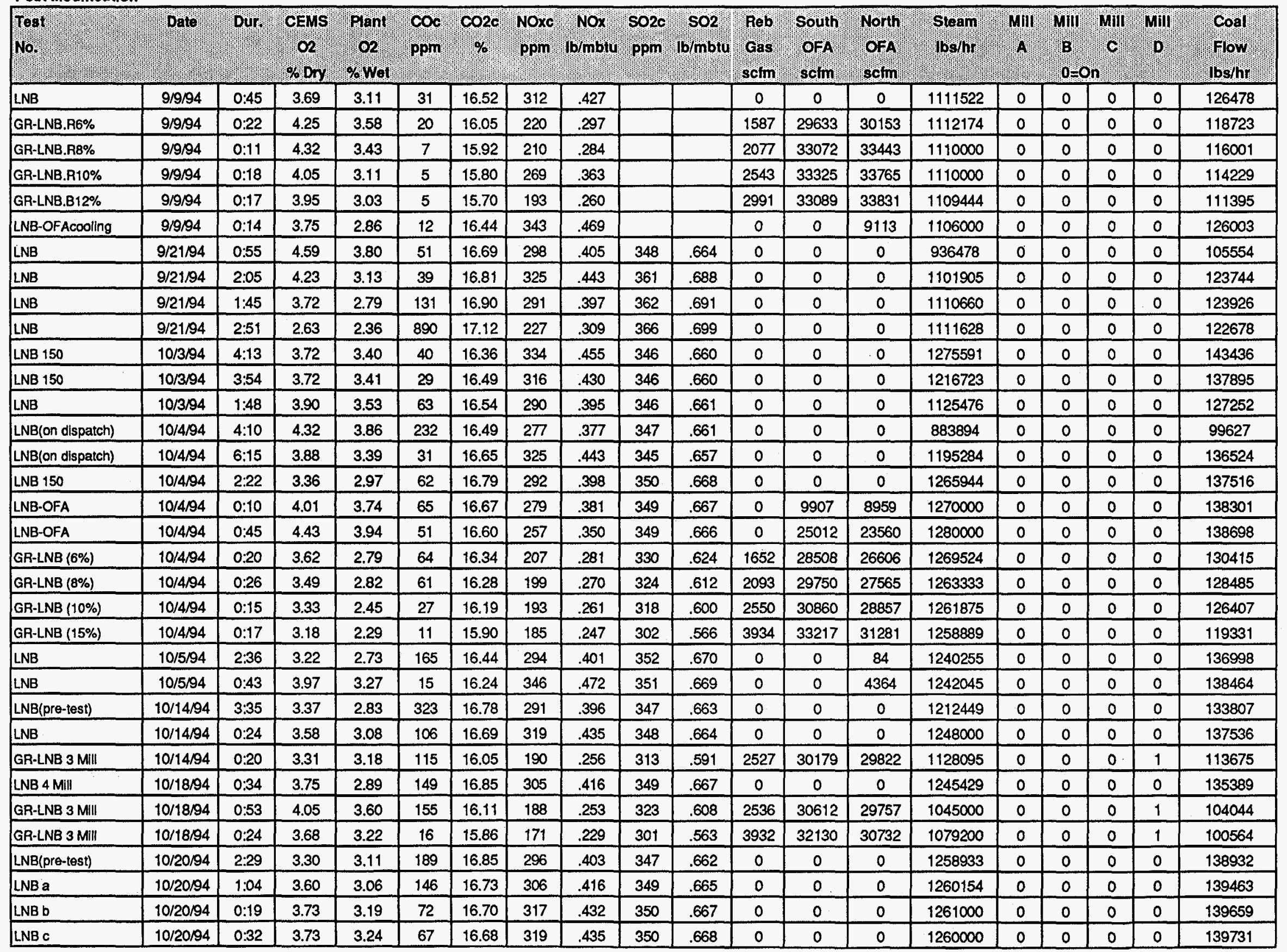


Post Modification

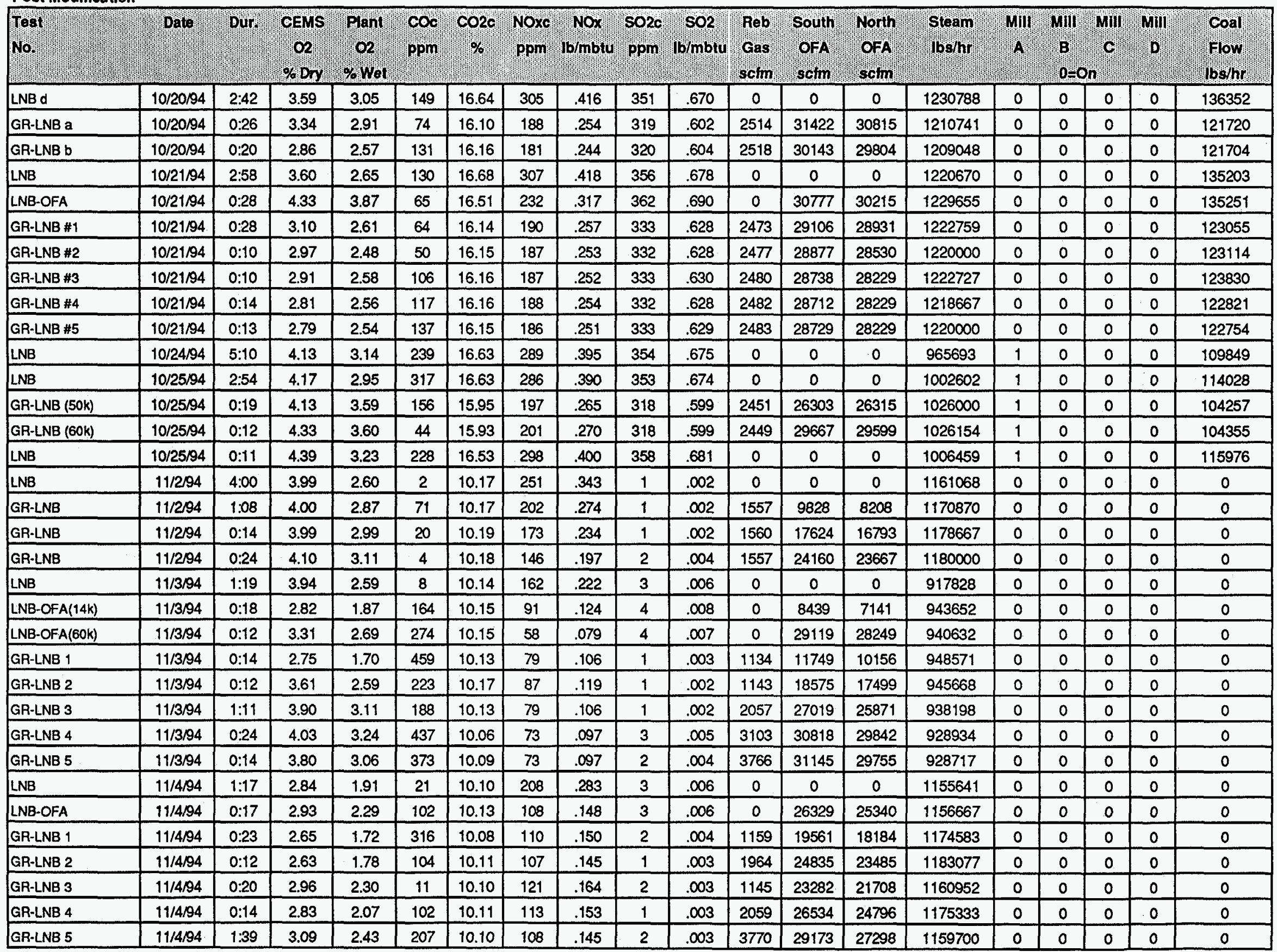


Post Modification

\begin{tabular}{|c|c|c|c|c|c|c|c|c|c|c|c|c|c|c|c|c|c|c|c|}
\hline rest & Wpaten & Durm & CEMs! & Whant) & poc & con & 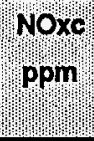 & 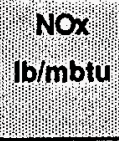 & 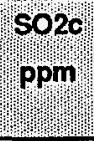 & 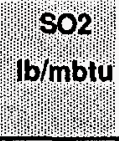 & $\begin{array}{l}\text { heb } \\
\text { Gas" } \\
\text { scim }\end{array}$ & 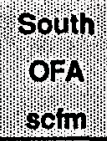 & Worth & 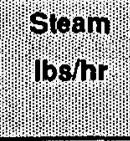 & maim & $\prod_{\text {Bum }}$ & min & Min & 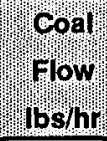 \\
\hline LNB & $11 / 7 / 94$ & $1: 43$ & 2.83 & 1.98 & 30 & 10.08 & 164 & .225 & 3 & .005 & 0 & 0 & 0 & 910874 & 0 & 0 & 0 & 0 & 0 \\
\hline GR-LNB & $11 / 7 / 94$ & 0.24 & 2.95 & 2.24 & 460 & 9.98 & 74 & .100 & 3 & .007 & 1142 & 22705 & 23423 & 917025 & 0 & 0 & 0 & 0 & 0 \\
\hline GR-LNB & $11 / 7 / 94$ & $1: 35$ & 3.09 & 2.29 & 120 & 10.07 & 86 & .117 & 2 & .004 & 2004 & 21657 & 22539 & 930763 & 0 & 0 & 0 & 0 & 0 \\
\hline LNB (D out) & $11 / 7 / 94$ & $0: 15$ & 3.31 & 2.31 & 303 & 10.01 & 122 & .166 & 2 & .003 & 125 & 0 & 2408 & 908066 & 0 & 0 & 0 & 0 & 0 \\
\hline GR-LNB & $11 / 7 / 94$ & $0: 16$ & 4.59 & 3.25 & 1 & 10.06 & 98 & .134 & 1 & .003 & 1127 & 22552 & 24025 & 939974 & 0 & 0 & 0 & 0 & 0 \\
\hline GR-LNB & $11 / 7 / 94$ & $0: 12$ & 3.98 & 2.67 & 80 & 10.08 & 82 & .110 & 1 & .002 & 1915 & 22253 & 23554 & 935959 & 0 & 0 & 0 & 0 & 0 \\
\hline LNB & $11 / 8 / 94$ & $1: 03$ & 2.69 & 1.71 & 85 & 10.09 & 147 & .201 & 1 & .002 & 0 & 0 & 0 & 917594 & 0 & 0 & 0 & 0 & 0 \\
\hline GR-LNB(varied OFA) & $11 / 8 / 94$ & $0: 33$ & 2.80 & 1.74 & 263 & 10.08 & 75 & .102 & 1 & .002 & 1434 & 20196 & 18670 & 927040 & 0 & 0 & 0 & 0 & 0 \\
\hline GR-LNB(OFA op) & $11 / 8 / 94$ & 2.55 & 3.03 & 2.05 & 110 & 10.09 & 80 & .108 & 1 & .002 & 1414 & 20546 & 19077 & 930000 & 0 & 0 & 0 & 0 & 0 \\
\hline GR-LNB(D@80\%) & $11 / 8 / 94$ & $0: 40$ & 3.10 & 2.24 & 276 & 10.08 & 75 & .102 & 0 & .001 & 1472 & 21108 & 19077 & 925250 & 0 & 0 & 0 & 0 & 0 \\
\hline LNB 1 & $11 / 9 / 94$ & $0: 18$ & 2.85 & 1.64 & 12 & 10.12 & 150 & .205 & 1 & .003 & 0 & 0 & 0 & 909096 & 0 & 0 & 0 & 0 & 0 \\
\hline GR-LNB 1 & $11 / 9 / 94$ & $3: 29$ & 3.39 & 2.80 & 297 & 10.06 & 80 & .108 & 2 & .003 & 1878 & 21406 & 18873 & 949455 & 0 & 0 & 0 & 0 & 0 \\
\hline GR-LNB 2 & $11 / 9 / 94$ & $0: 39$ & 3.00 & 2.23 & 170 & 10.06 & 74 & .100 & 1 & .002 & 1774 & 20218 & 18298 & 952800 & 0 & 0 & 0 & 0 & 0 \\
\hline GR-LNB 3 & $11 / 9 / 94$ & $0: 32$ & 3.18 & 2.44 & 12 & 10.06 & 108 & .145 & 1 & .002 & 1985 & 21405 & 19871 & 1084528 & 0 & 0 & 0 & 0 & 0 \\
\hline GR-LNB 4 & $11 / 9 / 94$ & $5: 31$ & 3.25 & 2.36 & 32 & 10.07 & 126 & .170 & 1 & .001 & 2060 & 22741 & 21369 & 1179970 & 0 & 0 & 0 & 0 & 0 \\
\hline GR-LNB 5 & $11 / 9 / 94$ & $0: 31$ & 4.01 & 2.88 & 52 & 9.93 & 100 & .136 & 0 & .000 & 1947 & 21053 & 18797 & 979889 & 0 & 0 & 0 & 0 & 0 \\
\hline LNB 2 & $11 / 9 / 94$ & $0: 45$ & 4.05 & 2.58 & 21 & 10.08 & 73 & .099 & 0 & .001 & 207 & 0 & 0 & 727470 & 0 & 0 & 0 & 0 & 0 \\
\hline GR-LNB 6 & $11 / 9 / 94$ & $0: 15$ & 3.89 & 3.01 & 318 & 10.04 & 46 & .062 & 1 & .001 & 1103 & 20306 & 17627 & 752259 & 0 & 0 & 0 & 0 & 0 \\
\hline GR-LNB 7 & $11 / 9 / 94$ & $0: 11$ & 3.33 & 2.75 & 399 & 10.02 & 43 & .057 & 0 & .000 & 1811 & 23037 & 20875 & 756596 & 0 & 0 & 0 & 0 & 0 \\
\hline GR-LNB 8 & $11 / 9 / 94$ & $0: 16$ & 4.22 & 3.40 & 69 & 10.08 & 49 & .067 & 1 & .001 & 1329 & 19425 & 16673 & 746665 & 0 & 0 & 0 & 0 & 0 \\
\hline $\operatorname{LNB}(120)$ & $11 / 10 / 94$ & $1: 15$ & 4.14 & 2.99 & 54 & 10.09 & 169 & .231 & 1 & .002 & 0 & 0 & 0 & 922657 & 0 & 0 & 0 & 0 & 0 \\
\hline $\operatorname{LNB}(150)$ & $11 / 10 / 94$ & $0: 27$ & 3.06 & 2.13 & 2 & 10.16 & 223 & .304 & 1 & .002 & 0 & 0 & 0 & 1151786 & 0 & 0 & 0 & 0 & 0 \\
\hline GR-LNB(43k) & $11 / 10 / 94$ & $0: 48$ & 3.11 & 2.06 & 174 & 10.13 & 129 & .174 & 1 & .001 & 2030 & 22647 & 20473 & 1160000 & 0 & 0 & 0 & 0 & 0 \\
\hline GR-LNB(46K) & $11 / 10 / 94$ & $1: 42$ & 3.06 & 1.84 & 161 & 10.08 & 118 & .159 & 0 & .000 & 2059 & 23997 & 22442 & 1164175 & 0 & 0 & 0 & 0 & 0 \\
\hline GR-LNB(53K) & $11 / 10 / 94$ & $1: 29$ & 3.26 & 2.26 & 66 & 10.07 & 116 & .157 & 0 & .000 & 2058 & 27089 & 25747 & 1157111 & 0 & 0 & 0 & 0 & 0 \\
\hline GR-LNB(61k) & $11 / 10 / 94$ & $9: 45$ & 3.52 & 2.55 & 23 & 10.10 & 113 & .152 & 0 & .000 & 2073 & 31630 & 29746 & 1160909 & 0 & 0 & 0 & 0 & 0 \\
\hline GR-LNB & $11 / 11 / 94$ & $9: 12$ & 3.66 & 2.65 & 13 & 10.09 & 115 & .155 & 0 & .000 & 2086 & 31757 & 29780 & 1159440 & 0 & 0 & 0 & 0 & 0 \\
\hline \multicolumn{20}{|c|}{$100 \%$ Gas Testing 11/2/94-11/1 1/94 (SR's calculated with Inner+Outer Total OFA) } \\
\hline LNB(coal/gas) & $12 / 1 / 94$ & $2: 41$ & 3.33 & 2.65 & 34 & 14.05 & 312 & .425 & 246 & .468 & 0 & 0 & 0 & 1280432 & gas & 0 & 0 & 0 & 140338 \\
\hline Test 21 & $1 / 19 / 95$ & $1: 00$ & 3.92 & 3.21 & 12 & 15.87 & 193 & .260 & 375 & .705 & 2808 & 30405 & 29755 & 1042295 & 0 & 0 & 0 & 0 & 105086 \\
\hline Test 22 & $1 / 19 / 95$ & $1: 02$ & 3.99 & 3.50 & 12 & 16.09 & 199 & .269 & 387 & .732 & 1832 & 30365 & 30264 & 1046032 & 0 & 0 & 0 & 0 & 110163 \\
\hline Test 24 & $1 / 19 / 95$ & 0.33 & 5.23 & 4.69 & 79 & 16.45 & 251 & .342 & 419 & .800 & 0 & 0 & 0 & 755388 & 0 & 0 & 0 & 0 & 89094 \\
\hline Test 25 & $1 / 19 / 95$ & $0: 30$ & 5.51 & 5.14 & 36 & 16.39 & 224 & .306 & 414 & .790 & 0 & 11022 & 8335 & 768385 & 0 & 0 & 0 & 0 & 90321 \\
\hline Test 27 & $1 / 19 / 95$ & $0: 25$ & 5.16 & 4.72 & 17 & 16.50 & 199 & .272 & 413 & .787 & 0 & 24346 & 22096 & 769978 & 0 & 0 & 0 & 0 & 89995 \\
\hline
\end{tabular}


Post Modification

\begin{tabular}{|c|c|c|c|c|c|c|c|c|c|c|c|c|c|c|c|c|c|c|c|}
\hline rest & Daty ty & pon & CEMS & plant & coct & Co2c & poxc & & porc & 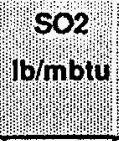 & Reb & South & $\begin{array}{l}\text { worth } \\
\text { of } \\
\text { sctm }\end{array}$ & Steam & mam & Min & miil & $\mathrm{Min}^{\mathrm{min}}$ & 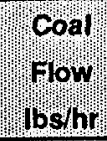 \\
\hline Test 30 & $1 / 20 / 95$ & 1.01 & 5.36 & 4.97 & 16 & 15.57 & 187 & .253 & 376 & .710 & 1362 & 27206 & 26552 & 768234 & 0 & 0 & 0 & 0 & 82063 \\
\hline Test 31 & $1 / 20 / 95$ & $1: 00$ & 5.16 & 4.94 & 13 & 15.06 & 207 & .277 & 336 & .630 & 2721 & 29036 & 28907 & 761751 & 0 & 0 & 0 & 0 & 75428 \\
\hline Test 32 & $1 / 20 / 95$ & 1.05 & 5.27 & 5.03 & 13 & 15.29 & 184 & .247 & 342 & .643 & 2027 & 28990 & 28992 & 760789 & 0 & 0 & 0 & 0 & 79161 \\
\hline Test 33 & $1 / 20 / 95$ & $0: 40$ & 5.19 & 5.06 & 16 & 15.56 & 171 & .232 & 352 & .664 & 1340 & 29029 & 29008 & 762120 & 0 & 0 & 0 & 0 & 82664 \\
\hline Test 1(R) & $1 / 24 / 95$ & $1: 00$ & 4.59 & 3.73 & 73 & 16.49 & 438 & .598 & 348 & .664 & 0 & 0 & 0 & 1168197 & 0 & 0 & 0 & 0 & 131893 \\
\hline Test 16 & $1 / 25 / 95$ & $0: 20$ & 3.49 & 2.80 & 22 & 15.85 & 224 & .301 & 308 & .579 & 2968 & 31572 & 29701 & 1170000 & 0 & 0 & 0 & 0 & 116109 \\
\hline Test 17 & $1 / 25 / 95$ & $0: 40$ & 3.64 & 3.11 & 18 & 16.07 & 229 & .308 & 319 & .602 & 1997 & 31584 & 29695 & 1171905 & 0 & 0 & 0 & 0 & 121061 \\
\hline Test 403 Mill & $1 / 25 / 95$ & $1: 00$ & 3.50 & 3.26 & 45 & 16.09 & 170 & .230 & 321 & .606 & 1750 & 23197 & 23341 & 1075574 & 0 & 0 & 0 & 0 & 109660 \\
\hline Test 413 Mill & $1 / 25 / 95$ & 1.00 & 4.04 & 3.74 & 40 & 15.47 & 168 & .225 & 291 & .546 & 3616 & 31902 & 32044 & 1069016 & 0 & 0 & 0 & 0 & 101488 \\
\hline Test 423 Mill & $1 / 25 / 95$ & $1: 00$ & 4.04 & 3.75 & 17 & 15.66 & 173 & .233 & 302 & .568 & 2760 & 31965 & 32040 & 1066557 & 0 & 0 & 0 & 0 & 106197 \\
\hline Test 433 Mill & $1 / 25 / 95$ & 0.45 & 4.28 & 3.96 & 20 & 15.86 & 179 & .242 & 316 & .596 & 1841 & 31889 & 31613 & 1076522 & 0 & 0 & 0 & 0 & 110748 \\
\hline Test 2(R2) & $1 / 25 / 95$ & $0: 39$ & 4.78 & 3.78 & 86 & 16.31 & 391 & .533 & 341 & .651 & 0 & 0 & 0 & 1197000 & 0 & 0 & 0 & 0 & 135349 \\
\hline Test 2(R) & $1 / 25 / 95$ & $0: 30$ & 5.18 & 4.50 & 49 & 16.17 & 386 & .527 & 336 & .640 & 0 & 0 & 0 & 1199677 & 0 & 0 & 0 & 0 & 135449 \\
\hline Test 14(R) & $1 / 25 / 95$ & $0: 20$ & 3.16 & 2.73 & 38 & 16.02 & 194 & .262 & 312 & .591 & 2057 & 31832 & 29943 & 1190476 & 0 & 0 & 0 & 0 & 123748 \\
\hline Test 15(R) & $1 / 25 / 95$ & $0: 50$ & 2.98 & 2.43 & 40 & 15.67 & 178 & .239 & 295 & .553 & 3654 & 31635 & 29753 & 1190980 & 0 & 0 & 0 & 0 & 115931 \\
\hline Test 16(R) & $1 / 26 / 95$ & $0: 24$ & 3.49 & 2.97 & 39 & 15.71 & 186 & .250 & 300 & .564 & 3003 & 31662 & 29786 & 1195600 & 0 & 0 & 0 & 0 & 118542 \\
\hline Test 44 & $1 / 26 / 95$ & $0: 25$ & 3.10 & 2.85 & 27 & 16.21 & 200 & .270 & 366 & .692 & 1752 & 31956 & 30533 & 1189615 & 0 & 0 & 0 & 0 & 125572 \\
\hline Test 45 & $1 / 26 / 95$ & 0.30 & 3.16 & 2.86 & 26 & 16.12 & 193 & .261 & 364 & .688 & 2073 & 31683 & 30292 & 1186774 & 0 & 0 & 0 & 0 & 123877 \\
\hline Test 46 & $1 / 26 / 95$ & $0: 48$ & 2.92 & 2.36 & 23 & 15.84 & 185 & .248 & 342 & .642 & 3511 & 31468 & 30056 & 1185102 & 0 & 0 & 0 & 0 & 116754 \\
\hline Test 47 & $1 / 26 / 95$ & $0: 30$ & 3.09 & 2.56 & 21 & 15.95 & 192 & .259 & 341 & .643 & 2871 & 31527 & 30403 & 1183548 & 0 & 0 & 0 & 0 & 119887 \\
\hline LNB 3 Mill & $1 / 27 / 95$ & $0: 45$ & 4.10 & 3.78 & 44 & 16.38 & 326 & .446 & 386 & .737 & 0 & 0 & 0 & 902758 & 0 & 0 & 0 & 1 & 111133 \\
\hline Test 50 & $1 / 27 / 95$ & $0: 42$ & 3.82 & 3.98 & 109 & 15.92 & 189 & .255 & 376 & .712 & 1630 & 24128 & 22117 & 901697 & 0 & 0 & 0 & 1 & 102860 \\
\hline Test 51 & $1 / 27 / 95$ & $0: 31$ & 3.83 & 3.58 & 62 & 15.50 & 171 & .230 & 339 & .634 & 3494 & 31122 & 29692 & 901542 & 0 & 0 & 0 & 1 & 93204 \\
\hline Test 52 & $1 / 27 / 95$ & $0: 30$ & 3.72 & 3.52 & 58 & 15.83 & 174 & .234 & 350 & .658 & 2558 & 31129 & 29751 & 901172 & 0 & 0 & 0 & 1 & 97741 \\
\hline
\end{tabular}




\section{Post Modification}

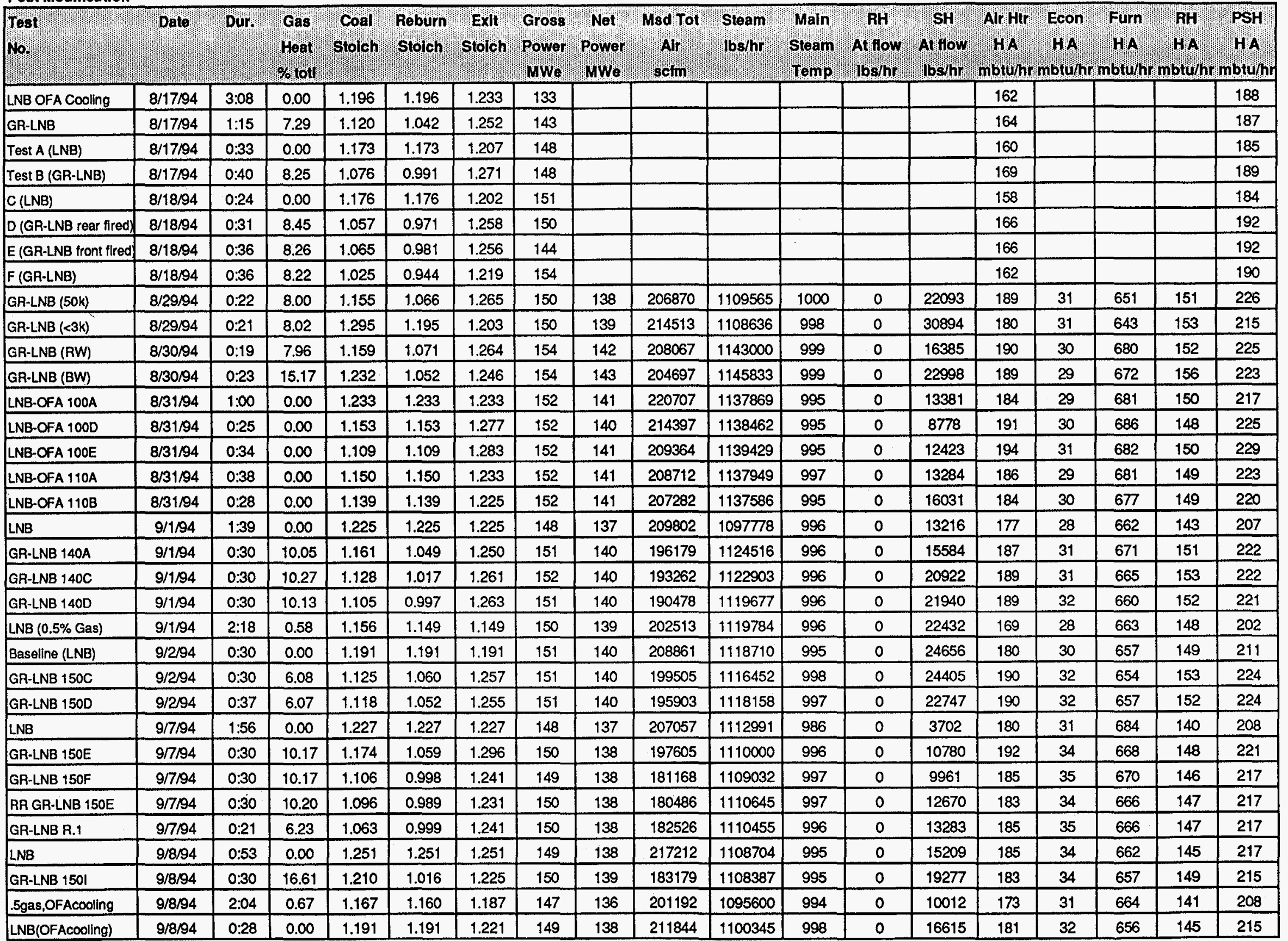


Post Modification

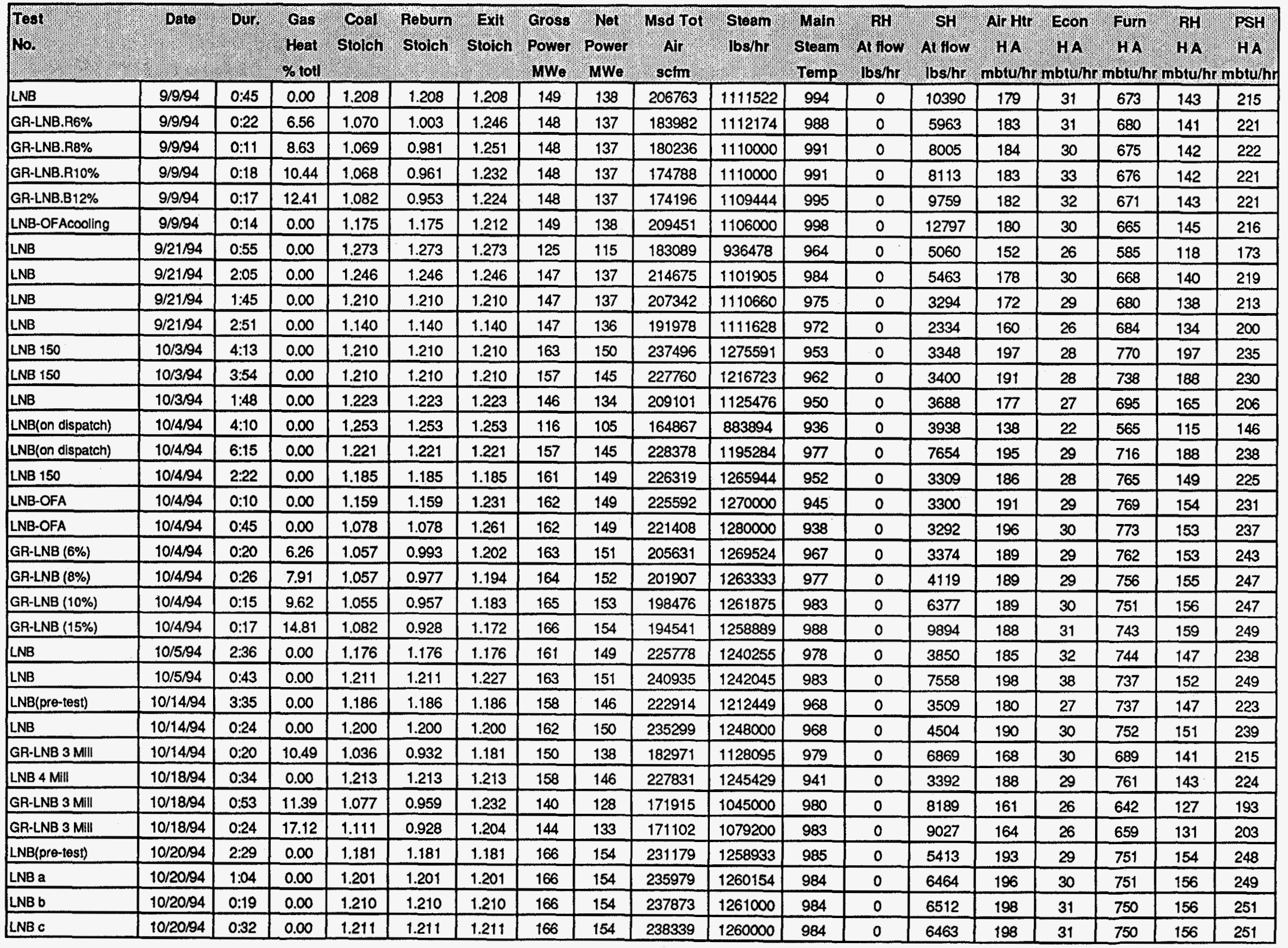


Post Modification

\begin{tabular}{|c|c|c|c|c|c|c|c|c|c|c|c|c|c|c|c|c|c|c|}
\hline 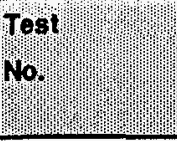 & / Date & Dur & 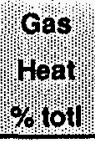 & coal. & Reburn & Exit"] & Gross: & 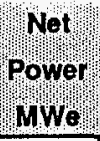 & 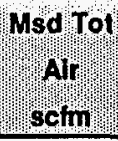 & Steam! & $\begin{array}{l}\text { Main } \\
\text { Steam } \\
\text { Temp }\end{array}$ & 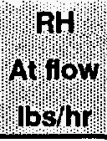 & 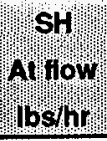 & 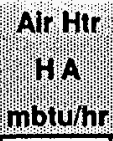 & 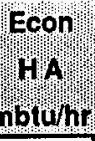 & 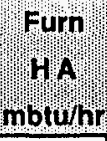 & 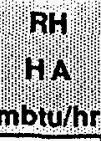 & 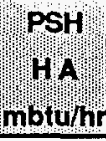 \\
\hline LNB d & $10 / 20 / 94$ & $2: 42$ & 0.00 & 1.202 & 1.202 & 1.202 & 162 & 150 & 229319 & 1230788 & 978 & 0 & 5748 & 190 & 30 & 739 & 152 & 240 \\
\hline GR-LNB a & $10 / 20 / 94$ & $0: 26$ & 9.82 & 1.037 & 0.939 & 1.184 & 161 & 148 & 191371 & 1210741 & 988 & 0 & 9851 & 185 & 28 & 722 & 152 & 242 \\
\hline GR-LNB b & $10 / 20 / 94$ & $0: 20$ & 9.84 & 1.013 & 0.918 & 1.153 & 162 & 150 & 186590 & 1209048 & 995 & 0 & 14859 & 181 & 28 & 714 & 155 & 238 \\
\hline LNB & $10 / 21 / 94$ & $2: 58$ & 0.00 & 1.201 & 1.201 & 1.201 & 161 & 149 & 226534 & 1220670 & 978 & 0 & 3636 & 186 & 29 & 738 & 150 & 235 \\
\hline LNB-OFA & $10 / 21 / 94$ & $0: 28$ & 0.00 & 1.015 & 1.015 & 1.253 & 160 & 147 & 204548 & 1229655 & 961 & 0 & 3476 & 192 & 30 & 745 & 148 & 235 \\
\hline GR-LNB \#1 & $10 / 21 / 94$ & 0.28 & 9.58 & 1.038 & 0.943 & 1.168 & 161 & 148 & .186096 & 1222759 & 979 & 0 & 4096 & 182 & 28 & 739 & 149 & 236 \\
\hline GR-LNB \#2 & $10 / 21 / 94$ & $0: 10$ & 9.59 & 1.034 & 0.939 & 1.161 & 161 & 149 & 186106 & 1220000 & 984 & 0 & 4683 & 181 & 29 & 735 & 151 & 238 \\
\hline GR-LNB \#3 & $10 / 21 / 94$ & $0: 10$ & 9.55 & 1.031 & 0.937 & 1.156 & 161 & 149 & 183471 & 1222727 & 984 & 0 & 4405 & 182 & 31 & 739 & 151 & 238 \\
\hline GR-LNB \#4 & $10 / 21 / 94$ & $0: 14$ & 9.63 & 1.024 & 0.929 & 1.151 & 162 & 149 & 187367 & 1218667 & 988 & 0 & 8369 & 180 & 28 & 729 & 153 & 238 \\
\hline GR-LNB \#5 & $10 / 21 / 94$ & $0: 13$ & 9.64 & 1.022 & 0.928 & 1.149 & 163 & 150 & 187196 & 1220000 & 992 & 0 & 10014 & 180 & 28 & 724 & 155 & 238 \\
\hline LNB & $10 / 24 / 94$ & 5:10 & 0.00 & 1.239 & 1.239 & 1.239 & 132 & 122 & 187081 & 965693 & 992 & 0 & 5244 & 154 & 24 & 602 & 122 & 177 \\
\hline LNB & $10 / 25 / 94$ & $2: 54$ & 0.00 & 1.241 & 1.241 & 1.241 & 137 & 127 & 194705 & 1002602 & 993 & 0 & 7276 & 158 & 25 & 620 & 130 & 178 \\
\hline GR-LNB (50k) & $10 / 25 / 94$ & $0: 19$ & 11.03 & 1.116 & 0.997 & 1.236 & 140 & 129 & 172606 & 1026000 & 997 & 0 & 13237 & 162 & 30 & 623 & 133 & 190 \\
\hline GR-LNB (60k) & $10 / 25 / 94$ & $0: 12$ & 11.07 & 1.090 & 0.974 & 1.249 & 140 & 129 & 170699 & 1026154 & 992 & 0 & 11836 & 164 & 30 & 625 & 134 & 192 \\
\hline LNB & $10 / 25 / 94$ & $0: 11$ & 0.00 & 1.255 & 1.255 & 1.255 & 137 & 127 & 198071 & 1006459 & 992 & 0 & 5216 & 163 & 31 & 629 & 129 & 186 \\
\hline LNB & $11 / 294$ & $4: 00$ & 0.00 & 1.203 & 1.203 & 1.213 & 159 & 149 & 244550 & 1161068 & 995 & 1135 & 27833 & 185 & 29 & 675 & 162 & 228 \\
\hline GR-LNB & $11 / 2 / 94$ & 1.08 & 5.18 & 1.194 & 1.118 & 1.214 & 160 & 150 & 234519 & 1170870 & 996 & 1582 & 23299 & 187 & 30 & 685 & 163 & 237 \\
\hline GR-LNB & $11 / 2 / 94$ & $0: 14$ & 5.19 & 1.105 & 1.035 & 1.213 & 161 & 150 & 228330 & 1178667 & 992 & 606 & 19216 & 186 & 29 & 692 & 161 & 239 \\
\hline GR-LNB & $11 / 2 / 94$ & 0.24 & 5.18 & 1.037 & 0.972 & 1.221 & 161 & 150 & 222340 & 1180000 & 994 & 0 & 15788 & 187 & 30 & 697 & 159 & 242 \\
\hline LNB & $11 / 3 / 94$ & 1:19 & 0.00 & 1.185 & 1.185 & 1.210 & 127 & 118 & 188684 & 917828 & 988 & 0 & 6352 & 143 & 23 & 577 & 122 & 169 \\
\hline LNB-OFA(14k) & $11 / 3 / 94$ & $0: 18$ & 0.00 & 1.041 & 1.041 & 1.141 & 127 & 118 & 164796 & 943652 & 951 & 0 & 3075 & 134 & 22 & 603 & 121 & 162 \\
\hline LNB-OFA(60k) & $11 / 3 / 94$ & $0: 12$ & 0.00 & 0.795 & 0.795 & 1.170 & 125 & 116 & 147078 & 940632 & 937 & 0 & 3133 & 135 & 22 & 602 & 117 & 157 \\
\hline GR-LNB 1 & $11 / 3 / 94$ & $0: 14$ & 4.80 & 1.049 & 0.988 & 1.137 & 125 & 116 & 162124 & 948571 & 932 & 0 & 3055 & 132 & 22 & 609 & 118 & 157 \\
\hline GR-LNB 2 & $11 / 3 / 94$ & $0: 12$ & 4.83 & 1.009 & 0.950 & 1.189 & 125 & 116 & 164817 & 945668 & 935 & 0 & 3071 & 138 & 23 & 606 & 118 & 161 \\
\hline GR-LNB 3 & $11 / 3 / 94$ & 1:11 & 8.38 & 0.962 & 0.862 & 1.208 & 126 & 116 & 157334 & 938198 & 952 & 30 & 2904 & 141 & 23 & 599 & 119 & 166 \\
\hline GR-LNB 4 & $11 / 3 / 94$ & $0: 24$ & 12.12 & 0.990 & 0.835 & 1.216 & 126 & 116 & 154021 & 928934 & 963 & 0 & 3119 & 142 & 23 & 592 & 119 & 170 \\
\hline GR-LNB 5 & $11 / 3 / 94$ & $0: 14$ & 14.34 & 1.013 & 0.820 & 1.201 & 126 & 117 & 153658 & 928717 & 974 & 0 & 3384 & 140 & 22 & 588 & 119 & 173 \\
\hline LNB & $11 / 4 / 94$ & $1: 17$ & 0.00 & 1.122 & 1.122 & 1.143 & 159 & 149 & 225234 & 1155641 & 993 & 2951 & 30680 & 177 & 29 & 669 & 163 & 220 \\
\hline LNB-OFA & $11 / 4 / 94$ & $0: 17$ & 0.00 & 0.878 & 0.878 & 1.148 & 157 & 147 & 194490 & 1156667 & 992 & 0 & 13697 & 174 & 29 & 689 & 154 & 231 \\
\hline GR-LNB 1 & $11 / 4 / 94$ & $0: 23$ & 3.91 & 0.978 & 0.931 & 1.131 & 160 & 149 & 199660 & 1174583 & 992 & 0 & 12841 & 175 & 28 & 700 & 157 & 236 \\
\hline GR-LNB 2 & $11 / 4 / 94$ & $0: 12$ & 6.45 & 0.952 & 0.877 & 1.130 & 161 & 150 & 195579 & 1183077 & 992 & 0 & 11849 & 176 & 29 & 705 & 159 & 236 \\
\hline GR-LNB 3 & $11 / 4 / 94$ & $0: 20$ & 3.86 & 0.953 & 0.908 & 1.149 & 158 & 147 & 196321 & 1160952 & 992 & 0 & 11869 & 175 & 29 & 694 & 154 & 231 \\
\hline GR-LNB 4 & $11 / 4 / 94$ & $0: 14$ & 6.74 & 0.951 & 0.871 & 1.142 & 159 & 149 & 193206 & 1175333 & 989 & 0 & 12390 & 176 & 30 & 702 & 156 & 233 \\
\hline GR-LNB 5 & $11 / 4 / 94$ & $1: 39$ & 11.68 & 1.013 & 0.857 & 1.157 & 157 & 147 & 190638 & 1159700 & 993 & 0 & 12858 & 176 & 31 & 692 & 154 & 233 \\
\hline
\end{tabular}


Post Modification

\begin{tabular}{|c|c|c|c|c|c|c|c|c|c|c|c|c|c|c|c|c|c|c|}
\hline rest & Datem & Dur & $\begin{array}{l}\text { Gas } \\
\text { (Heat } \\
\text { \% } 0 \text { ot }\end{array}$ & Stcon)" & Répurn & Stompl Ex & 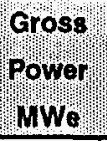 & 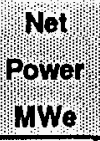 & Msd Tot & steam & $\begin{array}{l}\text { Main } \\
\text { Sicamp } \\
\text { Tomp }\end{array}$ & 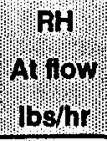 & $\begin{array}{l}\text { sh'm } \\
\text { Anfow } \\
\text { (nshrm }\end{array}$ & 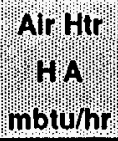 & 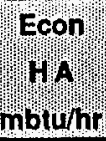 & 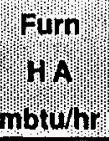 & 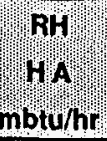 & mpstram \\
\hline LNB & $11 / 7 / 94$ & $1: 43$ & 0.00 & 1.118 & 1.118 & 1.142 & 127 & 118 & 179555 & 910874 & 995 & 0 & 7173 & 132 & 22 & 571 & 123 & 163 \\
\hline GR-LNB & $11 / 7 / 94$ & 0.24 & 4.83 & 0.893 & 0.840 & 1.149 & 123 & 114 & 154152 & 917025 & 960 & 0 & 3494 & 127 & 23 & 587 & 116 & 161 \\
\hline GR-LNB & $11 / 7 / 94$ & $1: 35$ & 8.18 & 0.961 & 0.864 & 1.157 & 125 & 116 & 156641 & 930763 & 965 & 0 & 3481 & 131 & 23 & 593 & 119 & 164 \\
\hline LNB (D out) & $11 / 7 / 94$ & $0: 15$ & 0.55 & 1.160 & 1.152 & 1.172 & 125 & 116 & 192922 & 908066 & 992 & 0 & 9841 & 132 & 26 & 566 & 120 & 164 \\
\hline GR-LNB & $11 / 7 / 94$ & $0: 16$ & 4.67 & 1.014 & 0.958 & 1.255 & 129 & 119 & 174548 & 939974 & 983 & 0 & 4645 & 151 & 29 & 593 & 125 & 181 \\
\hline GR-LNB & $11 / 7 / 94$ & $0: 12$ & 7.69 & 1.016 & 0.920 & 1.213 & 128 & 119 & 165910 & 935959 & 984 & 0 & 5705 & 144 & 29 & 590 & 122 & 175 \\
\hline LNB & $11 / 8 / 94$ & $1: 03$ & 0.00 & 1.118 & 1.118 & 1.134 & 129 & 120 & 181106 & 917594 & 995 & 0 & 17956 & 137 & 23 & 562 & 127 & 164 \\
\hline GR-LNB(varled OFA) & $11 / 8 / 94$ & $0: 33$ & 5.99 & 0.987 & 0.916 & 1.140 & 128 & 119 & 157570 & 927040 & 992 & 0 & 6189 & 137 & 22 & 581 & 123 & 176 \\
\hline GR-LNB(OFA op) & $11 / 8 / 94$ & $2: 55$ & 5.91 & 1.002 & 0.930 & 1.153 & 128 & 119 & 157795 & 930000 & 987 & 0 & 5048 & 139 & 23 & 586 & 121 & 176 \\
\hline GR-LNB(D@80\%) & $11 / 8 / 94$ & $0: 40$ & 6.14 & 1.005 & 0.930 & 1.158 & 128 & 119 & 158059 & 925250 & 986 & 0 & 5549 & 139 & 22 & 583 & 121 & 176 \\
\hline LNB 1 & $11 / 9 / 94$ & $0: 18$ & 0.00 & 1.118 & 1.118 & 1.143 & 127 & 118 & 180225 & 909096 & 996 & 0 & 11074 & 137 & 23 & 566 & 122 & 168 \\
\hline GR-LNB 1 & $11 / 9 / 94$ & $3: 29$ & 7.71 & 1.025 & 0.928 & 1.175 & 126 & 117 & 156626 & 949455 & 941 & 0 & 2896 & 135 & 21 & 611 & 119 & 152 \\
\hline GR-LNB 2 & $11 / 9 / 94$ & 0.39 & 7.31 & 0.998 & 0.909 & 1.152 & 127 & 118 & 157098 & 952800 & 951 & 0 & 2958 & 132 & 21 & 610 & 120 & 154 \\
\hline GR-LNB 3 & $11 / 9 / 94$ & 0,32 & 7.28 & 1.023 & 0.933 & 1.162 & 145 & 135 & 191383 & 1084528 & 984 & 0 & 5152 & 153 & 21 & 668 & 140 & 197 \\
\hline GR-LNB 4 & $11 / 9 / 94$ & $5: 31$ & 6.80 & 1.029 & 0.944 & 1.167 & 160 & 149 & 208246 & 1179970 & 994 & 0 & 10578 & 175 & 26 & 709 & 158 & 226 \\
\hline GR-LNB 5 & $11 / 9 / 94$ & $0 ; 31$ & 7.69 & 1.081 & 0.982 & 1.218 & 135 & 125 & 168945 & 979889 & 973 & 0 & 4377 & 155 & 27 & 626 & 130 & 179 \\
\hline LNB 2 & $11 / 9 / 94$ & $0: 45$ & 1.21 & 1.219 & 1.202 & 1.218 & 97 & 89 & 145192 & 727470 & 922 & 0 & 3838 & 106 & 17 & 483 & 94 & 93 \\
\hline GR-LNB 6 & $11 / 9 / 94$ & $0: 15$ & 6.17 & 0.969 & 0.900 & 1.207 & 97 & 88 & 120876 & 752259 & 884 & 0 & 3833 & 104 & 18 & 504 & 94 & 87 \\
\hline GR-LNB 7 & $11 / 9 / 94$ & $0: 11$ & 9.67 & 0.929 & 0.822 & 1.172 & 98 & 89 & 117573 & 756596 & 893 & 0 & 3777 & 102 & 17 & 504 & 95 & 89 \\
\hline GR-LNB 8 & $11 / 9 / 94$ & $0: 16$ & 7.41 & 1.023 & 0.935 & 1.229 & 96 & 87 & 121405 & 746665 & 884 & 0 & 3837 & 106 & 17 & 502 & 93 & 88 \\
\hline $\operatorname{LNB}(120)$ & $11 / 10 / 94$ & $1: 15$ & 0.00 & 1.176 & 1.176 & 1.226 & 129 & 119 & 187741 & 922657 & 995 & 0 & 14761 & 149 & 25 & 567 & 129 & 173 \\
\hline LNB(150) & $11 / 10 / 94$ & $0: 27$ & 0.00 & 1.148 & 1.148 & 1.155 & 159 & 148 & 232371 & 1151786 & 996 & 4589 & 37422 & 175 & 27 & 659 & 168 & 218 \\
\hline GR-LNB(43k) & $11 / 10 / 94$ & $0: 48$ & 6.76 & 1.022 & 0.937 & 1.159 & 159 & 148 & 205471 & 1160000 & 994 & 2418 & 22600 & 177 & 29 & 682 & 162 & 231 \\
\hline GR-LNB(46k) & $11 / 10 / 94$ & $1: 42$ & 6.85 & 1.024 & 0.938 & 1.155 & 159 & 149 & 202503 & 1164175 & 994 & 646 & 20786 & 177 & 28 & 686 & 162 & 232 \\
\hline GR-LNB(53K) & $11 / 10 / 94$ & $1: 29$ & 6.85 & 1.020 & 0.946 & 1.167 & 158 & 147 & 199579 & 1157111 & 994 & 0 & 18566 & 177 & 28 & 685 & 158 & 231 \\
\hline GR-LNB(61k) & $11 / 10 / 94$ & $9: 45$ & 6.89 & 0.998 & 0.965 & 1.183 & 158 & 147 & 197545 & 1160909 & 994 & 0 & 15637 & 180 & 32 & 689 & 157 & 233 \\
\hline GR-LNB & $11 / 11 / 94$ & $9: 12$ & 6.97 & 1.064 & 0.973 & 1.192 & 158 & 147 & 197979 & 1159440 & 994 & 0 & 15367 & 181 & 28 & 690 & 157 & 234 \\
\hline \multicolumn{19}{|c|}{$100 \%$ Gas Testing 11/2/94-11/11/94 (SP's of } \\
\hline LNB(coal/gas) & $12 / 1 / 94$ & $2: 41$ & 0.00 & 1.184 & 1.184 & 1.184 & 165 & 153 & 238196 & 1280432 & 957 & 0 & 3607 & 193 & 31 & 774 & 154 & 245 \\
\hline Test 21 & $1 / 19 / 95$ & 1.00 & 12.35 & 1.086 & 0.955 & 1.222 & 136 & 124 & 169881 & 1042295 & 996 & 0 & 12353 & 170 & 31 & 642 & 135 & 203 \\
\hline Test 22 & $1 / 19 / 95$ & $1: 02$ & 8.06 & 1.043 & 0.961 & 1.227 & 137 & 124 & 171290 & 1046032 & 994 & 0 & 9693 & 171 & 31 & 646 & 134 & 205 \\
\hline Test 24 & $1 / 19 / 95$ & $0: 33$ & 0.00 & 1.273 & 1.273 & 1.324 & 102 & 90 & 153165 & 755388 & 998 & 0 & 9710 & 136 & 24 & 483 & 104 & 144 \\
\hline Test 25 & $1 / 19 / 95$ & $0: 30$ & 0.00 & 1.226 & 1.226 & 1.348 & 103 & 91 & 145884 & 768385 & 992 & 0 & 8719 & 141 & 24 & 493 & 104 & 150 \\
\hline Test 27 & $1 / 19 / 95$ & $0: 25$ & 0.00 & 1.031 & 1.031 & 1.319 & 103 & 91 & 131427 & 769978 & 985 & 0 & 7880 & 138 & 25 & 495 & 102 & 149 \\
\hline
\end{tabular}


Post Modification

\begin{tabular}{|c|c|c|c|c|c|c|c|c|c|c|c|c|c|c|c|c|c|c|}
\hline pest & "pasp & pum & $\begin{array}{l}\text { Gas } \\
\text { Geat) } \\
\text { \% lot }\end{array}$ & coalm & spopyrn & Exit & $\begin{array}{l}\text { Grosss } \\
\text { Power } \\
\text { nwe }\end{array}$ & poner & 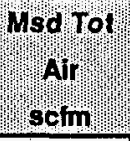 & steampy & $\begin{array}{l}\text { Main } \\
\text { Steam } \\
\text { Tomp }\end{array}$ & 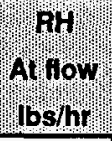 & 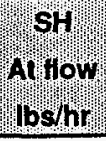 & 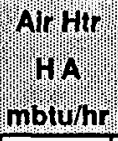 & Eccon & 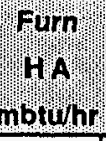 & Why & 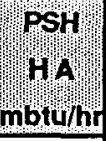 \\
\hline Test 30 & $1 / 20 / 95$ & 1.01 & 8.05 & 1.082 & 0.997 & 1.333 & 99 & 87 & 124710 & 768234 & 962 & 0 & 5317 & 133 & 25 & 502 & 97 & 131 \\
\hline Test 31 & $1 / 20 / 95$ & $1: 00$ & 15.99 & 1.135 & 0.958 & 1.315 & 100 & 88 & 121190 & 761751 & 983 & 0 & 5322 & 133 & 25 & 496 & 97 & 138 \\
\hline Test 32 & $1 / 20 / 95$ & $1: 05$ & 11.90 & 1.096 & 0.969 & 1.324 & 101 & 89 & 123472 & 760789 & 989 & 0 & 5381 & 135 & 24 & 494 & 98 & 141. \\
\hline Test 33 & $1 / 20 / 95$ & $0: 40$ & 7.88 & 1.043 & 0.963 & 1.319 & 101 & 89 & 124136 & 762120 & 985 & 0 & 5392 & 134 & 25 & 495 & 98 & 141 \\
\hline Test $1(\mathrm{R})$ & $1 / 24 / 95$ & 1.00 & 0.00 & 1.266 & 1.266 & 1.273 & 157 & 144 & 240133 & 1168197 & 976 & 0 & 10516 & 198 & 34 & 712 & 156 & 235 \\
\hline Test 16 & $1 / 25 / 95$ & $0: 20$ & 11.88 & 1.057 & 0.935 & 1.193 & 154 & 142 & 176451 & 1170000 & 967 & 0 & 4614 & 179 & 31 & 732 & 144 & 211 \\
\hline Test 17 & $1 / 25 / 95$ & $0: 40$ & 8.00 & 1.026 & 0.946 & 1.204 & 154 & 141 & 178597 & $\$ 171905$ & 962. & 0 & 4625 & 180 & 33 & 734 & 144 & 210 \\
\hline Test 403 Mill & $1 / 25 / 95$ & $1: 00$ & 7.76 & 1.055 & 0.975 & 1.194 & 136 & 124 & 164640 & 1075574 & 917 & 0 & 4907 & 153 & 28 & 693 & 125 & 168 \\
\hline Test 413 Mill & $1 / 25 / 95$ & $1: 00$ & 15.82 & $\$ .107$ & 0.936 & 1.230 & 138 & 126 & 165890 & 1069016 & 943 & 0 & 4939 & 162 & 30 & 682 & 129 & 186 \\
\hline Test $423 \mathrm{Mill}$ & $1 / 25 / 95$ & $1: 00$ & 12.05 & 1.062 & 0.937 & 1.231 & 139 & 127 & 169244 & 1066557 & 951 & 0 & 4944 & 163 & 32 & 680 & 130 & 190 \\
\hline Test 433 Mill & $1 / 25 / 95$ & $0: 45$ & 8.06 & 1.039 & 0.957 & 1.249 & 139 & 127 & 169884 & 1076522 & 932 & 0 & 4933 & 164 & 31 & 689 & 129 & 184 \\
\hline Test 2(R2) & $1 / 25 / 95$ & $0: 39$ & 0.00 & 1.282 & 1.282 & 1.288 & 158 & 145 & 248560 & 1197000 & 975 & 0 & 7173 & 198 & 36 & 740 & 151 & 232 \\
\hline Test 2(R) & $1 / 25 / 95$ & $0: 30$ & 0.00 & 1.280 & 1.280 & 1.320 & 158 & 145 & 246770 & 1199677 & 968 & 0 & 6086 & 203 & 35 & 743 & 151 & 234 \\
\hline Test $14(\mathrm{R})$ & $1 / 25 / 95$ & $0: 20$ & 8.07 & 0.997 & 0.919 & 1.172 & 158 & 145 & 183697 & 1190476 & 983 & 0 & 5424 & 180 & 33 & 740 & 146 & 225 \\
\hline Test 15(R) & $1 / 25 / 95$ & $0: 50$ & 14.25 & 1.055 & 0.909 & 1.160 & 159 & 146 & 179149 & 1190980 & 988 & 0 & 7247 & 180 & 33 & 735 & 149 & 227 \\
\hline Test 16(R) & $1 / 26 / 95$ & $0: 24$ & 11.79 & 1.061 & 0.940 & 1.193 & 157 & 144 & 181397 & 1195600 & 970 & 0 & 4533 & 182 & 32 & 747 & 141 & 214 \\
\hline Test 44 & $1 / 26 / 95$ & 0.25 & 6.85 & 0.977 & 0.912 & 1.168 & 157 & 144 & 184063 & 1189615 & 984 & 0 & 5671 & 179 & 34. & 738 & 147 & 228 \\
\hline Test 45 & $1 / 26 / 95$ & $0: 30$ & 8.11 & 0.996 & 0.918 & 1.172 & 158 & 145 & 183731 & 1186774 & 988 & 0 & 7277 & 181 & 34 & 733 & 149 & 229 \\
\hline Test 46 & $1 / 26 / 95$ & $0: 48$ & 13.69 & 1.042 & 0.903 & 1.156 & 159 & 146 & 180276 & 1185102 & 994 & 0 & 10782 & 180 & 35 & 726 & 153 & 229 \\
\hline Test 47 & $1 / 26 / 95$ & $0: 30$ & 11.21 & 1.025 & 0.913 & 1.167 & 158 & 146 & 183309 & 1183548 & 993 & 0 & 11016 & 182 & 35 & 725 & 152 & 231 \\
\hline LNB 3 Mill & $1 / 27 / 95$ & $0: 45$ & 0.00 & 1.221 & 1.221 & 1.237 & 134 & 122 & 200303 & 902758 & 997 & 0 & 12606 & 150 & 35 & 632 & 124 & 165 \\
\hline Test 50 & $1 / 27 / 95$ & $0: 42$ & 7.71 & 1.063 & 0.983 & 1.216 & 134 & 122 & 165722 & 901697 & 998 & 0 & 17967 & 146 & 36 & 623 & 126 & 163 \\
\hline Test 51 & $1 / 27 / 95$ & $0: 31$ & 16.51 & 1.090 & 0.914 & 1.215 & 134 & 122 & 156884 & 901542 & 998 & 0 & 23656 & 146 & 35 & 617 & 128 & 156 \\
\hline Test 52 & $1 / 27 / 95$ & $0: 30$ & 12.13 & 1.027 & 0.906 & 1.208 & 134 & 122 & 155392 & 901172 & 998 & 0 & 25146 & 145 & 36 & 614 & 128 & 156 \\
\hline
\end{tabular}


Post Modification

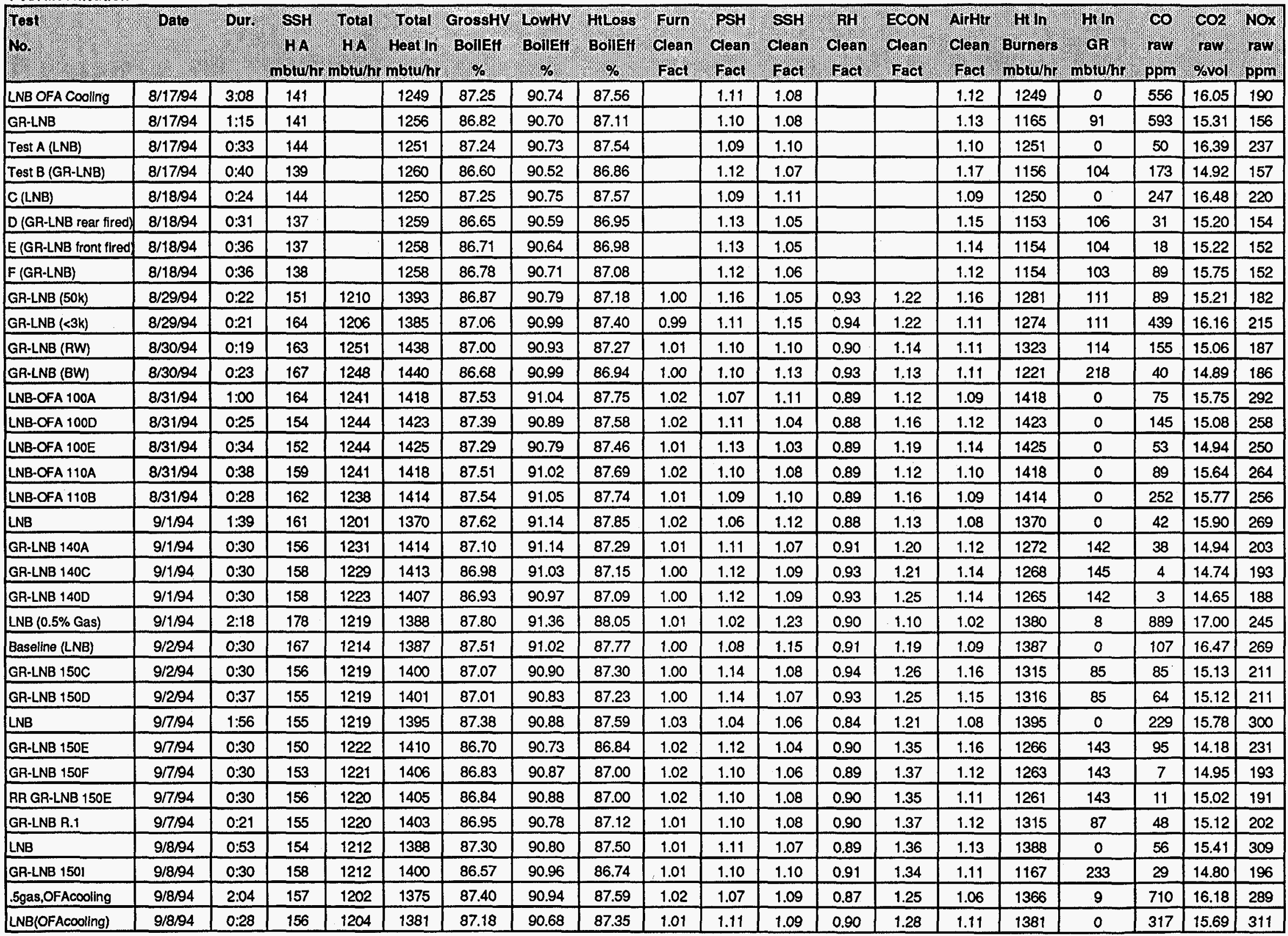


Post Modification

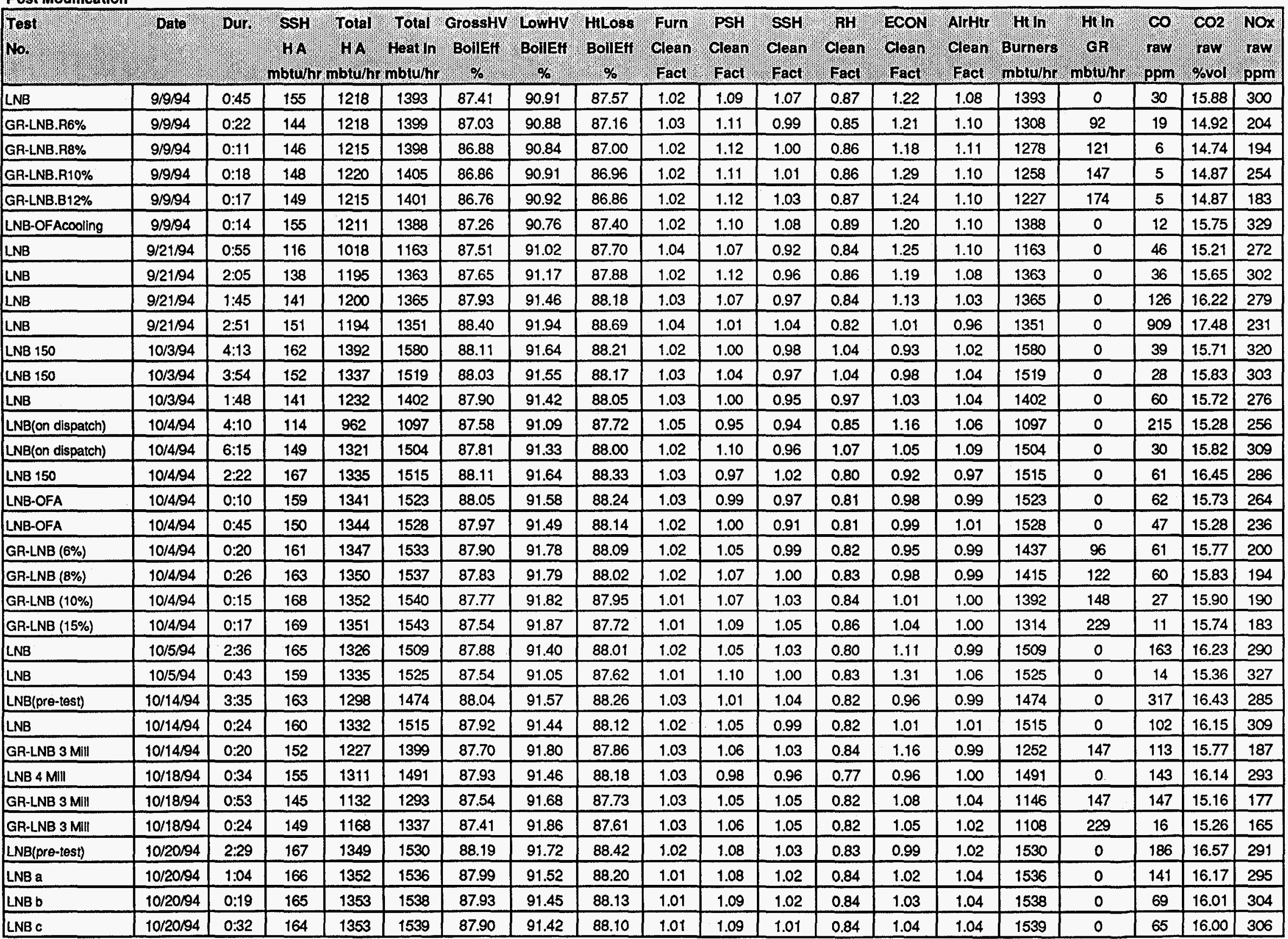




\begin{tabular}{|c|c|c|c|c|c|c|c|c|c|c|c|c|c|c|c|c|c|c|c|}
\hline & Dato & pw & 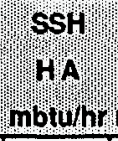 & 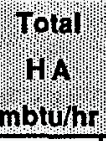 & 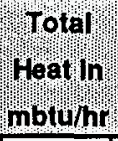 & Grosshy & Loify & 'rttoss & fruman & 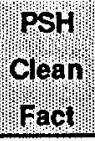 & 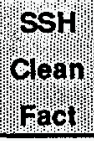 & 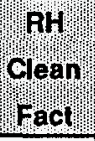 & Econ & Alphy & 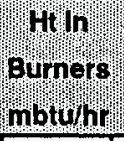 & 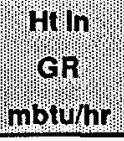 & raw & (cos) & $\begin{array}{l}\text { Nox } \\
\text { rawpy } \\
\text { ppon }\end{array}$ \\
\hline LNB d & $10 / 20 / 94$ & $2: 42$ & 161 & 1321 & 1502 & 87.92 & 91.45 & 88.11 & 1.02 & 1.07 & 1.01 & 0.83 & 1.03 & 1.03 & 1502 & 0 & 145 & 16.09 & 295 \\
\hline GR-LNB a & $10 / 20 / 94$ & $0: 26$ & 159 & 1303 & 1487 & 87.61 & 91.67 & 87.78 & 1.01 & 1.10 & 1.02 & 0.85 & 1.00 & 1.02 & 1341 & 146 & 72 & 15.79 & 184 \\
\hline GR-LNB b & $10 / 20 / 94$ & 0:20 & 170 & 1304 & 1487 & 87.68 & 91.74 & 87.87 & 1.01 & 1.09 & 1.09 & 0.87 & 1.00 & 1.01 & 1341 & 146 & 132 & 16.28 & 182 \\
\hline LNB & $10 / 21 / 94$ & $2: 58$ & 162 & 1313 & 1489 & 88.15 & 91.68 & 88.33 & 1.02 & 1.05 & 1.03 & 0.83 & 0.99 & 1.01 & 1489 & 0 & 126 & 16.12 & 297 \\
\hline LNB-OFA & $10 / 21 / 94$ & $0: 28$ & 152 & 1309 & 1490 & 87.88 & 91.41 & 88.03 & 1.02 & 1.05 & 0.95 & 0.81 & 1.02 & 1.04 & 1490 & 0 & 61 & 15.28 & 215 \\
\hline GR-LNB \#1 & $10 / 21 / 94$ & $0: 28$ & 162 & 1315 & 1499 & 87.72 & 91.77 & 87.90 & 1.02 & 1.06 & 1.02 & 0.82 & 0.98 & 0.98 & 1355 & 144 & 64 & 16.05 & 189 \\
\hline GR-LNB \#2 & $10 / 21 / 94$ & $0: 10$ & 163 & 1316 & 1500 & 87.73 & 91.78 & 87.91 & 1.02 & 1.07 & 1.03 & 0.83 & 1.01 & 0.99 & 1356 & 144 & 50 & 16.18 & 187 \\
\hline GR-LNB \#3 & $10 / 21 / 94$ & $0: 10$ & 165 & 1323 & 1508 & 87.75 & 91.80 & 87.93 & 1.02 & 1.06 & 1.04 & 0.83 & 1.07 & 0.98 & 1364 & 144 & 107 & 16.24 & 188 \\
\hline GR-LNB \#4 & $10 / 21 / 94$ & $0: 14$ & 166 & 1314 & 1497 & 87.78 & 91.83 & 87.96 & 1.02 & 1.08 & 1.06 & 0.85 & 0.98 & 0.98 & 1353 & 144 & 119 & 16.33 & 190 \\
\hline GR-LNB \#5 & $10 / 21 / 94$ & $0: 13$ & 168 & 1313 & 1496 & 87.77 & 91.82 & 87.95 & 1.01 & 1.08 & 1.08 & 0.86 & 0.98 & 0.99 & 1352 & 144 & 138 & 16.34 & 189 \\
\hline LNB & $10 / 24 / 94$ & 5:10 & 139 & 1064 & 1210 & 87.92 & 91.45 & 88.10 & 1.03 & 1.05 & 1.07 & 0.84 & 1.13 & 1.07 & 1210 & 0 & 224 & 15.58 & 271 \\
\hline LNB & $10 / 25 / 94$ & $2: 54$ & 152 & 1105 & 1256 & 87.97 & 91.49 & 88.14 & 1.03 & 1.01 & 1.14 & 0.87 & 1.09 & 1.06 & 1256 & 0 & 297 & 15.54 & 268 \\
\hline GR-LNB $(50 \mathrm{~K})$ & $10 / 25 / 94$ & $0: 19$ & 153 & 1129 & 1291 & 87.51 & 91.63 & 87.65 & 1.02 & 1.06 & 1.13 & 0.88 & 1.30 & 1.07 & 1148 & 142 & 146 & 14.94 & 185 \\
\hline GR-LNB (60k) & $10 / 25 / 94$ & $0: 12$ & 148 & 1130 & 1292 & 87.43 & 91.54 & 87.57 & 1.02 & 1.07 & 1.09 & 0.88 & 1.31 & 1.08 & 1149 & 143 & 41 & 14.75 & 186 \\
\hline LNB & $10 / 25 / 94$ & $0: 11$ & 147 & 1122 & 1277 & 87.82 & 91.34 & 87.98 & 1.03 & 1.04 & 1.09 & 0.85 & 1.35 & 1.08 & $12 \pi$ & 0 & 211 & 15.25 & 275 \\
\hline LNB & $11 / 2 / 94$ & $4: 00$ & 167 & 1260 & 1428 & 88.26 & 91.79 & 85.79 & 1.00 & 1.11 & 1.12 & 0.95 & 1.10 & 1.08 & 1428 & 0 & 2 & 9.61 & 237 \\
\hline GR-LNB & $11 / 2 / 94$ & 1.08 & 161 & 1276 & 1448 & 88.07 & 91.95 & 85.78 & 1.00 & 1.14 & 1.07 & 0.95 & 1.10 & 1.08 & 1358 & 90 & 67 & 9.60 & 191 \\
\hline GR-LNB & $11 / 2 / 94$ & $0: 14$ & 158 & 1279 & 1451 & 88.12 & 92.00 & 85.85 & 1.00 & 1.14 & 1.04 & 0.93 & 1.07 & 1.07 & 1360 & 91 & 19 & 9.62 & 163 \\
\hline GR-LNB & $11 / 2 / 94$ & $0: 24$ & 156 & 1283 & 1457 & 88.10 & 91.98 & 85.82 & 1.01 & 1.14 & 1.02 & 0.92 & 1.10 & 1.07 & 1366 & 90 & 4 & 9.56 & 137 \\
\hline LNB & $11 / 3 / 94$ & $1: 19$ & 128 & 1018 & 1149 & 88.58 & 92.13 & 86.42 & 1.04 & 1.07 & 1.03 & 0.89 & 1.12 & 1.05 & 1149 & 0 & 8 & 9.61 & 154 \\
\hline LNB-OFA(14K) & $11 / 3 / 94$ & $0: 18$ & 125 & 1032 & 1159 & 89.04 & 92.60 & 87.11 & 1.05 & 0.98 & 0.98 & 0.85 & 1.05 & 0.95 & 1159 & 0 & 166 & 10.26 & 92 \\
\hline LNB-OFA(60k) & $11 / 3 / 94$ & $0: 12$ & 119 & 1019 & 1144 & 89.01 & 92.58 & 87.07 & 1.05 & 0.96 & 0.94 & 0.83 & 1.04 & 0.96 & 1144 & 0 & 269 & 9.97 & 57 \\
\hline GR-LNB 1 & $11 / 3 / 94$ & $0: 14$ & 121 & 1028 & 1156 & 88.87 & 92.75 & 87.08 & 1.05 & 0.94 & 0.94 & 0.83 & 1.05 & 0.92 & 1091 & 65 & 466 & 10.27 & 80 \\
\hline GR-LNB 2 & $11 / 3 / 94$ & $0: 12$ & 118 & 1025 & 1156 & 88.70 & 92.57 & 86.83 & 1.05 & 0.97 & 0.92 & 0.83 & 1.08 & 0.97 & 1090 & 66 & 215 & 9.82 & 85 \\
\hline GR-LNB 3 & $11 / 3 / 94$ & $1: 11$ & 118 & 1025 & 1160 & 88.38 & 92.50 & 86.51 & 1.05 & 1.02 & 0.93 & 0.84 & 1.10 & 1.00 & 1041 & 119 & 178 & 9.62 & 75 \\
\hline GR-LNB 4 & $11 / 3 / 94$ & $0: 24$ & 118 & 1023 & 1161 & 88.09 & 92.49 & 86.29 & 1.05 & 1.05 & 0.94 & 0.85 & 1.12 & 1.02 & 981 & 180 & 413 & 9.48 & 68 \\
\hline GR-LNB 5 & $11 / 3 / 94$ & $0: 14$ & 120 & 1022 & 1162 & 87.98 & 92.56 & 86.27 & 1.04 & 1.08 & 0.96 & 0.86 & 1.07 & 1.02 & 943 & 219 & 356 & 9.64 & 70 \\
\hline LNB & $11 / 4 / 94$ & $1: 17$ & 173 & 1254 & 1415 & 88.61 & 92.16 & 86.30 & 0.99 & 1.08 & 1.17 & 0.97 & 1.09 & 1.04 & 1415 & 0 & 22 & 10.18 & 209 \\
\hline LNB-OFA & $11 / 4 / 94$ & $0: 17$ & 154 & 1257 & 1416 & 88.74 & 92.30 & 86.52 & 1.01 & 1.12 & 1.03 & 0.91 & 1.09 & 1.02 & 1416 & 0 & 102 & 10.17 & 108 \\
\hline GR-LNB 1 & $11 / 4 / 94$ & 0.23 & 159 & 1280 & 1444 & 88.65 & 92.46 & 86.54 & 1.01 & 1.12 & 1.04 & 0.91 & 1.05 & 1.00 & 1377 & 67 & 323 & 10.28 & 113 \\
\hline GR-LNB 2 & $11 / 4 / 94$ & $0: 12$ & 162 & 1290 & 1458 & 88.52 & 92.51 & 86.48 & 1.01 & 1.11 & 1.06 & 0.91 & 1.05 & 1.00 & 1344 & 114 & 106 & 10.32 & 109 \\
\hline GR-LNB 3 & $11 / 4 / 94$ & $0: 20$ & 156 & 1264 & 1428 & 88.56 & 92.37 & 86.41 & 1.02 & 1.11 & 1.04 & 0.90 & 1.09 & 1.01 & 1361 & 66 & 11 & 10.13 & 121 \\
\hline GR-LNB 4 & $11 / 4 / 94$ & $0: 14$ & 159 & 1280 & 1447 & 88.46 & 92.46 & 86.40 & 1.01 & 1.10 & 1.05 & 0.90 & 1.09 & 1.00 & 1330 & 117 & 104 & 10.20 & 114 \\
\hline GA-LNB 5 & $11 / 4 / 94$ & $1: 39$ & 155 & 1264 & 1435 & 88.06 & 92.44 & 86.12 & 1.01 & 1.12 & 1.03 & 0.90 & 1.15 & 1.02 & 1216 & 219 & 206 & 10.04 & 107 \\
\hline
\end{tabular}


Cheorkee Unit *3, Average Test Data

Post Modification

\begin{tabular}{|c|c|c|c|c|c|c|c|c|c|c|c|c|c|c|c|c|c|c|c|}
\hline теs. & paren & phry & $\begin{array}{l}\text { Why } \\
\text { nown } \\
\text { mowh }\end{array}$ & 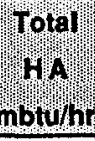 & 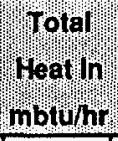 & Grossyy & Lown & Hiloss & 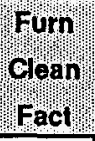 & בpspl & chan & Crap) & $\begin{array}{l}\text { EcoN } \\
\text { clean } \\
\text { Fact }\end{array}$ & Ahanty & 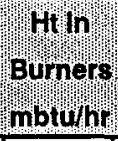 & 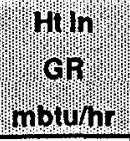 & pom & con & Nox \\
\hline LNB & $11 / 7 / 94$ & $1: 43$ & 137 & 1016 & 1147 & 88.56 & 92.11 & 86.38 & 1.04 & 1.04 & 1.11 & 0.90 & 1.12 & 0.98 & 1147 & 0 & 31 & 10.16 & 174 \\
\hline GR-LNB & $11 / 7 / 94$ & $0: 24$ & 120 & 1008 & 1141 & 88.33 & 92.19 & 86.24 & 1.05 & 1.01 & 0.97 & 0.84 & 1.14 & 0.93 & 1074 & 66 & 462 & 10.01 & 74 \\
\hline GR-LNB & $11 / 7 / 94$ & $1: 35$ & 125 & 1025 & 1164 & 88.09 & 92.18 & 86.08 & 1.05 & 1.02 & 0.99 & 0.85 & 1.12 & 0.94 & 1048 & 116 & 121 & 10.02 & 86 \\
\hline LNB (D out) & $11 / 7 / 94$ & $0: 15$ & 132 & 1009 & 1142 & 88.35 & 91.93 & 86.08 & 1.03 & 1.06 & 1.08 & 0.89 & 1.33 & 0.99 & 1135 & 7 & 305 & 9.83 & 119 \\
\hline GR-LNB & $11 / 7 / 94$ & $0: 16$ & 124 & 1052 & 1198 & 87.81 & 91.63 & 85.42 & 1.04 & 1.10 & 0.97 & 0.88 & 1.38 & 1.07 & 1132 & 65 & 1 & 9.17 & 89 \\
\hline GR-LNB & $11 / 7 / 94$ & $0: 12$ & 128 & 1045 & 1191 & 87.79 & 91.83 & 85.60 & 1.04 & 1.08 & 1.01 & 0.87 & 1.39 & 1.03 & 1079 & 111 & 76 & 9.53 & 77 \\
\hline LNB & $11 / 8 / 94$ & 1.03 & 142 & 1018 & 1147 & 88.69 & 92.25 & 86.60 & 1.02 & 1.05 & 1.16 & 0.93 & 1.15 & 1.01 & 1147 & 0 & 87 & 10.27 & 150 \\
\hline GR-LNB(varied OFA) & $11 / 8 / 94$ & $0: 33$ & 127 & 1029 & 1162 & 88.53 & 92.48 & 86.62 & 1.04 & 1.10 & 1.02 & 0.88 & 1.08 & 1.00 & 1079 & 83 & 266 & 10.19 & 76 \\
\hline GR-LNB(OFA op) & $11 / 8 / 94$ & $2: 55$ & 126 & 1032 & 1165 & 88.56 & 92.51 & 86.66 & 1.04 & 1.09 & 1.00 & 0.87 & 1.10 & 1.00 & 1083 & 82 & 109 & 10.07 & 80 \\
\hline GR-LNB(D@80\%) & $11 / 8 / 94$ & $0: 40$ & 124 & 1026 & 1158 & 88.59 & 92.55 & 86.71 & 1.04 & 1.10 & 0.99 & 0.87 & 1.08 & 1.01 & 1073 & 85 & 275 & 10.02 & 75 \\
\hline LNB 1 & $11 / 9 / 94$ & $0: 18$ & 132 & 1012 & 1139 & 88.81 & 92.37 & 86.79 & 1.03 & 1.09 & 1.08 & 0.90 & 1.15 & 1.02 & 1139 & 0 & 12 & 10.21 & 152 \\
\hline GR-LNB 1 & $11 / 9 / 94$ & $3: 29$ & 130 & 1032 & 1166 & 88.58 & 92.65 & 86.74 & 1.06 & 0.91 & 1.01 & 0.83 & 0.98 & 0.95 & 1057 & 109 & 291 & 9.84 & 79 \\
\hline GR-LNB 2 & $11 / 9 / 94$ & $0: 39$ & 134 & 1039 & 1172 & 88.62 & 92.66 & 86.78 & 1.05 & 0.92 & 1.04 & 0.84 & 1.00 & 0.93 & 1070 & 103 & 171 & 10.06 & 74 \\
\hline GR.LNB 3 & $11 / 9 / 94$ & $0: 32$ & 153 & 1179 & 1330 & 88.64 & 92.67 & 86.70 & 1.04 & 1.03 & 1.08 & 0.87 & 0.84 & 0.95 & 1215 & 115 & 12 & 9.96 & 107 \\
\hline GR-LNB 4 & $11 / 9 / 94$ & $5: 31$ & 171 & 1289 & 1456 & 88.56 & 92.57 & 86.51 & 1.02 & 1.06 & 1.12 & 0.91 & 0.94 & 0.99 & 1336 & 120 & 32 & 9.93 & 124 \\
\hline GR-LNB 5 & $11 / 9 / 94$ & $0: 31$ & 141 & 1103 & 1248 & 88.32 & 92.36 & 86.19 & 1.04 & 1.01 & 1.05 & 0.87 & 1.19 & 1.03 & 1135 & 113 & 53 & 9.35 & 94 \\
\hline LNB 2 & $11 / 9 / 94$ & $0: 45$ & 111 & 799 & 899 & 88.84 & 92.47 & 86.96 & 1.06 & 0.79 & 1.07 & 0.85 & 1.10 & 0.99 & 887 & 12 & 20 & 9.48 & 68 \\
\hline GR-LNB 6 & $11 / 9 / 94$ & $0: 15$ & 109 & 811 & 914 & 88.80 & 92.75 & 87.10 & 1.06 & 0.69 & 1.02 & 0.82 & 1.11 & 0.93 & 850 & 64 & 303 & 9.54 & 44 \\
\hline GR-LNB 7 & $11 / 9 / 94$ & $0: 11$ & 112 & 816 & 920 & 88.74 & 92.94 & 87.16 & 1.06 & 0.71 & 1.04 & 0.82 & 1.05 & 0.90 & 815 & 105 & 392 & 9.84 & 42 \\
\hline GR-LNB 8 & $11 / 9 / 94$ & $0: 16$ & 106 & 806 & 909 & 88.68 & 92.71 & 86.97 & 1.06 & 0.71 & 1.00 & 0.81 & 1.08 & 0.95 & 832 & 77 & 64 & 9.39 & 46 \\
\hline LNB(120) & $11 / 10 / 94$ & $1: 15$ & 132 & 1026 & 1160 & 88.44 & 91.99 & 86.19 & 1.02 & 1.10 & 1.07 & 0.94 & 1.22 & 1.10 & 1160 & 0 & 55 & 9.45 & 157 \\
\hline $\operatorname{LNB}(150)$ & $11 / 10 / 94$ & $0: 27$ & 179 & 1250 & 1409 & 88.70 & 92.26 & 86.48 & 0.99 & 1.08 & 1.21 & 1.00 & 1.06 & 1.04 & 1409 & 0 & 2 & 10.13 & 222 \\
\hline GR-LNB(43K) & $11 / 10 / 94$ & $0: 48$ & 162 & 1266 & 1433 & 88.35 & 92.34 & 86.27 & 1.00 & 1.12 & 1.08 & 0.95 & 1.07 & 1.03 & 1316 & 117 & 174 & 10.07 & 128 \\
\hline GR-LNB(46K) & $11 / 10 / 94$ & $1: 42$ & 163 & 1271 & 1440 & 88.25 & 92.25 & 86.10 & 1.00 & 1.12 & 1.08 & 0.94 & 1.06 & 1.02 & 1321 & 120 & 160 & 10.05 & 118 \\
\hline GR-LNB(53k) & $11 / 10 / 94$ & $1: 29$ & 160 & 1262 & 1431 & 88.20 & 92.20 & 86.01 & 1.01 & 1.12 & 1.07 & 0.93 & 1.06 & 1.03 & 1312 & 120 & 65 & 9.92 & 115 \\
\hline GR-LNB(61K) & $11 / 10 / 94$ & $9: 45$ & 158 & 1269 & 1438 & 88.24 & 92.25 & 86.09 & 1.01 & 1.12 & 1.05 & 0.92 & 1.20 & 1.04 & 1318 & 120 & 22 & 9.80 & 110 \\
\hline GR-LNB & $11 / 11 / 94$ & $9: 12$ & 156 & 1264 & 1433 & 88.23 & 92.24 & 86.07 & 1.01 & 1.13 & 1.04 & 0.92 & 1.04 & 1.05 & 1312 & 121 & 12 & 9.72 & 111 \\
\hline \multicolumn{20}{|c|}{$100 \%$ Gas Testing 11/2/94-11/11/94 (SR's ca } \\
\hline LNB(coal/gas) & $12 / 1 / 94$ & $2: 41$ & 157 & 1361 & 1546 & 88.07 & 91.60 & 87.43 & 1.03 & 1.04 & 0.95 & 0.81 & 1.01 & 1.00 & 1546 & 0 & 33 & 13.79 & 306 \\
\hline Test 21 & $1 / 19 / 95$ & 1.00 & 146 & 1156 & 1321 & 87.56 & 91.76 & 87.70 & 1.04 & 1.11 & 1.06 & 0.88 & 1.32 & 1.10 & 1157 & 163 & 11 & 15.06 & 183 \\
\hline Tost 22 & $1 / 19 / 95$ & $1: 02$ & 141 & 1158 & 1320 & 87.74 & 91.71 & 87.88 & 1.04 & 1.12 & 1.03 & 0.87 & 1.32 & 1.10 & 1213 & 106 & 11 & 15.20 & 188 \\
\hline Test 24 & $1 / 19 / 95$ & $0: 33$ & 104 & 859 & 981 & 87.56 & 91.07 & 87.68 & 1.04 & 1.17 & 0.99 & 0.92 & 1.56 & 1.24 & 981 & 0 & 69 & 14.40 & 220 \\
\hline Test 25 & $1 / 19 / 95$ & $0: 30$ & 100 & 871 & 995 & 87.50 & 91.01 & 87.61 & 1.04 & 1.19 & 0.94 & 0.90 & 1.50 & 1.26 & 995 & 0 & 31 & 14.09 & 192 \\
\hline Test 27 & $1 / 19 / 95$ & $0: 25$ & 98 & 869 & 991 & 87.65 & 91.17 & 87.79 & 1.04 & 1.18 & 0.92 & 0.88 & 1.52 & 1.23 & 991 & 0 & 15 & 14.51 & 175 \\
\hline
\end{tabular}


Post Modification

\begin{tabular}{|c|c|c|c|c|c|c|c|c|c|c|c|c|c|c|c|c|c|c|c|}
\hline resp & 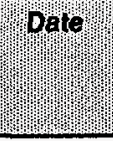 & Wחy & mbtukn & motompla & 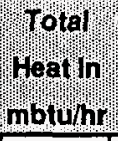 & Gross.jp & 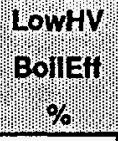 & poingoss & 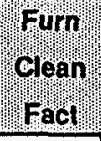 & Prył" & 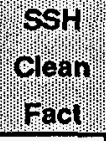 & 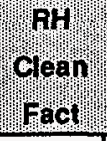 & $\begin{array}{l}\text { Ecow } \\
\text { ceaph } \\
\text { rract }\end{array}$ & 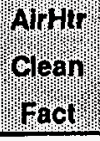 & 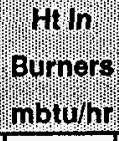 & 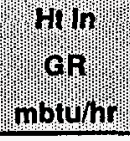 & papan & 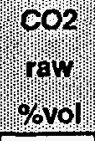 & $\begin{array}{l}\text { Nox } \\
\text { raw } \\
\text { ppm }\end{array}$ \\
\hline Test 30 & $1 / 20 / 95$ & 1.01 & 104 & 859 & 983 & 87.37 & 91.32 & 87.37 & 1.05 & 1.04 & 0.97 & 0.83 & 1.56 & 1.18 & 904 & 79 & 14 & 13.51 & 162 \\
\hline Test 31 & $1 / 20 / 95$ & 1.00 & 105 & 860 & 989 & 86.95 & 91.32 & 86.92 & 1.05 & 1.10 & 0.98 & 0.84 & 1.55 & 1.19 & 831 & 158 & 11 & 13.24 & 182 \\
\hline Test 32 & $1 / 20 / 95$ & 1.05 & 104 & 861 & 990 & 87.03 & 91.17 & 87.00 & 1.05 & 1.13 & 0.97 & 0.86 & 1.52 & 1.21 & 872 & 118 & 11 & 13.36 & 160 \\
\hline Test 33 & $1 / 20 / 95$ & $0: 40$ & 103 & 862 & 988 & 87.22 & 91.15 & 87.20 & 1.05 & 1.13 & 0.97 & 0.85 & 1.58 & 1.20 & 911 & 78 & 14 & 13.66 & 150 \\
\hline Test $1(\mathrm{R})$ & $1 / 24 / 95$ & $1: 00$ & 140 & 1276 & 1453 & 87.86 & 91.38 & 88.00 & 1.05 & 1.14 & 0.94 & 0.92 & 1.28 & 1.15 & 1453 & 0 & 67 & 15.02 & 399 \\
\hline Test 16 & $1 / 25 / 95$ & $0: 20$ & 158 & 1276 & 1451 & 87.94 & 92.13 & 88.06 & 1.06 & 1.01 & 1.05 & 0.84 & 1.15 & 1.02 & 1279 & 172 & 21 & 15.42 & 218 \\
\hline Test 17 & $1 / 25 / 95$ & $0: 40$ & 156 & 1276 & 1449 & 88.06 & 92.03 & 88.18 & 1.07 & 1.00 & 1.03 & 0.83 & 1.20 & 1.03 & 1333 & 116 & 18 & 15.49 & 220 \\
\hline Test 403 Mill & $1 / 25 / 95$ & 1.00 & 139 & 1153 & 1309 & 88.06 & 92.02 & 88.18 & 1.08 & 0.88 & 0.98 & 0.78 & 1.12 & 0.95 & 1208 & 102 & 44 & 15.63 & 166 \\
\hline Test $413 \mathrm{Mill}$ & $1 / 25 / 95$ & 1.00 & 134 & 1162 & 1328 & 87.49 & 91.88 & 87.57 & 1.07 & 0.98 & 0.96 & 0.81 & 1.24 & 1.02 & 1118 & 210 & 38 & 14.57 & 158 \\
\hline Test 423 Mill & $1 / 25 / 95$ & 1.00 & 135 & 1166 & 1330 & 87.70 & 91.89 & 87.78 & 1.07 & 1.01 & 0.96 & 0.82 & 1.30 & 1.02 & 1170 & 160 & 16 & 14.75 & 163 \\
\hline Test 433 Mill & $1 / 25 / 95$ & $0: 45$ & 133 & 1166 & 1327 & 87.90 & 91.87 & 87.97 & 1.07 & 0.96 & 0.94 & 0.81 & 1.27 & 1.02 & 1220 & 107 & 18 & 14.73 & 166 \\
\hline Test 2(R2) & $1 / 25 / 95$ & $0: 39$ & 152 & 1312 & 1491 & 87.99 & 91.51 & 88.08 & 1.06 & 1.08 & 0.99 & 0.86 & 1.30 & 1.11 & 1491 & 0 & $\pi$ & 14.69 & 352 \\
\hline Test 2(R) & $1 / 25 / 95$ & $0: 30$ & 146 & 1310 & 1492 & 87.79 & 91.31 & 87.84 & 1.06 & 1.09 & 0.95 & 0.86 & 1.27 & 1.14 & 1492 & 0 & 43 & 14.21 & 339 \\
\hline Test 14(R) & $1 / 25 / 95$ & $0: 20$ & 162 & 1307 & 1483 & 88.14 & 92.12 & 88.25 & 1.06 & 1.05 & 1.06 & 0.84 & 1.21 & 1.02 & 1363 & 120 & 37 & 15.87 & 192 \\
\hline Test 15(R) & $1 / 25 / 95$ & $0: 50$ & 164 & 1309 & 1489 & 87.87 & 92.19 & 87.98 & 1.06 & 1.07 & 1.08 & 0.86 & 1.21 & 1.02 & 1277 & 212 & 40 & 15.68 & 178 \\
\hline Test 16(R) & $1 / 26 / 95$ & $0: 24$ & 166 & 1300 & 1480 & 87.85 & 92.03 & 87.94 & 1.07 & 1.00 & 1.08 & 0.80 & 1.15 & 1.02 & 1306 & 174 & 38 & 15.28 & 181 \\
\hline Test 44 & $1 / 26 / 95$ & $0: 25$ & 159 & 1307 & 1485 & 87.99 & 91.90 & 88.14 & 1.06 & 1.07 & 1.04 & 0.84 & 1.25 & 1.01 & 1383 & 102 & 27 & 16.12 & 199 \\
\hline Test 45 & $1 / 26 / 95$ & $0: 30$ & 161 & 1306 & 1485 & 87.94 & 91.92 & 88.08 & 1.06 & 1.08 & 1.06 & 0.86 & 1.24 & 1.03 & 1364 & 120 & 26 & 15.98 & 191 \\
\hline Test 46 & $1 / 26 / 95$ & $0: 48$ & 165 & 1307 & 1490 & 87.75 & 92.03 & 87.89 & 1.05 & 1.09 & 1.09 & 0.88 & 1.28 & 1.03 & 1286 & 204 & 24 & 15.91 & 185 \\
\hline Test 47 & $1 / 26 / 95$ & $0: 30$ & 163 & 1306 & 1487 & 87.83 & 91.97 & 87.97 & 1.05 & 1.10 & 1.08 & 0.88 & 1.30 & 1.04 & 1320 & 167 & 21 & 15.88 & 191 \\
\hline LNB 3 Mill & 1/27/95 & $0: 45$ & 124 & 1080 & 1224 & 88.20 & 91.74 & 88.30 & 1.21 & 1.14 & 1.06 & 0.96 & 1.89 & 1.18 & 1224 & 0 & 42 & 15.37 & 306 \\
\hline Test 50 & $1 / 27 / 95$ & $0: 42$ & 130 & 1078 & 1228 & 87.83 & 91.77 & 87.91 & 1.20 & 1.13 & 1.11 & 0.98 & 1.96 & 1.16 & 1133 & 95 & 104 & 15.19 & 180 \\
\hline Test 51 & $1 / 27 / 95$ & $0: 31$ & 140 & 1075 & 1230 & 87.47 & 91.89 & 87.56 & 1.19 & 1.09 & 1.20 & 1.00 & 1.92 & 1.16 & 1027 & 203 & 59 & 14.79 & 163 \\
\hline Test 52 & $1 / 27 / 95$ & $0: 30$ & 140 & 1074 & 1225 & 87.67 & 91.86 & 87.79 & 1.18 & 1.09 & 1.21 & 1.00 & 1.93 & 1.16 & 1077 & 149 & 56 & 15.20 & 167 \\
\hline
\end{tabular}


Post Modification

\begin{tabular}{|c|c|c|c|c|c|c|c|c|c|c|c|c|c|c|c|c|c|c|}
\hline Tost NWW & 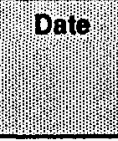 & our & $\begin{array}{c}\text { son } \\
\text { raw } \\
\text { ppm }\end{array}$ & 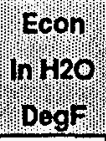 & 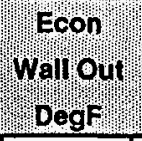 & coldan & 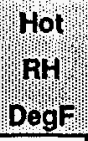 & $\begin{array}{l}\text { shy } \\
\text { artumpo } \\
\text { Dogr }\end{array}$ & प्रel] & Prespm & 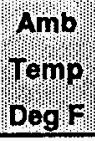 & 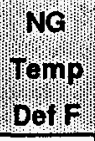 & 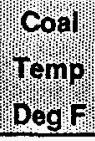 & 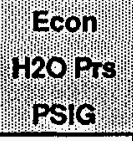 & 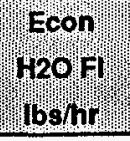 & 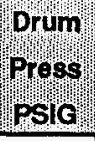 & 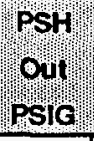 & 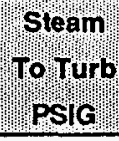 \\
\hline LNB OFA Cooling & $8 / 17 / 94$ & 3.08 & & & & & & 780 & & & & & & & & & & \\
\hline GR-LNB & $8 / 17 / 94$ & $1: 15$ & & & & & & 779 & & & & & & & & & & \\
\hline Test A (LNB) & $8 / 17 / 94$ & $0: 33$ & & & & & & 776 & & & & & & & & & & \\
\hline Test B (GR-LNB) & $8 / 17 / 94$ & $0: 40$ & & & & & & 782 & & & & & & & & & & \\
\hline$C$ (LNB) & $8 / 18 / 94$ & $0: 24$ & & & & & & 776 & & & & & & & & & & \\
\hline$D$ (GR-LNB rear fired) & $8 / 18 / 94$ & $0: 31$ & & & & & & 785 & & & & & & & & & & \\
\hline$E$ (GR-LNB front fired) & $8 / 18 / 94$ & $0: 36$ & & & & & & 785 & & & & & & & & & & \\
\hline$F(G R-L N B)$ & $8 / 18 / 94$ & $0: 36$ & & & & & & 783 & & & & & & & & & & \\
\hline GR-LNB (50k) & $8 / 29 / 94$ & $0: 22$ & & 499 & 523 & 811700 & 999 & 790 & 50.5 & 14.3 & 88 & 80 & 80 & 2014 & 1042174 & 1943 & 1883 & 1824 \\
\hline GR-LNB (<3k) & $8 / 29 / 94$ & $0: 21$ & & 499 & 523 & 813789 & 1003 & 772 & 50.5 & 14.3 & 88 & 80 & 80 & 2011 & 1028636 & 1941 & 1881 & 1822 \\
\hline GR-LNB (RW) & $8 / 30 / 94$ & $0: 19$ & & 501 & 523 & 833448 & 996 & 783 & 50.5 & 14.3 & 87 & 80 & 80 & 2026 & 1091000 & 1953 & 1889 & 1825 \\
\hline GR-LNB (BW) & $8 / 30 / 94$ & $0: 23$ & & 502 & 524 & 835391 & 1005 & 777 & 50.5 & 14.3 & 87 & 80 & 80 & 2025 & 1078750 & 1953 & 1889 & 1825 \\
\hline LNB-OFA tOOA & $8 / 31 / 94$ & 1.00 & & 499 & 521 & 826044 & 989 & 777 & 50.5 & 14.3 & 76 & 80 & 80 & 2020 & 1085574 & 1947 & 1885 & 1822 \\
\hline LNB-OFA 1000 & $8 / 31 / 94$ & 0.25 & & 499 & 521 & 826614 & 983 & 790 & 50.5 & 14.3 & 78 & 80 & 80 & 2022 & 1095769 & 1949 & 1886 & 1823 \\
\hline LNB-OFA 100E & $8 / 31 / 94$ & $0: 34$ & & 500 & 523 & 829383 & 987 & 791 & 50.5 & 14.3 & 79 & 80 & 80 & 2024 & 1092286 & 1951 & 1888 & 1824 \\
\hline LNB-OFA $110 \mathrm{~A}$ & $8 / 31 / 94$ & $0: 38$ & & 500 & 522 & 828107 & 987 & 784 & 50.5 & 14.3 & 79 & 80 & 80 & 2022 & 1087692 & 1949 & 1886 & 1823 \\
\hline LNB-OFA $110 \mathrm{~B}$ & $8 / 31 / 94$ & $0: 28$ & & 500 & 522 & 828981 & 986 & 779 & 50.5 & 14.3 & 78 & 80 & 80 & 2021 & 1082069 & 1948 & 1885 & 1822 \\
\hline LNB & $9 / 1 / 94$ & $1: 39$ & & 495 & 518 & 799327 & 980 & 775 & 50.5 & 14.3 & 69 & 80 & 80 & 2010 & 1047497 & 1938 & 1880 & 1823 \\
\hline GR-LNB 140A & $9 / 1 / 94$ & $0: 30$ & & 498 & 521 & 817103 & 995 & 785 & 50.5 & 14.3 & 72 & 80 & 80 & 2020 & 1070645 & 1947 & 1887 & 1826 \\
\hline GR-LNB $140 \mathrm{C}$ & $9 / 1 / 94$ & $0: 30$ & & 499 & 523 & 820045 & 998 & 782 & 50.5 & 14.3 & 76 & 80 & 80 & 2021 & 1062581 & 1949 & 1888 & 1828 \\
\hline GR-LNB 140D & $9 / 1 / 94$ & $0: 30$ & & 498 & 522 & 818605 & 997 & 781 & 50.5 & 14.3 & 77 & 80 & 80 & 2018 & 1055161 & 1946 & 1886 & 1826 \\
\hline LNB (0.5\% Gas) & $9 / 1 / 94$ & $2: 18$ & & 498 & 520 & 819750 & 987 & 759 & 50.5 & 14.3 & 78 & 80 & 80 & 2017 & 1054892 & 1945 & 1885 & 1826 \\
\hline Baseline (LNB) & $9 / 2 / 94$ & $0: 30$ & & 498 & 521 & 813779 & 990 & 769 & 50.5 & 14.3 & 72 & 80 & 80 & 2015 & 1048065 & 1943 & 1884 & 1825 \\
\hline GR-LNB $150 C$ & $9 / 2 / 94$ & $0: 30$ & & 498 & 523 & 813081 & 1002 & 784 & 50.5 & 14.3 & 73 & 80 & 80 & 2016 & 1047097 & 1944 & 1885 & 1826 \\
\hline GR-LNB 150D & $9 / 2 / 94$ & $0: 37$ & & 498 & 523 & 814670 & 999 & 784 & 50.5 & 14.3 & 77 & 80 & 80 & 2017 & 1050526 & 1945 & 1886 & 1827 \\
\hline LNB & $9 / 7 / 94$ & $1: 56$ & & 494 & 518 & 808973 & 959 & 778 & 50.5 & 14.3 & 82 & 80 & 80 & 2015 & 1083419 & 1941 & 1882 & 1823 \\
\hline GR-LNB 150 E & $9 / 7 / 94$ & $0: 30$ & & 495 & 522 & 808325 & 990 & 790 & 50.5 & 14.3 & 86 & 80 & 80 & 2016 & 1066129 & 1943 & 1884 & 1825 \\
\hline GR-LNB 150F & $9 / 7 / 94$ & $0: 30$ & & 494 & 520 & 808605 & 984 & 786 & 50.5 & 14.3 & 90 & 80 & 80 & 2014 & 1066452 & 1940 & 1882 & 1822 \\
\hline RR GR-LNB 150E & $9 / 7 / 94$ & $0: 30$ & & 494 & 521 & 809922 & 987 & 784 & 50.5 & 14.3 & 91 & 80 & 80 & 2015 & 1060968 & 1941 & 1883 & 1823 \\
\hline GR:LNB R.1 & $9 / 7 / 94$ & $0: 21$ & & 494 & 521 & 810580 & 987 & 783 & 50.5 & 14.3 & 92 & 80 & 80 & 2014 & 1060909 & 1941 & 1882 & 1822 \\
\hline LNB & 9/8/94 & 0.53 & & 494 & 521 & 803494 & 984 & 784 & 50.5 & 14.3 & 78 & 80 & 80 & 2009 & 1053148 & 1937 & 1878 & 1820 \\
\hline GR-LNB 150I & $9 / 8 / 94$ & $0: 30$ & & 495 & 522 & 808899 & 990 & 779 & 50.5 & 14.3 & 89 & 80 & 80 & 2012 & 1047419 & 1940 & 1882 & 1823 \\
\hline .5 gas, OFAcooling & 9/8/94 & 2.04 & & 494 & 519 & 801171 & 972 & 778 & 50.5 & 14.3 & 93 & 80 & 80 & 2011 & 1053167 & 1938 & 1881 & 1823 \\
\hline LNB(OFAcooling) & $9 / 8 / 94$ & $0: 28$ & & 496 & 521 & 806122 & 985 & 782 & 50.5 & 14.3 & 95 & 80 & 80 & 2012 & 1045172 & 1939 & 1881 & 1823 \\
\hline
\end{tabular}


Post Modification

\begin{tabular}{|c|c|c|c|c|c|c|c|c|c|c|c|c|c|c|c|c|c|c|}
\hline $\begin{array}{l}\text { Tosi } \\
\mathrm{No}\end{array}$ & Dare & Durf & $\begin{array}{l}\mathrm{SO} 2 \\
\mathrm{rw} \\
\mathrm{ppm}\end{array}$ & $\begin{array}{l}\text { Econ } \\
\text { hrito } \\
\text { DegF }\end{array}$ & $\begin{array}{l}\text { Econ } \\
\text { Wallout } \\
\text { Degr }\end{array}$ & $\begin{array}{l}\text { Cold } \mathrm{pH} \\
\text { Fow } \\
\text { fos } / \mathrm{hr}\end{array}$ & $\begin{array}{l}\text { Hot } \\
\mathrm{RH} \\
\text { DegF }\end{array}$ & $\begin{array}{c}\text { SH } \\
\text { Artmpo } \\
\text { DegF }\end{array}$ & $\begin{array}{l}\text { Ref } \\
\text { hump } \\
\text { pun } \\
\text { \% }\end{array}$ & $\begin{array}{l}\text { Amb } \\
\text { Pross } \\
\text { P } \mathrm{HgA}\end{array}$ & $\begin{array}{l}\text { Amb } \\
\text { Temp } \\
\text { Deg } F\end{array}$ & $\begin{array}{l}\text { Na } \\
\text { Temp } \\
\text { Def } F\end{array}$ & $\begin{array}{l}\text { Coal } \\
\text { Tepp } \\
\text { Deg F }\end{array}$ & 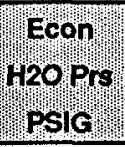 & $\begin{array}{l}\text { Econ } \\
\text { H2O F } \\
\text { ibshr }\end{array}$ & $\begin{array}{l}\text { prum } \\
\text { Press } \\
\text { PSIG }\end{array}$ & $\begin{array}{c}P S H \\
\text { owp } \\
\text { PSIO }\end{array}$ & $\begin{array}{l}\text { steam } \\
\text { To Turb } \\
\text { rsia }\end{array}$ \\
\hline LNB & 9/9/94 & $0: 45$ & & 495 & 519 & 806305 & 975 & 783 & 50.5 & 14.3 & 85 & 80 & 80 & 2015 & 1067609 & 1943 & 1883 & 1824 \\
\hline GR-LNB.R6\% & 9/9/94 & $0: 22$ & & 495 & 519 & 809019 & 964 & 792 & 50.5 & 14.3 & 89 & 80 & 80 & 2018 & 1079130 & 1945 & 1886 & 1826 \\
\hline GR-LNB.R8\% & $9 / 9 / 94$ & $0: 11$ & & 496 & 519 & 808955 & 969 & 792 & 50.5 & 14.3 & 91 & 80 & 80 & 2017 & 1072500 & 1944 & 1884 & 1825 \\
\hline GR-LNB.R10\% & 9/9/94 & $0: 18$ & & 494 & 519 & 808419 & 971 & 790 & 50.5 & 14.3 & 92 & 80 & 80 & 2018 & 1073077 & 1944 & 1885 & 1825 \\
\hline GR-LNB.B12\% & $9 / 9 / 94$ & $0: 17$ & & 496 & 520 & 807355 & 976 & 790 & 50.5 & 14.3 & 94 & 80 & 80 & 2014 & 1064444 & 1942 & 1882 & 1823 \\
\hline LNB-OFAcooling & 9/9/94 & $0: 14$ & & 496 & 520 & 806524 & 983 & 784 & 50.5 & 14.3 & 96 & 80 & 80 & 2011 & 1055333 & 1939 & 1879 & 1820 \\
\hline LNB & $9 / 21 / 94$ & 0.55 & 318 & 479 & 503 & 705244 & 910 & 777 & 50.5 & 14.3 & 70 & 80 & 80 & 1954 & 897281 & 1888 & 1849 & 1808 \\
\hline LNB & $9 / 21 / 94$ & 2.05 & 336 & 496 & 520 & 821270 & 953 & 794 & 50.5 & 14.3 & 72 & 80 & 80 & 2008 & 1060714 & 1936 & 1877 & 1818 \\
\hline LNB & $9 / 21 / 94$ & $1: 45$ & 348 & 496 & 518 & 828132 & 938 & 785 & 50.5 & 14.3 & 66 & 80 & 80 & 2013 & 1076218 & 1940 & 1881 & 1822 \\
\hline LNB & $9 / 21 / 94$ & $2: 51$ & 374 & 496 & 516 & 827793 & 926 & 771 & 50.5 & 14.3 & 55 & 80 & 80 & 2012 & 1077791 & 1938 & 1880 & 1823 \\
\hline LNB 150 & $10 / 3 / 94$ & $4: 13$ & 332 & 509 & 527 & 941684 & 931 & 773 & 50.5 & 14.3 & 67 & 80 & 80 & 2071 & 1247992 & 1989 & 1910 & 1831 \\
\hline LNB 150 & $10 / 3 / 94$ & $3: 54$ & 332 & 505 & 524 & 901863 & 932 & 779 & 50.5 & 14.3 & 67 & 80 & 80 & 2051 & 1188340 & 1972 & 1900 & 1828 \\
\hline LNB & $10 / 3 / 94$ & $1: 48$ & 329 & 496 & 517 & 838070 & 911 & 770 & 50.5 & 14.3 & 66 & 80 & 80 & 2023 & 1100204 & 1948 & 1887 & 1827 \\
\hline LNB(on dlspatch) & $10 / 4 / 94$ & $4: 10$ & 321 & 471 & 494 & 668437 & 872 & 751 & 50.5 & 14.3 & 67 & 80 & 80 & 1954 & 852892 & 1888 & 1854 & 1819 \\
\hline LNB(on dispatch) & $10 / 4 / 94$ & $6: 15$ & 328 & 505 & 525 & 886498 & 956 & 791 & 50.5 & 14.3 & 67 & 80 & 80 & 2044 & 1155183 & 1967 & 1898 & 1828 \\
\hline LNB 150 & $10 / 4 / 94$ & $2: 22$ & 343 & 508 & 526 & 935442 & 922 & 765 & 50.5 & 14.3 & 68 & 80 & 80 & 2065 & 1238182 & 1984 & 1907 & 1829 \\
\hline LNB-OFA & $10 / 4 / 94$ & $0: 10$ & 329 & 507 & 527 & 938161 & 927 & 769 & 50.5 & 14.3 & 70 & 80 & 80 & 2063 & 1244545 & 1982 & 1903 & 1824 \\
\hline LNB-OFA & $10 / 4 / 94$ & $0: 45$ & 321 & 508 & 527 & 944936 & 915 & 773 & 50.5 & 14.3 & 70 & 80 & 80 & 2072 & 1254783 & 1990 & 1911 & 1832 \\
\hline GR-LNB (6\%) & $10 / 4 / 94$ & $0: 20$ & 318 & 510 & 528 & 936635 & 942 & 782 & 50.5 & 14.3 & 70 & 80 & 80 & 2070 & 1238571 & 1989 & 1910 & 1831 \\
\hline GR-LNB $(8 \%)$ & $10 / 4 / 94$ & $0: 26$ & 315 & 510 & 529 & 934141 & 955 & 786 & 50.5 & 14.3 & 70 & 80 & 80 & 2070 & 1231111 & 1989 & 1910 & 1831 \\
\hline GR-LNB $(10 \%)$ & $10 / 4 / 94$ & $0: 15$ & 312 & 510 & 530 & 933228 & 965 & 786 & 50.5 & 14.3 & 70 & 80 & 80 & 2070 & 1225625 & 1990 & 1911 & 1833 \\
\hline GR-LNB (15\%) & $10 / 4 / 94$ & $0: 17$ & 299 & 510 & 531 & 931481 & 977 & 787 & 50.5 & 14.3 & 70 & 80 & 80 & 2067 & 1212778 & 1987 & 1909 & 1830 \\
\hline LNB & $10 / 5 / 94$ & $2: 36$ & 347 & 506 & 528 & 919057 & 945 & 782 & 50.5 & 14.3 & 83 & 80 & 80 & 2061 & 1207261 & 1981 & 1905 & 1829 \\
\hline LNB & $10 / 5 / 94$ & $0: 43$ & 332 & 505 & 530 & 923736 & 959 & 792 & 50.5 & 14.3 & 85 & 80 & 80 & 2062 & 1202045 & 1983 & 1906 & 1829 \\
\hline LNB(pre-test) & $10 / 14 / 94$ & $3: 35$ & 340 & 505 & 524 & 899536 & 940 & 772 & 50.5 & 14.3 & 73 & 80 & 80 & 2047 & 1184388 & 1968 & 1896 & 1824 \\
\hline LNB & $10 / 14 / 94$ & 0.24 & 337 & 508 & 527 & 924742 & 944 & 781 & 50.5 & 14.3 & 76 & 80 & 80 & 2059 & 1219200 & 1978 & 1901 & 1824 \\
\hline GR-LNB 3 Mill & $10 / 14 / 94$ & $0: 20$ & 308 & 497 & 520 & 844097 & 946 & 779 & 50.5 & 14.3 & 76 & 80 & 80 & 2026 & 1095714 & 1950 & 1888 & 1826 \\
\hline LNB 4 Mill & $10 / 18 / 94$ & $0: 34$ & 335 & 505 & 524 & 923859 & 900 & 766 & 50.5 & 14.3 & 69 & 80 & 80 & 2057 & 1223429 & 1977 & 1900 & 1824 \\
\hline GR-LNB 3 Mill & 10/18/94 & $0: 53$ & 304 & 492 & 513 & 785675 & 928 & 773 & 50.5 & 14.3 & 68 & 80 & 80 & 1997 & 1005333 & 1926 & 1872 & 1819 \\
\hline GR-LNB 3 MIII & $10 / 18 / 94$ & 0.24 & 289 & 495 & 516 & 810663 & 934 & 777 & 50.5 & 14.3 & 68 & 80 & 80 & 2007 & 1041020 & 1934 & 1876 & 1819 \\
\hline LNB(pre-test) & $10 / 20 / 94$ & $2: 29$ & 341 & 510 & 529 & 930584 & 966 & 788 & 50.5 & 14.3 & 58 & 80 & 80 & 2065 & 1223200 & 1983 & 1905 & 1827 \\
\hline LNB a & $10 / 20 / 94$ & 1.04 & 337 & 510 & 530 & 933268 & 966 & 788 & 50.5 & 14.3 & 65 & 80 & 80 & 2066 & 1224000 & 1984 & 1907 & 1829 \\
\hline LNB b & $10 / 20 / 94$ & $0: 19$ & 336 & 511 & 530 & 934105 & 968 & 790 & 50.5 & 14.3 & 67 & 80 & 80 & 2067 & 1225000 & 1985 & 1907 & 1829 \\
\hline LNB C & $10 / 20 / 94$ & 0.32 & 336 & 510 & 530 & 933836 & 968 & 790 & 50.5 & 14.3 & 68 & 80 & 80 & 2067 & 1224242 & 1985 & 1907 & 1829 \\
\hline
\end{tabular}


Post Modification

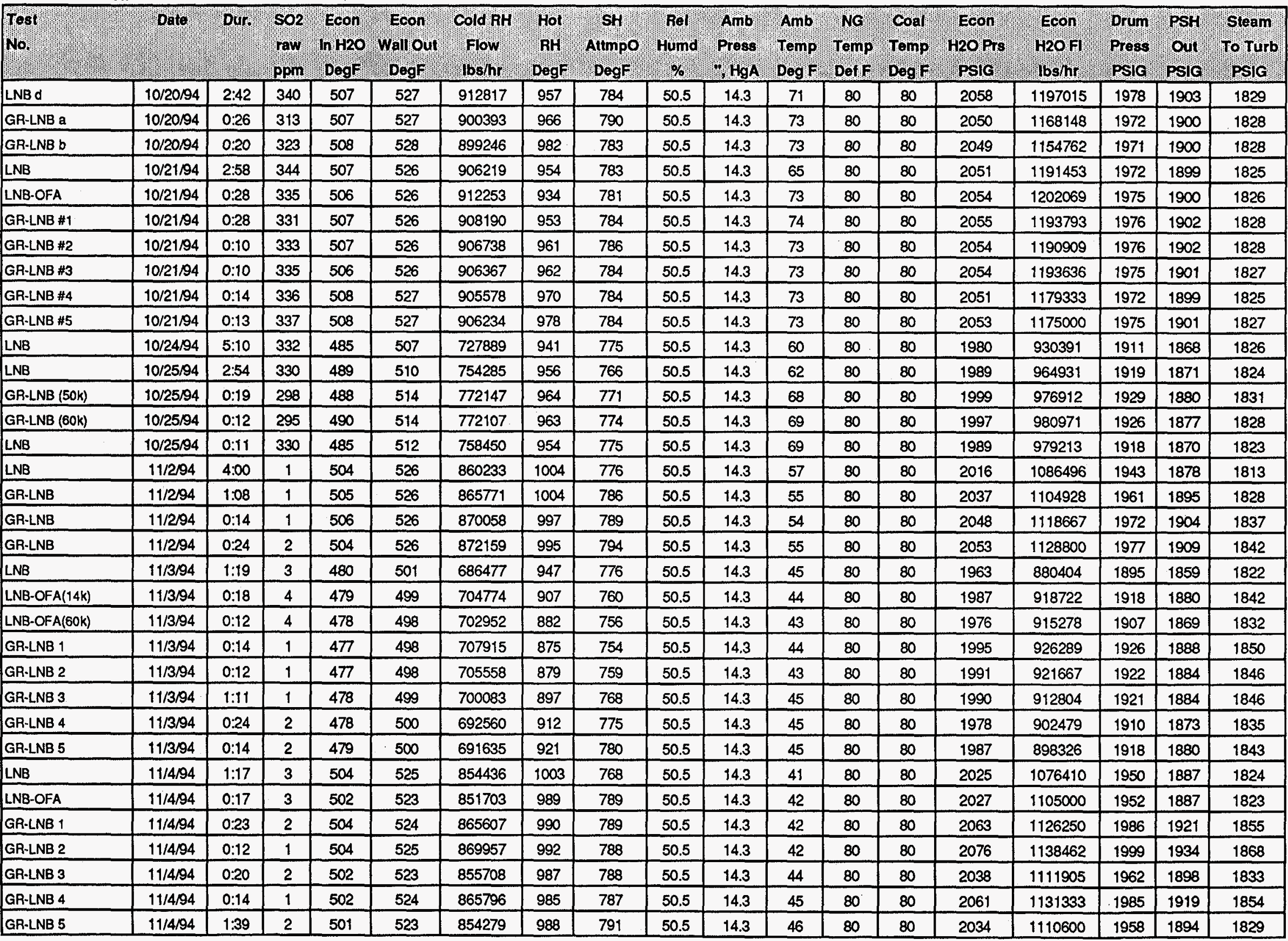


Cheorkee Unil \#3, Average Test Data

\section{Post Moditication}

\begin{tabular}{|c|c|c|c|c|c|c|c|c|c|c|c|c|c|c|c|c|c|c|}
\hline Tos & סate & pur & 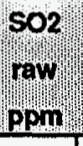 & $\begin{array}{l}\text { Econ } \\
\text { nfy } \\
\text { Dogf }\end{array}$ & $\begin{array}{l}\text { Econ } \\
\text { Waltony } \\
\text { Degr }\end{array}$ & 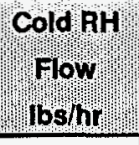 & पhot & 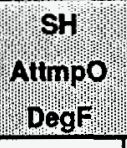 & 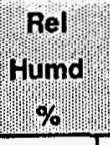 & 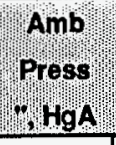 & Amb & 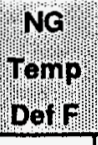 & coal" & 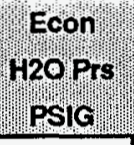 & שदcon] & prumy & Pry, & 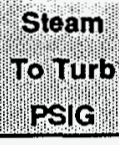 \\
\hline LNB & $11 / 7 / 94$ & $1: 43$ & 3 & 479 & 501 & 681301 & 958 & 768 & 50.5 & 14.3 & 67 & 80 & 80 & 1973 & 872120 & 1907 & 1869 & 1832 \\
\hline GR-LNB & $+1 / 7 / 94$ & $0: 24$ & 3 & 476 & 498 & 687500 & 908 & 766 & 50.5 & 14.3 & 80 & 80 & 80 & 1942 & 887829 & 1876 & 1836 & 1797 \\
\hline GR-LNB & $11 / 7 / 94$ & $1: 35$ & 2 & 478 & 499 & 695488 & 915 & 767 & 50.5 & 14.3 & 80 & 80 & 80 & 1973 & 903752 & 1906 & 1866 & 1825 \\
\hline LNB (D out) & $11 / 7 / 94$ & $0: 15$ & 2 & 475 & 501 & 681412 & 945 & 769 & 50.5 & 14.3 & 79 & 80 & 80 & 1947 & 861992 & 1880 & 1842 & 1804 \\
\hline GR-LNB & $11 / 7 / 94$ & $0: 16$ & 1 & 477 & 504 & 701142 & 943 & 785 & 50.5 & 14.3 & 76 & 80 & 80 & 2003 & 912536 & 1934 & 1894 & 1853 \\
\hline GR-LNB & $11 / 7 / 94$ & $0: 12$ & 1 & 476 & 503 & 699582 & 939 & 778 & 50.5 & 14.3 & 76 & 80 & 80 & 1997 & 905594 & 1929 & 1889 & 1848 \\
\hline LNB & $11 / 8 / 94$ & $1: 03$ & 1 & 481 & 503 & 690200 & 967 & 761 & 50.5 & 14.3 & 49 & 80 & 80 & 1966 & 859931 & 1900 & 1863 & 1826 \\
\hline GR-LNB(varied OFA) & $11 / 8 / 94$ & 0.33 & 1 & 481 & 502 & 694408 & 950 & 783 & 50.5 & 14.3 & 48 & 80 & 80 & 1988 & 890654 & 1919 & 1882 & 1844 \\
\hline GR-LNB(OFA op) & $11 / 8 / 94$ & $2: 55$ & 1 & 481 & 502 & 696962 & 940 & 782 & 50.5 & 14.3 & 45 & 80 & 80 & 1991 & 897271 & 1923 & 1885 & 1848 \\
\hline GR-LNB(D@80\%) & $11 / 8 / 94$ & $0: 40$ & 0 & 481 & 501 & 693401 & 941 & 783 & 50.5 & 14.3 & 42 & 80 & 80 & 1982 & 891622 & 1913 & 1876 & 1839 \\
\hline LNB 1 & $11 / 9 / 94$ & $0: 18$ & 1 & 479 & 502 & 681989 & 959 & 774 & 50.5 & 14.3 & 41 & 80 & 80 & 1958 & 863433 & 1892 & 1855 & 1819 \\
\hline GR-LNB 1 & $11 / 9 / 94$ & $3: 29$ & 2 & 479 & 498 & 709457 & 893 & 747 & 50.5 & 14.3 & 46 & 80 & 80 & 1955 & 925134 & 1887 & 1847 & 1807 \\
\hline GR-LNB 2 & $11 / 9 / 94$ & $0: 39$ & 1 & 479 & 498 & 711483 & 901 & 750 & 50.5 & 14.3 & 52 & 80 & 80 & 1969 & 925877 & 1901 & 1860 & 1820 \\
\hline GR-LNB 3 & $11 / 9 / 94$ & $0: 32$ & 1 & 494 & 511 & 801736 & 952 & 773 & 50.5 & 14.3 & 52 & 80 & 80 & 2021 & 1045847 & 1948 & 1891 & 1836 \\
\hline GR-LNB 4 & $11 / 9 / 94$ & $5: 31$ & 1 & 504 & 523 & 867950 & 994 & 779 & 50.5 & 14.3 & 49 & 80 & 80 & 2054 & 1137590 & 1977 & 1909 & 1842 \\
\hline GR-LNB 5 & $11 / 9 / 94$ & $0: 31$ & 0 & 485 & 509 & 728195 & 956 & 767 & 50.5 & 14.3 & 45 & 80 & 80 & 1982 & 967967 & 1912 & 1868 & 1823 \\
\hline LNB 2 & $11 / 9 / 94$ & $0: 45$ & 0 & 453 & 474 & 548391 & 855 & 719 & 50.5 & 14.3 & 45 & 80 & 80 & 1912 & 699783 & 1850 & 1832 & 1813 \\
\hline GR-LNB 6 & $11 / 9 / 94$ & $0: 15$ & 1 & 452 & 473 & 565049 & 805 & 709 & 50.5 & 14.3 & 45 & 80 & 80 & 1924 & 729800 & 1861 & 1842 & 1822 \\
\hline GR-LNB 7 & $11 / 9 / 94$ & $0: 11$ & 0 & 453 & 473 & 568404 & 808 & 712 & 50.5 & 14.3 & 44 & 80 & 80 & 1946 & 730165 & 1883 & 1862 & 1843 \\
\hline GR-LNB 8 & $11 / 9 / 94$ & $0: 16$ & 1 & 452 & 473 & 560502 & 804 & 710 & 50.5 & 14.3 & 44 & 80 & 80 & 1909 & 725196 & 1846 & 1827 & 1807 \\
\hline $\operatorname{LNB}(120)$ & $11 / 10 / 94$ & $1: 15$ & 1 & 481 & 504 & 689772 & 976 & 774 & 50.5 & 14.3 & 46 & 80 & 80 & 1957 & 869549 & 1891 & 1853 & 1816 \\
\hline L.NB(150) & $11 / 10 / 94$ & $0: 27$ & 1 & 504 & 525 & 850431 & 1013 & 762 & 50.5 & 14.3 & 47 & 80 & 80 & 2026 & 1061071 & 1953 & 1890 & 1828 \\
\hline GR-LNB(43K) & $11 / 10 / 94$ & $0: 48$ & 1 & 503 & 524 & 854965 & 1000 & 783 & 50.5 & 14.3 & 48 & 80 & 80 & 2039 & 1096531 & 1964 & 1900 & 1835 \\
\hline GR-LNB(46k) & $11 / 10 / 94$ & $1: 42$ & 0 & 504 & 524 & 859041 & 1002 & 783 & 50.5 & 14.3 & 54 & 80 & 80 & 2049 & 1104369 & 1973 & 1908 & 1843 \\
\hline GR-LNB(53k) & $11 / 10 / 94$ & $1: 29$ & 0 & 503 & 524 & 854097 & 999 & 785 & 50.5 & 14.3 & 55 & 80 & 80 & 2037 & 1099556 & 1962 & 1897 & 1832 \\
\hline GR-LNB(61k) & $11 / 10 / 94$ & $9: 45$ & 0 & 500 & 524 & 856880 & 994 & 789 & 50.5 & 14.3 & 50 & 80 & 80 & 2043 & 1108094 & 1967 & 1902 & 1837 \\
\hline GR-LNB & $11 / 11 / 94$ & $9: 12$ & 0 & 503 & 524 & 856270 & 994 & 790 & 50.5 & 14.3 & 48 & 80 & 80 & 2041 & 1107649 & 1965 & 1901 & 1836 \\
\hline \multicolumn{19}{|c|}{$100 \%$ Gas Testing 11/2/94-11/11/94 (SR's of } \\
\hline LNB(coal/gas) & $12 / 1 / 94$ & $2: 41$ & 241 & 507 & 526 & 935691 & 937 & 780 & 50.5 & 14.3 & 76 & 80 & 80 & 2071 & 1253272 & 1989 & 1909 & 1829 \\
\hline Test 21 & $1 / 19 / 95$ & $1: 00$ & 356 & 480 & 506 & 702467 & 988 & 783 & 50.5 & 14.3 & 53 & 80 & 80 & 2000 & 992734 & 1943 & 1885 & 1827 \\
\hline Test 22 & $1 / 19 / 95$ & $1: 02$ & 366 & 479 & 506 & 704213 & 983 & 788 & 50.5 & 14.3 & 53 & 80 & 80 & 2002 & 997971 & 1945 & 1886 & 1828 \\
\hline Test 24 & $1 / 19 / 95$ & $0: 33$ & 367 & 451 & 481 & 512866 & 974 & 782 & 50.5 & 14.3 & 48 & 80 & 80 & 1929 & 709453 & 1880 & 1852 & 1824 \\
\hline Test 25 & $1 / 19 / 95$ & $0: 30$ & 356 & 453 & 482 & 521349 & 965 & 788 & 50.5 & 14.3 & 47 & 80 & 80 & 1933 & 724262 & 1884 & 1854 & 1825 \\
\hline Test 27 & $1 / 19 / 95$ & $0: 25$ & 363 & 452 & 481 & 523254 & 950 & 787 & 50.5 & 14.3 & 45 & 80 & 80 & 1933 & 727547 & 1884 & 1854 & 1825 \\
\hline
\end{tabular}


Cheorke Unit \#3, Average Test Data

\section{Post Modification}

\begin{tabular}{|c|c|c|c|c|c|c|c|c|c|c|c|c|c|c|c|c|c|c|}
\hline Nost & papte & Dur. & pop & 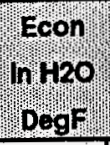 & 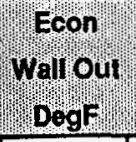 & cold RH & $\begin{array}{l}\text { Hot } \\
\text { refy } \\
\text { Degr }\end{array}$ & 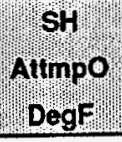 & $\begin{array}{l}\text { Treel } \\
\text { rumd }\end{array}$ & Press & 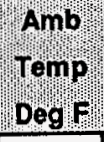 & पemp" & 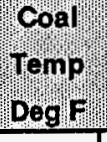 & 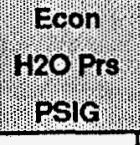 & 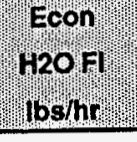 & Prom & בpsw & 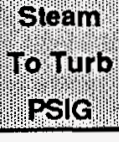 \\
\hline Test 30 & $1 / 20 / 95$ & $1: 01$ & 326 & 448 & 478 & 520143 & 908 & 760 & 50.5 & 14.3 & 50 & 80 & 80 & 1930 & 733013 & 1881 & 1851 & 1820 \\
\hline Test 31 & $1 / 20 / 95$ & $1: 00$ & 296 & 449 & 479 & 516331 & 931 & 773 & 50.5 & 14.3 & 52 & 80 & 80 & 1930 & 725507 & 1881 & 1851 & 1820 \\
\hline Test 32 & $1 / 20 / 95$ & 1.05 & 298 & 450 & 480 & 515585 & 942 & 779 & 50.5 & 14.3 & 52 & 80 & 80 & 1930 & 725056 & 1882 & 1851 & 1821 \\
\hline Test 33 & $1 / 20 / 95$ & $0: 40$ & 309 & 449 & 479 & 517065 & 938 & 778 & 50.5 & 14.3 & 54 & 80 & 80 & 1931 & 725773 & 1883 & 1852 & 1820 \\
\hline Test 1(R) & $1 / 24 / 95$ & 1.00 & 317 & 482 & 507 & 922972 & 965 & 794 & 50.5 & 14.3 & 51 & 80 & 80 & 2035 & 1108033 & 1973 & 1899 & 1824 \\
\hline Test 16 & $1 / 25 / 95$ & $0: 20$ & 300 & 478 & 502 & 923459 & 930 & 769 & 50.5 & 14.3 & 46 & 80 & 80 & 2035 & 1128095 & 1972 & 1898 & 1824 \\
\hline Test 17 & $1 / 25 / 95$ & $0: 40$ & 307 & 478 & 502 & 924220 & 925 & 768 & 50.5 & 14.3 & 46 & 80 & 80 & 2034 & 1128095 & 1970 & 1897 & 1823 \\
\hline Test 403 Mill & $1 / 25 / 95$ & $1: 00$ & 312 & 467 & 490 & 853942 & 852 & 741 & 50.5 & 14,3 & 64 & 80 & 80 & 2004 & 1043934 & 1944 & 1882 & 1819 \\
\hline Test 413 Mill & $1 / 25 / 95$ & $1: 00$ & 274 & 468 & 493 & 845764 & 888 & 762 & 50.5 & 14.3 & 66 & 80 & 80 & 2003 & 1031311 & 1944 & 1881 & 1819 \\
\hline Test 423 Mill & $1 / 25 / 95$ & $1: 00$ & 285 & 468 & 494 & 845948 & 897 & 767 & 50.5 & 14.3 & 65 & 80 & 80 & 2004 & 1029016 & 1946 & 1884 & 1820 \\
\hline Test 433 Mill & $1 / 25 / 95$ & $0: 45$ & 293 & 467 & 493 & 854228 & 880 & 758 & 50.5 & 14.3 & 62 & 80 & 80 & 2007 & 1041957 & 1949 & 1886 & 1822 \\
\hline Test 2(R2) & $1 / 25 / 95$ & $0: 39$ & 307 & 479 & 505 & 940963 & 948 & 785 & 50.5 & 14.3 & 54 & 80 & 80 & 2048 & 1149000 & 1984 & 1906 & 1827 \\
\hline Test 2(R) & $1 / 25 / 95$ & $0: 30$ & 295 & 479 & 505 & 944091 & 940 & 787 & 50.5 & 14.3 & 55 & 80 & 80 & 2049 & 1153226 & 1985 & 1907 & 1829 \\
\hline Test 14(F) & $1 / 25 / 95$ & $0: 20$ & 310 & 479 & 504 & 938854 & 942 & 780 & 50.5 & 14.3 & 51 & 80 & 80 & 2048 & 1144762 & 1984 & 1907 & 1829 \\
\hline Test $15(R)$ & $1 / 25 / 95$ & 0.50 & 295 & 480 & 505 & 936472 & 959 & 781 & 50.5 & 14.3 & 50 & 80 & 80 & 2047 & 1141373 & 1984 & 1906 & 1829 \\
\hline Test 16(R) & $1 / 26 / 95$ & 0.24 & 291 & 480 & 502 & 943674 & 920 & 768 & 50.5 & 14.3 & 51 & 80 & 80 & 2047 & 1154400 & 1983 & 1906 & 1828 \\
\hline Test 44 & $1 / 26 / 95$ & $0: 25$ & 364 & 478 & 503 & 935783 & 946 & 783 & 50.5 & 14.3 & 59 & 80 & 80 & 2046 & 1142308 & 1983 & 1906 & 1828 \\
\hline Test 45 & $1 / 26 / 95$ & $0: 30$ & 361 & 479 & 504 & 933791 & 957 & 784 & 50.5 & 14.3 & 57 & 80 & 80 & 2046 & 1136452 & 1983 & 1905 & 1828 \\
\hline Test 46 & $1 / 26 / 95$ & $0: 48$ & 343 & 480 & 506 & 932893 & 970 & 783 & 50.5 & 14.3 & 55 & 80 & 80 & 2045 & 1127959 & 1983 & 1905 & 1828 \\
\hline Test 47 & $1 / 26 / 95$ & $0: 30$ & 340 & 480 & 506 & 933121 & 970 & 785 & 50.5 & 14.3 & 54 & 80 & 80 & 2045 & 1128065 & 1983 & 1905 & 1828 \\
\hline LNB 3 Mill & $1 / 27 / 95$ & $0: 45$ & 363 & 351 & 393 & 822191 & 928 & 776 & 50.5 & 14.3 & 50 & 80 & 80 & 1963 & 814965 & 1909 & 1865 & 1821 \\
\hline Test 50 & $1 / 27 / 95$ & $0: 42$ & 359 & 350 & 394 & 820813 & 936 & 768 & 50.5 & 14.3 & 56 & 80 & 80 & 1962 & 804710 & 1908 & 1865 & 1822 \\
\hline Test 51 & $1 / 27 / 95$ & $0: 31$ & 323 & 351 & 395 & 819892 & 941 & 753 & 50.5 & 14.3 & 55 & 80 & 80 & 1960 & 796547 & 1907 & 1864 & 1821 \\
\hline Test 52 & $1 / 27 / 95$ & $0: 30$ & 336 & 352 & 395 & 819807 & 940 & 751 & 50.5 & 14.3 & 56 & 80 & 80 & 1959 & 793331 & 1906 & 1863 & 1820 \\
\hline
\end{tabular}


Post Modification

\begin{tabular}{|c|c|c|c|c|c|c|c|c|c|c|c|c|c|c|c|c|c|}
\hline Tost & Date & but & $\begin{array}{l}\text { RH In } \\
\text { press } \\
\text { PSia }\end{array}$ & $\begin{array}{l}\text { RH } \\
\text { Tomp } \\
\text { ogg }\end{array}$ & $\begin{array}{l}\text { Hot RH } \\
\text { out prs } \\
\text { PSIG }\end{array}$ & Prycass & $\begin{array}{l}\text { Moist } \\
\text { htiss } \\
\text { of }\end{array}$ & 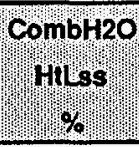 & $\begin{array}{l}\text { Refuse } \\
\text { pilsss } \\
\%\end{array}$ & $\begin{array}{l}\text { Radiat } \\
\text { Htuss } \\
8\end{array}$ & 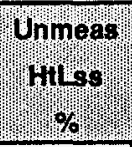 & $\begin{array}{l}\text { Total } \\
\text { piss } \\
\text { 8s }\end{array}$ & $\begin{array}{l}\text { Comb } \\
\text { Afr } \\
\text { Temp }\end{array}$ & $\begin{array}{l}\text { Ecoon } \\
\text { Gas ont } \\
\text { Temp }\end{array}$ & $\begin{array}{l}\text { AH Gas } \\
\text { cour } \\
\text { Temp }\end{array}$ & 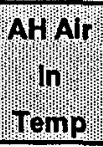 & $\begin{array}{l}\text { AH Ait } \\
\text { Out } \\
\text { Temp }\end{array}$ \\
\hline LNB OFA Cooling & $8 / 17 / 94$ & 3.08 & 329 & & 316 & 5.04 & 1.11 & 4.27 & 0.61 & & & 12.44 & & & 313 & & 624 \\
\hline GR-LNB & $8 / 17 / 94$ & $1: 15$ & 352 & & 332 & 5.15 & 1.03 & 4.74 & 0.56 & & & 12.89 & & & 315 & & 621 \\
\hline Test A (LNB) & $8 / 17 / 94$ & $0: 33$ & 364 & & 339 & 5.06 & 1.11 & 4.28 & 0.61 & & & 12.46 & & & 318 & & 627 \\
\hline Test B (GR-LNB) & $8 / 1794$ & $0: 40$ & 362 & & 337 & 5.35 & 1.02 & 4.81 & 0.56 & & & 13.14 & & & 319 & & 627 \\
\hline$C(L N B)$ & $8 / 18 / 94$ & $0: 24$ & 371 & & 348 & 5.03 & 1.11 & 4.28 & 0.61 & & & 12.43 & & & 318 & & 625 \\
\hline D (GR-LNB rear fired) & $8 / 18 / 94$ & $0: 31$ & 370 & & 349 & 5.25 & 1.02 & 4.82 & 0.56 & & & 13.05 & & & 319 & & 626 \\
\hline$E$ (GR-LNB front fired) & $8 / 18 / 94$ & $0: 36$ & 354 & & 334 & 5.23 & 1.02 & 4.81 & 0.56 & & & 13.02 & & & 317 & & 624 \\
\hline$F$ (GR-LNB) & $8 / 18 / 94$ & $0: 36$ & 384 & & 363 & 5.12 & 1.02 & 4.81 & 0.56 & & & 12.92 & & & 321 & & 629 \\
\hline GR-LNB (50k) & $8 / 29 / 94$ & $0: 22$ & 369 & 646 & 347 & 5.22 & 1.02 & 4.79 & 0.56 & 0.24 & 0.98 & 12.82 & 80 & 730 & 317 & 88 & 637 \\
\hline GR-LNB $(<3 k)$ & $8 / 29 / 94$ & $0: 21$ & 371 & 646 & 350 & 4.99 & 1.02 & 4.80 & 0.56 & 0.25 & 0.98 & 12.60 & 80 & 727 & 319 & 88 & 641 \\
\hline GR-LNB (RW) & $8 / 30 / 94$ & $0: 19$ & 380 & 649 & 359 & 5.21 & 1.02 & 4.78 & 0.56 & 0.23 & 0.93 & 12.73 & 80 & 713 & 314 & 87 & 622 \\
\hline GR-LNB (BW) & $8 / 30 / 94$ & $0: 23$ & 382 & 650 & 360 & 5.18 & 0.94 & 5.26 & 0.52 & 0.23 & 0.93 & 13.06 & 80 & 717 & 318 & 87 & 628 \\
\hline LNB-OFA $100 \mathrm{~A}$ & $8 / 31 / 94$ & 1.00 & 381 & 645 & 365 & 5.10 & 1.11 & 4.27 & 0.61 & 0.23 & 0.94 & 12.25 & 80 & 705 & 311 & 76 & 624 \\
\hline LNB-OFA 1000 & $8 / 31 / 94$ & $0: 25$ & 379 & 643 & 362 & 5.28 & 1.11 & 4.26 & 0.61 & 0.23 & 0.93 & 12.42 & 80 & 710 & 310 & 78 & 622 \\
\hline LNB-OFA $100 E$ & $8 / 31 / 94$ & $0: 34$ & 379 & 645 & 361 & 5.39 & 1.11 & 4.27 & 0.61 & 0.23 & 0.93 & 12.54 & 80 & 719 & 313 & 79 & 629 \\
\hline LNB-OFA $110 A$ & $8 / 31 / 94$ & $0: 38$ & 379 & 646 & 361 & 5.15 & 1.11 & 4.27 & 0.61 & 0.23 & 0.94 & 12.31 & 80 & 714 & 312 & 79 & 629 \\
\hline LNB-OFA 110B & $8 / 31 / 94$ & $0: 28$ & 379 & 645 & 361 & 5.11 & 1.11 & 4.27 & 0.61 & 0.23 & 0.94 & 12.26 & 80 & 715 & 312 & 78 & 629 \\
\hline LNB & $9 / 1 / 94$ & $1: 39$ & 369 & 639 & 356 & 4.95 & 1.11 & 4.26 & 0.61 & 0.25 & 0.98 & 12.15 & 80 & 699 & 306 & 69 & 621 \\
\hline GR-LNB 140A & $9 / 1 / 94$ & $0: 30$ & 379 & 644 & 364 & 5.07 & 1.00 & 4.91 & 0.55 & 0.24 & 0.95 & 12.71 & 80 & 714 & 309 & 72 & 627 \\
\hline GR-LNB $140 \mathrm{C}$ & 9/1/94 & $0: 30$ & 379 & 644 & 364 & 5.19 & 0.99 & 4.93 & 0.55 & 0.24 & 0.96 & 12.85 & 80 & 719 & 311 & 76 & 630 \\
\hline GR-LNB $140 D$ & 9/194 & $0: 30$ & 377 & 643 & 361 & 5.25 & 1.00 & 4.92 & 0.55 & 0.24 & 0.96 & 12.91 & 80 & 720 & 312 & 77 & 632 \\
\hline $\operatorname{LNB}(0.5 \%$ Gas) & $9 / 1 / 94$ & $2: 18$ & 375 & 643 & 358 & 4.73 & 1.10 & 4.31 & 0.61 & 0.24 & 0.96 & 11.95 & 80 & 705 & 312 & 78 & 627 \\
\hline Baseline (LNB) & 9/294 & $0: 30$ & 377 & 641 & 363 & 5.02 & 1.11 & 4.28 & 0.61 & 0.24 & 0.97 & 12.23 & 80 & 718 & 317 & 72 & 639 \\
\hline GR-LNB $150 C$ & $9 / 2 / 94$ & $0: 30$ & 377 & 645 & 363 & 5.22 & 1.04 & 4.66 & 0.57 & 0.24 & 0.97 & 12.70 & 80 & 729 & 314 & 73 & 639 \\
\hline GR-LNB 1500 & $9 / 2 / 94$ & $0: 37$ & 376 & 644 & 360 & 5.28 & 1.04 & 4.67 & 0.57 & 0.24 & 0.97 & 12.77 & 80 & 728 & 317 & 77 & 640 \\
\hline LNB & $9 / 7 / 94$ & $1: 56$ & 369 & 631 & 354 & 5.23 & 1.11 & 4.28 & 0.61 & 0.24 & 0.95 & 12.41 & 80 & 698 & 318 & 82 & 624 \\
\hline GR-LNB 150E & $9 / 794$ & $0: 30$ & 372 & 641 & 356 & 5.48 & 1.00 & 4.93 & 0.55 & 0.24 & 0.96 & 13.16 & 80 & 714 & 316 & 86 & 626 \\
\hline GR-LNB $150 F$ & $9 / 7 / 94$ & $0: 30$ & 369 & 641 & 352 & 5.31 & 1.00 & 4.94 & 0.55 & 0.24 & 0.96 & 13.00 & 80 & 710 & 320 & 90 & 630 \\
\hline RR GR-LNB $150 E$ & $9 / 794$ & $0: 30$ & 370 & 642 & 351 & 5.31 & 1.00 & 4.94 & 0.55 & 0.24 & 0.97 & 13.00 & 80 & 711 & 321 & 91 & 632 \\
\hline GR-LNB R.1 & $9 / 7 / 94$ & $0: 21$ & 369 & 642 & 351 & 5.37 & 1.04 & 4.69 & 0.57 & 0.24 & 0.97 & 12.88 & 80 & 712 & 321 & 92 & 631 \\
\hline LNB & 9/8/94 & $0: 53$ & 372 & 640 & 358 & 5.30 & 1.11 & 4.27 & 0.61 & 0.24 & 0.97 & 12.50 & 80 & 710 & 315 & 78 & 630 \\
\hline GR-LNB 1501 & 9/8/94 & $0: 30$ & 372 & 641 & 356 & 5.25 & 0.93 & 5.36 & 0.51 & 0.24 & 0.97 & 13.26 & 80 & 713 & 322 & 89 & 635 \\
\hline .5gas,OFAcoolling & 9/8/94 & $2: 04$ & 364 & 637 & 345 & 5.15 & 1.11 & 4.33 & 0.61 & 0.24 & 0.98 & 12.41 & 80 & 701 & 321 & 93 & 628 \\
\hline LNB(OFAcooling) & 9/8/94 & $0: 28$ & 365 & 642 & 344 & 5.41 & 1.11 & 4.29 & 0.61 & 0.25 & 0.98 & 12.65 & 80 & 711 & 325 & 95 & 634 \\
\hline
\end{tabular}


Post Modification

\begin{tabular}{|c|c|c|c|c|c|c|c|c|c|c|c|c|c|c|c|c|c|}
\hline Trest & Date & Dur & $\begin{array}{l}\text { phin } \\
\text { Press } \\
\text { PSIC }\end{array}$ & $\begin{array}{l}\text { RHIh } \\
\text { remp } \\
\text { Degi }\end{array}$ & $\begin{array}{l}\text { Hot Rh } \\
\text { outprs } \\
\text { PSia }\end{array}$ & 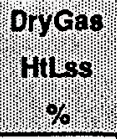 & $\begin{array}{l}\text { Moist } \\
\text { htiss } \\
\%\end{array}$ & combrizo & $\begin{array}{l}\text { pefuse } \\
\text { putss } \\
\text { pis } \\
\%\end{array}$ & $\begin{array}{l}\text { Radiat } \\
\text { ptrss } \\
\%\end{array}$ & $\begin{array}{l}\text { Unmeas } \\
\text { unss } \\
\text { uswo }\end{array}$ & $\begin{array}{l}\text { Tolal } \\
\text { nntss } \\
\text { \% }\end{array}$ & $\begin{array}{l}\text { comb } \\
\text { Arr. } \\
\text { Temp }\end{array}$ & $\begin{array}{l}\text { Ecoon } \\
\text { Gas out } \\
\text { Tomp }\end{array}$ & $\begin{array}{l}\text { AH Gas } \\
\text { Oury } \\
\text { Temp }\end{array}$ & $\begin{array}{l}\text { Ah Air } \\
\text { Temp } \\
\text { Thy }\end{array}$ & $\begin{array}{l}\text { AH Alt } \\
\text { out } \\
\text { Temp }\end{array}$ \\
\hline LNB & 9/9/94 & $0: 45$ & 371 & 637 & 357 & 5,23 & 1.11 & 4.28 & 0.61 & 0.24 & 0.96 & 12.43 & 80 & 706 & 319 & 85 & 630 \\
\hline GR-LNB.R6\% & 9/9/94 & 0.22 & 368 & 632 & 351 & 5.35 & 1.04 & 4.70 & 0.57 & 0.24 & 0.95 & 12.84 & 80 & 708 & 317 & 89 & 626 \\
\hline GR-LNB.R8\% & 9/9/94 & $0: 11$ & 368 & 634 & 350 & 5.40 & 1.02 & 4.84 & 0.56 & 0.24 & 0.96 & 13.00 & 80 & 710 & 319 & 91 & 628 \\
\hline GR-LNB.R10\% & 9/9/94 & $0: 18$ & 367 & 635 & 349 & 5.34 & 1.00 & 4.96 & 0.55 & 0.24 & 0.96 & 13.04 & 80 & 709 & 320 & 92 & 629 \\
\hline GR-LNB.B12\% & 9/9/94 & $0: 17$ & 366 & 638 & 347 & 5.33 & 0.98 & 5.09 & 0.53 & 0.24 & 0.96 & 13.14 & 80 & 710 & 322 & 94 & 631 \\
\hline LNB-OFAcoolling & 9/9/94 & $0: 14$ & 365 & 641 & 345 & 5.37 & 1.11 & 4.29 & 0.61 & 0.24 & 0.97 & 12.60 & 80 & 710 & 324 & 96 & 633 \\
\hline LNB & 9/21/94 & $0: 55$ & 315 & 590 & 302 & 4.88 & 1.10 & 4.24 & 0.61 & 0.31 & 1.16 & 12.30 & 80 & 678 & 294 & 70 & 607 \\
\hline LNB & $9 / 21 / 94$ & $2: 05$ & 372 & 629 & 356 & 4.93 & 1.10 & 4.25 & 0.61 & 0.24 & 0.98 & 12.12 & 80 & 702 & 302 & 72 & 619 \\
\hline LNB & 9/21/94 & $1: 45$ & 374 & 621 & 359 & 4.67 & 1.10 & 4.24 & 0.61 & 0.24 & 0.96 & 11.82 & 80 & 694 & 298 & 66 & 613 \\
\hline LNB & 9/21/94 & $2: 51$ & 381 & 618 & 373 & 4.17 & 1.10 & 4.23 & 0.61 & 0.24 & 0.96 & 11.31 & 80 & 684 & 289 & 55 & 607 \\
\hline LNB 150 & $10 / 3 / 94$ & 4:13 & 428 & 548 & 412 & 4.88 & 1.10 & 4.25 & 0.61 & 0.17 & 0.76 & 11.79 & 80 & 698 & 301 & 67 & 608 \\
\hline LNB 150 & 10/3/94 & 3:54 & 410 & 548 & 396 & 4.84 & 1.10 & 4.25 & 0.61 & 0.20 & 0.83 & 11.83 & 80 & 700 & 301 & 67 & 613 \\
\hline LNB & $10 / 3 / 94$ & 1:48 & 379 & 548 & 365 & 4.83 & 1.10 & 4.25 & 0.61 & 0.23 & 0.93 & 11.95 & 80 & 690 & 298 & 66 & 609 \\
\hline LNB(on dlspatch) & $10 / 4 / 94$ & 4:10 & 295 & 548 & 285 & 4.80 & 1.10 & 4.23 & 0.61 & 0.32 & 1.21 & 12.28 & 80 & 660 & 291 & 67 & 597 \\
\hline LNB(on dispatch) & $10 / 4 / 94$ & 6:15 & 406 & 562 & 392 & 4.95 & 1.11 & 4.26 & 0.61 & 0.21 & 0.87 & 12.00 & 80 & 713 & 306 & 67 & 624 \\
\hline LNB 150 & $10 / 4 / 94$ & $2: 22$ & 423 & 622 & 406 & 4.75 & 1.11 & 4.26 & 0.61 & 0.18 & 0.78 & 11.67 & 80 & 697 & 304 & 68 & 612 \\
\hline LNB-OFA & $10 / 494$ & $0: 10$ & 425 & 620 & 407 & 4.86 & 1.10 & 4.25 & 0.61 & 0.17 & 0.77 & 11.76 & 80 & 696 & 300 & 70 & 604 \\
\hline LNB-OFA & $10 / 4 / 94$ & $0: 45$ & 426 & 612 & 407 & 4.97 & 1.10 & 4.25 & 0.61 & 0.17 & 0.76 & 11.86 & 80 & 700 & 299 & 70 & 603 \\
\hline GA-LNB (6\%) & $10 / 4 / 94$ & $0: 20$ & 424 & 634 & 405 & 4.70 & 1.03 & 4.65 & 0.57 & 0.18 & 0.78 & 11.91 & 80 & 702 & 299 & 70 & 608 \\
\hline GR-LNB (8\%) & $10 / 4 / 94$ & $0: 26$ & 424 & 643 & 405 & 4.68 & 1.02 & 4.76 & 0.56 & 0.18 & 0.78 & 11.98 & 80 & 705 & 301 & 70 & 612 \\
\hline GR-LNB (10\%) & $10 / 4 / 94$ & $0: 15$ & 425 & 649 & 406 & 4.66 & 1.00 & 4.87 & 0.55 & 0.18 & 0.79 & 12.05 & 80 & 707 & 302 & 70 & 615 \\
\hline GR-LNB (15\%) & $10 / 4 / 94$ & $0: 17$ & 426 & 655 & 407 & 4.63 & 0.94 & 5.20 & 0.52 & 0.18 & 0.80 & 12.28 & 80 & 711 & 304 & 70 & 620 \\
\hline LNB & $10 / 5 / 94$ & 2:36 & 412 & 643 & 390 & 5.00 & 1.11 & 4.27 & 0.61 & 0.19 & 0.81 & 11.99 & 80 & 705 & 313 & 83 & 621 \\
\hline LNB & $10 / 5 / 94$ & $0: 43$ & 415 & 648 & 391 & 5.38 & 1.11 & 4.28 & 0.61 & 0.19 & 0.81 & 12.38 & 80 & 716 & 319 & 85 & 627 \\
\hline LNB(pre-test) & $10 / 14 / 94$ & 3:35 & 405 & 631 & 385 & 4.73 & 1.11 & 4.25 & 0.61 & 0.20 & 0.84 & 11.74 & 80 & 697 & 304 & 73 & 612 \\
\hline LNB & $10 / 14 / 94$ & $0: 24$ & 416 & 636 & 394 & 4.92 & 1.11 & 4.26 & 0.61 & 0.18 & 0.80 & 11.88 & 80 & 709 & 309 & 76 & 618 \\
\hline GR-LNB 3 MIII & $10 / 14 / 94$ & $0: 20$ & 377 & 630 & 356 & 4.53 & 0.99 & 4.91 & 0.55 & 0.23 & 0.93 & 12.14 & 80 & 700 & 295 & 76 & 609 \\
\hline LNB 4 Mill & 10/18/94 & $0: 34$ & 406 & 609 & 383 & 4.88 & 1.11 & 4.26 & 0.61 & 0.18 & 0.79 & 11.82 & 80 & 702 & 306 & 69 & 616 \\
\hline GR-LNB 3 Mill & 10/18/94 & $0: 53$ & 344 & 620 & 321 & 4.51 & 0.97 & 4.95 & 0.54 & 0.26 & 1.03 & 12.27 & 80 & 691 & 287 & 68 & 602 \\
\hline GR-LNB 3 Mill & 10/18/94 & $0: 24$ & 356 & 625 & 333 & 4.41 & 0.91 & 5.32 & 0.50 & 0.25 & 1.00 & 12.39 & 80 & 695 & 289 & 68 & 608 \\
\hline LNB(pre-test) & $10 / 20 / 94$ & $2: 29$ & 425 & 653 & 408 & 4.64 & 1.10 & 4.25 & 0.61 & 0.18 & 0.79 & 11.58 & 80 & 714 & 301 & 58 & 623 \\
\hline LNB a & $10 / 20 / 94$ & 1.04 & 429 & 652 & 413 & 4.86 & 1.11 & 4.26 & 0.61 & 0.18 & 0.79 & 11.80 & 80 & 717 & 306 & 65 & 625 \\
\hline LNB b & $10 / 20 / 94$ & $0: 19$ & 428 & 652 & 412 & 4.93 & 1.11 & 4.26 & 0.61 & 0.18 & 0.79 & 11.87 & 80 & 718 & 307 & 67 & 626 \\
\hline LNB C & $10 / 20 / 94$ & $0: 32$ & 428 & 652 & 411 & 4.96 & 1.11 & 4.26 & 0.61 & 0.18 & 0.79 & 11.90 & 80 & 718 & 308 & 68 & 626 \\
\hline
\end{tabular}


Cheorkee Unit \#3, Average Test Data

Post Modification

\begin{tabular}{|c|c|c|c|c|c|c|c|c|c|c|c|c|c|c|c|c|c|}
\hline 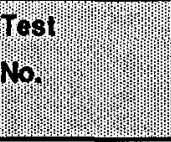 & 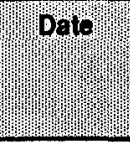 & Dump & PHIn' & $\begin{array}{l}\text { Rh In } \\
\text { pemp } \\
\text { Degn }\end{array}$ & 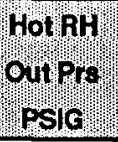 & DryGas"y & Moist & combras" & Rpensed & Radjay & 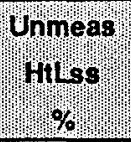 & Trota) & comb & 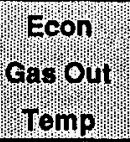 & 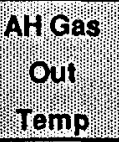 & 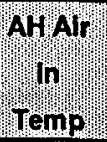 & 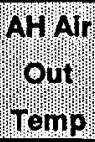 \\
\hline LNB d & $10 / 20 / 94$ & $2: 42$ & 415 & 643 & 397 & 4.90 & 1.11 & 4.26 & 0.61 & 0.19 & 0.82 & 11.89 & 80 & 711 & 307 & 71 & 622 \\
\hline GR-LNB a & $10 / 20 / 94$ & $0: 26$ & 408 & 648 & 388 & 4.74 & 1.00 & 4.89 & 0.55 & 0.20 & 0.85 & 12.22 & 80 & 717 & 305 & 73 & 623 \\
\hline GR-LNB b & $10 / 20 / 94$ & $0: 20$ & 409 & 656 & 390 & 4.64 & 1.00 & 4.89 & 0.55 & 0.20 & 0.86 & 12.13 & 80 & 717 & 307 & 73 & 627 \\
\hline LNB & $10 / 21 / 94$ & $2: 58$ & 409 & 643 & 390 & 4.69 & 1.10 & 4.24 & 0.61 & 0.19 & 0.83 & 11.67 & 80 & 702 & 297 & 65 & 613 \\
\hline LNB-OFA & $10 / 21 / 94$ & $0: 28$ & 409 & 628 & 389 & 5.00 & 1.10 & 4.25 & 0.61 & 0.19 & 0.82 & 11.97 & 80 & 706 & 300 & 73 & 610 \\
\hline GR-LNB \#1 & $10 / 21 / 94$ & $0: 28$ & 409 & 643 & 387 & 4.66 & 1.00 & 4.87 & 0.55 & 0.19 & 0.83 & 12.10 & 80 & 706 & 304 & 74 & 617 \\
\hline GR-LNB \#2 & $10 / 21 / 94$ & $0: 10$ & 409 & 647 & 387 & 4.64 & 1.00 & 4.87 & 0.55 & 0.20 & 0.83 & 12.09 & 80 & 707 & 305 & 73 & 618 \\
\hline GR-LNB \#3 & $10 / 21 / 94$ & $0: 10$ & 409 & 648 & 387 & 4.63 & 1.00 & 4.87 & 0.55 & 0.19 & 0.82 & 12.07 & 80 & 706 & 305 & 73 & 619 \\
\hline GR-LNB \#4 & $10 / 21 / 94$ & $0: 14$ & 409 & 651 & 387 & 4.58 & 1.00 & 4.87 & 0.55 & 0.20 & 0.84 & 12.04 & 80 & 709 & 304 & 73 & 620 \\
\hline GR-LNB \#5 & $10 / 21 / 94$ & $0: 13$ & 410 & 655 & 388 & 4.59 & 1.00 & 4.87 & 0.55 & 0.20 & 0.84 & 12.05 & 80 & 711 & 304 & 73 & 622 \\
\hline LNB & $10 / 24 / 94$ & $5: 10$ & 327 & 621 & 314 & 4.56 & 1.10 & 4.22 & 0.61 & 0.29 & 1.12 & 11.90 & 80 & 682 & 285 & 60 & 605 \\
\hline LNB & $10 / 25 / 94$ & $2: 54$ & 338 & 627 & 320 & 4.57 & 1.10 & 4,22 & 0.61 & 0.28 & 1.08 & 11.86 & 80 & 679 & 285 & 62 & 599 \\
\hline GR-LNB (50k) & $10 / 25 / 94$ & $0: 19$ & 349 & 634 & 333 & 4.57 & 0.98 & 4.93 & 0.54 & 0.27 & 1.06 & 12.35 & 80 & 693 & 287 & 68 & 604 \\
\hline GR-LNB (60K) & $10 / 25 / 94$ & $0: 12$ & 349 & 631 & 333 & 4.65 & 0.98 & 4.93 & 0.54 & 0.27 & 1.06 & 12.43 & 80 & 694 & 288 & 69 & 605 \\
\hline LNB & $10 / 25 / 94$ & $0: 11$ & 342 & 629 & 326 & 4.74 & 1.10 & 4.23 & 0.61 & 0.27 & 1.07 & 12.02 & 80 & 687 & 289 & 69 & 603 \\
\hline LNB & $11 / 294$ & $4: 00$ & 397 & 648 & 380 & 7.14 & 1.10 & 4.22 & 0.61 & 0.23 & 0.92 & 14.21 & 80 & 720 & 284 & 57 & 617 \\
\hline GR-LNB & $11 / 2 / 94$ & 1.08 & 396 & 648 & 375 & 6.88 & 1.03 & 4.61 & 0.57 & 0.22 & 0.90 & 14.22 & 80 & 723 & 282 & 55 & 614 \\
\hline GR-LNB & $11 / 294$ & $0: 14$ & 397 & 647 & 376 & 6.83 & 1.03 & 4.61 & 0.57 & 0.22 & 0.89 & 14.15 & 80 & 722 & 281 & 54 & 612 \\
\hline GR-LNB & $11 / 2 / 94$ & $0: 24$ & 397 & 649 & 376 & 6.87 & 1.03 & 4.61 & 0.57 & 0.21 & 0.89 & 14.18 & 80 & 721 & 280 & 55 & 610 \\
\hline LNB & $11 / 3 / 94$ & $1: 19$ & 312 & 607 & 302 & 6.22 & 1.09 & 4.18 & 0.61 & 0.31 & 1.18 & 13.58 & 80 & 672 & 258 & 45 & 589 \\
\hline LNB-OFA(14k) & $11 / 3 / 94$ & $0: 18$ & 315 & 579 & 303 & 5.59 & 1.08 & 4.17 & 0.61 & 0.30 & 1.14 & 12.89 & 80 & 662 & 250 & 44 & 582 \\
\hline LNB-OFA(60k) & $11 / 3 / 94$ & $0: 12$ & 312 & 563 & 300 & 5.64 & 1.08 & 4.16 & 0.61 & 0.30 & 1.14 & 12.93 & 80 & 659 & 247 & 43 & 577 \\
\hline GR-LNB 1 & $11 / 3 / 94$ & $0: 14$ & 314 & 556 & 303 & 5.38 & 1.02 & 4.52 & 0.57 & 0.29 & 1.13 & 12.92 & 80 & 658 & 249 & 44 & 577 \\
\hline GR-LNB 2 & $11 / 3 / 94$ & $0: 12$ & 313 & 559 & 303 & 5.62 & 1.02 & 4.52 & 0.57 & 0.30 & 1.14 & 13.17 & 80 & 662 & 249 & 43 & 576 \\
\hline GR-LNB 3 & $11 / 3 / 94$ & $1: 11$ & 312 & 573 & 301 & 5.71 & 0.97 & 4.81 & 0.55 & 0.30 & 1.15 & 13.49 & 80 & 666 & 251 & 45 & 579 \\
\hline GR-LNB 4 & $11 / 3 / 94$ & $0: 24$ & 310 & 583 & 299 & 5.68 & 0.91 & 5.14 & 0.51 & 0.30 & 1.16 & 13.71 & 80 & 669 & 252 & 45 & 581 \\
\hline GR-LNB 5 & $11 / 3 / 94$ & $0: 14$ & 311 & 590 & 300 & 5.53 & 0.88 & 5.35 & 0.49 & 0.31 & 1.16 & 13.73 & 80 & 670 & 253 & 45 & 583 \\
\hline LNB & $11 / 4 / 94$ & $1: 17$ & 397 & 642 & 383 & 6.63 & 1.10 & 4.21 & 0.61 & 0.23 & 0.93 & 13.70 & 80 & 716 & 280 & 41 & 620 \\
\hline LNB-OFA & $11 / 4 / 94$ & $0: 17$ & 394 & 646 & 380 & 6.43 & 1.09 & 4.21 & 0.61 & 0.22 & 0.92 & 13.48 & 80 & 710 & 274 & 42 & 612 \\
\hline GR-LNB 1 & $11 / 4 / 94$ & $0: 23$ & 401 & 646 & 387 & 6.23 & 1.04 & 4.50 & 0.58 & 0.22 & 0.89 & 13.46 & 80 & 711 & 274 & 42 & 612 \\
\hline GR-LNB 2 & $11 / 4 / 94$ & $0: 12$ & 403 & 646 & 390 & 6.16 & 1.01 & 4.70 & 0.56 & 0.21 & 0.88 & 13.52 & 80 & 711 & 275 & 42 & 613 \\
\hline GR-LNB 3 & $11 / 4 / 94$ & $0: 20$ & 395 & 646 & 382 & 6.34 & 1.04 & 4.50 & 0.58 & 0.22 & 0.91 & 13.59 & 80 & 708 & 274 & 44 & 610 \\
\hline GR-LNB 4 & $11 / 4 / 94$ & $0: 14$ & 400 & 644 & 386 & 6.21 & 1.00 & 4.72 & 0.56 & 0.21 & 0.89 & 13.60 & 80 & 709 & 275 & 45 & 611 \\
\hline GR-LNB 5 & $11 / 4 / 94$ & $1: 39$ & 394 & 647 & 380 & 6.13 & 0.93 & 5.18 & 0.52 & 0.22 & 0.91 & 13.88 & 80 & 709 & 276 & 46 & 611 \\
\hline
\end{tabular}


Cheorkee Unit \$3, Average Test Data

Post Modification

\begin{tabular}{|c|c|c|c|c|c|c|c|c|c|c|c|c|c|c|c|c|c|}
\hline & Whaty & Dur & PrH In & 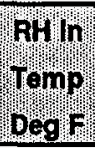 & 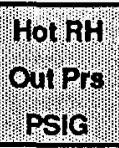 & Prycas" & Moista & combriñ & pue pusso & Radiat & 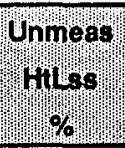 & 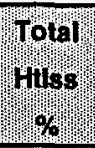 & comp & 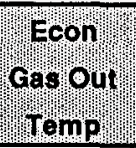 & 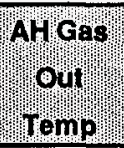 & 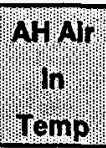 & 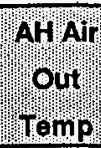 \\
\hline LNB & $11 / 7 / 94$ & $1: 43$ & 299 & 611 & 279 & 6.22 & 1.09 & 4.19 & 0.61 & 0.31 & 1.19 & 13.62 & 80 & 667 & 268 & 67 & 591 \\
\hline GR-LNB & $11 / 7 / 94$ & $0: 24$ & 293 & 583 & 269 & 6.11 & 1.03 & 4.56 & 0.57 & 0.31 & 1.17 & 13.76 & 80 & 659 & 267 & 80 & 581 \\
\hline GR-LNB & $11 / 7 / 94$ & $1: 35$ & 298 & 588 & 273 & 6.10 & 0.98 & 4.83 & 0.55 & 0.30 & 1.16 & 13.92 & 80 & 663 & 270 & 80 & 583 \\
\hline LNB (D out) & $11 / 7 / 94$ & $0: 15$ & 293 & 606 & 268 & 6.48 & 1.08 & 4.24 & 0.61 & 0.32 & 1.20 & 13.92 & 80 & 667 & 270 & 79 & 585 \\
\hline GR-LNB & $11 / 7 / 94$ & $0: 16$ & 304 & 602 & 279 & 6.98 & 1.03 & 4.55 & 0.58 & 0.30 & 1.14 & 14.58 & 80 & 679 & 274 & 76 & 590 \\
\hline GR-LNB & $11 / 7 / 94$ & $0: 12$ & 303 & 604 & 278 & 6.60 & 0.99 & 4.80 & 0.55 & 0.30 & 1.15 & 14.40 & 80 & 674 & 275 & 76 & 591 \\
\hline LNB & $11 / 8 / 94$ & $1: 03$ & 310 & 615 & 295 & 6.01 & 1.09 & 4.19 & 0.61 & 0.31 & 1.19 & 13.40 & 80 & 686 & 263 & 49 & 604 \\
\hline GR-LNB(varied OFA) & $11 / 8 / 94$ & $0: 33$ & 312 & 611 & 299 & 5.70 & 1.01 & 4.63 & 0.57 & 0.31 & 1.17 & 13.38 & 80 & 685 & 258 & 48 & 597 \\
\hline GR-LNB(OFA OP) & $11 / 8 / 94$ & $2: 55$ & 312 & 606 & 299 & 5.68 & 1.01 & 4.62 & 0.57 & 0.30 & 1.16 & 13.34 & 80 & 682 & 255 & 45 & 594 \\
\hline GR-LNB(D@80\%) & $11 / 8 / 94$ & $0: 40$ & 310 & 605 & 296 & 5.61 & 1.00 & 4.63 & 0.56 & 0.31 & 1.17 & 13.29 & 80 & 681 & 253 & 42 & 593 \\
\hline LNB 1 & $11 / 9 / 94$ & $0: 18$ & 307 & 614 & 294 & 5.83 & 1.08 & 4.18 & 0.61 & 0.32 & 1.19 & 13.21 & 80 & 684 & 257 & 41 & 600 \\
\hline GR-LNB 1 & $11 / 9 / 94$ & $3: 29$ & 313 & 572 & 300 & 5.55 & 0.98 & 4.75 & 0.55 & 0.30 & 1.13 & 13.26 & 80 & 655 & 249 & 46 & 571 \\
\hline GR-LNB 2 & $11 / 9 / 94$ & 0.39 & 314 & 578 & 300 & 5.53 & 0.99 & 4.72 & 0.56 & 0.30 & 1.13 & 13.22 & 80 & 654 & 252 & 52 & 570 \\
\hline GR-LNB 3 & $11 / 9 / 94$ & $0: 32$ & 361 & 620 & 344 & 5.78 & 0.99 & 4.72 & 0.56 & 0.25 & 0.99 & 13.30 & 80 & 677 & 258 & 52 & 579 \\
\hline GR-LNB 4 & $11 / 9 / 94$ & $5: 31$ & 398 & 649 & 379 & 6.12 & 1.00 & 4.71 & 0.56 & 0.21 & 0.88 & 13.49 & 80 & 700 & 267 & 49 & 594 \\
\hline GR-LNB 5 & $11 / 9 / 94$ & 0.31 & 332 & 616 & 315 & 6.17 & 0.99 & 4.75 & 0.55 & 0.28 & 1.08 & 13.81 & 80 & 678 & 258 & 45 & 587 \\
\hline LNB 2 & $11 / 9 / 94$ & $0: 45$ & 237 & 522 & 226 & 5.40 & 1.06 & 4.22 & 0.60 & 0.38 & 1.39 & 13.04 & 80 & 623 & 233 & 45 & 557 \\
\hline GR-LNB 6 & $11 / 9 / 94$ & $0: 15$ & 242 & 490 & 232 & 5.05 & 1.00 & 4.57 & 0.57 & 0.37 & 1.35 & 12.90 & 80 & 616 & 229 & 45 & 548 \\
\hline GR-LNB 7 & $11 / 9 / 94$ & $0: 11$ & 244 & 493 & 234 & 4.79 & 0.95 & 4.84 & 0.54 & 0.37 & 1.35 & 12.84 & 80 & 617 & 228 & 44 & 548 \\
\hline GR-LNB 8 & $11 / 9 / 94$ & $0: 16$ & 241 & 491 & 231 & 5.11 & 0.98 & 4.66 & 0.56 & 0.37 & 1.36 & 13.03 & 80 & 617 & 228 & 44 & 548 \\
\hline $\operatorname{LNB}(120)$ & $11 / 10 / 94$ & $1: 15$ & 313 & 617 & 301 & 6.44 & 1.09 & 4.18 & 0.61 & 0.31 & 1.18 & 13.81 & 80 & 686 & 261 & 46 & 597 \\
\hline $\operatorname{LNB}(150)$ & $11 / 10 / 94$ & $0: 27$ & 395 & 641 & 380 & 6.44 & 1.09 & 4.20 & 0.61 & 0.23 & 0.94 & 13.52 & 80 & 716 & 274 & 47 & 614 \\
\hline GR-LNB(43K) & $11 / 10 / 94$ & $0: 48$ & 396 & 642 & 379 & 6.30 & 1.00 & 4.73 & 0.56 & 0.22 & 0.91 & 13.73 & 80 & 719 & 276 & 48 & 614 \\
\hline GR-LNB(46k) & $11 / 10 / 94$ & $1: 42$ & 395 & 646 & 377 & 6.47 & 1.00 & 4.74 & 0.56 & 0.22 & 0.91 & 13.90 & 80 & 719 & 280 & 54 & 616 \\
\hline GR-LNB(53k) & $11 / 10 / 94$ & $1: 29$ & 390 & 648 & 369 & 6.54 & 1.00 & 4.75 & 0.56 & 0.22 & 0.92 & 13.99 & 80 & 716 & 280 & 55 & 614 \\
\hline GR-LNB(61k) & $11 / 10 / 94$ & $9: 45$ & 390 & 648 & 371 & 6.48 & 1.00 & 4.74 & 0.56 & 0.22 & 0.91 & 13.91 & 80 & 714 & 276 & 50 & 609 \\
\hline GR-LNB & $11 / 11 / 94$ & $9: 12$ & 392 & 648 & 375 & 6.50 & 1.00 & 4.74 & 0.56 & 0.22 & 0.91 & 13.93 & 80 & 713 & 275 & 48 & 609 \\
\hline \multicolumn{18}{|c|}{$100 \%$ Gas Testing 11/2/94-11/11/94 (SR's ce } \\
\hline LNB(coal/gas) & $12 / 1 / 94$ & $2: 41$ & 420 & 626 & 399 & 5.66 & 1.11 & 4.26 & 0.61 & 0.17 & 0.76 & 12.57 & 80 & 716 & 307 & 76 & 624 \\
\hline Test 21 & $1 / 19 / 95$ & 1.00 & 325 & 619 & 311 & 4.48 & 0.96 & 5.01 & 0.53 & 0.27 & 1.04 & 12.30 & 80 & 704 & 286 & 53 & 616 \\
\hline Test 22 & $1 / 19 / 95$ & 1.02 & 325 & 618 & 312 & 4.51 & 1.01 & 4.74 & 0.56 & 0.27 & 1.04 & 12.12 & 80 & 705 & 285 & 53 & 616 \\
\hline Test 24 & $1 / 19 / 95$ & $0: 33$ & 234 & 579 & 225 & 4.67 & 1.09 & 4.21 & 0.61 & 0.37 & 1.37 & 12.32 & 80 & 677 & 274 & 48 & 608 \\
\hline Test 25 & $1 / 19 / 95$ & $0: 30$ & 237 & 578 & 229 & 4.76 & 1.09 & 4.20 & 0.61 & 0.37 & 1.35 & 12.39 & 80 & 680 & 274 & 47 & 610 \\
\hline Test 27 & $1 / 19 / 95$ & $0: 25$ & 236 & 570 & 227 & 4.59 & 1.09 & 4.20 & 0.61 & 0.37 & 1.35 & 12.21 & 80 & 680 & 272 & 45 & 610 \\
\hline
\end{tabular}




\section{Post Modification}

\begin{tabular}{|c|c|c|c|c|c|c|c|c|c|c|c|c|c|c|c|c|c|}
\hline 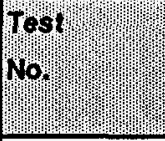 & "party & pury & 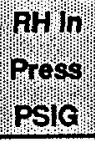 & 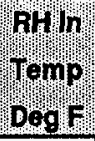 & 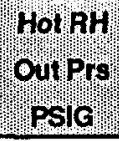 & Dry ${ }^{a s}{ }^{a s}$ & Molst & 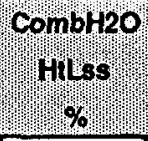 & 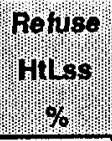 & nadiat & 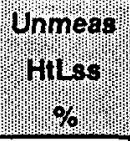 & "זotal & אomb & 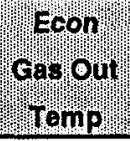 & 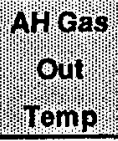 & 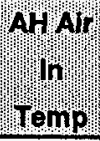 & 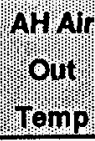 \\
\hline Test 30 & $1 / 20 / 95$ & $1: 01$ & 226 & 547 & 210 & 4.65 & 1.00 & 4.71 & 0.56 & 0.37 & 1.35 & 12.63 & 80 & 657 & 269 & 50 & 592 \\
\hline Test 31 & $1 / 20 / 95$ & $1: 00$ & 224 & 564 & 207 & 4.71 & 0.92 & 5.22 & 0.51 & 0.37 & 1.36 & 13.08 & 80 & 665 & 275 & 52 & 601 \\
\hline Test 32 & $1 / 20 / 95$ & $1: 05$ & 223 & 571 & 206 & 4.81 & 0.96 & 4.96 & 0.54 & 0.37 & 1.36 & 13.00 & 80 & 669 & 277 & 52 & 604 \\
\hline Test 33 & $1 / 20 / 95$ & $0: 40$ & 223 & 568 & 205 & 4.79 & 1.01 & 4.71 & 0.56 & 0.37 & 1.36 & 12.80 & 80 & 670 & 277 & 54 & 604 \\
\hline Test $1(R)$ & $1 / 24 / 95$ & $1: 00$ & 407 & 646 & 381 & 4.91 & 1.10 & 4.24 & 0.61 & 0.22 & 0.92 & 12.00 & 80 & 721 & 293 & 51 & 621 \\
\hline Test 16 & $1 / 25 / 95$ & $0: 20$ & 406 & 635 & 384 & 4.34 & 0.97 & 4.98 & 0.54 & 0.22 & 0.90 & 11.94 & 80 & 688 & 284 & 46 & 601 \\
\hline Test 17 & $1 / 25 / 95$ & $0: 40$ & 406 & 631 & 385 & 4.40 & 1.01 & 4.73 & 0.56 & 0.22 & 0.90 & 11.82 & 80 & 689 & 284 & 46 & 601 \\
\hline Test 403 Mill & $1 / 25 / 95$ & $1: 00$ & 360 & 576 & 334 & 4.29 & 1.01 & 4.71 & 0.56 & 0.25 & 1.00 & 11.82 & 80 & 662 & 280 & 64 & 584 \\
\hline Test 413 Mill & $1 / 25 / 95$ & $1: 00$ & 359 & 600 & 332 & 4.50 & 0.92 & 5.23 & 0.51 & 0.25 & 1.01 & 12.43 & 80 & 675 & 283 & 66 & 591 \\
\hline Test 423 Mill & $1 / 25 / 95$ & $1: 00$ & 359 & 606 & 331 & 4.47 & 0.96 & 4.98 & 0.54 & 0.26 & 1.01 & 12.22 & 80 & 678 & 281 & 65 & 592 \\
\hline Test 43 3 Mill & $1 / 25 / 95$ & 0.45 & 362 & 594 & 335 & 4.49 & 1.01 & 4.72 & 0.56 & 0.25 & 1.00 & 12.03 & 80 & 676 & 278 & 62 & 589 \\
\hline Test 2(R2) & $1 / 25 / 95$ & $0: 39$ & 413 & 645 & 387 & 4.90 & 1.10 & 4.23 & 0.61 & 0.21 & 0.87 & 11.92 & 80 & 701 & 289 & 54 & 603 \\
\hline Test 2(R) & $1 / 25 / 95$ & $0: 30$ & 414 & 639 & 389 & 5.14 & 1.10 & 4.23 & 0.61 & 0.21 & 0.87 & 12.16 & 80 & 705 & 291 & 55 & 603 \\
\hline Test $14(\mathrm{R})$ & $1 / 25 / 95$ & $0: 20$ & 412 & 649 & 387 & 4.35 & 1.01 & 4.74 & 0.56 & 0.21 & 0.88 & 11.75 & 80 & 696 & 286 & 51 & 604 \\
\hline Test 15(R) & $1 / 25 / 95$ & $0: 50$ & 414 & 657 & 389 & 4.33 & 0.94 & 5.14 & 0.52 & 0.21 & 0.88 & 12.02 & 80 & 698 & 288 & 50 & 609 \\
\hline Test 16(R) & $1 / 26 / 95$ & $0: 24$ & 412 & 639 & 388 & 4.50 & 0.97 & 4.98 & 0.54 & 0.21 & 0.87 & 12.06 & 80 & 691 & 289 & 51 & 603 \\
\hline Test 44 & $1 / 26 / 95$ & $0: 25$ & 409 & 650 & 382 & 4.49 & 1.03 & 4.68 & 0.57 & 0.21 & 0.88 & 11.86 & 80 & 698 & 295 & 59 & 607 \\
\hline Test 45 & $1 / 26 / 95$ & $0: 30$ & 410 & 656 & 382 & 4.49 & 1.01 & 4.76 & 0.56 & 0.21 & 0.89 & 11.92 & 80 & 700 & 294 & 57 & 610 \\
\hline Test 46 & $1 / 26 / 95$ & $0: 48$ & 411 & 661 & 385 & 4.41 & 0.95 & 5.11 & 0.53 & 0.22 & 0.89 & 12.11 & 80 & 702 & 294 & 55 & 613 \\
\hline Test 47 & $1 / 26 / 95$ & $0: 30$ & 412 & 661 & 386 & 4.45 & 0.98 & 4.95 & 0.54 & 0.22 & 0.89 & 12.03 & 80 & 703 & 294 & 54 & 614 \\
\hline LNB 3 Mill & $1 / 27 / 95$ & $0: 45$ & 357 & 641 & 335 & 4.23 & 1.09 & 4.19 & 0.61 & 0.33 & 1.25 & 11.70 & 80 & 661 & 268 & 50 & 577 \\
\hline Test 50 & $1 / 27 / 95$ & $0: 42$ & 358 & 643 & 337 & 4.25 & 1.01 & 4.69 & 0.56 & 0.33 & 1.25 & 12.09 & 80 & 659 & 273 & 56 & 579 \\
\hline Test 51 & $1 / 27 / 95$ & $0: 31$ & 358 & 643 & 338 & 4.18 & 0.91 & 5.25 & 0.51 & 0.34 & 1.25 & 12.44 & 80 & 657 & 272 & 55 & 579 \\
\hline Test 52 & $1 / 27 / 95$ & $0: 30$ & 358 & 643 & 338 & 4.16 & 0.96 & 4.97 & 0.54 & 0.34 & 1.26 & 12.21 & 80 & 658 & 272 & 56 & 579 \\
\hline
\end{tabular}


Post Modification

\begin{tabular}{|c|c|c|c|c|c|c|c|c|c|c|c|c|c|}
\hline Tost & Date & Dur & $\begin{array}{l}\text { calc coal } \\
\text { cowy } \\
\text { ibshr }\end{array}$ & $\begin{array}{l}\text { Msd Coal } \\
\text { Frow } \\
\text { Fis }\end{array}$ & $\begin{array}{l}\text { Calc Trur } \\
\text { Fow } \\
\text { scim }\end{array}$ & $\begin{array}{l}\text { Msd TAlr } \\
\int_{\text {rnow }} \\
\text { scrm }\end{array}$ & $\begin{array}{l}\text { heat } \\
\text { Raic } \\
\text { Gross }\end{array}$ & $\begin{array}{l}\text { heal } \\
\text { Rato } \\
\text { Net }\end{array}$ & $\begin{array}{l}\text { OFA } \\
\text { Inner } \\
\text { morm }\end{array}$ & $\begin{array}{l}\text { ora } \\
\text { outerf } \\
\text { scim }\end{array}$ & 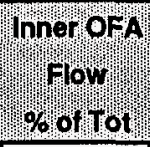 & $\begin{array}{l}\text { ofa } \\
\text { qor } \\
\text { ror Arr }\end{array}$ & $\begin{array}{l}\text { Carbon } \\
\text { nAsh } \\
\text { fro }\end{array}$ \\
\hline LNB OFA Cooling & $8 / 17 / 94$ & 3.08 & 113427 & & 273493 & & 9410 & 10791 & & & & & \\
\hline GR-LNB & $8 / 17 / 94$ & 1:15 & 105744 & & 278326 & & 8801 & 10850 & & & & & \\
\hline Test A (LNB) & $8 / 17794$ & 0.33 & 113539 & & 267875 & & 8428 & 10802 & & & & & \\
\hline Test B (GR-LNB) & $8 / 1794$ & $0: 40$ & 104933 & & 283276 & & 8499 & 10881 & & & & & \\
\hline$C$ (LNB) & $8 / 18 / 94$ & $0: 24$ & 113527 & & 266830 & & 8286 & 10801 & & & & & \\
\hline D (GR-LNB rear fired) & $8 / 18 / 94$ & $0: 31$ & 104654 & & 280215 & & 8367 & 10875 & & & & & \\
\hline E (GR-LNB front fired) & $8 / 18 / 94$ & $0: 36$ & 104776 & & 279520 & & 8777 & 10865 & & & & & \\
\hline$F$ (GR-LNB) & $8 / 18 / 94$ & $0: 36$ & 104790 & & 271152 & & 8149 & 10862 & & & & & \\
\hline GR-LNB (50k) & 8/29/94 & $0: 22$ & 116311 & 152531 & 308184 & 206870 & 9304 & 10061 & 15874 & 43010 & 26 & 19.11 & \\
\hline GR-LNB (<3k) & $8 / 29 / 94$ & $0: 21$ & 115678 & 152289 & 291728 & 214513 & 9224 & 9946 & 2670 & 531 & 87 & 1.10 & \\
\hline GR-LNB (RW) & $8 / 30 / 94$ & $0: 19$ & 120129 & 155038 & 317426 & 208067 & 9365 & 10123 & 16088 & 43169 & 26.95 & 18.67 & \\
\hline GR-LNB (BW) & 8/30/94 & $0: 23$ & 110898 & 142454 & 312564 & 204697 & 9343 & 10089 & 15972 & 43283 & 26.38 & 18.96 & \\
\hline LNB-OFA 100A & $8 / 31 / 94$ & 1.00 & 128750 & 157650 & 302403 & 220707 & 9310 & 10023 & 2062 & 0 & 100.00 & 0.68 & \\
\hline LNB-OFA 100D & $8 / 31 / 94$ & $0: 25$ & 129214 & 160086 & 314706 & 214397 & 9376 & 10131 & 11509 & 26092 & 30.15 & 11.95 & \\
\hline LNB-OFA $100 E$ & $8 / 31 / 94$ & $0: 34$ & 129393 & 155090 & 317066 & 209364 & 9357 & 10111 & 14632 & 38048 & 27.00 & 16.61 & \\
\hline LNB-OFA $110 \mathrm{~A}$ & $8 / 31 / 94$ & $0: 38$ & 128735 & 154923 & 303296 & 208712 & 9332 & 10070 & 8645 & 17008 & 33.21 & 8.46 & \\
\hline LNB-OFA $110 B$ & $8 / 31 / 94$ & $0: 28$ & 128402 & 157425 & 300094 & 207282 & 9289 & 10026 & 10581 & 15525 & 40.03 & 8.70 & \\
\hline LNB & 9/1/94 & 1:39 & 124423 & 147446 & 288320 & 209802 & 9288 & 10016 & 2566 & 0 & 100.00 & 0.89 & \\
\hline GR-LNB 140A & 9/194 & $0: 30$ & 115440 & 141268 & 302918 & 196179 & 9337 & 10086 & 15917 & 43320 & 26.13 & 19.56 & \\
\hline GR-LNB $140 C$ & 9/1/94 & $0: 30$ & 115141 & 140037 & 306565 & 193262 & 9314 & 10066 & 17131 & 52000 & 23.00 & 22.55 & \\
\hline GR-LNB 1400 & $9 / 1 / 94$ & $0: 30$ & 114824 & 139688 & 306357 & 190478 & 9315 & 10070 & 17132 & 52000 & 21.00 & 22.57 & \\
\hline LNB (0.5\% Gas) & $9 / 1 / 94$ & 2:18 & 125263 & 156065 & 276362 & 202513 & 9233 & 9951 & 625 & 0 & 100.00 & 0.23 & \\
\hline Baseline (LNB) & 9/2/94 & $0: 30$ & 125958 & 149537 & 284456 & 208861 & 9209 & 9912 & 2056 & 0 & 100.00 & 0.72 & \\
\hline GR-LNB $150 \mathrm{C}$ & 9/2/94 & $0: 30$ & 119357 & 144091 & 302450 & 199505 & 9256 & 9999 & 15159 & 42559 & 26.00 & 19.08 & \\
\hline GR-LNB 150D & 9/2/94 & $0: 37$ & 119504 & 141632 & 303679 & 195903 & 9274 & 10017 & 15210 & 44670 & 25.00 & 19.72 & \\
\hline LNB & $9 / 7 / 94$ & $1: 56$ & 126621 & 146206 & 297794 & 207057 & 9428 & 10169 & 1874 & 0 & 100.00 & 0.63 & \\
\hline GR-LNB 150E & $9 / 7 / 94$ & $0: 30$ & 114968 & 133687 & 318510 & 197605 & 9408 & 10180 & 17335 & 52000 & 24.00 & 21.77 & 4.12 \\
\hline GA-LNB $150 F$ & $9 / 7 / 94$ & $0: 30$ & 114681 & 129903 & 305931 & 181168 & 9420 & 10180 & 16580 & 52000 & 22.00 & 22.42 & 1.16 \\
\hline RR GR-LNB 150E & $9 / 794$ & $0: 30$ & 114508 & 129861 & 303832 & 180486 & 9389 & 10146 & 16491 & 52000 & 22.00 & 22.54 & 3.56 \\
\hline GR-LNB R.1 & $9 / 7 / 94$ & 0.21 & 119425 & 134921 & 306665 & 182526 & 9373 & 10134 & 16472 & 52000 & 22.05 & 22.33 & \\
\hline LNB & 9/8/94 & $0: 53$ & 126047 & 145801 & 301011 & 217212 & 9310 & 10037 & 1891 & 0 & 100.00 & 0.63 & 5.11 \\
\hline GR-LNB 1501 & $9 / 8 / 94$ & $0: 30$ & 105990 & 125020 & 299429 & 183179 & 9354 & 10099 & 15073 & 47033 & 23.94 & 20.74 & 5.03 \\
\hline .5 gas, OFAcooling & 9/8/94 & $2: 04$ & 124006 & 145959 & 289283 & 201192 & 9347 & 10085 & 527 & 8006 & 5.70 & 2.95 & \\
\hline LNB(OFAcooling) & 9/8/94 & $0: 28$ & 125401 & 148069 & 299943 & 211844 & 9296 & 10021 & 1598 & 7596 & 16.86 & 3.07 & \\
\hline
\end{tabular}


Cheorkee Unit \#3, Average Test Data

Post Modification

\begin{tabular}{|c|c|c|c|c|c|c|c|c|c|c|c|c|c|}
\hline Thst & Date & Dur & Calc coal & Msd Coal & Calc 'Ai & Msd Talr & 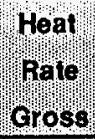 & $\begin{array}{l}\text { Heat } \\
\text { nate } \\
\text { חyes }\end{array}$ & 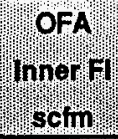 & 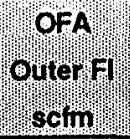 & 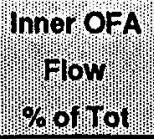 & 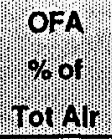 & carbon \\
\hline LNB & 9/9/94 & $0: 45$ & 126478 & 143063 & 294212 & 206763 & 9373 & 10096 & 1804 & 0 & 100.00 & 0.61 & \\
\hline GR-LNB.R6\% & 9/9/94 & $0: 22$ & 118723 & 134174 & 305964 & 183982 & 9463 & 10240 & 17074 & 51950 & 22.91 & 22.56 & \\
\hline GR-LNB.R8\% & $9 / 9 / 94$ & $0: 11$ & 116001 & 130098 & 307513 & 180236 & 9440 & 10212 & 17098 & 52000 & 20.75 & 22.47 & \\
\hline GR-LNB.R10\% & 9/9/94 & $0: 18$ & 114229 & 126396 & 304822 & 174788 & 9488 & 10263 & 16920 & 52000 & 20.00 & 22.61 & \\
\hline GR-LNB.B12\% & $9 / 9 / 94$ & $0: 17$ & 111395 & 124652 & 302478 & 174196 & 9448 & 10217 & 16739 & 52000 & 20.00 & 22.73 & \\
\hline LNB-OFAcooling & $9 / 9 / 94$ & $0: 14$ & 126003 & 142224 & 299381 & 209451 & 9347 & 10076 & 2152 & 9190 & 18.40 & 3.79 & \\
\hline LNB & $9 / 21 / 94$ & $0: 55$ & 105554 & 130810 & 254057 & 183089 & 9313 & 10143 & 328 & 0 & 100 & 0.13 & \\
\hline LNB & $9 / 21 / 94$ & $2: 05$ & 123744 & 155908 & 292234 & 214675 & 9246 & 9960 & 360 & 0 & 100 & 0.12 & \\
\hline LNB & $9 / 21 / 94$ & $1: 45$ & 123926 & 158548 & 282965 & 207342 & 9271 & 9996 & 393 & 0 & 100 & 0.14 & \\
\hline LNB & $9 / 21 / 94$ & $2: 51$ & 122678 & 160665 & 261862 & 191978 & 9204 & 9907 & 390 & 0 & 100 & 0.15 & \\
\hline LNB 150 & $10 / 3 / 94$ & $4: 13$ & 143436 & 173553 & 327470 & 237496 & 9698 & 10498 & 4177 & 0 & 100 & 1.28 & \\
\hline LNB 150 & $10 / 3 / 94$ & $3: 54$ & 137895 & 164111 & 314857 & 227760 & $965 t$ & 10458 & 4110 & 0 & 100 & 1.31 & \\
\hline LNB & $10 / 3 / 94$ & $1: 48$ & 127252 & 151168 & 293184 & 209101 & 9589 & 10443 & 4159 & 0 & 100 & 1.42 & \\
\hline LNB(on dispatch) & $10 / 4 / 94$ & $4: 10$ & 99627 & 121382 & 234936 & 164867 & 9443 & 10464 & 4167 & 0 & 100 & 1.77 & \\
\hline LNB(on dispatch) & $10 / 4 / 94$ & $6: 15$ & 136524 & 158901 & 314524 & 228378 & 9552 & 10350 & 4137 & 0 & 100 & 1.32 & \\
\hline LNB 150 & $10 / 4 / 94$ & $2: 22$ & 137516 & 161788 & 307908 & 226319 & 9383 & 10147 & 4133 & 0 & 100 & 1.34 & \\
\hline LNB-OFA & $10 / 4 / 94$ & $0: 10$ & 138301 & 174939 & 322073 & 225592 & 9397 & 10190 & 17982 & 4735 & 79 & 7.05 & \\
\hline LNB-OFA & $10 / 4 / 94$ & $0: 45$ & 138698 & 173750 & 331031 & 221408 & 9440 & 10256 & 17726 & 40951 & 31 & 17.73 & \\
\hline GR-LNB (6\%) & $10 / 4 / 94$ & $0: 20$ & 130415 & 163403 & 315849 & 205631 & 9381 & 10168 & 17974 & 48685 & 27 & 21.10 & \\
\hline GR-LNB (8\%) & $10 / 4 / 94$ & $0: 26$ & 128485 & 161191 & 314308 & 201907 & 9346 & 10122 & 18000 & 51571 & 26 & 22.13 & \\
\hline GR-LNB $(10 \%)$ & $10 / 4 / 94$ & $0: 15$ & 126407 & 157096 & 311880 & 198476 & 9321 & 10083 & 18000 & 51953 & 24 & 22.43 & \\
\hline GR-LNB (15\%) & $10 / 4 / 94$ & $0: 17$ & 119331 & 148693 & 308969 & 194541 & 9282 & 10040 & 18000 & 52000 & 23 & 22.66 & \\
\hline LNB & $10 / 5 / 94$ & 2.36 & 136998 & 167252 & 309347 & 225778 & 9357 & 10136 & 1918 & 18 & 99 & 0.63 & \\
\hline LNB & $10 / 5 / 94$ & 0.43 & 138464 & 169055 & 327460 & 240935 & 9350 & 10133 & 1944 & 3722 & 38 & 1.73 & \\
\hline LNB(pre-test) & $10 / 14 / 94$ & $3: 35$ & 133807 & 165386 & 301299 & 222914 & 9328 & 10089 & 1995 & 0 & 100 & 0.66 & \\
\hline LNB & $10 / 14 / 94$ & 0.24 & 137536 & 171784 & 314042 & 235299 & 9357 & 10116 & 3989 & 0 & 100 & 1.27 & \\
\hline GR-LNB 3 MiII & $10 / 14 / 94$ & $0: 20$ & 113675 & 143012 & 284221 & 182971 & 9336 & 10144 & 18000 & 52000 & 24 & 24.63 & \\
\hline LNB 4 Mill & $10 / 18 / 94$ & $0: 34$ & 135389 & 163089 & 310544 & 227831 & 9444 & 10229 & 2022 & 0 & 100 & 0.65 & \\
\hline GR-LNB 3 Mill & $10 / 18 / 94$ & $0: 53$ & 104044 & 130455 & 271971 & 171915 & 9262 & 10110 & 17845 & 50920 & 25 & 25.28 & \\
\hline GR-LNB 3 M:II & $10 / 18 / 94$ & $0: 24$ & 100564 & 123822 & 274186 & 171102 & 9275 & 10096 & 18000 & 52000 & 24 & 25.53 & \\
\hline LNB(pre-test) & $10 / 20 / 94$ & 2:29 & 138932 & 162305 & 307899 & 231179 & 9208 & 9939 & 2094 & 0 & 100 & 0.68 & \\
\hline LNB a & $10 / 20 / 94$ & 1.04 & 139463 & 160037 & 315814 & 235979 & 9234 & 9966 & 2059 & 0 & 100 & 0.65 & \\
\hline LNB b & $10 / 20 / 94$ & $0: 19$ & 139659 & 160970 & 318930 & 237873 & 9241 & 9974 & 2026 & 0 & 100 & 0.64 & \\
\hline LNB C & $10 / 20 / 94$ & $0: 32$ & 139731 & 162056 & 319703 & 238339 & 9249 & 9983 & 2085 & 0 & 100 & 0.65 & \\
\hline
\end{tabular}


Post Modification

\begin{tabular}{|c|c|c|c|c|c|c|c|c|c|c|c|c|c|}
\hline TrostwW & Date & Dur & $\begin{array}{l}\text { Calc coal } \\
\text { row } \\
\text { ibshr }\end{array}$ & 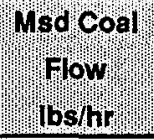 & $\begin{array}{l}\text { Calc Tair } \\
\text { rrowy } \\
\text { scrm }\end{array}$ & $\begin{array}{l}\text { Msd TAir } \\
\text { Frow } \\
\text { scem }\end{array}$ & $\begin{array}{l}\text { Peat } \\
\text { prate } \\
\text { Gross }\end{array}$ & $\begin{array}{l}\text { Heay } \\
\text { pale } \\
\text { Not } \\
\text { Not }\end{array}$ & 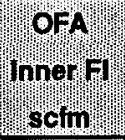 & 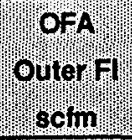 & $\begin{array}{l}\text { mner ofa } \\
\text { prow/ } \\
\text { \% of to }\end{array}$ & $\begin{array}{l}\text { ora } \\
\text { sor. } \\
\text { Tol Af }\end{array}$ & $\begin{array}{l}\text { Carbon } \\
\text { nusph } \\
\text { pis }\end{array}$ \\
\hline LNB d & $10 / 20 / 94$ & $2: 42$ & 136352 & 157741 & 310186 & 229319 & 9275 & 10027 & 2028 & 0 & 100 & 0.65 & \\
\hline GR-LNB a & $10 / 20 / 94$ & $0: 26$ & 121720 & 142169 & 301807 & 191371 & 9259 & 10039 & 18000 & 52000 & 25 & 23.19 & \\
\hline GR-LNB b & $10 / 20 / 94$ & $0: 20$ & 121704 & 142861 & 294057 & 186590 & 9185 & 9945 & 17740 & 52000 & 24 & 23.72 & \\
\hline LNB & $10 / 21 / 94$ & $2: 58$ & 135203 & 152974 & 306087 & 226534 & 9257 & 10020 & 1922 & 0 & 100 & 0.63 & \\
\hline LNB-OFA & $10 / 21 / 94$ & $0: 28$ & 135251 & 160782 & 321588 & 204548 & 9340 & 10148 & 17867 & 52000 & 24 & 21.73 & \\
\hline GR-LNB \#1 & $10 / 21 / 94$ & $0: 28$ & 123055 & 145254 & 300810 & 186096 & 9325 & 10102 & 17188 & 52000 & 24 & 23.00 & \\
\hline GR-LNB \#2 & $10 / 21 / 94$ & $0: 10$ & 123114 & 146491 & 299036 & 186106 & 9303 & 10076 & 17016 & 52000 & 24 & 23.08 & \\
\hline GR-LNB \#3 & $10 / 21 / 94$ & $0: 10$ & 123830 & 144806 & 299300 & 183471 & 9350 & 10127 & 16939 & 51977 & 24 & 23.03 & \\
\hline GR-LNB \#4 & $10 / 21 / 94$ & $0: 14$ & 122821 & 148619 & 295649 & 187367 & 9253 & 10020 & 16890 & 51990 & 24 & 23.30 & \\
\hline GR-LNB \#5 & $10 / 21 / 94$ & $0: 13$ & 122754 & 149473 & 295137 & 187196 & 9198 & 9953 & 16835 & 51995 & 24 & 23.32 & \\
\hline LNB & $10 / 24 / 94$ & $5: 10$ & 109849 & 133649 & 255505 & 187081 & 9175 & 9933 & 2260 & 0 & 100 & 0.88 & \\
\hline LNB & $10 / 25 / 94$ & $2: 54$ & 114028 & 135504 & 266180 & 194705 & 9163 & 9902 & 2343 & 0 & 100 & 0.88 & \\
\hline GR-LNB (50k) & $10 / 25 / 94$ & $0: 19$ & 104257 & 120496 & 272340 & 172606 & 9209 & 9969 & 17737 & 46370 & 27 & 23.54 & \\
\hline GR-LNB (6OK) & $10 / 25 / 94$ & $0: 12$ & 104355 & 119494 & 275604 & 170699 & 9229 & 9993 & 17566 & 50599 & 24 & 24.73 & \\
\hline LNB & $10 / 25 / 94$ & $0: 11$ & 115976 & 131978 & 275332 & 198071 & 9304 & 10055 & 2001 & 0 & 100 & 0.73 & \\
\hline LNB & $11 / 2 / 94$ & $4: 00$ & 129627 & 0 & 298347 & 244550 & 8970 & 9595 & 2442 & 0 & 100 & 0.82 & \\
\hline GR-LNB & $11 / 2 / 94$ & 1.08 & 123281 & 0 & 301494 & 234519 & 9030 & 9676 & 17981 & 3996 & 82 & 7.29 & \\
\hline GR-LNB & $11 / 2 / 94$ & $0: 14$ & 123507 & 0 & 301648 & 228330 & 9031 & 9682 & 18000 & 22753 & 46 & 13.51 & \\
\hline GR-LNB & $11 / 2 / 94$ & $0: 24$ & 124041 & 0 & 305088 & 222340 & 9070 & 9728 & 18000 & 39246 & 32 & 18.76 & \\
\hline LNB & $11 / 3 / 94$ & $1: 19$ & 104334 & 0 & 238156 & 188684 & 9046 & 9702 & 4652 & 0 & 100 & 1.95 & \\
\hline LNB-OFA(14k) & $11 / 3 / 94$ & $0: 18$ & 105262 & 0 & 225604 & 164796 & 9142 & 9830 & 17969 & 303 & 98 & 8.10 & \\
\hline LNB-OFA(60K) & $11 / 3 / 94$ & $0: 12$ & 103897 & 0 & 228758 & 147078 & 9185 & 9906 & 18000 & 49820 & 28 & 29.65 & \\
\hline GR-LNB 1 & $11 / 3 / 94$ & $0: 14$ & 99044 & 0 & 223795 & 162124 & 9252 & 9962 & 16578 & 10633 & 69 & 12.16 & \\
\hline GR-LNB 2 & $11 / 3 / 94$ & $0: 12$ & 98919 & 0 & 234144 & 164817 & 9249 & 9969 & 18000 & 25523 & 42 & 18.59 & \\
\hline GR-LNB 3 & $11 / 3 / 94$ & $1: 11$ & 94480 & 0 & 238421 & 157334 & 9242 & 9965 & 18000 & 45302 & 30 & 26.55 & \\
\hline GR-LNB 4 & $11 / 3 / 94$ & $0: 24$ & 89078 & 0 & 239895 & 154021 & 9247 & 9971 & 18000 & 52000 & 25 & 29.18 & \\
\hline GR-LNB 5 & $11 / 3 / 94$ & $0: 14$ & 85610 & 0 & 236414 & 153658 & 9188 & 9902 & 18000 & 52000 & 25 & 29.61 & \\
\hline LNB & $11 / 4 / 94$ & 1:17 & 128506 & 0 & 275614 & 225234 & 8903 & 9514 & 4538 & 0 & 100 & 1.65 & \\
\hline LNB-OFA & $11 / 4 / 94$ & $0: 17$ & 128567 & 0 & 276875 & 194490 & 9006 & 9654 & 18000 & 42308 & 32 & 21.78 & \\
\hline GR-LNB 1 & $11 / 4 / 94$ & $0: 23$ & 124981 & 0 & 277473 & 199660 & 9030 & 9668 & 16467 & 29117 & 38 & 16.43 & \\
\hline GR-LNB 2 & $11 / 4 / 94$ & $0: 12$ & 121999 & 0 & 279476 & 195579 & 9058 & 9696 & 17969 & 40325 & 31 & 20.86 & \\
\hline GR-LNB 3 & $11 / 4 / 94$ & 0.20 & 123566 & 0 & 279096 & 196321 & 9045 & 9696 & 17583 & 36850 & 33 & 19.50 & \\
\hline GR-LNB 4 & $11 / 4 / 94$ & $0: 14$ & 120727 & 0 & 280561 & 193206 & 9074 & 9725 & 18000 & 43875 & 29 & 22.05 & \\
\hline GA-LNB 5 & $11 / 4 / 94$ & 1:39 & 110410 & 0 & 281403 & 190638 & 9116 & 9775 & 18000 & 50094 & 26 & 24.20 & \\
\hline
\end{tabular}


Cheorkee Unit \#3, Average Test Data

Post Modification

\begin{tabular}{|c|c|c|c|c|c|c|c|c|c|c|c|c|c|}
\hline 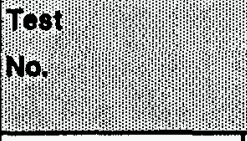 & 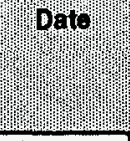 & WחW & 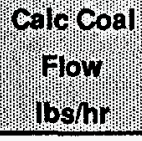 & 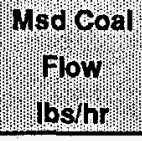 & 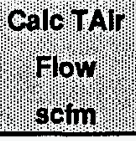 & 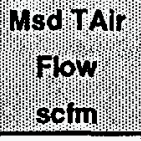 & "reat" & "Heat" & 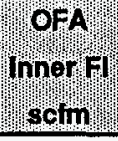 & 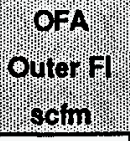 & 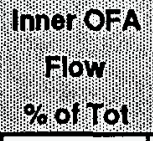 & 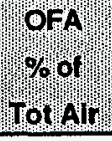 & 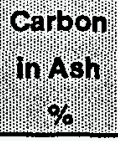 \\
\hline LNB & $11 / 7 / 94$ & $1: 43$ & 104166 & 0 & 226620 & 179555 & 9057 & 9720 & 4412 & 0 & 100 & 1.95 & \\
\hline GR-LNB & $11 / 7 / 94$ & $0: 24$ & 97534 & 0 & 228785 & 154152 & 9289 & 10027 & 18000 & 37469 & 33 & 24.25 & \\
\hline GR-LNB & $11 / 7 / 94$ & $1: 35$ & 95103 & 6 & 234855 & 156641 & 9303 & 10029 & 17414 & 36536 & 32 & 22.97 & \\
\hline LNB (D out) & $11 / 7 / 94$ & $0: 15$ & 103039 & 0 & 234376 & 192922 & 9151 & 9850 & 818 & 2617 & 24 & 1.47 & \\
\hline GR-LNB & $11 / 7 / 94$ & $0: 16$ & 102784 & 0 & 263748 & 174548 & 9316 & 10036 & 18000 & 38190 & 32 & 21.30 & \\
\hline GR-LNB & $11 / 7 / 94$ & $0: 12$ & 97990 & 0 & 251490 & 165910. & 9294 & 9999 & 18000 & 37180 & 33 & 21.94 & \\
\hline LNB & $11 / 8 / 94$ & 1.03 & 104171 & 0 & 222210 & 181106 & 8927 & 9572 & 2928 & 0 & 100 & 1.32 & \\
\hline GR-LNB(varled OFA) & $11 / 8 / 94$ & $0: 33$ & 97972 & 0 & 225477 & 157570 & 9051 & 9734 & 15436 & 25757 & 37 & 18.27 & \\
\hline GR-LNB(OFA Op) & $11 / 8 / 94$ & $2: 55$ & 98297 & 0 & 228459 & 157795 & 9091 & 9784 & 15464 & 25509 & 37 & 17.93 & \\
\hline GR-LNB(D@80\%) & $11 / 8 / 94$ & $0: 40$ & 97387 & 0 & 227764 & 158059 & 9078 & 9772 & 15686 & 25925 & 37 & 18.27 & \\
\hline LNB 1 & $11 / 9 / 94$ & $0: 18$ & 103402 & 0 & 221694 & 180225 & 8961 & 9618 & 4465 & 0 & 100 & 2.01 & \\
\hline GR-LNB 1 & $11 / 9 / 94$ & $3: 29$ & 95928 & 0 & 233095 & 156626 & 9271 & 9998 & 17318 & 28290 & 38 & 19.57 & \\
\hline GR-LNB 2 & $11 / 9 / 94$ & $0: 39$ & 97106 & 0 & 230237 & 157098 & 9248 & 9959 & 16761 & 28075 & 37 & 19.47 & \\
\hline GR-LNB 3 & $11 / 9 / 94$ & $0: 32$ & 110324 & 0 & 263474 & 191383 & 9153 & 9821 & 17493 & 30546 & 36 & 18.23 & \\
\hline GR-LNB 4 & $11 / 9 / 94$ & $5: 31$ & 121306 & 4 & 289358 & 208246 & 9086 & 9741 & 17875 & 33377 & 34 & 17.71 & \\
\hline GR-LNB 5 & $11 / 9 / 94$ & $0: 31$ & 103057 & 0 & 257695 & 168945 & 9223 & 9951 & 17060 & 29331 & 36 & 18.00 & \\
\hline LNB 2 & $11 / 9 / 94$ & $0: 45$ & 80558 & 0 & 187468 & 145192 & 9238 & 10131 & 2218 & 0 & 100 & 1.18 & \\
\hline GR-LNB 6 & $11 / 9 / 94$ & $0: 15$ & 77144 & 0 & 187638 & 120876 & 9424 & 10362 & 16139 & 28192 & 36 & 23.63 & \\
\hline GR-LNB 7 & $11 / 9 / 94$ & $0: 11$ & 73962 & 0 & 182679 & 117573 & 9405 & 10338 & 17208 & 33600 & 34 & 27.81 & \\
\hline GR-LNB 8 & $11 / 9 / 94$ & $0: 16$ & 75500 & 0 & 190446 & 121405 & 9448 & 10393 & 15310 & 26882 & 36 & 22.15 & \\
\hline $\operatorname{LNB}(120)$ & $11 / 10 / 94$ & $1: 15$ & 105327 & 0 & 243751 & 187741 & 8977 & 9724 & 9058 & 0 & 100 & 3.72 & \\
\hline $\operatorname{LNB}(150)$ & $11 / 10 / 94$ & $0: 27$ & 127960 & 0 & 278429 & 232371 & 8884 & 9509 & 1709 & 0 & 100 & 0.61 & \\
\hline GR-LNB(43K) & $11 / 10 / 94$ & $0: 48$ & 119440 & 0 & 282498 & 205471 & 9025 & 9676 & 16522 & 33585 & 32 & 17.74 & \\
\hline GR-LNB(46k) & $11 / 10 / 94$ & $1: 42$ & 119922 & 6 & 284056 & 202503 & 9043 & 9690 & 17041 & 32384 & 34 & 17.40 & \\
\hline GR-LNB(53k) & $11 / 10 / 94$ & $1: 29$ & 119100 & 0 & 285541 & 199579 & 9059 & 9716 & 17927 & 32144 & 35 & 17.54 & \\
\hline GR-LNB(61k) & $11 / 10 / 94$ & $9: 45$ & 119633 & 2 & 290387 & 197545 & 9115 & 9780 & 18000 & 31529 & 36 & 17.06 & \\
\hline GR-LNB & $11 / 11 / 94$ & 9:12 & 119106 & 7 & 291347 & 197979 & 9070 & 9732 & 18000 & 31599 & 36 & 17.02 & \\
\hline \multicolumn{14}{|c|}{$100 \%$ Gas Testing 11/2/94-11/11/94 (SR's co } \\
\hline LNB(coal/gas) & $12 / 1 / 94$ & $2: 41$ & 140338 & 115680 & 316227 & 238196 & 9373 & 10096 & 4162 & 0 & 100 & 1.32 & \\
\hline Test 21 & $1 / 19 / 95$ & $1: 00$ & 105086 & 120385 & 272558 & 169881 & 9683 & 10660 & 17486 & 52000 & & 25.49 & \\
\hline Test 22 & $1 / 19 / 95$ & $1: 02$ & 110163 & 125496 & 273892 & 171290 & 9657 & 10634 & 17469 & 52000 & & 25.36 & \\
\hline Test 24 & $1 / 19 / 95$ & $0: 33$ & 89094 & 102883 & 219841 & 153165 & 9622 & 10871 & 9940 & 0 & & 4.52 & \\
\hline Test 25 & $1 / 19 / 95$ & $0: 30$ & 90321 & 104154 & 226947 & 145884 & 9647 & 10902 & 17688 & 6401 & & 10.61 & \\
\hline Test 27 & $1 / 19 / 95$ & $0: 25$ & 89995 & 102816 & 221107 & 131427 & 9666 & 10949 & 17609 & 29388 & & 21.26 & \\
\hline
\end{tabular}


Post Modiflcation

\begin{tabular}{|c|c|c|c|c|c|c|c|c|c|c|c|c|c|}
\hline Noș & pate & pwr & 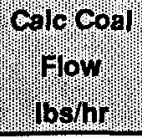 & 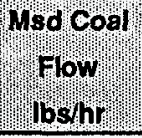 & 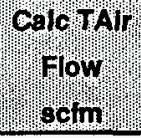 & & "मeat" & 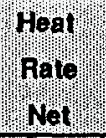 & & 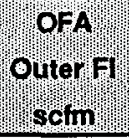 & 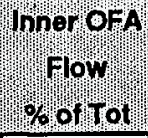 & 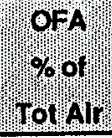 & Carbon \\
\hline Test 30 & $1 / 20 / 95$ & 1.01 & 82063 & 95660 & 221154 & 124710 & 9910 & 11250 & 17361 & 37041 & 26 & 24.60 & \\
\hline Test 31 & $1 / 20 / 95$ & $1: 00$ & 75428 & 88124 & 218886 & 121190 & 9889 & 11214 & 17501 & 40412 & 24 & 26.46 & \\
\hline Test 32 & $1 / 20 / 95$ & $1: 05$ & 79161 & 92484 & 221228 & 123472 & 9819 & 11132 & 17452 & 40424 & 24 & 26.16 & \\
\hline Test 33 & $1 / 20 / 95$ & $0: 40$ & 82664 & 96988 & 220575 & 124136 & 9819 & 11131 & 17453 & 40425 & 24 & 26.24 & \\
\hline Test $1(\mathrm{R})$ & $1 / 24 / 95$ & 1.00 & 131893 & 157780 & 313392 & 240133 & 9242 & 10064 & 1679 & 0 & 100.0 & 0.54 & 7.87 \\
\hline Test 16 & $1 / 25 / 95$ & $0: 20$ & 116109 & 134058 & 291006 & 176451 & 9391 & 10237 & 18000 & 43468 & 29.2 & 21.12 & \\
\hline Test 17 & $1 / 25 / 95$ & $0: 40$ & 121061 & 140617 & 293926 & 178597 & 9410 & 10259 & 18000 & 43454 & 29.2 & 20.91 & \\
\hline Test 403 Mill & $1 / 25 / 95$ & $1: 00$ & 109660 & 132074 & 266472 & 164640 & 9615 & 10556 & 17385 & 29889 & 36.08 & 17.74 & \\
\hline Test 413 Mill & $1 / 25 / 95$ & 1.00 & 101488 & 119843 & 277703 & 165890 & 9598 & 10527 & 18000 & 46046 & 28.03 & 23.06 & \\
\hline Test 423 Mill & $1 / 25 / 95$ & $1: 00$ & 106197 & 125473 & 278347 & 169244 & 9568 & 10484 & 18000 & 46194 & 28.02 & 23.06 & \\
\hline Test 433 Mill & $1 / 25 / 95$ & $0: 45$ & 110748 & 129346 & 281475 & 169884 & 9550 & 10474 & 18000 & 45635 & 28.41 & 22.61 & \\
\hline Test 2(R2) & $1 / 25 / 95$ & $0: 39$ & 135349 & 159913 & 325870 & 248560 & 9422 & 10256 & 1545 & 0 & 100.0 & 0.47 & \\
\hline Tost 2(R) & $1 / 25 / 95$ & $0: 30$ & 135449 & 158981 & 334512 & 246770 & 9449 & 10304 & 9647 & 0 & 100.0 & 2.88 & \\
\hline Test 14(R) & $1 / 25 / 95$ & $0: 20$ & 123748 & 146504 & 293668 & 183697 & 9400 & 10226 & 18000 & 43935 & 29.0 & 21.09 & \\
\hline Test 15(R) & $1 / 25 / 95$ & $0: 50$ & 115931 & 135319 & 291035 & 179149 & 9360 & 10170 & 18000 & 43557 & 29.1 & 21.15 & 7.01 \\
\hline Test 16(R) & $1 / 26 / 95$ & $0: 24$ & 118542 & 138834 & 297704 & 181397 & 9450 & 10290 & 18000 & 43672 & 29.0 & 20.72 & \\
\hline Test 44 & $1 / 26 / 95$ & $0: 25$ & 125572 & 154134 & 294304 & 184063 & 9484 & 10332 & 18000 & 44567 & 29.0 & 21.26 & \\
\hline Test 45 & $1 / 26 / 95$ & $0: 30$ & 123877 & 150080 & 294975 & 183731 & 9424 & 10257 & 18000 & 44113 & 29.0 & 21.06 & \\
\hline Test 46 & $1 / 26 / 95$ & $0: 48$ & 116754 & 141053 & 290926 & 180276 & 9400 & 10219 & 18000 & 43858 & 29.0 & 21.26 & 9.98 \\
\hline Test 47 & $1 / 26 / 95$ & $0: 30$ & 119887 & 143674 & 293337 & 183309 & 9386 & 10207 & 18000 & 44165 & 29.0 & 21.19 & \\
\hline LNB 3 Mill & $1 / 27 / 95$ & $0: 45$ & 111133 & 141006 & 256621 & 200303 & 9134 & 10049 & 3256 & 0 & 100.0 & 1.27 & \\
\hline Test 50 & $1 / 27 / 95$ & $0: 42$ & 102860 & 132139 & 252815 & 165722 & 9143 & 10064 & 17749 & 29199 & 37.2 & 18.57 & \\
\hline Test 51 & $1 / 27 / 95$ & $0: 31$ & 93204 & 118033 & 252213 & 156884 & 9144 & 10068 & 18000 & 42769 & 30.0 & 24.09 & \\
\hline Test 52 & $1 / 27 / 95$ & $0: 30$ & 97741 & 122686 & 250319 & 155392 & 9113 & 10037 & 18000 & 42870 & 30.0 & 24.32 & \\
\hline
\end{tabular}

